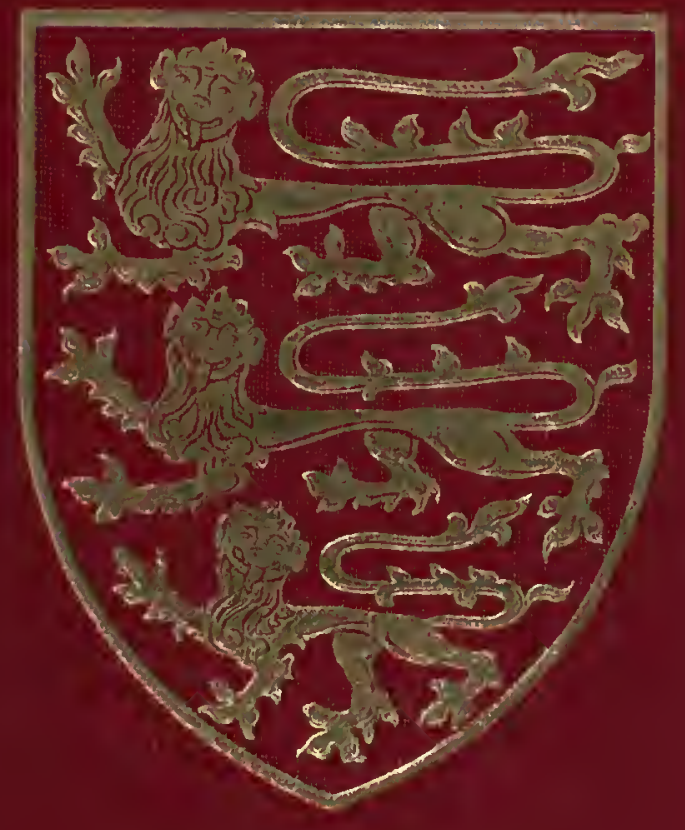




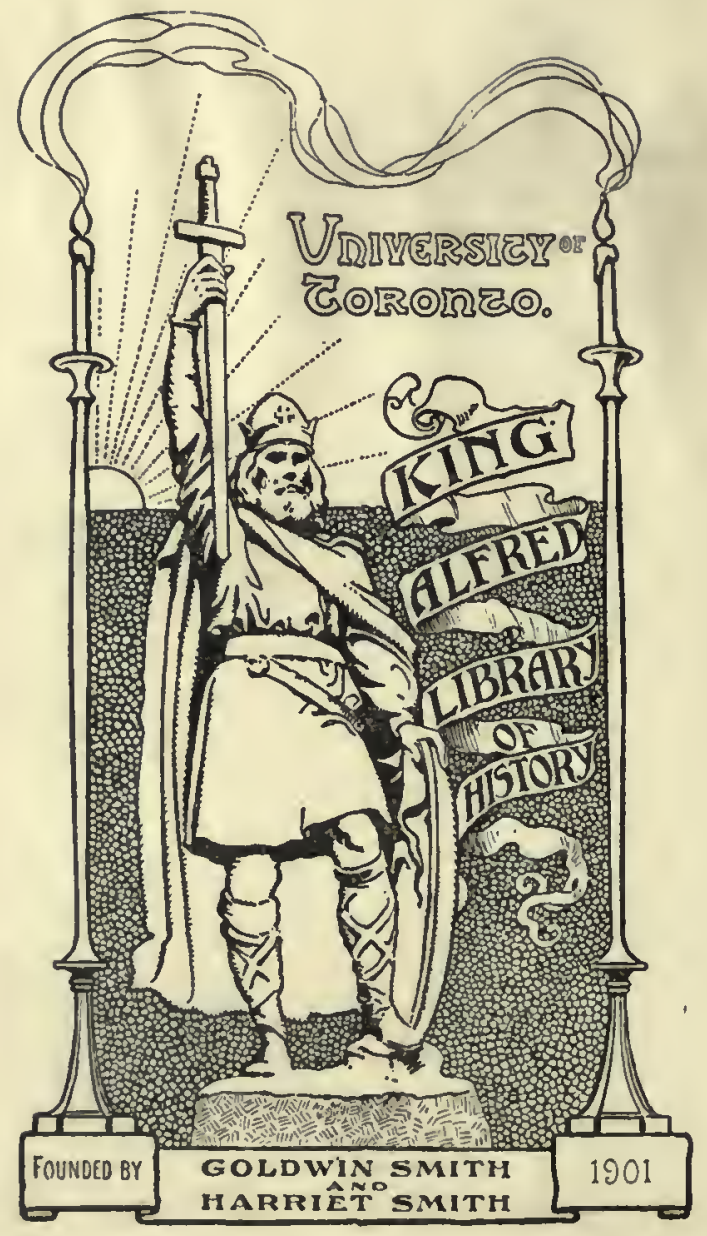






\section{THE VICTORIA HISTORY OF THE \\ COUNTIES OF ENGLAND}

A HISTORY OF

ESSEX

VOLUME IV 



\section{THE VICTORIA HISTORY OF THE \\ COUNTIES OF ENGLAND}

EDITED BY R. B. PUGH



THE UNIVERSITY OF LONDON INSTITUTE. OF HISTORICAL RESEARCH 
Oxford University Press, Amen House, London, E.C.4 GLASGOW NEW YORK TORONTO MELBOURNE WELLINGTON BOMBAY CALCUTTA MADRAS KARACHI CAPE TOWN IBADAN Geoffrey Cumberlege, Publisher to the University

PRINTED IN GREAT BRITAIN

646017

17.11 .56 


\author{
INSCRIBED TO THE \\ MEMORY OF HER LATE MAJESTY \\ QUEEN VICTORIA \\ WHO GRACIOUSLY GAVE THE TITLE TO \\ AND ACCEPTED THE DEDICATION \\ OF THIS HISTORY
}








Aerial View of Chipping Ongar from the North-East

Copyright Aerofilms The castle mound is shown in the mid-foreground 


\title{
A HISTORY OF THE COUNTY OF ESSEX
} EDITED BY W. R. POWELL

\section{VOLUME IV}

ONGAR HUNDRED

\author{
PUBLISHED FOR \\ THE INSTITUTE OF HISTORICAL RESEARCH \\ BY THE \\ OXFORD UNIVERSITY PRESS \\ AMEN HOUSE, LONDON \\ 1956
}




$$
\begin{aligned}
& \text { DA } \\
& 670 \\
& E 7 V_{6} \\
& V .4
\end{aligned}
$$




\section{CONTENTS OF VOLUME FOUR}

Dedication.

Contents

List of Illustrations and Maps

Editorial Note

Essex V.C.H. Committee

Classes of Public Records used

Classes of Documents in the Essex Record Office used

Note on Abbreviations.

Topography

Where not otherwise stated, Architectural Descriptions by MARGARET TOMLINSON; bridges, roads, postal services, and public services (except in Chigwell) by Gladys A. Ward; Roman Catholicism from information supplied by the REvD. B. C. FoleY; Methodist Churches (except in Lambourne) by G. HARRINGTON; all other Nonconformist Churches by W. R. PowelL; Primary Schools by A. F.J. BRown; Charities by SUSAN ReYNolds.

Ongar Hundred .

Bobbingworth.

Chigwell

By W. R. PowelL

By Audrey M. Taylor

By E. J. ERITh. Architectural Descriptions from information supplied by the Ministry of Housing and Local Government . - I 8

Fyfield

Greenstead

By Audrey M. Taylor . . . . 43

By W. R. Powell . . . . 58

By E. E. Barker, W. R. Powell, and Audrey M. TAYLOR . • . . . 63

Lambourne

By W. R. Powell. Parish Government and Poor Relief by D. M. M. SHorrocks . 72

High Laver

Little Laver

Magdalen Laver

By Audrey M. Tarzor. Parish Government and Poor Relief by J. H. Holmes . . 97

By Audrey M. Taylor. Parish Government and Poor Relief by J. H. Holmes . . 103

Loughton

By W. R. Pow elr. Architectural Descriptions from information supplied by the Ministry of Housing and Local Government .

By Audrey M. Taylor. Parish Government and Poor Relief by D. M. M. Shorrocks . I 29

By E. E. Barker, W. R. Poweli, and Audrey M. TaYlor .

By W. R. Powell

BY W. R. Powell . . . . . I55

By W. R. Powell • • • . . $17 \mathrm{I}$

By W. R. Powell. Parish Government and Poor Relief by D. M. M. Shorrocks.

By W. R. Powelz. Parish Government and Poor Relief by D. M. M. Shorrocks . 197 ix 


\section{CONTENTS OF VOLUME FOUR}






\section{LIST OF ILLUSTRATIONS AND MAPS}

The three maps are based on the Ordnance Survey, and like the illustration of painted glass facing page $\mathrm{r} 85$ are published with the sanction of the Controller of H.M. Stationery Office, Crown Copyright reserved. Additional information for the map facing p. I ro was supplied by the Chigwell Urban District Council. The drawings of Fy field Hall and Lampetts are by Miss Cynthia Booth, based on a survey made by the National Buildings Record in I 954. Thanks for the loan of photographs and other pictures are due to Mrs. C. Blaxall (Kelvedon Hatch Old Church), the Cement and Concrete Association (Bank of England Printing Works), Mr. D. A. J. Buxton (Town Hall, Chipping Ongar), the Minister and Deacons of White Roding Congregational Church (Abbess Roding Congregational Church), and the Minister and Deacons of Chipping Ongar Congregational Church (Stanford Rivers Congregational Church); and to the National Buildings Record and the Essex Record Office for the loan of several photographic and other prints. The portrait facing p. 280 is reproduced by courtesy of the Mayor and Corporation of Saffron Walden. The block for the illustration of Lucton Secondary Modern School was lent by the Essex Education Committee. Unless otherwise stated, all photographs were taken in 1955 by Mrs. Margaret Tomlinson.

Air View of Chipping Ongar, 6 June 1951

Map of the Hundred of Ongar, drawn by Cynthia Booth . . . . . page 3

Arms of Chigwell Urban District, granted I95 I . . . . . . . . . $\quad$ " 18

Buckhurst Hill. Air View from the west, 4 June 1952 . . . . . . facing " I8



Barns at Rookwood Hall, Abbess Roding. Photograph by G. N. Kent, 1940 • . " " " 19

Dews Hall, Lambourne, refronted c. 1740 , demolished c. I 840 . Drawn by J. P. Neale and included in his Views of the Seats of Noblemen and Gentlemen in England ... (and Ser.), Vol. i ( 1824 )

Luxborough House, Chigwell, rebuilt 1716-20, demolished c. I 800 . Drawn by Metz.

From a print, published in 1783 by Harrison \& Co., in the Essex Record Office

Fyfield Hall, sections and plan

Lampetts, Fyfield, sections and plan

Fyfield Church .

Bomb Damage at Navestock Church. Photograph by G. N. Kent, I $940^{\circ} \cdot \dot{-}$
Fyfield Church: chancel in 1834 . Drawn by A. Suckling and published in his Memorials

Fyfield Church: chancel in 1834. Drawn by A. Suckling and published in his Memorials

Lambourne Church in 1825 . Drawn by J. P. Neale. From a print, published 1825 , in the Essex Record Office

Greenstead Charch in 1748. From Vetusta Monumenta (Soc. Antiq.), Vol. ii (1789) .

Kelvedon Hall, built c. I743. Photograph from Country Life, I94I.

Lambourne Place, formerly the Rectory, built c. 1740 . . . . . .

Map of Loughton, drawn by Cynthia Booth and Margaret Tomlinson . . .

Loughton Street Plan, drawn by Cynthia Booth . . . . . . .

Mid-2oth-century Buildings at Debden.

Roman Catholic Church of St. Thomas More, opened I953 .

Bank of England Printing Works (Architects, Easton \& Robertson; Consulting Engineers, Ove Arup \& Partners). Interior of main printing hall under construction, I954.

Nonconformist Churches.

Abbess Roding Congregational Church, built 17.29, demolished c. 1900. From an oil painting

Stanford Rivers Congregational Church, built 1820 , burnt 1927. From a photograph of 1927 .

Buckhurst Hill: Palmerston Road Congregational Church, built 1874 .

Loughton: Methodist Church, built 1903 .

Former village school at Greenstead, built c. I 846 .

County Primary School, High Ongar, built 1867 


\section{LIST OF ILLUSTRATIONS AND MAPS}

Loughton County High School for Girls, built 1908 . . . . . . facing page I27

Lucton Secondary Modern School, Debden, built 1950 . • . • • • " " 127

Navestock Hall, built early I 8 th century, demolished I 8 I I. Drawn by J. Chapman. From A... History of Essex by a Gentleman, Vol. iii (1771). . . . . . " " " 1 36

The former Rectory, Stondon Massey, built early 17 th century, demolished c. 1800 . Drawn by 'C.H.' From The Gentleman's Magazine, lxxv (1), facing p. I05 (1805).

Wynter's Armourie, Magdalen Laver, containing part of a I4th-century aisled hall . Black Hall or Guildhall Cottage, Moreton, probably a Guildhall of $c$. I473 . . .

Former Steam Mill, Navestock . . . . . . . . . . "

Town Hall, Chipping Ongar, demolished 1896-7. Photograph of $c .1890$. . .

Castle House and the Moat of Ongar Castle in I 832. From Thomas Wright's History of ... Essex, ii, 330

Greenstead Hall in the later I 8th century. From $A$ New Display of the Beauties of England (3rd ed.), Vol. i (1776)

High Ongar Church: I 2th-century Tympanum. Photograph by G. N.Kent, I942 .

Little Laver Church: I 2th-century Font Bowl

Painted Glass in High Ongar Church: Arms of Jane Seymour. From Hist. Mon. Com. Essex, Vol. ii (1924), plate facing p. xxxvii.

Shelley Hall, Mural Painting of $c .1590$. From E.A.T (19r3) N.s. xii, 26. . .

Beauchamp Roding Church .

Magdalen Laver Church

Toot Hill Windmill, Stanford Rivers. Shattered by lightning 1829 . Print as sold for the benefit of the miller

Old Loughton Hall, burnt 1836 . From an early-I gth-century water-colour, E.A.T.(I g03) N.s. viii, 345 .

Albyns, Stapleford Abbots (derelict in 1955). From an estate map of I654, E.R.O. $\mathrm{D} / \mathrm{DC} 27 / 112 \mathrm{I}$

The River Roding and Passingford Mill from Passingford Bridge.

Loughton: Trees in Epping Forest showing the effects of lopping

Cutlers Forge, Stapleford Tawney

Stanford Rivers: Tent and Tarpaulin Factory, formerly the Ongar Union Workhouse

Post-Reformation Churches.

Kelvedon Hatch Old Church, built 1750-3. Photograph by Constance Blaxall, c. I 942 Theydon Bois, built 1850

Theydon Mount, built 1611-14

The Church and Priest's House, Theydon Garnon. Drawn and published by W. Franklin in 1818 . From a print in the Essex Record Office.

Stondon Massey Church in 1 833. Drawn by A. Suckling, and published in his Memorials of the ... Architecture of Essex (1845)

Portrait of Sir Thomas Smyth (I I 3 -77). By an unknown artist. The original, which is in Saffron Walden Town Hall, was presented to the corporation by Sir Charles Smyth in $177 \mathrm{I}$ and is presumed to have been copied about that time from an earlier work

Hill Hall. East front, reconstructed c. I7 14. Photograph from Country Life, 1908.

Hill Hall. The Great Hall before 2oth-century alterations. Photograph from Country Life, 1908

Semi-detached Houses at Theydon Bois, built c. 1900

Post-1 945 Housing Estate at North Weald 


\section{EDITORIAL NOTE}

THE first volume of the Victoria History of Essex was published in 1903 and the second in 1907. A little work on other volumes was put in hand in I 907 and I 909 , but nothing came of it, and it was not until 1950 that any desire to add to the Essex volumes in the series openly displayed itself. In that year, however, two conferences of the Local Authorities in Essex, specially convened, resolved to raise a local fund so that work on the history of their county might be resumed. The three County Boroughs, and most of the Municipal Boroughs, Urban Districts, and Rural Districts agreed to contribute in proportion to their populations, and the money thus found was used to meet the local editorial expenses. The Essex County Council extended some useful practical help. A 'Victoria History of the County of Essex Committee' was set up in I95 I to ensure a proper use of the money, and appointed a local editor (Mr. W. R. Powell) and assistant editor (Miss Audrey M. Taylor). It has met ever since under the chairmanship of Sir John Ruggles-Brise, Bt., and besides a few co-opted individuals, consists of representatives of the participating Local Authorities and the learned societies in Essex. Mr. J. G. O'Leary, Public Librarian of Dagenham, who had cheerfully shouldered the burden of appealing for financial support, undertook the duties of secretary. With this Committee the University of London agreed to collaborate, and so was formed another of those partnerships for the promotion of local historiography, the prototype of which is described in the editorial note prefixed to the seventh volume of The Victoria History of Wiltshire. The-University of London will ever gratefully recall the local generosity which made this partnership possible, and the Essex Authorities the opportunity thus afforded them of bringing out in instalments a modern history of their county.

The present volume presents some special features. Thanks to the extensive system of topographical indexing adopted in the Essex Record Office it has been possible to exploit the large accumulations of historical material in that Office in systematic fashion. This has enabled contributors to prepare fuller accounts of parish government, the administration of poor relief, and the maintenance of roads and bridges than have as yet appeared in the series, while the history of the descent of land since the i 7 th century has been enriched, as perhaps never before, by the use of private estate documents. Secondly, the publication by the County Council of Essex Parish Records $1240-1894$ so recently as 1950 suggested that the brief descriptions of the earlier parochial registers of each parish, commonly included in the topographical volumes of the History, might be dispensed with here. Thirdly, in I92 I the Royal Commission on Historical Monuments published the second volume of its report upon the buildings of the county earlier than I 7I4. The existence of this volume rendered comparable treatment of the buildings in Ongar hundred superfluous, but the 


\section{EDITORIAL NOTE}

ground had to be traversed anew in pursuit of later buildings falling outside the Commission's purview. In the course of this inquiry it was found possible to correct or amplify some statements appearing in the Commission's reports, particularly in the light of recent research on medieval timberframed structures. In later volumes, however, it is probable that a lessdetailed treatment of the buildings will be found advisable, especially in areas that are richer in architectural interest than this one. Similarly, other features may be modified where this can be done without rendering them less scholarly.

The compilers have received help from many people living in Essex or connected with the county. The Essex Education Committee, the County Planning Department, and Chigwell Urban District Council permitted access to certain records and answered questions. The Eastern and North Thames Gas Boards, the Eastern Electricity Board, and the London Co-operative Society also supplied much information. The records of the Wanstead and Woodford Methodist Circuit were examined by permission of the Revd. J. R. S. Hutchinson. Information from the records of the Essex Congregational Union was communicated by Mr. J. S. Appleby. The Ministry of Housing and Local Government allowed the use of their unpublished lists of buildings of architectural or historical interest. Certain architectural descriptions, notably those of medieval houses, owe much to the Royal Commission on Historical Monuments, and in the parish of Fyfield special surveys were made on request by the National Buildings Record. Many local residents, whose kindness is acknowledged in footnotes, gave information or permitted the inspection of their houses. The galley proof of each parish article was read by at least one person, usually the incumbent, living or working in the parish, and many valuable suggestions resulted. The County Archivist (Mr. F. G. Emmison) and his staff performed special services at all stages, Mr. Emmison himself reading many of the articles in draft or in proof. Mr. D. W. Hutchings of Ongar carried out field surveys for all parishes, gave much information, supplied references from periodicals, and read the whole volume in proof.

R. B. PUGH

W. R. POWELL 


\title{
ESSEX \\ VICTORIA COUNTY HISTORY \\ COMMITTEE
}

\author{
President \\ CoL. Sir Francis Whitmore, Bt., K.c.B., c.M.G., D.s.o., Her Majesty's Lieutenant
}

Chairman

SIR John Ruggles-BRise, BT., O.B.E., T.D., D.r.

Representatives of the following Local Authorities*

County Boroughs:

East Ham

West Ham Southend-on-Sea

Municipal Boroughs:

$\begin{array}{llll}\text { Barking } & \text { Chelmsford } & \text { Chingford } & \text { Colchester } \\ \text { Dagenham } & \text { Harwich } & \text { Ilford } & \text { Leyton } \\ \text { Maldon } & \text { Romford } & \text { Walthamstow } & \text { Wanstead and Woodford }\end{array}$

$\begin{array}{llll}\text { Benfleet } & \text { Braintree and Bocking } & \text { Brentwood } & \text { Burnham-on-Crouch } \\ \text { Canvey Island } & \text { Chigwell } & \text { Clactor } & \text { Epping } \\ \text { Frinton and Walton } & \text { Halstead } & \text { Harlow } & \text { Hornchurch } \\ \text { Rayleigh } & \text { Thurrock } & \text { Waltham Holy Cross } & \text { West Mersea } \\ & \text { Witham } & \text { Wivenhoe } & \end{array}$

Urban Districts:

Rural Districts:

$\begin{array}{llll}\text { Braintree } & \text { Chelmsford } & \text { Epping and Ongar } & \text { Halstead } \\ \text { Lexden and Winstree } & \text { Maldon }\end{array}$

Representatives of the following Societies

Barking and District Archaeological Society

Brentwood and District Historical Society

Chingford Antiquarian Society

Essex Archaeological Society

Essex Field Club
Roman Essex Society

Southend-on-Sea and District Antiquarian and Historical Society

Waltham Abbey Historical Society

Walthamstow Antiquarian Society

Woodford and District Historical Society

\section{Co-opted Members}

W. Addison, Esq.†

Councillor H. A. Bridge†

Alderman A. L. Clarke

Alderman L. Dansie† (resigned 1954)

F. G. Emmison, EsQ. $†$
M. Fitch, EsQ.† (from I954)

M. R. HuLr, EsQ. $\dagger$

K. J. Lace, EsQ.

E. O. REED, EsQ.

G. O. RICKWORd, EsQ.

F. W. Strer, EsQ.† (resigned 1953)

- The following Local Authorities, not being regular subseribers, have made donations: the Municipal Borough of Saffron Waldon; the Urban District of Basildon. $\dagger$ Members of Editorial Committee. 


\title{
ESSEX V.C.H. COMMITTEE
}

\author{
Editorial Committee \\ Alderman D. Thorogood (Chairman) Professor H. C. Darby, o.b.e. \\ Professor F. J. Fisher Canon J. L. Fisher \\ E. R. Gamester, Esq. (from I954) Mrs. G. A. Ward \\ together with the persons marked with a dagger \\ County Secretary: J. G. O'Learý, Eso.†
}

Treasurer: C. H. Chown, EsQ.† (resigned I955) Alderman D. L. Forbest (from I955)

General Editor: R. B. Pugr, EsQ.†

Essex Editor: W. R. Powelu, Ese. $†$

$\dagger$ Members of Editorial Committee 


\section{LIST OF CLASSES OF PUBLIC RECORDS}

\section{USED IN THIS VOLUME, WITH THEIR \\ CLASS NUMBERS}

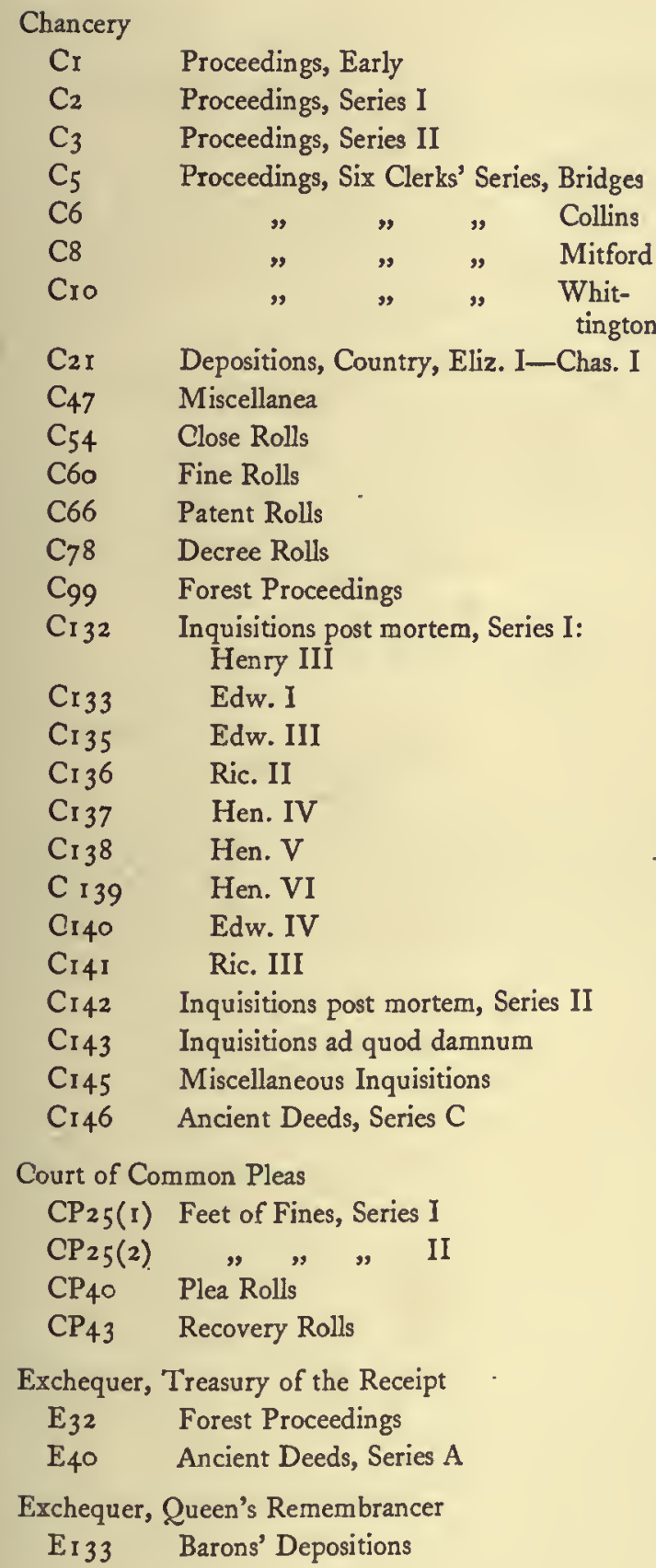

\author{
Er 34 Depositions by Commission \\ E 137 Estreats \\ EI 50 Inquisitions post mortem, Series II \\ Er64 Miscellaneous Books, Series I \\ EI79 Subsidy Rolls, \&c. \\ E210 Ancient Deeds, Series D \\ Exchequer, Augmentation Office \\ $E_{30}$ Certificate of Chantries and Colleges \\ E3 5 Miscellaneous Books \\ $\mathrm{E}_{32}$ I Proceedings of Court of Augmentation \\ E326 Ancient Deeds, Series B
}

Exchequer, First Fruits and Tenths E33 I Bishops' Certificates of Institution to
Benefices

Exchequer, Lord Treasurer's Remembrancer

E 372 Pipe Rolls

Home Office

HO67 Acreage Returns

HOro7 Census Returns

Duchy of Lancaster

DL25 Ancient Deeds, Series L

$\mathrm{DL}_{30}$ Court Rolls

Justices Itinerant

JII Assize Rolls, Eyre Rolls, \&c.

Special Collections

$\mathrm{SC}_{2} \quad$ Court Rolls

State Paper Office

SPI 2 State Papers Domestic, Eliz. I.

SPI6 ", " Chas. I.

SP44 " " " Entry Books

Court of Wards and Liveries

Wards 5 Feodaries' Surveys

Court of Star Chamber

St. Ch. 8 Proceedings, Jas. I.

Court of Requests

Req. 2 Proceedings 


\section{LIST OF CLASSES OF DOCUMENTS IN THE ESSEX RECORD OFFICE

\author{
USED IN THIS VOLUME, WITH THEIR \\ CLASS NUMBERS
}

$\begin{array}{ll}\text { Court of Quarter Sessions } \\ \text { Q/SR } & \text { Sessions Rolls } \\ \text { Q/SB } & \text { Sessions Bundles } \\ \text { Q/SO } & \text { Sessions Order Books } \\ \text { Q/AB } & \text { County Bridges } \\ \text { Q/AC } & \text { Committees } \\ \text { Q/RDc } & \text { Inclosure Awards } \\ \text { Q/RRP } & \text { Returns of Papists' Estates } \\ \text { Q/RRw } & \text { Returns of Nonconformists' and Roman } \\ & \text { Catholics' places of worship } \\ \text { Q/RTh } & \text { Hearth Tax Assessments } \\ \text { Q/RPI } & \text { Land Tax Assessments } \\ \text { Q/RPr } & \text { Registers of Parliamentary Electors } \\ \text { Q/RUm } & \text { Public Undertakings: plans of schemes } \\ \text { Q/RSg } & \text { Deputations to Gamekeepers } \\ \text { Q/RSw } & \text { Workhouse Agreements } \\ \text { Q/RLv } & \text { Recognizances of Licensed Victuallers } \\ & \text { and Alehouse-keepers } \\ \text { Q/CP } & \text { Clerk of the Peace: Precedents }\end{array}$

Q/CR Clerk of the Peace: Pariiamentary Returns

County Council Transferred Records

G/EM Poor Law Guardians, Epping Union: Minute Books

G/OnM Poor Law Guardians, Ongar Union: Minute Books

Deposited Records

D/D Estate and Family Archives (many subclasses)

D/AE Archdeaconry of Essex Records

D/CT Diocesan Records: Tithe Apportionments and Maps

D/P Parish Records

$\mathrm{D} / \mathrm{Q} \quad$ Charity Records

$\mathrm{D} / \mathrm{T} \quad$ Turnpike Records

Transcripts

$\mathrm{T} /$
(Document or collection indicated by addition of another letter)

Some of the foregoing classes contain sub-classes which are denoted by additional letters, not shown here but fully cited in footnotes in this volume. The group called 'Transcripts' includes all forms of copies or catalogues of documents of which the originals are elsewhere. The wills proved in the court of the Archdeacon of Essex (D/AE), cited in this volume as 'Archd. Essex', were transferred from Somerset House, London, to the Essex Record Office while this volume was being printed. 


\section{NOTE ON ABBREVIATIONS}

Among the abbreviations and short titles used the following may require elucidation:

E.A.S.

E.R.O.

P.M.G.

Ch. Bells Essex

Ch. Plate Essex

\section{E.A.T.}

E.R.

Essex Par. Recs.

Feet of $F$. Essex

Hist. Essex by Gent.

Hist. Mon. Com. Essex

\section{Morant, Essex}

Newcourt, Repert.

P.N. Essex (E.P.N.S.)
Essex Archaeological Society

Essex Record Office

Postmaster-General

C. Deedes and H. B. Walters, The Church Bells of Essex (1 gog)

G. M. Benton, F. W. Galpin, and W. J. Pressey, The Church Plate of Essex (1926)

The Transactions of the Essex Archaeological Society

The Essex Review

Essex Parish Records, ed. E. J. Erith (1950)

Feet of Fines for Essex (E.A.S., issued in parts: Vol. i, 1899-1910; Vol. ii, 19I 3-28; Vol. iii, 1929-49; Vol. iv, pt. I, I947)

A New and Complete History of Essex by a Gentleman ( 6 vols. 1769-72)

Royal Commission on Historical Monuments (England): An Inventory of the Historical Monuments in Essex (4 vols. 1916-23)

P. Morant, The History and Antiquities of Essex (2 vols. 1768)

R. Newcourt, Repertorium Ecclesiasticum Parochiale Londinense (2 vols. I 7 10)

P. H. Reaney, The Place Names of Essex (English Place Name Society, xii, 1935) 



\section{THE HUNDRED OF ONGAR}

W HE hundred of Ongar, lying in the south-west of the county is roughly oval in shape and about 17 miles long. Although only io miles from London at the nearest point and 27 miles at the farthest it is still mainly rural. The River Roding flows south-west through the hundred. In the summer it is usually no more than a narrow stream but is sometimes severely swollen in winter, and the repair of its many bridges was a serious problem down to the I 9 th century. In the Roding valley the land is never more than $200 \mathrm{ft}$. above sea-level. Elsewhere it is usually under $300 \mathrm{ft}$. and there are few hills.

The south-west corner of the hundred is largely urbanized, for here is Chigwell Urban District, which includes the towns of Loughton (with Debden), Buckhurst Hill, and Hainault, and now has a population of about 56,000. Even here, however, the forests of Epping and Hainault and the old houses and cottages of Chigwell recall a simpler society. Farther north and east there is gently undulating country with high hedges, meadows, ploughed fields, streams, and spinneys as far as Chipping Ongar. The soil of this south-western half of the hundred is mainly London Clay, with some areas of Boulder Clay and some patches of glacial sand or gravel. I It is a land of mixed farming, with many dairy herds and sheep.

Chipping Ongar, which gave its name to the hundred and was for long the principal place in it, was an ancient market-town and contained a Norman castle. Though very small it still has some local importance as the administrative centre of the Ongar Rural District. North of it the landscape changes. There are low hedges, few trees or meadows, and the roads are narrow. The soil is almost entirely Boulder Clay. It is good corn land and cattle are comparatively rare. The end of the hundred is reached at Beauchamp Roding and Abbess Roding, which are as remote and isolated as any part of Essex.

Nucleated villages are unusual but there are many hamlets and scattered farms. The older farm buildings are timber-framed and either plastered or weather-boarded. They are often enclosed by moats, especially in the north. Brick houses of the 18 th century and later are fairly common. Few are older, but among them is Hill Hall (in Theydon Mount), a 16 th-century mansion noted for its early use of renaissance detail. In and after the I 6th century the south-western part of the hundred was a fashionable residential area for wealthy landowners and a number of large houses were built there. In the I 8 th century and later landscape gardeners transformed the surroundings of some of these houses. In most parishes the church stands on an isolated site beside the principal manor house, and is usually a small flint building with a short, shingled spire. But by far the best-known church, the Saxon church at Greenstead, is not of fint at all, but has walls of timber.

I For the geology of the area see V.C.H. Essex, i, I (map), which still represents the latest information available cartographically. 


\section{A HISTORY OF ESSEX}

In 1086 the west of the hundred-Loughton, Chigwell, the Theydons, and North Weald-and the area around Chipping Ongar were thickly wooded.2 By the end of the I 6 th century the only large areas of woodland remaining were Epping and Hainault forests. Most of Hainault Forest was destroyed about I 860 but Epping Forest was preserved after a notable controversy. Hardly any evidence has been found of open-field arable cultivation in the hundred. Commons survive in several parishes. In others they were inclosed in the 18 th or I 9 th centuries but in most they had been inclosed before 1700 . Apart from the forest inclosures the landscape of the hundred probably changed little between the Conquest and the middle of the I gth century. Building development started in the south-west about 1860 , when the railway from London was extended to Loughton, Epping, and Ongar, and continued slowly until 1939. Since 1945 the London County Council has built two large housing estates, at Debden and Hainault.

Until the I gth century most of the inhabitants of the hundred were engaged in agriculture and its ancillary trades. There were many water-mills along the Roding and a few windmills on higher ground. Brickmaking was carried on in many parishes in the London Clay area and there was a little beer-brewing with hops grown locally. Agriculture is still predominant outside the towns. Brickmaking continues in a few places but brewing has entirely ceased. There are light industries in Loughton and Buckhurst Hill but the towns are mainly residential.

Domesday Book lists some 40 estates under Ongar hundred. ${ }^{3}$ Seven other estates, though not so listed, seem clearly in this hundred in 1086.4 These 47 estates contained 103 hides in 26 villages distinguished by separate names. Most of these villages later gave their names to the parishes of the hundred, but there were several exceptions. The Domesday Theydon was later split into the three parishes of Theydon Bois, Theydon Garnon, and Theydon Mount. The Domesday Laver similarly became three parishes and Stapleford and Ongar each became two parishes. The Domesday Rodinges, to which three Ongar hundred and thirteen Dunmow hundred entries relate, was eventually divided into eight parishes, two of which were in Ongar hundred. In contrast to these places where 'the fission of vills' occurred were some which later became part of parishes larger than themselves: Alderton and Debden, which were separate Domesday villages were later included in the parish of Loughton, Woolston was merged in Chigwell parish, Passfield in High Ongar, and Little Stanford in Stanford Rivers. The case of Stanford is specially interesting, for it shows the process of fission starting in I 086 but later reversed. This may also have happened in two other places: there are separate references in Domesday to Fyfield and 'the other Fyfield' and to Navestock and 'the other Navestock', but there was no later fission in either village. One place which later became a parish in this hundred is not specifically mentioned in Domesday: Stondon Massey which was probably included in an entry for Margaret Roding (Dunmow hundred). The connexion between Stondon Massey and Margaret Roding was subsequently maintained by the payment of tithes from Marks Hall in Margaret Roding to the Rector of Stondon. A tithe-rent charge is still

2 Cf. V.C.H. Essex, i, 375. or three.

3 Ibid. 427-574 passim. Occasional ambiguities in Domesday Book make the total doubtful to within two 4 V.C.H. Essex, i, $537 b, 538 a, 540 a, 554 a$. 


\section{ONGAR HUNDRED}

paid by the owner of Marks Hall to the Rector of Stondon, and until early in the I $9^{\text {th }}$ century the parishioners of Stondon included Marks Hall in their annual beating of the parish bounds. Loughton, which in 1086 was partly in Becontree hundred, was from the I 4 th century or earlier wholly in that of

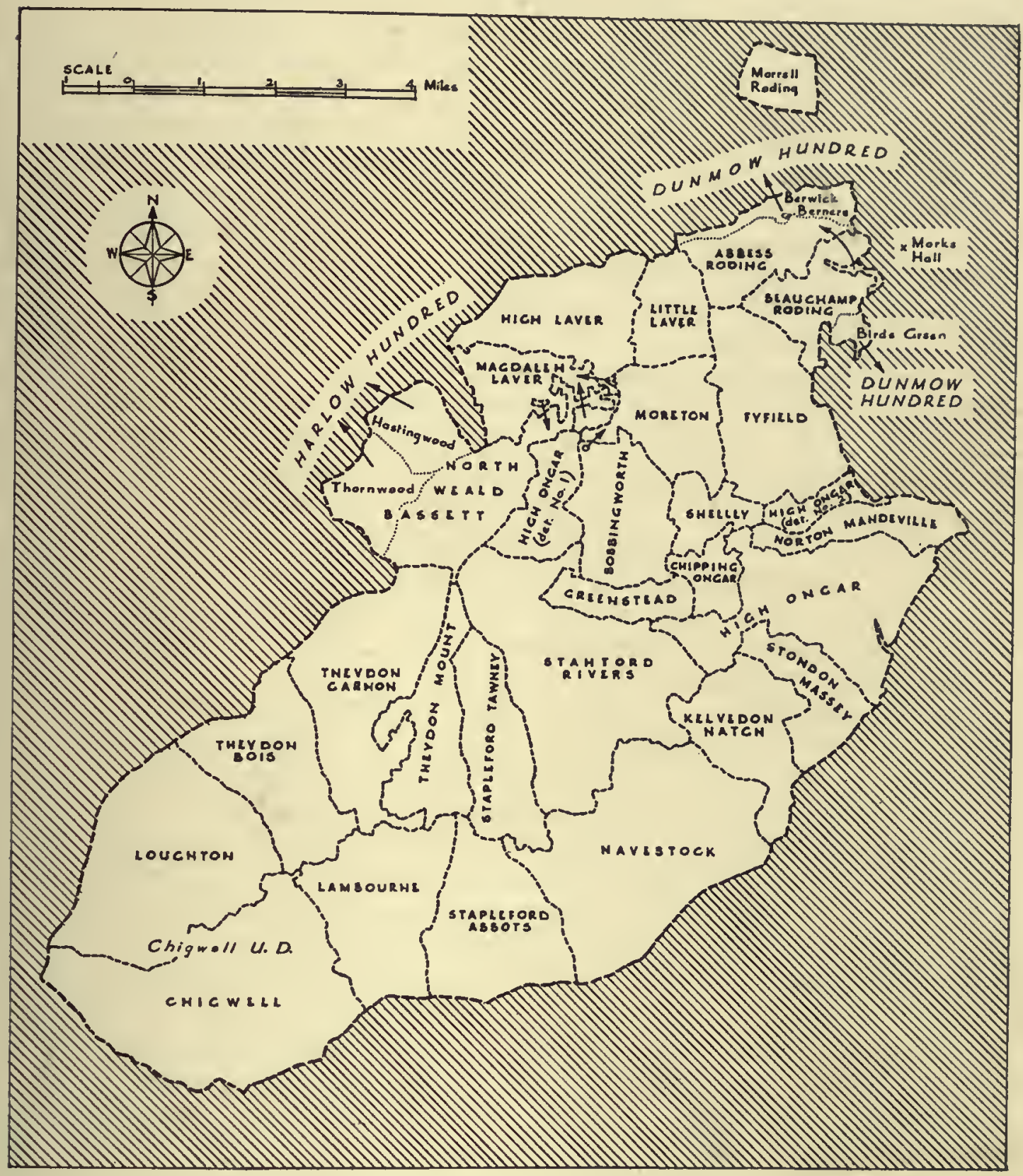

x Marks Hall in Margaret Rading has olwoys poid tithe to Stondon Mossey

Ongar. North Weald Bassett seems to have been partly in Harlow half-hundred in 1086 and continued to be thus divided between Harlow and Ongar. ${ }^{5}$ One very small place, Plumtuna, has not been certainly identified. 6

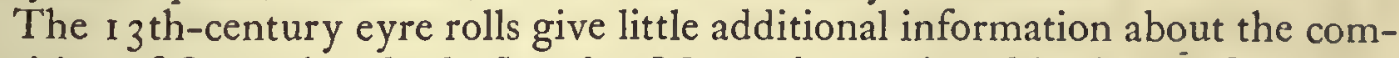
position of Ongar hundred. Stondon Massey is mentioned in the roll for I 2267.7 In the same year a tithing of Epping was listed under Ongar hundred; 8

5 Ibid. i, 397, ii, $35^{\circ}$.

7 J.I. $1 / 229$.
6 Ibid. i, 529. But see P.N. Essex (E.P.N.S.), I 53.

8 Ibid. 


\section{A HISTORY OF ESSEX}

this was probably part of Theydon Garnon, whose boundary in later times ran through the middle of Epping town. 9 In and after the 13 th century there were usually reckoned to be 26 parishes in the hundred, including North Weald and Loughton. Greenstead, a very small parish adjoining Chipping Ongar, was sometimes omitted from official lists. ${ }^{10}$ In the Middle Ages the parishes in Ongar hundred were normally identical with the 'vills'. There were occasional exceptions: in the taxation assessment of $\mathrm{I} 320$, for example (see below, p. 300 ), Norton Mandeville was included in High Ongar. The same assessment and others of the I $4^{\text {th }}$ century listed under Ongar hundred the hamlet of Roding Morrell, which was situated locally in White Roding parish (Dunmow hundred). For the purpose of these assessments Roding Morrell was included in Abbess Roding, but there was never any permanent and parochial connexion between them. The inclusion of Roding Morrell in Ongar hundred possibly originated in the acquisition of the tenancy in chief of the manor of Roding Morrell by the lords of Ongar hundred.II

A document concerning the hundred drawn up in $1543^{-6}$ and based on earlier records includes a list of 'the names of the vills, parishes and hamlets' in the hundred. ${ }^{12}$ Marden Ash (in High Ongar) and Greenstead appear to have been grouped with Chipping Ongar, and Ashlyns (a detached part of High Ongar) with Bobbingworth. Chivers End was mentioned as a hamlet of High Ongar: it was probably identical with the Passfield of 1086. Barringtons was mentioned as a hamlet of Chigwell and Abridge of Lambourne. There was an entry for Roding Morrell and one for Westwood (a detached part of High Ongar), which was grouped with Chipping Ongar. A part from the above all the places mentioned were parishes.

Saxton's Map of Essex, 1576 shows hundred boundaries and the location of parish churches. It correctly places the 26 churches of Ongar hundred, although the hundred boundary is inaccurately drawn in relation to some natural features, for example in the south-west corner, at Chigwell. Morrell Roding is not shown as belonging to the hundred. ${ }^{13}$ The Map of Essex, 1678 , by John Ogilby and William Morgan, has a more accurate delineation of the hundred boundary. That of Robert Morden and Joseph Pask, about I690, shows Thornwood (in North Weald) as in Harlow hundred. That of Philip Overton and Thomas Bowles, I 726,-also shows Hastingwood (in North Weald) as in Harlow hundred, Berwick Berners (in Abbess Roding) as in Dunmow hundred, and Roding Morrell as a detached part of Ongar hundred. ${ }^{14}$ Chapman and Andrés Map of Essex, I777 shows the hundred boundaries with precision. C. and J. Greenwood's Map of Essex, I824 is the first to give parish boundaries, but the delineation of these is often inaccurate. The first edition of the Ordnance Survey 6 inch Map (published I 868-84) indicates parish boundaries precisely and shows the detached parts of several parishes, in this hundred notably High Ongar, Magdalen Laver, and North Weald. The origin of such detachments, where it can be explained, lies in the manorial and church history of the parishes concerned. 15

The census reports of $180 \mathrm{I}-41$ give Roding Morrell as a separate hamlet of

\footnotetext{
9 See Theydon Garnon. Epping parish was in Waltham half-hundred.

10 e.g. Feud. Aids, ii, 204-6.

12 E.R.O., D/DRg I/s 97 , and see further below.

13 Copies of this and the other maps mentioned below are all in the Essex Record Office.

14 For Berwick Berners see also Morant, Essex, i, I 38 is See especially High Ongar, Church.
} 


\section{ONGAR HUNDRED}

Ongar hundred. Those of I 8 I I-4 I note that Thornwood and Hastingwood were in Harlow hundred and those of $1821-41$ show Berwick Berners as in Dunmow hundred.16 The I 85 I census, though not arranged by hundreds, states that the hamlet of Birds Green was partly in Beauchamp Roding and partly in Willingale Doe (Dunmow hundred). In the late I 8 th and early I 9 th centuries Birds Green was for some purposes certainly reckoned as part of Dunmow hundred, though no evidence has been found that this was so at any earlier date.

The lordship of Ongar hundred was given by Henry II to Richard de Lucy. ${ }^{7}$ It descended along with the manor of Chipping Ongar (q.v.) to the Rivers family and subsequently to the Staffords, earls of Stafford, and later dukes of Buckingham. At various times in the 14 th and I 5 th centuries the hundred was in the king's hands for short periods owing to the minority or forfeiture of its owners. ${ }^{18}$ It was finally forfeited to the Crown along with the manor of Chipping Ongar in 1521 . In that year Henry VIII appointed his yeoman Robert Stoner as bailiff and 'wardstaff' of the hundred, ${ }^{19}$ and in I 543 the hundred was granted for life to John Stoner, serjeant-at-arms. ${ }^{20}$ In I 547 it was granted to Richard Rich on his creation as a baron.2I It descended along with Paslow Hall in High Ongar (q.v.) until the death in 1673 of Charles Rich, Earl of Warwick. In the subsequent partition of the earl's estates the hundred was allotted to Henry St. John, who in 1689 granted it to Philip and Rowland Traherne. ${ }^{22}$ In 1694 the Trahernes conveyed it to Sir Eliab Harvey of Barringtons in Chigwell (q.v.) and it subsequently descended along with Barringtons. Vice-Admiral Sir Eliab Harvey was lord of the hundred in I 8 I $4 .{ }^{23}$ The original meeting-place of the hundred is not definitely known. The site of Ongar castle and Toot Hill in Stanford Rivers have both been suggested. ${ }^{24}$ In and after the I $5^{\text {th }}$ century Ongar hundred was closely associated with Harlow half-hundred, whose lordship had also been acquired by the Staffords. ${ }^{25}$ From the late i 6 th century Ongar and Harlow were grouped with Waltham half-hundred, the common meeting-place being at Waltham Holy Cross. ${ }^{26}$ These Waltham meetings, however, were probably for business other than that anciently associated with the hundred. It is not known whether separate meetings for Ongar hundred alone were held in the I $7^{\text {th }}$ century.

On a quo warranto inquiry in 1277 John de Rivers, lord of the hundred, claimed no return of writs within the hundred except the withdrawal from the sheriff of the King's debts and the execution of the other orders of the king therein. ${ }^{27}$ As to pleas of withernam he said that the hundred had been grante $d$ by Henry II to his ancestor Richard de Lucy and that Richard and his descendants had had those pleas. The Crown advocate rejoined that in Henry II's time there were no such pleas and that in any case they were not mentioned in Richard de Lucy's charter.

16 But in and after I 83 I the population was enumerated in Abbess Roding as part of Ongar hundred

17 Plac. Quo Warranto (Rec. Com.), 232; Rot. Husdr. (Rec. Com.), i, 153.

18 e.g. Cal. Fine R. 1413-22, 362; Cal. Pat. 1467-77, 56 I.

19 L. E P. Hen. VIII, iii (2), p. 973.

20 L. E P. Hen. VIII, xviii ( I), p. I93. According to the I 543 grant Stoner was to be bailiff and wardstaff of the hundred, not its lord, but the I 547 grant to Rich, quoting that of 1543 , states that the hundred had been granted to Stoner for life.

22 E.A.T. N.s. ix, 402 ; E.R.O., D/DCw T26. ${ }_{21}$ Cal. Pat. I 547-8, I I0- I I.

23 E. Ogborne, Hist. Essex, 236.

24 E.A.T. N.s. xviii, 192.

25 Morant, Essex, ii, 482 ; E.R.O., D/DP M $570,585,588,595$.

26 Norden, Description of Essex, I 594 (Camd. Soc.), I2; E.R.O. Guide, i, 3.

27 Plac. Quo Warranto (Rec. Com.), 232. 


\section{A HISTORY OF ESSEX}

On the same occasion Rivers also claimed view of frankpledge. This was not opposed but in fact before $\mathrm{I} 277$ this jurisdiction had in some cases already been alienated to the lords of individual manors. It was stated in 1274-5 that the lords of Fyfield, Stapleford Tawney, Woolston (in Chigwell), Stapleford Abbots, Loughton, Navestock, Beauchamp Roding, and Theydon (Mount?) possessed view of frankpledge and the assize of bread and ale, that the lord of Woolston also had gallows and the lord of North Weald Bassett had all pleas. 28

In the document of $1543^{-6}$, already mentioned, the lord of the hundred held no courts leet in any of these places nor in Chipping Ongar, Greenstead, Stanford Rivers, Abbess Roding, and Shelley. At four other places, Norton Mandeville, Roding Morrell, High Laver, and Navestock, courts leet were said to be held by the lords of the manor but the common fine was customarily paid by them to the lord of the hundred. During the Middle Ages the manors of Chipping Ongar and Stanford Rivers (q.v.) were held in demesne by the lords of the hundred and there was thus no need to include them in the list of leets. At Greenstead, which was also omitted from the list, the lords of the hundred were tenants in chief of the manor. ${ }^{29}$ Courts leet. for the manor of Abbess Roding (q.v.) were certainly being held in the $15^{\text {th }}$ century. But it is clear that the document of $1543^{-6}$, so far as it relates to courts leet, does not describe 16th-century practice, for it omits many manorial leets that are known to have existed in the $14^{\text {th }}$ and $15^{\text {th }}$ centuries.

At High Ongar (q.v.) courts leet were being held for the manor of Paslow Hall at least as early as $127 \mathrm{r}$, and for that of Newarks Norton in 1487 . At Abbess Roding, in addition/to the leet of the capital manor, there was one for Berwick Berners manor in and after $\mathrm{I}_{3} 82$. At Kelvedon Hatch (q.v.) there was a court leet from 1390 .

The manuscript of $1543^{-6}$ quoted above was probably drawn up for John Stoner when he acquired the hundred and revised somewhat during the next three years. ${ }^{30}$ It includes the text of the grant of the hundred to Stoner, and states that the customs and duties it records were observed in the time of Edward III and Robert Bruce, King of Scots, and long before 'when the Saxons inhabited this realm'. In support of this statement it refers to ancient records made by Humphrey de Bohun, Earl of Hertford [sic] and Essex, Constable of England, and 'lord of the said liberties and hundreds' dated at Pleshey, 10 July II Edward III (1337) and to other records 'written in the Saxon tongue'. These records have not been traced. Humphrey de Bohun (d. I36r) is not known to have held the hundred of Ongar, but his successor and namesake Humphrey de Bohun, Earl of Hereford and Essex (d. I 373) held the hundred of Harlow, which later came into the possession of the earls of Stafford, the lords of Ongar hundred. The document of $\mathrm{I} 543^{-6}$ was probably prepared so that Stoner might exact his legal dues as lord of the hundred. All tenants' names in it were up to date but the section relating to the courts leet and some others described below certainly did not represent I6th-century practice; an antiquarian interest may have led to their inclusion. Probably much of the docu-

${ }_{28}$ Rot. Hundr. (Rec. Com.), i, I 53. For North Weald see also Cat. Anct. D. i, A. 755.

29 But Roding Morrell, which was included in the list, was also held in chief by the lords of the hundred.

30 E.R.O., D/DRg $1 / 197$. The MS. was formerly in the Round collection at Birch Hall, Colchester. It was calendared in Hist. MSS. Com. I4th Rep. App. pt.IX, p. 5, and was also described and partly printed by W. C. Waller, E.A.T. ..s. ix, 2 1 2-19. 


\section{ONGAR HUNDRED}

ment was indeed based on early-14th-century records and described the customs of that period.

The document lists the names and tenements of all those owing suit at the three weeken court or other courts of the hundred, and the names and tenements of those liable by reason of tenure to maintain prisons and pounds. It also lists the vills which by custom came to the sheriff's tourn, in each case with the reeve, the copyhold tenants from which the four suitors at the tourn were chosen, and the free suitors at the tourn. These places are identical with those in which, according to the document, courts leet were held by the lord of the hundred, or from which he received the common fine, except that Abbess Roding and Beauchamp Roding occur only in the tourn list.

The document describes at length the annual ceremony of the wardstaff of the hundred.3r This started on the Sunday before Hock Monday, when the hundred bailiff cut a willow wand from Abbess Roding Wood: this was the wardstaff, which gave its name to the bailiff's alternative title. The staff was conveyed from the wood to Rookwood Hall, where it was placed in the hall. There it remained while the bailiff refreshed himself. It was then taken 'by sun shining' to Wardhatch Lane near Longbarns (in Beauchamp Roding) and was there met by the lord of Rookwood Hall with all tenants of the Abbess Roding 'Watch', whose duty it was to guard the staff. The lord of Rookwood Hall had also prepared 'a great rope called a barr' which he now caused to be stretched across the lane to stop passers-by. The wardstaff was laid beside the rope while the bailiff called the roll of the watch, and charged them 'to watch and keep the ward in due silence so that the king be harmless and the country scapeless'. 'The watch lasted until sunrise next day, when the lord of Rookwood Hall took up the wardstaff and made a notch in it, signifying that he and his men had performed their duty for the year. Finally he handed the staff to the bailiff to be taken to the lord of the manor of Fyfield, delivering as he did so 'the tale of the wardstaff', a narrative in Middle English verse relating how his watch had carried out its duty. ${ }^{32}$ 'The staff was then presented to the lord of Fyfield Hall, who examined the notch made in it by the lord of Rookwood and then went through a ceremony similar to that at Abbess Roding. The Fyfield Watch, which was kept at the 'Three Wants' in Fyfield, was followed on successive days by seven other watches at different places in the hundred, proceeding in a clockwise direction.

Elsewhere in the same document there are details of the number of men in each watch, and the names and tenements of those who were bound to provide the men. The smallest watches were those of Abbess Roding (3 men) and Theydon Garnon (5), the largest Magdalen Laver ( I9) and Chigwell ( 14 ). Those who furnished the men for the watches had to pay $2 d$. a man, probably for food. The lord of Lambourne Hall also provided straw for his watch. ${ }^{33}$

There is a reference to the wardstaff of Harlow hundred in the reign of Henry III 34 but the earliest contemporary reference that has been found to the wardstaff of Ongar was in I 33 I, when Robert William of Havering, who had been outlawed for felony, was said to have held land in Lambourne for which

31 This part has been printed: Salmon, Hist. Essex, 68-70; Morant, Essex, i, I 26-7.

32 Although the narrative appears to be basically in Middle English it is not entirely homogeneous and there are some later word forms.

${ }^{33}$ For the watches and their services see E.A.T. N.s. ix, 2 r6-19.

34 Morant, Essex, i, r 27 n. 


\section{A HISTORY OF ESSEX}

he paid Is. a year to the bailiff of the hundred for sheriff's aid, did suit at the three weeken court, and paid $2 d$. a year for the wardstaff. He had to find two men to watch the wardstaff for a night and to pay $4 d$. a year for this, and also had to provide a pound for distraints taken in the hundred for debts owed to the king and a prison to guard prisoners taken in the hundred for a day and a night. 35 It seems unlikely that a wardstaff ceremony was still observed in the I 6 th century, but references to the wardstaff occur in records as late as the reign of James $I .36$ 


\section{ONGAR HUNDRED}

\section{BOBBINGWORTH}

Bobbingworth, commonly called Bovinger, is a parish immediately to the north-west of Chipping Ongar. ' The middle element in the name of the parish suggests early Saron settlement. ${ }^{2}$ Bobbingworth now has an area of 2,595 acres. ${ }^{3}$ It was formerly I,642 acres but was increased in 1946 by the incorporation of the detached part of High Ongar lying immediately to the west of Bobbingworth and of the detached part of Moreton ( $\frac{1}{2}$ acre) lying to the north-east of Ashlyns (see below). 4 In 1801 the population was 216.5 By I 84 I it had grown to 357 ; then it declined to 270 in I gor.$^{6}$ In the first half of the 2oth century it was a little above 300 until the incorporation of the detached part of High Ongar brought it to 483 in 1951.7

The land rises from about $\mathrm{r} 50 \mathrm{ft}$. above sea-level in the east and $200 \mathrm{ft}$. in the north to $330 \mathrm{ft}$. in the extreme south-west. A stream flowing into the Cripsey Brook forms part of the northern boundary. Reynkyns Wood lies on the western boundary. The road from Chipping Ongar to Epping enters the parish by Ackingford Bridge over the Cripsey Brook and runs north-west. About 200 yds. from Ackingford Bridge Pensons Lane, formerly called Pinings or Pinions Lane, runs south-westward to Greenstead. Nearly $\frac{1}{2}$ mile farther along on the north side of the Ongar-Epping road lies Waterend Farm, a building probably of the 17 th century but with additions on three sides of late 18 th-century or early I 9 th-century date. Bilsdens ${ }^{8}$ is 1 mile west of Waterend, to the south of the road. About I mile from the bridge the main road is joined by Blake Hall Lane which leads north to the village of Bobbingworth. Blake Halla stands in a park to the east of the lane. The rectory ${ }^{10}$ is near the north entrance to the park. About $100 \mathrm{yds}$. farther north a small gate leads to a thatched and weather-boarded tithe barn of the I 7 th or 18 th century. At this point the lane branches, one branch, known as Gainthorps Road, running northwards towards Moreton, and the other, known as Church Road, running westwards past the church and school." The church is on the south side of Church Road immediately to the west of Gainthorps Road. A short lane divides the church from the school on the west and leads south to Bobbingworth Hall.12 On the south-east side of the churchyard is an incomplete moat, suggesting the presence of an earlier manor house.

On the east side of Gainthorps Road, some $400 \mathrm{yds}$. from the church, stands Gainthorps Cottage, a timberframed house recently converted from two tenements; it dates from the 16 th or early 17 th century. A little farther along this road are four pairs of council houses. Opposite these houses a lane leads westward to Newhouse, a timber-framed farm-house, of the i6th or early I 7 th century, built on a half-H plan. The wings originally projected to the north with a small staircase block in the angle of the east wing. ${ }^{13}$ There are two pairs of council houses on the lane leading to Newhouse Farm.
Hobban's Farm is $\frac{1}{2}$ mile west of the church, to the north of Church Road. It is an I8th-century house, similar in appearance to Bobbingworth Hall. Opposite Hobbans, Church Road is joined by a road running south to Lower Bobbingworth Green and Greenstead. At the Green is Sayers Farm, a square red brick house apparently rebuilt in the middle of the Igth century. At Notts Corner, about 300 yds. west of Hobban's Farm, Church Road is joined by a road which runs north to Padler's End and by Mill Road which runs south from Notts Corner to meet the Epping-Ongar road at the hamlet of Bovinger Mill. Here the singlestory brick and roughcast buildings, including the present post-office, standing to the north of the site of the old mill, formed the mill-house and an adjoining bakery. ${ }^{14}$

About $\frac{1}{4}$ mile north of Notts Corner on the east side of the road to Padler's End stands Muggin's Farm, an I 8 th-century house. About mile farther north a lane leads west to Bobbingworth Lodge, a farm-house of the I 7 th century, much altered about r920. A fine brick chimney-stack with six octagonal shafts was damaged by blast in 1944 and later rebuilt to its original design.

Five pairs of council houses stand on the east side of Moreton Bridge Road, in the north-east corner of the parish, near Moreton Bridge. Ashlyns is in the northwest, and Cold Harbour in the south-west, of the present parish of Bobbingworth. Is Wardens Farm, to the south of Bovinger Mill, is timber-framed and weatherboarded and probably dates from the second half of the

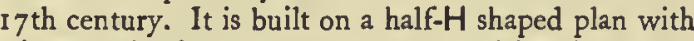
wings projecting to the north-west. The front was faced with brickwork in the 18 th century. Ashlyns, Cold Harbour, and Wardens were all in High Ongar parish until I946.

References in the sessions rolls to communications in Bobbingworth chiefly relate to Ackingford Bridge. ${ }^{16}$

In 1582 and in 1600 Pinings Lane, from Ackingford Bridge to Greenstead Green, was said to be in decay, the parish of Bobbingworth being responsible for its upkeep. ${ }^{17}$ In 1618 it was said that Bobbingworth and Shelley shared the responsibility for the highway leading from Ongar via Shelley Bridge to Moreton. ${ }^{\mathrm{I}} 8$ This road evidently then, as now, lay partly in Bobbingworth, partly in Shelley, and partly on the boundary between these two parishes.

The London-Ongar railway, which was opened in 1865 , runs across the south of Bobbingworth. ${ }^{19}$ Blake Hall station on this line is situated about $r$ mile south of Lower Bobbingworth Green in the parish of Stanford Rivers.

Postal facilities were extended to Bobbingworth when a receiving office was set up at Moreton in I 846.20 It had its own sub-post-office in $1874 .{ }^{21}$ According to the county directories letters came through the Ongar office.
I O.S. $2 \frac{1}{2}$ in. Map, sheet $52 / 50$.

2 Chief Elements in Eng. Place-Names

(E.P.N.S. i $\langle 2\rangle), 42$.

3 Inf. from Essex County Council.

4 Census Retns. 1931; County of Essex

(Rural Parishes) Confirm. Order 1946.

s V.C.H. Essex, ii, 350.

6 Ibid.

7 Census Retns. 19 I f.; Inf. from Essex

County Council.

8 See below, Manor of Bilsdens.

- See below, Manor of Blake Hall.

10 See below, Church.

II See below, Schools.

12 See below, Manor of Bobbingworth.

13 Hist. Mon. Com. Essex, ii, 22.

14 Inf. from Mrs. Burling at i I Bovinger

Mill, opposite site of old mill.
15 For Ashlyns see Hígh Ongar.

16 See Chipping Ongar, p. 157.

17 E.R.O., Q/SR 80/58, $149 / 43$.

18 E.R.O., Q/SBa $1 / 32$.

19 See Chipping Ongar, p. 158

20 P.M.G. Mins. 1846, vol. 87, p.

5.

21 Ibid. I 874, vol. 132, min. 4759 .

E3. IV 


\section{A HISTORY OF ESSEX}

Water was supplied in the village by the Herts. and Essex Waterworks Co. in 1899.22 Two of the four pairs of council houses in Gainthorps Road have a sewerage system. ${ }^{23}$ There is no supply of gas, ${ }^{24}$ but electricity was laid on in 1951.25 There is a small parish room, and a large army hut at Blake Hall can be used for meetings. ${ }^{26} \mathrm{~A}$ branch of the county library was opened in February 1939.27 The football and cricket clubs have their own grounds. 28

Bobbingworth has always been a rural parish devoted almost exclusively to agriculture. The large landowners were all resident in the parish from the last quarter of the I6th century until the beginning of the i 8 th century. ${ }^{29}$ It is not clear whether the owners of Blake Hall were resident in the parish during the first quarter of the 18 th century. By 1735 the lord of the manor, Richard Clarke, lived at the manor house but did not farm the estate. ${ }^{30} \mathrm{He}$ let Blake Hall manor farm to Robert Crabb and Bilsdens farm to Samuel Corney. ${ }^{31}$ These two farms continued to be let until after Capel Cure purchased the estate in 1789.32 After John Poole sold the manor of Bobbingworth to Charles Houblon in I 708, the owners of Bobbingworth Hall were generally not resident in the parish until J. A. Houblon sold the estate to Capel Cure in $1834 .{ }^{33}$

In 1840 the parish consisted of $\mathrm{r}, 628$ acres. 34 Capel Cure of Blake Hall owned 1,058 acres of which he farmed nearly 700 acres himself. 35 He let Water End Farm (297 acres) to Jonathan Lewis, and Hobban's Farm (6r acres) to G. Pavitt. ${ }^{36}$ This Capel Cure, son of the purchaser of Blake Hall, was a conscientious farmer and landlord. After his father's death in 1816 he kept a notebook recording his farming activities and the entries show him to have been energetic and methodical.37 He toured his estate personally and carefully noted down the area of the individual farms, their state of cultivation, the condition of the buildings, the repairs which he had ordered, and the industry of the tenant farmers. ${ }^{38} \mathrm{He}$ put a new tenant into Bilsdens in 1827 , some three years after he had observed that this farm was 'shamefully mismanaged'.39 But he was kind and encouraging to industrious tenants. On a rent day in $x 828$ he gave a rebate of fro to one tenant "who is an industrious man, with a large family'.40 At the end of his estate notebook Capel Cure copied a well-known passage from Sydney Smith: 'there are so many temptations in the life of a country gentleman to complete idleness, so many examples of it, and so much loss to the community from it, that every exception to the practice is deserving of great praise'.41 Capel Cure himself was certainly one of the exceptions.

In 1840 there were only two other substantial owners in the parish; J. Stacey owned Perrils Farm ( 89 acres) and Sayers Farm (I r 2 acres), both of which he farmed himself, and G. 'Thistlewood owned, but

\footnotetext{
22 Inf. from Herts. \& Essex Waterworks Co.

of Bobbingworth.

24 Ibid.

23 Inf. from East. Elec. Bd.

26 Inf. from Canon Gallop.

27 Inf. from County Librarian.

23 Inf. from Canon Gallop.

29 See below, Manors of Bobbingworth, Blake Hall, Bilsdens.

30 E.R.O., D/DCc TI/3.

31 Ibid.; D/P $127 / 8$.

32 E.R.O., Q/RPI 685-700.

33 See below, Manor of Bobbingworth.

34 E.R.O., D/CT 38.
}

did not occupy, Newhouse Farm (I 19 acres). ${ }^{42}$ There was only one other farm of over 40 acres. 43

Then, as now, there was mixed farming in Bobbingworth. A three-course rotation of crops was generally followed, wheat, barley, and either beans or clover being the usual crops.44

In 1848 there were in the parish a cornmiller, who was also a baker, and a land surveyor. ${ }^{45}$ The windmill was a wooden post-mill, turned by hand, with a brick 'round house' below.46 It probably dated from the I 8 th century and the post, which was inscribed ' $1640^{\prime}$ ', may have been an earlier one reused. 47 The mill became disused between 1912 and $19 \times 4.48$ The upper part of it was blown down in $19233^{49}$ the round house stood for some time afterwards.

The land surveyor mentioned in 1848 was Jonathan Lewis. 50 It was probably the same Jonathan Lewis who drew up some of the local tithe maps at this period and who did much surveying and other work for Capel Cure on the Blake Hall estate. ${ }^{51}$

This estate, totalling some 3,800 acres in Bobbingworth and other parishes, 52 must have employed a considerable amount of domestic as well as agricultural labour in the middle of the r 9 th century.

In $1066 B O B B I N G W O R T H$ was held by 2 freemen as I hide and 30 acres and was worth

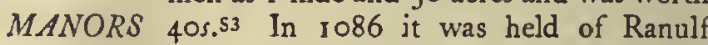
brother of Ilger by Richard and was worth 60 s. $^{4}$ In the early $\mathrm{r}$ th century it seems to have been held in chief by Hamon de Marcy.5s Hamon apparently left as his heir Serlo de Marcy, lord of Stondon Massey (q.v.), who was dead by $\mathrm{r} 244 . .^{.6}$ In that year Serlo's sisters and heirs, Alice wife of John de Merk and Agnes wife of Nicholas Spigurnel agreed to divide between them the tenements in Bobbingworth and elsewhere which Denise, widow of Hamon, and Agnes, widow of Serlo, then held in dower.S7 Afterwards it was evidently agreed that the Spigurnels should hold the Bobbingworth tenements of the Merks, for in I 3 I I12 William son and heir of Ralph de Merk granted the overlordship of these tenements to Humphrey, Earl of Hereford and Essex (d. I 322) who in 1 3 12-1 3 granted it in fee tail to his youngest son William de Bohun, later Earl of Northampton.58 In 1328 the manor of Bobbingworth was held of William by the service of $\frac{1}{2}$ knight's fee. 59 He died in 1360 and was succeeded by his son Humphrey, later Earl of Hereford and of Essex. ${ }^{60}$ After Humphrey's death in 1373 the overlordship passed through his daughter Eleanor to Anne wife of Edmund Earl of March.61 After the deaths of Edmund (1425) and Anne (1432) the overlordship passed to Anne's brother Humphrey, Duke of Buckingham (d. 1460). ${ }^{62}$ In 1475 the manor was held of Humphrey's widow Anne. ${ }^{63}$ In I 485 and 1493 it was held of Jasper, Duke of Bedford (d. I 495) and his

35 Ibid.

37 E.R.O., D/DCc E

38 Ibid.

40 Ibid.

42 E.R.O., D/CT 38

36 Ibid.

39 Ibid.

4 Ibid.

43 Ibid.

44 E.R.O., D/DCc E6.

45 White's Dir. Essex (1848), 4 I 4

46 E.R. xl, 163. Photograph at E.R.O.

47 Ibid.

48 Kelly's Dir. Essex (1912, 1914).

49 inf. from Mrs. Burling.

50 White's Dir. Essex (1848), 414.

SI E.R.O., D/DCc E6. The evidence suggests that J. Lewis may have been Cure's estate manager. He also acted as overseer of the parish for many years before ${ }_{1} 827$ (see below, Parish Government and Poor Relief).

52 See below, Manor of Blake Hall.

s3 V.C.H. Essex, i, 540a.

s4 Ibid.

ss Feet of $F$. Essex, i, 148-9.

56 Ibid. 57 Ibid.

S8 DL25/1592, 1453 .

so Cal. Ing. p.m. vii, p. 104.

60 Complete Peerage, vi, 472-3.

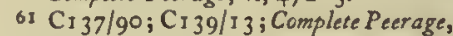

vi, 474-5, viii, 453. Anne was grand. daughter of Eleanor.

${ }_{62}$ Complete Peerage, ii, 388.

$63 \mathrm{C}_{14} 0 / 52$. 
wife Katherine whose first husband had been Henry Stafford, Duke of Buckingham (d. 1483 ). ${ }^{64}$

Nicholas Spigurnel died before 1275.65 Sir Edmund Spigurnel, son of Nicholas, died in $1295-6$ leaving his widow Clarice to hold for her life I messuage, I carucate of land, and 50s. rent in Bobbingworth.66 In I 297 his brother and heir John granted the reversion of this estate after the death of Clarice to Henry Spigurnel, probably his younger brother, and to the heirs of Henry. ${ }^{67}$ In 1328 Henry Spigurnel died in possession of this estate, which was then described as a manor. ${ }^{68} \mathrm{He}$ was succeeded by his son Thomas who in 1332 quitclaimed all his rights in the manor to Robert de Hakeney, citizen of London, and his wife Katherine.69 In 1361 Thomas son of Robert de Hakeney granted an annuity of 210 from the manor to James de Lacy and his heirs. 70 Thomas de Hakeney left at least one sister, Katherine, as his heir.71 In 1389 Maud de Enfield, who was perhaps the widow of John de Enfield and perhaps also the sister of Thomas de Hakeney, granted the reversion of the manor, then held for life by Joan wife of Luke Morell, to Ralph de Tyle and his wife Alice, daughter of John de Enfield, to John their son and to the heirs of Alice.72 In 1403 Thomas Horsman and his wife Margaret and John Abberbury and his wife Alice granted the reversion of the manor, after the death of Joan Morell, to Sir John Ashley and his heirs. 73 The conveyances of 1389 and 1403 led, after the death of Joan Morell, to a contest for possession of the estate.

Joan Morell died on 16 May 1409.74 At that time Alice and Ralph de Tyle and their son John were dead and the next of kin of Alice was her cousin Thomas, a minor, son of her father's brother Thomas de Enfield.75 On 22 May 1409 William Wodeward and his wife Agnes, a kinswoman of Thomas, were granted custody of the manor. ${ }^{76}$ Shortly afterwards, by letters patent which apparently were antedated to 20 May 1409 the custody of the manor was given to Helming Legat, who was closely connected with Sir John Ashley, and William Loveney.77 The grant to the Wodewards was annulled and they were removed from possession of the estate. ${ }^{78}$ They then proceeded to complain by petition in Parliament and in June 1410 the case was examined by the king's council.79 In the course of the hearing Helming Legat stated that at the instance of Sir John Ashley he had released all his claim in the estate to John Habhale, a servant of Ashley. ${ }^{80}$ At the close of the hearing the council declared that the grant to Legat and Loveney should be revoked on the ground that when it was made the grantees did not fulfil their legal obligation of revealing other gifts which they had received from the king. ${ }^{81}$ At the same time the council secured an acknowledgement by Loveney that the letters patent dated 20 May were sealed after the letters dated 22 May. 82 In accordance with the council's judgement the Wodewards were restored as custodians of the estate in October 1410.83

It is not clear whether Sir John Ashley took any further steps to obtain possession of the manor after his attempt in 1409. An inquisition taken in 1412 declared that Thomas de Enfield was the heir to the estate in virtue of the fine of $1389 .{ }^{84}$ By 1420 , however, a lawsuit was begun to contest Thomas's claim. $8 \mathrm{~s}$ In 1420 William Ashley, brother and heir of Sir John, came to an agreement with Nicholas Thorley whereby Nicholas was to pay the costs of the action and a further 70 marks to William in return for which William was to enfeoff him with the manor or with half of it, if only half was recovered. 86 It is not clear how far the action was pursued. In January 1424 an inquisition declared that in virtue of the fine of 1389 Thomas de Enfield, who had come of age in October 1423 , was entitled to the estate. 87 In March 1424 Thomas conveyed what he described as 'all my manor of Bobbingworth' to Sir Lewis Robessart and others who granted it to Nicholas Thorley. ${ }^{88}$ In August 1424 William Ashley conveyed what he also described as 'my manor of Bobbingworth' to Nicholas Thorley and the heirs of Nicholas. ${ }^{89}$

In 1442 Sir Nicholas Thorley died leaving as his heir Walter Estoft, son of his sister Katherine. 90 Alice, Countess of Oxford and widow of Nicholas, apparently held a life interest in the manor of Bobbingworth.9I In 1445 she granted this life interest to her son John de Vere, 1 2 th Earl of Oxford, and to Sir Reynold West and Richard Wentworth who immediately sold it to Sir Thomas Tyrell.92 At the same time Sir Thomas purchased the reversion from Walter Estoft. ${ }^{33}$ In January ${ }^{4} 464$ Sir Thomas Tyrell conveyed the manor to Sir Peter Arderne and others who in December 1466 granted it to Walter Wrytell.94 After Walter's death in 1475 the manor. of Bobbingworth followed the same descent as that of High Laver (q.v.) until 1510.95

In 1510 , when they made a partition of the rest of their inheritance, James and Eleanor Walsingham and Edward and Gresilda Waldegrave agreed that they, and the heirs of Eleanor and Gresilda, should hold Bobbingworth manor in common.96 In 1575 , however, the owners of the manor, Sir Thomas Walsingham, grandson of James and Eleanor, and John Rochester of Terling, son of William, son of Gresilda by her first husband John Rochester, made a physical division of it.97 It was agreed that John Rochester's share of the estate should be the manor house which, with its appurtenant 6 acres, was then in the occupation of John Poole who was a freeholder and copyholder of the manor; 175 acres of demesne land of which II 7

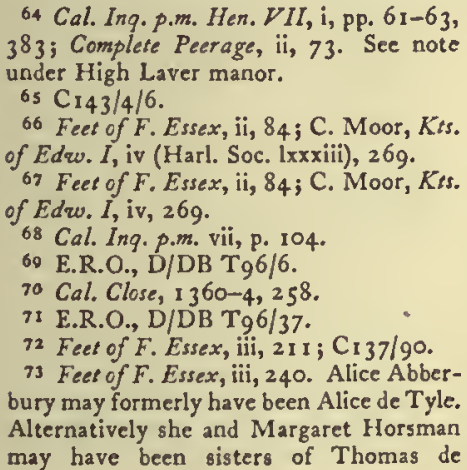

64 Cal. Ing. p.m. Hen. VII, i, pp. 61-63, 383 ; Complete Peerage, il,

65 $\mathrm{C}_{143 / 4 / 6}$

60 Feet of $F$. Essex, ii, 84 ; C Moor, Kts. . Harl. Soc. Ixxxiii), 269 of Edwo. I iv, 6 .

68 Cal. Ing. p.m. vii, p. 104

69 E.R.O., D/DB T $96 / 6$

70 Cal. Close, I $360-4,258$

7 E.R.O., D/DB T $96 / 37$

73 Feef of $F$. Essex, iii, 240. Alice Abberbury may formerly have been Alice de Tyle. may have been sisters of Thomas de

74 C I $37 / 90$

75 Ibid.

${ }^{26} \mathrm{Cal}$. Pat. 1408-1 3, 231, 240; Cal.

Fine R. xiii, 148, 192-3

77 Cal. Pat. 1408-1 3, 231, 240; Cal. Fine $R$. xiii, $192-3$.

${ }_{78}$ Cal. Pat. 1408-13, 231, 240; Cal.

Fine $R$. xiii, 192-3.

79 Cases Before King's Council $2243-1482$ (Selden Soc. $x \times x v$ ), 92-95; Cal. Pat. $1408-$ 13, 240; Cal. Fine R. xiii, I 92-3 Cases Before King's Council 1243-1482, 93. 83 Cal. Pat. 1408-1 3, 240; Cal. Fine R. xiii, 192-3. 


\section{A HISTORY OF , ESSEX}

acres lay together, 56 acres which were in the occupation of four copyholders at rents totalling $£_{2} I_{3}$ s. a year; and the rents, amounting to $\delta_{2} 19 s .5$ d. a year, and services of all the twelve frecholders. 98 'The share of Sir Thomas Walsingham was to be 218 acres of demesne land which lay in two parcels of 122 acres and 71 acres and several smaller ones, and 44 acres which were in the occupation of four copyholders at rents totalling $\ell_{4} 4$ s. a year. 99

John Rochester was dead by $1584^{\circ}$ He was succeeded by his second son Edward who in I 586 sold his half of Bobbingworth manor to the above mentioned John Poole. ${ }^{2}$ This estate afterwards became known as the manor of BOBBINGWORTH HALL. ${ }^{3}$

The demesne land acquired by Sir Thomas Walsingham in 1575 was sold by his son Sir Thomas Walsingham in 1598 to Robert Bourne, owner of Blake Hall (see below). 4 The greater part, if not all, of this land afterwards remained as a permanent part of Blake Hall estate, some of $i t$ being attached to the manor of Blake $\mathrm{Hall}$ and some of $\mathrm{it}$ to the manor of Bilsdens (see below). 5

John Poole died ir. I 602 having devised Bobbingworth $\mathrm{Hall}$ to his son John with the stipulation that his widow Lora was to have "her dwelling and house room in the new parlour belonging to Bobbingworth hall and the two upper rooms over the same parlour'. ${ }^{6}$ John Poole the son, a London alderman, died in $1633.7^{7} \mathrm{His}$ considerable estate consisted largely of claims on foreigners and these had to be recovered before legacies totalling about $6,10,000$ could be paid. ${ }^{8} \mathrm{He}$ devised the manor of Bobbingworth to his wife Anne for life and then to his brother Richard after whose death John son of Richard was to inherit the estate. 9 Richard Poole died in about $1642 .{ }^{10}$ In 1674 John Poole, son of Richard, made a settlement on his own son John when the latter married Mary Powel.11 By this the manorjal rights, the capital messuage with its appurtenances, and $93 \frac{1}{2}$ acres passed immediately to John the son who was also to receive a further 7 I acres on the death of his father. ${ }^{22}$ The elder John retained the free disposition of about 12 acres. ${ }^{13}$ Immediately after the settlement he leased to the younger John $39 \frac{1}{2}$ acres of the $7 \mathrm{I}$ acres in which he retained a life interest, at a rent of $\{20$ a year. 14 The elder John died in about 1676.1s The younger John died before 1701 , leaving his widow Mary to enjoy a life interest in the manorial royalties, the manor house, and $93 \frac{1}{2}$ acres under the terms of the settlement of $1674 . .^{16} \mathrm{He}$ left the $7 \mathrm{I}$ acres which he had inherited on his father's death to his son John who was also to have the reversion of Mary's estate. ${ }^{17}$ In 1701 John Poole mortgaged his rever- sionary interest to Charles Houblon for 6600.18 In I 704 he sold to Houblon for $f_{1}, 080$ the 7 I acres he had in hand.19 In 1708 Houblon also bought the manor house and the lands mortgaged to him by John Poole in 1701 , Mary Poole selling her life interest for f498 and John Poole his reversionary interest for $f_{0}, 000.20$

The estate which John and Mary Poole sold to Houblon in 1704-8 consisted of a large part of the estate acquired by John Rochester in 1575 . Houblon also bought other property in Bobbingworth. ${ }^{21} \mathrm{He}$ may have bought a small part of the lands sold by Walsingham to Bourne in 1598.22

Houblon never made his home in Bobbingworth. ${ }^{23}$ He died in 17 I 1.24 From this time the manor descended in the direct male line of the Houblon family until $1834 .{ }^{25}$ From 1729, when Jacob Houblon took up residence at Great Hallingbury, until I 834 the owners of Bobbingworth manor did not live on their Bobbingworth estate. ${ }^{26}$ In 1833 this estate consisted of 6 acres of woodland in hand; $23 \mathrm{I}$ acres of arable and pasture in the occupation of John and Thomas Speed at a rent of $\{205$ a year; 6 copyhold messuages and 26 acres of copyhold land, rents for which totalled $f_{1} 16 s$. Id. a year; and freehold lands, rents "for which totalled f. 1 7s. 9d. a year. ${ }^{27}$ In 1834 John Archer Houblon sold this estate, and his share of the advowson of Bobbingworth (see below) to Capel Cure of Blake Hall for $£ 8,077$ of which $£, 577$ was paid for the timber on the estate. ${ }^{28}$ The manor of Bobbingworth has subsequently remained in the family of Capel Cure. It had copyhold tenants as late as I 919.29

The present farm-house is timber-framed and weatherboarded and is probably of early-1 8th-century date. It is L-shaped and has a hipped tiled roof with moulded brickwork to the central chimney.

In the I th century the manor of $B L A K E H A L L$ was held of the honor of Boulogne by Pharamus of Boulogne, great-grandson of Count Eustace of Boulogne. ${ }^{30}$ It is not clear whether Pharamus held the manor in demesne. He died in I $83-4$ and was succeeded by his only daughter and heir Sibyl de Fjennes.3t Sibyl was holding the manor of the honor of Boulogne in $122 \mathrm{I}-2.32$ By the early I 4 th century, however, the manor was, apparently, no longer considered part of that honor. ${ }^{33}$

Sibyl's heir was her son William de Fiennes. ${ }^{34}$ William's grandson, Sir William de Fiennes (d. I 302), was second cousin of Eleanor of Castile, to whom he pledged part of his estate in 1275 when, at his request, she engaged to pay $£, 1,000$ to Humphrey de Bohun on the latter's marriage with William's sister Maud. 35 It

\footnotetext{
98 E.R.O , D/DB T98. 90 Ibid.

1 Ibid. 2 Ibid.

$4 \mathrm{CP}_{25}(2) / 13^{8 / 175^{\circ}}$.

3 E.R.O., D/DCe E6; T/M $210,213$. Morant stated (Essex, i, 148) that the estate which Walsingham sold to Bourne in 1598 was reattached to Bobbingworth Hall by the Houblons in the 18 th cent. but surveys of c. I 725,1804 , and 1820 make it clear that at least 160 acres re. mained attached to Blake Hall.

6 E.R.O., D/DB T98. This is a large group of documents.

I E.R.O., D/DB T96/83

E.R.O., D/DB T98.

- E.R.O., D/DB T $96 / 83$

10 E.R.O., D/DB T98.

11 Ibid. 12 Ibid.

14 Ibid. 15 Ibid.

17 Ibid. 18 Ibid.

13 Ibid.

16 Ibid.

19 Ibid.
}

20 Ibid.; E.R.O., D/DWv T51. At the time of the sale Poole still owed Houblon the 6600 he had borrowed in 1701 and 6185 interest on the loan. Houblon had therefore to pay Poole only $\delta_{0} 215$ in cash. 21 A. A. Houblon, The Houblon Family, ii, I-2.

22 Cf. Morant, Essex, i, 148. And see note 8 above.

2) A. A. Houblon, The Houblon Family, ii, 2 . 24 Ibid.

2s Ibid.; E.R.O., D/DCe Tz; D/DCe $E_{2}, 6$.

26 A. A. Houblon, The Houblon Family, $i$, is f. From I7I7 until 1729 Jacob son and heir of Charles Houblon lived in Bobbingworth with his uncle Jacob, then sector of the parish.

27 E.R.O., D/DCc E2. The lands occupied by John and Thomas Speed were divided into 4 farms: Bobbingworth Hall Rachells, Hobbans, and Gainthorps. In 1829 they had agreed to pay a rent of $\{270$, but this had been reduced to 205 when J. A. Houblon succeeded to the estate in I 831 . 28 E.R.O., D/DCc T 2 ; D/DCc E6. 29 E.R.O., D/DCc M I

$30 \mathrm{Bk}$. of Fees, 1428 ; Genealogist, N.s. xii, 145-51. For Pharamus see also Manor of Lambourne.

3i Bk. of Fees, 234-5; Gerealogist, N.s. xii, $145-51$.

$12 B k$. of Fees, 240,1435

33 Cal. Inq. p.m. v, p. 349

14 'Bk. of Fees, 235 ; Genealogist, N.s.'xit, 149.

is Complese Peerage, vi, 466 , ix, 283 ; C. Moor, Kis. of Edw. I (Har\}. Soc. 1xxxi), ii, 21-23; De La Chenaye-Desbois et Badier, Dictionnaire de la Noblesse, viii, 39-4I. 
is likely that William granted the overlordship of Blake Hall to Eleanor of Castile, for her grandson, Gilbert, Earl of Gloucester, was holding it when he died in I 3 14.36 Gilbert was succeeded by his sister and coheir Elizabeth de Burgh, Lady of Clare, of whom the manor was held by the service of $\frac{1}{2}$ knight's fee. ${ }^{37}$ Afterwards the tenancy in chief followed the same descent as that of Magdalen Laver manor (q.v.). ${ }^{38}$

In 1314 the tenant in demesne was Robert de Hastings who sold the manor to Adam Atforth. 39 It was subsequently held by Sir John de Loundres.40 In 142 I Sir Robert Brent died in possession of the manor leaving as his heir his sister Joan wife of John Trethek.4I In 1424 John and Joan Trethek conveyed the manor to William Trethek.42 William immediately granted it to Sir Reynold West, Richard Wentworth, and Richard Arderne in exchange for the manor of Poldu (Cornw.) which they had acquired from Nicholas Thorley and his wife Alice, Countess of Oxford.43 West, Arderne, and Wentworth were probably acting as trustees for Nicholas Thorley in the purchase of Blake Hall as they certainly were in the purchase of Bobbingworth manor (see above) in the same year. Sir Nicholas Thorley died in 1442 , leaving as his heir Walter Estoft, son of his sister Katherine.44 In about I 504 William Thomson became lord of the manor.45 At the same time he purchased 217 acres of land from Robert Brent.46 William and his wife Agnes, who may have been a daughter of Walter Estoft, were still in possession of the manor in 15 I , but by September I 512 Sir William Capel was lord. 47 At that time John Glascock farmed the manor at a rent of $£^{8}$ a year. ${ }^{48}$ Capel died in $15 \mathrm{I} 6$, leaving as his heir his son Giles who, with his sons Henry and Edward, conveyed it in 1539 to Sir Richard Rich, later Ist Baron Rich. 49 In $156_{3}$ Rich conveyed the manor to John Waylett.50 In I564 Waylett granted it to John Glascock who in 1562 had been described as "of Blake Hall'.5I In 1598 John Glascock, perhaps the son of the purchaser of 1564 , sold the manor to Robert Bourne but retained 56 acres of its demesne land for his own son George.52 In the same year Bourne purchased from Sir Thomas Walsingham the demesne lands which Walsingham's father had acquired in 1575 as his share of Bobbingworth manor (see above). ${ }^{53}$ In I 628 Bourne purchased some land from John son of George Glascock.54 In 1639 Robert Bourne died, having settled Blake Hall manor on his wife Katherine for life with remainder to his son Robert.5s The younger Robert had only one child, a daughter Alice who in 1656 married John, 3rd Baron Digby, and afterwards 3 rd Earl of Bristol. 56 She died without issue in I658.57 Robert Bourne made a settlement whereby
Digby was to hold the manor for life with remainder to John Cooper, nephew of Bourne. ${ }^{58}$ Bourne died in 1666.59 In about 1675 Cooper tried unsuccessfully to sell his reversion.60 At that time he rented the manors of Blake Hall and Bilsdens (see below) from Digby for $\oint_{462}$ a year. ${ }^{61}$ He succeeded to the estate on Digby's death in 1698 and died in 1701.62 His heirs were his sisters Dorothy, wife of Richard Thompson, and Anne, wife of Charles Fowler. ${ }^{63}$ In 1709 they sold the estate to John Clarke for $\$ 8,000.64$ Clarke died in 1726 having devised the manor to his eldest son Richard.65 In 1735 the manor house was in the occupation of Richard Clarke and the manor farm in that of Robert Crabb. 66 Richard died in 1770 , apparently leaving considerable debts. He had devised the manor to his brother Dennis who by his will of 1770 devised it to his sisters Ann, wife of Sir Narbrough D'Aeth, and Catherine, wife of Barnabas Eveleigh Leigh, for their lives with remainder to his nephew Narbrough D'Aeth. ${ }^{67}$ Catherine Leigh died before 1780.68 In I780 Sir Narbrough D'Aeth, nephew of Clarke, mortgaged his reversion of the manors of Blake Hall and Bilsdens (see below) and the advowson of Bobbingworth for $L_{1}, 000.69$ Between 178I and $1788 \mathrm{Sir}$ Narbrough and his mother Lady Ann D'Aeth borrowed further sums on the security of their Bobbingworth estate, making the total mortgage 67,700 in March 1788.70 Before this they had mortgaged their other properties for sums totalling at least $\oint_{0} 14,500 .^{71}$ It may have been this load of debt which made Sir Narbrough sell his Bobbingworth estate to Capel Cure in 1789.72 Since that time Blake Hall has remained in the family of Capel Cure. By Morant's time it no longer had manorial tenants. ${ }^{73}$ In I 840 Blake Hall farm consisted of nearly 220 acres and was in the occupation of Capel Cure. ${ }^{74}$ At about that time Blake Hall was the centre of an estate of some 3,800 acres, mainly in Bobbingworth and neighbouring parishes.75 It included the manors of Blake Hall, Bobbingworth Hall, Bilsdens, and Ongar Park (in High Ongar, q.v.) and a total of some 20 farms. 76 Capel Cure was the impropriator of Norton Mandeville (q.v.) and Compton Abdale (Glouc.) as well as patron of Bobbingworth. ${ }^{77}$

In about 1700 Blake Hall was a typical timberframed Essex building with two gables to the front. ${ }^{78}$ This house appears to have been completely demolished early in the 18 th century. The central rooms at the front of the present house are part of the Georgian mansion which superseded it. In 1804 the house was of two stories with seven windows across the front, a colonnaded porch, and a central pediment. 79 By I 804 the straight avenue of trees, which in the late 18 th
36 Cal. Inq. p.m. v, p. 349; Complete Peerage, v, 707, 712-14. Joan of Acre, daughter of Edward $I$ and Eleanor of Castile, martied Gilbert, Earl of Glouces- ter, and had by him a son Gilbert who became Earl of Gloucester on his father's death in 1295 .

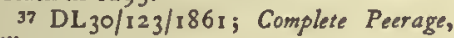 iii, 245 .
${ }_{38} \mathrm{Cr}_{36 / 106 ;} \mathrm{C}_{13} 8 / 56 ; \mathrm{C}_{139 / 1959 ;}$ Cal. Close, $1419-22$, 177 ; Cal. Close, $1422-$ $9,248-9$.
9, 248-9. $\mathrm{DL}$ 30/123/1859; Cal. Inq. p.m. v, p. 349 .
P. ${ }_{40}^{349 .}$ DI. $30 / 123 / 1859$ and 186 r. Possibly the John Loundres who was knighted in 1397 : Shaw, Knights of Engl. 1A, Ix. ${ }_{11} \mathrm{C}_{3} 8 / 56$.
42 Feet of F. Essex, iv, 3.
43 Cal. Close, $1422-9,120,144$.
44 Complete Peerage, $x, 236$.
$45 \mathrm{DL}_{30} / 123 / 1859$ and 1862.
$46 \mathrm{DL}_{30 / 123 / 1859 .}$
$47 \mathrm{CP} 25(2) / 1$ I/ 5 I Mich. 3 Hen. VIII.
48 B.M. Add. MS. $40,632 \mathrm{~s}$.
$49 \mathrm{Cr}_{42} / 30 / 16 ; \mathrm{CP}_{25}(2) / 12 / 67 \mathrm{Mich}$ 31 Hen. VIII.
50 $\mathrm{CP}_{4} \mathrm{O} / \mathrm{I} 207$
${ }^{12} \mathrm{CP}_{25}(2) / 127 / 1624 ;$ E.R.O., Q/SR 4.
52 DL $30 / 123 / 1861$.
$53 \mathrm{CP} 25(2) / 138 / 1750$.
$54 \mathrm{DL}_{3}$ 이 $123 / 1861$.
55 Sepulchral Mems. of Bobbingworth, ed. F. A. Crisp, 33.
s6 E.R.O., D/DMg T 31 ; Complete Peer- age, ii, 322.
57 Complete Peerage, ii, 322
${ }_{58} \mathrm{DL} 30 / 123 / 186 \mathrm{I}-2$; E.R.O., D/DAc 24-25. 39 E.R.O., D/DMg T31.
60 E.R.O., D/DAc 24-25. 61 Ibid.
$62 \mathrm{DL}_{3} / \mathrm{r} 23 / \mathrm{I} 862 ;$ E.A.T. N.s. xi, 177. $63 \mathrm{DL}_{30} / 123 / 1862$; E.R.O., D/DCc $\mathrm{T} I / 1-3$.
64 E.R.O., D/DCc T/ $1 / 1-3$.
65 E.R.O., D/DCc $\mathrm{T}_{1 / 3}$.
66 Ibid. 62 Ibid.
68 Ibid. 69 Ibid.
70 E.R.O., D/DCc $\mathrm{Tr} / \mathrm{I}$ and 2.
71 Ibid.
72 Ibid.; E.R.O., D/DCc T4.
73 Morant, Essex, i, 148
74 E.R.O., D/CT 38.
75 E.R.O., D/DCc E6
76 Ibid. 77 Ibid. See below, Church.
78 As shown in a small drawing on an un- dated map at Blake Hall. For photostat of map see E.R.O., T/M 210.
79 This is.shown on an estate map of 1804. For photostat of map see E.R.O., $\mathrm{T} / \mathrm{M} 213$. 


\section{A HISTORY OF ESSEX}

century had led direct from the doorway to the road, had been abandoned in favour of curved approaches to north and south. ${ }^{80}$ In 1822 the house was remodelled by George Basevi, ${ }^{8 I}$ but it is not clear how much work was done at this time. The rooms facing the garden with their two semicircular bays may be of this date or a little earlier. A service wing to the north was also built by 1822 . About the middle of the I 9 th century the house was greatly extended. ${ }^{82}$ A third story was added to the central block and a new wing was built on the south side. Early in the 20 th century a fine lateI 7 th-century staircase, which came originally from a house on the south side of Pall Mall, was inserted in the hall. ${ }^{83}$ Between I 940 and I948 Blake Hall was requisitioned by the R.A.F. and during this time the library and drawing room with the bedrooms above were thrown together to form an operations room. This wing has not yet been restored. 84

The manor of BILSDENS derived its name from the family of Billesdon. In 1496 Joan, widow of Sir Robert Billesdon and daughter and heir of John Williams, died in possession of a messuage, 280 acres of land and 20 acres of meadow in Bobbingworth and other parishes. ${ }^{85}$ This estate, which was then called 'Monkis alias Bobynford', was worth roos. and was held of one Brent. ${ }^{86}$ Joan's heir was her son Thomas Billesdon. 87

After Joan's death her Bobbingworth estate may have passed, with her Marshalls estate in North Weald (q.v.), to Sir William Fitzwilliam. In 158 I William Bourne died in possession of the Bobbingworth estate which he apparently purchased from Richard, Ist Baron Rich, in 1566.88 William bequeathed to his wife Margaret 'household stuff, corn and cattle at Gippes alias Billesdons'.89 In his will he also mentioned his house there.90

Bourne's son Robert purchased the manor of Blake Hall (see above) in 1598 and the Billesdon estate, which was described as a manor in 1675 and later, afterwards descended with Blake Hall.91 It was occupied by a tenant until 1828 , after which it was farmed by the owner himself. 92 In 1840 Bilsdens farm consisted of 237 acres of which 136 were arable. 93

The back part of Bilsdens house is timber-framed and probably dates from the 15 th or early i 6 th century. It apparently consisted of a central hall with two crosswings. The hall has been much altered but in both cross-wings the lower part of arch-braced roof trusses are visible on the first floor. In the roof space at least one king-post with four-way struts remains. This was evidently the manor house of which William Bourne died possessed in $158 \mathrm{I}$. An estate map of Bilsdens dated $1761^{94}$ has a rough drawing of the house from which $i t$ appears to have been $L$-shaped and gabled. The present front rooms were added late in the 18 th century and these were faced with brickwork probably about 100 years later.

It seems that Hamon de Marcy held the advowson of Bobbingworth in the early $13^{\text {th }}$ cen-

CHURCH tury.95 After his death, which occurred before 1 244, his widow Denise held it in dower.96 In 1244 it was agreed that at the death of Denise it should pass to Alice and John de Merk and to the heirs of Alice who, by another agreement, became overlords of the manor of Bobbingworth (see above). 97 In about I 262 John de Merk was patron of the living. ${ }^{8}$ In I 280 Ralph de Merk, probably the son of John, granted the advowson, with $\frac{1}{2}$ acre of land, to John de Lovetot for 30 marks.99 Lovetot still held the advowson at his death in 1293 , but by 1328 it was in the possession of Henry Spigurnel, tenant in demesne of the manor of Bobbingworth.I In 1332 Thomas Spigurnel granted the advowson as well as the manor to Robert de Hakeney. ${ }^{2}$ In I 365 and I 368 John King presented to the living. ${ }^{3}$ In 1389 Joan Morell was holding a life interest in the advowson which from that time descended with the manor of Bobbingworth until I 575.4 In 1575, when Sir Thomas Walsingham and John Rochester divided Bobbingworth manor between them, they agreed that the advowson should remain in common and that they should present to the living in turn.5 In 1582 Thomas Barefoot presented pro hac vice by concession of Sir Thomas Walsingham. ${ }^{6}$ In $159^{8}$ Sir Thomas Walsingham granted his rights in the advowson to Robert Bourne, owner of Blake Hall (see above). ${ }^{7}$ Afterwards the owners of the manors of Blake Hall and Bobbingworth had alternate rights of presentation. They sometimes sold their single turns. In I 669 John, 3rd Baron Digby, then life tenant of Blake Hall, granted his next turn to John Robinson of Stapleford Tawney. 8 In I673 Robinson sold it to Sir John Archer, a Justice of the Court of Common Pleas, who presented in 1678.9 In 1692 James Lordell presented Jacob Houblon.10 When Charles Houblon, brother of Jacob, purchased the manor of Bobbingworth from John and Mary Poole in 1708 he also purchased their right to half the advowson. II At that time Mary Poole held a life interest in jt with remainder to John Poole.12 The advowson remained divided between the owners of the manors of Bobbingworth and Blake Hall until 1834 when Capel Cure of Blake Hall purchased the manor of Bobbingworth and the alternate right of patronage annexed to it. ${ }^{13}$ In 1838 Capel Cure presented W. M. Oliver. ${ }^{14}$ Since that time the living has remained in the gift of the Capel Cures. Is

In about 1254 the rectory was valued at 5 marks. ${ }^{16}$ In 1291 it was valued at $\{.6135 .4 d .17$ In 1428 the church was still taxed on this valuation. ${ }^{18}$ In 1535 the rectory was valued at $\mathrm{fs}_{3} 6 \mathrm{~s}$. $8 d^{19}$ Its 'improved' value was $£ 60$ in $1604, £ 81$ in 1650 , and 6100 in

\footnotetext{
Bo Ibid.; Chapman and André, Map of

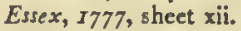

8s Drawings at Blake $\mathrm{Hall}$ in the possession of Major N. Capel Cure.

82 Drawings and photographs as above.

83 Inf. from Mrs. Capel Cure. This was probably Schomberg House, built in the last decade of the $17^{\text {th }}$ cent.

84 Information from Mrs. Capel Cure.

s5 Cal. Ing. p.m. Hen. VII, i, pp. 54 I-2.

86 Ibid. 87 Ibid.

18 Sepulchral Mems. of Bobbingworth, ed.

F. A. Crisp, 31; Morant, Essex, i, 149.

s9 Sepulchral Mems. of Bobbingworth, 3 I. 90 Ibid.

91 E.R.O., D/DAc 24-25; D/DCc T 94 E.R.O., T/CT 38 .

$9 s$ Feet of F. Essex, i, $148-9$. 96 Ibid.

97 Ibid. 98 E.A.T. N.s. xviii, 19.

99 Feet of $F$. Essex, ii, 28.

I Cal. Ing. p.m. iii, pp. 131, I33, vii,

p. 124. 2 E.R.O., D/DB T 96/6.

3 Reg. Sudbury (Cant. \& York Soc.), i, 244,260 .

4 Feet of F. Essex, iii, 211 ; Newcourt, Repert. ii, 66.

3 E.R.O., D/DB T98.

6 Newcourt, Repert. ii, 66.
}

$7 \mathrm{CP}_{25}(2) / 138 / 1750$.

8 E.R.O., D/DB T98.

2o Newcourt, Repert. ii, 66 .

II E.R.O., D/DB T 98 ; D/DWv T5 12 Ibid.

13 E.R.O., D/DCc Tr/1-3; D/DCe T2;
$\mathrm{D} / \mathrm{DCc} \mathrm{T}_{4}$; J. Ecton, Thesaurus, 270 ; J. Bacon, Lib. Reg. 615.

14 Sepulchral Mems. of Bobbingworth, ed. F. A. Crisp, 38 .

is Kelly's Dir. Essex (1874 f.); Chel. Dioc. Year Bk. 1952.

16 W. E. Lunt, $V$ al. of Norwich, 336.

17 Tax. Eccl. (Rec. Com.), $21 b$.

18 Feud. Aids, ii, 205.

19 Valor Eccl. (Rec. Com.), i, 437. 
1661.20 The tithes were commuted in 1840 for $6455 ;^{21}$ there were then 32 acres of glebe. 22

The rectory was built by the Revd. W. M. Oliver in $1839^{23}$ near the site of an earlier parsonage. ${ }^{24}$ It is a three-story square house of gault brick with a twostory wing on the north. A difference in brickwork suggests that the top story may have been a later addition.

The parish church of $S T$. GERMAIN consists of nave, chancel, vestry, and north tower. At different periods parts of the church have been rebuilt so that very little medieval work now remains. In particular subsidence on the south side has necessitated constant repairs.

The date of the original nave is not known but it

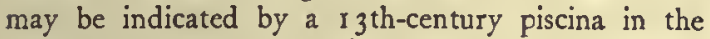
south wall, now reset, which has a pointed head and attached shafts. In 1909 Frederic Chancellor stated that during then recent work to the south wall ancient oak uprights were found embedded near its west end. 25 $\mathrm{He}$ suggested that these might have represented part of a pre-Conquest church, but in the absence of better evidence this must remain extremely doubtful.

The chancel, replaced in 1840 , was probably of the $14^{\text {th }}$ century. In $1835^{26}$ it is described as of ancient appearance and the east window as "a good specimen of the decorated style of architecture'. The nave roof is of the trussed rafter type and may be of the $15^{\text {th }}$ century. Probably also in the $15^{\text {th }}$ century a wooden bell tower was added beyond the west end of the nave. ${ }^{27}$ This appears to have been in two stages, the upper one of smaller diameter, and to have had a small shingled spire. ${ }^{28}$ The church still had a small north porch in the early I 9 th century 29 and this may have been of late medieval origin.

The nave is said to have been rebuilt in red brick in 1680.30 In 1770 considerable work was done to the interior of the church including the erection of a west gallery presented by Jacob Houblon. ${ }^{31}$ 'The nave walls were again largely rebuilt in 1818 and fitted with oak windows. 32 In 1840 the chancel was rebuilt in gault brick at the rector's expense. ${ }^{33}$ 'The 14 th-century style of the demolished work was probably copied, particularly with regard to the east window. In 1840 a north tower and porch were built, a Mr. Burton being the architect. ${ }^{34}$ 'They are of gault brick and the style is again inspired by the $14^{\text {th }}$ century. The tower has three stages with pointed openings and a castellated parapet. The lowest stage combines the functions of a ringing chamber and a north porch to the church. The red-brick vestry was built in 1864 at the expense of the Capel Cure family. ${ }^{35}$ It occupies the same position as the wooden bell tower demolished in 1840 . In 1902 seven new nave windows with stone tracery were presented by the Revd. W. M. Oliver after his retirement. ${ }^{36}$ These replaced the wooden windows of 1818 . The nave roof was restored in $1907 .{ }^{37}$. In $1931-2$ repairs were carried out to the roof and the south wall of the nave and the 18 th-century gallery was removed. ${ }^{38}$

20 E.A.T. N.s. xxi, 78,83 .

21 E.R.O., D/CT 38

22 Ibid. ${ }_{23}$ E.R. xiv, I 86.

24 Chapman and André, Map of Essex,

1777 , sheet xii.

${ }_{25}$ E.A.T. N.s. xi, 175 .

26 Wright, Hist. Essex, ii, 359 .

27 Ibid. "The Steeple and the steeple end

of the building is of wood.'

28 Drawing on a Blake Hall estate map of 1804 . Photosta tat E.R.O. (T/M 213 ).
The stone font is of the 15 th century with an octagonal bowl and a moulded shaft. In 1770 the bowl was removed and a new one fitted to the pedestal.39 In 1936 the original bowl, carved with the initials 'J.P.', was discovered in the churchyard at Little Parndon. It was presented to Bobbingworth by the Netteswell and Little Parndon Parochial Church Council and now occupies its original position. 40 'There is an iron-bound chest with two locks of the 17 th century. The pulpit

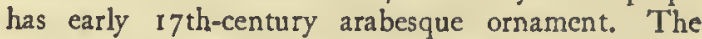
panelling and reading-desk in the nave appear to have been made up of woodwork of various dates, the oldest probably of the early 17 th century. The seating in the nave is of early rgth-century date, the more elaborate pitch pine pews of the chancel probably date from I 840 .

The plate includes a cup of 1635 inscribed with initials ' $T . G$ ', also a paten inscribed 'Bovinger 1684 '.

The plate now in use is of 1933 .

Six bells were presented by the Revd. W. M. Oliver in 1841.41 In 1834 an acre of land in the parish called Bell Acre formed part of the glebe; by tradition the rector was supposed to provide bell ropes and hassocks for the church from the rent it yielded.42 The then rector, however, refused to observe the tradition since there was no documentary evidence to support it.43 The custom appears never to have been revived.

In the chancel are two reset brass inscriptions, one to William Bourne ( 1581 ) with an achicvement of arms and one to Robert Bourne (1639) with two shields. Before its rebuilding in 1840 there were several inscriptions in the chancel to members of the Bourne family and others which have now disappeared.44 These included an unusual incised slab bearing the arms of the City of London and of the Grocers' Company together with a standing figure of William Chapman (1627) who married a daughter of Robert Bourne. 45 In the nave are several tablets to the Capel Cure family including the first Capel Cure of Blake Hall (1820) and his two wives (1773 and 1804 ). On the nave roof are painted hatchments of the Capel Cures and Pooles.

Vestry minute books for Bobbingworth survive for the periods $1667-1789$

\section{PARISH GOVERNMENT and $1808-1922$. There} $A N D$ POOR RELIEF is also a separate book of overseers' accounts

for the period $1789-1827.46$

Until 1702 vestry meetings usually seem to have been held only at Easter in each year.47 From 1702 until 1758 meetings were held at Easter and Christmas. From 1758 there were several meetings each year, held at irregular intervals of between 2 and 19 weeks. Intervals of 5-10 weeks were common. In the early roth century between four and eight meetings a year were recorded.

Until Jacob Houblon became rector in 1692 the vestry minutes were bricf and uninformative. It was
30 Inf. from Canon E. H. Gallop, Rector of Bobbingworth.

31 E.R.O., D/P $127 / 25$.

32 Vestry book 1808-1922.

33 Ibid. 34 Ibid.

33 Ibid. 36 Ibid.

37 Kelly's Dir. Essex (1929).

38 Inf. from Canon E. H. Gallop.

39 E.R.O., D/P $127 / 25$.

40 Inf. from Canon E. H. Gallop.
$41 \mathrm{Ch}$, Bells Essex, I 8 I-2.

42 Rep. Com. Char. (Essex), H.C. 216, p. 218 (1835), xxi (I).

43 Ibid.

4 Wright, Hist. Essex, ii, 359

43 E.A.T. N.s. xii, $32 \mathrm{I}-2$

46 The following information is derived almost entirely from these books which are at the Essex. Record Office, on lozn from the Rector of Bobbingworth.

4 E.R.O., D/P $127 / 8$. 


\section{A HISTORY OF ESSEX}

the practice to record only the appointment of officers and the balances remaining in officers' hands at the end of each year.48 Moreover the minutes were ncver signed.49 Houblon exercised an immediate influence on the parish records. He scarcely ever missed a vestry meeting and he wrote the minutes himself. At Easter I693 he began a separate account book containing detailed overseers' accounts, which were always duly audited and were signed by the parishioners who passed them. Thomas Velley, who succeeded Houblon as rector in 1740 also attended vestry meetings regularly and during his incumbency the parish records were kept, though rather less methodically, on the lines that Houblon had laid down. J. Lipyeatt who succeeded Velley in 175 I appears, however, to have taken practically no part in conducting parish business. He did not sign any minutes after December $175 \mathrm{I}$. In the next four years his curate, J. Wells, usually signed the minutes but afterwards neither incumbent nor curate appears to have attended vestry meetings until 1782 . The complete absence of officers' accounts in the parish books between Easter 1755 and $175^{8}$ may reflect the initial apathy aroused by the incumbent's lack of interest. In April 1782 the curate, then J. Lipyeatt the younger, did sign the vestry minutes and his signature appeared twice more in the next seven years. During the period $1759-89$ the churchwarden was almost invariably the first to sign the minutes and this practice continued into the second quarter of the I 9 th century. The rector rarely attended a meeting in the early igth century.

The number of parishioners who attended vestry meetings varied between I and 8 but was usually between 2 and 4 . In the century after 1666 members of the Poole family, lords of the manor of Bobbingworth until 1708, took an active and leading part in parish government. John Poole, lord of the manor from I 674 until about 1701 , and his son and heir John, frequently held parish office. Each of them held the office of overseer for several years. They nearly always attended vestry meetings and signed immediately after the rector. The younger John continued to take an equally prominent part in parish affairs after he had sold Bobbingworth manor in 1708 . From I 708 until 1720 he never missed an Easter vestry. From I 72 I until I 740 William Poole was equally active and prominent. 'The Houblons, owners of the manor of Bobbingworth from 1708 , were not resident in the parish and took no personal part in its government. In the period down to 1789 the owners of Blake Hall scarcely ever attended a vestry meeting but Robert Crabb, who occupied the manor farm in 1735 , frequently held some parish office between 1726 and 1781 .

The work of the vestry consisted mainly in nominating parish officers, granting rates, agreeing on the recipients of weekly collections, and approving officers' accounts. One of the rare occasions in the 18 th century when other business was recorded was in April 1708 when it was resolved that in future the church clerk should be paid 20 s. a year out of the churchwarden's or overseer's rate 'in lieu of what he has hitherto received yearly by the house as a former custom it being a great hindrance to him in the loss of time to go about to receive the same'.so

There were two churchwardens each year from 1666 until 1682.5r During this period these officers usually served for $2-4$ years consecutively. ${ }^{52}$ From
I68I until about 1793 there was only one office of churchwarden. From 1690 until 1771 it was the practice to spend many consecutive years in this office. Thomas Nicholls served as churchwarden from 1700 until 1724, William Poole from 1724 until 1740, Samuel Corney from 1741 until 1753, and Robert Crabb from 1759 , if not before, until $177 \mathrm{I}$. For a time after 1771 the number of consecutive years spent in the office tended to lessen and from about 1793 it again became the practice to have two churchwardens.

There was usually one overseer. Until 1717 it was usual for the overseer to serve for 2 or 3 years consecutively. George Read served for 4 years from I 7 I 7 until $172 \mathrm{I}$. After his appointment for a fourth year in April 1720 it was agreed that 'having served 4 years he shall be excused 7 years following'. Read's successor, William Hamshire, also served 4 years consecutively, but 3 years remained the usual term of office until 1744 . From 1744 until I 8 I 0 the overseers neariy always served for one year only. They seem to have been chosen on a rota system and occasionally the officer chosen appointed another man to perform the duties of the office. 'Thomas Woodthorp acted for Capel Cure in 1796-7 and again in $1801-2$. Jonathan Lewis, the vestry clerk, acted as overseer for Capel Cure in I 808-9 and for William Clark in the following year. During the year ending at Easter I8I I Lewis again acted as overseer, but on what basis is not clear. If he received any payment for performing the duties of overseer during these years, such payment was not made, it would seem, out of the poor rate. In April I 8 I I, however, a meeting of the vestry agreed 'for Jonathan Lewis to be the acting Overseer for the year ensuing and to have a salary of $f_{1} 10 \mathrm{p}$. annum and to be paid for journeys'. Lewis continued to act as salaried overseer every year from I 8 I I until I 835 with the possible exception of the year $1819-20$. Each year there was a formal agreement at the Easter vestry to renew his appointment. In 1822 his salary as overseer was increased to $\ell_{0} 13 \mathrm{I} 3 \mathrm{~s}$.

Constables were nominated in Vestry at least from 1667. Until I72I the parish always had two of these officers, each of whom served several years consecutively. From I72I there was only one constable for the parish and he usually served for many years. Richard White was constable from 172 I until at least 1740 , and R. Perry from 1744 until at least 1760 .

Two surveyors of highways were nominated annually until 1700 after which there was usually only one nomination until 1742 . The surveyor was chosen from a rota of landholders, as appears from the rector's note on 26 December 1722, 'Mr. William Poole Surveyor as a Deputy for the Revd. Tho. Wragg Clerk for Gainthrops'.s3 From 1742 there were several nominations each year for the office of surveyor but there are indications that there was only one acting surveyor.

From I666 until after 1750 the overseers, churchwardens, constables, and surveyors were each granted separate rates for which they were directly responsible to the parish. Until 1702 it was the custom for each officer to present an annual account at the Easter vestry. Occasionally one officer was ordered to pay another officer's deficit out of his surplus. From I 702 the surveyors submitted their accounts at Christmas instead of at Easter but the other officers continued to make their annual account at Easter. From 1758, if not before, the oversecr submitted interim accounts to the vestry
43 E.R.O., D/P $127 / 8$
49 Ibid.
so Ibid.
st Ibid.
52 Ibid.
53 Ibid. 
at intervals of $5-10$ weeks in addition to his final annual account at Easter. There is no evidence that the interim accounts continued after 1775 , but in view of the increasing costs of poor relief it is very probable that they did so. By 1772 , perhaps before 1760 , the churchwardens, constables, and surveyors were no longer granted separate rates. Their expenditure was met by the overseer who included it in his account. This practice continued until I $8 \mathrm{II}$. From I 8 II to 18 I 2 there was again a separate highway rate and from 18 I 3 to 1814 there was a separate church rate.

In 1720 the rateable value of the parish was about 6917. In 1790 a 2 s. $6 d$. rate produced $\oint_{1} 106$ I 5 s.; this implies a rateable value of about $\oint_{8} 84$. During the Napoleonic wars the rateable value was generally between $£ 900$ and 6912 . In 1815 a reassessment was ordered as a result of which the rateable value became $f_{1}, 635$; in 1823 it fell to $£_{1}, 559$ and in $183 \mathrm{I}$ rose to Es, 586 .

There was evidently a poorhouse in Bobbingworth in $1692-3$, for in that year $10 s$. was paid by the overseer for 'straw at the allmnshouse'. By 1783 the poorhouse was situated in Pensons Lane, and seems to have been the cottage which Robert Bourne (d. 1666) left in trust to provide clothing for the poor. ${ }^{54}$ It was rented by the overseer at $f_{0} \mathrm{I}$ Ios. a year. In $1779-80$ the poorhouse was fitted with a 'poor's oven.' In I $784-5$ the building housed at least one poor family and in each of the years $1791-2,1797-8,1800-1,1803-7$, and 1 $819-20$ it housed at least one poor person. In $1807-8$ 7 s. $6 \mathrm{~d}$. was paid by the overseer for " 6 yards cloth for strawbed for poorhouse'. Minor repairs were often carried out and in $1807-8$ more substantial repairs were done at a cost of 6,55 . In 1823 the stove was repaired.

In most cases, however, poor relief was given, in various forms, outside the poorhouse. In each of the years I 8 I $3-15$ there were $20-2$ I adults on 'permanent' outdoor relief.ss Provision for the poor was made in various ways including the binding out of paupers' children as apprentices, the provision of spinningwheels, the payment of rent and allowances for lodging or nursing, the provision of wood and clothes, and the payment of weekly doles.

Parish apprentices were allotted on a rota system to farmers in the parish. In the period between $\mathrm{I} 68 \mathrm{I}$ and I 7 I 8 three 'great' farms and thirteen 'lesser' farms were on the rota. About I I children were apprenticed during the period.

In 1787-8 a spinning-wheel was purchased for John Little at a cost of $2 s$. $6 d$. In 1799-1800 spinningwheels cost the overseer $£ 24$ s. In several of the following years 'the poor's spinning' occurs as an item of expenditure in the overseer's accounts.

In $1692-3$ there seem to have been 2 widows receiving weekly doles, the cost to the parish being 5 s. $6 \mathrm{~d}$. a week. In 1719 there were 4 weekly doles amounting to 7 s. In the years between $175^{8}$ and $1775^{\text {there were }}$ usually 9 households, including several widow households, receiving weekly doles, totalling between I6s. $9 d$. and f, I is. a week. In 1777-8 there were ro households which throughout the year received doles which totalled $\delta_{5}$ 5s. a week. In each of the years from 1780 to 1797 there were $15-21$ houscholds in receipt of regular weekly doles which cost the parish between $E_{1}$ 5s. and $\oint_{2} 2$ 2s. 6 d. a week. From 1797 the doles increased, reaching their maximum of $f_{8} 85.6 d$. a week in 1801 . They then declined to $f_{2}$ 17s. $6 d$. a week in 1808 . From then until 1819 there were usually about 16-18 households in receipt of constant relief at a total cost to the parish of about $6217 \mathrm{s.} 6 \mathrm{~d}$. a week. From I 8 ig until 1827 the number of households dependent on weekly doles varied between 20 and 27 , the total weekly cost ranging from $£ 3$ to $£ .5$.

In I6I 3-14 the cost of poor relief was f 4 ros. which was distributed to 5 people.s6 In the last years of the $17^{\text {th }}$ century the total cost of poor relief was always below $f_{2} 20$ a year and was sometimes as little as 67. In the 1 8th century much higher figures were soon reached, rising to an average of $£ .32$ a year in the three extreme years 17 I $6-19$. There was then a rapid fall to a minimum of $£ 3$ I 4 s. 5 d. in $1723-4$. In the period 1725-42 figures have survived for only seven years. These are within a range $6 \mathrm{r} 6-\oint_{3} \mathrm{r}$. In the period 1743-54 expenditure only once fell below $£ 45$ and on two occasions reached nearly $\{60$. In $1754-5$ it was 671 . Between 1759 and 177 I it averaged about 685 . In 1772 the cost reached the 6100 level and from then until 782 it remained fairly stable between $\oint_{1}$ soo and $E_{1} 20$ a year. It then rose to $\oint_{1} 65$ in $1782-3$ and to f197 in $1784-5$. In the next ten years the cost remained within the range $f_{0} 160-\delta_{0} 190$. In $1794-5$ it was $£$ r 70 . In $1795-6$ it jumped to $£ 273$. After a slight drop in the next three years it rose to $\$ 290$ in I 799-1800 and then in the following year to 6505 , its maximum. In $180 \mathrm{I}-2$ the cost was 6450 . It then dropped to 293 in I $802-3$. Between I 803 and I 8 I I it varied between $£_{246}$ and $£ 33 \mathrm{I}$ a year. It then rose to $£ 477$ in $1812-13$. After this it varied between $£_{2} 80$ and $f_{0} 80$, the peak year being $1819-20$.

In 1836 Bobbingworth became part of Ongar Poor Law Union.

In 1807 and 1818 it was stated that there was no school in the parish.57 In 1822 , with the SCHOOL support of Capel Cure of Blake Hall (see above), a girls' school was established which by 1833 had 24 pupils. 58 It was a dame school, with a Sunday school attached, $s 9$ and it is said to have been situated in a house which the estate carpenter had erected in the churchyard. 60 In $1846-7$ there were still only 24 girls attending, the sole educational provision for boys being the Sunday school.6I W. M. Oliver, Rector of Bobbingworth, considered a National School to be 'much wanted'. ${ }^{2}$ In $1855-6$ Capel Cure built 'a good, substantial schoolroom' $6_{3}$ and a teacher's residence next to the church, but until about i 869 only girls seem to have attended it.64 By 1871 , however, the pupils included 18 boys, ${ }^{65}$ an addition made possibly in anticipation of the requirements of the Education Act. In the same year an inspector reported to the Education Department that only 47 places were needed to secure universal elementary schooling in the parish and that 55 places were available at the school. ${ }^{66}$

54 See below, Charities.

55 E.R.O., Q/CR I/10.

36 E.R.O., Q/SBa 3 .

57 E.R.O., D/AEM 2/4 (Archdeaconry)

Retns. Educ, Poor, H.C. 224, p. 248 (1819), ix (I).

38 Educ. Enquiry Abstr. H.C. 62 , p. 267 (1835), xli.

59 Nat. Soc. Rep. 1832 , p. 36 ; Nat. Soc. Enquiry into Church Schs. I 846-7, Pp. 2-3 60 Ex. inf. Mrs. G. Day, Headmistress, 1952 .

61 Earlier, in $1822-3$, Capel Cure had sent boys from his estate to Moreton school (E.R.O., D/DCc E6). Whether he continued to do so, after 1823 , does not appear.

62 Nat. Soc. Enquiry into Church Schs. $1846-7$, Pp. 2-3

63 E.R.O., D/AEM I/I/I.

64 Kelly's Dir. Essex (18\%o)

$6 s$ Retns. Elem. Educ. H.C. 201, pp. I 1011 (I871), Iv.

${ }_{66} \mathrm{Min}$. of Educ. File $13 / 26 \mathrm{~A}$. 


\section{A HISTORY OF ESSEX}

The Capel Cures continued to support the school until 1904, apparently without assistance from public funds, ${ }^{67}$ retaining it as their property but allowing it to be administered as a Church school.68 An inspector, visiting it in 1896 , found the buildings in good repair but the scholastic standard low. 69 The school did not officially pass under the control of the Essex Education Committee until some three years after the 1902 Education Act. In 1904, when there were 42 pupils, the senior teacher received his salary of 640 not from the Local Education Authority but presumably from Capel Cure and the proceeds of the weekly fees of $2 d$., paid by each pupil.70 In that year the Education Committee considered the provision of a Council school in the parish, but decided to give the existing school nonprovided status if the managers would spend $£ 150$ on an additional classroom. The Education Committee accepted some financial responsibility for the school until the new classroom was completed in 1906.71 The average attendance rose from 36 in 1905 to 53 in 1910 , but fell to 42 in 1927 . After the reorganization of the school for juniors and infants in 1936 and the transfer of seniors to Chipping Ongar, it fell further to 27 in I938. In I95 I the school was granted controlled status.72 In May 1952 it had two teachers and 33 pupils.73 It stands a little west of the church. It is a red-brick gabled building with stone dressings dated 1856 and inscribed with the initials of Capel Cure.

Robert Bourne of Blake Hall (see above), by will proved $\mathrm{r} 666$, left a cottage and land to CHARITIES provide clothing at Christmas for four poor old people of the parish.74 The rent was $\oint_{4} 5$ s. in 1708 and $\oint_{1} 3$ in 1866 when the property was sold for $£, 500$ which was invested. The house seems to have been used before then as the parish poorhouse. 75 In 1950 the income of $f_{\mathrm{J}} 3 \mathrm{9s}$. $4 d$. was used to buy clothing vouchers of $£ 4$.

John Pool, by will proved I 839 , left $£ 100$ in trust for the repair of three graves in the churchyard. This was not legally a charitable bequest and the legacy was apparently never paid, although in 192 I it was thought that the income had once been received. 76

For the Bell Acre see above-Church.

\section{CHIGWELL}

Chigwell lies in the south-west corner of Ongar hundred, on both banks of the Roding, at a distance of 12 miles from London. 'The ancient parish had an area of 5,009 acres. $^{2}$ It contained three distinct sections. The village of Chigwell, on the east side of the Roding, was the main settlement and included the parish church. Chigwell Row, a mile south of the village, was a roadside hamlet on the edge of Hainault Forest. The third section was Buckhurst Hill, I $\frac{1}{2}$ mile from the village on the west bank of the river. Until the $\mathrm{I} g$ th century much of Buckhurst Hill was within Epping Forest and there were only a few scattered houses in that part of the parish before the modern development took place. The soil of the parish is mainly London Clay, but there are thin patches of glacial gravel in and around Chigwell village and smaller patches at Buckhurst Hill and Chigwell Row.

For ecclesiastical purposes the ancient parish was divided by the formation of the district of Buckhurst Hill in 1838 and that of Chigwell Row in $1860^{\circ}$. Both these districts became separate ecclesiastical parishes in I 867.3 Buckhurst Hill was made a separate urban district in 1895.4 Chigwell and Chigwell Row together constituted the civil parish of Chigwell from I 895 until I 933, when that parish was merged with the Urban Districts of Buckhurst Hill and Loughton to form the new Urban District of Chigwell.5

For several centuries the south-west end of the parish and Chigwell Row have been predominantly residential, with houses occupied mainly by people with interests in London, while the rest of the parish has always been devoted to agriculture. Modern development has emphasized this contrast. Buckhurst Hill and much of Chigwell Row have been built up but Chigwell village has retained its rural appearance.

From the west bank of the Roding the ground rises steeply from about $50 \mathrm{ft}$. to $267 \mathrm{ft}$. at Buckhurst Hill, and then falls to about I $5 \circ \mathrm{ft}$. at Ching Brook, which roughly defines the western boundary of the ancient parish. On the east of the river the land rises to $2 \mathrm{I} 3 \mathrm{ft}$. in Chigwell village and then falls away to Chigwell (formerly Edensor's) Brook, which flows south-west from the centre of the parish to join the Roding near Luxborough. South of the brook the land rises to Grange Hill (235 ft.) and the ridge of Chigwell Row $(280 \mathrm{ft}$.). From these heights there are long views over the Thames valley to the hills of Kent. Near the northeast boundary is Lambourne Brook, another tributary of the Roding.

Chigwell was formerly in the forest of Essex and two small patches of woodland still exist within the area of the ancient parish. Lords Bushes at Buckhurst Hill cover 90 acres belonging to Epping Forest. At Chigwell Row there are some 50 acres which form part of Hainault Forest.

The main road from London to Ongar, here called High Trict. Or, a stag at rest Road, passes north-east through proper, on a chief gules Chigwell village. From the vil- three axe-heads bendwise lage Roding Lane runs west to sinister with blades downlage Roding Lane runs west to wards argent.
Buckhurst Hill; near the lane on [Granted 195I.] the east bank of the river are the R.A.F. Station, Chigwell, and the Buckhurst Hill County High School for boys. The R.A.F. Station is on the site of the ancient manor house of Chigwell Hall. Beyond the river to the west Roding Lane passes a public park and finally joins Palmerston Road, Buckhurst Hill.

Buckhurst Hill is a residential area developed mainly during the past century. It consists of an inner ring on

\footnotetext{
67 Ibid.; Retn. of Schs., 1893 [C. 7529], Standard, 29 Oct. 1904 p. 714 H.C. $(1894)$, lxv.

68 Retns. Elem. Educ. ( 187 I), pp. I 1 $10-1$ I.

60 Min. of Educ. File $13 / 26 \mathrm{~A}$.

70 Ibid.; Essex Educ. Cttee. Handbk. 1904, p. 183 .

$71 \mathrm{Min}$. of Educ. File $13 / 26 \mathrm{~A}$; Essex

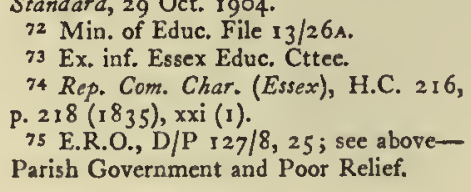

$72 \mathrm{Min}$. of Educ. File $13 / 26 \mathrm{~A}$.

73 Ex. inf. Essex Educ. Cttee.

74 Rep. Com. Char. (Essex), H.C. 2 I6, p. $2 \times 8$ ( 1835$)$, xxi (I).

75 E.R.O., D/P I27/8, 25 ; see aboveParish Government and Poor Relief.

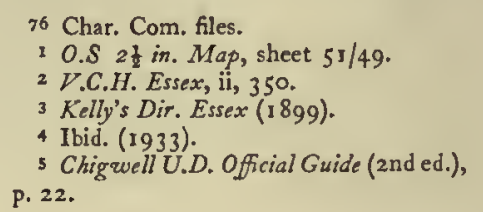




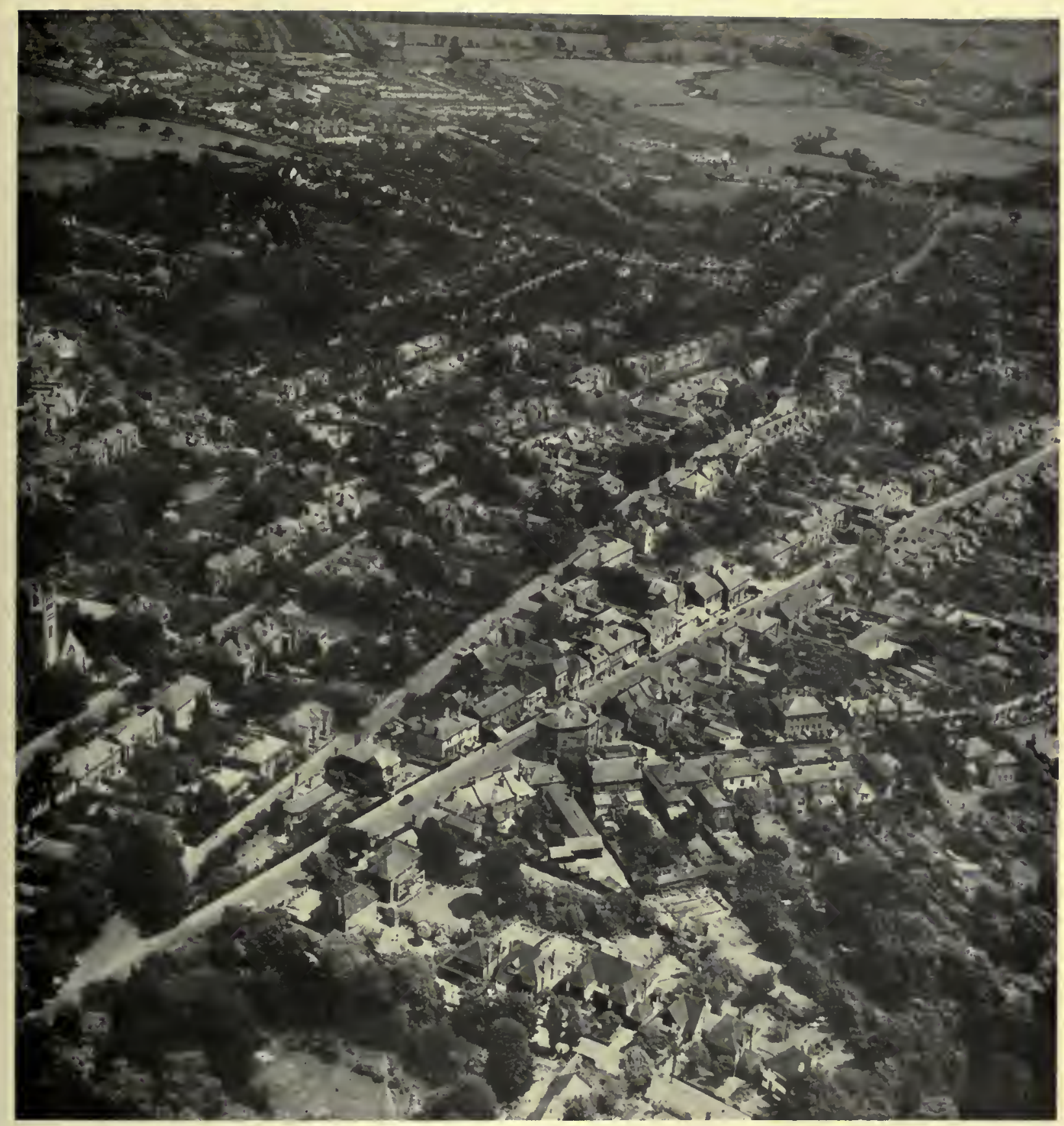






Chigwell Village

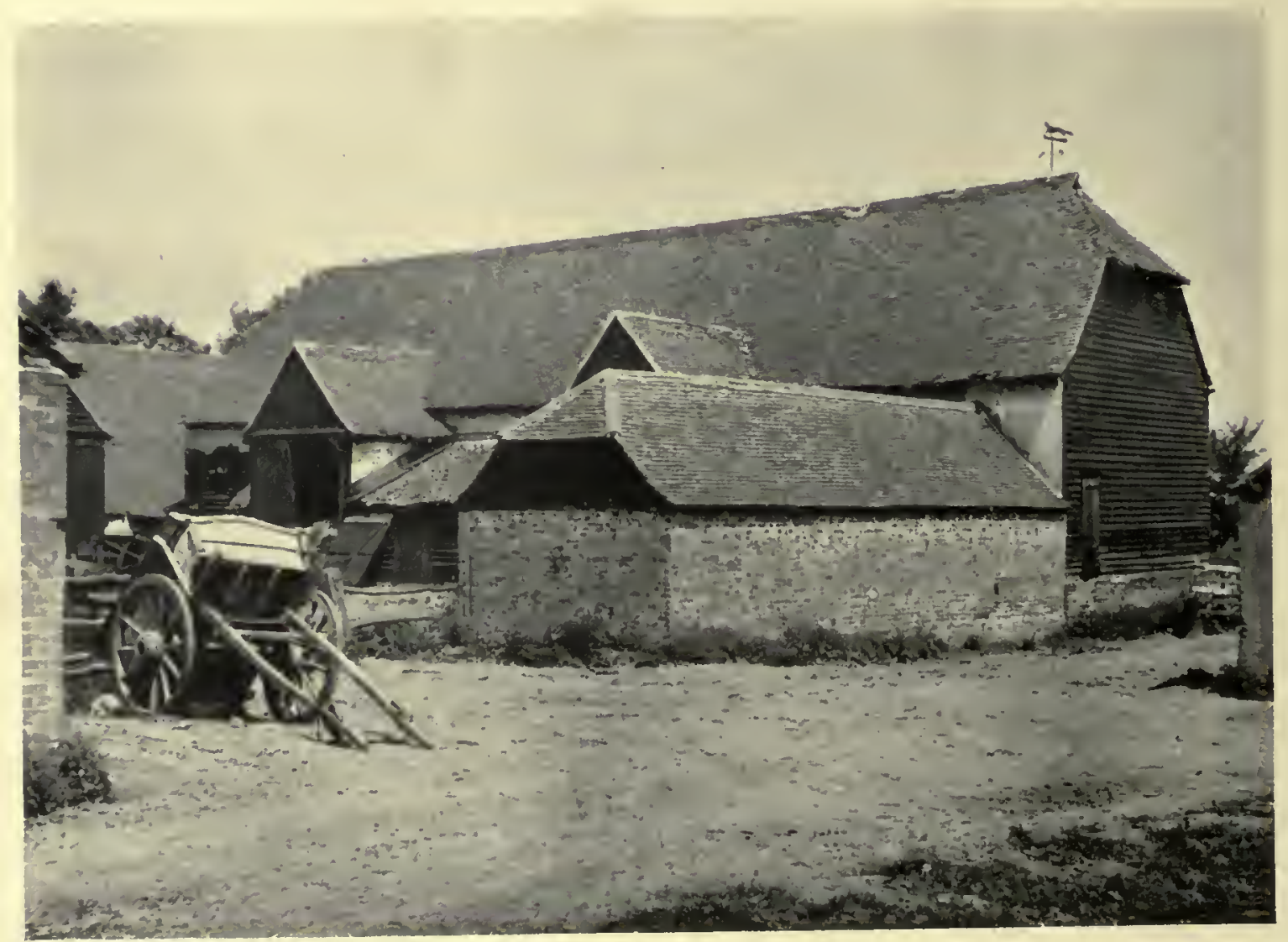

Barns at Rookwood Hall, Abbess Roding 
both sides of the railway station, dating from about 1850-1900, with building to the north and south mainly of 1920-39. From West Buckhurst Hill the Loughton road and the Epping New Road run north, the London road (via Woodford) runs south and the Chingford road runs west.

From Chigwell village Vicarage Lane runs southeast to Chigwell Row. Half a mile north of the village on the High Road are Rolls Park and the site of Barringtons (see Manors). Opposite Rolls the main road is joined by the road leading from Loughton via Loughton Bridge. North of Rolls the main road is called Abridge Road. Half a mile north-east of Rolls, immediately south of the Roding, is Woolston Hall (see Manors). Pudding Lane and Gravel Lane run south from Abridge Road near Woolston to Chigwell Row.

Half a mile south of Chigwell village High Road joins Hainault Road which leads to Grange Hill, and then via Fencepiece Road to Ilford. A mile south-west of Chigwell, to the west of High Road is Great West Hatch (see Manors) and near this on the opposite side of the road is the Manor House (formerly the Bowling Green, see Manors). Luxborough Lane, leading from Great West Hatch north-west to Buckhurst Hill, takes its name from an ancient manor in this area.

High Road leaves the parish just before reaching Woodford Bridge. Manor Road, leading from Woodford Bridge to Chigwell Row enters the parish immediately to the south of the Manor House. Between Manor Road and High Road at this point there is a small built-up area dating mainly from about 1900 . There is recent ribbon-development farther east on Manor Road before the junction with Hainault Road. At Grange Hill there is a housing area of $1920-39$, and in Fencepiece Road there is some similar development and also some houses built since I 945 . To the east of Grange Hill is the large Hainault housing estate built since I 945 by the London County Council. Part of this is in Chigwell Urban District, and part in the Boroughs of Ilford and Dagenham. Other houses west of Chigwell Row are mostly modern. From Chigwell Row Romford Road runs south-east to Romford and Dagenham. Manor Road continues east of Chigwell Row to Lambourne End as Lambourne Road.

Chigwell village, Chigwell Row, Gravel Lane, and Pudding Lane contain a number of houses dating from the 17 th and 18 th centuries, many of which are described below.

The railway from London to Epping passes through Buckhurst Hill, where there is a station. A loop line from Woodford to Hainault, Newbury Park, and Leytonstone branches east from the Epping line. There are stations at Roding Valley (South Buckhurst Hill), Chigwell ( $\frac{1}{2}$ mile south of the village), and Grange Hill. Hainault station, which serves the London County Council estate, is just outside Chigwell parish. Both these lines are now electrified and form part of the Central London Line.

Before the $17^{\text {th }}$ century the repair of the parish

6 Archd. Essex I I 3 Thonder.

7 P.C.C. 98 Leicester.

8 E.R.O., Q/SR I I9/29.

- E.R.O., D/DEs MIO2.

10 E.A.T. N.s. xvii, 188; Notes on a Romano-British Settlement at Chigruell (Essex Field Club, 1903).

11 E.R. xix, $\mathrm{I}-7,70-77$. For the later history of the endowment see Charities.

12 E.R.O., Q/SR 332/51.

13 Essex Highways Repairs Act, 3 Geo. roads was largely a matter of charity, and many bequests were made for this purpose, for example, those of Cicely Rypton (I 55I) ${ }^{6}$ and George Scott (I 588).7 In 1592 the surveyors of Chigwell presented eight parishioners at Quarter Sessions for refusing to do their statute duty on the roads. ${ }^{8}$ In 1682 the Woolston manor court presented the surveyors themselves for failing to repair a footbridge and threatened them with a penalty of $\ell_{5} 5$ if they failed in the future. 9

The most important road in the parish in early times was the London-Abridge road, which was also the main road (via Theydon Bois) to Epping. This follows closely the line of an old Roman road, passing near the site of a Romano-British settlement near Woolston. ${ }^{10}$ The charity founded in I557 and I 562 by Joan Sympson for the repair of this road is described below (see Charities). Her endowment was regularly used for this purpose in the 16 th and 17 th centuries, $I I$ but in spite of it ten rods of the road between Chigwell village and Abridge were in a bad condition in 1647.12 From 1763 the road was maintained by the Middlesex and Essex Highway Trust. ${ }^{13}$ In 1866 the parish resumed responsibility for the road. 14 In 1668 part of the road between Chigwell and Abridge was diverted near Rolls to enable the owner of that house, Sir Eliab Harvey, to extend his grounds. ${ }^{15}$

It is remarkable that until I 890 there was no proper road between Chigwell and Buckhurst Hill. Before that there was only a track running from Luxborough Lane, through the Roding and along Squirrels Lane, which lay approximately on the line of the present Lower Queen's Road, Buckhurst Hill. This track was often obstructed.'6 A 'church way' from Buckhurst Hill to the parish church at Chigwell existed in I 586 . As it included three stiles it was presumably a footpath. ${ }^{17}$ The construction of a new road across the Roding from Buckhurst Hill to Chigwell was discussed by the parish vestry in 1855 and I 864 . Nothing, however, was achieved until in 1890 the present Roding Lane was opened. 18 Before this the people of Buckhurst Hill could only reach Chigwell, without fording the river, by way of Woodford or by Loughton Bridge.

Gravel Lane, 19 Pudding (formerly Patsalls) Lane, ${ }^{20}$ Vicarage Lane, ${ }^{2 !}$ and Hainault Road (formerly Fortey or Horn Lane) ${ }^{22}$ all figure in records from early times. They were all gated at the forest end to keep out stray animals. ${ }^{23}$ The gate house at the upper end of Hainault Road still exists.

The road from Grange Hill to llford was not made until I 833, and that from Chigwell Row to Romford about 30 years earlier; both were paid for by public subscription. ${ }^{24}$ In the former case, however, a track must previously have existed, for in 1662 Fortey Lane was described as the road from Chigwell to Barking. ${ }^{25}$

Manor Road undoubtedly replaced an ancient track. $^{26}$ As late as I 817 , however, it was held that it was not a public highway because it was only a "fair

$$
\begin{aligned}
& \text { III, c.58, established this responsibility. } \\
& \text { I4 E.R.O., D/P 166/8/I1. } \\
& \text { is Cal. S.P. Dom. i667-8, 72. The } \\
& \text { Crown granted Harvey licence to alter the }
\end{aligned}
$$




\section{A HISTORY OF ESSEX}

weather road'.27 Its extension from Chigwell Row to Lambourne End (c. 1790) has been described under Lambourne.

At Buckhurst Hill the Loughton-Woodford road is of ancient origin. It became important early in the 17 th century when the road from Loughton to Epping through the forest was completed, thus providing a new direct route from London to Newmarket. ${ }^{28}$ In the I 8 th century it came under the control of the Epping and Ongar Highway 'Trust, which about 1780 remade the section between Buckhurst Hill and Loughton. ${ }^{29}$ In I 834 the trust completed its new road from Woodford to Epping, by-passing Loughton. ${ }^{30}$ A short stretch of this Epping New Road runs through Buckhurst Hill.

The only other roads in Buckhurst Hill before the Igth century seem to have been a lane leading from the 'Bald Faced Stag' to Langfords (now Westbury Lane) and another, on the opposite side of the main road, leading to Whitehall in Chingford (now Whitehall Lane). In I79I and 1796 the parish resisted magistrates' orders to repair the latter road.3r Of the newer roads in Buckhurst Hill Queens Road was taken over by the parish in 1867 , Princes Road and Victoria Crescent in 1870 , Victoria Road in $188 \mathrm{I}$, and Alfred Road, Albert Road, Gladstone Road, and Russell Road in 1883 . Kings Place Road was taken over in sections in $1870,1879,1881$, and 1883.32

The combined Domesday figures for Chigwell Hall and Woolston give a total of 23 villeins, 4 bordars, and 8 freemen in 1066 , to which a further 4 bordars had been added by 1086.33 In I 391 there were 72 houses in the parish. There was a small concentration round the church in Chigwell Street but most of the houses were scattered throughout the parish. ${ }^{34}$ 'They probably included most of those known to have existed in the $15^{\text {th }}$ century, among which were the following: 35 Little Londons, Turnours, Martins (now Marchings), Brownings, Serjeants, Birds, and Coles (now Taylors Farm) in Gravel Lane; Billingsbourne in Millers Lane (off Gravel Lane); Pettits and Barns alias Fulhams in Pudding Lane; Appletons (now Old Farm) in Green Lane (a track off Vicarage Lane); Tailours and the manor house of Barringtons (later Rolls) in High Road, and Woolston Hall off Abridge Road. At Chigwell Row were Sheepcotes, near the Lambourne boundary, Whitehall (formerly Gullivers) with Goodhouse and Haywards near by, Skynners which later became the 'Maypole' and stood behind the site of the more recent inn of the same name, Old Bennetts, Hatchmans, Pearsmiths, and Page Hall, all of which stood near the present Hainault Hall, and Hatch House near the later Clare Hall, with perhaps a dozen smaller houses. At Grange Hill there was Grange Farm and in Hainault Road, Elces (formerly Youngs). In Chigwell village a few houses are known to have existed in the Middle Ages, and in the $15^{\text {th }}$ century there were probably more than a dozen, including the Grange, Church House, and Ringleys on the site of Grange Court. Farther south in High Road there were houses at Broomhill and West Hatch, Brookhouse Farm and the old mansion at Luxborough. At Buckhurst Hill there were a few houses in the $15^{\text {th }}$ century, among them King's Place and Monkhams.

Some of these houses have disappeared and the others have been rebuilt or so much altered as to leave few traces of their early origin. Among the oldest surviving houses in the parish are the Retreat at Chigwell Row, Woolston Hall (see Manors), Marchings, and Brownings, all of which date from the 16 th or early 17 th centuries. Marchings is a two-story house, timberframed and roughcast. It was probably built early in the 16 th century but has been much altered. Brownings is a two-story building, also timber-framed and roughcast, with an old tile roof. It has a front of three gables, the centre one being much wider than the others. The Retreat, now a café, was probably built in the 16 th century but only a small part of the present building is original. There are old timbers inside. Details of some Chigwell houses and their furnishings in the $15^{\text {th }}-17^{\text {th }}$ centuries are contained in the printed series 'Old Chigwell Wills'. ${ }^{6}$

In 1671 there were 168 houses and two forges in the parish. ${ }^{37}$ In addition to the houses already mentioned were Bacons (on the site of Montfort House), Morgans (later Great House and now the Grove), Wheelers alias Butlers Bennetts (now the Chace), Langhall (now the Foxhounds), Taylors Hall (on the site of Willow House), Clare Hall, Bowls, and some cottages, all in Manor Road. In Pudding Lane Clark's tenement (later Burnt House) had been built and in Chigwell village there were houses on nearly all the present sites. The original manor house of Chigwell Hall had fallen into disuse after the building of a new house near the church (see Manors). Existing houses which in their present form date from the 17 th century are the 'King's Head', Chigwell School, Harsnetts, Woodlands at Chigwell Row, the Foxhounds, Brookhouse Farm, Church House, Pettits Hall lodge, Turnours and possibly Grange Court.

'The 'King's Head' in Chigwell village was made famous by Dickens in Barnaby Rudge, where it figures as the 'Maypole'. It was an important inn. From I 7 I 3 and possibly earlier it was regularly used for meetings of the Court of Attachments of Waltham Forest. ${ }^{38}$ In the I 850 's it was a favourite resort of public authorities banqueting at the public expense, and was famous for pigeon pie. ${ }^{39}$ The main part of the building is of three stories with attics and cellars and exposed timberframing. Each upper story overhangs and there are four various-sized gables. There is a large roughcast chimney-stack with diagonal shafts. There have been many alterations and additions to the building. The Chester Room on the first floor has 17 th-century panelling.

The original part of Chigwell School was built soon after the foundation of the school in 1629.40 It is a one-story building of red brick with an old tile roof. There have been additions in the 18 th century and later. Harsnetts is a two-story building opposite the school, now divided into two houses.

Woodlands, at Chigwell Row, is a two-story building, roughcast, with a tile roof and a rebuilt chimneystack of four shafts. The 'Fox and Hounds' consists of

\footnotetext{
27 Chelmsford Chronicle I Aug, and 14 Nov. 181 7 : indictment at Essex Assizes against the parish for failure to repair the road.

28 See history of Loughton.

29 Ibid.

30 Ibid.
}

3I E.R.O., D/P I66/8/10. 32 E.R.O., D/P I66/8/I I. 33 V.C.H. Essex, i, $432 b, 553 b$. $34 \mathrm{E}_{179 / 147 / 60 .}$

35 The following details of local houses have been gathered from the author's collection of notes and abstracts of court rolls,

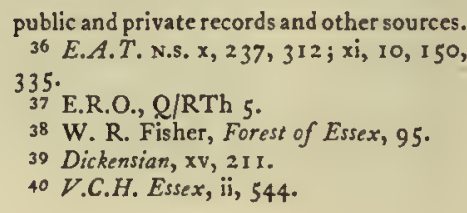

public and private records and other sources. 36 E.A.T. N.s, x, 237, 312 ; $\mathrm{xi}, 10, \mathrm{I} 50$, 335. 37 E.R.O., Q/RTh 5 . 38 W. R. Fisher, Forest of Essex, 95. 39 Dickensian, $x \mathrm{v}, 2 \mathrm{I} \mathrm{I}$. 40 V.C.H. Essex, ii, 544. 
two stories and attics and is of red brick. Brookhouse Farm is a timber-framed and roughcast building having an old tile roof and a central chimney-stack with six diagonal shafts. Church House, though mainly of the 18 th century, incorporates obvious remains of a I 7 thcentury building, including a chimney-stack. It is of two stories, timber-framed, and roughcast. Pettits Hall lodge is of similar construction, with a cross gable overhanging to the right.4I Turnours, on one of the oldest sites in the parish, is particularly interesting. In the entrance hall there is a fine 17 th-century fireplace. Late in the rgth century the house was encased in red brick in Gothic style. Cloisters were built on the north side and a chapel behind the house to the west. These alterations were probably planned by Miss Ada Palmer. The Palmers lived at Turnours from about 1860 to about $1914.4^{42}$ Ada was a painter and sculptor and many of her works are preserved in the house. During the Second World War Turnours was used for military purposes and a hutted camp was built in the fields to the north-west. After the war the house was acquired by Dr. N. Beattie of Ilford and maintained by him as an International Youth Centre.43 Grange Court, which was remodelled in 1774 was probably built in the late I 7 th or early 18 th century. It is a large and handsome three-story house with lower side wings, and is built mainly of stock brick. It is now part of Chigwell School.

During the 18 th and early 19th centuries several new houses were built in the parish and many old ones greatly altered or completely rebuilt. Among those which in their present form date from the 18 th century are Chigwell Lodge, Brook House, the stables at Barton Friars (originally the stables to Grange Court), Vine Cottage, and Tailours, in High Road, and Sheepcotes and Hainault Hall at Chigwell Row. Flint Cottage, The Haylands, Little Haylands, and Belmont Park, in High Road, are of the early Igth century. Crosby House at Chigwell Row is an early-I gth-century remodelling of an 18 th-century house. Great West Hatch, New Barns in Luxborough Lane, and Barrington Lodge and Forest House at Chigwell Row were entirely new houses built in the I 8 th century. Many smaller houses also date from the I 8 th and earlier I 9 th centuries. The old house at Luxborough was replaced about 1720 by a large mansion, but this was demolished about 1800 . There was small-scale but continuous new building throughout the parish and by $185 \mathrm{I}$ there were 396 houses of all sizes. 44

The population of the parish was 1,351 in 1801 . By $184 \mathrm{I}$ it had risen to 2,059 . It declined slightly to 1,965 in 1851.45 Between 1850 and 1870 Chigwell Row was greatly changed by the inclosure and destruction of most of Hainault Forest (see Agriculture). At Buckhurst Hill part of Epping Forest was inclosed and some of it built over.

The rapid building at Buckhurst Hill was a result of the extension of the railway from Woodford to Loughton. By I 87 I there were 1,080 houses in Chigwell parish, nearly all the increase being at Buckhurst Hill.46 The only other building of any importance had been in Hainault Road. ${ }^{47}$ By 1891 the number of houses had increased to $1,271.48$ The population of the parish rose to 6,324 in 1891 and 7,294 in 1901.49

It is interesting to compare the development of Buckhurst Hill between 1851 and IgOI with that of Loughton (q.v.). Both places were'affected at the same time by the coming of the railway and both were involved in the controversy concerning the inclosure of Epping Forest. ${ }^{50}$ At Buckhurst Hill development was much more rapid than at Loughton and was much more concentrated round the railway station. Inclosures from the forest were much smaller at Buckhurst Hill than at Loughton, mainly because Buckhurst Hill had a smaller forest frontage, but most of the inclosures at Buckhurst Hill were more quickly built over and thus became exempt from the provisions of the Epping Forest Act of 1878. Loughton's growth took place within the framework of an ancient village. At Buckhurst Hill a new town sprang up on farm land and forest.

Growth was much slower after 1901. The opening of the Woodford-Ilford loop line in I 903 caused some building in Chigwell village and at Grange Hill, and there was also some development near Woodford Bridge. In I93 I the total population was 8,948 (Buckhurst Hill U.D. 5,486; Chigwell C.P. 3,462). Between I93 I and I 939 there was much new building, in Hainault Road, Manor Road, Forest Lane, High Road, and in various parts of Buckhurst Hill, especially at Monkhams. Shortly before 1939 Chigwell lost one of its oldest houses, the Grange in High Road, which was demolished after a fire.5I It dated from the I 5 th century. 52

Since I 945 restrictions have prevented large-scale private building, and much of Chigwell has been designated as a part of 'the Green Belt'. The new Hainault estate, however, has added 1,900 houses to the urban district since 1945. There has also been some building of local council houses.. The Grange Farm Camp, Chigwell, opened in 195 I, provides large-scale facilities for camping, swimming, and many other types of athletics (see also Charities). In 1953 the population of Chigwell Ward was estimated at 14,000 and that of Buckhurst Hill Ward at $12,000.53$

There was a regular coach service from Chigwell to the 'Blue Boar' at Aldgate from 1790.54 In the 1820 's Mary Draper of the 'King's Head' ran a daily service to Aldgate.55 In I 840 a coach left the 'Maypole' at Chigwell Row every morning, calling at the 'King's Head' on its journey to the 'Three Nuns', Whitechapel, and returning by the same route in the evening. ${ }^{56}$ In 1845 the Ongar coach to London also passed the 'King's Head'. 57 William Powling kept a coach at his house next to the 'Maypole' at Chigwell Row; from I 844 it ran from there to the 'King's Head' and back to connect with the Ongar coach. ${ }^{8}$ After his death in I 84859 his widow kept two coaches for some years, one ran to London daily and the other to the newly opened railway station at Ilford. 60 In 1858 these coaches were taken over by William Claydon who in 1864 moved to Vicarage Lane.6I For many years before the building

\footnotetext{
41 This is the old Pettits Hall. The present house of that name is modern.

42 Kelly's Dir. Essex (I 859 f.).

43 Inf. from Mrs. Beattic.

44 H.O. $107 / 1770,195 / 1$.

45 V.C.H. Essex, ii. 350.

46 Census Retn. 1871.

47 E.R.O., D/P $166 / 11 / 16-18$.
}



(1827) ${ }_{56}$ Pigot's Dir. Essex (1840). 7 Kelly's Dir. Essex (1845). 38 Ibid. 59 Chigwell Par. Reg.

60 White's Dir. Essex (1848).

61 Chigwell Par. Reg.; E.R.O., D/P $166 / 11 / 12-28$. 


\section{A HISTORY OF ESSEX}

of the Ilford loop a coach ran every morning and evening to Woodford station, the Ilford coach being discontinued.62 Coaches owned by Nelson of the 'Bull', Aldgate, ran to Chigwell Row until I 868.63 In 1848 Henry Chipperfield ran a wagon three times a week from Chigwell to London and John Wilton ran one daily from Chigwell Row. 64 In I 878 William Claydon ran a wagon to London four times a week. ${ }^{6 \mathrm{~s}}$

Before the building of the railways Buckhurst Hill had many coaches passing through every day, to London, Cambridge, Norwich, Bury St. Edmunds, Dunmow, and elsewhere.

The Eastern Counties Railway extended its line from Woodford to Loughton in 1856 , with a station at Buckhurst Hill. In 1903 the Ilford loop was opened, with stations at Chigwell and Grange Hill.66 In I 937 a new station was opened at Roding Valley, on this loop, to serve the southern part of Buckhurst Hill.

In 1839 there were postal receiving houses at Chigwell and Chigwell Row. ${ }^{67}$ By 1863 there were two post-offices at Chigwell, and sub-post-offices at Chigwell Row and Buckhurst Hill.68 By 1874 there was a telegraph office at Chigwell.69 In I 886 there were two post-offices at Buckhurst Hill, one of them having the telegraph, and the Chigwell Row office also had the telegraph.70 The telephone was in use at Buckhurst Hill by about 1906.71 By 1922 there was a telephone exchange in Chigwell village. 72

The first serious attempt to improve sanitation was in 1854 , when the Epping PUBLIC SERVICES Guardians appointed a parochial committee to remove nuisances. ${ }^{73}$ Such committees were again appointed in I 857 and I 859.74 In 1868 the vestry decided to appoint a Sewer Authority under the Sewage Utilization Acts, I 865 and I 867 , and the Sanitary Acts, I 866 and I 868.7s Two months later it resolved to appoint members of this authority, but another resolution to form a Special Drainage District for Buckhurst Hill was withdrawn after strong opposition.76 A sewage-disposal plant was installed at Buckhurst Hill, but the growth of this part of the parish soon overtaxed the plant. In 1876 a local doctor complained to the vestry of the filthy state of the roads, ponds, and cesspools in lower Buckhurst Hill.77 This protest was largely instrumental in obtaining an improved plant. ${ }^{78}$ From 1870 the local committee was controlled by the Epping Rural Sanitary Authority. 79 In 1895 the Buckhurst Hill Urban District Council became responsible for sewage disposal within its area, and the Epping Rural District in the rest of the ancient parish. 80 In I 933 the whole area was taken over by Chigwell Urban District Council.

In 1874 water was being supplied to Buckhurst Hill by the East London Waterworks Co. In that year the parish vestry tried unsuccessfully to arrange for supplies to be extended to Chigwell and Chigwell Row. ${ }^{81}$ It made another attempt in 1879.82 The date at which the extension took place is not known, but by 1907 Chigwell and Chigwell Row were being supplied by the Metropolitan Water Board, successor to the East London company. ${ }^{83}$ The company had opened a reservoir at Buckhurst Hill about I 895 , to replace the previous water tower. ${ }^{84} \mathrm{~A}$ mineral spring at Chigwell Row which existed in the I 8 th century had fallen out of use by about 1800.85

The Chigwell and Woodford Bridge Gas Co. was formed in $\mathrm{I} 86_{3}$ and gradually extended its area. By 1867 it was supplying gas to Buckhurst Hill. In 1873 it was reincorporated as the Chigwell, Loughton and Woodford Gas Co. Its works were in Snakes Lane, Woodford. ${ }^{86}$ In I9I 2 it was taken over by the Gas Light and Coke Co. ${ }^{87}$

Electricity was brought to Chigwell soon after the First World War by the County of London Electric Supply Co. 88

An unsuccessful attempt in 1792 to build a pesthouse in Chigwell is described below (see Parish Government and Poor Relief). A Village Hospital, supported by subscription, was opened at Buckhurst Hill about 1875 , on the initiative of Dr. C. H. Livingstone. ${ }^{89}$ The Medical Provident Home, Buckhurst Hill, was opened about 1890.90 These hospitals were closed in I 912 when the Forest Hospital was opened at Buckhurst Hill.91 This was extended in 1920 and 1930.92 It is now administered by the Forest Hospital Management Committee. ${ }^{93}$

Great West Hatch was formerly a branch home of the Royal Eastern Counties Institution for Mental Defectives.94 It was taken over by the London County Council about 1938 and is now under the South Ockendon Hospital Management Committee.9s The neighbouring Little West Hatch is under the same management.96 The Epping Hospital Management Committee has recently opened a Chest Clinic at Buckhurst Hill. 97

The Female Refuge Home, Buckhurst Hill, opened about $\mathrm{I} 875$ and later known as the Preventive Training Homes, under the Rescue Society for Girls, continued until I 914.98

A Female Benefit Society meeting at Chigwell Row was registered in 1808, and the Anchor and Hope Benefit Society meeting at Buckhurst Hill in 1832.99

In 1884 the vestry resolved to maintain a fire engine which was to be purchased by public subscription. This was later taken over by the Buckhurst Hill Urban District Council, which built a new fire station. ${ }^{2}$ This

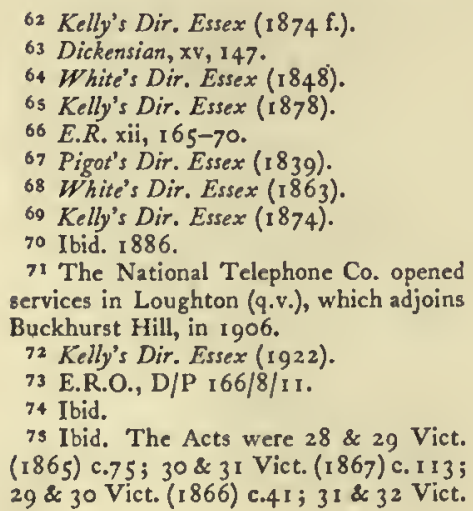

73 Ibid. The Acts were 28 \& 29 Vict. (I865) c.75; $30 \& 3$ I Vict. (I 867) c. II3; $29 \& 30$ Vict. (I 866) c.4I; 31 \& 32 Vict.

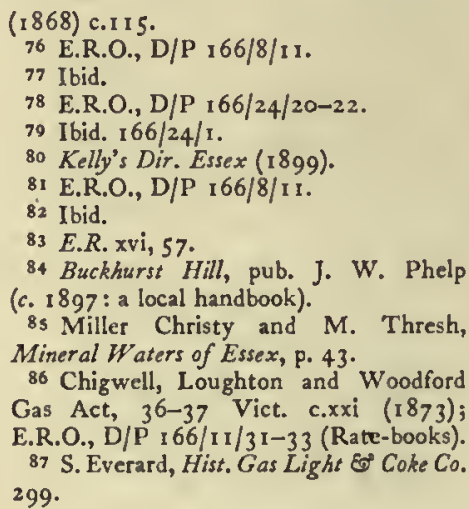


was closed in 1933 , after the opening of the stations at Loughton and Grange Farm, Chigwell. ${ }^{3}$

Allotments were instituted by the parish vestry in I 867 at Grange Hill and Chigwell Row.4

The origin of the Chigwell Row recreation ground is mentioned below (see Agriculture). It has been taken over by the Urban District Council, which has also provided grounds near Chigwell station and at Roding Valley. The Buckhurst Hill recreation ground has also been taken over by the council.s

Until the I $g^{\text {th }}$ century Chigwell was a rural parish devoted mainly to agriculture.

AGRIC ULT URE The soil is clay. At Buckhurst Hill and Chigwell Row there were formerly extensive stretches of woodland forming part of Epping Forest and Hainault Forest. Apart from the forests the southern part of the parish has always been used for pasture, possibly because most of the wealthier inhabitants lived there and preferred such surroundings. The remainder of the parish has always contained a higher proportion of arable land, but even there pasture has predominated.

Little is known of agricultural practices in the parish during the Middle Ages. Certain fields at Buckhurst Hill appear to have been still divided into strips in the I $3^{\text {th }}$ century but were consolidated after coming into the possession of Waltham Abbey about 1300.6 Such records as remain of this period show that pigs were the main source of revenue, as was usual in this part of Essex, where the forests provided good pannage. Assarts from the forests were numerous in the 13 th and I $4^{\text {th }}$ centuries, although rarely of more than an acre in extent. ${ }^{8}$ At Woolston in the $15^{\text {th }}$ century pigs were still the most common animals, but cattle, sheep, and geese were also kept. 9 Most of the arable land appears to have been worked by the lord of the manor using customary labour until towards the end of the 15 th century, when labour services had been generally commuted. Io Between I 3 I 2 and 1534 some IOO acres arable belonging to the demesne of Woolston had been converted into pasture. II Grazing land was certainly regarded as more profitable than arable. The will of John Fuller of Serjeants, dated $167 \mathrm{r}$, charged his widow to 'make no waste by ploughing' on the land which he left her in trust for his children.12 An unusual crop, greenweed, was raised in a field at Buckhurst Hill in $1664 .^{13}$ It was probably used for dye.

During the 18 th century more land probably passed under cultivation. A tithe survey of I 800 shows that there were then 973 acres of arable. Wheat accounted for 280 acres, oats 291 acres, potatoes 32 acres, barley 25 acres, beans, peas, and vetches 26 acres, and seeds I 29 acres with I 90 acres fallow. There were 2,310 acres of grassland and 30 acres of privately owned woodland. The remaining 1,696 acres of the parish were made up mainly of the forest waste at Chigwell Row and Buckhurst Hill.14 According to Vancouver's tables of 1794 the yield of crops was slightly above the average for the county. Is James Hatch of Claybury in Barking, lord of Chigwell Hall, who owned some 800 acres in Chigwell apart from waste, was one of the correspondents who supplied Arthur Young with information for his General Viewo of Agriculture in Essex ( 1807$)$. He reported that crops of potatoes, well manured on a rotational system, had obviated fallow land. He stated also that fourtcen years was the minimum lease that he would grant because tenants could not 'make the necessary exertions in draining and manuring under a shorter term' ${ }^{16}$ Young considered that the forest waste in Chigwell was a handicap to good husbandry, any advantage gained by rights of common being far outweighed by the damage done by deer and poachers. ${ }^{17} \mathrm{He}$ suggested that $75^{\circ}$ acres waste worth $2 s .6 d$. an acre could be improved to 25 s. by inclosure.

Small inclosures had been continuing in the 16 th and I 7 th centuries, sometimes by grant in manor courts and sometimes by silent encroachment. ${ }^{8}$ In 185 I Hainault Forest was disafforested by Act of Parliament. ${ }^{19}$ The Hainault Forest Allotment of Commons Act, I 858,20 provided that 701 acres (mainly within the parish of Chigwell) should be allotted as common of that parish. By the Chigwell Inclosure Award I 863 most of this common was inclosed.21 The largest allotments went to James Mills, lord of the manor of Chigwell Hall, who received 209 acres, and Mrs. Lloyd of Barringtons, who was granted 72 acres absolutely and an additional $5^{\circ}$ acres on condition that she maintained it for use as a public recreation ground. ${ }^{22}$

Meanwhile, at Buckhurst Hill, inclosures were being made from Epping Forest. In 1858 James Mills purchased the forestal rights of the Crown in his manor of Chigwell Hall.23 The Epping Forest Commission reported in 1877 that 257 acres had been illegally inclosed within this manor between $\mathrm{I} 85 \mathrm{I}$ and $\mathrm{I} 87 \mathrm{I} .24$ By $\mathrm{I} 877$ most of these inclosures had been built on or had become private gardens and were therefore exempt from the provisions of the subsequent Epping Forest Acts. An important exception was Lords Bushes, which contained 92 acres and became part of the forest once more under those Acts. Unlike those at Chigwell Row, therefore, the inclosures'at Buckhurst Hill did not significantly increase the agricultural acreage.

A fair proportion of the parish is still devoted to farming, mostly in the north and east, and is now evenly divided between arable and pasture land.

From medieval times men with interests in London have made their country homes

OTHER OCCUPA- in Chigwell, ${ }^{25}$ and the indiTIONS genous population, when not engaged in agriculture, has

been largely occupied in catering for their needs, either in goods or services. In the second half of the $\mathrm{I}$ th century four cordwainers, a butcher, a weaver, a mason, a carpenter, and a brickmaker are named in various records. ${ }^{26}$ They are typical of the tradesmen generally

\footnotetext{
3 Buckhurst Hill, Chigwell and Loughson Official Guide.

4 E.R.O., D/P $166 / 8 / 11$

5 Official Guide. 6 E.R. Ivii, 96-99.

$7 \mathrm{E}_{32 / 12}, 13,16$.

8 Ibid.; W. R. Fisher, Forest of Essex, 323.

E.R.O., D/DEs M 94 ff. (Court Rolls of Woolston)

10 E.R.O., D/DEs M94-95. For a manorial grange and bakehouse in the Middle Ages see Parish Government.
}

It E.R. lxii (Jan.), 5 1.

12 Archd. Essex, I 31 Atterbury.

13 E.R.O., Q/SR $402 / 131$.

It E.R.O., D/P I66/3/x.

is Young, Gen. View of Agric. in Essex, i, 325,354 .

16 Ibjd. i, 395. 17 Ibid. ii, 95

18 E.R.O., D/DDa M $14, \mathrm{D} / \mathrm{DU} 97 / 2$.

1914 \& 15 Vict. c.43.

2021 \& 22 Vict. c. 37.

21 E.R.O., Q/RDc 66 . For Hainault

Forest before inclosure see Chapman and

\footnotetext{
André, Map of Essex, 1777, sheet xvi.

22 The recreation ground was at $C$ higwel Row, adjoining the remaining portion of Hainault Forest.

23 W. R. Fisher, Forest of Essex, 352.

24 Rep. of Epping Forest Com. H.C. I87, Pp. 79-8I (1 877), xxvi.

25 Court Rolls : E.R.O., D/DDa MI-I D/DEs M8o-109, D/DU 97/I-9; Wills and other records.

${ }_{26}$ Abstracts of records in possession of
} the author. 


\section{A HISTORY OF ESSEX}

until late in the $19^{\text {th }}$ century. In 1848 , in addition to the usual shopkeepers, there were a pianoforte maker (at Chigwell Row), a violin-bridge maker (at Chigwell), and a brewer. ${ }^{27} \mathrm{~A}$ map of $185^{8}$ shows "Hainault Brewery' in the position of the present Forest Cottages, near the 'Maypole' at Chigwell Row, ${ }^{28}$ but it seems to have closed soon after. 29

In 185 I there were 1,294 persons over 14 years of age in the parish, of whom $43^{8}$ were engaged in agriculture, 320 were domestic servants or gardeners, 22 I were professional business people or gentry, I 55 local tradesmen, 60 were engaged in the building trades, 35 were licensed victuallers or their servants, 19 were police, forest keepers, or other officials, I I carriers, 8 were still at school, and 27 unemployed paupers. One house, Rolls, had 15 servants, another Io, and 5 houses had 6 or $7.3^{30}$

There is evidence of brickmaking from the 17 th century onwards. In 1668 Sir Eliab Harvey of Rolls was granted a royal licence to inclose land near his house to make bricks. ${ }^{31}$ A brickworks at Luxborough has operated intermittently for nearly a century, and bricks have been made at the lower end of Buckhurst Hill since 1870.32 Much of the output of these works was used for local building. Both works have been owned in recent times by Messrs. W. and C. French Ltd. of Buckhurst Hill, a business which was started by Mrs. Elizabeth French in the I860's, with a fleet of carts largely occupied in supplying gravel to parish authorities for roads. Frum this beginning it has risen to be one of the largest public works contractors in the world. The head office is still at Buckhurst Hill..$^{33}$

From 1800 until 1843 a watch-making business was carried on at Marchings in Gravel Lane by John Roger Arnold. ${ }^{34}$ He was the son of John Arnold (1736?-99), a noted watchmaker who made a number of improvements in the design of chronometers. ${ }^{35} \mathrm{~J}$. R. Arnold was associated with Dent and Arnold of the Strand, London, and in $182 \mathrm{I}$ patented, from Chigwell, an improved expansion balance for chronometers. ${ }^{36} \mathrm{His}$ foreman, Thomas Prest (d. 1852), started business on his own account at Chigwell Row in $1821.37 \mathrm{He}$ patented in 1820 the attached winding movement of watches, as opposed to the detached key. ${ }^{38} \mathrm{His}$ business was continued by his son Thomas Prest (d. 1877 ). ${ }^{39}$

In recent years planning authorities have not considered the parish suitable for industrial development, except for a small area in lower Buckhurst Hill.40 Local employment has therefore been mainly confined to agriculture, the distributive trades, and catering for visitors to Epping and Hainault Forests.4I

A hiring fair was being held at Chigwell on 30 September each year in the period 1792 to about $\mathrm{I} 860$. It had ceased before 1888.42

The best-known inn at Chigwell, the ' $\mathrm{K}$ ing's Head', has been mentioned above (see p. 20). The present
'Maypole' at Chigwell Row was built in front of an earlier house. ${ }^{43}$ There has been an inn there at least since I 770, and the old house, now demolished, can be traced back to I 505.44 In I 843 the 'Maypole' served over 2,000 customers from Fairlop Fair after the magistrates had refused permission for refreshments to be sold in the neighbourhood of the fair.45 At Buckhurst Hil the 'Roebuck' now stands slightly south of its former site, where it stood at least since 1770.46 It was popular in the late 19 th century as a resort of Londoners visiting Epping Forest. 'The 'Bald Faced Stag' has been traced by name back to 1752.47 It was probably the house of Richard Dennis who in 1720 described himself as a victualler. ${ }^{48}$ The 'Bald Hind' at Grange Hill was known in I 770 as the 'Bald Faced Hind'.49 The 'Jolly Wheelers' near Woodford Bridge first appears by name in 1778.50

James Basire (1769-1822), engraver, lived and died at Chigwell Row. His eldest son

WORTHIESSI James (1 796-1 869), also an engraver, was born there. Samuel Bellin ( 1799 -

1893), another engraver, spent his early life at Burnt House in Pudding Lane. Henrietta Lady Chatterton (1 806-76), miscellaneous writer, lived at Rolls from I 852 to 1855 . Roger Fenton ( $565-1616$ ), theological writer and one of the translators of the Authorized Version of the Bible, was Vicar of Chigwell $1606-16$ Samuel Harsnett ( $156 \mathrm{I}-163 \mathrm{I}$ ) is mentioned below (see Church). Admiral Sir Eliab Harvey (1758-1830), who commanded the Temeraire at Trafalgar, was lord of the manor of Barringtons (see above) and lived at Rolls House. He was M.P. for Maldon 1780 and for Essex I 803-12. Richard Hollingworth (1639-1701), Royalist pamphleteer, was Vicar of Chigwell I6901701. Samuel Howitt (1765?-1822), painter and etcher, lived at Chigwell Row in his youth. Admiral Sir Edward Hughes (1720?-94) was lord of the manor of Luxborough and lived at Luxborough House. Joshua Jenour ( $1755-1853$ ), author, lived at Chigwel Row from 1792 to I $804 .{ }^{52}$ Thomas Johnson (fl. 17 I 8 ), classical scholar, was headmaster of Harsnett's Grammar School 1715-18. Admiral Richard Lestock (1679?-1746) lived at Chigwell Row 1709-46. William Penn (r644-17 18), Quaker and founder of Pennsylvania, was educated at Harsnett's Grammar School. George Robert Rowe (1792-1861), physician and medical writer, lived and practised in Chigwel village from about 1823 and was buried in the churchyard. Helen Maria Williams (1762-1827), authoress, was living at Grange Hill in 1826 .

The manor of CHIGWELL, later known as $C H I G$ WELL HALL alias CHIGWELL-AND.

MANORS WEST HATCH, was held in 1066 by Earl Harold. After the Conquest it was given to Ralph de Limesi, whose chief seat was at Wolverley in Solihull (Warws.). ${ }^{53}$ The tenancy in
27 White's Dir. Essex ( 1848 ).

28 E.R.O., D/DLo P5.

29 No brewer is mentioned in Kelly's Dir. Essex (1 859).

$30 \mathrm{H} .0 .107 / 1770,195 / 1$. Wives and children over i 4 have been included under their husbands' or fathers' occupation unless stated to have been otherwise $\mathrm{em}$ ployed.

${ }_{11}$ Cal. S.P. Dom, I 667-8, 72

32 E.R.O., D/P I 66/11/34-51; Kelly's

Dirs Essex, passim; personal knowledge.

33 Ibid.

34 E.R.O., D/DEs M8I; Par. Reg.; personal knowledge.

35 D.N.B. ${ }^{36}$ Pigot's Dir. London, (1817-32); E.R. Ivi, 79. 37 E.R.O., D/DEs M8I. ${ }_{38}$ E.R.1vi, 78 ; M.I. in Chigwell churchyard.

30 M.I. in Chigwell churchyard.

40 W. Essex Reg. Planning Schm. 1933, p. $\operatorname{ros}$

41 Kelly's Dir. Essex (1879-1933); personal knowledge.

12 Rep. Com. Mkt. Ris. [C. 5550], p. I6r, H.C. (I 888), liii; White's Dir. Essex (1 848); Kelly's Dir. Essex (1859).

43 E.R.O., D/CT 78
44 E.R.O., D/DEs M95; Q/RLv 25.

45 Dickensian, Xv, 147.

46 E.R.O., Q/RLv 25; D/CT 78.

47 Authentick Tryals of Fohn Swan and Elizabeth Feffryes. They were hanged for murder near this house.

48 Archd. Essex, 89 Goates.

49 E.R.O., Q/RLv 25.

51 For all Worthies see D.N.B.

52 See also Parish Government, below, and E.R.O. D/DEs M80-8I.

53 V.C.H. Essex, i, $553^{b}$; Dugdale, Hist. Warrus. $342-3$, gives the Limesi-Dodyngsells pedigree. 
chief of the manor descended in the Limesi family and their heirs the Dodyngsells. John de Dodyngsells held it in 1350.54

Alan de Limesi, son of Ralph, granted the tenancy in demesne of the manor to Richard de Lucy, the Justiciar of Henry II, to hold for I knight's fee.55 The grant was confirmed before I 63 by Gerard de Limesi, Alan's son. ${ }^{56}$ De Lucy's interest in the manor subsequently passed through his daughter Maud, wife of Walter Fitz Robert of Woodham Walter to the Fitzwalter family. ${ }^{57}$ Walter, Lord Fitzwalter (d. I406) held I knight's fee in Chigwell. 58

After acquiring the tenancy of the manor Richard de Lucy enfeoffed Ralph Brito, who held of Richard for I knight's fee. 59 Some time after this Richard appears to have enfeoffed William de Goldingham so that he became the overlord of Brito, holding of Richard for I knight's fee. ${ }^{60}$ In I I 69-70 William de Goldingham enfeoffed Robert son of Ralph Brito with the manor, to hold for I knight's fee. ${ }^{\text {6I }}$

During the reign of Richard I Robert Brito suffered imprisonment and forfeiture for his adherence to Prince John. ${ }^{62}$ In the 20 years that followed there were several disputes concerning the ownership of Chigwell. Before his imprisonment Robert Brito had leased the manor for ten years to Andrew Blund of London. The lease still had six years to run when the manor was seized by the king. ${ }^{6}$ While the king had possession a suit was brought by Geoffrey Mauduit, claiming the manor. ${ }^{64}$ Manduit apparently succeeded in getting possession of it for a time but he was later ejected through the legal action of William son of Robert Brito and William's mother Philippa.65 In 1214 Andrew Blund sued William Brito for the unexpired portion of the ten-year lease, and the court awarded him 50 marks in compensation. ${ }^{66}$ In 1226 Gilbert Mauduit, presumably Geoffrey Mauduit's heir, quitclaimed a knight's fee in Chigwell to William Brito.67 About 1235 Alan son of John de Goldingham quitclaimed all his rights in Chigwell to William son of William Brito. 68 In or about 1254 William Brito's daughter was patron of the rectory and probably held the manor also.69 Soon after this, however, the Goldinghams appear to have acquired the tenancy in demesne. In 1258 William de Goldingham made a conveyance of property in Chigwellio and in 1298 John de Goldingham was lord.71 John died before 1316 , leaving a son and heir John. ${ }^{72}$

John son of John de Goldingham was knighted and was still living in $1349 .{ }^{73} \mathrm{He}$ died about I 362 and was succeeded by his son Sir Alexander de Goldingham. ${ }^{74}$
In 138 I Sir Alexander had licence to impark his garden and 50 acres of land adjoining his manor of Chigwell. 75 He died in 1408 leaving his estates to his wife Isabel for life with remainder to his son Sir Walter Goldingham. ${ }^{76}$ Sir Walter was dead by 1435 when his widow had become the wife of Matthew Hay.77 Sir Walter's daughter Eleanor married John Mannock of Stoke by Nayland (Suff.) who inherited the manor in right of his wife after the expiration of a life interest held by Matthew and Elizabeth Hay.78 Mannock died in 147179 and was succeeded by his son John who died in I 476, leaving Chigwell to George Mannock his elder son.80

In I 53 I George Mannock leased the manor to John Kempe for 15 years, ${ }^{81}$ but four years later sold it to the king. ${ }^{82}$ In 1537 a 2 I-year lease was granted to William Rolte, serjeant-at-arms, ${ }^{83}$ and this was upheld when Kempe claimed in respect of the earlier lease. ${ }^{84}$ Rolte died in 1541 , leaving the residue of his lease to George Stoner ${ }^{85}$ who apparently transferred it soon after to his son John. ${ }^{86}$ In I $55^{\circ}$ Edward VI sold the manor to Sir Thomas Wroth, who died in $1573 .{ }^{87}$ Sir Robert Wroth, son of Sir Thomas, married, before 1578 , Susan daughter of John Stoner. 88 Chigwell descended in the Wroth family in the same way as the manor of Loughton (q.v.) until the death in 1642 of John Wroth. ${ }^{89}$ John's estates were then apparently divided between the two sons of his brother Henry: John Wroth, who took Loughton (and Luxborough, see below), and Sir Henry Wroth, who took Chigwell.90

Sir Henry Wroth sold Chigwell in 1669 to Sir William Hicks of Ruckholts in Leyton, Ist Bt.91 The manor descended with the baronetcy to Sir Henry (commonly called Harry) Hicks who took possession after the death of his mother in $1723.92 \mathrm{Sir} \mathrm{Henry,}$ while retaining the manorial rights, sold the demesne lands of the manor and built himself a house near Woodford Bridge, formerly called the Bowling Green but now the Manor House. ${ }^{93} \mathrm{He}$ died in $1755 .^{.94} \mathrm{His}$ elder son, who became the $4^{\text {th }}$ baronet, was blind and Sir Henry left his estates to his second son Michael Hicks, who died unmarried in 1764.95 Michael left the estates in trust for the benefit of his blind brother Sir Robert and his sisters Ann Burton and Martha Petty, with successive remainders to Howe Hicks of Witcombe (Glos.), a relative, and Howe's second son Michael. 96

Sir Robert Hicks died unmarried in 1768 but the trust continued until $\mathrm{r} 799$ when Michael Burton, son of Ann, sold his interest in Chigwell to Michael, son of Howe Hicks. 97 This Michael had changed his name
$54 \mathrm{Cr}_{43 / 298 / 15}$; cf. V.C.H. Warws. vi, $125-6$.

55 Madox, Formulare Anglicanum, p. 42.

36 Ibid. Cf. Stenton, First Century of Anglo-Norman Feudalism, 161.

57 Complete Peerage, v, 472. For de Lucy's heirs see also Chipping Ongar.

38 Cal. Inq. p.m. (Rec. Com.), iii, p. 312. 59 Madox, Formulare Anglicanum, p. 78. 60 1bid. $368 . \quad 61$ Ibid. $44,179$.

62 Cur. Reg. R. 1213-15, 205.

63 Ibid.

64 Ibid. I 199-1201, 196, 207.

65 Ibid. Robert Brito was dead by 1200 . King John appears to have reversed the forfeiture in favour of William Brito.

66 Ibid. $1213-15,205$.

67 Feet of $F$. Essex, i, 7 I.

$68 \mathrm{E}_{3}$ I $5 / 3 \mathrm{I} / 204$.

69 E.A.T. N.s. xviii, 18.

70 Feet of $F$. Essex, i, 235 .

${ }^{7}$ Cat. Anct. D. i, B. 974. According to
W. A. Copinger, Manors of Suffolk, iii, 272 , Alice daughter of the last named William Brito married Sir William de Goldingham.

72 Cat. Anct. D. i, B. $912,961,963$.

${ }^{3}$ Feet of $F$. Essex, iii, 95.

74 Reg. Sudbury (Cant. \& York Soc.), i, 235 ; and see Church, below.

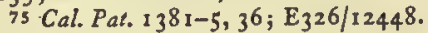

76 P.C.C. 16 Marche.

77 Feet of F. Essex, iv, 2 I, 22.

78 E210/1055I.

79 P.C.C. I Wattys. $\quad 80 \mathrm{C}_{14} / 59$.

81 E.A.T. N.s. ix, 273.

$82 E_{315 / 31 / 126 .}$

$83 \mathrm{E}_{326 / 6420}$

${ }_{4} \mathrm{E}_{321 / 2 / 54}$

85 P.C.C. 36 Alenger.

86 E.R.O., D/DRg I/I 97 : MS. relating to the 'wardstaff' of Ongar hundred c. 1550 . The MS. is described and partly printed in E.A.T. N.s. ix, 212 f. And see above, the Hundred of Ongar.
87 Cal. S.P. Dom. I 547-80, 28 ; Cal. Pat. 1 549-51, 68; ibid. I $550-3$, I 7 ; P.C.C. 16 Pyckering.

88 E.A.T. N.s. viii, 148

89 Ibid. 348 .

90 Ibid. 348 . Sir Henry Wroth probably did not inherit until after the death of his father, Henry Wroth, the elder, which occurred between 1653 and 1656 : P.C.C. 437 Berkeley.

${ }_{91} \mathrm{C}_{5} / 499 / 6 ; \mathrm{CP}_{25}(2) / 653$ Trin. 21 Chas. II ; $\mathrm{CP}_{43 / 346}$ rot. 130 .

92 Burke's Peerage (19 I 3): St. Aldwyn;

E.R.O., D/DDa M4. -

93 Lysons, Environs of London ( 1810$), \mathrm{i}$, $64 \mathrm{I}$; T. Wright, Hist. Essex, ii, 386.

94 Burke's Peerage (19 13), St. Aldwyn.

95 W. Hicks-Beach, $A$ Cotswold Family, Hicks and Hicks-Beach, 259 ; Burke's Peerage (1913), St. Aldwyn.

96 Hicks-Beach Estate Act, 40 Geo. III, c. 78 (priv. act).
97 Ibid. 


\section{A HISTORY OF ESSEX}

in 1790 to Hicks-Beach. 98 In I 800 a private Act of Parliament was passed to enable him to sell Chigwell and other property, which were still subject to the limitations imposed by the settlement under the will of Michael Hicks in 1764.99 The purchaser was James Hatch of Bromley (Mdx.), a wealthy malt-distiller. He paid over $\oint_{30}, 000$ for the manor of Chigwell (including West Hatch) and the estate of I, 430 acres. ${ }^{I}$

Hatch died in 1806 , leaving three daughters, Caroline wife of John Rutherforth Abdy, Jemima later wife of Christopher James Mills, and Louisa later wife of William Rufus Rous. The eldest daughter and her husband, who changed his name to Hatch-Abdy, acted as joint lords of Chigwell until her death without issue in 1838 . The lordship then passed to Caroline's nephew James Mills, who died in 1884 , also without issue. ${ }^{2}$ Mills was succeeded by William John Rous, son of the above Louisa. Since Rous's death in 1914 the manor has been invested in trustees, chief among whom was the Earl of Stradbroke. ${ }^{3}$ In 1839 James Mills's estate in Chigwell comprised about 900 acres. 4 This included Luxborough and Buckhurst (for both of which see below).

The original manor house of Chigwell Hall was beside the Roding where the R.A.F. Station now stands. 5 The moat which had surrounded the house survived until 1937, when it was filled in by the contractors building the R.A.F. Station. 6 The site had been deserted by the middle of the 17 th century and a new manor house built near the church and the site of the modern Bramstons.7 This house had evidently been rebuilt by about 1870.8 The house now known as Chigwell Hall is a little to the south of the previous house, on the opposite side of Roding Lane.9 The Manor House near Woodford Bridge has been greatly altered. It has fine wrought iron gates dating from the I 8 th century. It is now a convent.

In 1359 William de Melcesborn appointed attornies to give seisin of his manor of WEST HATCH to Nicholas Ploket. ${ }^{10}$ In I 389 William Tasburgh clerk and John Bekke granted to Sir Alexander de Goldingham lands and tenements in the vills of Chigwell and Barking called 'le Westhach and Bookhurst', once belonging to Nicholas Ploket and previously to William de Melcesborn.II West Hatch subsequently passed along with the main manor of Chigwell Hall. ${ }^{12}$ The two manors were usually described in the $I 7$ th century and later as the manor of Chigwell-and-West-Hatch. The present house of Great West Hatch dates from about 1800 . It is of stock brick with two stories. It is now used as a hospital (see Public Services).

The manor of APPLETONS, now known as Old Farm, was in Green Lane. It probably took its name from the family of Thomas Apilton, who with his wife Anne was party to a fine of 1402 relating to 180 acres of land and 20 acres of meadow in Chigwell. ${ }^{13}$ Later in the I $5^{\text {th }}$ century Philip Malpas held Appletons: it passed on his death to his daughter Elizabeth wife of Sir Thomas Cooke. ${ }^{14}$ She died about $\mathrm{I}_{4} 84$ having settled it upon her son John Cooke in reversion. ${ }^{\mathrm{Is}}$ John died in 1486 holding it as a tenant of John [George ?] Mannock, lord of Chigwell Hall; his brother Sir Philip Cooke was his heir. ${ }^{16}$ Appletons was later in the hands of William Cooke, probably the brother of Sir Philip. 17 In I 520 William sold the manor to Sir John Brygges and John Senewe of London. 18 Senewe died in 1537 leaving Appletons to the children of his sister Elizabeth, who had married John Hill. 19 About I 540 Tristram Cooke, son of'Thomas, son of the above William Cooke, sought possession of the manor. ${ }^{20} \mathrm{He}$ appears to have had some success, for in I 564 the children of John Hill took proceedings against his representatives for unlawful entry. ${ }^{21}$ The plaintiffs seem to have won their case: the Woolston court roll of 1567 recorded a declaration that Thomas Colshill, Thomas Fuller, and others who were shown to be the descendants of John Hill, jointly held the freehold of various lands, part of their ruined tenement called Appletons. ${ }^{22}$ Colshill sold his share to Thomas Fuller who died about 1575 leaving the house of Appletons, in which he lived, to his nephew Henry Fuller of North Weald Bassett, probably a relative of the Henry Fuller who owned Stocktons (sce below) about this time. ${ }^{23}$ Thomas Fuller had presumably bought the other shares in the property, in addition to that of Colshill.

Henry Fuller died in i602. ${ }^{24}$ Appletons passed successively to his son (d. 1623) and his grandson, both named Henry. ${ }^{25}$ Henry Fuller of Appletons appears in a presentment of I 668.26 Thomas Buckford held Appletons from $167 \mathrm{I}$ until his death in $1688.27 \mathrm{In}$ 1692 another Thomas Buckford sold it to Francis More. ${ }^{28}$ More's granddaughter Winifred Pitfield (d. I753) married Solomon Ashley, who died in 1778 holding Appletons. ${ }^{29} \mathrm{He}$ left it to Humphrey Stuart, presumably in trust for his son Solomon Ashley who was named as the owner in 1783.30 In 1802 Stuart sold it to John Blades, on whose death in 1830 it passed to his daughter Elizabeth, wife of John Blackburn.31 A Joshua Blackburn was given as the owner in 1839 : the farm then comprised 63 acres. ${ }^{32}$ Appletons was still owned by the Blackburns in 1873.33 The present farmhouse is a red-brick building that appears to date from the late Igth century.

The manor of BARRINGTONS (or LITTLE CHIGWELL) took its name from the family of Barrington which held the tenancy in demesne from the I 2 th to the I 6th century. It is probably identical with the estate of 2 hides and I 5 acres which Robert Gernon was said to hold in Chigwell in 1086.34 The overlordship appears to have descended like that of Battles in Stapleford Abbots (q.v.) until the death in 1267 of Richard de Montfichet. In I $274 \frac{1}{2}$ knight's fee in Chig-

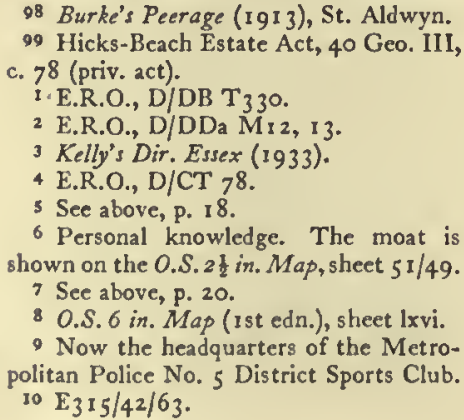

$13 \mathrm{E}_{326 / 5532}$.

12 Morant's statement (Hist. Essex, i, 166) that Walter Wrytell held West Hatch in 1475 is incorrect; Wrytell held the reversion only: $\mathrm{cf} . \mathrm{E}_{326 / 8684}$

13 E.A.T. N.s. $x, 318$.

14 Cal. Ing. p.m. Hen. VTI, i, p. $3^{8}$. Sir Tho. Cooke was Lord Mayor of London, 1463 .

is Ibid.

16 Ibid.

17 Visits. of Essex (Harl. Soc.), 39

$18 \mathrm{CI} / 390 / 29$.

19 P.C.C. 13 Dyngeley; $\mathrm{C}_{3} / \mathrm{sor} / 23$. $20 \mathrm{C} I / 969 / 43-44$.

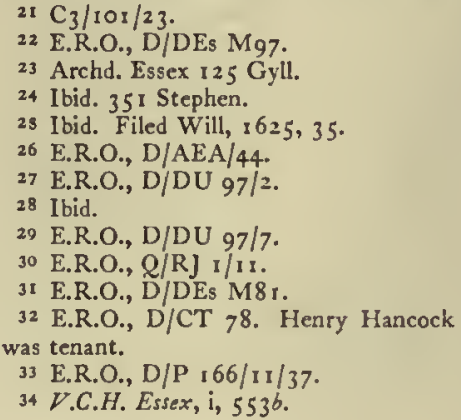


well and elsewhere was assigned to Philippa, wife of Roger de Lancaster and granddaughter of Margaret de Bolbec, sister of Richard de Montfichet. 35 On his death in I 360 John de Vere, Earl of Oxford, held $\frac{1}{2}$ knight's fee in Chigwell..$^{36}$ It had probably come to him by reversionary grant in the same way as Stansted Mountfichet. 37

The manor continued to be held of the earls of Oxford. In 1537 it was heid of the then earl as of the honor of Hedingham Castle. ${ }^{38}$

The de Veres appear to have had an earlier interest in the manor than that which came to them in the 14 th century. Early in the 12 th century an Aubrey de Vere, one of the ancestors of the earls of Oxford, enfeoffed Eustace de Barrington with land in Chigwell which afterwards descended in the Barrington family. ${ }^{39}$ It seems probable that before enfeoffing Barrington Aubrey de Vere had been tenant in demesne holding of Robert Gernon.

The family name of Barrington was derived from Barrington (Cambs.). Eustace de Barrington held land there in $1130.40 \mathrm{He}$ also held land in Hatfield Broad Oak which was later known as Barrington Hall, and he was a forester of Hatfield Forest, serving under Robert Gernon.4I His son Humphrey de Barrington received confirmation by Aubrey de Vere of the grant previously made to Eustace. ${ }^{42}$ Humphrey was succeeded by his son, another Humphrey, who was a minor at his father's death, which took place early in the reign of Henry II.43 The younger Humphrey lived until the early 13 th century; he was under-sheriff of Essex and Hertfordshire in I 197.44 He was succeeded by his son Sir Nicholas de Barrington who held the manor in 1249.45 Sir Nicholas was succeeded by his grandson, Nicholas, who was lord in 1274 and died about 1330.46 The manor then passed to the younger Nicholas's son Nicholas Barrington III, who settled it in I 344 on his eldest son John. ${ }^{17}$ John died about I 368 and his son and successor John about 1426.48 Several deeds relating to Chigwell between I 319 and 1384 suggest that the Barringtons were at least occasionally resident in Chigwell during that period. 49 Certain copyhold lands within the manor of Woolston were held by this family and the descent of these as shown in the court rolls was probably the same as that of the manor of Barringtons. 50

Thomas son of the last named John Barrington died in 1472 leaving his manor of Chigwell to his wife Anne for life with reversion to his son Edmund.sI Anne is said to have died on the day after her husband. 52 In 1479 Margaret, formerly the wife of a Thomas Barrington, was declared to have previously held the manor jointly with her husband. 53 On her death in that year

\footnotetext{
35 Cal. Close, $1272-9,82$.

36 Cal. Inq. p.m. x, p. 522 .

37 Cf. Morant, Essex, ii, 577.

${ }_{38} \mathrm{C}_{142} / 82 / 62$.

39 Morant, Essex, i, 166

to W. Farrer, Feud. Hist. Cambs. 233.

In the 12 th -14 th cents. the usual form of the name was Barenton.

41 G. A. Lowndes, "Hist. of Barrington family', E.A.T. N.s. i, 25 I f. The original charters used by Lowndes are now in the British Museum: Add. Ch. 28313-637. Some of them are calendared in Hist. MSS. Com. 7th Rep. App. pp. $537 \mathrm{f}$.

42 Morant, Essex, 766.

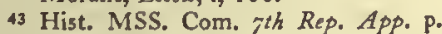
588.

4 E.A.T. N.s. i, 255 ; P.R.O. List of

Sheriffs, 48.

43 E.A.T. N.3. i, 257 ; B.M. Add. Ch.
}

Barringtons passed to her husband's brother Humphrey Barrington. Humplirey and his brother were probably sons of the Thomas Barrington who had died in 1472.54 Humphrey Barrington died before 1487 and was succeeded by his son Nicholas, who died in 1505.55 Nicholas's son and heir Nicholas died in $1515.56 \mathrm{John}$ Barrington, son of the younger Nicholas, died in 1537.57 He was succeeded by his son Thomas Barrington, who sold the manor of Barringtons in $156_{3}$ to Thomas Wiseman of Great Waltham, 58 thus breaking a connexion which had lasted for as long as 450 years. 59

Thomas Wiseman died in the year that he bought the manor and was succeeded by his third son Stephen, who died childless in I 567.60 Stephen's heir was John Wiseman, son of his brother William.61 In 1573 William Tyffin of Wakes Colne did homage for Barringtons, presumably on account of his marriage to Mary, widow of Stephen Wiseman, who had a life interest. ${ }^{62}$ During his lifetime Stephen had demised the manor with certain lands in Chigwell to John Morley and one Goldringe who were to pay rent to him and after his death to his widow; this rent was in arrear and was the cause of legal proceedings. ${ }^{63}$ John Wiseman died in 1615 , leaving Barringtons to his eldest son Thomas, who conveyed it in 1617 to John Hawkins. ${ }^{64}$

In 1626 Hawkins and his wife Sarah sold the manor to William Rolfe.65 Rolfe sold it in 1629 to Henry Jackson, who in 1630 and 1634 claimed forest rights in respect of the manor.66 In 1639 Jackson sold Barringtons to Thomas Wilmer, whose father had already purchased Rolls, the mansion house of the manor. ${ }^{67}$ The first surviving court roll of the manor (1653) gives as lords Edmund Denny and Thomas Wilmer. 68 Wilmer was a major in the royalist army; he had probably sold half the manor to Denny to pay the fine for his delinquency.69 In 1655 . he sold the remaining half to Robert Abdy of Albyns (in Stapleford Abbots, q.v.) and John Chapman of London.70 Abdy and Chapman were apparently trustees for Robert Abbott of London, who made his will in 1657 , leaving a moiety of Barringtons to his wife for life and in 1658 added a codicil leaving all his manors to his executors in trust to provide portions for his children.71 The executors were Abbott's wife Bethia and John Chapman her brother. In I 668 $\mathrm{Abdy}$ and Chapman conveyed this half of the manor to Sir Eliab Harvey and John Prestwood. ${ }^{72}$ Eliab died in 1699 , leaving all his manors in Essex to his son William.73

Edmund Denny, who had acquired the other half of Barringtons from Thomas Wilmer, died in 1656 , leaving it to his wife Anne for life with reversion to his cousin William Gardner.74 In 1657 Anne married Francis Comyn of London, vintner, and in the same year

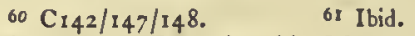
sister of Andrew Jenour of Great Dun-


222 ; Visits. of Essex (Harl. Soc.), 222. $63 \mathrm{C}_{3} / 327 / 2$.

$64 \mathrm{C}_{142 / 359 / 1} 15$; Morant, Essex, i, 166 . $65 \mathrm{CP}_{25}(2) / 415$ Mich. 2 Chas. I; $\mathrm{CP}_{43} / 176$

${ }_{66} \mathrm{CP}_{43} / 184 ; \mathrm{C}_{99} / 130 \mathrm{~m} .88 ; \mathrm{C}_{99 / 132}$ m. 16 .

${ }_{67} \mathrm{C} 66 / 3067 \mathrm{~m} \cdot \overline{3}_{4} ; \mathrm{CP}_{25}(2) / 418$

Mich. I 5 Chas. I.

68 E.R.O., D/DU 97/1.

69 Cal. Ctee. for Compounding, 2535.

$70 \mathrm{C}_{54} / 4020 \mathrm{~m} .2 \mathrm{I}-22$

$71 \mathrm{P} . \mathrm{C} . \mathrm{C} 305 \mathrm{~W} 00 \mathrm{tton}$

${ }_{22} \mathrm{CP}_{25}(2) / 653$ Hil. 19 \& 20 Chas. II.

73 P.C.C. 42 Pett.

74 P.C.C. 3 I 7 Berkeley 


\section{A HISTORY OF ESSEX}

Gardner surrendered to Comyn all his rights in the halfmanor. 75 The court roll for 1659 names as lords Abdy, Chapman, Thomas King, John Jekyll, Edward Cotton, and John Berrisford. ${ }^{76}$ The last four were presumably trustees to the settlement made on the marriage of Anne and Francis Comyn. Anne died in 1694 and Francis in $1697 .{ }^{77}$ Their half of the manor passed to their son Francis Comyn who sold it in 700 to William Harvey, who thus became owner of the whole manor. ${ }^{78}$

William Harvey died in I $73 \mathrm{I}$ and was succeeded by his son, also named William, who died in 1742.79 The younger William was succeeded by his son, a third William Harvey, who died in $1763 .{ }^{80}$ The manor then passed to William Harvey (IV), son of the last owner, who died unmarried in 1779 , leaving Barringtons to his brother Eliab, later Admiral Sir Eliab Harvey. ${ }^{81}$ The admiral died in 1830 without surviving male issue. He left the bulk of his estate, including Barringtons, to his eldest daughter Louisa, wife of William Lloyd of Aston Hall (Salop). In I 839 the estate in Chigwell consisted of about 420 acres. ${ }^{82}$ Lloyd and his wife acted as joint lords of the manor until his death in $\mathrm{J} 843$, after which Louisa was sole lady until her death in 1866.83 . Her son Richard T. Lloyd succeeded to the manor and died in 1 898. Barringtons then passed to Richard's eldest son Lt.-Gen. Sir Francis Lloyd, who died without issue in 1926. The manor then passed to the Revd. Rossendale Lloyd, brother of Sir Francis. 84 Soon after this the manorial rights were sold to Philip Savill, from whom they passed to his son Mr. Lawrence L. Savill of Comenden Manor (Kent) who is their present owner. 85 The freehold of the Barringtons estate, however, remained in the Revd. Rossendale Lloyd who died in I 940 and was succeeded by his son Mr. Andrew F. Lloyd. 86

Rolls House, the capital mansion of the Barringtons estate in modern times, is now (1953) in process of demolition, much of the older part having already disappeared. It was a two-story building with attics, partly timber-framed and partly of brick. The former kitchen block was built about 1600 and late in the 17 th century the north-east and north-west wings were built or rebuilt, making the house L-shaped. Early in the 18 th century a long addition was made on the south-east side of the north-east wing and there were later additions on the south and south-west. ${ }^{87}$

The manor of $B U C K H U R S T$ alias MUNKENHILL alias MONKHAMS probably formed part of Barringtons (see above) until I I 35 , when William de Montfichet granted to the abbey of Stratford Langthorne his wood of Buckhurst. ${ }^{88}$ The grant was later confirmed by Henry I1.89 The abbey's estate was increased by other grants: in 1217 Matthew de St. Tronius and Rose his wife quitclaimed to the abbey a third part of 55 acres in Chigwell which was her dower from her former husband Geoffrey Levenoth, and in
1230 William Fitz Edric granted to the Abbot of Stratford $\frac{3}{4}$ carucate and $8 \frac{1}{2}$ acres in Chigwell. 90 In I 240 the Abbot of Stratford came to an agreement with the Abbot of Waltham, a neighbouring landowner, concerning the agistment of cattle.9I In 1253 Henry III granted the Abbot of Stratford free warren in his demesne in Chigwell and Woodford.92 The boundary of the parish at Buckhurst Hill was for long ill defined and the manor of Buckhurst seems to have extended into Wood ford.

Stratford Abbey retained Buckhurst until the Dissolution.93 In 152 I John Saunders had a 4I-year lease from William Etherway, then abbot, of a tenement called 'Buckhurst alias Monkyn'.94 By I 527 the lease had passed to Ralph Johnson of Woodford.95 In 1547 the king granted a tenement called Buckhurst and a grove called Monk Grove, formerly belonging to Stratford Abbey, to John Lyon alderman of London and Alice his wife, to hold by $\frac{3}{40}$ knight's fee. ${ }^{96} \mathrm{Sir}$ John Lyon died in 1564 seised of this property. ${ }^{97} \mathrm{He}$ was succeeded by Richard Lyon, son of his brother Henry, who died in 1579.98 Richard's son Henry Lyon died in I590.99 In I6I I Henry's son George Lyon leased the manor to the sitting tenant Joan Newman for 21 years. In I6I 6 John Lyon sold the property to Thomas Hill of London, ${ }^{2}$ and Hill sold it in 1649 to William and George Nutt who were brothers. ${ }^{3}$

George Nutt was dead by 1656 when his son George sold his interest in Monkhams to his uncle William Nutt.4 In 1669 William Nutt settled it on his son on the marriage of the latter. 5 The younger William died in 1721 , leaving the manor to his son William who sold it in 1725 to William Cleland of Woodford. ${ }^{6}$ Cleland sold Monkhams in I 735 to Sir Joseph Eyles, Kt., who was already owner of the neighbouring estate of Luxborough (see below). 7 Eyles died in 1740 and his widow and executors sold the manor in 1746 to Robert Knight, Ist Baron Luxborough, whose father had bought Luxborough from them three years earlier. ${ }^{8}$ Lord Luxborough sold both properties in $175^{\circ}$ to James Crokatt. ${ }^{9}$ Crokatt sold them in 1767 to Baker J. Littlehales, who conveyed them a few days later to Sir Edward Walpole, K.B. ${ }^{10}$ Walpole sold them in I775 to Samuel Peach. II In I78 I Peach went bankrupt and Buckhurst and Luxborough were bought from his creditors by Sir Edward Hughes, whose widow Ruth sold them in 1799 to James Hatch, lord of Chigwell Hall. ${ }^{12}$ Thereafter they passed along with Chigwell Hall. In 1839 the farm of Monkhams included 178 acres and was let by James Mills to William Death. ${ }^{13}$ The farm survived until 1936 , when it was broken up for building. The house, which was then demolished, stood at the south-west corner of Lords Bushes. ${ }^{14}$ Its site is now Farm Way and Farm Close.

\footnotetext{
$75 \mathrm{C} 6 / 139 / 54,142 / 39 ; \mathrm{CP}_{25}(2) / 552$ Mich. 1657. 76 E.R.O., D/DU 97/r. 77 E.R.O., D/DEs MI04; P.C.C. 90 Pyne.

${ }_{78} \mathrm{CP}_{25}(2) / 830$ Trin. $12 \mathrm{Wm}$. III.

79 Morant, Essex, i, 167. 80 Ibid.

81 P.C.C. 204 Warburton. For the admiral see above, Worthies.

82. E.R.O., D/CT 78.

83 E.R.O., D/DU $97 / 9$.



is Inf. from L. L. Savill, Esq.

86 Burke's L.G. (17th edn.), p. $153^{8 .}$

87 Hist. Mon. Com. Essex, ii, 48 .

88 V.C.H. Essex, ii, I30. For this manor
}



I E.R.O., D/DB T 347 (deed of 1649 ); $\mathrm{C}_{3 / 359 / 34}$. 2 Ibid. 3 E.R.O., D/DB T347. 4 Ibid.

5 E.R.O., D/DB T 345 .

6 P.C.C. 200 Marlboro'; E.R.O., $\mathrm{D} / \mathrm{DDa} \mathrm{T}_{42}, 43$

7 Guildford Museum Deeds 5r/3/50.

8 Ibid. Knight's father had originally purchased Lux borough (see below) in 1716 . - E.R.O., D/DDa T42.

10 Ibid. 11 Ibid.

12 E.R.O., D/DDa T39, 40; ibid. D/DB T 352 .

13 E.R.O., D/CT 78

i4 Ramsey, Monkhams, 10. 
The manor of GRANGE, which gave its name to Grange Hill, was originally part of Chigwell Hall (see above). In $125^{8}$ William de Goldingham and Aline his wife confirmed to Robert, Abbot of Tilty, gifts to the abbey of 3 messuages and $234 \frac{1}{2}$ acres of land in Chigwell. Is The original donors were Herbert the chaplain, John Fitz Gilbert, Margery de Chigwell, and John the Miller and Agnes his wife, all of whom were evidently tenants of Chigwell Hall. The land so granted became a grange of Tilty Abbey and remained in the possession of the abbey until the Dissolution. ${ }^{16}$ In 1536 William Baker of Epping, carpenter, rendered his first account to the king as lessee of Chigwell Grange. He held the manor on a $3 \mathrm{I}$-year lease from Michaelmas 1532 , at an annual rent of 6.3 10s. ${ }^{17}$ In 1538 the manor was bought from the Crown by 'Thomas Addington of London, skinner, for $f 60.18$ Addington died in 1543 and was succeeded by his son Thomas. ${ }^{19}$ The younger Thomas conveyed the manor to James Altham of London, clothworker, at a date not exactly known, and in 1555 Altham granted it to Anthony Browne of South Weald.20 In I 555 the manor was said to consist of 4 messuages, 60 acres of land, 200 acres of meadow, 40 acres of pasture, and ro acres of wood: it would thus appear to have been reduced by about 100 acres since the I 3 th century. Later in 1555 Browne sold I $4 \frac{1}{2}$ acres of land in Chigwell, of which II $\frac{1}{2}$ acres were part of the manor of Grange, to John Stonarde and others. This small holding later became the endowment of a road charity founded by Joan Sympson. ${ }^{2 I}$

In $155^{8}$ Browne endowed his newly founded grammar school at Brentwood with this manor and other property, confirming the grants by his will of 1565.22 The grammar school remained owners of this estate until about 1900 , since when various sales have taken place, mostly for building. In I 839 the property consisted of some 140 acres. ${ }^{23}$ Grange farm-house was a bout $300 \mathrm{yds}$. east of the junction between Hainault Road and Manor Road.24

'The manor of KING'S PLACE alias LANG. FORDS alias POTELLS, at Buckhurst Hill, probably originated in the purchase by Edward III (through his son John of Gaunt) in I 360 of a messuage and 92 acres of land from Matthew de Torkeseye. ${ }^{25}$ In $\mathrm{I} 372$ Alexander de Goldingham, lord of Chigwell Hall, released to the king all his rights in this property 'now commonly called the Neweloggelands in Chigwell'.26 From this release it is clear that Matthew de Torkeseye had held the estate as a tenant of the manor of Chigwell Hall. In 1378 Alan de Buxhull was granted custody of the king's new lodge in Waltham Forest, free of rent on condition that he kept the houses in repair. ${ }^{27}$ In I 476 Edward IV enlarged the estate by the purchase of a neighbouring cstate from Robert Langford and others. ${ }^{28}$ Soon after this Edward IV granted the custody of the whole property for life to Sir John Risley and in I 485 Henry VII confirmed the grant.29 Risley appears to have later received a grant of the estate in tail male, but he died without a male heir and in 1513 King's Place was granted in tail male to William Compton..$^{30}$ Compton was later knighted and died in 1528 , leaving a son and heir Peter, who died in $1539 .{ }^{31}$ Peter's son Henry was created Baron Compton in 1572 and died in 1589.32 William, 2nd Baron Compton, negotiated with the queen in 1596 for the reversion of the manor of King's Place (in default of the issue of the Ist baron), but nothing appears to have come of this. ${ }^{33}$ Early in 1597 the queen granted the reversion to Thomas Spencer and Robert Atkinson.34 During the 16th century the estate was leased to at least two different tenants. In his will dated I 54 I William Rolte, tenant of Chigwell Hall, mentioned his lease of King's Place. ${ }^{3 s}$ In 1576 Richard Hayle left his lease of the property to his wife Agnes. 36

Although there was no failure of the heirs male of the Ist Baron Compton King's Place seems to have passed out of the hands of the 2nd baron soon after I 597. In 16I2 Thomas Covell described himself in his will as of King's Place. ${ }^{37}$ His daughter Elizabeth had married Roger Forster in 1610.38 She died in or before 1622, when Forster married Mary, eldest daughter of John Penington. ${ }^{39}$ In 1624 King's Place was settled on Forster and Mary. 40 Forster died in I6 33 and Mary married Michael Ernle, who died in 1645.4I Mary finally married Sir Thomas Perient and lived at King's Place until her death. ${ }^{42}$

The estate was, however, settled in 1657 on her daughter Mary Ernle on the marriage of the latter to Henry Goodricke of Grays Inn.43 Mary and Henry are said to have sold it a year later to William Livesaye, 44 whose son and namesake later sold it to Elizabeth Colwall, widow, with successive remainders to her sons John and Arnold. John Colwall died without issue before 1680 , when his mother settled King's Place upon Arnold Colwall.45 By I705 the manor had passed to Arnold's son, Daniel Colwall of the Friary, Guildford (Surr.). ${ }^{46}$ Arnold's widow Susanna married Foot Onslow and appears to have had some interest in King's Place in 1705 and 1708.47

In I 7 I 6 Thomas Gibson and John Jacob, trustees under Daniel Colwall's will, sold the property to Percival Chandler, who lived at the farm until about $1730.48 \mathrm{He}$ is said to have sold King's Place in I74I to Oliver Marton, who died in $1744.4^{49}$ Marton was succeeded by his son Edward, who died in 1758 , leaving the property to his brother the Revd. Oliver Marton.50 A year later Oliver sold King's Place to
15 Feet of $F$. Essex, i, 225.

16 In 129 I it was valued at 64 1 8 s. $4 d$.: Tax, Eccl. (Rec. Com.), $25 b$.

17 E.R. xix, I.

${ }_{18} \mathrm{C}_{142 / 70 / 32}$. 19 Ibid.

20 Cal. Pat. I $554-5,234,255$. Later in 1555 Anthony Browne was granted custody of the person and lands of Ralph Addington, son of the younger Thomas, who was a congenital idiot: ibid. 73 .

21 Cal. Pat. I 554-5, I2; E.R. xix, I. See above, p. I9; Charities.

22 P.C.C. 20 Stonarde.

23 E.R.O., D/CT 78.

24 O.S. 6 in. Map (ist edn.), sheet lxvi.

25 Feet of F. Essex, iii, $128 ; E . A . T$. N.5. $x, 313-14$.

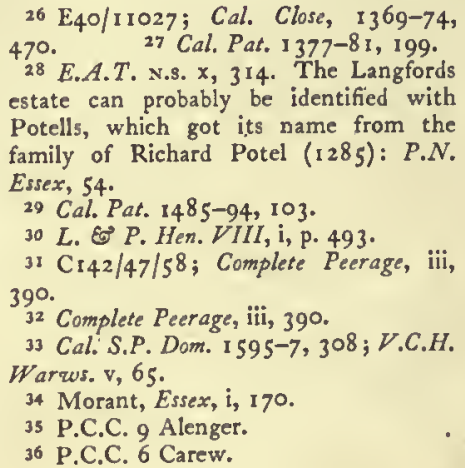




\section{A HISTORY OF ESSEX}

Robert Jones of Babraham (Cambs.). ${ }^{51}$ Jones died in 1774, leaving an only daughter Anne who married General J. W. Adeane, who inherited all Jones's property. ${ }^{2}$ The general died in 1782 and was succeeded by his son Robert Jones Adeane. ${ }^{3}$ On Robert's death in 1810 King's Place passed to Henry J. Adeane, who died in 1847.54 In I 839 the property consisted of 156 acres.5s In 1853 the executors of $\mathrm{H}$. J. Adeane sold it to the National Freehold Land Society who shortly after broke it up for building development. ${ }^{36}$ The name of this ancient manor is retained in King's Place and King's Avenue, Buckhurst Hill.

The manor of $L U X B O R O U G H$ probably took its name from the family of Loughteborough which lived in Chigwell in the I $4^{\text {th }}$ century. William de Loughteborough was named in a Forest Roll in 1324 and in 13 I 6 Henry Doule and Eve his wife quitclaimed to William de Loughteborough a messuage and 132 acres in Chigwell.57 Robert de Loughteborough and Margaret his wife were assessed to the subsidy of I 390.58 In 1559 Francis Saunders and Margaret Valentyne, widow, sold the manor of 'Loughbroughes' to John Stoner, who built himself a house there.59 Stoner died in 1579 , leaving the manor and the house to his wife Anne with reversion to his only daughter Susan, wife of Sir Robert Wroth, lord of Chigwell Hall (see above). ${ }^{60}$ In I 580 Anne conveyed her interest to Robert and Susan, ${ }^{61}$ and Luxborough passed along with Chigwell Hall until 1642 , when the estates of John Wroth were divided. Luxborough then passed to John, elder son of Henry Wroth and nephew of the above John Wroth, by virtue of a settlement made in 1640 on the marriage of John the nephew with Anne Gallard, widow.62 Anne's will, dated 1675, was cited in legal proceedings in 1676.63 She left Luxborough for life to her son by her first marriage, John Gallard, with successive remainders to her son John Wroth for life and her grandson John Wroth for ever. ${ }^{64} \mathrm{Her}$ husband John Wroth had died in $1662 .{ }^{65}$ John Wroth her son died in 1708.66 In 1716 her grandson John Wroth sold Luxborough, then heavily mortgaged, to Robert Knight, cashier of the South Sea Company. ${ }^{67}$ After the failure of the company in 1720 Knight's estates, with those of the governors and directors, were vested in trustees and in 1724 the manor of Luxborough was bought from these by Sir Joseph Eyles, Kt. ${ }^{68}$ Eyles died in 1740 and in 1743 his trustees contracted to sell the property to Knight, who had returned from abroad on receiving a royal pardon for his activities in the South Sea Company.69 Knight died in 1744 , before the completion of the sale. Before his death he had settled his estates on his son, Robert
Knight later created Baron Luxborough, and the manor passed to the son on completion of the sale. ${ }^{70}$ In I 746 Eyles's trustees also sold Buckhurst to Lord Luxborough, and the two manors subsequently descended together, becoming part of the Chigwell Hall estate in 1799.71

The 16th-century manor house at Luxborough built by John Stoner was rebuilt, probably in $1716-20$, by Robert Knight. ${ }^{22}$ Prints of 1787 and 1788 show respectively the south and east fronts of the house. ${ }^{73}$ It was of two stories and appears to have been of brick with stone or plaster dressings. To the north and east were lower two-story ranges of stables and outbuildings. The south or garden front had a central doorway with a small classical porch. The entrance front on the east side was more impressive. Between two projecting wings was a recessed portico of five bays. Corinthian columns the full height of the building supported an entablature and pediment. Flanking this the parapet was balustraded. The house was demolished about I 800 by James Hatch. ${ }^{74}$

The small manor of STOCKTONS alias SERFEANTS lay in Gravel Lane. John Stokton was mentioned in the Woolston court rolls in $1462.75 \mathrm{He}$ was Iater knighted and became Lord Mayor of London in $1470.76 \mathrm{He}$ died about 1473 , leaving his Chigwell property to his younger son William, who died in 1483.77 In 1543 Edward Brockett conveyed Stocktons to John Potter. ${ }^{78}$ Potter died about 1546 , leaving all his lands in Chigwell to his son Thomas, who jointly with his wife Margaret conveyed Stocktons in I 567 to John Watson and Elizabeth his wife.79 In 1590 Henry Fuller of North Weald Bassett left Serjeants to his son Richard. ${ }^{80}$ Henry Fuller of Serjeants was mentioned several times in the Woolston court rolls between I6I 4 and $\mathrm{I}_{2} \mathrm{I}^{8 \mathrm{I}}$ and the property seems to have remained in the Fuller family until the end of the I 7 th century. About 1700 John Fuller sold it to Edward Green who died in I 707, leaving his 'farm in Gravel Lane' to his son John. ${ }^{82}$ John Green died soon after, leaving it to his mother Ann Green. ${ }^{83}$ In 1709 she left her freehold estate called Serjeants to her son Charles Green. ${ }^{84} \mathrm{By}$ 1763 it had passed into the hands of the Harveys, owners of the manor of Barringtons: in that year it was let by Emma Harvey, as guardian of her son William Harvey. ${ }^{85}$ The lease described the property as fields, barns, \&c., containing $2 \mathrm{I}$ acres. After the 16 th century the farm was never termed a manor. In 1687 it was even questioned whether it was a freehold. ${ }^{86}$

In 1066 the manor of WOOLSTON was held by Earl Harold. It was then taken by King William and in 1086 was held by him in demesne. ${ }^{87}$ During the
sI Lysons, ibid. $\$ 2$ Ibid.

s3 Burke's L.G. (I $5^{\text {th }}$ edn.), p. I I.

54 Ibid.

ss E.R.O., D/CT 78.

56 E.R.O., D/P I 66/1 1/1 7-20.

$57 \mathrm{E}_{32} / \mathrm{x} 6$; Feet of F. Essex, ii, 165.

s8 Er $79 / 147 / 60$.

so $\mathrm{CP}_{25}$ (2)/126/1607; for the house see below.

60 P.C.C. 50 Arundell.

6I E.R. xiv, 2.

62 E.A.T.N.s. viii, $347-8$

$63 \mathrm{CrO} / \mathrm{I} 81$.

64 Ibid.

6s Ibid.

66 E.A.T. N.s. viii, $\mathrm{I} 8 \mathrm{I}$.

67 E.R.O., D/DDa T37. For the

Knights see Complete Peerage, iii, I 10.

68 Ibid. For Eyles see Burke's Extinct

and Dormant Baronetcies, 190. He was

Sheriff of London 1726 . His brother Sir
John Eyles, Bt., was a governor of the South Sea Co. Sir Joseph bought Buckhurst (see above) in 1735 .

69 E.R.O., D/DDa T 37.

70 E.R.O., D/DDa T 37.

71 See Buckhurst.

72 Hist. Essex by Gent. iv, I I.

73 E.R.O., Prints, Chigwell. They are from Harrison's Picturesque Views of the Principal Seats (c. I790) which states, probably in error, that Lord Luxborough built the house. And see plate facing p. 30 74 Ogborne, Hist. Essex, 245-6. The house is shown on the O.S. I in. Map (Ist edn.) for which surveys were made about 1797. Hatch died in 1806 , having acquired the house in 1799 .

78 E.R.O., T/P I7. No mention has been found of tenants in Chigwell named Serjeant from whom the alternative name

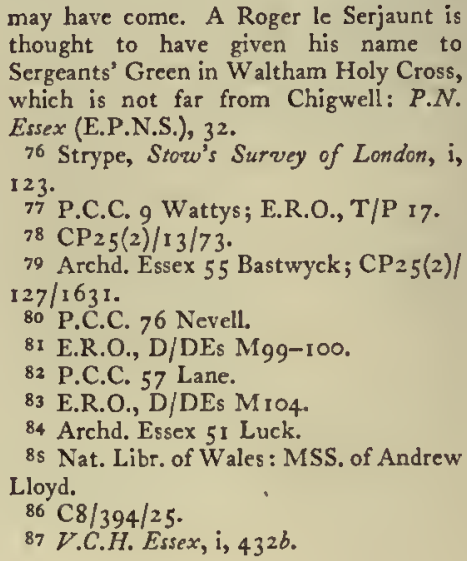

may have come. A Roger le Serjaunt is thought to have given his name to Sergeants' Green in Waltham Holy Cross, which is not far from Chigwell: P.N. Essex (E.P.N.S.), 32.

76 Strype, Stow's Survey of London, i, 123 77 P.C.C. 9 Wattys; E.R.O., T/P I 7. ${ }_{78} \mathrm{CP}_{25}(2) / 13 / 73$.

79 Archd. Essex 55 Bastwyck; $\mathrm{CP}_{25}(2) /$ $127 / 1631$

80 P.C.C. 76 Nevell.

8I E.R.O., D/DEs M99-100.

82 P.C.C. 57 Lane.

83 E.R.O., D/DEs M IO4

84 Archd. Essex 5 I luck.

$8 \mathrm{~s}$ Nat. Libr. of Wales: MSS. of Andrew

Lloyd.

$86 \mathrm{C} 8 / 394 / 25$

87 V.C.H. Essex, i, $43^{2 b}$. 


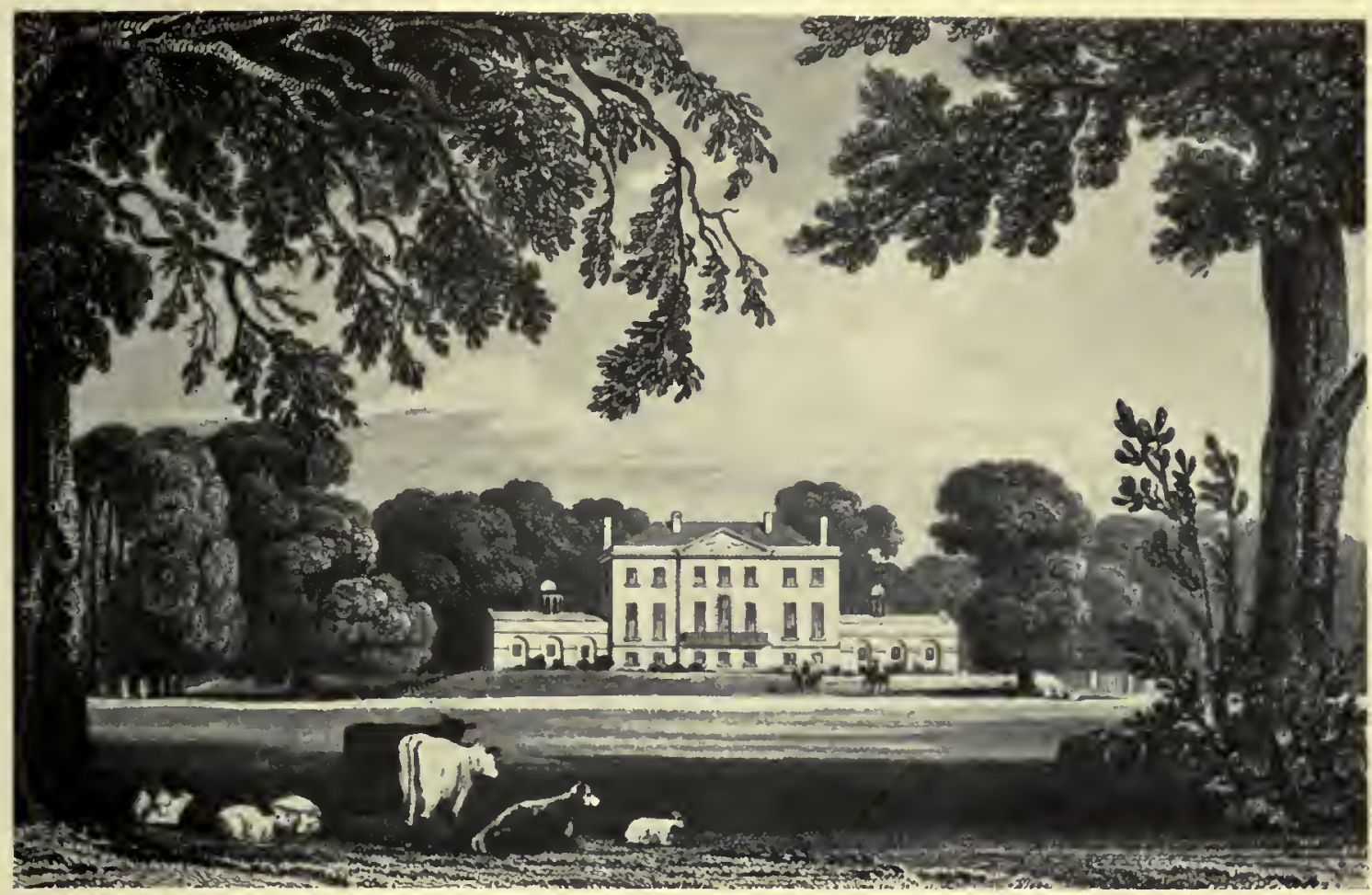

Dews Hall, Lambourne

Refronted $c .1740$, demolished $c .184^{\circ}$



Luxborough House, Chigwell

Rebuilt I 7 I6-20, demolished c. I 800 

12 th century the manor was granted to the Sanford family to hold in serjeanty by virtue of the office of chamberlain to the queen. 88 A John de Sanford held the manor in $1210-12^{89}$ and Cecily de Sanford in 1219.90 Gilbert de Sanford held Woolston in 1236 , in which year he officiated at the coronation of Eleanor of Provence. ${ }^{91}$ He was still living in 1248,92 but was dead by April 1249 when the wardship of his daughter and heir Alice de Sanford was bought by Fulk Basset, Bishop of London.93 In June 1249 the bishop sold the wardship to Hugh de Vere, Earl of Oxford, who married Alice to his son and heir Robert.94 In 1259 John de Rivers, lord of Ongar hundred, granted to Robert de Vere and Alice his wife a release of $4 d$. rent at their view of frankpledge at Woolston.9s In 1265 Robert's estates were forfeited for his part in the Barons' War; the township of Woolston was then said to be worth $f_{6} 6$ s. $8 d$. a year. 96 Robert recovered his estates under the Dictum of Kenilworth, but before this, in October I 265, all Alice's hereditary lands had been restored to her. 97

In 1284 Robert and Alice granted the reversion of Woolston after their deaths to their daughter Joan and her husband William de Warenne, son and heir of John de Warenne, Earl of Surrey (d. 1 304).98 Robert died in 1 296; Woolston was then being held of him and Alice by William le Plomer.99 Alice died in 1312 She had outlived both her daughter Joan and William de Warenne and Woolston passed to John, Earl of Surrey, son of Joan and William. I Before I 32 I John conveyed the manor to his sister Alice and her husband Edmund Fitz Alan Earl of Arundel. ${ }^{2}$ Woolston did not escheat after the execution of Arundel in 1326 because $\mathrm{jt}$ was his wife's inheritance. ${ }^{3}$ Alice dled between $133^{\circ}$ and $133^{8}$, and the manor passed to her son Richard Fitz Alan, who had been restored to the earl dom of Arundel in 1330.4 In 1345 Woolston was being held for life by Isabel Dispenser, the divorced wife of Richard.s Richard died in 1376.6 The manor passed to his son Richard, Earl of Arundel, who was executed in 1397.7 The attainder of this earl was reversed in 1400 and his titles and estates were restored to his son Thomas, who in 1405 granted Woolston for life to his servant John Wele. ${ }^{8}$ Thomas died in 1415 and John Wele in 1420.9 Shortly before he died Wele was involved in a Chancery action against the king in respect of Woolston. ${ }^{10}$ In 1421 the manor was divided between Thomas's three daughters, Elizabeth, Duchess of Norfolk, Joan, Lady Bergavenny, and Margaret, wife of Rowland Lenthal. II

In 1425 , shortly before her death, the Duchess of

88 J. H. Round, Kings Sergeants and Officers of State, $132 \mathrm{f}$. Woolston was one of five manors ippurtenant to this serjeanty, the others being Margaretting and Fingrith (in Blackmore) in Essex, and Great Hormead and Nuthampstead (in Barkway) in Herts.

89 Red Bk. of Exch. 507 ; Bk. of Fees, 121. 90 Bk. of Fees, 275.

9 I Ibid. 589 ; J. H. Round, op. cit. 133.

$92 B k$. of Fees, $1361,1412$.

93 Complete Peerage, $x, 214$

94 Ibid.

95 Harl. Chart. 55 D. 24.

${ }^{\circ}$ Cal. Chart. R. ii, 57; Cal. Inq. Misc.

i, p. 200 .

97 Complete Peerage, x, 216.

$98 \mathrm{Cal}$. Pat. $1281192,173$.

99 Cal. Inq. p.m. iii, p. 230 ; Cal. Fine $R$. $1272-1307,378$.

I Cal. Inq. p.m. v, p. 2 I6.
Norfolk granted her third part of Woolston to Norman Babington and Margaret his wife. ${ }^{12}$ Norman died holding it in 1434 and Margaret held it at her death in $145^{1 .} .^{13}$ It then passed to Norman's brother Sir William Babington. ${ }^{14}$ In the same year Sir William settled the manor upon his sons William, Robert, and Thomas Babington and the heirs of Robert.15 Sir William died in 1454, his son William in 1474 and Thomas in 1471,16 but it is not known how this third of the manor passed between $147 \mathrm{I}$ and 1485 , when it had come to William Scott (see below).

In 1428 Joan Lady Bergavenny enfeoffed Robert Darcy and others with her third part of Woolston. ${ }^{37}$ In 1457 the surviving feoffees settled the property on Joan's grandson, Thomas Ormond, with successive remainders to his brothers John Ormond and James, Earl of Wiltshire. 18 In 1476 Thomas Ormond conveyed it to William Scott and Robert Hardyng. ${ }^{19}$

After the death of Margaret Lenthal her third part of the manor was held by her husband until he died in 1450. It then passed to John de Mowbray, Duke of Norfolk, grandson of the above Elizabeth, Duchess of Norfolk, and to George Neville, later Lord Bergavenny, great-grandson of Joan, Lady Bergavenny.20 In the division of Margaret Lenthal's inheritance between Mowbray and Neville the third part of Woolston was assigned to Mowbray.21 In 1468 John de Mowbray, Duke of Norfolk, conveyed the property to Thomas Hoo and others.22 This was the first of a complicated series of conveyances between various parties, including George Neville, by which this third of Woolston was conveyed to William Scott and Robert Hardyng. ${ }^{23}$

By 1485 all three parts of the manor had been united in the hands of William Scott, who had been acting as lord three years earlier when he signed an agreement between his bailiff and his tenants, detailing the services to be performed by the latter. 24 He died in $149 \mathrm{r}$, leaving Woolston to his fifth son George, who died without issue in 1534.25 George probably lived at Woolston Hall. At his death the manor was said to include ro acres of arable, 24 acres of meadow, 80 acres of pasture, 8 acres of wood, and $f_{0} 9$ rent. ${ }^{26}$

George Scott's heir was Walter Scott, lord of the manor of Stapleford Tawney (q.v.), who was the grandson of John Scott (d. I 527 ), eldest son of William Scott (d. I 491).27 Walter Scott died in $155^{\circ}$ and his son Roger in $1585 .{ }^{28}$ George, son of Roger Scott, died in $1589 .{ }^{29}$ Neither Walter nor Roger nor George acted as lord of the manor, for by the will of George son of William Scott a 99-year lease of Woolston had been granted to William's sixth son Hugh. ${ }^{30}$ Hugh
2 Feet of F. Essex, ii, 204.

3 Complete Peerage, i, 242.

4 Ibid. 243.

5 Cal. Pat. $1343-5,488$.

6 Complete Peerage, i, 244.

$7 \mathrm{C}_{3} 36 /$ ror

$8 \mathrm{Cr}_{3} 8 / 45$.

- Ibid.; Complete Peerage, i, 246.

10 Cal. Close, 1419-22, I 6 .

I1 Cal. Fine $R$. 1413-22, 389-9o. Elizabeth was widow of Thomas de Mowbray, Duke of Norfolk (d. 1399). Joan was widow of William Beauchamp, Ist Lord Bergavenny.

12 Feet of F. Essex, iv, 6; Cal. Pat. $1422-9,341$.

${ }_{13}$ Cal. Close $1429-35,33^{8-9} ; \mathrm{Cr}_{39} / 62$; $\mathrm{C}_{139 / 142 .}$.

14 Ibid.; Cal. Fine R. 1445-52, 222. is Cal. Pat. 1446-52, 5 12.

$16 \mathrm{~J}$. C. Wedgewood, Hist. Parliament:



Biographies 1439-1509, 31-32.

17 Feet of $F$. Essex, iv, 12; Cal. Pat. $1422-9,486$; E.R.O., D/DP T 51 .

18 Cal. Pat. 1452-61, 355 ; E.R.O. D/DP T5I.

is E.R.O., D/DP A470. Hardyng was London goldsmith and was probably acting as Scott's financial agent.

$20 \mathrm{Cr}_{33} / 143$.

21 Cal. Fine $R$. 1445-52, 266.

22 E.R.O., D/DP T 51.

23 Ibid.; E.R.O., D/DP A468, 460 The conveyances cover the period $1468-$ 73. 24 E.R.O., D/DEs M95. 25 P.C.C. 19 Dogett; Cal. Inq. p.m. Hen. VII, i, p. 334. For the early history of the Scotts see E.R. lxii (Jan.), Pp. 42-44. ${ }_{26} \mathrm{Cr}_{12} / 82 / 4$. $27 \mathrm{Cr}_{12} / 82 / 4$. $28 \mathrm{C}_{142 / 208 / 18 \mathrm{I}}$.

29 Crisp, Par. Reg. of Stapleford Taruney, $3^{8 .}$ 


\section{A HISTORY OF ESSEX}

acted as lord of the manor until his death in 1540 , and so also did his son George. ${ }^{31}$

When George son of Roger Scott died in 1589 he left Woolston in his will to his two daughters Elizabeth and Mary.32 This bequest was, however, invalid owing to a settlement made under the will of William Scott (d. I 49I). By that settlement the manor passed to George Scott, son of Hugh, who was already the tenant of Woolston under the 99-year lease. This George Scott was living at Woolston Hall when he became its owner. ${ }^{33}$ He died a few months later, in December I $589.34 \mathrm{He}$ had made his will before inheriting the freehold, leaving his lease of Woolston to his grandson George son of William Scott. According to the settlement of I49I the heir to the freehold was William Scott, eldest son of the George Scott who died in December 1589 . William never acted as lord of the manor. He died in $1597 . .^{35}$ George, son of William Scott, who had inherited the lease of the manor, acted as lord from 1590 onwards. ${ }^{36} \mathrm{He}$ died in $1648.37 \mathrm{He}$ never lived at Woolston Hall, which was let to various tenants. ${ }^{38}$ About I640 he had settled Woolston on his son and heir George Scott, who inherited the manor in 1648 and died in $1683 .{ }^{39}$ The last named George Scott was succeeded by his son William, who died in $1725.4^{40}$ William's elder son George inherited the manor but died unmarried in I 727.41 He was succeeded by his brother Thomas who died in 1733.42 Thomas's son, George Scott, was a minor, and manor courts were held until I $74 I$ in the name of his guardian, Sir Robert Abdy, Bt.43 George died childless in 1780 , leaving Woolston to his second cousin Robert Bodle of Clare Market, London, a picture-frame maker. ${ }^{44}$

Robert Bodle died in 1785 , leaving Woolston in trust for the benefit of his son Robert, who came of age in I791.45 The younger Robert held Woolston until his death in $185 \mathrm{I}$. In 1839 his estate consisted of $35^{\circ}$ acres in Chigwell parish. 46 He left two daughters, of whom the elder, Mary Elizabeth, inherited the manor but died unmarried in 1872.47 The younger daughter, Louisa, had married George Watlington as his second wife, but died without issue before her sister. After the death of Mary Elizabeth Woolston passed to John Watlington Perry Watlington, son of Thomas Perry by his wife Maria Jane, daughter of George Watlington by his first wife. J. W. Perry Watlington died childless in 1882 , and his estates passed to his sister Louisa wife of Robert Peel Ethelston. She died in 1892 , leaving Woolston to her second son Robert W. Ethelston. He died in 1914 and the manor was subsequently vested in trustees. ${ }^{4}$ Shortly before 1939 Woolston Hall was sold, possibly for the first time since the I 2 th century.
It is now a sports club belonging to the Co-operative Wholesale Society.49 The building is L-shaped in plan, with the main front facing south-east. It is of two stories with attics, partly timber-framed and plastered and partly of brick. It was built about 1600 , possibly incorporating remains of an earlier house. The southwest front has an early 18 th-century eaves cornice and a Doric porch with paired outer columns. The house was 'modernized and improved' early in the I 9 th century, probably by Robert Bodle. 50 Over the mantel shelf in the entrance hall is an oil painting, installed by George Scott (d. I780) depicting his arms impaling those of his wife Jane (Gibson) and several trophies. ${ }^{51}$

Chigwell church (see below) has existed at least since the 12 th century. The advowson CHURCHES was originally appurtenant to the manor of Chigwell Hall (see above). ${ }^{52}$

By about I 254 a vicarage existed as well as a rectory. 53 The names of the vicars have been recorded from the early I 4th century. They were presented by the rectors and at first held only permissive office. In 1374 , however, a vicarage was formally ordained by the Bishop of London on the application of Henry Marmion then rector and Richard de Benlace, then vicar. 54 Shortly before this, in I 362 , Sir John de Goldingham, lord of Chigwell Hall, conveyed the advowson of the rectory to Corpus Christi College, Cambridge,55' but there is no evidence that the grant became effective. In the same year as the grant Alexander de Goldingham, son of Sir John, presented to the rectory, and he did so on several later occasions up to 1386.56 In I $388 \mathrm{Sir}$ Alexander conveyed the advowson to Iohn, Lord Bourchier. 57 Bourchier presented in 1392 and his son Bartholomew, 3rd Lord Bourchier, in 1400.58 In 1404 Bartholomew conveyed the advowson to John son of William Doreward of Bocking. 59 This grant was confirmed in 1425 by Sir Walter de Goldingham. 60 In 1439 John son of John Doreward gave the advowson to the priory of St. Botolph, Colchester, and in 1440 the rectory was appropriated to the priory, which presented to the vicarage of Chigwell in 1442 and $14433^{.61}$ The appropriation was short-lived. In 1447 a new rector was presented by the Archbishop of Canterbury and in 145 I a new vicar was presented not by the priory but, as previously, by the rector. ${ }^{62}$

In 1460 the priory presented Ralph Bird to the rectory. ${ }^{63}$ In 1465 the king granted the rectory to Kemp's Chantry in St. Paul's cathedral, newly founded by Thomas Kemp, Bishop of London. ${ }^{4}$ The office of priest in this chantry was united with that of penitentiary in the cathedral. In I 470 Ralph Bird became Prebendary of St. Pancras in the cathedral. ${ }^{65}$ Soon after this the prebend was formally united with the offices

\footnotetext{
31 E.R. Ixii (Apr.), p. 53 .

32 P.C.C. 24 Leicester.

33 E.R. Lxii (Apr.), pp. 53-54

34 P.C.C. 98 Leicester.

35 Chigwell Par. Reg.

36 E.R.O., D/DEs M98. On several occasions during George Scott's lifetime the manor was vested in trustees.

37 P.C.C. 75 Essex.

38 E.R. lxii (July), p. 40.

39 P.C.C. 75 Essex; P.C.C. 22 Hare.

40 P.C.C. 164 Romney.

41 Chigwell Par. Reg.; P.C.C. 74

Farrant.

42 Par. Reg.

43 E.R.O., D/DEs Mro8.

44 P.C.C. 417 Collins. William Bodle,

father of Robert, had married Elizabeth,
}

daughter of George Scott, brother of the William Scott who had died in 1725 : Visits. of Essex (Harl. Soc.), 706. 45 P.C.C. 491 Ducarel. 46 E.R.O., D/CT 78.

47 Par. Reg.

48 Burke's L.G. (15th edn.), 712 ; Kelly's Dir. Essex (1933).

49 E.R. Ixii (Sept.), p. 45.

so Ibid.

51 Ibid. For recent photos. of Woolston Hall see E.R. Ixii (Apr.) 49, (July) 37. For some details of the furnishings of the house in 1588 see E.A.T. N.s. xi, 338 . 'The house then included a 'great chamber', a 'garden chamber', a 'gallery chamber', a 'green chamber', a kitchen and a brewhouse.
52 Newcourt, Repert. ii, 140-2.

53 E.A.T. N.s. xviii, 18.

54 Reg. Sudbury (Cant. \& York Soc.), i, $176-9$; Marmion died in 1375 . For his will see $E . A . T$. N.s. xi, 1 I.

55 Challenor Smith, Additions to Nervcourt, 29 .

56 Newcourt, Repert. ii, 142.

s7 Feet of F. Essex, iii, 209

58 Newcourt, ibid.

59 Cal. Close, 1402-5, 297-8.

60 Feet of F. Essex, iv, 5 .

61 Newcourt, Repert. ii, 140-2.

62 Ibid.

63 Ibid.

64 Ibid. 141.

65 Ibid. i, I 95. 
of penitentiary and priest of Kemp's chantry, and subsequent prebendaries of St. Pancras were sinecure rectors of Chigwell and presented to the vicarage until 1848 , when the rectory was vested in the Ecclesiastical Commissioners and the advowson of the vicarage in the Bishop of London. ${ }^{66}$ 'The patronage has subsequently been exercised by the bishops of the diocese in which Chigwell has been, and the present patron is thus the Bishop of Chelmsford. ${ }^{67}$

In about 1254 the value of the rectory was stated to be 15 marks and that of the vicarage 10 marks. ${ }^{68}$ In 1291 the church was valued at 25 marks. ${ }^{69}$ When the church was appropriated in 1440 its annual value was said not to exceed $£ 24$ and the vicarage was then valued at I 8 marks. 70 In 535 the vicarage was valued at $6_{0} 18.78$ In 1839 the rectorial tithes were commuted for $£ 900$, and the vicarial tithes for $£ 500$. There were then 54 acres of rectorial glebe and 10 acres of vicarial glebe.72

In and after the I6th century the impropriators usually farmed out the rectorial glebe and tithes. Thus in 1540 the rectory was leased for 31 years to Hugh Fen of Stepney. ${ }^{73}$ In 1564 William Colshill and Barbara his wife, who had succeeded to Fen's interest in the lease, conveyed it to Nicholas Fulham of Chigwell.74 In 1569 Fulham sold the lease to Robert Spakman.75 From I635 to 1660 Thomas Andrews, a relative of Roger Andrews, vicar in $1605-6$, was lessee of the rectory. ${ }^{76}$ William Andrews was lessee in $1697-$ 1729.77 In 1753 the rectory was being leased by James Crokatt of Luxborough.78 On his death it passed (1 776) to his daughter Jane, wife of Sir Alexander Crauford, Ist Bt.79 In I79I a new lease was granted to Sir Alexander for the term of the lives of his children James, John, and Cecilia. 80 The reversion of the lease was offered for sale in 1800 for $\oint_{1} 3,000$. It was bought by George Clark of West Hatch ${ }^{81}$ on whose death it was sold to William le Gros, also of West Hatch. ${ }^{82}$ Le Gros died in I 820 and John Boote bought the lease. ${ }^{83}$ Boote held it until 1848 when the rectory came into the hands of the Ecclesiastical Commissioners. They evidently bought out the unexpired portion of Boote's lease about the same time. ${ }^{84}$

The Guild of the Holy' Trinity had an altar in the parish church. ${ }^{85}$ At the time of its dissolution in 1548 the guild owned a house and some 9 acres of land, and also had 60 sheep and 10 cows. The net annual value of these endowments was $6 \mathrm{I}$ IOs. $6 d .{ }^{86}$ The land consisted of Fishes, Little Berdes, and Brockesfeld (Brookhouse field). It had been given by Thomas Ilderton, stockfishmonger of London (d. I 527-8), for the purpose of endowing a priest to sing at Trinity altar. Ilderton also left the Io cows to the guild. ${ }^{87}$ The sheep were the gift. of William Bntler. When the property of the guild was valued by the royal officials in 1548 the net income was assessed at 4 Is. $6 d$., the value of the stock at $£^{8}$ and the total valuc for purchase at $£_{5} 3 \mathrm{I} 3 \mathrm{~s}$. In the same year the property was sold to John Whytehorne and John Bayly of Chard (Som.). ${ }^{88}$ It is not clear when the guild had been founded. The earliest reference to it is in 1517 , in the will of one John Fullham. ${ }^{89}$

The parish church of ST. MARY THE VIRGIN consists of nave, chancel, south aisle, and chapel. The timber bell-turret at the west end of the aisle is surmounted by a small copper spire. There is a south porch and a vestry on the north side of the chancel. The walls are of fint rubble covered with cement and have dressings of limestone. The roofs are tiled. In the churchyard, between the south porch and the main road, is a double row of ancient yew trees.

In its original form the church dates from the late I 2 th century, when it would have covered the ground now occupied by the south aisle, which was then the nave, with a chancel somewhat smaller than the present chapel. Of this early church only the south wall now remains. In this wall is a fine Norman doorway with semicircular arch ornamented with doublc chevrons, panelled tympanum, segmental soffit, and free-shafted jambs. The window immediately to the east of this door also probably dates from the $\mathrm{I} 2$ th century but has an inserted mullion and is modern externally. On the inside of the south wall on the east of the door is a holy-water stoup from which the basin has long disappeared.

In the $15^{\text {th }}$ century a north aisle was added, the original north wall being opened to insert the existing arcade of four bays, of which the two centre arches are moulded, with moulded piers, capitals, and bases. The Scott family of Woolston Hall (see above) claimed the chapel of this aisle as their private property. 90 As they first obtained possession of the manor about 1475 it is not unlikely that they were responsible for this addition to the church. About the same time the chancel was probably lengthened and the western bell-turret added to the end of the former nave. The turret is made of eight stout vertical timber posts with curved braces and the whole frame stands independently of the fabric, being walled round at the time of its erection, with a window of three pointed lights in the west wall. Soon after this the aisle was extended from the old north door (opposite the present south door) to bring its west wall level with the bell-turret. This extension was carried out by Thomas Ilderton, the benefactor of the Trinity Guild (see above), who gave instructions in his will ( 1527 ) that he should be buried in the aisle and that an inscription on his grave should record the extension for which he had been responsible and also his gifts to the guild.91 This brass inscription existed as late as 1810 but has since disappeared.92 At about the same time as these works were carried out the nave was probably re-roofed. Many of the existing roof
66 E.R.O., D/P 166/II/12. Several prebendaries between $147^{\circ}$ and $184^{8}$ presented themselves to the vicarage.

67 Crockford's Cler. Dirs. passim; Chel.

Dioc. Year Bk. (1952).

68 E.A.T. N.s, xviii, 18.

og Tax. Eccl. (Rec. Com.), 2 I b.

20 Newcourt, Repert. ii, I 40.

II Valor Eccl. (Rec. Com.), i, 437.

72 E.R.O., D/CT 78. At that time the Revd. A. R. Chauvel, Prebendary of St. Pancras, was also vicar.

73 Cat. Anct. D. iii, A. 5524 ; Newcourt, Repert. ii, 14 I.

74 Ibid. 75 $\mathrm{C}_{3} / 62 / 52$.

76 E.R.O., D/AEV/5, 7

77 E.R.O., D/AEV/r6-2 I

78 E.R.O., D/DB T3.37.

79 Lysons, Environs of London ( 1810 ), $\mathrm{i}$,

648. $\quad 80$ Ibid.; E.R.O., D/DB T 337.

81 Lysons, op. cit. i, 648 . For a survey of the glebe of the rectory and of all tithe payers $c$. 1800 see E.R.O., D/P I 66/3/3. 82 Ibid.

83 White's Dir. Essex (1 848), 415; E.R.O., D/P I66/11/2-11; E.R.O., D/CT 78.

84 E.R.O., D/P 166/11/12; ibid. $166 /$

$3 / 3$

Ss E.A.T. N.s. ×, 236-8.
86 Ibid. The gross income was 43 s. $4 d$. Reserved rents of 75 , Iod, and an annual payment of 5 s. to the poor were chargeable against this.

87 Ibid. 238 . For Ilderton's will see ibid. 3I6. He also extended the north aisle (see below).

88 E.A.T.N.s, x, 238 ; Cal. Pat. 1 547-8, 287.

89 Archd. Essex 3 Sell.

90 F.R.O., D/DEs M82, L3. Many members of the family were buried in this chapel. QI E.A.T. N.s. $x, 316$.

92 Lysons, Environs of London (1810), i, 647. 


\section{A HISTORY OF ESSEX}

timbers in the present south aisle date from this period.

Early in the 16th century the church must have been in good repair, but a century later the chancel was said to be ruinous. ${ }^{93}$ About 1600 a gallery was built at the west end of the old nave, on the order of Samuel Harsnett (vicar 1597-1605, later Archbishop of York). 94 At the Archdeacon's Visitation in 1638 it was ordered that the chancel floor should be raised by three steps and properly paved, that a new rail should be made round the communion table, the belfry boarded with deal and the spire shingled.95

In 1704 the church was undergoing repair.96 In I 722 a second gallery, for the charity girls (see below, Schools), was built at the west end of the north aisle. In I 745 a subscription was raised for 'ornamenting the steeple', when presumably the weather-vane was added.97 The roof of the old nave was repaired in 1800: this involved repair of some of the old roof timbers and the replacement of the lead covering with tiles.98 Meanwhile, in 1793 , another gallery had been added, and in 1805 a fourth was built. 99 One of the new galleries was probably that at the cast end of the north aisle which was the private pew of the Hatch family, lords of Chigwell Hall (see above).'

The spire was re-shingled in $1835^{2}$ By this time the accommodation of the church was becoming insufficient for the needs of a growing population. In I 853 there was a proposal to extend the church by the addition of a south aisle. ${ }^{3}$ This plan, which would have destroyed the south door and all the remaining Norman fabric, was abandoned, but in 1854 there was considerable restoration. This included alterations to the windows in the south wall. It was carried out under the direction of F. T. Dollman.4 The church was not actually enlarged until I 886, when Sir Arthur Blomfield prepared plans upon which the present nave and chancel are based.5 The old nave became the present south aisle and the old north aisle was demolished to make way for the present nave, which is considerably larger. In 1896 the nave and chancel were redecorated and the alabaster reredos and pulpit, both designed by G. F. Bodley, were installed. ${ }^{6}$ The oak screen in the south aisle is a War memorial, unveiled in 1920.7

In 1552 there were three bells, to which three more were added in 1693 . The three original bells were replaced in 1737,1743 , and 1771 . All five bells were recast in I9IO, and at the same time a sixth was added. ${ }^{8}$

The church plate is among the finest in Essex. There are two silver cups, one given in 1607 by John Penington of Chigwell Hall, the other inscribed 'a widow's gift A. A. 1633' (she was Alice Andrews, a relative of Roger Andrews, vicar 1605-6, and Thomas Andrews, lessee of the rectory $1635-60$ ). There are four silver patens of $1609,1632,1633$ and 1832 , and a silver flagon inscribed with the arms of William Scott of

Woolston Hall and dated I 7 I3. The 1632 paten was also given by Alice Andrews. 9

In the chancel is the well-known brass to Samuel Harsnett (d. 1631), Vicar of Chigwell and later successively Bishop of Chichester, Bishop of Norwich, and Archbishop of York. ${ }^{10}$ There is a brass in the nave to Robert Rampston ( 1585 ), a benefactor to the poor of this and other neighbouring parishes. ${ }^{I}$ In the south chapel is a wall monument to Thomas Colshill (1 595), Surveyor of the Customs under Edward VI, Mary, and Elizabeth, and Mary (Crayford) his wife. On the south wall of the nave is a monument to George Scott (1683) and Elizabeth (Cheyne) his wife. (1705). Along the roof of the south aisle is a series of painted hatchments of arms relating to families that have been prominent in the parish, including those of Scott of Woolston, and Hatch-Abdy of Chigwell Hall. The brasses of Thomas Ilderton (1527-8) and an unknown man (c. I5IO), which were formerly in the church, have now disappeared.12

Numerous small bequests to the church of Chigwell in the $15^{\text {th }}$ and 16 th centuries were recorded in the series of articles on 'Old Chigwell Wills' by W. C. Waller. ${ }^{13}$

The ancient parish of Chigwell was divided in the I 9 th century by the creation of new parishes at Buckhurst Hill and Chigwell Row (see below). In 1935 the small church of $S T$. WINIFRED was built at Grange Hill as a chapel of ease to St. Mary's, Chigwell. It is a small brick building faced with cement. Adjoining it is an iron mission room, erected about $1886 .^{\mathrm{t}}$

The parish church of $S T$. FOHN THE BAPTIST, Buckhurst Hill, was built in 1837 as a chapel of ease. In the following year Buckhurst Hill was constituted a separate ecclesiastical district. Is In 1848 the minister there had an income of 660 a year, of which 640 came from the Ecclesiastical Commissioners and the remainder from pew rents. ${ }^{16}$ Buckhurst Hill became a separate parish in 1867 . The living was endowed with f200 tithes by the Ecclesiastical Commissioners (as owners of the rectorial tithes of Chigwell) and was declared a rectory under the District Church Tithes Act, $1865 .{ }^{17}$ The patron of the new rectory was the Vicar of Chigwell until about $193 \mathrm{I}$, when the advowson passed to the Bishop of Chelmsford. ${ }^{18}$

The church consists of nave, chancel, aisles, north porch, and tower with pinnacles and spire. It originally consisted of nave, chancel, and tower, ${ }^{19}$ and has been several times enlarged.20 It is a stone building in the Early English style.

The mission church of $S T$. STEPHEN, Albert Road, Buckhurst Hill was built as a chapel of ease to St. John's in 1876.21 The mission church of $S T$. ELISABETH, Chestnut Avenue, Buckhurst Hill, which is also in this parish, was opened in 1938.22 They are both small brick buildings. E.R.O., D/AEA/I 4 94 Chigwell Register (1 907), I4. os E.R.O., D/AEV/7. 96 Ibid. I7. 97 E.R.O., D/P I66/8/I I. The copper covering was not paid for by this subscription. This came much later.

98 E.R.O., D/P I 66/8/10.

99 Ibid. I $66 / 5 / 6$.

I E.A.T. N.s. xii, I 37 f. Probably the 1805 gallery, since James Hatch acquired Chigwell Hall in 1800 .

2 E.R.O., $166 / 5 / 6$.

3 Ibid. $166 / 8 / \mathrm{I}$ I.

4 E.A.T. N.s. xii, 138.

s E.R.O., D/P I 66/8/11.
7 E.R. $\mathrm{xxx}, 46$.

6 E.R. v, 65.

8 Ch. Bells Essex, 209 ; E.R. xix, 204.

- Ch. Plate Essex, 98. The 1607 plate illustrated, P. I 22.

10 For Harsnett see E.R. xxi, 2 I and li, 9 For his brass see V.C.H. Essex, ii, 544 It was originally set over his grave in the old chancel, now the south chapel.

11 Rampston was buried in Chingford church: E.A.T. N.s. x, 186.

12 For Ilderton's brass see above. For the unknown man see E.A.T. N.s. $\mathrm{x}, 185$. 13 E.A.T. N.s. x, 237,312 ; xi, I0, 150 , 335.

14 St. Winifred's was the gift of Mr. J.
Sanders; for the iron room see Kelly's Dir. Essex (1 886, I 890 ).

is Kelly's Dir. Essex (1859, 1933).

16 E.R.O., D/P $166 / 3 / 3$

17 Kelly's Dir. Essex (1895); E.R.O., D/P $\mathrm{I} 66 / 3 / 3$. The Act was 28 \& 29 Vict. c.42.

18 Kelly's Dir. Essex, passim.

19 White's Dir. Essex (1848)

20 Kelly's Dir. Essex (I933); Buckhurst

Hill, pub. J. W. Phelp (c. I897: a local handbk.).

21 Kelly's Dir. Essex (1933).

22 Inf. from Canon I. Whitehouse,

Rector of Buckhurst Hill. 
In 1848 a room in the old workhouse at Chigwell Row was being used for services. It had accommodation for 100 but was then overcrowded.23 Chigwell Row became a separate ecclesiastical district in 1860.24 The parish church was built in 1867 , and in the same year Chigwell Row became a separate parish.25 The living, like that of Buckhurst Hill, was declared a rectory, having been endowed with tithes which in I 886 were estimated to produce $£ 343$ a year, and 6 acres of glebe. ${ }^{26}$ The advowson was at first vested in the bishop of the diocese, but from about 1874 has been exercised alternately by the bishop and the Crown. ${ }^{27}$

Bartholomew Hartley Foulger of Chigwell Row, by will proved 1930 , left $£ \mathrm{I}, 000$ for the upkeep of the churchyard, provided that certain graves and his family memorial tablet were kept in repair. In 1950 the whole income was spent on the churchyard. ${ }^{28}$

The Revd. Alfred W. Gross of Woodford Wells, by will proved 1931 , left 6100 duty-free to maintain Chigwell Row church and churchyard. In 1950 the whole income was spent on the churchyard.29

The church of $A L L S A I N T S$ is a stone building in Gothic style. It originally contained nave, chancel, aisles, and west porch. A tower was added in 1903.30

The church of $S T$. PAUL, Hainault, was built in 1951 , and in 1953 became the centre of a new Conventional District which includes parts of the parishes of Chigwell Row, Chigwell, and the Ascension, Collier Row, together with part of the Conventional District of St. Francis of Assisi, Barkingside. ${ }^{3 I}$

A private chapel at Turnours Hall, Gravel Lane, was used for public worship for some years about I 912.32

The Convent of the Sacred Heart of Jesus and Mary (formerly the Manor House) at ROMAN Woodford Bridge was consecrated CATHOLICISM in 1925 . It is served from Woodford. ${ }^{33} \mathrm{~A}$ school is carried on in connexion with the convent. ${ }^{34}$ The church of the Assumption was opened in Manford Way, Hainault, in November $1953 .{ }^{3 \mathrm{~s}}$

On 3I May 1804 a nonconformist chapel was PROTESTANT The minister was a $\mathrm{Mr}$ opened at Chigwell Row. ${ }^{36}$ NONCONFORMITY Booth. Among the original trustees were Joseph Fletcher, shipbuilder of Shadwell Dock, and Isaac Gould of Loughton. Henry Fletcher had bought Clare Hall in 1801 , and its name had been changed to Chapel House. 37 The chapel was usually described during the 19 th century as Independent and supported the Essex Congregational Union. In 1829 the minister reported that his congregation numbered $200-50$, of whom 100 'may properly be called dissenters, according to our system'.38 In 183 I the chapel opened a school (see Schools). During the early 1840's, under its minister the Revd. 'T. Hill, it made itself responsible for the mission at Abridge (in Lambourne, q.v.). ${ }^{39}$ During the next ten years the Chigwell Row church was in difficulties.40 In 1857 the British School was temporarily closed and the church itself barely survived. In the following year, however, the school was reopened and the church was said to be reviving.41

The church experienced further difficulties during the next few years, partly as the result of Anglican opposition.42 About I 866, however, it began to support a mission in Chigwell Road, which later developed into a small church (sce below). ${ }^{43}$ The church at Chigwell Row could usually afford to keep a minister at this period. In or about 1882 it once again undertook to support the Abridge church.44 In 1904 there were 37 members, 80 Sunday school pupils, and 3 teachers. 45 In 1925 the numbers were 52,53 , and 10 respectively.46 The society is now (1952) a United Free Church with 80 members, 50 Sunday school pupils, and 18 teachers. It has had a lay pastor since I 938.47

The church is a rectangular building of gault brick with stone or cement dressings. If this is the original building of 1804 the front must have been altered during the second half of the 1 $9^{\text {th }}$ century. Beside it is an iron building used as a schoolroom. This was brought from Leytonstone in 1880.48

In 1866 the Essex Congregational Union was making a small grant to help mission work in Chigwell.49 In the following year it was reported that a room in Chigwell Road had been opened for worship and that congregations numbered about $13^{\circ}$. Services were held by the Revd. F. Neller, of the Chigwell Row Congregational Church.50 In 1870 the mission was fourishing, but the landlord had given the members notice to quit.si About 1875 the Chigwell Road society appears to have become associated with one at Woodford Bridge: in that year they had a joint superintendent, E. W. Skinner. 52 From this time support was being given by the Woodford Congregational Church. 53

In 1890 the two missions were united under the superintendence of G. H. Giddins, minister of the Ray Lodge Congregational Church, Woodford, which church had itself been founded by the Woodford Congregational Church.54 Land was bought in Smeaton Road, Chigwell, near Woodford Bridge, and an iron chapel was given by T. W. Orr. Financial support by W. H. Brown enabled a resident missionary to be retained from 1903 to 1932.55 The chapel remained under the care of the Woodford Congregational Church when Ray Lodge became independent in 1930, and in I 947 became a branch of the Woodford Green United Free Church, in which the Woodford Congregational Church was merged.56 There is a lay pastor at the Smeaton Road church. The iron building was damaged by enemy action during the Second World War. 57

\footnotetext{
23 E.R.O., D/P I $66 / 3 / 3$.

24 Kelly's Dir. Essex (1870).

25 Ibid.

26 Ibid. (1886).

27 Ibid. (I 870 f.)

28 Char. Com. Recs.

29 Ibid.

30 Kelly's Dir. Essex (1933).

31 Inf. from the Revd. P. H. Wingham.

32 Kelly's Dir. Essex (1912); inf. from Mrs. Beattic of Turnours Hall. The chapel is still used for private services.

33 Brentwood R.C.) Diocesan Year Bk. 1953.
}

47 Congr. Year Bk. 1952.

48 Essex Congr. Union Rep. 1880.

49 Essex Congr. Union Rep. 1866

so Ibid. 1867. The room was in the house of a Mr. Root.

s1 Ibid. 1870 .

52 Ibid. 1875 .

53 A. G. Kidd, 'The Pioneers, 2 Short

Hist. of the Woodford Green United Free

Church' (Typescript, I948).

54 Ibid.

55 Ibid.

56 Ibid.

57 Ibid. 


\section{A HISTORY OF ESSEX}

The first nonconformist meetings at Buckhurst Hill took place soon after the extension of the railway from Woodford. In I 860 Mr. Gingell, of Hill Farm, Buckhurst Hill, a Baptist missioner at Epping, built two cottages near his home. In one of them his daughters opened a Sunday school.58 About 1863 he built a mission room in Alfred Road, where he and Noah Heath held services, assisted by students from Spurgeon's College, London.59 In I 864 the Woodford Congregational Church started a Sunday school at Buckhurst Hill.60 Congregational services were opened soon after this in a room next door to the "Bald Faced Stag' and also at the house of a Mr. Straker, 'Fairlands', Epping New Road.6r In 1866 all the above missions united to form the Buckhurst Hill Congregational Church. In that year a schoolroom was opened in Palmerston Road, at a cost of 6480 for the land and $£_{0} \mathrm{r}, 700$ for the building. ${ }^{62}$ About $£_{0}, 500$ was already promised by supporters of the new church. ${ }^{6}$ The church was at first associated with that at Woodford, but in 1868 William Dorling came to Buckhurst Hill as the first minister. ${ }^{64}$ Three years later he left the church after a disagreement with some of the members and took part of the congregation with him to form the King's Place Independent Church (see below). In $1872 \mathrm{~W}$. H. Charlesworth became minister at Palmerston Road and in I 874 a new church was built there at a cost of $£ 6,000.6 \mathrm{~s}$ Charlesworth remained until 1890 . In 1904 there were 75 church members, 80 Sunday school pupils, and ro teachers. ${ }^{66}$ A new organ was installed in 1907 at a cost of $\$ 35^{\circ}$ and in 1913 the schoolroom was enlarged.67 In 1914 there were Ioo members, 65 pupils, and I I teachers. ${ }^{68}$ The church celebrated its jubilee in 1924 and a brief history was compiled to mark the event. ${ }^{69}$ In 1925 there were I 7 members, I 60 pupils, and 20 teachers. 70 A mission station was opened at Roding Valley in 1948 and in 1952 the church had in all 164 members, 140 pupils, I 8 teachers, and 2 lay preachers. The minister, the Revd. N. F. Perry had been there since $1947 .{ }^{7 r}$

The church is an imposing stone building consisting of nave, chancel (facing north), transepts, and south tower with pinnacles. Behind it to the north is the earlier schoolroom, of red brick with a slate roof.

In I87I the Revd. W. Dorling seceded from Palmerston Road and took some of the members with him to form the King's Place Independent Church. He was a man of strong character and advanced thought, a powerful preacher and an able writer for The Christian World. His resignation from Palmerston Road was the result of a controversy that had arisen within that church concerning the doctrine of the 'larger hope', of which Dorling was a strong advocate. This doctrine was distasteful to part of his congregation, which preferred that of eternal punishment. Among his supporters, however, was a large and influential section of the church.72 These people acquired a site at the other (east) end of Palmerston Road opposite King's Place and there built an iron church which was opened in October 1871. Dorling was appointed 'Pastor of the said chapel for life or until he should voluntarily resign the ... office'.73 'The King's Place church was known locally as 'Mr. Dorling's church'. It is remarkable that those who contributed to its erection were largely those who had subscribed towards the original building at Palmerston Road in 1866.74

Dorling remained pastor at King's Place for 35 years, retiring in 1906 . He died in 1912.75 His congregation had in 1887 built a brick church on the site, apparently retaining the original iron church until I 900 , when they sold it to the Baptists. After Dorling's retirement the brick church was also sold to become the Palmerston Road Baptist Church (see below). The proceeds of the latter sale went to Cheshunt College, where Dorling had been trained for the ministry. 76

The Queen's Road Baptist Church, Buckhurst Hill, was formed about I 861, when the Revd. H. Cousens became minister. 77 In 1866 a church was built at a cost of $f_{0} 1,200$, with accommodation for 250.78 In I 869 there were 37 members. 79 Cousens remained until 1885 , and was succeeded by the Revd. E. G. Ince, who came from Australia. ${ }^{80}$ Soon after I 890 the church was closed. ${ }^{81}$ It later became known as Buckhurst Hill Hall and was used for public meetings and entertainments. It was enlarged in 1912.82 It is now used as a branch of the County Library. It is a small red-brick building.

Soon after the closing of the Queen's Road Baptist Church meetings were resumed by some of the members under the leadership of Noah Heath. They hired Rigg's Retreat, Princes Road, from 1894 to 1897 and in 1899 founded a church, with the Revd. J. R. Cox as minister. ${ }^{83}$ In 1902 an iron building was erected in Princes Road. The church lost some members soon after this to the Palmerston Road Baptist Church (see below). ${ }^{84}$ In $1906 \mathrm{Cox}$ was succeeded by his son F. A. Cox and in 1910 there were 55 members, 70 children in the Sunday school, and 7 teachers. ${ }^{85}$ By 1930 there were only 25 members, 45 children, and 3 teachers. ${ }^{86}$ From 1924 to about 1933 F. A. Coxwas again minister, but the church appears to have closed about $1934 .{ }^{87}$ It stood near the west end of Princes Road on the north side. ${ }^{88}$

The Baptist church, Palmerston Road, Buckhurst Hill, was founded in I 900 , when the iron building that had been the original King's Place Congregational Church was bought by the London Baptist Association. 89 Many early adherents came from the Princes
\$8 G. Teverson, Brief Chronicle of 50 rears Service, 1874-1924 (a history of Palmerston Rd. Congregational Church, Buckhurst Hill); W. T. Whitley, Baptists of London, 189 .

s9 Ibid. For the later history of the Alfred Road Hall see below.

60 A. G. Kidd, 'The Pioneers'.

61 Essex Congr. Union Rep. i 866; G. Teverson, Brief Chronicle.

62 Teverson, op. cit.

63 Essex Congr. Union Rep. 1866.

64 Congr. Year Bk. 1867, 1868, 1869 Mr. A. W. Dorling of Woodford Green, grandson of the Revd. W. Dorling, now owns the original letcer inviting his grandfather to Palmerston Road at an annual salary of $6_{3} 300$, guaranteed for the first three years. $6 s$ Teverson, op. cit. 66 Ibid.; Congr. Year Bk. I go4. 67 Teverson, op. cit. 68 Congr. Year Bk. I914.

69 G. Teverson, Brief Chronicle of 50 Years Service.

70 Congr. Year Bk. I925.

71 Ibid. I952.

72 Inf. from Mr. A. W. Dorling.

73 Ibid.; Congr. Year Bk. I9I3 (obit. of Revd. W. Dorling).

74 Inf. from Mr. A. W. Dorling.

75 Ibid. A note on his career was printed in Congr. Year Bk. I913; The Christian World 2 Apr. I93I contained a note on the centenary of his birth. 76 Ibid.
77 Bapt. Handbk. 1869 ; W. T. Whitley, Baptists of London, 189 .

78 Kelly's Dir. Essex (1886)

79 Bapt. Handbk. 1869.

80 Whitley, Baptists of London, 189

81 Kelly's Dir. Essex (1 894).

82 Ibid. I 933

83 W. T. Whitley, Baptists of London, 244.

85 Bapt. Handbk. 1910

86 Ibid., I930. It seems possible that the church was closed for a time about $1917-$ 20: Whitley, Baptists of London, 244; Bapt. Handbk. $1916-20$.

87 Bapt. Handbk. I933, 1934

88 O.S. 6 in. Map (1921 edn.), sheet lxix 89 Whitley, Baptists of London, 249. 
Road Baptist Church. A Baptist church was formally constituted in $19 \circ 9$, taking over the brick building of the King's Place Congregational Church, which had closed in $1906.90 \mathrm{By} 1930$ there were 56 members, 45 Sunday school pupils, and I 3 teachers.91 In 1951 there were 74 members, 87 pupils, and 16 teachers. 92 For most of its history the church has supported a minister.

The church is of red brick, in similar style to the Methodist church (see below) which was built two years earlier. Beside it is the earlier iron church.

For a short time before 1827 there was a Wesleyan Methodist congregation meeting at Chigwell. This had certainly ceased by 1829.93 This mission had probably been carried on by members of the North East London Circuit, which a few years later built a small church at Abridge in Lambourne (q.v.).

No other reference has been found to Methodism in Chigwell until 1878. In that year Edward Pope, founder of the Loughton Methodist Church (q.v.), bought land for $\oint_{200}$ in Queen's Road, Buckhurst Hill, upon which an iron church was erected.94 In 1880 this was put in trust and included in the Wanstead and Woodford Circuit. In 1886 a new brick church was built to the design of Charles Bell of New Broad Street, London, at a cost of $f_{\mathrm{r}}, 940$. In $\mathrm{I} 898 \mathrm{new}$ flooring was installed for $E_{1}$ i 40 . In February 1908 the organ of the Palmerston Road Congregational Church

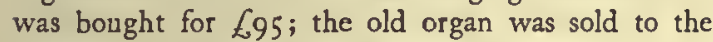
Loughton Wesleyan Church for $£ 45$.

In $\mathrm{I} 910$ it was decided to station a minister at Buckhurst Hill. A house was leased in 19r 7 and bought two years later.

In 1928 the jubilee of the church was celebrated by the building of the Jubilee Room, behind the schoolroom. This cost 6580 . In 1934 the Buckhurst Hill minister was transferred to Loughton and a lay pastor, Mr. G. J. Gaisford, was appointed to Buckhurst Hill. This arrangement continued until 1937, when Mr. Gaisford left. The church now (I 953) shares a minister with the Hermon Hill church at Wanstead. Its membership is 90 . The building is of red brick, in Gothic style.

A new Methodist church was opened in Burrow Road, on the Hainault estate in $1952.9 \mathrm{~S}$

The present Salvation Army hall at the north end of Alfred Road, Buckhurst Hill, is probably the building erected about $186_{3}$ by Mr. Gingell (see above, Palmerston Road Congregational Church). The Salvation Army has used it for at least 20 years. ${ }^{96}$ It is a small building of stock brick.

The Plymouth Brethren have a small hall in Queen's Road, Buckhurst Hill; it is of stock brick and was built in 1884.97

Princes Hall, Princes Road, Buckhurst Hill, has been used for religious meetings since 1886 or earlier. ${ }^{98}$ It is a small red-brick building.

90 Ibid.

91 Bapt. Handbk. 1930.

92 Ibid. I95I.

93 E.R.O., Q/CR 3/1/66.

94 The following acct. is based on an address by $A$. W. Leach at Wanstead, 1919 (reported in Mins. of Local Preachers Mtg. Wanstead and Woodford Circuit),

Trust Deeds and other church records.

95 Inf. from Revd. P. H. Wingham.

96 Inf. from local resident.

97 Kelly's Dir. Essex ( 1886 ).
The surviving court solls of the manor of Woolston

PARISH
GOVERNMENT
AND POOR
RELIEF
Hall run from 1423 to $1749^{99}$ and are continued by court books for the period I7501863. There are no rolls for $1460-82$ and $1509-46$ and there are a few short gaps later in the series. The manor court took an active part in local affairs until the end of the 17 th century. Aletasters were appointed regularly until i 640 and constables until i 840 . In the early igth century, when there was a single constable, he combined this office with that of woodward, and the court continued to appoint a woodward by that title alone up to 1862 . There appears to have been a manorial grange and bakehouse which was derelict by $1463 .^{2}$ The court dealt with minor nuisances and occasionally with cases of assault. In 1578 the Poor Relief Act of $1576^{3}$ was invoked to deal with an 'idle woman' harboured in the house of a manorial tenant. In 1427 and 1606 it was presented that the lord of the manor ought to repair bridges, but in 1682 the parish surveyors were presented for failing to repair a footbridge.

There are court rolls for the manor of Chigwell Hall for the periods $1595-1619$ and $1687-1721$ and books for $1734-99$ and $1882-1901.4$ So far as can be judged from these rolls alone this court during the $17^{\text {th }}$ century and later dealt only with business' relating to the copyhold tenements of the manor. There are no records of the appointment of local officials in the court, but in I $79^{\circ}$ the parish vestry nominated two constables, one for Chigwell Hall lordship and one for Barringtons lordship (see below). 5 Neither was the same man as was appointed constable by the Woolston court in the same year.

Existing court rolls of the manor of Barringtons cover the period $1652-1751 .^{6}$ On every occasion except one during this period the court met only as a.court baron. In 1695 it also viewed frankpledge, and appointed a constable. The appointment by the vestry in 1790 , however, suggests that a constable was appointed for this manor on occasions after 1695 which were not recorded in the rolls.

There is little information concerning poor relief before the 18 th century. The Guild of the Holy Trinity (see above, Church) took a regular part in relieving the poor. The poor men's chest in the parish church is mentioned in 1550,7 and the collectors of the poor in $1564 .{ }^{8}$

Vestry minute books have survived for 17 I 2-49, $1789-1804$, and $1847-94 .^{\circ}$ 'There are overseers' accounts for $182 \mathrm{I}-36$ and an almost complete series of bills for $1784-1836.10$

For a large and fairly populous parish attendance at the vestry was normally not numerous; there were rarely more than twelve ratepayers present. Meetings were usually held in the vestry room, but in 1870 and 1872 exceptionally large attendances necessitated an

\author{
98 Ibid. $1886 \mathrm{f}$. \\ 99 E.R.O., D/DEs M94-109. \\ I E.R.O., D/DEs M80, 8i, D/DZn \\ $I, 2$. \\ 2 E.R.O., T/P 17 \\ 3 I 8 Eliz. I, c.3. \\ 4 E.R.O., D/DDa Mi-12. \\ S E.R.O., D/P 166/8/10. \\ 6 E.R.O., D/DU 97/1-6. \\ 7 Will of John Hill: Archd. Essex 2 I \\ Thonder; Will of Nicholas Sympson: \\ Comm. Ct. London I 44 Clyffe.
}

8 Will of Thomas Hewett: Archd. Essex I 4 Newington. For Charity relief see Charities, below.

- E.R.O., D/P I 66/81 I, 10, I1.

10 Ibid. $166 / 12 / 1-7,10-12$. There are many other miscellaneous parish records: see Essex Par. Recs. 78. Unless otherwise stated information below is from the vestry minutes and overseers' accounts and bills. 


\section{A HISTORY OF ESSEX}

adjournment to the 'King's Head'. At the 1872 meeting more than 200 attended to discuss an advance to the Chigwell School Board. In the later I gth century the ratepayers of Buckhurst Hill, who outnumbered those in the rest of the parish, disliked travelling to Chigwell for vestry meetings, especially because there was still no direct road between those two parts of the parish.

There seems to have been no particular system of rotation in appointing parish officers. Until $177^{\circ}$ churchwardens were appointed for two successive years but afterwards they often served for longer terms. From 1730 , or earlier, one churchwarden was appointed by the vicar and the other by the parish. Overseers of the paor usually served only for one year, two being appointed each Easter. There is a vague suggestion that during the $\mathrm{I} 8$ th century one was appointed for the lordship of Chigwell Hall and the other for that of Woolston. Three surveyors of highways were appointed each year, one each for the lordships of Chigwell Hall, Woolston, and Barringtons. This office was often taken by the gentry, and in the middle of the 18 th century William Harvey, lord of Barringtons, served his own lordship for many years. There is no evidence that the vestry nominated constables before I 790. A resolution of 1721 prohibited the appointment of a deputy by any parish officer without the vestry's approval. A paid assistant overseer was appointed in 1827 and served continuously until I 839 , when he became the relieving officer for Epping District under the Epping Board of Guardians. An assistant overseer was again appointed in 1840 , and in I 852 he was also made collector of the poor rate and paid a commission of 3 per cent. of the rates collected. ${ }^{I I}$

In 1727 there were 2 men, 5 women, and 5 children receiving regular poor relief. A year later a house in Chigwell was converted into a workhouse and in 1733 the vestry resolved to send all out-pensioners there. In I 730 a workhouse master had undertaken to maintain the poor for a $10 d$. rate, but this arrangement seems to have lasted only a few years. In I 745 all pensioners were ordered to wear the parish badge. The workhouse remained adequate for the needs of the parish until ' 1790 , when a larger house in Gravel Lane was taken on lease. This was used as the parish workhouse until I 836 when it was taken over by the Epping Union, ${ }^{12}$ which used it until the new Union house was opened in $183_{3} 8.13$ In 1796 the poor were farmed out to a workhouse master at 15 guineas a year; he also received 2 guineas for acting as parish beadle.

Of the 94 surviving settlement certificates dated between 1699 and 1791 received by the parish officers 60 were issued by parishes in south-west Essex, I 2 elsewhere in the county (mostly in the north-west), 6 in Hertfordshire, Cambridgeshire, Norfolk, and Suffolk, I 2 in London, Middlesex, Surrey and Kent. One was for a blacksmith from Taunton and one for a barber and wig-maker from Berwick-on-Tweed. The others were from Wellingborough (Northants.) and Steeple Aston (Oxon.). ${ }^{14}$

The 106 surviving apprenticeship indentures drawn up between I67I and I 809 show that most pauper children were apprenticed to masters within the parish.is For many years the ratepayers took these children as apprentices on a rota system. In I 727 a woman paid a fine of fio to avoid taking a child allotted to her. In 1730 it was resolved not to pay relief to travellers through the parish even though they carried passes; it was considered that as the main road through Chigwell led only to Ongar such passengers had no need of assistance.

In 1792 one of the overseers was Joshua Jenour, a well-known author and pamphleteer and a man of advanced views. ${ }^{16}$ In that year he planned to build a pest-house out of the poor rates. As he had not consulted either his fellow officers or the vestry, the churchwardens ordcred him to desist. He moved a resolution at a subsequent vestry meeting that the house should be built, but this was defeated. Among his supporters were three local doctors, while the opposition came mainly from the farmers and larger ratepayers. In I 794 the vestry supported a plan proposed by John Conyers for the relief of the poor of the hundreds of Ongar, Harlow, and Waltham, but later withdrew support. In 1795 the high price of flour was met by subsidizing from the rates the bread bought by the poor from local bakers, and by the agreement of the wealthier inhabitants to use flour from which $7 \mathrm{lb}$. bran a bushel had been extracted. In 1800 it was decided to provide the poor with substitutes for flour, mainly rice and potatoes, and the ratepayers were urged to use similar substitutes themselves.

The overseers' expenditure in the year ending at Easter 1724 was $\ell_{0} I 51$, and in $1745\{180$. In 1783 the total poor rate was $\oint_{0} 485 .{ }^{17}$ Expenditure rose to 6716 in 1791 and in 1801 the poor rate was $f_{0} 1,086.18$ Between I 801 and I $82 \mathrm{I}$ the rate fluctuated considerably; it was highest in $1820(£ 2,519)$ and lowest in I 8 I I $\left(f_{6} 630\right)$, but was usually between $\ell_{1}, 000$ and $f_{0}, 000.19$ Overseers' expenditure was $\oint_{0} 1,339$ in 1823 and $6,1,614$ in 1836 .

There are few references to the work of the surveyors of highways. Some of their activities are described above (see p. I9). Nor is there much information about the constables. In 17 I 4 the vestry ordered that the stocks, watch house, and whippingpost should be repaired. John Rowe, constable in $1828-32$, arrested while in office 207 offenders, including burglars, highway robbers, and cattle thieves. Probably most of the offences took place not in Chigwell itself but in the forest at Buckhurst Hill or Chigwell Row, both notorious haunts of criminals. ${ }^{19 a}$

In 1840 Chigwell became part of the Metropolitan Police District. ${ }^{20}$ In 1851 there were a sergeant and four constables in the parish. ${ }^{21}$ In 191 I there were 3 sergeants, 2 acting sergeants, and 18 constables, attached to J Division, Metropolitan Police. ${ }^{22}$ Chigwell $\mathrm{Hall}$ is now the sports club for No. 5 District, Metropolitan Police.

The history of Chigwell School, founded in 1629 by Samuel Harsnett, Arch bishop of York, SCHOOLS was described in an earlier volume of this History. ${ }^{23}$ It is now an independent public school. A new dining-hall and workshop building was opened in $1910 ;^{24}$ a memorial chapel was added in $1924 ;^{2 S}$ an assembly hall was built to mark



II E.R.O., D/P 166/1 I/6, 166/8/I I.

12 E.R.O., G/EM 1 .

13 E.R.O., G/EM 2.

14 E.R.O., D/P $166 /$ I $_{3} /$ I B.

Is Ibid. I66/14/I.

$16 \quad 1755-1853: \sec$ D.N.B.

17 E.R.O., Q/CR I/1. The poor rate had to meet some charges other than relief of the poor, such as rates for county bridges. 18 E.R.O., Q/CR I/9. 19 Ibid. $1 / 12$. 19a Kent and Essex Mercury, 2 Aug. 1832.

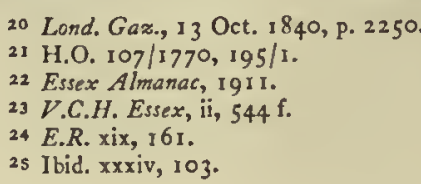


the tercentenary of the school (1929) and in 1948 Grange Court was acquired as a junior school. In 1953 there were 350 boys, under the headmaster, 17 assistant masters, and I mistress. ${ }^{26}$ Buckhurst Hill County High School for boys was opened in 1938. In 1953 there were 549 boys under the headmaster and I 9 assistant masters. ${ }^{27}$

In I I I there was a Charity School at Chigwell attended by 10 poor girls who also received caps, bands, and aprons from a private benefactor. ${ }^{28}$ In 1713 the school was receiving $f_{\mathrm{s}} 6$ a year from subscriptions and a girl had recently been put out as an apprentice.29 There were still only 10 pupils in about 1768 , when the school was supported mainly by the collection at an annual sermon. ${ }^{30}$ By the early I th century, however, 'the Charity School' (presumably the same) was attended by 72 girls. ${ }^{31}$ It was then endowed with $\oint_{1} 32$ Stock and was called the Blue School because a dozen or more children received a blue uniform. ${ }^{32}$

In 18 I 8 the Blue School was united with a School of Industry for girls, founded in 1815 . The latter had been supported by subscriptions, charity sermons, and by the proceeds of the pupils' work, which amounted to 67 in $1815-16$ and 616 in $1817-18$. It was held in a house which in $1815-16$ was rented for 69 a year, and its mistress was paid 614 14s. in $1815-16$ and 8276 s. in $1817-18$. From its foundation it had been in union with the National Society, and this association was maintained after the amalgamation with the Blue School, the first title of the new school being the National School of Industry for Girls. In the new school the "blue girls' continued to wear their uniform as long as they behaved well. Misconduct was punished by the transfer of the uniform to others considered more deserving. The endowment of the Blue School was transferred to the new school and a further legacy of $f_{1} 100$ seems to have been received in 1818 from a Mr. Lewis. 33

Until about 1838 the number of pupils seems to have remained constant at about 45.34 After I 8 I 8 the salary of the mistress rose to $\$ 30$ together with 10 per cent. of the children's earnings and a coal allowance. Subscriptions rose steadily and income continued to be received from the children's work. ${ }^{35}$ 'The school was supervised by a Ladies Committee. In 1836 this decided to build a new school, with accommodation for 100 girls, in order to provide for the increasing population. The vicar gave a site on the Vicarage Field. ${ }^{36}$ The committee realized 6202 from the sale of endowments, collected $£ 173$, and received $£ 55$ from the government, 225 from the National Society and firo from the Diocesan Board. ${ }^{37}$ The new schoolroom was built opposite the grammar school. ${ }^{38}$ It was opened as a National School in 1838.39

The Ladies Committee continued to manage the school. It was energetic and successful in obtaining subscriptions and other local support. But the standard of teaching was low. In 1841 an inspector found a poor achievement in the three main subjects 40 and in I 852 another inspector reported that the curriculum was limited and that the teaching methods were those of the early monitorial system.4I The school also had a bad reputation locally at this time. In I 848 the retiring Vicar of Chigwell described it as very ineffcient ... principally because of some antiquated rules enforcing the wearing at church of . . ugly caps and short-cropped hair-this offends the little tradespeople, who prefer sending their daughters $2 \frac{1}{2}$ miles to a British and Foreign [i.e. Dissenting] school at Chigwell Row'.42

In 1875 the school appears to have received its first annual grant from the government. The average attendance was then only 47.43 The population of the parish was increasing rapidly, however, and attendance rose to 75 in I 886 and I I4 in I 902.4 The annual grant rose from $£ 28$ in 1875 to $\oint_{54}$ in 1886 and $\oint_{1}$ I 9 in 1902.45 In 1904 there were I 55 children under 3 teachers and a monitor, and the average attendance was $\mathrm{I} 3 \mathrm{I} .46$ In order to provide for the increased number of pupils the school was enlarged in $\mathrm{I} 8 \mathrm{gI}$ to accommodate 200.47 Under the I902 Education Act it passed under the administration of the Essex Education Committee, Epping District, as a non-provided school. The average attendance fell to IOI in 1915 and 85 in 1929 , but rose to 138 in 1938 . In 1935 , at the request of the managers, the name of the school was changed to St. Mary's Girls and Infants Church of England School. In 1947 the school was granted controlled status. In 1948 it was reorganized for junior girls and infants and in $195^{\circ}$ it was closed in accordance with the County Development Plan.48 The building is opposite the grammar school. It is single-storied, of red brick with a tiled roof.

In I807 there was a Church of England Sunday school in Chigwell, apparently for boys and girls. 49 In I 820 , after the establishment of the National day school for girls, the Sunday school seems to have been reserved for boys. It was then in union with the National Society and had some 50 pupils. so It did not lead to the formation of the usual type of National day school for boys because the English School, which was part of Archbishop Harsnett's foundation, already provided the necessary facilities.si The English School was sometimes called the National School.s2 In or shortly before I $88 \mathrm{I}$ the English School was discontinued. In that year the parish vestry passed a resolution deploring this fact and protesting against the refusal of the governors of Harsnett's Schools to allow the Chigwell School Board (founded 1871 : see below) the free use of the English School building and the annual grant of $£ 20$ that had been paid to the English School. The resolution pointed out that this refusal contravened one of the clauses of the scheme drawn up by the Charity Commission for the management of Harsnett's Schools.53 'The protest was forwarded to the Commission and appears to have been successful
26 Public Schs. Year Bk. (1953).
27 Inf. from Essex Educ. Cttee.

28 S.P.C.K. Acci. of Char. Schs. (I 7 I I),

22.

30 Morant, Essex, i, 170 .

3I E.R.O., D/AEM $2 / 4$.

32 E.R.O., D/P I 66/28/3

33 Ibid.; Nat. Soc. Reps. I $820,1828$.

34 Ibid.; Educ. Enquiry Abstr. H.C. 62,

p. $270(1835)$, xli.

35 E.R.O., D/P I $66 / 28 / 3$

36 Ex. inf. Nat. Soc.
37 E.R.O., D/P $166 / 28 / 3$

38 Ex. inf. Nat. Soc.; E.R.O., D/CT 78 .

39 E.R.O., D/P I $66 / 28 / 4$.

40 Ibid. $166 / 28 / 3,4$.

41 Mins. Educ. Ctice. of Council, 1852 vol. ii [1624], p. 286, H.C. $(1852-3)$, lxxx (1). 42 E.R.O., D/P $166 / 3 / 3$ 43 Rep. of Educ. Cutee. of Council, 1875 [C. $1513-1]$, P. 53 I, H.C. $(1876)$, xxiii.

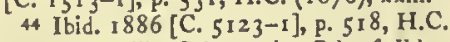
(1887), xxviii; Schs. under Bd. of Educ. I902 [Cd. I490], p. 68, H.C. (1903), li.

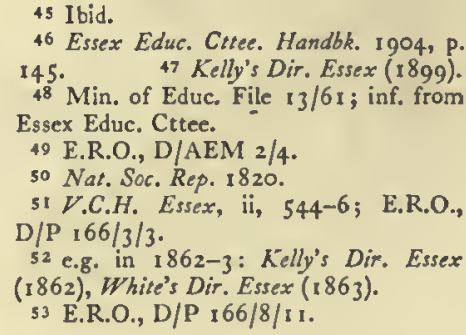




\section{A HISTORY OF ESSEX}

at least as to the building, for in 1886 the English School was stated to be under the supervision of the school board.s4 It was handed back to the grammar school in 1898.55

In $\mathrm{s} 886$, however, the school board completed the building of a new boys' school in Chigwell village, on a site to the east of the High Road, at a total cost of $f_{2} 2,893.56$ There was accommodation for 153 boys. The average attendance rose from 55 in 1886 to 105 in 1902 and the annual grant from $£ 32$ to $£ .121 .57$ By the Education Act of 1902 the school passed under the administration of the Essex Education Committee, Epping District. In 1904 there were 128 boys under 4 teachers. ${ }^{5}$ Numbers fell to 85 boys in 1930.59 When St. Mary's School was closed in I 950 the County School was reorganized for mixed juniors and infants and in May 1952 there were 199 children on the roll and 6 teachers. ${ }^{60}$

In 1831 the nonconformists in Chigwell Row set up a day school at which in 1833 there were some 50 pupils who paid a fee of $2 d$. a week. ${ }^{6 I}$ In I 839 its supporters built a permanent schoolroom near Miller's Lane. The government made a building grant of $f_{0} 80$ and the school was completed in 1844 . The trust deed stated that the purpose of the school was to educate the poor according to the principles of the British Schools Society. ${ }^{62}$ During its early years the school gained some pupils at the expense of the National School for Girls at Chigwell, which was unpopular among the small tradesmen of that village. ${ }^{63}$ In spite of this it encountered difficulties and in 1857 seems to have been closed. In May i 858 it was reopened with the help of the Essex Congregational Union: there were then over 70 pupils. 64 But difficulties continued. ${ }^{65}$

In I 87 I a school board of 5 members was set up for the parish of Chigwell.66 In 1873 the supporters of the British School transferred their building to the board, retaining their right to use it for religious purposes. ${ }^{67}$ There were then some 52 children in attendance. ${ }^{68}$ In 1885 the school was rebuilt, after a fire, to accommodate some 165 children. ${ }^{69}$

Average attendance rose from 86 in 1886 to 104 in 1902 and the annual grant from 67 I to 6 IOI. ${ }^{70} \mathrm{By}$ the Education Act of I 902 the school passed under the administration of the Essex Education Committee, Epping District, as a provided school. It was reorganized for girls and infants, the accommodation being estimated in I 1 I I at 90 places for girls and 60 for infants. The average attendance was 88 in 1910 , 72 in 1929 , and 56 in 1938 . In 1948 it was reorganized for junior girls and infants, the seniors being transferred to Grange Hill Temporary Secondary School.7I In May 1952 there were 93 pupils and 3 teachers. ${ }^{72}$ The increase was due to the building of the Hainault estate. The school is on the north of
Lambourne Road near the Lambourne boundary. It is single-storied, of red brick with a tiled roof and has a teacher's house attached.

By I 845 there was a National School at Chigwell Row. ${ }^{73}$ It was apparently held in a cottage. In 1852 local Churchmen raised figo or more towards the cost of a permanent schoolroom. The government gave 670 , the National Society 625 , and the owner of the site gave the land. The building was finished in $1853 .{ }^{74}$ It was used as an infant school in connexion with the National School at Chigwell.75 It still existed in I 874 but it was discontinued shortly after, presumably because of the establishment of the new board school. ${ }^{76}$ The building was subsequently used for parochial purposes, and was known as All Saints Schoolroom. ${ }^{77}$ It is of red-brick and stands on the north side of Lambourne Road near All Saints Church.

St. John's National School, Buckhurst Hill, was built in 1838 by local Churchmen. The lord of the manor gave a site next to the church and the National Society contributed $£ 35$. The building cost $\$ 209$, most of which was defrayed by local subscribers. 78 By I 840 there were about 50 pupils, nominated by subscribers. Parents paid 2d. a week for the first and Id. each for other children.79 In 1846 there were 43 children under a mistress who was paid 645 a year and 3 monitresses. 80 In 1866 the Charity Commissioners authorized a new scheme of management which gave control of religious teaching to the minister (later the Rector of Buckhurst Hill) and the management to the Vicar of Chigwell, the minister, and 6 representatives of the subscribers. ${ }^{81}$ In 1869 Edward North Buxton gave additional premises in Albert Road. These were used for an infants' school. ${ }^{82}$

The district of the Chigwell school board, founded in $187 \mathrm{I}$, included Buckhurst Hill, and a board school (see below) was promptly built there. The National School main tained its volun tary character and continued to use the building next to the church. The managers, however, let the Albert Road infants' school to the board at a nominal rent, retaining the right to use the building on Sunday and two week-nights. ${ }^{83}$ The average attendance at the National School rose from 7 I in I 872 to I 58 in I 886 , and the annual grant from 648 to $\oint_{1} 40.84$ By I 882 or earlier the school had ceased to take boys, but in spite of this the rapid increase necessitated its enlargement and this was carried out in I 887.85 The average attendance continued to rise: in I 899 there were 237 girls and 88 infants. 86 In 1904 there was official accommodation for 394 , but there were 403 children on the roll, under I I teachers and 3 monitresses. ${ }^{87}$ By the Education Act of 1902 the school passed under the administration of the Essex Education Committee, Epping District, as a nonprovided school. The average attendance fell to 298 's4 Kelly's Dir. Essex (1886). The vestry minutes for I $88 \mathrm{I}-6$ also contain references to 'the Board School, Chigwell' which must mean the English School.

ss E.R.O., D/P I 66/28/10.

$56 \mathrm{Min}$. of Educ. File $13 / 60$.

57 Rep. of Educ. Cttee. of Council, 1886 , p. 518 ; Schs. under Bd. of Educ. 1902, p. 68 .

58 Essex Educ. Cttee. Handbk. 1904, p. 145 .

$59 \mathrm{Min}$ of Educ. File $13 / 60$.

60 Ibid.; inf. from Essex Educ. Cttee.

6I Educ. Enquiry Abstr. H.C. 62, p. 270

(1835), xli.

62 Min. of Educ. File $\mathrm{I}_{3} / 62$.
63 See above.

64 Essex Congr. Union Reps. 1858 , p. I I.

6s Ibid. 1860 , p. 7

66 County Companion, I 880.

67 Min. of Educ File $13 / 62$; Chelmsford Chronicle, 26 Jan. 1872.

68 Rep. of Educ. Cttee. of Council, 1874 [C. $1265-1$ ], p. 322 , H.C. (1875), xxiv. 69 Min. of Educ. File $13 / 62 ;$ Rep. of Educ. Ctice. of Council, I 886, p. 518.

70 Ibid.; Schs. under Bd. of Educ. 1902, p. $68.71 \mathrm{Min}$. of Educ. File I $3 / 62$. 72 Inf. from Essex Edue. Cttee.

73 Kelly's Dir. Essex (1 845).

74 Inf. from Nat. Soc.

7s Kelly's Dir. Essex (1855, I862, 1870 ).
76 I bid. I 874,1878 .

77 Ibid. I 902.

78 Inf. from Nat. Soc. 79 Ibid.

80 Nat. Soc. Enquiry into Ch. Schs.

I $846-7$, PP. 4-5.

81 Min. of Educ. File $13 / 46$

82 Ibid. $13 / 45$.

$83 \mathrm{Min}$. of Educ. Files I $3 / 45,46$.

84 Rep. of Educ. Cttec. of Council, 1872

[C. 812 ], p. 407, H.C. (I 873), xxiv; ibid. I 886, p. 5 I 8 .

8s Inscription on school building; Kelly's

Dir. Essex (1882).

86 Kelly's Dir. Essex (1809).

87 Essex Educ. Cttee. Handbk. I 904, p. 
in 1914 and 225 in 1930 . In 1938 it was reorganized for junior girls and infants. ${ }^{88}$ In May 1952 there were 326 children and I I teachers. ${ }^{89}$ The school was given controlled status in 1951.90

The school board for Chigwell parish was at first strongly opposed locally and in 1872 a petition for its removal was sent to the government.91 This failed, but with other protests it may have caused the board to drop its plan to build a school to replace the National School at Buckhurst Hill. In $\mathrm{r} 872$ the Board built a school in Princes Road and accepted the use of the infant department of the National School (see above), paying only a nominal rent but accepting responsibility for repairs. ${ }^{92}$ The board school at first accepted both boys and girls, but from about I 886 it took only boys, the girls attending the National School.93 Attendance at the board school rose from an average of 139 in 1873 to 246 in 1886 and the annual grant from 695 to 236.94 In 1884 the infants' school was enlarged to about I 64 places and in 1894 the boys' school to about 362 places. 95 By the Education Act of 1902 the schools passed under the administration of the Essex Education Committee, Epping District. In 1904 there were 290 boys on the roll, under 9 teachers, of whom 2 were certificated, and I 53 infants under 5 teachers, I of whom was certificated. ${ }^{96}$ Attendance declined to 229 boys and 91 infants in 1938 , when the schools were reorganized for junior boys and infants, and in $194^{\circ}$ the boys' and infants' departments were amalgamated in a single establishment.97 In May I 952 there were 326 children, under 13 teachers. 98 The building in Princes Road is single-storied, of yellow brick with a slate roof. Attached is a teacher's house of similar construction.

Owing to the building of the large London County Council housing estate at Hainault the Essex County Council has since 1945 been carrying out a programme of school development in this area which was still incomplete in 1952-3. The following schools were established during this period. ${ }^{99}$

The Grange County Secondary Modern School (mixed), Manford Way, was opened in September I 950. In May I 952 it had 42 I pupils and 24 teachers.

Manford Way County Primary School was opened in November 1948. In May I 952 the junior school had 468 pupils and I 2 teachers and the infants' school had 320 pupils and 9 teachers.

The Coppice County Primary School, Manford Way, opened an infants' department in September I 952 and in the following November had 2 I 3 pupils. The junior department was to be opened in 1953 .

Grange Hill County Primary School, Woodman Path, is a temporary school, opened in February r $94^{8}$ with accommodation for 240 juniors and 160 infants.
In September 1950 there was accommodation for 760 children. In May I 952 there were 888 pupils at the school.

A branch of St. Anthony's Roman Catholic School was established at Woodman Path in September I952, and in November 1952 had 344 pupils. This and all the above primary schools are for mixed juniors and infants.

There have also been a number of private schools in the parish of Chigwell. In I588 John Cambes of Chigwell was presented before the Archdeacon of Essex for 'that he teacheth a scoole'. In I795 a Mrs. King advertised the opening of a school in Chigwell for young ladies. ${ }^{2}$ In 18 Io there was a boarding academy for young gentlemen at Chigwell under the supervision of John Ray, the fee being 30 guineas a year. ${ }^{3}$ Ray died in 1816 , when the school apparently closed.4

About I 824 F. C. L. Klingender opened a school at Buckhurst Hill House, 5 held on lease. By I 83 I he had raised mortgages totalling $£_{0} \mathrm{r}, 000$ on the property ${ }^{6}$ and in 1833 he offered the premises for sale at $\{1,690$, asking nothing for any goodwill attached to the school.7 He was adjudged bankrupt in $1834 .^{8}$ Francis Worral Stevens, who had been a master at Bruce Grove, Tottenham (Mdx.), under Rowland Hill, took over the school and continued it until r 848.9 The house was then empty for a year but the school was reopened in $185 \mathrm{I}$ by Thomas Bickerdike who in that year had an assistant master and $\mathrm{r} 5$ boarders between 9 and 14 years of age. ${ }^{10}$ Bickerdike left Buckhurst Hill in I 853 and the house was not afterwards used as a school.11

Between 1850 and 1859 there was a school near Broomhill run by Mary Moss. 12 In 1851 she had $\mathrm{r} 5$ boarders of both sexes between 3 and 10 years of age. ${ }^{13}$ I Tiss Howell and Miss Lake had a girls' day school in the High Road from I 848.14 In 1854 they moved into part of the premises of Harsnett's Grammar School and remained there until $1865 .{ }^{\text {.s }}$

Hannah Hurren had a day and boarding school at Chigwell Row from i 848 to I 850.16 From 1856 to 1869 the Revd. William Earle, M.A., had a boys' school at Grange Court in Chigwell village. ${ }^{17}$ In 1878 the Misses Ann and Catherine Howell had a private school at Broomhill, the Revd. W. L. Wilson a collegiate school at Oakhurst in Horn Lane and there were five private schools at Buckhurst Hill. ${ }^{8}$ Oakhurst later became a school and home for destitute Armenian boys under the Revd. G. Thoumaian. ${ }^{19}$ From the late r gth century the Sisters of the Sacred Hearts of Jesus and Mary have kept a school at the Manor House in High Road, near Woodford Bridge.20 In 1950 there were also two private schools at Buckhurst Hill.2r
$88 \mathrm{Min}$. of Educ. File $13 / 46$.

89 Inf. from Essex Educ. Cttee.

$90 \mathrm{Min}$. of Educ. File $\mathrm{r} 3 / 46$.

91 Ibid. $13 / 45$. See also E.R.O., D/P 166/8/11: 9 May 1872 , for a resolution of the vestry protesting against the proposed expenditure of the school board.

92 Min. of Educ. File $13 / 45$; Chelmsford Chronicle, 26 Jan., 12 July, 15 Nov. 1872. ${ }_{93}$ Kelly's Dir. Essex (1 882, 1886,1890 ). 94 Rep. of Educ. Ctree. of Council, 1873 [C. 1019-1], p. 407, H.C. (1874), xviii; ibid. 1886, p. 518.

${ }_{95} \mathrm{Min}$. of Educ. File 13/45; Schs. under Bd. of Educ. 19oz, p. 68.

96 Essex Educ. Cttee. Handbk. 1904, p. 144.

RS. IV

97 Min. of Educ. File $13 / 45$.

98 Inf. from Essex Educ. Cttee.

99 The following account is based on information from the Ministry of Education, Essex Education Cttee. and Miss E. A. Phillips, Headmistress of Staples Road Infant School, Loughton.

1 E.R.O., D/AEV/I4.

2 Chigwell Church Mag. Feb. 1939.

3 Essex Union, 9 Jan. 18 ro.

4 Chigwell Par. Reg.

E.R.O., D/DDa M 33.

6 Ibid.

7 Kent and Essex Mercury, 29 Oct. 1833 .

Essex Union, $18 \mathrm{Feb} .1834$.

9 E.R.O., D/DDa M 3.
10 H.O. $107 / 1770, \mathrm{I} 95 / 1$.

II E.R.O., D/P $166 / 1 \mathrm{I} / \mathrm{I} 7$.

12 E.R.O., D/P $166 / 11 / 14^{-23}$.

13 H.O. $107 / 1770$, $195 / \mathrm{r}$.

14 White's Dir. Essex (1848), 417.

is E.R.O., D/P I 66/1 1/ $12-29$.

16 White's Dir. Essex (1848), 417 ;

E.R.O., D/P 166/11/12-14.

I7 E.R.O., D/P I 66/\$/11, 166/11/20-

33. This house has recently been bought

by the governors of Chigwell School.

${ }_{18}$ Kelly's Dir. Essex (1878).

19 Ibid. (1899).

20 Ibid. (1899).

1t Chigrvell U.D. Offrial Guide (2nd edn.), p. 34 ."

$4 \mathrm{I}$ 


\section{A HISTORY OF ESSEX}

Nothing certain is known concerning the foundation of Coulson's Almshouses, which adjoin CHARITIES Chigwell School to the north-east. The words 'Coulson's Almshouses I $557^{\prime}$ inscribed upon the building were evidently added at the rebuilding of 1858 . In 1849 the grammar school records were said to include a document of I6 I 9 implying that the almshouses built by Thomas Coulson then stood on the east of the school. ${ }^{22} \mathrm{~A}$ family called Coulson had lived in the parish since 1592 at least. ${ }^{23}$ One of the hourses in 1849 also bore the date 1664 , but this may have commemorated an extension to the buildings. ${ }^{24}$ In the late 18 th century the owners of land called Cardhams paid a rent charge of $\oint_{4} 4$ for the maintenance of four poor widows and also repaired the almshouses and nominated the inmates. In 1803 the owner was not allowed to nominate them because he did not live in the parish and he refused to repair the houses unless his obligation could be proved. ${ }^{25}$ This could apparently not be done and a subscription was raised for the purpose in 1820.26 In 1831 the rentcharge was reassigned to Brookhouse Farm:27 it was thereafter paid until its redemption in 1938 for $£_{1} 60$ which was invested. 28

In 1834 the almshouses consisted of three tworoomed tenements under one roof. The parishioners then nominated the inmates. ${ }^{29}$ After various earlier attempts, the almshouses were rebuilt in 1858 by public subscription in their present enlarged form. In 1864 the vestry added to the endowment $\oint_{1} 100$ received by them in consideration of the closure of a footpath. This was used to pay each almswoman $6 s$. $8 d$. a quarter. ${ }^{30} \mathrm{~A}$ further gift of 620 was added in 1869 . In $195 I^{-2}$ the charity's income was $£ 77$ s. Over $£$ io was spent on the almshouses and their occupants, the excess being met out of the other funds of the United Charities (see below). ${ }^{31}$

By his will of 1585 Robert Rampston of Chingford left rent charges to be applied for the benefit of the poor in various Essex parishes. ${ }^{32}$ That for Chigwell is 62 a year, charged on Stone Hall in Little Canfield. In 1835 it was spent on bread which was distributed about Lady Day to poor persons in proportion to the size of their families. In $195 \mathrm{I}-2$ it was used for the general purpose of the United Charities.

Mary Fountain, by will proved I 804 , left 690 after expiry of a life interest, in trust for two blind women of the parish. ${ }^{33}$ The will was unsuccessfully disputed in Chancery and the legacy was paid in 1817 . In 1834 there were no qualified beneficiaries in Chigwell and the income was intermittently paid to two blind women in Whitechapel. In $195 \mathrm{I}-2$ the income was $£ 26$ s. $8 d$. and gifts of $\oint_{\mathrm{I}} \mathrm{I}$ each were made to two blind women, one in Chigwell and one in Buckhurst Hill.

James Hatch, lord of Chigwell Hall manor, by will proved 1807 , left $\oint_{0} 1,000$ in trust to maintain his tomb at Little Ilford, to make an inscription in Chigwell church recording the bequest, and for the most deserving poor of Chigwell not in receipt of parish relief. ${ }^{34}$ The provision for the tomb was invalid, but payments were apparently made for it at various times. In $1834 £ 30$ was distributed in small cash gifts. In $195 \mathrm{I}-2$ the income was $E_{25}$, of which $\mathrm{E}_{20}$ were distributed in gifts of $\mathrm{E}_{\mathrm{I}}$ each.

Mary Grainger, by will proved 1808 , left $£_{1}, 000$ in trust for eight poor widows of Chigwell of over $5^{\circ}$ years of age. ${ }^{35}$ Preference was to be given to the moral and industrions and distribution was to take place on St. Thomas's Day. In I 835 £ 31 I 0 s. was distributed. In 195 1-2 the income was $f_{22}$ Ios., of which $£ 20$ was distributed in eight gifts of $£_{2}$ Ios.

Mrs. Barbara Fisher in I 809 bequeathed $\oint_{1} 100$ to the poor of Chigwell.36 In 1834 the interest was used to buy bread which was distributed to the poor according to the size of their families. In $195 \mathrm{I}-2$ the income of $£_{3} 6$ s. was used for the general purposes of the United Charities.

Mrs. Rosetta Waddell, by will proved 1866 , left $\$ 25$ for the benefit of the deserving poor of the parish who were not receiving parish relief. 37 In 1896 the income was used to supplement the endowinent of the almshouses, in gifts to the almswomen. In $195 \mathrm{I}-2$ it amounted to $13 s$. and was used for the general purposes of the United Charities.

By a scheme of 1899 all the above charities were united under one board of trustees who were to carry out the original purposes of each. ${ }^{38}$ In $195 \mathrm{I}-2$, in addition to the payments specifically mentioned above, a payment of 6.74 s. was made to Chigwell County Primary School. Apparently the trustees believed that this sum had formerly been paid to St. Mary's Girls' School, but there appears to be no mention of such a payment in the scheme of 1899 or elsewhere in the Charity Commission Records.

Joan Sympson, by will proved 1562 , left $£ 80$ for the repair of the highway between Chigwell and London. ${ }^{39}$ This was added to a trust which she had founded three years earlier. In I 87 I a small piece of land, apparently allotted earlier in respect of common rights, was sold for $£ 44.40$ In 1938 a field comprising the whole landed property of the charity was sold for f. 3,150 . By I 95 I the charity held $£_{1}, 080$ stock. In the early I 9 th century the charity appears to have been virtually dead, probably because the road was then being repaired by a turnpike trust.4I Trustees were appointed in I 857 and later in the century the charity's income was used to repair the footpath along the Abridge-Woodford road. In the 2 oth century the charity has paid the county council for the repair of the road. Much of the income has been reinvested: in 1947 none was spent.

The Harsnett Charity ( 1629 ), the main provision of which was for the foundation of the schools at Chigwell, included an endowment of $f_{\mathrm{r}} \mathrm{O}$ a year to be spent on bread to be given to those poor people of the parish who attended church, and 20s. a year to the parish

\footnotetext{
22 E.R.O., D/P 166/8/II. The date must have been an error since the school was not founded until 1629 .

23 Chigwell Par. Reg.

24 E.R.O., D/P I 66/8/1 I.

25 Rep. Com. Char. (Essex), H.C. 216 Pp. $223-5(1835)$, xxi (I); E.R.O., D/P I 66/8/II.

26 E.R.O., D/P I 66/8/I1.

27 Rep. Com. Char. (Essex), pp. 223-5.

28 Char. Com. files.

29 Rep. Com. Char. (Essex), pp. 223-5.

30 E.R.O., D/P I $66 / 8 / 11$; Kelly's Dir. Essex (1899, 1933). 31 Char. Com. files.

32 P.C.C. 40 Brudenell; Rep. Com. Char. (Essex), ibid.; Char. Com. files.

33 Rep. Com. Char. (Essex); Char. Com. Rees.; MS. Book 'An Acct. of Donations \&c., to the Poor of Chigwell', in possession of the Trustees of Chigwell United Charities. For Mrs. Fisher see below, Fisher's Charity. 34 Ibid.
}



${ }^{38}$ Char. Com. files; Chigruell Par. Mag., Sept. I 926.

39 Char. Com. files; E.R. xix, 1-7, 7077 ; E.A.T. N.s. xi, 153 . See also Topography, above.

40 See Agriculture, above.

41 There is no mention of this charity in the 1835 Report. 
clerk for ringing the church bell daily at 6 a.m.42 In 1834 both these payments were still being made, though the clerk was no longer required to ring. A Chancery order of 1863 ignored the provision for the clerk, which thereafter lapsed, but continued the payment for bread. In $187 \mathrm{I}$ this also was stopped by an Endowed Schools Scheme which ruled that the fro was to be applied to educational purposes. An old bread cupboard used in connexion with this charity was for many years attached to the inside wall of the church near the south door. About Igoo it was found to be delapidated and was moved to the vestry.43
John Crowfoot, by will proved 1903 , left $\oint_{6} 500$ in trust for the distribution of coal at Christmas among the poor of the parish of All Saints, Chigwell Row. 14 For some years part of the income was used to give a bonus to the parish coal club, but in 1950 the whole income of fil 5s. $4 d$. was used to buy coal for 22 people.

Philip Savill, by will proved 1922 , left $\oint_{\mathrm{o}} \mathrm{r}, 000$ in trust for gifts to roo deserving poor of the parish of Chigwell Row, preferably Anglicans.45 In 1950 the income was $\mathrm{E}_{25}$, which was distributed in cash to 12 people.

\section{FYFIELD}

Fyfield is about 2 miles north of Chipping Ongar, and has an area of $2,45^{\circ}$ acres. ${ }^{2}$ Its name is derived from the 5-hide unit of assessment used by the AngloSaxons. ${ }^{3}$ In several respects it is one of the most interesting parishes in the hundred. There is an unusual number of moated sites and pre-1 8 th-century houses. Four houses, Fyfield Hall, Lampetts, Dame Anna's Farm, and the rectory, date from the Middle Ages. The church, which dates from the 12 th century, is one of the few in the district with a central tower and north and south aisles. Considerable sums must have been spent on its erection and on alterations and additions in the I $3^{\text {th }}$ and $14^{\text {th }}$ centuries. Fyfield thus seems to have been a place of some importance and wealth in the Middle Ages and this is borne out by the taxation statistics printed below (pp. 300 f.). As late as $167 \mathrm{I}$ it was more densely populated than any other place in the hundred except Chipping Ongar and Moreton (see below, pp. $306 \mathrm{f}$.). In I 801 the population was 511.4 Fyfield was then sixth of the parishes in the hundred in order of population density. 5 The population rose slowly to 629 in 1861.6 It subsequently declined to 468 in 1881.7 There was some later fluctuation but in I 92 I it was again $468 .{ }^{8}$ There was an increase to 693 in $193^{9}$ and in 1951 the population was $710 .{ }^{10}$ The present density is much lower than in those parishes of the hundred where there has been great building development but is still higher than in most of the rural parishes. At the end of the I 8 th century the principal centre of population was Norwood End, in the north of the parish. Since that time most of the houses there have disappeared and the population is now concentrated mainly in the village of Fyfield near the centre of the parish. This is one of the few nucleated villages in the hundred and near it to the east are the parish church and the ancient manor house of Fyfield Hall.

There are hills rising to about $260 \mathrm{ft}$. above sea-level in the south-east and $280 \mathrm{ft}$. in the north-west. In the valley between these two hills is the River Roding which enters the parish in the east and flows south to form part of the southern boundary before leaving Fyfield in the south-west. At this point the land is below $150 \mathrm{ft}$ Witney Wood is in the south-east, and there are some small patches of woodland in the north-west. The road from Chipping Ongar enters the parish in the extreme south-west and runs north-east to the Rodings and Dunmow. Close to the south-west corner a drive leads off the east side of the road to Folyats, an irregularly shaped roughcast house built about IgI4 by J. W. Newall of Forest Hall in High Ongar (q.v.). The site was chosen for its fine view over the Forest Hall estate. "I About $\frac{1}{2}$ mile farther along the road a lane leads eastwards to Herons Farm. ${ }^{12}$ The West Ham Open Air School stands on the west side of the road about $250 \mathrm{yds}$. beyond the turning to Herons. A little farther to the north is the hamlet of Clatterford End. Here there is an L-shaped block of cottages of late 17 th or early i 8 thcentury date, with pargeted plaster panels of zigzag pattern. Clatterford Hall, on the east side of the road, is a red-brick house, probably of the late 18 th or early I gth century. There have been picturesque alterations at various later dates. Clatterford House on the opposite side of the road has similar chimney-pots. It was probably built about the middle of the 1 th century. ${ }^{13}$

Beyond Clatterford End Ongar Road is joined by a road which leads westward to Moreton and by a lane which leads northward to Lampetts. ${ }^{14}$ - About $\frac{1}{2}$ mile along on the north side of the road to Moreton is Pennyfeathers. This house stands on a moated site and appears to date from the late 17 th or early 18 th century. Farther west on the same road are four pairs of council houses.

Nearly $\frac{1}{2}$ mile north-east of the road junction, on the south side of Ongar Road, is the village of Fyfield. The post-office is at the north end; from there a road known formerly as the Street and now as Queens Street, runs southward. On the east side of Queens Street is a row of houses of which the most northerly is the Queens Head Inn. These have external details mostly of the I 8 th and early 19 th centuries but the structures are older. At the south end stands the block of two houses, called Bruetts, devised by Anthony Walker in 1687 for the use of the church clerk ${ }^{15}$ and of the schoolmaster. ${ }^{16}$ North of Bruetts is another house known as Brewitts. This appears to be a r 6 th-century structure with later additions: It is said that there was once a tannery at the back of it. ${ }^{17}$ All the buildings on the west side of the Street have been built since the middle of the I gth century. They include the Mission Hall. ${ }^{18}$

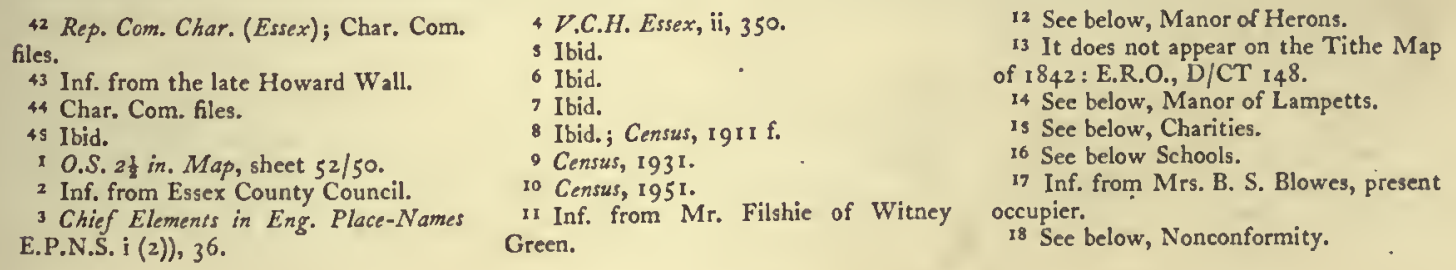




\section{A HISTORY OF ESSEX}

South of the school the road turns sharply eastward by Fyfield Bridge and continues to the eastern boundary of the parish as Willingale Lane. West of the bridge a drive leads northward to Fyfield Hall. ${ }^{9}$ Nearly opposite the drive is the church.20 At the south-west corner of the churchyard stands the building which in the late I 9 th century was known as the Vicarage. ${ }^{2 I}$ There is a water-mill22 on the River Roding about $200 \mathrm{yds}$. southwest of the church. Until early in the 20 th century there was a windmill 23 about $200 \mathrm{yds}$. west of the water-mill; the track leading to the windmill still exists. A little to the east of the church a lane known as Church Lane leads southward to Cannon's Green, formerly Bury Green. Wethers, formerly White Hall, stands at the north end of Church Lane on its east side. This house contains a fine oak staircase of late I6th-or early I 7 th-century origin. Near the staircase is the base of an original chimney. The house was altered and probably much reduced in size in the early 18 th century. Later still brick wings were built at the back. On the west side of Church Lane, opposite Wethers, is a row of three cottages which has gabled dormers and one chimney with diagonal shafts. At present only one tenement is occupied. South of the row is a single-story threeroomed cottage which was church property from at least the 17 th century until 1947.24 It probably dates from the 16th century. Since 1947 it has been rethatched and plastered and thoroughly reconditioned. South of this cottage there are seven pairs of council houses. The cottages at Cannon's Green are mostly of the I 8 th or early I 9 th centuries. Two of these have some curious coursed rubble walling consisting of knapped flints mixed with broken brick, possibly material from a demolished building. One of the two may have belonged to the church in 1835.25 Near the church to the east is Fyfield House, a brick building which dates from about 1830 . Almost opposite Fyfield House is the rectory. 26 At Witney Green, about $\frac{1}{2}$ mile east of the church, there was in about I 768 a 'fair mansion house, some time the seat of George Pochin Esquire, Sherriff of this county in 1700 '. ${ }^{27}$ 'The present farm-house appears to be mostly of the early I 9 th century with an addition of about I 860 , but at least one wing has evidently been demolished. In the yard is a fine symmetrical red-brick stable range dated 1777 . An old farm-house and buildings, all demolished in $1886,{ }^{28}$ stood about 100 yds. to the north. ${ }^{29}$ Little Witney Green, opposite Witney Green on the west side of Willingale Lane, is in course of demolition. It appears to have been a small timber-framed house of the early i 7 th century.

North of the village the road from Ongar is known as Dunmow Road. Ponders Lodge Farm, on the east side of this road near the post-office, is a two-story timber-framed house with a T-shaped plan. Part of the front oversails and has curved brackets to the soffit probably dating from about 1500 . The large chimney and back wing may be later additions. The sash windows and pargeting patterns on the plaster are of the I 8 th century. On the opposite side of the road there are several cottages which date from the I 7 th century and earlier. A little to the north of Ponders Lodge

Farm is the Black Bull Inn, beyond which there is a single-story weather-boarded cottage belonging to the church and perhaps dating from the 17 th or 18 th century.

Opposite the Black Bull Inn a road leads northwestwards to Norwood End. This area of the parish is now more sparsely populated than it was in $1777.3^{30} \mathrm{At}$ Holme Garden in Norwood End there is a moat enclosing an area which is about I 50 yds. across and consists of two adjacent sites of roughly rectangular shape. In $177^{\circ}$ there was a local tradition that Henry, Lord Scrope (d. I4IS) had a 'magnificent seat' on this spot.3I On the west side of the road, opposite the moat, stands the Nook, a small timber-framed building which probably dates from the early I 9 th century. It has the appearance of a small school or nonconformist chapel of that period and is said to have been a 'nonconformist academy'. ${ }^{32}$ It is now a private dwelling and is in process of being rebuilt. A little to the north of the Nook a track, formerly a lane, leads south to Green's Farm and then to Maltings Farm. Green's Farm stands on a moated site and appears to date from the late 17 th or early I 8 th century. Maltings Farm probably dates from the early 17 th century. It is much altered but retains a chimney with diagonal shafts. North-west of Holme Garden is Dame Anna's Farm. This stands on a moated site and is a timber-framed two-story house of medieval origin. It appears to have consisted originally of an open hall possibly with a two-story wing at the west end. The vertical timbers, which are exposed internally, are close-set and heavy. The screens passage across the east end of the hall is still in existence. The screen itself is of chamfered oak studs alternating with tall single panels, probably of I 6th- or early I 7 thcentury date. There is a two-story porch at the front of the house and a small staircase wing at the back; these two features may have been added when a ceiling was inserted in the hall. The heavy beams supporting this ceiling, now sagging, are probably of the i6th century. The brick chimney with four diagonal shafts appears to have been inserted near the west end of the hall at the same period. There are indications that the east end of the house is also a rather later addition, as two separate partitions exist side by side to the east of the screens passage. The westernmost of these has two curved braces to the tie-beam which are visible on the first floor. The upper story of the gabled porch oversails on three sides and has curved brackets to the soffit. The moulded oak door-frame is of 16 th-or early 17 thcentury date. In the window east of the porch is a fragment of heraldic glass of the 17 th or $I 8$ th century. This has the incomplete inscription 'Chard and Brom'. Probably in the present century the west part of the front was faced with red brick. Three-light sash windows were inserted, those on the ground floor having large decorative lintels of stone or cement. There is a brick single-story addition at the east end of the house. From Dame Anna's Farm a lane leads north-westwards to Hales Farm, formerly Old Hides Farm, which probably dates from the early 17 th century.

Nearly $\frac{1}{2}$ mile from the Bull Inn northward along Dunmow Road is the site of a big house, called Pickerells,

19 See below, Manor of Fyfield.

20 See below, Church.

21 Ibid.

22 See below.

23 See below.

24 See below, Church.

$2 s$ Ibid.
26 Ibid.

27 Morant, Essex, i, I 35 .

28 Inf. from Mr. Filshie, present occupier.

29 E.R.O., D/CT 148.

3o Chapman and André, Map of Essex 1777 , plate xii. Cf. O.S. 6 in. Map (Ist edn.), sheet $x$ lii.

31 Hist. Essex by Gent. iii, 334

32 Inf. from Rector of Fyfield. $\mathrm{Mr}$.

Cooke of Dame Anna's Farm calls it

'Norwood End Church'. See below, Nonconformity. 
which in the 18 th century belonged to the Brands of Herons. ${ }^{33}$ Unlike Herons, Pickerells descended to Thomas, 20th Lord Dacre (d. I85 I).34 By 1835 the house had disappeared, 35 but old foundations have been found on the site during the last few years. ${ }^{36}$ The farm which has been called Pickerells since before $1873^{37}$ was known as Ash's Farm until after I 842 when it was owned by Lord Dacre. ${ }^{38}$ It stands about 300 yds. to the north of the site of the former Pickerells and probably dates from the late 17 th, or early 18 th, century, with a front addition of about 1800 .

The inhabitants of Fyfield were at first responsible for the upkeep of Fyfield Bridge, ${ }^{39}$ but in 1616 Robert, 3 rd Baron Rich, lord of the manor of Fyfield, was said to be responsible for it.40 The parish was again responsible for the bridge in the early s gth century. It is not included in the list of county bridges about $1800^{41}$ or in 1830.42 In or shortly before 1835 it was said that the occupier of Fyfield Hall estate, with the assistance of the neighbouring gentry, had recently erected a bridge at Fyfield, from plans and specifications by George Bridges, a London builder. 43 In I 835 part of the bridge appears to have been a county charge. ${ }^{44}$ In 1858 the county surveyor noted that the bridge was built of oak and that in 1856 it had been widened at the expense of the county which was responsible only for the additional width. 45

In 1791 a wagon went at noon on Saturdays from Fyfield to the 'Saracen's Head', Aldgate.46 In 1826-7 a coach ran from Ongar and Fyfield on every day except Sunday, to the 'Bull', Aldgate, passing through Abridge and Chigwell.47 The vans of S. Clements and the wagons of Thomas Nichol also served Fyfield and other villages. ${ }^{48}$ In 1848 George Yeallett was carrier to London on Tuesday, Thursday, and Saturday.49 In 1862 a coach went daily to London. 50

In 1840 a 'memorial' for a postal service in Fyfield and other parishes was sent to the Postmaster-General51 and in 1845 Fyfield asked for a receiving office. 52 The request was shortly granted. 53 In 1877 an application for a money-order office was refused, 54 but in I 88 I a post-office was established, serving also Cannons Green, 55 with delivery extended in the next year to Norwood End. ${ }^{56}$ A telegraph office was opened under

33 See below, Manor of Herons; Hist. Essex by Gent. iii, 333.

34 E.R.O., Q/RPJ 685-737.

ss Rep. Com. Char. (Essex), H.C. 216 , pp. $227-8$ (1835), xxi (1). The explanation of the disappearance of the house may lie in the fact that from 1780 , if not before, until after 1842 the land belonging to Pickerells Farm was occupied by the Asb family who also occupied other farms in the vicinity. Pickerells was possibly demolished for better utilization of the land. In 1842 William Ash lived at Ash's farm-house (see below).

36 Inf. from Mrs. Doe of present Pickerells.

37 O.S. 6 in. Map (1st edn.), sheet xlii. 38 E.R.O., D/CT 148. The Brands owned 'John Ash farm' before 1768: Morant, Essex, i, I 35 . This was almost certainly the farm described as 'Ash's Farm' in I 842 . The latter was, however, described as Golds in Chapman and André, Map of Essex 1777 , plate xii. John Ash occupied nearly all the Brands' estate in Fyfield, including Pickerells and another, slightly larger, farm, by 1780 . He was succeeded in $1827-8$ by Mrs. Ash who was still the occupier in 1832 . In 1842 William Ash occupied 'Ash's Farm' which guarantee in $1893^{57}$ and the telephone service was established in 1923.58 A police officer is stationed in the parish.59

Water was supplied by the Herts, and Essex Waterworks Co. in the later I 9 th century ${ }^{60}$ but there is no sewerage system. ${ }^{61}$ Electricity was supplied to most of the parish in 1938.62 The village hall was built about 1920,63 and a sports ground was opened in 1951.64 A branch of the county library was opened in 1937.

Fyfield has always been a rural parish devoted mainly to agriculture. No evidence has been found to support the tradition that Henry, Lord Scrope (d. 1415), lord of the manor of Fyfield, lived in the parish, 65 nor is there evidence that any other lord of this manor lived in Fyfield in medieval times. Certainly no owner of the manor has been resident since early in the 16 th century.66 The owners of Herons never lived in Fyfield except for a period in the 18 th, and perhaps in the 17 th, century. ${ }^{67}$ The Brands lived in Fyfield during the first part of the I 8 th century, 68 but by 1768 Thomas Brand, then lord of the manor, was no longer resident. 69 Subsequent owners of Herons never lived in Fyfield. 70 The owners of Lampetts lived in the parish in the 17 th century and in the first half of the I 8 th century, 71 but after the death of John Collins in $175^{\circ}$ they were not resident until at least the latter half of the 19 th century. ${ }^{72}$

In I 842 E. F. Maitland owned 387 acres in Fyfield, the Hon. W. P. T. Long-Wellesley 288 acres, the Revd. J. B. Stane (of Forest Hall in High Ongar, q.v.) 263 acres, J. B. Stane $2 \mathrm{I} 6$ acres, and the trustees of Eleanor Kirwan 238 acres.73 None of these owners farmed their land themselves.74 J. M. Wilson owned I 2 acres which were part of the manor of Envilles in Little Laver (q.v.).75 There were three other substantial owners in the parish; Lucy Evans owned but did not occupy Dame Anna's Farm ( 131 acres); Thomas, Lord Dacre owned but did not occupy Ash's Farm (I 6 acres); and Captain Harry Ord held, as trustee of Mrs. Ord, Green's Farm (70 acres) which was occupied by W. Whitney, and Hale's Farm (58 acres) which was occupied by J. White. ${ }^{76}$ There were three other farms of over 40 acres. 77

Fyfield has always been a parish of mixed farming with a heavy predominance of arable. In 1086 there included the land on which the first Pickerells had stood.

39 E.R.O., Q/SR 75/33, $142 / 24$.

40 E.R.O., $Q / S B a ~ i / 26$.

41 E.R.O., Q/ABz 2 .

42 E.R.O., Q/ABz I.

43 Wright, Hist. Essex, ii, 338 n.

44 E.R.O., Q/ABz 2.

4 E.R.O., Q/ $/ \mathrm{ABz}_{3}$.

46 Universal Brit. Dir. (I 79I), i, 24.

47 Pigot's Com. Dir. (1826-7), App. 51.

48 Ibid. 82. Cf. Chipping Ongar, p. I 58.

49 White's Dir. Essex (1 848), 4 I 9.

so White's Dir. Essex (1863), 726.

si P.M.G. Mins 1840, vol. 52, p. 535

s2 Ibid. I 845 , vol. 80 , p. 406 .

s3 White's Dir. Essex (1863), 725.

s4 P.M.G. Mins. 1877 , vol. 168 , min.

5933.

55 Ibid. 1881 , vol. 219 , min. $895^{8}$.

s6 Ibid. 1882 , vol. 232 , min. 7276 .

57 Ibid. 1893 , vol. 497 , min. 8078 .

58 Ibid. 1923 , min. 5644 .

59 Inf. from Chief Constable of Essex.

Kelly's Dir. Essex first mentioned a sergeant-in-charge in 1898 .

60 Inf. from Herts, and Essex Waterworks Co.

61 Inf. from Rector of Fyfield.

62 Inf. from East. Elec. Bd.
63 Inf. from County Librarizn.

64 Inf. from Rector of Fyfield.

$6 s$ See above; and below, Church.

66 See below, Manor of Fyfield; E.R.O., Q/RTh I, 5; ibid. Q/RPI 685-737; ibid. D/CT 148 .

67 See below, Manor of Herons.

68 Hist. Essex by Gent. iii, 338; Wright,

Hist. Essex, ii, 339 n.; see below, Church.

The Brands may have lived at Pickerells,

substantial house; see above; and

Morant, Essex, i, 135. A new house was

built at Herons soon after Thomas Brand disposed of the manor: see below, Manor of Herons.

69 Morant, Essex, i, 135; Hist. Essex by Gent. iii, 334; Complete Peerage, iv, I617.

70 E.R.O., Q/RP1 685-737; see below, Manor of Herons.

${ }^{2}$ E.R.O., Q/RTh I, 5 ; Morant, Essex, i, 135; Wright, Hist. Essex, ii, 339.

72 E.R.O., Q/RP] 685-737; ibid.

D/CT 148.

73 E.R.O., D/CT 148

74 Ibid.

75 Ibid.

76 Ibid.

77 Ibid. 


\section{A HISTORY OF ESSEX}

were 5 ploughs in the manor of Fyfield; there was woodland for 400 swine, 10 acres of meadow, and also a hive of bees. ${ }^{78}$ In 184 I it was estimated that there were 1,655 acres of arable, 425 acres of meadow, and I 20 acres of woodland.79

In 1086 the manor contained a mill, 80 and in $128 \mathrm{I}$ there was a windmill there. ${ }^{81} \mathrm{~A}$ windmill was in use in the parish until about $1910^{82}$ when it was blown down and cleared away. It was an open-based wooden post mill.83 A mill on the River Roding is still using waterpower to grind cattle food. ${ }^{84}$ The building is weatherboarded and appears to date from the 18 th or early rgth century. The mill house is a double fronted plastered cottage probably built about 1840 .

The Fyfield Pea (Lathyrus tuberosus) $8 \mathrm{~s}$ has been naturalized at Fyfield since about I 800 . It is a native of Europe and West Asia.86 It can still be found in hedges and fields in Fyfield, in particular in a field east of the rectory, but is considered to be not so plentiful as formerly.

The works of Ernest Doe \& Son, tractor repairers, are opposite Pickerells.

In I066 F YFIELD was held by Leuric as a manor and as $I \frac{1}{2}$ hide and 30 acres and was worth MANORS $£ 5 .{ }^{87}$ In 1086 it was held by Roger of John son of Waleran and was worth $£_{07} .^{88}$ In 1094 the manor was still held of John by Roger. ${ }^{89}$ Maud wife of Hasculf de Tany was heiress of John.90

It is almost certain that Maud held the manor of Fyfield in demesne early in the 12 th century.91 Graeland de Tany, son of Maud, died in I I 79-80.92 His son and heir Hasculf, and the successors of Hasculf, undoubtedly held the manor in demesne of the king in chief by knight service, the amount of which was reported as I fee until I 4.28 and afterwards as $\frac{1}{20}$ fee. 93

Hasculf de Tany died in $1 \mathrm{I92-3.94} \mathrm{He}$ was succeeded by Gilbert de Tany who was probably his son and who died in $122 \mathrm{I}$ leaving a widow Emma who had dower in Fyfield.95 In 122 I the heirs of Gilbert were described as William de Fambridge, Maud wife of Adam de Legh, and Nicholas de Beauchamp. ${ }^{96}$ In I 223 Adam and Maud de Legh granted their rights in the inheritance to Stephen son of Alan de Normanby and Alice his wife and to the heirs of Alice.97 This Stephen seems to have been known later as Stephen de Langton. 98 In 1230 it was reported that Stephen de Langton held $\frac{2}{3}$, and Nicholas de Beauchamp $\frac{1}{3}$, of Gilbert de Tany's barony of $7 \frac{1}{2}$ fees. ${ }^{99}$ A large part of Gilbert's estate in Fyfield was evidently allotted to Nicholas de Beauchamp, who died in 1243 in possession of an estate there consisting of 254 acres of arable, 8 acres of meadow in demesne, 6 acres of pasture, a wood, rents amounting to $6 \mathrm{gs}$. $\frac{1}{2} d$. a year, and some works. ${ }^{1}$ It is not certain what happened to this estate when Nicholas died. He left a minor, whose name is unknown, as the heir to his other estates. ${ }^{2}$ Part of his Fyfield estate, however, may have passed to Stephen de Langton. Stephen and his wife Alice had some interest in Fyfield at least as early as 1228 , but it is not clear what was the extent of this interest before the death of Nicholas. ${ }^{3}$ It is certain, however, that in $125^{8}$ Stephen had in Fyfield a messuage and a carucate of land which he then granted to Roger de Beauchamp and to the adult heirs of Roger to hold of him by the service of $\frac{1}{2}$ fee and a yearly rent of I I Is. 4 d., I 30 quarters of wheat, and I 50 quarters of oats. ${ }^{4}$ After Stephen's death Roger was to hold the premises in fee and to be quit of the annual rent.s Stephen was dead by $1261 .^{6}$ In the quo warranto inquiries of $1274-5$ it was reported that Roger de Beauchamp held the manor of Fyfield of the king in chief at I fee and that he held the assize of bread and ale and view of frankpledge, but by what warrant was unknown. 7 Roger died in $\mathbf{I} 28 \mathrm{I}$ in possession of an estate in Fyfield consisting of a messuage, 2 carucates arable, 20 (l) acres of meadow, ro acres of pasture, 80 acres of wood, a windmill, and rents amounting to 66 i $35.4 d$. a year. ${ }^{8} \mathrm{He}$ was succeeded by his son John. ${ }^{9}$ In $\mathrm{I} 295$ John de Beauchamp received licence to enfeoff Henry de Enfield, Alice his wife and John their son with 44 acres of land which they were to hold of the king by $\frac{1}{30}$ fee. ${ }^{10}$ Henry de Enfield was probably lord of Envilles manor in Little Laver (q.v.). In I 303 it was reported that John de Beauchamp and his tenants held I fee in Fyfield. "I In I 309 John de Beauchamp settled the manor of Fyfield on his son Nicholas but reserved a life interest for himself. 12 John was still alive in 1320 , but by 1329 Nicholas was in possession of the manor. ${ }^{13}$ In I 332 Nicholas received licence to enfeoff John Hotham, Bishop of Ely, with the manor. ${ }^{14}$ In 1334 the king granted to John Hotham and his heirs free warren in all their demesne lands of the manor.' Is In November I $334 \mathrm{John}$, Bishop of Ely, received licence to grant the manor to John son of Peter Hotham. ${ }^{16}$ In 1337 Sir John Hotham received licence to grant the manor to his son John and Ivetta his wife to hold to them and their issue with remainder to Ivetta's brother Henry, son of Geoffrey le Scrope, and his heirs. ${ }^{17}$ John died without issue in 1351.18 In 1355 his widow Ivetta granted the manor to her brother Henry le Scrope to hold during her life at a rent of $f_{0} 62$ I 35 . 4 d. during the lifetime of Mathias de Beauchamp, who was probably the occupier, and 666 I 3s. 4d. after the death of Mathias. ${ }^{19}$ Ivetta was dead by $1374 .{ }^{20}$ Her brother Henry, Ist Lord Scrope of Masham, then held the manor in his own right until he died in 1392 , leaving as his heir his son Stephen, and Lord Scrope, who died in

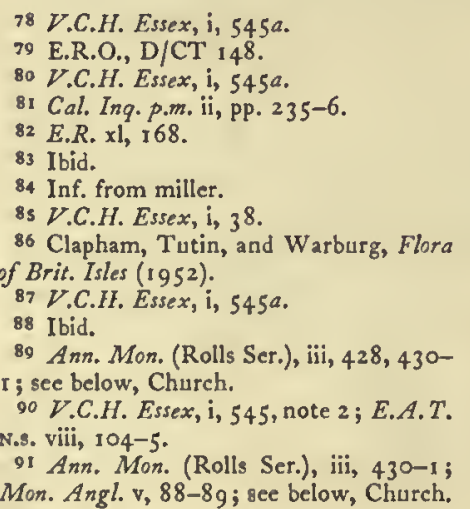

92 Ann. Mon. (Rolls Ser.), iii, 430-1; E.A.T. N.s, viii, $104-5 ;$ Pipe R. 1180 (P.R.S. $x x i x$ ), 6.

${ }_{93}$ E.A.T. N.s. viii, $104-5$; Feud. Aids, ii, 136, 160, 222 ; Cal. Close, 1454-61, 94-95.

94 Pipe R. I193 (P.R.S. N.s. iii), 8

93 Ex. e Rot. Fin. (Rec. Com.), i, 71-72; Feet of $F$. Essex, i, 67 .

96 Excerpta e Rot. Fin. i, 72.

97 Feet of F. Essex, i, 67

98 Feet of $F$. Essex, i, 74

99 Pipe R. 1230 (P.R.S. N.s. iv), 137

I Cal. Ing. p.m, i, 288; Ex, Rot. Fin.

(Rec. Com.), i, 402. Nicholas also held the advowson.

2 Cal. Inq. p.m. i, p. 288.

3 Feet of F. Essex, i, 74, $116,120,134$.
4 Feet of F. Essex, i, $232 . \quad$ S Ibid.

6 Cal. Close, 1261-4, 16; Ex. \& Rot. Fin. (Rec, Com.), ii, 364

7 Rot. Hund. (Rec. Com.), i, 153

8 Cal. Inq. p.m. ii, pp. 235-6.

9 Ibid.

10 Cal. Pat. 1 202-1 301, 144.

11 Feud. Aids, ii, 136 .

12 Feet of $F$. Essex, ii, 125.

13 Feet of F. Essex, ii, 200-1; Cal. Pat. $1327-30,450$.

14 Cal. Pat. I $330-4,235$

is Cal. Chart. R. 1327-41, 320.

16 Cal. Pat. $1334-8,46$.

17 Ibid. 487 .

18 Cal. Inq. p.m. ix, pp. 429-30.

19 Cal. Pat, $1354-8,174$

20 Cal. Pat. $1374-7,34-35$ 
I 406.21 The king then assigned the manor to Margery widow of Stephen in dower, for life, with reversion to Henry, 3rd Lord Scrope, son and heir of Stephen.22 In May I 4 I 3 Margery granted the manor to Henry for 40 years at an annual rent, on condition that the estate should revert to her if Henry should die within her lifetime. ${ }^{23}$ Henry was beheaded in I 4 I 5 and the king then took possession of the manor of Fyficld with the rest of Henry's lands. ${ }^{24}$ Margery immediately petitioned for restitution of the manor as her right and in November I4 I 5 obtained it. 25 She died in 1422.26 The Crown then took possession of the manor the custody of which was in February 1423 granted to Sir John de Langton and John de Aske. ${ }^{27}$ In December I 423 John le Scrope, brother and heir of Henry, 3 rd Lord Scrope, recovered the lands which his mother Margery had held in dower. ${ }^{28}$ Later John recovered the barony. When John, Lord Scrope, died in $\mathbf{1} 455$ he held the manor of Fyfield jointly with his wife Elizabeth who survived him. 29 She died in 1466 and the manor then passed to her son Thomas, Lord Scrope, who died in 1475.30 In I 476 Elizabeth widow of Thomas was granted custody of the manor during the minority of her son Thomas, Lord Scrope. ${ }^{31}$ When Thomas, Lord Scrope, died in I 493 he was seised of Fyfield jointly with his wife Elizabeth who survived him. ${ }^{32}$ Elizabeth died in 1517 , having outlived both her only child Alice, suo jure Baroness Scrope, and her grandchild Elizabeth. ${ }^{33}$ 'The heir to the manor of Fyfield was then Eleanor, widow of Ralph, Lord Scrope, who had settled the reversion on her before his death in 1515.34 Eleanor died before 25 March I53I.35 The manor then passed to the daughters of Elizabeth, sister and coheir of Geoffrey, roth Lord Scrope: Alice wife of Charles Dransfeld, Elizabeth wife of Nicholas Strelley, Dorothy wife of Lancelot Esshe, and Agnes wife of Marmaduke Wyvill. ${ }^{36}$ In I 537-8 these sold the manor to Sir Richard Rich, afterwards Ist Baron Rich. ${ }^{37}$ Afterwards the manor followed the same descent as Paslow Hall manor in High Ongar (q.v.) until the death of the Earl of Mornington in $1863 .{ }^{38}$ It then passed to Henry, Ist Earl Cowley, a cousin of the Earl of Mornington. ${ }^{39}$ After Lord Cowley's death in 1884 the manor was held by his son William, Earl Cowley, who died in 1895.40 By 1898 the manor had passed to Andrew Alfred Collyer Bristow of Beddington (Surr.) who kept it until his death in 1906-12, after which it was held by his trustees until after 1937.41

In I 842 Fyfield Hall farm consisted of 288 acres which were in the occupation of Thomas Horner.42 At that time the farm was still owned by the Wellesley family, lords of the manor of Fyfield.43 By the end of I 865 , however, the farm, or at least part of it, had become separated from the manor. J. L. Newall who was at this time purchasing the Forest Hall estate (see High Ongar), bought part of Fyfield Hall farm in 1865 and the remainder in 1874.44 Afterwards the farm descended with Forest Hall until the estate was sold, in several lots, in 1919.45 At that time the farm consisted of 224 acres which were let to G. and D. W. White at a rent of $£ 342$ a year. ${ }^{46}$

Fyfield $\mathrm{Hall} 47$ is a timber-framed house of various dates. The plan is complex, having at the core part of an aisled hall, possibly of the carly I 4 th century. This was of two approximately equal bays, the axis running east and west. The south aisle is now missing. At the cast end, also on an east-west axis, is another medieval structure, probably of later date than the original hall. Parallel to the hall and built against its north aisle is a two-story range, dating from about 1500 . Three more gabled wings have been added at different dates. One, at the north-west corner of the house, contains the staircase and is probably of the I6th or early I 7 th century. The others, at the south-west corner and across the east end of the north range, date from the I 8 th century or later. The early plan is remarkable for its use of the east-west axis throughout instead of the more usual cross-wings of medieval times.

The timbers of the north aisle of the I4th-century hall are mostly in position, although concealed by later work. 48 Between the bays stands an oak post from which the curved braces forming the two arches of the 'nave arcade' spring. 'The lower part of this post, octagonal on plan and about 15 in. in diameter, can be seen in a cupboard on the ground floor. The capital has a I 4 th-century moulding and the base has long spur stops. Above the level of the springing the post has a square section and is carried up to support a massive plate running longitudinally at the junction of the 'nave' and aisle roofs. At each end of the hall the projection of the plate is over I $\mathrm{ft}$. in length, suggesting that the original I 4 th-century building had overhanging gables. Most of the original timbers of the 'nave' roof, which is of the trussed rafter type, are in position, all heavily blackened with smoke from an open hearth. An unusual feature is the presence of straight wind-braces, pegged through to each rafter and crossing at the top. The bracing members of the central truss are missing but the position of mortices and slots in the main members strongly suggests that long straight braces crossed between the collar and the apex of the roof and formed a scissor truss. There are indications of smaller braces below the tiebeam. In the north aisle the position of a window can be determined by the presence of mortices for diagonal mullions on the underside of the wall plate. The south aisle has been destroyed, but the central post is still in place. It has been cut back so that its mouldings and octagonal shape are obliterated.

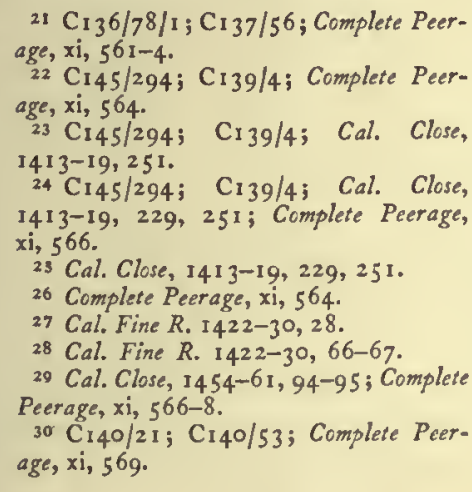

31 Cal. Pat. 1467-77, 582, 599; Complete Peerage, xi, 569-7o.

32 Cal. Inq. p.m. Hen. VII, i, p. 396.

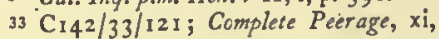
57 I.

${ }_{34} \mathrm{C}_{142 / 33 / 121}$; Complete Peerage, xi, 57 I -2.

35 Complete Peerage, xi, 572.

36 E.R.O., D/DCw Mioz; V.C.H. rorks. N.R. i, 234 ; Complete Peerage, xi, 572. Geoffrey, Lord Scrope, son of Thomas, Lord Scrope (d. I475) had sueceeded his brother Ralph in 1515 and died unmarried in 1517.

$37 \mathrm{CP}_{4}$ o/1098 Ro. $148 ; \mathrm{CP}_{25}$ (2)/12/65 East. \& Trin. 29 Hen. VIII; $\mathrm{CP}_{25}(2) /$ $12 / 66$ Trin. 30 Hen. VIII; E.R.O.,


under the auspices of the Royat Commission on Historical Monuments and the National Buildings Record. 

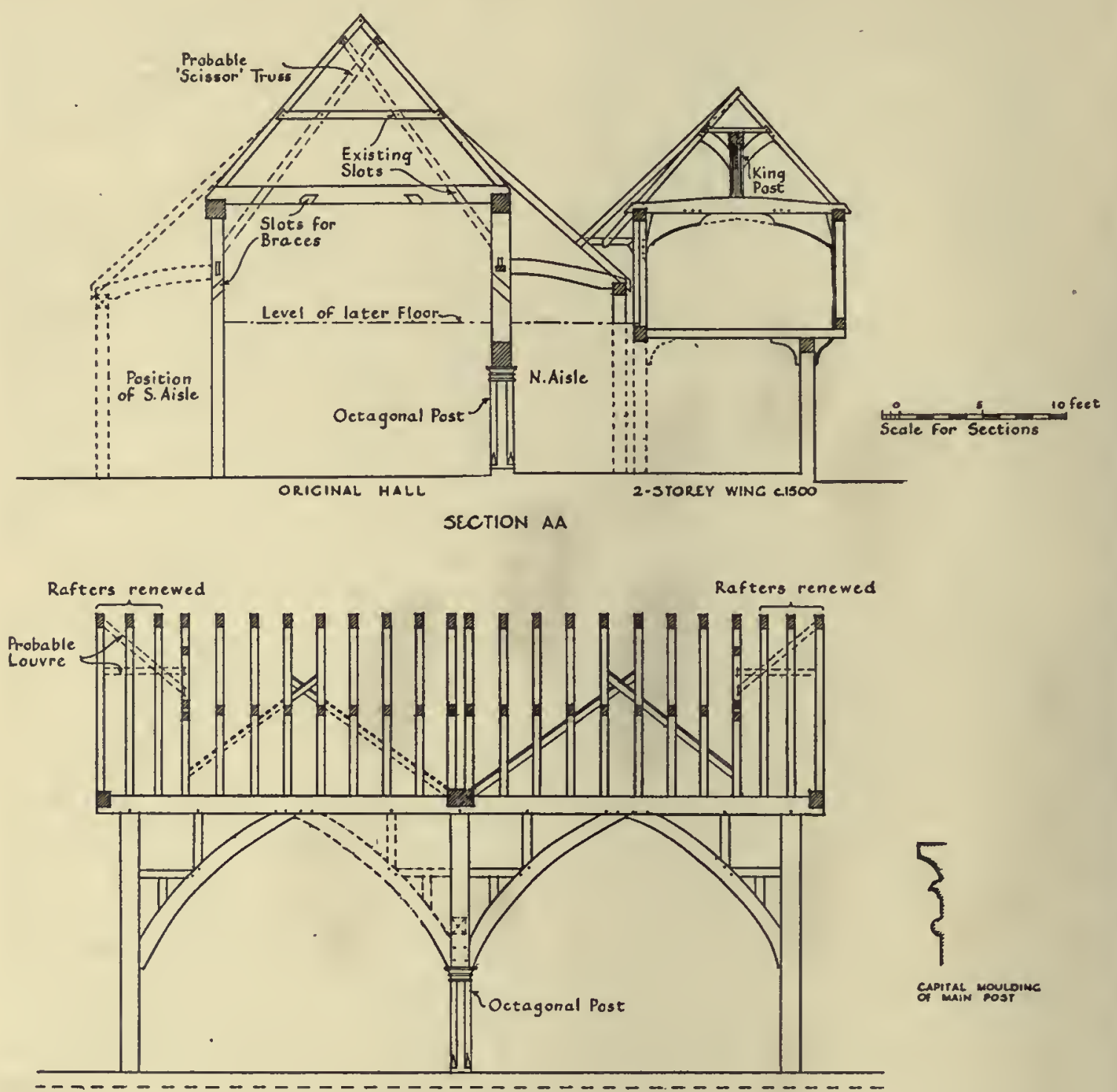

SECTION BB OF ORIGINAL HALL

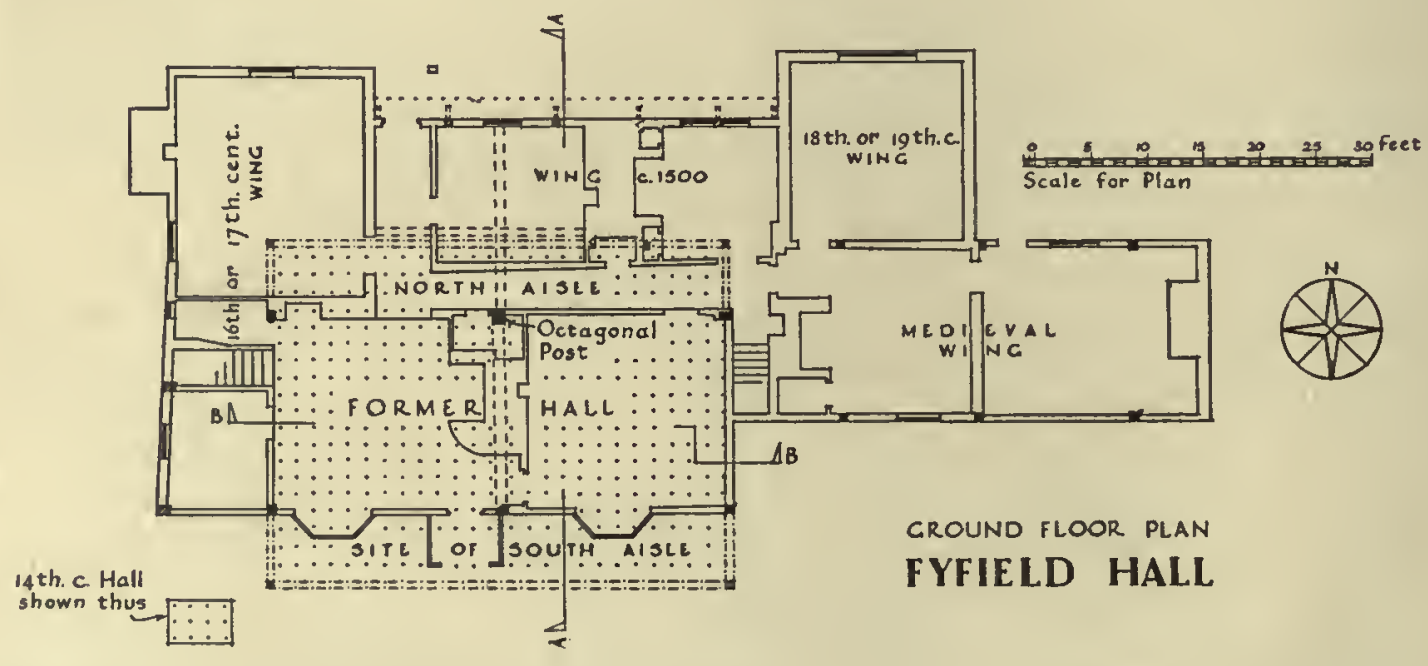


The structure east of the hall is divided from it by a space about $6 \mathrm{ft}$. wide, possibly an external passage. Part of it was open to the roof and at one time a central truss was fitted with a king-post. There is some smokeblackening of the roof timbers.

The two-story north range is built alongside the aisle wall but is independent of it structurally. It is of four bays, divided in the roof by three king-post trusses. The westernmost king-post is rebated and hollow-chamfered, suggesting that at this end there was an open roof visible from an important upper room or solar. The upper floor oversails along the north side and has curved brackets to the soffit. The ends of the joists are concealed by a moulded bressummer, over $40 \mathrm{ft}$. long, enriched with a running design typical of about 1500 . The nail-studded entrance door is probably original.

The reconstruction of the hall probably took place in the I6th century. A ceiling was inserted and the central chimney built. The introduction of an upper story needing light and head-room would necessitate the demolition of the south aisle. The staircase wing may be of the same period but the other additions are later. The chimney in the north range was built in two stages, the older stack having a shaped panel which probably carried a date or initials. The upper part of the south chimney is now dated 1700.

The sash windows, including the splayed bays on the south front, were all inserted about 1886. The timber porch and the loggia were added after I945. In the garden to the east of the house there is a rectangular fish-pond known as the 'Catholic Pond'.

The manor of HERONS was in the ownership of the priory of Little Leighs when the latter was dissolved in I 536.49 Its earlier history is uncertain but its origins are perhaps to be found in several estates which may have been merged by the priory at the end of the $3^{\text {th }}$ century.

Leighs priory may have possessed lands in Fyfield before I 247. In I 2 I I-I 2 Oger son of Ernald de Curton held I fee in Tendring and Fyfield. ${ }^{50}$ Oger apparently granted the fee to Thomas de Lungevill' who in 1223 conveyed at least part of it, including lands in Fyfield, to William de Curton, brother of Oger. ${ }^{\text {st }}$ In I 233 Eustace de Curton, who may have been the son of William, granted roo acres of land in Fyfield to Ralph Gernon, probably the founder of Leighs priory. 52 Ralph, who apparently owned no lands in Fyfield at his death in 1247 , may have granted this estate to the priory. ${ }^{53}$

After 1282 the priory may have acquired in Fyfield two other estates each of which had formed a separate manor in the I I th century. In 1066 one was held by Alwin as 80 acres and as one manor worth 30 s. 54 In I 86 this was held of Count Eustace of Boulogne by 'Iunanus' and was then worth $40{ }^{55}$ The other manor was held in 1066 by Brictmar as 40 acres and as one manor worth 55.56 In 1086 this manor was held of Count Eustace by Richard and was worth 105.57 These two manors werc probably merged in the I 2 th century. The overlordship passed with the honor of Boulogne to the Crown after the death in I I 59 of William, Count of Boulogne. The mesne tenancy was held in the reign of Henry II by Pharamus of Boulogne, great-grandson of Count Eustace of Boulogne.58 It descended to Pharamus' daughter Sybil wife of Ingram de Fiennes and subsequently to her son William de Fiennes.59 Afterwards Ingram son of William de Fiennes apparently held the manor. ${ }^{60}$ In 1248 he granted to Ralph de Marcy I messuage and I 20 acres of land in Fyfield to hold of him at a rent of 325.2 year. ${ }^{61}$ This estate was equal in extent to the combined acreage of the two Fyfield manors which were held of Count Eustace in I086. In 1282 William de Fiennes, son of Ingram, conveyed some rights in Fyfield to Robert Burnell, Bishop of Bath and Wells. ${ }^{62}$ It is not clear what was the effect of this conveyance. Soon afterwards, however, Leighs priory may have acquired the manor and added to it lands acquired previously from Ralph Gernon. In I 29 I the priory had an estate in Fyfield valued at 6.7 Ios. I $d{ }^{63}$ In $\mathrm{r} 303$ and 1346 it was reported that the priory held in Fyfield $\frac{1}{8}$ fee of the honor of Boulogne. ${ }^{64}$ This estate may have derived its name of Herons from one who farmed it in the I 4 th or $15^{\text {th }}$ century. 65

Immediately after the dissolution of Leighs priory in I 536 the manor was granted by the Crown to Sir Richard Rich, afterwards Ist Baron Rich. ${ }^{66}$ On his death in 1567 it passed to his son Robert, 2nd Baron Rich, who settled it on his eldest son Richard when Richard married Katherine Knevett. ${ }^{67}$ Richard's death without issue in I 580 was followed by that of his father in 1581.68 The manor then passed to Robert, 3 rd Baron Rich, who in 1612 conveyed it to Robert Bourne. ${ }^{69}$ In 1643 Richard Bourne, who may have been a nephew of Robert Bourne, conveyed the manor to Alexander Benton and Richard Master. ${ }^{70}$ In 1694 Thomas Richardson and his wife Anne granted it to Charles Nowes to hold during Anne's life.71 In 1697 Charles Nowes and his wife Ann, and John Brett Fisher and Judith his wife conveyed the manor to John Savill. ${ }^{72}$ By I 7 I I the manor was owned by Timothy Brand of London. ${ }^{73}$ Afterwards it passed to Thomas Brand who may have been Timothy's grandson and who also owned Pickerells Farm.74 Before I768 Thomas Brand was succeeded by his son Thomas who in 1771 married Gertrude, suo jure Baroness Dacre.75 Before I 780 Thomas Brand granted Herons to Thomas Brand Hollis, although he retained in Fyfield a considerable estate, including Pickerells and Ash Farms, which later descended to his son Thomas, Lord Dacre (d. I 85 I).76 Thomas Brand Hollis was owner of Herons until about I 804 when it passed to Dr. Disney. 77 In $1811-12$ Disney was succeeded by the Revd. John Bramston

49 L. 60 P. Hen. VIII, x, p. 420.

so Red Bk. of Exch. 580 ; Bk. of Fees, 238 .

\$1 Bk. of Fees, 242, 1435; Feet. of $F$. Essex, i, 49, 63 .

32 Feet of F. Essex, i, 93,$514 ;$ Y.C.H. Essex, ii, I 55 ; E.A.T. N.5. xii, 90.

$\$ 3$ Cal. Inq. p.m. i, p. 292 ; Ex. \& Rot. Fin. (Rec. Com.), ii, 23.

s4 V.C.H. Essex, i, 4676 .

55 Ibid. 56 Ibid. 57 Ibid.

58 Bk. of Fees, 1428; Genealogist, N.s. xii, $145-51$.

s9 Bk. of Fees, 235-6, 240, $1428,1435$. 60 De La Chenaye-Desbois et Badiet,

ES. IV

Dictionraire de la Noblesse, viii, 39-4r. 6s Feet of $F$. Essex, i, 181 .

62 Feet of $F$. Essex, ii, 36 ; C. Moor, Knights of Edw. I (Harl. Soc. Ixxxi), ii, 23 ; De La Chenaye-Desbois et Badier, Dictionnaire de la Noblesse, viii, 39-4I.

63 Tax. Eccl. (Rec. Com.), 25.

64 Feud. Aids, ii, I $36,160$.

65 P.N. Essex (E.P.N.S.), xii, 57; Feet

of $F$. Essex, ii, 123 .

66 L. $\sigma^{\circ}$ P. Hen. VIII, x, p. 420.

$67 \mathrm{C}_{142 / 147 / 141} ; \mathrm{C}_{142 / 192 / 29}$.

$68 \mathrm{C}_{142 / 192 / 29}$.

$69 \mathrm{CP}_{25}(2) / 294$ Trin. 10 Jas. I.

$70 \mathrm{CP}_{25} 5(2) / 4$ I9 Mich. I9 Chas. I;
Sepulchral Memorials of Bobbinguvorth, ed. F. A. Crisp, $31-33$.

${ }^{11} \mathrm{CP}_{25}$ (2)/828 Trin. $6 \mathrm{Wm}$. \& Mary. ${ }_{72} \mathrm{CP}_{25(2) / 829}$ Hil. $9 \mathrm{Wm}$. III

73 E.R.O., Q/RSg 1.

74 Morant, Essex, i, 135. A Thomas Brand was buried in Fyfield in 1718 : Wright, Hist. Essex, ii, 339. He was probably the father of the Thomas Brand of Pickerells mentioned by Morant.

73 Ibid.; Hist. Essex by Gent. iii, 336; Complete Peerage, iv, 16 .

76 E.R.O., Q/RPI 685-737; ibid.

D/CT 148.

77 E.R.O., Q/RPI 709-15. 


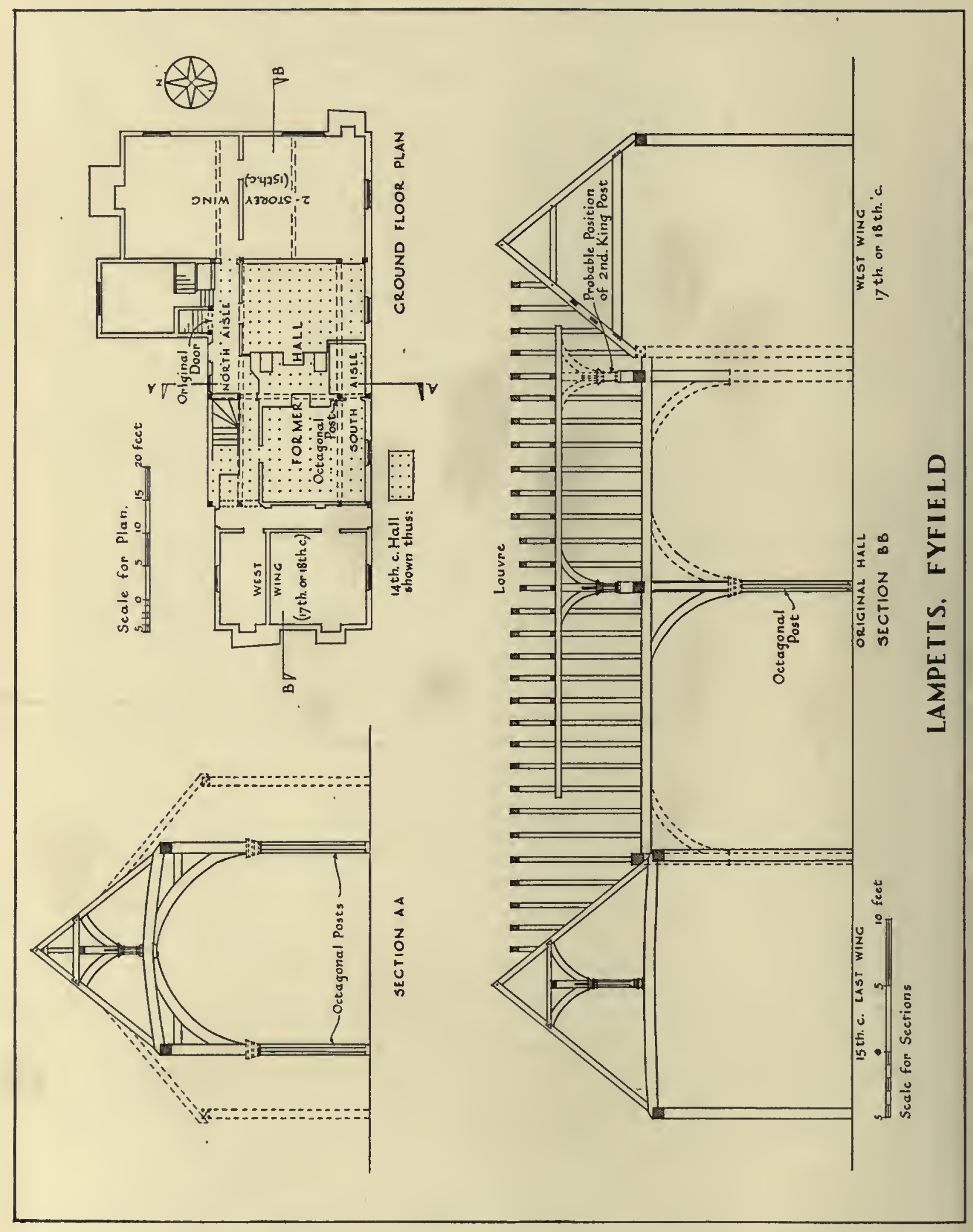


Stane of Forest Hall, High Ongar (q.v.). 78 Herons remained part of the Forest Hall estate until that estate was put up for sale by auction in I 919.79 In 1842 Herons Farm consisted of 262 acres of which 205 acres were arable. ${ }^{80}$ From 1813 untilafter 1842 the occupier was James Lucking. ${ }^{81}$ In 1919 the farm consisted of 234 acres of arable and pasture, all of which was let to $R$. and $H$. Oliver at a rent of $£_{3} 386$ a year. ${ }^{82}$

The site of the original manor house, partly covered by farm buildings, is south of the existing farm-house. It was surrounded by a moat with a second moated enclosure, perhaps for cattle, to the west of it. ${ }^{83}$ The present house dates from the late 18 th or early igth century with a wing of about I 870 on its west side. One of the timbered barns may be of the 17 th century.

The manor of LAMPETTS appears for the first time under that name in the I 5 th century. 84 It probably derived the name from 'Thomas Lampet (see below). ${ }^{85}$

The early history of the manor cannot be traced with certainty. It is possibly to be identified, however, with the manor which was held in 1066 by Alestan and in 1086 by Roger of John son of Waleran. ${ }^{86}$ It was then held as 30 acres and was worth 205.87 It is likely that after 1086 this small estate was held of the manor of Fyfield. In 1475 Lampetts was held of Thomas, Lord Scrope, lord of the manor of Fyfield. ${ }^{88}$ In 1485 it was said to be worth $40{ }^{89}$

Thomas Lampet was a tenant of the manor of Fyfield by 1385 and from then until at least $x 396$ he was continually presented for failing to do suit at the manor court.90 He was dead by 1411.91 In 1412 it was reported that Isabel Lampet held lands and tenements in Fyfield.92 Later the estate passed into the ownership of the Wrytell family which had connexions with the Lampets in 1411.93 In 1473 Walter Wrytell apparently gave instructions that after his death his manor of Lampetts was to be used for the maintenance of an obit in Bobbingworth church.94 Later, however, he must have changed his mind, for at thet ime of his death in 1 475 Lampetts was settled, by his demise, on his wife Katherine for life with remainder to his heirs. 95

After I 475 the manor of Lampetts followed the same descent as that of High Laver (q.v.) until 15 Io. In I 5 10 Lampetts was allotted to Edward and Gresilda Waldegrave to hold to them and to the heirs of Gresilda. 96 In I 539 William Rochester, son of Gresilda by her first husband John Rochester, granted the manor to Sir Richard Rich, later Ist Baron Rich. 97 In I 564 Rich conveyed the manor to John Waylett. 98 In 1565 Waylett granted it to Nicholas Collins. ${ }^{99}$ The estate remained in the Collins family until after the death of John Collins in 1750.1 He was succeeded by his only child Mary who brought the manor in marriage to Jacob Wragg, Rector of North Cadbury (Som.). ${ }^{2}$ After Wragg's death in $1785-6$ Mrs. Wragg held the estate until she died in $1804-5 .{ }^{3}$ Her executors then sold it in 1806 to Ebenezer Maitland who retained ownership until after 1863.4 In 1842 the estate consisted of $33^{\circ}$ acres. ${ }^{5}$ The manor house, ${ }^{6}$ which stands on a moated site, is a timber-framed structure of two stories. The central part was originally an aisled hall of the i 4 th century, built on an east-west axis and consisting of two or more bays. The cross-wing at the east end, which projects slightly to the south, was added in the 15 th century. The division of the hall into two stories may have taken place in the 16 th century and at the same time the north aisle roof was replaced by two gables to give light to the upper floor; the raising of the eaves level on the south side is of much later date. The small staircase block in the angle between the hall and the east wing is also probably of the r6th century. The west cross-wing was probably built or rebuilt early in the 18 th century.

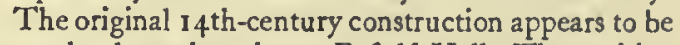
somewhat later than that at Fyfield Hall. The position of the two longitudinal plates marking the limits of the 'nave' can be seen in the roof space. Below these lay the nave arcades. The post in the centre of the arcade on the south side is still partly visible behind plaster in a ground-floor cupboard. It is octagonal in section and about I ft. in diameter. The corresponding post of the north aisle is buried in a later partition. A curved timber forming one side of the easternmost arch of the south arcade can be seen both from the roof space and against the later chimney breast on the first floor. The construction of the upper part of the north aisle can also be traced, but several of the timbers are missing. In the roof space above the nave all the timbers are much smoke-blackened. Across the centre is a king-post truss with a cambered tie-beam below which were originally two large arched braces. One of these is still in position. The short king-post is octagonal. It has four-way struts and a moulded capital and base. There are indications of a second king-post truss near the west end of the hall where the addition of the later cross-wing has cut into the I4th-century construction. This may represent the site of a demolished screens bay. An original doorway near the east end of the north aisle, however, suggests an alternative site for the screens passage.

The roof of the two-story east wing is divided into three bays by two original trusses, the timbers of which are not smoke-blackened. One of the king-posts is octagonal, the other octagonal on a square base and both have fairly elaborate mouldings. 'This was almost cer-

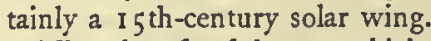

The chamfered beams which support the inserted ceiling in the hall have bar-stops of the 16 th or early $17^{\text {th }}$ century. The central chimney and one at the south-east corner of the house have diagonal shafts and moulded brickwork and are probably of much the same date. There is panelling of a similar period near the west end of the house. Most of the fittings and panelling in the west wing date from the first half of the 18 th
78 E.R.O., Q/RP1 $715-37$.

79 E.R.O., Sale Cat. A. 225.

so E.R.O., D/CT 148.

8: E.R.O., Q/RP1 718-37; ibid. D/CT 148.

${ }_{82}^{148 .}$ E.R.O., Sale Cat. A. 225

${ }_{83}$ Hist. Mon. Com. Recs.

84 Cal. Inq. p.m. Ilen. VII, i, pp. $6 \mathrm{x}-6 \mathrm{z}$ $383 ; \mathrm{C}_{14} \% / 52$.

${ }_{8 s}$ Cal. Ing. p.m. Hen. VII, i, pp. 61-62, 383.

${ }_{86}$ V.C.H. Essex, i, 545a; see above, Manor of Fyfield.

87 V.C.H. Essex, i, 545a.
${ }_{88} \mathrm{C}_{14}$ o/52.

89 Cal. Inq. p.m. Hen, VII, i, pp. 61-62.

90 E.R.O., D/DCw M97.

91 Feet of $F$. Essex, iii, 256

92 Feud. Aids, vi, 439.

93 Feet of $F$. Essex, iii, 256 .

94 Morant, Essex, $\mathrm{i}, 135$.

95 $\mathrm{C}_{140 / 52}$; Cal. Ing. P.m. Hen. VII, $\mathrm{i}$, pp. $61-62,383$.

96 E.R.O., D/DB T $96 / 69$.

${ }_{97} \mathrm{CP}_{4} \mathrm{O} / \mathrm{x} 102$ rot. 157.

$98 \mathrm{CP}_{25}(2) / 127 / 1624$. Cf. Blake Hall

Manor in Bobbingworth.

99 P.R.O., MS. Cal. Feet of F. Essex,
Mich. 7-8 Eliz. (the original final concord is now missing).

${ }_{1} \mathrm{CP}_{25}(2) / 135 / 1725 ; \quad \mathrm{CP}_{25}(2) / 922$ Trin. 4 Anne; $\mathrm{Cr}_{42} / 48 \mathrm{r} / 44$. In the records the family name is sometimes spelt Collins, sometimes Collin, and occasionally Collen.

${ }^{2}$ Hist. Essex by Gent. iii, 336 .

3 E.R.O., Q/RPl 685-710.

4 E.R.O., Q/RP1 711-37; ibid. D/CT 148 ; ibid. $Q / \operatorname{RPr} 1 / 27$; White's Dir. Essex (1863).

3 E.R.O., D/CT 148.

${ }^{6}$ See pl. p. 50. 


\section{A HISTORY OF ESSEX}

century. The roof on the south side, the present sash windows, and other details are of the early I 9 th century. Part of the house is now in use as a farmworker's dwelling; the rest is unoccupied.

The rectory of Fyfield was never appropriated although for a long period in the I 2 th cenCHURCH tury the Cluniac priory of Bermondsey (Surr.) had the right to receive the greater part of the tithes of the parish as well as the advowson of the rectory.

In 1094 Roger, lord of the manor of Fyfieid, with the consent of his overlord John son of Waleran, gave 'the tithes of Fyfield' to Bermondsey priory. ${ }^{7}$ In 1 I07 or later Maud wife of Hasculf de Tany and her son Graeland confirmed this gift and also granted to the priory the advowson of Fyfield church. ${ }^{8}$ In is 83 the priory released the advowson to the then lord of the manor, Hasculf son of Graeland de Tany. After this the advowson was held by the lords of the manor of Fyfield until I $890-1$ when it was granted by William, Earl Cowley, to George Mayor. 9 'The advowson was held by Mayor until I 897 or 1898 after which it was held by Mrs. A. Hewitt until I 914 or I $915 .^{10}$ Mrs. J. Worthington Atkin then held it until 1929 or 1930 after which it was held by Canford School (Dors.). ${ }^{\text {II }}$ The living is now (1955) in the gift of the Church Pastoral Aid Society which controls the Martyrs' Memorial Trust, of which the Canford School Trust forms part. ${ }^{12}$

In return for the release of the advowson in 1183 Hasculf de Tany confirmed to the priory $\frac{2}{3}$ of the tithes from his demesne, together with those from his demesne assarts made or to be made, and undertook to give them I acre of land on which to erect a tithe barn, and also to secure to them a perpetual annuity of 40 s. payable by the parson of Fyfield. ${ }^{13}$ In about I 254 it was reported that the rectory of Fyfield was worth 24 marks and that the monks of Bermondsey received $\frac{2}{3}$ of the tithes from the demesne of 'two lords of that vill' as well as 40 . from the parson. ${ }^{14}$ In I 29 I the church of Fyfield was valued at $E_{1} 2 ;^{15}$ the prior of Bermondsey had there a portion worth $\varepsilon_{3} 6 s .8 d$. and a pension of $£ 2 .{ }^{16}$ In I 342 the prior of Bermondsey brought an action against the parson of Fyfield for payment of the annuity of 40 s. due to his house. ${ }^{17}$ In 1427 the church was still taxed on the valuation of $\mathrm{I} 291.18$ In I 535 the abbey of Bermondsey still held in Fyfield a pension and a portion which were then valued together at $\delta .4 .^{19}$ At that time the rectory of Fyfield was valued at $£ 257$ s. $2 \frac{1}{2} d .{ }^{20}$ The abbey was surrendered on I January I $538 .{ }^{21}$ In I $65^{\circ}$ the 'improved' value of the tithes was $\oint_{1} 20$ and the value of the glebe lands and buildings 635.22 The tithes were commuted in 1842 for $674 \mathrm{I}$; there were then 64 acres of glebe. ${ }^{23}$

Anthony Walker D.D., Rector of Fyfield from $165^{\circ}$ until 1692 , helped in the publication of Eikon Basilike and published various books and sermons. ${ }^{24}$

The rectory stands on a large moated site about 400 $y d s$. to the north-east of the church. It is irregularly shaped and has been altered and extended at different periods. Running from front to back in the centre of the house is a medieval timber roof, probably representing part of a two-storied cross-wing of the I 5 th century. The north end of the roof has curved wind-braces and in the south bay is an arch-braced collar beam with the king-post missing. East of this roof and at right angles to it is another timber-framed wing which may be of medieval origin. There are additional wings of later date at the west end of the house. In the 18 th century the whole front was faced with red brick and there are some interior details of the same period. In about 1770 the house was described as 'a large stately brick building almost surrounded with a moat which, with the house, encloses a pleasant garden'.25 In 1944 blast from a flying bomb caused considerable damage and in 1952 the front was rebuilt in yellow brick and parts of the roof were renewed. The porch and the original sash windows were replaced.

Although this building is certainly of medieval origin, in the middle of the I 6th century at least the rector lived in another house, which was then known as 'the parson's house' and was situated on the south side of the church. In October I 546 Robert Nooke, then rector, let to Humphrey Nycolls, servant to Sir Richard Rich, afterwards Ist Baron Rich, for 5 I years, at $£ 2575.2 \frac{1}{2} d$. a year, the rectory, church, and parsonage of Fyfield, reserving, however, for his own residence his house south of the churchyard called 'the parsonnes house'. ${ }^{26}$ By I6ro, however, the house to the south of the church was not regarded as the parsonage-house for a terrier of 1610 described the rectory as including "a ParsonageHouse, with two barns, and other edifices within the yard, and a house abutting upon the churchyard, then in dispute at law'.27 In 1650 the rectory was said to include 'a parsonage house, glebe lands and a small tenement'. ${ }^{28}$ Whatever the source or the outcome of the dispute of 1610 , a property at the south-west corner of the churchyard was part of the glebe in 1842 and remained so until 1948 , when it was sold.29 In the late I 9 th century it was known as the Vicarage. ${ }^{30}$ The back part of the building is timber-framed and weatherboarded with a tiled mansard roof and dates from the 18 th century, if not earlier. The front was added in the I $9^{\text {th }}$ century and the building now comprises two attached cottages.

The parish church of $S T$. NICHOLAS consists of nave, north and south aisles, chancel, central tower, north porch, and organ chamber. The nave and the first stage of the tower are mostly of flint rubble with some Roman brick. The second stage of the tower is
7 Ann. Mon. (Rolls Ser.), iii, 428, 430-1. Roger held only 2 of the 4 manors in Fyfield at this time. Presumably his grant was only of his own tithes.

${ }^{8}$ Ann. Mon. (Rolls Ser.), iii, 430-1. In these annals the date assigned to Maud's gift was 1ro7. J. H. Round thought this date too early to be probable: E.A.T. N.s. viii, $104-5$.

- Newcourt, Repert. ii, 26I-2; Kelly's Dir. Essex ( 1870 f.); Clergy List, I $842-$ 91; Crockford"s Cler. Dir. (1889, 1891). 10 Clergy List, i 892-7; Kelly's Dir. Essex (1898f.); Chel. Dioc. Year Bk. 1915.

91 II Clergy List, I 916 f.; Crockford's Cler.
Dir. (1929, 1930); Chel. Dioc. Year Bk. $1937 \mathrm{f}$.

${ }_{12}$ Chel. Dioc. Year Bk. I 940 f. Inf. from the Revd. K. C. Stevenson.

${ }_{13} E . A . T$. N.s. viii, $104-5$. In 1181 the parson of High Ongar, who had cure of souls in Norton Mandeville (q.v.), paid to the church of Fyfield a sack of corn and a sack of oats because Norton was so near to that church. Norton had its own church by $11 \mathrm{go}$, however.

14 Lunt, Val. of Norwich, 337. The identity of one of the "lords of that vill' is uncertain : see Manors of Fyfield, Herons, and Lampetts.

Is Tax. Eccl. (Rec. Com.), 21.
16 Ibid.

17 E.A.T. N.s. viii, 104 .

28 Feud. Aids, ii, 205.

19 Valor Eccl. (Rec. Com.), ii, 58 .

20 Ibid. i, 437

21 V.C.H. Surr. ii, 74.

22 E.R. xliv, 161 .

23 E.R.O., D/CT I 48.

24 E.R. xliv, i $56-72$

2s Hist. Essex by Gent. iii, 334.

26 Lond. Episc. Reg. Bonner f. 876 .

27 Newcourt, Repert. ii, 26 I.

28 E.R. xliv, 161.

29 E.R.O., D/CT I 48 ; inf. from present rector.

30 E.A.T. N.s. vii, 184 . 




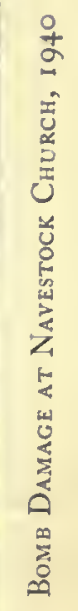

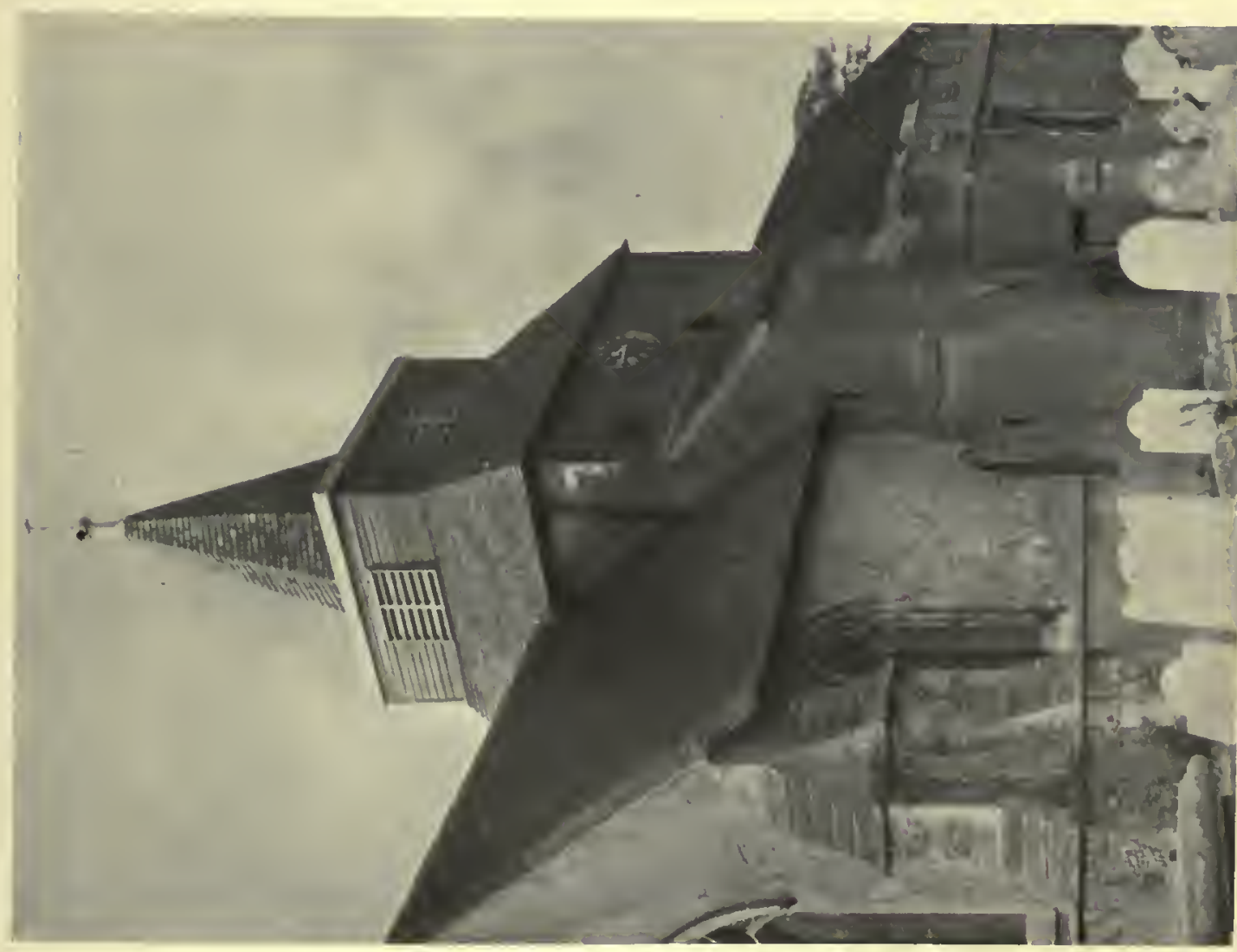






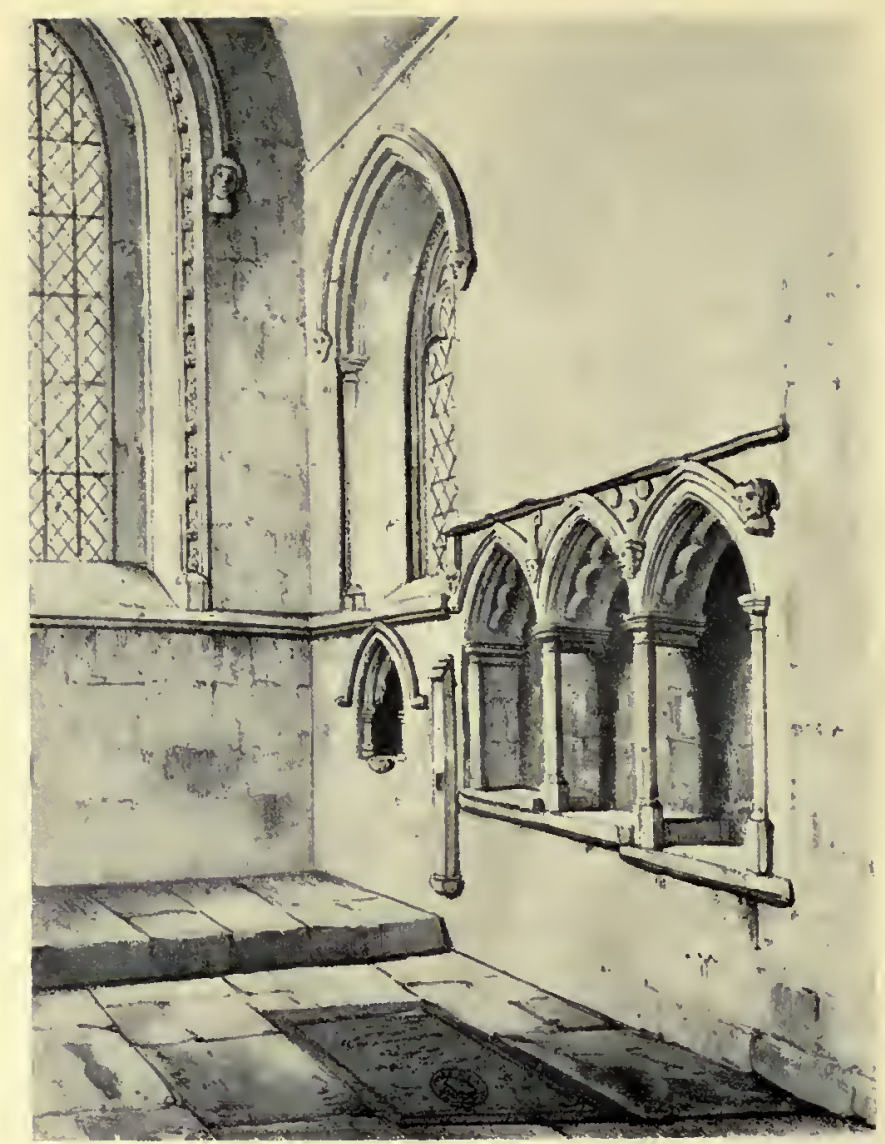

Fyfield Church: Chancel in I 834

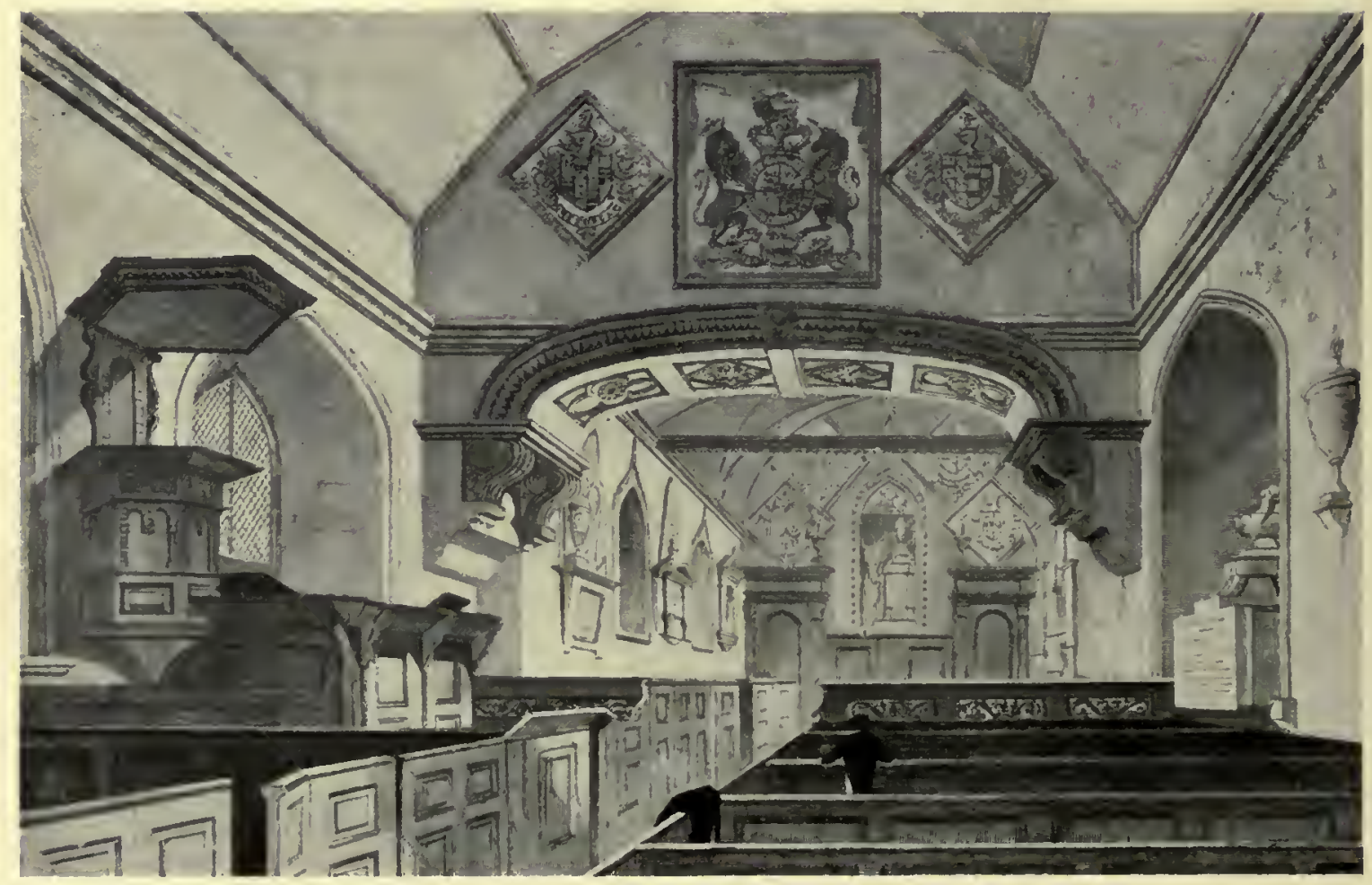

Lambourne Church in I 825 
largely of red brick. There is a timber belfry. The exterior of the church is mostly covered with cement, now in poor repair, and numerous buttresses of the I 8 th and I th centuries show where weaknesses have developed in the structure. The building differs in several respects from the type of parish church found in the district. The I 2 th-century plan with the tower standing 'cathedralwise' ${ }^{31}$ is unusual, and it is evident that large sums were spent on improvements during the $13^{\text {th }}$ and 14 th centuries. The chancel in particular has some good interior features.

The nave was built in the 12 th century. The walling at each end of the two arcades is $3 \mathrm{ft}$. thick and is evidently the original I 2 th-century work. The lower part of the tower is of the same date, including the large stair turret on the north side reaching to the second stage. The stair has a circular newel of Roman brick and there are arches of Roman brick to the round-headed windows in the south and west walls of the second stage of the tower. The former window has been blocked by brickwork and the latter opens in to the roof space above the nave. There is one very small rectangular opening in the north wall of the stair turret, and there are two in the east wall.

In about I 220 a north aisle of three bays was added to the nave. The pointed arches are of two chamfered orders and rest on circular columns with moulded capitals and bases. Attached half-columns form the responds against the ends of the r 2 th-century walls. In the middle of the I $3^{\text {th }}$ century the south aisle was added. This is similar in general arrangement to the north aisle but the arches are moulded and the supporting columns are octagonal. The single-light window in the west wall is probably of the $13^{\text {th }}$ century but its four-centred head was added later. There are traces of colour decoration of uncertain date on both arcades.

The chancel was built about I 330-40. The date can be fixed approximately by the detail of the interior. All the windows are of the I 4th century and have moulded labels and head stops. The tracery of the east window has been replaced, but the fine carving of the jambs and rear arch survives. On the north side the arch has beasts of the chase and on the south a series of cowled heads. The jambs are carved with flowers and leaves in high relief. In both north and south walls are two windows, the easternmost being two-light with shafts to the internal splays. The other windows are single light, the sill of that on the south side being taken down to form a 'low side' window. Between the windows in the south wall are stepped sedilia of three bays. The arches are cinquefoiled and between them are octagonal shafts of Purbeck marble. The moulded label has four carved head stops, one head wearing a mitre ${ }^{32}$ and another - a curious pointed head-dress terminating in a flower. In the spandrel above $a$ third head are three balls carved in relief; it has been suggested that these are the emblems of St. Nicholas. ${ }^{33}$ East of the sedilia is a piscina of similar detail and farther east there is a credence with one jamb cut off by the east wall of the chancel.34 Below the chancel is a vault which has a wide arched opening externally under the east window.
This opening was sealed during the restoration of 1893 , but one account of the church suggests that it was formerly pierced with quatrefoil openings, ${ }^{35}$ possibly for the viewing of relics. Another account, given in 1898 by the then rector, the Revd. L. Elwyn Lewis, referred to the existence of arcading internally below the east window. 36 The fact that part of the credence is now cut off suggests that the lower part of the east wall has been widened, perhaps obliterating the arcade.

Some windows were inserted elsewhere in the church in the $14^{\text {th }}$ century. 'These include one in the south wall of the tower and the westcrnmost windows in the north and south aisles. The other aisle windows may have been of the same date, but if so they were replaced in the I 9 th century. The south doorway has 14 th-century splays and the stoup on the north side has a I 4 thcentury trefoiled head, probably taken from a window. The arch between the tower and the nave is of the I 4 th century, much restored. The responds have three attached shafts. The north porch retains moulded timbers of the late I 4 th century and a pointed timber arch of which the spandrels were probably once filled with tracery.

Early in the 15 th century there were some alterations at the east end of the north aisle. An east window was inserted of which the tracery is now missing; the window itself was blocked by the early I $9_{\text {th }}$ century.37 Also in the I $5^{\text {th }}$ century a niche was built across the north-east corner of the aisle. It has an elaborately carved canopy with a ribbed vault and probably once held a figure of the Virgin. ${ }^{38}$ The nave roof has three I 5 th-century trusses; the square king-posts have fourway struts and two have moulded capitals and bases.

Some years before $1768^{39}$ part of the tower fell, perhaps after being struck by lightning. ${ }^{40}$ Before the end of the I 8 th century the second stage was largely rebuilt in red brick and a window was inserted on the north side. Above the brickwork is a hipped roof, above which is a square weather-boarded belfry with ball finials at the corners. There is a small boarded spire. The west wall of the nave may have been rebuilt in the 18 th century.

In the first half of the roth century a vestry was formed by extending the north aisle eastward as far as the stair turret of the tower. ${ }^{41}$ In 1853 the church was restored 42 and in 1875 tracery was inserted in the east window at the expense of W. S. Horner. ${ }^{43}$ In 1893 $\{, 1,300$ was spent on restoration.4 Some blocked windows were uncovered and a new west door and window inserted. The window replaced a "hideous wooden structure' of the I 8 th century.45 Both the tower arches were largely rebuilt and the chancel roof may have been reconstructed at the same time. The oak reredos and chancel seating were installed, the oak coming from St. Paul's, Knightsbridge. ${ }^{46}$ The seating in the nave is also of the late rgth century, incorporating some $r 6$ thcentury moulded rails.

During the incumbency of the Revd. L. Elwyn Lewis ( 1895 -r905), who held high church views, a surpliced choir was started and the old organ was moved from the west end of the church into the vestry. 47 In rgor a new
31 Morant, Essex, i, 135.

32 This perhaps represents the mitred Abbot of Bermondsey: E.A.T. N.s. vii, I84. 33 E.A.T. N.s. vii, I84.

34 A print of 1834 by A. Suckling shows that the credence was walled-up at that time: E.R.O. Prints, Fyfield. See plate facing P. 53 .
35 Methuen's Little Guides: Essex, 108.

${ }_{36}$ E.A.T. N.s. vii, $185-6$.

37 Ibid. 38 Ibid.

39 Morant, Essex, i, I 35 . Cf. Hist.

Essex by Gent. iii. 337.

40 E.A.T. N.s. vii, 186.

11 Ibid. 185 .

42 Kelly's Dir. Essex (1 886 f.). The
Directory of 1874 gave the year of restoration as 1852 .

43 Inscription in situ.

44 Kelly's Dir. Essex (1895).

45 E.R. iii, 6.

46 Ibid.

47 Inf. from Mrs. T. W. Gamage a member of the choir at the time. 


\section{A HISTORY OF ESSEX}

organ was installed against the north wall of the tower, 48 largely at the rector's own expense. ${ }^{49}$ The vestry is now an organ chamber.

The square font bowl of Purbeck marble is of the late 12 th century. ${ }^{50}$ Two of the sides are decorated with recesscd arcading and the other two have a central fleur-de-lis flanked by vine leaves.

The oak screen between the nave and the tower was carved by A. J. B. Challis of Clatterford Hall in $1914 . .^{31}$ The pulpit is of the same date.

There are six bells, all modern or recast. One was originally of the I 5 th century, recast twice. The sixth, which is inscribed 'Salus et Victoria', was added as a war memorial and was dedicated in 1952.52 Under the organ on the north side of the chancel there is said to be a slab bearing the indent of a foliated cross, flanked by square pennons or axes. 53 There is a tradition that this covers the headless body of Henry, Lord Scrope, beheaded in 1415.54 Also in the chancel are some I 8 thcentury floor slabs. with shields of arms to members of the Pochin family and to one of the Beverley family. There are also several 18 th-century slabs to the Collins family of Lampetts and to the Brands of Herons.

The plate includes a large cup of 1699 given by Dr. Anthony Walker, one paten of 1638 and another of I 798.55

In 1570 Elizabeth 1 granted to Thomas, 2nd Lord Wentworth, in fee such 'concealed' estates as he could discover to a total annual value of $\oint_{200.56}$ In March 1572 , in fulfilment of this grant, she conveyed many concealed estates, including one in Fyfield, to Richard Hill of Heybridge and William James of London. 57 The Fyfield estate consisted of 3 messuages or cottages, called the Church Houses, and an acre belonging, then or lately in the tenure or occupation of the inhabitants of the vill of Fyfield, appointed for the maintenance of an obit, a guild, and other similar objects. ${ }^{58}$ Despite the grant of 1572 , Fyfield church property undoubtedly included three houses in the early I 7 th century. In May 1659 it was agreed at a vestry meeting that the rental of the church rents, then torn and defaced, should be copied out 'and be esteemed as the former rental was'.59 The 'Rental of the church houses of Fyfield' was then copied into the vestry minute-book. It totalled E. 3 3s. $4 d$. and included $f_{0}$ f from 'the church house at Widney Green', fI from 'the house in Fyfield street', I 5s. from 'the house by the church in which the Clarke dwelleth', 3s. from 'Pyckerells', 2s. 7d. from 'Long Harry's', Is. Iod. from 'John Palmers houses', gd. from ' $\frac{1}{2}$ a. meadow in moor-mead', and $2 d$. from 'the tenement called Hatches' 60 In I 668 the 'church field belonging to the church house on Widney Green and containing $\mathbf{I}$ a.' was let by the churchwardens to Henry Spooner for twelve years at a rent of $£_{7} 7$ for the whole term 'which money was advanced and employed towards the now [or new] building of the church house aforesaid'.6r In I687 Dr. Anthony Walker devised a house called Bruetts, in Fyfield Street, for the church clerk to dwell in free.62 By 17 I0 the church house "by the church' seems to have been occupied by a poor man whose rent of $£_{1}$ I OS. was paid for him by the parish.63 The total of the church rents was then 64 Ios. $5 d$., the increase since 1659 being due partly to the higher rent for the house by the church and partly to a new item of I 6 s. for 'the hoppit by the churchyard'. ${ }^{64}$ The annuities amounted to $6 s$. $5 d$., being $2 s .6 d$. from John Bull for Long Harris field, $\mathrm{I}$ Id. from 'Thomas Palmer', and 3 s. 'out of Pickrills'.65 By March I7I9 the rents totalled 65, there being another fresh item of 13 s. for 'the hoppett by Berrys Green', later known as Cannon's Green. ${ }^{66}$ In February 1720 a vestry meeting agreed with John Pochin of Witney Green that he should demolish a cottage upon the green belonging to the church on condition that he erected another cottage of equivalent value. ${ }^{67}$

In 1786 it was stated that unknown donors had given to the parish for purposes also unknown 'a rent-charge of 6 s. $5 d$.', tenements of the then annual value of $f_{2} 4 \mathrm{~s} .7 d$. and land of the then annual value of $f_{0} I$ gs.68 The value of the land was evidently the same in 1786 as it had been in I I I 9 but the value of the houses was apparently reduced. 69

In 1835 rents totalling $f_{12} 9$ s. from the church houses and lands as well as annuities totalling $6 s .5 d$. went into the churchwardens' general account. ${ }^{70}$ 'The hoppets by the church and on Cannon's Green were both let to the rector for 16 s. and 13 s. a year respectively, the sums at which they had been let early in the I 8th century. ${ }^{71}$ The church houses which the overseers rented from the churchwardens at $f_{\mathrm{I}} \mathrm{I}$ a year for the use of the poor were described in 1835 as 'Street House', a 'house by the church', and 'a house on Cannons Green' which was said to have been 'built by the parish upon the site of an old house, of which the rent used to go to the churchwarden's account'. ${ }^{72}$ 'The church cottage on Witney Green, whose demolition had been ordered in 1720 , had apparently been replaced by a house on Cannon's Green which, it would seem, was rebuilt before 1835 . By I 842 , however, the church owned only two cottages. 73 One of them was on the east side of the church, fronting upon Church Lane, and was undoubtedly the house which had appeared as 'by the church' in the rentals drawn up before and after 1659.74 The other cottage, situated immediately north of the Black Bull Inn ${ }^{75}$ on what is now known as Dunmow Road, is probably to be identified with 'Street House'. The church still owned some land at Cannon's Green in 1842 , but by that time it had apparently disposed of its house there. ${ }^{76}$ The hoppet south of the churchyard still belonged to the church.77

In I 903 part (c. 29 p.) of the meadow called Church Hoppet, situated south of the churchyard, was sold for $\ell_{1} 4$ to the parish council for use as a burial ground. ${ }^{78}$ When the sale was made it was established in the face of some doubt that the trustees of the church estate were the churchwardens: in fact then and in 1922
48 E.R. ix, I74.

49 Inf. from Mrs. T. W. Gamage.

50 There are similar bowls at Moreton,

Little Laver, and Norton Mandeville.

5) Tablet in situ.

3a Inf. from present rector.

53 E.A.T. N.s. viii, 257; Hist. Essex by

Gent. iii, 334.

34 Hist. Essex by Gent. iii, 334 ; inf. from present rector.

$35 \mathrm{Ch}$. Plate of Essex, 135.

$56 \mathrm{C} 66 / 1083 \mathrm{~m} .7$.
52 Ibid.

38 Ibid. m. 2 I.

59 E.R.O., D/PI $44 / 8 / 1$.

60 Ibid.

6 I Ibid.

62 Rep. Com. Char. (Essex), H.C. 216 ,

Pp. 225-7 (1 835), xxi (1).

63 E.R.O., D/P I $44 / 8 / 1$

64 Ibid.

65 Ibid.

66 Ibid.

68 Rep. Com. Char. (Essex), pp. 227-8.
69 Cf. Morant, Essex, i, 135 , where the charities were said to include 'Six pounds a year towards the reparation of the church, the donor's name unknown'. 70 Rep. Com. Char. (Essex), pp. 227-8. 71 Ibid.

72 Ibid.

73 E.R.O., D/CT 148

74 Ibid.

75 Ibid.

76 Ibid.

78 Char. Com. files.
77 Ibid. 
the 'parish warden'-presumably the people's warden -acted as trustee, though later the rector and parochial church council took some share in the administration of the estate. ${ }^{79}$ In 1922 a further part (I r., I 2 p.) of Church Hoppet was sold for $£ 20$ to the parish council also for use as a burial ground. ${ }^{80}$

From the latter part of the I 9 th century until shortly after 1930 a small outbuilding at the back of the cottage near the Black Bull Inn was let as a separate dwelling. ${ }^{81}$ In about r 930 the three dwellings were let for a total of about $£_{19.82}$

In I 947 the cottage, then known as Walker Cottage, 83 on the east side of the church, was sold for 6190 , most of which went to repay Dr. Walker's School Foundation and the parochial church council for money spent on it in the past. ${ }^{84}$ The residue was invested. $8 \mathrm{~s}$

In 195 I the charity was divided in to two: one part, the Church Estate, had an endowment of $6,50 \mathrm{I} 4 \mathrm{~s}$., presumably arising from the sales of church land, of which the income was used for general church purposes. ${ }^{86}$ The other is known as the Charity for the Poor, and has an endowment of $66 \mathrm{I} 4$ s. 3 d., which was provided by the sale of the 'Walker Cottage'. 87 Its income was to be devoted to the poor of the parish, since the cottages of the charity were in I 834 used for the benefit of the poor. ${ }^{88}$

The cottage north of the Black Bull Inn still belongs to the church but is at present up for sale. ${ }^{89}$

Fyfield was one of the places at which a new Congregational church or school was

NONCONFORMITY started soon after the formation of the Essex Congregational

Union in 1798.90 There was, however, no mention of such a church or school at Fyfield in the returns of 1829. A nonconformist mission hall was opened in the village in 1894 and is still in use.91 It is a small redbrick building bearing that date.

Medieval court rolls for the manor of Fyfield survive for the periods $1385-97$,

PARISH GOVERNMENT I $401-4$, and $1413-43.92$ $A N D$ POOR RELIEF In the it th century the number of courts held each year varied between 2 and 4 . Usually two of them included view/of frank-pledge. In the $15^{\text {th }}$ century courts were usually held twice a year, at Easter and Whitsun, and nearly always included view of frank-pledge. The homage numbered $1 z$ or more.

The courts were largely concerned with the control of trade. The commonest subject of presentment was breach of the assize of ale; the offenders against this assize were often women, who were presented year after year on the same charge. Breach of the assize of bread was also frequently presented. Occasionally fines were imposed on regrators. Apart from trade offences, the most common subjects of presentment at the courts were the failure to scour wayside ditches and the obstruction of watercourses. Small fines were sometimes imposed for minor assaults.

Two constables and two aletasters were chosen at the Easter court in most years. Aletasters were often fined for inefficiency.

\footnotetext{
79 Ibid.

80 Ibid.

81 Church Account Book in possession of rector; local information.

82 Church Account Book; Char. Com. files.

${ }_{83}$ This name seems to have originated in the confusion, apparent for some time
} past, between the Church Estate Charity

The modern series of court rolls for Fyfield runs, with some short breaks, from 1509 until 1865.93 In the first half of the I6th century courts were held in most years and often twice in a year. From the middle of the 16 th century until about 1640 they were held once a year. They usually included view of frankpledge. After r $64^{\circ}$ courts were no longer held annually and did not always include view of frank-pledge. In the second half of the 17 th century there were 23 courts of which 13 included the view. In the I 8 th century courts which, nominally at least, included view of frankpledge, took place in $1703,1709,171 \mathrm{I}$, and, for the last time, in 1749.

Most of the business transacted at the courts after 1509 concerned minor nuisances and breaches of manorial custom. In the reign of Henry VIII the presentment of breaches of the assizes of bread and ale were still common. There were still occasional presentments for assault until 1617 . In 1585 a man was presented for 'keeping bad order' in his house. Towards the end of the I 6 th century the number of presentments of nuisances declined markedly. After 1589 there were rarely more than two or three such presentments at any one court. From the beginning of the reign of Charles I there were frequently no leet presentments even when the court nominally included view of frank-pledge.

In the 17 th century, particularly in the latter half, the jurisdiction of the manor court was yielding to that of the parish vestry. In 1626 the manor court ordered that no one should demise any cottage within the manor to any person living outside Fyfield and no one should entertain any pauper from outside the parish without leave from the churchwardens, overseers, and the parishioners. In 1647 the manor court elected as constables Thomas Gynne and John Church who in 1648 rendered an account to the parish vestry. 94 Afterwards the constables continued to account to the vestry 95 although they were sometimes appointed in the manor court until the last decade of the 17 th century. A court appointed R. Church and J. Church as constables in I654. No appointments were made by the next court leet which was held in May 1656; it does not appear what body appointed I. Allam and A. Kent who were constables from 1657 , if not before, until $166 \mathrm{r}$. A court leet chose two constables in 1661 and one in 1662 'for the parish of Fyfield'. The rolls do not record any further appointments by the manor court until 1692 . On the other hand, until r 680 the vestry minutes did not include the constables in the lists of appointments and reappointments made by the vestry. 96 In 1680 , however, it was recorded that at a meeting of the parish on Easter.Monday all the old officers, including the constables, were 'continued for the following year'. 97 In $168 \mathrm{I}$, shortly before a court leet, a vestry meeting chose two new constables for the year $168 \mathrm{I}-z, 98$ but the next court leet, which was held in May 1692 , chose two constables. The following court leet, held in October 1696, also chose T. Luck and E. Havers as constables for the parish. It may be, however, that the court merely confirmed appointments made at a vestry meeting earlier in the year, for in the vestry minutes it

and those founded by Dr. Anthony Walker in the 17 th cent.

84 Char. Com. files.

$8 \mathrm{~s}$ Ibid.

86 Ibid.

87 Ibid.

88 Ibid.

89 Inf. from present rector.

90 R. Burls, Essex Congr. Union, 19.
The Nook at Norwood End (see above, p. 44) may have been used as the church, or school.

91 Kelly's Dir. Essex (1933). 92 E.R.O., D/DCw M97-10 93 E.R.O., D/DCW Mroz-15. 94 E.R.O., D/P I 44/8/1. 95 Ibid. 96 Ibid. 97 Ibid. $\quad 98$ Ibid. 


\section{A HISTORY OF ESSEX}

was recorded that "T. Luck and E. Havers were chosen as constables for the year 1696 '.99 The rolls record no later appointments of constables in the manor court.

Two vestry minute-books survive.' 'The first covers the period 1648-1732. 'The second contains overseers' accounts from $\mathrm{I} 827$ to $\mathrm{I} 836$ and vestry. minutes from I 854 to I 89 o.

During the period r 648-1732 meetings of the public vestry usually seem to have been held only at Easter in each year. In only seven years in the whole of this period was more than one meeting recorded and in only two of these years were as many as three meetings recorded. If a resolution of 1704 was carried out, however, there must have existed from that time a select committee which met often in each year: the vestry ordered 'that there be always three persons chosen by a vestry at Easter to assist the churchwardens in the repair of the church and that the overseers of the poor and constables and churchwardens shall not disburse above 20 s. without an order of vestry or the major part of the three persons with the churchwardens'.

The vestry minutes were usually signed only when there was an important resolution. The number of those attending the meetings, in addition to the churchwardens and overseers, usually varied between one and seven but on five occasions there were more than ten. The chairman was never named as such in the minutes. The rector signed first when he attended the meetings, but there were some important meetings which he did not attend. In his absence one of the larger landowners signed first. Members of the Collins family, of Lampetts, were always prominent at the meetings, and John Collins often signed first, or first after the rector.

The work of the vestry consisted mainly in nominating parish officers, granting rates, and approving officers' accounts. There were usually two men in each office. Until 1672 the overseers sometimes continued in office for three or more years. After 1672 they often served two years consecutively but rarely more. The churchwardens and constables usually remained in office for at least two years and often for much longer. The overseers, churchwardens, and constables were each granted separate rates for which they accounted separately throughout the period I648-r732. Until 1672 the overseers sometimes presented several years' accounts at once. After 1672 they always presented annual accounts. The churchwardens and constables, on the other hand, occasionally presented two or even three years' accounts in one until the end of the period covered by the first vestry minute-book.

In $1662-3$ the constables' receipts from rates totalling $6 d$. in the pound were 628 I $3 s .2 d$. This implies a rateable value of about $\oint_{0}$, I 50 . In I669-72, however, a $2 d$. rate yielded 6 I I I $2 s .3 d$. This implies a rateable value of about fr, 194 and this continued to be the rateable value until after 1690 . In the period I $827-36$ the rateable value was about $f, 1,750$.

In I 835 the parish owned three houses known as the 'Poorhouses' and for which the overseers paid to the churchwardens $\oint_{\text {I I }}$ a year. ' 'Street House' and a house on the east side of the churchyard were occupied rentfree by poor women, placed there by the parish officers. ${ }^{3}$

99 Ibid.

1 E.R.O., D/P 144/8/1-2. Unless otherwise stated all the following information is derived from these minute-books.

2 Rep. Com. Char. (Essex), H.C. 2 I 6 , p. 228 (1835), xxi (1); E.R.O., D/P 144/8/2. The church had owned 3 houses since the 16 th cent., if not before: see

It does not appear how the third house, on Cannon's Green, was used, but it may have been a workhouse.

There is no doubt, however, that in most cases poor relief was given, in various forms, outside a workhouse. In 18 I $3-15$ there was no person on 'permanent relief' inside a workhouse, but in each of those years there were $4 \mathrm{r}-43$ adults on permanent relief outside. 4 Provision for the poor was made in various ways, including the binding out of paupers' children as apprentices and the payment of rents and weekly doles. In I 7 I I the rents of I I poor persons were paid, the total cost to the parish being $f_{0} \mathrm{I} 2$ I 4 s.: in addition weekly doles, amounting to fI os. $8 d$., were paid to ro households of whom 4 also had their rent paid. In one case at least, early in the I 8 th century, a pauper was allotted to parishioners on a rota system. In $\mathrm{I} 708 \mathrm{it}$ was agreed at a vestry meeting that if "Thomas Ashfeld, a poor fellow that is to go about the parish by a former agreement, should fall sick or lame in any place that he goes to he shall not lie altogether upon those persons where he is present but that it shall be at the charge of the whole parish'. In $\mathrm{r} 72 \mathrm{r}$, when the same Thomas Ashfeld was put on an eightyear rota of some 32 parishioners, there was a similar resolution to the effect that 'if any sickness or lameness should happen during these years it shall be at the cost of the parish and likewise his clothing'.

Under the Commonwealth the total cost of poor relief usually varied between $\oint_{0} 15$ and $\oint_{2} 25$ a year. From 1675 until 1693 it was frequently between $£_{30}$ and $£_{4} 40$ a year. No figures survive for $1693-6$. From Easter 1696 until Easter 1701, however, it averaged about $f_{0} r o 0$ a year. These expensive years were followed by five years in which the cost ranged between $£ 7 \mathrm{I}$ and $£ 85$ a year. In $1706-7$ it rose to a new maximum of $f_{117}$. In April 1707 the vestry ordered the badging of the poor according to law ( 8 and 9 William III, c. 30 ( I 697)) and ordered that an inventory should be made of every pauper's goods. There was a slight decline, to $f_{0} 103$, in the cost of relief in the following year and at Easter 1708 the vestry agreed 'that if any overseer in the parish shall relieve any person by a weekly collection that does not wear the badge or come themselves for their collection unless they are sick or lame, the said overseer shall forfeit the sum of 40 s.' Nevertheless the cost of relief, after remaining at $f_{0} \mathrm{r} \circ 3$ for two more years, began to rise again in 17 IO-I I and in 17 I 5-16 reached $f_{5} 42$. In the next year it fell again to fro3. From 1717 until I 73 I it fluctuated between 669 and 6108 . No figures survive for $173 \mathrm{I}-75$. In I 776 expenses were $\oint_{1} 56$ and the average for the three years $1783-5$ was 6268.5 In $1800-1$ the cost of relief was $£ 765$. It fell to a minimum of $\oint_{324}$ in $1807-8$, and rose to $6_{6} 683$ in 18 I $3-14$ and $6_{6} 6$ I 3 in $1816-17.6$ In the years $1827-32$ it was between $£ 500$ and $£_{600}$ each year. It then declined to about $£ 350$ a year in I 834-6.

In June 1836 Fyfield became part of the Ongar Poor Law Union.

In 1687 Dr. Anthony Walker, Rector of Fyfield, devised a house and about $\frac{1}{2}$ acre of land in SCHOOLS Fyfield and a farm of 56 acres in High Ongar, mainly for the support of a free school for poor children. ${ }^{7}$ For $f_{8} 8$ a year and the use of

above, Church. Another house, called Bruetts, was devised by Dr. Anthony Walker in 1687 for the church clerk to live in free; since 1873 this has been occupied by the parish clerk: see below, Charities.

3 Rep. Com. Char. (Essex), p. 228.

4 E.R.O., Q/CR I/IO. The number of persons 'relieved occasionally' was 32 in 1813,37 in 1814 , and 29 in 1815 .

5 E.R.O., Q/CR I/I.

6 E.R.O., Q/CR I/9.

7 Rep. Com. Char. (Essex), H.C. 216 , PP. $225-7$ (1835), xxi (I). For other minor charges on the charity income see above, Church and, below, Charities. 
the larger of the two tenements called Bruetts in Fyfield Street, the teacher was to instruct pupils in reading, writing, arithmetic, and the catechism and to supervise them in prayer. ${ }^{8}$

The history of the school is obscure until I 807 when 15 pupils attended it. They were then being taught according to the founder's direction, the girls learning plain needle-work in addition. Any child might attend whom the rector and churchwardens judged to be poor.9 Where the school was held is not clear; it may have been in the master's house. By I 8 I 8 the managers were planning to expand the school. The charity income had recently increased and the master, now paid fi 6 a year, also took paying pupils. ${ }^{10}$ In I 8 I 9 a new schoolroom was built for 6170 from the accumulated surplus of the charity income. It was behind the master's house in Fyfield Street, had a playground attached, and could accommodate 70 children. "I There was no immediate increase in attendance, however; in I $827-8$ there were still only 15 free pupils. 12

From about 1830 the number of pupils increased. In 1832 there were 21 and in 183349 , some of whom paid fees. The charity income was then $\oint_{4} 47$, the master's salary $£_{32}$. The only other school in Fyfield was one with four pupils. ${ }^{13}$ By 1835 there were 30 free pupils at Walker's school, almost all of them children of Fyfield labourers, and 25 paying pupils, of whom 12 were boarders. The curriculum was as in 1807 except that the boys were taught some history and geography. The master, who still received $\oint_{32}$, paid two assistants and hired an additional classroom, presumably for his paying pupils. He also supplied pens, ink, and fuel. No poor child was refused a place on denominational grounds, but all the free pupils attended church and were taught the catechism. Trustees were in control, with the rector as treasurer. ${ }^{14}$ The school was united to the Diocesan Board of Education ${ }^{\mathrm{IS}}$ and, at least between 1807 and 1847 , was administered jointly with the Sunday school.16 It has subsequently been regarded as a Church school, as it probably had been from its inception, but it appears not to have been in union with the National Society. 17

Until the Education Act of I 870 there was little change from the conditions of 1837 , except that the boarding establishment was probably discontinued at some point; in 1863 there was another boarding-school in the village. ${ }^{8} 8$ In 1867 there were 76 pupils under a master and mistress, 19 but in 1871 there were only about 56.20 In $187 \mathrm{I}$ it was reported that the school could provide 57 of the 94 places necessary to ensure universal education in Fyfield. ${ }^{21}$ In 1875 a new school was built near the site of the old. ${ }^{22}$ The estimate of cost was $655^{\circ}$. Charity property was mortgaged for 6400 and the deficit met by a voluntary rate. ${ }^{23}$ Average attendance increased slightly until 1891 , when the building was enlarged to provide I 30 places. ${ }^{24}$ The average attendance was 83 in 1893 and 74 in $1905 .{ }^{29}$

The school had received a government grant of $f_{0} 64$ in 1880 and this rose to firo in 1899.26 After the Education Act of 1902 the school passed under the administration of the Essex Education Committee as a non-provided school. After a further fall to 58 in I 910 the average attendance rose to 78 in 1920 and 84 in I929. In 1926 the annual income was nearly 660.27 In I 936 the school was reorganized for mixed juniors and infants. In I 948 the managers applied for aided status. 28 In May I 952 there were three teachers and 89 children. 29

The school is a single-story brick building on a $T$. shaped plan. The larger of the two tenements called Bruetts is still the schoolmaster's house. This was rebuilt in the late I 8 th or early igth century.

West Ham County Borough Council Residential Open Air School was erected at a cost of $f 8,000$ in $1885^{30}$ It was certified in May 1885 as an Industrial School for boys, not to exceed I 10 in number. ${ }^{31}$ In April 1925 it was converted to a residential open-air school for 80 boys. ${ }^{32}$ In I93 I it was enlarged to take 60 girls in addition. ${ }^{33}$ The school consists of a considerable collection of buildings. The main block is two to three stories high and of gault brick with red-brick dressings.

For the 'Unknown Donors or Church Estate Charity' see above-Church.

CHARITIES In I 687 Dr. Anthony Walker, Rector of Fyfield, devised property in

Fyfield and High Ongar ${ }^{34}$ for the provision of a school ${ }^{35}$ and a rent-free house for the church clerk, and for the benefit of the poor. In I $834 \mathrm{f}^{2}$ I $2 \mathrm{~s}$. was distributed to the poor in bread. This part of the charity, however, seems to have disappeared later, since by I 905 the whole of the endowment was held for educational purposes except the clerk's house and a small yearly sum for its maintenance.

The house left for the clerk was the smaller of the two tenements called Bruetts, in Fyfield Street, the larger being for the schoolmaster or dame. In 1873 it was disputed whether the charity was for the church clerk or the parish clerk; the decision went in the church clerk's favour, and the house is still occupied by his successor. In I 949 the school charity and the parochial church council both advanced money for the repair of the house, which had been little altered for some centuries. It is timber-framed with a steep roof and dates from the 16 th century or earlier. ${ }^{36}$

John Collins, ${ }^{37}$ by will dated $1751,3^{38}$ left a field in Moreton to the poor of Fyfield. It was let at $£_{5}$ a year in 1834 and in 1907 , when it was sold for $£ 120$ which was invested. In 1834 the income was spent on bread, distributed with Walker's Charity, and on Is. doles to
8 Rep. Com. Char. (Essex), pp. 225-6.

- E.R.O., D/AEM 2/4.

so Retns. Educ. Poor, H.C. 224 , p. 256

(1819), ix (1).

II Rep. Com. Char. (Essex), pp. 226-7.

12 Nat. Soc. Rep. 1828 , p. 53.

13 Educ. Enquiry Abstr. H.C. 62, p. 276

(1835), xli ; Nat. Soc. Rep. 1832 , p. 50.

14 Rep. Com. Char. (Essex), pp. 226-7.

is Nat. Soc. Enquiry into Church Schs.

I $846-7$, pp. 8-9.

16 Ibid.; Nat. Soc. Reps. 1828,1832 ; E.R.O., D/AEM $2 / 4$.

17 Min. of Educ. File $13 / 127$.

18 White's Dir, Essex (1863).

19 V.C.H. Essex, ii, 561 .
20 Retns. Elem. Educ. H.C. 201, pp. 112-13 (1871), lv.

21 Min. of Educ. File I $3 / 127$.

22 O.S. 6 in. Map (rst edn.), sheet xlii.

$23 \mathrm{Min}$. of Educ. File 1 3/127.

24 Rep. of Educ. Cttee. of Council, 1880 [C. 2948-1], p. 577, H.C. (1 881), xxxii; Rep. of Educ. Cttee. Council, 1886 [C. 5123-I], p. 519, H.C. (1887), xxviii. is Retn. Schools, I 893 [C. 7529 ], p. 7 I 4 , H.C. (1894), lxv; Min. of Educ. File 13/127.

${ }_{26}^{16}$ Rep. of Educ. Cttee. of Council, 1880 , p. 577; Retn. Schools, 1899 [Cd. 315], p. 70 , H.C. (1 goo), lxv (2).

27 Kelly's Dir. Essex (1926).
28 Min. of Educ. File 1/3/1 27.

29 Inf. from Essex Educ. Cttee.

3o Kelly's Dir. Essex (1926). For this school see D. McDougall, Fifty rears a Borough: the Story of West Ham, IO3-4, $122 \mathrm{f}$. 31 Ibid. 32 Kelly's Dir. Essex (1933). 33 Ibid. 34 See Frith Hall in High Ongar.

35 See above, Schools.

36 Rep. Com. Char. (Essex), H.C. 216 , pp. 225-7 (1835), xxi (1); Char. Com. files.

37 Ibid.; Hist. Essex by Gent. iii, 336-7.

38 This date, given in Rep. Com. Char. (Estex), p. 227 , is evidently a mistake. Collins died in Sept. 1750 . 


\section{A HISTORY OF ESSEX}

widows and other poor persons. The bread doles were stopped in I 917 under a scheme of I9I 5 . In I 935 the income of 63 I Is. 8d. was distributed in small sums of cash and the same practice appears to have been followed since.

The Revd. Robert Gibson, by will proved r 840 , left 6200 in trust for distribution among the poor of the parish, preferably those who were sober and industrious and attended church regularly. Charlotte Gibson, by will proved 1859 , left 6200 in trust for the yearly distribution of blankets, sheets, coals, or clothing to the poor of the parish. These two charities have generally been distributed together. In I $95^{\circ}$ the income of $£ 5$ from each was given away in food and clothing. ${ }^{39}$

\section{GREENSTEAD}

Greenstead is a small parish adjoining Chipping Ongar to the west. ${ }^{I}$ From I 548 to I 554 jt was united with Chipping Ongar. ${ }^{2}$ Its population has always been small until the last 20 years. In I $80 \mathrm{I}$ it was I02, and in $193 \mathrm{I}$, I I9. The population in $195 \mathrm{I}$ was 785 , the large increase being mainly accounted for by the building of houses on the estate adjoining Chipping Ongar. ${ }^{3}$ The main centres of population are at the east and west ends of the parish, not in the centre by the hall and the church.

The land rises from about $200 \mathrm{ft}$. above sea-level in the east to $300 \mathrm{ft}$. in the west. A stream which rises in the west flows east to join Cripsey Brook near the north-east corner. Greenstead Wood is in the west, between the stream and the north boundary. The road from Chipping Ongar enters Greenstead in the south-east and runs through the parish to Greenstead Green in the north-west. At the Ongar end of this road there is a small built-up area, mostly of the r gth century and later. To the north of this is a large housing site consisting of 100 privately built houses, 30 post-r 945 council houses, and two groups of prefabricated houses.

The rectory lies on the road about $\frac{1}{2}$ mile from Ongar. To the west of it, lying close together to the north of the road, are the parish church and Greenstead Hall. They are joined to Ongar by an avenue of trees about a mile long. ${ }^{4}$

There are a number of houses at Greenstead Green. Little Thorbens (now called The Cottage) is a small two-story timber-framed house with a cross-wing and an overhanging gable at its west end. The date I 564 is cut on one of the roof timbers. ${ }^{5}$ Blackstock House and Tudor Cottage formerly made up a single house, named New House. Tudor Cottage is timber-framed and partly weather-boarded, and dates from the late I 6 th or early i $7^{\text {th }}$ century. Blackstock House, on the west, is a gault brick addition dating from about 1870 . Greenstead House is a two-story stucco building, dating from the 18 th century with a large addition of about r860. Ivy Cottage adjoins it (see below, Schools). Hardings Farm is opposite Ivy Cottage. Also at Greenstead Green, on the south side of the road leading to Ongar, are five pairs of council houses. The green from which this part of the parish took its name no longer exists, but within living memory there was a long triangular open green on the west side of the road here, reaching nearly to Toot Hill in Stanford Rivers. ${ }^{6}$ The present road from Greenstead Green to Toot Hill appears to have been constructed between I 838 and
I 873-4.7 Pensons Lane runs from Greenstead Green north-east to Ackingford Bridge (see Chipping Ongar). Another road runs north from Greenstead Green to Bobbingworth. A road from the centre of the parish runs south to Stanford Hall and the church in Stanford Rivers. Half a mile to the east of this road, on the southern border of the parish, is Lodge Farm. It is a timber-framed house of mid-or late-I 7 th-century date, and it contains a round-headed corner cupboard of the same period.

The railway from Epping to Ongar passes through a small part of the parish on the north east. Blake Hall station, on this line, is mile north of Greenstead Green but is in the parish of Stanford Rivers.

Few references have been found to the parish roads. In 1598 Greenstead was presented at quarter sessions for the bad state of its highways. ${ }^{8}$ In $16 \times 8-19$ the road from Chipping Ongar to Greenstead was in a bad condition and the parishioners of Greenstead and High Ongar were said to be jointly responsible for its upkeep. 9

For transport and postal services Greenstead has always depended on Chipping Ongar (q.v.)

The Greenstead housing estate has all the public services. ${ }^{10}$ Water was supplied to some parts of the parish in 1908, from Chipping Ongar as far as Greenstead church. ${ }^{\text {II }}$ There is sewerage as far as the Croft. ${ }^{12}$ $G$ as was first supplied in 1934. It at first extended along the road to Blake Hall Station.13 Greenstead Green has had electricity since I $932 .{ }^{14}$

In 1086 there were in all 8 plough-teams in Greenstead, woodland for 520 swine, 35 acres of meadow. There were then only I 4 pigs on the manor: the number had declined from 30 in 1066 . There were 40 goats and 20 sheep, a rouncy, and 3 beasts. Is The parish was less densely wooded than Chipping Ongar (q.v.) to the east.

The manor of Greenstead in I 349 was said to contain 60 acres of (arable) land, 8 acres of meadow, 15 acres of pasture, and a wood. ${ }^{16}$ In 1625 it was said to contain 100 acres of land, 20 acres of meadow, 60 acres of pasture, and 60 acres of underwood. 17 In 1690 there were I0o acres of land, 80 acres of meadow, I 00 acres of pasture, and 80 acres of underwood. 18 These figures seem to indicate that from the I4th century onwards the demesne farm gradually increased in size until, by the end of the I 7 th century it contained about half the total area of the parish. In the I 8th century there were at least three farms in the parish apart from the home farm of Greenstead Hall.19 During the first

\footnotetext{
39 Char. Com. files.

I O.S. $2 \frac{1}{2}$ in. Map, sheet 52/50. Area

683 acres. 2 See Chipping Ongar.

3 Census; inf. from Essex County Council.

4 The avenue existed in 1770 : Hist. Essex by Gent. iii, 378 .

$s$ Inf. from the occupier, Mr. Ginger.

6 Inf. from Mrs. Kinsman of Greenstead House. The green is well shown on
}



$7 \mathrm{Cf}$. Tithe Map and O.S. 6 in. Map

(ist edn.), sheet 1 (1873-4).

8 E.R.O., Q/SR I 4 I $/ 2$ I.

- Ibid. Q/SBa I/35.

10 Inf. from Councillor Hadler.

11 Inf. from Herts. and Essex Waterworks Co.

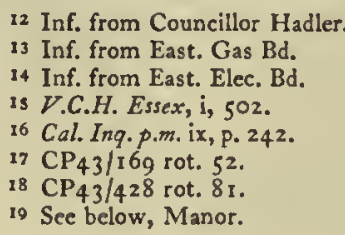

12 Inf. from Councillor $\mathrm{Hadler}$

13 Inf. from East. Gas Bd.

14 Inf. from East. Elec. Bd.

is V.C.H. Essex, i, 502 .

16 Cal. Inq. p.m. ix, p. 242.

$17 \mathrm{CP}_{43} / \mathrm{I} 6$ g rot. 52 .

$18 \mathrm{CP} 43 / 428$ rot. $8 \mathrm{I}$.

19 See below, Manor. 
half of that century almost all the land in the parish was acquired by a single owner. It was split up again after $1750 .{ }^{20}$ In 1839 the parish was estimated to contain 289 acres of arable, 325 acres of meadow and pasture, 3 I acres of woodland, and 23 acres of common, waste, and roads. ${ }^{2 I}$ 'The Hall farm contained 263 acres. There were three other farms of 50-roo acres. More than 400 acres were owned by the lord of the manor, and within the next 30 years two other farms were added to the main estate, leaving very little land in the parish outside the estate. ${ }^{22}$

Inclosure was probably facilitated in Greenstead by the small number of interests involved. A rental of about 1525 has numerous references to crofts in Greenstead, which suggests that much inclosure had already taken place. ${ }^{23}$ It is, however, interesting that the green which gave its name to Greenstead Green should have survived until modern times. ${ }^{24}$

There was a mill at Greenstead in 1086.25 In 1349 there were two mills in the manor, one driven by water and the other by wind. ${ }^{26}$

The sale of timber from Greenstead during the Napoleonic wars is mentioned below. ${ }^{27}$ It is clear from the maps that Greenstead wood was much larger in 1777 than it was a hundred years later..$^{28}$

In the time of Edward the Confessor GREENSTEAD was held by Gotild 'as a manor and

MANOR 2 hides'.29 In 1086 it was held in demesne by Hamon dapifer. ${ }^{30}$ It was also stated in

Domesday that one Serlo held 40 acres of the manor, that three freemen had before 1066 held $\frac{1}{2}$ hide and 45 acres, and that 'of this land' one Ralph was in 1086 holding $\frac{1}{2}$ hide and 5 acres. As J. H. Round has commented, this is a confused passage: 'for it is not clear whether the holding of the 3 free men was valued as part of the main manor, nor if it were is it clear of which two portions Ralph's holding was part.'31 It seems most likely, however, that Ralph had taken over the greater part of the land previously occupied by the three men.

From Hamon the lordship of the manor descended in the same way as Norton Mandeville (q.v.) to Robert, Ist Earl of Gloucester, bastard son of Henry 1.32 In about I I 70 William, 2nd Earl of Gloucester, granted the manor to Richard de Lucy, along with the service of 4 knights owed by Richard de Marcy, 2 knights owed by Ralph de Marcy, 3 knights owed by Maurice de Toheham, and I knight owed by Manasser de Dammartin. ${ }^{33}$ It is not unlikely that Richard and Ralph were relatives of the Domesday tenants Ralph and Serlo.34 Greenstead thus became part of Richard de Lucy's honor of Ongar, and the tenancy in chief of the

20 Ibid.

21 E.R.O., D/CT 153.

2a See below, Manor.

23 E.R.O., D/DFa M $1 / 5$.

24 See above, p. 58 . In I 839 the green contained c. 16 acres, reckoned as waste: E.R.O., D/CT 153 .

25 V.C.H. Essex, i, 502.

26 Cal. Ing. p.m. ix, p. 242.

27 See Manor.

28 Chapman and André, Map of Essex 1777, sheet xvii; $0 . S .6$ in. Map (1st edn.), sheets $1, \mathrm{li}$.

29 V.C.H. Essex, i, 502.

30 Ibid.

31 Ibid.

32 L. C. Loyd, Origins of Some AngloNorman Families (Harl. Soc.), 50; Domesday Monachorum of Christ Church, Canterbury (ed. D. C. Douglas), 55-56.

33 E.A.T. N.s. vii, 148 . The grant was manor descended in the same way as Chipping Ongar (q.v.).3s

The descent of the tenancy in demesne between about II 70 and about I 250 is obscure. It is possible that the Marcy family continued as tenants for part of this time. ${ }^{36}$ By about I250, however, the tenant was Walter de Baskerville. ${ }^{37} \mathrm{He}$ was the son of Walter de Baskerville (d. 1244) of Orcop (Herefs.). ${ }^{38} \mathrm{He}$ fought against the king in the Barons' Wars and in 1265 his lands at Orcop, Greenstead, and elsewhere were granted to Roger de Clifford. ${ }^{39}$ Baskerville subsequently regained possession and in 1279 granted Greenstead to Roger de la Hay in exchange for land in Great Cowarne (Herefs.).40

William de la Hay was lord of the manor in 1328 and 1333.41 In 1346 he granted Greenstead to Sir Robert Bourchier. ${ }^{42}$ Bourchier was subsequently summoned to Parliament as a peer. ${ }^{43} \mathrm{He}$ died in 1349 and was succeeded by his son, John Lord Bourchier. ${ }^{44}$ Greenstead descended with the title to Henry, Lord Bourchier, who was created Viscount Bourchier (c. I 445) and Earl of Essex (146I).45 The manor passed to Henry Bourchier, 2nd Earl of Essex, and on his death in 1540 to his daughter Anne, suo jure Baroness Bourchier, wife of Thomas Parr, Baron Parr of Kendal.46 Parr was created Earl of Essex in I 543 and in the following year conveyed Greenstead to Sir Richard Rich, later created Baron Rich.47

In 1578 Robert, 2nd Baron Rich, conveyed the manor to William Bourne. ${ }^{48} \mathrm{He}$ was the son of William Bourne of Bobbingworth.49 $\mathrm{He}$ died in I608, leaving an eldest son William (b. 1589), and younger sons Richard (b. 1599) and John (b. I602).so The manor was probably held until her death by Anne (d. I624) widow of William Bourne. 51 She married Richard Young in I6 I 3.52 After her death the manor appears to have been settled on her son John.53 In I6:2 complaint was made to quarter sessions that Richard Bourne, owner of Greenstead Hall, had been dispossessed by Thomas Smith, labourer, and others (named). The justices ordered that Richard should be given possession of the property. $54 \mathrm{He}$ was probably identical with Richard (b. 1625) son of John Bourne.55 He died in 1660.56

The next owner of the manor who has been traced was John Hulson, who held it in 1683.57 Robert Hulson was the owner in 1690.58 In 1695 he sold Greenstead to Alezander Cleeve, citizen and pewterer of London.59 Cleeve's initial purchase comprised about balf the land in the parish. He subsequently added to it most of the other half. 60 After his death confirmed by the king in $1167-74$. For the Dammartins see Norton Mandeville. 34 Ibid. 149. A Serlo de Marcy held Stondon Massey (q.v.) in the I $3^{\text {th }}$ cent.

3s The last record of overlordship is I 566 : Morant, Essex, i, 152.

36 For the Marcy family see Stondon Massey, Kelvedon Hatch, Navestock, and Magdalen Laver.

37 E.A.T. N.s. xviii, I 8.

38 C. Moor, Knights of Edw. I (Harl. Soc.), i, 5o; W. H. Cooke, Hist. Hereford (1892), 187 .

39 C. Moor, ibid.

40 Feet of F. Essex, ii, 24.

41 Newcourt, Repert. ii, 288.

42 Cal. Close, i 346-9, 5 r.

43 Complete Peerage, ii, 246.

44 Ibid.; Cal. Ing. p.m. ix, p. 242.

45 Complate Peerage, ii, $248-9$.

46 Ibid.; Newcourt, Repert. ii, 288-9.
$47 \mathrm{CP}_{25}(2) / \mathrm{I}_{3} / 75$ Trin. $36 \mathrm{Hen}$. VIII. $48 \mathrm{CP}_{25(2) / 131 / 1684}$

49 Visits. of Essex (Harl. Soc.), pp. 156, 354-5.

so Par. Regs. of Greensead, ed. F. A. Crisp, 4, 31. Richard and John were the sons of their father's second marriage, to Anne Day, widow.

sI See below, Church; Par. Regs. of Greenseead, 19, 3 I

52 Ibid. I 9.

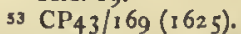

s4 E.R.O., Q/SBa $2 / 29$.

ss Par. Regs. of Greenstead, 6.

56 Ibid. 32. He founded Bourne's

Charity (see below, Charities).

$57 \mathrm{CP}_{25}(2) / 655$ Hil. 34-35 Chas. II.

$58 \mathrm{CP} 43 / 428$ rot. 81 .

59 P. J. Budworth, Memorials of Greenstead-Budworth, 6.

60 Ibid. 8. 


\section{A HISTORY OF ESSEX}

in 1738 his widow Anne held the estate for life. ${ }^{61}$ She died in 1750 and the estate was then divided among Alexander Cleeve's children. John Cleeve, Rector of High Laver, inherited New House Farm, Jane Velley received Hardings, Anne Cleeve had Repentance Farm, and Mary Hatt had Lodge Farm.62 In 1752 Greenstead Hall and the manorial estate were sold by the nine surviving children of Alexander Cleeve to David Rebotier of London, merchant. ${ }^{63}$

David Rebotier died in 1769 and in 1771 his son Charles and his daughter Esther Rebotier sold the manor to John Redman of Mile End in the parish of St. Dunstan (Mdx.). ${ }^{64}$ Redman died in 1798; he left the manor to Craven Ord of the Cursitors Office, who had married his daughter Mary. ${ }^{6 s}$ It was provided that Greenstead should be held in trust for the younger children of Craven and Mary. During the Napoleonic Wars, however, Craven made sufficient profits from the sale of timber from Greenstead to satisfy the portions of his younger children, and on his death in 1832 the manor passed to his eldest son, the Revd. Craven Ord (d. 1836 ). 66

In I 837 the manor was bought by the Revd. Philip Budworth, who was a grandson of Jane, daughter of Alexander Cleeve and wife of the Revd. Thomas Velley. ${ }^{67}$ In 1843 Budworth also bought New House Farm, which had been sold in 1778 by the executors of John Cleeve and had become the property of Sympson Jessopp. 68 Captain Philip J. Budworth was the only surviving son and heir of the Revd. Philip Budworth. He settled at Greenstead Hall in I 854.69 In I 867 he bought Lodge Farm from the representatives of Mrs. Holbrook and thus became owner of all but a small part of the land in the parish.70 $\mathrm{He}$ continued to live at Greenstead Hall until his death in $1885^{71}$ and took an active part in local affairs. ${ }^{72} \mathrm{He}$ is commemorated by the Budworth Hall in Chipping Ongar. His sons, or their representatives, were the main landowners in Greenstead in 1926.73

Greenstead Hall is a large house of two stories with attics. It is of timber-framing partly covered with a later facing of red brick. As it exists today most of the house dates from about 1700 when it was largely rebuilt, probably by Alexander Cleeve. The date 1695 is carved on the cast front and a sundial on the south front bears the date 1698 and the initials $A$ and $M C$ (Alexander and Mary Cleeve). There are, however, timbers near the west end which appear to be older, and in two places there is panelling of the early i 7 th century. The report $74^{\circ}$ of an open hearth under the centre of the present drawing-room on the south side suggests that there was originally a medieval hall in this position. A view from the east drawn about $177^{\circ}$ shows the house as altered 70 years before. 75 It was then plastered and roughly square in shape but with two projecting wings on the south side. The main entrance front to the east had seven windows and a central pediment. Part of the north side of the house with a projecting bay no longer exists. This may have been the dining-room which John Redman is said to have demolished in the late I 8 th century in order to curb the extravagant hospitality of his son. ${ }^{76}$ Redman made many improvements to the house and its grounds, including the existing timber-framed brick-fronted stables.77 Large alterations were carried out in 1875 by P. J. Budworth. ${ }^{78}$ The east front was largely rebuilt, including the central pedimented feature in moulded brickwork. The east and south fronts were faced with red brick, and one of the south wings was extended. The dates 1695 and 1698 were probably recut at this time. Inside the house there are some good pine chimney-pieces and panelling of about 1700 and a fine staircase with twisted balusters and carved string of the same period. This is very similar to work at Hill Hall, Theydon Mount (q.v.). The present occupier has made some interior alterations in the same style. The detached 17 th century-brewhouse was converted into a cottage in $195^{\circ}$.

There seems to be no reason to doubt the established tradition that Greenstead church was buil

CHURCH in the IIth century to mark the place where St. Edmund's body rested on its way from London to Bury St. Edmund's in IOI3. A description of the event, written about 1300 , says that the body was accommodated at Ongar and that 'a wooden chapel built in his name remains until today'. 79 This is the only documentary evidence for the identification. Greenstead is a mile from Chipping Ongar, but it is curious that the wooden church, which is described in detail below, is dedicated not to St. Edmund but to St. Andrew. 80

Walter de Baskerville was patron of Greenstead in about $1254 .^{81}$ William de la Hay held the advowson in $1328-33$ and it subsequently descended along with the manor until the 17 th century. ${ }^{82}$ Richard Young and Anne his wife presented Edward Young to the rectory in $1617 .^{83}$ Anne had previously been the wife of William Bourne (d. I608), lord of the manor. Her son John Bourne made a conveyance of the manor in 1625.84 Thomas Spencer presented in I64I pro hac vice. ${ }^{8 s}$ Presentation was made in $\mathrm{I} 646$ by Katherine Young, widow, and Robert Young her son, and in I 66 I by Katherine alone. ${ }^{86}$ Nathan Lacy, rector I 66 II 700, married a second wife Mary. ${ }^{87}$ After his death Mary Lacy, widow, presented. 88 Soon after this the advowson was bought by Benjamin Pratt, curate of

\footnotetext{
6r Budford, Memorials of GreensteadBudworth, 9

62 Ibid. 10. For a full list of the children see ibid. 7. Repentance, which no longer exists, was in the extreme south of the parish on the road to Stanford Rivers. ${ }_{63}$ Ibid. 16; $\mathrm{CP}_{25}(2) / 1124$ East. 25 Geo. II.

64 Budworth, op. cit. 17 ; CP25(2)/1308 Hil. 12 Geo. III.

65 Budworth, op. cit. 17. Ord was an antiquary who collaborated with Gough, Nichols, and others : see D.N.B.

66 Budworth, op. cit. $17 . \quad 67$ Ibid.

68 Ibid.

69 Ibid.

7o Ibid.

7 E.A.T. N.s. iii, 115

72 See Chipping Ongar, Public Services.

73 Kelly's Dir. Essex (1 926), cf. Budworth, op. cit. 26. From c. 1895 Greenstead Hall was the residence of Howel J. J. Price (d. I943).

${ }_{4}$ Inf. from Mrs. Tugendhat, the present occupier.

75 Hist. Essex by a Gent. iii, 378 .

76 Budworth, op, cit. 20

77 Ibid.

78 Cf. ibid. 26.

79 'Apud Aungre hospitabatur vero ejus nomine lignea capella constructa permanet usque hodie': B,M. Add. MS. 14847 f. 20 .

80 It is of course possible that the dedication has been changed. It is interesing to note that the church of Greenstead by Colchester has the same dedication to St. Andrew.
}

81 E.A.T. N.s. xviii, 18.

82 Newcourt, Repert. ii, 289 .

83 Ibid.

${ }^{34} \mathrm{CP}_{43 / 169}$ rot. 52 .

85 Newcourt, Repert. ii, 289. One institution was missed by Newcourt, for the rector who died in 1641 was William Young: cf. Par. Regs. Greenstead, ed. F. A. Crisp, 32.

86 Newcourt, Repert. ii, 289.

87 Par. Regs. Greenstead, 8, 9

88 Newcourt, Repert. ii, 289 . In $168 \mathrm{~g}$ and $169 \mathrm{I}$ conveyances of the advowson were made by James Lacy, clerk, presumably the son of Nathan Lacy: CP43/ 424 rot. 205 ; ibid. 430 rot. 22 ; J. and J. A. Venn, Alumni Cantabrigienses, pt. i, iii, 33 . 



St. Botolph's, Aldgate about 1708-15. By his will, dated 1714 , Pratt bequeathed the advowson in trust to the Bishop of London, with the provision that at each presentation the curate of St. Botolph's was to have first refusal.89 The patronage has subsequently remained with the bishop, subject to this provision.

The rectory was valued at 40 s. in about 1254,90 at fir ros. in 1291,91 and at $66135.4 d$. in 1535.92 The tithes were commuted in 184 I for $£ 210$; there were then 30 acres of glebe. 93 The rectory house is an earlyroth-century building, whitewashed externally.

In 1548 the parishes of Greenstead and Chipping Ongar were united by Act of Parliament. In spite of its small size the Greenstead church became the parish church of the combined parish. This union, however, was dissolved in 1554 and the parish of Greenstead returned to its ancient size and constitution.94

The parish church of ST. ANDREW consists of nave, chancel, west tower with spire, and south porch. The nave is a unique survival of early timber construction, probably of the early IIth century. The chancel is partly of flint rubble and partly of brickwork. The tower is timber framed and the porch is also of timber.

The circumstances in which the church was probably built, in or soon after ror 3 , have been described above. The present nave was probably the original church. It is $29 \mathrm{ft}$. long by $17 \mathrm{ft}$. wide. The timber walls remain on the north and south sides. They are $5 \mathrm{ft} .6 \mathrm{in}$. high and consist of oak logs, varying in width from 7 to $I 7$ in., cut in half and set vertically, the flat surfaces facing inwards. At the two western angles three-quarter logs are used with a right-angular rebate cut internally. The south doorway still exists and nearly opposite there was originally a north doorway $2 \mathrm{ft} .5$ in. wide. The nave was thoroughly restored in 1848 . Descriptions of it before and during this restoration are of particular value. In 1748 Smart Lethieullier sent an account of it to the Society of Antiquaries, 95 together with elevational drawings which were later published. 96 A hundred years later the Revd. P. W. Ray, then rector, wrote as follows: 97

the building ... is formed of split trunks of oak trees, the top part being cut to a thin edge which is let into a deep groove in the plate and pinned. The bottoms of the upright timbers were morticed into the sill. Their sides were grooved, with tongues of oak let in between them so as to make the whole firm and weathertight 98 ... upon the face of the timbers within the church were a great number of triangular cuts, having a rough bur on one side such as would be produced by the angle of an adze. These cuts were the key for the plaster with which the interior of the church was covered. . . . The west end was carried up in the middle as high as the ridge of the roof and consisted of two layers of planks fastened together with tree nails. The planks are not long enough to reach the whole height, they are therefore so arranged as to break both the perpendicular and horizontal joints.

The external elevation of this west end, part of which disappeared in 1848 , is shown in Lethieullier's drawing. The narrow opening which can be seen just south of the centre was probably made to give access to the tower after that was added.

The chancel was probably added to the original wooden church in the I 2 th century. Parts of the flint rubble plinth remain. The east wall of the nave was presumably removed then.

The small stoup with a pointed head to the west of the former north door probably dates from the $13^{\text {th }}$ or $14^{\text {th }}$ century.

In the 15 th or I 6 th century the square tower was added to the west end of the nave a little to the south of the centre line. It is weather-boarded externally and has louvred openings. The lower story of the tower is now used as a vestry. There is a broach spire. About I 500 the chancel was rebuilt in brick. On the south side is an early-16th-century doorway with moulded brick jambs and an elliptical head. Next to it on the west is a window of similar date also with an elliptical head. The four-centred chancel arch is probably of the 16th 'century. In that century also the nave was probably reroofed. Views of the church before the restoration show a sagging roof line, lower than that of the chancel, with two dormers on the north side and one on the south. 99

The church was being repaired in 1683 . Beams had recently been set on the inside of the chancel but it was feared that this would not prevent the cracks on both sides of the east window from getting worse. ${ }^{I}$

Extensive repairs were carried out in 1848 . The oak sills of the nave walls, which originally rested on the ground, were completely decayed, together with the lower ends of the logs. These last were shortened from the base and tenoned to new sills supported on dwarf brick walls. The plaster was stripped internally and oak fillets fixed over the joints. The north doorway, which had already been plastered up before this time, was blocked by the insertion of three new timbers. The nave roof was replaced and three additional dormer windows constructed so that there are now three on each side. A new window was inserted in the west gable. In the chancel the east wall was rebuilt and a new east window with stone 'perpendicular' tracery was inserted. A new window was also placed in the north wall and another in the south wall to the east of the doorway. The east wall and the chancel arch were strengthened by the external addition of buttresses. A traceried window was placed in the tower, and a new timber porch, a copy of I 5 th-century work, replaced a small weather-boarded structure. ${ }^{2}$

In $1891-2$ the roof, which was of fir, was again found to be decayed. A subscription list for a new roof was started by William Hewett, tenant of Greenstead Hall and churchwarden, and the work was carried out in oak by Frederic Chancellor, the diocesan surveyor. He followed the same design on the assumption that it was a copy of the roof taken down in 1848.3 At the same time a brick buttress on the north side of the nave was removed, exposing sound timbers behind it. 4 No important alterations have been carried out since 1892 ,

\footnotetext{
89 Morant, Essex, i, 153 ; J. and J. A. Venn, Alumni Cantab. pt. i, iii, 390; G. Hennessy, Novum Repert. Eccl. Paroch. Lond. Ixvii, 107.

90 Lunt, $V_{a l}$ of Norwich, 336. 91 Tax. Eccl. (Rec. Com.), 236.

92 Valor Eccl. (Rec. Com.), i, 437.

93 E.R.O., D/CT 153 .

94 For the details of this temporary union see Chipping Ongar.

9s B.M. Stowe MS. 752, f. 49 .

96 Vetusta Monumenta, ii, pl. 7. See plate facing p. $6 r$.

97 P. W. Ray, Hist. of Greenstead Church, 18-20. Ray was rector when the church was restored, 1848 .

98 Lethieullier's description of the jointing, "the edge of one tree made to slip a little within its neighbour', is probably less accurate.

99 A. Suckling, Memorials of Essex, 4; P. W. Ray, Hist. Greenstead Church. E.A.T. N.s. xix, 268.

2 For various pictures of the church before and after 1848 see E.R.O., Prints.

3 E.A.T. N.s. iv, 223 ; E.R. i, I 39 ; Notes \& Queries, I $89 \mathrm{I}, 316$.

4 E.A.T. .ं.s. iv, 223 .
} 


\section{A HISTORY OF ESSEX}

but the spire was recently covered with shingles of Canadian cedar.s

There is one bell by William Land, 1618 , and a sanctus bell, uninscribed. In 1552 there were two Rogation bells weighing $10 \mathrm{Ib}$. and two great bells weighing $300 \frac{1}{2} 1 b^{6}$ Early in the Igth century an old bell larger than the present bell, being cracked and unhung, was sold.?

In the chancel is a stone pillar piscina with an octagonal bowl, probably late $15^{\text {th }}$ century. The Igthcentury quatrefoil window in the west gable of the nave contains an early 16 th-century roundel of stained glass, showing a man's head and shoulders in the dress of the time. A crown suggests that he may represent St. Edmund. ${ }^{8}$ Two other pieces of stained glass, probably of similar date, were removed from the church before 1836 . They came into the possession of a Bobbingworth farmer who took them with him to New Zealand. He was persuaded to return them to the church but they were lost in a shipwreck off the Scilly Isles on their return journey in 1871.9 Hanging in the nave is a round-headed wooden panel on which is an oil painting of about $\mathrm{I} 500$ showing the martyrdom of St. Edmund.ro The octagonal oak pulpit was presented by Alexander Cleeve in I698.11 One panel has the date and I. H. S. inlaid in darker wood. The stone font is of the Igth century. The stained glass in the four chancel windows was inserted in memory of William Smith, d. I 87 I : the north window shows the martyrdom of St. Edmund and the east window the Last Supper and Crucifixion. The oak screen dividing the vestry from the nave was given in memory of Gerard Noel Hoare and his son, between them churchwardens from 1907 to 1949 .

The church plate consists of a cup, I739, paten, 1699 (the gift of Alexander and Mary Cleeve), flagon $185^{8}$ (the gift of the Revd. P. W. Ray and family), and an alms-dish, $18 \mathrm{I} 7$. The last piece was obtained in compliance with the archdeacon's instructions in 1817 to 'sell pewter plate and provide patens for the offerings'.12

On the north wall of the chancel is an alabaster tablet in memory of Jone, second wife of Alane Wood ( 1585 ). There are also tablets to the Revd. W. H. Warren (1 825) and Mary wife of Craven Ord (I 804). On the south wall is a tablet to Richard Hewyt, rector (I724). In the nave are tablets to P. J. Budworth (1885) and his son Major-Gen. Charles E. D. Budworth (I92I).

In 1792 the rector opened a Sunday school in Greenstead. Only one child attended SCHOOLS from this parish, however; the others came from Chipping Ongar, and when the Chipping Ongar Sunday school was started the
Greenstead school was discontinued. ${ }^{13}$ In 1807 there was no school in the parish, but by 1818 the Sunday school had been reopened by the rector and the lord of the manor, Craven Ord. It then had 22 pupils and it continued with varying attendances at least until I $846-7 .{ }^{14}$ In I 828 a small day school existed, Is but by 1833 it had been closed. ${ }^{16}$

In 1839 the rector began to collect subscriptions for a parish school. 17 By $1846-7$ this was being attended by some 34 children. The mistress then received $£ 30$ a year. ${ }^{18}$ About this time a new building was erected, evidently by subscription, on a site on the waste on Greenstead Green, presented by the Revd. Philip Budworth, lord of the manor. The rector exercised a close supervision over it. ${ }^{19}$ It provided 33 places, 'abundant accommodation' for the small and declining population of the parish. In 1870 there were about 23 pupils. ${ }^{20}$ Between 1878 and 1882 the school was closed; the children subsequently attended the schools at Chipping Ongar and Stanford Rivers.21

The former school house stands on Greenstead Green, beside Greenstead House; it is now known as Ivy Cottage. (See plate facing p. I 26.)

No parish records are known to survive except the registers. A few figures of poor

POOR RELIEF relief are available from Parliamentary returns but these are prob-

ably not very reliable. ${ }^{22}$ In 1776 expenditure on poor relief was $\mathrm{SII}^{23}$ For the three years $1783-5$ the average annual expenditure was $\left\{29 .{ }^{24} \mathrm{By}\right.$ I $800-\mathrm{I}$ the annual expenditure had risen to $\oint_{1} 150$, but in I $802-3$ it was only $\oint_{074.25}$ Figures of expenditure on poor relief alone are missing for the years I $803-$ I I ; the poor rates, which also include administrative expenses and county rates, rose from $\oint_{9} \mathrm{I}$ in $5803-4$ to $\oint_{2} 55$ in $1810-11.26$ The cost of relief rose from f I 174 in I 8 I I -12 to $£ 486$ in I 819-20.27 The cost for I 820-I was, however, only $f_{0} 144.28$

There was a parish poorhouse by 1776.29 In I 841 there were 'almshouses' belonging to the parish, situated at Greenstead Green, opposite Greenstead House. ${ }^{30}$ These had probably been provided by the parish for the accommodation of its poor: there is no evidence that they were a privately endowed charity. They had disappeared by $1873-4.31$

In 1836 Greenstead became part of Ongar Poor Law Union.

For an account of Petit's Charity see Stanford Rivers.

CHARITIES Richard Bourne of Greenstead Hall (d. I 660) left to the poor of the parish 40 s. issuing from Lee Fields. ${ }^{32}$ In 1834 the money was used to buy coal for all the poor householders. The rent-charge was not collected from I 908 to 1924 but

\footnotetext{
5 Inf. from present rector, Revd. W. A. Hewett.

6 E.A.T. N.s. ii, 236.

7 Ch. Bells Essex, 265 .

8 See Hist. Mon. Com. Essex, pl. p. xxxv

p. 112 .

- E.R. iii, I 35 ; xxii, 45 .

to See E.R. xlvii, 78 .

i1 P. J. Budworth, Mems. of Greenstead-Budworth.

${ }_{12}$ Ch. Plate Essex, $135-6$.

13 E.R.O., D/AEM $2 / 4$.

14 Ibid.; Retns. Edue. of Poor, H.C. 224 p. 256 (1819), ix (1); Nat. Soc. Reps. 1820,1828 ; Nat. Soc. Enquiry into Church Schs. $1846-7,8-9$.

15 Nat. Soc, Rep. 1828
}

${ }^{6}$ Educ. Enquiry Abstr. H.C. 62, p. 276 $(1835), x l i$

17 E.R.O., D/P $30 / 28 / 18$

18 Nat. Soc. Enquiry, $1846-7,8-9$.

19 Kelly's Dir. Essex $(1855,1862)$.

20 E.R.O., D/AEM I/I/1 ; Retns. Elem.

Educ. H.C. 201, pp. 112-13 (1871), lv.

21 Kelly's Dir. Essex (1878, 1882, 1922).

The school was sold in 1890 for 200 :

Char. Com. files. The income from this sum, known as the Greenstead School Foundation, is used to give book tokens at Christmas to children recommended by the headmasters of the Ongar Primary and Secondary Schools: inf. from rector.

22 The parliamentary returns can often be checked for parishes with surviving poor law records; for other places in Ongar hundred they have been found inaccurate. 23 E.R.O., Q/CR I/I. 24 Ibid. 25 E.R.O., Q/CR $1 / 9$. 27 Ibid.; Q/CR I/12.

$28 \mathrm{Q} / \mathrm{CR} \mathrm{I} / \mathrm{12}$. A remarkable drop, if the figure is correct; but it may be an error.

29 Rep. Sel. Cttee. on Overseers Retns. 1777, H.C. Ser. I, vol. ix, p. $35^{\circ}$

30 E.R.O., D/CT i 53. The almshouses, apparently 4 in number, were in a terrace. 31 O.S. 6 in. Map (Ist edn.), sheet (1 $873-4)$

32 Rep. Com. Char. (Essex), H.C. 216 pp. 228-9 (1835), xxi (1); Char. Com. files. 
it is now being paid and is used for the general purposes of the charities.

Mary Rayner, by will proved I 873, left $\{200$ for the purchase of blankets and clothing to be distributed to the deserving poor in winter. ${ }^{33}$

Edward Sammes, by will proved I 882 , left to the rector $f_{1} 0$ and $f_{1} 100$ duty-free to be invested respectively for the upkeep of his grave and for the purchase of tea and sugar to be distributed on 6 January to eighteen poor families in the parish. ${ }^{34}$ The first bequest was void by the rule against perpetuities.

The three charities of Bourne, Rayner, and Sammes were united in 1904 to form the Consolidated Charities.3s Their income was to be used for the poor and sick, primarily as gifts in kind, and in help to hospitals \&c., caring for the sick of the parish. In 1945 the income was used to give $f_{0}$ I $\mathrm{I}$. each to the Ongar nurse and the Ongar Hospital and to give coal to two poor people.

Howel J. J. Price (d. 1943) left $\int_{100}$ in trust for the repair of his grave and the benefit of the poor of the parish. ${ }^{36}$ The former purpose was void. In 1950 fI was given to the Greenstead School Foundation and $f_{\text {I }}$ to the Greenstead Consolidated Charities.

\section{KELVEDON HATCH}

Kelvedon Hatch is 3 miles south of Chipping Ongar and 4 miles north-west of Brentwood, on the east bank of the Roding. I It contains 1,683 acres. The soil is mainly London Clay with some patches of Boulder Clay and Bagshot beds. The land slopes up from the river to a height of about $350 \mathrm{ft}$. above sea-level in the south-east and $300 \mathrm{ft}$. in the north-east. Two tributaries flow into the Roding in the north of the parish through shallow valleys. The parish was part of the ancient forest of Essex and the suffix 'Hatch' by which it is distinguished from Kelvedon in Witham hundred probably refers to a forest gate. ${ }^{2}$ Considerable areas of woodland still survive and there are also parks attached to three big houses. The main road from Ongar to Brentwood enters the parish in the north-west by Langford Bridge and runs south-east. In the south of Kelvedon Hatch it crosses a stretch of land which was formerly open common but now largely inclosed. The boundary of the common on the west side followed a line 50 to $100 \mathrm{yds}$. back from the present road. On the north it was bounded by the road now called School Lane and on the east it extended to Fox Hatch in Doddinghurst parish. This accounts for the apparently haphazard arrangement of the older houses, which bears little relation to the modern road. There has been considerable development in this area during the past 150 years and it now forms the village centre of the parish. From the village roads also run west to Navestock and east to Blackmore and Stondon Massey.

There were three ancient manors in Kelvedon Hatch. The capital manor was centred on Kelvedon Hall, a mile south-east of Langford Bridge. The ancient parish church was beside the hall and the 18 th-century building which replaced it still stands there, though disused and ruinous. In the 17 th and 18 th centuries the manor house which dominated the little church was owned by Roman Catholics, the Wrights, who were buried in the parish church and erected sepulchral monuments there but worshipped secretly in the chapel which they had built in the hall itself. The other old manors were Myles's, $\frac{1}{2}$ mile north-east of Kelvedon Hall, and Germains, $\frac{1}{4}$ mile south of the hall. None of the medieval manor houses has survived. The present Germains dates from the 16th century and Kelvedon Hall from the I 8 th, while old Myles's was demolished in 1837.3 These three manor houses were all in the north or centre of the parish, but medieval houses also existed farther south at Hatch Farm, Brizes, Priors, and Woodlands. 4 Priors is on the main road mile east of Germains. The other three are in or near the modern village of Kelvedon Hatch. Only Woodlands now retains medieval features. It is a timber-framed house about $50 \mathrm{yds}$. west of the main road and south of the Eagle Inn, and probably dates from the late I 5 th century. It has been partly demolished so that the original construction is exposed. It consists of a singlestory hall with smoke-blackened timbers and a twostory cross-wing at the south end. The latter is of three bays, divided above the first floor by king-post trusses with two-way struts. The hall also has a king-post and the remains of what was possibly a second truss. Chimneys which may have been inserted in the I6th or 17 th century have recently been demolished. In the I8th century the house was weather-boarded and the older windows replaced by sashes. Hatch Farm, on the north side of the former common, and about $100 \mathrm{yds}$. east of the modern parish church, is a timberframed house probably dating from the second half of the 16 th century. The house was originally L-shaped with the staircase in the north wing, but there is now a later addition in the angle between the wings. At the junction of the two wings is part of a large original chimney-stack with a moulded capping. The interior retains a staircase, plasterwork, and door-frames of the original date. In the I 8 th century the roof of the main wing was rebuilt and two sides of the house faced with red brick. Sash windows and Georgian doorways were inserted. Parts of a moat are in existence to the north and east of the house.

Priors is held by local tradition to have been rebuilt early in the I 7 th century by the brothers Richard and Anthony Luther.s It was originally a timber-framed structure, but the front was refaced in red brick, probably in the second half of the 18 th century. Brizes was also rebuilt in the $r 8$ th century. Morant $(1768)$ refers to it as 'a good old house ... built by Thomas Bryce, citizen and mercer of London, about $149^{\prime} .{ }^{\prime}$ This earlier house had, however, been replaced before Morant's time by the present mansion. The exact site of the previous house is not known. In the grounds of the present house, about $75 \mathrm{yds}$. from the road, is a small moated site. It does not appear, however, that the island could have accommodated a medieval house of any size and the moat itself may be an ornamental feature of the I 8 th century.

The present house was probably built about 1720 :

\footnotetext{
${ }^{33}$ Char. Com. files.

34 Ibid. Sammes was a prominent builder and shopkeeper in Chipping Ongar (q.v.).

33 Ibid.

36 Ibid. Price lived for many years at
}

Greenstead Hall.

1 O.S. 2t in. Map, sheets $51 / 59,52 / 50$.

2 P.N. Essex (E.P.N.S.), 59 .

3 See below, Manors.

4 For the first three of these see P.N.
Essex, 59.

3 Inf. from Capt. F. L. Fane. For the Luther brothers see Myles's.

6 Morant, Essex, i, 187. 


\section{A HISTORY OF ESSEX}

this date is said to be on one of the rainwater heads.7 At that time the property was owned by the Glascock family. 8 The building is of three stories and has an imposing front of nine bays. The centre projects slightly and is surmounted by a pediment. The porch, which may be a later addition, is of the Roman Doric order and is supported on four columns. Above the doorway is a round-headed niche. The house was evidently altered late in the I 8 th century when the interior was remodelled. The hall has a Venetian arch enriched with plaster ornament and behind this is a fine double staircase. The staircase window is round-headed and fitted with painted glass. These alterations were probably carried out for William Dolby, who succeeded his brother Charles as owner of Brizes in 1781.9 In I 788 William Dolby employed Richard Woods, who in 1771 had carried out ornamental alterations to the gardens at Myles's (see below) to replan those of Brizes. The plan made by Woods still exists. ${ }^{10}$ It included 'an alcove seat or temple', 'the truss Paladian bridge', plantations of oak, chestnut, pine, and elm and other features, covering 74 acres. Most of these features were adopted. II

By the I 6th century there were probably a number of other houses around the common in the south of the parish. One of these, Dodd's Farm to the south of Church Lane, is of much the same date as Hatch Farm. It is an L-shaped building, timber-framed and plastered. There are two large external chimneys of a similar type to those at Hatch Farm, and in this case the short octagonal shafts are original. Internally there is said to be a fireplace of the I6th century. ${ }^{12}$

Poor's Cottages, ${ }^{13}$ which date from the I 7 th century, were also built at the common, which suggests that by that time the common was the most important centre of population in the parish. By 1777 there were many houses round the common and also a windmill.14 The mill was in use until the First World War but was demolished about I 916 as it was thought to be a landmark for zeppelins. Is It was a weather-boarded smock mill. The mill house still exists, on the east side of the main road nearly opposite the 'Eagle'. It is a singlestory cottage dating from the mid-I gth century. During the I 8 th century Kelvedon Hall, Myles's, and Brizes were all rebuilt as imposing Georgian mansions and the medieval parish church was also rebuilt.

The building of houses at the common had been facilitated by small inclosures made there, and no doubt also by the existence of common rights. The inclosures seem to have been carried out by purely local arrangement, through the manor courts. Examples of such inclosures occur in the case of Poor's Cottages (see above) in the 17th century and again in 1786.16 By I 838 the common was wholly in private ownership, though perhaps not physically inclosed. ${ }^{17}$

During the Igth century there was further building at the common. The village school and post-office were both set up there. When the railway from London through Brentwood to Colchester and East Anglia was built in the 1840 's the road between Ongar and Brentwood took on a new importance and this probably increased the concentration at the common, through which the road ran. In 1893 a new parish church was built in the village and the old church beside Kelvedon Hall became disused. Other I 9 th-century buildings were Mushroom Hall, the Church House, and a nonconformist mission hall (now the village hall). ${ }^{18} \mathrm{Mush}$ room $\mathrm{Hall}$ is a single-story house in the 'picturesque' style of the early I th century. It lies about $100 \mathrm{yds}$. east of the main road near the mill house.

Building at the common has continued in the 2oth century. On the east side of the main road opposite Briźes are two rows of single-story terrace houses known as The Thorns and The Briars. These and The Avenue, a similar block on the road to Doddinghurst, were built early in the century. There are ten pairs of council houses on the north side of Church Lane. A red-brick police house was completed in 1953. Some new bungalows are now being built to the south of School Lane.

The population of the parish was 297 in $18 \mathrm{II}$. It rose steadily to 502 in $185 \mathrm{I}$ but subsequently declined to $36 \mathrm{I}$ in 1901.19 Since then it has again increased, to 542 in 1931 and 557 in $1951 .{ }^{20}$

Until recent times communications between Kelvedon Hatch and the outside world were poor. In particular there seems to have been no good road to Brentwood ${ }^{21}$ until the I gth $^{\text {th }}$ century. It is now a class A road, although still very narrow in places. In the Ongar direction the present main road was altered between 1777 and I 800.22 'This eliminated a right-angle turn to the west of the present road. Part of the existing drive to Myles's follows the line of the old road. After the opening of Brentwood railway station coaches running to the station from Ongar passed through Kelvedon Hatch. Today there is a good bus service to Brentwood and a choice of two routes to Ongar.

The most direct road to Ongar crosses the Roding by Langford Bridge. In I 35 I it was said that John Pekkebrigge, lord of Kelvedon Hatch, and his tenants in High Ongar were to repair the bridge. ${ }^{23}$ It is not clear who Pekkebrigge was and what was his manor. The nearest manor to Langford Bridge was Myles's and there is no other evidence that Pekkebrigge was lord of this. He may, however, have been a lessee. He was probably identical with John Peghbrigg (1 356 ) whose park is thought to have given its name to Park Wood in Kelvedon Hatch, which is not far south of the bridge. ${ }^{24}$ In I 570 the owners of the lands adjoining the bridge, Mr. Wood on one side and George Preston and Thomas Auger on the other, were held responsible for its repair. ${ }^{25}$ In 1582 the bridge was said to be in ruins. Kelvedon Hatch parish was to pay part of the cost of repair, but it was not known if Chipping Ongar should pay the other part. ${ }^{26}$ Uncertainty as to the responsibility for repair continued until about $1673-$ 4 when it was said to be a charge on the county. ${ }^{27}$ In 1773 the bridge was again in need of repair. It was

\footnotetext{
7 Inf. from Hon. Simon Rodney.

8 The descent given by Morant, Essex,

i, 187 , can be supplemented and corrected from deeds in E.R.O., D/DRo TI.

- E.R.O., D/DRo TI. Charles Dolby, who had succeeded his father Charles Dolby in 1755 , was an ensign in the service of the East India Company.

10 E.R.O., D/DRo PI.

11 O.S. 6 in. Map (Ist edn.), sheet lix.

12 Hist. Mon. Com. Essex, ii, 143.
}

13 See Charities, below.

14 Chapman and André, Map of Essex 1777 , sheet xvii.

is Inf. from Mr. J. P. Fitch.

16 See Charities.

I7 E.R.O., D/CT 197; cf. O.S. 6 in. $\operatorname{Map}$ (Ist edn.), sheet lix.

18 For Church House see below, Church, and for the mission hall see Protestant Nonconformity.

is V.C.H. Essex, ii, 350.
20 Census, $1911-51$.

21 Chapman and André, Map of Essex 1777, sheet xvii.

22 Ibid.; E.R.O., D/DFa P6.

${ }_{23}$ Public Works in Med. Law (Selden Soc.), i, 99.

24 P.N. Essex, 59

25 E.R.O., Q/SR 32/1 7

26 Ibid. $81 / 25$.

27 E.R.O., $Q / \mathrm{CP}_{3}$ p. 39,$114 ; \mathrm{Q} / \mathrm{SR}$ $426 / 33$. 
proposed that it should be rebuilt in brick, but it was eventually decided to rebuild in timber at a cost of f 140.28 In 1857 Langford Bridge was described by the county surveyor as a timber structure of considerable span. Its condition was then good.29 It was restored in $1878-9$ and about 1913 was replaced by the present concrete bridge. ${ }^{30}$

In 1845 an official post-office was established at Kelvedon Common. ${ }^{3 !}$ In 1848 the office was at William Nutt's.32 A telegraph office was set up in 1885 and the telephone service in 1923.33

Piped water has been supplied since 1935 by the Herts. and Essex Waterworks Co. ${ }^{34}$ There is no main drainage. ${ }^{3 s}$ Kelvedon Hatch was in the area of the original Romford Gas Co. but powers to supply the parish were not obtained until $1935 .{ }^{36}$ There is now a supply to part of the parish. ${ }^{37}$ There is no electricity except in a few outlying farms. ${ }^{38}$

Early in the present century the Church House was used as a Working Men's Club and coffee house.39 In 1953 a newly formed village hall committee bought from the owner of Reed's Stores the building once used as a mission hall. The same committee holds 6 acres, formerly part of the charity lands, on the south side of School Lane. This has been sown with grass for a playing field and is the intended site of a new hall.40 A branch of the county library was opened in 1928.45 A police officer is stationed at Kelvedon Common.42 The first reference to a constable there is in the directory of 1908.43

The ownership of the land in Kelvedon Hatch was from the 16 th to the 20 th century mainly in the hands of two families, the Wrights of Kelvedon Hall and the Luthers (and their heirs the Fanes). In 1838 John Fane and J. F. Wright between thein owned almost 1,300 acres, leaving less than 400 acres for all other owners. 44 Two other properties contained more than 50 acres: Brizes ( 76 acres) and 83 acres forming part of the Waldegrave estate (see Navestock). Until the death of J. F. Wright in 1868 he and his family usually lived in the parish. For long periods between 1600 and 1900 the Luthers and Fanes were also resident in Kelvedon Hatch, and so were the owners of Brizes, the third of the big houses of the parish. Their mansions with the ornamental gardens must have provided a good deal of employment during the 18 th and Igth centuries. Apart from such domestic work, agriculture has been the main occupation in the parish. In 1838 it was estimated that there was about the same quantity of arable land in the parish as meadow and pasturesome 700 acres in each case-while there were 193 acres woodland. There were some seven farms in the parish, mostly small.45 Other occupations have been those incidental to agriculture. The existence of a village smithy is attested as far back as 1729, when the effects of the smith, which had been distrained upon for arrears of rent, were bought by the churchwardens of Stanford Rivers. ${ }^{46}$ There was still a blacksmith in the parish in 1906.47 The mill at Kelvedon Common has been mentioned above. In 1845 the miller also kept the 'Eagle'.48

Although Kelvedon Hatch had resident gentry in the rgth century it is clear that they did not provide the vigorous leadership in parish affairs that might have been expected. The most important reason for this was that the Wrights were Roman Catholics. Their lack of interest in the village school may be inferred from the early difficulties of the school and from the fact that a compulsory school board had to be established in order to provide a permanent school building.

Three estates were listed under Kelvedon Hatch in

Domesday Book. One was held in 1066 MANORS by Leueva as a manor and as I hide and 45 acres and in 1086 by Ralph de Marcy of Hamon dapifer.49 This estate may have become part of the manor of Navestock (q.v.) held by the Marcy family and later formed part of the manor of Myles's (see below). Another estate in Kelvedon Hatch was held in 1066 by Algar, a freeman, as $\frac{1}{2}$ hide and 20 acres and in 1086 by Ivo nephew of Herbert as tenant of the Bishop of Bayeux. ${ }^{50}$ The subsequent history of this estate has not been traced. The largest of the three estates was held in the time of Edward the Confessor by Ailric as a manor and as 2 hides.51 This estate was later known as the manor of KELVEDON HATCH alias KELVEDON HALL.

In 1066 Ailric 'went to take part in a naval battle' against William of Normandy. ${ }^{52}$ Probably he joined the fleet asembled by King Harold off the Isle of Wight during the early' summer of 1066.53 On his return home (possibly in September 1066) he fell ill and then gave his Kelvedon Hatch estate to Westminster Abbey. ${ }^{54}$ In 1086, however, the Domesday Commissioners reported that this gift had not received King William's sanction.55 It is not clear whether the king ever confirmed the gift, but it is certain that the manor was held by Westminster Abbey as tenant in chief until the dissolution of the abbey in 1540.56

By 1225 the abbey had granted the tenancy in demesne of the manor to the Multon family of Egremont (Lincs.). In that year Thomas de Multon was given to does and a buck for stocking his wood at Kelvedon. 57 In 1232 he received licence to inclose and impark the wood. 58 He died in 1240 and his son and heir Lambert in 1246.59 Lambert was succeeded by his son Thomas who supported Simon de Montfort in the Barons' Wars. ${ }^{60}$ In 1265 the manor of Kelvedon Hatch, then worth fro os. $6 d$., was taken into the king's hands with the rest of Thomas's lands. ${ }^{6}$ I Soon afterwards, however, he recovered the property. ${ }^{62}$ In I 277 he subinfeudated Kelvedon Hatch to Henry, son of 'Thomas de Multon (possibly his own younger son),

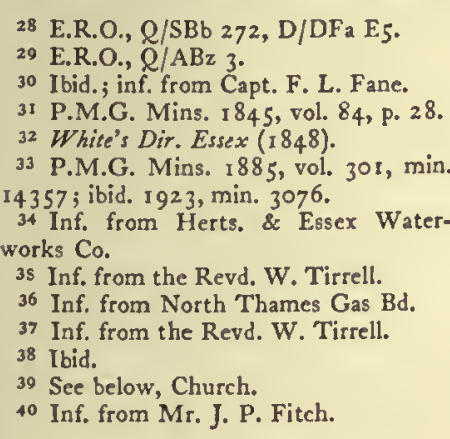

Es. IV

41 Inf. from County Librarian.

42 Inf. from Chief Constable of Essex.

${ }_{43}$ Kelly's Dir. Essex (1908)

4 E.R.O., D/CT 197.

45 Ibid.

46 E.R.O., D/P 140/6/2.

47 Kelly's Dir. Essex (1906).

48 Kelly's Dir. Essex (1 845).

49 V.C.H. Essex, i, 503a.

so Ibid. $i, 457 b$.

sI Ibid. i, $445 a$.

52 Ibid.

80.

3 Stenton, Anglo-Saxon England, 579-

54 V.C.H. Essex, i, $445 a$. ss Ibid. A charter of 1066 (Kemble, Cod. Dipl. iv, 173) purporting to be a grant of this among other properties to Westminster Abbey by Edward the Confessor, is spurious: E.A.T. N.s. xvii, 16 . ${ }_{56}$ B.M. Cott. MS. Faust. A. iii, f. 60 ; Westm. Abbey Mun. 29469; C142/36 $71 ; \mathrm{C}_{142 / 55 / 6 \mathrm{r}}$

$s 7$ Rot. Litt. Claus. (Rec. Com.), ii, 896 . s8 Cal. Chart. R. i, I I I.

39 Complete Peerage, ix, 40I-2.

60 Ibid.

${ }^{61}$ Ibid.; Cal. Inq. Misc. i, p. 201.

62 Complete Peerage, ix, 402. 


\section{A HISTORY OF ESSEX}

to hold by a rent of $f 20$ a year. After Thomas's death Henry was to hold the manor of his heirs by a nominal rent. ${ }^{63}$ Thomas died in 1294 . His heir was his grandson Thomas, Lord Multon (d. 1322) who was succeeded by his son John, Lord Multon (d. 1334).64 At his death John was mesne lord of an estate in Kelvedon Hatch which consisted of a messuage and a carucate of land, and which was held of him by the service of knight's fee.65 John's heirs were his three sisters: Joan widow of Robert Fitz Walter, Elizabeth wife of Walter de Birmingham, and Margaret wife of Thomas, later 2 nd Lord Lucy (d. 1365). ${ }^{66}$ It was agreed that Joan, Margaret, and Elizabeth should each hold $\frac{1}{3}$ of the $\frac{1}{4}$ fee. ${ }^{67}$ No further reference has been found to the mesne lordship of the heirs of John de Multon. In the I 6th century the tenants in demesne were said to hold the manor directly of Westminster Abbey. 68

Henry de Multon, tenant in demesne from 1277 , was still living in 1314 but was dead by January 1322.69 His heir was his daughter Juliane wife of Richard de Welby.70 In 1333 Richard and Juliane made a settlement by which the manor was to pass, after their deaths, to their male issue with successive remainders to their daughters, Elizabeth de Welby and Joan wife of John de Haugh. ${ }^{75}$ Juliane still held the estate in 1338.72 Afterwards the manor passed to the heirs of her daughter Joan de Haugh. John de Haugh, son of Joan, was living in 1347.73 Thomas de Haugh, son of John, came into possession of the manor during the life-time of his father. ${ }^{74}$ In February 1370 Thomas conveyed it to his father and other trustees to hold, apparently during the minority of his own heir John.75 By $I_{3} 8$ the last named John de Haugh had reached his majority. ${ }^{76} \mathrm{He}$ was lord of the manor until after I 395.77 Before 1406 he was succeeded by Thomas de Haugh, probably his son. ${ }^{78}$ Richard de Haugh was lord of the manor before the end of 1417.79 In November 1427 he conveyed the manor to trustees who were to hold it first apparently for John de Haugh, probably his son, and then (presumably if John had no issue) for Richard's daughters, Joan, Katherine, then or later wife of John Bolles, and Agnes, then or later wife of William Haltoft.80 John de Haugh was described as lord of the manor in November I 450 and afterwards until May I456.81 He presented to the church in April I $457 .{ }^{82} \mathrm{He}$ was evidently dead by $1459 .{ }^{83}$ In 1461 John Hardbene, the sole surviving trustee appointed by Richard de Haugh in 1427 , conveyed the manor to Katherine Bolles, Agnes Haltoft, and Joan Haugh. ${ }^{84}$ In 1466 these sisters agreed that Katherine and her husband John Bolles should have sole rights in the manor, with remainder in default of her issue to Agnes and her issue. ${ }^{85}$ John Bolles was alive in November 1482 but dead by November $1495 .{ }^{86}$ Katherine survived him and was succeeded by her son Richard, who died in $152 \mathrm{I}$ leaving as his heir his son John. ${ }^{87}$ In 1526 John mortgaged the manor for $\oint_{200.88} \mathrm{He}$ redeemed the mortgage and died holding the manor in $1533 .^{89}$ His heir was his brother Richard, who in I 538 sold the manor to John Wright of South Weald, yeoman, for $£ 493.90$

The descendants of John Wright held Kelvedon Hatch for nearly four centuries. There were ten successive John Wrights. 91 The last of these died in 1826 and was succeeded by his grandson John Francis Wright, who died without issue in 1868 . The manor then passed to J. F. Wright's nephew, Edward Carrington Wright, who died in 1920 , leaving it to his own nephew Sir Henry J. Lawson. 92 From 1891 Kelvedon Hall had been occupied by John Algernon Jones as tenant and in 1922 it was bought by his widow from Sir Henry Lawson. After her death it was sold in 1932 by her son J. W. B. Jones to the Mother Superior of St. Michael's Roman Catholic School. Mr. Jones bought and moved to the old rectory (see Church):93 Owing to a succession of misfortunes the school did not prosper and the house acquired the reputation of being haunted. 94 Much of the timber in the grounds was felled at this time.95 In 1937 the property was bought by Mr. Henry and Lady Honor Channon who restored the house and built the entrance gateway and lodges. ${ }^{96}$ From 194I to 1945 it was used as a Red Cross convalescent home.97 It is now again the residence of Mr. Channon.

In $1838 \mathrm{~J}$. F. Wright owned 880 acres in Kelvedon Hatch; the estate appears to have remained substantially intact until after the death of Sir Henry Lawson. 98

The manor house was entirely rebuilt by the seventh John Wright (d. 175 I).99 Later in the 18 th century the garden front and parts of the interior were altered but otherwise the building has remained almost unchanged. The house as it stands today remains a very good example of one of the less grandiose country seats of the Georgian period. The restoration of 1937-8 was carried out to the designs of Lord Gerald Wellesley (later Duke of Wellington) and Trenwith Wills' and in sympathy with the original.

The entrance front has a three-story central block with seven windows to each of the upper floors. On either side curved screen walls connect this with identical two-story pavilions. These are set forward, giving a three-sided forecourt. The pavilions have hipped roofs, surmounted by clock turrets and cupolas. On their front face two round-headed panels are pain ted to simulate sash windows. Above oval panels are similarly painted. The basement windows have wrought-iron grilles and the principal doorway has a Roman Doric order with engaged columns and a pediment. The rainwater heads on this front are dated I 743. The garden front of the main block is of similar
63 Feet of $F$. Essex, ii, 14.
64 Complete Peerage, ix, 403-4.
65 Cal. Ing. p.m. vii, p. 431.
66 Complete Peerage, ix, 405.
67 Cal. Inq. p.m. vii, pp. 435-7; ibid.
viii, pp. 15 1-2; Cal. Close, $1337-9,366-7$, $476,486,494$.

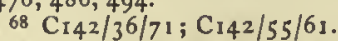
69 E.R.O., D/DFa T33/14; Cal. Fine
R. $1319-27,89$.
$70 \mathrm{Cal}$. Fine $R$. I $319-27,89$
71 Feet of $F$. Essex, iii, 28.
72 Cal. Close, $1337-9,366-7,476,486$, 494.
${ }_{73}$ Feet of F. Essex, iii, 28 ; Lincs. Pedi-

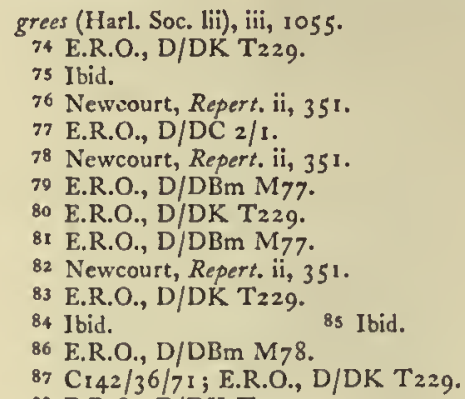

grees (Harl. Soc. lii), iii, I055.

74 E.R.O., D/DK Tzza.

75 Ibid.

76 Newcourt, Repert. ii, $35 \mathrm{r}$.

77 E.R.O., D/DC $2 / 1$.

78 Newcourt, Repert. ii, 351.

79 E.R.O., D/DBm M77.

so E.R.O., D/DK T229.

81 E.R.O., D/DBm M77.

82 Newcourt, Repert. ii, 351.

83 E.R.O., D/DK T 229.

84 Ibid.

$87 \mathrm{C}_{142 / 36 / 71}$; E.R.O., D/DK T229.
88 E.R.O., D/DK T 229.
$89 \mathrm{Cr}_{24 / 55 / 6 \mathrm{I}}$
90 E.R.O., D/DK T229.
91 For the pedigree see Burke, Land. Gent. (1894), 2275-6.
${ }_{92}$ Country Life, Lxxxix, no. 23 II (May 194 I), p. 388.
93 Inf. from Mr. Jones.
94 Country Life (May I 941), p. 386
95 Inf. from Mr. Jones.
96 Country Life (May 194I), p. 386.
97 Inf. from Mr. Jones.
98 E.R.O., D/CT 197; Kelly's Dir. Essex (1 922 ).
99 Hist. Essex by Gent. iv, 56.
I Country Life (May I941), p. 38 9. 
proportions but the central bay projects slightly and is surmounted by a pediment. The porch, which is supported on columns with fluted capitals, has an enriched entablature of about 1780 . The single-story flanking wings were probably added or modified at the same period; the north wing contained the kitchens and the south wing a private Roman Catholic chapel dedicated to St. Joseph. ${ }^{2}$

Internally the best examples of the original mid18 th-century rococo decoration occur in the entrance and staircase halls and in one of the bedrooms. The staircase has a balustrade of wrought-iron scrollwork and the walls have elaborate plasterwork panels in which are trophies representing War, Music, and the Chase. The drawing-room, dining-room, and music room were all redecorated in the 'Adam' style of about I780. The drawing-room has an enriched ceiling and the dining-room a circular medallion above the chimney-piece. Both rooms have good fire-places. The former chapel is of about the same period: on the curved end wall is an arched recess for the altar, flanked by Ionic columns and having a dove in plaster relief above it. The side walls are divided into panels by Ionic pilasters and the segmental ceiling has plaster enrichments. The chapel was restored by Sir John Oakley during the occupation of the Hall by St. Michael's School. ${ }^{3}$ The red-brick stable block and the orangery probably date from the late 18 th century.

The manor of GERMAINS derived its name from a family which probably held it in the 14 th and $15^{\text {th }}$ centuries. It is possibly to be identified with the estate which in $128 \mathrm{I}$ was held of Denise de Munchensy by Thomas son of Lambert de Multon, lord of the manor of Kelvedon Hatch.4 If this identification is correct it suggests there was a connexion, in 1086 or later, between Germains and the manor of Theydon Garnon (q.v.).

In the I $5^{\text {th }}$ century Germains was held of the manor of Kelvedon Hatch.s It is not clear when the Germain family became the tenants. A Roger Germain was a witness to a deed of 1355 relating to land in Kelvedon Hatch and other parishes. ${ }^{6}$ In 1368 a William Germain was witness at a proof of age taken at Navestock. He then had a son and heir Gilbert. ${ }^{7}$ In 1398 another William Germain of Kelvedon Hatch had royal letters of protection when going on service to France; the letters were revoked because he failed to go. ${ }^{8}$ In $1421-2$ he was one of the commissioners appointed to collect a tenth and fifteenth in Essex.9 It was possibly this William Germain who before $145^{8}$ made a bequest to Navestock church (q.v.).

In 1444 Henry Chaderton died holding the manor of Germains and was succeeded by his son Henry. ${ }^{10}$ The manor subsequently passed to Sir Humphrey Starkey, lord of Slades in Navestock (q.v.). He died in 1486 and Germains then descended along with Slades until I604. In I604 Sir Thomas Joscelin sold Germains to John Wright, lord of Kelvedon Hatch, and it subsequently descended with that manor. II In 1838 Germain's Farm consisted of 242 acres and the tenant was John Thomas. 12 It now belongs to the Iveagh trustees. ${ }^{13}$

The farm-house is timber-framed and plastered and probably dates from the early I6th century. It consists of a central block with gabled cross-wings to east and west. The wings are of two stories and each has three bays. On both floors the stop-chamfered tie-beams dividing the bays are visible and in several cases the small curved braces below them are also in position. A four-centred door-head has been exposed in an upper room in the west wing. The timbering is not visible in the central block so that it is not possible to establish whether this part of the house has an earlier origin than the I6th century. There are indications that two large Tudor fire-places have been bricked up. The doorways and sash windows of the house were probably inserted in the 18 th century.

The manor of MYLES'S alias GREAT MYLES'S derived its name from Miles de Munteny (see below). In the I6th century it was said to be held of the Dean and Chapter of St. Paul's, and later of the Waldegraves, as of their manor of Navestock. ${ }^{14}$ No earlier statement of this tenure has been found and the I 6thcentury statements cannot be regarded as certain evidence of earlier tenure, but it is possible that Myles's was identical with an estate in Navestock and Kelvedon Hatch held in the i 2 th and early i 3 th century by the Marcy family. Before I I 20 the Marcys agreed to pay rent for their Navestock estate (q.v.) to the Dean and Chapter of St. Paul's, and they still held that estate of St. Paul's in 1222 . The estate which Ralph de Marcy held in Kelvedon Hatch (see above) in 1086 probably came to be considered part of the Navestock estate in the I 2th century, and later of Myles's.

In the I $3^{\text {th }}$ century the manor was held by Nicholas le Convers. Is He conveyed it to Roger le Convers who no doubt added to it 85 acres which he acquired in 126I from Henry Belret. ${ }^{16}$ The manor later passed to Roger son of Roger le Convers who in i 318 released his rights in it to Miles de Munteny and his wife Agnes. ${ }^{17}$ Miles was still alive in 1336.18 In 1355 the estate was granted by John Munteny to Richard de Salyng of London. ${ }^{19}$ The Muntenys seem, however, to have retained some interest, for in 1378 Thomas de Munteny released all his rights in the estate to Richard de Salyng. ${ }^{20}$ Richard was still alive in I $398 .{ }^{21}$

In 1412 Myles's was held by Edmund Prior of Bois Hall in Navestock (q.v.) and it descended with that manor until I 566 .

In I 566 Myles's was bought by Thomas Luther who was still alive in $1585 .{ }^{22}$ Richard Luther was son and heir of 'Thomas. ${ }^{23}$ From about 1587 to 1627 , however, the manor was apparently shared between Richard and his brother Anthony Luther. 24 According to an epitaph quoted by Morant, Richard and Anthony were 'so truely loveing brothers that they lived neare fortie years joynt housekeepers together at Miles without anie accompt between them'.2s Anthony died in 1627 leaving his share of the estate to Richard.26 Richard died in 1638 leaving as his heir his son

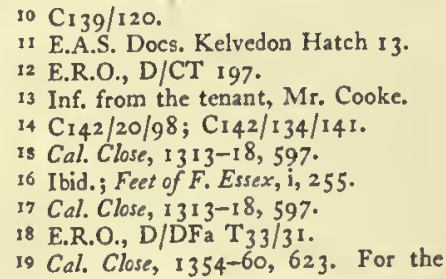

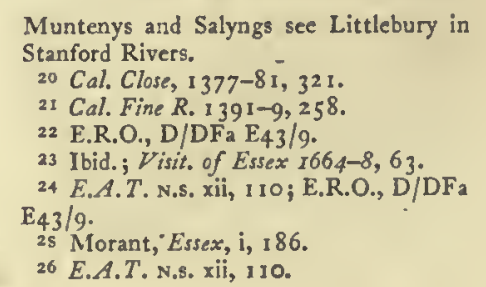




\section{A HISTORY OF ESSEX}

Anthony, a barrister of the Middle Temple and J.P. for Essex. ${ }^{27}$ Anthony was succeeded on his death in 1665 by his son Richard. ${ }^{28}$ Richard died before I 69I, leaving Myles's to his son and heir Edward Luther, who was Sheriff of Essex in I 70r.29 In I 729 Edward settled the manor on his son Richard when the latter married Charlotte Chamberlain. The estate then consisted of $25^{\circ}$ acres in Kelvedon Hatch, Stondon Massey, and High Ongar. ${ }^{30}$ Through his mother Richard also inherited the considerable property of the Dawtreys of Doddinghurst Place. He died in 1767.35 His son and heir was John Luther, knight of the shire for Essex $1763-84$, who died without issue in 1786 . Myles's then passed to Francis Fane, younger son of Charlotte, sister of John Luther and wife of Henry Fane of Wormsley (Oxon.). ${ }^{32}$ Francis died in 1813 , leaving as his heir his elder brother John. ${ }^{33}$ Myles's subsequently descended in the Fane family. ${ }^{34}$ In 1838 the estate comprised $4 \mathrm{r} 7$ acres in Kelvedon Hatch of which some 200 acres belonged to Little Myles's Farm in Stondon Massey, 32 acres to Great Myles's, 93 acres to Clap Gates, and 31 acres to Priors Farm. ${ }^{35}$ In 1849 the Stondon Massey part of the Fane estate comprised I 28 acres, of which 52 acres belonged to Little Myles's and 76 acres to Clap Gates Farm. ${ }^{36}$ The mansion house of Myles's had by this time been demolished (see below). Its site was sold in 1943 by John Luther Fane to the present owner, Mr. Parrish. ${ }^{37}$

A diagrammatic sketch of an early house at Great Myles's appears on an estate map of about 1700.38 It shows a long red brick front of two stories with dormers in the roof and projecting wings at either end. Shell hoods are drawn above the doorways and the windows have lattice panes. It was probably built during the second half of the 17 th century.

Before he gave up the estate to his son in 1762 Richard Luther is said to have 'much enlarged and beautified the house'. ${ }^{39}$ 'The result was the imposing Georgian mansion which occupied the site until its demolition in the 19th century. A sale notice of about I 830 shows two many-windowed fronts facing southwest and south-east.40 The tradition that there was a window for each day of the year ${ }^{4}$ is probably an exaggeration, but there were at least I 6 rooms on the bedroom floor with garrets above for the domestic staff.42 In I770-I a tributary of the Roding was dammed to form a long expanse of water in front of the house. The cost was $£ 600$ and the graceful brick bridge which still spans the lake was built for an additional $\{250.43$ These improvements were designed for John Luther by Richard Woods, who later replanned the gardens at Brizes (see above, p. 64). After John Luther's death in 1786 the house was let furnished to Francis Ford and later to a Dr. Chandler. ${ }^{44}$ Attempts to sell it early in the I 9 th century were apparently un- successful and in 1837 it was demolished at the wish of John Fane's widow.45 A small red-brick range, probably part of a service wing, remains standing and has been converted into a residence. The fine stable block, advertised about 18,30 as capable of accommodating 22 horses, 46 is also in existence.

The advowson of Kelvedon Hatch descended with the manor until the roth century. John CHURCH Wright presented to the rectory in 1607.47 His successors as lords of the manor were Roman Catholics. As such they were disqualified by law from presenting, and their rights of patronage vested in the Chancellor of Cambridge University.48 It is not clear how far the law was observed in this case. There was at least one presentation ( 1760 ) by the Chancellor of Cambridge. Other presentations in the 17 th and 18 th centuries were made by various persons who had perhaps bought the right pro hac vice.49 By I 848 the advowson was held by W. H. Ashpitel.50 Owing to the long incumbency of the then rector, John Bannister $(1833-70)$ he did not live to exercise it. It passed to his son and was sold in 1864 to E. Slocock.sI From him it descended to his son the Revd. Samuel Slocock who presented himself in 1870 and remained rector until I $880 .{ }^{.22}$ The advowson was then sold to E. W. Puxon of Croydon (Surr.). ${ }^{53}$ After his death in 1896 it remained in the hands of his trustees for some years. $54 \mathrm{He}$ had presented his son-in-law, D. W. Peregrine. in 1889, s5 and the advowson had by 1912 come to Mrs. C. M. Peregrine. ${ }^{56}$ She gave it in I 928 to the Revd. William Tirrell who has been rector and patron ever since. ${ }^{57}$

The rectory of Kelvedon Hatch was valued at 6 marks in about 1254 . It was then stated that the rector of the church of (Magdalen) Laver received part of the tithe from the demesne of Gilbert de Breauté and Ralph de Asevile. 58 The value of the rectory was stated to be 10 marks in 1291 and $\oint_{1} 12$ in 1535.59 In I 838 the tithes were commuted for $£ 438$; there were then 28 acres of glebe. ${ }^{60}$

A terrier of 16 Io mentions a rectory house of two stories, part newly built, "with several rooms in it both above and below",6I The north end of the old rectory (now Kelvedon Grange), consisting of a gabled crosswing and part of the central block, may well be the 'newly built house' referred to in the terrier. There is a massive stop-chamfered beam in the present kitchen and the principal chimney has grouped diagonal shafts. Early in the 18 th century the south end of the central block was rebuilt and the roof level raised. The groundfloor hall retains sash windows of this date with wide glazing bars. Further alterations were probably made about 1800 . During the incumbency of the Revd. D. W. Peregrine at the end of the r th $^{\text {th }}$ century the house was enlarged and altered at a cost of about
$27 \mathrm{C}_{242 / 724 / 15}$

28 E.R.O., D/DFa E43/9; ibid. Q/RTh

5.

29 E.R.O., D/DFa E43/9; Newcourt, Repert. ii, 545 .

30 E.R.O., D/DFa E42/2, D/DFa F6.

31 Reeve, Stondon Massey, 125; Gents.

Mag. xxxviii, 47.

32 E.R.O., Q/RPI 685-717; D/DFa

$E_{45 / 22-23 ;}$ Burke, Land. Gent. (1871),

$i, 417$. Henry was a younger brother of

Thomas, Earl of Westmorland.

33 E.R.O., D/DFa E45/22, 23, 26; Q/RPI 7 I $7-18$.

34 Burke, Land. Gent. (1 855 ), 366.

35 E.R.O., D/CT 197.
36 E.R.O., D/CT 337 .

37 Inf. from Capt. F. L. Fane.

18 F.R.O., D/DFa PI.

19 Morant, Hist. Essex, i, 187.

40 E.R.O., D/DFa E 33 .

4 E.A.T. N.s. xii, III-I 2.

42 E.R.O., D/DFa E43/I.

43 E.R.O., D/DFa E $43 / 32$

44 Ibid. E43/I, 5 .

41 Inf. from Capt. F. L. Fane of Priors

46 E.R.O., D/DFa E33.

47 Newcourt, Repert. ii, $35 \mathrm{I}-2$

48 Popish Recusants Act $3 \& 4$ Jas. I, c.5 (1606).

40 Newcourt, Repert. ii, 352 ; Morant, Essex, $\mathrm{i}, 187$.
30 White's Dir. Essex (1848), 420.

11 Clergy List (1 865), 119.

52 Kelly's Dir. Essex (1 870); Crockford's

Cler. Dir. I $870-8$

33 Kelly's Dir. Essex ( 1890 ).

14 Ibid. I 899, I 906.

is Ibid. 1890 ; inf. from Mr. J. W. B.

Jones.

56 Kelly's Dir. Essex (I912).

37 Inf. from the Revd. Wm. Tirrell.

58 E.A.T. N.s. xviii, 18.

19 Tax. Eccl. (Rec. Com.), 2 Ib; Val.

Eccl. (Rec. Com.), i, $437^{b}$.

60 E.R.O., D/CT 197.

6I Newcourt, Repert. ii, 35 I. 


\section{A HISTORY OF ESSEX}

In $1854 \mathrm{~J}$. F. Wright of Kelvedon Hall wrote to Dr. Tavarez, the Roman Catholic ROMAN

CATHOLICISM priest at Brentwood, in reply to tion concerning the history of Roman Catholic worship in the Kelvedon Hatch area. 'At Kelvedon Hall, where my family have resided for upwards of 300 years I have little doubt (though I have no positive proof of the fact) that a priest was maintained during the greater part of that time, though possibly only at intervals during times of persecution. The inscription on the ciborium belonging to Kelvedon Hall chapel (Ora pro Eugenia Wright I 7 IO) is pretty good proof of there having been a priest and chapel then. 88 The family tradition here stated was probably well founded. In I 605, when William Byrd of Stondon Massey (q.v.) was presented to the archdeacon as a Popish recusant, it was also urged against him that he had led astray John Wright of Kelvedon, the son of the then lord of the manor and later to become lord himself, and his sister Anne, into the same heresy. ${ }^{89}$ This may be evidence that the Wrights were not Roman Catholics between the time when they acquired the manor and the end of the 16 th century. It has not been definitely established that they were Roman Catholics throughout the I 7 th century; Bishop Compton's census ( 1676 ) lists no Roman Catholics in Kelvedon Hatch.90 But for the 18 th century there is confirmation of J. F. Wright's statements. John Wright of Kelvedon Hall was registered at quarter sessions in I 7 I 7 as a papist, and so also was his son John Wright the younger.91 Eugenia, widow of John Wright of Kelvedon Hall, was similarly registered in $173 \mathrm{I}$ and another John Wright in 1761.92 In the 17 th and 18 th centuries the Wrights, although they held the advowson of Kelvedon Hatch, do not appear to have presented to the rectory themselves except in 1607.93 Priests from the Jesuit College of the Holy Apostles also appear to have visited Kelvedon Hall regularly in the middle of the I8th century. 94 Continuing his letter to Dr. Tavarez, J. F. Wright stated that his family left Kelvedon $\mathrm{Hall}$ in $\mathrm{I} 788$ for a few years. 'In consequence a small chapel was fitted up in a room in a farm-house on Kelvedon Common and the Revd. Richard Antrobus, then the priest at Wealdside (in South Weald), used to attend there at Indulgences, for the accommodation of the Catholics about here.' 95 J. F. Wright went on to describe the return of his family to Kelvedon Hall in I 799 and gave the names of three Roman Catholic priests who lived there as chaplains between 1799 and I 8 I 3 , when his grandfather again left the hall. 96 There was no resident priest there after I 8 I3. The few Roman Catholics in Kelvedon Hatch were served by the priest at Ingatestone $\mathrm{Hall}$ and later by the priest in charge of the church at Brentwood, opened in 1837 . In J. F. Wright's own time the private chapel at Kelvedon $\mathrm{Hall}$ was again in use for Catholic worship. In I 857 he was again corresponding with Dr. Tavarez, this time about the proposal to install a confessional in the chapel. He told Tavarez that he considered that the chapel was too small for the secrecy of the confessional to be maintained-' 'and where the confessor is at all hard of hearing the danger is still greater'. And he was further unwilling to obey an order by Archbishop Errington to destroy some old altar stones in the chapel.97 'I beg to say that they will never be used and that they take up very little room. As for saying "cui bono" do they remain, that, I submit concerns me alone and I do not hesitate to say that ... they have acquired an interest from the fact of their having been here for several generations. ... It is I think no improbable supposition that over some of them mass has been celebrated in times of persecution by priests who subsequently became martyrs.' Wright concluded his letter with a dignified reproach: 'Into these feelings, however, I cannot expect you to enter, as you cannot feel as we English Catholics do on these subjects, who know with how much trouble and difficulty our religion was kept alive in England in former days.' 98

Roman Catholic worship no doubt continued to be held at Kelvedon Hall during J. F. Wright's life-time and while his nephew and successor, E. C. Wright, lived at the hall. The chapel at the hall, which was dedicated to St. Joseph, became disused during the occupation of Mr. and Mrs. J. A. Jones, but was again taken into use and was restored during the years when the hall was occupicd by St. Michael's School. 99

In 1829 nonconformist worship was being conducted in a licensed house at KelveROTESTANT don Common by the Revd. NONCONFORMITY D. Smith an Independent minister from Brentwood.

It is possible that there was some continuity between this congregation and that which later in the $19^{\text {th }}$ century met in the building now used as the village hall. Services were conducted there by a visiting minister until about I $890 .{ }^{2}$ The building is timber-framed and weather-boarded and was probably built early in the I 9 th century. ${ }^{3}$

Vestry minute-books for Kelvedon Hatch survive for the periods $1736-60$ and

PARISH GOVERN- I835-8I

$M E N T A N D$

POOR RELIEF

During the period $1736-60$ vestry meetings usually seem to have been held only at

Easter in each year. In only one year ${ }^{5}$ during this period was more than one meeting recorded. The minutes were brief but were always signed. The Revd. C. Wragg, rector of the parish from I 73I until $175^{8}$, seems never to have attended the meetings. His successor, the Revd. N. Griffinhoeff (1758-60) attended the only Easter vestry held during his incumbency and was the first to sign the minutes. The number of parishioners who attended the meetings varied between 3 and 6. Members of the Wright family, lords of the manor of Kelvedon Hatch, ${ }^{6}$ always attended and usually signed first.

The minutes rarely did more than record the ap-
88 R.C. Parish of Brentwood, MSS. Book. Inf. supplied by Revd. B. C. Foley. 89 E.R.O., D/AEA 23, quoted in A. C Edwards, English History from Essex Sources, $1550-1750$, I 3 .

90 See Table on p. 3 I I.

91 E.R.O., Q/RRp I/ I 2, 21.

92 Ibid. $3 / 4,4 / 6$.

93 Newcourt, Repert. ii, 352. And see above, Church.

94 E.R. xxvii, $73-76$
95 R.C. Parish of Brentwood, MSS. Book.

96 As to the first chaplain, John Clarkson, J. F. Wright's statement is confirmed by the Register of Papists' Mecting Places: E.R.O., Q/RRw 3 .

97 George Errington (1804-86), Archbishop of Trebizond in partibus (1855), was co-adjutor to Cardinal Wiscman, I $855-62: D . N . B$.

98 R.C. Parish of Brentwood, MSS.
Book.

99. Kelly's Dir, Essex (1914 f. and 1933). And see Manors.

E.R.O., Q/CR 3/2/14

2 Inf. from Mr. J. P. Fitch.

3 See also above, p. 60

- Unless otherwise stated all the follow ing information is derived from these minute-books, which are kept by the rector.

6 See above, Manor of Kelvedon Hatch. 
pointment of officers and the balances remaining in officers' hands at the end of each year. In the period I736-60 there was only one office of churchwarden and one office of overseer. George Wright was churchwarden throughout the period. Until 1744 the overseers served for two years consecutively, but after that date they served for one year only. As late as 1835 there was an illiterate overseer. In $1614^{7}$ there were two constables, but in the period $1736-60$ there was only one office of constable. These officers usually served for several years consecutively. The appointment of surveyors was not recorded in the minute-book, but there appears to have been one office of surveyor. The rateable value of the parish was $£ 700$ in $1738^{8}$ and $f_{1}, 676$ in 1835 .

Until 175 I the overseers, churchwarden, and constables were each granted separate rates for which they were directly responsible to the parish. Occasionally one officer was ordered to pay another officer's deficit out of his surplus. In April I75 I it was decided that the constable's charges for the ensuing year should be paid by the churchwarden. In March 1752 the same constable was reappointed, but on this occasion it was resolved that his charges should be paid by the overseer. No further resolutions were recorded on this matter and it is not clear how the charges of either the constable or the churchwarden were met in the years after 5753. By 1833, however, their expenditure was evidently met by the overseers who included it in their account. It is not clear what the practice was in regard to the surveyors' accounts.

There was a poorhouse ${ }^{9}$ in Kelvedon Hatch, situated on Kelvedon Common, and in 1835 there were at least two male paupers in it. In most cases, however, poor relief was given outside the poorhouse. In each of the years I $813^{-15}$ there were thirteen adults on 'permanent' outdoor relief. ${ }^{10}$ Provision for the poor included the payment of weekly doles.

In 1776 the cost of poor relief was 690.11 In 1783-5 it averaged $\oint_{0} 104$ a year. ${ }^{12}$ It reached $\delta_{5} 50$ in $1800-1$ and 6538 in $\mathrm{I} 80 \mathrm{I}-2$, but in the next six years it was always between $f, 300$ and $f, 400$ a year. ${ }^{13}$ In the years $1808-17$ the cost was usually above $\$ 400$ and reached a maximum of 6567 in $1812-13.14$ In each of the years I 833 and 1834 it was $\$ 275$ and in I 835 \&250.

In 1836 Kelvedon Hatch became part of the Ongar Poor Law Union.

In 1807 there was no day school in Kelvedon Hatch, though there were two just outside the SCHOOLS parish boundaries. The rector was teaching reading every Sunday to about 30 'regular and orderly' children. Is 'This Sunday school seems to have-led to the establishment of a day school which in 1816 was attended by I 3 boys and 29 girls. ${ }^{16}$ For the next 20 years a parish school under Church direction existed in one form or another. ${ }^{17}$ In 1818 there were 40 children in two schools, one supported by a benevolent lady and the other by the rector's wife. ${ }^{18}$ One of these schools was later discontinued and the attempt to provide week-day schooling for boys was abandoned, although they continued to attend the Sunday school. In 1833 there was only one school in the parish, attended by about 30 girls and maintained by voluntary subscriptions. It was a dame school under the rector's control. Its mistress was in failing health and the rector was planning to build a permanent school with separate rooms for boys and girls. He collected some 675 in subscriptions and obtained the promise of a site from the lord of the manor. The National Society agreed to make a grant but the undertaking was eventually abandoned and a schoolroom was rented in which the rector set up a successful Church school.19 In I 839 , when it was still the only school in the parish, 20 boys and 30 girls attended it, paying no fees except for additional tuition in writing. The boys were given smocks, stockings, hats, and handkerchiefs and the girls complete sets of clothing. Subscriptions, including one particularly large one, amounted to $£ 37$ a year, but they were difficult to obtain. The rector also complained that many children left school for service at too early an age. ${ }^{20}$

By I 846-7 the school had as many as 53 boys and 33 girls in attendance, some of whom paid fees. There were a master and a mistress, earning $£ 43$ a year between them.21 A few years later an inspector found it 'a very nice small village country school under an able and promising young master', but he thought the classrooms inconvenient and the equipment inadequate. The monitorial system seems then to have been in use. The school was situated on a green which was used as the playground. ${ }^{22}$ In $18,6-7$ the school received a capitation grant of $f_{\mathrm{I}} 2 \mathrm{~s} 8 \mathrm{~s}$. Most of its income, however, continued to be derived from subscriptions. ${ }^{23}$

In 1860 a new school was established, but it appears to have had smaller accommodation than the one it replaced. The number of children attending had -dropped by 187 I to about 20 and a master was no longer employed.24 The school was still apparently without permanent premises ${ }^{25}$ and in 1875 a school board of five members was compulsorily established. In 1878 the board built a school in the village and the Church school was then closed.26 Kelvedon Hatch was one of the few rural parishes in the hundred where a school board had to be formed. In this case it is significant that the lord of the manor was a Roman Catholic; he clearly gave no support to the Anglican school.

The board school, built at a cost of $\mathrm{E}_{\mathrm{I}}, \mathrm{I} 5 \mathrm{O}$, had accommodation for 80 children. ${ }^{27}$ It was enlarged in I 898.28 The annual government grant rose from $£ 59$ in 1893 to $\delta 82$ in $1899^{29}$ Further income was derived from the school rate, which in $189 \mathrm{I}-2$ was Is. $4 d$. in the $f_{1} .^{30}$ In 1902 the school passed under

\footnotetext{
7 E.R.O., Q/SBa 3.

8 E.R.O., D/DFa E44/27.

9 There was a poorhouse by 1776 , at latest: Rep. Sel. Citce. on Overseers Retns. 1777, H.C. ser. s, vol. ix, p. 350 . The parish officers may have tented the cottages which had been given to the parish for use as almshouses: see below, Charities.

so E.R.O., Q/CR I/10.

sI E.R.O., Q/CR I/I.

82 Ibid.

13 E.R.O., Q/CR I/9.

54 Ibid.

is E.R.O., D/AEM 2/4.
}

16 Nat. Soc. Rep. 18 1 6, p. 52.

17 E.R.O., D/P 30/28/18.

18 Retns. Educ. Poor, H.C. 224 , p. 259

(I 8 I g), ix (I).

19 Educ. Enquiry Abstr. H.C. 62, p. 280

(I 835$), x l i$; inf. from Nat. Soc.

20 E.R.O., D/P 30/28/1 8.

21 Nat. Soc. Enquiry into Ch. Schs. I 846-7, pp. 10-1 I.

${ }_{22}$ Educ. Citee. Rep. $1853-4$, p. 295.

23 Mins. of Educ. Cttee. of Council, 1857

[2380], p. 97, H.C. $(1857-8), x l y ;$

Kelly's Dir. Essex (1855, 1862, I870).

24 Kelly's Dir. Essex (1862, I874);
Retns. Elem. Educ. H.C. $20 \mathrm{I}$, Pp. $\mathrm{I}^{12-\mathrm{I} 3}$ (1 $87 \mathrm{r}), \mathrm{lv}$.

25 No school is shown on O.S.6 in. Map (Ist edn.), sheet lix.

26 Courty Companion, 1880; Min. of Educ. File 13/214; Kelly's Dir. Essex (r 882 )

27 Kelly's Dir. Essex (1882); Min. of Educ. File $\mathrm{I}_{3} / 2 \mathrm{r} 4$

$28 \mathrm{Min}$. of Educ. File $13 / 214$

29 Retr. of Schs. 1893 [C. 7529 ], 0. 714 H.C. (1894), lxv, ibid. I 899 [Cd. 315], p. 7 I, H.C. $(1900), \operatorname{lxv}(2)$.

30 Essex Standard, 12 Sept. I 891 . 


\section{A HISTORY OF ESSEX}

the administration of the Essex Education Committee, Ongar District. There was then an average attendance of $68 .{ }^{31}$ In 1904 there were three teachers, one of them certificated. ${ }^{32}$ The average attendance remained about 70 until I930, when the school was reorganized for mixed juniors and infants, after which it fell to 59 in I938.33 In May 1952, however, there were I I I children and 4 teachers at the school.34 The building stands a short distance from the parish church on the Stondon Massey road. It has one story and is of yellow brick.

A r gth-century transcript of a deed records that John Wright and his son John gave to CHARITIES 35 Anthony Luther and others, parishioners, part of the lord's waste next to Kelvedon Common, with the cottages thereon, to be the site of parish almshouses. This appears to be the real origin of the charity which by 1786 was called Jane Luther's Charity in the erroneous belief that it had been established by her will in 1745 (see below). The original endowment may have been supplemented by an exchange made in 1786 by which the parish received a small plot inclosed from Kelvedon Common in place of another plot on which a cottage formerly stood. This was probably the cottage on the road to Beacon Hill which according to a vestry book extant in the I gth century was given to the parish in $1644 .{ }^{36}$ This exchange of 1786 may explain the statement made in 1835 that the property of the charity was received about 60 years before from John Wright of Kelvedon $\mathrm{Hall}$ in exchange for some small pieces of land formerly belonging to it.

There is no clear record that the cottages were ever used as almshouses, though it seems possible that they were rented by the parish officers for use as a poorhouse. 37 In 1834 the property was all let: it consisted of four cottages on Kelvedon Common, and land ad joining. The whole income was $f_{2} 1$ ros., and after deduction of expenses it was distributed on the first Monday in the year to all poor married parishioners in equal shares. Between then and 1929 there was little change in administration. In $195 \mathrm{I}$ the field was sold to the village hall committee for use as a recreation ground. The proceeds were invested in stock. In the same year the rent due from the cottages was $£ 34$ I 2s.; but for many years there has been no profit from rents and a demolition order was pending in $1953 .{ }^{38}$

Poor's Cottages were probably built in the $17^{\text {th }}$ century and consist of a timber-framed T-shaped block, partly plastered and partly weather-boarded. There are gabled dormers in the tiled roof. These are undoubtedly the four cottages of 1834 and earlier.

At some time in the 18 th century it was believed that 40s. was due to the parish by the gift of Anthony Luther (d. 1627 ) but there is no record that this was ever paid.

By her will proved in 1745 Jane Luther of Suttons (in Stapleford Tawney, q.v.) gave fo $2^{175}$ s. 6d. a year issuing from a farm in Little Warley to be distributed in bread three times a year to the poor of the parish. In 1834 bread was distributed twice a year with preference to widows. By 1857 the rent was being paid from the Suttons estate. It was redeemed in $195^{\circ}$ for EI I 5 stock.

In 1786 it was stated that an unknown donor gave a rent charge of $\mathcal{E}_{\mathrm{I}}$ IOS. to the church and the poor of the parish. In I 834 Charles Dolby of Brizes held a lease from 1789 at $f_{2}$ Ios. a year of "the property of this charity', consisting of an acre of land in his park. In fact the endowment must have been the land itself, not the rent, and the land was certainly sold in 1860 for $£ 200$ which was invested in stock.

Louisa Dolby, by will proved I 868 , left $\oint_{1}$ oo dutyfree in trust for the benefit of the poor. The legacy was paid in 1876 , together with $£ 28$ arrears of interest, and was invested in stock.

In the I 9 th and early 20 th centuries these charities were in practice administered together. From 1855 the three earliest shared trustees. By a Scheme made in 1929 all four were combined to form the United Charities. Their income is to be spent for the benefit of the sick and poor, chiefly in gifts in kind and gifts to hospitals serving the parish. In I95 I, after payments for expenses, the income was spent on the cottages belonging to Jane Luther's Charity, and in gifts in cash to six persons.

Richard Thomas Lagden, by will proved 1866 , left 6.7 a year for the purchase of coal for the poor families of the parish. Lagden's wish that the money be paid was not, however, binding, and the bequest consequently became invalid.

\section{LAMBOURNE}

Lambourne adjoins the Urban District of Chigwell to the north-east.I With an area of $2,47 \mathrm{I}$ acres it is one of the larger parishes in the hundred. From an early date much of the population has been centred in the village of Abridge, in the extreme north-west of the parish. ${ }^{2}$ The remoteness of the village from the church and the manor houses has helped to determine the history of the parish. Abridge was in Lambourne, but not of it. The population of the parish in 1801 was 515 . It rose steadily to 904 in $184 \mathrm{I}$ and subsequently remained at about that figure until $192 \mathrm{I}$, when it was 780 . In I $93 \mathrm{I}$ it was 893 . The population in $195 \mathrm{I}$ was $\mathrm{I}, 37 \mathrm{I}$, the increase being due mainly to the building of council houses. ${ }^{3}$

31 Schs, under Bd. of Educ. 1902 [Cd. I490], p. 7 r, H.C. (I 903), li.

32 Essex Educ. Cttee. Mandbk. 1904, p. 185 .

33 Min. of Educ. File $13 / 214$

34 Inf. from Essex Educ. Cttee.

3s Rep. Com. Char. (Essex), H.C. 216 ,

The land rises from roo ft. above sea-level in the north to $325 \mathrm{ft}$. in the centre, falling to about $200 \mathrm{ft}$. in the south. The River Roding forms the northern boundary of the parish. There are numerous ponds and springs in the parish. Lambourne End, in the south, contains most of what remains of Hainault Forest, now preserved as a recreation ground by the London County Council.4 There are several other smaller patches of woodland. The main road from Chipping Ongar to Chigwell and London passes through the north of the parish. Abridge lies along this road at a distance of about 3 miles from Chigwell. It derives its name from the bridge which crosses the river here, carrying the road running north to Theydon Bois. A concentration

. 229 (1835), $x x$ (1); Char. Com. Files.

36 This date would be consistent with the participation of an Anthony Luther (see above, Myles's).

37 See above, Parish Government and Poor Relief.

${ }^{38}$ Inf. from the Revd. W. Tirrell.
O.S. $2 \frac{1}{2}$ in. Map, sheet $5 \mathrm{r} / 49$.

2 Although the earliest known ref. to Abridge is in 1203 the name is of preconquest origin: P.N. Essex (E.P.N.S.), 60.

3 Census; inf. from Essex County Council. 4 See below. 
of houses on both sides of the main road at Abridge is shown on a map of 1695.5 'The oldest surviving buildings appear to be the house on the east side of the main road, immediately north of the post-office, and Brighty's shop on the opposite side just west of the bridge. Both probably date from the early i 6 th century and in each case there is an oversailing gable-end facing the road at one end of the front. At Brighty's shop the plaster was stripped from the gable about 30 years ago, ${ }^{6}$ revealing rounded joist ends, heavy closely-spaced studs, and curved braces. The other house, formerly the postoffice, but now a butcher's shop, remains plastered but is probably of similar construction. 'The Sycamores, on the sou th side of the road near the east end of the village, was a house possibly of similar date, but rebuilding has destroyed all its old features except the brick fireplaces forming the base of its central chimney. Other buildings in the village probably incorporate parts of timber structures of the 17 th century or earlier.

The deeds of White Hall go back to I $729 .{ }^{7}$ It has a plastered two-story Georgian front, considerably altered, with a contemporary doorcase. The gabled house east of it may also date from the early i 8 th century, and the buildings flanking Brighty's shop are probably of similar date. 'The 'Maltster's Arms' and the two cottages adjoining it form an attractive 18 thcentury group. They have weather-boarded fronts and the inn has a pedimented doorcase with engaged Tuscan columns. The slightly later house to the east retains a small bowed shop window. The post-office, which has a symmetrical weather-boarded front, is of the late I 8 th century.

In 1848 it was stated that many good houses had been built in Abridge in the past 30 years. ${ }^{8}$ Maryon Terrace is a red brick row of eight small cottages with round-headed doorways. It is dated 28 January $\mathrm{I} 84 \mathrm{I}$, but the central cottages may be older. Gould's Cottages are of gault brick and date from about 1840 . They form a terrace of five houses, of which the central has a pedimented gable. The Parish Room, formerly a Congregational chapel, was built in $1833 .^{\circ}$ Holy Trinity Church, built in 1836 , is a chapel of ease to the parish church. Io 'The 'Blue Boar' is also of mid-rgthcentury date; it has a gault brick symmetrical front. The 'White Hart' was rebuilt on its ancient site in the late I gth century. The school, at the north end of Hoe Lane, dates from 1878.11 On the north side of the main road west of Abridge there is considerable 2oth-century building, which includes thirteen council houses. North of the school are about twenty council houses. There are also four pairs on the north side of the road just east of the village. The Evangelical Free Church, Maryon's Chase, dates from I 924.12 Hillman's Cottages, six pairs on the main road $\frac{1}{4}$ mile east of the village, were built about 1935 for employees at the neighbouring airfield. ${ }^{13}$ The Pancroft estate, east Abridge, includes a group of prefabricated houses and fifty post- 1945 council houses.

Hoe Lane runs from Abridge south-east to Lambourne End, passing to the east of St. John's Farm (see below, manor of St. John's) and to the west of Bishops Hall (see below). In this lane are some larger houses with good gardens, built after the break-up in 1929 of the Bishops Hall estate. On the road $\frac{1}{2}$ mile south of
Bishops Hall are Augusta Cottages and Emmanuel Chapel. At Lambourne End Hoe Lane is joined by Manor Road, which leads to Chigwell Row, and also by the road running east to Knolls Hill in Stapleford Abbots. Near Blue House Farm the latter road is joined by Hook Lane, which runs north-east to Stapleford Abbots church. Three farm-houses at Lambourne End are timber-framed and probably date from the I 7 th century. Harmes Farm has a gabled cross-wing at the south-west end. Forest Lodge Farm has two massive external chimneys with diagonal shafts. Blue House Farm also has diagonal shafts to its central chimney. Church House, opposite Forest Lodge, dates from about $167 \mathrm{I}$, with an extension of about 1810 (see below, Charities). Lambourne Square, consisting of two rows of cottages, one of mid-1gth-century date and one earlier, was built for workers at the neighbouring Banks Farm. ${ }^{14}$ Young's Farm was demolished about 1935 and some of the buildings converted into recreation rooms for the Fairbairn and Mansfield House Boys' Clubs. is In the grounds are a camping site and an openair swimming-pool. The East End Mission playingfields on the opposite side of the road have a cementrendered pavilion with a flat roof, also dating from the I930's. 'There is some scattered modern development on the north side of Manor Road, opposite Hainault Forest. Park Square is a three-sided court consisting of ten council houses. There are also four pairs of council houses on the north side of the road east of Forest Lodge. The Parish Room at Lambourne End is a small wooden building probably of mid-I 9 th-century date.

New Farm is mile south-east of Abridge. It is a red-brick house dated 1744. Although considerably altered it has brickwork detail similar to the Old Rectory (see below) on a much smaller scale. Lambourne Halli6 and the parish church are mile south-east of New Farm. The site of the former Dews Hall (see below) adjoins Bishops Hall to the east. Bishops Moat, the original site of Bishops Hall, is 1 mile east of Dews Hall. A mile east of Abridge is Lambourne Place, for- merly the rectory. ${ }^{17}$ Pryors and Patch Park (formerly Hunts) are near Lambourne Place to the east. ${ }^{8}$ Arnolds, formerly Arneways (see below) is on the main road in the extreme north-west corner of the parish. Opposite it is a civil airfield.

The road system in this parish has never been very satisfactory. There has never been a direct road from Abridge to the parish church. Until about I 800 ther. was no road from Lambourne End to Chigwell Row. In the north and centre of the parish the roads were often flooded in wet weather. 19 'The most serious flooding occurred on the main London road, between Arnolds and Abridge. About $\frac{1}{2}$ mile west of Arnolds the Roding flows beside the road and is joined by a stream which rises near Lambourne Hall. It was at this junction between the river and the stream that flooding was worst. In I 575-6 the road from Arnolds to London was 'in decay', and the parish was distrained for the condition of 'Arnesway' Bridge. ${ }^{20}$ This was no doubt a bridge over the stream at the junction. The same road was the subject of discussion in the parish vestry in $1727 . .^{21}$ 'The lord of the manor of Lambourne had apparently been obliged to keep a horse- and foot-

\footnotetext{
5 Camden's Britannia (ed. Gibson), p.

340 (Map by Rbt. Morden).

6 Inf. from Mr. Bayles, owner.

7 Ibid. 8 White's Dir. Essex (1848).

- See below, Nonconformity.

to See below, Church.
}

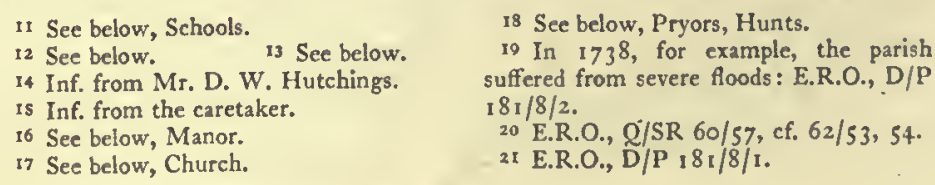




\section{A HISTORY OF ESSEX}

bridge 'wharfed and planked over a certain brook' towards Ongar. This was probably the same bridge as that of 1575-6. John Barfoot, lord of the manor in 1727 , offered to seek the support of the neighbouring gentry for a scheme to build a brick bridge.

At the other end of the London road was the important Abridge Bridge. In the late 16 th century there was uncertainty as to who was responsible for it. One entry in the rolls of Quarter Sessions for 1570 attributes responsibility to Sir Anthony Coke, who owned land at the Lambourne side of the bridge, and Sir Thomas Wroth, who owned land on the Theydon Bois side. ${ }^{22}$ Another entry of the same year leaves the matter undecided. ${ }^{23}$ In and after 1594 the bridge seems to have been accepted for repair by the county. ${ }^{24}$ In 1657 it was said to be in a dangerous state. ${ }^{25}$ In 1707 a carpenter was paid the large sum of $\oint_{0} 78$ for rebuilding it. ${ }^{26}$

In 1855 the inhabitants of Abridge complained to the justices of the peace of the dangerous state of the road to Theydon Bois and of the foot-bridge at Abridge. During floods it was impossible to use the bridges and a circuit of 6 miles was necessary. A committee was formed in 1856 to investigate the matter and the county surveyor produced plans for an embankment with culverts. He reported that a plank and rail foot-bridge to serve pedestrians in time of flood had for 30 years been repaired by the county. ${ }^{27}$ Thomas Savill, of Barley near Royston, was willing to undertake the work on the bridges and the final estimate was $£ .380$, of which the parish was to pay $f_{2} 200$ and the county the remainder. ${ }^{28}$ In the following year the surveyor described the bridge as a substantial brick structure in excellent repair. 29

Abridge is a mile from the parish church, and until 1833 there was no other place of worship in the parish. It is therefore remarkable that there has never been a direct road to the church from Abridge. The inhabitants of Abridge had an ancient right of way by a footpath to the church. In 1589 Henry Palmer of Dews Hall was presented at Quarter Sessions for having "enclosed abowte with a great pale a chace waye which is our church waye and hath been time out of mind'. 30 In 1624 this path was 'by discontinuance overgrown, and overworn by the current of the brook which ran by it'.31 In that year Edward Palmer of Dews Hall granted the parish vestry a new right of way in exchange for the old. The course of the new way, which is described in the vestry book, appears to be the same as the present footpath from east Abridge to the church, via New Farm and the north-east corner of Soapleys Wood.32 The parish was to erect three gates, one at the entrance to 'Pencroft' (near the main road at the Abridge end of the path), ${ }^{33}$ one at the upper end of 'Goody Land' entering into Maple's land, and the third over the brook entering lower 'Soap place'. At the third point they' were also to provide a bridge. They were to provide locks for the gates and give Edward Palmer a key, and they were responsible for the upkeep of the gates and the bridge. In 1727 the vestry accepted the offer of
Catlyn Thorogood of Dews Hall to provide a brick arch over the brook in place of the old wooden one. The parish was to main tain the foot-path as before. ${ }^{34}$ In spite of these arrangements the moral condition of Abridge seems to have been bad at the beginning of the I gth century. ${ }^{3 \mathrm{~s}}$ The foot-path was hardly a satisfactory substitute for a church in Abridge itself. Perhaps more important was the fact that the rectory was just as far from the village as was the church. In 1734 the vestry had resolved to make a new road from the church to the rectory through the glebe land. ${ }^{36}$ This would have helped the rector to get to church. For access to Abridge he probably had to use foot-paths.

Communications between Lambourne End and the parjsh church have been little better than those between the church and Abridge. Church Lane, which ran from the church past Dews Hall to Lambourne End, is marked on Chapman and Andrés map of 1777 (sheet xvi), but by 1841 it had become impassable. In the latter year the vestry decided that it should be repaired, ${ }^{37}$ but the north end of the road is now overgrown and disused.

Manor Road, between Lambourne End and Chigwell Row, was constructed about 1790 , mainly at the expense of Admiral Sir Edward Hughes, of Bishops Hall (see below) and Luxborough in Chigwell (q.v.). ${ }^{38}$

Hook Lane, which joins Lambourne End and Stapleford Abbots, was maintained by the two parishes jointly. In 1832 the Lambourne vestry agreed to an alteration in its course "when a sufficient subscription can be caused to carry the same in to effect, the parish of Stapleford having agreed to repair the same distance in proportion as prior to the exchange'. 39

There was a regular service of coaches from Abridge to London and Ongar at the beginning of the I gth century. In 1817 a coach went daily to the 'Three Nuns' and the 'Bull', Whitechapel, while a wagon went on Tuesday and Friday to the 'Blue Boar', Whitechapel.40 In $1826-7$ and 1832 the Ongar coach called at Abridge. ${ }^{41}$ In 1832 also a wagon run by Joseph Wilson ran to the 'Saracen's Head', Aldgate, and the 'Flower Pot', Bishopsgate, on Tuesday, Thursday, and Saturday; a wagon run by one Clements went on Wednesday and Saturday to the 'Blue Boar', Aldgate, and another, under the name of Willey, went on Tuesday, Thursday, and Saturday to the 'Three Nuns', Aldgate.42 In 1848 a coach left for London every morning except Sunday and for Dunmow every evening, starting from the 'White Hart'. William Hanchett was carrier to London every Tuesday and Friday.43 In 1862 the Fyfield coach called daily at Abridge and a carrier went to London daily. 44 By this time the railway from London had been extended as far as Loughton, about 4 miles by road from Abridge, and the further extension in 1865 to Epping and Ongar included a station at Theydon Bois, $\mathrm{I} \frac{1}{2}$ mile from Abridge. Since 1949 Theydon Bois has been on the Central London (underground) line.

There was a postal receiving house at Abridge in

\footnotetext{
22 E.R.O., Q/SR $32 / 17$.

23 Ibid. $34 / 6$

24 Ibid. $129 / 17,314 / 59$. Cf. $Q / A B z$ $1,2$.

25 Ibid. Q/CP 3, pp. 185,188 : cf. pp.

$197(1659), 213$ (1660).

26 Ibid. P. 704.

27 E.R.O., Q/ABp 36, Q/ABb is.

28 This foot-bridge had previously been the responsibility of the parish of Theydon Bois, q.v. 29 E.R.O., Q/ABz 3 .
}

${ }_{38} \mathrm{~T}$. Wright, Hist, Essex, ii, 408. The rozd was presumably built after Hughes acquired Bishops Hall in 1785 . He died in $1798 . \quad 39$ E.R.O., D/P $181 / 8 / 4$.

40 Fohnstone's Dir. (18I7), pt. iv, 2.

41 Pigot's Dir. $(1826-7), 51$; Robson's London Dir. pt. iv, 22. See Chipping Ongar, p. 157.

42 Robson's Dir. pt. iv, 22.

43 White's Dir. Essex (1848), 422.

44 Ibid. (1863), 729 . 
1793.45 In 1839 a Mr. Mead was appointed receiver. ${ }^{46}$ By I 856 a sub-post-office had been established.47 A telegraph service was set up in $1891^{48}$ and the telephone by $192 \mathrm{I} .49$

The Herts. and Essex Waterworks Co. extended its mains to Abridge and some other parts of the parish in 1917, and a further extension took place in 1937.50 There is a sewerage system, chiefly at Abridge.5i Gas was first supplied by the Chigwell, Loughton, and Woodford Gas Co.s2 Electricity was supplied to parts of Abridge and Lambourne in 1929. ${ }^{53}$ At Abridge there is a parish room (formerly the Congregational chapel), and a village hall called the Gymnasium. There is another parish room at Lambourne End. A branch of the county library was opened in 1929.54 The Abridge Coffee Rooms and Club existed in 1886 and later. ${ }^{55}$ There was a cricket club at Abridge in 1895.36 There was a police sergeant at Abridge in 1898.57 There is now a policeman at Abridge and another at Lambourne End. 58

A writer of about 1770 noted that "husbandry alone seems to be the employ of the inhabitants' of Lambourne. 59 This was not entirely true; as is shown below there were some inns and shops at Abridge, which must have employed a few people in the I 8 th century. But agriculture was certainly the main occupation. During the Middle Ages the ownership of the land in the parish was shared among some eight chief lords. From the middle of the 16th century onwards the estates tended to coalesce. In the 18 th century three large estates, attached to Lambourne Hall, Bishops Hall, and Dews Hall, accounted for much of the parish. By 1850 the greater part of the parish was owned by a single family, that of Lockwood, of Bishops Hall. Their estate was broken up in 1929.60 Until the 16 th century it is probable that few of the chief landowners were resident in the parish: this may partly explain the unsatisfactory relationship between Abridge and the rest of the parish. ${ }^{61}$ In and after the 16 th century there was some improvement. The Taverners of Arneways and the Palmers of Dews Hall lived in the parish. In the 18 th century this area became remarkably fashionable for the gentry. Lord Fortescue, the Walkers, the Lockwoods, the Thorogoods, and Sir Edward Hughes all lived in Lambourne or in neighbouring parishes. ${ }^{62}$ All contributed in various ways to the improvement of the parish, and their paternal interest in it was maintained in the $19^{\text {th }}$ and 20 th centuries by the Lockwoods. They must have been large employers of domestic as well as agricultural labour.

The landowners do not seem to have attempted direct large-scale farming. In 1841 there were three farms over 200 acres in extent, of which the largest was 235 acres. There were five farms of $100-200$ acres and six of $40-100$ acres. $^{63}$ All these farms were let to tenant farmers. In 1929 most of Lord Lambourne's estate was occupied by tenants, although the home farm of Lambourne $\mathrm{Hall}$ was in hand.64

In this parish, as elsewhere in this area, mixed farming is carried on. In $184 \mathrm{I}$ there were some 750 acres of arable, 1,300 acres of meadow and pasture, and $35^{\circ}$ acres of woodland and forest. ${ }^{65}$ At that date there was also a small amount of ozier-growing. ${ }^{66}$ Of greater interest is the persistence of hop-growing. In 1841 there was $I \frac{1}{2}$ acre of land under hops. As is noted below, brewing was carried on in Abridge at this time.67

There is little evidence concerning inclosure in the parish, which so far as it concerned common field and meadow had evidently been completed before the I 8 th century. A small exception is shown on a map of $174^{\circ}$ : strips in Rye meadow, north of Arneways in the northeast corner of the parish. ${ }^{68}$ Inclosure of woodland was much slower, for royal rights were involved. About 200 acres in the south of the parish formed part of Hainault Forest. In 1305 William de Sutton, lord of Battles Hall in Stapleford Abbots, who also held land in Lambourne, was granted licence to fell and sell the great trees and underwood of 7 acres in his wood of Lambourne, which was within the Forest of Essex, as it appeared that there was not a frequent resort of the deer there. ${ }^{69}$ 'This grant was made to enable him to pay his debts at the Exchequer. In 1630 six unauthorized inclosures of the forest were said to have recently been made in Lambourne; one of these was on the waste, the others on old inclosures. 70

In 185 I Hainault Forest was disafforested. 'The part of the forest in Lambourne was, however, not affected. ${ }^{73}$ In 1858 the Hainault Forest Allotment of Commons Act (21 \& 22 Vict. c. 37 ) provided that 314 acres in Lambourne, Chigwell, and Dagenham should be allotted as common to the parish of Lambourne. The map attached to the act shows a small existing inclosure at Lambourne End. It is possible that this was the area inclosed in $1832-3$ by the parish vestry with the consent of E. L. Percival, the lord of the manor. ${ }^{72} \mathrm{By}$ an award of 1861 , under the act of 1858,186 acres in Lambourne became common for the parish; more specifically it was waste of the manor of Lambourne. ${ }^{73}$ In $190_{3}$, by the Hainault (Lambourne Burrows and Grange Hill) Act 74 the then lord of the manor, A. R. M. Lockwood, was authorized to sell Lambourne Common for $\oint_{2}, 830$ to the London County Council, so that it might become a public park.75 This is now all that remains of Hainault Forest.

Abridge fair, on 2 June, was abolished in 1878.76 It had existed in 1780.77 In 1848 it was stated to be for cattle. ${ }^{78}$ Its origin has not been traced. No lord or owner of tolls was known in 1878 .

The existence of the fair suggests that Abridge was an important village in the 18 th century. A list of 1723 names three inns, the 'Crown', the 'Blue Boar', and the
45 Cary's Eng. Atlas, r 793.

46 P.M.G. Mins. 1839 , vol. 46 , p. 462.

47 Brit. Post. Guide, 1856 . Cf. P.M.G.

Mins. 1865 , vol. 43 , min. 4070 .

48 P.M.G. Mins. $189 \mathrm{r}$, vol. 448 , min. $1486 \mathrm{r}$.

49 Brit. Post. Guide, 1921 .

so Kelly's Dir. Essex (1917, 1937).

si Inf. from the rector.

52 Inf. from the North Thames Gas Bd.

33 Inf. from Eastn. Elec. Bd.

54 Inf, from County Librarian.

ss Kelly's Dir. Essex (1 886 f.).

s6 Kelly's Dir. Essex (r895).

57 Ibid. 1898
38 Inf from Chief Constable of Essex.

59 Hist. Essex by Gent. iv, 20.

60 For details see below, Manors.

6I Sec above; and below, Parish Government.

62 Fortescue lived at Stapleford Abbots, Hughes in Chigwell.

63 For these figures see E.R.O., D/CT

64 See below, Manor.

65 E.R.O., D/CT 202.

67 Ibid. For a reference to a hop-garden in 1727 see E.R.O., D/P $181 / 8 / 1$.

68 Map in poss, of Mr. H. E. Clarke of Arnolds.

69 Cal. Pat. $1301-7,315-16$.
70 W. R. Fisher, Forest of Essex, 327.

71 Ibid. 349.

72 See below, Parish Govt. and Poor Relief.

73 Details of the award are given in the act of 1903 (see below).

743 Edw. VII, c.257 (priv. act.).

75 The purchase included the 186 acres in Lambourne and 54 acres in Chigwell and Dagenham, which were included in the price.

${ }_{76}$ Lond. Gax. 26 July 1878, p. 4318

77 Essex, Herts. \& Cambs. Almanack

1780 .

78 White's Dir. Essex (1848). 


\section{A HISTORY OF ESSEX}

'White Hart'.79 In 1772 two chandlers, a victualler, and a baker are named. 80 In 1845 there were, in addition to the tradesmen normally found in a growing village, an auctioneer and surveyor, a surgeon, a plumber and glazier, a brick-maker, and a brewer. ${ }^{81}$ The brickmaker was still there in 1851.82 There had been a brewery in Abridge in 1729 , when its owner is said to have been the owner of White Hall. ${ }^{83}$ Abraham Oliver, brewer of Lambourne, occurs in 1808.84 During the Jater Igth century the brewery became the Abridge Brewery Co.8s This was later acquired by Whitbread $\&$ Co. and by 1914 was being used by them as a store. ${ }^{86}$ The private airfield was opened about $1935 .{ }^{87}$ During the Second World War it was taken over by the R.A.F.88 It has recently been reopened as a private airfield. Part of its site is occupied by branches of 'Thorn Electrical Industries, Ekco Electric Ltd, and Ferguson Radio Ltd. There is a small printing works at Abridge.

Thomas Winniffe, Bishop of Lincoln, and his nephew Peter Mews, Bishop of Winchester, are mentioned below (see Church). Thomas Day (1748-89), eccentric author of Sandford and Merion, bought a house at Abridge in 1779, shortly after his marriage, and lived there for two years. 'He studied architecture and astonished the builder by having a wall made first and the windows knocked out afterwards. ${ }^{189}$

Only one entry in Domesday Book relates specifically to $L A M B O U R N E$. The manor of that MANORS name had been held in 1066 by Lefsi as 2 hides and 80 acres. 90 In 1086 this manor formed part of the honor of Eustace, Count of Boulogne, and was held of him by David.91 It is likely, however, that the part of the parish of Lambourne later known as the manor of Arneways (see below) originally formed part of the manor of Battles Hall in Stapleford Abbots. The tenancy in chief of the manor of Lambourne passed with the honor of Boulogne to the Crown after the death in 1159 of William, Count of Boulogne. Lambourne was still considered to be part of the honor early in the $13^{\text {th }}$ century, 92 but not, apparently, after that.

In the I 2 th century the tenancy of the manor came to Pharamus of Boulogne, the grandson of Geoffrey, which last was probably a bastard son of Eustace of Boulogne.93 It descended to Pharamus's daughter Sybil, wife of Ingram de Fiennes, and subsequently to her son William de Fiennes.94 In about 1220 the manor was held of the honor of Boulogne by Sybil. 95 In 1282 it was conveyed to Robert Burnell, Bishop of Bath and Wells and Chancellor of England (d. I 292), by William de Fiennes, probably grandson of the lastnamed William. 96 In $r 300$ the manor was among the lands left at his death by William de Lambourne. It was then said to be held of the heirs of Philip Burnell for 2 knights' fees. 97 Philip, who had died in 1294 , was the nephew and heir of the bishop. 98 There is no further mention of the Burnells in connexion with Lambourne. In 1485 the manor was said to be held as of the hundred of Ongar, and in the 16th century it was held of the hundred by service of the ward-staff. 99

The manor had been subinfeudated to the Lambourne family long before I 300 . That family held land in the parish in 1203 , when Robert of Lambourne is mentioned, 1 and this Robert, or a namesake, was the owner of the advowson before $1218 .^{2}$ A John de Lambourne occurs in 1240.3 In 1261 it was stated that Christopher of Lambourne, lately hanged for felony, had held $\frac{1}{4}$ knight's fee in Lambourne of William of Lambourne. This tenement had been in the king's hand since December 1259; the king had given his year, day, and waste to Elizabeth widow of Christopher who was said to have wholly spoiled the land.4 A William of Lambourne was among those who did fealty to Bishop Burnell for their lands in Lambourne in 1282.5 He was probably identical with the man of that name who held the manor at his death in $1300 .^{6}$

William de Lambourne was succeeded by his son James. The manor was then said to include 140 acres of arable, worth $f_{2} 135.4 d ., 7$ acres of meadow, worth I 4 s., 8 acres of pasture worth 8 s., and 2 acres of wood, wasted and valueless. There were 19 free tenants rendering $\delta_{2}$ IOs. IId. in rents of assize and 3 capons, valued at $2 d$. each, at Christmas. Nine customary tenants rendered 2 hens, valued at $2 d$. each, at Easter. Their services were valued at I $2 d$. The total value of the manor was 66 igs. $9 d .7$

James de La mbourne (knighted 1306 ) made a settlement of the manor in $1307 . .^{8}$ He was still alive in $1325.0^{\circ}$ Thomas de Lambourne held the manor in $1351.10 \mathrm{He}$ died in 1361 and his son and heir William died in the same year." William was succeeded by his sister Joan, wife of William de Chene. Before 1376 Lambourne had been conveyed to Sir John de Sutton, William de Chene retaining a life interest. ${ }^{12}$ Chene was evidently still alive in 1386 , when he held the manor of Polstead (Suff.). ${ }^{13}$ By I 4 I I the manor had passed to Thomas Lampet, whose widow Elizabeth was then holding it for life. ${ }^{14}$ In that year it was settled upon William Lampet, 'kinsman' of 'Thomas. ${ }^{15}$ In 1412 it was said to be held by Isabel Lampet. ${ }^{16}$ She was probably identical with the Elizabeth of $14 \mathrm{r}$. The manor subsequently passed to John Lampet, who was succeeded before 1 456-60 by his daughter Cecily wife of William Curzon.17 A William Curzon died holding Lambourne in 1485 . It was then stated that Robert Curzon had enfeoffed certain persons with the manor. ${ }^{18}$ This
79 E.R.O., D/P $181 / 8 / 1$.

80 E.R.O., Q/SBb 269 .

81 Kelly's Dir. Essex (1845).

82 Ibid. (1851).

${ }^{83}$ Inf. from Mr. Bayles, owner of White Hall.

84 E.R.O., D/DU 45/28-32.

85 Kelly's Dir. Essex $(1886,1890)$

86 Ibid. (1 902, 1914).

87 Inf. from Mr. H. E. Clarke.

88 Ibid.

89 D.N.B.

90 V.C.H. Essex, i, 467b. This does not suggest a large manor, which is surprising in view of the present size of the parish. Some parts of Lambourne may have been included in 1086 in entries for other places : and see below.

of V.C.H. Essex, i, $467 b$.
92 Red Bk. of Exch. (Rolls Ser.), 576; Bk. of Fees, 236.

93 For Pharamus see 1. H. Round's article, Genealogist, N.s. xii, 145-51. See also Magdalen Laver, Blake Hall in Bobbing worth. Pharamus died in $1183-4$. 94 Bk. of Fees, 236, 240, 1428; Red Bk. of Exch. 576 .

is $B k$. of Fees, 236, 240, 1428 ; Red $B k$. of Exch. 576 .

96 Feet of $F$. Essex, ii, 36. Another Ingram de Fiennes was probably father of the William of 1282: cf. W. Farrer, Feudal Cambs, 248-9.

97 Cal. Inq. p.m. iii, p. 440

98 D.N.B. Robt. Burnell.

99 Cal. Inq. p.m. Hen. VII, i, p. 86;

$\mathrm{C}_{142 / 84 / 55}$. For the wardstaff see the Hundred of Ongar, above.
1 Cur. Reg. R. ii, 206.

2 See below, Church.

3 Feet of F. Essex, i, 123.

- Cal. Ing. Misc. i, p. $18 \mathrm{I}$

5 Feet of $F$. Essex, ii, 36 .

6 This Wm. of Lambourne was an active local official under Edward 1 : see C. Moor, Knights of Edw. I, iii, 7 .

$7 \mathrm{C}_{1} 33 / 93 / 10$.

8 Feet of F. Essex, ii, 115.

- C. Moor, Knights of Edw. I, iii, 7 .

10 Cal.Inq. Misc. iii, p. 24.

1 Cal. Ing. p.m. xi, p. 81.

12 Feet of $F$. Essex, iii, 182.

13 W. A. Coppinger, Manors of Suffolk,

i, 180 . 14 Feet of $F$. Essex, iii, 256.

$x$ Ibid. $\quad 16$ Feud. Aids, vi, 439.

$17 \mathrm{C}_{1} / 26 / 472$.

${ }_{18}$ Cal. Ing. p.m. Hen. VII, i, pp. 85-86. 
implies that Robert was the predecessor of the lastnamed William. That the William Curzon who died in 1485 was a young man and not identical with the William Curzon of $1456-60$ is also suggested by the fact that he left an infant daughter, Mary, as his heir. ${ }^{19}$ Mary apparently married a member of the Tey family, of Ardleigh, probably Sir Thomas Tey (d. I 540). ${ }^{20}$ Sir Thomas made a conveyance of the manor in 1520.21 Lambourne was apparently not among his possessions at his death. By I 547 it had passed to Robert Barfoot, who died in that year.22

Robert's successor was his son Thomas. The manor descended in the Barfoot family until $\mathbf{1 7 3 3}$, when John Barfoot, probably great-great-grandson of Thomas, sold it to $\mathrm{Sir}$ John Fortescue-Aland. ${ }^{23} \mathrm{Sir}$ John was a distinguished lawyer and for many years a judge. In 1746 he became Baron Fortescue of Credan. ${ }^{24} \mathrm{He}$ died in the same year and was succeeded by his son Dormer, and Baron Fortescue.25 The latter died childless in I 780 . He left his Essex property to his cousin Mary, widow of Richard Barford, D.D., of Titchmarsh (Northants.). ${ }^{26}$

In 782 Mary Barford sold Lambourne to the Revd. Edward Lockwood, Rector of St. Peter's, Northampton.27 He died in 1802 and the manor of Lambourne passed to his second son Edward Lockwood, who assumed the additional surname of Percival.28 Edward Lockwood Percival died in 1804 , leaving a son and heir with the same names. 29

Edward Lockwood Percival the younger died in 1842 and was succeeded by his cousin William J. Lockwood, owner of Dews Hall (see below). ${ }^{30}$ In I $84 \mathrm{I}$ Lambourne Hall farm consisted of 208 acres. ${ }^{31}$ It was occupied by Charles Blewett. The manor subsequently descended to Lt.-Gen. William M. Wood, son of W. J. Lockwood who had assumed the surname of Wood in $18{ }_{3} 8$ on inheriting the property of an uncle. ${ }^{32} \mathrm{Lt} .-\mathrm{Gen}$. Wood died in 1883 and was succeeded by his son Amelius R. M. Lockwood, who had reassumed the original family name in 1876.33 The latter was Conservative M.P. for Epping for many years and achieved distinction as chairman of the kitchen committee of the House of Commons. He became ist Baron Lambourne in 1917 and Lord-Lieutenant of Essex in 1919. He died in 1928.34

The Lockwood estate in Lambourne was latterly known as that of Bishops $\mathrm{Hall}$, from the family seat. In addition to the manors of Lambourne and Bishops Hall (see below) it included those of St. John's and Dews Hall (see below). The estate was put up for sale in 1929. It then consisted of 1,6 I 5 acres. Some 500 acres were in hand, including Lambourne Hall farm, whose extent was 37 I acres. 35
Lambourne $\mathrm{Hall}$ is said to have been built by Thomas Barfoot in $1571 .{ }^{36}$ This date and the initials T.B. are carved on oak panelling formerly in the house and now in the Lever Art Gallery, Port Sunlight. ${ }^{37}$ 'The central hall and the Oak Room adjoining it to the east are part of the original timber-framed building. Oak panelling now at the west end of the hall was originally incorporated in a partition across it and may represent the I 6th-century screens. The Oak Room has original finely moulded ceiling beams, a fire-place with a fourcentred arch, and three doorways with four-centred heads. The house was reroofed and much altered in the I 8 th century. In 1937 a new east wing was built, the dated weathercock above it being brought from elsewhere. ${ }^{38}$ Panelling in the dining-room and the overmantel in the Oak Room came from Marks Hall, near Coggeshall, which was demolished about $1950 .{ }^{39}$

The manor of $L A M B O U R N E-A N D-A B R I D G E$, later known as $S T$. $\mathcal{F} O H N S$, originated in an estate in the north and west of the parish acquired by the Knights Hospitallers from various donors in the I $3^{\text {th }}$ century and perhaps earlier. 40 The estate remained in the hands of the Hospitallers until the Dissolution. In I 553 it was granted, as the 'manors' of Lambourne and Abridge, to Richard Morgan and Thomas Carpenter.41 Soon after this it was acquired by Robert Taverner, who died holding it in 1556.42 Thomas Taverner his son and heir was an infant and became a royal ward: In I 557 the manor was valued at $\delta_{2} 3$ 15s., and Elizabeth Taverner, widow of Robert, was granted dower in jt.43

Thomas Taverner sold the manor in $1597-8$ to Sir Robert Wroth, Kt.44 Sir Robert died in 1606 and was succeeded by his eldest son, another Sir Robert. 45 In I 608 the manor was said to include 4 messuages, 2 gardens, 100 acres of land, 20 acres of meadow, 100 acres of pasture, 80 acres of wood, and 8 s. rent. 46 Sir Robert Wroth the younger died in 1614.47 James, infant son of Sir Robert, died two years later and was succeeded by John Wroth his uncle.48 John Wroth still held the manor in 1621.49 He apparently sold it before September 1630 , when Richard Peacock received the royal confirmation of all rights and privileges connected with the manor. ${ }^{50}$ Peacock died in I634, leaving the manor to his son Edward.si In I64I Edward Peacock conveyed it to John Charles. 52 This was probably a lease, for in 1645 Charles was occupying St. John's Wood, which was part of the manor.53 In 1647 Charles Peacock, John Charles, and others conveyed the manor to George Bagstar. 54 In I648 Bagstar sold St. John's farm, which formed the southern portion of the manor, to William Browne the younger of Abridge.5s The northern portion, together with the manorial rights, did not go to Browne but was sold by Bagstar in I 649 to
39 It is perhaps significant that William Curzon died on the day of the battle of Bosworth.

$20 \mathrm{~W}$. A. Coppinger, Manors of Suffolk, iii, 11; Morant, Essex, i, 432 ; Visits. of Essex (Harl. Soc.), 207.

$21 \mathrm{CP}_{25}(2) / 11 / 54$ East. $12 \mathrm{Hen}$. VIII.

$22 \mathrm{C}_{142 / 84 / 55}$. He was a momber of the Mercers' Co.

${ }_{23}$ E.R.O., D/DLo T56. For the Barfoot pedigree see Morant, Essex, i, 172, and E.R.O., T/G $30 / 5$.

24 Complete Peerage, v, 562.

23 Ibid. 563 .

26 E.R.O., D/DLo T2.

27 Ibid. T 56 ; T. Wright, Hist. Essex, ii, 397.

${ }_{28}$ Burke, Commoners (1833-8), iv, 82.
29 Ibid.; E.R.O., D/DLo T54.

30 E.R.O., D/DLo Ez.

31 E.R.O., D/CT 202.

32 E.R. xxxviii, 34 ; Burke, Land, Gent.

(1906), ii, 1035 .

${ }_{33} \mathrm{~J}$. Grant, Essex - Historical, Biographical and Pictorial, Lockwood.

34 E.R. xxxviii, 34-36.

35 E.R.O. Sale Cat. A. 1046.

${ }_{36} \mathrm{~T}$. Wright, Hist. Essex, ii, 396.

37 Inf. from Mrs. S. Padfield, present occupier, and from Mr. R. B. Pugh.

${ }^{38}$ Ibid.

39 Ibid.; For a photo. of Lambourne Hall, 1929, see E.R.O., Sale Cat. 1046.

For the demolition of Marks Hall see E.R. lix, 164 .

to Morant, Essex, i, 173; Feet of $F$.
Essex, i, 215 ; P.N. Essex (E.P.N.S.), 60. 11 Cal. Pat. $1550-3,309$.

$42 \mathrm{C} 142 / 109 / 54$.

43 Cal. Pat. $1555-7,466$.

$4 \mathrm{CP}_{25}(2) / 138 / 1750$. For the Wroths see also Loughton.

$45 \mathrm{C}_{142 / 294 / 87}$.

$46 \mathrm{CP}_{43} / 103$ rot. 34.

47 See Manor of Loughton, in that parish.

$4 \mathrm{CP}_{25}(2) / 296$ East. 19 Jas. I.

so E.R.O., D/DLo MI (copy from

Forest Roll). $\quad 51 \mathrm{C}_{142 / 590 / 15}$

${ }_{32} \mathrm{CP}_{25}(2) / 418$ Trin. 17 Chas. I.

53 Hist. MSS. Com. 6th Rep. App. 616.

s4 $\mathrm{CP}_{5}(2) / 419$ East. 23 Chas. I;

E.R.O., D/DLo Tr.

55 E.R.O., D/DLo T56. 


\section{A HISTORY OF ESSEX}

Edward Palmer, owner of Dews Hall (see below). ${ }^{56}$ It subsequently descended along with that manor.

St. John's Farm was mortgaged by William Browne in 1658 to John Eyver of Tilty. 57 Browne died in r 665 and was succeeded by William Browne, probably his son..$^{8}$ In 1678 the latter sold the farm to William Scott of Chigwell.s9 In I699 it was settled upon Scott's daughter Anne on her marriage to William Derham, Rector of Upminster. ${ }^{60}$ Derham (1657-r 735) became a Fellow of the Royal Society and published many books and articles on science and theology. In 1714 he became chaplain to the Prince of Wales and in 1716 a canon of Windsor. ${ }^{61}$ In 1733 he sold St. John's farm to Sir John Fortescue-Aland. The farm was thus merged in the main manor of Lambourne and subsequently descended along with it (see above) .62

In 1723 the court of the manor was being held at a house called Tobys 'near Clay Grove' ${ }^{63}$

In 184 I St. John's farm consisted of 88 acres in the occupation of James Clark.64 In 1929 the area of the farm was 160 acres. 65

The manor of $A R N E W A Y S$, whose name has been corrupted to the modern $A R N O L D S$, probably took its name from Adam Arneway, who is said to have held land in Lambourne 'about the reign of Henry VI' under the Earl of Oxford, who held the neighbouring manor of Battles in Stapleford Abbots (q.v.). ${ }^{66}$ This tenure suggests that Arneways was originally part of Battles.

In 1525 Arneways was among the possessions of Sir William Fitzwilliam of Milton (Northants.) and was settled in that year to the uses of his will.67 $\mathrm{He}$ also owned the manor of Hunts (see below), and his property descended on his death in 1534 to his son and heir Sir William. ${ }^{68}$ In a list of owners drawn up about I 543-6 Anthony Browne is given under Arneways. 69 By I 556, however, Arneways and Hunts had come to Robert Taverner, lord of the manors of Pryors (see below) and Lambourne-and-Abridge (see above) who died in that year. ${ }^{70}$ Arneways remained in the possession of 'Thomas, son of Robert Taverner, after Lambourne-and-Abridge had been sold, and descended on Thomas's death in 16 ro to his son Robert.71 In 1625 Robert Taverner sold Arneways and Pryors to Robert Draper, merchant tailor of London. ${ }^{72}$ Taverner evjdently remained tenant of the estate. Draper died in 1635 and was succeeded by his younger son William. ${ }^{73}$ At its fullest extent the Taverner estate probably comprised about 500 acres.

In I64I William Draper of Oxford sold Arneways to Robert Broomfield of Stratford.74 The estate descended to John Broomfield, son of John, son of Robert, who in I68I assigned the lease of Arneways 'heretofore in the occupation of Robert Taverner', to John Todd of Walthamstow.75 In 1687 this estate 'once in the occupation of Robert Taverner and afterwards of Lance Nash' was sold to John Todd. ${ }^{76}$ 'Todd is said to have

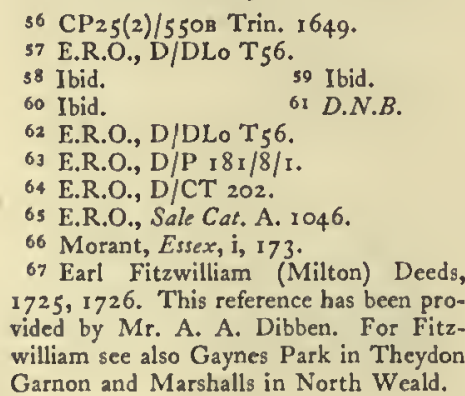

given half the estate to William Church, who married his daughter; their daughter and heir married Peter Searle who sold Arneways to Thomas Scott (d. 1733) of Woolston in Chigwell (q.v.). 77 The estate passed to Thomas's son George Scott who was holding it in 1746 . A map of the farm was drawn for George Scott in that year by Josiah Taylor. ${ }^{78}$. Arnolds then consisted of 215 acres in Lambourne, most of which lay opposite the farm-house to the south of the main road. There were also a few acres in Stapleford Abbots. George Scott still held the farm in 1771,79 but by $\mathrm{r} 782$ it was owned by Edward Sewell. ${ }^{80} \mathrm{He}$ was returned as the owner until I 788 when the farm belonged to Mrs. Sarah Sewell, probably his widow.81 After Mrs. Sewell's death about r80I Arneways came to Samuel Sewell who still held it in 1841.82 In the latter year the farm consisted of 203 acres in Lambourne. It was occupied by Mrs. Kitty Collyer and Philip B. Collyer. ${ }^{83}$ The Collyer family had been tenants since 1788.84

Arnolds Farm was advertised for sale in 1843 . It was then stated to contain 203 acres freehold in Lambourne and a further 10 acres copyhold of the manor of Stapleford Abbots. ${ }^{85}$ It was bought by Samuel Crane, whose family continued to farm it until about Igr 6 when it was sold to Mr. Jacob Saward. In I 925 the farm was bought by $\mathrm{Mr}$. A. Clarke, whose son, $\mathrm{Mr}$. H. E. Clarke, is the present owner. ${ }^{86}$

The manor house, now a farm, is a timber-framed and weather-boarded structure with three gables to the front. Its present plan, which is approximately square, is the result of additions and alterations at various dates. The centre part of the front was once a 15 th-century open hall, divided into two bays by a massive archbraced roof truss with a rebated king-post. Smokeblackened roof timbers indicate that there was an open hearth, probably in the eastern bay. Flanking the hall to east and west are two-story cross-wings, each with a front gable. These are probably of the same date or a little later. A ceiling has now been inserted in the hall and the central gable constructed to give light and headroom on the upper floor. The original truss has been incorporated in a bedroom partition. These alterations were probably made early in the I6th century. At about the same time a central chimney was inserted and a new two-story wing built out bchind the hall. This would give a somewhat unusual T-shaped plan, the chimney providing fire-place openings both in the hall and the new wing. The ground-floor room of the added wing has fine moulded ceiling beams and joists of typical early-r6th-century character and there is said to be a carved external bressummer, now covered over, at the north end. 87 The next addition was probably the north extension of the east cross-wing, which incorporates a I 7 th-century staircase. On the first floor of the west cross-wing there is panelling of the late $: 6$ th or early I $7^{\text {th }}$ century, and later still this wing was also extended northwards, giving the house its present square plan.

Arnolds in 1723 : E.R.O., D/P I $81 / 8 / 1$. ${ }_{78} \mathrm{Map}$ in possession of Mr. H. E. Clarke of Arnold's Farm and kindly lent to the editor. A photo. of this: E.R.O., $\mathrm{T} / \mathrm{M} 227$.

79 Hist. Essex by Gent. iv, 24.

80 E.R.O., Q/RP1 687.

81 Ibid. $688-93$.

82 Ibid. 694-737; D/CT 202

83 Ibid. D/CT 202.

84 Ibid. Q/RPl $693 \mathrm{f}$

8s E.R.O., Sale Cat. B. I 68

86 Inf. from Mr. H. E. Clarke.

87 Ibid. 
There are said to be two earlier windows to the hall, now blocked. 88 The whole house has been reroofed.

The manor of BISHOPS HALL originated in an estate in Lambourne held by the Bishop of Norwich. It is probable that this estate extended into Stapleford Abbots. In I $250 \mathrm{~W}$ alter le Blunt and Maud his wife granted to Walter de Suffield, Bishop of Norwich, a messuage, 60 acres of land, 6 acres of meadow, and I acre of wood in Lambourne, which tenement had formerly been held by Andrew le Draper. ${ }^{89}$ In 1252 the bishop received a royal grant of free warren in his demesnes at Lambourne.90 In 1260 Roger le Hunt and Estrilda his wife gave Simon de Wauton, Bishop of Norwich, I 4 acres of land in the parish to hold in free alms.91 Early in 1384 the temporalities of Henry Despenser, Bishop of Norwich, were taken into the king's hands as a result of the disastrous expedition to Flanders which the bishop had led.92 At a subsequent inquisition it was found that the manor called ' $\mathrm{La}$ Bisshoppeshall of Norwich' was held of the Knights Hospitallers and of Sir John Sutton by the service of 6s. a year, of the king in chief as of the manor of Havering, by service of making 60 perches of the park pale with his own timber, and of the Earl of Oxford by suit at his three weeken court. 93 The manor contained 80 acres of arable worth I 3 s. 4 d. a year, 12 acres of wood which could be cut every 20 years and was worth 25 . an acre, $135.8 d$. rents of assize, and 17 (?) acres (of meadow or pasture?) each of which was worth $25.6 d$.

The manor was restored to the bishop with his other property in 1385 and remained appurtenant to the see of Norwich until I 534, when the then bishop, Richard Nix, was deprived of his property on the charge of infringing the Statute of Praemunire. 94 Nix was later pardoned, but in 1536 , immediately after his death, the temporalities of the see were vested in the king by Act of Parliament in exchange for the former estates of the abbey of St. Benet's Hulme and of the priory of Hickling. 95 In October I 536 the bishop's manor in Lambourne was conveyed to the chancellor, Sir Thomas Audley. 96 Audley transferred it in $153^{8}$ to William Hale. 97 In I 556 Hale settled the manor on himself for life with remainder tu Thomas Hale. 98 This may have been the Thomas Hale of Codicote (Herts.) from whom descended the Hales of King's Walden (Herts.). 99 How long Bishops Hall was held by the Hales is not certain. It appears to have passed about 1606 to the family of Stoner of Loughton (q.v.) and together with land in Stapleford Abbots (q.v.) formed the estate of Knoll's Hill.' In I606 the 'manor or messuage of Bishops Motte' was in the possession of Clement Stoner. 'The site was then 'wasted and overgrown'. The fields belonging to the manor were Nether Barnfield, Upper Barnfield, Wheelers Ridden, Great Perryfield, Little Perryfield, Sedwins, Blackcroft, Stanes, and Sagars.
The total extent was about 100 acres. $^{2}$ Stoner died in 16 I 2, leaving Francis his son and heir. ${ }^{3}$

Bishops Hall seems subsequently to have been separated from the Knoll's Hill cstate. Later in the I7th century the manor came into the possession of Edmund Colvill, salter of Maidstone (Kent). He was evidently a Parliamentarian, for in 1662 he was removed from the common council of Maidstone for refusing the oaths of Supremacy and Allegiance.4 $\mathrm{He}$ died in $1675 .^{\circ}$ In I 686 his widow Katherine sold Bishops Hall to William Walker, citizen and ironmonger of London. ${ }^{6}$

William Walker died in 1708 and was succeeded by his eldest son Thomas (d. 1748). ${ }^{7}$ Thomas Walker was surveyor-general to George II and M.P. for West Looe (1733), Plympton (1734), and Helston (1741). ${ }^{8} \mathrm{He}$ left all his Essex estates to his nephew Stephen Skinner.9 Skinner died in 1762 and his widow Mary in 1769 . The will of Thomas Walker had provided that his estates should pass after Skinner's death to Skinner's three daughters and their heirs. ${ }^{10}$

In 1772 a private Act of Parliament was passed for dividing the estates." Bishops Hall was included in Lot $C$ of the subsequent partition and became the property of Mary wife of Sir Thomas Aubrey, 6th Bt. of Boarstall (Bucks.), and daughter of Sir James Colebrooke, Ist Bt., by Mary, eldest daughter of Stephen Skinner. ${ }^{12}$ In 1774 Sir Thomas and Lady Aubrey sold the manor to William Waylett of Lambourne. ${ }^{13}$ Waylett sold it in 1785 to Admiral Sir Edward Hughes, who had recently returned to England from service against the French as Commander-in-Chief, East Indies. ${ }^{14}$

On Sir Edward Hughes's death in $179^{8}$ the manor passed to his stepson Edward Hughes Ball (d. I 863), who later assumed the additional surname of Hughes and became a social celebrity and dandy, familiarly known as 'Golden Ball'. Is In I 8 I 8 Ball Hughes leased Bishops Hall to W. J. Lockwood of Dews Hall (see below) for fourteen years. ${ }^{16}$ The unexpired portion of the lease was surrendered in $1827 .{ }^{17}$ The manor is said to have been sold about this time to Edward Dowdeswell, Rector of Stanford Rivers, who gave it to Miss Lockwood Percival (presumably Louisa Elizabeth, sister of Edward Lockwood Percival the younger, for whom see above, Manor). ${ }^{18}$ After Miss Percival's death (before 6 . $183^{8}$ ) Bishops Hall apparently descended along with the main manor of Lambourne.

The original manor house of Bishops Hall was no doubt that which in 1606 was described as Bishops Motte, and was then wasted and overgrown (see above) This moated site can still be identified. Buried tiles and debris at the south-west corner may be the remains of former buildings.

The second Bishops Hall was built $\frac{3}{4}$ mile west of the first, probably by William Walker (d. 1708) or his son

\section{Ibid.}

89 Feet of F. Essex, i, 183.

90 Cal. Chars. R. $1226-57,404$

9x Feet of $F$. Essex, i, 237.

92 Cal. Close, $1385-9,3-4$. For the career of Despenser see D.N.B.

${ }_{93} \mathrm{C}_{145 / 229}$. The document is badly stained but the name of the manor seems to be as given above. This makes it reasonably certain that the manor was named after the Bishop of Norwich, and not, as suggested by Dr. Reaney (P.N. Essex, 60-6I) after a family named Bishop.

94 For Nix see D.N.B.

9527 Hen. VIII, c.45 (priv. act.)
96 L. 65 P. Hen. VHII, xi, p. 377.

97 Ibid. xiii (1), p. 325.

$98 \mathrm{Cal}$. Pat. $1555-7,90$.

99 Burke, Land. Gent. (1906), 746-

7.

Morant, Essex, i, 178

$=$ E.R.O., D/DFa El : this includes a sketch map of the estate. Franeis Stoner (d. 1604 ), father of Clement, does not appear to have owned Bishops Hall: C $142 / 285 / 116$

3 Morant, Essex, i, 178.

- Recs. of Maidstone (1926), 146

s P.C.C. Wills, 1671-5 Brit. Rec.

Soc.), 49 .

6 E.R.O., D/DLo T14.
7 Ibid.

8 T. Wright, Hist. Essex, ii, 398-9.

9 E.R.O., D/DLo Ti4.

so Ibid.

II Skinner's Estate Act, 12 Geo. III, c. 96 (priv. act.). Cf. E.R.O., D/DLo T 14 .

12 E.R.O., D/DLo TI4.

13 Ibid.

14 Ibid.; for Hughes see D.N.B. He had fought 5 battles in about a year.

is D.N.B. x, 174

16 E.R.O., D/DLo T 24.

17 Ibid.

18 T. Wright, Hist. Essex, ii, 399;

Burke, Commoners (1833-8), iv, 82 . 


\section{A HISTORY OF ESSEX}

Thomas (d. 1748). ${ }^{19}$ 'This became the seat of the Lockwood family and gave its name to their estate in the r 9 th century. It was much enlarged by Lord Lambourne about 1900. After the break-up of the estate (1929) the house was demolished $(1936)^{20}$ and the present Bishops Hall, the third of the name, was built in the grounds about $150 \mathrm{yds}$. south-east. This is a two-story gabled building, partly half-timbered. Various features from the earlier house are incorporated, including the carved stone Lockwood arms on the south front and the 17th-century Dutch panelling in the library.

The manor of $D E W S H A L L$ took its name from the family of Deu or Dew. Thomas Deu held land in Lambourne in $1248 .{ }^{21} \mathrm{He}$ and John Deu made a conveyance of 9 acres of land and $\mathrm{I}$ acre of meadow in 1262.22 A Richard Deu of Lambourne occurs in $1280-1.23$ A John Deu was verderer for the regards of Chelmsford and Ongar in 1285 . He was probably identical with the man of the same name who was a juror at the perambulation of the forest of Essex in 1301.24 In $1304-5$ Hamon de Deu conveyed to Richard of Chigwell and Joan his wife a messuage, 120 acres of land, 24 acres of pasture, and 9 acres of meadow in Lambourne and Theydon Bois. 25

In 1305 Juliane, widow of John de Deu, conveyed to Henry de Multon and Agnes his wife a messuage, 200 acres of land, 6 acres of meadow, 15 acres of wood, and 20 acres of pasture in Lambourne. ${ }^{26}$ It was provided in this conveyance that the property should descend to the heirs of Agnes; probably therefore she was the daughter of John Deu. In or about 1322 the estate passed to Juliane, daughter of Agnes and Henry and wife of Richard de Welby of Multon (Moulton, Lincs ?). ${ }^{27}$ In 1333 it was said to consist of a messuage, 220 acres of land, 7 acres of meadow, 20 acres of pasture, 20 acres of wood, 24s. rent and $\frac{1}{2}$ messuage all in Lambourne. A settlement in that year provided that the estate should descend to the male heirs of Juliane and Richard, with successive remainders to their daughters Margaret, Elizabeth, Joan, and Ada. ${ }^{28}$ No sons are mentioned by name and it is probable that Dews Hall descended through one of the daughters.

In 1419 John de Leventhorpe held an estatẻ in Lambourne, described as I messuage, 220 acres of land, roo acres of meadow, 20 acres of pasture, 20 acres of wood, 24 s. rent and $\frac{1}{2}$ messuage. ${ }^{29}$ A Thomas de Leventhorpe had connexions with the parish in $1469 .{ }^{30}$ The Leventhorpe estate was probably Dews Hall. Reynold Bismere (d. 1506) held Dews Hall of the Duke of Buckingham as of Ongar castle by doing what are called 'white services' at the wardstaff of the hundred of
Ongar. ${ }^{31}$ Two other Essex manors held by Bismere in I 506 had formerly belonged to the Leventhorpes. ${ }^{32}$

By $154^{\circ}$ Dews Hall had passed to Sir William Sulyard who died in that year. ${ }^{33} \mathrm{He}$ was succeeded by his half-brother Eustace Sulyard (d. I 547). Eustace's heir was his eldest son Edward, but Dews Hall, then in the occupation of James Haydon, was left to a younger son John.34 There is no further mention of John. In 1580 Edward Sulyard and Anne his wife conveyed Dews Hall to Henry Palmer. ${ }^{35}$

The manor descended in the direct male line of Palmer to Henry Billingsley Palmer, son of Edward Palmer. ${ }^{36}$ Between 1668 and 1697 a number of mortgages were taken out on Dews Hall.37 Among the mortgagees was Richard Lockwood. In 1709 Henry Billingsley Palmer sold the manor to Catlyn Thorogood, an official of the Sonth Sea Company. ${ }^{38}$ Thorogood died in 1732.39 His son Pate Thorogood sold Dews Hall in 1735 to Richard Lockwood, 'an eminent 'Turkey merchant', the son of the above-mentioned Richard Lockwood.40

Lockwood settled at Dews Hall and the manor descended to his eldest son Richard (d. 1794).41 The latter left no children and was succeeded by his brother the Revd. Edward Lockwood, owner of the main manor of Lambourne (see above). In I 802, after the death of the Revd. Edward Lockwood, Dews Hall passed to William Joseph Lockwood, son of his elder son. It was thus separated from the manor of Lambourne, but the two manors were reunited in 1842 and Dews Hall subsequently descended along with Lambourne.

In $184 \mathrm{I}$ Dews Hall farm consisted of 40 acres occupied by William Wootton.42 In 1929 it consisted of 87 acres, in hand. 43

When Richard Lockwood acquired Dews Hall in I735 the manor house was 'an old brick building'.44 He enlarged and refronted it in the classical style. ${ }^{5} \mathrm{~A}$ print of 5824 shows a fine three-story Georgian mansion with seven windows across the front. ${ }^{46}$ The central bay had a pediment and a first-floor balcony. The arcaded side wings were of one story. The house was demolished shortly before 1841.47 The site is now occupied by a red-brick stable court belonging to Bishops Hall and dating from about 1900 .

The estate or farm known as HUNTS and later as PATCH PARK never seems to have been styled a manor. It derived its original name from the family of Richard le Hunte who with Cecily his wife held land in Lambourne in 1306.48 In 1360 John Hunte and his 'parceners' held $\frac{1}{2}$ knight's fee in Lambourne of the Earl of Oxford. 49 The name Patch Park probably came

\footnotetext{
19 William Waiker was resident in the parish (cf. E.R.O., D/P 181/8/1). Before him the owners of Bishops Hall manor in the $17^{\text {th }}$ cent. were probably nonresident. The house existed by the time of Morant (cf. Morant, Essex, i, 173).

20 Inf. from Col. J. C. Lockwood, present owner of Bishops Hall. For the building demolished in 1936 see E.R.O., Sale Cat. 1046 (includes photo.). For the contents of that great house in 1929 see E.R.O., Sale Cat. A. 623. They included a 'magnificent French state bedstead' upon which Edward VII had slept during his visit to Bishops Hall.

21 Feet of $F$. Essex, i, 161.

22 Ibid. 245.

23 E.A.T., N.s. xviii, 139.

24 Ibid. xvi, 93-94.

2s Feet of F. Essex, ii, $9^{8}$.

26 Ibid. 100.
}

27 Cal. Fine R. 1319-27, 89

28 Feet of $F$. Essex, iii, 28.

29 Feet of $F$. Essex, iii, 270.

30 Cal. Pat. $1467-77,173$.


reference to the estate as a manor. For the wardstaff see above, Hundred of Ongar.

32 Leventhorpes in Wennington and

Launders in Rainham: see Morant, Essex, i, 86, 89.

${ }_{33} \mathrm{C}_{142} / 64 / 89$. For the Sulyards see Morant, Essex, ii, 42 and also Manor of Otes in High Laver. $\quad 34 \mathrm{Cr}_{42} / 86 / 63$. 3s E.R.O., D/DLo T5. An Edward Paimer probably occupied Dews Hall before 1547 ; E.A.T. N.s. ix, 217.

${ }^{36}$ For the descent see $V$ isits. of Essex (Harl. Soc.), $46_{3}$.

37 E.R.O., D/DLo T $5,6$.

38 Ibid. T7; Morant, Essex, i, 174.

39 Morant, Essex, i, 174. For his part in renovating the church and the subsequent dispute between the parish and his executors see below, Church. 40 Ibid.; E.R.O., D/DLo T9.

41 For the Lockwood pedigree see Burke, Commoners (1833-8), iv, $8 \mathrm{r}$. 42 E.R.O., D/CT 202.

43 E.R.O., Sale Cat. A. 1046

44 Morant, Essex, i, 174. 4 Is Ibid.

46 See plate facing p. 30. A view in Gents. Mag. Oct. 1821 is less good: here the apparent position of the house to the south-east of the church is probably due to faulty perspective.

47 E.R.O., D/CT 202. The Tithe Map and Award slow the "scite of old mansion" at the position of Dews Hall. T. Wright, Hist. Essex (1835), ii, 401-2 speaks of the house as still standing. 48 Feet of $F$. Essex, ii, 107. 49 Cal. Inq. p.m. x, p. 522. 
from the family of John Patche of Lambourne, a woodward of the bailiwick of Ongar in Waltham forest in 1498.50 The estate or at least the farm-house was still known as Hunts as late as 1714.51

In 1525 Hunts was held along with Arneways (see above) by Sir William Fitzwilliam. ${ }^{52}$ It passed with Arneways to Robert Taverner, who was holding it in 1556.53 In 1716 'a parcel of pasture or marsh known as Patch Park', comprising about 60 acres, belonged to Thomas Luther, lord of Suttons in Stapleford Tawney (q.v.) and the farm subsequently descended along with Suttons. ${ }^{54}$ After Pryors (see below) had been added to the Suttons estate Patch Park and Pryors were worked as a single farm.

The present farm-house of Patch Park was originally timber-framed and may be of 17 th-century date or earlier. It probably consisted of a central block with cross-wings projecting to the south and oversailing at first floor level. The house has been much altered, particularly in the mid-rgth century when most of the lower story was faced with gault brick.

The manor of PRYORS took its name from the priory of Dunmow, to which it belonged in the Middle Ages. In 1273 Roger Bishop and Alice his wife and Geoffrey Sleybrond and Rose his wife conveyed to Hugh, Prior of Dunmow, 43 acres of land and 2 acres of meadow in Lambourne. 55 In 1291 the property of the prior in Lambourne was valued at $18 s .2 d .56$ In I 3 I I the priory was granted licence to acquire a further small property in the parish. 57

In 1536 , after the dissolution of the priory, the lands in Lambourne formerly belonging to it were granted to Robert, Earl of Sussex (d. 1542).58 In 1554 Henry, Earl of Sussex (d. 1557), sold Pryors to Robert Taverner. 59 The manor subsequently descended with Arneways (see above) until 1681. In that year Arneways was sold by John Broomfield to John Todd, but Pryors remained in the possession of Broomfield, who left it by his will (1687) to his sister Elizabeth, wife of Nicholas Staphurst, M.D.60 Nicholas Staphurst, son of Elizabeth, sold the estate in 1713 to Dr. Thomas Tooke, Rector of Lambourne.6r A sketch map of Pryors and the glebe land made in 1714 is a little difficult to follow but appears to show that Pryors proper consisted of 35 acres and that an additional II acres belonging to the glebe were farmed as part of Pryors. ${ }^{62}$ Tooke died in 1721 , leaving Pryors to his wife for life with remainder to his brother John Tooke (d. 1764) who also succeeded him as rector. ${ }^{63}$ John Tooke was succeeded as rector and owner of Pryors by his son Robert Tooke (d. 1776).64 Robert left Pryors to his sister Mrs. Calvert, who held it until her death about 1794.65 She was succeeded by her daughter Mary, wife of John Martin, who sold the farm about 1798 to Charles Smith of Suttons in Stapleford Tawney (q.v.). Pryors was

50 E.R. xiv, 200.

3 E.R.O., D/DSd PI; Chapman and André, Map of Essex, $x 777$, sheet xvi, give Hunts as name of present Great Downs farm. This was probably an error.

52 Earl Fitzwilliam (Milton) Deeds, $1725,1726$.

$33 \mathrm{Cr} 42 / 109 / 54$.

54 E.R.O., D/DSd T2.

35 Feet of F. Essex, ii, I.

36 Tax Eccl. (Rec. Com.), $25 b$.

57 Cal. Pat, $R$. I 307-1 3, 395.

38 L. \&ै P. Hen. VIII, xi, p. 87 .

39 CP.25(2)/70/579 Mich. I \& 2 Ph. \& Mary.

60 Morant, Essex, i, 174; E.R.O., thus merged in the Suttons estate. ${ }^{66}$ In 1841 Pryors and Patch Park (see above) together contained 136 acres. 67

A small timber-framed and weather-boarded house, now known as Patch Park Cottage, is thought to represent the former manor house of Priors. Until recently it was divided into two tenements. Externally it appears to be of the 18 th or early I th century, but two groundfloor rooms have stop-chamfered beams, probably of the 17 th century and it is possible that at one time the building was of greater extent.

The priory of Stratford Bow (Mdx.) owned 6 acres of land in Lambourne called MVNCHYNLANDS, which were granted after the Dissolution to Sir Ralph Sadler, who in 1546 received licence to grant the property to John Lowe.68 It may have been in connexion with these lands that the Abbot of Waltham was paying $\frac{1}{2}$ mark a year to Stratford priory in about 1254.69

The advowson of the church of Lambourne was originally appurtenant to the manor of

CHURCH Lambourne. It was given by Robert of Lambourne to Waltham Abbey. This grant was confirmed by the Bishop of London in 1218.70 The confirmation appears to have included the permission required for the ordination of a vicarage, but there is no evidence that this ever took place.71

The first presentation to the rectory after the Dissolution was made in 1546 by Sir Anthony Cook.72 In 1553 the king granted the advowson to Lord Francis Russell and James Bridges.73 Robert Taverner of Arneways (see above) who died in 1556 was said to own the advowson.74 In 1557, however, Sir Nicholas Bacon and George Medley presented.75 Katherine Barfoot, widow of Robert Barfoot (see above, Manor), presented in $1569 .{ }^{76}$ She is stated to have done so by reason of a grant of the advowson for one turn, made by Waltham Abbey. It is not unlikely that the presentations of 1546 and 1557 also derived from. grants made before the dissolution of the abbey.

The advowson appears to have been held for some time by the Taverners, although the presentation was made by a member of the family on one occasion only (1608).77 The advowson was sold with Arneways to Robert Draper in $1625 .{ }^{78}$ In 1641 William Draper conveyed it to William and Thomas Overman.79 The presentation of 1642 was made by the king; it had previously been granted for this turn by Robert Taverner to Thomas Winniffe, Rector of Lambourne. ${ }^{80}$ Winniffe was Dean of Gloucester (1624) and later of St. Paul's (1631). He was chaplain to Charles I and became Bishop of Lincoln in 1642.81 No doubt the king presented on his behalf. In 1646 , after the revenues of his see had been confiscated by Parliament, Winniffe retired to Lambourne where he died in 1654 . He bought the next presentation and evidently intended to give the
D/DSd $\mathrm{T}_{42}$

6t Ibid.

62 E.R.O., D/DSd Pr.

63 Morant, Essex, i, I74-5.

64 Ibid.

65 T. Wright, Hist. Essex, ii, 402 E.R.O., Q/RPI 686-99; ibid. D/DSd $T_{42}$ 66 Ibid.

67 F.R.O., D/CT 202. The name of this Pryors is not now used locally. Priors near Bishops Hall is a modern house with no known connexion with the Dunmow priory estate.

68 L. $80^{\circ} P$. Hen. VIII, xiv (I), p. I6I ibid. xxi (2), p. 348

69 E.A.T. N.s. xviii, 18.
70 Newcourt, Repert. ii, $69 \mathrm{r}$.

71 There was a rector in $1297: \mathrm{Cal}$. $\mathrm{Pat}$. $1292-1301,296$.

72 Newcourt, Repert, ii, 360.

73 Cal. Pat. 1553,76. Russell was the eldest son of the 3 rd Earl of Bedford, whom he succeeded in 1555 .

${ }_{74} \mathrm{Cl}_{42 / 109 / 54 .}$

75 Newcourt, Repert. ii, 360 .

76 Ibid.

77 Ibid.; $\mathrm{CP}_{25}$ (2)/135/172I; C60/457.

The king presented in 1606

${ }_{78} \mathrm{CP}_{25}$ (2)/4I5 Mich. I Chas. I.

$79 \mathrm{CP}_{25}(2) / 418$ Mich. I 7 Chas. I.

${ }^{80} \mathrm{C}_{142 / 525 / 130}$

8 I D.N.B. 


\section{A HISTORY OF ESSEX}

living to his nephew Peter Mews (I6I9-I706). ${ }^{82}$ Mews, who served in the royalist forces during the Civil War, presented to the rectory in $1660.83 \mathrm{He}$ later became Bishop of Winchester.

The advowson appears to have descended subsequently along with Pryors (see above) but to have been granted for single turns to persons not connected with that manor. In 17 I 2 it was sold by Nicholas Staphurst to Dr. Thomas Tooke, then rector. Tooke provided in his will that his heirs should have the advowson for 50 years after his death and that it should then pass to Corpus Christi College, Cambridge. ${ }^{84}$ The college presented for the first time in 1778 and has continued to do so ever since. 85

The rectory was valued at $£_{6} 6$ I $35.4 d$. in about 1254 , I 29I, and $1428^{86}$ and at $f_{0} 14$ in $1535 .{ }^{87}$ The tithes were commuted in 1841 for 6610 ; there were then 35 acres of glebe. 88

The Old Rectory, now called Lambourne Place, was originally a timber-framed house, probably of the I 7 th century.89 It was largely faced with red brick about I740. The fine symmetrical front has rusticated brickwork to the lower story, while above there are rusticated quoins, a moulded brick cornice, and a central pediment. A high parapet conceals the dormer windows. The pedimented doorcase of wood is said to have come from Dews Hall (see above). ${ }^{90}$ It formerly had a shield of arms in the tympanum. Inside there are panelled rooms and a staircase with turned balusters of about 1740. Some of the chimney pieces are of this date and some later. There are later additions at the back of the house. It is now the home of the Rt. Hon. John Strachey, P.C., M.P., Minister of Food 1946-50 and Secretary of State for War 1950-1.

The present rectory was built in 1925 on a site presented by Lord Lambourne.9I It is a two-story house of dark-red brick.

The church of ST. MARY AND ALL SAINTS consists of nave, chancel, and west bell turret. It formerly had north and south porches. The walls are of flint rubble with stone and brick dressings and are covered externally with cement. The bell turret is timber-framed and weather-boarded and has a lead spire.

The nave dates from the middle of the 12 th century. It has north and south doorways which were blocked and reset in the 18 th century. The south door has some of the original voussoirs to the semicircular arch. The north doorway has original scalloped capitals externally but the shafts are missing. The outer order of the opening is semicircular, enriched with chevron ornament. Below is a tympanum now resting on a wood lintel. Some of the reset stones of the tympanum are decorated with axe-cut formy crosses and similar designs. At a high level and partly behind the timber-work of the bell turret on both north and south sides are round-headed single-light I 2th-century windows. Part of the internal jamb and arch of a similar window was uncovered farther east on the north side in $195 \mathrm{I}$.

An original chancel, built at the same time as the nave, was largely rebuilt in the $13^{\text {th }}$ century. The thicker walls adjoining the nave may be the remains of the I 2 th-century chancel. A I 3th-century blocked lancet window is visible externally on the south side.

In the I $4^{\text {th }}$ century new windows may have been inserted in the nave and chancel.

The nave roof, with its tie-beam and king-post with four-way struts, probably dates from the I 5 th century. Timber porches, later removed, may have been added in this or the following century.

The bell-turret was probably added early in the 16 th century. The timber-framing, reaching to the floor of the nave, has angle-posts, tie-beams, and curved braces.

In $1704-5$ the west gallery was built at the expense of William Walker of Bishops Hall. It is supported on moulded columns and is ornamented with foliage carving incorporating Walker's monogram. The panels are inscribed with a list of benefactions to the parish. A new chancel scrcen may have been inserted soon afterwards. The panels, which now form a dado at the back of the choir stalls, have similar foliage carving and the monogram T.T. (possibly Thomas Tooke, rector $1707-21$ ).

The church was restored and altered between 1723 and 1727 . In $1726-7$ about $£ 220$ was spent on this work.92 The renovations were inspired by Catlyn Thorogood of Dews Hall, a churchwarden. After his death in 1732 there was a dispute between the parish and his executors concerning his accounts for the period of renovation. ${ }^{93}$ The work included the removal of the timber porches to north and south and probably the blocking and resetting of the I 2 th-century doorways. A new west door was inserted, having a moulded hood on foliated brackets (dated 1726 ) and an cval window above it. New or altered windows were provided in the chancel and nave. At the same time the interior was decorated. The chancel arch is now three-centred, resting on voluted brackets and enriched with 18 th-century plasterwork. The tie-beams across the nave and chancel are covered with moulded and enriched plaster, the mouldings being carried round the walls to form a cornice. The king-post of the nave roof has been clothed in ornamental plaster and acanthus leaves. It was probably at this time, also, that the oak reredos with its fluted Corinthian pilasters was installed, and also a three-decker pulpit and box pews. The renovation was so thorough that the interior gives the impression of a Georgian church, an effect heightened by the large number of painted hatchments and of 18 th-and early I gth-century monuments. A print dated I 824 gives a good general view of the interior at this time, including the three-decker pulpit with an enriched soundingboard and the box pews. It also shows a late- 8 th-century monument above the altar, blocking the east window. 94 An upper tier was added to the gallery in I 820.95

In 1889 a new organ was installed and a new brick organ chamber was built for it on the north of the chancel. At the same time the church was reseated, the pulpit probably lowered, and a new heating system installed. These alterations were the gift of Col. Lockwood of Bishops Hall.96 In 1933 a new vestry and
82 D.N.B.

83 Ibid.; Newcourt, Repert. ii, 360.

84 Morant, Essex, i, 175.

85 Michael Tyson (1740-80) was instituted in 1778 after a long legal struggle concerning the advowson. He was a former scholar of Corpus Christi, antiquary, and artist: D.N.B.
86 E.A.T. N.s. xviii, 18; Tax. Eccl.

(Rec. Com.), 2 Ib; Feud. Aids, ii, 204.

87 Valor Ecel. (Rec. Com.), i, 437.

88 E.R.O., D/CT 202.

89 Possibly the house mentioned in the glebe terrier of I610: Newcourt, Repert. ii, 360 .

go Hist. Mon. Com. Essex, ii, 144.
91 Inf. from the present rector.

92 E.R.O., D/P $18 \mathrm{I} / 8 / \mathrm{r}$. This vestry book contains details of the renovation.

93 Ibid. $18 \mathrm{r} / 8 / \mathrm{I}, 2$.

94 E.R.O., Prints, Lambourne. See plate facing P. 53 .

os T. Wright, Hist. Essex, ii, 403.

96 Kelly's Dir. Essex (1 89o). 


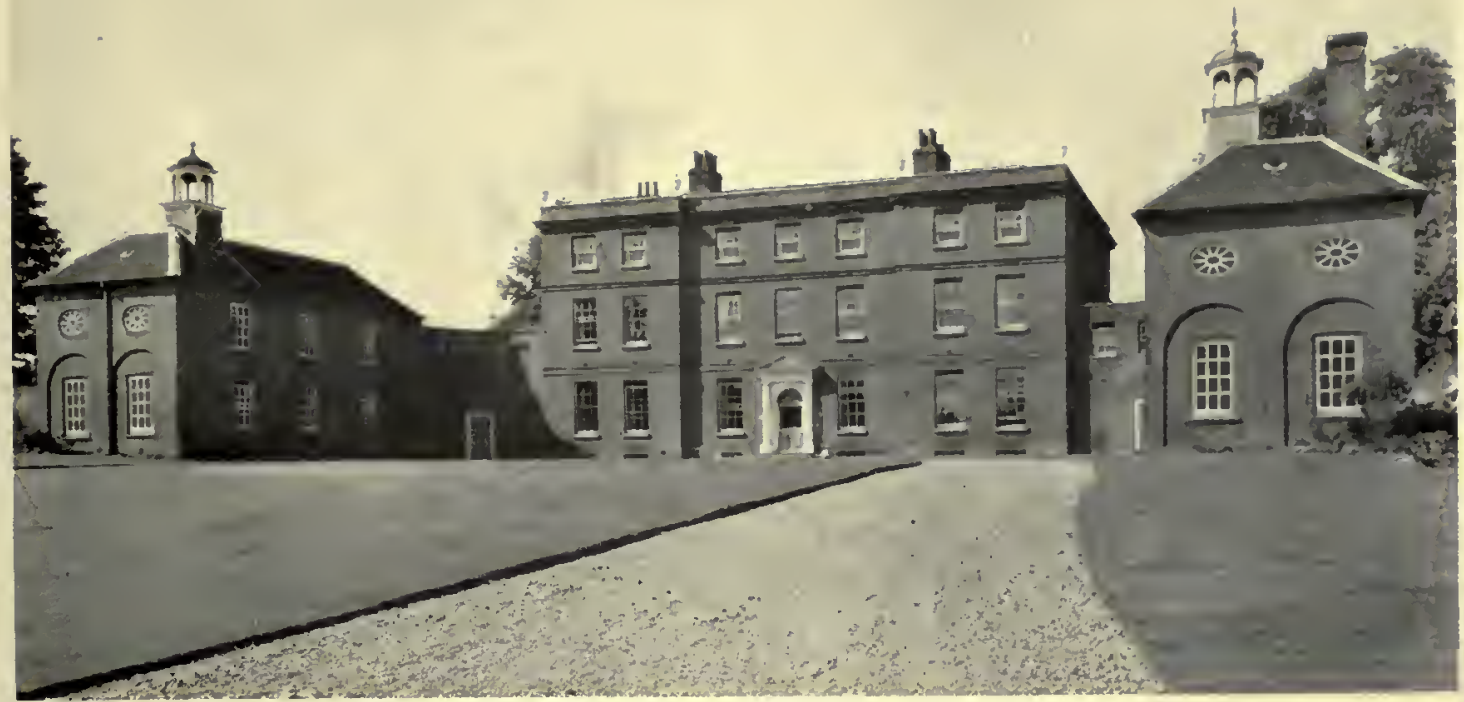

Kelvedon Hall

Copyright Counsry Life Built c. 1743



Lambourne Place, formerly the Rectory

Built c. $174^{\circ}$ 

entry were constructed under the gallery, the partitions being of oak from Bishops Hall.97 There is a two-light window in the vestry, on the north wall of the church.

There are three bells, of I 640 by John Clifton, of I 684 by James Bartlet, and of 1784 by William Mears. In 1552 there were three bells, breadth 24 in., 20 in., and $2 \mathrm{I}$ in., and also two little handbells and a sacring bell. ${ }^{98}$ The Bartlet bell was installed in obedience to the direction of the archdeacon at his visitation of 1683.99

The glass in the south windows of the chancel was installed in 1817 , having been brought from Basle. ${ }^{1}$ The subjects are as follows: the Choice between Good and Evil, dated 1630; the Adoration of the Magi, dated 1637 ; the Incredulity of St. Thomas (with the Annunciation in the spandrels) dated 1623; Christ and St. Peter on the sea (with the Apocalyptic Vision in the spandrels) dated 1631 ; the Adoration of the Shepherds, the Virgin and Child and St. Anne and the Virgin and Child (with St. Christopher and a female saint in the spandrels) dated 1631. The inscriptions are in German. ${ }^{2}$ The glass in the east window, representing the Adoration of the Shepherds, was presented in memory of Lord Lambourne (d. 1928).

During repairs in 1951 part of a wall-painting of St. Christopher was uncovered between the windows on the south side of the nave. It is thought by Mr. Clive Rouse to be of the 15 th or early 16 th century and to show traces below of an earlier painting of the same subject. At the same time painted red and yellow strapwork was uncovered farther west. This formed a frame for texts and is of post-Reformation date. ${ }^{3}$

The pulpit in oak is four sides of an octagon. The panels are enriched with carved arcading dating from the 16 th or early 17 th century. This was probably incorporated in the 18 th-century three-decker pulpit and


tury. The base is probably part of one of the lower tiers of the three-decker. The font has an I 8 th-century marble bowl on a tall moulded stone base.

The plate consists of a communion cup of 1559 , a plain silver paten of 1703 presented by John Wroth, a silver flagon of 1736 presented by Richard Lockwood, and a silver alms dish of 1817 . In 1552 the commissioners found at Lambourne a chalice weighing $170 z$. They delivered for divine service an $8 \mathrm{oz}$. chalice, of silver parcel gilt. 4

At his visitation of 1683 the archdeacon directed that a bible of the new translation should be provided. ${ }^{5}$ This suggests that the Great Bible was still in use at Lambourne more than 70 years after the publication of the Authorized Version.

In the chancel is a brass to Robert Barfott (1546) and Katheryn his wife. 6 It has figures of a man and woman together with a group of five sons and another of four sons and ten daughters, also the arms of the Mercers' Company and a merchant's mark. Also in the chancel is a black and white marble tablet with a broken pediment and three shields of arms to Thomas Wynnyff (1654) (see above). On the south wall of the chancel is a tablet with shield of arms and Latin inscription to Thomas Tooke, rector $(1721$ ). There are also other tablets to later members of the Tooke family who were rectors. Both in the chancel and nave are many memorials to members of the Lockwood family. Richard Lockwood, the Turkey merchant who bought Dews Hall, is commemorated by a white marble tablet with an urn, broken pediment, garlands, and shield of arms. On the wall of the nave is a tablet in memory of Capt. George Lockwood, killed at Balaclava in 1854 . There are floor slabs in the chancel to John Wynnyff (1630), father of Thomas, to Robert Bromfield (1647), and members of his family. In the churchyard are the tombs of Admiral Sir Edward Hughes (1794), his wife, and his two stepsons.7

The church of THE HOLY TRINITY, Abridge, was built in 1836 as a chapel of ease to the parish church. ${ }^{8}$ It was then a plain rectangular building with lancet windows along the sides and was of gault brick with red brick dressings. The gabled street front dates from 1877 . A new chancel and vestries were added in I938.9

For the Church House see below, Charities.

On 2 July 1833 a Wesleyan chapel was opened at Abridge. Sermons were

NONCONFORMITY preached at the first services by the Revd. J. T. Yeates of

Romford and the Revd. T. R. Fisher of Hammersmith. The chapel was estimated to accommodate I 50 . The original cost was $£ 270$ with ground freehold; $\delta 70$ was raised by private subscriptions and collections at the opening. The chapel was in the North East London Circuit. ${ }^{10}$ An account of the opening made bold claims as to the beneficial results already achieved by Methodist preaching in Abridge. 'This village, from its exceeding wretchedness and open profanity, was usually called the Little Sodom; but by the introduction of Methodist preaching its moral character is entirely changed.'II 'The chapel did not remain Wesleyan for long. There were no other Wesleyan churches near and pulpit supply must have been difficult. About I 844 the chapel was taken over for Congregational use. ${ }^{12}$

In 1844 the Essex Congregational Union helped the Revd. T. Hill of Chigwell Row to establish a church at Abridge, using the building previously erected for the Wesleyans. ${ }^{13}$ By 1847 the church was self-supporting. ${ }^{14}$ In I 850 it was superintended by a Mr. Hanley of London; there were 28 members and many adherents: 'the little church is well filled.'1s Soon after this a Mr. Knight worked at Abridge as the agent of the Country Towns Mission. In $185^{8}$ he reported that the village was still known as Little Sodom. ${ }^{16}$ In that year the Essex Congregational Union made a grant to Knight, who was also preaching at Lambourne End and Bourne Bridge in Stapleford Abbots. ${ }^{17}$ The deeds of the Abridge church had been acquired by one of the treasurers of the E.C.U. ${ }^{8}$ Knight remained until I 860 , when he left, apparently in unhappy circumstances. ${ }^{19}$ The church was placed under the superintendence of that at Epping, and there was confidence that it would

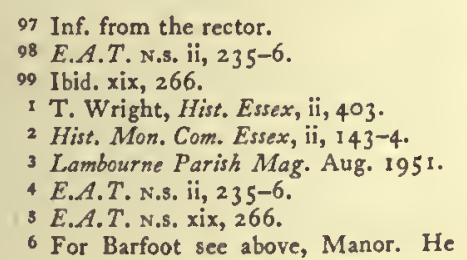

died in Jan. $1546 / 7$. 7 T. Wright, Hist. Essex, ii, 407-8. 8 White's Dir. Essex (t848). It cost 6520

9 Inf. from the rector.

10 Wesleyan Methodist Mag. 1833, p. 729.

12 White's Dir. Essex (1848); E.R.O.,
D/CT 202 ; see below.

13 Essex Cong. Union Rep. 1847.

14 Ibid.

Is Ibid. 1850 .

16 Ibid. 1858 .

17 Ibid.

18 Ibid. The treasurers were Isaac Perry and W. C. Wells.

19 Essex Congr. Union Rep. 1860. 


\section{A HISTORY OF ESSEX}

revive. ${ }^{20}$ The E.C.U. was making an annual grant amounting to $£ 40$ in $1859-60$ and $£ 37$ ros. in I $860-1.21$

The church remained attached to Epping until I 881.22 In I 86I new pews were installed; the Sunday school numbered about $30 .{ }^{23}$ A room had been rented at Lambourne End and a Sunday evening congregation of 30-40 met there. ${ }^{24}$ In 1869 it was reported that 'a Spanish Protestant' was holding a bible class in connexion with the church. 25 In 1870 the cottage service at Lambourne End was transferred to the care of the church at Chigwell Row; about 80 now attended the service. ${ }^{26}$ A. M. Kemsley, a missioner who worked at Moreton, took the Sunday school at Abridge in I 876.27 The church was flourishing at this time: in 1877 new classrooms were built at a cost of $£ 25$, all of which had been paid off during the year. ${ }^{28}$ In 1879 , however, the E.C.U. considered withdrawing its annual grant of 6.25 because there was an evangelical ministry at the anglican chapel in Abridge. 29 This was not done, but the grant was reduced to 620.30 In 1880 the church had II members, an average congregation of 90 , and a Sunday school of 100 with 6 teachers. ${ }^{31}$ The expenses in connexion with it amounted to about $640 .{ }^{32}$

In I 881 the church was removed from association with Epping and placed under the charge of Chigwell Row. ${ }^{33}$ By this time the cottage service at Lambourne End appears to have ceased; 34 it had been thriving in 1873, when it had become financially self-supporting. ${ }^{35}$ From I 886 the Abridge church was included in the London Congregational Union. ${ }^{36}$ It was apparently given up by the Congregationalists about 1905.37 It is now used as a parish room. It is a plain building of gault brick.

The Evangelical Free Church was started about 1923 when a Mr. White from Woodford held services first in the Parish Room (former Congregational Chapel) and later with a tent and caravan. In 1924 the church was built. ${ }^{38}$ It is a wooden building with a cement-rendered front and it stands set back on the south side of the London road.

At Augusta Cottages, near Lambourne End, there is a small wooden hut called Emmanuel Chapel, probably not more than 50 years old.

Vestry minute-books for Lambourne survive for the periods $167 \mathrm{I}-\mathrm{I} 764$ and

PARISH GOVERNMENT I 8 IO- $45 .{ }^{39}$ BeforeI 733 $A N D$ POOR RELIEF the vestry usually met only at the two appointed times for the election of officers, but these meetings were well attended, there being often ten and sometimes as many as fourteen present. In November 1733 it was resolved to hold a vestry on the first Sunday in every month. This resolution was not fully carried out, but for the next fifteen years meetings were frequent and well attended and a strict control was maintained by the vestry over all sides of parish government. Be- tween 1810 and 1826 four or five meetings were held each year. John Tooke, rector $1721-64$, often attended after 1733. Richard Lockwood of Dews Hall often attended between 1736 and 1747 and he or the rector presided over the vestry when present. A dinner was usually held in conjunction with the Easter vestry at one of the public houses in Abridge; the expenses were charged to the churchwarden's accounts. A vestry clerk was appointed in I745 at an annual salary of $I \frac{1}{2}$ guinea; the person then appointed signed the minutes as clerk.

In 1826 a public vestry resolved unanimously to adopt the second Sturges Bourne Act (59 Geo. III, c. 12) and set up a select vestry. Fifteen members were elected with the addition of the rector, Robert Sutcliffe, as chairman, and the parish officers. The select vestry functioned until May I 836, fortnightly meetings being held in the workhouse during the whole period. Poor relief and the management of the workhouse were its main concern. Public vestries were still held occasionally to deal with general matters and to appoint fresh select vestries at intervals of one or two years. The lord of the manor, Edward Lockwood Percival, and the curate, Morgan Lewis, were usually among those appointed to the select vestry, and either one of them or of the churchwardens presided.

In 1723 a rate of $I$ s. in the $f_{1}$ produced almost $f_{6} 9$ This was a general rate levied by the overseers, out of which they paid the accounts of the other parish officers. In 1716 deficiencies in the surveyors' and constable's accounts were met out of the churchwardens' and overseers' accounts and the final balance of $8 s .7 \mathrm{~d}$. was spent at the vestry. In 1807 a rate of $I s$. in the $f_{0} I$ produced over 690.40 The parish was surveyed in 1827 by James Thompson and a new valuation made. The rateable value was then over $£_{3}, 200.4$ I A public vestry fixed the scale of rates per acre and according to different qualities of arable, pasture, and woodland. ${ }^{42}$ In 1837 , under direction from the Poor Law Commissioners, the rateable values were raised by 25 per cent.

Relations between the vestry and its officers were not always harmonious. The dispute with the executors of a former churchwarden is mentioned above.43 In 1737 the constable's absence from the vestry was the subject of complaint, and there were other occasions when officers were censured. It is possible that this disharmony was caused by a conflict of interests between the shopkeepers of Abridge and the farmers of the parish.44

The normal parish officers were appointed until I $83 \mathrm{I}$, when a salaried assistant overseer was appointed at $£ 5$ a year. Women were chosen as overseers in 1730 and 1737 and both served. The son of the earlier overseer, however, attended the vestry and signed on her behalf. The constables elected in 1676 were described as being for the 'townside or leite and for the end' (i.e. Abridge and Lambourne End). In 1678 the former was succeeded by the constable for the manor of St.

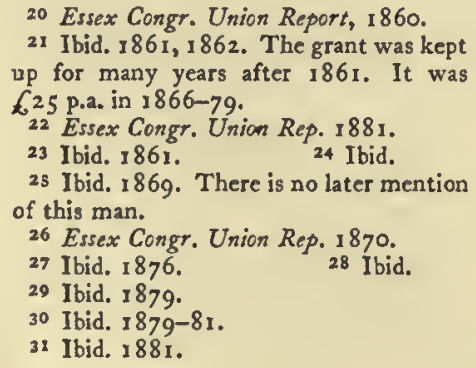

32 Ibid.

33 Ibid.

34 Ibid. I88 I-2; Congr. Tear Bk. 1879 , 1880. It is possible that the service continued outside the Congregational Union.

35 Essex Congr. Union Rep. 1873.

36 Ibid. 1885 .

37 Congr. Year Bk. 1905, 1906. A Congregational chapel is listed in Kelly's Dir. as late as 1914 , but this is perhaps an error.

38 Inf. from Mrs. Brewster of Abridge. 39 E.R.O., D/P I $81 / 8 / 1,2,4$. Unles otherwise stated all information is derived from these sources.

40 E.R.O., D/P I $81 / 11 / 1$ (Overseers Rate Bk.).

4 E.R.O., D/P $18 \mathrm{x} / \mathrm{1} 1 / 2$

42 125.-185. per acre for arable, I5s.285. for pasture, 125. for woodland, and IOs. for forest underwood, with a deduction of one third for waste in the measurement.

43 See above, Church.

44 For the position of Abridge in relation to the rest of the parish see above, pp. 73-74. 
John's with a colleague for the 'Countess of Warwick's leet'.45 An ale-conner was appointed in 1685, an assessor of land-tax in 1752 , and a reeve in 1826 and 1828 , all by the parish vestry.

There were stocks at Abridge in 1585 , when a vagrant was reported to have escaped from them. ${ }^{46}$ In 1728 it was decided to build a parish cage at Abridge with the timber recently removed from the church porches. 47 In I 84 I the parish pound stood about $\frac{1}{2}$ mile south of Abridge to the west of Hoe Lane. ${ }^{4}{ }^{\prime}$ In 1832 some labourers were paid 3 s. for working the fire-engine.

In 1589 the parishioners subscribed towards the building of a cottage for the poor and petitioned Quarter Sessions for permission to erect it without the statutory 4 acres of land.49 During the early 18 th century the parish cottages at Abridge were sometimes used to accommodate the poor, 50 but they were not very satisfactory for this purpose. Plans to convert them into a workhouse were rejected in 1738 and again in 1828.55

In 742 three houses in 'the Alley' at Abridge were leased by the parish at $f_{4} 4$ IOs. a year, and in I748 a house called 'The Old Crown' was leased for use as a poorhouse at $£ \mathrm{I} O$ a year. The repair and extension of Church House at Lambourne End, about 1810 , were for the purpose of housing the parish poor, and this house remained in use as a workhouse until the formation of the Ongar Union.

An Epping surgeon and an apothecary were paid for attending the poor and supplying medicine in 1748 , and a midwife received 5 s. in 1723 for delivering a bastard child, but it was only from 18 I 0 that regular medical contracts were made for the treatment of the poor. In that year a parish doctor was employed at a salary of I 4 guineas. This included all inoculations and attendance at two childbirths, but other childbirths and surgical treatment were excluded, as well as travelling expenses outside the parish. Between I 824 and 1834 further agreements on similar lines were recorded, the appointments usually being reviewed each year.

The annual amounts raised by the poor rates in the I 8 th century were only irregularly recorded, but by the middle of that century the overseers' expenditure was usually over $\oint_{1} 00$ a year. 'The vestry was fairly strict with its poor. On several occasions individuals and families were moved around, presumably to make the best use of existing accommodation. Orders for badging the poor were issued, chiefly between 1729 and 1745 , but once as late as I 825 . In I 83 I a woman was ordered to wean her child. The policy of the vestry was not, however, merely repressive. In I 743 a silk thrower was brought down from London to instruct the poor in winding silk, and others who were not receiving relief were encouraged by financial assistance to be similarly employed. In 1832 and 1833 several pieces of land, some given by E. Lockwood Percival, the lord of the manor, were acquired for giving employment to the poor.

As elsewhere the cost of poor relief mounted steeply after 1780 . Over $£ 840$ was raised by rates in $1800-I$, and this rose to 6923 in $1806-7.5^{2}$ Between 1810 and 1826 a number of agreements with workhouse masters were recorded. The first of these was for a lump sum, but all the others were on a capitation basis, the tenders varying from $2 s$. $4 d$. to $5 s .6 d$. a head a week. The terms always included an allowance for fuel and an additional allowance for material and the master was allowed to retain all profits. After 1826 the select vestry brought the management of the workhouse more closely under parish control by ensuring that all profits went to the parish. 'The master's subsequent offer to revert to the old system was rejected. Contracts for the supply of food and other goods for the workhouse were reviewed every six months and a high standard of quality was always required. In 1833 the cheesc and soap were sent back to a new contractor as unfit for use and a sample was sent to show the quality required.

In 1836 Lambourne became part of the Ongar Poor Law Union.

The foundation statutes of Harsnett's schools at Chigwell ( 1629 ) provided that two boys sCHOOLS from Lambourne should be taught at the English school at Chigwell and two at the Latin school.53 In 1734 Sir John Fortescue-Aland, lord of the manor of Lambourne and owner of Knolls Hill in Stapleford Abbots, founded a free school in Stapleford Abbots, at which twenty boys from Lambourne were to be given places. 44

There was no school in Lambourne in 1807 except a Sunday school with twenty pupils. 55 'Twenty places were still available at the Stapleford Abbots school, but not all of these were filled. 56 In 18 I 8 there was still no day school at Lambourne, but by I 833 much progress had been made. All the available places in the free school were taken and a day school had been founded at Abridge. In I 833 there were 64 pupils at this school, of whom 50 paid fees and 14 were paid for by benefactors. 57 The school was probably then under church guidance, and in about 1835 it seems to have passed under more direct church control. The chapel of ease at Abridge was used as a schoolroom for girls and the Wesleyan chapel hired for the teaching of boys. In - 838 the annual expenses were about 670 , towards which subscribers gave 640 . About $£ 7$ was collected at the annual sermon and further income was derived from the weekly fee of $2 d$. for each child. About 80 children were on the roll, but the average attendance was low. 58

The population of Lambourne was increasing steadily at this time and in 1839 there were still some 50 children not attending a school of any kind. $\ln 1838$ local churchmen set up a committee, with the rector as secretary, to build a new school at Abridge. Subscriptions were collected, chiefly from local landowners, and the rector approached the government and the National Society for grants. After a delay due to difficulties over a site and to the National Society's dispute with the government in 1839 , building started in $184 \mathrm{I}-2$ on a site given by W. J. Lockwood of Dews $\mathrm{Hall}$ and his son W. M. Wood. The National Society gave 640 , the government 6.54 , and the Diocesan Board 220 . A further I $_{9} 99$ was given by 35 subscribers, including Lady Mildmay, owner of Battles Hall in Stapleford
45 The Countess was the widow of Charles Rich, Earl of Warwick. Her leet was presumably that of the hundred of Ongar, which had been granted to Sir Richard Rich in 1547.

46 E.R.O., Q/SR 95/66.

47 See above, Church.

48 E.R.O., D/CT 202.
49 E.R.O., Q/SR 1ro/41. The site chosen was 'near unto barackes abouttinge uppon Chigewell upon the wast soule'. so See below, Charities.

sI Ibid.

s2 E.R.O., Q/CR I/9.

53 V.C.H. Essex, ii, 544 .

$\$ 4$ See Stapleford Abbots. s5 E.R.O., D/AEM 2/4: Lambourne Retns.

s6 Ibid. Stapleford Abbots Retns.

57 Retns. Educ. Poor, H.C. 224 , p. 260 (1819), ix (1); Educ. Enquiry Absir. H.C. 62, Pp. $280-1$ (1835), xli. 58 E.R.O., D/P $30 / 28 / 18$; ex inf. Nat. Soc. 


\section{A HISTORY OF ESSEX}

Abbots, Archer Houblon, owner of Bobbingworth Hall, the rector and Corpus Christi College, Cambridge, the patron of the living. ${ }^{59}$ The school was situated on the west side of Hoe Lane at Abridge. 60 It seems to have been a National School and for some years to have remained closely connected with the Sunday school. In 1 $846-7$ there were 68 pupils under a master and two mistresses who between them received 660 a year and had the use of a house rent-free. ${ }^{6 r}$ Attendance declined slightly in subsequent years. In $\mathrm{I} 85 \mathrm{I}-2$ there were 62 children present when the inspector visited the "neat schoolrooms'. He found the equipment poor, the master untrained, the educational standard low, but the children 'nice and well-behaved'.62 In 1859 an inspector found a slight improvement in standard but only 52 children in attendance. ${ }^{63}$ In 1871 , when there was said to be accommodation for 62 children, the attendance was still about 52.64 At this time the school was in financial difficulty and soon after (probably in I 878 ) it was discontinued as the result of the building of a Board School.

In 1874 a school board of five members was set up for Lambourne and Stapleford Abbots (q.v.) which had been united into a single school district according to the recommendation of the Education Department. ${ }^{65}$ The first plans submitted by the board were rejected by the Education Department as too expensive, but after this delay the board school was opened in September 1878 , on or near the site of the former National School. ${ }^{66} \mathrm{It}$ had accommodation for about I 50 pupils and a teacher's house was attached.67 Within a few years it was receiving an annual grant, amounting to 672 in I 886 ,

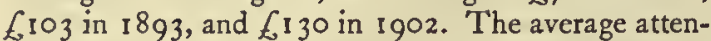
dance rose from ro4 in I 886 to $\mathrm{I} 20$ in $\mathrm{I} 893$ and $\mathrm{I} 25$ in 1902.68 By 1904 , when the accommodation was said to be for 178 , there were I4I children under 4 teachers and a monitress. 69

By the Education Act of 1902 the school passed under the administration of the Essex Education Committee, Ongar District. Its average attendance was I 27 in 1915 and 130 in 1938. In 1914 it was enlarged to accommodate 196 and in 19362 acres were added to the site. In 1947 it was reorganized for mixed juniors and infants.70 In May 1952 there were $\$$ teachers and ro6 children.71 The school is a single-storied building of brown and red brick, with teacher's house attached.

There was a private school at Abridge in 1845 , kept by Mrs. Sarah Giles. 72

59 Ex. Inf. Nat. Soc.; E.R.O., D/DLo 2 $1 ;$ ibid. D/P I $8 \mathrm{I} / 8 / 4$; Lady Mildmay owned about 200 acres of land in the east of the parish: E.R.O., D/CT 202.

60 O.S. 6 in. Map (rst edn.), sheet lviii (1870-2).

61 Nat. Soc. Enquiry into Church Schs. $1846-7$, Pp. IO-I I.

62 Mins. Educ. Cttee. of Council, I 851 , vol. ii [ 1480 ], p. 286 , H.C. (I 852 ), xli.

63 Educ. Cttee. of Council, Reps. on Schs. in Norfolk, Suffolk and Essex, I 858-9, p. 44. (in Min. of Educ. Libr.).

64 Retns. Elem. Educ., H.C. 201, pp. I I 2-I 3 [I 87 I], Iv; E.R.O., D/AEM $2 / 8$.

63 Chelmsford Chronicle, 9 Aug. 1872.

$66 \mathrm{Min}$ of Educ. File $13 / 219$.

67 Kelly's Dir. Essex (1899).
Thomas Barfoot of Lambourne Hall, by will proved 1592 , left $6 s .8 d$. a year charged on CHARITIES Sym's Croft for the relief of the poor of the parish.73 The charge was paid regularly until 1661 , and after 1664 payment was resumed.74 In 1731 the money was being distributed to those of the poor who were not receiving any weekly allowance. 75 In 1834 it was believed that the charge should be spent on bell-ropes, although in fact it was paid into the churchwardens' general account. ${ }^{76}$ In $1947-9$ it was distributed in money to buy coal. 77

John Broomfield, by will dated I687, left I os. issuing from his farm of Pryors for the poor of the parish. ${ }^{78}$ The rent charge was redeemed in 1950 for $f_{2} 20$ which was invested. The rent was being paid from 1689 onwards 79 and was distributed to the poor on 1 January. 80 In I 834 it was carried to the churchwardens' general account, although it was said to be spent on bread for the poor. ${ }^{8 I}$ It was spent on general church purposes in the mid-rgth century and for some years before $195^{\circ}$, but from 1950 it has been distributed in money to buy coal. 82

The parish owned two pieces of land in the common meadow of Theydon Bois (q.v.). The income from them rose from $35 \mathrm{~s}$. in 1673 to $f_{05}$ in $1834 .{ }^{83}$ It was spent on the church and the poor in the 18 th century 84 and was carried to the churchwardens' account in 1834.85 In $195^{\circ}$ it was distributed in money to buy coal. 86

The parish also owned property at Lambourne End, on which a house was built by the parish in about I671.87 The house was enlarged in about I 810.88 Until then it had been rented, sometimes to the parish clerk, 89 but from then until 1836 it was used as a poorhouse. 90 From 1838 it was once again rented and the income was applied to general church purposes, 98 as the rent of the land had been in 1834.92 In 1950 the total rents were $f_{34} 2 \mathrm{~s} .6 \mathrm{~d}$. which were spent on church repairs and improvement.93 Church House has a tall front with a mansard roof and dormer windows. The lower cottage attached to it at the rear is probably the Old Church House of about $167 \mathrm{I}$.

The parish formerly owned cottages near the river next to Hull Mead at Abridge. In I 73 I they were said to be for the use of the poor. ${ }^{94}$ They, were sold in I 830 to clear the debt incurred in rebuilding the Church House in $18 \mathrm{Io}$.
68 Rep. of Educ. Cttee. of Council, 1886 [C. 5123-I], p. 5 I 9, H.C. (1887), xxviii ; Retn. of Schs. 1893 [C. 7529], P. 7 I 4 H.C. (I 894), lxv; Schs, under Bd. of Educ. 1902 [Cd. 1490], p. 7 I, H.C. (1903), li. 69 Essex Educ. Cttce. Handbk. 1904 , p. 185 .

$70 \mathrm{Min}$. of Educ. File $\mathrm{I}_{3} / 2 \mathrm{Ig}$

7 Ex. Inf. Essex Educ. Cttee.

72 Kelly's Dir. Essex (1845).

73 E.R.O., D/P I 8 I/8/1; Rep. Com. Char. (Essex), H.C. 2 I6, p. 230 (1835), $\mathrm{xxi}$ (I)

74 E.R.O., D/P I $81 / 8 / \mathrm{I}$

73 Ibid. I $81 / 8 / 2$.

76 Rep. Com. Char. (Essex), p. 230.

77 Char. Com. files.

78 E.R.O., D/P 18 I $/ 8 /$ I, 2. See above,
Pryors. 79 Ibid.

80 Rep. Com. Char. (Essex), p. 230; E.R.O., D/P I 8 I/8/I.

81 Rep. Com. Char. (Essex), p. 230

82 Char. Com. files.

83 E.R.O., D/P I 8 I/8/I.

84 Ibid. $18 \mathrm{I} / 8 / 2$.

$8 s$ Rep. Com. Char. (Essex), p. 230

86 Char. Com. files.

87 E.R.O., D/P 18 I/8/1-2.

88 Ibid. $18 \mathrm{r} / 8 / 4$ (18 10 )

89 Ibid. $18 \mathrm{r} / 8 / \mathrm{r}$

90 Ibid. $181 / 8 / 4$

9 I Ibid. $18 \mathrm{I} / 8 / 3$

92 Rep. Com. Char. (Essex), p. 230

E.R.O., D/P I 8 I $/ 8 / 3$.

93 Char. Com. files.

94 E.R.O., D/P I 8 I/8/2. 


\section{HIGH LAVER}

High Laver is a parish about 4 miles north-west of Chipping Ongar and 5 miles south-east of Harlow. I It has an area of 1,895 acres. $^{2}$ From the 18 th century or earlier much of the population has been concentrated in the village of Matching Green and in the two hamlets of Thrushesbush, alias Threshers Bush, and Tilegate Green, all of which are situated on the borders of the parish. ${ }^{3}$ There were 74 inhabited houses in 1801,77 in 1811 , and 80 in 1821.4 In 1801 the population was 346.5 By I 85 I it had grown to $534 .^{6}$ It was a little below this level until the last decade of the century when there was a sharp decline to 386.7 In the first half of the zoth century it rose gradually to 463 in 1951.8

The land is nearly $300 \mathrm{ft}$. above sea-level in the south-west, about $250 \mathrm{ft}$. in the north and $230 \mathrm{ft}$. in the east. The Cripsey Brook runs eastward across the northern part of the parish and then southward near the eastern boundary of the parish towards Moreton. The road from Ongar to Harlow enters the parish at High Laver Bridge. The former rectory' is on the north side of the road about 1 mile from the bridge. The road then turns northward for about $\frac{1}{2}$ mile to its junction with the roads leading eastward to Little Laver and northward to Matching Green. Along the road to Little Laver is the church ${ }^{10}$ and to the north of the church on the east side of the road to Matching Green is High Laver Hall. II Behind church and hall is a windpump. About $\frac{1}{2}$ mile north of High Laver $\mathrm{Hall}$ on the west side of the road to Matching Green is High Laver Grange. This has a fine barn, in one bay of which are two grotesque carved brackets of the I6th or early I 7 th century. About I mile north of High Laver Grange is Newhouse Farm, formerly Chalkpits, a timber-framed house which has been much restored but of which part may date from the $17^{\text {th }}$ century. On the east side of the road north of Newhouse Farm there are thirteen council houses in two groups known as Culvers Cottages and Chalkpit Cottages. Beyond these is the village of Matching Green, the south side of which is just inside the parish boundary. Here there are several i gth-century brick houses, including the Chequers Inn.

From the east side of Matching Green a road runs south-east to Waterman's End, Little Laver, and the Rodings. On the west side of this road, immediately to the south of the parish boundary, is the chapel of ease ${ }^{12}$ and, next to it, High Laver school. ${ }^{13}$ Immediately to the south of the school the road is joined by another road leading south to Ongar. Near this junction on the north side of the road to Little Laver there are four pairs of council houses known as Hull Green Cottages.

From High Laver church the Harlow road runs west past Church Farm, formerly Whites, and Travellers Joy, formerly Herberts. Both these houses are timber-framed and may date from the I6th century; they have been much restored. A little beyond Travel- lers Joy the Harlow road is joined by Faggoters Lane which runs northward to Loyters Green. About $\frac{1}{2}$ mile along Faggoters Lane is Faggoters Farm, a timberframed and roughcast house probably built in the 18 th century. By the east side of Faggoters Farm is a footpath leading to the site of Otes. ${ }^{14}$ On the Harlow road to the west of Faggoters Lane is Mashams, a timberframed house which may date from the I 6th century. Beyond Mashams the road runs past Great Wilmores and Spinneys, formerly Little Wilmores, to Tilegate Green. At Spinneys, which stands on the north side of the road about $\frac{1}{2}$ mile beyond Mashams, there are indications of a former moat. Tilegate Farm, on the north side of the road at Tilegate Green, may be of the I6th century but has a later farm-house built in front of it, the whole being much modernized; the restored barn has I6th-century timbers. Opposite Tilegate Farm a road leads southward to Magdalen Laver. There are two pairs of council houses on the west side of this road, which forms part of the southern boundary of the parish. Also on the west side of the road and just within the boundary are Magdalen Laver school, 's built in I 862 , and, next to it, a row of timber-framed cottages called Melanese Cottages, of which part may date from the 17 th century or earlier.

West of 'Tilegate Farm the Harlow road turns northwest to Thrushesbush, alias Threshers Bush, on the western boundary of the parish. At Herds Farm, on the north side of the road $\frac{3}{4}$ mile north-west of 'Tilegate Green, there are indications of a former moat. The farm-house is probably of the 17 th century and has an original brick chimney. West of Herds Farm is the John Barleycorn Inn, formerly the 'King's Arms', a timber-framed house of which part dates from the $I 7$ th century or earlier. The former Methodist chapel ${ }^{16}$ is on the north side of the Harlow road at Thrushesbush, just outside the parish boundary.

High Laver Bridge was accepted as a county charge by 1800.17 In $185^{8}$ it was described in detail by the county surveyor. ${ }^{18}$

The inhabitants of High Laver were several times indicted for the bad condition of their roads. In 1644 it was said that High Laver and Little Laver were to share the responsibility for the highway from Matching Green to Sheepcroft Bridge. ${ }^{19}$ In 1776 the parishes of High Laver and Magdalen Laver agreed that the roads which these two parishes are obliged in conjunction to mend shall be equally divided and that the part which lies nearest to each parish shall be appropriated to it, by a post set up at the expense of both parishes, and marked on one side "M.L. mends thus far" and on the opposite side "H.L. mends thus far" ' 20

High Laver was one of the villages served from Moreton when a postal receiving house was set up there in 1846.21 A sub-post-office was opened at High Laver in November 1936 , following a petition from the inhabitants. ${ }^{22}$
O.S. 2 in in. Map, sheets $52 / 40,52 / 50$, $52 / 5 \mathrm{I}$.

2 Inf. from Essex County Council.

3 Chapman and André, Map of Essex 1777, plates xi and xii.

4 Census, 1801 , I811, 1821 .

S.C.H. Essex, ii, 350.

6 Ibid.

7 Ibid.
8 Census, IgIIf.; inf. from Essex County Council.

See below, Church.

10 Ibid.

II See below, Manor of High Laver.

12 See below, Church.

i3 See below, School.

14 See below.

is See below, School.
16 See below, Nonconformity.

17 E.R.O., $\mathrm{Q} / \mathrm{ABz}$ I \& 2.

18 E.R.O., $Q / \mathrm{ABz}, 3$.

I9 E.R.O., Q/SR $322 / 45$.

20 E.R.O., D/P $111 / 22$.

21 P.M.G. Mins. 1846 , vol. 87, p. 5

22 Inf. from Head Postmaster of Brentwood. 


\section{A HISTORY OF ESSEX}

Water was supplied by the Herts. and Essex Waterworks Co. in I 9 I $2 .{ }^{23}$ There is no sewerage system. ${ }^{24}$ Electricity was laid on in part of the village in $1950.2 \mathrm{~S}$ A sports ground is used by the football club. ${ }^{26}$

High Laver has always been a rural parish devoted almost exclusively to agriculture. The owners of the capital manor never lived in the parish after the first decade of the 16 th century. ${ }^{27}$ The owners of Otes lived in the parish during most of the period I6I4I 767.28 They were not resident from 1767 until shortly before $1841 .{ }^{29}$ For a few years after I $84 \mathrm{I}$ they did live in the parish but ceased to do so before 1863 and were never resident again. ${ }^{30}$

In 1848 the parish consisted of 1,894 acres. ${ }^{31}$ William St. Quintin owned 475 acres but farmed none of it himself. George Starkins Wallis owned, but did not occupy, High Laver Farm ( 340 acres). ${ }^{32}$ John and Thomas Inkersole owned 223 acres of which Thomas farmed 74 acres. ${ }^{33}$ There were two other substantial farms in the parish: Holts Farm ( 1 I 8 acres) and Tilegate Farm (100 acres). The respective owners, Joseph Davies and J. M. Gilbertson, did not occupy them. ${ }^{34}$ There were five other farms of over 40 acres. 35

High Laver has always been a parish of mixed farming with a heavy predominance of arable. In 1086 there were $10 \frac{1}{2}$ ploughs in the manor of High Laver; there was woodland for 200 swine and $37 \frac{1}{2}$ acres of meadow. ${ }^{36}$ In 1847 there were estimated to be 1,428 acres of arable, 368 acres of pasture, and 12 acres of woodland. 37

In the 17 th and 18 th centuries Otes manor house, the residence of the Mashams, was a large and wellknown dwelling which must have employed a considerable amount of domestic labour. In 169 I John Locke the philosopher (1632-1704) went to live there as a paying guest of $\mathrm{Sir}$ Francis Masham and his wife Damaris, who had been Locke's friend for some years. ${ }^{38}$ He paid fI a week for himself and his manservant and Is. a week for his horse. ${ }^{39} \mathrm{He}$ was given two of the best rooms in the house and he remained until his death. ${ }^{40}$ While he lived there Otes was 'one of the really important addresses in the world of European letters'.4I Locke assembled there a library of nearly 4,000 volumes. ${ }^{42} \mathrm{He}$ also had 'his desk and his specially constructed chair, his meteorological instruments set up "in the Drawing Room", his telescope, his botanical specimens, and a great porous stone through which all the water he drank-and he drank nothing else-had to be carefully filtered'. 43

From 1723 Otes was occupied by Samuel, Ist Baron Masham, and his wife Abigail who from 1707 until

23 Inf. from Herts, \& Essex Waterworks Co.

24 Inf. from sub-postmistress of High Laver.

25 Inf. from East. Elec. Bd.

26 Inf. from 8ub-postmistress of High Laver.

27 D.N.B. xx, 685-7; E.R.O., D/DW $\mathrm{T}_{41}$; ibid. Q/RTh 1, 5 ; ibid. Q/RP 685-737; ibid. D/P III/27/2; Kelly's Dir. Essex (I 859 f.).

28 See below, Manor of Otes; P. Laslett, Hist. To-day, iii, 536-43.

29 See below, Manor of Otes; P. Laslett, Hist. To-day, iii, 542-3; E.R.O., D/DEw $T_{2}$; ibid. Q/RPI 685-737; ibid. D/P II $1 / 27 / 1$.

30 E.R.O., D/P $111 / 27 / 2$; White's Dir. Essex (1863); Kelly's Dir. Essex (1870 f.). 3' E.R.O., D/P III/27/2.

I 7 I 4 had been Queen Anne's friend and one of the most powerful persons in the country.44 Abigail died in 1734.45

It is not possible to distinguish with certainty between High Laver and Little Laver in $M A N O R S$ Domesday but it is probable that before the Conquest Lewin held a manor in High Laver worth $\oint_{1} 6.46$ Alwin held 'another part of that manor as a manor but Ingelric added it to his own manor' in another parish.47 In 1086 High Laver was probably held in demesne by Eustace, Count of Boulogne, and valued at 20.48 Eustace's heir was his daughter Maud, wife of King Stephen. William, Count of Boulogne, son of Stephen and Maud, apparently granted the manor in free alms to the Benedictine abbey of St. Sulpice in Brittany.49 This grant must have been made by I I 59, when William died, but it was ignored until shortly after 1234.50 After the death of William the honor of Boulogne passed to the king, who held the manor of HIGH LAVER in demesne until I 84 or I 185 and from that time until 1237 as immediate overlord of the Alchers. ${ }^{\text {sI }}$ Between 1234 and I 237 Mabel, abbess of St. Sulpice, claimed the manor from Richard fitz Alcher.52 A lawsuit ensued after which the parties came to an agreement.s3 In I 237 Richard fitz Alcher acknowledged the manor to be the right of St. Sulpice which was to hold it in chief as $\frac{1}{4}$ fee. ${ }^{5+}$ The abbess, Amice, then granted the estate to Richard fitz Alcher and his heirs to hold of the abbey as $\frac{1}{4}$ fee and at an annual rent of 610. ss In I $259 \mathrm{St}$. Sulpice transferred its rights in the manor to Waltham Abbey.s6 After 1267 Henry fitz Alcher, then lord of the manor, refused to admit that Waltham had any rights in the estate.57 In 1275 a jury declared that he held the manor as tenant of the abbey. ${ }^{58}$ Afterwards, at the command of the king's justices, Henry did homage to the abbot and paid his arrears of rent. 59 Henry fitz Alcher died in 1303 holding the manor of Waltham abbey. ${ }^{60}$ It is not clear how much longer the abbey retained the tenancy in chief. In 1475 the manor was held of Anne, widow of Humphrey Stafford, Duke of Buckingham (d. 1460 ). ${ }^{61}$ In 1485 it was held of Jasper, Duke of Bedford (d. I 495), and his wife Katherine, whose first husband had been Henry Stafford, Duke of Buckingham (d. 1483 ). ${ }^{62}$ The manor was still held of Jasper and his wife in 1493.63 By 15 IO the Crown received fio a year from the manor, ${ }^{64}$ and this rent was paid until after I $559 .{ }^{65}$ In $15^{84}$ the manor was held of Robert, 3 rd Baron Rich, at a rent of $8 d$. a year. ${ }^{66}$

In 1 I 67 it was reported that the estate could not be farmed because it was not stocked but during the

32 Ibid. 33 Ibid.

36 V.C.H. Essex, i, $467 a$.

37 E.R.O., D/P I $11 / 27 / 2$.

38 P. Laslett, Hist. To-day, iii, 536-9.

39 Ibid. 42 Ibid.

43 Ibid.

44 Complete Peerage, viii, $540-1 ; D . N . B$. xii, 1295-7; Hist. To-day, iii, 539-40. 4s D.N.B.

46 V.C.H. Essex, i, $467 a$ and n. 2.

47 Ibid. For Ingelric see Manors of Chipping Ongar and Stanford Rivers.

48 V.C.H. Essex, i, $467 a$.

49 B.M. Harl. MS. 3739, f. 93.

so Ibid.

s I See below.

52 B.M. Harl. MS. 3739, f. 93.

s3 Ibid.

54 Ibid. ff. $94-96,108$. ss Ibid.

s6 Ibid. If. $96-98,110-12$

s7 Ibid. ff. 98-104. For details of this dispute see below.

58 B.M. Harl. MS. 3739, ff. I02-3.

59 Ibid. ff. 103-4.

60 Cal. Inq. p.m. iv, p. 112

$61 \mathrm{C}_{4}$ o/52.

62 Cal. Inq. p.m. Hen. VII, i, pp. 61-63; Complete Peerage, ii, 73. In the inquisitions post mortem on John Wrytell (d. 1485) and Katherine (d. 1493) widow of Walter Wrytell, the wife of Jasper, Duke of Bedford (d. 1495), was wrongly described as Anne.

${ }_{63}$ Cal. Inq. p.m. Hen. DII, i, p. $3^{8} 3$.

64 E.R.O., D/DDw M78.

$6 s$ Ibid.

66 Ibid. 
following year it was restocked at a cost of $6525.8 d^{6}{ }^{67}$ In 1 I $84-5$ the king granted to William son of Alcher the huntsman land in Laver to the annual value of 68.68 In I I 99 Richard fitz Alcher gave King John 100 marks to have $f_{8} 8$ of land in Laver which his brother William had by the gift of King Richard and of which William died seised.69 In June I I 99 the king granted to Richard fitz Alcher all the land which his brother William had in Laver of the gift of King Henry, to hold in chief as 1 fee.70 In I 204 Richard fitz Alcher gave Io marks and a goshawk for licence to assart 15 acres of his land in Laver and to have them put outside the forest boundary. ${ }^{71}$ It was presented from the honor of Boulogne in 1212 that Richard son of Alcher held Great Laver in chief for 1 fee. 72 In February 1227 Henry son of Richard fitz Alcher was granted his father's lands in Laver according to King John's charter. ${ }^{73}$ Henry died in 1234 and his son Richard then had livery of 1 fee in Laver held in chief. 74 In 1237 this estate consisted of $\mathbf{2}$ carucates of land. 75 In 1253 Peter de St. Hilary paid a gold mark to escape proceedings for the death of Richard fitz Alcher. ${ }^{76}$ Richard was succeeded by his son Stephen. 77

Shortly after 1259 Stephen entered into an agreement with Simon, Abbot of Waltham, whereby the abbey was to farm the estate for eight years instead of receiving an annual rent from it. 78 Stephen was dead by 1267.79 Afterwards his brother and heir Henry would not let the abbey farm the estate and refused to pay rent. 80 In 1 269-70 servants of Geoffrey, Prior of Waltham, went to High Laver to distrain Henry for arrears of rent. ${ }^{81}$ 'They took some cattle but Henry's men then assaulted them and the cattle were restored. ${ }^{82}$ In 1272-3 Henry brought an action against Richard de Harewes, then Abbot of Waltham. Henry alleged that 24 of the abbot's men had, at his command, trespassed upon High Laver manor and carrjed off livestock to the value of $\$ 40$ after ill treating Henry's men and killing two of them. Henry claimed that he had suffered $\delta_{5} \circ$ damages in consequence of the assault. The abbot pleaded in defence that in taking the livestock he was exercising his lawful power of distraint, since Henry, unlike his predecessor Stephen, had refused to do homage to him for the manor and was five years in arrears with his rent. Henry denied that previous abbots had ever received either homage or rent for High Laver manor. In I 275, after the verdict against him, Henry made an agreement with the abbot whereby he paid four years' arrears in addition to the current year's rent, ${ }^{83}$ When Henry fitz Alcher died in 1303 the estate consisted of a dwelling house worth

67 Pipe R. 1 I 67 (P.R.S. xi), I 57 ; Pipe R. 1168 (P.R.S. xii), 45-46.

68 Bk. of Fees, 1432; Pipe R. 1185 (P.R.S. xxxiv), 44-45.

69 Rot. de Ob. et Fin. (Rec. Com.), 5.

70 Cal. Pat. 1436-41,26. The land was granted to Richard as the next heir of his brother William. See also Bk. of Fees, 121.

71 Rot. de Ob. et Fin. (Rec. Com.), 224.

$72 B k$. of Fees, 121 . In early documents

High Laver was also called Great Laver and King's Laver.

73 Cal. Chart. $R$. $1226-57,11$.

74 Ex. e Rot. Fin. (Rec. Com.), i, 255.

75 B.M. Hatl. MS. 3739 ff. 94-96, 108.

76 Ex. e Ros. Fin. (Rec. Com.), ii, 149.

77 B.M. Harl. MS. 3739, ff. 97-103, $110-12$.

78 Ibid. f. 103.

79 Ibid. ff. 97-103, $110-12$.

80 Ibid. f. 103 .

ES. JV
3 s. 4 d. a year, 362 acres of arable worth 66 os. $8 d$. a year, 13 acres of meadow worth $19 s .6 d$. a ycar, and 5 acres of pasture worth $35.4 d$. a year. ${ }^{84}$ "The rents of assize of freeholders amounted to $£ 56$ s. a year.85 Annual outgoings, including the $\oint_{10}$ rent due to Waltham Abbey, amounted to 6 io 85.86 The net annual value was thus 6.2 10s. $9 d .87$

Henry fitz Alcher left as his heir his son Alcher. ${ }^{88}$ In I 3 I 5 Alcher granted the manor to his son Henry and Henry's wife Beatrice and their heirs to hold of Alcher and his heirs and do all services to the chief lords. ${ }^{89}$ In 1324 Henry fitz. Alcher and his wife Beatrice granted a life interest in the manor to Robert Norman for $£ 10$ a year. 90 In 1343 Henry fitz Alcher and Beatrice granted the manor to John de Depeden and his heirs to hold of the chief lords except for f, Io of rent and the homage and services of seventeen tenants which were to be paid to Henry fitz Alcher and his heirs. 91 In I 346 John de Depeden was reported as holding $\frac{1}{2}$ fee in High Laver which Henry Alcher once held. 92 At the end of 1358 Maud, widow of John de Depeden, empowered the Rector of High Laver to sue for her dower of every frechold which belonged to her husband in the counties of Essex, Hertford, and York.93 A rental drawn up in 143 I suggests that Maud held the manor of High Laver in dower.94 After her death it passed into the possession of another John Depeden, probably her son or grandson. In July 1406 John de Neuton, treasurer of St. Peter's, York, and other trustees of Sir John Depeden's estate quitclaimed to Robert Ramsey and his heirs the manor of High Laver and all other lands in Essex and Herts. which belonged to Sir John Depeden in demesne and in reversion.95 In 1412 John Ramsey was reported as holding one manor in High Laver worth f, 10.96 In I 428 Robert Ramsey was holding the 1 fee which Henry Alcher once held in High Laver.97 According to the rental of I 43 I Robert Ramsey was still holding the manor of High Laver in that year, but shortly afterwards it came into the possession of his daughter Eleanor and her husband Richard Priour who in 1436 received confirmation from the Crown.98 In 1452 when he presented to the church, Richard Priour was still lord of the manor, but within a few years the estate came into the possession of Walter Wrytell, son of Eleanor Priour by her first husband Ralph Wrytell.99

Walter Wrytell died in 1475 ; his widow Katherine held the manor in dower until her death in 1493.' The estate then descended to John Wrytell, son of John (d. I 48 5), son of Walter Wrytell.2 In -1 493 the estate consisted of 230 acres and was valued at $6.4 .{ }^{3}$ John, son
$8 I$ B.M. Cott. MS. Tib. C. ix, f. 180. 82 Ibid.

83 B.M. Harl. MS. 3739 f. 98-104; B.M. Cott. MS. Tib. C. ix f. $180-1$. The effect of this agreement was that Henry paid all rent owing from the time that Richard de Harewes was elected abbot in October 1270. Richard died in 1273 and was succeeded by Reynold de Maidenheth (see V.C.H. Essex, ii, 171) who made the agreement with Henry fitz Alcher in 1275.

84 B.M. Harl. MS. 3739 , ff. $321-6$.

8 Ibid.

86 Ibid. 87 Ibid.

88 Ibid.; Cal. Inq. p.m. iv, p. 112.

89 Feet of F. Essex, ii, 156.

90 Ibid. 214.

91 Feet of $F$. Essex, iii, 65. John de Depeden acquired several other estates from Henry fitz Alcher about this time.
92 Feud. Aids, ii, 160.

93 Cal. Close, $1354-60,532$.

94 E.A.T. N.s. $\times x \mathrm{ii}, 256$. The rental refers to the manor as 'formerly of Maud Depeden'.

os Cal. Close, $1405-9,265$; Cf. Cal. Close, 1354-60, 611, 614. Sir John Depeden died c. 1403 (Cal. Close, I402-5, 12,305 ).

96 Ferd. Aids, vi, 441.

97 Feud. Aids, ii, 222.

98 E.A.T. N.s. xxii, 256 ; Cal. Pat. 1436-41, 26; E.R.O.,-D/DEI MI95; ibid. D/DB T96/69.

99 Newcourt, Repert. ii, 368 ; E.R.O. D/DB T96/69. For the Wrytells sce also Manors of Bobbingworth, Ashlyns in High Ongar, and Lampetts in Fyfield.

i Cal. Ing. p.m. Hen. VII, i, p. 383 .

2 Cal. Ing. p.m. IIen. VII, i, pp. $6 \mathrm{i}-63$, $3^{8} 3$. 


\section{A HISTORY OF ESSEX}

of John Wrytell, died in 1507.4 His heir, an infant daughter Juliane, was dead by November 1509.5 The heirs to High Laver and other manors were the daughters of Walter Wrytell: Eleanor wife of James Walsingham and Gresilda wife of Edward Waldegrave. ${ }^{6}$ A partition of their inheritance was made in May 1510 and the manor of High Laver was apportioned to Eleanor and her husband. 7 In 15 ro the manor was said to be worth $\oint_{0} 14 \mathrm{I} 4 \mathrm{~s}$. $8 d$. a year. 8 The demesne was apparently farmed out, the chief farmer being Reynold Foster.9 Rents from the farmed land amounted to $\mathrm{I}_{1} 7 \mathrm{gs}$. $4 d . \mathrm{I}^{10}$ In addition there were twelve freeholders paying rents totalling $£ 3$ ros. 5 d. a year and 4 copyhoiders paying rents amounting to 6465. 5d." A rental of 1540 showed no change in the value of the manor. ${ }^{12}$

James Walsingham died in $1540 . .^{13}$ Sir Edmund Walsingham, elder son of James, apparently succeeded to the estate, for in $155^{\circ}$, the year in which he died, his only surviving son Thomas held his first court for the manor. ${ }^{14}$ In June 1552 the demesne land consisted of 266 acres. Is By 1559 the annual value of the manor had risen to $\delta 179 \mathrm{~s}$., the rents from farmed land amounting to $£ 207 \mathrm{~s} .8 d .16$ There were apparently only three copyholders at this time. ${ }^{17}$ Sir Thomas Walsingham died in 1584 , leaving as his heir his son Edmund; the manor was then said to be worth $6.5 .^{18}$ Edmund died in 1589 and was succeeded by his younger brother Thomas who retained the manor until his death in 1630.19 His son and heir, Sir Thomas Walsingham, disposed of the estate about 1655 to Anthony Stanlake. ${ }^{20}$ During the ownership of the last two Walsinghams, at least part of the estate was leased, the lessees being in turn G. Day and Josias and Thomas Tunbridge. ${ }^{21}$

Stanlake was described as lord of the manor in 1659 and it may have been on his death, sometime after 1662 , that the estate descended to coheiresses: Sarah, wife of Jacob Foster, and Martha, wife of Richard Matthews. ${ }^{22}$ In 1682 and 1686 Foster and Matthews were described as lords of the manor in right of their wives. ${ }^{23}$ In I 695 , 1699, and I706 Richard Matthews and Abraham Foster, a London grocer and probably son of Jacob Foster, were lords. ${ }^{24}$ Mary, daughter of Richard Matthews, brought one half of the estate in marriage to her husband Samuel Beachcroft who was lord of the manor with Abraham Foster in 1713.25

On Abraham's death his widow Anna held her husband's half manor for life. ${ }^{26}$ On her death this half was divided between Abraharn's two daughters: Sarah, wife of Richard Merry, a London merchant, and Mary, wife of Lewis Scawen. ${ }^{27}$ The quarter inherited by Mary and Lewis Scawen descended to their only son
Thomas who in 1753 devised all his real estate to his uncle Robert Scawen. ${ }^{28}$ In addition to 'an undivided fourth part' of High Laver manor, Robert also held an 'undivided half' of Hayleys manor in Epping. ${ }^{29}$ In June 1766 he and the owners of the other 'undivided' half (of Hayleys) and quarter (of High Laver manor), Richard Merry and his heir Anthony, agreed that it would be to their mutual convenience to make a physical division of their properties. ${ }^{30}$ Lots were cast, as a result of which the two quarters of High Laver manor fell to the share of Robert Scawen. ${ }^{31}$

There must have been an agreement about the same time with the owner of the other half of the manor, which had remained in the Beachcroft family until after 1762 , for the sale of the whole manor, for by August 1767, when he held his first court, Thomas Darby had become sole lord. ${ }^{32}$ At the time of the sale to Darby the whole estate, which consisted of about 370 acres, was leased to Abraham Thorrowgood. ${ }^{33}$ Thomas Darby, who continued to live at Sunbury (Mdx.), died in 1769 , having devised the manor of High Laver to his wife Dulcibella for her life and then to his brother George. ${ }^{34}$ Dulcibella died in 1784 and George in 1790 .

George Darby was succeeded by his son William who changed his surname to St. Quintin. In 1802 William mortgaged the manor to Mrs. Elizabeth Dashwood for $£ 2,557$. The estate was still encumbered with this debt in 1805 when William died, leaving as his heir his son William, a minor. The trustees of the estate eventually repaid Mrs. Dashwood in 1812 . In $183 \mathrm{I}$ William St. Quintin mortgaged the manor for 65,000 . In each of the years 1840 and 1850 he borrowed a further $\oint_{1} 1,000$, making a total mortgage on the estate of $£ 7,000$. This was still outstanding when William St. Quintin died in 1859.

The St. Quintins never lived in High Laver. After the death of Abraham Thorrowgood and his wife the manor house and farm were leased to the Speed family and, from 1826 , to William Barnard and his son who paid a rent of $\oint_{4} 425$ a year for the first 12 years, $\oint_{3} 60$ a year for the next twelve, and $£ 373$ a year from 1850 .

William St. Quintin stipulated in his will, made 30 years before his death, that all his lands, except those in Yorkshire, should be sold by his trustees. The manor of High Laver was sold for $\oint_{1}$ 2,050 to John Watlington'Perry Watlington, M.P., and the mortgage on the estate was paid out of the purchase money. At the time of the sale the estate consisted of 374 acres.35 $\mathrm{J}$. W. Perry Watlington was still owner in $1874 .{ }^{36} \mathrm{By}$ I 886 he was dead and Robert Wicksted Ethelston had succeeded to the estatc.37 Ethelston died in $1914.3^{38}$

\section{$4 \mathrm{Cr}_{42 / 2 \mathrm{I} / 2}$}

s L. E' P. Hen. VIII, i, p. I03.

6 Ibid.

7 E.R.O., D/DB T96/69; ibid. D/DDw $\mathrm{M}_{7} 8$.

8 E.R.O., D/DDw $\mathrm{M}_{7} 8$.

9 Ibid.

10 Ibid.

11 Ibid.

13 Ibid.; Conyers Read, Sir Francis

Walsingham, i, 7 ; D.N.B. xx, 685

14 E.R.O., D/DDw M75; D.N.B. xx,

685-7. Thomas was knighted in 1573 .

Is E.R.O., D/DEl M 95 .

16 E.R.O., D/DDw M78.

17 Ibid.

18 Ibid.

I9 $\mathrm{C}_{142 / 467 / 7}$; D.N.B. xx, 686. He

had been knighted in 1597 .
$20 \mathrm{CP}_{25}(2) / 55$ I $B$ Mich. 1655.

2 I E.R.O., D/DW T 4 .

22 E.R.O., D/DW T41. A note in the register of burials describes Anthony Stanlake as lord of the manor in 1659 : D/P I I I/I/1. He presented to the church of High Laver in 1662: Newcourt, Repert. ii, 368.

23 E.R.O., D/DDw $\mathrm{M}_{76}$

24 Ibid.

2s Ibid.

26 Ibid.; E.R.O., D/DW T41.

27 E.R.O., D/DW T 4 I.

28 Ibid. 29 Ibid.

30 Ibid. 31 Ibid.

32 E.R.O., D/DDw M77.

33 E.R.O., D/DW $\mathrm{T}_{41}$; ibid. D/DDw

$\mathrm{T}_{32}$; ibid. D/DEs T88. Previous oc- cupiers were Samuel Brooks, Thomas Roddington, and John Pavell.

34 E.R.O., D/DEs T88. Information for all that follows has been obtained from this group of documents.

3s E.R.O., D/DEs T88. Cf. D/P II $1 / 27 / 2$ (Tithe Award 1848 ) which gave the acreage as 356 of which 278 were arable.

36 Kelly's Dir. Essex (1874). From I 870 the manor of High Laver was described in Kelly's Directories as the manor of High Laver Hall to distinguish it from Otes manor which was apparently described at this period as the manor of High Laver.

37 Kelly's Dir. Essex (1 886).

${ }^{38}$ Burke's L.G. (1 $5^{\text {th }}$ edn.), 7 I 2. 
By 1917 the estate was apparently no longer regarded as a manor. ${ }^{39}$

The present farm-house stands on a moated site immediately north of the church. South of it an arm of the moat may have enclosed the church itself. To the north there was formerly a third rectangular moated enclosure. ${ }^{40}$ The present house is of brick, partly plastered, and probably dates from the late 18 th or early 19th century. At least two of the timbered farm buildings are older than the house.

The manor of OTES alias OATES may originally have formed part of the manor of Little Laver (q.v.).

In 1288 Emma, daughter of Eustace fitz Walter, granted all her lands in High Laver and Housham (Matching) to Sir Henry de Enfield.41 In 1325 Sir John de Enfield, son of Henry, John Otes, and others were tenants of the manor of Little Laver.42 In 1329 Sir John divided his estates between his sons Richard and William. He conveyed to William his holding in Little Laver which became the separate manor of Envilles.43 To Richard he conveyed I messuage, 2 carucates of land, 12 acres meadow, and 40s. rent in High Laver and Housham (Matching). ${ }^{44}$ It is possible that at this time or shortly afterwards the lands held of Little Laver manor by John Otes were merged with the lands held by Richard de Enfield in High Laver to form a separate manor which descended in the Enfield family but which became known by the name of Otes.

The heir of Sir Richard de Enfield was his daughter Elizabeth, wife of Thomas Battail.45 In 1397 the manor of Otes was held by John Battail, son and heir of Thomas and Elizabeth. ${ }^{46}$ John Battail made his will in 1397 , on the eve of his departure for Jerusalem.47 He gave detailed instructions for the partition of his property between his sisters, Margaret, soon afterwards wife of John de Boys, and Alice, wife of John Barrington. Battail died shortly afterwards and Boys and Barrington quarrelled over the partition. ${ }^{8} 8$ The dispute was eventually referred to the arbitration of the Countess of Hereford who decided that Otes should be equally divided between Alice Barrington and Margaret de Boys, as John Battail had instructed.49 In 1412 John de Boys and John Barrington were each reported as holding lands in High Laver and elsewhere worth 620.30 Margaret de Boys apparently died without issue. 51 Afterwards two daughters of John Barrington, Elizabeth, wife of John Sulyard, and Katherine, wife of John Pykenham, each inherited half of Otes.52

Sir John Sulyard, son of Elizabeth and John Sulyard, died in 1488 in possession of half of Otes which he held of Edward, Duke of Buckingham, and which was worth 20 marks. ${ }^{53}$ His son and heir Edward died in 1516 and was succeeded by his son Sir William Sulyard who held his first court in 1523.34 William died without jssue in 1540 and his half-brother Eustace Sulyard inherited his half of Otes.5s Eustace died in 1547 leaving as his heir his son Edward.36 In 1574 Edward conveyed his half of the manor to John Collins who had already acquired the other half (see below). ${ }^{37}$

John Pykenham survived his wife Katherine and died in 1436 in possession of half of Otes. 58 In 1445 William Hasilden and others (named) conveyed this half of the manor to John Pykenham, evidently the son of John Pykenham (d. 1436), and his wife Margery. ${ }^{39}$ Margery Pykenham was still seised of this half in I 500 when her son and heir George died childless, leaving as his heirs his two nieces, Margery and Elizabeth Pykenham, daughters of his brother Thomas, 60 At that time this half of the manor was held of John, Earl of Oxford, and was worth 20 marks.61 Apparently the sisters Margery and Elizabeth Pykenham each inherited half of the moiety.

In 1539 John Heron and his wife Elizabeth, who was probably the daughter of Thomas Pykenham, conveyed a quarter of Otes to John Lymsey. ${ }^{62}$ The latter died in 1545 ; in 1558 Edward Lymsey, his son and heir, conveyed this quarter to John Collins. ${ }^{63}$

Meanwhile in $155^{\circ}$ John Collins had received the other half of the moiety from John Jennyns and his wife Joan, one of whom may have been the child or grandchild of Margery sister of Elizabeth Pykenham. ${ }^{64}$

Between $155^{\circ}$ and 1574 John Collins thus acquired the whole manor of Otes. It remained in the Collins family until shortly after 1614 when it was purchased by William Masham whose son William succeeded him and was created a baronet in 1621.63 In $1638 \mathrm{Sir}$ William Masham was visited at Otes by Oljver Cromwell, who was his relative by marriage.66 $\mathrm{Sir}$ William died about $16,6.67 \mathrm{His}$ heir was his grandson William Masham, 2nd Bt., who died unmarried about 1662 and was succeeded by his brother Francis Masham, 3 rd Bt. ${ }^{68}$ In 1668 there were 59 freeholders and copyholders on-the estate. ${ }^{69}$ The area in their hands was more than 354 acres $^{70}$ and they paid rents amounting to 69125 . 1 d.71 In 167822 tenants who failed to attend their lord's court were each fined $2 d .72$

From 169I until 1704 John Locke the philosopher lived at Otes as the paying guest of Sir Francis Masham.73 In 1723 Sir Francis died, leaving as his heir his son Samucl, rst Baron Masham of Otes (cr.
39 Kelly's Dir. Essex (1917 f.).

40 E.R.O., D/P $111 / 27 / 2$.

${ }^{4}$ Cal. Close, $1279-88,525$; Visits. of Essex (Harl. Sóc. xiii), 227 ; C. Moor, Knights of Edw. I (Harl. Soc. Ixxx), i, 305-6.

42 Cal. Inq. p.m. vi, p. 372; Morant, Essex, i, 543 .

${ }_{43}$ Feet of $F$. Essex, iii, 5. See Little

Laver, Manor of Envilles.

4 Feet of F. Essex, iii, 5 ; Visits. of Essex (Harl. Soc.), 227.

43 Visits. of Essex (Harl. Soc.), 227

46 E.A.T. N.s. i, 268-72; Visits. of Essex (Harl. Soc.), 227 ; Cal. Close, $1396-$ $9,282$.

47 E.A.T. N.s. i, 268-72.

48 Ibid.; Cal. Close, 1396-9, 282.

49 E.A.T. N.8. i, $268-72$.

so Feud. Aids, vi, $44^{\circ}$.

31 E.A.T. N.s. i, 272.

52 B.M. Add. Chart. 40792 ; Visits. of
Essex (Hatl. Soc.), $147 ;$ E.A.T. N.s. i, 272. The historian of the Barringtons (E.A.T. N.s. i, 272) believed that John Barrington, husband of Alice, had only one daughter, Elizabeth. The evidence of the B.M. charter, however, suggests strongly that he had several daughters.

33 Cal. Inq. p.m. Hen. VII, i, p. 1.77.

34 Ibid.; E.R.O., D/DEw M9; E.A.T. iii, 180 ; ibid. N.s. vi, 325 .

s5 E.A.T. iii, 180 ; ibid. N.s. vii, 16 . ${ }_{36} \mathrm{C}_{142} / 86 / 63$.

$37 \mathrm{CP}_{25}(2) / 129 / 1655$

58 B.M. Add. Chart. $4079^{2}$.

39 Cal. Inq. p.m. Hen. VII, ii, p. 246. When the half manor was settled on John and Katherine Pykenham it was stipulated that if they had no issue, the estate should descend to Margery, sister of Katherine or, if Margery died, to Alice also sister of Katherine.

$60 \mathrm{Cal}$.Ing. p.m. Hen. VII, ii, p. 246.
6 I Ibid.

${ }^{62} \mathrm{CP}_{25}(2) / 52 / 374$ Trin. 3 I Hen. VIII

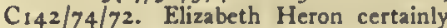
held the half manor in her own right.

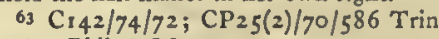
4 \& 5 Phil. \& Mary.

$64 \mathrm{CP}_{25}(2) / 57 / 421$ East. $4 \mathrm{Edw}$. VI.

63 $\mathrm{CP}_{25}(2) / 295$ Mich. 12 Jas. I \&

Trin. 17 Jas. I; Hiss. Essex by Gent. iii, 348; Morant, Essex, i, 14 1; G.E.C Complete Baronetage, i, 182 .

66 E.R. xviii, 201.

67 G.E.C. Complese Baronerage, i, 182. 68 Ibid.

69 E.R.O., D/DXs I.

70 Ibid. Some of the acreages in individual tenants' hands are not given in the rent roll.

7 I Ibid.

72 Ibid.

73 See above, p. 88 


\section{A HISTORY OF ESSEX}

17 12). ${ }^{74}$ In 1736 Lord Masham impoverished himself when he settled the greater part of his estates, including the manor of Otes, on his son Samuel at the time of the latter's marriage to Henrietta Winnington. ${ }^{75}$ The young Samuel had already inherited the property of his uncle General Hill and Henrietta brought him a dowry of some $f_{10,000.76} \mathrm{He}$ was a lord of the Bedchamber to George II and auditor-general of the household of George, Prince of Wales. $77 \mathrm{He}$ was, however, a wastrel 78 and before he succeeded his father as Baron Masham in $175^{879}$ he was already in need of money. In 1757 he mortgaged Otes and his two other manors of Matchinghall in Matching and Little Laver to Dr. Robert Taylor of Albemarle St., Hanover Square (Mdx.) for $£ 3,000{ }^{80}$ Part of the manor farm, which was valued at $£ 140$ a year, was then let to John Hinson. ${ }^{81}$ There were 100 acres of woodland, valued at $£ 35$ a year, in hand. ${ }^{82}$ The free and copyhold rents belonging to Otes and Matchinghall manors amounted to $f$ I I I 6 . I I $\frac{1}{2} d$. a year and the fines and reliefs for the two manors were estimated at $£ 5$ a year. ${ }^{83}$

In $176 \mathrm{r}$ Lord Masham was granted a pension of f 1,000 a year by George III.84 In February 1762 he still owed $£ 2,000$ of the $£ 3,000$ he had borrowed from Taylor in $1757 .^{85} \mathrm{He}$ then married as his second wife Charlotte Dive whose father John Dive of Queen Square, Westminster, gave her a dowry of $£ 8,000$, paying off the debt to Taylor as part of this sum. ${ }^{86}$ At about the time of the marriage Lord Masham sold to a bookseller part of his family library, including books bequeathed by John Locke, 'to make room', it was commonly believed, 'for books of polite amusement'. ${ }^{87}$ Charlotte Masham was as irresponsible and as extravagant as her husband, 88 and, less than three years after the marriage, Lord Masham began to borrow money on a scale which led rapidly to the loss of his estate. Between January 1765 and June 1766 he borrowed a total of $£ 8,600$ on the security of the estate. ${ }^{89}$ Most of this was lent by Robert Palmer of St. Andrew's parish, Holborn (Lond.) who had been manager of the estate from 1757 , if not before. 90 In 1766 the estate was valued at $f 25,369.91$ Early in 1767 Palmer acquired the freehold on terms which allowed Lord Masham to live at Otes for the rest of his life. ${ }^{92}$ Masham died there in 1776.93 Even at the

end he was 'so burdened with debt that he could not attend the House of Lords'. ${ }^{94}$ An interesting comment on the characters of Lord Masham and Kobert Palmer was written a century later by P. J. Budworth whose family had been connected with High Laver almost from the time when Masham lost his estate. ${ }^{95}$ In 1876 Budworth wrote that 'Lord Masham seemed to have been improvident and his improvidence had been taken advantage of by one to whom he confided the management of his estates and who built up his own fortune upon the ruins of that of his master'.96

Robert Palmer never lived at Otes.97 $\mathrm{He}$ died in 1786 leaving all his real estate to his only son Richard but charging it with the payment of $f_{0} 10,000$ to each of his two unmarried daughters. 98 In 1801 Richard Palmer put up his Essex estate for auction.99 This consisted of $1,25^{8}$ acres valued at $\oint_{1}, 075$ a year. ${ }^{1}$ Otes manor farm contained 279 acres which were valued, with the manor house, at $£ 385$ a year. ${ }^{2}$ Of these 279 acres, 160 were in the occupation of three leaseholders, called Browne, the elder and younger, and Crush, and 92 were occupied by the elder Browne as tenant at will. ${ }^{3}$ The manor house was empty. ${ }^{4}$ The quit rents on the manor amounted to about $£ 10$ a year and the royalties were valued at $f_{2} 20.5$ An offer for the leasehold land appears to have been accepted in 1801.6 The manor house and 116 acres in hand or in the occupation of the tenant-at-will were sold in $1802-3$ to John Hughes who held his first court in 1808.7 In I 81 I 12 the manor came into the possession of George Starkins ${ }^{8}$ who had already acquired much of the land in High Laver which was auctioned in $180 \mathrm{r}-2$. In I 824 there were 44 manorial tenants whose rents totalled 69 19s. $6 d$. a year 9 and in 183734 whose rents totalled 67 5. 8d. io In 1841 George Starkins owned $6 \mathrm{r} 3$ acres in the parish; of this he then occupied 426 acres. ${ }^{11}$

Between $184 \mathrm{r}$ and $\mathrm{r} 843$ John and Thomas Inkersole came into possession of the manor. ${ }^{12}$ In 1848 the manor farm consisted of 68 acres and was occupied by Thomas Inkersole. ${ }^{13}$ The Inkersoles also owned an estate of 155 acres which had previously been in the possession of George Starkins. ${ }^{14}$ They were still lords of the manor in 1860 when the last recorded court was held. ${ }^{15}$ By 1870 the manor had apparently come to Mrs.

74 Complete Peerage, viii, $54^{\circ}$; see above, p. 88 .

7s E.R.O., D/DEw T 1 ; P. Laslett, "The Mashams of Otes', Hist. To-day, iii, 54r.

76 Hist. To-day, iii, 541 ; D.N.B. xii, 1295.

77 D.N.B. xii, 1297.

78 Hist. To-day, iii, 541-2. Swift, who hated him from a boy, commented that he was "ill-natured and proud and very little in him'.

79 Complete Peerage, viii, 541 .

80 E.R.O., D/DEw Tr. Mr. Laslett believes (Hist. To-day, iii, p. 541) that this mortgage was probably owned, in fact, by Robert Palmer whose name appears as a witness only to the deed and who certainly lent Lord Masham a great deal of money between Jan. 1765 and June 1766 . There is no evidence, however, to support this view. The fact that Palmer was manager of Masham's estate in 1757 is sufficient to explain his attestation of the deed.

8I E.R.O., D/DEw TI.

82 Ibid.

83 Ibid. There are no separate figures for Otes at this date.

84 D.N.B. xii, 1297.

9s E.R.O., D/DEw TI.

86 Ibid.
87 Hist. To-day, iii, 542 .

88 Ibid. $541^{-2}$.

89 E.R.O., D/DEw T 1 ; ibid. D/DEw

90 E.R.O., D/DEw E 3 .

91 Berks. Rec. Off. D/EE F 38 .

92 Ibid.; ibid. D/EE Eı8; E.R.O.

D/DXs is ibid. D/DEw Mir. Mr.

Laslett's statement (Hist. To-day, iii, 542) that the transfer of ownership took place in 1766 is, on the basis of Palmer's notes, incorrect. The document to which $\mathrm{Mr}$. Laslett refers as the deed of sale contained in fact only the valuation of the estate and the terms submitted for Lord Masham's consideration.

93 Hist. To-day, iii, 542.

94 Ibid.

9s See below, Church.

96 P. J. Budworth, Memorials of Greensted-Budworth, Chipping Ongar and High Laver, 35 .

97 Nor did his son and successor, Richard (see below). Some of the contents of the house, including Locke's possessions, were, however, removed to the Palmers' residence: Hist. To-day, iii, 542-3; F.R.O., D/DEw T2.

98 E.R.O., D/DEw T2.
90 Ibid. I Ibid.

2 Ibid. The figures which Mr. Laslett gives both as to the extent and as to the value of Otes Manor in $180 r$ are incorrect.

3 E.R.O., D/DEw T2.

4 Ibid.

5 Ibid. 6 Ibid.

7 Ibid.; E.R.O., Q/RPI 707-8; ibid. $\mathrm{D} / \mathrm{DX} s \mathrm{l}$.

8 E.R.O., Q/RPI 716-17; ibid. D/DXs 1. He held his first court in Jan, 1815 .

- E.R.O., D/DXs 2.

10 E.R.O., D/DXs 3 .

i1 E.R.O., D/P $111 / 27 / 1$. According to the Land Tax Assessments Starkins owned much of this land before he acquired the manor but he did not occupy it for many years.

12 E.R.O., D/P $111 / 27 / 1$; ibid. D/DXs 1 .

13 E.R.O., D/P III/27/2.

14 Ibid.; ibid. D/P $11 \mathrm{I} / 27 / 1$. Most of the rest of George Starkins's land had passed to George Starkins Wallis by I 848 . is E.R.O., D/DXs 1. The sudden cessation of entries in the Court Book after i 860 suggests that the 1860 court was in fact the last one held for the manor. 
Wright and others who still held it in $1914 . .^{16}$ By 1917 the estate was apparently not regarded as a manor. ${ }^{17}$

There is no longer a house at Otes. The site, which is partly moated, is clear except for a well shaft and two large lime trees. South-west of the moated enclosure are the remains of an orchard wall and of two outbuildings. One of these buildings was constructed of re-used timbers. South of the site a small stream has been dammed, probably in the I 8 th century, to form an ornamental lake with a weir at its outlet.

In about I770 Otes was said to be one of the only two good houses in the parish: 'a large building, in a delightful situation, with a park, gardens, canals etc.' 18 A woodcut of the house, published in 1821,19 shows on the left hand a low three-gabled block, apparently timber-framed and plastered. It was probably of medieval origin, altered in the 16 th or early $17^{\text {th }}$ century. There were slightly projecting oriel windows and a two-storied porch with a pointed entrance arch. Adjoining the old house to the right there were two later additions. In front was a square three-story block, probably of the Queen Anne period.20 Behind this was a two-story wing in the picturesque style of the late I 8 th century. In 1801 it was said that the newer part of the house had been recently erected.21 The building is said to have been demolished in 1822.22 In 1835 it was described as 'completely destroyed'. ${ }^{23}$ Some outbuildings remained, however, for some time. ${ }^{24}$ The last of them fell in 1952.25

The advowson of High Laver was held by the lords of the capital manor until I 3 I $5 .{ }^{26}$ In that CHURCH year Alcher son of Henry retained the advowson when he granted the manor to his son Henry and Henry's wife Beatrice. ${ }^{27}$ In I 33 I and I 334 Alcher presented to the church. ${ }^{28}$ In I 337 he converted his interest in the advowson into a life interest with remainder to Sir John de Shardelowe for life and then to John, son of Sir John, in tail. ${ }^{29}$ In 1366 William de Ferrers, probably Lord Ferrers of Groby (d. I 37 I), presented.30 Later presentations were made by John de Beston and others in 1398 , by William, Lord Ferrers of Groby (d. I 445), in 1400, and by John Gwyne and others in 1426.31 By 1438 the advowson again belonged to the lord of the capital manor. ${ }^{32}$ It then descended with the manor until soon after 1662 when the manor passed to coheiresses, Sarah, wife of Jacob Foster, and Martha, wife of Richard Matthews. ${ }^{33}$ In 1683 Sarah and Jacob Foster, Martha and Richard Matthews, Samuel and Mary Lewin, and Joseph Reeve conveyed the advowson to Georgc Cole and John Knapp. ${ }^{34}$ In 17 ro Georgc Colc presented and in 1727 William Cheval. 35 In 1729 the advowson was held by the rector, Martin Hall, who in that year sold it to Alexander Cleeve. ${ }^{36}$ After Hall's death in I734 Alexander Cleeve presented his son John. ${ }^{37}$ Hall had encumbered the living with many debts. ${ }^{38}$ John Cleeve devised the advowson to his nephew Thomas Velley.39 In 1778 , after Clceve's death, Thomas Velley presented his brother-in-law Richard Budworth who held the living until his death in 1805.40 Afterwards Richard Budworth's trustees held the patronage until his son Philip was old enough to become rector and to hold the advowson.4I After Philip Budworth's death in I 86I the advowson was held by Captain Budworth, grandson of Richard Budworth, until his death in I 885.42 It was then held by Captain Budworth's trustees until after I906.43 In IgI 2 and IgI4 the living was in the gift of Mrs. Heales.4 By I 922 the advowson was held by Canon R. D. Budworth who retained it until his death in about 1938.45 In 1940 and I94 I it was held by the Revd.D.P.D. Budworth. ${ }^{46}$ Since I 942 it has been in the gift of the Bishop of Chelmsford,47 and since 1945 has been united with that of Magdalen Laver. ${ }^{48}$

In about 1254 and in 1295 the rectory was valued at 16 marks. 49 In 1428 the church was still taxed on this valuation. In 1535 the rectory was valued at fis Is. $6 d .50$ In 1637 there were about 47 acres of glebe. $^{5 I}$ In 1848 the tithes were commuted for $£ .520$; there were then 63 acres of glebe. ${ }^{52}$

In 1637 a terrier described the rectory as consisting of 'a parsonage-house, a kitchen by itself, a barn, a stable, and a hay-house, also an orchard, a garden-plat, a little court-yard and a great outer yard'.53 A separate kitchen was a feature of the parsonages at all three Lavers in the 17 th century and was certainly a survival from medieval times. No mention was made of a separate kitchen in a terrier of 1810 although the lathand-plaster house still existed then. 54 Shortly before he died in 1805 Richard Budworth had plans drawn up for rebuilding the rectory.55 On his death, however, the plan was abandoned and it was not until shortly after I 864 that the old parsonage was pulled down and a new one built on nearly the same site. ${ }^{56}$ The present building is a large red brick gabled house, part of it of three stories. It ceased to be used as a parsonage when the living was united with that of
16 Kelly's Dir. Essex (1870 f.). For Kelly's description of Otes Manor at this period see above, n. 36 .

I7 Kelly's Dir. Essex ( 19 I 7 f.).

18 Hist. Essex by Gent. iii, 346

I9 Monthly Magazine, lii; E.R.O.,

Prints, High Laver.

20 E.R. xvii, 212.

2 E.R.O., D/DEw T2.

22 E.R. xvii, 213.

23 T. Wright, Hist. Essex, ii, 346.

24 E.R.O., D/P $111 / 27 / 1 \& 2 ; O . S$.

6 in. Map (1st edn.), sheet xlii.

25 Hist. To-day, iii, 543.

26 Cal. Inq. p.m. iv, p. 112 ; Feet of F.

Essex, ii, I 56.

27 Feet of $F$. Essex, ii, 156.

28 Newcourt, Repert. ii, 368

29 Feet of F. Essex, iii, 4 1.

30 Newcourt, Repert. ii, 368.

31 Ibid. 32 Ibid. 33 Ibid.

$34 \mathrm{CP}_{25}(2) / 655$ Mich. 35 Chas. II.

$35 \mathrm{~J}$. Bacon, Thesaurus, 615.
36 P. J. Budworth, Memorials of Greensted-Budworth, Chipping Ongar, and High Lover, 35-36. Budworth said that before 1729 there had been 'several changes of patrons rapidly succeeding each other'. 37 Ibid. In J. Bacon, Thesaurus, 615, however, there is a record that a year before Alexander Clecve presented in 1734, John Turvin presented. ${ }_{38}$ P. J. Budworth, Mems. of GreenstedBudworth etc. 35-36. 30 Ibid.

40 Ibid. Budworth says that in 1777 Thomas Velley sold the advowson to Richard Budworth who bought it in order to present his son Richard, husband of Thomas Velley's sister. According, however, to the Bishop of London's certificate of institution ( $E_{3} 31 / 41$ ) Thomas Velley presented to the living in 1778 . What probably happened was that Thomas Velley presented his brother in law.

iI P. J. Budworth, Mems. of GreenstedBudworth etc. 36 ; Cler. Guide, $1817 \mathrm{f}$;
Clergy List, $1845 \mathrm{f}$.

42 P. J. Budworth, Mems, of GreenstedBudworth etc. 36; Clergy List, 1864. For the Budworths see also Greenstead.

43 Kelly's Dir. Essex (1 890, 1902, 1906).

44 Ibid. (1912, 1914).

45 Ibid. (1922, 1926, 1929, 1933)

Chel. Dioc. Year Bk. 1938.

46 Chel. Dioc. Year Bk. 1940, 1941.

47 Ibid. $1942 \mathrm{f}$.

48 Crockford's Cler. Dir. (1951-2); inf. from the Revd. W. D. Topping.

49 Lunt, Val. of Norwich, 337; Tax. Eccl. (Rec. Com.), 21.

so Valor Eccl. (Rec. Com.), i, 437.

5 Newcourt, Repert. ii, 368.

32 E.R.O., D/P I I 1/27/2. Tithes of the

glebe were not included in the $£ 520$.

53 Newcourt, Repert. ii, 368 .

s4 E.R.O., D/P III $/ 3 / 2$.

55 P. J. Budworth, Mems. of Greensied-

Budworth etc. 36 .

56 Ibid. 


\section{A HISTORY OF ESSEX}

Magdalen Laver and it is now a private house called High Laver House.

The parish church of ALL SAINTS consists of nave, chancel, west tower, south porch, and north vestry. The walls are of flint rubble roughly coursed, particularly in the chancel. Roman brick is found among the rubble and forms some of the quoins. Most of the dressings, originally of clunch, have been replaced.

The nave was built late in the 12 th century. It retains one small round-headed window in the north wall. West of this is an original doorway, partly restored, which now leads to the vestry. It has a semicircular arch and chamfered imposts.

The chancel, probably built about 1200 , has seven lancets with pointed heads. There are two in each of the north and south walls and three graduated lancets at the east end; all are much restored.

Two doorways, one in the north wall of the chancel and one in the south wall of the nave, are probably of the $13^{\text {th }}$ century. 'The former is now blocked but the arch in clunch is visible externally. The piscina, which has a trefoiled head and a double drain, may be of the $13^{\text {th }}$ century. There are fragments of $13^{\text {th }}$ - or $14^{\text {th- }}$ century glass in the small nave window.

The tower, of three stages, appears to have been added about 1340.57 It was originally of flint rubble, but this is now mostly plastered and much of the tower has been rebuilt in brick. The moulded tower arch is sharply pointed. In the west wall, but not axial with the arch, is a good I 4 th-century window with a pointed arch and two ogee-headed lights. There is a blocked window in the second stage of the tower on the north side. The chancel arch was probably rebuilt in the I $4^{\text {th }}$ century. The, responds and head are finely moulded. It has spread considerably at springing level and this may have caused the arch itself to drop, giving the unusual three-centred shape.

Late in the $14^{\text {th }}$ or early in the 15 th century four new windows were inserted in the nave and one in the chancel. These are all square-headed externally with label moulds and head stops. Internally the arches are three- or four-centred. The tracery, which has all been replaced, was probably originally of this date and has been copied with fair accuracy. 58

In the 15 th or 16 th century the roofs of the chancel and nave, which are ceiled in except for the plates and tie-beams, were renewed.

In 1737 the vestry agreed that the tower should be repaired and that "one Tarling should undertake it by the day and put up a brick buttress and restore the plaistering where it is necessary, the parish finding all materials'.s9 'The south-west buttresses may have been rebuilt in brick at this time as a result of this decision. In about 1789 the spire and part of the tower were found to be ruinous and were taken down.60 The upper stage of the tower, and probably the south-west

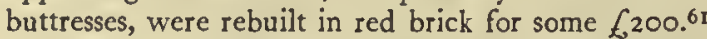
The parapet is castellated and there are round-headed windows to the belfry. The octagonal spire is shingled.
A general restoration of the church possibly took place in 1865 , when the font and tomb of John Locke were repaired. 62 The south porch and the vestry appear to date from this period. 'The porch, which is of flint with a timber superstructure, replaced a plastered porch ${ }^{63}$ of unknown date. The vestry, on the north side of the nave, is of flint with limestone dressings.

In 1873 an organ was built in the chancel.64 In 1927 the chancel was altered, the choir stalls and a igth-century stone pulpit being cleared away and the organ moved to the west end. The alterations cost E1 27 of which $6_{4} 43$ was contributed by the Rhode Island Society of America. ${ }^{65}$

The font, which stands in the tower, dates from the middle of the 14th century. It has an octagonal bowl on each face of which is a quatrefoil panel enclosing a shield. The prayer desk in the chancel is a memorial to those killed in the First World War ${ }^{66}$ and the oak pulpit is of the same style and date.

There is one bell in use and a small disused sanctus bell. In 1552 there were two bells in the steeple weighing about $18 \mathrm{cwt}$., two 'rogacione bells' weighing $9 \mathrm{lb}$, and a sanctus bell of $3 \mathrm{lb} .67$ In about 1768 there were three bells. ${ }^{68}$ In about 1790 the parishioners agreed that 'one large bell and a small bell or Saints Bell only shall be hung in the steeple of the church instead of three bells and that two of the said three bells shall be sold' and the money used to help defray the cost of rebuilding the steeple. ${ }^{69}$ In 1866 the cost of a new bell, evidently a replacement, was raised by a rate of $4 d .70$ 'The sanctus bell is inscribed 'XPE AUDi Nos' ${ }^{71}$ It is probably of the 14 th century and is one of the few remaining medieval sanctus bells in Essex. ${ }^{72}$

From $1657-8$, or earlier, the church owned Bell Acre ( 1 a. 3 r.), in the north-east of the parish. ${ }^{73}$ The rent from this land, which was 61 a year until at least 1805 , was usually spent on church repairs in the 8 th and 19 th centuries.74 In 1921 the rector informed the Charity Commissioners that the rent had been applied to church expenses since before 1915.75 In 1945 dividends of $f_{2}$ were spent in maintaining the church grounds.76 In 1952 the land was sold for $f_{1} 20.77$

Nearly all the church plate was given by Sir Francis Masham, Bt., and his son Samuel, Lord Masham (d. 1758). It includes two silver cups, one of 1674 given by Sir Francis and one of 1735 given by Lord Masham; two silver patens, one undated but given by Sir Francis, and one of 1735 given by Lord Masham; and a silver almsdish dated 1724 and given by Lord Masham in 1735.78

In the chancel is a brass to Myrabyll (Mirabel), wife of Edward Sulyard (c. 1495).79 There are figures of

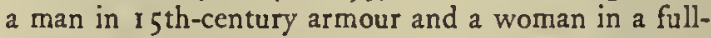
skirted gown and a pedimented head-dress. Below are figures of four sons and one daughter and a rhymed inscription. There are floor slabs in the chancel to Sir Francis Masham (1723) and his granddaughter Elizabeth Masham (1724). On the north wall is a marble tablet to Damaris, widow of Ralph Cudworth,
37 Hist. Mon. Com. Essex, ii, 130.

$\$ 8$ Early-19th-cent. engravings (E.R.O., Prints, High Laver) show much the same tracery.

59 E.R.O., D/P III $/ 8 / 2$. 60 Ibid. 61 Ibid. Of this, $\ell_{6} 150$ was borrowed from Thomas Speed of Harlow, maltster, because the parishioners were unwilling that so large a sum as 200 should be raised by one rate.

62 Kelly's Dir. Essex (1886).
63 Sketch dated 1821 : E.R.O. Prints, High Laver.

64 Vestry Minute Book 1863-1943, in possession of the rector.

63 Ibid. The society's contribution was in memory of Roger Williams, founder of the colony, who was married at High Laver in $1629 . \quad 66$ Insctiption in situ.

67 E.A.T. N.s. ii, 228-9.

68 Morant, Essex, i, 141

69 E.R.O., D/P I I $1 / 8 / 2$
70 Vestry Minute Book I863-1943; Ch. Bells Essex, 316.

7 Ch. Bells Essex, 316.

72 E.A.T.N.s. $\times x \mathrm{x}, 2 \mathrm{I7}$

73 E.R.O., D/P II $/ 8 / \mathrm{r}$; ibid. D/P

II $/ 27 / 2$.

74 E.R.O., D/P I $11 / 8 / 2$.

75 Char, Com. Files.

76 Ibid.

78 Ch. Plate Essex, 136.

79 E. A.T. N.s. vii, $13-17$. 
Master of Christ's College, Cambridge. ${ }^{80}$ The epitaph is thought to have been composed by John Locke. ${ }^{81}$ Also in the chancel are tablets to Samuel Lowe (1 709), Richard Budworth (1805), and Philip Budworth ( 1861 ), rectors. In about 1835 there was in the chancel a broken brass plate bearing an imperfect inscription in ancient characters in memory of Robert Ramsey (probably died about 1436 ) and his wife Joan; 82 this plate has now disappeared.

Outside the south wall of the nave is the brick altar tomb of John Locke ( 704 ). A mural tablet, originally above the tomb, was moved inside the church for preservation in 1932,83 the tercentenary of Locke's birth. Outside the church near the east end there are many other altar tombs, of the Budworth, Cleeve, Velley, and Masham families.

There is a chapel of ease at Matching Green dedicated to $S T$. EDMUND. It was built in $1874^{84}$ at the expense of Francis R. Miller, Vicar of Kineton (Warws.). ${ }^{85}$ It is of yellow brick with a small western bell-cote. It consists of a nave and chancel. In 1945 it was transferred to the ecclesiastical parish of Matching. ${ }^{86}$

The house of Robert Morris in High Laver was licensed for Presbyterian wor-

NONCONFORMITY ship in 1673,87 but no permanent congregation appears to have been established. About I $869 \mathrm{Mr}$. Vale, the Congregational evangelist from Moreton (q.v.), started preaching at Thrushesbush in High Laver. ${ }^{88}$ In 1870 Vale reported that the work at Thrushesbush was not going well, 'great influence is used to prevent the poor from attending'. ${ }^{89}$ For several years Thrushesbush continued to be associated with Moreton. In 1876 the Revd. W. Passmore of Moreton and the Revd. G. E. Singleton of Hatfield Heath both helped there, and in 1877 a chapel was opened, the gift of Mr. Matthews of Campions, near Hatfield Heath. 90 In 1882 it was attended by about 60 , but by ${ }^{2} 883$ it had ceased to be used by the Congregationalists. 91

In 1883 it was proposed that the Wanstead and Woodford Methodist circuit should take it over. The circuit refused, but Messrs. E. Pope, Godwin, and Bowes purchased the chapel, and it was subsequently accepted on the circuit plan.92 It was later taken over by the North West Essex Mission and had apparently been closed by 1906.93

It is now a dwelling house called 'Drinkwaters'. It lies outside the parish boundary on the north side of the Harlow road. The upper part of the structure is timber framed, the panels being filled with brick nogging and plaster. The front is altered.

Vestry minute-books for High Laver survive for

1657-1804 $4^{94}$ and 1863

PARISH GOVERN- 1943.95

$M E N T A N D \quad$ Until I682 vestry meetings

POOR RELIEF seem to have been held only at Easter in each year. From

1682 meetings were held at Easter and Christmas. In 1739 four meetings were recorded and if a resolution

80 Dr. Cudworth and his wife were Rector of High Laver.

parents of Damaris, second wife of Sir

Francis Masham, 3rd Bt.

81 Undated cutting c. 1 $\$ 30$ : E.R.O.

Prints, High Laver.

82 T. Wright, Hist. Essex, ii, 348 note.

83 Inscription in situ.

84 Kelly's Dir. Essex (1874).

85 Ibid. ( 1886 ).

87 G. L. Turner, Orig. Recs. of Early Nonconformity, ii, 929 .

88 Essex Congr. Union Reps. 1869.

89 Ibid. 1870

90 Ibid. $1876-8$.

91 Ibid. $1882-3$

92 Address by A. W. Leach, J.P., at Wanstead, Dec. 1919 , reported in Mins of Local Preachers' Mtg. Wanstead and of 23 April 1739 was carried out there must afterwards have been at least three meetings a year, at Easter, Michaelmas, and Christmas. In later years meetings were sometimes held at other times also.

Until John Clecve became rector in 1734 the minutes were brief and rarely signed. Only three resolutions were entered before 1735 and two of these were not signed. Only the appointment of officers and the approval of their accounts were usually recorded. Until the end of the 17 th century the totals of officers' receipts and disbursements were usually entered, but from 1696 until 1735 the minutes only recorded the annual balances and sometimes omitted even this. Cleeve exercised an immediate influence on the parish records. He attended vestry meetings regularly and he wrote the minutes. Vestry resolutions were recorded regularly and were always signed by him and the parishioners present. Moreover, from 1735 it was again the practice to record the details of accounts although it did not become customary to sign them. From Cleeve's death in 1777 until 1804 the accounts continued to be minuted in the same fashion, but only once, in $179^{\circ}$, was a vestry resolution recorded.

The number of parishioners attending vestry meetings before 1776 varied between 2 and 7 but was usually between 4 and 7 until 1745 and 2 or 3 after that date. At a vestry in 177 I it was agreed that in future anyone absenting himself from a meeting without a good excuse should be fined $6 d$. The next recorded vestry, in 1776 , was attended by six parishioners. Only once after this, in 1790 , were the minutes signed and then there were nine signatures. In the 17 th and early 18 th centuries the Mashams of Otes evidently took an active interest in parish affairs and attended vestry meetings. Of the five occasions on which minutes were signed before 1735 , Sir Francis Masham, 3rd Bt., signed twice, in 1665 and 1667 , and F. C. Masham, half brother of Samuel, Ist Lord Masham, and heir of John Locke, signed once, in $\mathrm{I} 728$. Sir Francis signed before, and F. C. Masham after, the rector. When it became the practice to sign the minutes the Mashams were usually not resident in the parish and their signatures never appeared in the minutes. The owners of the capital manor seem never to have attended vestry meetings, but Abraham Thorrowgood, tenant of the estate by 1767 , took an active part in parish affairs from 1764 and usually signed the minutes immediately after the rector.

The main work of the vestry consisted in appointing officers and approving their accounts. It evidently became the practice, however, for the poor to take complaints to vestry meetings and for individuals to use these occasions to settle their accounts with parish officers. In 1767 it was resolved that 'for the future no business whatsoever shall be done on the day the accounts are settled but what relates to the parish business of that day only, so that the poor shall bring their complaints on the vestry immediately preceding, and all private accounts between officers and others shall be settled either before or after that day'.

Woodford Circuit. For Pope see Loughton Nonconformity.

93 Ibid.; Kelly's Dir. Essex (1906)

94 E.R.O., D/P II $/ 8 / 1$ \& 2 . Unless otherwise stated all the following information is derived from these minute-books. A separate "Poor Book" was evidently kept hut this is now missing.

is In possession of the rector. 


\section{A HISTORY OF ESSEX}

In 17 I 2 it was agreed that 'Henry Marling shall have 20 . a year allowed for church clerk's wages'. In I 735 it was agreed that 'the clerk shall receive $4 d$. yearly of every householder that does not pay to the poor'. In 1743 it was resolved that Ios. a year should be added to the clerk's wages.

There were two churchwardens in each of the years I6I 3 and $16 i_{4}$. There were also two each year from I657 until I698. During this period they usually served for 2-4 years consecutively. From 1698 there was only one churchwarden, who usually served for many consecutive years.

Until 1672 there were two overseers each year and they usually served for two or three years consecutively. From 1672 there was only one overseer. Until 1724 it was usual to serve two years consecutively, but afterwards the overseers served for one year only. They were evidently chosen on a rota system and once, in 1802 , a woman, Mrs. Elizabeth Speed, tenant of the capital manor, was appointed to serve.

Constables were nominated in vestry at least from 1657. Until 1704 there were always two, each of whom usually served two years consecutively. Thereafter there was usually only one. Until 1743 this officer usually served no more than two years at a time, but after that date he usually served for at least three consecutively and sometimes much longer.

Two surveyors of highways were nominated annually. From I 682, if not before, they were appointed at Christmas. The number of years served consecutively varied from one to five. Sir Francis Masham was surveyor from 1672 until 1676 .

Until at least 1739, and perhaps until 1743, the overseers, churchwardens, and constables were each granted separate rates for which they were directly responsible to the parish. Occasionally one officer was ordered to pay another officer's deficit out of his surplus. In the churchwarden's account of expenditure for $1692-3$ there were four items, totalling is. I I $d$, 'for relief'. These items were passed only after some hesitation and it was resolved "never to allow any reliefs hereafter paid by churchwardens'. From I743, if not from 1739, the constables were no longer granted separate rates. Their expenditure was met by the churchwardens who included it in their account. There is no clear evidence that the surveyors accounted directly to the parish until $1743-4$ when they received a separate rate for which they accounted to the vestry. From I 744 until 1747 the churchwarden, who was also one of the surveyors, included their expenditure in his accounts, but after 1747 there was always a separate surveyors' account.

There was a workhouse in High Laver in 1767. In that year the vestry agreed "that the old persons in the workhouse shall have one-quarter of what they shall earn and the other three parts shall go to the governor of the workhouse'. By 1776 , however, the house had become a mere poorhouse where paupers were lodged rent free. ${ }^{96}$ It lay on the north side of the Harlow Road about 1 mile west of the church.97 In I $84 \mathrm{I}$, when it was no longer a poorhouse and belonged to George Starkins, it was a cottage, occupied by three tenants. 98

In most cases poor relief was given, in various forms, outside the poorhouse. In each of the years $1813-15$ there were 20-22 adults on 'permanent' outdoor relief. 99 Provision for the poor was made in various ways, including the binding out of paupers' children as apprentices, the payment of rent, and the provision of clothes. Parish apprentices were allotted on a rota system. In 1738 it was agreed that 'no poor person's rent should be paid by the parish for any time before he becomes chargeable without a special order of vestry'. In 1753 John Parsons agreed to attend the poor as apothecary and surgeon 'except midwifery and smallpox' for 3 years at $4 \frac{1}{2}$ guineas a year.

In I6I3-I 4 the cost of poor relief was 649 s. In I 734-5 it was 624 . It then rose sharply to a maximum of $6_{104}$ in $1741-2$. In 1776 it was $6133^{2}$ and in $1783-5$ it averaged $£_{1} 65.3$ In $1800-1$ it reached $£ 724$, but in the next seven years never exceeded $£_{5} 20$ and was sometimes much lower. ${ }^{4}$ In the remaining years of the Napoleonic war the cost averaged $\oint_{5} 82$ a year and in $1816-17$ it was 6634.5

In 1836 High Laver became part of the Ongar Poor Law Union.

There were no schools in the parish in 1807 and I 8 I 8 although at the latter date the rector,

SCHOOL P. Budworth, was helping to maintain a private school in Moreton, to which presumably he sent High Laver children. ${ }^{6}$ By 1828 a day school in union with the National Society had been established. In that year it had 30 pupils, 7 but attendance declined until in 1832 it seems to have been closed. ${ }^{8}$ In 1833 there was only a private school in the parish, founded in 1832 . It had 40 pupils and further accommodation was available at a dame school in Matching, which some 30 High Laver children attended in 1839.9 In 1833 , however, the Sunday school was refounded in High Laver and by $1846-7$ this had apparently led to the setting up of a day school, under the Diocesan Board, with 27 pupils and a further 7 on Sundays. The schoolmistress was paid EI6 a year. ${ }^{10}$ This school had ceased by 1865 when there was only an inefficient dame school in the parish. II

In about 1865 the rector, with the support of the largest landowner (J. W. Perry Watlington) and other churchmen, established a Building Committee to collect subscriptions for a new school for High and Little Laver, with a teacher's residence of six rooms attached. The school, with accommodation for about 75 children, was built in 1866 at Matching Green at a cost of $£ 668$, of which the Treasury contributed 6143 I $5 s$., the Diocesan Board £35, the National Society £37, and subscribers the rest. ${ }^{12}$ It was placed in union with the National Society and was managed by the rector and churchwardens. ${ }^{13}$ In 1870 there were 75 pupils at the school and 25 infants in an unsuitable room nearby. In $187 \mathrm{I}$ an infants' classroom was built with the help of 6.24 from the Treasury, 610 from the Diocesan Board, $£_{5}$ from the National Society, and some local subscriptions. ${ }^{14}$ In 1872 the Education Department



4 E.R.O., Q/CR I/9.

5 Ibid.

6 E.R.O., D/AEM $2 / 4$ (Archdeaconry) Reins. Educ. Poor, H.C. 224, Pp. 260, 262 (I 8 I 9 ), ix (I)

7 Nat. Soc. Rep. I 828 , p. 62

8 Nat. Soc. Rep. 1832, p. 61; Educ. Enquiry Abstr. H.C. 62, p. 28 I (1835), xli
9 Educ. Enquiry Abstr. H.C. 62, p. $28 \mathrm{I}$ (1 835), xli ; E.R.O., D/P $30 / 28 / 19$.

10 Nat. Soc. Enguiry into Church Schs. I $846-7$, pp. I $2-13$.

11 Inf. from Nat. Soc.

12 Ibid.

$13 \mathrm{Min}$. of Educ. File I $3 / 196$.

14 Inf. from Nat. Soc. 
said that the accommodation was sufficient for the parish.15 Attendance increased considerably in the next eight years and the annual grant rose from $£_{2} 6$ in 1872 to 6.58 in 1880.16 In 1899 , when there was accommodation for 132 pupils, there was an average attendance of $\dot{95}$ and a grant of 685 was received. 17 In 1900 about $5^{8}$ people were subscribing money for the school.18 Attendance, however, was falling as the population of the parish declined. In 1904 there were 84 pupils and 3 teachers. ${ }^{9} 9$

By the Education Act of 1902 the school passed under the administration of the Essex Education Com- mittee as a non-provided school. The average attendance fell to 76 in 1914 and 57 in 1938. In 1939 the school was reorganized for mired juniors and infants. ${ }^{20}$ In May 1952 there were 2 teachers and 44 pupils. ${ }^{21}$

The school is a single-story red-brick building. On the front is a combined chimney and bell-cote.

Magdalen Laver school, which is situated a little to the south-west of Tilegate Green just within the southern boundary of High Laver, is attended by children from this part of the parish as well as by those from Magdalen Laver (q.v.).

CHARITY. For Bell Acre charity see above, Church.

\section{LITTLE LAVER}

Little Laver is a small parish about 5 miles to the north of Chipping Ongar, ${ }^{1}$ with an area of 964 acres. $^{2}$ In 1428 it contained fewer than 10 households. 3 There were 15 inhabited houses in $180 \mathrm{r}, 20$ in $181 \mathrm{r}$, and 16 in 1821.4 In $180 \mathrm{r}$ the population was 90.5 By $184 \mathrm{I}$ it had grown to $128 .{ }^{6}$ It declined in the next 30 years to 104 , then rose to 124 in 1891.7 At the end of the century it fell just below 100 and has since remained about this level. ${ }^{8}$ In 195 I it was 96.9

The land is about $280 \mathrm{ft}$. above sea-level in the east and $230 \mathrm{ft}$. in the west. Three streams run across the northern half of the parish. There is a small area of woodland on the north-east boundary. The road from High Laver to Abbess Roding crosses the western boundary of the parish and runs eastward. On the south side of the road, about $\frac{1}{2}$ mile from the boundary, is Church Farm, where there is part of a large moat. Farther east are Little Laver Mill and the Mill House. ${ }^{10}$ Beyond the mill the road is joined by a road which runs southward to Moreton. On the east side of the road junction is the Red House, a timber-framed farmhouse of the 18 th century or earlier. To the south of the Red House, on the west side of the Moreton road, is the former rectory. "I East of the Red House on the road to Abbess Roding is the village hall. ${ }^{12}$ To the south of the road on the eastern boundary of the parish is Envilles. ${ }^{3} 3$

Nearly opposite the village hall a road runs northwest to Matching Green. On the west side of this road is Gosling Hall, a two-story timber-framed building probably of the I 5 th century. It originally consisted of an open hall of two bays with a two-story cross-wing at its north end. The south end of the hall block may be a later addition. In the 16 th or early 17 th century a chimney was built in the south bay of the hall, a ceiling was inserted and the roof was renewed and possibly raised. The lower part of the arched braces to the tiebeam of the original hall roof-truss can still be seen in

is Chelmsford Chronicle, 2 Aug. 1872.

16 Rep. of Educ. Cttee. of Council, 1872 [C. 812 ], p. 408 , H.C. (I 873 ), xxiv; ibid., I880 [C. $294^{8-1}$ ], p. 577, H.C. (188I), xxxii.

17 Retn. of Schs. I8g9 [Cd. 315], p. 71,

H.C. (1900), lxv (2).

18 Min. of Educ. File I $3 / 196$

10 Essex Educ. Cttee. Handbk. 1904.

p. 185 .

20 Min. of Educ. File I $3 / 196$.

21 Inf. from Essex Educ. Cttee.

O.S. $2 \frac{1}{2}$ in. Map, sheets $52 / 50$, $52 / 5 \mathrm{I}$.

2 Inf. from Essex County Council.

3 Feud. Aids, ii, 205.

4 Census, 1801, 18I I, I 82 I.

V.C.H. Essex, ii, 350. the ground floor room of this block. A cambered tiebeam, originally having arched braces, is also partly visible above the first floor room of the cross-wing. The gabled east end of this wing oversails and has curved supporting brackets. An external chimney on the north side, partly rebuilt recently, has diagonal shafts and is probably of the 16 th or early 17 th century. Beyond Gosling Hall to the north are the church ${ }^{14}$ and the old manor house, now called the Grange. ${ }^{15}$ Farther north there is a windpump on the west side of the road. Opposite this is a long drive north-east to Little Laver Hall. ${ }^{16}$ To the north of the drive on the road to Matching Green are Stone Cottages, formerly the parish poorhouse. ${ }^{17}$ About $\&$ mile farther north is Hull Green farm-house, which is probably of I 8 th-century date. From Hull Green the road turns westward and forms the parish boundary for a short distance before joining the road from Matching Green to Ongar. South of the junction the Ongar road, called at this point Water Lane, forms the western boundary of the parish for about a mile. On the east side of this road is Waterman's End House, a timber-framed building of the I 8 th century or earlier. North of the house is a pair of r 8 th-century cottages. South of Waterman's End House, on the same side of the road, is a brick house which until I 886-9018 was the Leather Bottle Inn. 19

Postal facilities were extended to Little Laver when a receiving office was set up at Moreton in 1846.20 Water was supplied by the Herts. and Essex Waterworks Co. in I9I2.21 Electricity was supplied to one end of the parish in 1950.22 There is a village hall, erected in $189 \mathrm{r}^{23}$

Little Laver has always been a rural parish devoted mainly to agriculture. The Collins family, owners of the manors of Little Laver Hall and Envilles for a century or more after 1559 , lived in the parish at least during the period I 599-167 I. ${ }^{24}$ It is not clear whether the owners were resident in the period immediately

Bottle Inn but the name of the inn was 6 Ibid. 7 Ibid. 8 Ibid.; Census, I 91 I $\mathrm{f}$. 9 Census, I951.

10 See below.

11 See below, Church. 12 See below, School.

13 See below, Manor of Envilles.

14 See below, Church.

is See below, Manor of Little Laver Hall. 16 Ibid.

17 See below, Parish Government and Poor Relief.

18 Kelly's Dir. Essex (1 886, 1890 ).

10 The location of this inn in Chapman and André, Map of Ersex 1777, plate xii, appears to be wrong. According to this map there was at that time a building on the site later occupied by the Leather attached to a building about I mile farther south on a site now occupied by America farm in High Laver. As there was undoubtedly a Leather Bottle Inn in Little Laver by 1769 it is almost certain that on the map of 1777 the name was attached to the wrong building: E.R.O., D/CT $210 ; 6$ in. O.S. Map (Ist edn.), plate xlii; $2 \frac{1}{2}$ in. O.S. Map, sheets 52/50, 52/51: E.R.O., Q/RLv 24-82.

20 P.M.G. Mins. I 846 , vol. 87, p. 5 .

2I Inf. from Herts. \& Essex Waterworks Co.

22 Inf. from East. Elec. Bd.

23 See below, School.

24 E.R.O., D/P 147/1/1; ibid. Q/RTh $1 \& 5$. 


\section{A HISTORY OF ESSEX}

after the Collinses disposed of the estates. The owners of Little Laver Hall certainly did not live in the parish from I7 I4 until after the Meyers acquired the estate in $1804-5.25$ Christian P. Meyer, who succeeded to the estate in I $828-9$, was resident by 1848 and since his time the owners of this estate have always lived in the parish. ${ }^{26}$ Whether the owners of Envilles did so in the first three quarters of the I 8 th century is not clear; certainly they were not resident between 1780 and I 897.27

In 1848 the parish consisted of 968 acres. ${ }^{28}$ C. $P$. Meyer owned 270 acres of which he occupied only i5 acres. ${ }^{29}$ John Maryon Wilson owned 249 acres but farmed none of it himself. ${ }^{30}$ The only other substantial owner in the parish was Thomas Poynder who owned, but did not occupy, Hull Green Farm (I I 9 acres). ${ }^{31}$ There were two other farms of over 40 acres..$^{32}$

Then, as now, there was mixed farming in the parish, with a marked predominance of arable. In I 847 it was estimated that there were 7 I 6 acres of arable, I 50 acres of pasture, and 23 acres of woodland. 33

There has been a windmill on the site of the present mill since the first half of the 17 th century. ${ }^{34}$ From the late I 8 th century until the First World War the mill descended from father to son, four consecutive millers being named Stephen Roast. ${ }^{3 S}$ The first of these, who died in 1797 , is said to have left money for his son to build the present mill. ${ }^{36}$ This was originally a weatherboarded post mill of the usual local pattern. The tall brick base, about $20 \mathrm{ft}$. high, is an improvement said to date from about I $860 .{ }^{37}$ The wooden superstructure was raised on jacks and props and a second story was added to the round house ${ }^{38}$ giving extra height and storage space. It thus became a combination of smock and post mill and appears to be the only example known of this type. The fantail was also added about $i 860$. A miller named Hart ${ }^{39}$ succeeded the last of the Roasts but the mill ceased working soon after I930.40 It is now the property of J. Brace \& Sons of High Ongar and is used for storage purposes by their tenant.4I The Mill House, which stands west of the mill, is a timberframed building probably dating from the 17 th century.

In ro66 LIT'TLE LAVER was held as a manor by Brictmar. 42 In 1086 it was held of Eustace MANORS Count of Boulogne by Richard and was worth ros.43 In I I go an assize was held to determine whether Eustace de Lagefare had more right to hold the 'land of Lagefare' of the king than the king had to hold it in demesne.44 In 1200 Ralph de Rochester brought a suit against Eustace de Lagefare, the tenant, for possession of the land.45 Afterwards they came to an agreement whereby Eustace de Lagefare acknowledged 'all the town of Lagefare' to be the right of Ralph de Rochester who granted to Eustace the services of 8 tenants and 27 acres of land to hold of him by the service of $\frac{1}{3}$ knight's fee. ${ }^{46}$ In 12 I 2 and 12 I 7-I 8 Ralph de Rochester held Little Laver in chief of the king by the service of $\frac{1}{2}$ fee and Richard de Rochester and his brother Eustace held the manor of Ralph. ${ }^{47} \mathrm{It}$ was probably from this division of the manor between Eustace and Richard that there came to be two manors in Little Laver: Little Laver alias Bourchiers Hall and Enfields alias Envilles (see below). It seems, however, that until 1325 , if not later, the estates held by the successors of Eustace and Richard were considered not as separate manors but as parts of one manor.48 In I 307 this manor was held of Robert, 2nd Lord Scales, whose great-grandfather Robert de Scales (d. before 1 250), had probably inherited it through his wife Alice de Rochester.49 Robert, and Lord Scales, died in 1325 and was succeeded by his son Robert, 3 rd Lord Scales.so After this Envilles and Bourchiers estates came to be regarded as separate manors but they probably continued under a common overlord. Certainly in I 428 the tenant in chief of both manors was Humphrey

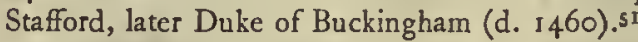

In 1303 Bennet le Brun held $\frac{1}{4}$ fee in Little Laver. ${ }^{52}$ Shortly afterwards the Bourchier family came into possession of this estate. In 1325 John le Bousser and others were tenants of the manor of Little Laver which was held by the service of I fee.\$3 Soon afterwards Bousser's estate became a separate manor known as LITTLE LAVER HALL alias BOURCHIERS HALL. In I 330 Robert, afterwards I st Lord Bourchier, was granted free warren in his demesne lands in Laver. ${ }^{54}$ In I 346 John Bourchier, son of Robert, held the $\frac{1}{4}$ fee which Bennet Broun once held.ss In 1384 John, now 2nd Lord Bourchier, was granted free warren in the demesne lands of his manor of Little Laver. ${ }^{56}$ This manor now followed the same descent as that of Bourchiers Hall in Moreton (q.v.) until 1559 when Richard, rst Baron Rich, conveyed it to John Collins.57 Thomas Collins was lord of the manor in I $584 . .^{58}$ The estate remained in the Collins familys9 until it was sold to Matthew Blucke of Hunsdon (Herts.) who died about I 7 I $3 .{ }^{60}$ From I 563 to I 660 or later the Collinses also held Envilles (see below). For some years Blucke had held the office of usher of the rolls of the Court of Chancery and after his death it had been decreed by the court that his private estate should be sold to meet debts arising from his term of office. ${ }^{61}$ Accordingly in 17 I 4 Little Laver manor was sold for $\oint_{2}, 100$ to Samuel, Ist Baron Masham.62 At that time the estate contained 300 acres and was in the occupation of Thomas Halden.63 In 1736 Lord Masham settled the manor on his son Samuel at the

\footnotetext{
25 See below, Manor of Little Laver Hall; E.R.O., Q/RPI 685 f.

26 See below, Manor of Little Laver Hall; E.R.O., D/CT 2 ro; Kelly's Dir. Essex, 1859 f.

27 See below, Manor of Envilles; E.R.O., Q/RPI 685-737; ibid. D/CT 210.

28 E.R.O., D/CT 2 Io.

29 Ibid.

31 Ibid.

32 Ibid.

30 Ibid.

34 F.R.O. Q/SR $28 \mathrm{I} / 9$; D. Smith

English Windmills, ii, 49.

35 D. Smith, English Windmills, ii, 49.

36 Ibid.

37 E.R. $x 1,163$.

38 D. Smith, English Windmills, ii, 49.

${ }^{39}$ Kelly's Dir. Essex (1926).

40 E.R. xl, I 63.
}

4 Inf. from present tenant.

42 V.C.H. Essex, i, 4676.

43 Ibid. See note under High Lave about the difficulty, emphasized by J. H.

Round, of distinguishing between High Laver and Little Laver in Domesday.

14 Pipe R. I I go (P.R.S. N.s. i), II I.

45 Rot. Cur. R. (Rec. Com.), ii, 259.

46 Feet of F. Essex, i, 22.

47 Bk. of Fees, i, I 2 I, 240.

48 Cal. Inq. p.m. vi, p. 372

49 Feud. Aids, ii, 439; W. Farrer, Hons. and Knights' Fees, iii, 269-70; Complete Peerage, xi, 499-50I. The exact relationship of Alice to Ralph de Rochester is uncertain but she may have been his granddaughter. Cf. Morant, Essex, i, 143. so Cal. Ing. p.m. vi, p. 372.
51 Feud. Aids, ii, 222

32 Feud. Aids, ii, 136 .

53 Cal. Inq. p.m. vi, p. 372.

s4 Cal. Chart. $R$. 1 327-4I, I9I.

ss Feud. Aids, ii, 160 .

56 Cal. Chart. R. I 341-1417, 296.

$57 \mathrm{CP}_{25}(2) / \mathrm{I} 26 / 1606$.

58 E.R.O., D/DK M 20 .

39 In the records the family name is sometimes spelt Collins, sometimes Collin, and occasionally Collen.

60 E.R.O., D/DEw TI ; Morant, Essex, i, 143 .

61 E.R.O., D/DEw Tr. 62 Ibid.

63 Ibid. The estate was reported to have been previously in the tenure or occupation of Richard Collins and William Collins 'or either of them or their assigns'. 
time of the latter's marriage to Henrietta Winnington.64 In 1757 the Hon. Samuel Masham mortgaged this manor and his two other manors of Otes in High Laver and Matchinghall in Matching to Dr. Robert Taylor for $\{3,000.65$ At that time the manor house and farm were rented by Thomas Halden for $\oint_{1} 35^{\prime}$ a year. ${ }^{66}$ There were no freeholders or copyholders. 67 In 1765 and 1766 the manor was included in the mortgage of the Masham estates to Robert Palmer and came into his possession with the other estates in 1767.68 In I 80 I it was sold by Richard Palmer to William Clark for $£ 5,855$ of which $£ 755$ was paid for the timber on the estate.69 At that time the manor farm consisted of about 285 acres of which 235 acres were arable.70 The whole farm except for 20 acres of woodland, which Richard Palmer had kept in hand, had been leased to John Hall in 1799 for 21 years at $£_{0} 60$ a year.71 There twere no quit rents and no royalties. 72

William Clark was owner of the estate until 1804 or 1805 when it was acquired by James Meyer. ${ }^{73}$ In I 828 or 1829 it passed to Christian P. Meyer who built a new house, afterwards known as Little Laver Hall, for his own occupation, leaving the old manor house for his tenant John Hall.74 C. P. Meyer still owned the estate in 1848 ; it then consisted of 270 acres of which he occupied I 5 acres and John Hall 255 acres.75 C. P. Meyer was succeeded before 1859 by his son Herman who died in 1893 leaving as his heir his son James. 76 In I930 James Meyer sold Little Laver Hall to Mr. E. W. Bovill.77 In 1943 he sold the rest of the estate, including the manor farm and the old manor house, to Mr. T. Glasse, who still owns and farms the property. ${ }^{78}$

The old manor house is now known as The Grange. It stands on a moated site; parts of the moat were filled in during living memory and only fragments now exist. The older part of the house is on its east side and consists of an L-shaped timber-framed structure with wings running east and north. In the centre is a massive brick chimney, cruciform above roof level, on which the date 1587 has been recut. The east wing may be a late-r 6th-century adaptation of an earlier structure and there are indications that it was formerly of greater extent. The north range was probably built in 1587 as a two-story 'solar' wing. The ground floor fireplace has a fine three-centred chamfered brick arch, $9 \mathrm{ft}$. wide, and there is a heavily moulded cross-beam in the same room. In the upper room an arch-braced roof truss is partly visible. A single-story extension to this wing at its north end is now a dairy. Various timberframed additions and a staircase were inserted later in the angle of the two wings. About the middle of the rgth century a gabled brick wing was added on the west side of the house.

Little Laver Hall was probably built about 1845 .
The original gabled house was of brick and stucco with hood-moulds to the windows and a two-story bay on the garden side. The south and east wings were added in 1930.79

In 1299 Sir Henry de Enfield was granted free warren in his demesne lands in Little Laver and Fyfield.80 In 1303 Ralph of Essex was reported as holding $\frac{1}{4}$ fee in Little Laver. ${ }^{81}$ Ralph probably held a life interest only, for it scems that Sir John, son and heir of Sir Henry de Enfield, afterwards held the estate. ${ }^{82}$ In 1325 John de Enfield and others were tenants of the manor of Littlc Laver which was held by the service of I fee. ${ }^{83}$ In 1329 Sir John de Enfield divided his estates in Little Laver, High Laver, and clsewhere between his sons. He granted to his sons William and Thomas, and to the heirs of William, a messuage, a mill, 2 carucates of land, 2 acres of meadow, 20 acres of wood, and 40s. rent in Little Laver, Moreton, Fyfield, and Beauchamp Roding. ${ }^{84}$ In 1346 William de Enfield was reported as holding the 1 fee which Ralph of Essex once held.85 In 1361 William died in possession of the estate which had been granted to him in 1329 and which became known as the manor of ENFIELDS alies ENVILLES.86 $\mathrm{His}$ heir was his son John, a minor. ${ }^{87}$ During the minority of John his lands were in the custody of Thomas Rokewood. ${ }^{88}$ John came of age in November I 368.89 In June 1369 he had seisin of his lands.90 Immediately afterwards he granted to John Bampton and John Lepyngeden in fee a yearly rent of 620 'to be taken of all his lands in Little Laver, Moreton and Beauchamp Roding'.91 John de Enficld died in 1375.92

In or soon after 1375 the manor descended to Alice, daughter of John de Enfield, and her husband Ralph de Tyle.93 In 1397, after the death of Ralph de Tyle, all his lands in Little Laver were committed to the custody of William de Stucle during the minority of John de Tyle, son and heir of Ralph.94 John de Tyle died in 1399 leaving as his heir Thomas de Enfield, uncle of his mother Alice. 95

The subsequent history of the manor has not been traced until May I 54 I when Robert Tirrell of Lynton (Devon) and his wife Joyce were licensed to alienate it to Richard, afterwards ist Baron Rich. ${ }^{96}$ In 1563 Lord Rich conveyed it to John Collins of Bourchiers Hall and his son Thomas.97 In I 603 Nicholas Collins held the manor. 98 In 1625 Thomas Collins, probably the son of Nicholas, and his wife Dorothy conveyed it to George Scott and John Rowley.99 In $\mathrm{r}_{32}$ and r634 Thomas Collins was lord of the manor.' In 1640 Thomas Collins and his wife Dorothy and Richard Collins held the estate. ${ }^{2}$ By 1660 Thomas Collins the husband of Dorothy was dead. ${ }^{3}$ In that year the widow Dorothy Collins and Thomas Collins, probably her
64 E.R.O., D/DEw TI.

65 Ibid. 66 Ibid. 67 Ibid.

68 Ibid. See Manor of Otes in High

Laver.

69 E.R.O., D/DEw T2

70 Ibid.

71 Ibid.

72 Ibid. The deed of sale drawn up in May 1802 described the estate as a 'manor or reputed manor'. Cf. E.R.O., D/DEw T I $(1765)$.

73 E.R.O., Q/RPI 708-11.

74 E.R.O., Q/RP1 732-5.

75 E.R.O., D/CT 2 IO.

76 Kelly's Dir. Essex (1859 f.); inscription on gravestone of Herman P. D. Meyer in Little Laver churchyard.
77 Inf. from Mr. E. W. Bovill. 28 Inf. from Mr. T. Glasse, the owner. 79 Inf. from Mr. E. W. Bovill.

so Cal. Chart. $R$. $1257^{-1} 300,47^{6}$. 81 Feud. Aids, ii, 136 .

82 Visies. of Essex (Harl. Soc.), $23,227$. 83 Cal. Inq. p.m. vi, p. 372 ; Morant, Essex, i, 143.

84 Feet of F. Essex, iii, 5. Sir John granted his estate in High Laver to hi son Richard. (See Manor of Otes in High Laver.)

$8 s$ Feud. Aids, ii, 160.

86 Cal. Ing. p.m. xi, p. 50.

87 Ibid.

88 Cal. Inq. p.m. xii, p. 363 .

89 Ibid.

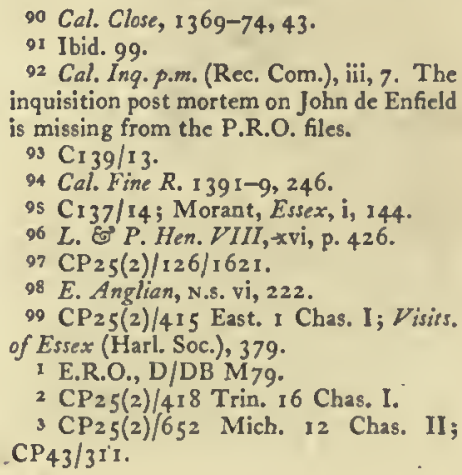
inquisition post mortem on John de Enfield is missing from the P.R.O. files. $93 \mathrm{C}_{139 / 13}$.

94 Cal. Fine R. $1391-9,246$.

9s $\mathrm{C}_{137 / 14}$; Morant, Essex, i, 144

96 L. E' P. Hen. VIII, - xvi, p. 426.

$97 \mathrm{CP}_{25}(2) / 126 / 1621$.

98 E. Anglien, N.s. vi, 222.

99 $\mathrm{CP}_{25}(2) / 415$ East. I Chas. I; Visits.

of Essex (Harl. Soc.), 379.

I E.R.O., D/DB M79.

$2 \mathrm{CP}_{25}(2) / 418$ Trin. 16 Chas. I.

$3 \mathrm{CP}_{2} 5(2) / 652$ Mich. 12 Chas. II

$\mathrm{CP}_{43 / 3} \mathrm{II}^{\prime}$. 


\section{A HISTORY OF ESSEX}

son, conveyed the manor to Henry Wheeler and Edwin Baldwin.4

By 1702 John Austry was in possession of the estate.s He was still lord of the manor in $1713 .^{6}$ Within the next 20 years the estate passed to John Evans, apparently Austry's grandson, who was described as lord of the manor in court rolls from I 734 until I 757.7 In I 745 there were thirteen manorial tenants who paid rents amounting to $f_{\mathrm{I}}$ os. $8 d$. a year. ${ }^{8}$ Between 1757 and 1766 the estate descended to Margaret Mary, who may have been the daughter of John Evans and who was the wife of John Jones in 1766.9 By 1780 the manor had passed to Sir 'Thomas Spencer Wilson, Bt., who in 1767 had married Jane daughter of Margaret Mary. ${ }^{10}$ Sir Thomas died in $1798 .{ }^{11} \mathrm{H}$ is son and heir, Sir Thomas Maryon Wilson, Bt., died in 1821 having devised the manor to his second son John Maryon Wilson, a minor at the time of his father's death. ${ }^{12}$ In 1848 the manor farm, which consisted of 249 acres, was in the occupation of William Nicholls Clay.13 John Maryon Wilson became 9 th baronet in 1869 and died in $1876.14 \mathrm{He}$ was succeeded by his eldest surviving son, Sir Spencer Maryon Wilson, Bt., who died in $1897 .{ }^{15}$ In 1899 Sir Spencer's trustees were lords of the manor but after the beginning of the 20 th century the estate was apparently no longer regarded as a manor. ${ }^{16}$

The manor house site had an elaborate system of moats of which considerable parts remain. There appear to have been at least three moated enclosures, one of which was triangular. There is no trace of an early manor house although the present farm-house probably occupies the same site. It probably dates from the early years of the present century. A sevenbay timber barn, which formerly had a thatched roof, may be of the 18 th century or earlier.

The early history of the advowson of Little Laver is not clear. It was certainly granted to the CHURCH priory of Rumilly, a Cluniac house in the Pas-de-Calais, by a count of Boulogne after the beginning of the I 2 th century. ${ }^{17}$ It is probable that the grant was made by Count Eustace during the reign of Henry $1 .{ }^{18}$

For some time in the I $3^{\text {th }}$ century, if not before, the prior and monks of Rumilly found it impossible to exercise their rights of presentation. 19 This led them in 1279 to make an agreement with Queen Eleanor, wife of Edward I.20 The queen was to help the priory to recover the advowson from usurpers. The prior and

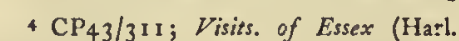
Soc.), 379 . 6 E.R.O., D/DB M79.

7 E.R.O., D/DB M79-80; Morant, Essex, i, 144. No court rolls exist for the period between 1713 and I734. Morant stated that Evans was grandson of Austry. 8 E.R.O., D/DB M79.

- E.R.O., D/DB M80.

to E.R.O., Q/RPl 685 ; ibid. D/DB M80; Burke, Peerage (I93I), 2496. Margaret Mary apparently married twice since Jane was her daughter by John Badger Weller.

11 Burke, Peerage (I93I), 2496.

12 Ibid.; E.R.O., D/DB M80; ibid. Q/RSg 5 .

13 E.R.O., D/CT 210.

14 Burke, Peerage (1931), 2497.

is Ibid.; Kelly's Dir. Essex (1 886, I 89o, 1895).

16 Kelly's Dir. Essex (1899, 1902). No court rolls exist for the period after 1823 . 17 E.A.T. N.s. viii, 228.
18 Ibid. In 1125 Count Eustace certainly gave to this priory a charge of $\oint_{0} 10$ on his manor of Fobbing and another of $E_{10}$ charged on Shenfield. J. H. Round thought it almost certain that this same Count Eustace gave to the priory the advowson of Little Laver.

19 Cal. Close, $127^{2-9}, 577^{-8}$. In 1250 the Bishop of Carlisle had claimed the right of presentation and the Bishop of London had upheld his claim: Newcourt, Repert. ii, 368-9.

20 Cal. Close, $1272-9,577-8$.

21 Feet of $F$. Essex, ii, 25.

22 Newcourt, Repert. ii, 369-70. The king held the advowson until at least 1540 when he granted it to John Gyes : $L . \delta^{3} P$ Hen. VIII, xv, p. 4II. Lord Rich presented to the church in 1554 : Newcourt, op. cit.

${ }_{23} \mathrm{CP}_{25}$ (2)/126/1606; Newcourt, Repert. ii, 370 .

24 Newcourt, Repert. ii, 370. 25 Ibid. ${ }_{26} \mathrm{CP}_{25}(2) / 293$ East. 7 Jas. I. were then to grant the advowson to the queen for themselves the penanted the advowson to the king and queen. ${ }^{21}$ 'There-

In I 559 Lord Rich conveyed the advowson with 1599.24 In I607 James I presented Eresented Edward Whiston.28 Presentations 1655 Samuel Burnet in I 690 , and Maurice Hunt in 6070 , Hall before his death in about $1713.3^{\circ}$ sold to manor of Bourchiers Hall until the manor almers or their trustees until Igro when it was Isabella, widow of the Revd. Henry Golding-Palmer, prentation was transferred from the Bishop of St. living has been united with that of Moreton in the In about 1254 the church was assessed at 6 marks. 40 his sum did not include the pension of $16 \mathrm{~s}$. which I the church was assessed at 68.42 In 1428 it was still taxed on this valuation. 43 In 1535 the rectory was d.44 Its 'improved' value was $£^{80}$

27 Newcourt, Repert. ii, 370.

28 E.A.T. N.s. vi, 326.

29 Newcourt, Repert. ii, 370

30 E.R.O., D/DEw 'TI.

31 Ibid.; J. Bacon, Thesaurus, 615

32 E.R.O., D/DEw TI; ibid. D/DEw $\mathrm{T}_{2}$

33 E.R.O., D/DEw T2.

34 Ibid.; J. Bacon, Thesaurus, 6i 5 .

3s E.R.O., D/DEw T2. ${ }_{36}$ Ibid.

37 Ibid.; Eccl. Reg. 1808; Cler. Guide, I 822 f.; Clergy List, 1845 f.; Lond. Gaz. I 3 Oct. I 880, p. 5431 ; ibid. I 1 Jan. I 9 Io, 230; Kelly's Dir. Essex (1 874 f.).

${ }_{18}$ Clergy List, I 913 f.; Kelly's Dir. Essex (1912, 1914).

39 Kelly's Dir. Essex (1933); Chel. Dioc. rear Bk. I952; Lond. Gaz. 26 May 1933. Pp. 3536-7.

40 Lunt, $V$ al. of Norwich, 337

41 Ibid.

42 Tax. Eccl. (Rec, Com.), 21.

43 Feud. Aids, ii, 205.

44 Valor Eccl. (Rec. Com.), i, 437. 
in 1604,690 in 1650 , and 6140 in 1661.45 In 1610 there were about 87 acres of glebe. 46 The tithes were commuted in I 848 for $\$ 260$; there were then 89 acres of glebe.47

A terrier of 1610 described the rectory as 'a fair dwelling-house, the greater part whereof was built by John Oliver, rector of this parish in 1600 ' with 'an old kitchen a little distant from the house, a great barn for corn, and a barn for hay, with a stable at the east end of it, two gardens, a little square green court, a great old orchard, and other yards and easements for the most part compassed about with a great ditch or small moat'.48 The separate kitchen was a medieval feature which evidently survived when the house was rebuilt by Oliver. The north side of the moat was still in existence in 184849 but only short stretches now remain. The house was rebuilt in 1831 at a cost of $\{2,000.50$ It consists of a square two-story block with a pedimented porch on the north side and a splayed bay to the south. A large wing adjoins it on the west. It ceased to be used as a parsonage after the living was united with that of Moreton in I 933 and it is now a private house called White Lodge.

The parish church of $S T$. MARY consists of nave, apse, south porch, and combined north vestry and organ chamber. The walls are of flint rubble. The porch is of timber. In 1872 the church was largely rebuilt and very little medieval work now remains.

Nothing is left of the pre-r $3^{\text {th-century church }}$ except the font (see below). The nave was probably rebuilt in the I 4 th century. It retains two windows, much restored, of this date. The south window has a chamfered hood-mould externally and two muchdecayed head stops. The braced collar-beam roof appears to be partly ancient. The only other original feature is the trefoil-headed piscina, which is probably of the I $4^{\text {th }}$ century and which has been reset in the apse.

Drawings of the church before 1872 showed that it had a square-ended chancel ${ }^{51}$ with a doorway and a $15^{\text {th-century }}$ window on its south side. 52 In about 1768 the church was described as 'small, of one pace, and the same width, with the chancel, and the whole tyled. The belfry stands in the middle of the church, with a spire shingled, in which there is only I bell.'s3

In 1872 the church was restored and enlarged at the expense of the Revd. Richard Palmer in memory of his brother, the Revd. H. Palmer.54 The architects were Messrs. Turner \& Son of Wilton Street, Grosvenor Place (Lond.). ${ }^{55}$ The west wall, the apsidal chancel, the porch, and the vestry are all of this date. In general the new work is a free interpretation of an early-I 4th-century style. The apse has three-light windows with an inner arcade resting on polished shafts of pink-veined marble. The west window is three-light and there are single-light lancets elsewhere. The south doorway of the nave is $\mathrm{I} 3_{\text {th-century in style }}$ with a Norman zigzag moulding superimposed on the arch. The opening from the vestry to the nave has a

large trefoil-headed arch. In 1884 the floor of the church was raised and relaid. 56

There is one bell by Anthony Bartlet inscribed 'All Glory Be 'To God' and dated 1674.57 It has been rehung in the stone cupola above the west end of the nave.

The square font bowl is of the late 12 th century and is similar in character to those in some neighbouring parishes. 58 The base is an addition of $1872^{59}$ and the carving of the bowl was probably recut at the same time. 'The decoration includes the fleur-de-lis, crescent, disk, and whorl found on other fonts of the type. (See plate facing p. 184.)

There is a chair which has early-17th-century carving and may have been made from a pulpit and sounding board of this period. 60 The stone pulpit, carved with niches and figures, dates from 1872.61 The carved stone reredos was given by the Revd. S. C. Beauchamp in 1886 in memory of Miss S. Caroline Palmer.62

The plate includes a silver cup with a bowl of $\mathrm{r}_{5} 62$ which has a gilded band of foliage ornament, a silver cup with a bowl of 1563 to which a stem with a scalloped collar, probably of the I 7 th century, has been added, and an undated silver paten of which the foot possibly fits the bowl of 1562 .

Little Laver was one of the two parishes in this

\section{$R O M A N$}

CATHOLICISM

Catholicism in this parish at a later date.

The surviving court rolls (1528-84) of the manor of Little Laver consist only of

PARISH GOVERN- odd membranes, manyillegible $M E N T A N D$ POOR RELIEF

ceedings at a court leet. This
court, which was held in 1564 , was attended by a jury of eleven.

The parish records of Little Laver are brief and uninformative. Only three isolated memoranda survive before 1705 . These are included in the parish register for $1538-1773 ;^{65}$ they are the minutes of the vestry held at Easter $166_{3}$ and two other memoranda, of 1668 and 1684 , also in the form of vestry minutes. A vestry minute-book survives for $1705-1944,66$ but until the end of the igth century the minutes were rarely signed, except in the period $17 \circ 9-14$, and did no more than record the appointment of officers and their annual balances. Overseers' account books and rate books survive only after I 836.67

Vestry meetings were held at Easter in each year and from 1725 , if not before, there were also regular meetings at Christmas. Occasionally, until I735, there were meetings at other times also.

The minutes of the vestry held at Easter I 663 were signed by' the rector and seven parishioners. The resolution of 1668 was signed by the rector and one

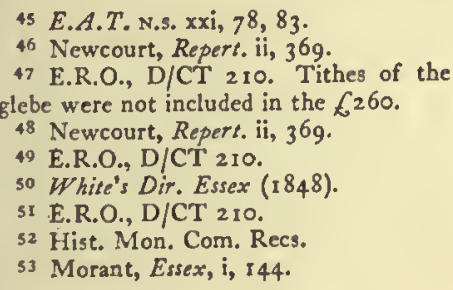

34 Kelly's Dir. Essex ( 1874,1886$)$

s5 E.R.O., D/P $147 / 8$.

36 Kelly's Dir. Essex (1886).

57 Ch. Bells Essex, 317 .

58 There are similar bowls at Moreton,

Fyfield, and Norton Mandeville.

59 Kelly's Dir. Essex (1874).

oo Hist. Mon. Com. Essex, ii, 57 .

o1 Kelly's Dir. Essex (1874).

62 Kelly's Dir. Essex (1 886).
${ }_{03} \mathrm{Wm}$. Salt. Libr. Stafford, Bp. Compton's Census, 1676 .

64 E.R.O., D/DK M27-29

65 E.R.O., D/P I 47/:/x.

60 E.R.O., D/P I $47 / 8$. Unless otherwise stated all the following information is derived from this minute-book and from the parish register quoted above.

67 E.R.O., D/P I 47/11 and I 2 . 


\section{A HISTORY OF ESSEX}

parishioner and that of 1684 by the rector and three parishioners. The minutes for the period $1705-9$ are imperfect but in 1706 and 1708 they appear to have been signed only by the rector. From I709 until I 7 I 4 the minutes were usually signed by the rector and by the parishioners present; it seems from these signatures and from those which appeared occasionally after 17 I 5 that the number of persons attending the meetings varied between two and four.

The main work of the vestry consisted in appointing officers and approving their accounts. In the first part of the I 8th century at least, however, vestry meetings were held as required to regulate the allotment of parish apprentices and the distribution of weekly doles and allowances.

In 1614 there were two churchwardens. ${ }^{68}$ At Easter 1663 , however, only one was elected for the following year and it is clear that during the period I705-1 844 there was never more than one. It was usual to spend many consecutive years in this office. From I 844 until I 852 there were two churchwardens each year, one being elected by the rector and the other by the parishioners. From 1852 only one seems to have been elected.

There were two overseers in each of the years 1613 and 1614.69 In 1663 and each year from 1709 until 1742 one overseer was appointed. These officers usually served for one year only, but occasionally for two consecutive years. They were evidently chosen on a rota system. On four occasions during the period 1709-42 a woman, Mrs. Collins, was nominated overseer but on at least two of these occasions, in $172 \mathrm{I}$ and 1729 , a man was appointed to serve the office for her. The minutes of the vestry held at Easter 1730 recorded, however, that 'Mrs. Collins oversecr gave up her account at this vestry for the year $1729^{\prime}$.

There was never more than one constable for the parish.70 It was customary for this officer to serve at least two years consecutively and sometimes much longer.

One surveyor of highways was appointed in each of the years $1614^{71}$ and 1663 . Only ten appointments to this office were recorded in the vestry minute-book after 1705; these were for the years 1725 and 1729 and for most years between 1758 and 1767. These appointments show that in the 18 th century one surveyor was appointed annually in December.

In the period $1705-42$ the overseers, churchwardens, and constables each submitted a separate annual account to the vestry at Easter. No record of overseers' accounts was kept in the surviving vestry minute-book after 1742. A separate overseers' account book was, however, probably kept from this time when, in other parishes in the hundred, 72 the cost of poor relief was increasing. The churchwardens and constables continued to account separately to the vestry until i 836 , after which no more constables' accounts appear in the minute-book. In the period $175^{8-67}$ the surveyors submitted an annual account to the vestry in December. In 1836 the rateable value of the parish was about 6545.73

\footnotetext{
68 E.R.O., Q/SBa 3.

69 Ibid.

70 Ibid. 7 I Ibid.

72 See for examples the parishes of Bobbingworth and High Laver.

73 E.R.O., D/P $147 / 12 / 1$.

74 There was a poorhouse by 1776 at latest: Rep. Sel. Citee. on Overseers' Retns.

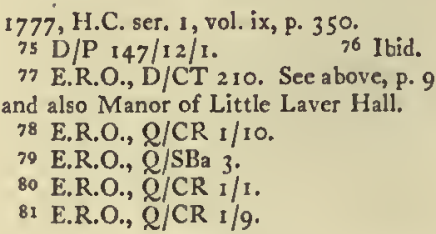

There was a parish poorhouse in Little Laver, situated on the east side of the road to Matching Green, about $\frac{1}{2}$ mile to the north-west of the church.74 In May 1836 the overseer paid $\oint_{4} 4$ 14s. 'at the workhouse'.75 In 1837 and 1838 he received rent for the property. ${ }^{76}$ By 1848 it belonged to C. P. Meyer and was said to comprise two cottages.77 It was refaced with fint rubble and largely rebuilt during the second half of the I $g^{\text {th }}$ century by Herman P. D. Meyer. It now forms two small dwellings, called Stone Cottages. They are timber-framed internally and may have an 18th-century or earlier origin.

In most cases poor relief was given, in various forms, outside the poorhouse. In each of the ycars 18 I $3-15$ there were 8 to 9 adults on 'permanent' ou tdoor relief. 78 Provision for the poor was made in various ways including the binding out of paupers' children as apprentices, the payment of allowances for lodging, the provision of clothes and the payment of weekly doles. The memorandum of 1668 recorded that the inhabitants whose names were subscribed consented that Thomas Ansell be transported 'into his Majesty's plantations of the Barbadoes', he having acknowledged himself willing to go.

It was agreed at a vestry held in 1709 that four parishioners should each take .. parish apprentice for three years, and at another vestry held in I 7 I 4 that William Clemmory should receive 20s. a quarter for providing his mother with 'meals, drink, washing and lodging only sickness excepted' and that the overseer should buy her a gown and a petticoat. Before this Clemmory had already received ros. from the overseer to buy bedding for her. At the same vestry it was agreed that the widow Oram should receive a weekly dole of 35 . Other doles recorded soon after this date ranged from is. to $2 s$. $6 d$. a week.

In $1613^{-14}$ the cost of poor relief was 61.79 In 1776 it was $£_{65}$ and in $1783-5$ it averaged $£ 77$ a year. ${ }^{80}$ In the hard years which opened the Igth century it rose to about $\oint_{200} 81$ The sums recorded for the years $1800-17$ show a minimum of 6100 in I $803-4$ but the cost was above $\oint_{1} 160$ in almost every other year, $1812-13$ and 18 i6-17 being particularly expensive years at $£_{2} 24 \mathrm{I}$ and $\oint_{2} 23 \mathrm{I}$ respectively. ${ }^{82}$

In 1836 Little Laver became part of the Ongar Poor Law Union.

In 1807 there was no school in the parish but the rector paid for a few children to SCHOOL AND attend a neighbouring school. 83 In CHARITY I 818 there was still no school of any kind in Little Laver, though the poor were said to desire education for their children. ${ }^{84}$ In I 833 some children were apparently paying $\mathrm{I} d$. a week to attend a school in Matching; in their own parish there was only a Sunday school, founded two years before and attended by 17 girls and 8 boys. ${ }^{85}$ In I 846-7 attendance at the Sunday school had fallen to 7 , a mistress being paid $\oint_{2} 2$ I 25 . a year to teach them. ${ }^{86}$ Some children probably attended the day school in High Laver (q.v.) after its erection in 1866 . In 1872 this school was said to have accommodation for all the




I9 children from Little Laver in need of places.87 Thereafter it continued to serve both parishes. 88

By a deed of 189 I Arbury Hill Hoppit (2 r. I7 p.) was vested in the rector, the rector's warden, and the owner or occupier of Little Laver Hall in trust for use as a Sunday school and parish room for the education of the poor. ${ }^{89}$ The building erected for this purpose is now known as the village hall and is administered by a village committee, its principal use being as a social club. 90 It is a single-story building of brown brick.

\section{MAGDALEN LAVER}

Magdalen Laver is a small parish about 5 miles to the north-west of Chipping Ongar and 4 miles to the south-east of Harlow.I A very small detached part $(5.6$ acres) lies on the boundary between Moreton and High Laver, to the east of the main part of the parish. The area of the ancient parish was 1,229 acres. ${ }^{2}$ It was increased by the incorporation of two detached portions of North Weald Bassett. One portion of North Weald (ro acres), lying to the north-west of Weald Lodge, was transferred to Magdalen Laver in I $883 ;^{3}$ the larger portion, lying to the north of the middle of Cripsey Brook, near Weald Bridge and including Weald Bridge Farm, Weald Lodge, and Bowlers Green, was transferred to Magdalen Laver in I946.4 Magdalen Laver now has an area of 1,443 acres. 5 The parish has an unusual number of ancient timber-framed farm-houses, the oldest of which probably dates from the 14 th century. ${ }^{6}$ Several of these, as well as the manor house and the old rectory, stand on or near moated sites. There were 28 inhabited houses in 1801,33 in 1811 , and 38 in 1821.7 In 1801 the population was $228 ;^{8}$ it reached 236 in $I 821$ and again in I $851 . .^{9}$ Then it declined irregularly to I 34 in 1931.10 By 195 I it had risen to 242 , II this being partly due to the incorporation of part of North Weald Bassett in 1946.

The land rises in the west of the parish to just over $300 \mathrm{ft}$. above sea-level. It slopes eastward and southward to less than $200 \mathrm{ft}$. along the streams that separate the parish from Moreton on the east and Bobbingworth on the south. Another stream rises in the north-west and flows south-eastward across the middle of the parish, joining one of the other streams on the southern boundary. A small area of woodland lies on the northern boundary.

The road from Epping crosses the southern boundary at Weald Bridge and runs northward for about $\frac{1}{2}$ mile until it is joined by a road from Bobbingworth. To the north of this junction the road meets another road which runs from east to west across the parish. About $\frac{1}{2}$ mile to the west, on the south side of this last road, is the 'Green Man', which was probably built early in the I 8 th century. Almost opposite the 'Green Man' is a single pair of council houses built during the Second World War. Immediately to the west, on the south side of the road, is the new rectory. ${ }^{12}$ On the north side of the road, by a drive leading north-eastward to Spencers, is Humphreys which probably derives its name from the family of John Humphrey, living in the I 3 th century..$^{13}$ This has a pedimented door-hood and appears to be an early-18th-century timber-framed

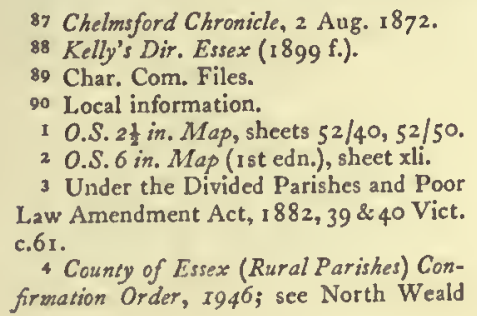

Bassett.

5 Inf. from Essex County Council.

6 See below.

7 Census Reports, $1801,1811,1821$.

8 V.C.H. Essex, ii, 350.

9 Ibid.

ro Ibid.; Census Reports, 1911 f.

II Census Report, 1951.

12 See below, Church.

13 P.N. Essex (E.P.N.S.), 64.

I4 In 1539 Rolls Farm, consisting of
, although the back wing may be oldcr. Immediately west of Humphreys is Mollmans, where another road leads north-eastward to Tilcgate Green in High Laver. At Mollmans a fragment of a moat remains. The south end of the house and the back wing were probably built in the late 16 th or early 17 th century. On the north side of the road leading westward from Mollmans is Rolls, 14 a timber-framed farm-house standing on a moated site. The moat, more than half of which remains, is curved in shape and of considerable size. The main axis of the house runs north and south and there is a cross-wing at the north end. This north wing has two stories and an attic and dates from the late I6th or early i 7 th century. It has a chimney with octagonal clustered shafts, now covered with cement. The upper flight of the staircase is original and has turned balusters and moulded newel caps. The main block also has two stories and an attic, but there are ture. The chimney, now cement-covered, has diagonal shafts. The doors and windows of the house mostly date from the 18 th and early 19 th centuries. From Rolls the road turns northward and then sharply westward past Wynters Armourie to the western boundary of the parish.

Wynters Armourie, formerly Winters, which probably derives its name from the family of Alice Winter, living in about $124.8,15$ stands on a moated site. 'The moat encloses a long narrow rectangle from north to south. There is part of a transverse arm in the centre but the south end has been obliterated by the farmcentral block with cross-wings to the east and west (see plate facing p. 1 37$)$. On the north side there is a singlestory addition and a small staircase wing. The central block originally consisted of a partially aisled hall of two bays, probably dating from the I4th century. Ceilings, fireplaces, and partitions have been inserted later and the west bay has been raised in height and rebuilt. Most of the main roof truss dividing the bays is still in position and at the east end of the hall are the remains of a 'spere truss', suggesting that the hall is of the transitional type where the aisles are retained in the screens bay only. The central truss has a steeply cambered collar below which are deep curved braces, moulded at their lower edge. The collar purlin and some of the original rafters are in position and there are indications of a former kingpost. All the timbers are blackened with smoke from an open hearth. Rising obliquely from near the base of one of the principal rafters and reaching to the underside of the plate is a wind-brace or strut. ${ }^{16}$ The others yard. The house is timber-framed and consists of a

\begin{abstract}
82 acres, belonged to Sir William Sulyard, who owned half of the manor of Otes in High Laver (q.v.): Merant, i, 143; by 1848 , however, Rolls no longer formed part of the Otes estate: E.R.O., D/CT' 211.

15 P.N. Essex (E.P.N.S.), 64

16 An almost identical truss at the $O$ ld Parsonage, Marlow (Bucks) retains its moulded king-post and has been dated c. 1340 (Fnl Brit. Arch. Assoc. 3rd ser. xii, 54-55).
\end{abstract}




\section{A HISTORY OF ESSEX}

are missing. In the east bay the north doorway of the screens passage is in position and there is one jamb of an opposite doorway on the south side. A post dividing the 'nave' from the north aisle still exists and the corresponding post of the south aisle has only recently been removed. On this side a large curved brace, springing from the east wall and rising to the underside of the plate, forms part of the 'nave arcade'. Below the main truss a later tie-beam spans the whole width of the hall. The detail here is similar to that of the open trusses on the upper floors of the two cross-wings and it is suggested that all these features represent additions, possibly dating from the late $15^{\text {th }}$ or early I 6 th century. The rebuilding of the west bay probably took place later in the 16 th century when the roof was raised to give higher rooms and an attic. The gable ends have unglazed windows with diagonal mullions and the roof has small curved wind-braces. The central chimney was probably inserted at this time and the single-story addition at the back of the house, which has an open queen-post truss and a large end chimney, may be a kitchen of the same period. The present owner restored the house, which was in poor condition, in about I $935 .{ }^{\mathrm{I}} \mathrm{7}$

On the north-west side of the road from Mollmans to Tilegate Green is the village hall. On the other side of the road is the former rectory, ${ }^{18}$ on a moated site. North of this, on the west side of the road, there are three pairs of white plastered council houses. Almost opposite these houses one drive leads south-eastward to Spencers and another, newly made, leads northeastward to Magdalen Laver Hall. ${ }^{9}$ Spencers, which probably derives its name from the family of John le Spenser, living in $1339,{ }^{20}$ is a large timber-framed farm-house with considerable remains of a moat. It has an irregular three-gabled front and additions on the other three sides. The stop-moulded ceiling bedms on the ground floor indicate an early-i 7 th-century date but it is possible that parts of the structure are older. The new drive to Magdalen Laver $\mathrm{Hall}$ is extended in a north-easterly direction to form an approach to the church.2I Previously the approaches to the church had been by the footpaths which run from the road to Spencers on the south and through the farm-yard of Magdalen Laver Hall on the north. Immediately north-west of the churchyard are traces of a large moated site, where the first manor house probably stood. ${ }^{22}$ To the south-east of the church, in a field known as Redmill Shot, a stone coffin containing a skeleton was discovered in about 1757 and human bones were found in other parts of the same field at different times. ${ }^{23}$ There was a tradition in the 18 th century that the church originally stood in this field but no trace of a church or of any other building has ever been found.24 It may be, however, that the field was once a burial ground belonging to the parish.

Immediately north of Magdalen Laver Hall the road to Tilegate Green becomes part of the northern boundary of the parish. On the north side of the road, within the parish of High Laver, is Magdalen Laver school. ${ }^{25}$ At Tilegate Green the road is joined by Pole Lane, now only a footpath, which leads eastward to the
Ongar-Harlow road. On the south side of Pole Lane, north-east of the church, is a moated mound, about $80 \mathrm{ft}$. in diameter. At the junction of Pole Lane and the Ongar-Harlow road is Start Farm, a small timberframed farmhouse, part of which may date from the I 6 th century.

To the south of Start Farm the Ongar-Harlow road is joined by the road which runs right across the parish to Mollmans and Wynters Armourie on the west. On the south side of this road, close to the eastern boundary of the parish, is Bushes, an L-shaped timber-framed farm-house with wings extending to the north and east. The north wing, now of four bays but formerly longer, was built as a two-story structure and probably dates from the late $15^{\text {th }}$ century. On the west side the upper floor overhangs on curved brackets. In I 933 the plaster was stripped away revealing a fine timbered front with close studding and curved braces. The roof is original except at its south end and there are two king-posts with two-way struts in position. The chimney is a later insertion. The east wing, lying at right angles to the two-story wing, may represent the medieval hall, much altered. A large chimney and ceilings have been inserted. The roof is not ancient but two of the rafters are formed from old moulded timbers. Also incorporated is a cambered and moulded tie-beam of medieval origin. The south porch and the brick chimney appear to be of the I6th century. There is a considerable amount of 16 th- or early-17 th-century panelling internally. In the angle between the wings there is a later timber structure. The house was restored and the staircase altered in $1933 .{ }^{26}$ The north and part of the east sides of a large moat are still in existence. To the west of Bushes is Ashlings, where traces of a moat remain. About $\frac{x}{2}$ mile south-west of Ashlings is Lunds, a timber-framed farm-house probably of the late $I$ th or early I 8 th century; it has been faced with yellow brick. To the west of Lunds, on the north side of the road, is Whites, a timber-framed farm-house probably dating from the late $17^{\text {th }}$ or early i 8 th century. Almost opposite Whites is the junction with the road leading south to Epping.

In 1776 the parishes of High Laver and Magdalen Laver came to an agreement about repairs to roads for which they were jointly responsible.27 These roads were to be equally divided by a white post and each parish was to repair the part lying nearest to it. 28

Water was supplied by the Herts. and Essex Waterworks Co. in I 912.29 Electricity was laid on in part of the parish in 1950.30 A branch of the county library was opened in June 1939. ${ }^{31}$

Magdalen Laver has always been a rural parish engaged almost entirely in agriculture. The lords of the manor lived in the parish during most of the period from I 622 until I 832.32 After John Cozens sold the estate in 1832 the owners were not resident until Matthew Torrance purchased the estate shortly after 1922.33

In 1848 James Ewing owned, but did not occupy, Magdalen Laver Hall Farm (I 9 I acres). ${ }^{34}$ 'There were only two other substantial owners in the parish; John Archer Houblon owned but did not occupy Spencer's
17 Inf. from Mrs. Fitzgerald

18 See below, Church.

Io See below, Manor.

20 P.N. Essex (E.P.N.S.), 64; Feet of F.

Essex, iii, 51 .

21 See below, Church.

22 See below, Manor.
23 Hist. Essex by Gent. iii, 354.

24 Ibid.

2s See below, School.

26 Inf from Mr. Radbourne, present owner.

27 E.R.O., D/P I I I/22. See also High Laver. 28 Ibid.
29 Inf. from Herts. \& Essex Waterworks $\mathrm{Co}$.

30 Inf. from East. Elec. Bd.

32 Inf. from County Librarian.

32 E.R.O., D/DA Tig9; Q/RPI 685-

737.
34 E.R.O., D/CT 211 . 
Farm (I 26 acres) and Christian P. Meyer owned Mollmans Farm (I I acres) but did not farm it himself. ${ }^{35}$ There were seven other farms of over 60 acres; of these three were more than 90 acres. ${ }^{36}$

Magdalen Laver, like neighbouring parishes, has always been a parish of mixed farming with a marked predominance of arable. In $\mathrm{J} 33 \mathrm{I}$ the manor contained 33 I acres arable, 30 acres pasture, 6 acres meadow, and 80 acres wood. 37 In 1847 it was estimated that there were 835 acres arable, I 50 acres meadow and pasture, and 15 acres woodland. 38

From I 680, if not before, until 173 I a regular item of income in the churchwarden's annual account was 6s. 8d. 'faire money'.39 'This suggests that until the second quarter of the 18 th century a fair was held annually in the parish, although it is not clear why it should have been a source of income for the churchwardens. No reference to 'faire money' has been found after 1731.40

In 1066 MAGDALEN LAVER was probably held as a manor by Sexi.4I In 1086 it was probMANOR ably held of Ralf de Toesni by Roger.42 At both dates it was worth 705.43 In the $\mathrm{I} 2$ th century the manor was held of the honor of Boulogne and of Pharamus of Boulogne, great-grandson of Count Eustace of Boulogne.44 Pharamus died in 1183 or I 84 and was succeeded by his only daughter and heir Sibyl de Fiennes.45 The manor was held of the honor of Boulogne and of Sibyl in I 22 I-2.46 Sibyl's heir was her son William de Fiennes, whose grandson Sir William de Fiennes died in I 302.47 In I 33 I the manor was held as $\frac{1}{2}$ knight's fee of Hugh, Lord Audley (d. 1347), and his wife Margaret 'as of her right and inheritance'. 48 By 1352 the tenancy in chief had passed to Elizabeth de Burgh, Lady of Clare, sister of Margaret.49 At that time the manor was held by the service of $\frac{1}{4}$ knight's fee. ${ }^{30}$ Elizabeth died in 1360.51 Her heir was her granddaughter Elizabeth, suo jure Countess of Ulster, wife of Lionel, later Duke of Clarence.52 In 136I the manor of Magdalen Laver was held of Lionel as of the honor of Clare.53 Lionel survived his wife Elizabeth and was succeeded on his death in 1368 by their only daughter and heir Philippe, wife of Edmund Mortimer, Earl of March (d. I 38 I). ${ }^{54}$
The heir of Philippe and Edmund was their son Roger, Earl of March, who was tenant in chief of Magdalen Laver at his death in 1398.55 Roger was succeeded by his son Edmund, who died in $1425 .{ }^{.66}$ The manor was then held of Edmund's widow Anne until her death in I 432.57 She was succeeded by Richard, Duke of York, son of Anne, sister of the last earl.58 Richard died in 1460 and the manor was then held of his widow. 59

It is not clear who held the tenancy in demesne of the manor in the first half of the $\mathrm{I} 2$ th century. It was probably during this period or shortly before, however, that it came into the possession of the Marcys. In the reign of Henry II the tenant was Ralph de Marcy who also held an estate in Navestock. 60 In Navestock at least Ralph had by I I 52 succeeded William de Marcy, son of the Ralph de Marcy who in 1086 held a manor in Kelvedon Hatch (q.v.). ${ }^{61}$ Ralph the younger was dead by I 89 when his son Wiliam paid a mark for a recognizance of mort d'ancestor. ${ }^{62}$ William died between I 198 and I 205 leaving his son Ralph as heir to his estates in Navestock and Magdalen Laver. ${ }^{63}$ Ralph was probably dead by 12 I $7-18.64$ He was succeeded by his daughter Joan wife of Gilbert de Breauté. 65 In 1237 Magdalen Laver was known as Laufar Breute.66 In 1270 Joan de Breauté acknowledged the manor of Magdalen Laver to be the right of Robert de Burnevill, her son or son-in-law, who granted a life interest in the estate to Joan with reversion to himself.67 In 1285 Cecil de Terling, son of Joan de Breauté, brought an action against Robert de Burnevill, grandson of Joan. ${ }^{6}$ Cecil claimed the manor from Robert on the ground that Joan, Cecil's mother, was seised in her demesne as of fee of the manor at the time of her death.69 A jury declared that Joan had granted the manor in fee to Robert de Burnevill, father of the defendant, and that Robert the father had then granted her a life interest in the estate. 70 Robert de Burnevill the son was therefore confirmed in his seisin.71

In I32 I John son of Robert de Burnevill conveyed the manor to Humphrey de Walden ${ }^{72}$ and it afterwards followed the same descent as the manor of Ongar Park in High Ongar (q.v.) until $\mathrm{I} 468.73$ In I 33 I the manor of Magdalen Laver, then worth $f_{\mathrm{I}} 2 \mathrm{I} 6 \mathrm{~s}$. 8d. a year, was granted to John de Cantebrigg to hold 3s Ibid.

36 Ibid.

$37 \mathrm{C}_{135 / 26}$.

38 E.R.O., D/CT 2 I I.

39 E.R.O., D/P 62/5.

40 Ibid.

$4 I$ V.C.H. Essex, $\mathrm{i}, 554 a$. It is impossible to distinguish with certainty between the three Lavers in Domesday.

42 Ibid.

43 Ibid.

44 Bk. of Fees, 1428; Genealogist, N.s. xii, 145-5r. Pharamus was grandson of Geoffrey, who was apparently a natural son of Count Eustace. For Pharamus and

his heirs see also Lambourne and Bobbingworth.

45 Bk. of Fees, 234-5; Genealogist, N.s. xii, $145-51$.

46 Bk. of Fees, 240,1435 .

47 Ibid. 235-6; Genealogist, N.s. xii, I49; De La Chenaye-Desbois et Badier, Dictionnaire de la Noblesse, viii, 39-4I; C. Moor, Knights of Edw. I, ii, 23 ; Cal. Ing. p.m. iv, p. 60 .

48 Cal. Inq. p.m. vii, p. 250 . Lord Audley was grandson of Margaret, daughter of Sir William de Fiennes (Complete Peerage, $i, 346,347$ ). As, however, the manor had apparently descended not to Lord Audley but to his wife Margaret it is likely that Sir William de Fiennes granted the overlordship of Magdalen Laver as well as that of Blake Hall in Bobbingworth (q.v.) to Margaret's grandmother, Eleanor of Castile, to whom he pledged part of his estate in 1275 .

49 Cal. Ing. p.m. x, p. 5 ; Complete Peerage, i, 346, iii, 245. Elizabeth de Burgh inherited the honor of Clare on the death of her brother Gilbert, Earl of Gloucester, in 13 I 4 (ibid. iii, 245). Her sister Margaret died in 1342,5 years before her husband, Lord Audley (ibid. i, 346).

so Cal. Inq. p.m. x, p. 5 .

s I Complete Peerage, iii, 245.

$\$ 2$ Ibid.

s3 Cal. Inq. p.m. xi, p. 184 .

st Complete Peerage, jii, 245.

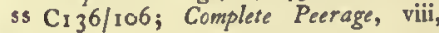
$448-50$.

s6 C139/19; Complete Peerage, viii, $450-3$.

s7 C139/59; Complete Peerage, viii, 453. s8 Cr39/98; Complete Peerage, viii, 453 . s9 $\mathrm{C}_{140 / 68}$

60 Cal. Chart. R. I 341-1417, 186-7, where a charter of Ric. I is quoted; Dom. of St. Paul's (Camd. Soc. Ixix), 133.

61 Domesday Studies (ed. P. E. Dove), ii, 553-5; Hist. MSS. Com. 9th Rep. pr. $i$, App. 3 I b, 66a; Dom. of St. Paul's (Camd. Soc. lxix), 133

${ }_{62}$ Cur. Reg. R. viii, 387 ; Pipe R. I 189 (Rec. Com.), 29.

63 Rot. Cur. Reg. R. (Rec. Com.), 197 Pipe R. I 205 (Pipe R. Soc. N.s. xix), I I9, 189 .

64 Bk. of Fees, 240. He was certainly dead by 1222 (see n. 65 below).

6s Dom. of St. Paul's (Camd. Soc. 1xix), 75; Feet of F. Essex, i, 100, $214,271$.

${ }_{66}$ E.A.T. N.s. xix, 35. It was so described by the assessors and collectors of the $\frac{1}{30}$ of 1237 . Cf. like description in the Norwich Taxation of 1254 (Lunt, $\mathrm{Val}$. of Norwich, 337).

67 Feet of F. Essex, i, 271 .

68 Just. Itin. $1 / 243 \mathrm{~m} .4^{2}$.

69 Ibid.

70 Ibid.

7 I bid.

72 Feet of $F$. Essex, ii, 197.

${ }_{33}$ Cal. Inq. p.m. vii, p. $250, x$, p. 5, xi, p. 184 , xii, p. 164 ; Feet of F. Essex, iii, 241 ; Cal. Close, $1419-22,78 ; C_{139 / 98}$; E.R.O., D/DA Tig9. 


\section{A HISTORY OF ESSEX}

during the minority of Andrew de Walden. 74 In 1367 , after he came of age, Thomas de Walden granted the estate for ten years to Sir John Wade who had had custody of it during the minority of Thomas.75 In I 412 the manor was said to be worth 612 a year. ${ }^{76}$ After the death of Thomas Bataille in 1439 his widow Isabel held in dower a bakehouse and some lands and rents in the manor. ${ }^{77}$ In 1439 the net annual value of the manor was $f_{1} 10.78$ In about 1450 there were some fifteen manorial tenants whose rents amounted to 6.5 is. a year. 79

In 1468 John Bataille mortgaged the manor to $\mathrm{Sir}$ Thomas Cooke for $£ 200.80$ Shortly afterwards Cooke became absolute owner of the estate. ${ }^{81} \mathrm{He}$ died in 1478 leaving as his heir his son John.82 In 1486 John Cooke died and was succeeded by his brother Philip who was knighted in $1497^{83}$ In about 1500 there were some fourteen manorial tenants paying rents amounting in all to $f_{4}$ Igs. Id. ${ }^{84}$ In 1502 Sir Philip Cooke leased the manor for five years to John King at an annual rent of 61255.85 The lease included all the manorial lands and the rents of manorial tenants but not the perquisites of the court. ${ }^{86}$ Cooke died in 1503 leaving as his heir his son John. ${ }^{87}$ In 1544 Margaret Cooke, widow-probably of John Cooke-received a life interest in the manor with remainder to Anthony Cooke (K.B. I 547) son of John Cooke, and the heirs of Anthony. ${ }^{88}$ In I 570 Sir Anthony Cooke settled the manor on his second son William when William married Frances daughter of Lord John Grey of Pirgo and cousin of Lady Jane Grey. ${ }^{89}$ William Cooke died in 1589.90 In 1608 his son and heir Sir William Cooke conveyed the manor to Sir John Poyntz. ${ }^{91}$

In 16 I4 Sir John Poyntz mortgaged the manor to Sir Edward Duncombe for $62,000.92$ It was then in the occupation of William Aylett.93 By June 1622 John son of William Aylett had become lord of the manor.94 In June 1650 John Aylett sold the estate, which then contained 160 acres, to John Throckmorton of Twickenham (Mdx.) for about $\{2,400.95$ In 1659 there were 22 manorial tenants whose rents amounted to 64 I 5 s. 9 d. a year. 96

John Throckmorton died in $1663-4$ having devised all his real estate to his son George. 97 In 1676 George Throckmorton made a settlement by which after his death the manor was to be held by his wife Elizabeth for her life and afterwards by his heirs. 98 In I692-5 there were 22 manorial tenants whose rents amounted to 64 I 75 . Iod. a year.99 In I703 George, William, and Thomas, sons of George and Elizabeth Throck- morton, sold to William Cole the reversion of the manor after the death of their mother. ${ }^{Y}$ William Cole had become lord of the manor by $1707 . .^{2} \mathrm{He}$ died on I February 1730 having devised all his real estate, subject to a life annuity of $\oint_{2} 200$ for his brother Henry, to his nephew William Cole in tail male with remainder to his nephew Henry Cole, brother of William. ${ }^{3}$ The nephew William Cole died without issue on 24 February 1730 and his brother Henry then succeeded to the property.4 By his will of 1760 Henry Cole devised all his real and nearly all his personal estate to his servant John Cozens.5 Between 1748 and 1764 there were 15 tenants of the manor of Magdalen Laver; the total of their rents varied irregularly between 64 2s. I $\frac{1}{4} d$. and $\delta_{4}$ I 8 s. $6 \frac{3}{4} d$. a year. ${ }^{6}$ John Cozens died in 1766 having devised this manor to his eldest son John.7 Some time before April I782 John Cozens mortgaged the estate to Mrs. George Sealy for $£ 7500^{8}$ He died in 1784 having stipulated that the estate should be redeemed out of the proceeds of sale of his freehold lands in Hornsey ( $\mathrm{Mdx}$.). 9 He devised the manor to his wife Elizabeth for her life with remainder to his son John. ${ }^{10}$ Elizabeth died in $179^{1-2.11}$ In I 832 John Cozens sold the estate to James Ewing. ${ }^{12}$

In 1848 the manor farm, which was occupied by James Edwards, consisted of I I acres of which 34 acres were meadow and nearly all the remainder arable. ${ }^{13}$ In December I 852 James Ewing died leaving as his heirs his four daughters: Mary Ann, wife of Robert Ewing Curwen, Anna Caroline, wife of Caledon Du Pré Alexander, Frances Elizabeth, later the wife of William James Tyrwhitt Walker, and Louisa, later the wife of Winthrop Mackworth Praed. I4 In 1865 they sold the estate, which then consisted of 223 acres, nearly all arable, to John Francis Clark of Exning (Suff.) for $68,380.15$ At that time the manor house and farm were still in the occupation of James Edwards who paid a rent of $£ 320$ a year. ${ }^{16} \mathrm{~J}$. F. Clark died in 1898 , having placed the property in the hands of trustees who were to apply the rents for the benefit of his daughters. ${ }^{17}$ At the time of Clark's death Matthew Torrance occupied the estate. ${ }^{18}$ In 1922 the estate was still in the hands of Clark's trustees but by 1926 Matthew Torrance had purchased the property. ${ }^{19}$ Torrance still lived at Magdalen Laver Hall and farmed the estate in 1937.20 In $1942^{21}$ the property was purchased by $\mathrm{Mr}$. Charles French who is still the owner.

The first manor house probably occupied the large moated site immediately north-west of the churchyard.
74 Cal. Fine R. $1327-37,256$.

$73 \mathrm{Cal}$. Inq. p.m. xii, p. I64; Cal. Close, $1364-8,405$.

76 Feud. Aids, vi, 443

77 E.R.O., D/DA Tr99; C $139 / 98$.

78 E.R.O., D/DA Trg9.

79 E.R.O., D/DU $199 / 9$

80 E.R.O., D/DK T 5 I.

81 Cr $40 / 68$.

82 Ibid.

83 Cal. Inq. p.m. Hen. VII, i, p. 38.

84 E.R.O., D/DU r $99 /$ ro.

8 E.R.O., D/DA TI99.

86 Ibid.

87 Cal. Inq. p.m. Hen. VII, ii, p. 472.

${ }_{88} \mathrm{CP}_{25}(2) / 13 / 74 \mathrm{Hil} .35 \mathrm{Hen}$. VIII.

$89 \mathrm{Cr}_{42 / 221 / 109}$. John Grey was the youngest son of Thomas, Marquess of Dorset (d. r 530): Complete Peerage, iv, $420-1$, vi, 135 .

$90 \mathrm{Cr} 42 / 22 \mathrm{I} / 109$.

91 Ibid.; $\mathrm{CP}_{25(2) / 293}$ East. 6 Jas. I; E.R.O., D/DA Trg9.
92 E.R.O., D/DA TIgg. For a later marriage alliance between the Duncombe and Poyntz families see Chipping Ongar. 93 Ibid.

94 E.R.O., D/DU 199/x. He held his first court on 4 June 1622 .

is CP25(2)/550B Trin. 1650 ; E.R.O., D/DA Trg9.

96 E.R.O., D/DU I $99 / 12$.

97 E.R.O., D/DA Trg9.

98 Ibid.

99 E.R.O., D/DU $199 / 55$.

E.R.O., D/DA Tig9.

2 E.R.O., D/DU $199 / 3$. He was high sheriff in 1716 and was for several years treasurer of St. Thomas's Hospital, Southwark: Wright, Hist. Essex, ii, 350 . In 1724 he purchased the manor of Nether Hall in Moreton (q.v.).

3 E.R.O., D/DA Trg9; ibid. D/DU 201/35.

4 E.R.O., D/DU $201 / 35$.
5 Ibid. 6 E.R.O., D/DU 199/17.

7 E.R.O., D/DU $201 / 35$.

E.R.O., D/DA Trg9.

9 Ibid.

II E.R.O., Q/RPI 695-8; ibid. Q/RSg 4 . She died between Aug. 179 r and June I792.

12 E.R.O., Q/RPl 734-7; Essex Arch. Soc. Docs. Magdalen Laver Io; Reg. Electors S. Essex, 1832 .

13 E.R.O., D/CT 211 . James Edwards occupied the estate at least as early as 1840: Reg. Electors S. Essex, I 840.

14 E.R.O., D/DU $199 / 22$. is Ibid.

16 Ibid. His lease, which was for 6 years, was due to expire in September 1866.

17 E.R.O., D/DTc T 12

18 Kelly's Dir. Essex (1899).

19 Kelly's Dir. Essex (r g22, r 926 ).

20 Kelly's Dir. Essex (r 937 ).

$2 I$ Inf. from Mr. C. French. 
A short stretch of dry moat still remains and there are traces of embankments to the south and east of this. Further south is a large pond or lake. The present house is immediately to the west of the old site. It was probably built during the second half of the I 8 th century and is of two stories, timber-framed and plastered. Alterations were made in the middle of the I 9 th century and by the present owner.

The advowson of Magdalen Laver was held by the lords of the manor until shortly after CHURCH I 468 when John Bataille sold the manor to Sir Thomas Cooke. ${ }^{22}$ At the sale Bataille apparently retained the advowson, for his son John presented to the church in $1497 . .^{23}$ In I $502 \mathrm{Sir}$ Philip Cooke, then lord of the manor, held the advowson and he retained it when he leased the manor to John King in that year. ${ }^{24}$ John Bataille, probably the patron of 1497 , presented in 1513.25 After this the advowson was held by the lords of the manor until $178 \mathrm{I}$ when it was conveyed by John Cozens and his wife Elizabeth to Thomas Altham. ${ }^{26}$ In 1783 Thomas Burford presented.27 In 1790 Peter Thomas Burford and Ann, probably his wife, conveyed the advowson to James Watts. ${ }^{28}$ James William Burford presented in $1794 . .^{29}$ After this the living remained in the gift of the Burford family until about I $857^{30}$ The Revd. S. C. Mason held it from 1857 until about $1870^{31}$ after which C. G. Jones, rector I $872-93$, held it until 1895.32 The advowson appears to have been acquired in 1895 by Mrs. E. Bellamy who held it until her death in $1912-$ I 3. ${ }^{33}$ After this it remained with her trustees until about 1928 when it passed to the Reformation Church Trust, ${ }^{34}$ who still owned it in I 941.35 Since 1942 the living has been in the gift of the Bishop of Chelmsford ${ }^{36}$ and since 1945 it has been united with that of High Laver. ${ }^{37}$

In about 1254 and in 129 r the rectory was valued at 10 marks. ${ }^{38}$ In 1428 the church was still taxed on this valuation. ${ }^{30}$ In 1535 the rectory was valued at EI 6 I 2s.40 In I66I its 'improved' value was $\$ 90.4 \mathrm{I}$ In 1621 there were 22 acres of glebe. ${ }^{42}$ In I 848 the tithes were commuted for $\mathrm{E}_{3} \mathrm{10}$; there were then 30 acres of glebe. ${ }^{43}$

Until I 950 the rectory house was situated on the east side of the road leading from Mollmans to Tilegate Green.44 A terrier of I62I described it as 'a dwelling-house all tiled, saving one end, which is thatched' with 'an old kitchen standing by itself'.45 The detached kitchen, a feature which the rectories at all three Lavers retained until the 17 th century, ${ }^{46}$ must have been of medieval origin. A new house was built in about 1850.47 This is of red brick with stone dressings. It was occupied by the rector until a new rectory was built in 1950.48 This new building stands on the south-west side of the road between Humphreys and the 'Green Man'.40 It is a white-plastered twostory house with red brick dressings.

The parish church ${ }^{50}$ of $S T$. MARY MAGDALEN consists of nave, chancel, west tower, and south porch. The walls are of flint rubble, those in the nave including also some Roman brick. The tower is of timber.

The nave was built early in the 12 th century. The flints are set in herring-bone courses in the lower part of the walls, while above there are indications that the Roman brick was arranged in decorative bands. The north wall retains a blocked single-light window of the original date. A window has been filled in on the south side and it is possible that this was also of the 12 th century. Two blocked bull's-eye windows in the west wall were noted in $1919^{51}$ but are not now visible. It is possible that the west doorway, which has brick jambs, chamfered imposts and a segmental-headed tympanum is also original. The door itself, of heavy oak battens with zigzag ornament to the strap hinges, is evidently of great antiquity.

The chancel, which is slightly narrower than the nave but has no chancel arch, was built or rebuilt in the I $3^{\text {th }}$ century. The north wall and the upper part of the other walls may have been reconstructed later.

Most of the windows in the church as well as the two south doorways appear to have been inserted at different times during the $14^{\text {th }}$ century. On the south side of the chancel the single-light window and the pointed door-way are of late- 13 th-or early-14th-century date. Two two-light windows in the chancel and three in the nave were probably added later in the $14^{\text {th }}$ century. These have square heads and segmental rear arches. The tracery has been restored or replaced but the design is probably near to the original. In the two easternmost windows of the nave there is some $14^{\text {th }}$ -

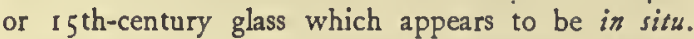
Similar glass in one of the chancel windows has been reset. The east window of the chancel, which has a pointed head and tracery in the I 4 th-century style, is largely modern, but retains original carved head-stops. The south doorway to the nave has a pointed head and moulded jambs. The door itself may be of late-14thcentury date.


of a central doorway with six bays flanking it on each side. Each bay has an ogee-headed arch supported on slender banded shafts with moulded capitals and bases. Above each arch the tracery consists of two quatrefoiled circles. The screen was evidently reconstructed in the $17^{\text {th }}$ century and part of the base panelling is of
22 E.A.T. N.3. xviii, Ig; Feet of F. Essex, i, 27 ; ibid, ii, 197 ; ibid. iii, 33 241 ; Cal. Close, r 364-8, 405 ; Newcourt, Repert. ii, 370-r.

23 Newcourt, Repert. ii, 37 I.

24 E.R.O., D/DA Trgg.

23 Newcourt, Repert. ii, 37 I.

${ }_{26} \mathrm{CP}_{25}(2) / \mathrm{I}_{309}$ Trin. 2 I Geo. III Newcourt, Repert. ii, 37 r. In the period between I 513 and 178 I the only known occasions on which a presentation was made by someone other than the lord of the manor were in I700 when Josias Harvey presented (Newcourt, Repert. ii, $37 \mathrm{r}$ ) and in 1702 when Thomas Harvey presented (J. Bacon, Thesaurus, 616).

27 P.R.O. Inst. Bks. Ser. C. i (I).

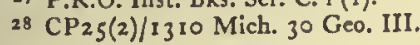

29 P.R.O. Inst. Bks. Ser. C. i ( 1 )

30 Eccl. Reg. I 808 ; Cler. Guide, I8 7 f.; Clergy List, 1845 f.

31 Clergy List, 1857 f.; Crockford's Cler. Dir. ( 1857 f.).

32 Kelly's Dir. Essex (1870, 1874); Crockford's Cler. Dir. (1880 f.).

33 Crockford"s Cler. Dir. (1 895 f.).

34 Crockford's Cler. Dir. (Igi3f.) Kelly's Dir. Essex (I914 f.).

$3 s$ Chel. Dioc. Tear Bk. 194 I.

36 Chel. Dioc. Tear Bk. $1942 \mathrm{f}$.

37 Crockford's Cler. Dir. (I951-2); inf.

from the Revd. W. D. Topping

${ }^{38}$ Lunt, Val. of Norwich, 337 ; Tax.

Eccl. (Rec. Com.), 2 I.

39 Feud. Aids, ii, 205.

to Valor Eccl. (Rec. Com.), i, 437.
41 E.A.T. N.3. $\times x \mathrm{i}, 78$.

42 Newcourt, Repert. if, 37 t.

43 E.R.O., D/CT 211 .

44 See above, p. 104.

43 Newcourt, Repert. ii, 371.

46 See parishes of High Laver and Little Laver.

47 In 1848 it was stated that a new parsonage house was about to be built: White's Dir. Essex (1 848 ).

48 Inf. from the Revd. W. D. Topping. 49 See above, p. 103.

30 See plate facing p. 202 . There was a tradition in the 18 th cent. that the church oncestood in the field known as Redmill Shot, to the south-east of the present site. See above, p. 104.

31 Hist. Mon. Com. Essex, ii, 168. 


\section{A HISTORY OF ESSEX}

this date. The doors and several of the shafts are replacements. Above the screen the tie-beam of the roof has mortice-holes for studs, suggesting that at one time the opening was filled with timber-work.

The westernmost window on the north side of the nave evidently replaces a north doorway and may have been inserted in the I 5 th century. The stonework has been replaced. The roof of the nave is also of the 15 th century. It is of the trussed rafter type with moulded wall plates and two tie-beams. The framing of the westernmost bay suggests that at one time there was a bell turret in this position.

The chancel roof, which has been restored, has two original tie-beams. On one of the ties is a nearly illegible inscription 'IT ANNo DOM. I6 15 H. L.' 52

The addition of the timber bell tower beyond the west wall of the nave may have been made in 1567 , a date which occurs on one of the bells. ${ }^{33}$ The lower stage is surrounded on three sides by an aisle, while the upper stage forms the belfry. The heavy timber frame consists of four angle posts resting on a massive plate. The westernmost posts have supporting struts. On the east and west sides the posts carry queen-post trusses with arched braces below the tie-beams and crossbracing between the queen posts. Externally the tower is crowned with a boarded pyramidal roof which was formerly leaded.54 Halfway down there is a penthouse roof to the aisle. In the lower stage there is a window with two pointed lights and there are louvred openings to the belfry. The exterior is weather-boarded. At a vestry held in April 1709 it was agreed that "the north side of the belfry shall be new boarded with oak boards'.55 'The old boards were to be used for patching the other sides, ${ }^{56}$ suggesting that some form of weatherboarding was already of long standing by 1709 . The presence of holes and grooves for fitting laths between the studs proves, however, that a plastered finish was originally intended.

In 1856 the church was repewed; the cost of this and other repairs was $f_{0} 138.57$ In 1875 there was a further restoration. 58 In 1883 the timberwork of the tower was strengthened $\$ 9$ and the boarded vestry inside the tower may have been inserted at the same date. In I 887 the south porch was rebuilt; ${ }^{60}$ it is of timber framing above a stone base and replaced a plastered porch of uncertain date. ${ }^{61}$ In 1912 a second-hand pipe organ was bought from Christ Church, Albany Street (Lond.). ${ }^{62}$

There are two bells. ${ }^{63}$ One is inscribed to the honour of St. John, and is probably of the early 14 th century. 64 The other is dated $1567 .{ }^{6} \mathrm{~s}$ In 1868 another bell was added ${ }^{66}$ but this must have been subsequently removed. In I 9 I 9 there were cages for three bells. ${ }^{67}$

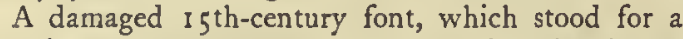
time in the rectory garden, was restored to the church early in the 20 th century. ${ }^{68}$ It has an octagonal bowl with quatrefoil pancls and carved bosses. The stem also has carved panels.

Painted boards on the north wall of the nave have round-headed panels inscribed with the Ten Com- mandments, the Creed, and the Lord's Prayer. These are surrounded by decoration of I 8 th-century design.

The plate includes a cup of 1665 with crest and shield of arms, given by George Throckmorton, lord of the manor, in 1666 ; a large flagon and a small paten, similarly dated and engraved, a salver of 1683 , similarly inscribed; an almsdish presented in 1925 to commernorate the safe return from a tour abroad of (Sir) Godfrey J. 'V. Thomas, then private secretary to Edward, Prince of Wales. A large silver communion cup which is mentioned in an inventory of church property in 1678 as 'in hands of John King of Ashlins' is not now among the church plate. ${ }^{69}$

On the south wall of the nave is a marble tablet in the form of a cartouche shield to the William Cole, lord of the manor, who died on 24 February 1730.70 A funeral helm with vizor hangs on the west wall of the nave. Three brackets for other trophies are now empty. The helm is probably of the 16th century: its crest, possibly not in situ, appears to be that of Cole. ${ }^{71}$ On the south wall of the nave is a tablet to John Cozens ${ }^{72}$ (1766) and members of his family. On the east wall of the chancel is a marble tablet surmounted by a segmental pediment. An oval panel enclosed by a wreath carries a Latin inscription to George Kindleton (1667), rector of the parish, who was dispossessed during the Commonwealth.

Outside the church immediately west of the south porch is the marble altar tomb of the William Cole, lord of the manor, who died on I February 1730.73 Cole had the tomb built before his death.74 The inscription is on a central panel, flanked by the figures of cherubs. The tomb is enclosed by a heavy iron railing, also ordered by Cole,7s and there is an achievement of arms on the wall above.

In May 1709 Thomas Redington applied to have his house, called Hum-

NONCONFORMITY phreys, licensed for a presbyterian minister to preach ${ }^{76}$ but there is no further evidence of dissent in the parish.

The only parish book which survives for Magdalen

Laver contains vestry

PARISH GOVERNMENT minutes and summar$A N D$ POOR RELIEF ized officers' accounts for the period $1667-$ 1764 and detailed churchwardens' accounts down to 1869.77

Until 169r'vestry meetings seem to have been held only at Easter in each year. From 1691 meetings were held regularly at Easter to 'examine officers' accounts and appoint or nominate fresh churchwardens, overseers, and constables, and at Christmas to nominate fresh surveyors. Occasionally meetings were held in September or October. Nearly every meeting was attended, and its minutes recorded, by the rector or his curate, who always signed first. Meetings were seldom attended by more than six parishioners.

The vestry minutes seldom recorded corporate resolutions as distinct from mere approval of the actions of officers. Two of the most notable resolutions were

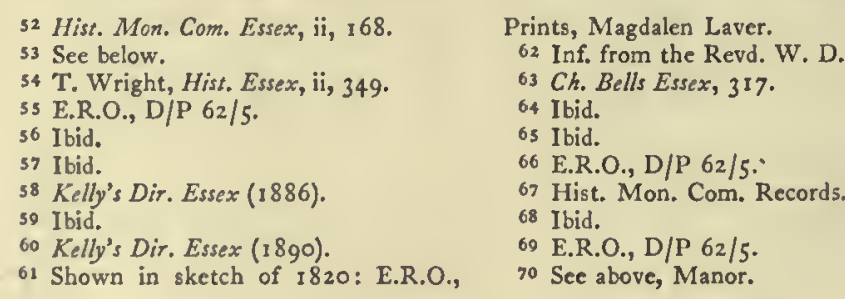

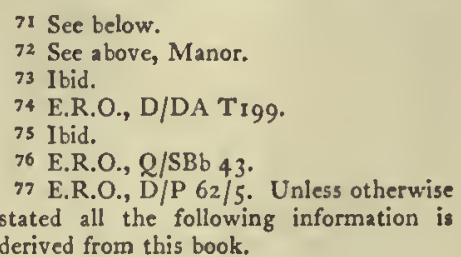

71 Sec below.

See a bove, Manor.

76 E.R.O., Q/SBb 43

stated all the following information is derived from this book. 
in 1708 , when it was agreed that a cottage should be leased for the use of the parish, 78 and in 1713 , when it was resolved that no officer should relieve a passenger on a pass with parish money. ${ }^{79}$ Occasionally there were resolutions on matters relating to poor relief. Generally, however, the officers seem to have been allowed to act without guidance or interference from the vestry.

From 1667 until 1686 one churchwarden, one overseer, two constables, and two surveyors of highways were nominated annually at Easter. From 1686 until 1690 only one surveyor was nominated each year but from 1691 two were nominated annually at Christmas. From 706 only one constable was nominated. From 1732 two names appear 'in nomination for overseer' but it seems that only one acted. There continued to be only one churchwarden. A paid church clerk appears first in 1731 when the churchwarden accounted for $f_{1}$ paid to him as his annual salary. In 1797 the clerk was receiving $\oint^{2}$ a year. His status may be deduced from the payment in September 1778 of $\mathrm{is}$. to 'the Clark for Cleaning the Churchyard'.

The surveyors do not appear to have levied a separate rate but each of the other officers did so until at least 1766. The proceeds of an officer's rates were, however, indiscriminately applied in settlement of other officers' accounts. ${ }^{80}$ 'The surveyors' small disbursements of 5s.-10s. a year were always paid by another officer. Sometimes officers' own personal money was used to provide the working funds of the parish. This occurred for example in the case of the churchwarden during the period $1713^{-15}$. No churchwarden's rate was levied in 1713 or in 1714 . At the end of 1713 the parish owed the churchwarden 64 9s. $3 d$.; during the following year the debt rose to $6714 \mathrm{~s} .6 \mathrm{~d}$. Not until 1715 was a rate levied to raise $f_{8} 85.6 d$. in partial settlement of his account.

In 1682 a $1 d$. rate produced $£_{65}$ i $2 s .4 d$. Later, only the total product of rates was recorded. From at least I680 a regular, and unexplained, source of income for the churchwardens was 'money for the fair', always 6s. $8 d$. a year; it was last received in 1731 .

There was a parish house in Magdalen Laver from at least 1708. In October of that year the vestry resolved to take a lease of a cottage, yard, and orchard called Maggots for the use of the parishioners for 2 I years at a rent of $\delta_{2} 25$. a year. The lessor, William Cole, lord of the manor, covenanted to do certain repairs. The vestry which met in October 1714 acknowledged the receipt of $£_{5}$ from him in discharge of this obligation which, it was stated, he had been unable to perform since the cottage was occupied by 'several pensioners of the parish'. At the date of the meeting the cottage was empty. The preceding Easter vestry had resolved to have a chimney built and to have an oven inserted and a new floor made in the same room'. In September 1716 Francis Bowtell was instructed to come to the 'little end' of the parish house and Goodman Harrod to remain in the other end. In March 1717 it was agreed that Goodman Storey and his family should be removed into the house.

In most cases poor relief was given, in various forms, outside the parish house. In each of the years I 8 I $3-15$ there were $16-19$ adults on 'permanent' outdoor relief. 81 Provision for the poor was made in various ways including the payment of rents and the provision of wood, food, clothing, and medicine. All these forms of relief were used in the first years of the period (1670-1764) for which accounts have survived. At a vestry held in October 1692 it was agreed that the overseer should have full power "to dispose and order all things necessary and convenient for the poore as hee in his prudence shall think fitt'. In March 1693 , however, a vestry meeting agreed that the same overseer should 'dispose of the goods of the widow King for the use of the parish and remove Shipton into her house and pay 40s. to Mrs. Wankford for Shipton's rent and do all other things for the good of the poor and the parish as shall seem expedient'. In the following September it was agreed that the overseer should have "full power to provide a house in this parish or elsewhere for Richard Benton or so to agree with his landlord that he may continue where he now is'. One common form of parish relief, the weekly dole, was mentioned in the parish book only once, in December 1693 , when the vestry resolved that a man should have a 'collection' of is. $6 d$., but the use of the common word on this occasion suggests that it was well known to the parish.

In 16 I 4 the cost of poor relief was 485.82 Late in the 17 th century and early in the 18 th century the cost was in most years between $f_{1} 3$ and $f_{22}$. It rose considerably during the second quarter of the 18 th century and in the third quarter was usually above $\delta_{6} 60$. In 1776 it reached $f_{101.83}$ At the beginning of the 19th century there was a maximum of $£ 595$ in $1801-2$ and the cost did not again fall below $\$ 226$ in the period before 1817.84

In 1836 Magdalen Laver became part of Epping Poor Law Union.

In 1807 there was no school in the parish; it was reported that the population was too poor

SCHOOL to support one. 85 By 1818 a school had been established, in which 13 children were being taught by a dame. ${ }^{86}$ This school, or one that replaced it, became united with the National Society in about 1820 and apparently continued under church guidance at least until $1846-7$. The number of pupils was 27 in 1828,25 in 1832 , and 30 in $1846-7$, the girls ou tnumbering the boys. In $1846-7$ the mistress was paid 67 ros. a year. ${ }^{87}$

In 1862 a permanent school was built on land given by Anna Maria Meyer. The trust deed appointed the rector and churchwarden as managers. The building could accommodate 60 pupils and had a teacher's residence attached. 88 The school was endowed with E999 raised in subscriptions from the congregation of St. George's Chapel, Albemarle St. (Lond.) by W. W. Ellis, then minister of the chapel, and presented to Magdalen Laver, of which he was then rector, in 1872.89 The money was invested.90 Average attendance rose from 39 in 1886 to 45 in 1899 , despite the falling population.91 In 1904 there were 47 children
78 See below.

79 Despite this resolution the constables frequently relieved 'passengers' as was their statutory duty.

$80 \mathrm{As}$ in 1715 when the constable and overseer paid the churchwarden and in I 725 when the constable paid the churchwarden.
81 E.R.O., Q/CR I/IO.

82 E.R.O., Q/SBa 3 .

83 E.R.O., Q/CR I/I.

84 E.R.O., Q/CR I/9.

8s E.R.O., D/AEM 2/4.

86 Retns. Educ. Poor, H.C. 224 , p. 260

(18 19), ix (I).

87 Nat. Soc. Rep. 1820, 1828, 1832 ;

\footnotetext{
Nat. Soc. Enquiry- into Church Schs. 1846-7, pp. $12-13$.

${ }_{88} \mathrm{Min}$. of Educ. File 1 $3 / 196$.

89 Kelly's Dir. Essex (1899). 90 Ibid.

91 Rep. of Educ. Cttee. of Council, 1886

[C. $5123^{-1}$ ], p. 520, H.C. (1887), xxviii; Rein. of Schs. I 899 [Cd. 3 I 5], p. 7 I, H.C. (1900), $\operatorname{lxv}(2)$.
} 


\section{A HISTORY OF ESSEX}

on the roll and they were taught by a teacher and a monitress. 92

By the Education Act of 1902 the school passed under the administration of the Essex Education Committee as a non-provided endowed school. Average attendance rose from 44 in 1900 to 53 in 1915 but fell again to 33 in 1938.93 In 1944 the school was reorganized for mixed juniors and infants, the seniors being transferred to Chipping Ongar. In $195^{\circ}$ the managers applied for aided status; a decision about this was still awaited in September 1952. There were 36 pupils and two teachers at the school in May 1952.94
The school is situated a little to the south-west of Tilegate Green, just within the southern boundary of High Laver and it is attended by children from High Laver as well as by those from Magdalen Laver.95 It is a single-storied red-brick building.

The Revd. Thomas James Robinson, by will dated 1876 , left an annuity of $£_{2}$ for the aged CHARITY and industrious poor of the parish. The will was disputed but the legacy was paid in 1883 in the form of $£ 59$ 5s. stock. In 1952 the income was used to give IOS. in cash to three people. ${ }^{96}$

\section{LOUGHTON}

The town of Loughton lies to the east of Epping Forest and west of the Roding, adjoining Chigwell; it is 12 miles from London. 'The ancient parish of Loughton became an urban district in 1900 and in I 933 was united with the Urban District of Buckhurst Hill and Chigwell civil parish to form the Chigwell Urban District. ${ }^{2}$ The area of the ancient parish was approximately that of the present Loughton (North) and Loughton (South) Wards of the urban district, taken together, and in 1931 comprised 3,961 acres. ${ }^{3}$ For ecclesiastical purposes the ancient parish was divided in 1887 by the creation of the new parish of St. Mary, in the south of the town. ${ }^{4}$

The best approach to Loughton is from the north, by the road through Epping Forest from the "Wake Arms'. The forest has always formed an important part of the landscape of Loughton. Over I, 300 acres of the forest were within the ancient parish and were preserved by the Epping Forest Acts of $187 \mathrm{I}-80.5$ The road leaves the forest about a mile south of the 'Wake Arms', at Goldings Hill and runs south down hill, becoming Church Hill and then High Road and continuing to Buckhurst Hill and London. For many centuries this road, 2 miles long, was the main focus of settlement in the parish. South-east of Goldings Hill is the new Loughton: the large housing estate of Debden, built since I 945 by the London County Council. The estate takes its name from the ancient manor of Debden, which lay at its northern end, around Debden Hall and Debden Green. Debden Green itself does not form part of the estate. It is a pleasant little hamlet of about eight houses, mostly of the Igth century and later, grouped about the ancient green. Loughton $\mathrm{Hall}$, on the site of another ancient manor, is now in the centre of the Debden estate, a mile south of Debden Green. Beside the hall is the little church of St. Nicholas (a chapel of ease to St. John, Loughton) which stands on the site of the original parish church. The Roding forms the boundary of the parish in this direction. There is an ancient crossing at Loughton Bridge a mile south-east of Loughton Hall. The railway from London via Stratford and Woodford, now part of the Central London Line, enters Loughton from the south. After passing through Loughton station it makes a wiche arc east and north to Theydon Bois and Epping. Debden (formerly Chigwell Lane) station is $\frac{1}{2}$ mile south-east of Loughton Hall. Rectory Lane, an old path which has become the main road through the new estate, runs from Church Hill south-east to Debden station and Loughton Bridge. Alderton Hall, which like Debden $\mathrm{Hall}$ and Loughton Hall was the centre of an ancient manor, is at the south-west edge of the new estate.

An early settlement in the parish was within the forest at what is known as Loughton Camp, about $\mathrm{I} \frac{1}{2}$ mile north of the railway station. The camp was a rough oval some $6 \frac{1}{2}$ acres in area, enclosed by a single rampart and ditch. It is thought to be pre-Roman. ${ }^{6}$

In the IIth century there were eight estates in Loughton. The largest were Alderton and Debden, which were probably the main centres of population at that time. 7 In 1086 there were 18 manorial tenants at Alderton and I I at Debden and the total number in the parish was $49 .^{8}$ In 1377 the parish contained 44 poll-tax-payers. 9

Although the total area of the parish was fairly large, the population was for long concentrated in a small part of it. Many medieval place-names survive and relate almost entirely to High Road and its immediate neighbourhood and to the areas around the three manor houses. Traps Hill, Algers Road, Goldings Hill, Borders Lane, Lyngs Lane (now Pump Hill), Pyrles Lane, Ollards Grove, and Ree Lane (now Englands Lane) have medieval names or the names of medieval tenants who held land in those areas. ${ }^{10}$ There appears to be a specific reference to High Road in 1404 when a tenant was presented at the manor court for throwing the scourings of his ditch upon the highway at Richard Algor's Gate. II 'The offence was evidently committed in the neighbourhood of the present Alger's Road. ${ }^{12}$

While the concentration of population along the High Road was probably of medieval origin it was no doubt increased by the construction, early in the I 7 th century, of the new road through the forest to Epping (see below). In 167 I there were 89 houses in the parish $^{13}$ and there were only II 19 in 1801 , when the population was 681.14 Chapman and André's map (1777) suggests that the appearance of Loughton was not very different from what it had been 100 years
92 Essex Educ. Cttee. Handbk. I go4, p. 148.

$93 \mathrm{Min}$. of Educ. File I $3 / 196$.

94 Inf. from Essex Educ. Cttee.

9s See above, p. 104 and also parish of

High Laver. 96 Char. Com. Files.

O.S. $2 \frac{1}{2}$ in. Map, sheet $51 / 49$.

2 Kelly's Dir. Essex (1902); Chigruel

U.D. Official Guide (2nd edn.), 22.

3 Official Guide, p. 22; Kelly's Dir.
Essex (1933). The ward boundary between Loughton (South) and Buckhurst Hill is mile north of the ancient parish boundary.

4 See below, Church. See below.

6 V.C.II. Essex, i, 277; Hist. Mon. Com. Essex, ii, $165-6$.

7 See below, Manor

8 V.C.H. Essex, i, 447a, 446b, $515 b$, $537 a, b$.
-W. C. Waller, Loughion in Essex, i, 20.

so P.N. Essex (E.P.N.S.), 67-68. For details of the descent of properties see Waller, Loughton, i, App. vii.

II Waller, Loughton, i, I 12 .

12 For the location see Waller, Loughton,

i, 112.

I3 E.R.O., Q/RTh 5 (Hearth Tax).

14 Census, 1801 . 


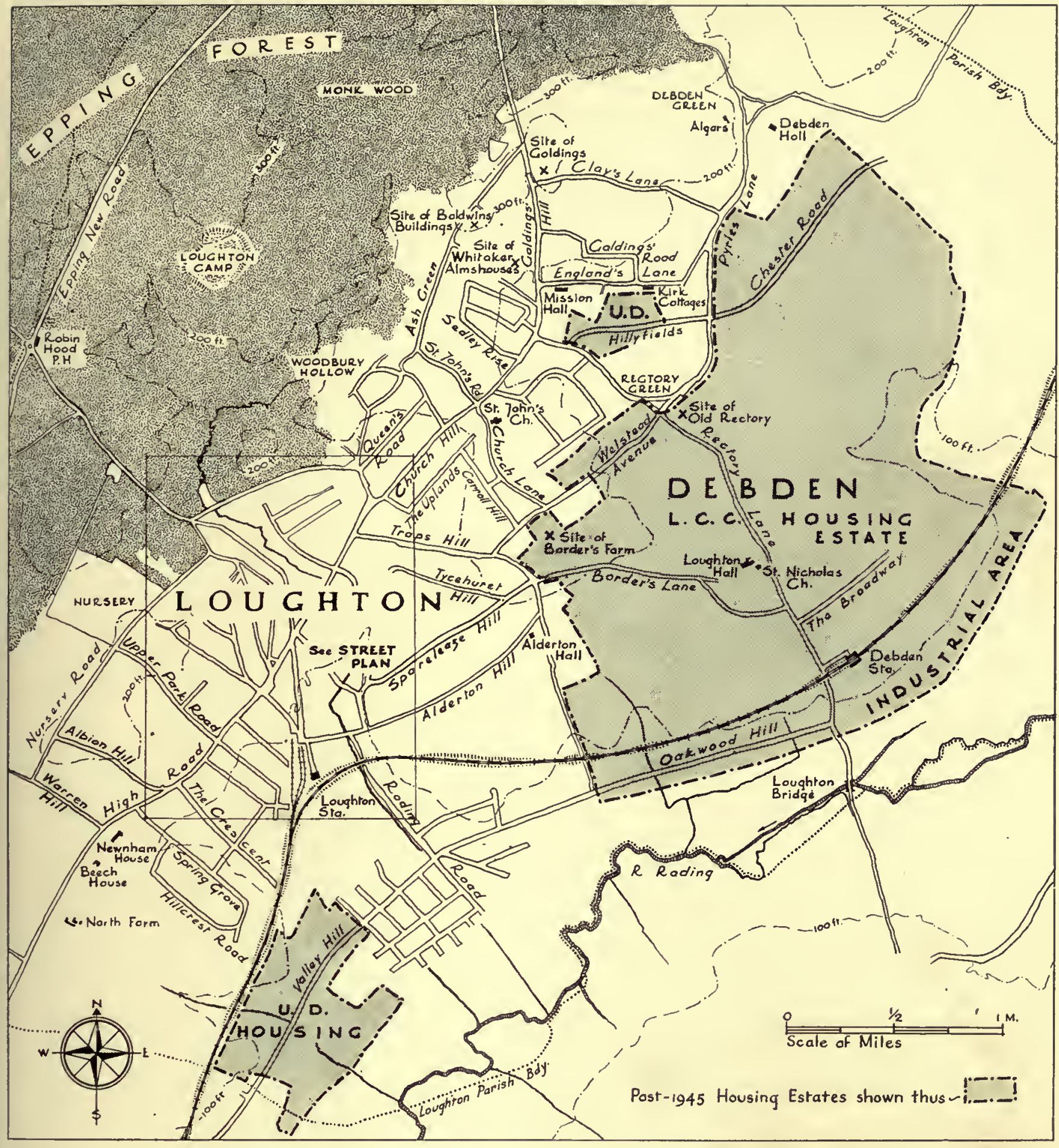

MaP of Loughton 


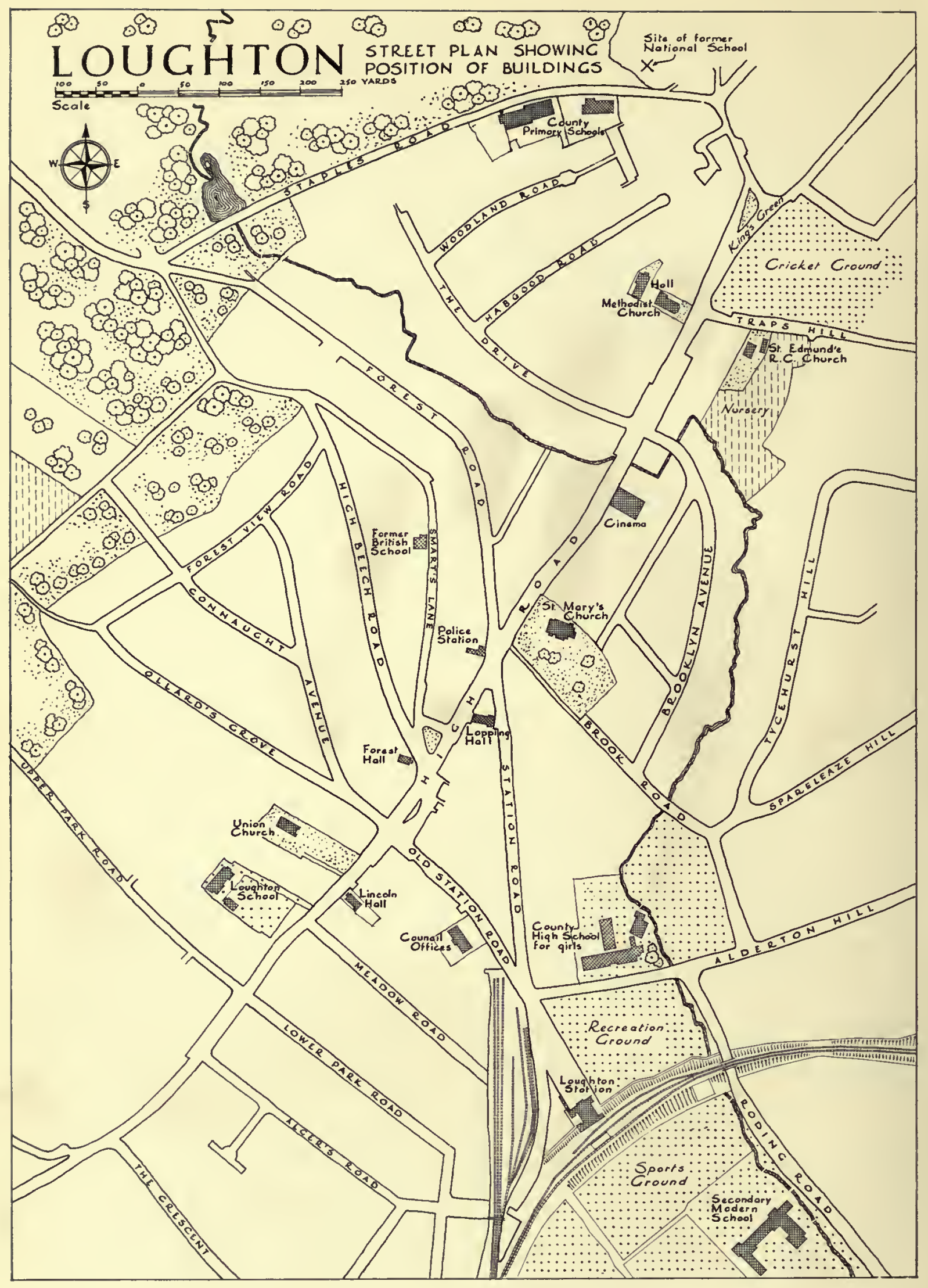


before. ${ }^{15}$ It shows houses dotted along High Road as far north as Rectory Lane. There were some houses around Mutton Row (now York Hill) and small groups round Debden Hall and in the centre of Englands Lane. Other roads shown were Smarts Lane, Pump Hill, Clays Lane, Traps Hill, and Borders Lane, Pyrles Lane, and Debden Lane. ${ }^{16}$ Larger houses specifically named were the Parsonage, Loughton Hall, Alderton Hall, Debden Hall, Golden Hill House, Hempstalls (later Borders Farm), 'The Reindeer' (later 'The' Warren) and High Standing, which lay in the southwest of the parish on the edge of the forest. The ancient parish church beside Loughton $\mathrm{Hall}$ is, of course, shown on the map.

Very few of the houses then existing have survived to the present day. Loughton $\mathrm{Hall},{ }^{17}$ which had been rebuilt about 1616 , was burnt down in $18{ }_{3} 6$, and Debden Hall has been twice rebuilt since $1777 . .^{18}$ Golden Hill House, shown on the map as the residence of Richard Lomax Clay, stood on the north side of Clay's Lane at its junction with the main road. It was the centre of a small estate built up by R. L. Clay and his father Richard Clay, a London draper. The estate included the White Lion Inn, which was demolished by R. L. Clay in $1777 .^{19}$ Golden Hill House was rebuilt on a large scale early in the 19 th century. It had three stories and the view from it was said to be "exccedingly rich and extensive, including most of London and much of the intervening district of suburban villas in Chigwell, Woodford, Walthamstow etc.'20 After the fire at Loughton Hall in $1836 \mathrm{~W}$. W. Maitland, the lord of the manor, moved to Golden Hill (Goldings) and lived there until his death.21 In I 940 the house was destroyed by a German land mine.22 The former stable block escaped destruction and has now been converted into a house called Stanmores. A small modern house of red brick called Goldings Manor Cottage has been built on the site of Goldings. ${ }^{23}$

Alderton Hall, which dates from about 1600 is the only one of the three ancient manor houses which has survived.24 North Farm, at the south of High Road, is of the I 6 th century. It has two stories and attics and is timber-framed and plastered. The north part has three gables, the central part of the house projecting and supported over the ground floor on posts.

Willow Cottage, High Road, about mile north of the farm also dates from the I 6 th century. It consists of two stories, timber-framed with painted weatherboarding. There are gabled cross-wings at each end of the front.

Beech House, High Road, bears the date I648 and the initials RWM (probably William and Margaret Rutland) and IR Age 4. It is a two-story brick building, altered externally but with some oak panelling of $c$. 1648 inside.

No. $36_{3}$ High Road was built late in the 18 th century. It is of two stories, in stock brick with three sash windows. A group of cottages in Pump Hill, Nos. 20, 22, and 24, date from the I 7 th century. They are of two stories with painted weather-boarding. Rose Farm, Traps Hill, is of the same period or somewhat later. It is of two stories with painted weather-boarding and small casements. In York Hill there is a group of cottages (Nos. 107-19 inclusive) most of which date from the 18 th century and are probably those shown on the map of 1777 . Some are of red brick, others weather-boarded. Algars at Debden Green dates from the 17 th or 18 th century. It is a two-story weatherboarded building having grouped chimney-stacks and a pedimented doorway with architrave and shaped brackets.

The population increased steadily after 1801 . By 1821 it was 979 and there were 166 inhabited houses. 25 In 1831 there were 1,269 inhabitants, but the population subsequently remained stationary until the 1850 's when the railway was built. ${ }^{26}$ The construction of the new by-pass road from Woodford to Epping (see below) may have been partly responsible for halting the growth. The tithe map ( 1850 ) shows the parish just before the coming of the railway. 27 The general picture had changed little since I777. There were a few more houses at the east end of Smarts Lane, in the York Hill area and along High Road. Albion Hill was now clearly marked as a road and some cottages had been erected at Baldwins Hill. Hatfields, in Rectory Lane, had been built in I 799. It consists of two stories and attics and is of stock brick. There is a central cemented Roman Doric porch. The date is on a rainwater head.

The Warren (formerly 'The Reindeer') had been rebuilt early in the I gth century. 'The Reindeer' was a resort of wealthy visitors and famous for its rabbit pie. About 1800 it was converted into a private house and became the home of General (later Field-Marshal) Thomas Grosvenor ( $1764-1851$ ), a friend of the Duke of Wellington. The house is of two stories, in Roman cement. To the rear is a weather-boarded wing of earlier date. The front looks north over a field containing a 'monument' said to have been erected by Grosvenor to the memory of his favourite horse, which had carried him at Waterloo. 28 The monument consists of a plain square pedestal above which is an obelisk resting on ball feet. ${ }^{29}$

Other buildings erected between 1777 and 1850 were the original National School at the corner of Staples Road (on the site of the present Ashley Grove flats), the British School in Smarts Lane, and the Whitaker Almshouses. 30 A directory of I 848 spoke of the 'many genteel houses' of Loughton. 31 Meanwhile, in 1846 a new parish church had been built in Blind Lane (now Church Lane) nearer to the main road, and there was also a police station.

Between 1851 and 1871 the population doubled, and there were considerable changes in the landscape of the parish.32 The railway was the most important new feature. The line from Woodford and London was followed within ten years by an extension to Epping and Ongar, which looped north-east in order to avoid hills and the forest. The station was placed at the south-east end of the town. On the south side of Albion Hill a number of large houses were built, and the land between them and Warren Hill was inclosed to form

\footnotetext{
is Chapman and André, Map of Essex, I777, sheet $x$ vi.

16 Of these only Traps Hill is named on the map.

17 See below, Manor.

18 Ibid.

I9 Waller, Loughton, i, 127-8.

20 White's Dir. Essex (1 848 ).

21 Waller, Loughton, i, I28; Kelly's Dir.
}

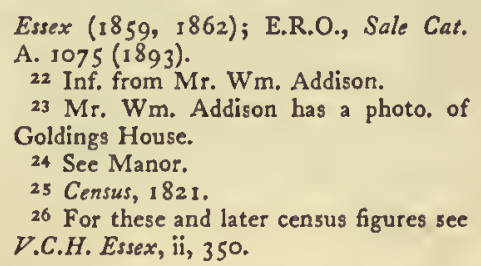

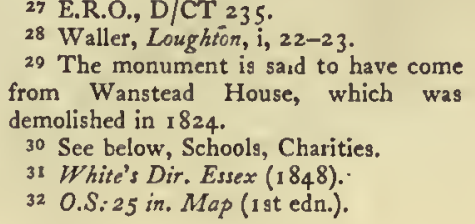




\section{A HISTORY OF ESSEX}

their gardens. This was the wealthiest part of the town. Farther north Upper Park Road and Lower Park Road were laid out although not yet built up by I 871. Forest Road had also been made, and it was there and in Smarts Lane that much of the new building had taken place. The houses in these two roads were of cottage type, in short terraces. Another new road was Staples Road, which had a few small houses. Old Station Road had been made, but was not built up, and the present Station Road was marked out. Many smaller houses had been built at Baldwins Hill. Some of the new building on the west of the town took place on land inclosed from the forest, but expansion in this direction was stopped by the Epping Forest Acts of $1871-80.33$ There was also some new building in High Road, including St. Mary's Church and the present Union church.

Loughton grew very slowly between I $87 \mathrm{I}$ and I $88 \mathrm{I}$, but between I 88 I and I I I the population rose from 2,851 to 5,433 . The progress of building was watched with a critical eye by William Chapman Waller ( 1850 1917) who lived at Ash Green at the top of York Hill. His articles in the parish magazine of St. Mary's and the entries in his manuscript notebooks provide valuable information about this period. 34

The new building after I 88 I took place mainly on several small estates along or near the main road. The 'Queen's Park' estate, consisting of I4 acres bounded by York Hill, Pump Hill, and Church Hill, was broken up for building in I 886 after the death of the last owner, George Burney.3s Building was much slower than had been expected. ${ }^{36}$ By 1895 there were some 25 houses along the Church Hill front of the estate, but in Queen's Road, which had been built parallel with Church Hill to the west, only about six had so far been built. ${ }^{37}$ There was further building in Queen's Road up to I9I4 but parts of the road remained empty until the I930's.

The Uplands estate, which lay opposite the Queen's Park estate to the east of Church Hill, consisted of I 8 acres, ${ }^{38}$ centred on a large house which had been a private residence and later a children's convalescent home. ${ }^{39}$ The estate was sold in 1902 for $£, 5,250$ and the house was demolished.40 By 1914 a number of small houses had been built along the Church Hill side of the estate, Uplands Park Avenue (now The Uplands) had been made and there were several houses there.4I But there, also, building was not completed until after the First World War.

Farther south the development of the area between Smarts Lane and Upper Park Road had begun. By I 895 High Beech Road, Forest View Road, Connaught Avenue, Junction Road (now Connaught Hill), Ollards Grove, and Park Hill had been laid out, though as yet there were very few houses there.42 As elsewhere in Loughton this area was built up gradually. In I9I4 there were a number of houses in Ollards
Grove, Connaught Avenue, High Beech Road, and Park Hill but none had been built in Forest View Road or Connaught Hill.43

On the east side of High Road near the railway station Meadow Road and Algers Road had been laid out by I 895 . Meadow Road was half built up but development had been slower in Algers Road and in Lower Park Road, which lay between the two new roads. ${ }^{4} 4$ South of Algers Road was then the Beech House estate, consisting of Beech House, Newnham House, and I 17 acres land. In I 899 this estate was put up for sale with the suggestion that it might be built upon.45 By I 914 The Avenue, The Crescent, and Spring Grove had been laid out on the north side of the estate and there were houses at the north end of 'The Avenue. 46

The areas mentioned above were those in which most of the town's development took place between I 880 and I9I4. A few houses were also built between 1895 and 1914 on the north side of Alderton Hill, and there was some new building in the older streets of the town, where there were still many vacant sites. There were also some new public buildings. Religious needs had been met by the formation of a new Anglican parish in south Loughton and by the building of a Wesleyan church and three mission halls. The Lopping Hall and the Loughton Club, both in Station Road, provided centres for secular activities. A new elementary school had been built in Staples Road and the High School for Girls in Alderton Hill. Many of the new buildings erected before 1899 were designed by Edmund Egan, a local architect who died in that year. 47

By I9I4 Loughton had changed from a village to a residential town, though still a very small one. The preservation of Epping Forest had prevented any expansion westward.48 To the east of the town much of the parish was owned by J. Whitaker Maitland (d. I 909), rector and lord of the manor, who rebuilt and lived at Loughton Hall. It may be supposed that he would hardly have welcomed any great expansion of the town on this side, and since he was also rich he had no need to sell any of his land for building. Social and economic factors also checked the development of the town. Loughton was mainly an upper-middle class residential area, and its inhabitants (of whom W. C. Waller was probably typical) were jealous of its amenities. There was no large-scale industry to attract workers and Loughton was not one of the suburbs to which population was drawn from London by cheap workmen's fares.49 A sale catalogue of 1912 quotes the rates for season tickets to Liverpool Street: $\{43$ s. $9 d$. a quarter first class and $f_{3} 4 \mathrm{~s} .3 \mathrm{~d}$. second class. 50 These were not rates to attract lower-paid workers.

Before 1914 , therefore, building was confined to a comparatively small part of the parish and even there it proceeded slowly. ${ }^{51}$ The population of Loughton in
33 For some details of new roads c. 1865 see Waller, Loughton, i, 107.

34 Offprints of the articles were later collected to form a volume, Loughton in Essex, of which 12 copies only were bound. The MS. notes are in the Essex Record Office: $T / P$ I 3.

35. For the earlier history of this estate see Waller, Loughton, $i, 137^{-8}$.

36 E.R.O., Sale Cat. B. 490 , 49 r. These catalogues give details of a proposed housing layout of some 100 houses.

37 O.S. 25 in. Map (2nd edn.), sheet lvii, 12.

${ }^{38}$ For its earlier history see Waller, Loughton, i, I 1 5-1 6.

39 Ibid.; Kelly's Dir. Essex (1 895).

40 E.R.O., T/P I 3 ii. The house stood almost opposite the 'King's Head'. Mr. Wm. Addison has a photo. from which it appears that it was built early in the 19th cent.

4 I O.S. 6 in. Map (3rd edn.), sheet lxix 42 O.S. 25 in. Map (2nd edn.), sheets lvii, 12,16 .

43 O.S. 6 in. Map (3rd edn.), sheet lxix.
44 O.S. 25 in. Map (2nd edn.), sheet Ivii, I 6.45 E.R.O., Sale Cat. A. 500. 46 O.S. 6 in. Map (3rd edn.).

47 E.R.O., T/P 13 ii.

48 For the Forest see below.

49 Cf. Retns. of Workmen's Trains, H.C. [C. 7541], Pp. 10-1 I (1894), Ixxv.

30 E.R.O., Sale Cat. B. 137.

51 For an interesting account of Loughton c. 1900-14 see articles by Will Francies, West Essex Gazette, 24 Dec. 1952, 16 Jan., 20 Mch., 24 Apr., 21 \& 28 Aug., 30 Oct., 6 Nov. 1953. 


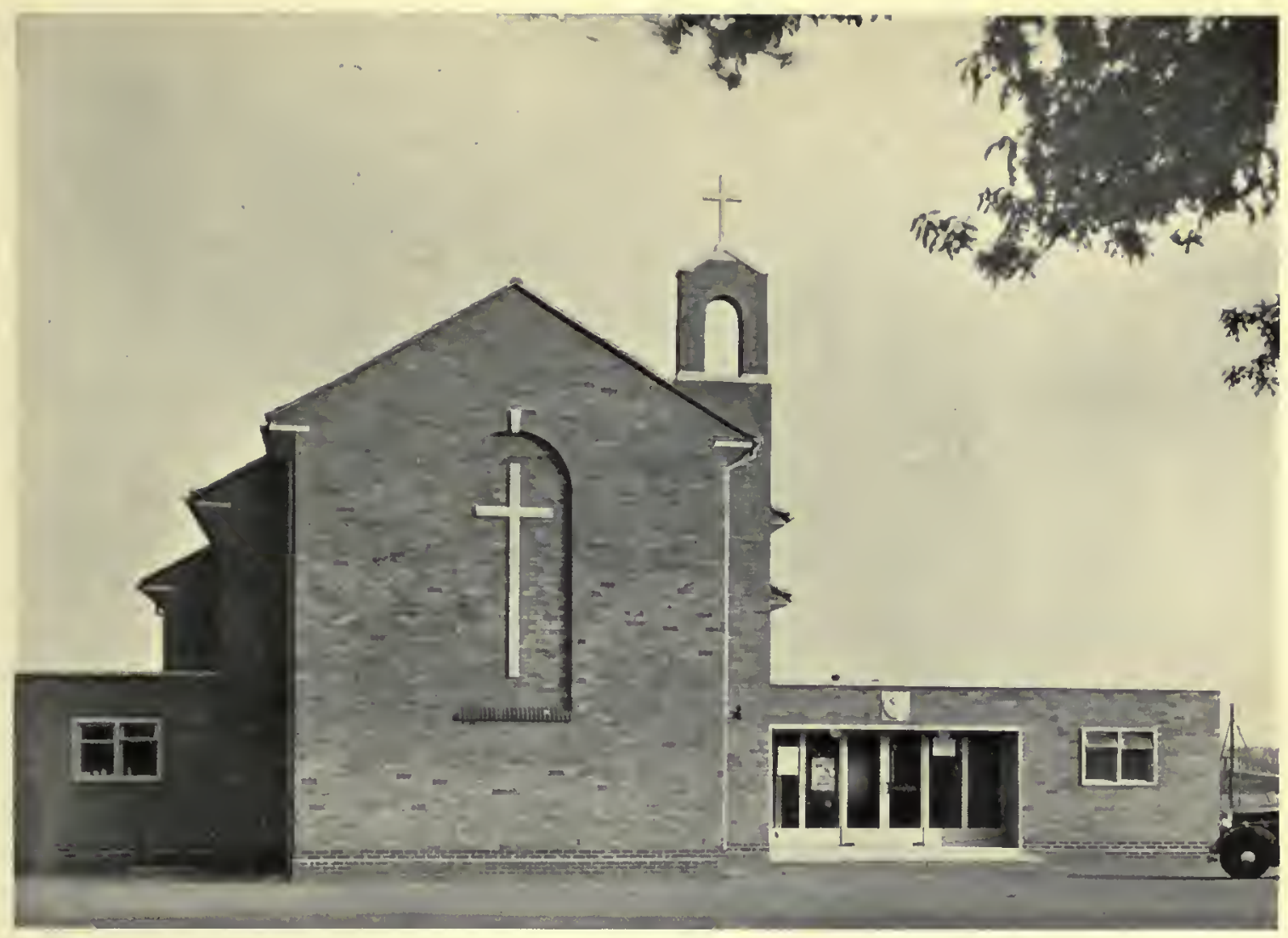

Roman Catholic Church of St. Thomas More, opened 1953

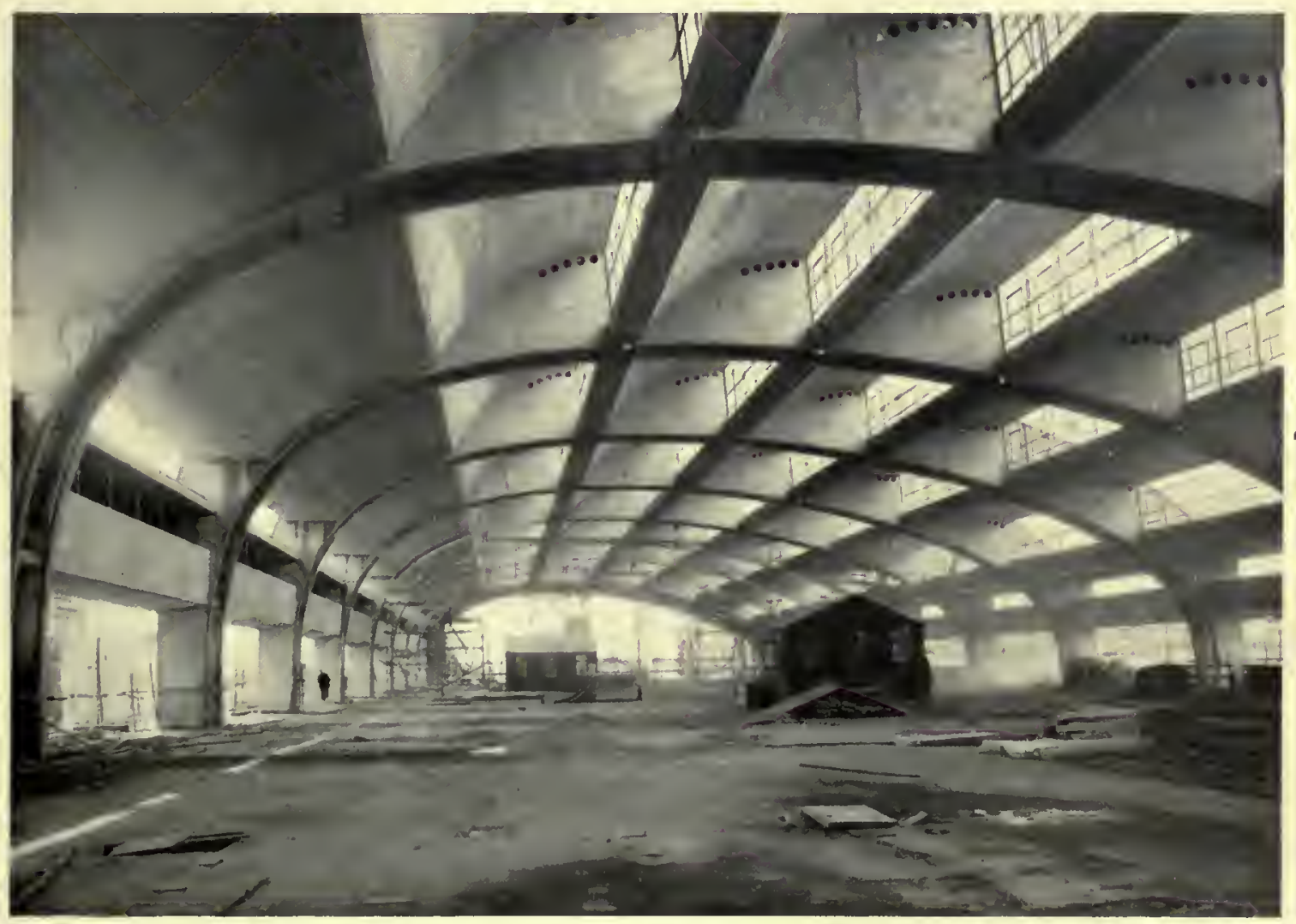

Bank of England Printing Works: Interior of Main Hall under construction, 954 Mid-Twentieth-Century Buildings at Derden 

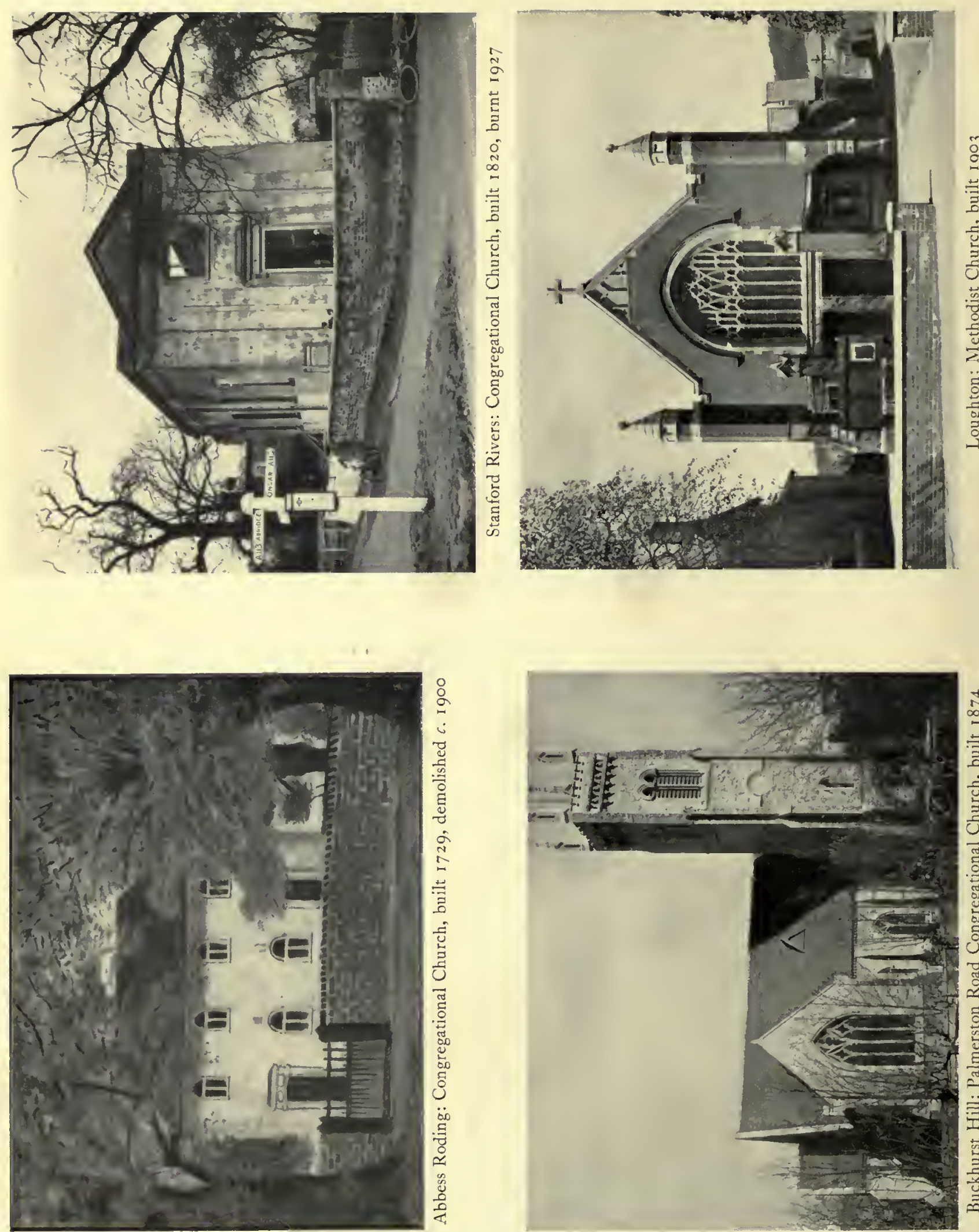
I 921 was 5,749 , little more than it had been in I9I I. By that time, however, building had been resumed, and between I9I 8 and 1939 it went on steadily. Among the new streets laid out and built up were Priory Road, Brooklyn Avenue, Brook Road,'Tycehurst Hill and Spareleaze Hill, all to the east of St. Mary's Church, Woodland Road and Habgood Road on the other side of the main road, and Hillcrest Road (near Newnham House). New houses were also built in The Drive, Englands Lane, High Beech Road, Forest View Road and in Connaught Hill, Connaught Avenue, and Upper Park Road. Several blocks of flats-a novelty in Loughton-were built at the south end of High Road and in York Hill. Development also took place to the east of the railway between Loughton and Buckhurst Hill, in Roding Road, Valley Hill and district. Debden Hall, at Debden Green, was demolished in 1929 and replaced by a modern house of red brick. ${ }^{52}$ Council houses were built in England's Lane, Goldings Road, and Woodlands Road.53 The most important new public buildings were the Council Offices in Old Station Road and the post-office in High Road, a Roman Catholic Church in Traps Hill and a Secondary Modern School in Roding Road. The north end of High Road was transformed by the building of new shops, including an impressive block called Brooklyn Parade. In 1939-40 the railway station was rebuilt.s4 The population in 1931 was 7,390 and by 1939 had increased well beyond that figure.

Since I 945 the landscape of Loughton has been transformed by the building of the Debden London County Council estate, which occupies most of the parish to the east of the old town. There are now (I953) 4,32 I dwellings on this estate.55 The urban district council has also provided over I, 000 houses (including prefabricated bungalows and shops), many of which are in the Loughton wards. Apart from the Debden estate most of the new building has been in the Roding Road area. Along Oakwood Hill to the east of Roding Road are .many prefabricated houses, some of which have been built by the L.C.C. and some by the local council. About 200 houses and flats are also being built by the Chigwell council on the Hilly Fields estate, in the England's Lane area. ${ }^{56}$ The population of Loughton is now (I 953) estimated at 29,974.57 Factories are being built on the Debden estate so that it will be more than a dormitory suburb. A number of schools and churches have been built and others are projected. Loughton Hall, now in the middle of the estate, is used as a community centre. The main shopping centre, now almost completed, is in the Broadway.

Planning has preserved some of the rural landscape at Debden: Both here and in the old town open spaces and many fine trees survive from Loughton's village days. Most of the houses built in the town during the past I 50 years are of red or yellow brick, some of which was probably made locally (see below, Industries, also Chigwell). There are a few roth-century weatherboarded houses in High Road, Smarts Lane, and elsewhere. In general the houses are well built. Even in the poorer streets they look solid and in good repair.

Until piped supplies were available water was often scarce in Loughton, and pumps were valuable property, separately assessed to the rates. ${ }^{58}$ Piped water was first supplied by the East London (later the Metropolitan) Water Board in 1866.59 Part of south Loughton was sewered about 1871.60 These improvements were overdue. Since I 848 there had been several Nuisance Removal Committees which tried to improve sanitation by the threat of legal proceedings against householders. In 1865 it was decided that a main sewer should be built for the Smarts Lane district but the matter had later been shelved.6r A sewerage scheme for north Loughton was carried out in I $89^{\circ}$ by Epping Rural District Council, from plans by Edmund Egan, at a cost of $£ 6,500.62$ The town was supplied with gas from about I 873 , by the Chigwell, Loughton and Woodford Gas Co.63 Electricity was first supplied in 1926 under the Woodford and District Electricity Special Order (1 925 ). ${ }^{64}$

Loughton became part of the Metropolitan Police District in 1840.65 There was a police station by 1845.66 In 1882 there was an inspector in charge. 67 In 1902 there were a station sergeant, three sergeants, and eleven constables. ${ }^{68}$

During the Middle Ages Loughton was an isolated parish dominated by the forest to the west. There were no roads through the forest from Loughton, though no doubt tracks existed. Until the I 7 th century the roads to both Epping and Waltham Abbey led through Theydon Bois. There was a road south to Buckhurst Hill and one to Chigwell over Loughton Bridge. The earliest reference to the bridge is in the $13^{\text {th }}$ century. ${ }^{69}$ In 1422 it was reported that the road near the bridge had been flooded for a period of two years.70 In the early I 7 th century there were the usual disputes concerning responsibility for repairing the bridge. ${ }^{7 x} \mathrm{By}$ the end of the century it had been accepted as a county bridge and there are records of various sums spent on its repair. ${ }^{72}$ In 1780 it was decided to rebuild it at a cost of $£ 471.73$ In 1809 it was destroyed by floods.74 The bridge which replaced it was badly sited and lasted only until I 824.75 The present bridge was built soon after and tunnels were inserted under the causeway on the Chigwell side to facilitate the passage of flood water. ${ }^{76}$

Early in the 17 th century (probably between I6 I I and 1622 ) a road was constructed through the forest from Loughton to Epping.77 This was of more than local importance, for it provided a new and shorter route through west Essex to Cambridge, Newmarket, and East Anglia. It was the subject of Acts of Parliament from the reign of William and Mary onwards and in 1768 came under the control of the Epping

52 See Manor.

53 Inf. from Planning Officer, Chigwell U.D.C.

st Inf. from Mr. William Addison.

s5 Inf. from Chigwell U.D.C.

56 Ibid.

57 Ibid.

38 Waller, Loughton, i, 106, notes the location of some springs and pumpe in Loughton.

39 Inf. from Metrop. Water Bd.; Kelly's Dir. Essex (1 898).

Es. IV

60 Inf. from Chigwell U.D.C.

61 Waller, Loughton, i, ro8.

62 Kelly's Dir. Essex (I894).

63 Inf from North Thames Gas Bd.

cf. Chigwell, Loughton and Woodford

Gas Act, 1873,36 Vict. c.2 r (priv. act).

64 Inf. from London Elec. Bd.

63 Lond. Gaz. 13 Oct. 1840, p. 2250.

66 Kelly's Dir. Essex (1 845).

67 Ibid. (1882)

68 Ibid. (I 902 ).

69 P.N. Essex (E.P.N.S.), 67.
$70 \mathrm{C}_{47 / 58 / 7 / 300}$

7I E.R.O., Q/CP 3, p. 37 ; Waller, Loughton, i, 70 .

72 E.R.O., Q/CP 3, PP. 404, 597, 563, 697,643 .

73 E.R.O., Q/SO r 3, Pp. $144,159$.

74 Ibid. 20, p. 374.

73 Ibid. 28 , p. 547.

76 Ibid. p. 594.

77 Winstone, Epping and Ongar High-

quay Trust, $9 \mathrm{r}$. 


\section{A HISTORY OF ESSEX}

Highway Trust. 78 Between 1770 and 1774 the trust remade the road at Goldings Hill in order to reduce the gradient.79 Soon after this the road between Loughton and Buckhurst Hill was also remade. ${ }^{80}$ Finally in $1830-4$ the trust built a new road through the forest from Woodford to the 'Wake Arms', running along the western boundary of Loughton parish and by-passing the village. $8 \mathrm{I}$

In I79I a daily coach ran from Loughton to London, and a wagon on Tuesday, Thursday, and Saturday. 82 In 1817 a daily coach from Loughton called at the 'Three Nuns' and the 'Bull', Whitechapel, and the 'Pewter Plate', Gracechurch Street, London. ${ }^{83}$ In 1839 there were coaches to London and Epping twice a day and carriers' wagons to London every weekday except Friday. ${ }^{84}$ The services remained unchanged until 1856 , when the railway from Stratford and London was opened. 85 By 1863 there were twelve trains a day to London; coaches still ran twice a day to Epping. ${ }^{86}$ The extension of the railway from Loughton to Epping and Ongar was opened in 1865.87 By $\mathrm{I} 892$ there were 42 trains a day to London. 88 The line from Woodford and London was electrified in 1948 and that from Loughton to Epping in $1949 .{ }^{89}$ This had been planned before 1939. It is now possible to travel direct from Loughton to central London. A bus service from London started in 1915 , and in 1920 was extended to Epping. 90

Loughton had a postal receiving house in the carly 19th century. The delivery was extended in $1815^{91}$ and a new receiver was appointed in $1828.92 \mathrm{~A}$ subpost-office was set up by 1867.93 Loughton now has a central post-office and sub-post-offices at Goldings Hill, Roding Road, and The Broadway. Telegraphy was introduced in $187 \mathrm{I}^{94}$ and the telephone in $\mathrm{I} 906.95$

The history of Epping Forest, including the events

\section{LOUGHTON AND THE PRESERVATION servation in the igth century, has been told by OF EPPING FOREST W. R. Fisher in his Forest} which led up to its preof Essex. 96 Minor inclosures from the forest had been going on in Loughton and other forest parishes from early times. 97 In 1666 Sir Henry Wroth, lord of the manor of Chigwell, applied to the Crown for licence to inclose 1,500 acres of the wastes of the manors of Chigwell and Loughton, but this was refused.98 Wholesale inclosure does not appear to have been suggested again until the I gth century, and then the Crown took the initiative.

In 1817 the Commissioners of Woods and Forests presented to Parliament a Bill to disafforest the whole forest, to extinguish the rights of common and to vest part of the forest in the Crown. 99 Anthony Hamilton, Rector of Loughton I 805-5 I, was one of the few supporters of this proposal, which was withdrawn after strong opposition. The commissioners, however, were still determined to inclose the forest. They connived at illegal inclosures and pressed private land-owners to purchase the forest rights of the Crown. Hainault Forest was disafforested in $185 \mathrm{I}$ and was inclosed soon after. I In 1857 the commissioners invited W. W. Maitland, lord of the manor of Loughton, to purchase the Crown's rights over I, 377 acres of uninclosed waste within his manor. He agreed to pay $£, 5,468$ and the conveyance was made in $1858-60.2$ These facts were never disputed during the evidence before the Epping Forest Commission in 1873 , and they are important because they show that the first move towards the inclosure of this substantial part of the forest was made not by the lord of the manor but by the Crown. Inclosure appears to have been considered locally during the lifetime of W. W. Maitland, and in 1859 a proposal to the Inclosure Commissioners was discussed. 3 Soon after this Maitland died and no further action appears to have been taken until I 864 , when his son the Revd. J. W. Maitland decided to inclose the forest. 4 According to the steward of the manor, W. C Metcalfe, Maitland was moved to this action 'at the instance of some of the principal freeholders and copyholders'.5

Maitland and his larger tenants stood to gain financially by the inclosure of more than I,000 acres of forest. On the other hand those who desired inclosure argued that the close proximity of the forest had had some bad social effects on Loughton in the past. In the I 8th century the forest was the haunt of highwaymen, among them the notorious Dick Turpin (170639) who is said to have roasted an old woman over a fire at Traps Hill Farm in order to make her reveal where her money was hidden. ${ }^{6}$ As a defence against such attacks many of the houses in Loughton contained 'Turpin traps', consisting of wooden flaps which were let down over the head of the staircase and kept there by a pole placed against the ceiling so that they could not be raised from below. As late as i 89 I there were those still living who had seen Turpin traps in some of the houses.7 It was not suggested in the $1860^{\circ}$ s that highwaymen were still a serious menace, but the forest still harboured some unwelcome characters, including gipsies. 8 The supporters of inclosure also believed that the poorer people of Loughton were tempted to idleness and crime by the custom of 'lopping' for frewood in the forest during the winter months. The views of the inclosures were summed up by a writer in I $86 \mathrm{I}$ : 'inclosures, however, seem to be commencing in the neighbourhood, which will probably check these irregular and to a certain extent demoralizing tendencies.' 9 As a final argument it was asserted that part of the forest was stunted and of poor quality. ${ }^{10}$

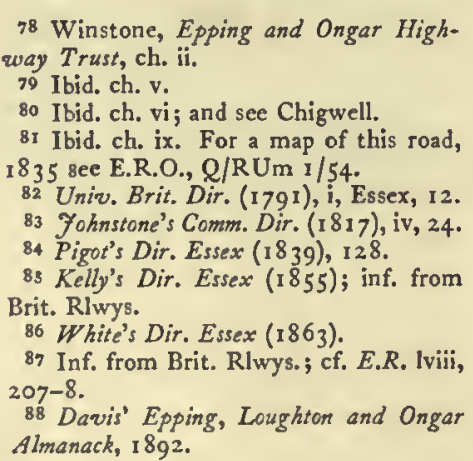

89 Inf. from Brit. Rlwys.

90 Will Francies, 'Memories of the High

Road", West Essex Garette, 20 Mar. 1953. 91 P.M.G. Mins. I 8 I 5 , vol. 29, p. 64. 92 Ibid. 1828 , vol. 33 , p. 267.

93 Brit. Post. Guide, 1867.

94 P.M.G. Mins. 1871 , vol. 92, $\mathrm{Min}$. 730.

9 S E.R.O., T/P I 3 iii.

96 Cf. V.C.H. Essex, ii, 615 f. For additional details about the forest and Loughton see Waller, Loughton, $i, 2$ I f., 32 f., 50 f., 66 f. See also Manor, below. 97 W. R. Fisher, Forest of Essex, 32 I f. And see Agriculture.

98 Ibid. 329.
99 Ibid. 339

I See Chigwell, Lamborne.

2 Proc. of Epping Forest Com. (1873), i, $53 \mathrm{I}-3$.

3 Ibid. 574-5.

4 Ibid. 543-4.

s Ibid. 544 .

6 E.R. xi, $2 \mathrm{I}, 80$

7 Ibid. $x x i v, 204$.

8 About 830 there appear to have been many criminals in hiding in the forest at Buckhurst Hill and in Hainault Forest: see Chigwell, Parish Govt.

9 D. W. Coller, People's Hist. Essex, 487 .

10 Proc. of Epping Forest Com. i, 582 . 
It was with these views that Maitland proceeded to inclose the forest within the manor of Loughton. He owned the forest rights formerly held by the Crown and there were ancient precedents in the court rolls of the manor for the inclosure of forest waste. II His principal tenants welcomed inclosure. In I 864 they agreed that the lord should have two-thirds of the inclosed land and the commoners one-third.12 Grants of land or money were subsequently made to a number of tenants of the manor in order to extinguish their common rights. Maitland then inclosed some 1,000 acres of forest, started to drive roads through it and sold some plots for building and other purposes. ${ }^{\mathrm{I}}{ }^{3}$

The opposition to these inclosures will always be associated with the Willingale family. The story has, however, gathered some accretions of legend and the whole truth is difficult to determine. The inhabitants of Loughton had an ancient right of lopping wood from the forest from I 2 November each year until 23 April following. ${ }^{14}$ They seem to have thought it necessary for the preservation of their rights that lopping should begin as the clock struck midnight on I I-I 2 November. They met in the woods for the purposes, usually at Staples Hill, and celebrated with a bonfire and beerdrinking. ${ }^{15}$ The other forest parishes had also possessed lopping rights.16 At Theydon Bois there was a lopping custom similar to that at Loughton. At Waltham Abbey and Sewardstone the lopping rights had been converted into fuel assignments attached to certain tenements in those manors. ${ }^{17}$ A polemical tract published in 1860 , at the beginning of the inclosure controversy, claimed that the people of Waltham Abbey had been deprived of their ancient lopping rights by means of a 'general drunk and supper', on I I November I 64 I '. . . which was a snare' and caused them to forget and so to lose those rights. ${ }^{18}$ The writer of the tract stated that the same scheme was tried without success at Loughton: 'although many accepted the supper there given, an old man gave the signal, when he with others at once proceeded to the forest and duly secured their charter.'19 'These stories may have some value as traditions explaining the different arrangements as to lopping at Loughton and Waltham Abbey. Their publication in 1860 must have increased the suspicion of the cottagers of Loughton that their rights were in danger. It is significant that it is from the I 860 's that there comes the story that Thomas Willingale saved the lopping rights in Loughton in a manner similar to that described in the tract. ${ }^{20}$ Willingale is supposed to have been one of the loppers who were entertained by the lord of the manor to a supper on I I November 1860. As midnight approached he 'rose up hastily from the table, shouldered his axe, called to his fellows and went out to lop as usual', thus 'defeating the lawyers'. There is good evidence that he did something of this kind, in the belief that the continued existence of the lopping rights depended upon his action. But he has a more

II Ibid. 547-8.

12 Ibid. 558 .

13 Ibid. 56I; Waller, Loughron, i, ro7; W. R. Fisher, Forest of Essex, 357 . 14 Fisher, Forest of Essex, $249 \mathrm{f}$. Rep. of Epping Forest Com. H.C. I87, p. (1877), xxvi. By the original custom lopping began on All Saints Day (I November) and ended on St. George's Day (23 Apr.). In 1753 the opening date was moved to 12 Nov. following the national adjustment of the calendar. For this custom see also below, Parish Government and Poor Relief. serious claim to fame as one of the preservers of Epping Forest.

In December $186_{5}$ Thomas Willingale (c. I793I 870), a woodman by trade, was summoned by $\mathrm{J}$. W. Maitland before the Epping bench for injuring forest trees in Loughton. ${ }^{2 I}$ "The case was dismissed. In March I 866 'Thomas's son Samuel Willingale (I 840I9I I) with Samuel's cousins Alfred Willingale (1843I934) and William Higgins (1842-70) were summoned at Waltham Abbey for a similar offence, and fined. All three refused to pay the fines and took the option of seven days' imprisonment. 22 In October I 866 old Thomas Willingale filed a suit in Chancery against J. W. Maitland and others in support of the lopping rights. ${ }^{23} \mathrm{He}$ was advised and financed by the newly formed Commons Preservation Society, of which the leading spirit was E. N. Buxton (1840-1924). ${ }^{24}$ The case was never brought to a final hearing and lapsed on Willingale's death in 1870 . Soon after this the first Epping Forest Act $^{2 S}$ set up a Royal Commission to investigate the whole problem of the forest, and about the same time the City of London started legal proceedings in defence of common rights throughout the forest. ${ }^{26}$ In 1875 the Epping Forest Commissioners made their preliminary report. They found that inclosures made within the 20 years before 187 I were illegal, since they contravened the rights of the commoners living in the forest parishes, and in some cases also the rights of the Crown. ${ }^{27}$ In their final report (1877) the commissioners specifically recognized the lopping rights of the inhabitants of Loughton.28 Meanwhile, in 1876 the City of London had purchased from J. W. Maitland the soil and the forest rights formerly held by the Crown in 992 acres of the open waste of the manor of Loughton. ${ }^{29}$ 'This was the whole area inclosed in the 1860 's within Loughton parish except for land actually built upon. In their final report the Forest Commissioners recommended that all the illegal inclosures should be retained by their occupants on payment of rent charges, but there was strong opposition to this proposal, led by George Burney, owner of a small estate in Loughton. ${ }^{30}$ The objectors removed the fences of some of the inclosures and were largely responsible for causing the government to disregard the recommendation that the inclosures should remain.

The forest question was finally settled by the Epping Forest Act of I 878.31 This Act appointed the Corporation of the City of London to be Conservators of the Forest, with the duty of keeping the forest as an open space for public recreation. All illegally inclosed lands, except those actually built on, were to be thrown open. The owners of waste lands not thrown open were to pay for the quieting of their titles. The Conservators were to buy up the lopping rights of Loughton.

The forest was thus saved. The City of London paid $£ 7,000$ for the extinction of the lopping rights and with this money the Lopping Hall was built. ${ }^{32}$ The is Fisher, Forest of Essex, 249-50.

16 Ibid.

17 Ibid. $248,251$.

${ }_{18} \mathrm{~T}$. Maynard, Concise Hist. of Epping Forest, 45 .

19 Ibid. 46.

20 E.R. xliii, I 20,$182 ; x$ lii, I 92.

21 Essex Naturalist, xxi, I63.

22 Ibid. 23 Ibid. I 66

24 Fisher, Forest of Essex, 358.

$2 s 34$ \& 35 Vict. c. 93 ( 187 I).

26 The legal pretext for the intervention of the City was its ownership of a small area of land within the bounds of the forest near Ilford.

27 Fisher, Forest of Essex, 366.

28 Rep. of Epping Forest Com. (1877), p. 4 .

${ }^{20}$ Fisher, Forest of Essex, 367. Maitland received $6,30,000$ : Speech of City Solicitor before Epping Forest Com. Nov. I 876, p. 60 .

30 The 'Queen's Park' estate, which was broken up for building in 1886 : see above, p. II2.

${ }^{31} 41$ \& 42 Vict. c. 213 (priv. act); Fisher, op. cit. 368-70.

32 See Social Life. 


\section{A HISTORY OF ESSEX}

lord of the manor and his principal tenants contended to the last that the inclosures of $I 85 \mathrm{I}-7 \mathrm{I}$ were beneficial to the parish by providing a larger rateable area and more work for the poor, and they continued to deny the existence of the lopping rights. ${ }^{33}$ In the end, however, it was J. W. Maitland himself who performed the official opening of the Lopping $\mathrm{Hall}$ in $1884 .{ }^{34}$ Though he has sometimes been severely criticized for his advocacy of inclosure he is in general a figure who commands respect.3s $\mathrm{He}$ was a faithful priest and zealous public servant, prominent on the Epping Board of Guardians and the Rural District Council and first Chairman of the Loughton Urban District Council. ${ }^{36}$ As for old Thomas Willingale it has been pointed out that he himself made illegal inclosures within the manor; but his general character appears to have been good. 37

Until the 19th century most of the inhabitants of Loughton were engaged in agriAGRICULTURE, culture or forestry. Waller has $T R A D E, A N D$ suggested that the amount of INDUSTRY forest land in the parish may not have altered greatly between 1086 and 1850.38 If the hide is taken as 120 acres the eight estates in Loughton included 2,165 acres exclusive of pannage for 970 pigs. 39 In I 85 I the parish contained 2,563 acres apart from forest, roads, and water.40 If the calculations from the Domesday figures are correct only about 400 acres were taken from the forest between 1086 and I 850 . Waller, however, doubted whether so much as 2,000 acres could have been cultivated by the small Domesday population.

Since most of the land in the parish descended from the IIth century as a single manor, information concerning the manor, its tenants, and land use has been included in the section on the manor. Apart from the forest most of the land in the parish, until built upon, seems to have been used for pasture. 'This was certainly the case in 1612.41 In 1850 it was estimated that there were 831 acres of arable, I, 55 I acres of pasture, I 3 I acres of woodland, and 1,309 acres of common forest in the parish, exclusive of 45 acres of glebe most of which was grass land.42 A directory of $\mathrm{I}_{3} 86_{3}$ listed 14 farmers in the parish.43 In 1933 the chief crops were wheat, oats, peas, and roots, but the land was chiefly in pasture. 44 Since the building of the Debden estate very little agricultural land has remained but there are still two farms, Hill Farm and North Farm, in the extreme south of Loughton.

Strip cultivation seems to have existed in the Buckhurst Hill area in the I 3 th century, but to have been discontinued after the land in question was acquired by Waltham Abbey.45

In 1066 and 1086 there was a mill at Loughton on one of the manors held by Peter de Valognes.46 Waltham Abbey had a mill in the parish in the $13^{\text {th }}$ century. ${ }^{47}$ In I 336 the abbot was presented before the forest court for erecting a windmill within the covert of the forest in the vill of Loughton. This mill probably gave its name to Mill Hill, where the Warren now stands. It had disappeared by 1739.48 The medieval court rolls contain several references to the mill and the mill-dam at Loughton Bridge.49 In 1270 some of the manorial tenants were fined for going to a mill other than that of their lord.50 In I 404 a fuller was charged before the manor court with spoiling some cloth given him to full in his mill.5I

Before the I gth century those not engaged in agriculture followed the usual village trades or were domestic servants, notably at Loughton $\mathrm{Hall}$ and Goldings. The last class became more numerous after about I 830 , when some middle-class houses were built. This was one of the main arguments urged in defence of the inclosures from the forest. "They have built', said a witness before the Epping Forest Commissioners, "large houses and greenhouses and so on. It employs a great deal of labour . . . the labour was I 2s. a week in 1864 and now I do not think you can engage a man under $18 \mathrm{~s}$. or $f_{\mathrm{I}}$.'s2 Domestic service of all kinds continued to be an important occupation in Loughton until the Second World War.

Wealthy residents required a wide range of goods and services. Many of these must have been obtained from London, especially after the completion of the railway. But in 1882 there was a much wider range of occupations than in 1848.53 The shopping centre of Loughton grew very slowly until after I9 18 . North Loughton was badly served until this time. Before I9I 8 there were only three shops in High Road north of Bincombe House (now Messrs. Parrott's). ${ }^{54}$ Between 1918 and 1939 the shopping centre was extended as far as Traps Hill. The shops now stretch for $\frac{1}{2}$ mile along High Road and provide a good range of commodities.

Industry in Loughton has been on a very small scale in the past. Brick- and tile-making was carried on at least from 1486 , when a tile-house was mentioned.55 There was a tile-kiln in 1556 ; it may have been the one at the foot of Albion Hill, whose history has been traced from 1673 to $185 \mathrm{I}$, and whose lastrecorded owner was Noah Heath. 56 Another kilnhouse was also mentioned in 1851.57 In the court roll for $172 \mathrm{I}$ there is an order which suggests that there were potters in Loughton. 58

There has been much nursery gardening in the parish since about I862, when Messrs. William Paul \& Son of Waltham Cross established their Loughton nursery, which grew to be one of the biggest in Essex. 59

During the 2oth century several small engineering works have been set up. One of the most interesting of these was the automobile assembly works of Leonard Wilson in Forest Road.60 Wilson, the son of a Canadian
33 Essex Naturalist, xxi, 159.

34 W. Addison, Epping Forest, 222.

35 Essex Naturalist, xxi, I66. For tributes paid to him at his jubilee as rector in I 906 see E.R.O., T/P 13 ii.

36 E.R.O., T/P 13 iii

37 Essex Noturalist, xxi, I67. The papers of Cmdr. J. W. Maitland, M.P., of Harrington Hall, Spilsby, Lincs., include some material relating to the forest question; this was not examined for the present survey. There are also many documents about the forest question in the Public Record Office and the Guildhall, London.

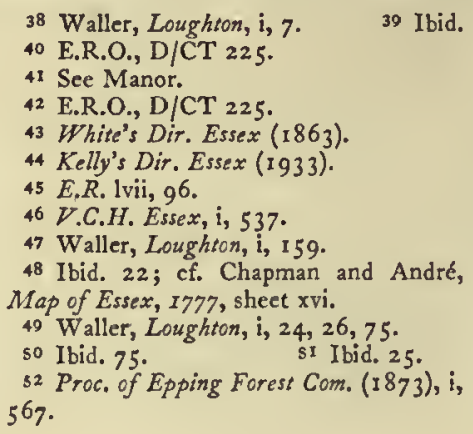
bricklayer and builder: White's Dir. Essex (I 848 ).

57 E.R.O., D/CT 225

58 E.R.O., T/P I 8.

s9 V.C.H. Essex, ii, 480,482 . For later nurseries see e.g. Kelly's Dir. Essex (1933)

60 Will Francies, 'My Loughton' (3), West Essex Gaz. 27 Feb. 1953. 
mining engineer, bought a butcher's business in Smart's Lane about 1898 . In I 906 he opened the motor works and accepted the sole Essex agency for Panhard and Levasseur cars. Only the chassis of these cars came over from France. The processes necessary for completing them, including the making of the bodies, were carried out at the Forest Road works. During the First World War the Wilson works produced munitions. Afterwards, in the 1920's, Wilson had an agency for another French car, the Citröen.

When completed the Debden estate will have several large factories, including one for making banknotes for the Bank of England.61

Balthasar de Guercis, an Italian surgeon to Queen Katherine of Aragon, became a WORTHIES AND tenant of the manor in 1538.62 SOCIAL LIFE Early in the 17 th century, when Sir Robert Wroth and Mary his wife lived at Loughton Hall, they were visited by Ben Jonson and other poets. James I was entertained at the hall in 1605 and the Prince of Wales in 1606 (see below, Manor). Sarah Adams ( $1805-48$ ) author of 'Nearer my God to Thee' lived at Woodbury Hill.63 Walter Kerr Hamilton (1 808-69), Bishop of Salisbury, was the son of a Rector of Loughton and spent his early childhood there. ${ }^{64}$ Sarah Catherine Martin (1768-1826) reputed author of 'Old Mother Hubbard', in its metrical form, ${ }^{65}$ is buried in the old parish churchyard. She was the sister of Admiral Sir Thomas B. Martin (1773-1854). When she was 17 Prince William (later King William IV) fell in love with her. She and her parents handled the affair very discreetly. ${ }^{66}$ The Martins were connected with Loughton through relatives, the Powells, who lived there. ${ }^{67}$ Sir George Carroll (d. 1860) Lord Mayor of London $1846-7$ and Contractor for State Lotteries, was owner of Uplands, and lived there. ${ }^{68} \mathrm{~W}$. W. Jacobs (1 863-1943), the author, lived for many years at the Outlook, Upper Park Road. Soon after 19 ro he moved to Feltham House, Goldings Hill.69 Rudyard Kipling (1865-I936) stayed when a boy at Goldings Hill Farm, opposite Goldings Hill Pond.70 Sir Jacob Epstein lived at Baldwin Hill for some years after 1920. While there he carved his 'Rima' and 'Visitation'.71

During the late Igth and early 20 th century Loughton was strongly represented in the Essex Field Club and the Essex Archrological Society, and it produced three local antiquaries of ability: $\mathrm{H}$. W. Lewer (I 859-I949), I. Chalkley Gould (I 845-1908), and W. C. Waller, the historian of Loughton.72 Millican Dalton (d. 1947), pioneer camper and mountaineer, lived for a time at Baldwins Hill. ${ }^{73}$

In the late 19 th century there was a fairly sharp division in Loughton between Anglicans and the nonconformists, which coincided roughly with the political division between Conservatives and Liberals. It gave rise to controversy over the establishment of a school board 74 and was shown in the duplication of some local societies. In 1892 the president of the Loughton
Liberal and Radical Association was Julius Rohrweger, owner of Uplands, and one of the vice-presidents was Edward Pope, a prominent local Methodist. 75 The rector, J. W. Maitland, was a councillor of the Primrose League. Edward Pope was secretary of the Temperance League; the rector was president of the Church of England Temperance League. Julius Rohrweger was president of the Loughton Cricket Club; the Loughton Park Cricket Club had as its president Sir Henry Selwin-Ibbetson, Bt., Conservative M.P. for West Essex. There were also the Epping Forest Military Band (president the rector) and the Excelsior Brass Band (president H. H. Francis). ${ }^{76}$ There were other clubs, for football, lawn tennis, and a number of charitable or provident purposes.

By 1900 Loughton was quite well provided with facilities for social intercourse and recreation. There were two parish churches and three nonconformist churches. The local Volunteers had a drill hall, and the Lopping Hall provided a valuable centre for all kinds of social activities. As already described, 77 the Lopping Hall had been erected out of $\{7,000$ paid by the City of London for the extinction of lopping rights in Epping Forest. Out of that sum $\{\mathrm{I}, 030$ was set aside as compensation to householders. The remainder formed the capital of the Lopping Hall Endowment Trust. ${ }^{78}$ Land was bought at the corner of High Road and Station Road and the hall was built and furnished at a cost of $f_{0}, 2,36$. The official opening took place in $\mathrm{r} 884$. The hall contained reading and lecture rooms and accommodation for parish meetings. In 1902 it was enlarged at a cost of $\{, 1,330$ by a new wing of which the upper floor was let to the newly formed urban district council for a council chamber and offices and the lower floor to the Midland Bank Ltd. In 1933 proposals to improve the hall and stage accommodation at the expense of the reading-room provoked a public inquiry. It was decided that although the provision of books and a reading-room was one of the original objects of the endowment more people made use of the lecture and concert halls. A readingroom was retained, but it was smaller and contained only newspapers. In 1936 the library was sold. In 1937 further alterations to the hall were made at the cost of the Midland Bank. In I 95 I the endowment consisted of over $f_{2}, 400$ stock in addition to the premises. The income was mainly used on general maintenance and improvement, wages and newspapers. There are six trustees, elected by ratepayers.

Two bequests have supplemented the original endowment of the Lopping Hall. In Igo5 William F. Turner left $f_{1} 100$ to be invested for the purchase of books.79 When the library was closed this was diverted to the purchase of newspapers. In I9I 2 Henry Lincoln left $£ 200$ to be spent for the general purposes of the hall.80 The hall remains a valuable social centre. It is a red-brick building with a tower, designed by Edmund Egan.

Opposite the Lopping Hall in Station Road is the Men's Club, built in Igor by the Revd. W. Dawson

\footnotetext{
61 Inf. from Mr. Wm. Addison; West Essex Gaz. $18 \mathrm{Feb}$. I955.

62 Waller, Loughson, $i, 39,40$.

63 Ibid. $i, 136$.

64 D.N.B.

65 For her claims to the authorship see I. and P. Opie, Oxford Dictionary of Nursery Rhymes, 320-1.

66 Letters of Sir H. Byam Martin (Navy Rec. Soc.), i, 2 I.
}

\author{
67 E.R. xxv, 117, 171 . \\ 68 E.A.T. N.s. xiv, 285 \\ 69 E.R. lii, 205. \\ 70 Addison, Epping Forest, 226. \\ 71 Ibid. 227. \\ 72 For Lewer see E.R. Iviii, 163 ; for \\ Gould see E.R. xvii, 31 . \\ 73 E.R. Ivii, 55- 56. \\ 74 See Schools, below. \\ 73 Davis' Epping, Loughson and Ongar
}

\author{
Almanack, 1892, 20-23; this almanack \\ gives details of all local societies and clubs. \\ ${ }^{76}$ Francis's religious and political affilia- \\ tions have not been traced. \\ ${ }_{77}$ See Preservation of Epping Forest, \\ above. \\ ${ }_{78}$ For the Lopping Hall Endowment \\ see Char. Com. Files. \\ 79 Char. Com. Files. \\ 80 Ibid.
}




\section{A HISTORY OF ESSEX}

and conveyed by him in 1903 to trustees for use as a club. In 1920 two houses in Meadow Road were conveyed to the trustees. Their rents provide much of the club's income, which in I94I was fig4 and was used for current maintenance and expenses. ${ }^{81}$

Loughton now (1953) has many clubs and societies, including at least four for amateur dramatics. ${ }^{82}$ The Loughton Community Association acts as a coordinating body. There are several private sports grounds, including that of the Loughton Cricket Club opposite the 'King's Head'. The local council has provided about roo acres along the Roding for playing fields and recreation grounds. 83 A branch of the County Library was first opened in 1936 . The present library, a full-time branch, was opened in 1948.84

During the First World War Loughton provided accommodation and financial support for Belgian refugees. The subscriptions totalled $£ 420$ in I9I 5 and $f 310$ in 1916.85

Domesday Book mentions no fewer than six separate estates in Loughton and also two others,

MANORS Alderton and Debden, which later became part of the parish of Loughton. A small holding of 20 acres in Loughton belonged to the manor of Havering: it had been held in 1066 by the reeve of King Harold and in 1086 was held by the reeve of King William. 86 Peter de Valognes had two manors in Loughton in 1086: each was worth 205.87 One of them, containing a hide and 30 acres was held of Peter by Ralph. Before the Conquest it had been held by Ulvric, a free man. The other, of I hide, was held in demesne. It had been held in ro66 by Leofcild. The descent of a part of these lands of de Valognes is traced below under Monk Wood. Some other parts became merged in the main manor of Loughton (see below).

An estate of 44 acres which had belonged to a free man before the Conquest was held in 1086 by W. Corbun of Robert Gernon; it was then worth 105.88 This also seems to have been later merged in the manor of Loughton.

By far the greatest part of the parish belonged in 1066 and 1086 to Waltham Abbey. The abbey's property was listed in Domesday book as four manors. Two manors were named Loughton: one contained 4 hides and 20 acres and was worth 40 s.; the other contained $2 \frac{1}{2}$ hides and was worth 205.89 These manors were said to be in Becontree hundred. The other two abbey manors, Alderton and Debden, were in Ongar hundred.90 Alderton consisted of $4 \frac{1}{2}$ hides and ro acres and was worth $\ell_{4}$ in 1086 . Debden consisted of 3 hides and 40 acres and was worth 40 s. All these lands in Loughton, Alderton, and Debden had been given to the abbey on its foundation in ro6o by Earl Harold. The gift was confirmed by Edward the Confessor in 1062.91

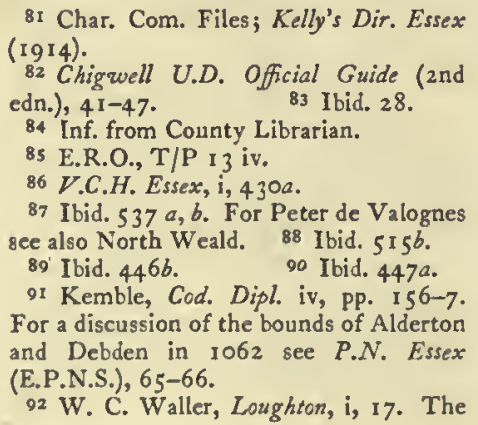

rental is in a Waltham Abbey cartulary, B.M. Cott. MS. Tib. c. ix. For Waller's comments on it see ibid. II-I7.

93 Waller, Loughton, i, 159. For the Gernon-Montfichet descent see Stapleford Abbots.

94 Ibid. I 58, 29-30. The modern name of the lane is a return to the ancient form. For centuries it was known as Pooles and Poles lane. 95 Ibid. I 58. 96 W. E. Lunt, Val. of Norwich, $52 \mathrm{I}$. 97 Waller, Loughton, i, 36-37. The original lease was for 40 years. In 1535 this had been extended for a further 40 years.
Waltham Abbey remained owner of most of the the manor of LOUGHTON. A detailed rental of about II 80 deals separately with the three estates although they had all belonged to the abbey for over y. It lists 32 tenants in Alderton who paid $5 s .3 \frac{1}{2} d$. in money rents in addition to rents in kind services. The tenants of Loughton numenants at Debden paying $16 s$. I I $\frac{1}{2} d .92$

It was probably soon after this time that the abbey acquired the manor in Loughton which in 1086 had Gernon's other lands to Richard de Montfichet (d. I 202). He or his son Richard de Montfichet (II) (d. I 267) granted the Loughton estate to Waltham tenants of the manor, Edward Reyntot, who paid an annual rent of $2 s .4 d$., and John son of Roger de Pyrle, Pourhood of the modern Pyrles Lane.94 About from Reyntot and Pyrle acquisition, early in the $13^{\text {th }}$ century, was of onequarter of Monk Wood; the remaining three-quarters Monk Wood).

In about 1254 the manor of Loughton (now apI 2 s., of which $f 8$ issued from the demesne and

property of Waltham Abbey was taken into the hands in $154^{\circ}$ on the dissolution of the abbey. toner died in the year of the dissolution and was sucas lessee by his son George. 98

In 551 the manor was given to Thomas Darcy, his barony, created in that year.99 A year later, however, he gave the manor back to the king in exchange for property in Surrey.I In 1553 Loughton was queen. ${ }^{2}$ The manor was thus again merged in Lancaster 3 It remained part of the duchy until 6 . 3. George Stoner, who had inherited the lease of the manor, died in $1559 . .^{5}$ His son and heir John Stoner a house at Luxborough in Chigwell (q.v.) in which he usually lived. It was, however, at Loughton Hall that he entertained the queen in $1578.6 \mathrm{He}$ died daughter Susan and her husband Robert Wroth. Susan and Robert were probably established at Loughton Hall before Stoner's death. ${ }^{7}$ Robert Wroth,
98 E.A.T. N.s. viii, $146-7$.

99 Cal. Pat. 1550-3, 136; Complete Peerage, iv, 78 .

1 Cal. Pat. I $550-3,458$.

2 Ibid. I 553 , 176 . Mary had also acquired the manor of Stanford Rivers (q.v.). 3 Ibid. I 557-8, 50. 4 Cal. S.P. Dom. I6 I I-18, 187; Waller, Loughton, i, 62.

5 E. $A . T$. N.s. viii, 147.

6 Ibid. For the Stoners and Wroths see also Chigwell Hall in Chigwell.

7 W. C. Waller, 'An Extinct County Family, Wroth of Loughton Hall', E.A.T. N.s. viii, 148 . 
knighted in 1597 , was a large landowner, a forest official, and a Member of Parliament. ${ }^{8} \mathrm{He}$ entertained James $I$ at Loughton Hall in $1605 .{ }^{9} \mathrm{He}$ died in 1606 and was succeeded by his son Sir Robert Wroth, who had married Mary, daughter of Robert, Baron Sidney of Penshurst, later Earl of Leicester, and niece of Sir Philip Sidney. Mary and her husband had literary interests and were intimate with a number of poets, including Ben Jonson, who dedicated 'The Alchemist' to Mary and 'The Forest' to Sir Robert. Mary was also a friend of the queen, Anne of Denmark. The Prince of Wales probably visited Loughton Hall in 1606 and it may have been through the influence of the queen that Sir Robert was permitted, in 1613 , to purchase the manor of Loughton from the Duchy of Lancaster. ${ }^{10}$

In 1608 a survey had been made of all the timber on the demesne lands of the manor, ${ }^{11}$ and in $I 6 \mathrm{I} 2$ the whole manor was surveyed.12 The latter survey gave the clear annual value of the manor as 6.5 I7. Allowance was made in this estimate for a fee-farm rent of $£_{0} 8$ and a further deduction of $£_{0} 192$ for the feeding of the king's deer on the grounds of the manor. The manor house, recently repaired, with its orchard and grounds, was valued at 66 a year. There were 640 acres of pasture, 304 acres of arable, and I 56 acres of meadow. The perquisites of the courts leet and baron were valued at $\oint_{6}$, the bailiwick of the manor at fo $6 s .8 d$., and the rents of the 29 copyholders at $£_{2} 3$. In addition to the demesne lands there was the moiety of a tenement called Hatfields, containing 24 acres. The timber trees in the manor were valued at $\oint_{\mathrm{O}} \mathrm{I}, 028$; the lessee had the right of topping and lopping. ${ }^{13}$ The waste of the manor consisted of 200 acres in Fair Mead, 1,000 acres in High Wood, and 100 acres in Monk Wood. In Fair Mead the ancient tenants of the manor and several inhabitants in adjoining manors claimed and usually had common of pasture for cattle without number at all times of the year, and the Loughton tenants also had common of estovers. In High Wood the ancient tenants had common of estovers, for which each paid annually a 'smoke hen' or Is. in lieu. In Monk Wood the lessees of the manor had always taken the lops and the ancient tenants had common of pasture only. Sixty pollard oaks in Fair Mead and High Wood were valued at $£ 24$.

Sir Robert Wroth paid $f_{1}, 224$ for the manor, which remained subject to a fee-farm rent of $£_{5} 8$, and for the advowson of the rectory (see below, Churches). ${ }^{14}$ 'The fee-farm rent was not extinguished until 1814.15 Shortly after purchasing the manor Sir Robert died (1614). His infant son died in $16.6 .16 \mathrm{His}$ estates were left heavily in debt and some of them had to be sold. Mary Wroth continued to live at Loughton Hall for some years, harried by creditors. ${ }^{17}$ In I62 I she published Urania, a pastoral romance which caused

\footnotetext{
8 Ibid. $14^{8-9 .}$

9 Ibid. I 54.

10 Ibid. $157-8,162-3$. In $1613 \mathrm{Sir}$ Rbt. was holding a lease due to expire in 1685 : Waller, Loughion, $i, 59 ; \mathrm{Cr}_{42} / 524 /$ 1.

1 Walier, Loughton, i, 59 .

12 Ibid. $60-6 \mathrm{r}$, where the survey is printed in full.

13 This was on the demesne lands and the lands held by tenants.

I4 E.A.T. N.8. viii, 163 . The purchase price seems low but clearly takes into account Sir Robert's previous purchase of a long lease.
}

her to be accused of libel. ${ }^{18}$ The next heir to Loughton was Sir Robert's brother John Wroth, who died in 1642.19 Before his death John settled the manor on John Wroth, son of his brother Henry. 20

Loughton descended in the Wroth family until the death in 1738 of Elizabeth, wife of John Wroth (d. 1718), the fourth of his name to hold the manor.21 The manor then passed to William, $4^{\text {th }}$ Earl of Rochford, grandson of Elizabeth Wroth's sister Jane. ${ }^{22}$

John Wroth (III), who was lord of the manor from 1662 to 1708 was described as 'a blustering county justice and gentleman grazier'. ${ }^{23}$ In $1688^{\text {'he is said to }}$ have entertained Princess (later Queen) Anne at Loughton Hall when she fled from London during the revolution which deposed James II.24 Between 1662 and 1667 the income from rents of the manor averaged about $£ 700$ a year. In addition to this over $£ 700$ was received during the whole period for fines and wood. ${ }^{25}$ About I 700 the manor was said to be worth about fr,000 a year. ${ }^{26}$ John Wroth (III) left I 24 neat cattle, I 2 horses, and over 200 sheep, Welsh and Weyhill, wool and wheat to the value of $\oint_{0}$ I 7 and $f_{0} \mathrm{I} 70$ respectively and I,000 oz. plate, valued at $\delta_{2} 254 .{ }^{27}$ A survey of 1739 gave the extent of the lands of the manor, including Monk Wood, but not the waste, as I,3 I 9 acres. It had thus increased by 35 acres since 1612.28 The largest farm, described as Jonathan Parker's tenure, was 455 acres. This ran from Wellfield across Rectory Lane to the Theydon Bois boundary. Alderton Hall farm was 267 acres. Elizabeth Gilderson's tenure was 224 acres stretching east of Chigwell Lane from the pound to the river. Loughton Hall farm was 202 acres from the hall south to the river. Debden Park covered 30 acres, Margery Field held 2 I acres, Monk Wood was IOI acres, and the remaining area was made up of Loughton Warren ( 8 acres), Loughton Piece ( 5 acres), and the tenements of three cottagers. 29

In 1745 the Earl of Rochford sold the manor to William Whitaker of Lime Street, London, an alderman of the City.30 Whitaker died in 1752 and Loughton passed to his widow Anne, and on her death in 1770 to their daughter Anne Whitaker. ${ }^{31}$

Whitaker had not been living at Loughton Hall at the time of his death, the tenant then being a Mr. Roberts. ${ }^{32}$ Miss Whitaker, however, did live there, 'a very formall lady of the old school or court, and reconned very rich, living in good style'. ${ }^{33}$ She died in I 825 , leaving the manor to John Maitland of Woodford Hall. 34

The manor passed from John Maitland (d. I 831 ) successively to his son William Whitaker Maitland (d. I86I) and his grandson John Whitaker Maitland, who also became Rector of Loughton and died in r $909 .{ }^{35} \mathrm{He}$ was succeeded by his son William W. Maitland (d. 1926). In I 944 Cmdr. J. W. Maitland,

16 Ibid. 164-5.

17 Ibid. $174-80$.

18 Ibid. $168-72$; D.N.B. Wroth, Lady Mary.

19 E.A.T. N.s. viii, $345-7$.

20 Ibid. 347.

2I Ibid. I $8 \mathrm{I}$, where the pedigree is given in Waller, Loughton, ii, are printed the wills of many members of the family.

22 E.A.T. N.s. viii, I 8 I.

23 Ibid. 351.

2s Walier, Loughion, i, 63-64.

26 Ibid. ii, 39

27 E.A.T. N.s. viii, 352.

28 Waller, Loughton, i, 64-65.
29 Loughton Warren was where the Warren (house) now is. Loughton Piece was near it on the Buckhurst Hill boundary. ${ }_{30}$ E.A.T. N.s. ix, I4; E.R.O., D/DC 27 729-30. 31 E.A.T. N.s. ix, 14 32 Waller, Loughton, ii, 47. Previous tenants had been a Jewish family named Suasso, emigrants - from Holland: ibid. ii, 62. 33 E.A.T. N.s. ix, I4.

34 Ibid.; cf. G. H. R. Harrison, Genealog. Acct. of Maitland Family; Burke's Landed Gentry, I 952, I 68 I.

35 Waller, Loughton, i, 65 ; E.R. xix, 50. The Reyd. J. W. Maitland left a fortune of $f_{126,000: \text { E.R.O., T/P }} \mathrm{I}_{3}$ ii. 


\section{A HISTORY OF ESSEX}

M.P., son and heir of W. W. Maitland, sold Loughton Hall and 644 acres of land to the London County Council for the building of the Debden housing estate, which started soon after I945. With a few short intervals Loughton $\mathrm{Hall}$ had been the home of the lords of the manor (including lessees under the Crown) since the I 6 th century.

In $185 \mathrm{I} \mathrm{W}$. W. Maitland owned some $\mathrm{I}, \mathrm{I} 20$ acres in Loughton. ${ }^{36}$ The tithe on most of his demesne land appears to have been commuted long before this. ${ }^{37}$ The estate was let out in ro farms of which the largest were Alderton farm (about 360 acres), Loughton Bridge farm (about 300 acres), and Loughton Hall farm (about 200 acres). Debden Hall farm, of I 64 acres, no longer formed part of the estate. In the 18 th century it had passed into the possession of the Hamilton family, one of whom, Archdeacon Hamilton, was Rector of Loughton 1805-5 I.38 In I85 I the farm was owned by John Williams.39

Between I 850 and 1930 the Maitland estate was gradually reduced by sales for building purposes, mainly in the neighbourhood of High Road.40 The Revd. J. W. Maitland was prominent in the Epping Forest inclosure controversy. If his plans had been successful some 650 acres of the forest waste would have become his freehold property as the result of inclosure. In the event he received $£_{3} 0,000$ for his rights in the 992 acres of forest waste. $4 \mathrm{I}$

The court rolls of the manor of Loughton are described below (see Parish Government and Poor Relief).

The present Loughton Hall, which stands in the middle of the Debden housing estate and is used as a community centre, is a large red-brick mansion erected by the Revd. J. W. Maitland in I 878.42 It was built on the site of an earlier house which was burnt down in 1836. The old house probably incorporated parts of a timber manor house of the I6th century or earlier. In 1602 , during the tenancy of the first Sir Robert Wroth, the Commissioners of the Duchy of Lancaster. made a report on the condition of the house.43 This indicates a typical medieval or 16 th-century establishment with many ancillary buildings including a detached gatehouse. It was then in poor repair, which suggests that it was already of considerable age. A large proportion of the estimated cost of repair was for carpentry and the quoted sum of froo specifically excluded the value of 70 trees to be had from the manor. This makes it clear that the house was of timber and was to be restored in the same material.

In 16 I 2 a new survey was made.44 The accommodation, apart from outbuildings, now included a hall, buttery, kitchen, larder, bakehouse, pastryhouse, milkhouse, and wash-house, together with "eight other lodgings with faire lodginge and greate roomes over the said roomes new built and redified at the chardgs of $\mathrm{Sir}$ Robert Wroth, the now farmer thereof'. 'The obliga- tion of entertaining royalty and the higher standard of comfort demanded by the times had evidently induced the second Sir Robert to increase the number and size of the reception rooms. There is some evidence that further improvements were put in hand when the manor had at last been acquired by the Wroths in I6r3: in 1630 it was stated that Sir Robert Wroth 'about sixteene yeres past' had built some part of Loughton Hall upon an old foundation. 45 The date on the front of the building at the time of the fire is said to have been I6I6.46 It seems possible that work was in progress at Sir Robert's death in 1614 and was completed two years later.

The description of a lodge in the forest, 'a faire house built on a Hill', which occurs in Lady Wroth's Urania, is thought to apply to Loughton Hall at the time of her marriage. 47 It includes a reference to the Lady's Walk, an avenue of trees leading up to the house from a bridge over the river. This was cut down during the Napoleonic Wars when a high price could be obtained for timber. 48

No record has been found of alterations to the house between 1616 and 1825 , but it cannot be assumed that none took place. The claim that parts of the interior, including a stone staircase, were designed by Inigo Jones should be taken with the usual reserve.49

After I 825, when the house became the property of the Maitlands, over $£ 6,000$ is said to have been spent on it. On I I December I 836 the house was burnt down. Contemporary newspaper reports stated that 50 rooms were destroyed or damaged.so There had been two frontages, both $162 \mathrm{ft}$. long, and one at least of these had the date 1616 on the rainwater heads. The style is said to have been Elizabethan, modernized later, and the interior was adorned with Ionic and Corinthian orders. ${ }^{\text {sI }}$

A picture of the building shows a very curious twostory front. ${ }^{52}$ It appears to be of brick and is divided into five bays by a pilaster treatment in stone or plaster. Each pilaster consists of two tiers of coupled Doric columns supporting detached entablature blocks. The only horizontal members which are continuous across the front are a string course at the upper cornice level and the coping of the parapet. This parapet rises in the centre to form a small curvilinear gable. Each story has ten tall sash windows and the roof has gabled dormers. A central doorway with a scrolled pediment is surmounted by a niche. If this front dated from 1616 it is clear that the doors and windows were altered later. In general the features are more consistent with a date near the middle of the 17 th century.

Alderton Hall is a timber-framed and weatherboarded building having two stories and attics. There is a main block with east and west wings. The oldest parts are the centre and the east wing, which date from the late 16 th or early 17 th century. The west wing was probably rebuilt early in the 18 th century.
36 E.R.O., D/CT 225 (Tithe Award). 37 See Churches.

38 Waller, Loughton, i, 98-99; ii, 53.

39 E.R.O., D/CT 225.

40 Nat. Reg. Archives, Rep. on MSS. of Cmdr. J. W. Maitland.

4I See above, Preservation of Epping Forest.

42 Architect Eden Nesfield: N. Pevsner, Buildings of Eng. Essex, $26 \mathrm{r}$.

43 Essex Naturalist, vii, I 6.

44 Ibid. 18.

4s Ibid. 21 .
46 Newspaper reports on the fire, see below.

47 E.A.T. N.s. viii, 173 , quoting Urania ii, 297-8.

48 Ibid.

49 Lewis's Topog. Dict. I 844 . It has been common practice to attribute any mature classical work of the first half of the $17^{\text {th }}$ cent. to Inigo Jones. In this case there might be some justification for the claim because of the Wroth's connexion with the Earl of Pembroke and with the court of James 1. Mary Wroth is known to have taken part in at least one court masque (the Masque of Blacknesse) for which Inigo Jones designed the costumes at the outset of his career.

so Essex Naturalist, vii, 20, quotes acets. from the Essex Standard and the Essex Herald. 5 I Ibid.

s2 E.A.T. N.s. viii, 345 : from a watercolour then in the possession of Miss $I$. R. Maitland. See plate facing p. 226. The will of Miss Whitaker (pr. 1826 ) refers to the 'Saloon', gallery and 'King's Rooms' in the hall: E.R.O., T/P 13 i. 
The present Debden Hall was built about I 930 to replace a previous building on the site which was demolished in the previous year..$^{53}$ A photograph of the earlier building ( $c .1898$ ?) shows a large house of two stories and attics having a pedimented doorcase and a long range of outbuildings. The house appears to have dated from the early igth century. ${ }^{54}$

The two manors held in 1086 by Peter de Valognes probably included what later became known as $M O N K$ WOOD. In I 66 Philip de Snaring held $\frac{1}{3}$ knight's fee and Geoffrey de Snaring $\frac{1}{2}$ knight's fee, both of the honor of Valognes.35 These tenements were probably in Loughton, for early in the $13^{\text {th }}$ century the Snaring family held an important position in the parish, part of which was for a time named after them. ${ }^{56}$ Before I 240 a wood in 'Loughton Snarryngs' had come to be divided between the abbeys of Stratford Langthorne and Waltham. Three-quarters of the wood had been granted to Stratford by Ralph de Assartis; the remaining quarter had been granted to Waltham by Geoffrey Reyntot and Roger Fitz Ailmar.57 Ralph de Assartis is known to have been a tenant of Geoffrey de Snaring. ${ }^{58}$ In 1236 he was holding $\frac{1}{8}$ knight's fee in Loughton of the barony of Valognes.39

In 1240 an agreement was made between the abbeys of Stratford and Waltham concerning their timber rights in their jointly owned wood. When one abbot wished to fell timber in the wood he was to notify the bailiff of the other abbot. Four trees of equal value were then to be selected, of which Stratford was to take the first, second, and fourth choices, and Waltham the third. Trees not required for immediate felling might be marked by either abbey for future use. ${ }^{60}$

The portion of the wood owned by. Waltham Abbey became merged from the I 3 th century in the main manor of Loughton (see above). The three-quarters owned by Stratford became known as Monk Wood and remained the property of that abbey until the Dissolution.

Like the manor of Loughton Monk Wood became part of the Duchy of Lancaster in the I6th century, and appears to have been leased along with the manor. In 1582 the wood was said to contain 53 acres but in I6I 2 its area was IoI acres of which 74 acres comprised Great Monk Wood and 27 acres Little Monk Wood.6! There was sometimes doubt whether the wood was demesne or waste land. Historically there is little doubt that it was demesne. ${ }^{62}$

After the I6th century Monk Wood descended along with the manor of Loughton. In I 767 , when Alderton Hall was leased, it was provided that the lessee should receive 1,000 faggots and 100 logs every year from the wood. In 1787 this was altered to 500 faggots and $250 \operatorname{logs.}{ }^{63}$

In 1851 -Monk Wood contained 97 acres of which 73 acres were in Great Monk Wood and 24 acres in Little Monk Wood. 64
There is a legend of Monk Wood which concerns a monk who murdered a maiden. ${ }^{65}$

The advowson of the rectory of Loughton has always descended along with the manor. The CHURCHES present patron is Cmdr. J. W. Maitland, M.P. 66

The rectory was never appropriated. It was valued at $£_{5}$ in about 1254 , at $£_{2}$ in 1291 , and $£_{55} 6 s .8 d$. in 1428.67 In 1535 the value was returned as $6,1844^{68}$ Tithe was commuted in $185 \mathrm{I}$ for $\ell_{5} 18.69$ It would have produced much more than this if a partial commutation had not taken place long before, by which I, 052 acres belonging to the lord of the manor had been freed from tithes in kind in return for an annual 'modus' of $£_{3} 75$. On another 326 acres the tithe rent was assessed at a much lower rate than in the main body of the parish. There were 45 acres of glebe in 1851.70 It had increased from 36 acres in 1610 and 41 acres in $1714{ }^{71}$ The old rectory house in Rectory Lane has been demolished.

The original parish church of $S T$. NICHOLAS stood beside Loughton Hall. ${ }^{72}$ After the building of the new parish church of St. John in 1846 most of the old church was demolished, but the chancel was preserved as a mortuary chapel until 1877 when it also was removed. The old church consisted of nave, chancel, north aisle, south porch, and weather-boarded tower with shingled spire. Nave and chancel were of the same width (about $18 \mathrm{ft}$.) and together measured about $60 \mathrm{ft}$. in length. A sketch of $182 \mathrm{I}$ shows a large 15 th-century window at the east end of the chancel. This is said to have been replaced before the final demolition of the church by an iron window. ${ }^{73}$ In the south wall of the chancel there was a two-light window, and also a low-side window. The aisle of the church measured about $\mathrm{I} 8 \mathrm{ft}$. by $54 \mathrm{ft}$. At its east end there was a chapel divided from the rest of the aisle by a wooden screen with a central doorway. The tower was of two stages, the lower of which projected to allow space for a vestry.

Julia Stokesby, by her will proved 1 384 , left 20 s. to the work of the church. ${ }^{74}$ The form of the bequest suggests that building operations were then in progress. The will of John Stoner (proved 1540) directed that he should be buried in the chapel of Our Lady in the parish church of Loughton. 75 George Stoner, son of John, similarly directed ( 1558 ) that he should be buried in the "new chapel" in the church.76 This chapel was probably that at the east end of the aisle which was later regarded as the private chapel of the lord of the manor. William Harryson of Loughton by his will proved 1540 left 40 s. towards the building of the steeple. 77 The tower and spire were repaired in 1737. General repairs to the church were carried out in $1825-7$ and 1829 .

In about i 768 the church had three bells. 78 One of them is said to have been sold at the end of the 18 th
53 Inf. from the present occupier of Debden Hall.

s4 E.R.O., Sale Cat. B. 9 .

ss Red Bk. of Exch. (Rolls Ser.), 360.

s6 Waller, Loughion, i, 156.

57 Ibid.

59 Bk. of Fees, 579.

60 Waller, Loughton, i, I56; Essex Naturalist, v, 174 .

6I Essex Naturalist, v, 177 ; and see above, Manor of Loughton.

62 Waller, Loughton, i, 52, 10-II ; cf. E.R.O., D/CT 255 .
63 Waller, Loughton, i, I I. 64 E.R.O., D/CT 255. os E. Hardingham, Lays and Legends of the Forest of Essex, I 13.

66 Newcourt, Repert. ii, 395-6; Morant, Essex, i, 164; Kelly's Dir. Essex (1 862 f.); Chel. Dioc. Year Bk. 1952.

67 E.A.T. N.s. xviii, 17; Tax Eccl. (Rec. Com.), 24 ; Feud. Aids, ii, 204.

68 Valor Eccl. (Rec. Com.), i, 435.

69 E.R.O., D/CT 225.

70 Ibid.

71 E.R.O., T/P I9. For the history of the glebe see Waller, Loughton, i, 55, I $19-22$.

${ }_{72}$ The following account is based on W. C. Waller, 'Some account of the vanished church of St. Nicholas, Loughton', E.A.T. N.s. xiv, 275 f. (illustrated). ${ }_{73}$ This alteration was said to have been made by Archdeacon Hamilton, rector I 805-5I.

74 Waller, Loughton, ii, I.

75 Ibid. 5 .

76 Ibid. 8 ,

78 Morant, Essex, i, 164 . 


\section{A HISTORY OF ESSEX}

century. The other two, dated 1621 and 1655 , were later recast to form the fifth bell of St. John's church (see below). There was a 16 th-century painted cupboard, some i6th-century glass and four sepulchral brasses; all of these are in the present church of St. Nicholas. Several floor slabs, left in situ when the old church was demolished, were examined by Waller in about I917. They included slabs to Teffery Lee, I670, and Thomas Tuson, 1702. A brass to Robert Rampston, I 585 , founder of a parish charity, existed in $\mathrm{I} 835$ but has now disappeared. 79 In 1790 there were several hatchments of arms of the Wroths, former lords of the manor, in the north aisle chapel. 80

Wright commented in 1835 that the parish church was inconveniently distant from the village. ${ }^{81}$ The destruction of Loughton Hall in 1836 left the church even more isolated than before. The new church of St. John was therefore built in 1846 to provide more effectively for the religious needs of the growing parish. It was decided that the old church should be demolished to defray part of the cost of building St. John's and a faculty was issued for this purpose in 1847 . It had been hoped that St. Nicholas' would fetch $£ 25^{\circ}$ but it was sold by auction for only $68 \mathrm{~g}$. The chancel was for some reason left standing and with the addition of new north and west walls (costing 636 ) became a mortuary chapel. This chapel was demolished in 1877 and the present church of St. Nicholas was built slightly to the west of it. This rebuilding was clearly connected with that of Loughton Hall, and St. Nicholas' was used for many years after I 877 as the private chapel of the hall. In 1947 it was repaired and refitted for use as a chapel of ease to St. John's for the Debden estate. 82 It is a small flint building consisting of nave, chancel, north porch, and bellcote with one bell. On the gable of the porch are carved bargeboards which are said to have come from the original church of St. Nicholas. In the chancel are brasses from the old church to John Stonnard (Stoner, I 540) and Joan and Katherine his wives, William Nodes (I 594) and Elizabeth (Wollsey) his wife. Others are probably to George Stoner (1558) and Abel Guilliams (1637).83 On the north wall of the chancel is a cupboard with elaborately carved double doors flanked by columns and strapwork and surmounted by an entablature. On the panel below the doors is a late-I6th-century painting of the Annunciation. The north and south windows have early-I6th-century glass showing two kneeling figures with coloured nimbi. ${ }^{84}$

The parish church of $S T$. FOHN THE BAPTIST was consecrated in November $1846.8 \mathrm{~s}$ It was built in Blind (now Church) Lane near the junction with the main road, on land most of which had previously been held by Samuel Brawn, the Baptist minister, copyhold of the manor of Loughton. ${ }^{86}$ The new church was much nearer the village than St. Nicholas', but the people of south Loughton had still to travel $\frac{1}{2}$ mile or more to the church, mostly up hill. The total cost of St. John's, including furnishings, was slightly less than
66,500. The rector gave $61,134, M$ rs. Pearse 6700 Mrs. Powell 6650 , and there were many other substantial voluntary contributions. By I 848 a total of $£, 5,850$ had been raised, of which $£, 1,000$ came from a church rate. The balance required was met by an Exchequer Loan, which was finally paid off in 1866.

The church is a yellow brick building in 'Norman' style, consisting of nave, chancel, transepts, north porch, and central tower. The architect was Sydney Smirke (1798-1877), brother of Sir Robert Smirke ( $178 \mathrm{I}-1867) .87$ He originally submitted three alternative designs, one 'Norman' and two 'Early English'. Between 1875 and 1878 the chancel was enlarged at a total cost of about $£_{1} 1,600$. The church was slightly damaged by bombing during the Second World War.

There are eight bells, all of which were installed between I 866 and 1874 . The fifth bell was recast from two of the bells of St. Nicholas' church, which had been dated I $62 \mathrm{I}$ and 1655 . The old church plate was destroyed when Loughton Hall was burnt down. It consisted of a silver cup, silver paten, plated flagon, and plated dish. A silver almsdish of I 848 formerly in the church was stolen in 1930 . The present plate includes many vessels, of which the oldest are of I 836.88 The parish chest, now kept in the south transept, probably dates from about 1607.89 It is remarkable for the geometrical patterns incised on the three front panels.

St. John's parish hall was built in $1914-15$ at a cost of 6808 . It adjoins the church to the west. In 1947 the mission church of $S T$. FRANCIS was built at Oakwood Hill on the Debden estate. It is a small timber building. ${ }^{90}$ In 1950 a church hall was opened opposite St. Nicholas' church, and in I 953 the mission church of $S T$. GABRIEL was opened in Grosvenor Drive, Debden; 91 this is a permanent brick church. St. Francis' and St. Gabricl's are chapels of ease to St. John's.

The church of ST. MARY THE VIRGIN, High Road, Loughton, was built in $187 \mathrm{I}$ and consecrated in the following year as a chapel of ease to St. John's.92 The site was given by the rector, J. W. Maitland.93 In 1887 the parish of St. Mary was formed out of that of St. John. ${ }^{94}$ Its endowment included $\$ 50$ from the mother parish. The patron of the vicarage is the Rector of Loughton. The church is a stone building in Gothic style, consisting of nave, chancel, aisles, south porch, and bellcote containing one bell. The north aisle was added in 1883 . The architect was T. H. Watson.95

The church of ST. MICHAEL AND ALL $A N G E L S$, Roding Road, was built and dedicated in or about September I 937, as a chapel of ease to St. Mary's. It received its present name about I942.96

Among parochial charities which include provision for the churches are Parish Clerk's Piece and W. C. Waller's Charity. ${ }^{97}$ The following charities are also for the use of the churches. ${ }^{98}$

Emily Jane Hanson, by will proved 1933 , left three cottages (now nos. 20, 22, and 24 Pump Hill) for the
70 T. Wright, Hist. Essex, ii, $3^{8} 5$.

80 E.A.T. N.s. ix, 11.

8I T. Wright, Hist. Essex, ii, 384

82 Inf. from Canon M. N. Lake, Rector of Loughton.

83 Cf. E.A.T. N.s. xiv, 278, 287-8; T. Wright, Hist. Essex, ii, $384-5$.

84 Cf. Hist. Mon. Com. Essex, ii, I 66.

8s For the following acct. see Percy

Thompson, Story of the Parish Church of

Loughton (illustrated), also E.R.O., T/P I 3 (cuttings from parish magazines)

86 E.R.O., T/P I 8 . For other sites considered see E.R.O., T/P 13.

87 See D.N.B. Sydney Smirke later designed (I 850 ) St. Mary's, Theydon Bois (q.v.)

88 Cf. Ch. Plate Essex, $\mathrm{IO}_{3}$

$89 \mathrm{Ch}$. Chests Essex, I 54 (illus.).

90 Inf. from Canon M. N. Lake, Rector of Loughton.
92 Kelly's Dir. Essex (I 926).

93 Waller, Loughton, i, I42. The site was formerly known as Thistley Field.

94 Kelly's Dir. Essex (I 926).

os Ibid.; N. Pevsner, Buildings of Eng., Essex, 260.

96 Inf. from the Revd. D. V. Wright of Loughton.

97 See below, Charities.

98 Char. Com. Files. 
additional endowment of St. Mary's Loughton, and for charitable purposes not connected with the parish.

Frederick Joseph Brand, by will proved I G40, left fo I 00 duty-free in trust for distribution each Christmas among the choirboys of St. John's. There is no further record of this charity at the Charity Commission.

The Roman Catholic church, Traps Hill, dedicated to St. Edmund of Canterbury,

ROMAN was built in I926-7.99 The

CATHOLICISM church of St. Thomas More, Debden, was opened in $1953 . .^{1}$

In 1672 Joseph Brown, who had been ejected from the vicarage of Nazeing in PROTESTANT the vicarage of Nazeing in
I662, was licensed to NONCONFORMITY minister to a congregaLoughton. 2 tion of Presbyterians at

On 3 October I 8 I 3 a small nonconformist chapel was opened at the south end of High Road. The preachers at the opening were the Revds. J. Hughes of Battersea, J. Clayton of Camomile Street, London (E.C. 3), and G. Collinson of Walthamstow. ${ }^{3}$ In I8I 7 Samuel Brawn, formerly of Stepney Academy, was ordained minister. ${ }^{4}$ The church supported the Baptist Union, though it was not at first affiliated to it. 5 Brawn remained until $r 868.6$ In $\mathrm{I} 829$ he reported a congregation of 175.7 A new church was built in I $860-I$. It cost $\oint_{0} \mathrm{I}, 800$, of which $\oint_{\mathrm{I}} \mathrm{I}, 400$ had already been raised by the opening day. ${ }^{8}$ This was attended in the I $860^{\prime}$ 's by W. 'T. Whitley, later a distinguished Baptist minister and historian. He gave some of his reminiscences of the church in 'A Scenario of Baptist Essex'.9 He mentioned the arrival of a new minister (W. Bentley, I 868) to help Samuel Brawn. The old minister watched his assistant from an armchair on the platform, 'snorting at any questionable doctrine'. Whitley helped to collect for the church soup kitchen. His mother did missionary work among the gipsies of Epping Forest.

In 1880 the church had 193 members and 2 ro Sunday school children, with a minister and two evangelists. ${ }^{10}$ It was and remains one of the strongest nonconformist churches in the district. Membership was 181 in 1900 and the Sunday school had risen to 356.11 In 1920 there were 2 I I members. ${ }^{12}$ A decline to 164 in 1930 has subsequently been reversed and in I95I there were I8I members and 143 pupils. ${ }^{13}$ Except for brief vacancies there has always been a resident minister. Although still closely connected with the Baptist Union the church is now a united free church, known as Loughton Union Church.

Associated with the church are the Lincoln Almshouses..$^{4}$ Henry Lincoln, by his will proved in I 912 , left $f_{0} \mathrm{I}, 300$ in trust to build five small almshouses to be let at low rents to people over 50 years old who had attended the church for the past ten years. The almshouses were built opposite the church. The sum of f.99 I7s. was received during the Second World War in local savings weeks, and the income from this, together with $£ 20$ I 6 s. in rents from four cottages, and

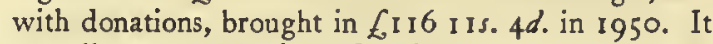
was all spent on repairs and maintenance.

The founder of Methodism in Loughton was Edward Pope, who came to the district in 1873 , when the nearest Methodist church was at Wanstead. 15 In that year he took over a small disused chapel in Englands Lane. ${ }^{16}$ Among the first converts were Mr. and Mrs. Fred Smith, whose nephews later became the famous gipsy evangelists. The chapel was placed on the plan of the Hackney (Wesleyan) Methodist circuit in 1874 and five years later became part of the newly formed Wanstead and Woodford circuit. In I 880 land was purchased on a more central site in Forest Road, and an iron church erected there, at a total cost of $\$ 697$. In 1885 the land was sold for 6250 and a new site in the High Road was bought for $f_{3} 300$. The iron church soon proved inadequate and in 1903 a new brick church with a schoolroom was built for $£ 3,300$, of which $f_{1}, 000$ was borrowed from an insurance company. This church was opened in I 903 (see plate facing $\mathrm{P}$. I I 3 ).

In I 934 the minister at Buckhurst Hill (see Chigwell) was transferred to Loughton at the request of the latter church. In I 934 also it was decided to build a new hall behind the church on land given nine years before by Sir Joseph Lowrey. ${ }^{17}$ The hall was opened in 1936. It cost $\oint_{0}, 880$, of which $\oint_{0} 2,024$ were raised by donations. In 1944 it was totally destroyed by $a$ bomb, and other church premises were badly damaged.

In 1946 further land was bought and a scheme was drawn up for the rebuilding of the hall. The work was to be done in three stages. The second of these was completed in June 1952, when the new Wesley Hall was opened. The present (1953) membership of the church is I59. The church is of red brick in gothic style. The chapel in England's Lane still exists, having been converted into dwellings called Kirk Cottages. It is a small building of stock brick probably dating from the middle of the 19 th century and somewhat similar in appearance to the former Congregational Chapel at Abridge (in Lambourne, q.v.). ${ }^{18}$

In June 1946 , on the recommendation of the Methodist General Purposes Committee, it was decided to negotiate for a site on the new London County Council estate at Debden. In I 949 a trust was formed and in $195^{\circ}$ land was offered by the L.C.C.


6.7,000, was opened in July 1952. The money came from compensation for a bombed church in Walthamstow. In March 1953 it was decided to apply for a deaconess. The church is at present under the supervision of the Loughton minister and has a membership of 19 .

Soon after the Methodists moved to Forest Road their former chapel in England's Lane was taken over by the Baptists, who held services there under the leadership of James Herbert Tee, a local solicitor, from

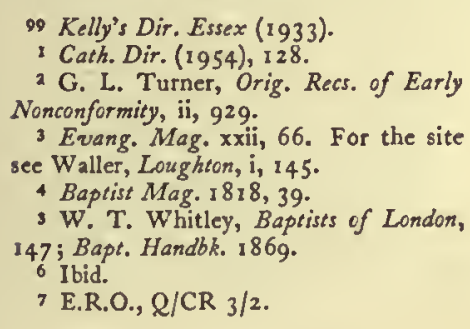

8 Bapt. Mag. 1860, 453; ibid. 1861 , 165 .

9 Bapt. Hist. Soc. Trans. N.s. $x, 56$.

10 Bapt. Handbk. I 880.

II Ibid. 1900.

13 Ibid. 1930, 1951.

24 Char. Com. Files.

is The following account is based on an address by $A$. W. Leach at Wanstead, Dec. I9I9 (reported in Mins. of Local Preachers Mtg., Wanstead and Wood- ford Circuit), Trust Deeds and other church records. Cf. also Methodism in Loughion $1903-53$ (Jubilee pamphlet).

16 It is said to have been a Congregational chapel. Nothing is known of its earlier history.

$17 \mathrm{He}$ was Director of the Salvage Association, London, and lived at the Hermitage, Loughton.

28 It was built after 1850 : cf. E.R.O., D/CT 225. 


\section{A HISTORY OF ESSEX}

I 884 to I $889 .^{19}$ About the same time Anglican mission services were being held by Mrs. John Pelly in a room over the coach house at Goldings Hill House. These services were primarily for poor people who might have hesitated to attend a regular place of worship owing to lack of suitable clothes. About 1887 Mrs. Pelly left Loughton and her congregation transferred to the Englands Lane chapel. In I $889 \mathrm{~J}$. H. Tee and his associates erected the present iron church at the corner of Englands Lane and Goldings Hill. The trust deeds of the new church made strict provision that the Goldings Hill Mission should be undenominational in character. Tee remained superintendent of the mission until his death in 1909 . He has had several successors, of whom Mr. E. S. Currey (c. I $925-40$ ) was superintendent for the longest period.

Other nonconformist places of worship are the Forest Mission Hall, High Beech Road, belonging to the Plymouth Brethren and the Lincoln Hall, built in I 9 I 2 and presented to the Loughton Brotherhood by Henry Lincoln. ${ }^{20}$ A Congregational church is now (1953) being built in Borders Lane, Debden, with support from the Loughton Union Church. ${ }^{2 r}$

The earliest surviving court roll of the manor of Loughton is for 1270.22 PARISH GOVERNMENT The next is for 1400 , $A N D$ POOR RELIEF and there are later rolls recording the proceedings of courts held on eleven occasions in the period I 404-69.23 There are rolls for I 5 I I, I 538, I 585 , and $1593 .{ }^{24} \mathrm{~A}$ roll for the period $1570-1602$ was used as evidence in connexion with the Epping Forest Commission in the I 870 's but could not be found in 1 894-5.2S Rolls and court books for 1609-1865 existed in the 1890 's when full abstracts from them were made by W. C. Waller. ${ }^{26}$ So far as it relates to the period after I 609 the present survey is based upon these abstracts, not the original rolls. ${ }^{27}$

The medieval rolls contain nothing unusual in connexion with local government. They note the appointment of manorial officials, the regulation of minor nuisances such as foul ditches and of the descent of copyhold tenements. There are also a few entries relating to petty civil suits. ${ }^{28}$

Although few rolls have survived for the I6th century there is evidence that courts were held regularly (perhaps once a year) after the manor had passed to the Crown.29 The series that began in 1609 was apparently complete apart from some gaps in the period I609-59. Courts leet were usually held once a year until about i 780 , when they became less frequent. The last was held in 1828 . The court retained its vitality for much longer than in many places. The reason was probably the survival of Epping Forest. The main business of the court during its last 300 years was to administer the customs relating to the lopping rights of the tenants. The conditions under which these rights of estover were exercised were frequently restated in the court. The rights were traditionally limited to those holding ancient tenements. Lopping was permitted only between I November and 23 April and might be done only on Mondays. ${ }^{30}$ The wood had to be removed on sledges, wheeled carts being forbidden, and no lopper might employ more than two horses to draw his sledge. As late as 1828 there were presentments for cutting wood on days other than Mondays, and for using wheeled carts. Encroachments on the waste of the manor (often the forest) were presented at the leet. Usually they were allowed to remain on payment of a small fine, but sometimes (as in 1794) the court ordered inclosures to be thrown open. There were frequent presentments of foul ditches and of clay pits that had been allowed to become full of water. On one occasion a tenant was ordered to make two foot-bridges. In I $72 \mathrm{I}$ it was ordered that each alehouse keeper, baker, and potter within the manor should pay 4Os. a year to the poor for the forest wood which he used in his trade. The court habitually appointed two constables and two woodwards. It was sometimes stated that one of the woodwards was elected by the tenants and the other by the lord of the manor (e.g. 1817).

Courts baron were held at the same time as the courts leet and on many other occasions. At some periods there were several courts baron in a year and they continued to be held regularly until 1865 . Their main business was the regulation of copyhold tenure, but after the leet had ceased to meet the courts baron became increasingly concerned with grants of waste. In I 864-5, when J. W. Maitland decided to inclose the forest, the manor court was used for the purpose of making grants of waste in extinguishment of common rights. ${ }^{31}$ After a long interval the court was held once more in October $\mathrm{I} 8 \mathrm{gI}$, when some copyhold business was transacted. ${ }^{32}$ One tenant complained of encroachments on his land and the bailiff of the manor was ordered to cause them to be abated. No evidence has been found of any later court.

The manorial pound was near the manor house (Loughton Hall). It still existed in $1895 .{ }^{33}$

A vestry minute-book survives for the period I720-41.34 In each year of that period there were two regular meetings, at Easter for the approval of the accounts of the parish overseer of the poor, the churchwardens and constables, and for the appointment of churchwardens and the nomination of the overseer, and on 26 December for the nomination of the surveyors of highways. As noted above the appointment of constables continued to be made in the manor court until the r 9 th century. In 1724,1725 , and 1738 these were the only meetings. In other years additional meetings were held when required. In 1726 there were nine meetings. The number of those signing the minutes varied from 4 to 19 . At the Easter vestry, which was best attended, 10-1 2 usually signed. There were two rectors during this period, Christopher

19 The following account, supplied by Mr. William Addison, is from a typescript history of the Goldings Hill Mission, 1889-1939, compiled by R. E. Currey.

2o Kelly's Dir. Essex (1933); inf. from

Mr. W. Addison.

21 Inf. from Revd. M. N. Lake.

$22 \mathrm{SC}_{2} / 173 / 30$.

$23 \mathrm{SC}_{2} / \mathrm{I} 73 / 3 \mathrm{I}-38,174 / 42 \mathrm{~A}$

$24 \mathrm{SC}_{2} / 174 / 42 \mathrm{~B}, 173 / 19, \mathrm{DL} / 30 / 6 \mathrm{r}$ 749.

25 E.R.O., T/P 18.

26 They were then in the possession of the Revd. J. W. Maitland. Their present location is now (1953) being investigated by the National Register of Archives. 27 E.R.O., T/P I 8.

28 For fuller details see Waller, Loughton, i, 46 .

29 Waller, Loughton, i, 46 .

30 The opening date was altered to 12

Nov. in 1753 : sce above, Preservation of Epping Forest.
31 For the Epping Forest question see above.

32 E.R.O., T/P 13 i. It is evident from the proceedings of the court of $\mathrm{r} 8 \mathrm{~g} \mathrm{r}$ that there had been no court since 1868 or earlier.

33 E.R.O., T/P I 3 i.

34 E.R.O., D/P 233/8/1. The book was used by Waller, Loughton, i, 149-53. It contains a single entry, out of order, of a meeting in July 1743 
Sclater (1706-35) and his son William Sclater (173578). Each regularly attended the vestry and usually kept the minutes. Mrs. Elizabeth Wroth of Loughton Hall was also a regular attendant until her death in $173^{8}$, and she frequently signed the minutes first. The parish clerk does not figure prominently in these minutes. There is no evidence that he was paid a cash salary, but there was a piece of land attached to his office. ${ }^{35}$ All parish expenses except the repair of roads seem to have been normally met out of a single, overseer's rate, but special church rates were sometimes levied. The overseer's rate was usually $6 d$. or $9 d$. in the $f_{0} \mathrm{I}$; a penny rate produced about $\oint_{0} \mathrm{I}$.

One churchwarden was elected by the rector, the other by the parishioners. One usually retired each year but the same man often held office more than once during the period. Most of those who served as churchwardens also served in other years as overseers. There was only one overseer at a time. In several cases a woman acted as overseer. Mrs. Wroth not only held the office but also carried out her duties in person. In r 720 the magistrates at Epping objected to the inclusion in her account of constables' and surveyors' bills, but the vestry reiterated its support of her action. The surveyors' bill, which comprised most of the money involved, was re-entered in the overseer's account in 1722 and was then apparently passed by the magistrates. There is very little other information about the surveyors. It is not even clear how many were appointed. Nominations of persons suitable for the office varied between 3 and 6 . No surveyors' accounts were entered in the vestry book.

Between 1720 and $174 \mathrm{r}$ poverty was not a serious problem, and was met mainly by out-relief in cash or in kind. The poor were provided with clothing, medical aid, home-help, and firewood from the forest. In 1723 special allowances were made to victims of smallpox. A few poor children were bound apprentices; usually they went to masters within the parish, but on one occasion ( 1720 ) the parish granted \&3 to a widow to apprentice her daughter to a cook in Shoreditch.

It is doubtful whether the parish owned a poorhouse at this time. In 1722 it was agreed 'that the overseer of the poor should pay a year's rent ending next Lady Day for the house which Heath lives in, being $50 s .$, and to get it as cheap as the officers can'. In the following year the vestry decided to repair 'the parish house'. Accounts for this work were allowed in 1724 and 1725 . In 1726 it was agreed that the parish officers should forthwith provide a workhouse to keep the poor employed, and later in the same year the vestry negotiated with widow Dimion and her son William Rich for the house which she held for life, in order to secure it as a workhouse. In 1743 it was agreed that 'Riches house' should be hired as a workhouse, which suggests that the negotiations of $1726 \mathrm{had}$ not then been successful. In 1726 , however, the parish had acquired a copyhold cottage, formerly the tenement of George Baldwin, for the use of the poor. It is fairly certain that this became the poorhouse later known as Baldwins Buildings. ${ }^{36}$

35 Sec Charities, below.

36 Waller, Loughton, i, 130.

37 E.R.O., Q/CR $x / 1,1 / 9,1 / 12$

38 In $1844-69$ the poor rates for Loughton were usually 25 . in the $f_{0} \mathrm{I}$ producing about 500 a year: Waller, Loughton, i, 106.
Later details of poor relief come from returns to government inquiries.37 In 1776 the poor rate produced $\ell_{2} 80$, in $1783 £ 39 \mathrm{I}$, in $1784 £_{464}$, and in $1785 \oint_{332}$. Between $\mathrm{I} 80 \mathrm{I}$ and $\mathrm{I} 82 \mathrm{I}$ the sums varied between $£_{08} 85$ and $f_{4} 49 \mathrm{I}$, being highest in I 804 and lowest in 1802 . Not all the money was spent on poor relief. Administrative and legal expenses, church repairs, the county rate for the maintenance of jails and bridges, and allowances to the dependants of militia-men on active service were all met out of these rates. Militia allowances were heaviest in $1804\left(\delta_{6} 63\right)$ and $1813(687)$. In $1813-16$ inclusive an annual salary of $£ 20$ was paid to the overseer. Between I 801 and 1817 the amount actually spent on the poor varied from 6785 (1 805 ) to 6442 (I 802 ).

In 1836 Loughton became part of the Epping Poor Law Union. ${ }^{38}$ Baldwins Buildings became the property of that union but were purchased by public subscription for use as almshouses for the people of Loughton. 39

After 1836 the vestry was mainly concerned with the church, the parish charities, rating assessments, and roads. The vestry book for 1844-69 gives details of these and a few other activities.40 In 1865 , when the forest inclosures were being made, the vestry adopted some of the new roads. In the same year it was stated that a manor court had directed that the building formerly used as the parish cage, situated on the waste, should be removed, and the vestry accepted an offer of $£ .7$ for the materials of the building. The cage stood opposite the 'King's Head'. In and after I 848 the vestry concerned itself with problems of drainage and sanitation through the formation of a nuisance removal committee.4r

A parish council was elected for the first time in I894-5.42 It became an urban district council in I 900 .

There is said to have been a school in Loughton in about $175 \mathrm{I}$, which had existed for many SCHOOLS years. In $176 \mathrm{I}$ the curate, Pierce Dod, obtained subscriptions from local persons and opened a school. Subscriptions soon decreased, however, so that pupils remained few, only $\mathrm{I} 3$ in 1766 , and teachers were poorly paid. Gradually, with the aid of an annual sermon, the school's position was improved,43 and in 1807 it had 20 pupils. These were all taught reading and writing and the girls were also learning housecraft, in accordance with the original rules of $176 r .44$ By this time local interest in the school was increasing. In 1810 James Powell gave fio to introduce the monitorial system, and a few years later two new schoolrooms and two teachers' houses were built at a total cost of $f 500.45$ In 1817 the school was united with the National Society, and the number of pupils increased rapidly to about I00.46

The population of Loughton was growing rapidly at this time and new private schools were being established for children of all classes. The National School also expanded. The number of boys attending it increased from 48 in 1833 to 75 in $1846-7$, and of girls from 58 to 85.47 This was made possible by the enlargement of the building soon after $r 834,48$ and
39 See Charities.

40 E.R.O., D/P 233/8/2. Cf. Waller,

Loughton, i, 104-0. See also Church,

Charities. 45 Sec above.

42 E.R.O., T/P ${ } 3 \mathrm{i}$.

43 Waller, Loughton, i, $102-4$, ii, 47.

4 E.R.O., D/AEM 2/4
45 Waller, op. cit. 102-4; Retns. Educ. Poor, H.C. 224 , p. 26 I (I8Ig), ix (r).

46 Nat. Soc. Rep. I 820,1828 .

47 Educ. Enquiry Abstr. H.C. 62 , p. 282 (1 835), xli; E.R.O., D/P 30/28/1 $9 ;$ Nat. Soc. Enquiry into Ch. Schs. $1846-7,12-13$ 48 E.R.O., D/P 30/28/19. 


\section{A HISTORY OF ESSEX}

again in 1842.49 At this time the children paid no fees and were sometimes given clothes. In $1838-9$ the school received $\oint_{05}$ from subscriptions and possibly also part of the $£ 52$ paid annually from Anne Whitaker's legacy to the Sunday school, which was administered jointly with the National School. In $\mathrm{I}^{846-7}$ the master was receiving $£_{50}$ a year and the mistress $£_{30} .^{50}$ Between 1851 and 1856 the school received grants from the government for training pupil teachers, ${ }^{51}$ but an inspection in 1850 or 1851 revealed a depressing situation. The master, though a decent man, was untrained and in very poor health. The mistress could not work in three figures, so that arithmetic was 'a nullity'.52

In 1863 the school was enlarged at a cost of 61,485 . The diocesan board contributed $\& 3^{\circ}$, the National Society $£ 75$, and local supporters the remainder. The government refused help on the ground that the additional accommodation was unnecessary. National Society officials suspected that its real motive in refusing aid was to protect the position of the local nonconformist school. The school committee was not able to provide as much new accommodation as they had hoped, ${ }^{53}$ but the rapid increase in the number of children attending the school, from 100 in 1862 to 150 in 1864 , encouraged the committee to appeal for funds for another classroom. The diocesan board gave Ero, the National Society I $_{5}$, and subscribers some 200. The building was finished in 1866 . At this time the committce, with the rector as chairman, was very active. In I 868 it introduced gas-lighting, defraying the cost by entertainments, and in the same year set up an infants' department. In 1871 the school garden was enlarged by a grant of land from the rector. A cricket club was started in 1866 , a night school in 1868 , and a scholars' bank in 1872.54 By 1875 the average attendance was 193 . By $186 ;$ the school was receiving an annual government grant. ${ }^{55}$ Additional income came from school fees, local contributions, and, in 1876 , the levy of a voluntary rate. Teachers' salaries had been improved. The headmaster, after long service at the school, was in 1879 receiving $£ 155$ a year, with a house allowance of $£_{2} 20$. In 1883 the mistress and the assistant master each received $£ 40$ a year. The educational standard also improved. ${ }^{56}$

As a result of the Education Act of 1870 a survey was made of the accommodation in Loughton schools. The National School was found to have places for 134 boys, 104 girls, and 42 infants, which, with the 104 places at the British School were declared by the government to be sufficient for local needs.57 The continued increase of population, however, soon made further accommodation necessary, and in $1878-9$ the government required the National School to provide this, failing which a school board would be set up. This Jed to a fierce controversy between Anglicans and nonconformists. In March i 879 the Anglicans convened a parish meeting to authorize a voluntary rate for the National School. The meeting does not appear to have bcen widely publicized except among the Anglicans. The nonconformists, suspecting that this had been deliberately contrived in order to prevent their attendance and probable opposition to the rate, arrived at the meeting in full force, led by C. H. Vivian, the Baptist minister. After a heated debate the voluntary rate was abandoned. 58 During I $879 £ 300$ was raised by subscription and by 1882 the school enlargement fund stood at $£_{4} 400$ out of an estimated $£_{0} 500$ required. 59 By I 886 the school had been extended to provide 342 places. 60 Even this, however, was insufficient for the growing town, and in 1887 the government insisted on the formation of a school board. In the same year the managers of the National School transferred their building to the board. When the Board School was opened in 1888 the former National School was used for girls and infants, the boys being accommodated in the new school. In 1891 the infants were moved to a new building in Staples Road, the girls remaining at the old school.61 In 1904 there were 240 girls, though the accommodation was then estimated at only 210 places. ${ }^{62}$ In 1907 the board resolved to build a new girls' school in Staples Road. When this was completed in I 9 I 1 the former National School was apparently no longer used for educational purposes. About $1938-9$ it was demolished to provide a site for Ashley Grove flats, which stand on the corner of York Hill and Staples Road.63

The British School was established between 1839 and 1845 . It may have originated in a Sunday school which was being held by the Baptists in 1833 and 1839.64 A mistress was in charge, apparently until I 865 when a master was appointed. He seems to have done much to improve discipline, attendance, and standards of work, winning the approval of the inspector, Matthew Arnold. The latter reported in I 867 that 87 children had been presented for examination, that the average attendance for the year had been 69 and that the building and staff would need enlargement if the number of pupils continued to grow. 65 There was some increase in attendance during the next 20 years. 66 The government grant rose from $£ 40$ in 1872 to $f_{62}$ in 1886.67 In 1887 the managers transferred the school to the new school board, which closed the British School in 1888.68 The building has subsequently been used for a variety of industrial purposes. It is of red brick, single-storied, and has a slate roof.

In 1887 the new school board built a school at the east end of Staples Road, giving accommodation for 320 boys. The cost was about 66,000 . In I 89 I a new infants' department was built beside the boys' school, giving a total accommodation of about 540.69 In 1899 there was an average attendance of 169 infants and 197 boys. 70 'The infants' department was
49 Waller, Loughron, i, 102-4.

so E.R.O., D/P 30/28/19; Nat. Soc.

Enquiry, I 846-7, $12-13$.

si Mins. of Educ. Ctuee. of Council, 1856 [2237], p. 95, H.C. (1 857, Sess. 2), xxxiii. 32 Ibid. 1850 [1357], p. 448, H.C. (1851), xliv.

33 Inf. from Nat. Soc.

34 E.R.O., D/P $233 / 25 / 1$.

ss Ibid.; Rep. of Educ. Ctiee. of Council,

1875 [C. $1513^{-1}$ ], p. 533 , H.C. $(1876)$, xxiii.

36 E.R.O., D/P $233 / 25 / 1$

37 Chelmsford Chron. 2 Aug. 1872.
58 Woodford Times, 22 Mar. 1879 (E.R.O., T/P 13 ).

39 E.R.O., T/P 13

60 Rep. of Educ. Cttee. of Council, 1886 [C. $\left.5 \begin{array}{lll}1 & 2 & -1\end{array}\right]$, p. 520, H.C. (1887), xxviii. 6I Gazette, 2 June 19 II (E.R.O., E/ML 5I/I); Kelly's Dir. Essex (I 899); Schs. under Bd. of Educ. 1902 [Cd. I490], p. 72 , H.C. (1903), li.

62 Essex Educ. Cree. Handbk. 1904, p. 148 .

${ }_{63}$ Garelte, 2 June 1911 ; inf. from Mr. William Addison.

64 Educ. Enquiry Abstr. (1835), p. 282 ;
E.R.O., D/P 30/28/19; Kelly's Dir. Essex (1845).

63 Kelly's Dir. Essex (1845, 1862); White's Dir. Essex $(1848$, I 863$)$, E.R.O. E/ML 5 I/I.

66 Chelmsford Chron. 2 Aug. 1872 ; Rep. of Educ. Ciree of Couneil, I886, p. 520.

67 Ibid.; Rep. of Educ. Cttee. of Council, 1872 [C. 812 ], p. 408, H.C. (1873), xxiv. 68 Gazette, 2 June I9II; E.R.O., E/ML $51 / 2$.

60 Min. of Educ. File $13 / 252$

70 Kelly's Dir. Essex (1899). 


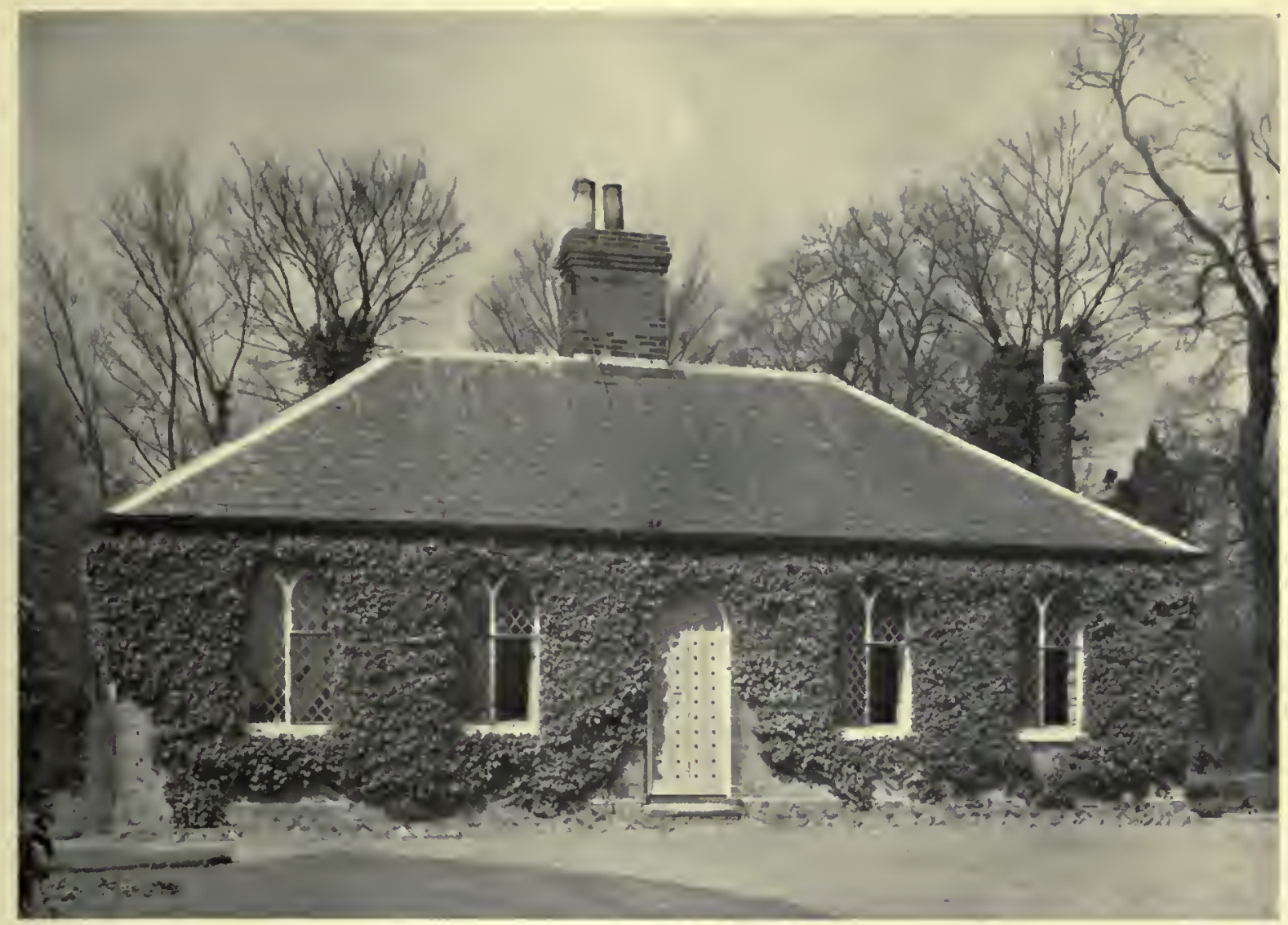

Former Village School at Greesstead

Built c. I 846

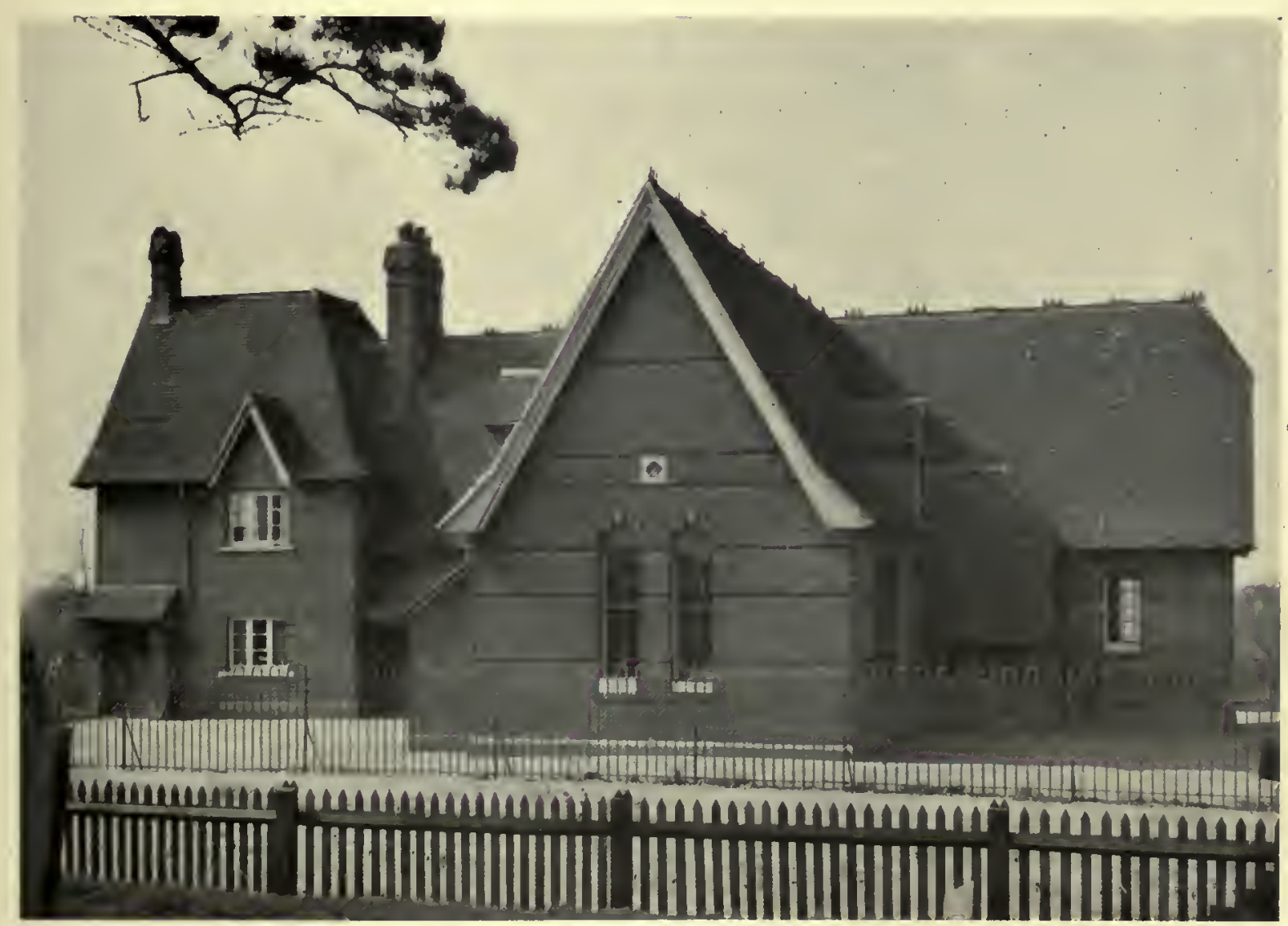

County Primary School: High Ongar

Built I 867 


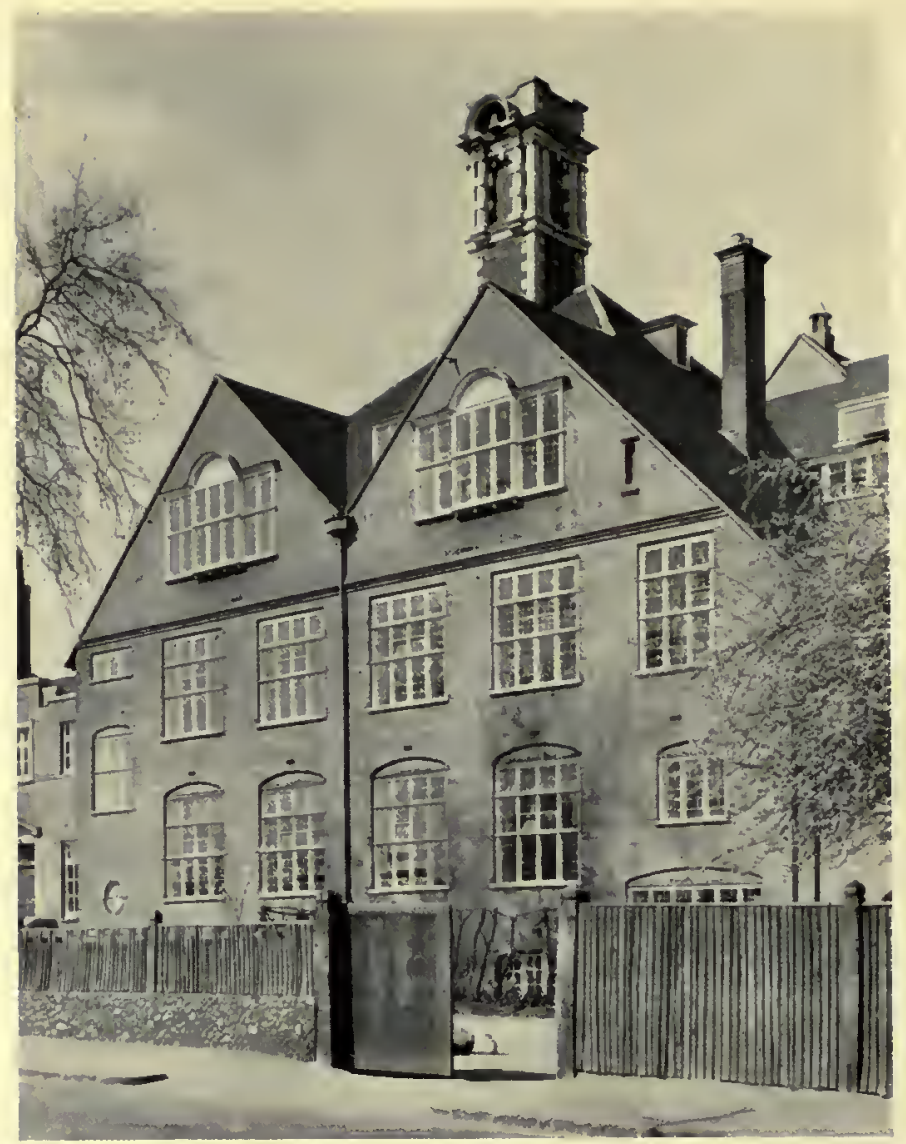

Loughton County High School for Girls Built 1908

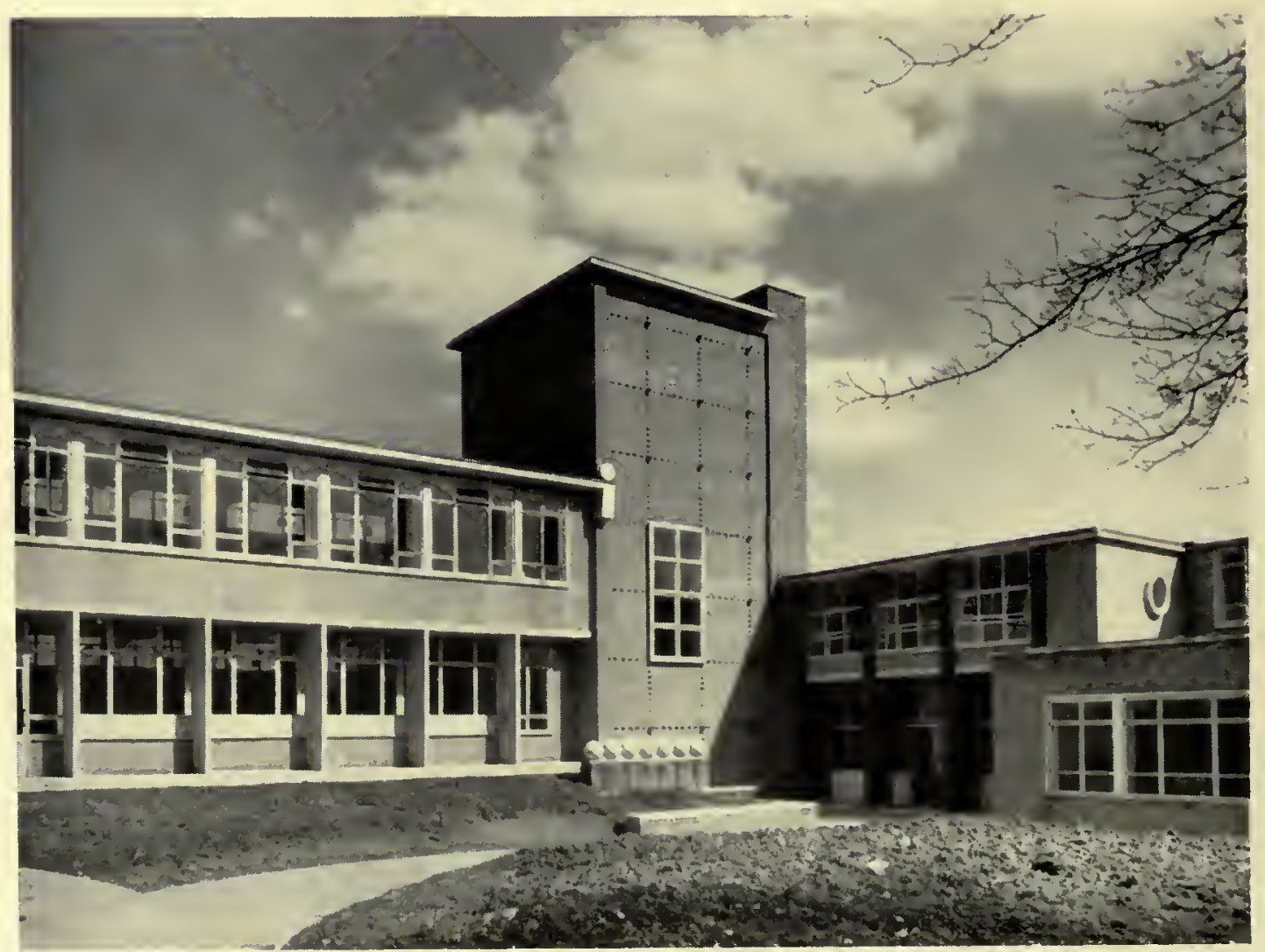

Lucton Secondary Modern School, Debden Built $195^{\circ}$ 
enlarged in 1906 to provide 360 places. 71 In 19 I I a girls' department was added to the Staples Road buildings, with accommodation for 316.72 In that year there was an average attendance of 231 boys, $23 \mathrm{I}$ infants, and $18 \mathrm{r}$ girls.73 A former pupil, Mr. W. R. Francies, has recently recorded that the headmaster at this period, George Pearson, was a man of vivid personality who left the school in 1913 to become one of the earliest film producers. The then second master, Herbert Lebbon, ran a string orchestra at the school, and to encourage this Mr. (later Sir) Joseph Lowrey present three violins to the School every year. ${ }^{74}$

In 1929 there was an average attendance of 213 boys, I 52 infants, and 185 girls. In 1938 the school was reorganized for mixed juniors and infants. 75 In May $195^{2}$ there were 345 children and 8 teachers in the infant school and 594 children and 16 teachers in the junior school.76 The buildings are chiefly of red and yellow brick, with tiled roofs. Prefabricated huts have been added recently.

Secondary education for boys was provided after I 902 by means of scholarships to Loughton school, a private school then run by William Vincent (see below). 77 Since 1938 Loughton boys have gone to Buckhurst Hill County High School (see Chigwell).

Loughton County High School for girls was opened in January 1906 in a house in York Hill. ${ }^{78}$ There were then 29 girls, under a headmistress and one assistant mistress, and there was also a visiting science master. In May 1908 the first part of the present building in Alderton Hill was opened, and in 1912 the average attendance was I I 8.79 Temporary buildings were added in 1917. In 1922 a swimming-bath was added and in 1923 the first part of a new permanent wing was built. By 1929 there was accommodation for $45^{\circ}$ girls. ${ }^{80}$ In 1930 a new assembly hall was built and the final part of the new wing added. Playingfield space has been increased from time to time. There are now (1954) approximately $55^{\circ}$ pupils and the staff, including the headmistress, numbers 30 .

The Loughton County Secondary Modern School, Roding Road, was opened as a senior school in 1938 . when it had places for 520 . In 1949 huts were added to provide a further I 50 places. In May 1952 there were 26 teachers and 485 pupils. ${ }^{81}$

As a result of the building of the Debden estate since 1945 there have been a number of new schools. The educational programme is still (1953) incomplete. ${ }^{82}$ Fairmead County Secondary Modern School (Mixed), Pyrles Lane, was opened in September I 949. In May I 952 there were 27 teachers and 977 pupils. Lucton County Secondary Modern School (Mixed), Borders Lane, was opened in June 1950. In May 1952 there were 24 teachers and 501 pupils. St. Nicholas County Primary School (Mixed Juniors and Infants), Borders Lane, was opened in February 1948. In May 1952 there were 12 teachers and 428 pupils in the junior school and 13 teachers and 445 pupils in the infant school. Alderton County Primary School (Mixed
Juniors and Infants), Alderton Hall Lane, was opened in September 1952. In November 1952 there were II teachers and 396 pupils in the junior school and I I teachers and 355 pupils at the infant school. White Bridge County Primary School (Mixed Juniors and Infants), Greensted Road, was opened in September 1952. In November 1952 there were 7 teachers and 235 children in the junior school and 7 teachers and 278 children in the infant school. Pyrles Lane County Primary School (Mixed Juniors and Infants) is regarded by the Ministry of Education as part of Chingford Forest View Camp School, which was opened in January 1950. In January I953 the school was temporarily situated in Fairmead Secondary School. Loughton Hall County Primary School (Infants), Rectory Lane, is a temporary school, opened in May 1950. In May 1952 there were 7 teachers and 232 pupils.

'There have been many private schools in Loughton. In $1833-9$ there seem to have been two private boarding-schools, one or two middle-class day schools, and three or more dame schools. ${ }^{83}$ One of these may have been the school at Algers House which was conducted by the curate, one Rogers. ${ }^{84}$ Between about I 850 and about I 870 a school was run by the Misses Brawn, daughters of Samuel Brawn, the Baptist Minister. ${ }^{83}$. Miss Fanny Hogard kept a girls' school in $1870-4.86$ In 1878 there was a school for boys kept by J. C. Holloway. ${ }^{87}$ This was known in 1886 as Madras Hall and was 'a middle class school for the sons of gentlemen'. ${ }^{88}$ By 1890 , as Madras House School, it had been taken over by William Vincent, who shortly afterwards acquired Loughton School, High Road. 89

Loughton School was opened in 1890 under the name of St. John's College, Loughton. Unlike many private schools it was specially built for its purpose. The proprietor and headmaster was the Revd. W. L. Wilson, of St. John's College, Cambridge. The school was planned on ambitious lines.90 The Bishop of St. Albans was patron and there was a council which included Col. Lockwood, M.P., of Bishops Hall in Lambourne (q.v.). Among the subjects taught were Latin, Greek, German, French, Science, and Bookkeeping. 'Many pupils take up commercial pursuits and a large number join the ranks of the medical profession, some proceed to the universities, to the naval service and the Indian Civil Service.' 'There were some pupils from the continent. Soon after its foundation the school was acquired by William Vincent, who remained owner and headmaster until his retirement in 1924.91 The school has been recognized as efficient by the Ministry of Education since 1907 . There were 140 boys in 1924, 168 in 1952, and 190 in September 1953. There are seven forms, of which the first is for boys of ages 7 to IO. Beside the headmaster there are seven trained and qualified masters and one part-timie master. ${ }^{92}$ Other private schools have existed for short periods in Loughton. 93
71 Ibid. (1910).

72 Ibid. (I922).

73 Min. of Educ. File 1 3/252.

74 'Staples Road. School', West Essex

Gaz. 16 Jan. 1953 ; inf. from Mr. Francies.

75 Min. of Educ. File 13/252.

76 Inf, from Essex Educ. Cttee.

77 West Essex Gex. 16 Jan. 1953.

78 This account has been supplied by

Miss M. E. Heald, headmistress of the school; and see plate facing p. 127.
79 Kelly's Dir. Essex (1912).

80 Ibid. (1929).

8I Inf. from Essex Educ, Cttee.

82 The following account is based on

information from the Min. of Educ., Essex Educ. Cttee. and Miss E. A Phillips, Headmistress of Loughton Staples Road Infant School.

${ }_{83}$ Educ. Enquiry Abstr. (1835), p. 282 ; E.R.O., D/P 30/28/19.

84 E.R.O., T/P 13 i. 8s Kelly's Dir. Essex (1855, 186z); Bapt. Hist. Soc. Trans. N.s. $x, 56$.

${ }_{86}$ Kelly's Dir. Essex (1870, 1874 ).

87 Ibid. ( 1878 ).

88 Ibid. (I 886).

89 Ibid. (I 890 ).

90 E.R.O., Avery Coll. Loughton.

9I Inf. from Mr. D. E. Winkworth, the present Headmaster.

92 Ibid.; School Prospectus.

93 Kelly Dir. Essex, passim. 


\section{A HISTORY OF ESSEX}

Robert Rampston, by will dated 1585 , left to the poor of Loughton $f_{\mathrm{I}}$ a year issuing CHARITIES 94 from Stone Hall Farm in Little Canfield. In 1834 the money was spent on bread which was distributed after church one Sunday in the spring to those poor parishioners who had attended the service. In 1872 it was decided that flannel was a more useful gift than bread. In I $95 \mathrm{I}-2$ the rent charge was spent, together with the income from the following six charities, on coal and clothing tickets.

In 1813 the Rector of Loughton was admitted as tenant of 3 acres formerly waste of the manor, to hold to the use of the poor to grow potatoes or other vegetables.9s The land was to be divided into allotments. In 1817 he was admitted to another 3 acres for the same purpose. In 1834 the land was divided into 48 gardens, each let at 2s. $6 d$. a year, and the income was spent on fencing and on twelve prizes for good cultivation. The Potato Ground lies north-west of Whitaker's Almshouses at Goldings Hill and in 1952 was divided in to 80 plots, let at $3 d$. a rood. The total rent of $\oint_{1} 2$ I 25 . was spent on maintenance and management.

Anne Whitaker, by will proved I 825 , left $£ 2,200$ stock in trust for $\oint_{4} 0$ to be spent each year on the charity school and the rest of the income given to the deserving poor, with preference to women lying in. In 1905 the two parts of the charity were separated and the Eleemosynary Charity was given an endowment of $£ 380$ stock. In $195 \mathrm{I}-2$ the income was spent on coal and clothing tickets.

Miss Whitaker also left $f_{0} \mathrm{r}, 000$ to repair the poorhouse. 96 In 1847 most of this money was spent on building six two-roomed almshouses under one roof, to the north-west of Arewater Green at Goldings Hill. The remaining LI $_{5}$ formed the permanent endowment of the almshouses. To this additions have been made by the charities of Jane M. Waller and Olivia Houghton (see below) and in the Second World War the charity also received Savings Certificates worth $\oint_{1} 10$, raised in local savings weeks. Part of this last sum has been spent on electric lighting. Part of the almshouse garden is now let as allotments with the neighbouring Potato Ground (see above). The almswomen, who live rent free, usually receive part of the other parish charities.

Nicholas Pearse, by will proved I 825 , left $£ 50$ in trust for the poor of the parish. In I 834 it was reported that the income was distributed every two or three years to poor parishioners selected by the vestry. In I $95 \mathrm{I}-2$ the dividend of $f_{1} 4 s$. $8 d$. was spent on coal and clothing.

In 1834 an inscription in the church recorded the existence of Poor's Piece, ${ }^{97}$ comprising part of the glebe land in Round Mead. In that year the rector paid 63 rent for it, which was distributed with the income from Rampston's Charity. In 1917 the land was sold for $f_{1} 20$ stock. In $195 \mathrm{I}-2$ this produced a dividend of $\oint_{3}$, which was spent on coal and clothing.

Sarah Pearse, by will proved before i 846 , left $£, 50$ to be invested for the poor of the parish. In $195 \mathrm{I}-2$ the income of $\oint_{1} 6 s$. was spent on coal and clothing.

The above seven charities, together with Olivia Houghton's (see below), are in practice administered together under the name of the Parochial Charities.
In I 95 I-2 they yielded together 69 Is. $2 d$. This was spent on coal and clothing tickets for seventeen people, five of whom were the inmates of Whitaker's Almshouses and two of Lincoln's Almshouses (see above, Protestant Nonconformity).

Baldwins Buildings or the Parish Houses were founded as a charity by a public subscription to buy the old parish workhouse after the Poor Law Unions were formed.98 The workhouse was divided into six tenements with gardens, which according to the foundation deed of I 837 were to be occupied free or at low rent. In I 873 five were occupied but all were in a very poor condition, so they were pulled down and the land was used as allotments. In I 927 the land, then said to front on Wroth's Path, was sold for $£ 430$. The charity now holds over $£ .500$ stock, the income from which is to be spent on the payment of weekly allowances to deserving parishioners. In 1951 I $67 \mathrm{gs}$. $6 d$. was spent on coal for the almshouses and $£ 6$ I Os. on gifts to poor people.

Eliza Watson, by will proved I $87 \mathrm{I}$, left $£ \mathrm{I}, 000$ in trust for the purchase of bread, coal, or clothing for poor parishioners. In I95 I the income of $\{2725.8 d$. was spent on Ios. vouchers and coal for the almshouses.

The Parish Clerk's Piece is of unknown but ancient origin. It may be identical with Sexton Acre, mentioned in 1585.99 In 1877 the parish clerk held a small piece of pasture on Traps Hill, supposedly by virtue of his office. Its origin could not then be traced. In 1922 the land was sold for $£ 650$ which was invested for the benefit of the parish clerk. The income in 1950 was 24 I 8 s. $6 \mathrm{~d}$. and was used for the general expenses of St. John's, Loughton.

Jane Miller Waller, by will proved 1882 , left f, I,000 in trust for distribution early each year to the six inmates of Whitaker's Almshouses. The endowment was augmented in 1897 by $£ 90$ from one of the trustees: this was to be spent with the main fund, and called the Longest Reign Augmentation Dole. In I 945 the income of $\int_{3} \mathrm{I}$ Ios. $4 d$. was given in cash half-yearly to the six almswomen.

William Frederick Turner, by will proved I g05, left two bequests of $£ 250$ in trust for the purchase of boots for deserving poor men and of underlinen for deserving poor women, respectively. In I95 I the whole income was I 4 7s. 4 d. Nineteen ros. vouchers were given away.

William Chapman Waller, by will proved 1917, left $£_{300}$ in trust to spend $\mathcal{E}_{\mathrm{I}}$ is . a year each on sermons at St. Mary's and St. John's, Loughton, and $f_{\text {I I s . }}$ a year in gifts to two or three deserving old parishioners of St. Mary's, preferably Anglicans, and an unspecified sum in the same way in St. John's parish. The lychgate at St. John's was to be maintained and $£_{2} 2$ s. spent on the maintenance of the graveyard there. In

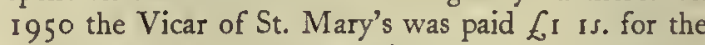
sermon and three poor parishioners of St. Mary's received 7s. each. The churchwardens of St. John's received $69 \mathrm{I} 5 \mathrm{~s} .8 d$. in I $95 \mathrm{I} ; \mathrm{f}_{\mathrm{I}} \mathrm{I}$ s. was spent on the sermon and f4 IOs. on mowing the churchyard.

Mrs. Olivia Houghton, by will proved I 922 , left f300 duty free for the general purposes of the Whitaker Almshouses. The money was invested in stock and in I $95 \mathrm{I}-2$ the income of $f_{0} \mathrm{r}_{3}$ I $3 \mathrm{~s} .6 \mathrm{~d}$. was handed over to the trustees of the almshouses.
94 This section is based on Rep. Com. Char. (Essex), H.C. 216 , pp. $230-2$ (I835), xxi (r) and Char. Com. Files. Charities not treated bere will be found in the sections relating to Churches, Protestant Nonconformity, and Worthies and Social Life.

95 See Waller, Loughton, i, 129. The
Potato Ground has also been known as the Potney Allotment Ground.

96 Ibid. i, 130. 97 Ibid. i, 47, 120 98 Ibid. i, I 30.99 Ibid. $i, 47,1$ I I, \& 


\section{MORETON}

Moreton is a parish about 3 miles north of Chipping Ongar. I Its area is 1,474 acres. ${ }^{2}$ In 1946 a small detached part of Moreton ( $\frac{1}{2}$ acre) lying immediately to the north of Bobbingworth Lodge was incorporated into the parish of Bobbingworth. ${ }^{3}$ A detached part of Magdalen Laver ( 5.6 acres) still lies in Moreton, to the north-west of High Laver Bridge. An unusual number of moated sites and of pre- 18 th-century houses confirms other evidence which indicates that Moreton was formerly an important place in the area. There were 63 inhabited houses in 1801,73 in 1811 , and 69 in 1821.4 In 1801 the population was 360.5 By I $85 \mathrm{I}$ it had grown to 544 ; then it declined to 378 in 1901.6 By 1931 it had risen again to $47 \mathrm{I}$ but in 1951 it was only $4 \mathrm{II} .{ }^{7}$ The soil is mainly Boulder Clay but there are patches of London Clay and glacial gravel.

The land rises from about $170 \mathrm{ft}$. above sea-level in the south-west to $280 \mathrm{ft}$. in the north-east. Cripsey Brook, a tributary of the Roding, flows through the south-western part of the parish and forms a small part of the southern boundary at Moreton Bridge. At Padlers End, 1 mile south-west of the bridge, are several small I 8 th- and early-I gth-century cottages and four pairs of council houses. Moreton Bridge Road enters the parish at Moreton Bridge and runs northward to join the Fyfield Road at Moreton End, the main centre of population. Moreton End includes some attractive groups of 18 th-century houses. The White Hart Inn at the road junction may be of 16 thcentury origin. At its east end the first floor oversails and is supported on curved brackets. It has been altered at various times. Opposite the 'White Hart' is the 'Nag's Head', a roughcast early-I 8th-century building with a moulded eaves cornice. Rose Cottage and the Castle House Stores form another group of the same date. Part of Ivylands, at the Moreton Bridge end of the village, has a pedimented door hood and may be of the I 8 th century or carlier. Black Hall, also known as Guildhall Cottage, ${ }^{8}$ stands immediately north of Ivylands. From Moreton End the Harlow road runs northward. There are five pairs of council houses on the west side of this road. On the east side about 1 mile farther north is the site of Church Farm, 9 from which a footpath, formerly North Lane, leads eastward to join Fyfield Road at Maltings Farm. Farther along on the west side of Harlow Road is a late-I 8th-century weather-boarded house, now called Crispins. This is said to have been built on the site of the Castle Inn ${ }^{10}$ and the Castle House Stores, now moved to Moreton End, occupied part of it for many years. "I Nearly opposite Crispins is a row of thatched cottages, apparently of early-I 8th-century date. From here Harlow Road runs north-west past the Congregational chapel ${ }^{\mathrm{I2}}$ to High Laver Bridge while Mill Road runs north past Moreton Mill.13 There are two pairs of council houses on the road north of the mill.
From Moreton End Fyfield Road runs east past the village school, 14 a red-brick police house built in I95 I, and a small cottage which has an oversailing gable-end and may be of the 16 th or early $17^{\text {th century. Opposite }}$ the cottage stands the rectory. ${ }^{15}$ "The church ${ }^{16}$ is immediately north-east of the rectory. Opposite the church is a lane to Nether Hall and Upper Hall.17 About 1 mile farther along the Fyfield road is Maltings Farm, a low two-story cottage, probably converted from an 18 th-century malt kiln. ${ }^{18}$ Beyond Maltings Farm stands Hill Farm, a small timber-framed house of the $15^{\text {th }}$ century. It originally had an open central hall of two bays, flanked by cross-wings to east and west. These have overhanging gables at the front of the house and still exist more or less in their original form. A ceiling has been inserted in the central block and the roof raised, so that the ridge level is now higher than that of the side wings. The moulded wall posts and arched braces of a central truss are visible on the ground floor, but the upper part of the truss is missing. The hall originally had a screens passage at its east end and the roughly four-centred head of its front entrance is still in position. The east wing retains an arch-braced roof truss above the first floor. It has a king-post and steeply cambered tie-beam. The rebuilding of the upper part of the hall probably took place in the late I 6 th or early 17 th century, and the four-centred arch of a fireplace of this date was observed in I 919.10 Both this chimney and that at the west end of the house have diagonal shafts.

At Hill Farm Fyfield Road is joined by a road running northward to Little Laver. About $\$$ mile along this road stands Newhouse, a timber-framed house on a moated site, probably built in the 16 th century. It retains original panelling and a brick fireplace with a moulded three-centred arch. The farm has a timber barn of the same date.

In this area of the parish are several disused roads 20 and the sites of several former houses. Spencer's Hoppet, north-west of Newhouse, contained a house from at least the middle of the I 4 th century but by I 840 it was only pasture land. The last of its farm buildings was taken down about then by the tenant, Henry Clarence. ${ }^{21}$ South of Newhouse a lane leads eastward to Greens, a timber-framed house on a moated site, rebuilt probably in the I 7 th century. From Greens a footpath, formerly a lane, leads southeast past a moated site where Tanner's Cottage 22 formerly stood, and thence to join Fyfield Road near Embley's Farm, a timber-framed house of the 17 th or early I 8 th century which may once have been two cottages.

Just before Fyfield Road leaves the parish it is joined by a lane running southward past Harriets and Cross Leys to Bundish Hall. ${ }^{23}$ Stacey's, which was situated nearly opposite to Harriets, is said to have lost
I O.S. $2 \frac{1}{2}$ in. Map, sheet 52/50.

2 Inf. from Essex County Council.

3 County of Essex (Rural Parishes) Confirm. Order 1946.

4 Census, I801, $18 \mathrm{Ir}, 1821$.

s V.C.H. Essex, ii, 350 .

6 Ibid.

7 Census, 19 II f.; inf. from Essex County Council.

8 See below, Church. 9 Ibid.

10 W. Talbot, MS. Hist. Moreton (in possession of rector). For the 'Castle' see
Chapman and André, Map of Essex 1777, plate xii.

II Inf. from Miss Ball.

12 See below, Nonconformity.

13 See below.

I4 See below, School.

is See below, Church.

16 Ibid.

17 For these manors see below.

18 W. Talbot, MS. Hist. Moreton.

19 Hist. Mon. Com. Recs.

20 Chapman and Andre, Map of Essex
1777 , plate xii.

21 Cal. Ing. p.m. ix, p. 298 ; E.R.O. D/CT 244. William Talbot, who lived at Moreton and wrote a history of the parish c. 1885 , said that Henry Clarence took down the last farm building in 1833 but a building was still marked on the Tithe Map in 1839 .

22 O.S. 6 in. Map (1st edn.), sheet li.

${ }^{23}$ From Cross Leys to Bundish Hall it is a green lane. 


\section{A HISTORY OF ESSEX}

the last of its farm buildings through a gale in I 834.24 Cross Leys is a timber-framed house on a moated site, rebuilt probably in the 17 th century, and encased in brickwork in the late 18 th or early I 9 th century. There is an old timber barn.

Bundish Hall is on the parish boundary, near its southern extremity.2S To the west, on the other side of the Cripsey Brook, stands Wood Farm on the road from Moreton to Shelley. This farm, formerly Southend Farm $^{26}$ or Henhouse Farm, ${ }^{27}$ has an i 8 th-century farm-house.

The inhabitants of Moreton were at first responsible for the upkeep of Moreton Bridge which spans the Cripsey Brook where it forms the boundary between the parishes of Moreton and Bobbingworth. ${ }^{28}$ At a vestry meeting held in 1761 the parishioners of Moreton agreed that a new cart bridge should be built in place of the old horse bridge and that, having obtained an estimate of the cost of a timber and of a brick bridge, they should meet the parishioners of Bobbingworth to determine of what materials it should be built.29 A combined meeting took place in May 1762 when it was agreed that the money raised should be spent on the bridge only and that each parish should 'make their way to the bridge at their own expense'. ${ }^{30}$ It was also agreed that work on the bridge should begin immediately. ${ }^{31}$ A grant of $£ 30$ was made from county funds towards the building. ${ }^{32}$ By 1783 the bridge had become a county charge and in the same year it was ordered that it should be rebuilt with brick according to the plan prepared by John Johnson, the county surveyor. ${ }^{33}$ In 1857 the county surveyor described it in detail. ${ }^{34}$

A postal receiving house was set up at Moreton in I 846 to serve the surrounding villages; the receiver was to have $f 4$ a year and a messenger I 25 . a week. 35 There is now a post-office in the village. The telephone service was established in $1927.36 \mathrm{~A}$ police officer is stationed in the village. ${ }^{37}$

Water is supplied by the Herts. and Essex Waterworks Co. ${ }^{38}$ "There is no sewerage but a site for a pumping-station has been agreed on. ${ }^{39}$ Electricity was provided in 1951.40 The village hut was built in $1920.41 \mathrm{~A}$ branch of the county library was opened in April I 929.42

Moreton has always been a rural parish devoted mainly to agriculture. Few of the large landowners have lived there. The owners of Upper Hall were never resident except possibly for a few years after I 349.43 During the whole of the period I $342-1832$ the owners of Nether Hall were not resident except in the time of William Cozens, lord of the manor from I 775 until I 790, and even he did not live at the manor house or farm the main part of the estate.44 W. H.
Alger, lord of the manor from 1829 , was resident at the Hall by 1840 and both he and his son, who died in I 900 , farmed most of the estate.45 The owners of Bundish Hall did not live in Moreton in the middle of the I 6th century; there is no further evidence about their place of residence until 1780 , when the owner was not resident. 46 After Richard Eve purchased the estate in 1787 it was occupied by members of the Eve family. 47

In I 840 W. H. Alger owned 256 acres in Moreton of which he farmed 197 acres himself. 48 J. H. Frere of Upper Hall owned 246 acres but farmed none of it himself.49 Bundish Hall Farm, then owned by the trustees of the late J. Chaplin, and occupied by W. Eve, consisted of 166 acres of which 107 acres lay in Moreton.so There were two other substantial owners in the parish; J. White owned Wood Farm ( 153 acres) which he farmed himself, and E. F. Maitland owned, but did not occupy, Newhouse Farm (I 29 acres). 51 There were three other farms of over 40 acres. 52

Moreton has always been a parish of mixed farming. In 1086 there were 5 plough teams in the manor, woodland for 400 swine and 20 acres of meadow. 53 In the late 12 th century the manor contained a flax ground. 54 In the 18 th century there was a malt kiln in the parish, situated probably at the east end of North Lane. 55 In 1838 it was estimated that there were I, I 5 I acres of arable, 273 acres of pasture, and II acres of woodland. .56

There was once a water-mill on the Cripsey.Brook near Padlers End. The mill house was demolished about I 860.57 Moreton windmill is still standing but ceased working about 1932.58 It is of a type formerly common in the area: a weather-boarded post mill, turned by hand, with the base enclosed by a brick 'round house'. At the base of the central post are three cross-trees instead of the more usual two. It is said that the mill was formerly at Bishop's Stortford and was erected in Moreton early in the 18 th century. 59 The central post is dated 1715 and 1821.60 The mill was reroofed in 1918.61 After it ceased working it was given by Messrs. C. and A. Gould to the Society for the Protection of Ancient Buildings.62 In 1951 one sail came off and another had to be removed for safety. ${ }^{63}$ The thatched mill house is partly occupied as an office for Messrs. C. and A. Gould.

In about 1885 it was said that until 1832 a fair was held in the village annually on I May ${ }^{64}$ but that 'having degenerated from its former social gathering into an annual disorderly assembly, an edict was issued by the magistrates for its abolition.65 ... Mr. George Rogers of Upper Hall ${ }^{66}$ attended personally in the village with the constable to force obedience to the edict, but the ancient fair still tries to lie on private premises.'67
24 W. Talbot, MS. Hist. Moreton.

25 See below, Manor of Bundish Hall.

26 Chapman and André, Map of Essex 1777, plate xii.

${ }_{27} \mathrm{~T}$. Wright, Hist. Essex, ii, 353; W. Talbot, MS. Hist. Moreton.

28 E.R.O., Q/SR r 75/53; ibid. Q/CP3,

p. 127.

29 E.R.O., D/P $72 / 8 / 1$.

30 Ibid.

39 Inf. from Rector of Moreton.

40 Inf. from East. Elec. Bd.

41 Inf. from Rector of Moreton.

42 Inf. from County Librarian.

43 See below, Manor of Upper Hall.

44 See below, Manor of Nether Hall.

45 Ibid.

46 See below, Manor of Bundish Hall; E.R.O., Q/RPI 685 .

47 E.R.O., Q/RPI 693-737.

48 E.R.O., D/CT 244.

49 Ibid.

50 Ibid.

33 Ibid. Q/SO I 3, pp. 360,384

34 E.R.O., Q/ABz 3 .

35 P.M.G. Mins. 1846 , vol. 87, p. 5 .

36 British Postal Guide, 1927

37 Inf. from Chief Constable of Essex.

38 Inf. from Herts. \& Essex Waterworks Co.
51 Ibid. 52 Ibid.

53 V.C.H. Essex, i, $551 a$.

54 Cal. Doc. France, ed, Round, 162.

55 W. Talbot, MS, Hist. Moreton.

56 E.R.O., D/CT 244. The woodland, which was south-east of Moreton Bridge, was uprooted in $1888_{3}$ 'to the general regret of the parish'.

57 W. Talbot, MS. Hist. Moreton.

58 It was still working in $193 \mathrm{x}:$ E.R. $x 1$, 130.

59 W. Talbot, MS. Hist. Moreton.

60 D. Smith, English Windmills, ii, $5 \mathrm{~g}$.

61 Ibid. 62 S.P.A.B. Ann. Rep. 1933.

${ }_{63}$ Inf. from Messrs. C. and A. Gould.

64 W. Talbot, MS. Hist. Moreton. It

did not appear, however, in the lists of

Essex fairs compiled in 1780 and 1792 :

Essex, Herts. and Cambs. Almanack, I780;

Rep. Com. Mkt. Rights [C. 5550], p. $16 \mathrm{t}$

(r888), liii.

65 This order cannot be traced.

66 See below, Manor of Upper Hall.

67 W. Talbot, MS. Hist. Moreton. 
In 1066 MORETON was held by Sexi as a manor and as I hide and 20 acres and was worth MANORS 68.68 In 1086 this was held in demesne by William de Scohies of the king in chief and was valued at $\oint_{10.69}$ Another $43 \frac{1}{2}$ acres which in I 066 did not belong to the manor of Moreton was annexed by William and in 1086 was held of him by Ralf.70 This tenement was worth 20 s. in 1086 as in 1066 but William received 30s. for it. ${ }^{71}$ In 1283 the manor was held of the king in chief by the service of finding for him when he went into Wales for 40 days 'a horse price IOs., with a leather sack and an iron skewer for fastening the sack, for carrying a weight of 2 bushels of corn, with one man'.72 'The manor continued to be held of the king in chief by this petty sergeanty until at least the middle of the 14 th century. ${ }^{.3}$

At some date between II 74 and II 82 the tenant of the manor was William d'Avranches.74 In 1212 it was held by another William d'Avranches.7s $\mathrm{He}$ died in $123^{\circ}$ leaving as his heir his son William who died before the end of $\mathrm{I} 235 .{ }^{76}$ The heir of William the son was his sister Maud, wife of Hamon de Crevequer. She had one son, who predeceased his father, and four daughters, Agnes wife of John de Sandwich, Iseult wife of Nicholas de Lenham, Eleanor wife of Bartholomew de Kyriell, and Isabel wife of Henry de Gaunt.77 On Hamon's death in I 263 the manor fell to the share of the youngest daughter Isabel and her husband.78 When Isabel died in 1283 , several years after her husband, she left as her heirs her sister Eleanor, John de Lenham son of her sister Iseult, and Juliane de Sandwich granddaughter of her sister Agnes.79 Within a few months the manor, which was valued at 629 I2s. 4d., was by order of the king divided between these three heirs. ${ }^{80}$ Eleanor was assigned land to the value of 345.81 The residue of the manor and the chief messuage were divided between Juliane and John, two-thirds of the messuage being given to John and one-third to Juliane. ${ }^{82}$ Eleanor seems to have disposed of her share in the manor shortly afterwards and its rights and services became divided equally between John and Juliane. An inquisition taken in September 1285 found that half of the manor was held by Robert Burnell as guardian of Juliane and half by John de Lenham and his wife Margery. ${ }^{83}$ From this date the two halves had separate histories. Though at first each was regarded as half a manor, they had before 1400 become separate manors, eventually known as Bourchiers or Nether Hall and Ladyhall or Upper Hall. After the division of Moreton manor, the services by which it had been held of the king were shared between the tenants of each half. 84

In 1305 John de Lenham granted a life interest in his half of Moreton manor to John de Burndish, on whose death in 1336 it reverted to Eleanor, wife of John Giffard and niece of John de Lenham. ${ }^{8 s}$ During the next few years John Giffard alienated a number of tenements, some of which were later held of the king in chief. ${ }^{86}$ In 1342 Giffard conveyed the residue to Robert, afterwards Lord Bourchier, and to Robert's son John. ${ }^{87}$ When Robert, Lord Bourchier, died of the plague in 1349 , leaving as his heir his son John, this 'half of Moreton manor', which had been worth $£ 10$, was valued at only $£ 6$, the decline in value probably representing the general fall in the value of land, occasioned by the plague. ${ }^{88}$ John, Lord Bourchier, died in May 1400 , and was succeeded by his son Bartholomew, Lord Bourchier, who died in 1409.89 The sole heir of Bartholomew was his daughter Elizabeth who died without issue in $1433^{\circ 9}$ In 1430 the manor had been settled, failing issue of Elizabeth, on her cousin Henry Bourchier, Count of Eu and afterwards Earl of Essex.91 $\mathrm{He}$ died in $\mathrm{I}_{4} 83$ leaving as his heir his grandson Henry, 2nd Earl of Essex (d. I 540). 92 The sole heir of the 2 nd earl was his daughter Anne who married William, afterwards Baron Parr, by whom the manor was conveyed in 1542 to $\mathrm{Sir}$ Richard Rich, afterwards Baron Rich. ${ }^{93}$ At this date the manor was described, for the first time as far as is known, as NETHER HALL or BOURCHIERS HALL. Lord Rich endowed the chantry which he founded in 1554 for the parishioners of Felsted, Little Leighs, and Great Waltham with 55 acres of land at Moreton. 94 On the death of the first, baron in 1567 , the manor passed to his son Robert, the 2 nd baron, and afterwards in I 58 I to Robert, the 3 rd baron, by whom it was conveyed in I 608 to Robert Bourne, lord of the manor of Blake Hall in Bobbingworth (q.v.). 95 In I636 Bourne (d. I639) settled Nether Hall on his second son Robert when the son married Rose Walcott.96 Alice, only child of Robert and Rose Bourne, and wife of John, 3rd Baron Digby, died in 1658.97 Robert Bourne died in I 666 having settled the manor on Digby for life with remainder to Martha King, niece of Bourne. 98 In 1669 Martha King conveyed the reversion to Richard Bourne who in 1682 granted it to Francis Drake.99 Digby died in I698.1 In 1699 Thomas Drake, heir of Francis Drake, was lord of the manor. ${ }^{2}$ In 1703 William Drake conveyed the manor to Josiah Woodward, D.D., Rector of

\footnotetext{
68 V.C.H. Essex, i, $551 a$.

69 Ibid. William's name was given in other documents as William de Escoiis and William de Scociis.

70 Ibid.

71 Ibid.

72 Cal. Inq. p.m. ii, p. 293.

$73 \mathrm{Cal}$. Inq. p.m. vii, p. 493 ; ibid. viii, p. 309 ; ibid. ix, Pp. 24 I, 268, 314 .

74 Cal. Doc. France, ed. Round, 162.

7s Bk. of Fees, I2 I; Dugdale, Baronage, $i, 468$. The heir to the estates of the William d'Avranches who held Moreton in I I 74-82 was Simon d'Avranches whose heir was the William d'Avranches holding Moreton in 1212 but the relationship of Simon to the two Williams cannot be ascertained.

76 Ex. e Rot. Fin. (Rec. Com.), i, 296 ; Dugdale, Baronage, i, 469 .

77 Cal. Inq. p.m. i, pp. 17 i-2.

78 Ibid.; Cal. Pat. 1258-66, 267.
}

79 Cal. Inq. p.m. ii, p. 293.

80 Cal. Close, $1279-88,226,244$.

81 Ibid.

82 Ibid.

83 Morant, Essex, i, r44. There is no evidence that either Eleanor or her husband or their issue died in possession of any rights in Moreton: Cal. Inq. p.m. iii, P. 168 ; ibid. iv, Pp. 40, 242 .

84 Cal. Inq. p.m. vii, p. 493 ; ibid. viii, p. 309 ; ibid. ix, pp. 24I, 268, 3 I 4 .

85 Cal. Inq. p.m. vii, p. 493 ; Cal. Pat. $1334-8,228$.

${ }_{86}$ Cal. Pat. 1338-40, 50, 247 ; ibid. 1340-3, 74; ibid. 1343-5, 306; ibid. 1 $350-4,486$; Feel of $F$. Essex, iii, 47 ; Cal. Inq. p.m. ix, p. 298.

87 Fees of $F$. Essex, iii, 64 .

88 Cal. Ing. p.m. ix, p. 241 ; Complete Peerage, ii, 246.

89 C1 $37 / 1$; Complese Peerage, ii, 247.

90 Ci39/59; Compleie Peerage, ii, 248.
91 Cr $39 / 59 ;$ Cal. Close, 1429-35, 8r, 216-17.

$92 \mathrm{Cr}_{41} / 3$; Complete Peerage, ii, 248-9. ${ }_{93} \mathrm{CP}_{25}(2) / 13 / 72$ Mich. $34 \mathrm{Hen}$. VIII; L. $6^{\circ}$ P.Hen. VIII, xvii, p. 563 .

o4 V.C.H. Essex, ii, 531-2. In 1564 Lord Rich converted the endowment to educational purposes.

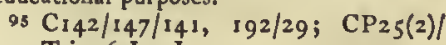
293 Trin. 6 Jas. I.

$96 \mathrm{CI}_{42 / 494 / 120 .}$

97 E.R.O., D/DMg T3I; Complete

Peerage, ii, 322.

98 E.R.O., D/DU 201/26-9; ibid. D/DMg T 3 I ; ibid. D/DDw T 122 .

99 E.R.O., D/DDw Tr22. Richard Bourne was probably a cousin of the Robert Boume who died in 1666. See Sepulchral Memorials of Bobbingworth, ed. F. A. Crisp, 30-33.

I Complete Peerage, ii, 322.

2 E.R.O., D/DU $201 / 5$. 


\section{A HISTORY OF ESSEX}

Poplar (Mdx.). ${ }^{3}$ By his will, made in I710, Josiah Woodward devised to his son John the Nether Hall estate which was then in the occupation of Thomas Prentice and was estimated to contain ' 180 acres land and 30 acres more called Moreton Wood'.4 In 1720 John Woodward sold the maror for $\oint_{1}, 75^{\circ}$ to Ambrose Page, a Director of the South Sea Company. ${ }^{5}$ At that time the estate was still in the occupation of Prentice who rented it at $f_{1}$ oo a year. ${ }^{6}$ Soon afterwards it came in to the hands of the trustees liquidating the South Sea Company and in 1724 they sold it for $f_{2}, 505$ to William Cole, lord of the manor of Magdalen Laver (q.v.). ${ }^{7}$ From I 724 until 1766 the Nether Hall estate descended with the manor of Magdalen Laver. ${ }^{8}$ Both the Coles and John Cozens lived at Magdalen Laver.9 When John Cozens died in 1766 the Nether Hall estate was in the occupation of William Schooling and James Edick.jo Cozens devised this estate to his second son Henry, a miller.II In 1773 Henry Cozens mortgaged the estate for $6600.12 \mathrm{He}$ died in 1775 leaving the manor, still mortgaged, to his youngest brother, William Cozens. ${ }^{13}$ Between 1782 and 1789 William Cozens borrowed further sums, making the total mortgage on the estate $f_{0} t, 250$, all of which was owing to Robert Ray.14 By March I79o Cozens had repaid only $\oint_{\mathrm{I}} \mathrm{Oo}$ of this debt and he then sold the manor to Robert Tindal for $\oint_{3}, 800$, it being agreed that Tindal should pay off the debt to Ray as part of the purchase money.Is Neither Henry nor William Cozens occupied the manor house or farmed the main part of the lands appurtenant to it. ${ }^{16}$ Henry Cozens was apparently a miller living in High Laver until at least 1773 and afterwards at Latton. ${ }^{17}$ William Cozens did live on the Nether Hall estate but occupied only a small piece of ground, formerly waste ground but enclosed by Henry Cozens, about 2 acres in area and having 'a messuage, stable and other buildings erected thereon' and had besides 3 acres of meadow for personal nse. ${ }^{18}$ The manor house and most of the estate were occupied by William Schooling until $\mathrm{I} 78 \mathrm{I}-2$ and afterwards by John Schooling until I790-I.19 A small part of the estate was occupied in 1790 , as in I 766 , by James Edick. ${ }^{20}$ A survey taken in July 1788 showed that on the average of the previous 57 years the lord of the manor received $6535.8 \frac{1}{2} d$. a year in fines, fI $8 s .2 \frac{3}{4} d$. a year in heriots, and $f_{3} \mathrm{I} 2 \mathrm{~s} .6 \mathrm{~d}$. a year in rents. ${ }^{21}$ In $177 \mathrm{I}$ there were nineteen freeholders and copyholders, several less than there had been in 1745.22

Robert Tindal sold the manor, in $179^{\circ}$, less than three months after purchasing it, to Stephen Alger, who held his first court baron in June $1793 .{ }^{23}$ Alger never lived on the Nether Hall estate which was occupied by Nathaniel Green from 1790-I until I 8 I 5-I 6 and then by James Green who was tenant until after Alger's death in 1829.24 Alger's heir was his son William Hill Alger who was lord of the manor until his death in 1880.25 James Green still occupied the estate in 1832 but by $1840 \mathrm{~W}$. H. Alger lived at Nether Hall and farmed most of the estate which then consisted of 256 acres. ${ }^{26} \mathrm{He}$ continued to farm until his death. ${ }^{27}$ In 1872 there were nine freeholders who paid rents totalling $f_{\mathrm{I}} \mathrm{gs} .2 d$. and eight copyholders who paid a total of I $6 s .3 \frac{3}{4} d .{ }^{28}$ During the time that W. H. Alger was lord of the manor the estate was mortgaged at least once. ${ }^{29} \mathrm{He}$ left as his heir his son William White Alger who also lived at Nether Hall and farmed the estate. ${ }^{30} \mathrm{He}$ died in May I 900 having provided that the manor should be sold by his trustees. ${ }^{3 \mathrm{I}}$ Nether Hall was accordingly put up for sale by auction in August 1900. The sale catalogue described the manor farm as consisting of 216 acres of which 176 were arable.32 Quit and free rents amounted to EI I 3s. $3 d$. a year and fines, reliefs and heriots amounted to $£ 5$ a year on the average of the previous 30 years. 33 The farm on the one hand and the manor "with courts, fines, heriots, reliefs, quit and free rents, profits and emoluments' on the other hand were offered as separate lots. The manor was sold for $\oint_{2} 60$ to the Revd. Frederick William Bussell of Brasenose College, Oxford. ${ }^{34}$ The farm passed into the hands of Ernest Schwier.3s The Revd. F. W. Bussell was still lord of the manor in I9I4 but by 1926 the Revd. Joseph Gordon Walker owned the manorial rights. ${ }^{36}$ In r 937 Walker was still lord of the manor and Nether Hall farm was still owned by the Schwier family. ${ }^{37}$

The present farm-house probably dates from the late I $7^{\text {th }}$ century. It is rectangular in plan with a small projecting wing at the back. The central chimney has diagonal shafts. Late in the I 9 th century there were additions to the back and front. In the farm-yard is an altered timber barn, probably of 17 th- or 18 th-century date.

Juliane de Sandwich married John de Segrave, younger son of John, Lord Segrave (d. I325), and on the death of her husband in 1343 , her half of Moreton manor passed to their only son John de Segrave whose death in 1349 was followed in little more than a month by that of his only child, an infant Mary. ${ }^{38}$ Both John and Mary were probably victims of the plague. As there remained no direct descendant of Juliane, the half manor passed to her cousin Nicholas de Sandwich, son of her father's brother Nicholas. ${ }^{39} \mathrm{He}$ conveyed it to William de Clynton, Earl of Huntingdon (d. I 354), who regranted it to Nicholas for life with remainder to John de Sandwich, brother of Nicholas, and his heirs and reversion to the earl and his heirs.40 Within a few years, however, the half manor passed to John, Lord Mowbray (d. I 368), the heir through his wife
3 E.R.O., D/DDw Tiz2

4 E.R.O., D/DMg T 31 .

3 $\mathrm{CP}_{25}$ (2)/1013 Hil. 6 Geo. I ; E.R.O., D/DDw Tr22; W. Talbot, MS. Hist. Moreton.

$6 \mathrm{~W}$. Talbot, MS. Hist. Moreton.

7 E.R.O., D/DU $20 r / 35$; ibid. D/DDw

Tr22; Hist. Essex by Gent. iii, 362 .

8 See Manor of Magdalen Laver.

- E.R.O., D/DA Trg9; ibid. D/DU $201 / 35$.

to E.R.O., D/DU $201 / 35$.

11 Ibid.

13 Ibid. 14 Ibid.

I5 Ibid,; $\mathrm{CP}_{25}$ (2)/1 3 10 East. $30 \mathrm{Geo.}$ III.

16 E.R.O., D/DU 201/35; ibid. Q/RPI
$685-94$.

17 E.R.O., D/DU $201 / 35$.

18 Ibid.

I9 E.R.O., Q/RPI $685-96$.

20 E.R.O., D/DU $201 / 35$; ibid. Q/RPI 694-5.

21 E.R.O., D/DU 201/2I.

22 E.R.O., D/DU $201 / 14^{-16}$ and Ig.

23 E.R.O., Q/RPI 695 ; ibid. D/DU $201 / 2$ and 35 .

24 E.R.O., Q/RPI 696-737; ibid. D/DU $201 / 36$

2s E.R.O., D/DU $201 / 36$.

26 E.R.O., Q/RPI 737 ; ibid. D/CT 244.

27 E.R.O., D/DU $201 / 36$; Kelly's Dir. Essex $(1855,1874)$.

28 F. R.O., D/DU 201/23. In I87I there had been 9 copyholders. One was enfranchised in 1872 .

29 E.R.O., D/DU $201 / 36$

30 Ibid.; Kelly's Dir. Essex (1890, 1895 , I 899).

31 E.R.O., D/DU 201/36.

32 E.R.O., D/DU $201 / 38$.

33 Ibid.

34 E.R.O., D/DU $201 / 37$.

35 Kelly's Dir. Essex (1 g06)

36 Kelly's Dir. Essex (1914, I 926).

37 Kelly's Dir. Essex (1937).

${ }_{3} \mathrm{Cal}$. Inq. p.m. viii, p. 309 , ix, p. 268 ;

Complete Peerage, xi, 609.

${ }_{39}$ Cal. Inq. p.m. ix, p. 268.

40 Cal. Pat. 1348-50, $43^{\circ}$; Feet of $F$. Essex, iii, 96. 
Elizabeth of John, Lord Segrave (d. I 353).4I Mowbray died in 1368 , leaving as his heir his son John, later Ist Earl of Nottingham.42 By I 383 , when John, Earl of Nottingham, died without issue, his estate at Moreton had become known as LADYHALL, apparently through its association with Juliane de Sandwich, and by the end of the century was described as a manor. ${ }^{43}$ From the I6th century it was more commonly known as UPPER HALL.

John was succeeded in 1383 by his brother Thomas, later Duke of Norfolk, who granted a life interest in Ladyhall to William Hall, with reversion to himself.44 Hall died in 1400.45 The Duke of Norfolk had died shortly before and left as his heir his son Thomas, a boy of I 4.46 At the end of I 401 , although Thomas's lands had been assigned for his household expenses, the king granted the custody of Ladyhall to John de Burgh during Thomas's minority provided that he accounted at the Exchequer for all issues above the value of 24 marks a year. 47

Thomas was beheaded in 1405 and his lands escheated to the Crown. ${ }^{48}$ In 1406 the king granted the 'messuage called Ladyhall' to his esquire Nicholas Alderwich and his wife Alice to hold for life 'to the value of $\delta_{20}$ a year so that they answer for any surplus at the Exchequer'.49 Within the next ten years the manor was restored to Thomas de Mowbray's brother and heir John, who was granted the title of Duke of Norfolk in $1425 ;^{50}$ the manor probably descended with the title until the death of the 4th Duke of Norfolk in 1476.51 Afterwards the manor was probably held by John, Lord Howard, who succeeded to a moiety of the Mowbray estates on the death in I48I of his cousin Anne, only daughter and heir of John, 4 th Duke of Norfolk.52 Lord Howard was created Duke of Norfolk in 1483 and Ladyhall probably descended again with this title until 1538.53 In 1538 Lord Edmund Howard, a younger son of Thomas, 7 th Duke of Norfolk, was licensed to alienate the manor to his brother Thomas, 8th Duke of Norfolk, who immediately granted it to Sir Richard Rich, later Ist Baron Rich.54 Subsequently for nearly two centuries the manor of Upper Hall followed the same descent as Nether Hall.5s In 1708 it had I I freeholders and i 7 copyholders whose rents amounted to 66 i is. Iod., much more than those of Nether Hall.56 In I 722, two years after selling Nether Hall, John Woodward conveyed Upper Hall to Lewen Cholmley of Sutton (Surr.). 57 Cholmley was succeeded by his son Lewen who died in $1753.5^{8}$ The manor was then held by Mary Cholmley, widow of Lewen, until at least
I 760.59 In 1763 John son of Lewen Cholmley conveyed the manor to John Hookham (d. 1786), a rich London merchant. 60 Hookham's heir was his only child Jane, wife of John Frere of Roydon Hall (Norf.). ${ }^{6 \mathrm{I}}$ John Hookham Frere, author and diplomatist, the eldest son of Jane and John Frere, succeeded to the family estates on his father's death in 1807.62 He died in 1846 having been for many years resident in Malta. ${ }^{63}$ Soon after his death the manor of Upper Hall seems to have dissolved. A manor court was held as late as $182 \mathrm{I}$ and writers during the next 40 years continued to describe the estate as a manor, but by 1874 Nether Hall had come to be described as the only manor in Moreton. ${ }^{64}$ The lords of the manor of Upper Hall were never resident in the parish. Henry Starkey was tenant of the estate before 1750 and members of his family continued to farm the land and live at the hall until I 809.65 In I 8 I I the Rector of Moreton wrote that before I 809 Upper Hall Farm had been 'occupied by a family of Dissenters for so long a period that no one living was able exactly to ascertain what seat in the church belonged to it'. ${ }^{66}$ In view of the uncertainty the rector gave the new tenant, John Ingham, permission to sit in his own pew. ${ }^{67}$ John Ingham was tenant of the estate until I 8 I 9-20 when he was succeeded by George Rogers. ${ }^{68}$ In 1840 Rogers still farmed the whole estate which then consisted of 246 acres. 69 After J. H. Frere's death in I846, D. Taylor Gingell took over the lease and farmed the estate for the remainder of the century. ${ }^{70}$

The present house may date from the I6th century but has been much altered. The older part has a $T$ shaped plan with a wing projecting on the north side. In the south wing a brick fireplace, probably of the I6th century, has been uncovered. It has a stopchamfered four-centred arch and the chimney above it has two diagonal shafts, now cement rendered. Several additions have been made to the house, the most recent in gault brick probably dating from the I gth century. There is an eight-bay timber barn with one porch wing. A post inside the barn is dated 1782 and initialed R. P.

The early history of $B U N D I S H$ alias BRENDISH alics $B R U N D I S H$ manor is obscure. It probably took its name from the family of John de Burndish which came from Brundish (Suff.). From I 305 until his death in 1336 John de Burndish held a life interest in the half of Moreton manor which belonged to John de Lenham. On the death of John de Burndish this half manor reverted to Eleanor Giffard, the heir of John de Lenham. ${ }^{71}$ In 1338 John and Eleanor Giffard
41 Complete Peerage, ix, 384. John, Lord Segrave (d. I 353), was a cousin of John de Segrave (d. I 349) and the heir of part of his lands in 1349 .

42 Complete Peerage, ix, 384. Cf. Cal. Inq. p.m. xii, p. 380 .

$43 \mathrm{Cr}_{3} 6 / 27 / 6$; Morant, Essex, i, 145. In 1383 the estate was still described as a half manor. In and after 1399 it was always described as a manor, though not always in the I5th cent. by the name of Ladyhall.


age, ix, 384 . $45 \mathrm{CI}_{37} / 82$.

46 CI $37 / 16$; Complete Peerage, ix, 384 .

47 Cal. Pat. I $40 \mathrm{I}-5,24$

$48 \mathrm{C}_{137 / 63}$; Complete Peerage, ix, 384 .

49 Cal. Pat. 1405-8, I 10.

so Cal. Pat. 1413-16, 320; Complete

Peerage, ix, 384, 605-6.

31 Compleie Peerage, ix, 608-9.
52 Complete Peerage, ix, 6ro-11. The manor of Bundish Hall (see below) was held of John, Lord Howard, in $148 \mathrm{I}$.

53 Complete Peerage, ix, 6I I-20.

$54 \mathrm{CP}_{25}(2) / 12 / 66$ Trin. 30 Henty VIII.

$55 \mathrm{C}_{142 / 147 / 141,192 / 29,494 / 120}$

$\mathrm{CP}_{25(2) / 293}$ Trin. 6 Jas. I; CP.25(2)/820

Hil. Io Will. III; E.R.O., D/DB T656; ibid. D/DGe T75.

56 E.R.O., D/DU $201 / 12$.

$57 \mathrm{CP}_{25}$ (2)/1014 Mich. 9 Geo. I

58 E.R.O., D/DB T656; W. Talbot, MS. Hist. Moreton.

59 E.R.O., D/DB T 656.

$60 \mathrm{CP}_{25}$ (2)/I $306 \mathrm{Hil} .3 \mathrm{Geo}$. III;

D.N.B. vii, 707 .

6I E.R.O., Q/RSg 4, p. 54 ; D.N.B. vii, 707.

${ }^{62}$ D.N.B. vii, 708. He was a friend of Canning and Coleridge. 63 Ibid.
64 E.R.O., D/P 72/25/I 8; D. W. Coller, People's Hist. Essex, 480; White's Dir. Essex (I 848), 426; Kelly's Dir. Essex (I874).

65 E.R.O., D/P 72/3/2; ibid. D/P $72 / 25 / 12$; ibid. Q/RPI 705-15.

66 E.R.O., D/P 72/25/20.

68 E.R.O., Q/RPl 7I 5-25.

69 E.R.O., D/CT 244; ibid. D/P 72/2 I. The owner of the estate in 1840 was described in the Moreton Tithe Award as Robert Henry Frere. No mention of Robert Henry can be traced in the Frere family lineage, however, and the name was probably a misinterpretation of 'Rt. Hon.', John Hookham Frere being a privy councillor.

70 E.R.O., D/P 72/2I; ibid. Q/RPr I/27 \& 34; Kelly's Dir. Essex (I8.74 f.).

7 Cal. Inq. p.m. vii, p. 493. See above, Manor of Nether Ha!l 


\section{A HISTORY OF ESSEX}

conveyed to Nicholas de Burndish 24 acres of land in Moreton to hold of the king in chief. 72 Nicholas de Burndish died, probably of the plague, in I 349 , still holding this 24 acres of the king. ${ }^{73}$ In addition he held another 60 acres in Moreton and $\frac{1}{2}$ messuage of the manor of Moreton by service of 2 Is. 3 d. a year and suit of court, and 20 acres land in Shelley and the other half of his messuage which he held of John de Legh, lord of Shelley manor, by service of $8 \mathrm{~s}$. Iod. a year and suit of court. ${ }^{74}$ It seems clear that these lands of Nicholas de Burndish formed the main core of the estate which later became known as Bundish or Brendish manor. Nicholas evidently occupied a house which was situated partly in Moreton and partly in Shelley and he farmed lands in both parishes. During the period when Bundish manor is known to have existed, its lands were situated in Shelley and Moreton and the manor house lay on the boundary between the two parishes which 'divided at the entrance end of the great hall'.7s

Nicholas de Burndish left as his heir his brother John, Rector of South Ockendon, who in I 353 enfeoffed Richard de Fifhide with 24 acres which he held in Moreton of the king in chief.76 When Fifhide died in 1374 his lands were described as tenements only.77 Thomas Wynslowe died in 148 I holding the 'manor of Brundisshe' of Henry, Earl of Essex (d. I 483), who was then lord of the manor of Nether Hall. ${ }^{78}$ At the time of his death Thomas also held 2 messuages, 79 acres of arable, and 5 acres of meadow, in Moreton, of John, Lord Howard, who was then probably lord of the manor of Upper Hall.79 Thomas apparently did not hold any tenement of the manor of Shelley.

He devised Bundish manor to his daughter Margaret, wife of William Nynge.80 Margaret died in I522, leaving as her heir her grandson Thomas Nynge. ${ }^{81}$ On 'Thomas's death, before March I 524 , he was succeeded by his sisters Amphyllis and Isabel. ${ }^{82} \mathrm{Sub}-$ sequently the manor seems to have come into the sole possession of the elder sister Amphyllis, for in 1533 it was held by her and her husband John Shereff. 83 In the same year Amphyllis conveyed the manor to Sir Richard Rich, later Ist Baron Rich, from whom it passed in 1567 to his son Robert, the 2 nd baron and afterwards in $158 \mathrm{I}$ to Robert, the 3 rd baron. 84 In 1585 Lord Rich conveyed the manor to William Ramsey. ${ }^{8 \mathrm{~s}}$

The history of Bundish in the I 7 th century is not clear, but at the end of the century it was apparently in dual ownership. In I 68 I Henry Herbert and his wife Anne conveyed half of the manor to Joseph and Thomas Offley. ${ }^{86}$ In I $690 \mathrm{Sir}$ William Boughton and his wife Mary, daughter of John Ramsey, alderman of the city of London, conveyed half the manor to Matthew and Robert Skinner. ${ }^{87}$ It may be that Lady Boughton and Anne Herbert were granddaughters of William Ramsey and had inherited Bundish as coheiresses of their father John Ramsey. Subsequently the manor came into the undivided ownership of John Lingard, common serjeant of the City of London, who died in 1729 leaving several daughters as coheiresses. 88 In 1740 Elizabeth, Sarah, Anne, and Frances Lingard conveyed the manor to Samuel Brackley, merchant. ${ }^{89}$ In 1753 Sarah and Anne Lingard and Robert Chase and his wife Frances, daughter of John Lingard, conveyed it to Francis Capper.90 In 1775 the estate was still described as a manor.9I In all later documents and histories it was described merely as a farm. In 1840 the farm consisted of 166 acres of which 107 acres lay in Moreton and 59 acres in Shelley; at that time the estate was held by Thomas Chaplin, trustee of John Chaplin, deceased. 92

Bundish Hall occupies a large moated site. At some time prior to 1835 , but probably after 1768 , the parishes of Shelley and Moreton agreed that the whole of the farm-house should be considered within the parish of Moreton. ${ }^{93}$ Consistently with this the parish boundary runsalong the west wall of the farm-house, leaving some of the outbuildings in Shelley. 94 Wright's statement that formerly the parish boundary was 'at the entrance end of the great hall'95 confirms the existence of a medieval manor house here, and the present farmhouse incorporates at its west end what was probably the late-I $5^{\text {th }}$-century solar wing. This is of two stories, the solar itself being on the first floor and having an open arch-braced roof truss above it. The roof is now ceiled in but the rebated king-post with four-way struts is still visible in the attic. The ceiling probably dates from the $I 6$ th or early 17 th century and in the solar is panelling of the same period and later. The timbers of the lower part of the great hall are probably still in position to the east, but this part of the house has been much altered. A northward extension of the solar wing has the date 1697 scratched on the brickwork. At some time previous to 1835 the house was reduced in size, 96 and at this period or later 97 was partly cased in brick and reroofed. It now gives the impression externally of a small farm-house of the early I 9 th century. The west wall was damaged by flying bombs in 1944 and has been rebuilt. 98 In the farm-yard are two large timber barns of the 17 th or 18 th century.

There was a church in Moreton before the end of the I I th century. William de Scohies, lord of CHURCH the manor of Moreton by 1086,99 gave the church with its land and tithe to the abbey of St. Stephen, Caen. ${ }^{1}$ Between I I 74 and I I 82 a charter of confirmation described the gift as the church of Moreton and the tithe of the demesne of William d'Avranches from his mill, pannage, poults, apples, nuts, and other tithes belonging to that church, according to William's charter; also the messuage of John the chaplain, near the churchyard, with the adjacent flax-ground of William's gift. ${ }^{2}$ A vicarage was ordained to which the prior of Panfield, a cell of the abbey of St. Stephen, usually presented until I 335.3 After this Edward III, having seized the priory

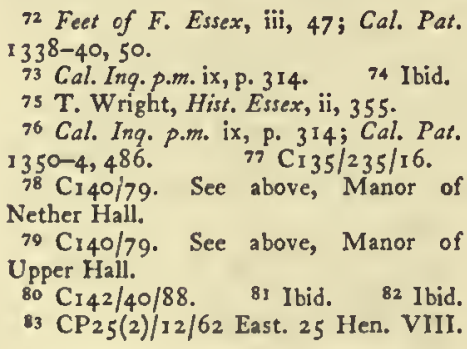

$8+C_{142 / 147 / 141 ;} C_{142 / 192 / 29 ; C_{1} /}$ $708 / 14$. $85 \mathrm{CP}_{25(2) / 132 / 1696 .}$ $86 \mathrm{CP}_{25}(2) / 76_{3}$ East. 33 Chas. II. $87 \mathrm{CP}_{25}(2) / 827$ Hil. I Wm. \& Mary G.E.C. Complete Baronetage, $1625-49$ I22. 88 Wright, Hist. Essex, ii, 356 ${ }_{80} \mathrm{CP}_{25}(2) / 1122 \mathrm{Mich}$. I4 Geo. II. $90 \mathrm{CP}_{25}$ (2)/I I 24 Mich. 27 Geo. II. $91 \mathrm{CP}_{43 / 767}$ rot. 426 . 92 E.R.O., D/CT 244.

93 Wright, Hist. Essex, ii, 355.

o4 O.S. 25 in. Map (2nd edn.), sheet li
(5). 96 Ibid.

97 The date 1839 is on the brickwork.

98 Inf. from Mr. Lavender, present occupier. 99 See above, Manor.

1 Cal. Doc. France, ed. Round, I56, 157; Newcourt, Repert. ii, 422; Dugd. Mon. ii, 957; V.C.H. Essex, ii, 198.

2 Cal. Doc. France, ed. Round, I 62.

3 Newcourt, Repert. ii, 423; Reg. Baldock, Seagrave, etc. (Cant. \& York Soc.), 306. 
on account of the war with France, presented to the living several times during the remainder of his reign. ${ }^{4}$ The advowson continued in the Crown during the reigns of Richard II and Henry IV.s In 14 I 4 Panfield priory and its possessions came to the king under the act suppressing non-conventual alien priories. ${ }^{6}$ In I44I Henry VI granted to Eton College from Moreton church an annual pension equal to the value of the church on the assessment of I29I (see below).7 The living remained, however, in the gift of the Crown, which presented to the church as a vicarage until at least $1484 .{ }^{8}$ In I 532 Henry VIII presented to it as a rectory and it afterwards continued as a rectory. 9 In I 538 the king granted the advowson first to Thomas, Archbishop of Canterbury, and then, in December, to Charles, Duke of Suffolk (d. I 545), who immediately alienated it to Sir Richard Rich, later ist Baron Rich. ${ }^{10}$ On the death of Lord Rich in 1567 the advowson passed to his son Robert, the 2nd baron, and afterwards in $158 \mathrm{I}$ to Robert, the 3 rd baron, later Earl of Warwick (d. 16I9)."I Jacob Morris and John Morrice presented pro hac vice in I $59 \mathrm{I} .{ }^{12}$ Between I 595 and I 632 the advowson was the subject of various conveyances but it remained in the hands of the Earl of Warwick and his heirs. ${ }^{13}$ In 1626 Robert, Earl of Warwick (d. I658), presented his chaplain Samuel Hoard (see below) to the rectory. ${ }^{14}$ In 1658 Edward, Earl of Manchester (d. I67I), and others, trustees of the earl, presented Edmund Calamy the younger (see below) to the living. ${ }^{15}$ Charles, Earl of Warwick (d. I673), presented in I662.16 After his death his nieces Anne, Mary, and Essex, daughters of his brother Robert, Earl of Warwick (d. I 659), all secured rights in the advowson as also did Frances, sister of Robert and Charles and wife of Nicholas, Earl of Scarsdale (d. I68 I). ${ }^{17}$ By 1687 Daniel, Earl of Nottingham (d. I 730), and husband of Essex, had apparently secured sole rights of patronage. ${ }^{18}$ Soon afterwards the advowson was acquired from Nottingham by Ralph Smith of Islip (Oxf.). ${ }^{19}$ In I693 it was purchased from Smith for $£ 420$ by St. John's College, Cambridge, who retained it until 1933.20 Since I933 the living has been united with that of Little Laver in the gift of St. John's College, who have first and third turns, and the Bishop of Chelmsford, who has second turn.21

In 1254 the church was assessed at I 8 marks and the vicarage at 5 marks. ${ }^{22}$ In I29I the church was assessed at $\oint_{12}$ and the vicarage at $f_{0} 6$ I $35.4 d .^{23}$ In I 324 it was recorded that Panfield priory received $£_{0} \mathbf{2}$ a year from Moreton church. ${ }^{24}$ In 1428 the church was still taxed on the valuation of 1291.25

In 144I Henry VI granted to the Provost of Eton College and to his successors an annual pension of 18 marks from Moreton church. ${ }^{26}$ In I 535 the rectory was valued at $6.1835 .4 d .27$ In 166 I the living was valued at $6_{1} 60 .{ }^{28}$ Previous estimates in the 17 th century had been $£_{50}$ in 1604 and $\oint_{0} 120$ in 1650.29
The tithes were commuted in 1840 for $£ 39055.30$ There were then 68 acres of glebc. ${ }^{11}$

A terrier of 1610 refers to "a dwelling house newly built by the incumbent'. ${ }^{32}$ 'The present rectory is an L-shaped building, originally timber-framed and plastered but now partly faced with brick. The base of the massive chimney at the south end and some of the timbers may be part of the early-1 7 th-century rectory. The house was evidently remodelled early in the 18 th century and the staircase and panelling are of this date. The north wing probably dates from the incumbency of W. Wilson (1796-1822) when the house was extended.33 The Georgian front, facing east, has six sash windows on the first floor. The doorcase has a Doric entablature, fluted pilasters, and a pediment.

Samuel Hoard, rector I 626-58, was a theological writer. ${ }^{34}$ The puritan Edmund Calamy the younger was rector from 1658 until ejected in 1662.35 Richard Vaughan, rector from I $591-2$ until I 596, was bishop successively of Bangor, Chester, and London. ${ }^{36}$

The parish church of $S T$. MARY THE VIRGIN consists of nave, chancel, west tower, south porch, and north vestry. The nave and chancel, which are structurally undivided, are of flint rubble. The dressings of clunch have now mostly been replaced with more durable stone. The tower and vestry are of red brick. The south porch is of wood.

Nothing remains of the pre-I $3^{\text {th-century church }}$ except the font (see below). The present nave and chancel date from the first half of the I 3 th century, the nave having been built first. The nave has two restored lancet windows in the north wall and one in the south. The position of the north and south doorways is probably original. The east wall of the chancel has three lancets, a central one in the gable and two below. The north wall of the chancel has two lancets, one of them being behind the organ.

In the $15^{\text {th }}$ century the chancel. and nave were probably reroofed. The chancel retains one moulded tie-beam of this date. The nave has two I 5 th-century roof trusses near the west end. These have long struts from the tie-beams to the heads of the octagonal kingposts as well as one short strut each to the central purlin. In both chancel and nave the rafters are ceiled in. The roof of the south porch retains some I 5 th-century timbers. The two-light window near the east end of the north wall of the nave was inserted in the late $15^{\text {th }}$ century. The single-light window on the south side of the chancel is also of this date. The perishable nature of the clunch of which the windows were constructed accounts for their replacement at different dates and for the extremely varied character of the windows on the south side of the church. The westernmost window in the nave, recently replaced, was probably originally of the I $5^{\text {th }}$ century. Two other windows, one of the 18 th and one of the I th $^{\text {th }}$ century, may also have replaced windows of the 15 th century or earlier.

\footnotetext{
4 Newcourt, Repert. ii, 423 ; V.C.H. Essex, ii, 198.

3 Newcourt, Repert. ii, 423.

6 Rot. Parl. iv, 22.

7 Newcourt, Repert. ii, 423.

8 Ibid.

- Ibid. ii, 424 .

to Ibid. ii, 423 ; L. E P. Hen. VIII, xiii (2), pp. $494,496$.

II $\mathrm{C}_{142 / 147 / 1_{41}} ; \mathrm{C}_{142 / 192 / 29}$

12 Newcourt, Repert. ii, 424.

13 $\mathrm{CP}_{25}(2) / 137 / 1738 ; \mathrm{CP}_{25}(2) / 292$ Hit. 3 Jas. I; $\mathrm{CP}_{25}(2) / 385$ East. \& Trin. 6 Jas. I; $\mathrm{CP}_{25}(2) / 296$ Trin. I9 Jas. I;
}

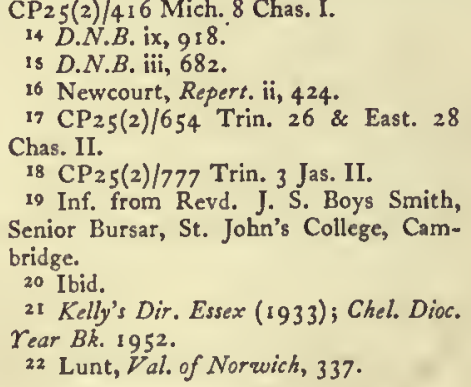

22 Lunt, Val. of Norwich, 337.






\section{A HISTORY OF ESSEX}

The tower may originally have been of the I6th or early I7th century. Morant (I768) described the tower as 'of brick, plaistered over, with a spire shingled'.37 Parts of the nave and chancel roofs date from the 17 th century.

The sonth doorway with its six-panelled door is of I 8 th-century date. The weather-boarded south porch, incorporating earlier timbers, may have been reconstructed at the same time. In 1727 twisted communion rails, chancel wainscoting, box pews, and a west gallery were given by Mrs. Judith Elford. ${ }^{38}$

In 1786 part of the tower fell in a gale. 39 It was rebuilt by James Marrable in 1787 'upon the model of the old'.40 It is of red brick, in three stages, and has a castellated parapet and a short shingled spire. The doorway into the nave was built at the same time. The two-light window near the east end of the nave on the south side is like the wooden west window of the tower and is probably of about the same period.

In I 868-9 there was a thorough restoration of the interior of the church.41 Many of the fittings, including the box pews, the chancel wainscoting, the lists of benefactions to the poor, texts and hatchments, were removed. New pine seating was installed. 42 The pulpit was reconstructed and the sounding-board removed. The vestry may have been built at the same time.

Between I 877 and I 89 I the nor th wall of the chancel was rebuilt, the lancet windows being restored and reset at the expense of the rector, the Revd. A. Calvert. 43 The easternmost window on the south side of the chancel appears also to be of late-I gth-century date, probably replacing a I $5^{\text {th-century two-light window. }}$

In 1897 the west gallery was removed.44 In 1904 a new organ was built.45

In 1953 the two lower lancets at the east end and the quoins at the west end of the church were restored in Clipsham stone. The westernmost window on the south side of the nave was replaced by a copy of a square-headed two-light late-1 5 th-century window in the same material.46 The tower was restored and the spire reshingled.

There are six bells. Two were recast in 1928 when the wooden framework supporting the bells was replaced by steel.47 The inscription on one of these, 'Miles Graye and William Harbert me fecit I 627', has been cut out and mounted on a pedestal in the church. Of the remainder one is inscribed 'Miles Graye I6 62', one 'Thomas Gardiner Sudbury I 712 ', and one 'Thomas Lester I75I'. The sixth bell (No. I) was presented by the ringers themselves in $1933 . .^{48}$

The Purbeck marble font is of the late I 2 th century. It consists of a square bowl standing on a circular base, which has four detached shafts. Two sides of the bowl are ornamented with fleur-de-lis, one has roundheaded arcading, and the fourth a crescent, disk, and spiral. The surface is much decayed and the carving incomplete.

37 Morant, Essex, i, 146.

38 Wright, Hist. Essex, ii, 353 ; w. Talbot, MS. Hist. Moreton.

39 W. Talbot, MS. Hist. Moreton.

40 E.R.O., D/P 72/25/12; W. Talbot, MS. Hist. Moreton; inf. from tablet in tower.

4 Kelly's Dir. Essex (1886).

42 W. Talbot, MS. Hist. Moreton.

43 Kelly's Dir. Essex (1899)

44 MS. notes in possession of present rector, the Revd. A. W. I. Weir. Cf. Kelly's Dir. Essex (1914), which gives
The oak pulpit is hexagonal and probably dates from the restoration of 1868 . It incorporates four carved panels and a cornice of about 1600 . The painting above the altar is a copy of the Holy Family by Andrea del Sarto and was acquired in 1951.49

On the south wall of the nave is an inscribed tablet to George Goodwin, rector ( 1625 ).

The plate consists of an almsdish of 1648 with a shield of arms, a cup of $166_{3}$, a paten of 1663 (dated I664), and a flagon of I 79 presented by A. Heron, rector (I698-I 733).

A Chancery decree of 1638 recognized the Church Lands Charity, the origin of which was then unknown. ${ }^{50}$ Its property was then and afterwards stated to be "a tenement and 6 acres of land called the Church Land', held in trust for the repair of the church.s1 The property was at the west end of North Lane. 52 In deeds from 1787 until 1832 it comprised a freehold cottage or tenement called 'the Church House', a close of pasture adjoining, 2 acres by estimation, and two other closes or crofts of arable, 4 acres by estimation, on the other side of the road leading towards Moreton windmill.53 The estate seems always to have been let together and in the roth century was called Church Farm. 54 In 1646 it was rented at 6.5 12s. a year.ss The annual rent remained at this figure until I 8 I I when it rose to $\oint_{12}{ }^{56}$ By I 879 it had risen to $£ 20$ but it fell to $£_{1} 8$ before 1895 when it was further rednced to $\oint_{1} 2$, after the farm-house had been destroyed by fire. 57 In I 947 the rent was 615.58 After I 895 the income from rent was supplemented by the interest on EII 2 2s. fire-insurance, which was invested.59 In I 869 f.I I 335.9 . stock, representing accumulations of surplus income, was sold and, supplemented by voluntary contributions, was used to erect new pews. 60 The sum of $£ 50$, invested in 1874 , was also used in 1878 for large repairs. ${ }^{61}$ In 1950 the income of 62 I 2s. 8d. from stock was spent in part payment of repairs, but apparently no rent was received from the lands of the charity. 62

The payment to the verger from Wilson's charity (1822) is mentioned below (Charities).

William Talbot, by will proved i 894 , left $\oint_{1} 00$ stock to the rector and churchwardens in trust for the maintenance of the churchyard. ${ }^{63}$ In 1950 the income of $\delta_{3}$ I Is. $2 d$. was spent in part payment for its upkeep. 64

The Guild of All Saints, Moreton, probably founded in 1473 , was a religious guild of a type common in rural parishes in the 14 th and 15 th centuries. Its statutes, ${ }^{65}$ drawn up in 1473 , prescribed that it was to hold an annual general meeting on the Sunday after All Saints Day, for worship and the election of officers. Any member who failed to attend mass on this Sunday, 'in his best clothynge', or failed to attend evensong the previous evening, was to pay I $\mathrm{lb}$. of wax 'to the amendment of the lyghtes'. The guild officers, who
1904 as date for removal. 45 Kelly's Dir. Essex (19 14).

46 Inf. from present rector.

47 Inscription in Ringing Chamber.

48 Ibid.

49 Inf. from present rector.

50 E.R.O., D/P 72/25/3, 4, 19.

51 E.R.O., D $/ P 72 / 25 / 3-4,10-16,19$, 20.

52 E.R.O., D/P 72/25/12-16; Hist.

Essex by Gent. iii, 363

33 E.R.O., D/P 72/25/12-16. Cf. ibid.

$\mathrm{D} / \mathrm{CT} 244$ where locations of the pasture and one of the arable fields are reversed.

54 Rep. Com. Char. (Essex), H.C. 216 , pp. 230-2 (1835), xxi (I); Char. Com.

Files.

55 E.R.O., D/P $72 / 25 / 20$.

56 Ibid.

58 Chat. Com. Files.

59 Ibid.

61 Ibid.

63 Ibid.

64 Ibid.

65 R. Gough, History of Pleshy, App. pp. II 3-3 I. 


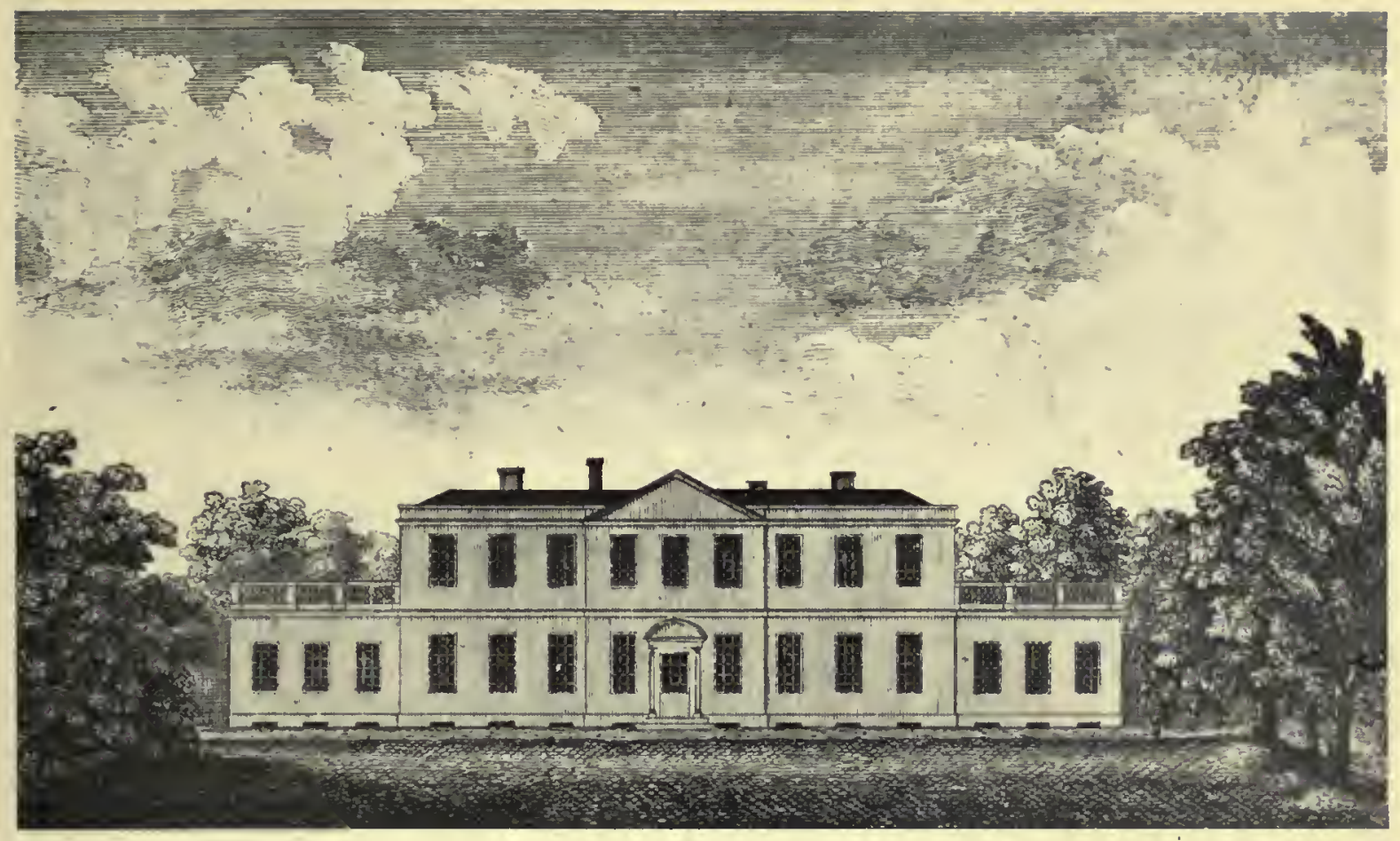

NAVESTOCK HaLL

Built in the early 18 th century, demolished I 8 I I

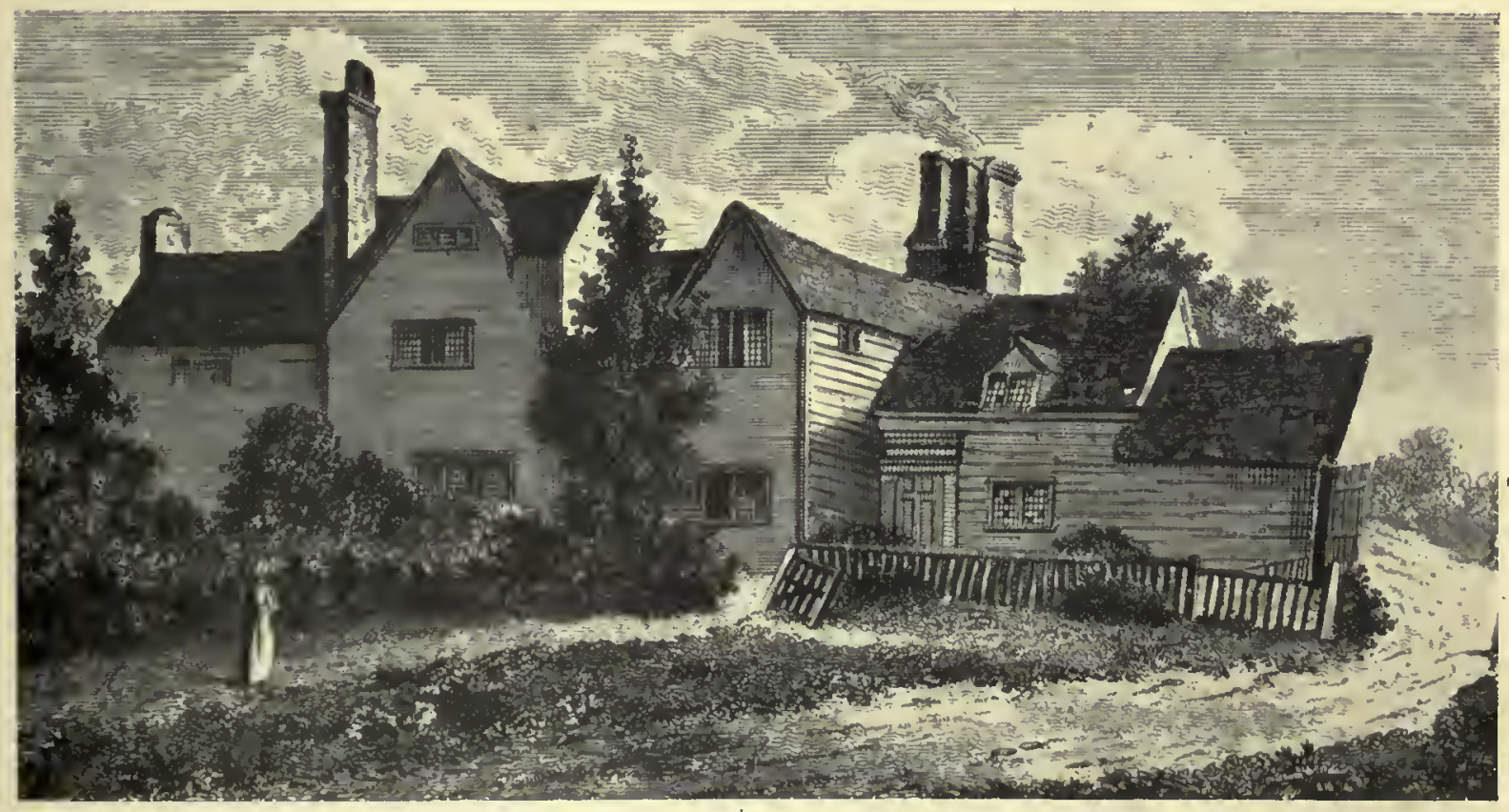

The Former Rectory, Stondon Massey

Built in the early 17 th century, demolished $c .1800$ 


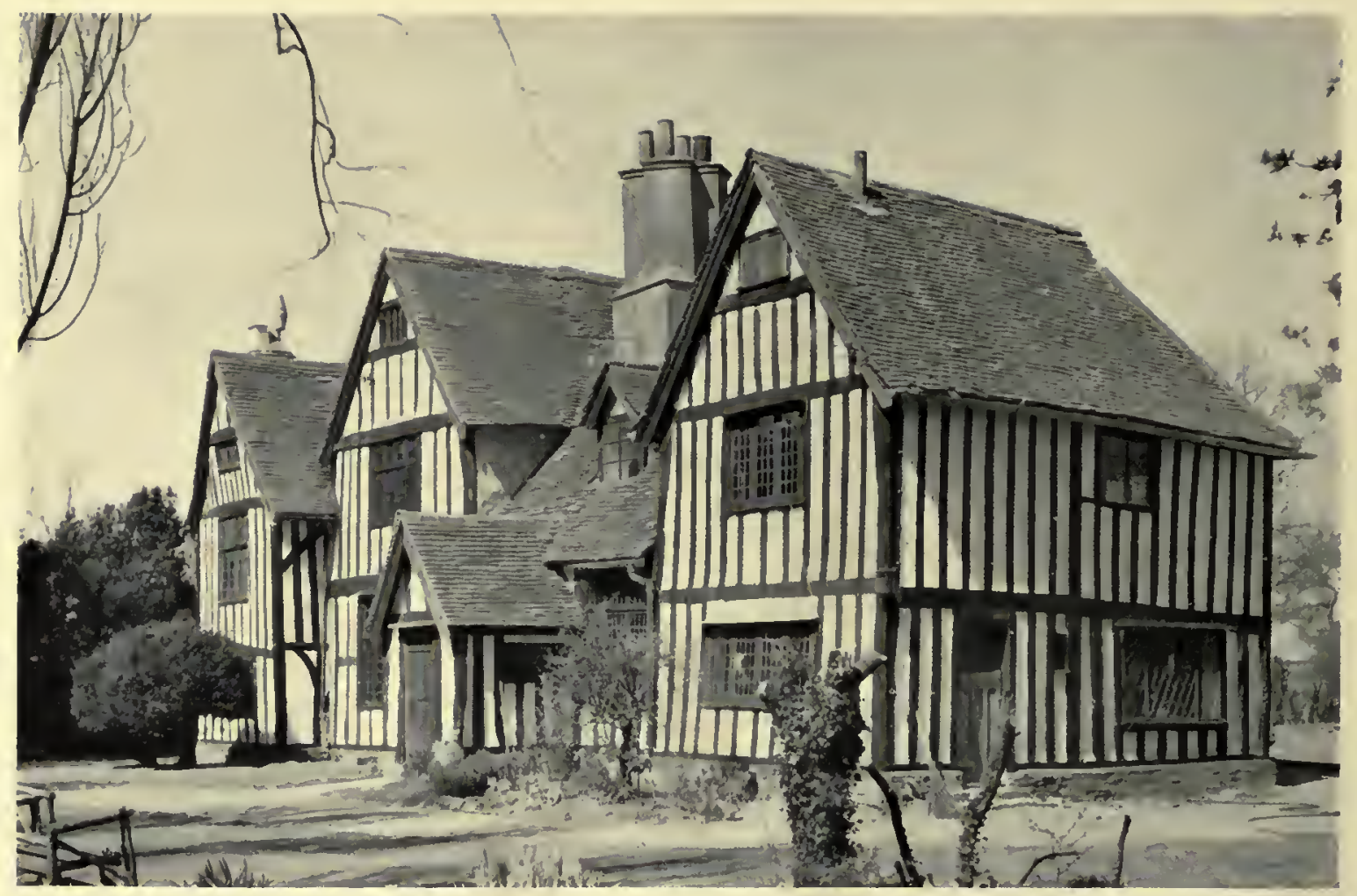

Wynter's Armourie, Magdalen Laver, containing part of a if 4 th-Century aisled hall.

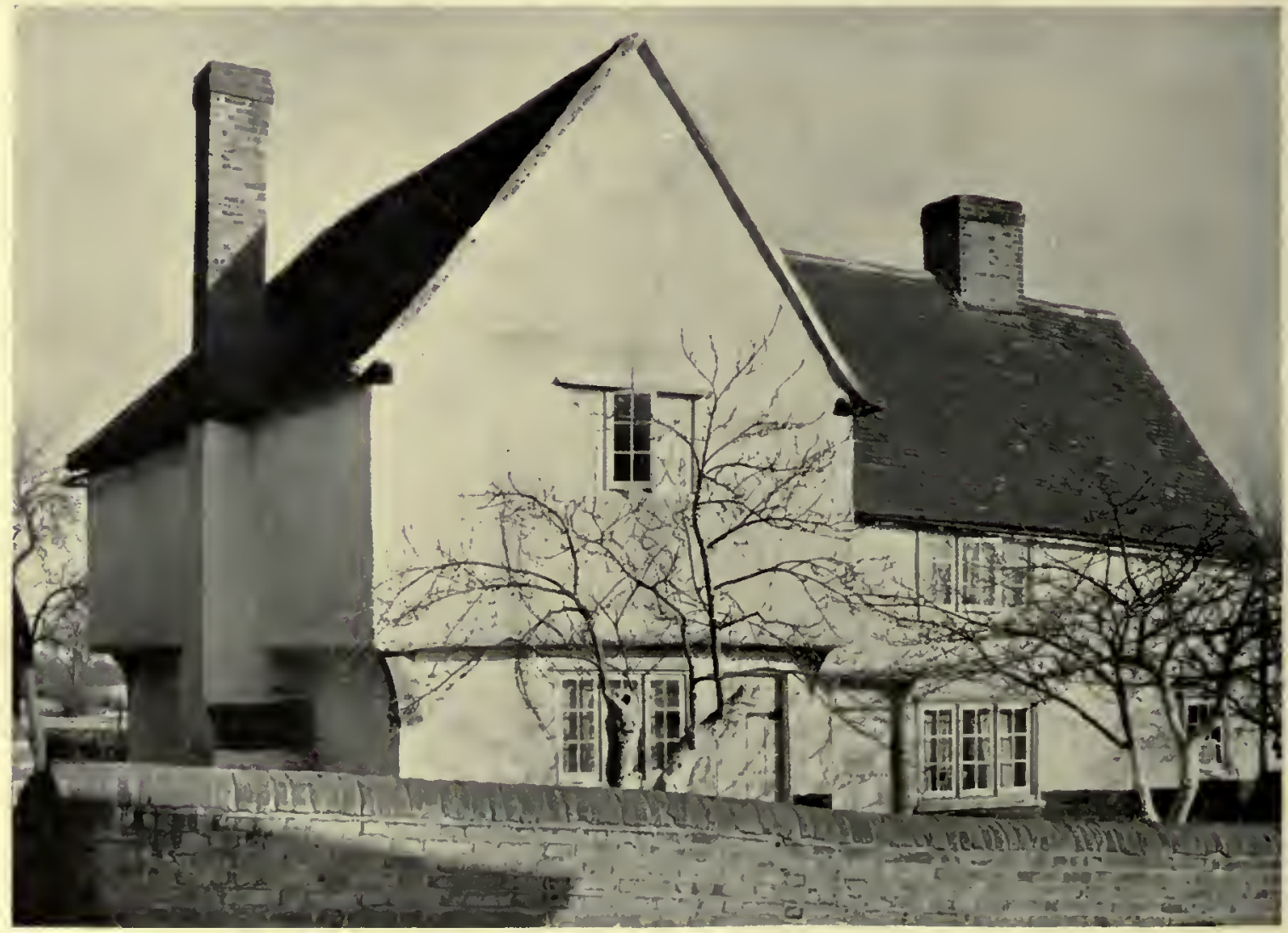

Black Hall, or Guildhall Cottage, Moreton

Probably a guildhall of $c$. 1473 
were to be elected at the meeting, were to be an alderman, two masters, a clerk, and a dean. At the feast after mass the allowance of ale was graduated to the status of the officers; the alderman had a gallon for himself and his guests, each master a pottle, the clerk a pottle, and the dean a quart. The clerk was to receive I $6 d$. and the dean $8 d$. a year. Every new member of the guild was to pay $2 s .6 d$. "to the sustynance and to the fortherance of the gylde' and $\mathrm{I} d$. each to the clerk and to the dean. When a member died the guild masters were to sing masses 'of the costys of the gylde' and all members "wythin the towne and having knowynge thereof' were, under penalty of $\mathrm{I} d$., to attend the funeral and 'to offyre for the sawle at the mess done therfor a 1 $d$.' The Vicar of Moreton was to be paid $4 s$. $4 d$. every year to pray and say masses every Sunday for guildsmen. It was further laid down that if any member 'fall into old age or into great poverty nor have noth wharwyth to be founden nor to helpe hymselfe' he was to have $4 d$. a week of the goods of the guild as long as its chattels were worth 40 . or more. If there were several such needy members, the $4 d$. was to be divided between them. It was also laid down that if a member accused any of his brethren of a trespass he should not in the first instance have recourse to the common law but should submit to the arbitration of 2 to 4 guildsmen. If the arbitration failed the alderman could license the disputants to go to law but if any member refused to submit to arbitration in the first instance, he was to pay $40 d$. to the guild. Under a statute of I $504^{66}$ every brother was to have at his death five priests, and every sister two priests, each of whom was to have $4 d$. at the cost of the guild; on every such occasion $6 d$. was to be given in bread to the poor people of the parish. There is no later reference to this guild. 67

The house known as Black Hall or Guildhall Cottage, at Moreton End, is traditionally supposed to have been the meeting place of the Guild of All Saints. The evidence of the building itself, which dates from the later $15^{\text {th }}$ century, confirms this. The comparatively elaborate moulding of the timbers internally and the reports of carving externally also suggest a building of more status than a small domestic house of the period. The present house (see plate facing P. I 37) is L-shaped and consists of what was originally an open hall of two bays with a two-story gabled wing at its north end. The external wall at the south end of the hall is of later construction and incorporates an arch-braced roof truss. It has been suggested ${ }^{68}$ that the hall may originally have had an additional bay, used for service purposes, at this end. Original door-heads at the front and back of the hall, adjacent to this south truss, would be consistent with a screens passage between the service bay and the hall proper. The two remaining bays of the hall are divided by another arch-braced roof truss of a more elaborate character. This has been partially enclosed in a later partition, but the moulded wall posts and a kingpost with a moulded base can still be seen. The north cross-wing, corresponding to the 'solar wing' of a domestic building, has two rooms to the ground floor and two above. In each case these were connected

66 Ibid. $13 \mathrm{x}-2$. The date 1404 given in the printed text is almost certainly a misprint for 1504 .

67 It is not mentioned in the Chantry Certificates of 1546 and $154^{8}$ ( $\mathrm{E}_{3} \mathrm{O} / \mathrm{I}$, 20 and 30 ).

68 Hist. Mon. Com. Records, revised 1953.

ES. IV
69 Inf. from Mr. Talbot, present occupier. 70 E.R.O., Q/RRw 1. 71 E.R.O., Q/CR 3/2. The Revd. Isaac Taylor of Chipping Ongar also preached at Moreton at this time.

72 Essex Congr. Union Reps. 1850.

73 Ibid. 1856 .

74 Ibid. $1857 \mathrm{f}$. Unless otherwise stated by doorways of which the four-centred heads remain. On both floors the front rooms are the more elaborately finished: the room below has moulded ceiling timbers, and that above has stop-moulded wall plates and an arch-braced roof truss of which only the lower part is now visible. There are indications that the back room on the first floor was once subdivided. In many cases the original position of the windows, some now blocked, can be traced. Externally the building is covered with rough-cast which is said to conceal carved or moulded timbers, in particular a carved sill to the first floor window at the front of the cross-wing. ${ }^{69}$ At the north-west corner, where the first floor oversails on both sides, is a moulded angle post and curved bracket. This post supports a diagonal or 'dragon' beam. Many of the alterations, including the insertion of the hall ceiling, the chimneys, and the present front door, probably date from the late 16 th or carly 17 th century. At this date or later a small staircase wing was inserted in the angle

In 1813 a house in Moreton was licensed for worship by nonconformists.70 In

NONCONFORMITY I 829 the Revd. J. Corbishley of Abbess Roding (q.v.) reported that he sometimes preached at Moreton. ${ }^{71}$ Some of his hearers may have formed the nucleus of the later Congregational society. This appears to have been started about 1850 , when Mr. Vale, the evangelist from North Weald (q.v.), began preaching at Moreton. ${ }^{72}$ Vale's work at Moreton, which was assisted by a small annual grant from the Essex Congregational Union, was so successful that by I 8,6 his Sunday evening congregation numbered 80-100, and there were also a Sunday school attended by 30 children and an adult evening school.73 About this time Vale moved to Moreton, where he continued to minister until about 1873.74 In 1857 it was reported that the Sunday school had been given up owing to opposition from to deter attendance', but in spite of this the work flourished. In 1862 a church was built at a cost of 6I 50 . In I875 A. M. Kemsley, an evangelist, had charge of the church under the superintendence of the Revd. J. R. Clarkson of Chipping Ongar. In the following year the Revd. W. Passmore, formerly of Welling (Kent), started to work at Moreton. Since that time the church has continued with fluctuating fortunes. It has frequently been under the pastoral charge of the minister from Chipping Ongar. In 1904 there were 7 church members, 34 pupils in the Sunday school, and 3 teachers.75 From 1939 to 1948 there was a lay evangelist, Mr. W. J. Frost.76 In I950 there were I 8 members, I 5 pupils, and 3 teachers.77 Since I9I I the church has been vested in the Essex Congregational Union. ${ }^{78}$ The building is of gault brick with red brick dressings and is dated 1862 .

The earliest parish book (I666-I 8 I 5) for Moreton was kept and written by

$P A R I S H$ GOVERNMENT the rector.79 In it the AND POOR RELIEF $\quad$ rectors from Jacob Houblon to William
Salisbury recorded every Easter from I 666 until I 76 I between the hall block and the cross-wing. neighbouring clergy" "who used promises and threats from these reports.

7 Cong. Year Bk. Igo4.

76 Ibid. 1939-48. 77 Ibid. 1950

78 Essex Congr. Union Trust Deeds.

79 E.R.O., D/P 72/8/r. Unless otherwise stated all information in the following account is based on this source. 


\section{A HISTORY OF ESSEX}

the annual elections of officers and summaries of the previous year's accounts. The few vestry resolutions which they entered related to the repair and cleaning of the church, the renting of the glebe and the responsibility for the maintenance of the churchyard fencing. After 1761 the rectors, William Salisbury (to 1796) and William Wilson ( $1796-1822$ ) used the few remaining pages to record occasional vestry minutes, notes of their own and amounts collected on charitable briefs. The only other surviving parish books are a volume of overseers' accounts for the period I 7 I 5-49 and a later parish book which was begun in 1828 but which contained vestry minutes only from $1845 .{ }^{80}$ Thus from the middle of the 18 th century there is no record of the general government of the parish. The annual audit of accounts in the rector's book was not signed by the parishioners present but the few vestry resolutions were signed. It seems from these signatures that normally no more than 6 persons attended the meetings. In 1761 and $1762^{81} 8$ or 9 persons attended the important meetings held to consider the repair of the bridge. There were probably other vestry meetings held during the year but not recorded in the rector's book, for in 1724-5 the overseer mentioned in his account book expenses incurred at 9 vestries. William Wilson gave a patriotic lead to the parish during the Napoleonic Wars, heading subscription lists for the dependants of those who fell at Trafalgar and Waterloo and for the relief of prisoners, and sponsoring voluntary bread rationing in 1800 . In his will also he left funds to provide annuities for the clerk and the beadle.

A distinction between the various officers' accounts and rates was not always maintained. In I 743 a surveyor's deficit was met out of the churchwarden's rate, and, conversely, in 1744 the surveyor was granted a $4 d$. rate and was ordered to pay any surplus to the churchwarden. When Jonas Crouchman was both churchwarden and constable between 1743 and I75I, the surplus of one of his accounts was allowed to balance a deficiency in the other. In 1739 a rate of $3 d$. in the pound produced just over $\oint_{0} 9$; the rateable value of the parish had only advanced to $£ 860$ by I 803.82 In I 840 a new valuation was made by order of the Ongar Union, when the rateable value was fixed at almost $£_{2}, 180.83$ This had risen to $£_{2} 2,452$ by $1874 .{ }^{84}$

The usual officers were appointed at Easter and Christmas and often remained in office for more than a year at a time. A woman occasionally served as surveyor or overseer. In 1673 a scale of expenses was fixed for journeys made by parish officers. Regular payments were made to the parish doctor from $174 \mathrm{I}$.

The average annual expenditure on poor relief in the second half of the I 7 th century was 625 . This had risen to about $f_{1}$ Ioo by 1749 when the detailed overseers' accounts ceased. In the overseers' account book (1715-49), each overseer kept his accounts in two sections called the 'standing' and the 'bye' collections; the former contained the regular weekly pensions, the latter all other payments. Information about parish expenditure on the poor after 1749 depends on summaries given in official returns. In 1776 the cost of poor relief was $\oint_{105.85}$ In the three years $1783-5$ the average annual cost was $£_{1} 40.86$ In the year $1801-2$ the cost was $\oint_{3} 80.87$ This was not exceeded until I 8 r 2-1 3 when nearly $£ 560$ or the equivalent of a rate of 13 s. in the pound was spent. 88 In December I 800 , following a royal proclamation, the vestry agreed to a form of bread rationing reducing consumption by 25 per cent. The same meeting also agreed to offer encouragement 'to render their poor industrious' by providing them with wool for spinning and allowing them to retain their earnings in full. In 1828 and 1829 meetings were held nearly every month, with the overseer presiding, to hear requests for clothing, footwear, and medical attention. Few of these requests were refused.89 After 1829 the meetings became less frequent and finally ceased in 1835 .

The overseer's accounts for 1726 included a bill for E. 9 for building a parish house. In 1809 'the able young persons who had been occupying three of the parish houses rent-free to the exclusion of widows and old poor people who had to be furnished with rooms at the parish expense' were ordered to give up possession or pay a weekly rent of Is. In 1840 there were two parish cottages at Padlers End.90 They were sold in 18,6 .

In 1836 Moreton became part of the Ongar Poor Law Union.

In 1807 there were two private day schools in Moreton, both of them elementary. In SCHOOL one a master taught some 28 children, mostly boys, of whom 9 had their fees paid by benefactors. In the other a dame taught some 37 children, mostly girls, the fees of 17 of whom were similarly paid. The rector, William Wilson, was troubled because both teachers appeared to be nonconformists; he himself had tried unsuccessfully to establish a Sunday school.91 By 1818 there were a Sunday school and a day school with more than 20 pupils, under the control of Wilson and the Rector of High Laver; only one of the two earlier day schools seems to have survived.92 Meanwhile Wilson was planning to build a permanent schoolroom. He collected subscriptions 93 and, in his will of $182 \mathrm{I}$, provided for its endowment. Having redeemed the Land Tax of $\oint_{23} 4$ s. a year on his living, he directed that this sum should be paid annually by future rectors for the support of the school. He made further arrangements which resulted in $\oint_{400} 3$ per cent. Reduced Annuities being added to the endowment. He required that the teachers should be Anglicans and should teach Church doctrine to their pupils. 'I do not', he wrote, 'feel disposed to allow more than $£_{2} 22$ a year for the master's salary.' The education was to be elementary and fees were to be paid, if the parents could afford them. 94

In 182 I the school was built on a site, purchased for fi 5 , on the north of the Fyfield road, about $300 \mathrm{yds}$. west of the church. Subscribers nominated pupils in numbers proportionate to the amount of their subscription, but any Moreton child could attend by right. 95 There were 62 pupils in 1828,76 in 1833,70 in 1835 , and 56 in $1846-7.96$ Most pupils paid $\mathrm{I} d$. a week; a

\footnotetext{
${ }_{80}$ E.R.O., D/P $72 / 12$; ibid. D/P $72 / 8 / 2$.

8 See below.

82 Retns. Exp. and Maint. of Poor, H. C.

I 75, P. I 60 (1803-4), xiii.

${ }_{83}$ E.R.O., D/P $72 / 11 / 2$

84 E.R.O., D/P $72 / 11 / \mathrm{I}$.

$8 S$ E.R.O., $Q / C R$ I/I.

87 E.R.O., Q/CR I $/ 9$.
}

88 Ibid.

89 E.R.O., D/P 72/8/2.

90 E.R.O., D/CT 244.

91 E.R.O., D/AEM $2 / 4$.

92 Retns. Educ. Poor, H.C. 224, p. 262

(18 I 9), ix (1).

93 Inscription on present school building, 1952 .
94 E.R.O., D/P 72/25/1.

95 Rep. Com. Char. (Essex), H.C. 216 pp. $230-2$ (1 835 ), xxi (I).

${ }_{96}$ Nat. Soc. Rep. 1828 , p. 70; Educ. Enquiry Abstr. H.C. 62, p. 283 (I835) xli; Nat. Soc. Enquiry into Church Schools, I $846-7$, PP. I 2-13. 
few paid more. 97 Some Bobbingworth children seem to have attended, their fees being paid by Capel Cure; in 1823 he paid 4 s. a week for the schooling of 12 boys. 98 The master received at least some of the fees in addition to his $\oint_{2} 2$ salary, and his wife was paid for teaching the girls.99 Further income came to the school from charity sermons and private subscriptions. ${ }^{\text {I }}$

After I 850 the school proved sufficient for the falling population of the parish. In 1867 there were 67 pupils, ${ }^{2}$ but in 187 i only about $50.3^{3}$ An inspector reported in 1871 that accommodation was necessary for 82 children to ensure universal elementary education in the parish and that 87 places were available at the school. ${ }^{4}$ By I 880 average attendance had fallen to 47,5 but it subsequently increased to 76 in I 899,6 possibly owing to the closing of a private school in the parish.7 The annual grant also increased from 628 I 35 . in $r 880$ to $£_{6} 5$ ros. in $1899 .^{8}$ In 1888 the Charity Commissioners allowed the sale of stock worth $£ 150$ towards the $f_{1} 70$ needed for a new teacher's residence and in 1909 a further sale was permitted to provide funds for a playground. 9 In a scheme of 1896 the Charity Commissioners directed that the trustees were to be the minister, 3 members elected by the subscribers, and 3 others to be co-opted; the teacher was to be an Anglican and the religious teaching was to be in accordance with Church doctrine, but admission was not to be refused on denominational grounds. ${ }^{10}$

By the Education Act of 1902 the school passed under the administration of the Essex Education Committee, Ongar District. In r 904 there were 3 teachers and 98 children. ${ }^{\text {II }}$ Average attendance fell from 72 in I 914 to 54 in 1929 . In 1936 the school was reorganized for mixed juniors and infants, the seniors attending the new Ongar Senior School. In $195^{\circ}$ it was granted 'aided status'. I2 In May I 952 there were 3 teachers and 59 pupils. 13

Soon after the foundation of the school in 1821 , it was described as 'a neat building with a centre containing convenient apartments for the master and mistress'. ${ }^{14}$ There was a wing for boys and one for girls. Additions in 1888 evidently spoilt the symmetry of the early building. is New classrooms have been added on the east side and a new master's house on the west. The buildings are of gault brick.

For Church Lands Charity see above, Church.

Jonathan Carver, citizen and cloth-

CHARITIES ${ }^{16}$ worker of London, ${ }^{17}$ by will dated I699, left $£_{5}$, issuing from lands at Moreton End 18 in trust for the poor of Moreton. In I 834 blankets and clothing were given to all the poor families in proportion to their size. In 1949 the income, which was paid ont of five separate properties, was spent together with Brecknock's, Wilson's, and Talbot's charities for the poor, in $£ 32$ worth of vouchers for seventeen persons in varying amounts.

Anne Brecknock, by will dated 1804, left $£ 200$ stock for the upkeep of her grave and for quarterly distribution to the poor of the parish. The first purpose was void by the rule against perpetuities. The income was spent with that of Carver's Charity in 1834 and I 949.

William Wilson, Rector of Moreton, by will proved 1822, made various legacies to the parish. That for the support of the school (see above) was much the largest; the others were $\oint_{0}$ roo and $\oint_{2} 00$ stock in trust for the beadle and parish clerk respectively, and $£ 300$ stock in trust for the poor. At least as late as 1933 the first two were duly paid to the clerk and beadle, but by 1947 the income of $\delta_{7}$ ros. from both was spent in part payment of the verger's fee. The charity for the poor was distributed in 1834 and 1949 along with Carver's Charity.

William Talbot, by will proved I 894, left $£ 200$ stock, subject to a life-interest, in trust for one or two poor persons yearly, who had been resident in the parish for ten years. The legacy came into effect in 1923 and in 1925 the bench of magistrates at Chipping Ongar, who were the original administrators, were replaced by five trustees as enumerated for Carver's Charity (above). In I 949 the income was distributed with that from Carver's Charity. ${ }^{19}$

\section{NAVESTOCK}

Navestock is about 3 miles south of Ongar and 4 miles north-east of Romford. ${ }^{1}$ With an area of 4,518 acres it is one of the largest parishes in the hundred. The varied scenery includes a patch of ancient woodland, an open green, and an open heath. Though so close to Romford, Navestock is not traversed by main roads and remains completely rural. It was one of the few parishes in this area to retain a large uninclosed common until the I 8th century, and where Roman Catholic worship ${ }^{2}$ continued after the Reformation.

The relief of the parish consists principally of two spurs, the larger in the west including Navestock Heath, the smaller in the north-east with Beacon Hill as its highest point. 3 Both spurs rise to a height of over $300 \mathrm{ft}$. They descend quite steeply to the north-west whcre the winding River Roding forms the parish boundary. On the south and south-east the boundary is not allied to any marked physical feature and the land slopes gently away to Havering Plain and South Weald Common. Between the spurs is the valley of the Wetstaff Brook, formerly a tributary of the Roding, now dammed to form the Lady's Pond, a rush-grown lake in Navestock Park. This pond is the largest stretch of inclosed water in the parish but the poor drainage afforded by the stiff London Clay has encouraged the formation of many other smaller ponds in various parts
97 Rep. Com. Char. (Essex), pp. $230-32$.

98 E.R.O., D/P 72/25/1; D/DCC E6.

99 Ibid.; Nat. Soc. Enquiry into Church

Schools, 1846-7.

I E.R.O., D $/ \mathrm{P} 72 / 25 / \mathrm{r}$.

2 V.C.H. Essex, ii, 558 .

3 Retns. Elem. Educ. H.C. 20r, pp. II $2-13(187 \mathrm{I})$, ]v.

+ Min. of Educ. File $13 / 269$.

5 Rep. of Educ. Citce. of Council, 1880

[C. $294^{8-1}$ ], p. $57^{8}$, H.C. (188r), xxxii.

6 Rein. Schools, 1899 [Cd. 3I5], P. 72, H.C. (1900), Ixv (2).
7 Retns. Elem. Educ. (1871), pp. I1213.

8 Rep. of Educ. Cttee. of Council, 1880 , p. 578 ; Retr. Schools, 1899, p. 72.

9 Min. of Educ. File I $3 / 269$.

1o Ibid.

11 Essex Educ. Cetce. Handbk. 1904, 185 .

12 Min of Educ. File 13/269.

13 Inf. from Essex Educ. Cttee.

14 T. Wright, Hist. Essex, ii, 353.

15 W. Talbot, MS. Hist. Moreton.

16 Rep. Com. Char. (Essex), H.C. 216,
Pp. 230-2 (1835), xxi (1); Char. Com. Files.

I7 E.R.O., D/P 72/25/17. Carver was apparently a native of Moreton: W. Talbot, MS. Hist. Moreton.

${ }_{18}$ E.R.O., D/P 72/25/20.

19 For another legacy left by Talbot see above, Church.

I O.S. 2 in. Map, sheet 5 I $/ 59$.

2 See below Manors, Roman Catholicism.

3 There was a beacon on this hill in I6 9 : E.R. xvii, 221. 


\section{A HISTORY OF ESSEX}

of the parish. There are several areas of parkland and plantation, mainly at the lower altitudes. Of these the principal are at Navestock Park and in the upper part of the Wetstaff Valley near Bois Hall. Curtismill Green in the extreme west of the parish is the patch of open woodland, about roo acres in extent, which was formerly part of the forest of Essex. Its northeastern and south-eastern corners are still marked by ihe old forest boundary stones, known respectively as Richard Stone and Navestock Stone. Navestock Common, the name of which survives in the south-west, was formerly much larger in extent, stretching across the south of the parish for most of its length and containing some 600 acres.

The main centre of population is Navestock Side in the extreme east of the parish, where the houses cluster round a green. There are also some houses around Navestock Heath which was formerly a more important hamlet than it is today. The former workhouse and the old almshouse, both now demolished, were at the south end. 4 'The village school has been closed and the vicarage, which adjoins it, is unoccupied. The Heath, which is still used for grazing cattle, has a desolate appearance.

The parish church is a mile north of Navestock Heath, adjoining the old manor house of Navestock Hall. A little to the north of them, in Navestock Park, is the site of the former mansion of Navestock Hall, built in the 18 th century by Lord Waldegrave but demolished about 100 years later. Other ancient manor houses were at Slades near Beacon Hill and Bois Hall $\frac{1}{2}$ mile south on the same spur. ${ }^{5}$ A homestead moat still survives at the former site of Slades and there are other moats at Dycotts in the southwest of the parish and at Yew Tree Farm to the north of Navestock Heath.

Fortification Wood, on the south side of the road about $\frac{1}{2}$ mile west of Bois Hall, covers an entrenchment some $350 \mathrm{ft}$. long by $240 \mathrm{ft}$. wide. ${ }^{6}$ It occupies a good defensive position and. has been thought to be a fortification at some unknown date. It is probably identical with a wood called 'the defence' which existed in 1222.7 Another ancient earthwork, of which hardly any traces remain, was situated on Navestock Common, by the road from Ditchleys (in South Weald) to Princesgate, near the parish and hundred boundary. It was visited on several occasions in the I 8 th century by William Stukeley $(1687-1765)$ who described it as an 'alate temple'. 8

Navestock probably means 'the stump on the headland', a derivation which suits the topography and suggests early Saxon settlement on one of the spurs. Although some of the parish place names, including those of the manor houses, are medieval, ${ }^{10}$ none of the present buildings, apart from the church, appear to be earlier than the I6th century. Navestock Hall (see Manors) is perhaps the most interesting of these. Like Stondon Hall in Stondon Massey it is an old manor house that has survived the grander house built in the I 8 th century to supersede it as the residence of the lord of the manor. Dabbs Farm, formerly Hole Farm, about $\frac{1}{2}$ mile south-west of Shonks Mill Bridge, is probably on the site of a medieval house. It is now approached by a track past Howletts Hall Farm, the lane leading from the east being impassable. The house, which was probably built in the late 16th century, is timber-framed. It retains a chimney with six shafts set diagonally. Sabine Cottage, about $\frac{1}{4}$ mile east of Navestock Heath, facing the end of Tan House Lane, is a small timber-framed building of the 16 th century or earlier. This house and the neighbouring Sabine's Green take their name from the family of a I $3^{\text {th }}$ century resident, William fitz Sabine. ${ }^{\text {II }}$

At Dycotts a medieval building undoubtedly occupied the moated site but the oldest building there now is part of an outbuilding which has I6th-century timbers. Wattons Green, which lies between Dycotts and the road, extends north-west as a narrow strip of common until it strikes the Navestock-Havering road south of Jenkins Farm. Its name is derived from the family of John de Walton (fl. I 3 I9). . $^{2}$

By the I 7 th century the pattern of settlement in the parish was probably very much as it is today. Larger houses dating from that period are Bois Hall (see Manors), Beacon Hill Farm, in the north-east corner of the parish, and Yew Tree Farm. Beacon Hill Farm is a red-brick house probably built in the late 17 th century. It was much altered in the 8 th or earlier I 9 th century but retains some original woodwork inside. The cottage which adjoins the house on the north is probably of the same period with fewer alterations. Yew Tree Farm, probably built in the I 7 th century, has a cruciform chimney set diagonally on a square base. Two wings at the back and other features date from the 18 th century. North of the house is part of a large rectangular moat. The surface of the ground inside it is uneven, suggesting the position of an earlier building. Several smaller buildings, all timber-framed, also date from the I7th century. Brook House, to the east of Curtismill Green, is a weather-boarded cottage probably built in the second half of that century. On the north side of the road almost opposite Bois Hall is a cottage of the 17 th century or earlier with an original chimney. At Navestock Side and near it there are other cottages of about the same period. Houghtons, on the north side of the road at Horseman Side, may well be an ancient house altered in the 18 th or early 19 th century. It is a weather-boarded range of four cottages.

Shonks Mill was probably rebuilt in the 17 th century. It took its name from a medieval family, but this may have come indirectly from some other topographical feature in the area. A map of 1835 , based upon one of 1785 , shows the old course of the Roding 'before Shonks Mill was erected'.13 'This suggests that the existing mill had been built not very long before I 785 , and the humped brick bridge that still survives on the site and has a small arch for the mill race is probably of the 17 th century. The parapets have been rebuilt. The mill itself was still standing in the present century but does not appear to have been used after about I 860 , and it has since been demolished. ${ }^{\mathrm{I} 4}$

Great changes took place in Navestock in the I 8th century. Early in the century the new mansion of Navestock Hall was built and a large park constructed around it. Is Later came the inclosure of Navestock

\footnotetext{
4 See below Parish Government, also Charities.

s For the manor houses, including Loft Hall, see below, Manors.

- For details see Hist. Mon. Com. Essex, ii, 193; V.C.H. Essex, i, 279. Described
}

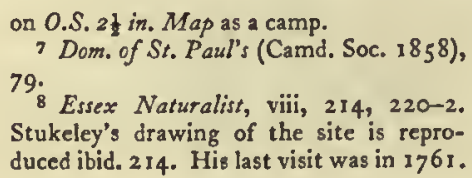

8 Essex Naturalist, viii, $214,220-2$. Stukeley's drawing of the site is reproduced ibid. 2 14. His last visit was in 1761 .

- P.N. Essex (E.P.N.S.), 70.

10 Ibid, $70 \rightarrow 71$.

II Ibid. 7 I.

13 E.R.O., D/DXa 24

34 Local inf.; Kelly's Dir. Essex (1 845 f.).

is See below, Manors. 
Common. These changes, while they altered the landscape of the parish, did not, however, alter the main pattern of settlement. ${ }^{16}$ Before the inclosure there were several houses along the north edge of the common, mostly at Horseman Side. Their occupants had no doubt found the situation convenient for the exercise of common rights. Inclosure of the common evidently led to the building of one new farm, Princesgate Farm, which existed by 1840,17 and a few of the houses to the south of the road between Navestock Side and Horseman Side are of late I 8 th- or I 9 th-century date. The extinguishment of the rights of common in this part of the parish may have led.to the building of cottages around the edges of the wood at Curtismill Green, which was not affected by the inclosure. This was not, however, the first development round Curtismill Green. ${ }^{18}$

Chapman and Andrés Map of Essex, 1777 shows houses along most of the western edge of Navestock Side but none on the eastern edge. 'The 'Green Man', which may have existed long before, was probably rebuilt in the I 8 th century when Navestock Side became a cricket centre. It is a tall rectangular building, recently modernized. During the late 18 th century Navestock Park was embellished by the construction of the Lady's Pond and at about the same time there were alterations to Bois Hall. Abbotswick, at Navestock Side, is a small country house standing in a welltimbered garden with a small lake. It seems to date from about $\mathrm{I} 800$ and has since been rebuilt probably early in the present century. In I 8 I 7 it was described as the seat of Adam Chadwick. 'The 1777 map shows a small piece of common at Slades, but this had been inclosed by 1840.20

In 1801 the population of Navestock was 623 , and by $182 \mathrm{I}$ it had risen to 840.21 It continued to rise until I 851 when a peak of 982 was reached. The number of inhabited houses in the parish increased from I 31 in 1801 to 188 in 1851.22 After 1851 there was a gradual decline in population which became most rapid between $187 \mathrm{I}$ and $188 \mathrm{I}$, the period of agricultural depression. By IgoI there were only 692 inhabitants.

The most remarkable event in the life of the parish in the rigth century was the demolition (I8I I) of Navestock Hall. During the course of the century some of the other larger houses in the parish were extended or improved and continued to offer opportunities of employment for the cottagers, but the disappearance of the great house of Navestock, at a time when the population was increasing rapidly, may have been partly responsible for the ultimate decrease. Even if it had no other effect the demolition increased the isolation of the parish church and must have reinforced the existing tendency for the population to concentrate in the east and south of the parish. This tendency may have been partly counteracted by the rebuilding of the vicarage at Navestock Heath and the erection beside it of a village school. On the other hand again there was the closure of Shonks Mill, which probably failed in competition with the new steam mill at Princesgate. The new mill was built adjoining Princesgate Farm. It is an impressive structure of black weather-boarding, with a tall chimney (see plate facing P. I 56). It is no longer used as a mill.

Between I 901 and I93I the population of Navestock fluctuated at around 700.23 In 1953 it was estimated at 680 , which is the lowest figure since 1801.24 Among the houses built during the past fifty years are five pairs of council houses at the north end of Navestock Heath and twelve pairs near Navestock Side on the road to Bentley church. Three of the last twelve have been erected since I945, two of them being of Swedish timber. The Navestock Club, built at Navestock Side in 1920 , increased the amenities in that part of the parish. Some provision for communal activities at Horseman Side had been made by the building there of the Navestock Mission Room in I 897 . This was originally a nonconformist chapel but is now used for services in connexion with the parish church. During the Second World War Slades Farm was totally demolished by enemy action and the parish church damaged.

The Brentwood-Ongar road touches Navestock's easternmost edge, forming the boundary with South Weald for a short distance. Its principal connecting link runs south-west through Navestock Side and Horseman Side to Havering and Romford, and another road goes west and south-west past Bois Hall, Navestock Hall, and Navestock Heath to Havering and Romford. Linking these two principal roads are several by-roads aligned from north-west to south-east. The most important of these follows the Wetstaff valley for most of $i$ ts course and passes out of the parish by Shonks Mill Bridge over the Roding to join the Ongar-Abridge road.

Most of the parish roads are probably earlier in origin than the I 8 th century. They may always have been poor in the west of Navestock, where the wood of Curtismill Green formed a barrier, but there was evidently a thoroughfare of some sort in that area as early as the I6th century. In 1583 it was reported at Quarter Sessions that the road from Brentwood through Navestock to Epping was blocked by a gate called 'Curtinsmill' Gate which was 'the only defence for the cattle commoning on that part of the forest there'.25 There are detailed reports from the surveyors of the highways on their statute labour for 1607-9, 1618, and $1645 \cdot{ }^{26}$

The inclosure award of $177^{\circ}$ contained the usual provisions concerning the construction of roads to serve the inclosed area.27 Ten new roads were specified but many of these were very short lengths and it is clear from the inclosure map that some of them already existed in whole or in part. The most important changes that resulted from the award were the continuation of the road from Horseman Side to Navestock Side and roads running south and south-east from that road. Not all the provisions of the award were actually carried out. This may have resulted from disputes concerning responsibility for the new roads. At a parish vestry meeting in I 844 it was resolved that the roads set out by the inclosure commissioners should not be repaired by the parish. ${ }^{28}$ This decision was repeated at vestry meetings later in the same year and in 1845 , when the parish surveyor was ordered to
16 Compare the Inclosure Map (E.R.O., Q/RDc i) with Chapman and André, Map of Essex, 1777 , sheets xvi, xvii and later maps.

17 E.R.O., D/CT 248

18 Cf. E.R. xiv, 180.
19 E.R.O., Prints, Navestock.

20 E.R.O., D/CT 248.

21 For census figures 1801-1901 see V.C.H. Essex, ii, 350. ${ }_{22}$ Census, $1801,1851$. 23 Census, $1901-31$.

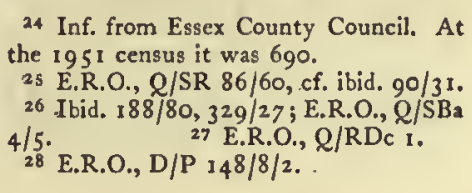




\section{A HISTORY OF ESSEX}

request the inhabitants whose lands abutted on Goats Wood Lane to repair it. 29

Much of the parish on the north-west is bounded by the Roding and there are many references to bridges in records relating to Navestock. The most important was Shonks Mill Bridge between Navestock and Stanford Rivers. In I 566 this lay between the land of Robert Shanke and William Melbourne: its timbers were then badly decayed. ${ }^{30}$ A little later there was some doubt whether it should be repaired by Navestock or by Stanford Rivers. In I6I7, when it had been damaged by floods, Navestock was ordered by Quarter Sessions to repair it, ${ }^{31}$ but in 16 I 8 both parishes were presented as responsible for the bridge, then 'very much in decay'.32 Both parishes were held responsible in 1641.33 By about 1800 the bridge had become a charge on the county and it appears in the later lists of county bridges. ${ }^{34}$ In I 857 it was described in detail by the county surveyor. ${ }^{35}$ It was damaged by floods in I943. One abutment was rebuilt in concrete and the decking was replaced with a temporary structure. ${ }^{36}$

A foot-bridge called Hawkes or Hackes Bridge was in need of repair in I 579 and 1580 and John Greene of Navestock Hall was said to be responsible. ${ }^{37}$ In I 586 floods destroyed this bridge (then said to be in Broad Mead) and the same John Greene and the parishioners of Stanford Rivers were ordered to repair it. ${ }^{38}$ In the same year Bartholomew Partrych of Navestock was ordered to replace a foot-bridge. 39

For its communications with the outside world Navestock has depended on Ongar, Brentwood, and Romford. Even today, no bus route passes through the parish, and this has the effect of making the centre of the parish, especially Navestock Heath, seem isolated and rural. This is the more remarkable as there is suburban development reaching out in this direction from both Romford and Brentwood, and the great new housing estate of Harold Hill is only 3 miles from Navestock Heath.

An application in 1840 for a post-office in Navestock was refused.40 A receiver was mentioned in I 855 and in 1856 Navestock had a post-office under Romford.41 There were several changes in the later postal arrangements for the parish. In 1870 and up to I 884 the only post-office was at Shonks Mill, where letters were received via Stanford Rivers from Romford. ${ }^{42}$ In 1884 a second post-office was opened at Navestock Side, and in the same year the telegraph was extended to both offices. 43 In about 1890 the main office was that at Navestock Side and the sub-postoffice at Shonks Mill had no telegraph.44 Four years later the Shonks Mill office had been replaced by one in the centre of the parish at Sabine's Green.4S During the past 60 years the Navestock Side office has continued to be the more important of the two. The
Sabine's Green (or Navestock Heath) office has existed for most of this period but does not appear to have been operating immediately after the First World War. ${ }^{46}$

Piped water is supplied to the parish by the Herts and Essex Waterworks Co. but there is no main drainage.47 The Romford Gas Co. acquired powers to supply gas in Navestock in 1935 and this has been laid on for Navestock Side.48 Electricity was supplied to Navestock Heath in $193 \mathrm{~J} .49$ The Navestock Club established at Navestock Side in I 920 has as its meetingplace a single-story wooden building given by $\mathrm{Mr}$.

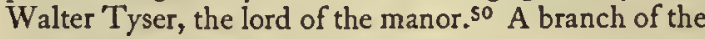
county library was opened in $193^{8} . \mathrm{sI}$

Cricket has been played at Navestock since 1784 and probably earlier.s2 In $179^{\circ}$ the 'Essex Cricket Club' was holding fortnightly matches at the 'Green Man', Navestock Side. 'The members of the club included Lord Petre and Lord Winchilsea.s3 A map of 1835 , based on one of 1785 , shows the cricket ground, 54 and for most of the I 9 th century this was the home ground of the West Essex Cricket Club, one of the best known in the county. 55

The map of 1835 marks the fields immediately to the east of the cricket ground at Navestock Side as a 'horse-race ground'.56 Occasional race meetings were being held at Navestock in the I $860^{\circ}$ 's but had long been discontinued by I $906 . \mathrm{s7}$

During the Middle Ages the most important estate in the parish was that owned by the Dean and Chapter of St. Paul's Cathedral. Their property passed in the I6th century to the Waldegrave family. From the I6th century to the Igth the Waldegraves (later barons and eventually earls) increased their estate until by 1840 it comprised almost three-quarters of the total area of the parish..$^{8}$ From the early i 8 th until the early I th century Navestock Hall was their main seat. Later in the Igth century, in spite of the demolition of the hall, Lady Waldegrave returned to the parish to live at Dudbrook. ${ }^{59}$

It was John, Earl Waldegrave who secured the inclosure of the common in 1770.60 The total area inclosed was 502 acres exclusive of 90 acres set aside for roads and waste. The earl's allotment was about 350 acres.

In 1840 there were some 25 farms in the parish, of which about $\mathrm{I} 2$ were over 100 acres and 9 between 50 acres and 100 acres. The largest was Bois Hall with Slades, 480 acres. It was one of the largest in the whole of Ongar hundred at that time. ${ }^{61}$ Two years earlier it had been estimated that some 2, I 50 acres of the parish were cultivated as arable and $1,85^{\circ}$ acres as meadow or pasture. ${ }^{62}$ These proportions of arable to pasture were typical of this area of mixed farming. As elsewhere in the hundred the arable open fields, if they ever existed, must have been inclosed at an early date. Open meadow lasted longer. The map of 1835 shows

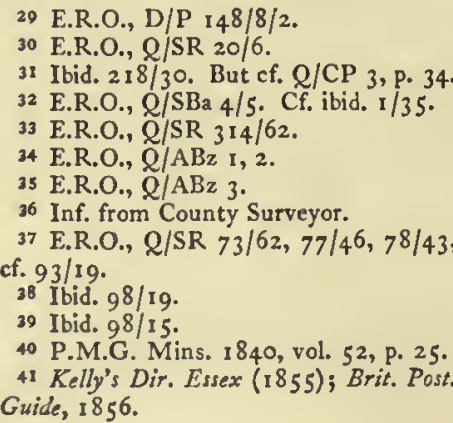

42 Kelly's Dir. Essex (1870 f.).

43 P.M.G. Mins. I 884 , vol. 272 , $\mathrm{min}$. 7096 ; vol. $274, \mathrm{~min} .8334$; vol. 271 , $\mathrm{min}$. 6546 ; vol. 277 , min. I 0446 ; vol. 280 , min. 13222 .

44 Kelly's Dir. Essex (1890)

45 Ibid. (1 894).

46 Ibid. (1898 f.).

47 Inf. from Herts. \& Essex Waterworks Co. and Miss O. Porter.

48 Inf. from North Thames Gas Bd. and Miss O. Porter.

49 Inf. from Eastn. Elec. Bd.

so Inf. from Mrs. L. F. Pryor.

51 Inf. from County Librarian.
32 E.R. Iviii, 49.

53 E.R.O., T/B 69

s4 E.R.O., D/DXa 24.

ss V.C.H. Essex, ii, 599.

s6 E.R.O., D/DXa 24.

57 I.C.H. Essex, ii, $5^{87}$

58 See Manors.

59 Ibid.

60 E.R.O., Q/RDe 1. For the inclosure Act $(\mathrm{r} 768)$ see E.R.O., Q/SBb 26 r

$6 I$ E.R.O., D/CT 248.

62 Ibid. These figures may both have been underestimates, but they probably express the proportions of arable to pasture correctly. 
strip holdings (in private ownership) in 'Navestock Common Mead' adjoining the Roding south of Shonks Mill.63 There is no suggestion that they were still farmed in common, but it is likely that they represented the areas of earlier strips in the open water meadow.

Navestock has always been an agricultural parish and there do not appear to have been any important occupations that were not connected with agriculture.

The fragment of the parish that was within the ancient forest of Essex escaped the destruction that overtook most of the neighbouring forest at Hainault. ${ }^{64}$ Curtismill Green was disafforested in $185 \mathrm{I}$ and in I 858 was allotted as common to the parish of Navestock. ${ }^{65}$

Apart from the Waldegraves, several of whom achieved distinction, ${ }^{66}$ Navestock numbers among its worthies William Stubbs (I825-I90I), the historian and Bishop successively of Chester (I884-8) and Oxford (I 888-I90I) who was Vicar of Navestock from i 850 to 1866.67 Much of his early work for the Rolls Series was done in the parish. He married a local girl, Catherine Dellar, who had been mistress of the village school. His predecessor as vicar, James Ford (1779-1850, vicar from 1830 to his death), founded the Ford Lectureship at Oxford University. ${ }^{68} \mathrm{He}$ is said to have made manuscript notes towards a history of the hundred of Ongar and to have left them to Trinity College, Oxford. $69 \mathrm{He}$ and Stubbs were not the only historians to be connected with Navestock, for Adam de Murimuth (1275 ?-1347), Canon of St. Paul's, to whom the manor was leased in I 335 by the Dean and Chapter, ${ }^{70}$ was the author of the Continuatio Chronicorum, a chronicle which is a primary authority for the history of England in the first half of the 14th century. ${ }^{71}$

The manor of NAVESTOCK was acquired in or before the I Ith century by the Dean and MANORS Chapter of St. Paul's. There is a charter purporting to have been issued by King Edgar $\left(95^{8-75}\right)$ but dated 867.72 In this the king is made to say that at the request of Bishop Deorwulf and Alderman Ealdred he has granted to the church of St. Paul I 5 mansiones of land at Navestock. The first witness to the charter, Oda the Archbishop, held the See of Canterbury from 942 to 958 . The other witnesses' names, 25 in number, are consistent with the date 867 , and so also are the names of Deorwulf (who was Bishop of London) and Ealdred. The formula by which the king makes the grant at the request of certain named persons is found occasionally in the gth century, but never in the roth. ${ }^{73}$ It therefore seems probable that the Navestock charter is based upon a genuine original of 867 or thereabouts. Perhaps the property was granted to St. Paul's in 867 and confirmed by Edgar in 958 , and some of the names from the confirmation have crept into the original through careless transcription.74 But in view of its inconsistencies the charter of 867 cannot be accepted as genuine in its present form, and must be treated with reserve.
If the canons of St. Paul's had ever held land in Navestock before the Norman Conquest they had evidently lost it by I066. In that year the landowners included Houard and Ulsi, who held two manors amounting together to 5 hides less 20 acres, Turstin the Red, who held a manor of I hide and 40 acres, seven unnamed freemen who held 2 hides between them, and Gotil, who held a manor of 80 acres. In I086 Gotil's manor was held by Ralph de Marcy of Hamon dapifer. All the other estates were held by St. Paul's. It was stated that the canons claimed the manors of Houard and Ulsi as of the king's gift, and that they had seized 'Turstin's manor. The Domesday Survey also recorded that a priest held $\frac{1}{2}$ hide and 20 acres in Navestock but that the hundred court considered this to be the rightful property of St. Paul's. It is not clear whether the 'priests' tenement was included in any of the other estates mentioned above. In 1086 it was in the king's hand.75 To support their title to the Navestock manor the canons of St. Paul's produced a charter stating that William I on his coronation day (25 December 1066) regranted to St. Paul's lands at Navestock and elsewhere which had belonged to the cathedral church before but which had been lost. ${ }^{76}$ This charter must be looked upon as a forgery.

The manor of Navestock, however acquired, remained in the possession of St. Paul's until the I6th century, and was annexed to a prebendal stall in the cathedral. 77 The manor in Navestock which Ralph de Marcy held in 1086 was probably merged by him or one of his immediate heirs with the estate which he held in Kelvedon Hatch (q.v.). Shortly after 1086 the canons of St. Paul's accused Ralph of seizing several lands belonging to their manor of Navestock. The dispute was not settled until after his death. Before I 20 William son of Ralph made a compromise with the canons whereby he was to hold all the lands in Navestock which his father had held at his death on payment to St. Paul's of 16 s. a year. ${ }^{78}$ Ralph de Marcy's heirs continued to hold this Navestock estate of St. Paul's until after I 222.79 They also held the manor of Magdalen Laver (q.v.). No certain reference to their Navestock estate has been found later than I 222, but it is possible that, together with their estate in Kelvedon Hatch, it became the manor of Myles's (q.v.) in Kelvedon Hatch.

In I 544 the manor of Navestock and other manors belonging to St. Paul's were surrendered to the king in exchange for properties elsewhere. ${ }^{80}$ Navestock remained in the possession of the Crown for ten years unitil in 1554 Queen Mary sold it with the advowson of the vicarage to Sir Edward Waldegrave, who had been appointed steward in $\mathrm{I} 553$, for $f_{0} \mathrm{I}, 228$, to hold for $\frac{1}{50}$ knight's fee. The manor was then occupied by Richard Greene on a lease granted by St. Paul's in 1526 for 40 years at a rent of $f, 50$ a year. ${ }^{81}$

On the death of Mary Sir Edward Waldegrave, who had been Chancellor of the Duchy of Lancaster, was imprisoned in the Tower of London, and he remained there until his death in $156 \mathrm{I}, 82 \mathrm{He}$ left Navestock in
63 E.R.O., D/DXa 24.

64 For Hainault Forest see Chigwell, Lambourne.

6s E.R.O., Q/RDc 42, 55 .

66 See Burke's Peerage, Waldegrave.

67 D.N.B. 2nd Suppl. 68 D.N.B.

69 Ibid.; E.R. 1, P. 77. The MSS. cannot now be found at Trinity College. For a MS. biography of Ford see E.R.O., T/G 35 .

70 See below, Manors.

7 D.N.B.

22 Birch, Cart. Sax. iii, p. 488 ; Early Charts. of St. Paul's (Camd. Soc. 3rd ser. Iviii), p. $2, \mathrm{n} .2$.

${ }_{73}$ Cf. Birch, op. cit. ii, p. 169.

74 For such occurrences see e.g. J. A.

Robinson, Times of St. Dunstan, 48 .

75 V.C.H. Essex, i, 443a, $502 b$.

76 Dugdale, Hist. St. Paul's ( 8 1 8 edn.),

297.
77 For tenants of the manor in the 14 th and $15^{\text {th }}$ cents. see Hist. MSS. Com. 9 th Rep. pt. i App. $32 \mathrm{f}$.

${ }_{78}$ Domesday Studies (ed. P. E. Dove), ii, $553-5$.

${ }_{79}$ Dom. of St. Paul's (Camd. Soc. 1858), $75,133$.

80. L. G P. Hen. VIII, xix (1), p. 495 .

8 Cal. Pat. I 553-4, 248, 393 .

82 D.N.B. 


\section{A HISTORY OF ESSEX}

his will to his wife Frances for life, with remainder to his eldest son Charles. ${ }^{83}$ Frances died holding the manor in 1599.84 Charles Waldegrave succeeded her and in the same year settled the manor on his son Edward on the latter's marriage with Eleanor, daughter of Sir Thomas Lovell.85 Edward was knighted in 1607 and created a baronet in 1643 for his services to the king in the Civil War, when he commanded a regiment of horse with distinction. ${ }^{86}$ Navestock descended with the family honours until the I 9 th century. In 1686 the $4^{\text {th }}$ baronet was raised to the peerage as Baron Waldegrave and in 1729 his son was created Earl Waldegrave. ${ }^{87}$ The original Waldegrave estate in Navestock was increased during the 17 th and 18 th centuries by the acquisition of the manors of Slades, Bois Hall, Loft Hall, and probably other properties in the parish. The 6th Earl Waldegrave (d. 1835) gave the whole estate to his eldest, but illegitimate, son John J. H. Waldegrave, who in I 840 was holding some 3,000 acres in Navestock, almost three-quarters of all the land in the parish.88 J. J. H. Waldegrave married Frances Braham. He died in 1840 and his widow married his younger, legitimate, brother George Edward, Earl Waldegrave (d. 1846). Through her marriages the countess acquired all the Waldegrave estates in Essex and elsewhere, for in 1876 they were alienated from the earldom and became her absolute property. She died in 1879 leaving Navestock to her fourth husband, Lord Carlingford. On his death in 1898 the manor was sold to James Tabor of Rochford. ${ }^{89}$ In 1919 it passed into the possession of Walter P. Tyser, who had leased the manor house since I $\mathrm{II}$. The estate is now (1955) owned by the Church Commissioners. 90

An inventory of I 335 gives interesting details of the manor house of Navestock.91 Adam de Murimuth, Canon of St. Paul's, to whom the manor was then committed, also received 'under one roof a bakehouse and dairy, a kitchen with an oven and two cisterns, a hen house, a hall with buttery and pantry at the west end of the hall and a chamber at the east with galleries. And a chamber with store room (celarium) and room above, roofed with tiles, and belonging to the same chamber a chapel of plaster of Paris roofed with timber (tendulis), an old granary with four bays (interfinis) and an old kiln and a little house for calves outside the door and a smithy, a sheepfold outside the door, a windmill.'

The building described in the inventory was possibly on the site of the present Navestock Hall, which is about $150 \mathrm{yds}$. south-east of the church. This house, now a farm, dates from the early i 6 th century. The north wing was probably added in the 18 th century or later. The explosion of a German landmine in September 1940 dislodged the external plaster, revealing the fact that much more of the house was of the original date than had been supposed. 92 This is a twostory timber-framed structure with a four-centred door- head on its north side. The timbering has been left exposed and a Georgian bay on the east side has been rebuilt with oak timbers from a demolished barn. One of the lead rainwater heads is inscribed ' $E$. W. I 757 '.

The site of a later manor house, now demolished, is about 400 yds. north-east of the farm. This was a mansion built in the first quarter of the 18 th century by Lord Waldegrave (d. I74I). A map of 1726 by Thomas Browne shows the layout of the garden and park. 93 The house faced south-east with a stable-yard and kitchen gardens on the north-east and formal gardens with ornamental water on the opposite side. Behind the house a deer park reached nearly to the Roding. In the park were two wooded duck decoys. A double avenue, over a mile long, is shown stretching across the river to join the Abridge-Ongar road. The house itself was described later in the century as 'a good regular brick building'.94 A print of the same date shows the main two-story block to be of nine bays, the three central windows being surmounted by a pediment. Flanking this are single-story wings with balustraded parapets, each having three windows. The principal entrance has a segmental pediment. Probably the revulsion against formality which took place in the late I 8 th century led to alterations in the park. The Wetstaff Brook was dammed to form the sheet of water known as the Lady's Pond and the straight avenue was abolished. 95 In 18 I I the house was taken down and the materials sold. 96 Later in the Igth century Frances, Countess Waldegrave often visited the site and built herself a summer-house there.97 After her death in 1879 her fourth husband, Lord Carlingford, erected a memorial on the same spot. This stone is still standing and bears a long inscription, now partly illegible, and a portrait medallion of the Countess. South-west of the mansion site a system of trenches with two small square islands 98 indicates the remains of the ornamental pond in the formal garden.

In the later I gth century the owners of the estate lived at Dudbrook which lies in the north-east corner of the parish. A house was already in existence here before the demolition of Navestock Hall, 99 but it appears to have been rebuilt or much enlarged at various subsequent dates. The style is mostly of the early and mid-rgth century, and there is a tower-like feature in the centre with four finials at the angles. For nearly 30 years it was the home of Mr. Walter Tyser, who also made additions to the building. In I 95 I it was bought by the East Ham County Borough Council for use as a home for old people.

The manor of BOIS HALL took its name from the family of Boys alias de Bosco. In 1298 John de Bosco and his wife Christine held a small estate in Navestock. ${ }^{2}$ This John was dead by I 317.3 In $1393 \mathrm{Sir}$ Richard Sutton conveyed to John Boys and others, with remainder to Boys's heirs, extensive properties in Essex including the manor of Navestock [sic].4 This manor was probably that which later became known

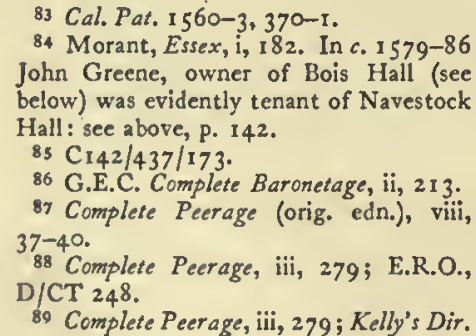

Essex (1808); Burke's L.G. 1937, P. 2202 ( Complete Peerage (orig. edn.), viii, 41 . 90 Inf. from Mrs. L. F. Pryor. The estate still comprises about three-quarters of the land in the parish.

91 Hist. MSS. Com. gth Rep. pt. i App. $38 a$.

92. Inf. from Miss Parrish.

03 E.R.O., D/DZn 3.

94 Ilist. Essex by Gent. iv, 48. And see plate facing p. 136 .

os The alterations are shown in a map of the parish, 1785 , revised $1835:$ E.R.O. $\mathrm{D} / \mathrm{DXz} 24$

96 T. Wright, Hist. Essex, ii, 4 I9.

97 Inscription on memorial stone.

98 Hist. Mon. Com. Essex, ii, I93. It was not a duck decoy as suggested.

99 Shown on Chapman and André, Map

of Essex, 1777 , sheet xvii.

I Inf. from the matron.

2 Feet of F. Essex, ii, 88.

3 Ibid. 17 I.

4 Ibid. iii, 219. 
as Bois Hall. John Boys was no doubt identical with the man of that name who succeeded the Suttons in the manor of Langenhoe. ${ }^{5} \mathrm{He}$ also had property in Tolleshunt d'Arcy where he was buried in $1419 .{ }^{6}$ Before his death, however, Bois Hall had passed out of his possession. In 1412 it was held by Edmund Prior,? and it remained in his family for over a century. In I 507 Andrew Prior died holding the manor of the Dean and Chapter of St. Paul's, and was succeeded by his son John, then a minor. ${ }^{8}$ John Prior still held the manor in $1527^{9}$ but soon after that date it passed to Constance, wife of Lawrence Claydon, with reversion to Alice, wife of John Prest. John Prest died in I 546 leaving a son William by a former marriage and a daughter Frances, heiress to her mother Alice. In I 547 Alice married, as her third husband, Richard Blackwall. ${ }^{10}$ She died in $156 \mathrm{I}$ and was succeeded by her daughter Frances, now the wife of William Bradborne." I In 1564 Frances and William conveyed the manor to William Tusser and Charles Belfield, who sold it in the following year to John Greene.12 Bois Hall remained in the hands of the Greenes for almost two centuries. John Greene was succeeded by his son Thomas and he by his son John Greene II (d. I653), a judge of the sheriff's court in London and serjeantat-law. The latter was succeeded by John Greene III, who became Recorder of London in 1659 and died in the same year. His son John Greene IV (d. 1725), serjeant-at-law, was succeeded by his son John Greene $\mathrm{V}$, who died in 1752 leaving Bois Hall to his cousin Dr. Maurice Greene, organist of St. Paul's Cathedral and a composer of some eminence. ${ }^{13}$ After Dr. Greene's death in 1755 the manor was bought by Earl Waldegrave (d. 1763 ) and was merged with the main manor of Navestock.14 From 1654 the Bois Hall estate included Loft Hall (see below). In 1840 Bois $\mathrm{Hall}$ farm, then including Slades (see below), comprised 480 acres and was occupied by a tenant farmer, Litchfield Tabrum. ${ }^{15}$ This was not the first time that the two places had been united, for the Greenes of Bois Hall had also held Slades between I 604 and 1637 .

There were formerly two rainwater heads on the front of Bois Hall house bearing the date 1687 with the arms and crest of Greene. ${ }^{16}$ If the present house is of this date considerable alterations must have taken place late in the 18 th or early in the 19 th century. It has a formal brick front of two stories with a moulded string and cornice. There are five sash windows to the first floor, three of them being grouped in a slightly projecting central bay. The porch has Doric columns and a dentil cornice. The front is flanked by screen walls and approached by a straight drive. A kitchen at the back of the house was demolished in 1948 and repairs to the roof in 1953 resulted in the removal of the dormer windows and the two inscribed rainwater heads. ${ }^{17}$

Bois Hall is now (1954) owned by the Church Commissioners and occupied by Mr. T. E. Bere, who farms the land here and at Beacon Hill. ${ }^{18}$

The manor of LOFT HALL probably derived its name from the family of Isabel atte Lofte who held land in Navestock about $1350 .{ }^{19}$ The first reference that has been found to the manor itself was the grant of a rent issuing from it in $1483 .{ }^{20} \mathrm{In} 1507$ Thomas Intilsham conveyed the manor to John Sedley, member of a well-known Kent family, who was auditor to the Exchequer under Henry VII and Henry VIII. ${ }^{21}$ The manor was held by the Sedleys for a century and a half. ${ }^{22}$ John Sedley was succeeded after 15I4 by his son William, Sheriff of Kent in 1547 , and he by his son John, Sheriff of Kent 1566 , who died in $158 \mathrm{I}$ leaving William Sedley his son and heir.23 In 16 I I William Sedley was created a baronet, and the manor descended with the baronetcy until I6;4, when Sir William Sedley, 4th Bt., sold it to John Greene III of Bois Hall. ${ }^{24}$ From that time Loft Hall descended along with Bois Hall and passed after the death of Dr. Maurice Greene in 1755 with Bois Hall into the Waldegrave estate of Navestock. In 1840 Loft Hall farm comprised 223 acres and was let to a tenant farmer, C. Pratt. ${ }^{2 s}$ The Pratt family remained tenants until I $92 \mathrm{I}$.

The present farm-house of Loft Hall was evidently rebuilt in red brick in the 19 th century. The remains of a moat lie to the north of it.

The manor of $S L A D E S$ appears to have belonged to Sir Humphrey Starkey who was Chief Baron of the Exchequer in 1483 and died in 1486 . His widow Elizabeth died in $\mathbf{1} 496$ holding it as life tenant with remainder to Sir Humphrey's heirs. ${ }^{26}$ 'The heirs were his four daughters. One of these, Emma, had married Henry Torrell (d. 1481), another landowner in Navestock, and her son Humphrey Torrell, aged 17 in 1496, inherited Slades as heir to his mother's purparty. ${ }^{27}$ In 1503 Humphrey made a settlement of the manor in connexion with the marriage of his son Henry with Anne, daughter of William Mordaunt. The marriage took place in 1513 and Henry died in $1526.28 \mathrm{He}$ was succeeded by his son Humphrey, who died in 1544 leaving an infant daughter Anne, later wife of Henry son of Sir Thomas Joscelin.29 Anne died in 1589 and Slades passed to her son Sir Thomas Joscelin. ${ }^{30}$ In 1604 Sir Thomas sold the manor to Thomas Greene of Bois Hall and his brother Robert.31 In 1637 Robert Greene sold Slades to Henry Alexander and John Howe. ${ }^{32}$ It afterwards belonged to the Howlands of Stone Hall in Little Canfield and was later purchased by the Waldegraves. In 1768 Slades belonged to Lord Waldegrave but was no longer styled a manor. ${ }^{33}$ It remained part of the Waldegrave estate (see above, Manor of Navestock) and in 1840 was part of Bois Hall farm (see above).

\footnotetext{
(s Morant, Essex, i, 417.

6 Ibid. 395-7.

7 Feud. Aids, vi, 443.

$\mathrm{C}_{142 / 467 / 173}$.

- CP40/1051 mem. 348 .

I0 $\mathrm{C}_{142 / 84 / 64}$.

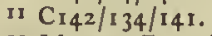

12 Morant, Essex, i, 183.

13 Ibid.; Gents. Mag. xxii, 44. For Dr. Greene see Walker, Hist. Music in Eng. (3rd ed. by J. A. Westrup), 243 f., 253 f. 14 Morant, Essex, i, 183 .

is E.R.O., D/CT 248 .
}

ES. IV

I6 Hist. Mon. Com. Essex, ii, 193.

17 Inf. from Mrs. T. E. Bere.

18 Ibid.

19 Hist. MSS. Com. $9^{\text {th }}$ Rep. pt. $i$ App pp. $33 b, 38 a$

${ }_{20} \mathrm{CP}_{25}$ (I)/72/29 I I Ric. III, 9

$21 \mathrm{CP}_{4} / 979$.

22 Cf. Burke's Extinct and Dormant

Baronetcies, Pp. 48:-3.

23 Ibid.; $\mathrm{CP}_{25}$ (2)/11/53 Mich. $7 \mathrm{Hen.}$ VIII; P.R.O. List of Sheriffs, P. 69; $\mathrm{C}_{142 / 199 / 94}$.

24 G.E.C. Complete Baronetage, i, 73-74.
23 E.R.O., D/CT 248.

${ }_{26}$ Cal. Inq. p.m. Hen. VII, i, pp. $514-$ 15. For the origin of the name Slades see P.N. Essex (E.P.N.S.), 7 I.

27 For Henry Torrell see Cal. Inq. p.m.

(Rec. Com.), iv, p. 402.

$28 \mathrm{Cr}_{\text {42 }} / 44 / 95$.

$29 \mathrm{C}_{142 / 70 / 22}$; Visits. of Essex (Harl.

Soc.), $230 ;$ V.C.H. Sussex, iv, 42

$30 \mathrm{C}_{142 / 224 / 44}$.

$31 \mathrm{CP}_{25}(2) / 292$ East. 2 Jas. 1.

$32 \mathrm{CP}_{5}(2) / 417$ Hil. I2 Chas. I.

33 Morant, Essex, i, 184. 


\section{A HISTORY OF ESSEX}

The medieval manor house of Slades is thought to have stood at the head of a small valley about $600 \mathrm{yds}$. west of Beacon Hill Farm. The site is marked by a group of earthworks, now much overgrown. On the west is a circular moat enclosing a mound about $65 \mathrm{ft}$. in diameter at the base. This may be of greater age than the site of the house itself, which is indicated by two arms of a large rectangular moat. Tudor bricks have been found in this enclosure. Outside the northwest arm and separated from it by a steep bank in which there was formerly a sluice are two rectangular fishponds. ${ }^{34}$ In the I 9 th century part of the site was occupied by cottages but these have now disappeared. Slades Farm, formerly known as 'Little Slades', stood about 1 mile to the west. The buildings were damaged by bombs during the Second World War and have now been demolished. 35

The church, which dates from the I Ith or 12 th century, had been appropriated by I I 8 I CHURCH to St. Paul's Cathedral, which owned the manor of Navestock. ${ }^{36}$ A vicar is mentioned in a document of about $1222-9.37$ The rectory and the advowson of the vicarage descended together along with the manor until I 555, when Sir Edward Waldegrave sold the rectory and advowson to $\mathrm{Sir}$ Thomas Pope to form part of the endowment of Trinity College, Oxford.38 They have remained in the, college ever since. In addition to their ownership of the rectory and advowson during the Middle Ages St. Paul's exercised peculiar jurisdiction over the parish of Navestock. The cathedral retained this after parting with the manor, rectory, and advowson in 1544 and continued to exercise the powers of ordinary until the reforming legislation of the I 9 th century. ${ }^{39}$

It was stated in I I 8 that the church of Navestock paid 6os. to St. Paul's per manum firmarii and that there were 46 acres of arable glebe and 40 acres wood. The church had the tithes tocius ville and the third sheaf from the demesne.40 In 1535 the vicarage was valued at $f_{0} 33$ s. $8 d .41$ The grant of the rectory to Trinity College ostensibly included lands but in spite of its wording the college does not appear to have acquired any glebe. Probably, as Stubbs suggested, the 86 acres mentioned in II 8 I had become lost among the lands of the manor as a result of the practice of farming out the manor and rectory together.42 In the 18 th century the vicarage "was amply endowed by the college on these conditions: the vicar for the time being is lessee for the great tithes, paying to the college a small quit rent, and a fine certain of $\{60$ per annum'.43 At the tithe commutation in 1840 the college (as rector) and the vicar were each allotted a tithe rent charge of $£ 574$. There were then 2 I acres of vicarial glebe.4 Part of this glebe was probably derived from a gift about ${ }_{3} 6_{5}$ by John Barnet, Bishop of Bath and Wells (formerly a canon of St. Paul's) of 9 acres of arable, 2 acres I rood of meadow, and I $2 d$. in Navestock.4s

The former vicarage stands at the north-east corner of Navestock Heath. A I gth-century pen-and-ink sketch shows the house which previously occupied the site. 46 It was evidently a timber-framed structure dating from before the middle of the 17 th century. A central block was flanked by two gabled wings and there were two old brick chimneys. The sash windows and pedimented doorcase were I 8 th-century insertions. The present house, which stands back from the road in a large garden, was built about 1867.47 It is a red-brick building with decorative stripes of yellow and black. At the front is a tall gable and a porch of carved stone. It has been empty for some years and has recently been sold.

The church of ST. THOMAS THE APOSTLE consists of nave, chancel, south aisle, and western belfry with spire. The belfry is one of the notable timber towers of Essex. The rest of the church is of flint rubble and pebbles plastered externally, with dressings of limestone and clunch. The roofs are tiled and the spire shingled. The church dates from the I I th or I 2 th century but was largely rebuilt in the 13 th and $14^{\text {th }}$ centuries. In 1940 it was badly damaged by a German land mine and by 1954 repairs had not been completed.

The north wall of the nave is part of the I I th-century church. The north doorway has a plain tympanum under a semicircular arch. Below this a segmental arch is ornamented with rounded billets. The door itself may also be of I I th- or I 2 th-century date.

The church was considerably enlarged in the 13 th century. A pointed arch in the north wall of the nave, now blocked, may have led to a chapel of this period. One of the jambs has an attached shaft with 'stiff-leaf' foliage to the capital. The south aisle and the chapel at its east end are also of the mid-I 3 th century. The arcade has four bays but the easternmost arch is of wood and is probably of much later date. The original arches are of two chamfered orders and are supported on circular columns with moulded capitals. There is one lancet window in the south aisle and there are traces of two more. The mid-1 3 th-century doorway has been much restored and the door itself, which may have been equally ancient, has been replaced. The east window in the south chapel was probably of the $13^{\text {th }}$ century but it has suffered later alterations and damage. Beside it is a I 3 th-century piscina with a trefoiled head. It is possible that this was already in existence by $125 \mathrm{I}$ and served one of the two altars mentioned in a visitation of that year..$^{48} \mathrm{~A}$ new chapel, to which there is a reference in 1297 , may have been this chapel or one which has now disappeared on the north side of the nave. 49

In the same visitation of $\mathbf{I} 297$ it was ordered that the chancel 'should be better united' to the nave.50 It was no doubt as a result of this order that the chancel was rebuilt during the first half of the I 4 th century. The three-light east window has net tracery and there are other early-14th-century windows in the chancel. There is also one of this date in the north wall of the nave.

In the $5^{\text {th }}$ century the south porch and the belfry
34 Details from Hist. Mon. Com. Essex, ii, $192-3$.

33 Inf. from Mr. T. E. Bere.

36 Dom. of St. Paul's (Camd. Soc. 1858), 150.

${ }_{37}$ Early Charts. of St. Paul's (Camd. Soc. 1939), p. 190.

${ }^{8}$ Cal. Pat. 1555-7, 210; Morant, Essex, i, 184 .
39 Morant, Essex, i, 184; Val. Eccl. (Rec. Com.), i, 460. 40 Dom. of St. Peul's (Camd. Soc. 1858 ), 150.

4 Val. Eccl. (Rec. Com.), i, 437.

$\$ 2$ W. Stubbs, Hist. Introd. to Rolls Ser. $7 \mathrm{I}$.

43 Morant, Essex, i, 184

44 E.R.O., D/CT 248.
48 Morant, Essex, i, 184.

46 E.R.O. Prints, Navestock.

47 E.R. xxvi, 221.

48 Camden Misc. ix (Camd. Soc. 1895)

22.

49 Visits. of St. Paul's Chs. 1297, \&ce. (Camd. Soc. I 895 ), I-2.

30 Ibid. 
were added. The belfry is timber-framed. The walls were formerly weather-boarded but have now been plastered. Round the base is a semi-octagonal aisle which once contained vestries. The central framework consists of four heavy oak posts with attached octagonal columns at their internal angles. The bell chamber has a louvred opening in each face and is surmounted by a shingled spire.

The timber south porch was destroyed in 1940. The four-centred outer archway had sunk spandrels, each with a shield, the eastern a fesse between two cherrons, the western said to have been Waldegrave. In the gable was an I 8 th-century clock-face. The sides were modern except for the posts and moulded wall plates. 51

During the $15^{\text {th }}$ century also new windows were added in the south wall of the aisle and the north wall of the nave, and a 'low side' window in the north wall of the chancel is of the same period. A window of 15 th-century date in the south wall of the chapel, which was reported as badly decayed in $1919^{\text {s2 }}$ has now been renewed.

In post-medieval times, probably in the early I gth century, alterations were made inside the church and the oak pier and arches put in the south arcade. This pier is roughly cut to a polygonal shape and has a moulded cap and a brick base. The wooden arches springing from it are rough and plain and the whole has been covered with plaster to resemble the rest of the arcade. There are similar wooden arches across the nave and aisle at this point springing from semicircular responds, also of plastered wood with moulded plaster caps.

Late in the rgth century the church was restored, the tower and spire being repaired in 1897 at the cost of David Sellar.s3 The west wall of the nave, which is of brick, was probably put in at this time. The roofs of nave and chancel also appear to have been renewed in the 1gth century. 54

The 18 th-century three-manual organ now in the south chapel was brought from Southwood Court, Highgate (Mdx.), and installed in 1930.55 In $193 \mathrm{I}$ the south porch and the windows were restored. ${ }^{56}$ On 2 I September 1940 a landmine fell in the churchyard near the south-west corner of the church. The south porch was destroyed, the belfry badly damaged, and much of the roof stripped of tiles. There was also considerable damage to the interior. A complete restoration of the church started in 1954. The site of the bomb crater is now occupied by a garden of remembrance. 57

There are five bells, the first being of $\mathrm{r} 862$ but the others older. The third is by John Walgrave and probably dates from about $1420-50$. It has the inscription 'Sancta Katerina Ora Pro Nobis'. The fourth is by John Hardyng and of about 1560 and the second and fifth by Miles Graye, $1637.5^{8}$

The plate consists of a cup and paten of 1625 , a pair of silver flagons of 1626 and 1630 given by Christian Greene in 1638 and 1639 , a brass almsdish, and a small silver cup and paten given in 1847 by the Revd.
James Ford, then vicar. There is also a pair of electroplated patens, undated.s 9

In the south aisle there are two I 4 th-century coffin lids which were at one time used as door steps. The font, also in the aisle, is modern, but beside it is the base of the 13 th century one. 'The octagonal oak pulpit is of the 18 th century but the pews are modern.

There are several brasses on the walls of the chancel, the oldest being to Richard Makyn ( 1603 ) and his wife 'Agnes (Colford) ( 1589 ), and to James Makyn (1616). On one of the window-jambs is a brass to John, son of Edward Moore (1624), a cursitor of the Chancery. Also in the chancel is a monument to John Greene, serjeant-at-law and Judge of the Sheriffs Court (1653) and his wife (I641). Other monuments are to the wife and child of Charles Snelling (1625) with effigies and shield of arms, and to Rebecca (Greene) wife of Thomas Thorold (1625).

There are a number of other monuments, including some floor slabs of the $17^{\text {th }}$ century. The most impressive are those to members of the Waldegrave family. They include the Ist Earl, 1741: a marble tablet on the north wall of the chancel; Hon. Edward Waldegrave, drowned off Falmouth on his return from Corunna, I 809 : a symbolic relief carved by John Bacon the younger; the 7 th Earl Waldegrave, I 846 , with portrait bust by Behnes; 60 Viscount Chewton, son of the 8th Earl, died of wounds at Scutari, 1854; and Frances, Countess Waldegrave, I879. There is also a monument to the Revd. James Ford, vicar, I850.

Sir Gilbert de Breauté, in right of his wife Joan, had licence from the Dean of St. Paul's, about $1223-7$, with the consent of the vicar, to found a private chapel at his court in Navestock. The founders and their kin were to maintain a chaplain at their own cost, pay all profits to the vicar, exclude the parishioners, swear to preserve the rights of the mother church, and give yearly to it two wax candles. The chaplain was to administer mass only with bread and holy water, saving that at Easter the founders and their kin, their free household and their guests but not their servants were to be admitted to the sacraments at the altar. ${ }^{6 \mathrm{I}}$

A chapel is mentioned in 1335 as belonging to the manor house of the Dean and Chapter of St. Paul's.62

The Navestock Mission Room at Horseman Side, originally a nonconformist chapel, is now (1954) used for services in connexion with the parish church.

Sir Edward Waldegrave (d. I56I), the first of his line to own the manor of ROMAN CATHOLICISM Navestock, suffered imprisonment under Eliza-

beth I for his recusancy. ${ }^{63}$ The Waldegraves appear to have remained Roman Catholics until early in the 18th century. In I7I7 Henrietta, dowager Lady Waldegrave and her son James Lord Waldegrave, both appeared in the county register of papists' estates. ${ }^{64}$ Soon after this James turned Protestant: in 1722 he took his seat in the House of Lords.65 There are records of a few other Roman Catholics in the parish
31 Hist. Mon. Com. Essex, ii, 192.

52 Ibid, I9I.

33 Kelly's Dir. Essex (1906).

34 E.R. iv, 22 I.

33 N. Pevsner, Buildings of Essex, 276;

Vestry Mins.

36 Kelly's Dir. Essex (1933).

57 For a drawing of the church made in
1895, showing the south porch and weather-boarded belfry, see E.R. iv, 200. The church was described in an article of the same year which contains a measured plan and other drawings: E.R. iv, 2 I 5-34. $58 \mathrm{Ch}$. Bells Essex, 345 ; Hist. Mon. Com. Essex, 192.
59 Ch. Plate Essex, 67.

60 N. Pevsner, Bdgs, of Essex, 277.

61 Newcourt, Repert. ii, 434.

62 See above, Manor.

63 See above, Manors, and D.N.B.

64 E.R.O., Q/RRp I/1 7, I/51.

65 Burke's Peerage (1913 edn.), p. 1939. 


\section{A HISTORY OF ESSEX}

in the $17^{\text {th }}$ and early 18 th centuries, ${ }^{66}$ and Roman Catholic worshippers at Kelvedon $\mathrm{Hall}^{67}$ and at Wealdside 68 in the 18 th and 19 th centuries may have included some from Navestock. For some time up to about 1939 Roman Catholic services were held in a small weather-boarded building immediately to the west of the 'King William IV' at Horseman Side. This building stands in the garden of a double-fronted weather-boarded cottage, formerly a school, 69 dating from the late i 8 th or early I 9 th century.

In 1705 the house of William Brock at Navestock

PROTESTANT

NONCONFORMITY was licensed for nonconformist worship. 70

In I 8 I 6 a house at Navestock occupied by Charles

Goodwin was similarly licensed. ${ }^{71}$ In 1829 this congregation, numbering 30 , was still meeting in a licensed room, under the leadership of William Temple, minister of the Congregational church at Stanford Rivers (q.v.). ${ }^{72}$ No later trace has been found of this society. It seems probable, however, that there was a nonconformist chapel later in the $19^{\text {th }}$ century, and that this was the building at Horseman Side now known as the Navestock Mission Room. This is a small rectangular biilding of gault brick with an entrance and porch, and is dated $\mathrm{r} 897$. It is said to have been built as a nonconformist chapel but the services lapsed. The building is now in private ownership and is used as a Sunday school and chapel of ease to the parish church.73

Vestry minute-books for Navestock survive for the period I 806 to I 870.74

PARISH GOVERNMENT Meetings of the public $A N D$ POOR RELIEF vestry were held at irregular intervals, aver-

aging about 8 a year until $\mathrm{I} 8 \mathrm{I} \mathrm{O}$ and subsequently about 5 a year. The number of persons attending the meetings, in addition to the churchwardens and overseers, varied between I and 7. Until i 838 the chairman was never named as such in the minutes but the vicar, or in his absence one of the churchwardens, always signed first. From 1806 until 1816 the vicar, J. Filkes, attended the vestry regularly, but after i 816 rarely, and between March I 8 I 8 and i 830 he attended only once. Ford, when vicar, always attended regularly and usually signed the minutes as chairman.

In 1824 the parish adopted the second Sturges Bourne Act (59 Geo. III c. I2) and set up a select vestry, which held its first meeting on 29 July of that year.7s In 1826 the select vestry included twelve members in addition to the vicar, churchwardens, and overseers. ${ }^{76}$ It apparently ceased to function after 12 April I 832.77

The work of the open vestry consisted mainly in nominating parish officers, granting rates, and auditing the overseer's accounts. The overseer presented interim accounts at nearly every meeting of the vestry and a final account at the end of his year in office. In I 806 a is. rate yielded $£_{1} 73$ and between then and I 834 there was no great variation.

66 E.R.O., $Q / \mathrm{SBa} 5$; ibid. $Q / \mathrm{RRP}_{\mathrm{S}} / 2 \mathrm{I}$, $2 / 6,3 / 3$.

67 See Kelvedon Hatch.

68 R.C. Parish of Brentwood, MS. Book: letter from J. F. Wright to Fr.

Tavarez, 1854 .

69 See Schools, below.

70 E.R.O., $Q / \mathrm{SBb} 40$.

"I E.R.O., $Q / R R_{w}$ i.

72 E.R.O., Q/CR $3 / 2$.
There was probably a poorhouse in Navestock from I741. In that year the churchwardens and overseers were negotiating with Elizabeth Merrick of Caversham (Berks.) for the lease of her house, called the White House, and two fields belonging to it, containing 10 acres, for the purpose of making a poorhouse. It was proposed that the premises should be leased for 2 I years at a rent of $\mathrm{fI}_{4}$ a year. It is not certain that these negotiations were completed, although they reached an advanced stage. ${ }^{78}$ It is certain that by 1770 the workhouse was on a site which it continued to occupy until i 836 . This was just south of the vicarage and was some way from a house owned in $177^{\circ}$ by Elizabeth Merrick.79 In 1826 the workhouse was repaired at a cost of $f_{6} 60$. In I 834 a cottage belonging to Green's Charity was also being used by the overseers to accommodate paupers. ${ }^{80}$

In $1776 £ 272$ was spent on poor relief in Navestock. ${ }^{81}$ In the three years $I 783-5$ the average poor rate amounted to $£ 444$, and the average cost of poor relief to $f 400 .{ }^{82}$ In the year I 800 I the cost of relief was $f_{1}, 705$. It was $\oint_{0}, 624$ in the following year. From then until I 8 I6-I 7 it varied between $\{1,020$ and $f_{1}, 674$, being highest in $181_{2}-13$ and lowest in I 8 I 5-16.83 In I 8 I $6-2$ I the poor rates varied between fr,oI 2 (I 8 I 5-I6) and $f_{1}, 433$ (I817-I8).84 The total sum collected in $1828-9$ was only $E_{5} \mathrm{II}$. The income from work done by the paupers in the workhouse was about 640 a year from I 806 to I 8 IO-I I. The rates were very high in $1809-10$ and $1810-11$ and it is probable that a special effort was made to increase paupers' earnings, which rose to $£ .57$ in I $8 I I-I 2$ and $f_{1} I$ I in $18 I_{2}-I_{3}$. That high level was not maintained but for some years the earnings ranged between $\delta_{52}$ and 692 . From I 82 I onwards they were much lower, reaching a minimum of $£_{23}$ in I $823-4$.

For some years before I 834 James Lash was governor of the workhouse; it may have been to this post that he was appointed in 1813 at a salary of $f_{1} 17$. In 1832 it was agreed that he should farm the poor at $3 s$. a head for all above one year of age. At that time there were 30 persons in the workhouse, of whom 7 were named Noaks, 5 Burns, and 3 Eldred. In 1834 Samuel Randal was appointed to succeed Lash. It was agreed that he should receive a minimum of $2 s .6 \mathrm{~d}$. a head for I7 paupers and 2s. $6 d$. a head for all above that number.

In December I 830 the salary of the parish surgeon was reduced from 40 to 35 guineas. ${ }^{85}$ In July I 83 I the vestry ordered that the overseer should pay the surgeon the amount of his extra charges, $f_{8}^{8} 6 s$., and request him to call at the poorhouse each week.

In 1836 Navestock became part of the Ongar Poor Law Union. In the same year the workhouse at Navestock was sold by the union to David Pinchon, at a net profit of $\oint_{1} 64 .{ }^{86}$ In 1840 the building consisted of several tenements. ${ }^{87}$ About 30 years ago it was demolished. ${ }^{88}$ The gardens are immediately south of the 'Plough'.

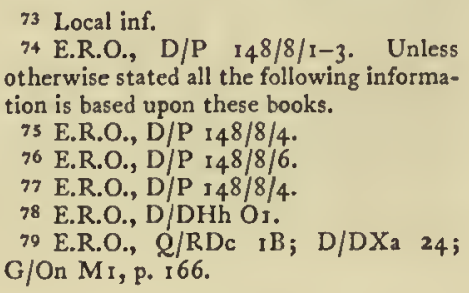

80 See below, Charities. 81 E.R.O., Q/CR I/I. 82 Ibid. 83 E.R.O., Q/CR I/9. $8+$ E.R.O., Q/CR I/I2. 8 S E.R.O., D/P 148/18.

86 E.R.O., G/On MI, p. $145,166,261$. 87 E.R.O., D/CT 248. 88 Inf. from local carpenter. 
In 1770 there seems to have been a school at Navestock Side, 89 but by I 8 I 8 this had SCHOOLS evidently ceased to exist.90 In the early igth century Lady Waldegrave and the vicar had jointly supported a school, probably a dame school on Navestock Heath, but about I 8 I 7 this was closed on the death of the mistress. Earl Waldegrave then built a schoolroom on the north side of Navestock Heath in which in 1818 a master was teaching some 40 children on the monitorial system. ${ }^{91}$ Under the patronage of the Waldegraves and the superintendence of the vicar the school increased its attendance to 50 in 1828 and 60 in 1833.92 In 1837 the Waldegraves built a new school, or rebuilt the old one on the same site, and added a teacher's house. 93 By I 839 the school was being used to full capacity by some 70 children, each of whom paid a penny a week. The total income for the previous year had been $£ 46$, of which $£ 3$ I had been obtained (with some difficulty) from subscribers. The school was supervised by the vicar and Litchfield Tabrum of Bois Hall. At that time there was also a dame school in the parish with about 50 pupils, but there were still some children not going to school. 94

School attendance continued to increase as the population rose. In $1846-7$ there were 75 children, taught by a master and mistress. 95 In 1859 an inspector found the schoolroom overcrowded with 95 pupils. 'The children seem nice', he reported. 96 'In I 862-3 the school was receiving an annual government grant. 97 Its supporters realized the need for more accommodation and this had been provided by about I 867 . Local subscribers gave $f_{0} 617$ towards the rebuilding and the government contributed $f_{1} 45.98$ By a deed of 1867 the vicar and churchwardens were made trustees and the management was entrusted to the vicar and six representatives of the subscribers. An inspector reported in 187 I that the new school had 146 places but that I 4 more places were needed to ensure universal elementary education in the parish.99

Attendance at the Navestock Heath school was io I in $187 \mathrm{I} . \mathrm{I}$ It fell with the declining population of the parish to 88 in $1902 .{ }^{2}$ The government grant, however, increased from $£ 45$ in 1873 to $£ 59$ in 1893 and flo1 in 1902.3 By the Education Act of 1902 the school passed under the administration of the Essex Education Committee, Ongar District, as a nonprovided church school. In 1904 there was an average attendance of 89 and there were four teachers. 4 'The attendance fell to an average of $7 \mathrm{I}$ in $I 9 I \mathrm{I}$ and 46 in 1938.5 In 1948 the school was reorganized for mixed juniors and infants and in July I 949 it was closed owing to the small attendance. ${ }^{6}$ The building is owned by the Diocesan Board and is used for village activities.? It is a rectangular one-story building of yellow brick with a slate roof with the former teacher's house attached, and it stands next to the Plough Inn.

89 E.R.O., Q/RDc I (Map).

90 Retns. Educ. Poor, H.C. 224, p. 263

(I8 I 9 ), ix (I). $9 \mathrm{I}$ Ibid.

92 Nat. Soc. Rep. 1828 , p. 70; Educ. Enquiry Abstr. H.C. 62, p. $284(1835)$, xli.

93 E.R.O., D/P 30/28/19. For the site sec E.R.O., D/DXa 24 (Map 1835) and later maps.

94 E.R.O., D/P 30/28/19.

95 Nat. Soc. Enquiry into Ch. Schs. 1846-7, Pp. 14-1 5 .

96 Educ. Cttee. Reps. on Schs. in Norfolk, Suffolk and Essex, $185^{8-9}$, p. 22 (in Min.

In about 187 I there was a school at Horseman Side, in the cottage which now adjoins the 'King William IV'. ${ }^{8}$ This may have been a private school mentioned by an inspector in I $87 \mathrm{I}$ as being at Navestock Side. 9

John Green, grocer of London, by will proved I 626, devised to the poor of Navestock, CHARITIES Io where he was born, all his property in the parish. He also left the parish 6.70 and the residue of his estate, which were used to buy more land. In 1834 the endowment consisted of freehold and copyhold land in Brentwood and Navestock, including an almshouse of two rooms occupied by paupers placed there by the parish officers. This stood at Navestock Heath opposite the road junction nearly $\frac{1}{2}$ mile south of the village school."I It was burnt down in 1892 . Parts of the property, including that in Brentwood, were sold between 1919 and 1942. In I 834 the charity's rental was $£ 48$ I $75.9 d$. In 195 I it held over a thousand pounds in stock and its income from this and rents was 692 I $75.7 d$.

In 1834 the income, after deductions for repairs, $\& c$. was used to buy shoes, jackets, and faggots for poor people, including some receiving parish relief. 'The sum of $\oint_{1} 5$ a year was given to the parish school from I 850 to I 872 . The rest of the income was being spent on clothes and coal. In $19526_{65}$ was given to the vicar to distribute at his discretion.

In 1669 Lewis Betts gave $£_{\mathrm{I}}$ a year for four of the oldest decayed labouring men of the parish and $\mathcal{E}_{2}$ towards binding poor apprentices. Both sums were charged on property at Romford, and were regularly paid in 1834 . The first was distributed, but no apprentice had been bound for 20 years. The money for apprenticing appears to have been used for that purpose for the last time in 1922 . In 195 I $£ 2$ was distributed to four old people.

An unknown donor before 786 gave the poor a rent charge of $f_{0} \mathrm{I}$ issuing from Dycotts in Navestock. In 1834 it was spent along with Green's Charity and in 195 I with Bett's Charity.

Elizabeth Prince, by will dated I 796, left L $_{5} 5$ in trust for a distribution every February to eight poor families or persons not in receipt of parish relief. In I 834 it was reported that the vicar was careful to choose people of good character and that all the poor of the parish received the charity in turn. In I 950 the income was $\oint_{6} \mathrm{Igs}$. and $\oint_{10} \mathrm{was}$ distributed among 20 people.

The Revd. Frederick Vane, by will proved i 865 , left 6.50 in trust for distribution to the poor of the parish on St. Thomas's day. 'The money was invested. In 1929 it was said that many years before the income had been distributed in fourpenny pieces. In I95 I the income had apparently not been spent for some years.

The charities of James Wallenger and Lady Tipper were reported as already lost in 1786 . The unknown

of Educ. Libr.).

97 Rep. of Educ. Cttee. of Council, 1863

[3349], p. 401, H.C. (1864), xlv,

98 Sch. Bdg. Grants [Cd. 1336], p. 39, H.C. ( 902 ), Ixxviti.

99 Min. of Educ. File $13 / 274$.

1 Retns. Elem. Educ. H.C. 20 I, pp. I 2-13 (187 I), Iv.

2 Schs. under Bd. of Educ. 1902 [Cd. 1490], p. 73 , H.C. (1903), li.

3 Rep. of Educ. Cttee. of Council, 1873 [C. 1019-I], p. 324, H.C. (1874), xviii Retn. of Schs. 1893 [C. 7529], p. 715 H.C. (1894), lxv; Schs, under Bd. of
Educ. 1902, p. 73 4 Essex Educ. Cttee. Handbk. 1904.

5 Min. of Educ. File I $3 / 274$.

6 Inf. from Essex Educ. Cttee.

7 Inf. from - Chelmsford Diocesan Council.

8 O.S. 6 in. Map (Ist edn.), sheet lix. For the cottage see also Roman Catholicism, above.

$9 \mathrm{Min}$. of Educ. File $13 / 274$.

10 This section is based on Rep. Com. Char. (Essex), H.C. 216, pp. 234-7 ( 1835 ), xxi (r) and Char. Com. Files. ix O.S. 6 in. Map (ist edn.), sheet lix. 


\section{A HISTORY OF ESSEX}

donor's charity above has now the alternative title of Wallenger's but it is not clear that there is any evidence for this identification. Sir William Sedley, by his will of 1617 , directed that his executors should buy annuities for the poor of Aylesford and Herne (Kent) and Navestock.12 Deeds were executed giving rent charges to the other parishes but there is no record of any for Navestock.

\section{NORTON MANDEVILLE}

The modern parish of Norton Mandeville lies to the north of High Ongar and is bounded on the north by Willingale. I Its present area is I, 3 I 8 acres. Until late in the $\mathrm{I} 2$ th century Norton was apparently included in the parish of High Ongar. ${ }^{2}$ During the later Middle Ages the parish of Norton may have included Forest Hall and Newarks Norton, but in and after the 16 th century those places became together a detached part of the parish of High Ongar (q.v.). At the Tithe Commutation (I 847) Norton Mandeville contained 757 acres. $^{3}$ The County of Essex (Review of Rural Districts and Parishes) Order, I939, provided that Forest Hall and Newarks Norton should be merged in Norton Mandeville. This was confirmed by the Minister of Health in 1946.4

Norton Mandeville has always been a small rural parish with few inhabitants.5 In 180 I the population was $93 .{ }^{6}$ In I95 I, after the enlargement of the parish, it was only 202.7 The soil is Boulder Clay with a patch of glacial loam at Norton Heath.

The River Roding forms the western boundary of the parish. A tributary of the Roding which rises near Dodd's Farm in the east of the parish flows west and south and forms the southern boundary for part of its course. From the river and the stream the land slopes gently upwards to the east and north. Forest Hall (see under High Ongar) is in the west of the present parish of Norton Mandeville, lying in a wooded park of about 200 acres. About 200 yds. north of it is the site of the original manor house of Forest (formerly Foliots) Hall. Little Forest Hall, $\frac{1}{2}$ mile north-west of the present Forest Hall, probably dates from the 17 th century. The north end is timber-framed and plastered and is of that period. Half a mile north-east of Forest Hall is the site of Newarks Hall (see High Ongar) which was demolished during the Second World War to make room for the large airfield which extended into this parish from Willingale. ${ }^{8}$ Offin's Cottages, a mile southeast of Newarks, are a pair of timber-framed and plastered cottages of 16 th- or early-I 7 th-century origin with an oversailing gable-end to the east supported by curved brackets. Near these cottages to the east is Spriggs, where two sides of a moat still exist. The present I th-century farm-house incorporates old timbers which may have come from an earlier house.

Norton Heath is in the extreme east of the farish. It consists of about I 2 acres of unfenced woodland with a number of small ponds and a road running diagonally through the centre. It has always been common land, and the hamlet around it has for long been the main centre of population, although it is 2 miles from Norton Hall and the parish church. The road that links the heath with the hall and the church to the west, formerly known as the Causeway, was mentioned in a charter of about 1260 , and gave its name to Great Causeway field and Little Causeway field which in I 740 lay to the south of the road about $\frac{1}{4}$ mile from the church.9

The building now known as Norton Manor House stands at the north-west corner of the heath.10 It is a mid-1 7 th-century timber-framed house and is built on a half $\mathrm{H}$-shaped plan with two projecting wings at the back. Adjacent to the northern wing is a small staircase wing containing an original staircase with moulded finials to the newels and heavy turned balusters. There are three brick chimneys, each with three octagonal shafts joined at the heads with moulded brick capitals. Two tablets on the south chimney have the date $165^{\circ}$ and the initials E. s. A." Considerable extensions took place early in the 18 th century, and much original work has been obliterated by a very thorough restoration of about 1900.12

The main road from Chipping Ongar to Chelmsford passes through Norton Heath and for a short distance forms the parish boundary. Ladyland is a timberframed and plastered farm-house on the north of this road. It probably dates from the early 17 th century with additions in the 18 th century and later. Readings, near Ladyland to the west, was probably the White Horse Farm of 1740.13 It is of red brick, the back dating from about 1780 and the front having been added by John Caton ${ }^{14}$ in the mid-rgth century. The White Horse Inn itself stands on the south of the road and is therefore in High Ongar parish. It is of colour-washed brickwork and is of mid-18th century date with early-Igth-century additions. Between Readings and Ladyland is a single-story roughcast cottage formerly a toll house dating from about I 830.15 A small red-brick forge on the west of the heath, probably built early in the Igth century, was closed in 1944. ${ }^{16}$ Several of the cottages round the heath are of I 8 th-century origin. Also at the heath are the church hall and the Congregational church. Near the heath, on the road to the parish church, are nine pairs of council houses of various dates. Dodd's Farm is near these houses to the west. Parsonage Farm is $\frac{1}{4}$ mile east of the church.

In 1086 a considerable proportion of the manor of Norton was woodland.17 By about I 250 , however, forest clearance must have given the parish something
12 Rep. Com. Char. (Kent), H.C. 681, p. 200 ( 1833 ), xix, and [C. 101], p. 3 ro, H.C. $(1837)$, xxiii

O.S. 22 in. Map, sheets 52/50, 52/60.

2 See below, Church.

3 Tithe Redemp. Com. Recs. Norton Mandeville Tithe Award and Map.

4 County of Essex (Rural Parishes) Confirmation Order, 1946.

s Some early taxation statistics, given below, pp. $300 \mathrm{f}$., must be used with caution in view of the possibility that the parish included Forest Hall and Newarks Norton in the Middle Ages.

6 V.C.H. Essex, ii, 350 .

7 Census, 1951.

8 Inf. from Mr. K. McCorquodale.

- For the charter of $c_{\text {. }}$ I 260 and the map of I 740 see below, Manor.

10 The name is recent. This was not an ancient manor house. In 1740 it was called Readings : E.R.O., D/DCe PI.

II In I662 Edward Sandford was taxed on a house at Norton Mandeville having 8 hearths: E.R.O., Q/RTh I mem. 24. No other house in the parish had as man hearths.

12 Inf, from Mr. E. H. S. Walde, the present occupier.

13 E.R.O., D/DCc PI : Map of Norton Mandeville 1740.

14 Inf. from Mrs. McKinlay, present occupier.

Is For details of its sale, 1870 , see E.R.O., D/TE I 3 .

16 Inf. from daughter of former blacksmith.

17 V.C.H. Essex, i, 375, 503 a. 
like its modern appearance. Most of the fields mentioned in the charter of about 1260 can be identified on the parish map of 1740 (see below, Manor). By the time of the tithe award (1847) there were rather more, and smaller, fields than in 1740 , but there have been no important changes since then. In 1740 there were four farms in the parish of over 50 acres but only one of these, Norton Hall farm ( 264 acres), was over 100 acres. ${ }^{18}$ The size of the farms has tended to increase since then. From about I 864 to I 9 I 9 all the western part of the parish belonged to the Forest Hall estate, and life at this end of the parish must have centred on Forest Hall, a great house with a private saw-mill and its own gas-works. ${ }^{19}$ As late as 1939 Forest Hall continued to offer opportunities of employment, though no longer the centre of a large estate, but since 1943 it has been empty.

The parish is supplied via Ongar with water purchased from the Herts. and Essex Waterworks Co. 20 Electricity was first supplied in February 1 943. ${ }^{21}$ There is no gas supply. Letters were formerly received from Ongar, and more recently from Ongar and Ingatestone. ${ }^{22}$ The parish has always depended mainly on road transport. The nearest railway station for London is at Chipping Ongar, about $3 \frac{1}{2}$ miles from Norton Heath, and for north Essex and E. Anglia at Ingatestone, about 5 miles away.

Two manors of NORTON were entered in Domesday Book. One of them had been held in MANOR 1066 by a woman named 'Godid', as $\frac{1}{2}$ hide. After the Conquest she had given it to the Dean and Chapter of St. Paul's but the gift was irregular; at least the canons "could not produce the king's writ or permission' for its alienation to the Domesday Commissioners. ${ }^{23}$ There is little doubt that this was the manor which later became known as Foliots Hall alias Forest Hall in High Ongar (q.v.).

The other manor of Norton was held in 1086 by Wimund as tenant of Hamon dapifer.24 It had been held in 1066 by 'Gotil' as a manor and as $I \frac{1}{2}$ hide and 15 acres. It is probable that Gotil and the above Godid were identical and thus that in 1066 both manors of Norton were held by the same person.

Hamon dapifer was succeeded (probably before $1100)$ by his eldest son Hamon, also dapifer, and Sheriff of Kent. The younger Hamon was alive in I 29 , but dead by Michaelmas I I 30 . He was succeeded by his brother Robert Fitz Hamon, whose daughter and heir married Robert, Earl of Gloucester, bastard son of Henry I.25 The overlordship of Norton followed the same descent and ultimately passed with the earldom of Gloucester to the Clares. Gilbert de Clare, Earl of Gloucester (d. I 314 ), was lord in 1311.26 The overlordship subsequently escheated to the Crown as part of the honor of Gloucester. In 1524 it was stated that Norton Mandeville was held of the king as of the honor of Mandeville. ${ }^{27}$ No doubt the similarity

\footnotetext{
18 E.R.O., D/DCc PI : Map of Norton Mandeville 1740. There were 84 acres in the parish belonging to Forest Hall, High Ongar. The fields at Norton Heath were smaller than those farther west, and included some of strip shape, suggesting previous open field cultivation in this part of the parish.

19 See High Ongar.

20 Inf. from Herts, \& Essex Waterworks $\mathrm{C}_{0}$.

21 Inf. from Eastn, Elec. Bd.

a2 Kelly's Dir. Essex (1845 f.).

23 V.C.H. Essex, i, $442 b$.
}

24 Ibid. $503 a$.

23 For Hamon dapifer and his heirs see Domesday Monachorum of Christ Church, Canterbury (ed. D. C. Douglas), pp. 5558.

26 Merton College Deed 3209.

$27 \mathrm{DL}_{30 / 73 / 899 .}$

28 Sir C. Hatton's Bk. of Seals (ed. L. C.

Loyd and D. M. Stenton), p. 230.

20 Ibid.

30 V.C.H. Bucks. i, 370. Another braneh of the Dammartins held several manors in

Surrey of the honor of Clare: V.C.H.

Surrey, iii, I 51, 191, 305, 316, 321, \&cc; of name had caused the manor to be treated as part of parish took their name from a family of tenants holdde Dammartin was acting as farmer of the manor of Fill in High Ongar (q.v.). William de Darnsucceeded his brother Bartholomew, who died before I 190; they were sons of Manasser de Dammartin. ${ }^{29}$ A Manasser de Dammartin was benefactor to the abbey

The heir of William de Dammartin was his daughter Galiena. After William's death the king gave the wardin of Galiena to William Brewer, who married her to d. I 210 ). 31 After John Brewer's some time after Easter 1 220 , and by I 228 Galiena had married a third husband, Ernald de Mandeville, name suggests that he was a descendant of Ernald de Mandeville was still alive in $125 \mathrm{I}$, and Galiena conveyed 80 acres of land in Ernald probably died soon after, for in 1254 Galiena conveyed the manor of Norton to her son John de andeville, retaining a life interest in it. 34 By another time John granted back the manor to receiving in return 60 acres in Norton. 35 In and 1258 Galiena granted to John 76 acres of iptions in it. Forty acres of the land granted lay estfield, next to the land of the Rector of High in a field called la Mora, 15 acres in Kelleveland and 3 acres in Westfield lying bethe land of Galiena which a path I perch in breadth in the north part (he king's cartage to her field called Longemad. John was to have free passage from the church of Norton by the road leading to Ongar, i.e. in the field called Chirchefeld near the long fence from the south. The location of

these Clare connexions are interesting, but may not be significant since the Clares did not become overlords of Norton Mandeville until the $13^{\text {th }}$ cent.

31 Sir C. Hatton's Bk. of Seals, p. 279.

32 Ibid.

$3 s$ Feet of $F$. Essex, i, 187 .

34 Ibid. 199. The name of the manor is hete wrongly transcribed.

3s Merton Coll. Deed 3195.

36 Sir C. Hatton's Bk. of Seals, p. 278.

37 Monceux was lord of the manor of Ongar in Hijgh Ongar (q.v.). 


\section{A HISTORY OF. ESSEX}

many of the fields named in this charter can be identified from the map of the parish made in 1740.38 Upper and Lower Westfield lay in the extreme south-west of the parish, Upper Westfield being the more easterly of the two. In 1740 their total acreage was 43. La Mora is probably Moors, a small field lying along the banks of the Roding, which in $1744^{\circ}$ contained 4 acres. Kelleveland is probably the Kellums Field of $I 740$, on the north-west border of the parish adjoining Forest Hall, then containing 8 acres. Churchfield adjoined the church to the east. Longmead was in the centre of the parish on its southern boundary, $\frac{1}{4}$ mile from the church.

The above grant was probably the immediate preliminary to another, in 1258 , by which John de Mandeville gave to the Dean and Chapter of St. Paul's 76 acres of land and I acre of meadow in Norton. ${ }^{39}$ From this time onwards this part of the inheritance of Galiena de Dammartin presumably formed part of the manor of Forest Hall in High Ongar.

No evidence has been found to show that John de Mandeville had any further connexion with the manor. It was probably soon after 1258 that Galiena granted the manor of Norton to her daughter Anastasia.40 Anastasia subsequently granted all her land in Westfield in Norton, with a way for carrying, \&c., from Norton Heath by the causeway and with a windmill and rents outside the parish, to her daughter Galiena on the marriage of the latter to Gilbert de Theydon.4I Anastasia was still living, in widowhood, in 1285 , when she granted land in Norton to John son of Henry.42 John son of John le Merk (the son or step-son of Anastasia) was a party to this transaction.

The next step in the descent of the manor is not quite clear. In I 296 John le Rous of Felsted granted the manor to John le Rous his father and Agnes, wife of the latter.43 In 1297 Gilbert de Theydon, formerly husband of Galiena le Merk, granted to John le Rous and Agnes his wife for life a windmill and 18 acres of land in Norton Mandeville with 5 s. rent from the lands that Emma la Brune had previously held of Anastasia le Merk, called 'Craneslond' in Stanford Rivers.44 This property, which Gilbert was holding by the courtesy of England, was no doubt Galiena's marriage portion mentioned above. In 1300 Peter son of Robert de Burgate quitclaimed to John the elder son of John le Rous a messuage, I carucate of land and $£_{4} \mathrm{I}_{3} 3 \mathrm{~s} .4 \mathrm{~d}$. rent in Norton Mandeville.45 This Peter may have been the son of Galiena de Dammartin, but if so he must have been a very old man. In any case the meaning of this transaction is probably that John le Rous was securing himself against a possible claimant to the manor. If Galiena de Dammartin had not granted Norton to her daughter Anastasia the manor would in the normal course of succession have passed to her son Peter de Burgate and his heirs.

John le Rous the father was dead before 2 May I 3 I I.

${ }^{38}$ E.R.O., D/DCe PI : Map of Norton Mandeville, $174^{\circ}$.

39 Feet of F. Essex, i, 225. Cf. Hist. MSS. Com. 9 th Rep. pt. i, $38 a, 31 b$; Merton Coll. Deed $32 \mathrm{r} 6$.

40 Merton Coll. Deeds 977, 3 I 94.

41 Ibid. 3211.

42 Feet of $F$. Essex, ii, 45.

43 Merton Coll. Deed $32 \times 6$.

44 Ibid. 3213.

45 Feet of F. Essex, ii, 89 ; Merton Coll. Deed 3205 .

46 Merton Coll. Deed 3209.

47 Ibid. $324^{\circ}, 3232$.

His elder son John had died before him and his heir was another son, also named John. In I 3 I I the wardship of John the last born (post natus) son and heir of John le Rous was granted by the Earl of Gloucester to Simon le Wylde and Joan his wife. ${ }^{46}$ John le Rous was alive in 1328 but dead by 4 April 1332 when a release of land was executed by his widow Maud. $47 \mathrm{He}$ left sons Robert, John, and Nicholas.48 Maud le Rous retained some interest in Norton Mandeville and was still alive in 1345.49 By I $35^{\circ}$ the manor had passed to John le Rous, probably her second son. ${ }^{50}$ This John le Rous was still alive in 1366 and probably also in I 374.51 His son and heir was probably Thomas le Rous alias Caune, who held Norton Mandeville in I 412.52 Thomas was dead by 18 November 1422 when his widow Elizabeth had seisin of the manor for life. He left sons John, Thomas, and Richard.53 It was provided that the eldest son John Caune should have the reversion of the manor on condition that he paid $f, 20$ to each of his brothers and of his three sisters. If he failed to do so the second son Thomas was to have Norton. 54

In 1440 the manor was held by Thomas Rous. $5 \mathrm{~s}$ He was probably the second son mentioned above, and had assumed the original family name again. ${ }^{56}$ He was apparently dead by 7 May $145 \mathrm{I}$, leaving a widow Elizabeth and a son Thomas. ${ }^{57}$ In 1473 Thomas Rous conveyed Norton Mandeville to his son Richard. 58 In 1490 Richard Rous sold Norton and Cawnes in North Weald (q.v.) to Merton College, Oxford, for 6493.59

The college retained the property until I 864 . From I 800 to I 832 Norton Hall farm, consisting of 264 acres was leased by the college to Capel Cure of Blake Hall, Bobbingworth (q.v.), who sub-let it to a tenant farmer, Robert Hadsley. ${ }^{60}$ The farm contained 207 acres of arable and 57 acres of pasture.

In 1847 the college owned 265 acres in Norton Mandeville, most of which lay around Norton Hall in the centre and west of the parish. Norton Hall farm now contained only I 64 acres, the rest of the property being separately leased. ${ }^{6 I}$ In 1864 the whole property was sold by the college and became part of the Forest Hall estate, High Ongar, which was then in the process of being bought from J. B. Stane by J. L. Newall. Stane and his father had previously leased Norton Hall farm. ${ }^{62}$ By 1919 the farm had increased to $42 \mathrm{I}$ acres. 63

There appears to be no trace of an ancient manor house. The present Norton Hall farm-house dates from about I 870 - the time when J. L. Newall was building up and improving the Forest Hall estate. It is of red brick.

In I 8 I Norton was included for ecclesiastical purposes in the parish of High Ongar. The CHURCH church of High Ongar received all tithes from the manor of Norton belonging to St. Paul's (see Forest Hall, High Ongar) but propter

48 Ibid. $3210,3232$.

49 Ibid. $3242,3250,3218,3251,3228$. so Ibid. 3234

51 Ibid. 3222, 3237 ; Cal. Close, $1374-7$, 107.

32 Feud. Aids, vi, 443. He had probably held it in 1400: Merton Coll. Deed 3276. For the change of name see Cawnes in North Weald.

33 Merton Coll. Deed 3267.

54 Ibid. ss Ibid. $3256,3288,3268$.

s6 See also Cawnes in North Weald.

57 Merton Coll. Deed $328 \mathrm{r}$.

${ }^{8} 8$ Ibid. $326 \mathrm{I}, 3283,3259$.
59 Reg. Ann. Coll. Mert. I483-152I (Oxf. Hist. Soc. Ixxxvi, ed. H. E. Salter). Most of the money was left to the college by Tho. Kemp, Bp. of London (d. 1489). For the conveyances preceding the sale see Merton Coll. Deeds 3280, 3297, 3277 , $3275,3285,3264,3284,3272,3253$. 60 E.R.O., D/DCc E6 (Blake Hall estate notebk.).

61 Tithe Redemp. Com. Norton Mandeville Tithe Award and $\mathrm{Map}, \mathrm{I} 847$.

62 Merton Coll. Liber Rationarius $1840-72$.

63 E.R.O., Sale Cat. A. 225. 
vicinitatem christienitatis rendered to the church of Fyfield I sack of corn and I sack of oats. ${ }^{64}$ Norton must, however, have had its own church within nine years of that date, for Bartholomew de Dammartin (d. before I I 90 ) and Galiena his mother granted the church to the priory of St. Leonard, Stratford-atteBow. 65 The rectory was appropriated by the nuns of Stratford, who retained it until the Dissolution. No vicarage was ordained, probably because the living was so small. In about 1254 the value was only 6 marks. ${ }^{66}$ The parish is not mentioned in the Taxatio of $\mathrm{I} 29 \mathrm{I}$. In 1428 the taxable value was said to be 8 marks de nov0.67

In 1539 the rectory and advowson were granted by the king to William Rolte, one of his serjeants-atarms. ${ }^{68}$ The benefice remained a donative. The impropriator took all tithes and the incumbent was usually styled a curate, not a vicar. In 1541 rectory and advowson were granted by the king to Sir Ralph Sadler, one of his chief secretaries. ${ }^{69}$ In I 543 Sadler conveyed them to William Pawne (d. 1570) lord of Chivers Hall in High Ongar (q.v.). ${ }^{70}$ They descended with Chivers Hall until I 578 , when Bridget and William Chatterton conveyed them to Edward Elliott in accordance with the will of William Pawne. ${ }^{71}$ Elliott died in 1595 leaving as his heir his son Thomas, later knighted. ${ }^{72}$ In 1627 Sir Thomas conveyed rectory and advowson to Edward Ditchfield senior, Thomas Ditchfield, and Edward Ditchfield junior. ${ }^{73}$ In 1656 they were conveyed by John Ditchfield and Elizabeth his wife to Anthony Nicholas. 74

Anthony Nicholas was impropriator in 1683.75 In 1685 he settled the rectory and advowson upon his son John (d. 1714).76 John was succeeded by his son Anthony, who died in 1727 , leaving his property to his brother William Nicholas. In the following year William sold the rectory and advowson to William Binkes of North Weald for $£ \mathrm{r}, 7 \mathrm{I} 2$. Binkes immediately mortgaged them to Nicholas for $f_{1}, 000$. In I 736 the mortgage was purchased from Nicholas by Elizabeth Bayley, widow. In 1739 rectory and advowson were bought by William Elderton, apothecary of London, who paid $£_{1}, 625$ to Binkes and $£_{1}, 29 r$ to Mrs. Bayley.77 A map of the parish drawn for Elderton in 1740 by Thomas Skinner still survives. ${ }^{8}$ Elderton died in 1755 , leaving William his son and heir. In 176. William Elderton mortgaged the property for $£_{600}$, and in 1763 he sold it to John Searle, who paid $£ 2,600$ for the freehold and $£ 600$ to redeem the mortgage. Searle or his father had been tenant of the glebe in 1740.79 He made his will in 1764 , on the eve of his departure to China as a supercargo in the service of the East India Co. ${ }^{80} \mathrm{He}$ died after 1772 , leaving an only dauighter and heir Mary Anne, wife of James Flint of Ospring, Kent. In I 800 Mrs. Flint sold the rectory and advowson to Capel Cure of Blake Hall in Bobbingworth (q.v.). ${ }^{8 \mathrm{r}}$ They remained in the Capel Cure family and had the same descent as Blake Hall until 1923, when the titular vicarage of Norton Mandeville was merged with the vicarage of Blackmore. ${ }^{82}$ The patronage of the joint vicarage has subsequently been vested in the Bishop of Chelmsford. ${ }^{83}$

Owing to impropriation the curate's income from the benefice continued to be very small after the Dissolution. In 1769 the curate received only $\& 6$ a year, and held services once a month for a congregation of 6 or 7 whose lives were said to be endangered by the damp of the church. ${ }^{84}$ By 1810 the income was 658 , of which 66 came from the impropriator, $\{\mathrm{I} 8$ from a cottage and 9 acres of land at Radley Green (in Roxwell), $f_{3}$ o from a house and 27 acres of land near Rochford and $£_{4}$ interest from a $£ 200$ endowment from Queen Anne's Bounty. In I 8 Io the curate raised the rent of the cottage to $£ 24$ and that of the house to 660 , thus bringing the total income to $694 .{ }^{85}$ In I 847 the tithes of the parish were commuted for $f_{0} g^{8}$, of which $£_{1}$ o were payable to John Caton, and $£_{3}$ to John Mullocks. The remaining $\oint_{0} 185$ was payable to Capel Cure, who also owned the 23 acres of glebe. ${ }^{86}$

In 1610 there was a parsonage house at Norton Mandeville, with barn, stable 'and other necessary houses pertaining thereto'. The house was probably on the site of the later Parsonage Farm, mile east of the church. By I 740, if not earlier, this had ceased to be occupied by the curate and in 1848 there was said to be no parsonage house. 87 The non-residence of the curates was no doubt caused in the first place by the poverty of the living, which made it necessary for them to hold another benefice in addition to that of Norton Mandeville. In the Igth century the curate sometimes held this living alone and in this case evidently had to find his own accommodation. ${ }^{88}$

The parish church of $A L L S A I N T S$ is a very small building consisting of nave, chancel, and south porch with a small bell-cote at the west end of the nave. The walls are of flint rubble dating mostly from the first half of the I $4^{\text {th }}$ century, but mixed with this are blocks of freestone from a 12 th-century church. Buttresses have been built externally at various dates. The south porch dates from 1903 .

As noted above there is reason to suppose that the original parish church of Norton Mandeville was built between II 8 I and IIgo. It is probable that this stood on the same site as the present church. The worked stone, visible in the external walls of the church, has late-12th-century detail, including nail-head ornament. The font bowl, set on a later base, is of Barnack stone, square, with angle shafts, and is of the 12 th century. Part of a pillar piscina in the nave with spiral fluting to the shaft is of the same period. The pointed inner arch of the south door may be of the $\mathrm{r} 3$ th century, later reset. The north doorway has a semicircular arch but it has been much restored and the date is obscure.

During the first half of the $14^{\text {th }}$ century the church

\footnotetext{
64 Dom. of St. Paul's (Camden Soc. I 858 ), I 50 .

6s Cal. Chart. 1 341-1417, 194.

66 Lunt, Val. of Norwich, 336 ; cf. E.A.T. N.s. xviii, I 9 .

67 Feud. Aids, ii, 205.

68 L. $\sigma^{\circ}$ P. Hen.VIII, xiv (1), p. I61.

69 Ibid. $x$ vi, p. $3^{8} 3$.

70 Ibid. $x$ viii (I), p. 199.

${ }^{11} \mathrm{CP}_{25(2) / 120}$ Mich. 20-2 I Eliz.; ibid. Hil. 21 Eliz.; $\mathrm{C}_{142 / 181 / 55}$.

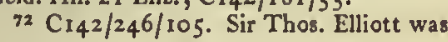

${ }_{73} \mathrm{CP}_{25}(2) / 526$ East. 3 Chas. I.

74 E.R.O., D/DCc T 48 .

73 E.A.T. N.s. xix, 268.

76 E.R.O., D/DCc $\mathrm{T}_{4} 8$. Much of what

follows is from this source.

77 Ibid.

78 E.R.O., D/DCc PI : Map of Norton

Mandeville $174^{\circ}$.

79 lbid.

80 E.R.O., D/DCe $\mathrm{T}_{4} 8$.
}

81 Ibid.

82 Chel. Dioc. rear Bk. $1923,1924$.

83 Ibid.

84 Description of Eng. and $W$ ales (1769), p. 26 .
85 E.R.O., D/DCc E6.

86 Tithe Redemp. Comm. Recs. Norton Mandeville Tithe Award and Map.

87 E.R.O., D/DCe PI : Map of Nort. Mand. 1740; White's Dir. Essex (1848).

88 Thus in 1874 the Revd. F. A. S. Fane was living at Priors, Kelvedor Hatch. 


\section{A HISTORY OF ESSEX}

was entirely rebuilt. There are two two-light windows of this period in both north and south walls of the nave, the tracery design being a little different on the two sides. On the south side the original stonework is much decayed. There is a double locker in the north wall and an original piscina with a trefoil head but without a drain on the south side. The roof of the nave has three trusses with I 4 th-century king-posts with moulded caps and bases and two-way struts. On the westernmost truss two braced posts support the bell-cote which may be of this century or the next. Fourteenth-century slip-ware tiles, recovered during the restoration of 1903 , have been set round the font. ${ }^{89}$ In the chancel the single-light window in the north wall is original, that in the south wall a copy, probably retaining its original splay. Farther west is a 'low side' window, probably also of the I 4 th century. 'The east window has an original chamfered rear arch and splay: the tracery is a copy of 14 th-century work. The piscina is modern but similar in design to that in the nave, the scalloped drain being original.

The chancel roof truss has a chamfered king-post with two-way struts and is probably of the I 5 th century. Some restoration of the church may have taken place in the I th $^{\text {th }}$ century. The wooden frame to the west window appears to be of this date. of a donation of 6900 from the Revd. W. M. Oliver, former Rector of Bobbingworth, given anonymously .90 The timber porch was built or rebuilt at this time, and among other items several windows were renewed. In 944 the church was damaged by blast from a rocket bomb.

The chancel screen, probably dating from $19 \circ 3$, incorporates tracery carving of the 15 th century. Six I6th-century benches in the nave have roughly carved finials. An hour-glass stand of wrought-iron, probably of the I $7_{\text {th }}$ century, was formerly fixed to the splay of one of the nave windows.91 It has recently been taken down but is still in the possession of the church. The communion table is of carved oak of the 17 th century. Carved and painted figures of the lion and unicorn from a royal arms of the early i 8 th century are set on brackets at the base of the westernmost rooftruss of the nave. The turned balusters of the communion rails are of mid-1 8 th-century date. The In the 'low-side' window is stained glass given in memory of John Caton (d. 1892 ). The glass in the east window was erected in memory of the anonymous benefactor of 1903 . There are inscribed floor slabs in the nave to Mary and Robert Hadsley, r 824 and 1840 .

There is one bell, dated I 872 , by John Warner \& Sons, London. It replaced a bell of the same size dated 1782, and 'obviously by Chapman \& Mears'.92 'The plate consists of a cup of 1724 , a paten of 1703 , given
In 1903 the church was restored largely by means altered pulpit has enriched I 8th-century mouldings.

by John Searle, and an almsdish, undated, also given by him. 93

The church hall at Norton Heath was built in I 913.94 It is a rectangular wooden building.

In 1875 land at Norton Heath was acquired for Elo from a Mr. Caton, and NONCONFORMITY vested in trustees for the erection of a Congregational church. Among the trustees was George A. H. Woods, missionary of Cooks Mill Green, Writtle.9s The church subsequently erected is now associated with those at Writtle and Cooks Mill Green.96 It is a small wooden building south of the main road to Chelmsford and is just inside High Ongar parish. ${ }^{97}$

No parish records are known to survive except the registers. Details of poor relief,

POOR RELIEF 1776-1821, which are given below, come from returns made to Parliament and may not always be very accurate. 98 In 1776 a total of 670 was said to have been spent on poor relief. 99 The average for $1783-5$ was 636.1 The cost of relief was given as 6140 for $1800-1$, and for $1816-17 .^{2}$ Between those years it fiuctuated, averaging slightly over $£$ roo a year. Only once, in $1815-16$, was it higher $\left(f_{1} 50\right)$ than in $1800-1$. In $1817-18$ it was given as 630 , in $1819-20$ as $£ 116$ and in $1820-1$ as fioo.3

There was a cottage in three tenements in Norton Mandeville which was used as a poor house. ${ }^{4}$ It was sold by the Ongar Union in 1837.5

There was no school in the parish in 1818 . The perpetual curate reported that the poor SCHOOLS would use any educational facilities made available, but that financial difficulties prevented the establishment of a school. 6 In 1833 there was still no church school, not even a Sunday school, but I I children were attending a private school, established in 1831.7 In 1836 a dame school was established at Norton Heath under church guidance. In 1839 it had I 4 pupils and received about $\left\{3\right.$ a year in voluntary subscriptions. ${ }^{8}$ In $1846-7$ i was attended by 14 boys and 16 girls and was administered in connexion with a Sunday school. The mistress was paid $f_{0} 5$ a year; a proper schoolroom was 'very much wanted'.9 This school seems to have existed in various forms for nearly 50 years. ${ }^{10}$ In 1870 $7 \mathrm{I}$ it was still 'a well-conducted dame school in a cottage'"I attended by some 22 children. ${ }^{12}$

In 1874 a school was built with 25 places. ${ }^{13}$ It was at Norton Heath and belonged to J. L. Newall of Forest Hall, who granted its use, rent free. ${ }^{14}$ Attendance rose to 46 in 1886 , when there was said to be accommodation for 43 ; an annual grant of 649 was then received. Is The school was closed about I 893 , the children being sent to High Ongar and Paslow Wood Common schools. ${ }^{16}$

\footnotetext{
89 E.A.T. N.s. xiv, 122.

90 E.R. xiv, 186. Inscription on east window.

91 Hist. Mon. Com. Essex, ii, 200.

92 Ch. Bells Essex, 348.

93 Ch. Plate Essex, I 39

94 Kelly's Dir. Essex (1933).

93 Essex Congr. Union Deeds.

96 Congr. Year Bk. 1948

97 E.C.U. Deeds.

98 Cf. Greenstead, Poor Relief.

99 E.R.O., Q/CR I/I. This seems high figure for the time, if correct, for the population can hardly have been more than
}

8 E.R.O., D/P 30/28/19.

- Nat. Soc. Enquiry into Ch. Schs. $1846-7$, Pp. 14-15

10 White's Dir. Essex (1848, 1863). Kelly's Dir. Essex (1855-82).

11 E.R.O., D/AEM I/1/1.

12 Retns. Elem. Educ. H.C. 201, pp. $112-13$ (187 I), Iv.

13 Kelly's Dir. Essex (1882)

14 Min. of Educ. File I $3 /$ / 99

is Rep. of Educ. Cttee. of Council, 1886

[C. 5123-1], p. 520, H.C. (1887), xxviii.

16 Min. of Educ. File 13/199; Kelly's Dir. Essex (1894). 
John Cooch Caton, by will proved 1896, left $£ 50$ in trust for the maintenance of his CHARITIES grave. Any balance was to be distributed in bread to the deserving poor at Christmas each year. The first bequest was void under the rule against perpetuities. In I933-4 the dividend of I $9 s .4 d$. was distributed in bread to 28 people. ${ }^{17}$

\section{CHIPPING ONGAR}

Chipping Ongar is a parish and small town I I miles west of Chelmsford and 2 I miles north-east of London. ${ }^{\text {I }}$ It has been known in the past as Castle Ongar. ${ }^{2}$ The modern form of the name dates from the I4th century and relates to the ancient market of the town. ${ }^{3}$ Ongar has been important for more than 1,000 years as the principal place in the hundred and later as the head of a poor law union, petty sessional district and rural district. The population has always been small and the main street is still only a few minutes walk from the open country, but the town houses, the concentration of shops, and the little gasometer by the bridge all proclaim the place to be more than a village.

Chipping Ongar is situated on one of the few patches of glacial sand in this clay area. The parish is bounded on the east by the River Roding and on the south and west by Cripsey Brook. The land rises sharply from I $50 \mathrm{ft}$. above sea-level in the south, east, and west to more than $200 \mathrm{ft}$. in the centre and north. The main road from Chelmsford to Epping enters the parish in the north-east by High Ongar Bridge and leaves it in the north-west by Ackingford Bridge. At Wants crossroads this road is joined by that which runs north to Shelley, Fyfield, and the Rodings, and by the main road from Chipping Ongar to Stratford and London. The town lies mainly along this last road, which runs south down the hill and leaves the parish in the southwest by Ongar Bridge. Beyond the bridge the road runs up Marden Ash Hill. Marden Ash is in High Ongar parish (q.v.) but is in fact a suburb of Chipping Ongar. The road from Ongar to Brentwood and Tilbury branches south-east from Marden Ash. To the west of Cripsey Brook, in the parish of Greenstead (q.v.), there is a new housing estate which is also part of the town. Ongar railway station, in the north of the parish, is the terminus of the line from Epping and London.

Soil and situation were favourable for early settlement. The name Ongar ('grass land') indicates that this place and High Ongar (q.v.) were less thickly wooded than the surrounding district. The possible use of Roman bricks in the castle gateway and the church (see below) and the importance of Chipping Ongar in and after the I I th century suggest that this was one of the oldest settlements in the hundred. The huge mound which formed the centre of the castle (see below, Manor), together with the other earthworks, probably dates from the IIth or the I 2 th century. ${ }^{4}$ 'The castle stood on the spur midway between the Roding and Cripsey Brook. 'T'o the west of it were the inner bailey and the town enclosure. The defences of the enclosure are well preserved on the north-east and consist of a rampart and outer ditch branching from the north end of the inner bailey. The ditch, now nearly dry, is $55 \mathrm{ft}$. wide and $7 \mathrm{ft}$. below the crest of the rampart. The profile diminishes westward and the rampart disappears before reaching the road. The south arm of the enclosure probably followed the line of what is now Castle Street. The course of the enclosure on the west appears to be marked by an escarpment running south through the gardens of the houses on the west of High Street. The entrances were probably at the points where the main road passes through the enclosure. 5

In the I 2 th century there were no doubt several buildings within the enclosure; for Ongar was then an important place, and its castle the home of Richard de Lucy, the Justiciar. Apart from the church (see below) there is no surviving building earlier than the 16 th century, although it is possible that some traces of medieval building are obscured by later work. ${ }^{6}$ The White House and the Castle House (for both of which see below, Manor) are the largest houses in the town which date from the r6th century. The other buildings of that century are actually outside the town enclosure. A house, now shops, which stands on the west side of High Street to the south of Castle Street retains an original central chimney-stack with grouped diagonal shafts. ${ }^{7}$ South $o$ ? it is another building of the same or slightly later date which has a half $\mathrm{H}$-shaped plan with wings extending towards the west. An upper story formerly projected on the east front of the north wing. ${ }^{8}$ Near these buildings, on the opposite side of the road, is The Old House, which may date from about the same period. 9 Apart from the Castle House and the White House the oldest secular buildings inside the town enclosure are the market house (see below, Occupations) and the house next to it (now shops). ${ }^{10}$ On the opposite side of High Street, on the corner of the street leading to the church, is a twostory shop with basement and attics, which bears on its original doorway (now blocked) the initial and date w. I642."1 Opposite this shop is that of Baugh, chemist, which with King, greengrocer, forms a threegabled building having the original central chimneystack with eight octagonal shafts. ${ }^{12}$ All the above buildings are timber-framed and plastered, but the King's Head Hotel, which bears the initials and date Rs 1697 , is built of red brick.13 By this time the rectory (see below, Church) had been built to the north of the town enclosure. ${ }^{14}$ Other buildings in the town probably include portions dating from the 17 th century, but these are obscured by later façades. In 167 I there were 94 houses in the parish, including the building
17 Char. Com. files.

I O.S. $2 \frac{1}{2}$ in. Map, sheet 52/5o.

2 P.N. Essex (E.P.N.S.), 72 .

3 See below, Occupations.

4 V.C.H. Essex, i, 296-7.

5 Hist. Mon. Com. Essex, ii, 53-54 (on which this account is mainly based) suggests that the town enclosure ran down to the Cripsey, but the escarpment that runs through the gardens is quite pronounced in places and this seems the more likely course.

6 Most of the older buildings have been greatly altered inside and out.

7 Hist. Mon. Com. Essex, ii, 55. Now (1953) the shops of G. T. Snelling, ironmonger, and E. L. Pullen, baker.

8 Ibid. Now S. Church, butcher, and the 'Royal Oak'.

- The owner, Mr. Scott, has a deed of
I61 3 relating to the house.

10 Hist. Mon. Com. Essex, ii, 53.

II Ibid.

12 Ibid. 55 and plate, p. I29. E.R.O., T/P

96, Ongar W.E.A. Survey I95 I, directed by Mr. P. R. Banham. This Survey includes many photographs.

${ }^{13}$ Hist. Mon. Com. Essex, ii, 53.

It Ibid. 55 . 


\section{A HISTORY OF ESSEX}

on the castle mound. ${ }^{15}$ In 1758 there were 93 premises assessed for the payment of rates. ${ }^{16}$ It is therefore probable that the buildings shown on the map of 1777 covered the same area as those that had existed a century earlier. ${ }^{17}$ The map shows that the built-up area extended down High Street from the north end of the town enclosure as far as Ongar Bridge. Roden House (near the bridge) existed, and there were a few buildings to the south of the bridge, on the parish boundary. The main body of the rectory had been built early in the 18 th century. 18 Lauriston, on the east side of High Street, below Castle Street, is also of the 18 th century. The doorway has a pediment supported by Ionic pilasters. ${ }^{19}$ The original Independent Meeting House was built in 1720.20 A letter dated at Ongar on I 6 October 1798 , which describes the illuminations by which the town celebrated the Battle of the Nile, mentions some of the larger houses that could then be seen in a walk through the town. ${ }^{21}$

Between I 777 and I 841 some cottages were built to the south-west of Ongar Bridge, probably to accommodate the labourers at the brickfield and gas works. ${ }^{22}$ This expansion of the town was accompanied by the improvement or rebuilding of some of the older houses. ${ }^{23}$ Much of this was carried out by the firm of Noble of Ongar, founded in $1805 .{ }^{24}$ The present façade of the White House, dating from about I 835 , is said to have been built by this firm. ${ }^{2 s}$ Holmlea, a short distance north of Lauriston, is a good house built about I 780 , with a central round headed window in the first floor and in the roof. ${ }^{26}$ Mayfield, a red-brick building in Castle Street, is said to date from $1809 .{ }^{27}$ Ongar House, of gault brick, and The Wilderness, which stand on the east of High Street, near the north arm of the town rampart, were refronted early in the 19th century. ${ }^{28}$ Ongar House has a symmetrical façade with five windows in each of the upper floors. The doorway has simple pilasters but no porch. The windows have external shutters. A third story was added to the house in 1952. ${ }^{29}$ The Wilderness is an $\mathrm{H}$-shaped house in which there have been many alterations at various times. One important building erected during this period was also demolished before I 840. This was the Assembly and Card Rooms, built in or soon after 1786 on ground in High Street, previously occupied by the parish pound, pillory, and cage. The Rooms were removed about 1830.30

Several buildings erected after I 84 I are in classical style. The most striking of these is Greylands, which adjoins King the greengrocer to the north. It was built in $\mathrm{I} 843$ by J. Gerry to the design of T. M. Baynes. ${ }^{31}$ It is a large symmetrical house of gault brick with an imposing porch flanked by heavy Doric columns. ${ }^{32}$ The wine shop, opposite Greylands, is roughly contemporary and is also of gault brick. It is said to have formed a pair with a building which once stood on the site of the present London Co-operative grocery. ${ }^{33}$ The old grammar school (see below, Schools) was built about 1850. The present façade of Roden House dates from the late I gth century (see below, Schools).

The police station (see below, Public Services) was the first large building in the town to depart from the classical style. Contemporary with it is the original portion of the Ongar Primary School (see below, Schools). The railway station came slightly later, the Budworth Hall, High Street, was built in I 886 and the offices of the Ongar R.D.C. in I 896.34 In $5896-7$ High Street was made more accessible to traffic by the removal of the old Town Hall.33 This had stood detached in the street at the point where it now widens, to the north of the church. ${ }^{36}$

Several of the smaller buildings erected about the middle of the I 9 th century were possibly the work of Edward Sammes, who was described as a builder in a directory of 1840.37 In 1837 he owned two houses in the town. ${ }^{38}$ By I 848 he owned some 20 houses and cottages. ${ }^{39}$ Sammes Cottages, near the gasworks, were named after him. He was a grocer and general broker as well as a builder. 40

Apart from those named above few buildings in Ongar were erected between I 875 and 19I4. There are some houses in Castle Street dating from this period, a small terrace to the south of the railway station, and also a few houses at the south end of the High Street, and in Bushy Lees.41 The building at the north end of High Street, which is now Great Stoney Boal ing Secondary School, was erected in 1903.42 It was originally a children's home of the Hackney poor law union. In 1931 there were 206 dwelling houses in the parish. 43

Medieval taxation assessments, printed below (pp. 300 f.) suggest that Chipping Ongar was then much more densely populated than any other place in the hundred, although its total population was not the greatest. Some idea of the population can be gathered from the fact that there were 108 poll taxpayers in I 377. In I $80 \mathrm{I}$ the population was 595 , and by I $84 \mathrm{I}$ had risen to 870.44 After some fluctuations it was 967 is E.R.O., Q/RTh 5.

36 Vestry Bk. 1743-75, at the rectory.

$17 \mathrm{~J}$. Chapman and P. André, Map of Essex, $x 777$, sheet xvii. For a drawing of the town from the west, dated July 1766 , see E.R.O., Prints, Chipping Ongar.

18 See below, Church

19 E.R.O., T/P 96, Ongar W.E.A. Survey, 1951.

20 See below, Protestant Nonconformity. 21 R. I. Porter, $A$ Few Notes on the Town and Parish of Chipping Ongar (Ongar, 1877), 24. The letter was written from what is now Shelley House, but which was then called Bowes House. The present Bowes House took over the name early in the rith cent. Shelley House is in the parish of Shelley, q.v.

22 E.R.O., D/CT 262. For a print of Ongar looking north across Ongar Bridge in 1832 see T. Wright, Hist. Essex, ii, 328. 23 For the increase in rateable values see below, Parish Government and Poor
Relief.

24 E.R.O., T/P 96. Some of the building was carried out in local brick-perhaps from the brickworks on the Greenstead Road. 2s Ibid.

26 N. Lloyd, History of the English House, pp. 286, 303, gives illustrations of Holmlea, which he refers to as the White House.

27 E.R.O., T/P 96.

28 Ibid.

29 Personal observation.

30 R. I. Porter, Notes on Chipping Ongar, 23. For the site see below, Parish Government and Poor Relief.

3I E.R.O., T/P 96.

32. In 1897 Diamond Jubilee celebrations were held outside Greylands: see photographs, E.R.O., Prints, Chipping 33 E.R.O., T/P 96.

34 Ibid. The Budworth Hall was built by Fothergill Watson of Nottingham : inf. from Mr. D. W. Hutchings.

3s Essex Almanack, 1906, 225. The deeds of the Town Hall were bought for foso in Dec. 1896 by Thomas Cowee, who undertook to pull the building down by 25 Mar. 1897 . There is some ironwork from the Town Hall at the back of Snelling's ironmonger's shop in Chipping Ongar: inf from Mr. D. W. Hutchings. 36 E.R.O., D/CT 262. And see below, Occupations. For a good print of the Town Hall, 1818 , by I. Hassall, see E.R.O., Prints, Chipping Ongar. It was a two story building, the ground foor being open at the end. For a photograph of it taken shortly before its demolition see plate facing p. 156.

37 See below, Occupations.

38 E.R.O., D/P $124 / 23 / x$.

39 E.R.O., D/P $124 / 23 / 2$

40 White's Dir. Essex (1848).

4 Inf. from County Planning Dept.

42 Inf. from Mr. D. W. Hutchings.

43 Census, 1931.

44 V.C.H. Essex, ii, 350 


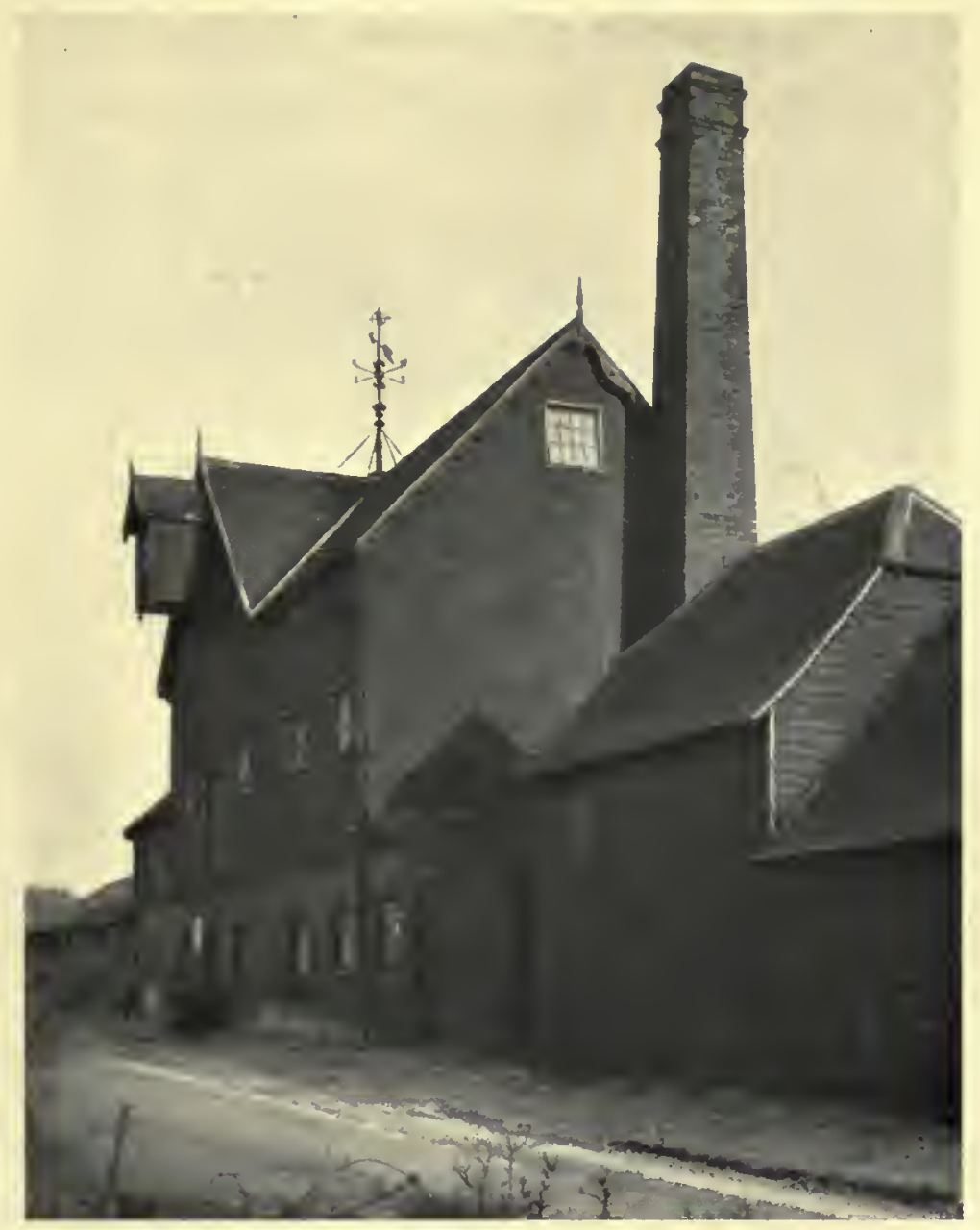

Former Steam Mill, Navestock

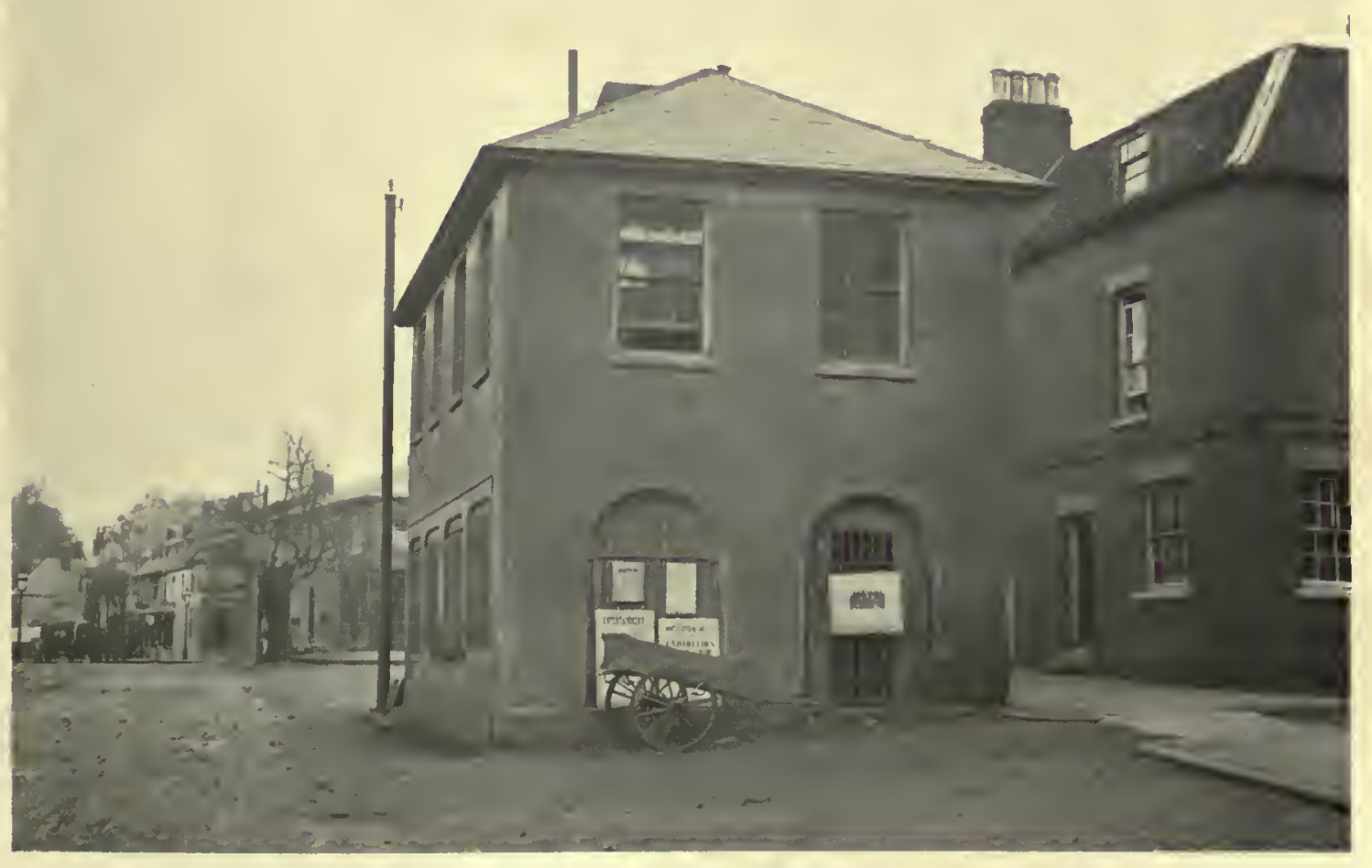

Town Hall, Chipping Ongar

Demolished I 896-7; photograph of $c$. 1890 




Castle House and the Moat of Ongar Castle in 1832

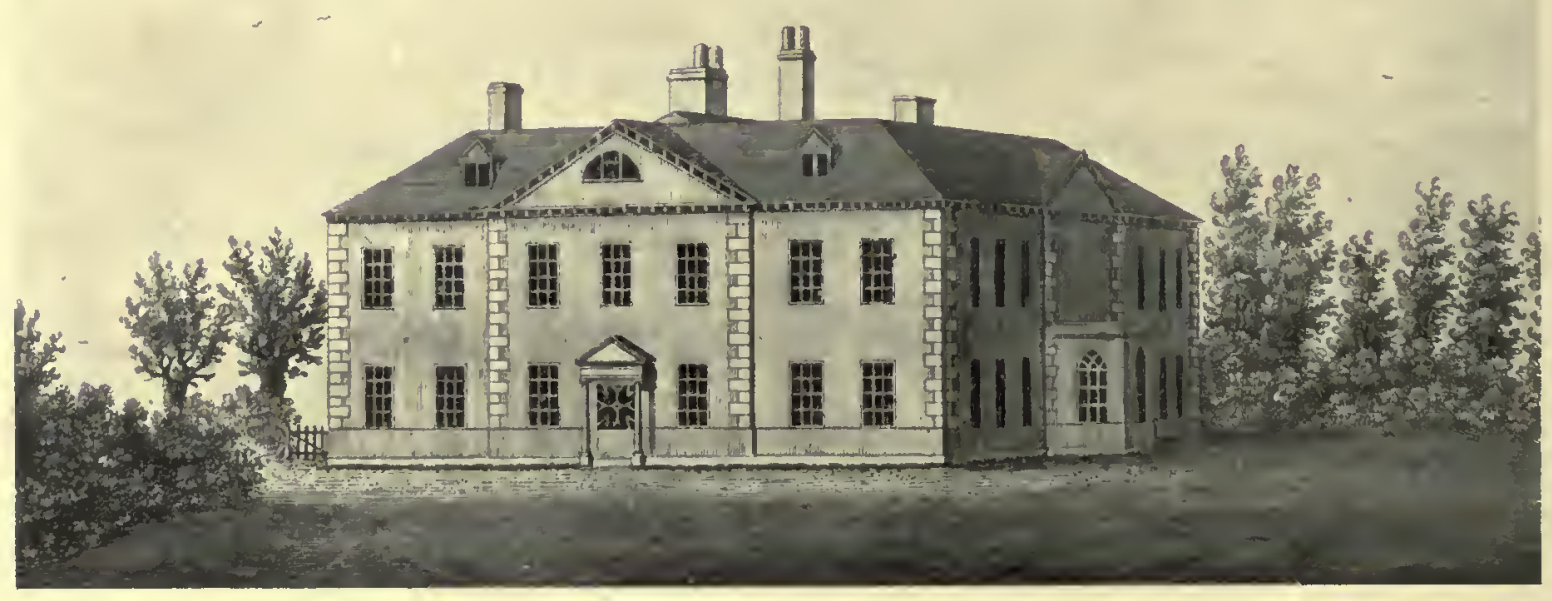

Greenstead Hall in the Late 18 th Century 
in 1901 . An increase to $I, 362$ in I 91 I was largely accounted for by the arrival of the children at the Hackney home. Population has decreased steadily since r 911 . One cause of this was the decline and closing of the grammar school. In I 95 I the population of the parish was 925.45 In the suburbs of Ongar, just beyond the parish boundaries, there has, however, been a considerable growth of population through the recent building on the Greenstead and Shelley estates and at Marden Ash. An attendance of over 300 pupils at the Ongar primary school in 1952 gives an indication of the population of the town and its suburbs (see below, Schools).

The roads leading out of Chipping Ongar to the south, east, and west all pass over bridges on or near the parish boundary. Ongar Bridge is entirely in the parish. Ackingford Bridge is common to Chipping Ongar and Bobbingworth and is treated here. High Ongar Bridge, although it spans the boundary between the two Ongars, has usually been considered as falling wholly in the parish from which it takes its name, and is treated under High Ongar (q.v.).

Ongar Bridge, on the most direct road to London, must have been of the greatest importance to the town. Sir Peter Siggiswyk, whose will was proved in I 503 , left ros. to be spent on the upkeep of the bridge.46 In I 574 it was stated at Quarter Sessions that the bridge was in decay and that responsibility for it was unknown.47 This presentment was later repeated.48 In I 58 I Quarter Sessions ordered that the county should assume responsibility.49 This decision had apparently been forgotten by 1626 when the bridge was once more in need of repair. ${ }^{50}$ It still needed repair in 1628 , and the sessions ordered a county rate to be levied for this purpose.5I Soon after this the hundred jury complained that although the rate had been collected the repairs had still not been carried out. 52 The bridge was again presented for disrepair in $164 \mathrm{I}$, and by order of the sessions a 'lean-to or rail' was set up on it. ${ }^{53}$ Repairs were again ordered in $1657 .{ }^{54}$ The next reference to the bridge in the sessions rolls is in 1660 , when it was stated that the wharf was decayed and should be repaired by the county.55 In 1677 the bridge was in a dangerous condition. ${ }^{56}$ The sessions ordered Richard Luther and Thomas Alexander to employ workmen to repair it without prejudice to the county if it should later be found that the parish was responsible.57 After this time Ongar Bridge seems to have been accepted without dispute as a county bridge. The county paid 685 for its repair in 1697 and 2166 in $1715.58 \mathrm{In}$ 1857 the county surveyor described the bridge as having three unequal arches finished with a brick parapet, the walls being coped with stone. 59 It has not been radically altered since. ${ }^{60}$

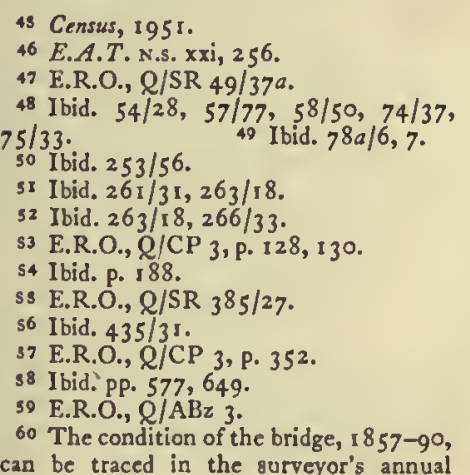

reports : ibid.

62 E.R.O., Q/SR 44/34. Ackingford is an Old English name of early origin. The first written reference to it is in 1248 : P.N. Essex, 53 .

62 Ibid. $166 / 143$. 63 Ibid. $209 / 55$. 64 Ibid. $231 / 25$. 65 Ibid. 232/27. 66 E.R.O., Q/ABb 4. For the career of John Johnson (1732-1814) see Jack Simmons, 'Notes on a Leicester Architect: John Johnson', Trans. Leics. Arch. Soc. xxy, 144. Johnson became Essex County Surveyor in 1782 . The article refers to Ackingford Bridge (p. 148, n. 24).

67 E.R.O., Q/SO 19, p. 602.

68 E.R.O., Q/ABz 3 .
Ackingford Bridge was in need of repair in 1573 , and responsibility for it uncertain. ${ }^{61}$ The hundred ury stated in 1604 that it should be repaired by the ought to mend their side of $i^{63}$ and in 1620 Bobbingsible.64 In 162 I the county was said to be responsible 65 ane the bridge always seems to have been the road which crossed it had been turnpiked doubt the reason for the building of a new bridge in I 806 . The plan of this bridge, drawn by the architect, John Johnson, still exists. ${ }^{66}$ The bridge was completed January 1807.67

The county surveyor, who visited Ackingford feptember I 857 , described it as being buil precisely similar to Leaden Wash Bridge (in Leaden Roding). ${ }^{68}$ It was then in good repair, but by 1862 the cnds of the main girders had begun to decay. ${ }^{69} \mathrm{Be}$ The bridge was rebuilt in 1913 , in con-

In I659 the inhabitants of Chipping Ongar were presented at Quarter Sessions for their failure to repair he foot-bridge called Bantons, which spanned Cripsey ' evidently a fairly important staging place for travellers: according to a survey of that year there was accommodation in the town for $7 \mathrm{I}$ lodgers and 104 horses. 74 These Harwich, Maldon, Witham, and Coggeshall; for lodgers Ongar had more accommodation than Billericay, Dunmow, Kelvedon, and Saffron Walden, and for there was more stabling than at Rayleigh. Ongar every Tuesday, Thursday, and Saturday,75 Tuesday a wace every started from the 'Saracen's Head', Aldgate, on 'Tuesday and Friday. ${ }^{76}$ In 18 I 7 coaches plied daily to Ongar from the 'Three Nuns' and from the 'Bull', Aldgate.77 There were wagons from the 'Three Nuns' on 'Tuesday nd Friday and from the 'Swan', Whitechapel, on ednesday and Saturday. ${ }^{78}$

1826-7 a coach left the Crown Inn, Ongar, the two carriers to London, Stephen Clements who left on Tuesday and Friday, and Thomas Nichols who left on Monday and Thursday.

$$
69 \text { Ibid. } 70 \text { Ibid. }
$$

71 Personal observation. The bridge bears the date of rebuilding. ${ }^{72}$ E.R.O., Q/SR $378 / 21$; i.e. Bansons bridge. ${ }_{3} \mathrm{E} R$ vii,

74 Ibid. liii, I I. The survey is among the War Office Records in the Public Record Office.

75 Universal Brit. Dir. 1791, vol. i, Pp. 508,540 . The details are somewhat doubtful because the directory is inconsistent. 76 Ibid. 77 Fohnsrone's London Commercial Dir. 1817 , pt. iv, p. 29

78 Ibid.

79 Pigot's Commercial Dir. (1826-7), 526 . 


\section{A HISTORY OF ESSEX}

Their terminus was the 'Three Nuns', and they returned on the following days. ${ }^{80}$ In 1833 the coaches belonging to A. Nelson \& Co., left the 'Bull' twice a day for Ongar, with accommodation for 6 passengers inside and 12 outside. ${ }^{81}$ Carriers' wagons also ran daily from the 'Bull'.82 In I 848 there was a daily coach to London from the 'Lion' at Ongar. ${ }^{83}$ 'There were also coaches to Brentwood railway station, leaving the house of John West, coach proprietor, twice daily. ${ }^{84}$ Stephen Clements's wagons still left for London on Tuesday and Friday. ${ }^{85}$ The wagons of Samuel Drake and Henry Wood left for Chelmsford on Monday, Wednesday, and Friday. ${ }^{86}$ In 1863 , shortly before the railway reached Ongar, there were still one daily coach to London and two to Brentwood station. 87 There was also a mail cart to Romford. ${ }^{88}$ Clements operated the same wagon service to London, and Samuel Drake to Chelmsford.89 John White's wagon went daily to Brentwood. 90

The railway service between Ongar and London was opened in 1865.91 Bus services have been operated since the 1920's. In 1922 there were daily services to Bishop's Stortford and Brentwood.92 Now (1953) there are good services to Epping, Brentwood, Romford and Chelmsford and others to the Rodings and to Harlow.

The earliest reference in the post-office records to a postal service in Chipping Ongar is in 1717 . In that year the name of Joseph King of Ongar occurs in a general list of sub-postmasters; he had a yearly salary of $\{25.93$ His successor in 1727 was Lionel King, who was still serving in 1756 , with the same salary. $94 \mathrm{He}$ was followed by Mrs. Eliza Bancilhon, at first with a salary of $\oint_{2} 25,95$ later of $\ell_{0} 1 \mathrm{I}$, with riding work reckoned at $\oint_{2}$ I.96 This last payment was made by the deputypostmaster to the district surveyor, and it indicates that Ongar was already the centre for some postal service to the surrounding villages. There are similar details for the Epping post-office and it is clear that a by-post served Epping and Ongar at least from the early i 8th century.

A directory of I79I includes this service, the post leaving Epping every day save Monday, with a return service from Ongar every day except Saturday; Mrs. Bancilhon was still postmistress, with 'Thomas Hendry, victualler, of the 'White Hart', as 'Post Office Keeper'.97 Ongar is also included in a list of the chief post and sub-post towns given in Cary's Atlas of I793, with a note that letters leaving London at 3 p.m. reached Ongar at ro a.m. the next day, the cost of a letter being 4d. 98 The rate was raised to $6 d$. in I 8 I 5.99

This by-post between Epping and Ongar is traced as a daily horse-ride in a post-office map of $1813 .{ }^{\mathrm{I}}$ The ride from Epping loops south as far as Abridge and goes on through Stanford Rivers.

In 18 10 James Merrington resigned and James Scruby was made deputy-postmaster at Ongar. ${ }^{2}$ Miss Maria Scruby was appointed six years later ${ }^{3}$ and still held the office in 1845 , when it was described as a postoffice issuing money orders. 4 William Scruby was subpostmaster at least between I $85 \mathrm{I}$ and I $886 . .^{5}$ Later holders of the office can be traced in the county directories.

In the mid-I gth century there were some changes. In I 847 application was made to the Postmaster General both by Epping and Ongar for a daily mail, which was set up later in the year; 6 and in 1852 Ongar was made a post town. 7 Moreover in addition to the old-established by-post between Epping and Ongar, there was a postal service between Romford and Ongar, described as a 'ride' in 1849,8 and as a mail-cart service in 1857.9 In 185,5 a contract was also made for an Ongar-Brentwood day mail service. ${ }^{10}$ After this time the Ongar post-office developed normally in line with the national service. The present post-office is in the centre of the town on the west side of the High Street. The telegraph was in use at Ongar after $1872^{\text {II }}$ and the telephone from I9I $3 .^{12}$

In I 890 Ongar's water supply was being obtained from wells $20-30 \mathrm{ft}$. deep. ${ }^{13}$

PUBLIC SERVICES Local waterworks were AND SOCIAL LIFE established in $1897 . .^{14}$ In 1879 the Herts. and Essex

Waterworks Co. had been empowered to supply Ongar and neighbouring parishes from the pipes between Epping and Sawbridgeworth ${ }^{15}$ and in I 907 the Herts. and Essex Co. took over the local company. ${ }^{16}$ Some form of main drainage was already in existence at Ongar in 1827.57 The Ongar Gas Co. began to supply the town in 1836.18 In 191 I it was absorbed by the Bishop's Stortford Gas Co. and in 1934 the Ongar works were closed, gas being supplied by a trunk main from Epping. ${ }^{19}$ The gasworks were situated to the south of Ongar Bridge, and were at first run in conjunction with the neighbouring brickfield. ${ }^{20}$ There is still a gasometer. Ongar was included in the area covered by the County of London Electricity Act, I927, and electricity was first supplied in I 932.21

The Royal Exchange Insurance Co. had a fireengine at Ongar in 1853 . It was kept in the former parish cage at the south entrance to the town. In that year the parish vestry resolved to demolish the cage and order the removal of the engine. 22 In 1886 there was a town fire-brigade consisting of a captain and eight men.23 The former engine house south of Ongar Bridge was demolished in 1951.24
80 Pigot's Commercial Dir. (1826-7), 526 .

81 Robson's London Dir. 1833 , pt. i, p. 14.

82 Ibid. pt. iv, p. 23.

83 White's Dir. Essex (1848).

84 Ibid. 85 Ibid. 86 Ibid.

87 White's Dir. Essex (1863).

88 Ibid. 89 Ibid. 90 Ibid.

91 A time-table of services from Ongar

to Fenchurch Street in Apr. 1865 was

still preserved at Ongar in $1952:$ inf. from

Mr. D. W. Hutchings.

92 Kelly's Dir. Essex (1922).

93 G.P.O. General Accounts, vol. iii, 17 I I -20 , f. 322.

94 Ibid, vols. iv-vii, $1721-60$, passim; and P.O. Establishment Books.

95 G.P.O. Establishment Books, 1760 , 1763,1769 , passim (not paged).
96 Ibid. I782.

97 Universal Brit. Dir. 1791, vol. iv, PP. $175-6$.

98 J. Cary, New and correct English Atlas... I793.

99 P.M.G. Minutes, 1815, vol. 29, P. 11.

1 G.P.O. Map entitled 'Mr. Western's district', Dec. 1813. A copy of the map is at the E.R.O.

2 P.M.G. Minutes, 18 ro, vol. 25, Pp. 256,272,351.

3 Ibid. 1816 , vol. 29, p. 175

4 Kelly's Dir. Essex (1845), 102.

3 Ibid. $1851-86$, passim.

6 P.M.G. Minutes, 1847, vol. 98 Pp. 232,525

7 Ibid. 1852 , vol. 127 , p. 137 .
8 Ibid. I 849 , vol. I I3, p. 559

9 Ibid. 1857 , vol. 179 , p. 412

10 Ibid. 1855 , vol. 160, p. 107.

II Ibid. I 87 I, vol. 92, min. 272.

12 P.M.G. Mins. 1913 , $\min .24879$

13 Kelly's Dir. Essex (1 89o).

14 Essex Almanac, 1906, p. 226.

Is E.R.O., Q/RUm 2/258.

16 Inf. from Herts. \& Essex Waterworks Co.

17 E.R.O., D/P I 24/8/3.

18 Inf. from Eastern Gas Bd.

19 Ibid. 20 See Occupations.

21 Inf. from Eastern Elec. Bd.

22 E.R.O., D/P $128 / 8 / 3$

23 Kelly's Dir. Essex (I 886)

24 For a photo. of it see E.R.O., T/P 96,

W.E.A. Survey, Ongar, 1951. 
The Ongar Cottage Hospital, consisting of two converted bungalows, was opened in 1928 . It had 30 beds. ${ }^{25}$ The Ongar and District War Memorial Hospital (in the parish of Shelley) was opened in 1932. ${ }^{26}$ The burial grounds attached to the parish church and the Congregational church were closed by government order in $1864^{27}$ and in 1866 a new cemetery was opened in the north of the town. ${ }^{28}$

In I 843 the committee of the newly formed Essex Constabulary rejected an application for a lock-up in Ongar. ${ }^{29}$ Negotiations were reopened in 1847 , when Mr. Budworth offered land for a police-station. ${ }^{30}$ By 1854 building was proceeding and in 1855 there was a police superintendent at Ongar, Joseph Catchpole. ${ }^{31}$

Before the 18 th century the social life of Ongar was probably limited to the parish church, the court house, the shop, and the inn. From about i 720 the Congregational church was drawing nonconformists from the villages as well as the town, and at the end of the 18 th century the building of the Assembly Rooms provided another social centre. During the ministry of lsaac Taylor at the Congregational church (I 8 I I-29) there is said to have been an improvement in the relations between dissenters and the other inhabitants of Ongar (see Protestant Nonconformity). It is probable that this was largely due to the personalities of Isaac Taylor and his family (see also Worthies).

In the second half of the I gth century the local gentry gave a strong lead in the social life of the town. Prominent among them was Capt. P. J. Budworth of Greenstead Hall. He was probably responsible for reviving the fair and was active in most local affairs. The Clerk of the Peace for Essex, Henry Gibson, lived at the White House and in 1870 he built a lecture hall for the town.32 In 1873 a drill hall was built by subscription for the Ist Volunteer Battalion, Essex Regiment; it was also used for meetings and concerts. ${ }^{33}$ The Budworth Hall was built in 1886 as a memorial to Captain Budworth. It contained a large assembly room, reading-rooms, and coffee rooms. A clock tower was added in 1887 and a museum in I 898.34 By this time also the Roman Catholic church had been built and the grammar school had greatly increased in size. A cricket club had been formed in 1845.35 A Mechanics' Institute is said to have been founded in 1848 , but it is not known how long this lasted.36 In 1906 there was an Ongar Agricultural Association, a Constitutional Association, a Horticultural Society, and a Reading and Recreation
Society. ${ }^{37}$ A branch of the county library was opened in 1930.38 Activities at the Budworth Hall have declined, but Ongar is now (1952) well provided with societies, including the Ongar Social and Sports Club with its own ground. 39 There is no cinema. The coming of the motor bus in the 1920's has diminished the importance of Ongar as a local shopping centre, but the town still supplies some of the surrounding villages with certain commodities, particularly foodstuffs.40 Expansion of the present town centre would be difficult owing to lack of suitable space.41

Thomas Velley ( $1748-1806$ ), botanist, was born at Chipping Ongar.42 Isaac Taylor WORTHIES (1759-1829) is mentioned below.43 His son Isaac Taylor (1787-1865), artist, author, and inventor, lived with his father at Ongar before moving to Stanford Rivers. Jane Taylor (1783-r824) and her sister Ann, later Mrs. Gilbert (1782-r 866), werealso children of Isaac Taylor. They collaborated in several books for children, including Original Poems for Infant Minds (1804) and Rhymes for the nursery (1806). Jane also wrote "Twinkle, twinkle little star'.44 John Spriggs Churchill (I 80 I75), medical publisher, was born at Ongar.45 David Livingstone (1 8 1 $3-73$ ) is mentioned below. 46

In early references it is sometimes difficult to distinguish CHIPPING ONGAR from High

$M A N O R$ Ongar (q.v.). By the will of Thurstan, son of Wine (or Lustwine), 1043-5, "the wood at Ongar, except the deer enclosure and the stud which I have there', were left to the servants of the testator, and to Thurstan's servant Thurgot was left $\frac{1}{2}$ hide 'which Allstan occupies at Ongar'.47 'Thurstan's wife was mentioned in the will as Æthelgyth; she appears in Domesday Book as 'Ailid', and was said to have held Ongar before the conquest as I hide and as I manor.48 From her the manor seems to have passed to Ingelric 'the priest'; for in I068 William the Conqueror confirmed the gift of Ongar by Ingelric to the house of St. Martin-le-Grand, London.49 In spite of the gift, however, Ongar was held in 1086 by Ingelric's successor

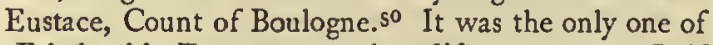
Ethelgyth's Essex estates that did not pass to Ralf Bainard.sI Ralf Bainard, however, held $\frac{1}{2}$ hide at Ongar in 1086 which had previously belonged to a freeman. ${ }^{52}$ Possibly this freeman had been Thurgot.

It was suggested by J. H. Round that Ongar castle, upon its mound, was thrown up by Count Eustace and was the caput of the count's Essex fief.s3 From
23 Inf. from Mr. C. H. Hackney. 26 Inf. from Councillor Miss Hadler. 27 E.R.O., D/P $128 / 8 / 3$.

28 Kelly's Dir. Essex (1886).

29 E.R.O., Q/ACm 15, p. 77. For the old parish cage see above, P. I 56, and Parish Government, below.

30 Ibid. p. 123.

31 E.R.O., Q/ACm 16, p. 8; Kelly's Dir. Essex (1855).

${ }_{32}$ Kelly's Dir. Essex (18go).

33 Ibid.

34 Ibid. (1906).

3s Inf. from Mr. D. W. Hutchings. The original printed rules still exist.

${ }_{36}$ Inf. from Mr. Hutchings.

37 Kelly's Dir. Essex (1 g06).

38 Inf. from County Librarian.

39 Inf. from Mr. D. W. Hutchings.

40 Mr. D. W. Hutchings of Ongar Secondary School recently carried out an inquiry among 200 children at the school, drawn from 35 places, mainly in Ongar
Rural District, concerning the use made by their families of goods and services provided by Chipping Ongar. The answers to his questions suggest that Chipping Ongar provides some goods and services for most of the places within 4 miles of it but that it is an important centre only for people living in 1 i villages : Bobbingworth, Fyfield, Greenstead, Kelvedon Hatch, Moreton, High Ongar, Norton Heath, Shelley, Stanford Rivers, Stapleford Tawney, and Toot Hill. Most of these places are within 2 miles of Chipping Ongar, and they lie mainly to the north and west of the town. For villages to the south and east Brentwood is no doubt the main centre.

${ }^{41}$ In The Greater London Plan (1944), Professor Patrick Abercrombie proposed that Chipping Ongar should be the nucleus of a new town of 60,000 inhabitants (see Pp. 169-7I). The suggestion has not been adopted. It involved a large area surrounding the present town but did not provide for an important alteration of the old town centre.

${ }^{42}$ D.N.B.

43 See Protestant Nonconformity.

44 For the Taylors see D.N.B. also D. M. Armitage, The Taylors of Ongar, and Isaac Taylor, The Family Pen.

4s D.N.B.

46 See Protestant Nonconformity. 47 D. Whitelock, Anglo-Saxon Wills, 82, 84.

48 V.C.H. Essex, i, $467 a$.

49 E.H.R. xi, 740.

so V.C.H. Essex, i, $467 a$.

sI For other lands of Ethelgyth see V.C.H. Essex, i, 347; D. Whitelock, Anglo-Saxon Wills, $190,195$.

s2 V.C.H. Essex, i, $467 a$.

s3 J. H. Round, 'The Honour of Ongar', E.A.T. N.s. vii, $142-52$. At this time Chipping Ongar was apparently a 'member' of Stanford (Rivers) q.v. 


\section{A HISTORY OF ESSEX}

Eustace Chipping Ongar passed as part of the honor of Boulogne to his daughter Maud and her husband King Stephen.54 Between December II 53 and October I I 54 the manor was granted by William, son of Maud and Stephen, to Richard de Lucy, later the justiciar of Henry II. Ongar castle became the caput of Richard's honor of Ongar. Henry II visited the castle in the spring of II 57 and was sought ont there by Richard's brother Walter de Lncy, Abbot of Battle.5s In I 58 Richard de Anesti went to Ongar castle to deliver a writ to Richard de Lucy.s6 Between I 55 and I 59 the king granted de Lucy roo acres of assarts 'in the forest from Stanford, and Greenstead and Ongar'.57

Richard de Lucy retired to the cloister in I I 79, and died in the same year. His son and heir Geoffrey had predeceased him and he was succeeded by Geoffrey's elder son Richard. ${ }^{8}$ Richard the younger was dead before Michaelmas i 82 , and was succeeded by his brother Herbert. 59 In I I 85 it was stated that Herbert and his lands were in the custody of his uncle Godfrey de Lucy (the future Bishop of Winchester). ${ }^{60}$ Godfrey was then said to have had custody for four years.6 6 Herbert de Lucy was dead by I I 89 , when Godfrey was holding the $\oint_{5} 5$ that had previously been his in the hundred of Ongar. ${ }^{62}$

The heirs of Herbert de Lucy were his sisters. The Bishop of Winchester, however, continued to hold the honor of Ongar until II94, when it was given to Geoffrey de Lascelles, the husband of Maud, daughter of Herbert de Lucy's sister Maud.63 In the same year Rose of Dover, another sister, promised the king 6700 for permission to marry and for half of the inheritance of her brother and grandfather. ${ }^{4}$ Geoffrey de Lascelles seems to have retained Ongar until 1 204, when it was granted to Geoffrey FitzPeter, the justiciar. ${ }^{65}$ FitzPeter farmed Ongar at $f_{8} 8$ a year until Christmas I 200, when Robert Peverel became kecper. ${ }^{66}$ In January I 2 I 4 he was credited with the amount he had spent on wine for use at the king's household at Ongar on the Thursday after Christmas. ${ }^{67}$

In I 2 I 4 Mand de Lucy, widow of Geoffrey de Lascelles, was married to Richard de Rivers, a veteran servant of the king. ${ }^{6} 8$ In 12 I 5 Richard was granted permission to make two deer leaps in his great park of Ongar 'as he had right and custom to do'.69 In I 217 I 8 Richard was holding Ongar with Maud de Lncy of the honor of Boulogne. ${ }^{70}$ This was a correct statement of the overlordship. The honor of Ongar built up by Richard de Lncy comprised fees held of the honors of Boulogne, Gloucester, and Mortain. Some of the Gloucester fees lay in Essex, and one of them, Greenstead (q.v.) was near Ongar. 71 'This was probably the reason for later incorrect statements that the manor of Chipping Ongar was held of the honor of Gloucester. ${ }^{2}$

Richard de Rivers died in $\mathbf{1} 2 \mathbf{2} \mathbf{I}-2$. In March $\mathbf{1 2 2 2}$ Richard his son and heir by Maud de Lucy was granted permission to hold a fair at Ongar until he came of age. ${ }^{73}$ Maud de Lucy herself survived until about i 243. Her heir was her grandson John, son of Richard, who was aged 4 in September 1243 (or 1 244).74 Custody of Mand's lands was granted to Philip Basset.75

John de Rivers died in 1294 and was succeeded by his younger son John. ${ }^{76}$ 'The younger John was summoned to Parliament as a peer and is thus held to have become Lord Rivers (of Ongar). 77 As John de Rivers, lord of Ongar, he was one of the barons who sent a letter to the pope in February I $30 \mathrm{I}$, but his seal is not appended to the letter.78 In 1302 he had licence to let the manor of Chipping Ongar to farm for five years to John de Sandale, a royal clerk, the castle and knights' fees being excluded.79 In 132 I or 1322 John de Rivers claimed the reversion of the manor and castle of Ongar which he had leased for their lives to Gilbert de Clare, Earl of Gloucester, and Maud his wife.80 The date of this conveyance is not known. Presumably it was between 1302 and the death of the Earl of Gloucester in I 314. Ongar was one of the places in which the earl had fees in that year, and which were being held in dower by his widow, who died in 1320.81

John de Rivers appears to have been in the rebellion of 1322 . He probably died in that year, but whether he held Ongar at his death is not clear. ${ }^{82}$ Nor is it clear whether he was the host when Edward II visited Ongar castle in November I $321.83 \mathrm{Hugh}$ de Audley, Earl of Gloucester (d. I 347) died in possession of the manor of Chipping Ongar, of the inheritance of Margaret of Clare his wife. ${ }^{84}$ Margaret had died in 1 342. ${ }^{85}$ Their daughter and heir Margaret was the wife of Ralph Stafford, Baron Stafford, and later Ear] of Stafford.86 In 1348 the king granted a licence for the manor of Ongar to be entailed upon Ralph and Margaret and their heirs. ${ }^{87}$ 'This settlement was carried ont in 1351.88 Ralph died in 1372 and was succeeded by his son Hugh.89 Hugh died in 1386 , leaving Chipping Ongar to his son Thomas.90

From this time Chipping Ongar descended with the other possessions of the earls of Stafford, who later be-

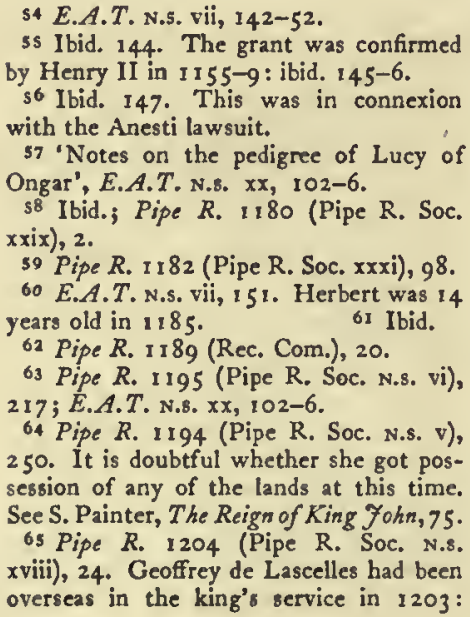

Complete Peerage, xi, 12, He was possibly killed in the war.

66 Pipe R. 1210 (Pipe R. Soc. N.s. xxvi), 206.

67 Rot. Litt. Claus. (Rec. Com.), i, 159. This was clearly for the entertainment of the king himself, for John was at Ongar on 30 and 31 Dec. 1213.

68 Complete Peerage, xi, 12. Richard gave $\ell_{0}, 500$ for the marriage.

69 Rot. Litt. Claus. i, 221 b.

70 Bk. of Fees, 241, 1433. The honor of

Boulogne was now a royal escheat.

II E.A.T. N.s. vii, $148-9$.

72 See e.g. Cal. Inq. p.m. i, p. 6 ; ibid. iv, p. 345. About 1300 the manor of Chippin Ongar was granted by John de Rivers to the Earl of Gloucester (see below), but this did not affect the overlordship.

73 Rot. Litt. Claus. i, 4906.

74 Complete Peerage, xi, $12-13$.

75 Ibid.
76 Cal. Inq. p.m. iii, p. 1og; $\mathrm{Cr}_{33} / 67$; Complete Peerage, xi, $13-14$.

77 Complete Peerage, xi, 14

78 The Ancestor, vii, 256 .

79 Cal. Pat. I $301-7,76$.

80 Complete Peerage, $\mathrm{xi}, 14$

81 Cal. Inq. p.m. v, p. 349.

82 Complete Peerage, xi, 14 ; Cal. Fine $R$ I 319-27, 54, 143-4.

83 Chrons. Edw. I and II (Rolls Ser.), i, 300. John de Rivers had a son and namesake who was apparently killed at Bannockburn: ibid. 231. There was some confusion in the period $1300-22$ between the lands of father and son.

84 Cal. Inq. p.m. ix, p. 56.

85 Complete Peerage, v, 719

86 Complete Peerage (orig. edn.), vii, 209. 87 Cal. Pat. $1348-50,19$.

$88 \mathrm{CP}_{25}(\mathrm{I}) / 287 / 44$, Trin. $25 \mathrm{Edw}$. III.

89 Complese Peerage (orig. edn.), vii, 2 ro; $\mathrm{C}_{3}$ 5/File $230 . \quad 90 \mathrm{Ci} 36 /$ File 47. 
came dukes of Buckingham.91 Henry Stafford, Duke of Buckingham, suffered execution and forfeiture in 1483. Ongar was named among his possessions and was granted by the king in 1484 to Sir Thomas Montgomery for life. ${ }^{92}$ Edward Stafford, son of Henry, was restored to the dukedom in 1485 . He was executed for treason in $\mathrm{I} 5 \mathrm{I}$ and his possessions, including Ongar, passed into the hands of the king. ${ }^{93}$

In I 524 Chipping Ongar was leased for 2 I years to Thomas Maple, yeoman.94 In I 537 William Morris, a gentleman usher of the king's chamber, was granted an 80 years' lease of the manor, to run from the expiration of Maple's lease in I 545.95 In 1542 , however, the king granted the manor absolutely to George Harper, who a month later transferred his interest to Morris. 96 Morris mortgaged the manor in the same year to Eustace Sulyard for $£ 400.97$ William Morris died in I554, leaving James Morris as his son and heir.98 By his will he devised to his wife Anne a life interest in two-thirds of the manor of Chipping Ongar.99 James Morris is said to have erected a pleasure house on the top of the castle mount.' A visit to the 'house of pleasure' may well have been a feature of the visit of Elizabeth I to Anne Morris at Chipping Ongar. ${ }^{2}$ In 1561 James Morris received the queen's licence to alienate the manor to Andrew Hemerford and Christopher Crowe. ${ }^{3}$ This was evidently for the purpose of a marriage settlement, for in $156_{3}$ Hemerford and Crowe were licensed to convey Ongar to James Morris and Elizabeth his wife and the heirs of James's body, with remainder to his right heirs. 4

James Morris died in 1597. Four years before Chipping Ongar had been settled on his son and heir John on his marriage with Katherine, daughter of Sir Gabriel Poyntz of North Ockendon.5 Sir Gabriel had settled the manor of North Ockendon (q.v.) and other property on his daughter and son-in-law and their joint issue and this explains why John Morris later changed his name to Poyntz. John Morris alias Poyntz was knighted and died in 1618.6 His son and heir Sir James Poyntz died in 1623.7 Sir James was succeeded by his son Richard, who died in France in August I643.8 Sir James's brother Poyntz Poyntz evidently succeeded Richard, but died in December of the same year. According to the inquisition on Poyntz Poyntz the next heir to Chipping Ongar was John Morris, son of Edward Morris brother of Sir John Morris alias Poyntz.9

The next step in the manorial descent is not entirely clear. In 1647 John Morris son of Edward was arraigned before the House of Lords on charges of forging various evidences, including Acts of Parliament, to secure his title to Chipping Ongar, North Ockendon, and other manors. The petitioners against him were Sir Adam Littleton, Bt., and Audrey Littleton his wife, Maurice Barrow, and Sir Fulke Greville.10 Audrey was daughter of Thomas Poyntz, son of Sir Gabriel."I There seems little doubt that she was the heir to North Ockendon under the settlements made by Gabriel. She had no claim to Chipping Ongar but here John Morris's title was apparently disputed by Barrow and Greville. Barrow is said to have married Sir James Poyntz's widow and Sir Fulke Greville to have married Anne, sister and coheir of Richard Poyntz. ${ }^{12}$ Elizabeth, the other sister and coheir was apparently the wife of William Duncombe. ${ }^{13}$ Apparently Elizabeth and Anne made good their claim to Ongar, for in 1650 and 1651 a series of conveyances was made by which they secured the manor upon $\mathrm{Sir}$ Thomas Whitmore, Bt.14 Thomas (d. 1653) was succeeded by his son William, the 2 nd baronet (d. 1699 ). ${ }^{15}$ In 1663 William's estate at Chipping Ongar was bringing in $£ 426$ Ios, a year. ${ }^{16}$ The largest tenant was 'Mr. Goldsborough', who paid a rent of $£$ ror. ${ }^{17}$

It must have been in 1663 or 1664 that Thomas Goldsborough, no doubt the tenant mentioned above, bought the manor from Sir William Whitmore. ${ }^{18}$ Goldsborough was dead by 9 September I $664 .^{19}$ Another Thomas Goldsborough was holding the manor of Chipping Ongar in 171820 and it appears to have been about this time that he sold it to Edward Alexander, second son of Nicholas Alexander of Marden Ash in High Ongar. ${ }^{21}$ Edward Alexander in 1744 demolished the house built by James Morris and built in its place 'a large and handsome summer house'. 22 He died in $175 \mathrm{I}$ and was succeeded by his grandson Richard Henry Alexander Bennet.23

Richard H.A. Bennet made a settlement of Chipping Ongar in 1766 before his marriage to Elizabeth Amelia, daughter of Peter Burrell of Beckenham (Kent). ${ }^{24} \mathrm{He}$ died in $\mathrm{I} 8 \mathrm{I} 4$ and was succeeded by his son, also named Richard Henry Alexander Bennet.25 The son died in 1818 , and Elizabeth Amelia his mother in 1837.26 Under the will of R. H. A. Bennet the father ( 1811 ), remainder was to his daughters Emilia Elizabeth, wife of Sir John Swinburne, Bt., and Isabella Julia, wife of Sir James Willoughby Gordon, $\mathrm{Bt}_{.}{ }^{27}$ By means of a private Act of Parliament ( 1838 )
91 Complese Peerage (orig. edn.), vii, 2 I I-12; Complete Peerage, ii, $388 \mathrm{f}$.

$92 \mathrm{C} 145 / 33^{\circ}$; Cal. Pat. 1476-85, 430.

93 Complete Peerage, ii, 390; E I $50 /$ File 306 , no. 6.

94 L. \& P. Hen. VIII, xii (2), p. 281. Maple had been farmer under the Duke of Buckingham as early as I 510-11 : E.R.O., D/DP M 588 .

9s Ibid.

96 L. \& P. Hen. VIII, xvii, p. 16 r.

$97 \mathrm{CP}_{4}$ \%/III4 m. 8.

$98 \mathrm{C}_{142} / 100 / 32$.

99 Ibid.

I Norden's Descrip. of Essex (Camd.

Soc. 1840$), 23$.

2 E.R. xxvi, 183.

3 Cal. Pat. $1560-3,136$.

4 Ibid. 552 ; $\mathrm{CP}_{4}$ o/ $12 \mathrm{II}$.

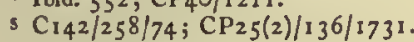

${ }^{6} \mathrm{C}_{142 / 369 / 148}$

${ }_{7} \mathrm{C}_{142 / 398 / 133}$.

8 P.C.C. Year Bks. of Probates, $1640-4$,
249 ; G.E.C. Complete Baronetage, Littleton (cr. 1642).

- $\mathrm{C}_{142 / 622 / 4} \& 10,744 / 39,745 / 65$. to L. F. Index Vol. to i-x, p. 386 ; cf. C. T. Gatty, Mary Davies and the Manor of Ebury, i, 89-96.

"L.F. ix, 293a-295a. For a 17th cent. MS. pedigree of the Poyntz and Morris families see E.R.O., D/DRu F7.

12 Morant, Essex, i, 129.

13 Ibid. It is suggested by Newcourt, Repert. ii, 450, that Anne and Elizabeth were the sisters of Sir James Poyntz. For the Poyntz and Duncombe families see also Magdalen Laver.

${ }_{14} \mathrm{CP}_{25}(2) / 5506$, Hil. 1650 , Mich. 1650 , Trin. 1651 .

is Complete Baronetage, Whitmore (cr. I641).

16 E.R.O., D/DAc 238.

37 There were 13 other tenants.

18 Morant, Essex, i, 129.

19 Parish Regs. of Ongar, ed. F. A. Crisp,
107.

${ }_{20} \mathrm{CP}_{25}(2) / 1012$ Hil. 4 Geo. I. He was probably the grandson of the Thomas Goldsborough who died in 1664 , and another Thomas Goldsborough, who died at Ongar in 1703 , was probably his father: Parish Regs. of Ongar, 119.

2 Morant, Essex, i, 129

22 Ibid. The summer house is well shown in a drawing of Ongar from the west, 1766: E.R.O., Prints, Chipping Ongar. Remains of the summer house appear in a drawing of 1821 : D. $M$ Armitage, Taylors of Ongar, 57 .

23 Edward Alexander's son Bennet Alexander had taken the additional surname of Bennet on succeeding to the property of an aunt: Morant, Essex, i, 129. 24 E.R.O., D/DC 27/736; Burke's Peerage, Gwydyr.

$2 s$ Ibid.

26 Ibid.

27 Ibid. 


\section{A HISTORY OF ESSEX}

and subsequent conveyances between the interested parties Chipping Ongar was settled upon Charles Henry Swinburne, Captain R.N., later Admiral. ${ }^{28}$ By this time most of the manorial rights had lapsed. The manor court is said to have been held for the last time in 1732.29 In 1835 one who had been resident at Ongar for 23 years stated that he had never heard of any quit or chief rents having been paid to the lord of the manor and that the only manorial rights exercised had been the lease of the fair and market tolls and the appointment of the gamekeeper of the manor.30 The fair and market tolls were sold in $184 \mathrm{I}$ and from that date if not before the manor may be said to have become extinct. ${ }^{31}$

Admiral Swinburne died in $1877 . .^{32}$ His widow Lady Jane Swinburne continued to hold the estate at Ongar until her death in 1896.33 After her death it was held for some years by her trustees. None of Admiral Swinburne's children left issue. The last of them to survive was A. C. Swinburne the poet (d. r 909). Ongar castle and some of the adjoining land was sold by the Swinburne trustees in 1918 to Joseph Bennett.34 In $1934 \mathrm{Mr}$. D. A. J. Buxton bought the castle from the executors of $\mathrm{Mr}$. Bennett. ${ }^{35}$

No part of the castle now survives except the earthworks. The plan consists of a flat-topped mount with encircling moat, an inner bailey, a weaker enclosure to the north and east, and the town enclosure to the west. ${ }^{36}$

The mount is $50 \mathrm{ft}$. high and is about $230 \mathrm{ft}$. in diameter at the base and $70 \mathrm{ft}$. at the top. It is now occupied by fragments of flint rubble and brick. The mount is surrounded by a symmetrical moat $50 \mathrm{ft}$. wide across the water. There is no trace of a bridge or causeway across the moat. 37 The bean-shaped inner bailey is defended by a strong inner rampart and moat and covers about 2 acres. The moat was formerly linked at both ends with that of the mound, and is about $80 \mathrm{ft}$. wide from crest to crest and $26 \mathrm{ft}$. deep from the top of the rampart. Parts of it have been destroyed during the past 20 years. ${ }^{38}$ The entrance from the town enclosure was in the centre of the west side through a gap in the rampart, on each side of which is a fragment of flint rubble containing what may be Roman bricks. The masonry does not appear to have extended along the rampart, which was probably surmounted by a wooden palisade. The outer enclosure on the north and east was less strongly fortified and is indicated by two ponds and a ditch of slight profile. ${ }^{39}$

Two existing houses appear to have been, at different times, the capital mansion of the estate. The White House was certainly the residence of Alexander Bennet in 1738,40 and may have remained so after he succeeded to the manor. In the late 1 th century Henry Gibson, Clerk of the Peace for Essex, lived there. ${ }^{4 I}$ The house is a timber-framed structure built originally on a half-H plan. A small staircase projection in the angle between the central block and the northeast wing has been enclosed by later brick additions and the plan is now roughly rectangular. In one of the attics is a plastered Tudor fireplace and near it there was formerly a beam dated 1599.42 This probably represents the date at which the house was built. A first-floor room at the north-west end has panelling of about 1700 . During the first half of the I 8 th century a new staircase was inserted, most of the principal rooms were panelled and the roof was probably rebuilt. The present front wall of gault brick was added about I 835 and at the same time a partition wall and chimney were built across the former central hall. 43 There are also extensive alterations at the back of the house.

The Castle House was described in about 1835 as the mansion house of the estate.44 About 20 years earlier it had been the residence of Isaac Taylor, minister of the Congregational church.45 The present house appears to be the central part of a considerably larger structure dating in the main from the 16 th century. It is partly timber-framed and partly of brick and has three stories. Prints of about $1830^{46}$ show the existing three-gabled block flanked on either side by two-story wings. Behind and to the south-west is a larger wing. The principal windows are shown with mullions and transoms. At this period the lane passed directly in front of the building. The reconstruction of the house took place about 1840 and most of the plaster detail in the Tudor style was applied at the same time. The attics retain 16 th-century cambered tie-beams and several of the rooms have panelling of this date or a little later.

As is shown below there has been a church at Chipping Ongar since about 1100 if not CHURCH earlier. In about 1254 the advowson belonged to the lord of the manor. 47 The institutions of rectors have been recorded from ${ }^{3} 363$ and show that the advowson continued to be appurtenant to the manor. ${ }^{8} 8$ William Bourchier presented pro hac vice in 1409 , the bishop by lapse in 1441,1487 , and 1557 and the Crown on several occasions during a minority. When the parish was temporarily united with that of Greenstead in I 548 (see below) the advowson of the new combined parish was vested in Richard, Ist Baron Rich, but after the revocation of the Act of union in 1554 the lord of the manor of Chipping Ongar again becarne patron of the living.

In 1635 Maurice Barrow and his wife presented to the living. ${ }^{49}$ Barrow presented in $165^{8}$ and $1664.5^{\circ}$ Elizabeth Goldsborough presented in 1670,1673 , and 1680.51 After this the advowson descended with the manor estate until the death of Lady Swinburne. In 1905 the Guild of All Souls acquired the advowson. ${ }^{52}$

In the account of Robert Peverel for the farm of Ongar in 1210 IOs. was allowed 'to the mother church
28 I \& 2 Vict. c.23; E.R.O., D/DC $27 / 736$.

29 R. 1. Porter, Notes on Chipping Ongar, $9 \mathrm{n}$. According to this statement the rolls had been burnt before 1805 .

so Ibid.

31 Ibid.

32 Burke's Peerage, Swinburne.

33 Ibid.; Kelly's Dir. Essex (1895, 1899).

34 Inf. from Mr. D. A. J. Buxton.

33 Ibid.

36 Hiss. Mon. Com. Essex, ii, 53-54. The description which follows is based on this account.
27 In c. 1820 'the only access across the moat was in an old beer cooler, suffered to float there': D. M. Armitage, Taylors of Ongar, 57.

${ }^{38}$ Inf. from Mr. D. A. J. Buxton.

39 For a description of the town enclosure see above, P. I55.

40 E.R. $x \times x, 184$.

41 See above, Public Services and Social Life.

42 The position of this has been marked by a former owner of the house.

${ }_{43}$ The work is said to have been done by Noble of Ongar.

44 T. Wright, Hist. Essex, ii, $33^{2}$. See plate facing p. I 57 .

43 D. M. Armitage, Taylors of Ongar, 57, shows a drawing of the house in I $82 \mathrm{I}$

46 E.R.O., Prints, Chipping Ongar.

47 E.A.T. ..s. xviii, 19.

48 Newcourt, Repert. ii, 449-5I.

49 Ibid. 451. For Barrow see above, Manor.

so Ibid.; E.A.T. N.s. vii, 57

31 Newcourt, Repert. ii, 451. She was probably the widow of Thomas Goldsborough (d. I664).

32 Inf. from the Guild of All Souls. 
of Ongar in annual rent for the cemetery'.53 In 1254 the rectory was valued at 4 marks. 54 Chipping Ongar was not included in the list of churches of Ongar deanery in the Taxatio of I29I, presumably because the rectory was worth less than 6 marks.55 It was not even included in the list of smaller livings of the archdeaconries of Essex and Colchester. ${ }^{56}$ John de Welde of Ongar, by his will proved in 1337 , directed that his body should be buried in the church of St. Martin, Ongar. He bequeathed $\ell_{.5}$ to cover the expenses of his funeral, at which a brown 'turthel' cow with its calf was to be led before the body as a mortuary, and he also left a cow and $3 \mathrm{lb}$. of wax to maintain a candle burning daily at Mass in the church before the altar of St. Mary and St. Margaret.57 In I 340 the taxable value of the living was stated to be $f_{0} \mathrm{ro}$, but this can hardly have been correct. ${ }^{88}$ In 1428 it was reported that the church was assessed for subsidy on a tax de novo of $48 s .59$ The taxable value was thus rather less than it had been in 1254 .

In 1535 the rectory was valued at $£ 6.60$ In 1548 it was united by Act of Parliament with that of Greenstead (q.v.) but the union was ended in 1554 by another Act which asserted that the Statute of 1548 had been brought about by the "sinister labour and procurement of William Morris' ${ }^{61}$ According to the Act of Union the church of Ongar was 'dissolved' and that of Greenstead became the parish church of the joint parish. The site of the church and the churchyard of Ongar became the property of William Morris, previously the patron of Ongar. ${ }^{62}$ This last provision was no doubt responsible for the charge against Morris. It is indeed difficult to believe that any worthy motives lay behind the Act of I 548 : had it not been revoked the inhabitants of Ongar would have been deprived of their own church and compelled to journey a mile or more to the tiny church at Greenstead. The Act of 1554 was opposed by some of the inhabitants of Ongar, evidently those with a vested interest in the site of the church and churchyard. In that year the Privy Council ordered Sir Henry Tirell, Anthony Browne, and William Barneys 'to call before them the inhabitants of Ongar and the widow of William Morris and examining the parties that without authority of their own heads attempted lately to pluck down the church walls there, to set such order among them for their good quiet and stay of their friends doing therein'.63

During the Protectorate the minister of Chipping Ongar received an augmentation of income from the Trustees for the Maintenance of Ministers. ${ }^{64}$ The church formed part of the Sixth Presbyterian Classis, called the Ongar Classis, formed in I648.65 In I66 I the rectory was valued at 640 . Previous estimates in the $17^{\text {th }}$ century had been $£_{1} 8$ in 1604 and $£ 50$ in I 650.66

In 1723 the living was augmented by the addition of the present rectory house, with about 5 acres of glebe adjoining. This was bought for $\$ 409$, of which fiog was contributed by the Revd. Jacob Houblon, Rector of Bobbingworth, $\oint_{1} 100$ by Edward Colston, and $\oint_{0} 200$ by Queen Anne's Bounty. ${ }^{67}$ Before its purchase the rectory house had been the home of William Atwood and had been named 'Lovings'. ${ }^{68}$ The north wing (now the kitchen, scullery, and pantry) had been built in the $17^{\text {th }}$ century. ${ }^{69}$ The main wing was added early in the 18 th century.70 It is a lath and plaster building of two stories with attics. The façade is symmetrical. The front door has pilasters and a pediment and there are two windows each side of $\mathrm{it}$. The former rectory house had stood near the church on the north side. ${ }^{7 x}$ In 1784 , by a faculty dated 2 August, the rector was empowered to take down the old house, with the stable adjoining it, which had for many years been let as two 'poor ruinous cottages' at 50 s. a year. ${ }^{72}$ A terrier of 1810 describes the land upon which the house had stood. It was $105 \mathrm{ft}$. long and measured $35 \mathrm{ft}$. across at the western end, $25 \mathrm{ft}$. at the eastern end and $12 \mathrm{ft}$. in the centre. There was another piece of glebe at the east side of the church, running down to the pond.73 By I 84 I both these pieces of land had become part of the estate of Brook Hurlock, owner of the White House.74 The Revd. R. I. Porter, who wrote his Notes on Chipping Ongar in 1877 , could find no record of a quid pro quo.75 The tithes of the parish were commuted in 1841 for $\oint_{0} 146.76$

Richard Vaughan ( I 550?-I607) successively Bishop of Bangor, Chester, and London, was Rector of Chipping Ongar 1578-80.77 John Lorkin, appointed minister of Chipping Ongar in 1659 or 1660 , was ejected in $1662 . .^{78}$ George Alsop, rector from 1670 to 1673 , seems to have been vigorously orthodox, for in 1670 he was appointed by the bishop to read divine service at the Quaker meeting house in Gracechurch Street, London. ${ }^{79}$

The parish church of ST. MARTIN consists of a nave, chancel, south aisle, north vestry, and west porch, with a western bell-turret surmounted by a shingled spire, and a gallery at the west end of the nave. ${ }^{80}$. The chancel and nave were built at the end of the I Ith century. The walls are of coursed fint-rubble with the quoins and jambs of the north doorway of bricks, possibly Roman, and some courses of tiles in the walls. In the chancel there are two original round-headed windows, one at the east end of the north wall, the other opposite to it on the south wall. Between the windows on the north wall is a round-headed recess pierced by a small opening or hatch with external hinges and bolt-socket, perhaps originally an anchorite's cell. Flanking the present window in the east wall of the chancel are traces of four single light lancet windows showing that there was an original arrangement of six windows in two tiers under a higher gable. The original doorway on the south of the chancel is now blocked. On the north wall of the nave there is one original round-headed window; another, to the west of the present west window of this wall is now blocked; there

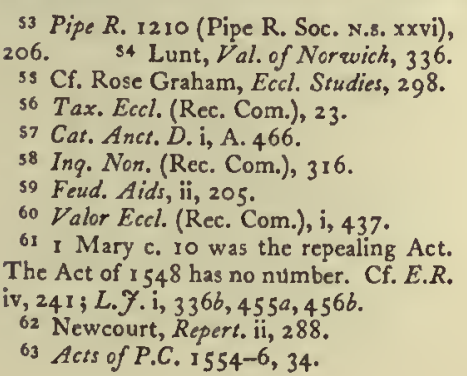

$64 E, R, \times \times x, 173-5$

Hist. Essex, 202, 213.

63 Davids Evang Nonconf in Ess

66 E.A.T. N.s. xxi, 78, 83.

67 R. I. Porter, Nores on Chipping Ongar, 12.

68 Ibid.

69 Hist. Mon. Com. Essex, ii, 55.

70 Ibid.

71 R. I. Porter, Notes on Chipping Ongar, 12.

72 Ibid. $13 . \quad 73$ Ibid. 14.

74 E.R.O., D/CT 262; R. I. Porter,

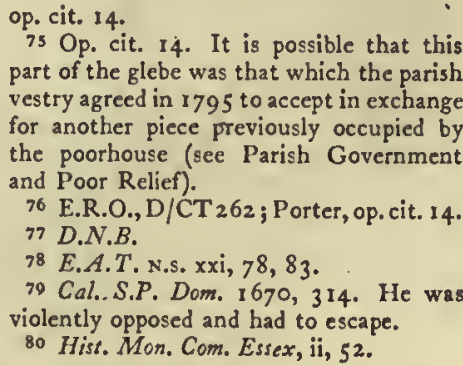
part of the glebe was that which the parish vestry agreed in 1795 to accept in exchange for another piece previously occupied by the poorhouse (see Parish Government and Poor Relief).

76 E.R.O., D/CT 262 ; Porter, op. cit. 14. 77 D.N.B.

78 E.A.T. N.s. xxi, 78, 83 .

79 Cal..S.P. Dom. 1670,314 . He was violently opposed and had to escape.

so Hist. Mon. Com. Essex, ii, 52 . 


\section{A HISTORY OF ESSEX}

are traces of a third original window near the east end of the wall. Between the third and fourth windows (counting from the east) is the original north doorway, now blocked. On the west wall of the nave there is another original round-headed window, and there are traces of two more. 'The western window on the south wall of the chancel dates from the $13^{\text {th }}$ century: it has three grouped and graduated lancet lights. About the middle of the I4th century the chancel arch was rebuilt. The splays of the east window also date from this century, which suggests that the original arrangement of six small windows was then first replaced by a large window. The roof of the nave probably dates from the 14th century; it is of four bays with king-post trusses. In the I 5 th century the weather-boarded bellturret and spire were added. Early in the 16 th century the present western window was built in the north wall of the chancel. It is of three lights of brick with fourcentred heads. It may have replaced an earlier window which matched the opposite window on the south wall of the chancel. It is not possible to trace any of the effects of the supposed attempt in 1554 to pull down the church walls (see above). It does not seem likely that much damage was then done. The roof of the chancel is mainly Jacobean. ${ }^{81}$ In $1752-3$ two dormers were added on each side of the nave roof in order to give light to the gallery. ${ }^{82}$ An engraving published in 1796 shows the north side of the church. ${ }^{83}$ There was a north porch, apparently of brick. A path leading to a north door in the chancel shows that the door was then in use. At the east end of the north wall of the nave there is depicted a two-light window approximately in the position of the present east window. Another window is shown, partly obscured by the roof of the porch. This was apparently in the position now occupied by the second window from the east. Although little can be seen of it the window appears to be large and pointed. It is not unlikely that both these nave windows were contemporary with the I $3^{\text {th-century }}$ window in the chancel. It was probably soon after this that the main entrance was moved from the north to the west end of the nave, for in May 1814 the parish vestry, which had for some time been considering plans to provide additional seating accommodation, resolved that the north door should be closed and a pew placed across the entrance, and a new west door be opened.84 In 1860 the church was restored and refitted at a cost of $\$ 700$, defrayed by voluntary contributions. 85 At the same time a stained-glass window by Chater \& Son, St. Dunstan's Hill, London, was placed on the north side of the nave in memory of Richard Noble, at the expense of his family. ${ }^{86}$ In the following year the vestry was built. ${ }^{87}$ In 1876 the pavement of the chancel in front of the altar rails was relaid with encaustic tiles, interspersed with white marble, at the expense of the Revd.T.M.R. Barnard, a parishioner ${ }^{88}$ In the same year memorial glass was inserted in the western window on the south wall of the chancel by
Edward Sammes in memory of his wife. 89 In 1884 the south aisle was built. It is divided from the nave by an arcade of four arches. 90 The Society for the Protection of Ancient Buildings opposed the alterations. Their objections were answered in a vigorous letter by the architect, C. Rolfe.91 This correspondence shows that the old south wall of the church contained two 'ancient' windows and a doorway of original Norman work, an injured 14th-century window and a piscina at the south-east corner of the nave.

In 1908 a stained glass window was placed in the west end of the aisle in memory of Lilla Tanner.92 Miss L. W. Tanner (d. I 920) left her residuary estate in trust, the income to be paid to her aunt for life, and thereafter towards the beautifying of the parish church. In 1935 the capital amounted to $£ 3,240$ and in $195^{\circ}$ the income was 6 I I 3.93 In 1929 the glass in the east window was installed in Miss 'Tanner's memory. 94

A new organ was installed in 1896 , replacing one that had been in use since 1835.95 The present vestry was built in I9 7.96

In I 284-5 John the clerk of Ongar was killed by the clapper of the church bell, which fell upon him while he was ringing. The value of the bell and clapper as a deodand was returned as $8 \mathrm{~s} .2 \mathrm{d.}{ }^{97}$ The church now has two bells. The first was cast in 1672 by Anthony Bartlet, the second in 1737 by Richard Phelps. 98

There is a paten dated 1705 , and a cup and a paten dated 1728 . All these are of silver gilt and were given by Elizabeth, wife of Richard Turner and daughter of Thomas Goldsborough. There is also a silver-gilt flagon, dated 1729, and a brass almsdish which was the gift of Miss Groves. 99 The parish registers survive from I 559.. In the chancel there is a monument to Nicolas Alexander ( 1714 ) and foor slabs (r) to Robert Hill (I648) and Anne (King) his second wife (I668) and Anne Greatherd his daughter (1683); (2) to Jane, wife of Tobias Pallavicine and daughter of (Sir) Oliver Cromwell of Hinchingbrook, Hunts. (1637); (3) to Horatio Pallavicine ( 1648 ). In the nave are floor slabs to (4) John King (1657) and Elizabeth his wife (166r) and Joseph King, his son (1679). The later monuments include one of 1776 by Nollekens. Among the graves in the churchyard are those of many members of the Boodle family, including that of Edward Boodle ( $1722-72)$ founder of Boodle's the club in St. James's Street, London. ${ }^{2}$

Ralph Jackson, a 'serving man' of Chipping Ongar, PROTESTANT Stratford in June I 556.3 was burnt at the stake at John Larkin, or Lorkin, who became minister of Chipping Ongar in 1659 or 1660 , was ejected for refusal to conform in 1662.4 No nonconformist conventicle was registered under the second Declaration of Indulgence (1672) as being held in this parish, but in I690-2 there was a congregation at Chipping Ongar that was said to consist of 200 hearers, "but poor'. Their minister was a Mr. Tyro, 'a worthy man, but

81 The date 1647 is carved on one of the principals: E.R.O., T/P96: Ongar W.E.A. Survey 1951 .

82 Vestry Bk. 1743-75, at the rectory. 83 Gents. Mag. Feb. 1796, p. 113

84 E.R.O., D/P 124/8/2. Cf. White's Dir. Essex (1848), 431 : 'at the west end a new porch has recently been erected'. 8s R. I. Porter, Nores on Chipping Ongar. IO.

87 Ibid.

88 Ibid. 89 Ibid.

9o E.A.T. N.s. xiv, i 5 .

os Letters at the rectory, Chipping Ongar.

02 E.R. xviii, 165.

93 Char. Com. Recs.

94 E.R. xxxviii, 151 . The glass was designed by Mr. Leonard Walker : E.R.O., T/P 96: Ongar W.E.A. Survey, 1951 . os E.R. v, 67 .

96 E.R.O., T/P 96: Ongar W.E.A. Survey, $195 \mathrm{I}$.
97 E.A.T. N.s. vii, $188-9$.

$98 \mathrm{Ch}$. Bells Essex, 350.

99 Ch. Plate Essex, 139

I Essex Par. Recs. 166. Those for I 559-1750 have been published by F. A Crisp, Parish Regs. of Ongar (1886).

${ }^{2}$ N. \& Q. 29 Apr. 1939, 301.

3 T. W. Davids, Evang. Nonconf. in Essex, 44-46.

4 A. L. Gordon, Freedom Afier Ejection, 322. 5 Ibid. 39 . 
poor', who was supported by subscriptions of $\oint_{2} 20$ a year.

In 1706 application was made to Quarter Sessions to license the house of Walter Buchanan in Chipping Ongar for worship by Presbyterians. 6 In 1707 a similar application was made in respect of the house of Samuel Clarke.7 The minister at that time was Nathaniel Lacy. ${ }^{8}$ In 1716 the congregation was said to number 200 persons, of whom 8 had votes for the county and 4 were described as 'gentlemen'.9 Before I 7 I 8 John Nettleton, brother-in-law of Philip Doddridge, had moved from Epping to Ongar as minister. ${ }^{10}$

The first Independent church was built about 1720 on the site behind High Street where the present church stands. "I The first trust deed dates from I722, when Simeon Weaver was pastor. ${ }^{12}$ The property was held of the manor of Chipping Ongar by copy of court roll..$^{13}$ In addition to the church it included several cottages fronting on the High Street. Access to the church was provided by removing the ground floor of one of the houses, thus forming an archway.

In 1784 the church needed considerable repairs and the cottages south of the gateway were sold to a Mr. Bingham to raise money for this purpose. ${ }^{14}$ They were subsequently repurchased. 15 In 184 I the church trustees held three cottages and a garden in addition to the church itself. 16

In I 8 I I Isaac Taylor (1759-1829) came to Ongar from Colchester as minister. He remained there until his death. From Ongar he and other members of his family issued many books for the young. For this reason, and in order to distinguish them from the contemporary literary family, the Taylors of Norwich, Isaac Taylor's family became known as the 'Taylors of Ongar. ${ }^{17}$ According to Burls 'during the last years of his ministry at Ongar Mr. Taylor saw, not merely a gradual increase of his congregation but a manifest decline of that strong immemorial prejudice in the town which had seemed quite to preclude the hope of winning souls to the gospel'.18 John Fordham (1774I 835) was a zealous deacon at the church during the later years of 'Taylor's ministry. ${ }^{\text {i9 }}$

In 1833 the original meeting-house was demolished and the present church built in its place. ${ }^{20} \mathrm{~A}$ drawing of the meeting-house was executed very shortly before its demolition.21 It shows a small building with a classical façade of three bays, having attached pilasters and a pediment. The foundation stone of the new church was laid on 24 April I 833, and the church was opened on 24 September.22 The total cost was about 6.900.23 Before 24 April $\oint_{25} 50$ had been raised and a further $£ 73$ was contributed in the collections on the opening day. ${ }^{24}$ The church is in classical style with pilastered windows and a string-course at eaves level

6 E.R.O., Q/SBb 35.

7 Ibid. 38 .

8 T. W. Davids, Evang. Nonconf. in Essex, 435. This Lacy carnot, however, have been a former Rector of Greenstead. The rector of that name died in occupation of the living in 1700: Newcourt, Repert. ii, 289.

9 Davids, op. cit. 435 .

10 Ibid.; D.N.B. under Doddridge.

11 R. I. Porter, Notes on Chipping Ongar, I9.

12 Ibid.; T. W. Davids, Evang. Nonconf. in Essex, 435.

13 Porter, ibid.

14 Ibid.

is Ibid.

16 E.R.O., D/CT 262.
17 D.N.B.

18 R. Burls, Essex Congr. Union, 94.

For an amusing description of an old man who used to sit at the top of the pulpit steps during services in Isaac Taylor's time see D. M. Armitage, The Taylors of Ongar, 16.

19 Burls, op, cit. I 50-3.

20 E.R.O., T/P 96.

21 D. M. Armitage, The Taylors of Ongar, 161. From the inclusion of Isaac Taylor's and his wife's tombstone the drawing would appear to have been made in or after 1830 .

22 E.R.O., T/P 96.

23 Ibid.

24 Ibid.

2s R. 1. Porter, Noies on Chipping Ongar, which accentuates the effect of the pediment. It is migger than its predecessor, and the graves of saac Taylor and his wife and their daughter Jane, in the churchyard, are now inside the church. Tozer. ${ }^{25}$ John Fordham was active in helping to raise money for the new church.26

Richard Cecil was pastor from about I 838 to 1847 . Wngar he directed a small training school for ing missionaries. Among his students, in $1838-9$, explorer. 27

In 1865 the Sunday school was built behind the of Nottingham. ${ }^{28}$ The building was of grey brick with red brick bands and dressings. There was a belfry on the entrance porch on the south side. The Sunday school was damaged by fire during the First World War partially rebuilt in 1920.29

During the 19 th century the church at Ongar had offshoots: to Stanford Rivers (q.v.) in In 1862 . In 1906 the total were also I 39 Sunday school pupils and 4 lay preachers. ${ }^{30}$ In 1926 there were I 35 members, I 55 Sunday school pupils, 5 lay preachers, and an evangelist who assisted In I95 I the church at Ongar alone had members and ro5 Sunday school pupils, and the istory of the church. 33

In October I 859 the Revd. Father Kyne, the priest at Brentwood, wrote to the Cardinal at Westminster: 'I have made a beginning at Chipping Ongar. I have taken in the eart of the town a house and premises for a year, Lord etre and Miss Tasker undertaking to pay the rent beeen them, and even to purchase the property for f success. . . . There are not many Catholics yet, but venture Kyne wrote again to the Cardinal: 'I wish there could be some beginning made at Chipping Ongar. Though contains only two Catholic families at present stil have no doubt if a mission were once started it would. in to something. I am on the look out for a suitable

It was apparently not until 1865 that anything permanent was achieved. In that year there was a Masscentre at Ongar which was served by the Revd. Henry E. Fox; the parish was placed under the patronage of

26 R. Burls, Essex Congr. Union, 153.

27 D.N.B. Livingstone.

28 E.R.O., T/P 96. J. C. Gilbert was probably a relative of Ann Gilbert, daughter of Isaac Taylor. The architect made no charge for his services.

29 Ibid.

30 Congr. Tear Bk. 1906. The pastor then was the Revd. A. Goodall.

31 Ibid. 1926.

32 Ibid. $195 \mathrm{I}$.

33 Inf. from Revd. W. H. Walker. A full list of records has been prepared for the National Register of Archives.

34 Westminster Archives, Letters and Papers of Cardinal Wiseman, Box for 1859 .

33 Ibid. Box for 1861 . 


\section{A HISTORY OF ESSEX}

Our Lady and St. Joseph. ${ }^{36}$ The priest was evidently not resident, for in I 867 Ongar was being served from Barnet. ${ }^{37}$

In 1869 there was Mass only on alternate Sundays, but plans for a church were already far advanced. 38 It was opened on 2 I April 1870.39 It is a small red-brick building with a western bell-turret, and it stands in the garden of a house on the west side of High Street, below Castle Street. The house is occupied by the priest.

There appears to have been a resident priest in I $870.40 \mathrm{By} \mathrm{I} 874$ the priest of Ongar was also serving a new Mass-centre at Dunmow. He was living at this time at Bentley Lodge, near Brentwood.41 In I 888 the Ongar priest served centres at Saffron Walden, Epping, and Dunmow. Ongar itself had a weekly Mass. ${ }^{42}$ There was no resident priest between $18 \mathrm{~g}^{2}$ and 1901.43 The Revd. Thomas Byles, priest from 1905 to I9I2, was drowned in the Titanic.44 The Revd. John Ryland became priest about 1916.45 In 1904-5 there was a Roman Catholic orphanage at Chipping Ongar known as St. Joseph's Home.46 It was founded by a Father Schaefer as a branch of the St. Joseph's Home at Bow, London, but apparently did not last for long.

In the I I th century much of Chipping Ongar was woodland. 'The "wood of Ongar' AGRICULTURE mentioned in 1044 in the will of Thurstan has been mentioned above.47 In 1086 the manor of Ongar contained woodland for 1,000 swine. 48 There were then 36 pigs on the manor. This was not a large number, but it is likely that pig keeping in this area was of some importance in the 12 th century and later, for in 1213 Robert Peverel, farmer of Ongar, was ordered to supply the king with I 38 sides of bacon from his bailiwick. 49 Peverel's account for 1209 -Io shows that he was then keeper of Stanford Rivers as well as Ongar. ${ }^{50}$ 'The rents of assize of the manors then amounted to 16 is. $6 d$. During the year he had stocked the manors with 20 oxen and 32 horses at a cost of $\$ 24$ ros. $6 d$. He had also bought for sowing 162 quarters of oats, costing fo 16 s. $8 d$., I $\frac{1}{2}$ quarters of barley for $2 s .3 d$., and beans costing $25.6 d$.

In about 1243 the manor of Ongar was said to contain $374 \frac{1}{2}$ acres of (arable) land, of which 200 acres were worth a total of $\delta_{5} 5$ a year, and $174 \frac{1}{2}$ acres were worth in all 62 i $8 \mathrm{~s} .2 d$. There were 7 acres of pasture worth 75 . and 28 acres of meadow, of which 18 were worth 30 s. a year and Io were worth I Is. $8 d$. sI There were rents of freemen and villeins worth $£ 312 s .3 d . .^{52}$ and the villeins owed a total of $1400 \frac{1}{3}$ labour services a year, worth $68 \mathrm{~s} .6 d .53$ There were 2 mills, one of them driven by water, worth 40 . and a dovehouse worth 25.54 This inquisition had been made on the death of
Maud de Lucy. About this time, in 1243, the king ordered the sheriff to buy oxen for 4 ploughs to till the demesne lands formerly held by Maud in Stanford and Ongar.s5

In 1294 the manor contained 200 acres of arable, worth 65 a year, 12 acres meadow worth 24 s., a park worth 20 s., 2 mills, one driven by wind and the other by water, worth $\ell_{55}$, and pasture worth 35.56

In 1372 there were in the manor 140 acres of arable worth 23s. $4 d$., 20 acres of meadow worth 20 s., 30 acres of poor pasture worth $I 0 s$. , and 'a certain pasture called le Park containing 40 acres' worth I mark. There was also a broken-down windmill.57

In 1386 there were 160 acres of arable worth 40s. $8 d$. a year, I 2 acres of meadow worth 24 s., and 42 acres of pasture worth $2 \mathrm{~s}$ s. The rents of assize were worth 27s. and the rents of 3 capons at Christmas were worth $6 d$. in all.s8 The same figures were given in returns made in I 392 and 1395.59

At the death of James Morris in 1597 the manor included a water-mill, a parcel of land called Betts, a tenement of about 30 acres called Tufftsfield, situated in 'boro field', a meadow called Rye meade, 4 parcels of meadow, pasture, and moor called Le Mores in High Ongar, occupied by Henry Barnard, and a croft called Parsons acre.60 A mill was mentioned in 16.18 as appurtenant to the manor. ${ }^{61}$

In the 17 th and 18 th centuries hop-growing was carried on in Ongar. In 1639 there was a dispute, heard at Quarter Sessions, concerning a crop of hops that had been grown on $3 \frac{1}{2}$ acres of 'hoppground' in the parish.62 Defoe, writing in 1722 described Ongar as part of an area 'famed for husbandry and good malt, but of no other note'. 63

In 1838 the area of the parish was estimated at 480 acres, of which 193 acres were arable and 273 acres meadow and pasture. ${ }^{64}$ The Castle Farm, owned by Sir John Swinburne and occupied by William Coe, contained I 68 acres. There were two smaller farms, of 97 and 62 acres, the Bowes House, with its gardens and pleasure grounds, covered 99 acres. Apart from these there was no tenement of more than 5 acres.

There is hardly any evidence as to how and when inclosure was carried out in this parish. A very small inclosure of waste ground in about 1800 is mentioned below. ${ }^{65}$

The occupations followed in Chipping Ongar have mainly been those normal in a

OCCUPATIONS small market-town. The relative importance of the place was no doubt greater during the Middle Ages before the decay of the castle.

It is not unlikely that a market was held as early as the 12 th century. ${ }^{66}$ The first explicit reference to one
36 Catholic Dir. 1865

37 Ibid. 1867. Mass was being said at 11.30 a.m. and Benediction given at 6.30 p.m. on Sundays.

38 Ibid. 1869

39 The Tablet, 25 Apr. 1870. It is dedicated to $S t$. Helen, which suggests the benefaction of Miss Helen (later Countess)

Tasker. A small red-brick building, now in ruins, standing at the back of the 'King's Head' is said to have been used as a Roman Catholic Church: inf. from Mr. J. G. O'Leary. Cf. E.R.O., T/P 96: Ongar W.E.A. Survey.

40 Catholic Dir. 1870.

41 Ibid. I 874

42 Ibid. I 888 .
43 Ibid. 1892-1901.

44 Ibid. 1905-12.

46 Char. Com. Recs.

45 Ibid. I9I6.

ably Ongar Park in High Ongar.

47 See above, Manor.

48 V.C.H. Essex, i, $467 a$; see also 375.

49 Rot. Lit. Claus. (Rec. Com.), i, I 45.

The bacon was evidently intended for shipment to France, no doubt to feed the king's troops.

50 Pipe R. 1210 (Pipe R. Soc. N.s. xxvi), 206. $31 \mathrm{C}_{132}$ /File I.

52 These figures are not entirely clear.

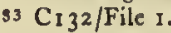
s4 Ibid.

35 Cal. Lib. R. $1240-5$, I 88. In 1086 there had been 2 ploughs in demesne at Ongar, and 5 at Stanford Rivers.

s6 $\mathrm{CI}_{33} /$ File 67. The park was prob-
$57 \mathrm{C}_{1} 35 /$ File 230.

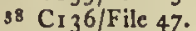

39 Ibid. File 76, File 107.

$60 \mathrm{C}_{142 / 258 / 74}$. At least part of Le Mores (Moors) was in Norton Mandeville (q.v.). $\quad 61 \mathrm{CP}_{43} / 143$ rot. 38 . 62 E.R.O., Q/SR $308 / 22$.

63 V.C.H. Essex, ii, 445. Hops are still found growing wild in the neighbourhood: inf. from Mr. D. W. Hutchings of Ongar. For the Igth-cent. brewery at Marden Ash see High Ongar.

64 E.R.O., D/CT 262

63 See Parish Government and Poor

Relief, below.

66 No market charter has survived. 
is in 1287 , when John de Olmestede, steward of Sir John de Rivers gave a bond to Hugh de Gloucester, tailor of London, in 8 quarters 'of the best, purest and cleanest dry corn, of the country and measure of Essex . . . as could be sold in the market of Angre within the quinzaine of Michaelmas last for 35.'67

In 1372 the market was appurtenant to the manor and was being held on Tuesdays. ${ }^{68}$ It remained in the possession of the lord of the manor until I 841 , when the market tolls were sold by Sir John Swinburne to P. Chaplin of Harlow. ${ }^{69}$ The 'Old Market House' was in about I $84 \mathrm{I}$ situated next to 'The King's Head' on the south side.70 Later in the I gth century the market was held in the Town Hall on Saturdays. ${ }^{71}$ It probably came to an end at the same time as the fair (see below). ${ }^{72}$ In 1 927-30 a brief unsuccessful attempt was made to revive the market: poultry were sold at 'The King's Head'.73 The poultry boxes in 'The King's Head' yard are now (I 952) being casually dismantled. ${ }^{74}$

The Old Market House had been converted into shops by 1877.75 Two market crosses, which still survived in 1842,76 had been removed by 1877.77 The house still survives. ${ }^{78}$ It dates from the 17 th century and consists of two stories with attics and basements, timber framed and plastered. The upper story projects on the east front. The lower part of the building was formerly open. 79

In 1222 Richard de Rivers, whose father had recently died, received the royal grant of an annual fair of three days' duration until he came of age. 80 The fair was to be held on 9-I I November. The implication in the grant seems to be that the fair was already being held and that Richard needed sanction for holding it because of his minority. A hiring fair, on I I October, was being held in $1763 .{ }^{81}$ In 1780 a fair was held on 30 September. 82 A list of 1792 stated that a fair was held on Easter Tuesday, and another for hiring on I I October. ${ }^{83}$ In about 1845 the fair was held on 12 October and there was 'much business in barley for malting' ${ }^{84}$ The fair apparently lapsed for a time in the middle of the I 9 th century. It was revived in 1872 and held in the Town Hall. A handbill advertising the roth fair since the revival, to be held on $\mathrm{I} 2$ October I $88 \mathrm{I}$, bears the name of Captain Budworth of Greenstead Hall as the chairman of the fair committee. ${ }^{85}$ The author of the bill claimed that the fair was a valuable aid to the mutual understanding of different classes of society. The fair was mainly for entertainment. It was not universally popular and in 1892 the tolls were bought by Henry Gibson, Clerk to the County Council, and a local resident, with a view to its abolition. ${ }^{86}$ A letter to Gibson from a certain $H$. Brown in that year states that 'those who have had to bear the brunt of the fair, being obliged to live in the midst of it will readily welcome ... . its a bandonment'. ${ }^{87}$

In the 17 th century there is slight evidence from trade-tokens of cloth-making at Chipping Ongar. ${ }^{88}$ Philip Trayherne, a dyer, occurs in 1677.89 In the same century are references to inter alia a tailor $(1605), 90$ a locksmith (1655), 91 a basketmaker (1667),92 and a haberdasher alios hatter (1667).93 In 1626 Edward Peacock, tallow chandler, and Robert King, apothecary, were presented at Quarter Sessions for using and maintaining a house "for to melt their tallow and "gravee" near unto the common market-place, which is a common annoyance to the inhabitants dwelling near'. 94

Pigot's Directory of Essex for 1840 listed the tradespeople in Chipping Ongar. There were eight public houses. The general pattern of employment has changed little since that time. The town is, however, sufficiently near to London to have reacted fairly quickly to new fashions. There was a photographer there in 1874 , when there were only 33 in the whole of Essex.95

The date at which the brickmaking industry began at Chipping Ongar has not been found, but it seems likely that this was about 1800.96 For many years the brickfield on the Greenstead Road was owned and operated by the proprietor of the adjoining gas works. 97 The brickfield was closed in 1917 , soon after the new brickfield at Hallsford in High Ongar (q.v.) was opened. 98

There was a printer in the town in 1845.99 A later printer, Slocombe, was in business about I $870-90.8$

Vestry books for Chipping Ongar survive for the periods $1743-75$ and PARISH GOVERNMENT I780-1 $863 .{ }^{2}$ The busi$A N D$ POOR RELIEF ness of the parish seems on the whole to have been conducted efficiently and honestly. From 1743 to 1759 meetings took place at Easter, for the approval of the accounts of the overseers, churchwardens, and constables, at Christmas for the approval of the surveyors' accounts and occasionally for other purposes. New officials were nominated when the accounts were passed. From 1759 monthly meetings were the rule, mainly for matters relating to poor relief. Attendance
67 Cat. Anct. D. ., A. II 885.

$68 \mathrm{C}_{135} /$ File 230.

69 R. I. Porter, Nores on Chipping Ongar, I. But see E.R.O., D/DC $27 / 736$. Chaplin still owned the tolls in 1856 : $\mathrm{D} / \mathrm{P}_{124 / 23 / 2}$

70 E.R.O., D/CT 262. The Old Market House is sometimes referred to locally as the Butter Market: inf. from Mr. D. W. Hutchings of Ongar.

"1 Kelly's Dir. Essex (1874 f.).

72 For the demolition of the Town Hall see above, p. I 56 . The Town Hall has sometimes been called the Market House. Its position and design suggest that this was for long one of its main functions.

73 Inf. from Mr. D. W. Hutchings.

74 Ibid.; personal observation.

is R. I. Porter, Notes on Chipping Ongar,

76 E.R.O., D/DC $27 / 736$

77 R. I. Porter, Notes on Chipping Ongar, 1.
78 It is now the Clifton Café.

79 Hist. Mon. Com. Essex, ii, 53. The Market House is shown in the print of Ongar by I. Hassell, 1818 : E.R.O., Prints Collection, Chipping Ongar. The building had three open arches on the east side.

so Rot. Lit. Claus. (Rec. Com.), i, 4906.

8 E.R.O., Q/SBb 268.

82 Essex, Heris. \&8 Cambs. Almanack, 780 .

83 Rep. Com. Mkt. Rights [C. 5550] p. 161 , H.C. (1 888), liii. The hiring fair is said to have been held at one time in the 'Lion' yard: inf. from Mr. D. W. Hutchings. $\quad 84$ Kelly's Dir. Essex (1 845) 85 Handbill in the possession of $\mathrm{Mr}$. Avery, Shelley House, Ongar.

86 Inf. from Mr. D. W. Hutchings.

87 Ibid. This letter is now (1955) in the Essex Record Office.

88 V.C.H. Essex, ii, $398 ;$ E. Anglian, iii, 127 ; E.A.T. N.s. xvii, 248.

89 E.R.O., Q/SR $437 / 42$.
90 Ibid. $173 / 135$

91 Ibid. $365 / 22,23$.

92 Ibid. 4 I I $/ 70$.

93 Ibid. $411 / 42,71$.

94 Ibid. 252/52.

9s Kelly's Dir. Essex (1 874), 367 .

96 See above, P. 156.

97 White's Dir. Essex (1848, I863)

Kelly's Dir. Essex (1874 f.). For the Gas Works see above, Public Services.

98 E.R.O., T/P 96: Ongar W.E.A. Survey, 1951 .

99 He printed the rules of the Ongar Cricket Club: see above, Social Life.

1 He printed R: I. Porter's Notes on Chipping Ongar (1877) and P. J. Budworth's Memorials of Greensted-Budworth $(1876)$.

2 The book for $1743-75$ is at the rectory; the others are E.R.O., D/P $124 / 8 / 1-4$. Unless otherwise stated all the following information is derived from these minute-books. 


\section{A HISTORY OF ESSEX}

at the Easter meetings was sometimes I 5-20 but was usually about 12 . At the other meetings it was rarely more than 8. Thomas Velley, rector I 733-50, usually attended meetings and signed the minutes first. After his death the clergy rarely attended until 1792 , when W. Herringham became curate. He soon took his place as chairman of the vestry and when he left the town in I 806 he was given a silver cup worth 25 guineas. From I 806 to 1828 the clergy again played little apparent part in the vestry. For some years after I 828 Joseph Stanfield, the curate, acted as chairman. In the absence of the clergy the churchwardens presided.

The vestry clerk, who also acted as caretaker and cleaner of the church, was voted an annual stipend of 40s. in 1770 . This was increased in 1805 to 5 guineas. In 18 ig the office of clerk was amalgamated with that of permanent overseer, at a salary of $£ 15$ for both dutics.

In 1823 the public vestry set up a select vestry under the second Sturges Bourne Act (59 Geo. III, c. I2). The select vestry contained the minister, churchwardens and overseers and fifteen other members. It functioned only for about three years. In I 836 the public vestry adopted the Lighting and Watching Act, 1833 ( 3 \& 4 William IV, c. 90).

All types of parish business were transacted at the same meetings of the public vestry. A distinction was usually maintained between rates for different purposes, but there were frequent adjustments between the accounts of different officers. In I 743 a rate of Is. $6 d$. in the pound produced about 660 . By 1783 a similar rate produced $6_{8} 8$. A new rating assessment was made in 1832 , when it was recommended that the rateable value of the parish should be fixed at E, 1,460 ros. 3 This was not the final assessment at this time, for in 1837 the rateable value was fixed at over f2,960. A rate of $4 d$. then produced $\{394$ s. 2 d.4 The rateable value rose steadily to $\left\{3,043\right.$ in $1842^{5}$ and in I 849 was $£ 3,856.6$ It then remained steady until I 858 , when evidence from the ratebooks ceases. There can be no doubt that these increases in rateable value had as their main cause the growth of the built-up area of the parish.7

The general policy of the parish vestry was to ensure that burdens were fairly shared. Thus in May I 800 it was resolved that 'every householder of sufficient ability shall in his turn either take an apprentice or yearly servant a boy or girl from the parish or shall provide a reputable master for such child'. In the following June it was decided to hold a ballot to decide the first allotment of pauper apprentices. In I 803 the vestry introduced an insurance scheme to assist those who had been selected in the ballot for the Army of Reserve.

All the normal parish officers were appointed until I 819 , when, as noticed above, a salaried overseer was appointed. This arrangement, however, only lasted for about six years. The offices of parish constable and beadle were sometimes held by the same individual, but in April 1805 William Ainsworth was dismissed from the two posts and it was resolved that George Archer be appointed constable and John Burrell beadle. Burrell was to receive an annual salary of 2 guineas and he was to be allowed a laced blue coat and hat once every four years. In I 8 I 3 the parish constable was allowed 5 guineas. In 1842 it was decided that a paid constable was no longer necessary. ${ }^{8}$ An entry of 1756 shows that the 'hamlet' of Greenstead was being assessed along with Chipping Ongar to the constables' rate. If this refers to Greenstead parish (q.v.) it means that the Ongar constables were also acting at Greenstead; but it may refer to the houses south of Chipping Ongar Bridge, on the Greenstead boundary. In the vestry minutes for 1792 there is a reference to the town crier.

The ancient pound, pillory, and cage apparently stood on the east side of High Street, opposite the postoffice. 9 They were removed in 1786 , when the Assembly Rooms were built, to a piece of waste ground 100 yds. north-west of the bridge. ${ }^{10}$ The cottage behind this piece of ground was subsequently bought by Edward Rayner, who persuaded the vestry to move pound, pillory, and cage to a place farther down the road, near the south-east end of the bridge. II

There was a poorhouse in Chipping Ongar in 1748 , if not earlier. It then adjoined the rectory. In $1752-4$ and perhaps later the duty of looking after the poor (i.e. presumably those in the poorhouse) was farmed out for $\delta_{4}$ a year. It was provided in 1752 that three men should take turns at this work, each doing it for a year. A parish doctor was appointed in $I, 6 \mathrm{I}$ at an annual salary of 5 guineas. 'This was reduced in $177^{\circ}$ to 64 . Before 1761 medical treatment appears to have been paid for as each case arose. In 1795 it was resolved that the parish poorhouses should be demolished and that one large building should be erected instead. In the same year it was decided 'that the site of the old building being inconvenient to the rector, the parishioners do agree to exchange the present site for a portion of the glebe of equal extent now offered by the rector'; the rector was to enclose and fence the new site. It is possible that the new poorhouse was built on the glebe immediately to the north of the church. ${ }^{12}$ But this is difficult to reconcile with the glebe terrier of 1810.13 It was estimated that the new poorhouse would cost $\oint_{0} 53$ and the vestry agreed that $\oint_{0}$ roo of this should be borrowed on a ten-year term. The building was apparently carricd out in 1797 . John Crabb of Shelley Hall lent $f_{0} \mathrm{roo}$ but in the same year required repayment. The vestry decided to meet half the debt immediately out of the rates and to borrow $f_{.50}$ from someone else. By this time poor relief was becoming an urgent problem. The poor rates had risen from $6 \mathrm{I} 19$ in 1744 to $£ 175$ in 1778 and about 6350 in 1798.14 In 1800 they were $6454 .{ }^{15}$ In July of that year the vestry resolved to enlarge the workhouse. Whether this was done is not clear, but before April I 802 there was a fire at the workhouse and rebuilding was necessitated on that account. The house had been insured. In May 1807 the vestry approved an estimate of 64 I 5s. for finishing 'the back chamber at the work-
3 The entry in the Vestry Minutes gives the name of every ratepayer and his assessment. There are several similar lists for $1758-60$.

4 Lighting and Watching Surveyors

Rate Bk. 18 37-43, E.R.O., D/P $124 / 33 /$ I. 5 Ibid.

6 Ibid. $1848-58$, E.R.O., D/P $124 /$
$33 / 2$.

7 The population increased from 595 in 1801 to 870 in $1841:$ V.C.H. Essex, ii, 350.

8 The County Constabulary had been set up in 1840 .

R. I. Porter, Notes on Chipping Ongar, 23. 10 Ibid.
II Ibid, 24. Perhaps the removal is referred to in the vestry minute-book entry of 1808 -see below.

12 See above, Church.

13 Ibid.

14 Overseers Rate Bk., E.R.O., D/P I $24 / 11 / 1$.

is Ibid. 
house'. A year later it also approved an estimate for a new parish cage. ${ }^{16}$ In April 1809 a Mr. Peake was appointed parish surgeon at a stipend of 67 I $75.6 d$. for medicine with additional fees of $\mathrm{s} 0 \mathrm{~s} .6 \mathrm{~d}$. for midwifery and $7 s$. for inoculation. It was laid down that in future the office of parish surgeon should be held in rotation by Peake and two other doctors.

Meanwhile the poor rates were still rising: in 1806 they were $f_{6}^{6} 74 .{ }^{17}$ In I 8 I 5 a committee was appointed to investigate recent extravagance in the conduct of the workhouse. Its report revealed that in 1813 and 1814 the average cost of maintaining one person in the workhouse was 7 s. $2 d$. a week. In all $\oint_{40} 7$ had been spent, of which $6_{6} 63$ was reckoned as the cost of maintaining the 'governess' and her two children. The vestry thereupon advertised for a governor who should contract to look after the poor in the workhouse at a fixed sum. A Mr. Jessup of Epping was given the contract in June 1815 . John Heard, who was granted the contract in July I 819 , was apparently Jessup's successor. He was paid 4 s. 3d. per person per week. Farming out of the poor was discontinued in June 1820 .

In 1821 the vestry adopted a long and detailed code of regulations for the relief of the poor, with special reference to the keeping of the overseers' accounts. An audit of the overseers' accounts revealed a debt of $\oint_{1} \mathrm{~g} 6$. It is probable that there was no separate master of the workhouse for some years at this period, but in 1828 it was resolved that one should be appointed, and a month later the vestry drew up a code of regulations for the conduct of the workhouse, and appointed William Wood senior as master at a salary of fro a year for himself and his wife. Improvements were made in the workhouse during the same year.

In June 1832 the vestry formally adopted the rules laid down in Gilbert's Act ( 22 Geo. III, c. 83 ) for the conduct of the workhouse. In May I 835 it was further resolved to join with the neighbouring parishes in a poor law union. The first meeting of poor law guardians for the Ongar Union took place in April I8 36 . In June I 837 the Chipping Ongar vestry resolved to sell the 'timber built messuage used as a workhouse'. ${ }^{8}$

A school teacher at Chipping Ongar was mentioned in $1655^{19}$ A school also existed in the SCHOOLS town in 1671.20

By will dated 1678 Joseph King (d. 1679) left five cottages on the west side of the High Street, producing $£ 353$ s. a year, in trust for educational purposes.21 From the income $f_{1}$ I o a year was to be paid to a schoolmaster for teaching 6 poor boys; 65 as a premium for an apprentice to be chosen annually from among these boys, or $£_{5}$ a year for four years to the parents of a boy "who should prove to be of rare and extraordinary parts and like to make a good minister';

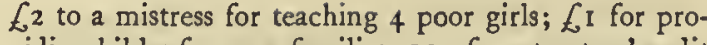
viding bibles for poor families; ros. for a trustees' audit and dinner and 4 . for the sexton to keep clean a tablet in the church recording the bequest. Any surplus was to provide teaching for more poor children.

In 1714 f 10 was being used to maintain a boys' school with 26 pupils and $\delta_{0} 2$ for a girls' school with 12 pupils. Both schools were further supported by voluntary .contributions. ${ }^{22}$ The boys' school evidently flourished in subsequent years, in 1755 having some 100 pupils. The master was then offering a secondary schooling to fee-paying pupils as well as teaching the 6 free pupils.23 In 1779 the 'Free School' was apparently situated in the High Street. ${ }^{24}$

Early in the 19th century boys and girls were being taught by a master and a mistress in a single establishment, probably in one of the trust cottages, which the master rented for $f_{1} 14$ in 1835 and was still occupying in 1841.25 The free pupils seem to have varied in number according to the amount of surplus income from the trust: there were 15 in $1807,,^{26}$ I 9 in 1818,27 and 16 in 1833.28 In 1835 the income from the charity was 6747 s. a year. The schoolmaster received L16 I $35.4 d$. for teaching Io free boys, with an additional allowance of 75 . a boy for books and stationery. ${ }^{29}$ $\mathrm{He}$ also took paying pupils: in 1833 there had been 20 of these. 30 Only one boy had recently been apprenticed: a premium of $\oint_{2}$ I had been paid for him to a shoemaker. ${ }^{31}$ In $1835 \mathrm{f}_{2}$ was also being paid to a mistress to teach 4 girls. ${ }^{32}$ The trustees had a balance in hand of $\{204$ I Is.33 The children entered the school at 6 or 7 years of age on the nomination of trustees, and left at about $14 .{ }^{34}$ The school seems to have been under Anglican control, as it was in $1871 .^{35}$

In 1846 a new school was built behind the trust cottages. ${ }^{36}$ It had accommodation for 63 pupils but no teacher's residence. 37 By 1870 it had not received a parliamentary grant and its growth had been slow owing to the success of the local private schools; ${ }^{38}$ only 66 attended it in 1871.39

An inspector reported in 1871 that the school was adequate to the needs of Chipping Ongar, but would require enlargement to accommodate 30 children from Shelley, which had no school of its own and which he suggested should be united with Chipping Ongar in a single School District.40 In 1873 , therefore, the school was enlarged at a cost of $£ 320^{41}$ and began to receive an annual parliamentary grant.42 By 1877 there were over 100 pupils, including the 6 free boys. 43 Children also attended from Greenstead when the school there was closed.44 In 1893 , when there was accommodation for 172 children, the average attendance had reached I 27.45 In 1904 there were 162 pupils, 4 teachers, of whom one was certificated, and a needlework super-

16 The cage was dismantled by the resolution of the vestry in 1853 . It stood on the site of the present fire-station. 17 Ibid.

18 In 1846 some of the local paupers were housed in the lower story of the Town Hall : E.R.O., G/On $\mathrm{M}_{3}$.

to E.R.O., Q/SO 1, p. $210 a$

20 E.R.O., Q/RTh 5.

21 Rep. Com. Char. (Essex), H.C. 216 , pp. $237-8$ (1 835$)$, xxi (1); V.C.H. Essex, $\mathrm{ii}, 560$. For King see above, Church.

${ }_{22}$ S.P.C.K. Acct. of Charity Schs. 1714 , p. 27.

${ }_{23}$ Ipswich $\mathcal{F}_{n l} .24 \mathrm{M}$ (y, 2 I June 1755. 24 F.R.O., D/DQk I.

35 Rep. Com. Char. (Essex), p. 238;

ES. IV

E.R.O., D/CT 262

26 E.R.O., D/AEM $2 / 4$.

27. Reins. on Educ. of Poor, H.C. 224 p. 264 (1819), ix (1).

${ }_{28}$ Educ. Enquiry Abstr. H.C. 62, p. 284 (1835), xli.

29 Rep. Com. Char. (Essex), p. 238.

30 Educ. Enquiry Abstr. (1835), p. 284.

32 Rep. Com. Char. (Essex), p. 238.

32 Ibid. 33 Ibid. 34 Ibid.

35 Retns. Elem. Educ. H.C. 201, pp. I I 2-I 3 (I 87 I ), Iv.

36 E.R.O., D/CT 262; White's Dir. Essex (1863); 0.S. 6 in. Map (1st edn.), sheet li (surveyed 1873-4); E.R.O., T/P 96: Ongar W.E.A. Survey. A stone bearing the date of foundation lay in 195 I in the cul-de-sac between Ongar Grammar School and Little Bansons.

37 Reens. Elem. Educ. (1871), pp. $112-$ 13 ; V.C.H. Essex, ii, 561 .

38 E.R.O., D/AEM $1 / 1 / 5$; Min. of Educ. File $13 / 66$.

39 Retns. Elem. Educ. ( 1871 ), pp. $112-$ 13.

40 Min. of Educ. Fite $13 / 66$.

41 Kelly's Dir. Essex (1899), 284.

42 Essex Standard, 28 Oct. I 874.

43 R. I. Porter, Notes on Chipping Ongar, 21.

44 Kelly's Dir. Essex (1899), 284

45 Retn. of Schs. 1893 [C. 7529], p. 713 , H.C. $(1894), 1 \times v$. 


\section{A HISTORY OF ESSEX}

intendent. 46 The trust income had risen from $£_{0} 74$ in 1863 to $f_{82}$ in 189847 and the annual grant from $£_{0} 7$ in 1873 to $\oint_{0} 108$ in 1893 and $\oint_{1} 131$ in 1902.48 After the Education Act of 1902 the school passed under the administration of the Essex Education Committee, Ongar District, as a non-provided mixed school. Its pupils continued to increase; in 1913 the accommodation and average attendance were each estimated at 1 72.49 Meanwhile, in 1905, King's Charity had been divided into 'King's Educational Foundation' and 'King's Charity for Bibles and Sexton' (see below, Charities).

In Igog the Board of Education had urged that the school should be enlarged.50 The trustees hesitated to spend the $\ell_{s}, 500$ estimated as the cost of the required rebuildingst and when in I9I I the Essex Education Committee published its intention of providing a new school in the town, ${ }^{52}$ they decided to offer the existing school to the Education Committee for use as a County school.53 The Education Committee accepted transfer in 1913 and, after extensive rebuilding, opened the new school in June 1915 with accommodation for 278 pupils. 54 By 1929 average attendance had risen to 188 . In 1936 , when a senior school was opened in the town, the primary school was reorganized for mixed juniors and infants, the average attendance falling to 143 in 1938.5s In May 1952 there were 315 pupils and 9 teachers. ${ }^{\mathrm{s}}$

The school lies behind the Budworth Hall and the trust cottages. It is single-storied, mainly of yellow brick and with a partly tiled, partly slated roof. The greater part of the 1846 building is incorporated in it. An adjacent building, of green corrugated iron, was erected in 1913 to accommodate the children while the rebuilding took place. 57 King's Trust is administered by 12 trustees, with the rector as chairman. In 195 I its income was $£_{2} 87$, of which $\oint_{0} 63$ was paid in educational grants. 58

Ongar County Secondary School was built by the Essex Education Committce at the north end of the town on the road to Dunmow and was opened as a senior school for the district in 1936. It had accommodation for 520 children. 59 Attendance subsequently increased and in 1948 temporary accommodation was provided for go pupils. 60 In May 1952 there were 25 teachers and 550 children. ${ }^{6}$ Pupils are drawn from I 8 primary schools. The buildings are of red brick. The garden is about I acre in size and the playingfields about 12 acres. ${ }^{62}$

In the early igth century local churchmen seem to have devoted their attention more towards the maintenance of their Sunday school than to the expansion of King's Trust School, possibly because the latter enjoyed an assured income. The Sunday school existed as early as $1807^{63}$ and in 1815 , when 115 children attended it from Chipping Ongar, Greenstead, Shelley, and Stanford Rivers, it received $£_{3} I$ in annual subscriptions. ${ }^{64}$ An infants' school was also set up, apparently under Anglican direction, in which in $1846-7$ a mistress taught 45 children; ${ }^{65}$ it was possibly the same infants' school which in $1873-4$ was situated at the north-east of Ongar Bridge.66 The Independents also maintained a Sunday school, which was attended in 1833 by 50 children. ${ }^{67}$ The rector reported in I 846-7 'the educational wants are well supplied'. ${ }^{68}$

Throughout the igth century private schools flourished in the town. In 1807 the curate reported that there were two girls' schools and a boys' school, the latter attended by 60 pupils. 69 In 18 I 8 there were said to be 4 schools with 60 pupils altogether. ${ }^{70} \mathrm{~A}$ more detailed survey in 1833 notes the existence of 6 day schools with 82 pupils, a boarding-school with I 3 boys, and a dissenting boarding school with 7 girls.71 In I 845 there were said to be I I schools in the town, including the King's Trust school, with 140 daily and 95 Sunday pupils. 72 In 1855 a 'seminary' was being conducted by the Misses Noble.73 It is possible that this was the 'school for ladies' which in 1866 was run by Mrs. Julia Webster.74 In 1872 a 'school for ladies' was being held at Roden House, and offered 'every branch of English ... together with the accomplishments'.75 In 1874 this school was being conducted by Emily Willets, and in 1890 by Amy and Edith Bishop. ${ }^{76}$ About rgro it moved up the road to Holmlea, still under the control of the Bishops, but it seems to have come to an end soon after.77

The most important private school in the town was Ongar Grammar School, said to have been founded in I 8 I by William Stokes, M.A.78 This was probably the boarding-school which had 13 boys in 1833 (see above). In 1845 it was known as Ongar Academy, and the proprietor was Richard Stokes. ${ }^{79}$ Among the pupils in I 846-7 were Nathaniel and Walter Barlow, sons of Dr. Nathaniel Barlow of Blackmore. In September I 847 Walter wrote to an elder brother Alfred: "Tomorrow and the following day we are going to have two lectures on Electricity and Galvanism by Mr. Thornthwaite, a lecturer from London. We have 41 young gentlemen, 3 of which are day boarders and I weekly boarder. . . ?80

A school magazine was started in September 1869. The three (weekly) numbers which have survived show that there were then three assistant masters in addition to the head, Dr. Clark. ${ }^{81}$ There were athletic clubs, libraries, a fencing-club, and an elocution society. Advertisements include the request for a 'chain for a sparrow-hawk'. In 1878 Williarn Clark was headmaster. There were then 130 boarders. ${ }^{82}$ In 1899 the

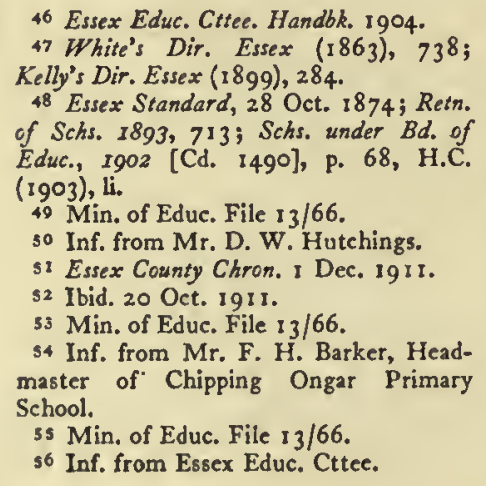

46 Essex Educ. Cttee. Handbk. I 904. 47 White's Dir. Essex (1863), 738; Kelly's Dir. Essex (1899), 284.

48 Essex Standard, 28 Oct. 1874 ; Retn. of Schs. 1893,713 ; Schs. under Bd. of Educ., I902 [Cd. 1490], p. 68, H.C. (1903), li.

40 Min. of Edue. File I $3 / 66$.

so Inf. from Mr. D. W. Hutchings.

s1 Essex County Chron. I Dec. 19 II.

52 Ibid. 20 Oct. 1911.

$33 \mathrm{Min}$. of Edue. File $13 / 66$.

s4 Inf. from Mr. F. H. Barker, Headmaster of Chipping Ongat Primary School.

ss Min. of Educ. File $13 / 66$

s6 Inf. from Essex Educ. Cttee.

37 Inf. from Mr. F. H. Barker.

58 Inf. from Mr. D. W. Hutchings.

$59 \mathrm{Min}$ of Educ. File $13 / 66$

$60 \mathrm{Min}$. of Educ. File $13 / 66$

62 Inf. from Essex Educ. Cttee.

62 Inf. from Mr. J. W. Butler, Headmaster of Ongar Secondary School.

63 E.R.O., D/AEM I/I/r.

64 Nat. Soc. Rep. 1815 , p. 40.

os Nat. Soc. Enquiry into Church Schs. $1846-7$, Pp. 14-15.

66 O.S. 6 in. Map (Ist edn.), sheet li. 67 Educ. Enquiry Abstr. (183.5), p. 284. 68 Nat. Soc. Enquiry I846-7, I4-1 5 .

69 E.R.O., D/AEM I/I/I.

70 Retns. on Educ. of Poor (1 819$),$ p. 264

71 Educ. Enq. Abstr. (1835), p. 284.

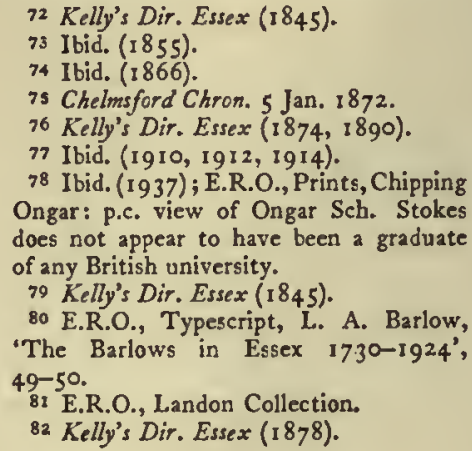


headmaster was Oswald Clark, M.A.83 At the I9I I census there were I 64 children at the school.84 In the following year the principals were O.W. Clark, M.A., and Benjamin Brucesmith, LL.D.85 In 1926 the principal was Percival H. Bingley and the 'Director of Studies' was William Attlee, M.A. There were 7 assistant masters; the rector acted as chaplain. ${ }^{86} \mathrm{By}$ I 937 P. H. Bingley and Thomas A. Owen, B.A., M.R.S.T., were joint principals. There was provision for $\mathrm{I} 40$ boarders and there were two university leaving scholarships of $£ 30$ a year, tenable for 2 years. ${ }^{87}$ The school closed about 1940.88

The Grammar School was situated on the west side of the High Street at the north end of the town. The tithe map ( $c .184 \mathrm{I}$ ) shows a number of buildings on this site. They were all owned by Richard Stokes, who also owned the adjoining Little Bansons. 89 Between that time and I 874 a large new building was erected. 90 In 1937 the school was said to include music and recreation rooms, gymnasium, swimming-bath (added in 1885), carpentry shop and rifle-range with playingfields and grounds of over 100 acres. The boarders were accommodated in 3 houses.91 The main Grammar School building fronts upon High Street and has an imposing symmetrical façade. 92
The origin and terms of King's Charity (founded 1679) have been described above, in CHARITIES connexion with the King's Trust School. By a scheme made in 1905 648 of capital was set aside for the provision, which had been customary, of $\mathcal{L}_{\mathrm{I}} \mathrm{a}$ year for bibles and $4 \mathrm{~s}$. for the sexton. ${ }^{93}$

Mrs. Septame Mitchell, by will proved 1804 , left 650 in trust for a yearly distribution to the poor on I January. In I 834 a quartern loaf was given to each poor adult and a half quartern to each child. 94 In I $95^{\circ}$ the income of $\oint_{1} \mathbf{2 s} .8 \mathrm{~d}$. was applied to the relief of the poor. 95

Edward Sammes of Chipping Ongar, by will proved I 882, left $\oint_{1} 100$ in trust for the purchase of tea and sugar to be given annually to 30 poor families of Chipping Ongar. The income was $£ 2$ 8s. $8 d$. in 1950.96

In 1786 it was stated that William Green, by will dated I 554, devised a rent charge of $£ 2$ to I 2 of the poorest inhabitants of Stanford Rivers and of $\mathcal{L}_{\mathrm{I}}$ to six poor of Chipping Ongar, but that this had not been paid since I739. Nothing was known of this charity in 1835 except that a suit-the result of which was unknown-had been instituted 'many years ago' to recover these bequests. 97

\section{HIGH ONGAR}

The parish of High Ongar adjoins Chipping Ongar to the east and south, being divided from it by the River Roding and Cripsey Brook. Until I 946 it included two detached parts, the most important of which was some 3 miles west of the main body of the parish. The main body itself contains two distinct areas. Marden Ash, to the south of Chipping Ongar, is a residential suburb of the town. The soil there is glacial loam and Boulder Clay. The area to the east of the Roding is entirely rural. It includes two villages, High Ongar in the north-west and Paslow Wood Common in the south-east, and numerous farms. The soil is Boulder Clay with a small patch of glacial loam. The detached parts raised special administrative probleras, which were made more serious by the poor road system in the main body of the parish.

Uncertainty as to the area of the parish during the Middle Ages makes it difficult to use the taxation returns for that period as a guide to population density and relative wealth, but if the area of High Ongar in and after the I 4 th century was about the same as it was in 1945 it is probable that the parish was sparsely populated in the Middle Ages. In 1671 High Ongar had only 57 houses compared with the 81 of Stanford Rivers, a neighbouring parish of similar area. ${ }^{2}$ The development of Marden Ash and High Ongar village during the 18 th century increased the relative as well as the total population of the parish, and in $180 \mathrm{I}$ High Ongar had 74I inhabitants-one more than Stanford Rivers. The population rose to 1,126 in 1821 and remained at about that figure for the next century. It then increased to $1,4 \mathrm{I} 9$ in $193 \mathrm{I}$, and to $\mathrm{I}, 675$ in $\mathrm{I} 95 \mathrm{I.} .^{3}$
Recent growth is mainly due to the building of council houses.

The ancient parish of High Ongar consisted of 4,519 acres of which 1,505 acres were in the two detached portions. The main body of the parish, 3,0 4 acres in extent, was situated to the east and south of Chipping Ongar. 4 Detached Part No. I, of 962 acres, lay between North Weald and Bobbingworth. Its western boundary was that which is now common to those two parishes. Its eastern boundary ran from Bobbingworth Lodge in the north to the southern boundary of Bobbingworth near Blake Hall railway station. 5 Detached Part No. 2, of 543 acres, lay to the north of Norton Mandeville. Its northern boundary was part of that which now divides Norton Mandeville from the parishes of Fyfield and Willingale. Its southern boundary ran from the Roding at a point about $\frac{1}{4}$ mile north of High Ongar Bridge east to the present Norton Mandeville-Willingale boundary near Bassett's Farm in Willingale. These detached parts belonged to High Ongar until 1946, when Detached Part No. I was merged in Bobbingworth and No. 2 in Norton Mandeville. ${ }^{6}$

Reasons are given below (see Church) for supposing that in about $\mathrm{I} 280$ a substantial part of the then parish of High Ongar was transferred to Stanford Rivers (q.v.). It is suggested that High Ongar had previously extended continuously from Marden Ash, south of Greenstead and round to Ongar Park Hall and Ashlyns, and that the southern boundary of this part of High Ongar may have been the stream which joins the Roding at Wash Bridge. It is further suggested that

\author{
83 Ibid. (1899). \\ 84 Ibid. (1912). \\ 83 Ibid. \\ 86 Ibid. (1926). \\ 87 Ibid. (1937). \\ 88 Inf. from Mr. D. W. Hutchings. \\ 89 E.R.O., D/CT 262 \\ 90 Cf. O.S. 6 in. Map (1st edn.), sheet li. \\ 91 Kelly's Dir. Essex (1937).
}

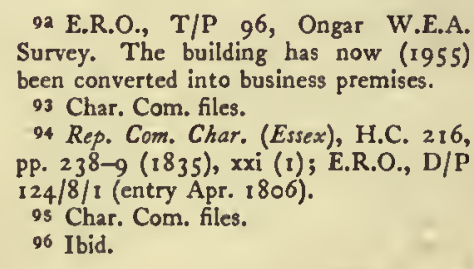

92 E.R.O., T/P 96, Ongar W.E.A. Survey. The building has now (1955) been converted into business premises.

93 Char. Com. files.

94 Rep. Com. Char. (Essex), H.C. 216 , Pp. $238-9$ (1835), xxi (t); E.R.O., D/P I24/8/1 (entry Apr. 1806).

95 Char. Com. files. 96 Ibid.

97 Rep. Com. Char. (Essex), p. 243.

1 For statistics see below, pp. $300 \mathrm{f}$.

a E.R.O., Q/RTh 5.

3 V.C.H. Essex, ii, 350 ; Census Rep.

I $921,1931,1951$.

4 O.S. $2 \frac{1}{2}$ in. Map, sheet $52 / 50$.

3 O.S. 6 in. Map (Ist edn.), sheet 1.

6 Co. of Essex (Rural Parishes) Conf. Order, $1946, \mathrm{p} .5$. 


\section{A HISTORY OF ESSEX}

the part of High Ongar which may have been transferred to Stanford Rivers about I 280 was this belt between Marden Ash and Ongar Park Hall. This transfer would have had the effect of making the Ashlyns-Ongar Park section of High Ongar a detached part of the parish. This detached part was known as Bobbingworth hamlet or as Westwood hamlet. Throughout most of its history Detached Part No. I has consisted of two estates: Ashlyns in the north, and Ongar Park in the south.7 Ongar Park was originally part of the manor of Stanford Rivers (q.v.).

Detached Part No. 2 was separated from the main body of the parish by Norton Mandeville (q.v.). In I 18 I there was no church at Norton. The tithes from the manor of Norton (Foliot) which belonged to St. Paul's and which was later known as Forest Hall (see below) were then payable to the church of High Ongar.

The church of Norton Mandeville was built after II 8 I and before I I 90 on the manor of Norton (Mandeville). It drew tithes from that manor but there is no evidence that it ever received the tithes of Forest Hall or those of the manor of Newarks Norton (see below). This would seem to be the origin of the second detached part of High Ongar, which included the manors of Forest Hall and Newarks Norton. It is possible that this detached part became for a time part of the parish of Norton Mandeville and was restored to High Ongar after the Dissolution, when the Ist Baron Rich was trading in tithes and monastic lands in these parishes. ${ }^{8}$

The main body of the ancient parish of High Ongar now stands alone, without detached parts. It consists of two sections, linked by a narrow neck of land. The section to the south of Chipping Ongar is small, but it includes Marden Ash. The name Marden goes back at least to the IIth century and means 'boundary valley': it suggests that this was the boundary between Chipping Ongar and High Ongar even at that time.9 Cripsey Brook is the present northern boundary of this part of High Ongar. 'The brook here joins the River Roding which flows south-east across the neck of High Ongar and forms the boundary of Marden Ash on the east and south. The road from Chipping Ongar southwest to London rises steeply up Marden Ash Hill to a height of $200 \mathrm{ft}$. above sea-level. Near the top of the hill it joins the road to Brentwood and Tilbury, which runs south-east and leaves the parish via Langford Bridge (see Kelvedon Hatch). Most of the houses at Marden Ash are built along these two main roads and in the streets branching from them. In general the character of Marden Ash is purely residential. The sophisticated quality in some of the 18 th- and early I th-century houses is of special interest. It suggests that the residents were not dependent on local resources.

Marden Ash House, described in 1768 as a 'seat', was probably built by Nicholas Alexander late in the 17 th century. Io It retains a fine staircase of this period. Externally the appearance of the house was entirely altered in the middle of the I 8 th century, when it was cased in red brick and a new front was added. The front is of two stories with nine windows to the first floor. It has a central doorway with half-round Ionic pilasters and a pediment. There is a modillion cornice and a parapet, with pedimented dormers above. Internally there is some good mid-I 8 th-century detail and a later 'Adam' ceiling. The oak overmantel in the Jacobean style was carved in the Igth century. II The I8thcentury brick stable block has a clock turret and cupola. North of the house is a consciously picturesque gardener's cottage, probably dating from the late i $8 \mathrm{th}$ century. It is of one story with a deep thatched roof, the eaves supported on rustic veranda posts. The windows are pointed, with gothic glazing bars and leaded lights.

Opposite Marden Ash House is Dyers, a much smaller house which was also brought up to date in the I 8 th century. Similarity of detail suggests a connexion between the two houses at this time. Dyers

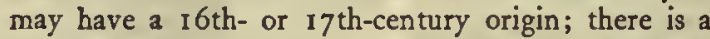


side. The mid-I 8 th-century front of plastered brickwork is not symmetrical, which suggests the adaptation of an earlier building. Internally the house is extremely rich in mid-1 8th-century decorative features, including door-heads and overmantels. The fine staircase has enriched strings and there is a Roman Doric order on the half landing.

Houses which probably date from the second half of the I 8th century are the White House, near the north end of the Brentwood road, the Two Brewers Inn and houses near it on the Greenstead road, and 2 red-brick house with a wall sundial on the main road south of Ongar Bridge.

Grey End, formerly 'The Nook, appears to have been a weather-boarded 18 th-century house, part of $_{j}$ which was refronted in brick and stucco early in the Igth century. The altered part of the south front has somewhat elaborate detail of the period.

Brewery Cottages, on the Brentwood road, were probably built in connexion with the former brewery at Dyers (see below). They are of whitewashed brick and probably date from about 1830 . Orchard Cottage, built by Noble of Ongar in 1837 , is a typical small middle-class house of the period with a trellis porch and sash windows. There are several fairly large lateIgth-century houses, the most important of which is The Gables, built in 1887 with additions of $\mathrm{I} 89 \mathrm{I}$ and $1894^{12}$ For some years before the Second World War it was the Mary Macarthur Holiday Home for Working Women.13 Most of the houses along the London road were built during the second half of the Igth century. Three cul-de-sac roads have houses of a later date including seven pairs of red-brick council houses in St. James's Avenue and three pairs in Landview Gardens. Also in St. James's Avenue is the site of the former St. James's Church. ${ }^{14}$ There is a Gospel Hall on the west side of Marden Ash Hill.

A quarter of a mile east of Marden Ash the Brentwood road is joined by the road running west from Hallsford Bridge. Newhouse Farm, on this latter road, is a timber-framed and plastered house dating from about 1600 . The original structure is $L$-shaped with a small staircase wing in the angle. There may have been a second cross-wing at the east end, giving the more
7 For these manors sec below.

8 Cf. Newcourt, Repert. ii, 452. The topography of the former detached parts is deseribed under the parishes of Bobbing worth and Norton Mandeville.

- P.N. Essex (E.P.N.S.), 73
10 Morant, Essex, i, 3 32. In 19 Ig it was reported that there was a sundial in the garden, dated 1697: Hist. Mon. Com. Recs.

"Inf. from Mr. S. H. Jones, the present owner.
12 E.R.O., T/P g6 (Ongat W.E.A. Survey 1951).

13 Kelly's Dir. Essex (1933 f.).

14 See below, Church. 
usual half-H plan. There are two rather closely set gables at the front, decorated during the past 30 years with imitation half-timbering. ${ }^{15}$ 'The central chimney has six octagonal shafts with moulded bases. There are two original ground floor rooms, that to the west having a very wide fireplace opening surrounded by old carving reset. The east room is completely panelled with a carved frieze and fine carved overmantel, all of about 1600 . If these fittings are in situ they suggest a house of considerable status which is likely to have been more extensive at the time it was built. Alterations took place in the I 8 th century when a low two-story wing was added at the back and most of the small mullioned windows were replaced by larger casements. The two doorways are Georgian, one retaining an earlier nail-studded door. Single-story additions at the back of the house are of a still later date.

At Hallsford Bridge there is a brickworks. To the east of the bridge the Stondon Massey road runs southeast, and Mill Lane, leading to High Ongar village and the east part of the parish, runs north. This section of the parish is bounded on the west by the Roding, from which the land rises gradually to the east, reaching a height of $300 \mathrm{ft}$. at Paslow Wood Common. The main road from Epping to Chelmsford enters the parish in the north-west by High Ongar Bridge across the Roding. Near the bridge to the south of this road is the rectory (see below, Church). High Ongar village is $\frac{1}{2}$ mile east of the bridge, lying along the road. Here are the parish church, the village school, the village hall, the post-office, and a small sawmill. There has been a village in this place since the beginning of the 17 th century and no doubt earlier, although in the Middle Ages it may have been no more than a tiny hamlet. In 1637 there were nine tenements in ' $\mathrm{High}$ Ongar Street' belonging to the rectory manor (see below, Church) and there may have been other houses in the village not included in that manor.

The oldest surviving house in the village is the timber-framed and weather-boarded building immediately east of the church; this dates from the late I6th or early I 7 th century and may have been built as the rectory. It has a half $\mathrm{H}$-shaped plan, the wings projecting to the north. The front has two flanking gables and the upper floor oversails across its entire length. East of the centre is a brick chimney with four octagonal shafts with moulded bases and joined caps. The weather-boarding was probably added in the 18 th century and at some time the west wing was extended northwards and further chimneys added. A small lean-to shop, now the post-office, was added to the front of the east wing, probably early in the I 9 th century. There is also a single-story addition at the back between the two wings. Before these extensions were made the house probably had fourteen rooms. The house is now divided into four tenements. Part of it was at one time used as a lock-up, and the postmasters' tenement contains a small room that may have been one of the cells. ${ }^{16}$

Opposite the church is a row of timber-framed houses known as 'The Street'. They are fairly uniform in character and probably date from the early or midI 8 th century. The fronts, some altered, are mostly roughcast but one pair is weather-boarded and the
Three Horseshoes Inn has timber framing recently exposed. Several houses near The Street appear to be of the same period, faced later with brick. The Tabor almshouses (see Charities, below) were situated near the post-office to the east.

Mill Lane, running south from the village, took its name from the windmill which formerly stood to the west of the lane $\frac{1}{2}$ mile from High Ongar. ${ }^{17}$ The Old Cottage also on the west of the lane has diagonal shafts to the chimney and is of the I 7 th century. Nash Hall cottages are an attractive row with a mansard roof and gabled dormers. There are 9 pairs of council houses on the west side of the lane immediately south of the village. Farther south on the same side are 7 pairs. Behind these is Millfield, a council housing estate consisting of some 20 pairs of houses and 4 pairs of old people's bungalows. It was built about 1948. Also in Mill Lane is a small chapel (see Nonconformity, below). Clatterford Bridge, in Mill Lane, spans a stream which flows west to join the Roding.

South of the main Chelmsford road mile east of the village is Nash Hall (see below). Chivers Hall (see below) is north of the road I mile east of the village. At Cozens Farm, on the road I $\frac{1}{2}$ mile east of the village, there is an incomplete moat. The house itself is not older than the 17 th century. It is timber-framed and plastered and has an original chimney. Spurriers, $\frac{1}{2}$ mile east of Cozens Farm, is a brick farm-house of the late 18 th or early 19 th century. Half a mile east of Spurriers is Norton Heath, a hamlet partly in High Ongar and partly in Norton Mandeville. ${ }^{18}$

At Spurriers the main road is joined by the road running south-west through Nine Ashes and Paslow Wood Common to Stondon Massey. Bluegates, which is mile south of Spurriers on this latter road, has a late-1 8 th-century front. Withers Pawne (see below), now called The Rookery, is $\frac{1}{2}$ mile south-east of Spurriers. Rookery House, formerly called The Rookery, is mile west of Withers Pawne. It is a substantial brick house built about I870. Nine Ashes Farm, now divided into tenements for the employees of Paslow Hall farm, is probably of the early. 18 th century. North of Nine Ashes the road is joined by King Street, which runs north-west to the main road. In King Street are Paslow Hall (see below) and Old Thrifts (see Frith Hall). Old Withers, a timberframed and plastered farm-house, on the north side of King Street, appears to be of the late I7th or early I 8 th-century. This is an ancient moated site, which derives its name from the family of Richard Wyther (f. 1 340).19 The three-sided moat is now (1953) being filled in. There are eight pairs of council houses in King Street.

The village of Paslow Wood Common takes its name from the common which formerly adjoined the road here (see below). It has a primary school and a mission church. There is fairly continuous building on both sides of the road; most of this dates from the I 9 th and 20 th centuries and there is a large proportion of small modern bungalows. Larkins Farm is a timberframed housc, probably of the 17 th century but encased in red brick early in the 18 th century. In the King Street-Paslow Wood Common area there are several I 8 th-century cottages. In 1777 there were eight houses 1s The timbering is not shown either in a sketch of 1903 : E.R.O., Prints, High Ongar, or in a photo. of 1919 : Hist. Mon. Com. Recs.
16 In a Map of Essex by C. and J. Greenwood (1825) a 'Dungeon' is shown in the east of High Ongar Street, on the north side. This was no doubt the lock-up in question. 18 See below.

18 All. buildings at Norton Heath are described under Norton Mandeville.

19 P.N. Essex (E.P.N.S.), 74. 


\section{A HISTORY OF ESSEX}

around the common itself, but most of these have now disappeared. ${ }^{20}$

There are several references in the Quarter Sessions records of the late 16 th and early 17 th centuries to the bad condition of the roads in the parish. It is significant that most of the references concern the remote detached part of the parish to the west of Bobbingworth. More than one complaint was made of the lane between Bobbingworth Green and Reynkyns Brook (apparently the present main road, A. I 22). ${ }^{21}$ Both that detached part and the main body of the parish were served by the Epping-Chelmsford road which was turnpiked late in the I 8th century. A toll-gate was erected across the road opposite High Ongar Church. The toll house was sold in 1870.22 It stood against the south wall of the churchyard.23 King Street probably owes its name to the family of Richard le Kyng (f. 134I).24 The most serious defect in the road system of the parish has always been the absence of a direct road from Marden Ash to Paslow Wood Common. The road from High Ongar village to Paslow Wood Common is also somewhat roundabout. There is no reason to suppose that these defects ever had serious social results, as did the bad road system of Lambourne (q.v.). Marden Ash could supply its social needs in Chipping Ongar. Until the I 8 th century there were probably few residents at Paslow Wood Common, and they were not far from Blackmore.

High Ongar Bridge, which carries the main Chelmsford road across the Roding, has been important from the I6th century and no doubt earlier. It was often presented at Quarter Sessions as needing repair. In 1563 it was not known who should repair it. ${ }^{25}$ In 1574-5 it was said to be the responsibility of the county. ${ }^{26}$ Complaints continued to be made about its condition, and the county indicted for failure to repair it. 27 In the late I 7 th century, however, considerable sums were spent on its repair, and the county continued to maintain the bridge. ${ }^{28}$ In 1858 the county surveyor made a detailed report on it; it was then a brick bridge. ${ }^{29}$ In 1913 it was rebuilt in concrete. ${ }^{30}$

A foot-bridge between Chipping Ongar and High Ongar was also presented at Quarter Sessions at various times in the I 7 th century. It apparently adjoined High Ongar Bridge.31 In 1677 the inhabitants of High Ongar were indicted for not repairing the foot-bridge leading to Brentwood-presumably a bridge at Marden Ash. Hallsford Bridge is dealt with under Stondon Massey.

For transport High Ongar has depended mainly upon Chipping Ongar, and upon services along the main Epping-Chelmsford road. High Ongar village is now (1953) well served by buses between Epping and Chelmsford, and also by those between Chipping Ongar and Brentwood via Blackmore and Nine Ashes. Marden Ash has buses to Romford and Brentwood passing through and the terminus for the services to
Epping and to Brentwood via High Ongar is at the foot of Marden Ash Hill.

A post-office at High . Ongar is listed in 1856.32 Edward Knights was receiver between 1862 and 1890.33 In I $895-1902$ there was a sub-postmaster. ${ }^{34}$ The post-office was closed for a short time about I $905-$ 6 , but was reopened after a petition from the parish council.3s

Water was supplied to High Ongar village in I9I4 by the Herts. and Essex Waterworks Co. ${ }^{36}$ Between I 894 and 1908 there were many complaints of foul and open drainage ditches in the parish, but in spite of this a proposal by Chipping Ongar for a joint sewage scheme was rejected in I901.37 The main drainage of High Ongar village had been completed by I9I 5 , although the school was not connected to the main sewer until $1925 .{ }^{38}$ There is main drainage on the Millfield estate and at Marden Ash. The Ongar Gas Co. supplied gas to Marden Ash, no doubt from its early days. Marden Ash also received electricity when Chipping Ongar was supplied in 1932. Gas was supplied to High Ongar village in I 910,39 and electricity mains were extended there in 1935.40 Paslow Wood Common has electricity but no gas or main drainage.4I

In 1895 the parish council considered that a policeman was needed in High Ongar village, ${ }^{42}$ and one was stationed there by 1898.43 The constable was retained until $1914^{4}$ but appears to have been withdrawn during the First World War. In Ig2I the parish council examined complaints that the village youths were disorderly and decided to apply for a resident policeman.45 The application was not immediately successful, but there is now (I953) a policeman in the village. 46

A village hall was opened in High Ongar in 1925. It had an original endowment of Mill Lane allotment field, the income from which was to be used in the maintenance of the hall. The trustees were to be a committee of twelve elected residents. In 1928-34 the allotment field was sold in several lots for L $_{1} 87$. The money was invested and in 1949 brought in


raised by letting the hall for social and recreational purposes, including film shows. 47 A branch of the county library was opened in 1928.48 There was a club room at Marden Ash in I9I4, possibly in connexion with St. James's Church.49

The Fane Memorial Nursing Home was set up by a deed of I 901.50 A public subscription in memory of the Revd. F. A. S. Fane (d. 1894), for many years Curate of Norton Mandeville, and chairman of the Ongar Board of Guardians, had been used to buy property fronting on the main road at Marden Ash and this deed put the house in trust to be used as a home for a nurse employed by the residents of Ongar Union.Sr Before $194^{8}$ the house was for many years used by the district nurse provided by the Ongar and District

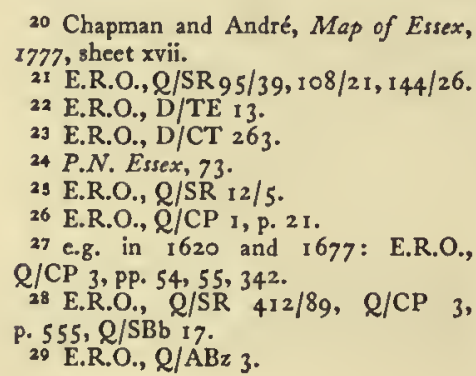

20 Chapman and André, Map of Essex, 777 , sheet xvii.

21 E.R.O.,Q/SR 95/39, 108/21, 144/26.

23 E.R.O., D/CT 263

24 P.N. Essex, 73.

23 E.R.O., Q/SR $12 / 5$

27 e.g. in 1620 and 1677 : E.R.O.

/CP 3, PP. 54, 55, 342 .

29 E.R.O., Q/ABz 3.

30 Inf. from Essex Co. Surveyor.

31 E.R.O., Q/SR 388/32; Q/CP 3,

p. $129,203,282,45^{8}$.

32 Brit. Post. Guide, 1856

33 Kelly's Dir. Essex (1862 f., 189o).

34 Ibid. (1895, 1902).

35 Parish Council Mins. 1906-8.

extracts by Mr. D. W. Hutchings.

${ }_{36}$ Inf. from Herts, \& Essex Waterworks Co.

37 Par. Council Mins. I 894-1 908.

38 Ibid. $1915,1925$.

39 Inf. from Eastn. Gas Bd. $40^{\prime}$ Inf. from Eastn. Elec. Bd.

41 Inf. from the rector, Revd. B. Hartley.

12 Par. Council Mins. 1895.

43 Kelly's Dir. Essex (1898).

44 Ibid. (I 9 I4).

45 Par. Council Mins. I921.

46 Inf. from Chief Constable of Essex.

47 Char. Com. files.

48 Inf. from County Librarian.

49 Par. Council Mins. IgI4.

so Char. Com. files.

$3 t$ For Fane's career see E.R. iv, 4. 
Nursing Association. In 1949 the property was transferred to the county council.

For much of its history High Ongar has been occupied mainly by tenant farmers. During the Middle Ages the Waldens and Batailles of Ongar Park were probably resident lords, from the 15 th century to 1578 the Pawnes probably lived at Chivers Pawne, and from the r6th century onwards the Stanes of Forest Hall lived on their manor, but with these exceptions it is doubtful whether any of the lords lived in the parish until the I 8 th century. About 1730 the leading vestrymen were William Stane and William Baker (of Withers Pawne).52 By this time the Stanes owned the manors of Newarks and Chivers Hall as well as Forest Hall. A hundred years later their new mansion of Forest Hall was the centre of an expanding estate of more than 1,000 acres. $^{53}$ Meanwhile, in the detached part of the parish adjoining Bobbingworth, the manor of Ongar Park had been acquired by the Capel Cures, of Blake Hall in Bobbingworth. Both the Stanes and the Capel Cures let most of their land to tenant farmers, but being themselves resident were in a position to exercise fairly close supervision over the tenants. ${ }^{54}$ In I 849 the parish contained some 20 farms of more than 30 acres.5s Of these the largest (Paslow Hall) contained 705 acres. There were five others of more than 200 acres, six of 100-200 acres, four of 50-100 acres, and four of $30-50$ acres. In the previous year it had been estimated that 2,500 acres of the parish were arable and 1,500 acres were meadow and pasture. ${ }^{56}$ As these figures indicate, mixed farming was then, as now, being carried on in High Ongar. In general this applied to individual farms: in about $1820-30$ Ongar Park Hall farm (in High Ongar and Stanford Rivers) consisted of 42 I acres, of which I I 9 acres were pasture and 302 acres arable.57 In I $827-9$ wheat, barley, clover, and oats were the main crops. ${ }^{8}$ Warden's Farm in the same parishes contained 93 acres of pasture and 176 acres of arable. 59 Newhouse Farm, on the other hand, was entirely pasture (I06 acres). ${ }^{60}$

The Capel Cures still live at Blake Hall (1953) but the Newalls were not resident at Forest Hall after about 1900 and their estate was broken up in I 919-20. The largest farm of the estate, Paslow Hall, was acquired as a dairy farm by the Stratford (now the London) Co-operative Society. A previous tenant of Paslow, Hugh Craig, attained distinction as a maker of cheese. During the summer of 1904 he made several Cheddar cheeses, using as much as 160 gallons of milk. ${ }^{6}$

There is little information about inclosure in the parish. Richard I granted Waltham Abbey 60 acres assarts in the manor of Paslow. ${ }^{62}$ Paslow Wood Common, which contained 83 acres, was inclosed in I $859 .^{63}$
There was a windmill in Mill Lane in 1777.64 The mill was still working in 1874 , but fell out of use soon after.65 A bakery was run in conjunction with it, which continued after the mill itself had closed. ${ }^{66}$ The base of the old windmill, now an outhouse, stands in the garden of Mill Cottage. It is of unusual octagonal shape and has thick battered walls of red brick. The cross-trees are still in position. The mill may date from the 17 th century. Mill Cottage, which included the bakery, is probably of the same period. It has been considerably extended by the present owners.

In $1833-4$ and 1848 malting was being carried on at Marden Ash by Henry Johnston. ${ }^{67}$ In 1848 there was also a brewer, Henry Saltmarsh, in the parish. ${ }^{68}$ In $1874 \mathrm{~J}$. and J. Palmer were brewers at Marden Ash, and their business was still being carried on in 1906 by E. J. Palmer. ${ }^{69}$ The brewery was behind Dyers 70 and must have been a flourishing concern if Brewery Cortages (see above) were built to house its workers.

In 1823 a lacemaking school was established in or near Marden Ash by Charles Walker, who took pauper apprentices from local parishes.7I

The brickworks at Hallsford Bridge were opened about 1914.72 Other occupations that have been noted were mainly of the types common in rural areas, but a marine store dealer and a fishmonger occur in 1886.73 There is now (1953) a sawmill opposite the church in High Ongar village.

About 1220 there were two separate grants of a fair in High Ongar, one to William de Monceux, lord of the manor of Ongar (later Nash Hall), and the other to the Rector of High Ongar.74 In 1657 Quarter Sessions suppressed a fair in the parish that was said to have been held illegally. ${ }^{75}$

The manor of ONGAR alias LITTLE ONGAR, later known as $A S H H A L L$ alias $N A S H$

MANORS HALL was held in 1066 by Leuric as a manor and 3 virgates. In 1086 it was held

by Roger of John son of Waleran. ${ }^{76}$. There is no direct reference to the manor in the I 2 th century, but in 1212 it was held by William de Monceux of the king in chief 'de Mareschaucie', and it was added that it had been 'de baronia Gileberti de 'Tani'.77 This marshalship consisted of looking after the prostitutes at the king's court, dismembering condemned malefactors, and measuring the king's 'gallons' and 'bushels'. 78 In I 66 this strange office had been held by William Fitz Audelin, who had received it in marriage with Juliane, daughter of Robert Doisnel.79 This Robert may have been a descendant of the Domesday tenant Roger. ${ }^{80}$ Gilbert de Tany, of whose barony the manor had been held, was the successor of the Domesday overlord John son of Waleran. ${ }^{81}$ The tenure of the manor of Ongar was probably converted from knight service to

\footnotetext{
32 Sec below, Parish Government.

53 See below, Forest Hall.

54 The notebook of Capel Cure (1797-

I 878 ) for c. $1820-30$ records such supervision: cf. E.R.O., D/DCc E6.

35 E.R.O., D/CT 263. These figures relate to farms being worked as single units. In some cases two or more farms were at this time merged in one.

36 Ibid.

57 E.R.O., D/DCe E6.

38 Ibid. 39 Ibid.

60 Ibid.

61 V.C.H. Essex, ii, 371

62 Cal. Chart. J 226-57, 306.

63 E.R.O., Q/RDc 50.

64 Chapman and André, Map of Essex, 1777, sheet $x$ vii.
}

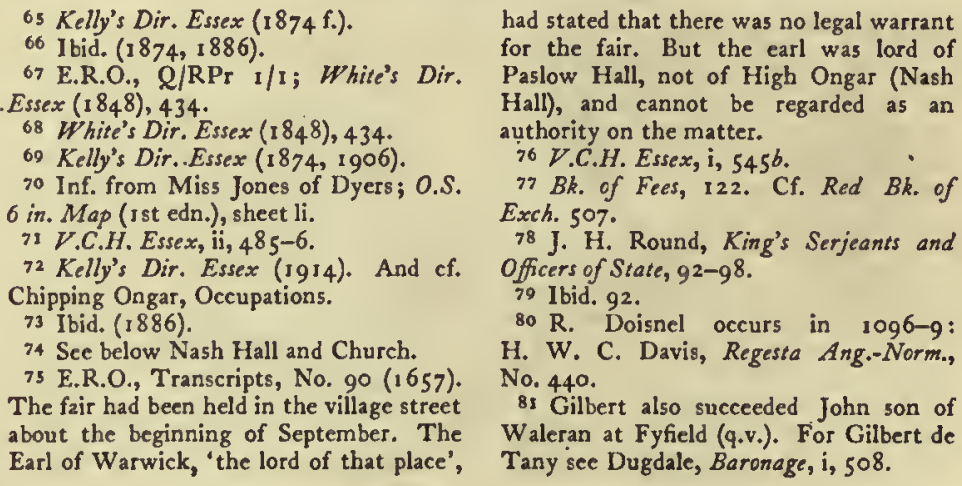

had stated that there was no legal warrant for the fair. But the earl was lord of Paslow Hall, not of High Ongar (Nash Hall), and cannot be regarded as an authority on the matter.

76 V.C.H. Essex, i, 5456 .

77 Bk. of Fees, 122. Cf. Red Bk. of Exch. 507 .

${ }^{78}$ J. H. Round, King's Serjeants and Officers of State, 92-98.

79 Ibid. 92.

80 R. Doisnel occurs in $1096-9$

H. W. C. Davis, Regeste Ang.-Norm., No. $44 a$.

81 Gilbert also succeeded John son of Waleran at Fyfield (q.v.). For Gilbert de Tany see Dugdale, Baronage, i, 508 . 


\section{A HISTORY OF ESSEX}

grand ser jeanty early in the 12 th century. This would have had the effect of dissolving the mesne lordship.

Juliane wife of William Fitz Audelin died in or before I I99, without sons. Her heirs were William de Warblington and Enguerrand de Monceux, possibly the sons of two of her daughters. ${ }^{82}$ In I 204 William de Warblington paid a fine to the king for having Ongar, but in the following year there was a partition of Juliane's land as the result of which Ongar came to Waleran de Monceux, who was probably brother and successor of Enguerrand.83 Waleran was succeeded by his son William de Monceux, the tenant of I I 2. The marshalship ultimately passed to William de Warblington and his heirs and it is not surprising that there was confusion over the tenure by which Ongar was held. In I 375 the manor was said to be held of the Earl of Stafford in socage and by suit at the hundred court. ${ }^{84}$

In 1220 William de Monceux owed a palfrey for having an annual fair at his town of 'Old Ongar'.85 He died in $1243 .{ }^{86}$ There is a curious absence of references to this manor for the rest of the 13 th century, and when it reappears again it is under the new name of Ashhall. In 1332 John de Fiennes and his wife Maud made a conveyance of Ashhall. ${ }^{87}$ Maud was sister and heir of John de Monceux, great-greatgrandson of William de Monceux. ${ }^{88}$ From this it is clear that the descent of the manor was the same as that of Herstmonceux (Sussex) and Compton Monceux (in King's Sombourne, Hants). ${ }^{89}$ Nash Hall continued to descend with Herstmonceux until I600, when it was conveyed to Thomas Mildmay by Samson Leonard and Margaret Lady Dacre his wife.90 Thomas, who was also lord of the manor of Barnes in Springfield, was later knighted and died in I6 $2.91 \mathrm{He}$ was succeeded at Nash Hall by one of his younger sons, Walter Mildmay. 92

Walter Mildmay held courts as lord of the manor from I 6 I 3 to 1654.93 By I 66 I he had been succeeded by his eldest son Ambrose who held court in that year and later up to 1681.94 Ambrose probably died without children soon after $168 \mathrm{I}$, for in 1696 and 1698 the manor was the subject of conveyances by Walter Wallinger, Anthony Wallinger, and Judith Wallinger, spinster.9s Walter and Judith were the children of Benjamin Wallinger, who had 'married Judith, daughter of Walter Mildmay. ${ }^{96}$ Anthony was possibly their brother; they were probably making a division of the manors as heirs of their uncle Ambrose.

Anthony Wallinger was lord of the manor in 1714,97 but by 1728 it had passed to Peter Champion. 98 Peter or a namesake was lord in 1757 and about $1770.99 \mathrm{By}$ I 780 Anthony Champion was lord.I He continued to hold it until about $1800-1 .^{2}$ Henry Partridge was lord in $1803 .{ }^{3}$ About $1813-14$ Nash Hall was acquired by the Revd. J. Bramston Stane, and thus became part of the Forest Hall estate (see below).4 In 1849 the Nash Hall section of the estate consisted of 204 acres occupied by James Palmer.s In I 862 Nash Hall farm contained 195 acres and was occupied by Mrs. Palmer on an eight-year lease at an annual rental of $£ 3000^{6}$ In I 19 the farm was 268 acres. 7

The present farm-house is timber-framed and plastered. It shows no obvious signs of antiquity, and if it formed part of the medieval manor house it was probably largely reconstructed in the I 8th century.

The manor of ONGAR PARK alias BATELLS was originally part of that of Stanford Rivers (q.v.), and was known late in the I 3 th century as the manor of Stanford Park. In the I 4 th century and later it lay on the boundary of the parishes of High Ongar and Stanford Rivers. Before this, although part of the manor of Stanford Rivers, it may have been wholly in the parish of High Ongar (see below, Church, c. I 280).

Humphrey de Walden, to whom the manor was granted in I 300 , died in $133 \mathrm{I}$, seised of 'the park of Stanford, held of the king as parcel of the manor of Stanford Rivers'. 'The manor was then said to consist of 270 acres of arable, worth $5 d$. an acre, land at farm worth $2 s$. (?) $8 d$., and pasture worth $60 s$. beyond the fees of'Thomas 'Tracy, Thomas de Caune, and John de Rychyng (?). ${ }^{8}$ John de Cantebrigg was granted custody of Humphrey's heir Andrew, son of Roger de Walden.9 In 1336 a royal licence was granted to Andrew de Walden to enfeoff trustees with a messuage, a carucate of land, and 800 acres of wood in Stanford Rivers, Ongar, and (North) Weald, held of the king in chief.ro The purpose of this conveyance was to settle the property on Andrew, with remainder to Humphrey and Thomas de Walden his brothers.

Andrew de Walden died in 1352 and his estate was then held in dower by his widow Joan." She died in I 361. ${ }^{12}$ Thomas de Walden, son and heir of Andrew, was still a minor, and in I 362 the king granted custody of Ongar Park to John de Bampton in return for an annual payment of 10 marks. ${ }^{13}$

Thomas de Walden made proof of age in 1367.14 In 1367 and 1368 he settled Ongar Park upon himself and his wife Margaret. ${ }^{5}$ In 1404 Thomas and Margaret settled the reversion of the manor after their deaths upon Thomas Bataille, son of Thomas de Walden's sister Alice, and Eleanor his wife, daughter of Thomas Oudeby. ${ }^{16}$ In 1412 Thomas de Walden's manor of 'Park Hall' was valued for taxation purposes at $£ 12$ a year. ${ }^{17} \mathrm{He}$ died in 1420 . The manor was then said to contain 200 acres of land worth $4 d$. an acre and 800 acres of wood worth $3 d$. an acre, held of the king in chief. It was held after 'Thomas's death by his widow Margaret. ${ }^{18}$ In I422 it was settled upon

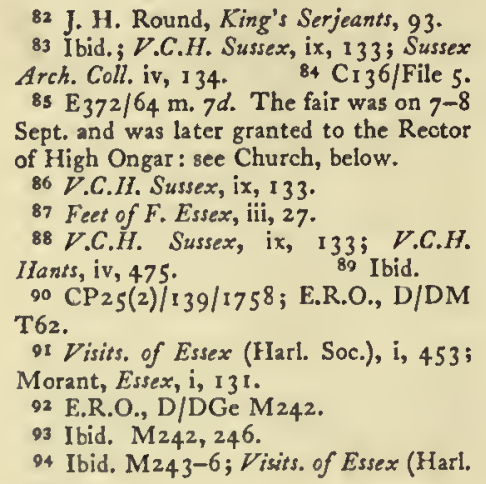

Soc.), i, 453 . $95 \mathrm{CP}_{25}(2) / 820$ Trin. Io Wm. III.

96 Visits. of Essex, i, 516.

97 E.R.O., D/DGe M244

$98 \mathrm{CP}_{25}(2) / 1120$ Mich. 2 Geo. II;

E.R.O., D/DGe M245.

99 E.R.O., D/DGe 277; Hist, Essex by

Gent. iii, 326.

E.R.O., Q/RP1 685.

2 Ibid. 705, 706.

3 E.R.O., Q/RSg 4.

4 E.R.O., Q/RPl 718, 7 I9.

5 E.R.O., D/CT $26_{3}$.

6 Forest Hall Sale Cat. 1862.

7 Forest Hall Sale Cat. I 19.

8 Ci 35/File 26. For Tracy see Traceys in Stanford Rivers; for Caune see Canes in North Weald.

9 Cal. Fine R. $1327-37,256$

10 Cal. Pat. $1334-8,236$.

11 Cal. Ing. p.m. x, p. 5 ; Cal. Pat. I 354-

$8,216$.

12 Cal. Inq. p.m. xi, p. 184 .

13 Cal. Fine $R$. I 356-68, 206.

14 Cal. Inq. p.m. xii, p. I64. He was said to have been born at Magdalen Laver.

15 Cal. Close, 1364-8, 405; Cal. Pat. I $367-70,99$.

16 Cal. Pat. I 401-5, 354; Feet of $F$.

Essex, iii, 241.

17 Feud. Aids, vi, 443.

${ }_{18} \mathrm{C}_{3}$ 1/File 50 $\mathrm{Ca}$. Close, I419-22, 78. 
Thomas Dryffeld, goldsmith of London and Margaret his wife.19 Probably Margaret de Walden had married Thomas Dryffeld.

By 1434 the manor had come to Thomas Bataille, by virtue of the settlement of 1404.20 It was from his family that the manor derived its alternative name of Batells or Batailles. Thomas was succeeded on his death in 1439 by his son John. ${ }^{2 I}$ A third part of the manor was retained in dower by Isabel, wife of Thomas Bataille. She was alive in 1447 and was then the wife of Robert Thornhill.22 In 1454 John Bataille temporarily forfeited two-thirds of the manor. He had pledged the property as surety for the good behaviour of Robert Poynings, who had been 'carver and swordbearer' to Jack Cade and had subsequently been bound over to keep the peace, but had failed to do so. ${ }^{23}$ Now the king seized Bataille's part of the manor and delivered it to John Leventhorpe and Richard de la Felde to be kept for fifteen years 'if the premises shall remain so long in the king's hand' at an annual farm of 20 marks. ${ }^{24}$ In 1473 Bataille received the royal licence once more freely to hold the manor.25 Presumably he had by this time become seised of the third of it formerly held in dower by Isabel. He died in 1474 , leaving John Bataille his son and heir. ${ }^{26}$

Richard Bataille, perhaps son of the last named John Bataille, died in 1540.27 Under a settlement made in 15 I 8 the manor passed to Richard's niece Joan (Ferne) and her husband William Shelton. ${ }^{28}$

William Shelton was dead by I 553 , when a conveyance of the manor was made by his widow and their son Humfrey Shelton.29 In or about 1590 Ongai Park was being leased by Humfrey Shelton to Edmond Felton. ${ }^{30}$ Humfrey died in 1605 and was succeeded by his son William Shelton. ${ }^{31}$ In 1615 William Shelton conveyed the manor to William Copley, ${ }^{32}$ but after Shelton's death in 1620-I there was a dispute over this transaction, between Copley and Robert Napper, Shelton's executor. ${ }^{33}$ An agreement was eventually reached providing for the payment by Copley to Napper of 64,300 , for which Copley gave as security a bond for $£ 6,000$ and a lease of Ongar Park for 99 years.

William Copley died in I623.34 Shortly before his death he had settled the manor on trustees for the repayment of his debts. It was probably these trustees who sold Ongar Park to Sir Richard Minshull, who held it in 1641.35 He was a zealous royalist in the Civil War and after the fall of Oxford compounded for his estates in Bucks., Essex, and elsewhere. ${ }^{36} \mathrm{He}$ died in 1667 and was succeeded by his son Richard.37 In I 700 the manor was conveyed to trustees by Richard Minshull in order that it should be sold to pay his debts and to provide for his only child Mary.38 In
1705 Ongar Park was sold to Sir Thomas Webster, Ist Bt. (d. I 751) of Copped Hall, Epping. ${ }^{39}$

In 1738 Webster sold the manor to Aaron Franks of London, who held it in trust for Henry Franks, son of his brother Isaac (d. 1736).40 Henry, who was a lunatic, died childless in 1796, and Ongar Park then passed under the terms of his father's will to Jacob Henry Franks, son of Henry's sister Phylah (d. 1764) by her husband Napthali Franks (d. 1796). ${ }^{4 I}$ In I 805 Jacob H. Franks sold the manor to Capel Cure of Blake Hall in Bobbingworth.42 It subsequently descended along with Blake Hall (q.v.). An undated plan of the manor 'belonging to Mr. Franks' shows all field boundaries and farm buildings. The total extent of the estate was then I, 327 acres. 43 It included six farms, of which the largest was 300 acres. Ongar Park Wood was 280 acres and was the only substantial part of the estate kept in hand. The manor extended into the parish of Stanford Rivers. In 1849 the part of it in High Ongar alone consisted of some 700 acres, including Cold Harbour, Wardens, and Newhouse farms.44 There was in addition about 1,000 acres in Stanford Rivers by that time.45 Ongar Park farm was put up for sale in 1919. It then comprised 637 acres of which 392 acres were in High Ongar. It was then let to James and T. C. Kerr at an annual rent of $£ 600.46$

The timber-framed east wing of Ongar Park Hall is probably of medieval origin. Timbers in a partition between two bedrooms represent part of a roof truss which may have divided the open hall into two bays. The ridge purlin is still in position at the level of the bedroom ceiling, but the rest of the construction has been destroyed by the insertion of a later chimney. The sou th wing, also timber-framed, was built or reconstructed in the 18 th century. Later additions were made in the rgth century.

The manor of $A S H L Y N S$ lay partly in High Ongar and partly in Bobbingworth and North Weald.47 It derived its name from Richard Ascelyn who made conveyances of land in and near High Ongar in 1320 , I 324 , and 1327.48

The estate is first described as a manor in 1475 , when it was among the possessions left by Walter Wrytell, at his death. ${ }^{49}$ His son and heir John Wrytell died in 1485 leaving an infant son, also named John. so Katherine widow of Walter Wrytell evidently held the manor in dower until her death in 1493. sI John son of John Wrytell died in 1507 . He was survived by his wife Audrey, daughter of John Shaa.52 His daughter and heir Juliane was dead by 25 November 1509 , when the heirs to Ashlyns and other manors were declared to be the daughters of Walter Wrytell: Eleanor, wife of James Walsingham and Gresilda wife of Edward Waldegrave.s3
19 Cal. Pat. I 422-9, 9 .

20 Ibid. $1429-36,343$.

21 CI $39 / 98$.

22 Cal. Pat. $1446-52,25$.

23 Cal. Fine $R$. 1452-61, 92.24 Ibid.

25 Cal. Pat. $1467-77,393$.

${ }_{26} \mathrm{C}_{140 / 44}$.

$27 \mathrm{C}$ (42/62/3 I. 28 Ibid.

29 Cal. Pat. I $553-4,364 ; \mathrm{CP}_{4}$ o/ I 156

m. 22 .

30 Cal. S.P. Dom. I $58 \mathrm{I}-90,7$ I0.

$31 \mathrm{C}_{142 / 293 / 54}$.

$32 \mathrm{CP}_{5} 5(2) / 295$ Trin. 13 Jas. I.

33. $\mathrm{C}_{3} / 320 / 61$. For Wm. Shelton's death see P.C.C. Year Bks. of Probates, I. $620-4$, p. 275

$34 \mathrm{C}_{142 / 405 / 559}$. He left infant

Es. 1V

daughters Mary and Anne.

${ }_{33} \mathrm{CP}_{25}$ (2)/41 8 East. 17 Chas. I.

36 Complete Peerage, vili, $7 \mathrm{II}$. His seat was at Bourton, Bucks. 37 Ibid.

${ }^{38}$ Notes $E^{\circ}$ Queries (4th ser.), xi, 458. According to Complete Peerage, viii, 7 I2, Ricd. son of Sir Ricd. Minshull died childless in 1673 , but no evidence is cited for this statement.

39 E.R.O., D/DCc T27. 40 Ibid. T28.

41 Ibid. During the lifetime of Henry the estate was administered by Napthali Franks: E.R.O., Q/RSg $3(1765)$ and 4 (I 784 ). ${ }_{42}$ E.R.O., D/DCc T28. 43 E.R.O., T/M 2 เ2.

44 E.R.O., D/CT 263

43 Ibid. 327 .
46 E.R.O., Sale Catalogue, I919.

47 P.N. Essex (E.P.N.S.), 72.

48 Feat of F. Essex, ii, 200, 209-IO; iii, 3 .

${ }_{49} \mathrm{Cr} 40 / 52$. For the earlier pedigree of the Wrytells see Visits. of Essex (Harl. Soc.), 62I-2. In 1475 the manor was said to be held of Anne, Duchess of Buckingham. The previous descent of the manor, in the is th century, may have been the same as that of Bobbingworth manor (q.v.).

so Cal. Inq. p.m. IIen. VII, i, p. 63.

s I Ibid. 384 . After Wrytell's death she had married Sir Richard Haute.

${ }^{32} \mathrm{C}_{142 / 21 / 2}$.

s3 L. छ' P. Hen. VIII, i (I), p. I 35. 


\section{A HISTORY OF ESSEX}

Ashlyns was allotted to Eleanor and she and her husband made a conveyance of the manor in I $55 \mathrm{I} .{ }^{34}$ James Walsingham died in 1540.55 There is no indication whether or not he then retained an interest in the manor. Ashlyns did not remain long in the Walsingham family: in 1584 it was among the possessions of William Ayloffe, who died in that year. ${ }^{56}$ He was the grandson of William Ayloffe of Great Braxted (d. I 5 I 7) who had married Audrey, daughter of Sir John Shaa, Lord Mayor of London. ${ }^{57}$ This Audrey was probably the widow of John Wrytell (d. I 507) and it is likely that her second husband bought Ashlyns from the Walsinghams. ${ }^{58}$

William Ayloffe was succeeded in 1584 by his son William, then 23.59 In 1610 Sir William Ayloffe conveyed Ashlyns to Richard Hale. 60 In I651 Robert Hale, probably son or grandson of Richard, conveyed the manor to Henry Hunter. ${ }^{61}$ Hunter transferred it in 1672 to Baldwin Hamey, F.R.C.P., who settled it in the same year on the Royal College of Physicians. ${ }^{62}$ Hamey provided that the revenues from the manor should be used to pay stipends of $\ell_{4} 40$ to a physician of St. Bartholomew's Hospital, $£ .30$ to a physician of St. Thomas's Hospital, and f, 10 to a physician of Christ Church Hospital for poor children, and also for the provision of certain amenities within the college itself. The pensioners were to be chosen in each case by the governors of the hospitals from two candidates nominated by the college. ${ }^{63}$ For 250 years Ashlyns remained the property of the college. In 1849 it consisted of 325 acres in High Ongar.64 In 1922 the college sold it to Matthew Torrance. ${ }^{65}$

A moated site north-east of the present farm-house indicates the position of the original manor house of Ashlyns. The present house, described by Morant as a 'mean farm-house or cottage', 66 appears to date from the late 17 th or early I 8 th century with later additions. Some of the timbers in the farm buildings appear to be older than the house.

The manor of CHIVERS HALL alias PASSFIELD CHIVERS was held in 1338 by Ralph son of William de Pebmersh and Cecily his wife.67 In I 475 it was held by Sir Robert Chamberlain and Elizabeth his wife. ${ }^{68}$ Elizabeth was the descendant and heir of Ralph de Pebmersh.69 In I482 she and Sir Robert conveyed Chivers Hall to Sir Thomas Stalbroke, Kt., who died holding it in 1484.70 In $149^{8}$ the manor was conveyed to William Pawne owner of Withers Pawne by William Luke and Alice his wife, widow of Sir Thomas Stalbroke. ${ }^{71}$ The precise significance of this conveyance is not clear, but it is likely that it was a family arrangement: the Pawne and Stalbroke families were related by marriage.72

A William Pawne was lord of the manor in 1565.73 He died in I 570 and was succeeded by his son of the same name.74 This last William Pawne died in I 578.75 His heir was Bridget, wife of William Chatterton and daughter of Roger Basing by his wife Anne, sister of the William Pawne who had died in I570. Bridget and William Chatterton immediately sold the manor to John Penruddock.76 The property was said to consist of 40 messuages, 6 cottages, 10 tofts, 2 dovehouses, 40 gardens, 40 orchards, 400 acres of land, I 20 acres of meadow, 300 acres of pasture, 60 acres of wood, 100 acres of furze, and 60s. rent in High Ongar, Blackmore, and Writtle. 77 These figures probably included Withers Pawne (see below).

John Penruddock was still alive in I 595, when he sold Withers Pawne. In I 608 a conveyance of Passfield Chivers was made by Joyce Clarke, widow, and William Bingham and his wife Elizabeth. ${ }^{78}$ In 1617 the manor was settled for life upon Joyce Clarke by William Austin who in January 1627 married Anne Bingham 'of the parish of St. Saviour's, Surrey, widow'.79 From this it seems likely that Joyce Clarke was the mother of Elizabeth or William Bingham and that she was holding the manor in dower. ${ }^{80}$ In November 1627 the manor was settled in tail upon William son of the above William Austin.81 William Austin the father died in 1634.82 In 1650 William Austin the son sold Passfield Chivers to Sir John Thorowgood. ${ }^{83}$ The manor was then described as 2 messuages, 2 barns, a dovehouse, 2 gardens, 2 orchards, 100 acres of land, 20 acres of meadow, 60 acres of pasture, and $\mathrm{I} 2$ acres of wood in High Ongar and Norton Mandeville. 84 Thorowgood sold the manor in 1675 to Dr. William Stane of London, and in 1688 a conveyance of the manor was made by William Stane and his father Richard. ${ }^{85}$ From that time its descent was the same as that of the manor of Forest Hall (see below). In 1849 Chivers Hall farm comprised 173 acres and was occupied by Thomas Stokes. 86 In I 862 it contained 170 acres and was occupied by Mrs. Stokes on a fourteen-year lease at an annual rent of $\$ 250.87$ By 1919 it had increased to 189 acres. ${ }^{88}$ At the break-up of the Forest Hall estate in that year the farm was bought by the tenant, W. Montgomerie, who later sold it to Mr. H. L. Bird the present (1953) owner. The tenant of Chivers Hall is now Mr. J. Clarke. The farm comprises 180 acres. ${ }^{89}$

The farm-house is timber-framed and is a lofty rectangular structure with a narrow two-story porch

\footnotetext{
s4 E.R.O., D/DB T96/69; $\mathrm{CP}_{25}$ (2)/II/ 51.

ss Conyers Read, Sir Francis Walsingham, $\mathrm{i}, 7$. He was the grandfather of Sir Francis Walsingham, Secretary of State to Elizabeth I.

$36 \mathrm{CI}_{42} / 206 / 2$.

37 Morant, Essex, ii, 138.

58 The Ayloffes were also connected with the Walsinghams through the marriage of Thomas, 2nd son of $\mathrm{Wm}$. Ayloffe the grandfather, to the daughter of a Walsingham: Visits. of Essex, 141 .

$50 \mathrm{CI}_{42} / 206 / 2$.

60 $\mathrm{CP}_{25}(2) / 293$ Mich. 8 Jas. I; ibid. Hil. 8 Jas. I. Ayloffe became Ist Bt. in Nov. I6II: G.E.C. Complete Baronetage, i, 93 .

${ }_{61} \mathrm{CP}_{25}(2) / 550 \mathrm{~B}$ East. I651. For the Hale pedigree see $V$ isits. of Essex, 209

$62 \mathrm{CP}_{25}(2) / 654$ Hil. 23 \& 24 Chas. II;
}

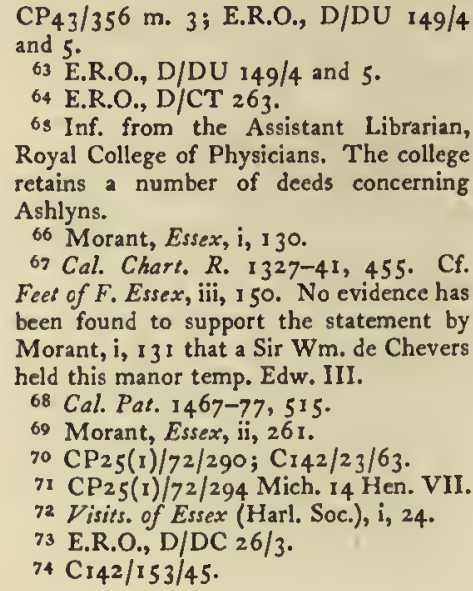
Royal College of Physicians. The college retains a number of deeds concerning Ashlyns.

66 Morant, Essex, i, 130

67 Cal. Chart. R. 1327-41, 455. Cf. Feet of $F$. Essex, iii, I 50 . No evidence has been found to support the statement by Morant, i, 13 I that a Sir Wm. de Chevers held this manor temp. Edw. III.

68 Cal. Pat. $1467-77,515$

69 Morant, Essex, ii, 26 I.

$70 \mathrm{CP}_{25}(\mathrm{I}) / 72 / 290 ; \mathrm{CI}_{12} / 23 / 63$.

${ }_{11} \mathrm{CP}_{25}(\mathrm{I}) / 72 / 294$ Mich. 4 Hen. VII

72 Visits. of Essex (Harl. Soc.), i, 24.

73 E.R.O., D/DC 26/3

${ }_{74} \mathrm{C}_{142 / 153 / 45}$.

\author{
$73 \mathrm{C}_{42} 2 / 181 / 55$ \\ ${ }_{76} \mathrm{CP}_{25}(2) / 130 / 1670$ \\ 77 E.R.O., D/DGe 260. \\ ${ }^{7} \mathrm{CP}_{25}(2) / 293 \mathrm{Hil} .5$ Jas. 1 \\ 79 Ibid. 294 Trin. I5 Jas. I; $\mathrm{C}_{142} /$ \\ $48 \mathrm{I} / 30$. \\ $80 \mathrm{~A}$ Laurence Bingham bad been \\ tenant of the manor in $3578: \mathrm{Cr}_{42} /$ \\ $18 \mathrm{I} / 55$. \\ ${ }_{81} \operatorname{Cr}_{42} / 481 / 30$ \\ 82 Ibid. \\ ${ }_{83} \mathrm{CP}_{25}$ (2)/5508 Mich. 1650. \\ 84 E.R.O., D/DGe 262-3. The decrease \\ in extent since 1570 is considerable. The \\ earlier figures probably included Withers \\ Pawne (see below) and other property. \\ Bs E.R.O., D/DGe 266-7 \\ 86 E.R.O., D/CT $26_{3}$ \\ 87 Forest Hall Sale Cat. 1862. \\ 88 Forest Hall Sale Cas. 1919. \\ 89 Inf. from Mr. J. Clarke.
}


wing in the centre of the south-west front. In general it appears to be of late i 7 th or early 18 th century date, but an oak mullioned window of about 1600 on the upper floor suggests that parts may be more ancient. The house was altered and restored about fifteen years ago when the present staircase was inserted. There is a kitchen wing of red brick at the north-east corner of the house.

The manor of WITHERS PAWNE alias WETHERS PANE alias CHIVERS PAWNE alias CHIVERS HALL appears to have been the original estate of the Pawne family, which later acquired the neighbouring manor of Chivers Hall (see above). The manor house is now known as The Rookery. A William Pawne held the manor in $1494^{\circ 0}$ and it descended to his namesake who died in 1578.91 By his will dated April I 578 William Pawne left Chivers Pawne to William Chatterton, who had married his sister's daughter Bridget.92 Withers Pawne evidently passed with Chivers Hall to John Penruddock but in I 595 was separated from the main manor and sold to Gregory Yonge, grocer of London. 93 Yonge held a manor court in $1596.94 \mathrm{He}$ died in or shortly before I6 10.95 The manor passed to the Holman family, to which he was probably related through the marriage of his daughter Jane. 96 In 16 I 8 a conveyance of Withers Pawne was made by Elizabeth Holman, widow. 97 She had probably been the wife of Alexander (d. 1617) son of George Holman. 98 Sir John Holman, Ist Bt. (cr. 1663), held Withers Pawne in 1679.99 He had probably inherited it from his father Philip Holman (d. I669) who was no doubt a collateral descendant of Alexander Holman, who had died childless." Sir John died shortly before May I700.2 In the same year Withers Pawne was conveyed by Anastasia Holman, widow, to William Baker. ${ }^{3}$ William Baker held a court in the manor in 1718.4 He was succeeded by his son Bramston Baker. 5 In I 849 Chivers Pawne farm was owned and occupied by William Baker and comprised I 34 acres. ${ }^{6}$ The farm was purchased in 1926 by the London Co-operative Society L.td. It now comprises $98 \frac{1}{2}$ acres freehold, with an additional I $9 \frac{1}{2}$ acres rented. Mixed arable and dairy farming is carried on there.7

The Rookery farm-house is a timber-framed building probably dating from the I 6 th century. It was originally built on a half $\mathrm{H}$-shaped plan. ${ }^{8}$ About 20 years ago it was thoroughly reconditioned: part of the northeast wing and also an 18 th-century addition between the two wings were demolished. At each end of the house is an original red-brick external chimney with two diagonal shafts.

The manor of FOREST HALL (formerly FOLIOT'S HALL) originated as a tenement of $\frac{1}{2}$ hide in Norton held in 1066 by a woman named 'Godid'.
After the Conquest it was given by her to the Dean and Chapter of St. Paul's.9 It continued to be known as the manor of Norton until the I 3 th century. In I I 8 I it was farmed for St. Paul's by Odo de Dammartin, a member of the family which held the neighbouring manor of Norton, later Norton Mandeville.10 It was then stated that the manor satisfied the royal demand for hidage in the time of Henry I and William the Dean by paying for 40 acres and by giving to the bailiff of the hundred $12 d$. and I $2 d$. for wardpenny. There were $I 00$ acres of arable land, 5 acres of meadow, and I 2 acres of wood. There was. I plough in demesne and the manor rendered to St. Paul's 40s. in the octave of Easter and 6os. at the Exaltation of the Cross."

Another inquisition into the lands of St. Paul's was held in $1222 .{ }^{12}$ John de Dammartin was now the farmer. The hidage of the manor was the same as in I 8 I. The manor was free from suit of county, but followed the hundred of Ongar, at the suit of which I $2 d$. were paid from the demesne to the reeve of the hundred and $I 2 d$. from the tenants. There were now I02 acres of arable, 6 acres of meadow, and 12 acres of poor (gracilis) woodland. The arable could be tilled with one plough team of eight beasts. Seven marks had been spent on fertilizing the land with marl and the erection of new buildings. The names and services of six tenants were given.

In the middle of the I 3 th century the manor was held, under St. Paul's, by Richard Foliot, Archdeacon of Middlesex. John son of Ernald de Mandeville (see Norton Mandeville) granted 60 acres of land in the parish of 'Great Norton' to Foliot for the use of St. Paul's in free alms.13 In 1258 John de Mandeville granted to St. Paul's 76 acres of land and I acre of meadow in Norton in pure and perpetual alms. ${ }^{14}$ Perhaps this last grant included all or some of that to Foliot.

The manor remained in the possession of St. Paul's throughout the Middle Ages, and was known sometimes as Norton and sometimes as Norton Foliot. In I 535, under the name of Folyathall it was valued at f6 I 3 s. 4d. Is In 1544 St. Paul's exchanged the manor for other lands with the king, who in the same year sold Folyathall and a wood called Folyatswood to

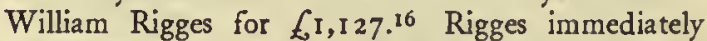
transferred the property to Sir Richard Rich, later Ist Baron Rich. ${ }^{17}$

In 1562 Lord Rich conveyed Foliots Hall to Richard Stane of Shelley, yeoman, and Richard his son. ${ }^{18}$ Richard Stane the elder died in I60I and was succeeded by Richard the younger, then aged 40.19 Foliots Hall had been settled upon the latter in I 589 , on his marriage to Ann Rabett.20 He died in I6I4, leaving a son and heir John.2I A Richard Stane held Forest Hall in $1687.22 \mathrm{He}$ died in 1714 and the manol

\footnotetext{
90 P.N. Esssex (E.P.N.S.), 73.

${ }^{21} \mathrm{C}_{142 / 181 / 55}$. See Chivers Hall,

above. 92 Ibid.

${ }_{93} \mathrm{CP}_{25}(2) / 136 / 1736$.

94 E.R.O., D/DC $26 / 6$.

95 P.C.C. Wills, 1609-19 (Index Libr.),

502.

96 Visitr. of Surrey, 1530, \&cc. (Harl. Soc.), 96. The pedigree states that Jane, daughter of George Young of London, married George Holman, but there is no trace of a George Young at this time. ${ }_{97} \mathrm{CP}_{25}(2) / 295$ Hil. I5 Jas. I.

98 Visits. of Surrey, 96; P.C.C. Wills, 1609-19 (Index Libr.), 235. According to Morant, Essex, i, 13 I Alexander
}

Holman held Wetherspane in 3614.

$99 \mathrm{CP}_{25}$ (2)/295 Trin. 31 Chas. II.

I G.E.C. Complese Baronerage, ii, 277

Morant, Essex, i, 131 refers to Philip Holman in his account, of Chivers Hall.

2 G.E.C. op. cit. 277.

${ }_{3} \mathrm{CP}_{25}(2) / 830$ Trin. $12 \mathrm{Wm}$. III.

4 E.R.O., D/DC 26/7.

- Motant, Essex, i, 131 .

6 E.R.O., D/CT 263 .

7 Inf. from London Co-operative Soc.

8 Hist. Mon. Com. Essex, ii, 133.

- V.C.H. Essex, i, 442b. And sec Norton Mandeville.

to Dom. of St. Paul's (Camd. Soc. 1858 ), III.
12 Ibid. 73.

13 Hist. MSS. Com. 9th Rep. pt. i, P. 38a. For the parish boundaries of Norton Mandeville and High Ongar see above, P. 172.

34 Feet of F. Essex, i, 225.

15 Valor Eccl. (Rec. Com.), i, 3606.

${ }^{36}$ L. EO P. Hen. VIII, xix (1), p. 495 ; ibid. (2), p. 72 .

37 Ibid. p. 86.

18 E.R.O., D/DGe 259; CP25(2)/ 18

Mich. 4 Eliz.

I9 $\mathrm{C}_{42 / 266 / 87}$. 20 Ibid.

21 Motant, Essex, i, 13i; C60/469, no. 34 .

22 E.R.O., D/DGe 265. 


\section{A HISTORY OF ESSEX}

passed to his son William.23 In I725 a settlement of the manor was made by William Stane and Alice his wife, William Stane the younger and Richard Stane.24 By I 774 Forest Hall had passed to John Westbrook who in 1770 had married Mary Alice daughter of William Stane. ${ }^{25}$ Forest Hall farm, surveyed in 1774 , contained 277 acres. ${ }^{26}$ Mrs. Westbrook died in r 801 , having devised the estate to the Revd. John Bramston, son of Thomas Berney Bramston of Skreens in Roxwell.27 As a result of this legacy John Bramston assumed the additional surname of Stane. Forest Hall gave its name to an estate in High Ongar and neighbouring parishes which included the manors of Nash Hall, Chivers Hall, Newarks Norton, Herons in Fyfield (q.v.), Norton Mandeville (q.v.), and Rockells in Willingale Doe. A map of the estate drawn about 1840-50 shows all these except Rockells, which was acquired later. At that time the total area of the estate was about 1,000 acres, of which about 750 acres were freehold. 28

The Revd. J. B. Stane died in 1857 and was succeeded by J. Bramston Stane his son.29 In 1862 J. B. Stane bought an estate at Sherfield upon Loddon, Hants, where he built himself a house. ${ }^{30}$ In the same year the Forest Hall estate was put up for sale. It then consisted of 2,228 acres of which 271 acres were leasehold. Some 750 acres were in hand and there were eight farms let to tenant farmers on leases varying from 8 to I 2 years. The total rent roll (including estimates for the lands in hand) was $£ 3,52 \mathrm{r} .{ }^{31}$ The estate was purchased over the next four years by J. L. Newall. The conveyances included the purchase of the freehold of Norton Hall farm and manor (see Norton Mandeville) which had been the leasehold part of the estate. ${ }^{32}$ During the next 30 years Newall made substantial additions to the estate. He lived at Forest Hall until his death about r 900 . His son, J. W. Newall, leased the hall from about I 902 to H. M. McCorquadale. ${ }^{33}$ In 1919 the whole estate was put up for sale and broken up. At that time it consisted of $3,83 \mathrm{I}$ acres in the parishes of High and Chipping Ongar, Norton Mandeville, Fyfield, Shelley, Willingale Spain, and Willingale Doe.34 In addition to the manors named above, it included Paslow Hall (see below) and Fyfield Hall, which belonged to the estate, but without the manorial rights formerly appurtenant to them. There were altogether seventeen farms in the estate, ranging in size from Paslow Hall (6I9 acres) to Welchman's (64 acres, in Fyfield). Forest Hall house, together with Little Forest Hall and Newarks Hall, were bought about 1924 by $\mathrm{H}$. M. McCorquodale, who lived at the Hall until his death in $1943 .{ }^{35}$ His executors sold the property to the Air Ministry, which

\section{Morant, Essex, i, 131.}

$24 \mathrm{CP}_{2}$ (2)/1014 Hil. $11 \mathrm{GeO}$. I. Ried.

Stane was probably the twin of $\mathrm{Wm}$.

Stane the elder : Hist. Essex by Gent. iii, 329

25 E.R.O., D/DC $27 / 1$ I 15 ; Gents. Mag.

xl (1770), 344; ibid. Lxxi, 276.

26 E.R.O., D/DC 27/1115.

27 Gents. Mag. Ixxi, 276.

28 E.R.O., D/DC 27/1127. Norton

Mandeville manor was being leased from Merton College.

29 Gen 's. Mag. cxl, 496.

30 V.C.H. Hants, iv, $103,107$.

31 Sale Catalogue, 1862.

32 Sale Cat. 1919, lent by London Co-Op. Soc.

33 Kelly's Dir. Essex (Ig02 f.). Inf. from Mr. K. McCorquodale.

34 Sale Cat. 1919. resold the house and some 80 acres adjoining to the Essex County Council.36

An 'elegant family mansion of brick' was built by Richard Stane about I 700.37 The present mansion, about 300 yds. farther south, replaced it about 1845 . It was built by the Revd. J. B. Stane and is a large square three-story house of gault brick with stone and stucco dressings. The front has seven windows to each of the upper floors and a central pediment. The Tuscan portico has three bays. There are extensive service quarters and out-buildings. The house has been empty since 1943.38

Forest Hall is one of the largest mansions in this part of Essex. In the late Igth century, during the ownership of J. L. Newall, it employed some 50 indoor and outdoor servants, and had its own gasworks and sawmill. 39

FRITH HALL alias OLD FRITH alias OLD THRIFTS gave its name to William del Frit (temp. Henry III) who was probably the tenant. It may originally have been associated with Chivers Hall (see above). 40 In 1414 a conveyance was made by Thomas Roche, vintner, and William Leverpole, goldsmith, both of London, to John Cosoun, Arundel Herald and Agnes his wife of I messuage, I 50 acres of land in Norton Mandeville and High Ongar called Frythall.41

Henry Parker (d. 154I) left to his son Roger the manor of Frith Hall in the same parishes. ${ }^{22}$ Roger Parker conveyed it in 1555 to Richard Sampforth.43 In I63I John Sandford, no doubt a relative of Sampforth, conveyed the manor to Robert and John Sorrell.4 In $\mathrm{I} 660$ a conveyance of Frith $\mathrm{Hall}$ was made between Thomas Sorrell of the one part and Robert Sorrell and Anne his wife of the other.45 They were probably members of the Sorrell family of Writtle. ${ }^{46}$ The Sandfords may have remained on the estate as tenants: in I671 a Sandford occupied a house with eight hearths in High Ongar, and an Edward Sandford occupied a house (probably Readings) in Norton Mandeville (q.v.). 47

By 1687 the manor was acquired by Dr. Anthony Walker, Rector of Fyfield, who by his will of that year left Old Frith as part of the endowment of the charity which he founded for the education of the children of Fyfield (q.v.).48 The charity became effective on Walker's death' in 1692.49 In 1835 Old Thrifts Farm consisted of 56 acres, occupied by Thomas Stokes as tenant of the charity trustees at a rent of $£ 45$ a year. ${ }^{50}$ Stokes was still tenant in 1849.51 In 1926 the farm was let by the trustees for 660 a year. ${ }^{32}$ Now (1953) it is let by them to the London Co-operative Society and forms part of Paslow Hall farm. 53
35 Inf. from Mr. K. McCorquodale. 36 Ibid.
37 T. Wright, Hist. Essex, ii, 334. No remains of the old house now survive, but the old caretaker of Forest Hall remembers that a stable-yard pump existed on the site until the First World $W$ ar, when it was removed for scrap.
38 E.R.O., Sale Cat. A. 225 A (1919) gives photograph and description of Forest Hall. For another photograph, showing the front of the house, see Nat. Bdgs. Rec.
39 Inf. from caretaker, Forest Hall. The gasworks stood north-east of the house: see O.S. 6 in. Map (1st edn.), sheet I. They were demolished early in the 20 th cent. when an electric generator was installed.
to P.N. Essex (E.P.N.S.), 74, cf. 73
'Cheversfrith'.
41 Feet of F. Essex, iii, 262. Cf. Burke's Landed Gentry, 1952, cviii.
${ }^{22} \mathrm{C}_{142 / 64 / 78}$. For the Parkers see $V$ isits. of Essex (Harl. Soc.), 259.
$43 \mathrm{CP}_{25}(2) / 83 / 710$.
$4 \mathrm{CP}_{2} 5(2) / 527$ Mich. 7 Chas. I. $43 \mathrm{CP}_{25}(2) / 652$ Trin. 12 Chas. II. 46 Visits. of Essex (Harl. Soc.), 490. 47 E.R.O., Q/RTh 5.
4 Rep. Com. Char. (Essex), H.C. 216 , p. $225(1835)$, xxi (I). See Fyfield, also Charities below.
49 Newcourt, Repert. ii, 262.
so Rep. Com. Char. (Essex), p. 226.
sI E.R.O., D/CT 263.
32 Kelly's Dir. Essex (1926).
s3 Inf. from London Co-Operative Society Ltd. 
A weather-boarded barn is now the only building on the property.

The manor of NEWARKS NORTON appears to have been granted about 1068 by Ingelric 'the priest' to the college of St. Martin-le-Grand, London.54 It does not appear among the possessions of the college as recorded in Domesday Book, possibly because of the confusion that existed between the descent of Ingelric's personal property and that of the estates with which he had endowed St. Martin's. When the prebends of St. Martin's were constituted in $115^{8}$ the ninth prebend was endowed with land in Norton and Shelley and was known as that of Norton Newarks. 55 According to the late I 5 th-century statutes of the college this prebend was charged with the support of the vicar sub-deacon. ${ }^{56}$ King Stephen granted the canons of St. Martin free warren on their lands of Norton.57 In I 257 Henry III gave them licence to enclose the wood in the prebend of Norton. 58 In 1487 courts were being held in the manor of Newarks Norton by William Stillington. 59 He was no doubt a relative of Robert Stillington, Dean of St. Martin's $1458-85$.

In I 503 the properties of St. Martin's were given to Westminster Abbey.60 In I 542, when the college was finally suppressed, the gift of Newarks was confirmed to the Dean and Chapter of Westminster. ${ }^{61}$ In the following year, however, the manor was granted by the king to Sir John Williams and Anthony Stringer, who immediately conveyed it to Sir Richard Rich, later Ist Baron Rich.62

In I 562 Lord Rich conveyed Newarks Norton to John Waylett of Berners Roding, yeoman. ${ }^{6}$ Waylett died in I 566.64 His heir was his son John, but in 1569 the freedom of the manor was granted by the Crown to William, son of John Waylett.6s A John Waylett was lord of the manor in $1591-1612.66 \mathrm{He}$ died in 1612 and was succeeded by his son, another John, who held courts in the manor in 1613,1618 , and 1626.67

By 1649 the manor had passed to Richard Stane, lord of the manor of Forest Hall (see above). ${ }^{68}$ It was thus merged in the Forest Hall estate and subsequently had the same descent. In 1849 Newarks farm consisted of 303 acres and was occupied by the owner. 69 It was still in hand in 1862 but was then farmed along with Forest Hall farm, the combined farm containing 464 acres. 70

During the Second World War Newarks became part of the large airfield built in this area, and the farmhouse was demolished. In I 9 I 9 the house was described as being of early-r6th-century date with a cross-wing at the east end. A porch on the south side had an original moulded door-frame. To judge by a photograph taken at this time it may originally have been a house with an open hall.7x
The manor of PASLOW HALL alias PASFIELD was given to Waltham Abbey by Earl Harold. The gift was confirmed in 1062 by Edward the Confessor in a charter setting out the bounds of Pasfield. ${ }^{72}$ In I086 Pasfield was held by the abbey as a manor and as 2 hides less 30 acres and included woodland suffcient for 700 swine. ${ }^{73}$ The bounds of the manor as given in the charter of 1062 suggest that Pasfield then included a considerable area in the east and south of the parish, extending as far as the Stondon Massey boundary in the south-east and as far as the Roding in the west.74

Pasfield remained in the possession of Waltham Abbey until the Dissolution. In I 199-I 200 the abbot received royal permission to take into cultivation 8 acres of land from his pastures at Pasfield. 75 Shortly before this, in I I 89 , Richard I had granted the abbey 60 acres of assarts. ${ }^{76}$ In 1292 the abbot had licence to sell wood from his forest at Pasfield to the value of $\delta_{10} 10.77$

At the dissolution of the abbey in 1540 the abbot had a grant for life issuing out of a number of manors formerly belonging to the abbey, including Paslow.78 In 1542 the manor of Paslow Hall was granted by the king to George Harper, who immediately conveyed it to Sir Richard Rich, later Ist Baron Rich.79 The manor remained in the possession of Rich and his heirs until the death of Charles Rich, 4th Earl of Warwick of that creation, in 1673 . At the division of the earPs estates Paslow Hall fell to the share of Robert, Earl of Manchester (d. I683), the son of Anne, daughter of Robert Rich, 2nd Earl of Warwick.

In 1676 a conveyance of the manor was made to the Earl of Manchester by Mary, dowager Countess of Warwick, as her late husband's executor. ${ }^{80}$ In 1684 Charles, 4th Earl of Manchester, settled Paslow for life on his mother Anne, Countess of Manchester. ${ }^{81}$ She died in 1698 but in 1697 the earl sold Paslow with her consent to Sir Josiah Child, Ist Bt. (d. I699), the merchant and financier. ${ }^{82}$ In the same year Child settled the manor upon his 3 rd son Richard.83 Richard Child succeeded as 3 rd baronet in 1704,84 and was created Viscount Castlemaine (I 7 I 8) and Earl Tylney of Castlemaine (173I).85 He was also owner of Wanstead, and Paslow Hall descended with Wanstead until after the marriage of Catherine Long to William Wellesley Pole (181 2).86 A map of Pasfield Hall in I 74I shows that it then consisted of 692 acres in the centre of the parish. ${ }^{87}$ In 1786 Sir James Tylney Long, Bt., mortgaged the manors of Paslow Hal land Fyfield for $f_{0}, 000$. The mortgage was cleared in $1793 .{ }^{88}$

Unlike Wanstead, Paslow Hall was not sold by William Pole-Tylney-Long-Wellesley. He remained lord of the manor until 1850 or later, by which time



68 E.R.O., D/DSp $\mathrm{M}_{3} 6$.

69 E.R.O., D/CT 263

70 E.R.O., Forest Hall Sale Cat. 1862.

7 Hist. Mon. Com. Essex, ii, 133. For the photo. see Hist. Mon. Com. Rees.

72 Kemble, Cod. Dipl. iv, 154

73 V.C.H. Essex, i, $447 a$.

74 For an interpretation of the bounds see P.N. Essex (E.P.N.S.), 73 n. It cannot be correct, however, that the boundary ran south along the Roding from Hallsford Bridge. To return to its starting-point it would have had to run north.

75 Pipe R. 1200 (Pipe R. Soc. N.8. xii), 45.

76 Cal. Chart. R. $1226-57,306$.

77 Cal. Pat. 128 r -92 , 505.
78 V.C.H. Essex, ii, 170.

79 L. \& P. Hen. VIII, xvii, pp. 161-2.

80 E.R.O., D/DCw T2O.

81 Ibid.

82 Ibid. The price was 69,000 , which, however, included the manor and advowson of Fyfield (q.v.).

83 Ibid.

84 G.E.C. Complete Baronetage, iv, ro7.

8s Complete Peerage, iii, 92

86 The descent of $W$ anstead will be given in another volume.

87 E.R.O., D/DCw $\mathrm{P}_{4} 6$

88 E.R.O., D/DCw T2O. The purpose of the mortgage was to raise money to pay a legacy by the last Earl Tylney to his daughter Lady Dorothy Child. 


\section{A HISTORY OF ESSEX}

he had become Earl of Mornington.89 In I 849 Paslow Hall consisted of 705 acres and was occupied by Andrew Ling and John Brown.90 Lord Mornington died in $x 857$ but by 1855 the lordship of Paslow Hall had passed to his son, later 5 th Earl of Mornington.91 After the death of the 5 th earl in 1863 the manor was held for some years by trustees. ${ }^{92}$ By 1899 it had become the possession of Alfred C. Bristow, ${ }^{93}$ who in 1906 still held the manorial rights. 94 Paslow Hall Farm was separated from the manor in $1866-7$ and sold to J. L. Newall, thus becoming part of the Forest Hall estate (see above). 95 On the break up of the estate in Ig19 the farm was bought by the Stratford Cooperative Society. 96 Paslow Hall Farm is now (1953) owned by the London Co-operative Society, in which the Stratford society is merged. Its area is 687 acres. This includes 56 acres rented from Dr. Walker's Trust (see Frith Hall, above) and 8 acres rented from W. and C. French. The society has a number of other farms in the district, which are managed from Paslow Hall farm: Rookery Farm (see Withers Pawne, above); Nine Ashes Farm, purchased in 1940 and consisting of I08 acres; Stanford Hall farm (in Stanford Rivers, q.v.); Berners Hall farm, including Parsonage Farm, in Berners Roding, which was purchased in 1936 and contains 860 acres; Torrells Hall farm, in Willingale, including Rowes and Old Lodge Farms, purchased in I939 and containing 417 acres; and Longbarns Farm, including Frayes (in Beauchamp Roding, q.v.). All these farms have been bought by the society since 1920 . Their total area is 3,186 acres and mixed arable and dairy farming is carried on throughout the estates. 97

Paslow Hall is a timber-framed L-shaped building, the south front being faced with red brick. The east or back wing is of two stories and basement and may be of the I 7 th century or earlier. The south wing probably represents the former great hall, but it appears to have been completely reconstructed in the middle of the I 8 th century and faced with brickwork. At about the same time a staircase block was added in the angle between the wings. 98 The south front has sash windows somewhat irregularly spaced and a pedimented hood to the doorway.

The early history of the church of High Ongar is closely bound up with that of Stanford CHURCH Rivers and Little Laver (q.v.). In 1086 Eustace, Count of Boulogne, was lord of the manors of Stanford Rivers and Little Laver. Early in the 12 th century he apparently granted the advowsons of Stanford Rivers, Little Laver, and High Ongar to the priory of Rumilly-le-Comte, a Cluniac house in the Pas-de-Calais. 99 'That he had possessed the advowsons of the first two churches is not surprising. Most parish churches in Essex originated as manorial churches and the church is usually close to the site of an ancient manor house whose lord possessed the advowson. At Stanford Rivers and Little Laver there is no doubt that the manors with which the churches are associated were



94 Ibid. (I906). For the court rolls of the manor see below, Parish Govt.

95 Forest Holl Sale Cat. I9:9 (in poss. London Co-op. Soc.)

96 Inf. from the Secy. London Co-op. Soc.

97 Ibid.

98 It is not shown on an estate map of 1741 : E.R.O., D/DCw $\mathrm{P}_{4} 6$.

99 E.A.T. N.s. viii, 227. Eustace founded Rumilly in $1105:$ V.C.H. Essex, ii, 126 .

1 Dom. of St. Paul's (Camd. Soc. 1857), 150. Norton had its own church by 1 I go.

2 Cal. Close, $1227-3$ I, 433

3 Cal. Chart. R. 1226-57, 108. The fair was to be held on 7 and 8 Sept. No further reference to it has been found after 1230. It was clearly identical with the those which belonged to Count Eustace. But the manor with which one would naturally associate High Ongar fopographical reasons is Nash Hall (see bove) and there is no evidence that Eustace had any in that manor, or on the other hand that the Hash Hall ever had the patronage of the . If the church had ever belonged to Nash Hall belonged to Eustace as lord of Chipping Ongar. In that case the advowson of High Ongar could have belonged to Eustace and his successors when its church full parochial status. 'There was certainly a parish church at High Ongar in II $8 \mathrm{I}$, when its parson of souls in Norton (Mandeville) (q.v.) and church of Fyfield a sack of corn and a sack of oats because Norton was so near to that church. ${ }^{\mathrm{x}}$ fair at his church each year until the king's ma jority. ${ }^{2}$ the then rector, Sylvester de Everdon, thester was granted oaks from the king's fores resigned from the rectory before $1237^{5}$ but in 1246 , when he was Archdeacon of Chester, he was granted the advowsons of High Ongar, Stanford Rivers, and official return of about 1254 stated that the patron Ongar and Stanford Rivers was Sir Philip ing Ongar and Stanford Rivers, and that the patronage of Little Laver belonged to the monks of Rumilly. 'Charges' issuing from High Ongar and Little Laver Ongar was 60 marks and that of Stanford Rivers

Rumilly had not in fact surrendered its claim to High Ongar and Stanford Rivers. In I 264 the king ex the priory ${ }^{8}$ and in the following year it fus expressly stated that this should not prejudice the I 277-80 there were several conveyances by which Arnulph, Prior of Rumilly, and John de Rivers, lord of fivers, both surrendered their rights in the cherches of Stan ford Rivers, High Ongar, and Little aver to Edward I and Queen Eleanor. Pensions from was stated that the church of Stanford Rivers was in the gift of John de Rivers and was worth 50 of the king and queen and was worth 50 marks, and that the church of Little Laver (worth 30 marks) was also in the gift of the king and queen. 11 In 1291 the churches of Stanford Rivers and High Ongar were both

fair granted in or before 1220 to $\mathrm{Wm}$. de Monceux : see above Nash Hall

4 Cal. Close, 1227-31, 3 I1. This probably means building at the rectory house rather than the church itself.

s Reancy, Early Essex Clergy, 124.

6 Feet of F. Essex, i, 152.

7 E.A.T. N.s. xviii, 19.

8 Cal. Pet. 1258-66, 382

9 Ibid. 504.

to Feet of F. Essex, ii, 15, 25; Cal. Close, $1272-9,577-8$

II E.R. lii, 44 ; J.I.1/244. 
valued at 40 marks. ${ }^{12}$ In and after the 14 th century the king always presented to Stanford Rivers as well as to High Ongar and Little Laver. ${ }^{13}$

The foregoing details are of great interest for they may explain how there came to be a detached part of High Ongar to the north of Stanford Rivers, some 2 miles from the main body of High Ongar parish. It is clear that there was a dispute between Rumilly and the lords of Stanford Rivers concerning the advowsons of Stanford Rivers and High Ongar and that about 1280 this was resolved by both parties surrendering their claims to the king and queen. It also appears that between about I 254 and I 29I the value of the rectory of High Ongar decreased from 60 marks to 40 marks while that of Stanford Rivers increased from 20 marks to 40 marks. It therefore seems likely that during the dispute or after its settlement the parish of Stanford Rivers was enlarged at the expense of High Ongar. The evidence of 1285 shows that John de Rivers retained some interest in the advowson of Stanford Rivers after I 280 , and it is possible that the enlargement of the parish was the consideration for which he surrendered his claim to the patronage of High Ongar and Little Laver. If the parish of High Ongar did in fact lose a substantial part to Stanford Rivers it seems most likely that this was the belt of land which now forms the north of Stanford Rivers, running from Marden Ash in the east to Ongar Park Hall in the north-west, and is bounded on the south by the stream which joins the Roding at Wash Bridge. If this area was previously part of High Ongar it was the link between the main body of the parish and the AshlynsOngar Park section. The area involved fits in well with the reasonable deductions that can be made from the valuation figures of about 1254 and I291. If we take the figures to mean that the total area of Stanford Rivers was doubled by the acquisition from High Ongar, this implies (in terms of the present acreage of Stanford Rivers) that some 2,200 acres were added between I 254 and I29I. The belt of land described above is approximately of that area. A final piece of evidence is that in the 17 th century the Rector of High Ongar en joyed part of the tithes from 16 acres of land near Colliers Hatch in Stanford Rivers (see below). Colliers Hatch is in the belt that may have been transferred from High Ongar to Stanford Rivers.

The king exercised the patronage of High Ongar until I 538 when Henry VIII granted it to Sir Richard Rich, later Ist Baron Rich. ${ }^{14}$ It descended with Paslow Hall (see above) to the 4 th Earl of Manchester, who presented to the rectory in 1701.15 John Turvin presented in 1733 , no doubt by grant pro hac vice, for in about 1755 the Duke of Manchester was returned as patron. ${ }^{16}$ About this time, however, the advowson passed out of Manchester's hands. In I770 Joseph Henshaw was rector and patron.17 From this time the advowson changed hands with each new rector, being held either by the rector himself or by a close relation. ${ }^{18}$ About I 942 it was acquired by the Church Association Trust, who are the present patrons. ${ }^{19}$

In 1535 the rectory of High Ongar was valued at
6. 39 10s. 4 d.20 In 1610 the glebe was about 80 acres.21 In 1637 the rectory was stated to be a manor "consisting of demeans and copyholds, viz. nine tenements in High Ongar street, one in Shelley parish, 16 acres of ground near Colliers Hatch'. These lands paid 'tithes in kind for corn, after two ridges to Stanford Rivers, and one ridge to High Ongar, which is taken standing'. Pasture and hay ground paid tithes in kind rateably to both parishes. Well Field, about 12 acres, paid "the third tenth sheaf' to High Ongar.22 The tithes were commuted in 1849 for $\{1,382.23$

In 1610 the Rectory house contained fourteen rooms and had extensive outbuildings. ${ }^{24}$ It is possible that this was the building which still stands, to the east of the church, and which is described above (see p. 1 73), for that house originally contained fourteen rooms and dates from the late I6th or early I 7 th century. The present rectory is a fine red-brick three-story house with five windows across the front and a pedimented porch. It is said to contain 22 rooms and was built in the late 18 th century.

The parish church of ST. MARY THE VIRGIN consists of nave, chancel, south tower, and north vestry. The nave dates from the middle of the I 2 th century and is of flint rubble with dressings of clunch partly replaced by limestone. The I 2 th-century south door is of special interest. The chancel was built or rebuilt in the middle of the $13^{\text {th }}$ century and is also of flint rubble. The tower, which incorporates a south porch, dates from 1858 and is of brown brick with limestone dressings. The vestry was added in 1885 and is of flint rubble.

The nave retains three single-light round-headed windows of $\mathrm{r}$ th-century date, two on the north side and one on the south. The western-most windows in the nave, although probably of the $\mathrm{I} 3^{\text {th }}$ century, have semicircular heads internally and may originally have been of the 12 th century. Both north and south doorways are original, the north door having a semicircular head and moulded imposts. Externally the south door is of two orders, the outer having a round arch with chevron ornament supported on attached shafts with moulded bases and scalloped capitals. The inner also has shafts with scalloped capitals supporting a segmental arch with chevron ornanient. Between the arches is a tympanum of which the stones are enriched with axe-cut ornament. There is similar ornament and a billet mould to the label above the doorway (see plate facing p. I 84).

Externally the flint coursing of the mid- $\mathrm{I} 3$ th-century chancel is a little more pronounced than in the nave. An unusual feature is a string-course of clunch at silllevel in both north and south walls. There is a shallow projection at the junction of nave and chancel on the north side, possibly in connexion with a rood-loft stair. The east end has three graduated lancets. Internally they are grouped under chamfered rear arches springing from attached shafts with moulded bases and capitals. There are two lancets in the north wall and one in the south. The piscina is of the I 3 th century. In the nave the western-most windows in both north
12 Tax. Eccl. (Rec. Com.), 2 Ib.

13 Newcourt, Repert, ii, 452-3.

14 Ibid.; L. \& P. Hen. VIII, xiii (1),

$569 ;(2)$, I 5 .

is E.A.T. N.s. vii, $5^{8}$.

16 Morant, Essex, i, 133 ; E.R.O.,

D/AEM 2/3. This was the 3 rd duke.

17 Hist. Essex by Gent. iii, $33 \mathrm{I}$.
18 E.R.O., D/AEM 2/3; Eccl. Reg. 1808; Cler. Guide, I817, 1829, 1836 ; Clergy List, 1842 f.; Crockford's Cler. Dir. 1882 f.; Chel. Dioc. Year Bk. 1915 f. 19 Chel. Dioc. Year Bk. 1942. The trust made its first presentation in 1946 . Since 1950 it has been known as the Church Society Trust.
20 Valor Eccl. (Rec. Com.), i, 437.

21 Newcourt, Repert. ii, 452.

22 Ibid.

23 E.R.O., D/CT 263. The tithes of the glebe (then 95 acres) were not included in this figure.

24 Newcourt, Repert. ii, 452. 


\section{A HISTORY OF ESSEX}

and south walls are I 3 th-century lancets. There are two lancets at the west end which may date from the I $3^{\text {th }}$ century but have probably been rebuilt.

In the I $4^{\text {th }}$ century windows were inserted on both north and south sides near the east end of the nave. These have three lights with sharply pointed cinquefoiled heads. That on the south side retains a label mould externally with corbel heads roughly restored in cement.

In the $15^{\text {th }}$ century the church was reroofed, the chancel roof having heavily moulded wall-plates. The nave roof has five king-post trusses, the posts being octagonal with moulded bases and capitals and having four-way struts. Probably at the same time a square timber bell tower was inserted near the west end of the nave. This had a tall spire and survived until 1858.25 The timbers of the western-most truss are not original and this may have been inserted when the tower was removed. The eastern-most truss is also new. The rafters of both roofs are ceiled in. During the $15^{\text {th }}$ century also a two-light window with a square head was inserted in the north wall of the chancel at the east end, and another uniform with it in the corresponding position in the south wall. A three-light window of similar design in the west end of the south wall of the chancel dates from the Igth century but may have replaced an original I 5 th-century window.

'The square-headed 'low side' window near the east end of the south wall of the nave is of the late $15^{\text {th }}$ or early i 6th century, and so also is the ogee-headed piscina below it.

The brick doorway on the south side of the chancel is probably of the 17 th century. It has chamfered jambs and a segmental head and was restored in 1883.26 In the early I gth century there still existed a timber porch dated I 640 outside the south doorway of the nave. ${ }^{27}$

The south side of the church was repaired in $1730-1$. It is unlikely that the work involved was extensive, for it appears to have cost not more than $£ 20$ in addition to the normal church rate. ${ }^{28}$

About I 800 it was reported that 'the church of High Ongar is shored up and threatens downfall'.29 Repairs to the west end and external rendering in Roman cement may have taken place about 1830 , when the west door was made and the shallow porch added. This has a segmental arch and a castellated parapet.

In 1858 the present tower was added on the south side of the church, incorporating a south porch. 30 The idea may have come from Bobbingworth, where a somewhat similar tower was built in 1840 . The tower

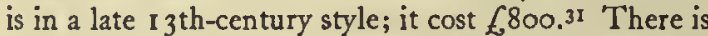
evidence that a spire was planned, ${ }^{32}$ but this was never built. The timber bell tower was removed at this time, and presumably also the 17 th-century timber porch. The west gallery also appears to have been built at this time.

The chancel was thoroughly restored in 1883 , the plaster being stripped from the walls externally and a vestry of uncertain date on the south side being cleared away. The three-light window on the south side of the chancel was inserted or renewed at the same time. ${ }^{33}$ In 1885 the north vestry was built to designs by Frederic Chancellor. This work and that of 1883 was carried out by Noble of Ongar. ${ }^{34}$

There are six bells. The two oldest are by William Carter, 1610 , and John Waylett, I 728.35 In 1746 the fourth bell in the peal was recast by Thomas Lester: an entry in the vestry book records his contract with the churchwardens. ${ }^{36}$ Other bells are by Pack and Chapman of London, I775, and T. Mears, I 822 (a recasting). ${ }^{37}$ In 1933 a sixth bell was added and all were rehung on a steel frame, the cost being met by the Barron Bell Trust. ${ }^{38}$

The pulpit and reading-desk, mostly of 1883 , incorporate enriched panels of the late 16 th or early 17th century.39 The communion rails have turned posts of the mid-I 7 th century. The stone font is of mid- or late-I gth-century date. On the north side of the chancel are two bench-ends, with shaped finials, one having the date 1680 and the other the initials R.s. (probably Richard Stane). West of this and below the wall monument to Richard Stane is an imposing early I 8 th-century square pew with foliated carving to the mouldings and panels. The panelling on the north side of the chancel is of similar date.

The coloured glass in the east windows is mostly of the I gth century, but in each of the flanking lancets is a shield of arms surmounted by a crown and encircled by a wreath. The arms are those of Jane Seymour with the initials 1.R. and those of Henry VIII with the initials H.1. (Henry and Jane). The date may be assumed to be about 1536 .

Ceiling paintings which were not obliterated until after 1855 may have been of 17 th-century origin. In 1768 and 1855 the roof was described as "lofty, arched and painted with clouds and a sun rising in a glorious manner'.40

The church plate consists of three silver cups dated 1683 , I 702 , and 1891 , three silver patens of, 1683 , I 702, and 1749 , and a silver flagon of 1883 and almsdish of 1747 . The cup and paten of 1702 were given by Mrs. Joanna Abdy and the paten of 1749 by William Denn.

On a floor slab in the chancel is the indent of a missing I 4th-century brass. This appears to have consisted of a foliated cross with a figure in the head and an Agnus Dei at the foot. A slab in the nave has a brass showing the standing figure of a man in early-I6thcentury dress. A brass in the chancel dated 1610 has initials M.T. and a text from I Corinthians xv, 36 . A companion brass with initials E.T. and a text is now lost, but a rubbing was taken about 1810.41 Also in the chancel is a floor slab and brass to William Tabor (I6II) Rector of High Ongar and founder of 'Tabor's Almshouses (see Charities, below). Floor slabs of other former rectors include William Alchorne (r7or), Josiah Tomlinson (I65 I), John Lavender (1670). There is also a floor slab to Richard Cartar (1659) with an inscription indicating that he,was the victim of persecution. Above the Stane pew is a handsome marble
25 E.R.O., Prints, High Ongar: drawing of $c .1766 ;$ T. Wright, Hist. Essex, ii, 335 .

26 Builders' Acct. in poss. of present rector, Revd. B. Hartley.

27 T. Wright, Hist. Essex, ii, 335

28 E.R.O., D/P 68/8/1: June 1730, Apr. 1731 .
29 E.A.T. N.s. $\mathrm{x}, \mathrm{1} 43$.

30 Kelly's Dir. Essex (1 866).

3 Ibid.

32 Water-colour in poss. of rector, probably an architect's drawing.

33 Builders' Acets. in poss. of rector.

34 Ibid.

35 Ch. Bells Essex, 351 .
36 E.R.O., D/P 68/8/2.

37 Ch. Bells Essex, 351.

38 Tablet in church.

30 Builders' Acets. 1883 .

40 Morant, Essex, i, I 32 ; cf. T. Wright, Ilist. Essex, ii, 335; Kelly's Dir. Essex (1855).

41 E.A.T. N.s. $x, 203$. 




High Ongar Church: I2th-century Tympanum



Littele Laver Church: I2th-century Font Bowl. 

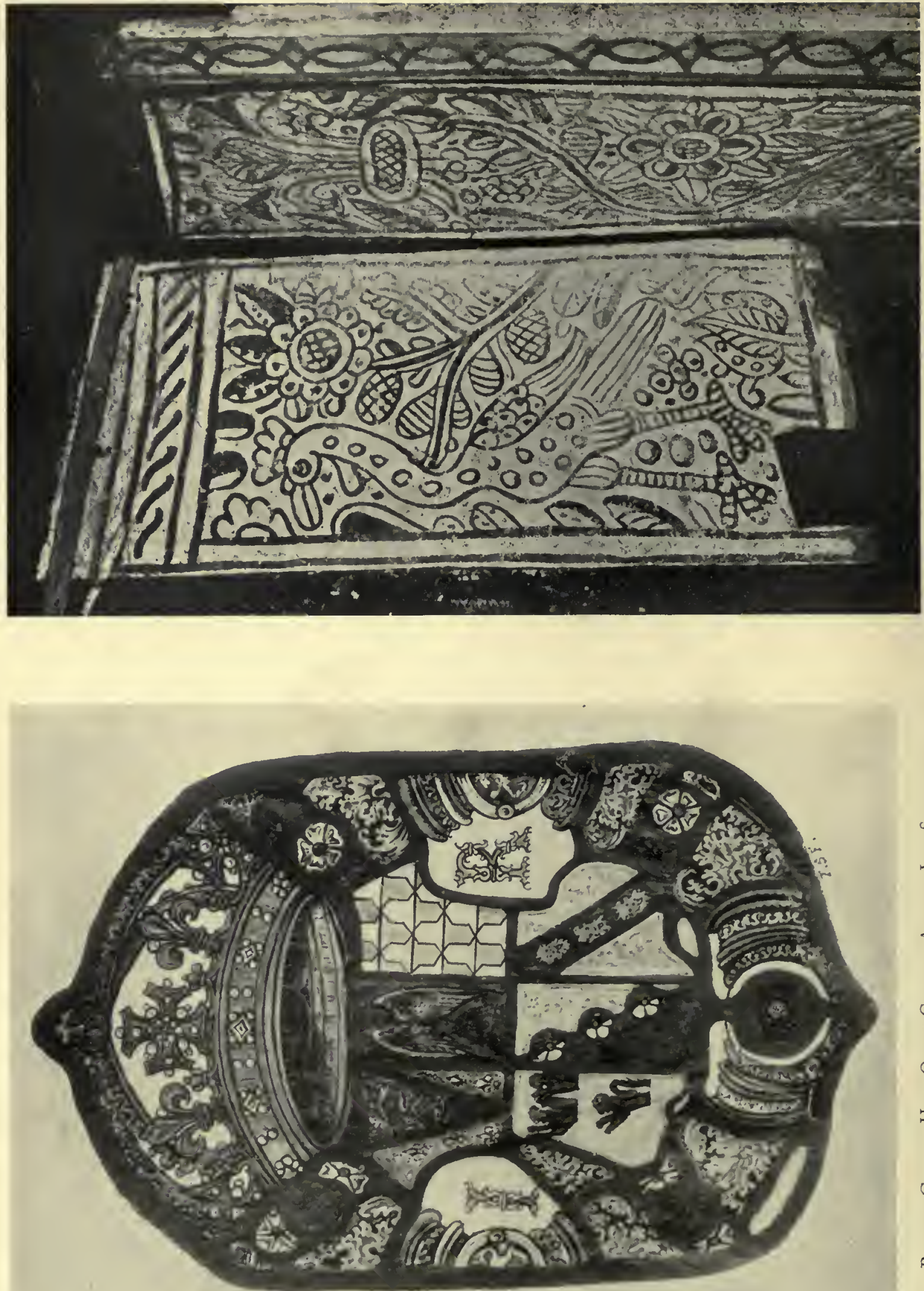

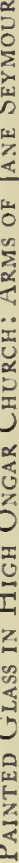


monument with Corinthian pilasters and a shield of arms to Richard Stane of Forest Hall (17r4). There are a number of other later memorials.

John de Welde of Ongar, whose will was proved in 1337 , bequeathed a cow called 'turtel' with its calf to maintain a candle on every double festival of the year before the great altar in High Ongar church.42 The will of Sir Peter Siggiswyk (proved I 503) provided 135. 4d. for keeping his obit in the church of High Ongar, and $8 d$. for the priest singing there.43

$S T$. $\mathcal{F} A M E S^{\prime} S$ Church, Marden Ash, was built in I 884 as a chapel of ease to the parish church. It was destroyed by a German rocket in 1945 . It consisted of a nave of flint and stone, and it had one bell.44

Paslow Wood Common Mission Church is a rectangular roughcast building with a low-pitched hipped slate roof. A small porch at the south end is dated 1865. Until I 895 it was a church school.45

In 1672 a room in Peter Foster's house in High Ongar was licensed for worNONCONFORMITY ship by Congregationalists. 46 In 1829 there was a small Congregational society meeting at Paslow Wood Common, under the ministry of the Revd. Isaac Taylor of Chipping Ongar (q.v.).47 The attendance then numbered about 50 , but there is no apparent evidence that it continued for long.

The Gospel Hall at Marden Ash was founded about 1900 as a result of the Tent Missions held in the neighbourhood. It is a very small red-brick building. ${ }^{48}$ A chapel in Mill Lane, founded about 1929 , was in connexion with the Gospel Hall, but is now rented by the Baptists of Blackmore.49 It is a small weather-boarded building.

The medieval court rolls of the manor of Paslow Hall provide a little PARISH GOVERNMENT information about the $A N D$ POOR RELIEF government of this important part of the parish. Most of the surviving rolls relate to courts held at Easter or in November. The Easter courts always included view of frank-pledge. The homage usually consisted of twelve men. Few of the entries are unusual. In the first roll (I $27 \mathrm{I}$ ) tenants of the manor are presented for obstructing a water-course, selling bread against the assize, and impeding the aletasters. ${ }^{50}$ Later rolls (for the $15^{\text {th }}$ century) contain similar entries.SI There were several disputes between tenants relating to the ownership of land. The roll for 1404 records a fine for insulting behaviour.52 There were two aletasters in 1404 . The election of a rent-collector for the manor is noted in the 1400 roll. 53

The modern series of court rolls for Paslow runs from 1542 to 1855 with only one extensive break. ${ }^{54}$ Some of the early rolls in the series may no longer exist, but from 1559 the record is complete until 1609 . There is then a break until I633, after which the series appears to be complete. Between I559 and 1609 courts were held in most years, and sometimes twice a year. Up to I 575 most of them were held at Easter, for view of frank-pledge and court baron business. Courts taron alone were sometimes held during this period, but usually later in the year. Between 1576 and 1609 the courts were usually held in the summer, most often in September. View of frank-pledge was included on almost every occasion. Between ${ }^{6} 633$ and 1647 courts were held every two or three years, and always included view of frank-pledge. The view was held in $165 \mathrm{I}$, but after that date, although courts were held at intervals of from one to three years, they were usually courts baron only. View of frank-pledge was next held in 1672 . It took place on only eight occasions after that, the last being in $172 \mathrm{I}$.

During the I6th century the homage usually numbered at least 12 and sometimes as many as 18 at courts with view of frank-pledge but was much smaller at courts baron. After $165 \mathrm{I}$ it consisted at courts baron of about $5 \mathrm{men}$, but occasionally sank to 2 . At courts with the view in and after 1672 it was usually I 2 .

The election of the constable of the manor is frequently recorded in the rolls. Two constables were elected in I7II. In I7 I 9 the court elected a man as constable 'of High Ongar'. In 172 I the constable was elected in the manor court for the last time, by the curious formula 'of High Ongar within this manor'. As will be shown below the jurisdiction of the manor court was at this time overlapping that of the parish vestry.

The woodward of the manor was frequently appointed up to 1660 , but after that only in 1672 . In I 7 I I Samuel Pond was elected 'beadle anglice hayward for Paslow Common'. An aletaster was chosen at irregular intervals, the last occasion being in 1605 . In I 567 he was also described as a bread weigher.

Most of the business transacted at the courts concerned minor nuisances and breaches of manorial custom. Special attention was paid to encroachments on Paslow Wood Common, either by inclosure or by the pasturing of excessive numbers of animals. There were occasional fines for assault, the last in $160 \mathrm{I}$.

In 1542 it was presented that there was no pillory in the manor, nor a tumbrel, and the matter was referred for discussion with the officials of the king, who was then lord. In I 573 there were said to be no stocks in the manor and the inhabitants were ordered to supply them.

A surviving court roll of the manor of Newarks Norton contains seventeen entries from 1487 to I 668.55 It is clear from some of these entries that there were a number of occasions during this period when the court met, but of which no full record now exists. View of frank-pledge was usually held up to I613, when it took place for the last time. Subsequent courts dealt with baron business only. The homage usually numbered 5 or 6 . In $16 \mathrm{I}_{2}$ it was presented that there was no pound in the manor and the lord was required to provide one.

The rolls for the manor of Nash Hall, which run from 1582 to 1729 , contain only the proceedings of courts baron. The homage usually numbered 2 or $3 .^{56}$

The existing vestry books for the parish of High Ongar cover the period 1702-76.57 Vestry meetings were held regularly at Easter and Christmas and often at other times. In 1732 it was resolved to hold monthly
42 Cat. Anct. D. i, A. 466.

43 E.A.T. N.s. xxi, 256.

44 Kelly's Dir. Essex (1 899); Ch. Bells

Essex, 35 I ; inf. from Mr. D. W. Hutchings.

45 Cf. Schools, below.

46 G. L. Turner, Orig. Rees. of Early

Nonconf. ii, $93^{8}$.

47 E.R.O., Q/CR $3 / 2$.

48 Inf, from Mr. D. W. Hutchings.

49 Ibid. $50 \mathrm{SC} 2 / 173 / 30$ (1271).

31 Ibid. $3 \mathrm{I}-38 ; \mathrm{SC}_{2} / 178 / 2 \mathrm{I}$. The dates of these rolls are $1400,1404,1409,1414$ $142 \mathrm{I}, 1460$, and 1464 .
32 Ibid. $178 / 21$.

$53 \mathrm{Ibid} .173 / 3 \mathrm{I}$.

54 E.R.O., D/DGn 317, D/DK M125-

7, D/DCw M $120-5$.

55 E.R.O., D/DSp $\mathrm{M}_{36}$

56 E.R.O., D/DGe M242-5

37 E.R.O., D/P 68/8/1, 2. 


\section{A HISTORY OF ESSEX}

meetings, but there is no evidence that this decision was acted on. Attendance varied from 5 to over 20 , being largest at Easter. Up to 1742 William Stane of Forest Hall appears to have acted as chairman of the vestry when he was present. When he was absent the rector was chairman, and after 1742 it was the rector who usually presided.58 Other prominent vestrymen were William Baker of Withers Pawne and his son Bramston Baker, and William Wright, who was tenant of Paslow Hall early in the I 8 th century.

In 1734 the vestry arranged that a house should be built on waste ground belonging to the manor of Withers Pawne for the use of James Paveley, the parish clerk. Later in the same year Paveley was ordered to sell off the beer he had brewed in his house and he was forbidden to brew any more. In 1736 he was granted a salary of 4 os. a year, to be paid quarterly, evidently in place of a gratuity at Easter. Robert Miller was appointed clerk in I775 at an annual salary of $£_{2}^{2} 2$.

For much of the period the Easter vestry was held in two sessions. At the first the overseers' rate was granted and usually also those of the churchwardens and constables. At the second and more important session, which actually took place in Easter week, the accounts of the above officials were examined. At the Christmas vestry, on 26 or 27 December, the accounts of the parish surveyors of highways were examined and their rates granted. Throughout the period a penny rate produced a little over 67 .

The great size of the parish and its detached parts raised unusual administrative problems. During the first 20 years of the 18 th century there was another problem also: the overlapping of the powers of the vestry with those of the manor court of Paslow, which has been described above. Constables' accounts are entered in the vestry book from 1703 onwards, and in I 707 Thomas Bridgman was elected constable in the vestry. William Mead and Samuel Barnard, who were both elected constables in the manor court in $\mathrm{I} 7 \mathrm{II}$, rendered their accounts as parish constables at subsequent vestries. The constables appointed for the manor in $I 719$ and I $72 \mathrm{I}$ also accounted to the vestry. In I7 I9 Samuel Barnard acknowledged the receipt of I $25.8 d$. from William Wood in respect of charges at the court at Paslow. Wood was apparently settling accounts on succeeding Barnard as a constable, and the entry seems to imply some financial relationship between manor court and vestry. After 1721 two constables continued to account to the vestry and no doubt were always nominated there. During the later part of this period the nominations were sometimes entered in the vestry book, and were confirmed in the usual way by the J.P.s. By about 1750 there was only one constable. 59 John Bettis held the office for many years between 1750 and 1775 . The constable's expenses were about $£^{8}$ a year at the beginning of the period and about $\{20$ at the end.

$\mathrm{Up}$ to about 1720 there were usually two parish surveyors of highways. From 1725, if not earlier, there were at least three. Each surveyor had responsibility for part of the parish. One usually looked after Marden Ash and 'Bobbingworth hamlet', a second 'the body of the parish', and the third 'Paslow Hall manor'.
In $1737-9$ an additional surveyor was appointed with separate responsibility for Bobbingworth hamlet. In I 740 and later the parish was usually divided into three areas as before but two surveyors were sometimes appointed for each area. In and after $175^{8}$ there was a variation in the areas. One surveyor looked after Marden Ash, the second Paslow and Bobbingworth hamlet, and the third the body of the parish. Up to 1735 the surveyors' rate was usually about $x_{2} \frac{1}{2} d$. For the rest of the period it was usually about $3 d$. In $174 \mathrm{I}$ it was $5 \frac{1}{2} d$. No reason has been found for this unusually high rate. In 1732 the vestry ordered the overseers [sic] of highways to charge their accounts with an allowance of $2 d$. a day for the labourers' beer, but with no other charges for beer provided for servants.

The parish overseers of the poor, like the surveyors, often accounted individually to the vestry. It is sometimes stated that one overseer was responsible for Paslow Hall manor and the other for the body of the parish. At the beginning of the 18 th century the cost of poor relief in the parish was about $\oint_{5} 50$. It rose to over $£ 130$ in I 716 but rarely exceeded that figure up to 1750 . In 1760 it was 6160 , in $17746_{0} 183$, and in I $783-5$ it averaged $£_{4} 470.60 \mathrm{By}$ I 80 I the total rate had risen to $£_{1} 1,9890^{61}$ It fell between 1805 and $I_{8} I_{2} 2$ to an average of about $£_{\mathrm{I}}, 300$ but rose to a new peak of $£ 2,054$ in 1817.62 In 1821 it was $£_{1} 1,670.63$

There is no evidence of a parish poorhouse before 1775. In October of that year the vestry paid $E_{2} 20$ towards the purchase of a house called Scarlets from William Coe of Stondon Massey. This was the first instalment of a purchase price of $\$ 220$. In the entries for 1776 (the last in the vestry book) there arc references to the parish house. Scarlets adjoined the Tabor almshouses to the west. The almshouses themselves had since their foundation been administered by the rector, churchwardens, and overseers; the accounts of the almshouses were entered in the vestry book and the almsmen were partly supported out of the poor rates. ${ }^{64}$ There is hardly any evidence about the number of persons supported out of the poor rates. In September I 752 there were 20 receiving a total of $E_{0} \mathrm{I} 9.3^{d}$. a week. The highest individual payment was 3 s., and the lowest $9 d$. In September I 757 the vestry ordered the provision of 'a pair of shoes and hat for the black boy'.

In 1836 High Ongar became part of Ongar Poor Law Union.

William Pawne (d. I 578) directed in his will that the residue of his estate should be used to SCHOOLS establish and maintain a school in his manor of Chivers Hall (see above). ${ }^{65}$ There is no sign that such a school was in fact founded.

By the terms of Dr. Walker's Charity (founded I687) a child from High Ongar might be sent to the charity school at Fyfield (q.v.). How long the right was exercised is not clear. It had been commuted by I 834 for a small cash payment and later lapsed altogether (see below, Charities).

About I 799 the rector's wife and two other ladies established a girls' school at High Ongar, and by 1807 some 20 girls were learning to read and sew. ${ }^{66}$ This experiment was probably the origin of the National
$\$ 8$ Robt. Salmon was rector $1701-33$. He was succeeded by Jos. Henshaw. It has been assumed that the person signing the minutes first was chairman.

so A single name was usually put before the J.P.'s but sometimes they made their choice from two.

$60 \mathrm{~F}$ or the last figure see E.R.O., Q/CR $1 / \mathrm{x}$.

61 E.R.O., Q/CR I/9. 62 Ibid.

63 Ibid. $Q / C R$ I/I 2. In 1817,1818 , and 18 ig the High Ongar rate was the largest in the hundred. In 1816,1820 , and 1821 it was second only to Chigwell, which had a larger population.

64 See below, Charities.

$65 \mathrm{C}_{142 / 181 / 55}$.

66 E.R.O., D/AEM 2/4 
School which by 1816 was receiving some $£ 31$ in annual subscriptions. ${ }^{67}$ In 1818 there were about 60 children at this school, mostly girls, and 74 others attended the Sunday schools held in conjunction with it. 68 In 1828 the day pupils were said to number 80 and in $1833,89.69$ 'These figures, however, were probably inflated by the inclusion of children who only attended the Sunday school, for in 1835 there were said to be only 60 at the day school. ${ }^{70}$ The rector seems to have owned the school building, which was situated at the east end of the village on the south side of the road; subscribers helped to maintain the school.7I In 1846-7 there were 77 pupils under a mistress who was paid $\ell_{5} \circ$ a year. ${ }^{72}$ About the same time the rector helped to maintain a dame school, possibly in some other part of the parish. ${ }^{73}$ There were also private and dame schools, unconnected with the church; in 1833 there were five, including one boarding-school, and 71 children were attending them. 74

In I 867 a new school was built opposite the church, with accommodation for I 35 and a teacher's house. Subscribers gave $\{, 1,097$ and the Education Department a building grant of $\oint_{2} 0 r^{75}$ Since a school had recently been established at Paslow Wood Common and there was also another school in the parish with I 5 pupils, 76 the new church school was sufficient for the needs of High Ongar's stationary population. The Education Department stated in 1872 that no more accommodation was necessary. 77 Attendance at the school rose hardly at all before 1880 , when it was only 72 , but by 1886 it had risen to I 19.78 The building was therefore enlarged in 1887 to accommodate 160.79 The annual grant rose from $£ .58$ in 1873 to $£ .95$ in 1886.80

In 1890 a school board was established at High Ongar and in that year it accepted transfer of the building for use as a board school on weekdays. ${ }^{81}$ By the Education Act of 1902 the school passed under the administration of the Essex Education Committee, Ongar District. In I 904 there were 153 children on the books, 4 teachers, 2 of them certificated, and a monitress. ${ }^{82}$ Attendance subsequently fell, to 91 in 1915 and 62 in 1938.83 In 1936 the school was reorganized for mixed juniors and infants, the seniors being transferred to the new school at Chipping Ongar. 84 In May 1952 there were 90 children under 3 teachers. ${ }^{85}$ The building, opposite the church, is single-storied and of red brick, with teacher's house attached.

In I 865 a wooden building was erected near Nine Ashes Farm, Paslow Wood Common, for use as a church school, the cost being met by subscription. ${ }^{86}$ The attendance was at first small: an average of 29 in 1880 and 28 in 1886.87 In 1892 it began to rise, additional pupils coming from Norton Mandeville, where the school had recently been closed, and Blackmore, where the school was overcrowded. ${ }^{88}$ By I 893 there were 56 children on the books, although there was adequate accommodation only for 50 . The school board, which had accepted transfer of the building in 1890 , considered its enlargement but eventually decided to build a new school a short distance to the south-west of the existing one. ${ }^{89}$ The new school was opened in 1895 with accommodation for 88.90 Attendance rose to 92 in 1904; there were then 3 teachers. 91 The annual grant increased from $£ 28$ in 1893 to $£ 67$ in 1902.92

By the Act of I 902 this school passed under the administration of the Essex Education Committee, Ongar District. The average attendance fluctuated in the following years: 52 in 1915 and 63 in 1929. In 1936 the school was reorganized for mixed juniors and infants and in 1938 the average attendance was only 34.93 In May 1952 there were 2 teachers and 35 pupils. ${ }^{94}$ The school is a single-story brick building with a slated roof (see plate facing p. I 26). The earlier school near Nine Ashes Farm is now used as a mission church.

From about I 890 to $193^{\circ}$ there was a private school for boys (and later girls) at Marden Ash, run by Francis Dawson and by Mrs. Dawson. ${ }^{95}$

By a scheme made in 1924 'Tabor's almshouses, Wyberd's, Thomlinson's, Peacock's, CHARITIES and Waller's Charities were united under the name of the Parochial Charities.96 Their income is expendable in general charitable purposes. In 195 I 6 . 8 I6s. 7 d. was spent on gifts in kind and on management.

Tabor's almshouses were founded by William Tabor, then Rector of High Ongar, who in 1607 gave some cottages on the north-east side of the village street, for the reception of old and deserving parishioners. By his will dated 1610 he added a rent charge of 610 for the support of the almsmen and the repair of the houses. The land charged lay in Bradwell-juxta-Mare. In 1834 the almshouses consisted of six tenements in pretty good repair', occupied by nine old people appointed by the rector and vestry. The total amount spent on the almspeople at this time was 17 s. a week. For many years they had been partly supported out of the poor rates, and the charity income was carried to the poor rate account. 97 By I 900 the almshouses were in poor repair and their maintenance was uneconomic. 98 By 1929 four of the houses had been empty for six years and soon after this they were condemned by the County Council. In 1937 the houses were sold for $£ 50$ and were demolished soon after. 99 The income from the investment and the rent charge are now used for the
67 Nat. Soc. Rep. 1816, p. 52.

68 Retns. Educ. Poor, H.C. 224, p. 264

(18 I9), ix (1).

60 Nat. Soc. Rep. I 828, p. 72 ; Educ.

Enquiry Abstr. H.C. 62, p. 285 (1835), xli.

20 Rep. Com. Char. (Essex), H.C. 2 I6, p. $240(1835), x \times i$ (I).

7 Ibid.; E.R.O., D/CT 263.

72 Nat. Soc. Enquiry into Church Schs.

1846-7, Pp. 14-15. 73 Ibid.

74 Educ. Enquiry Abstr. p. 285.

$75 \mathrm{Min}$. of Educ. File $13 / 198$.

76 Retns. Elem. Educ. H.C. 20I, Pp. I1 2-13 (1871), lv.

77 Chelmsford Chron. 2 Aug. 1872.

${ }_{78}$ Rep. of Educ. Cttee. of Council, 2880
[C. 2948-1], p. 577, H.C. (I 881), xxxii; ibid. 1886 [C. 5123-1], P. 519, H.C. (1887), xxviii.

79 Kelly's Dir. Essex (I 899).

80 Essex Standard, 28 Oct. 1874; Rep.

of Educ. Cttee. of Council, I 886, p. 5 I 9.

$81 \mathrm{Min}$. of Educ. File $13 / 198$.

82 Essex Educ. Cttee. Mandbk. 1904

p. I84. ${ }^{83} \mathrm{Min}$. of Educ. File $13 / 198$.

84 Inf. from Essex Educ. Cttee.

85 Ibid. 86 Min. of Educ. File $13 / 199$.

87 Rep. of Educ. Cttee. of Council, 1880, p. 577 ; ibid. 1886 , p. 519.

88 Min. of Educ. File $13 / 199$

89 Ibid.; Retn. of Schs. 1893 [C. 7529], p. 714 , H.C. (1 894), lxv.

90 Min. of Educ. File $13 / 199$; Schs. under Bd. of Educ, rgoz [Cd. I490], p. 7 I, H.C. $(1903)$, li.

oI Essex Educ. Cttee. Handbk. I904, p. I 86 .

02 Retn. of Schs. 1893, P. 714; Schs. under Bd. of Educ. 1902, p. 71.

93 Min. of Educ. File $13 / 199$.

๑4 Inf. from Essex Educ. Cttee

os Kelly's Dir. Essex (18go f.).

96 Char. Com. files.

97 Rep. Com. Char. (Essex), H.C. 216 , p. 240 ( 1835$)$, xxi (I). And see above Parish Govt. and Poor Relief.

98 Char. Com. files; Parish Council

Mins., extracted by Mr. D. W. Hutchings. 99 Char, Com. files; Paroch. Char. Mins., extracted by Mr. D. W. Hutchings. 


\section{A HISTORY OF ESSEX}

general purposes of the Parochial Charities. The almshouses were a row of six single-story cottages, with leaded casement windows. Each cottage contained a lofty room in the front with a lean-to scullery behind.

John Wyberd, citizen and haberdasher of London, by will proved 1625 , left 50 s. a year for bread for the poor, charged on property in Kirton-in-Holland, Lincs. Fourteen years' arrears were paid in 1820 . From then the charge was paid regularly until its redemption in 1910 for $f_{1} 100$ stock. In 1834 this charity, along with Peacock's and Waller's, was given in bread to all poor parishioners. ${ }^{2}$

William Peacock, at an unknown date, gave 20s. to the poor charged on a cottage in High Ongar. The rent-charge was being regularly received in 1834 and was distributed in bread. In 1926 it was redeemed for £. 40 stock. ${ }^{3}$

Humphrey Waller, at an unknown date, gave ros. charged on a copyhold farm called Farrows at Paslow Wood Common. In 1834 the rent-charge was being

\section{ABBESS RODING}

Abbess Roding and Beauchamp Roding (q.v.) form the south-west part of the area known before the Norman Conquest as Roding or Rodings. After the Conquest this area was divided into eight parishes, each retaining the word Roding as part of its name. Of these parishes only Abbess and Beauchamp Roding became part of Ongar hundred, the others being in that of Dunmow. There was also the hamlet of Morrell Roding, which although it was in White Roding parish was held to belong to Ongar hundred. The tithing of Berwick Berners in Abbess Roding seems to have been attached for some purposes to the hundred of Dunmow, but the connexion is less clear in this case. I

Geographically Abbess and Beauchamp Roding have much more in common with the other Roding parishes than they have with most of those in Ongar hundred. All the Rodings are situated on Boulder Clay in the valley of the River Roding, which takes its name from them. There are few trees or hedges in the area, which makes the landscape seem rather bleak. The soil, however, is exceptionally fertile, and is in fact reckoned among the best in Essex. Agriculture is mainly arable, the most important crops being wheat, barley, beet, and potatoes. Sheep are comparatively rare but pigs and beef cattle do well and provide dung for the cornland. ${ }^{2}$ Although only 30 miles from London the Rodings are entirely rural and very isolated; they have no railway, only infrequent bus services, and some houses in the area are still without main services of any kind. The population has been gradually declining over the past century. Abbess Roding had 205 inhabitants in 1801, 254 in 1841 , but only 169 in 1931.3 'This decline is reflected in the amalgamation of the parish with others for both civil and ecclesiastical purposes. For ecclesiastical purposes Abbess Roding is united road. 9 paid regularly and distributed with Wyberd's and Peacock's Charities. Except for a few years before 1907 the rent has apparently been received regularly.4

Mrs. Alice Thomlinson, by will dated 1655 , left 5 s. a year each to eight poor widows of High Ongar to help them buy waistcoats. 5 With similar charities for other parishes, it was charged on property in Hatfield Broad Oak. Up to 1769 the 'Widow's Crowns' were paid every year according to the will, 6 but in 1834 the money was distributed every two years to about 20 widows. 7 The money was still being paid in 1951.8

High Ongar participated in Walker's Charity (see Fyfield). No children were being sent to Fyfield school in 1834 but the Rector of High Ongar received ros. a year from the Walker Charity which was spent on school-leaving prizes of bibles and prayer books for the High Ongar children. This arrangement was not confirmed by the scheme controlling Dr. Walker's Foundation made in 1874.9

with Beauchamp Roding. ${ }^{4}$ For civil purposes it has since 1946 been united with Beauchamp Roding and Berners Roding. ${ }^{5}$ The ancient parish of Abbess Roding contained 1,619 acres including a detached portion of 41 acres. 6 It was bounded on the north by White Roding, on the west by Matching and Little Laver, and on the east by the River Roding and the parish of Margaret Roding. Its former boundary with Bealchamp Roding to the south ran from the river near Pig's Bridge west and south-west to the Little Laver boundary north of Envilles. The detached portion was situated locally in Beauchamp Roding and consisted of a narrow strip extending from Longbarns to the Roding.

The height of the land in Abbess Roding is about $225 \mathrm{ft}$. above sea-level in the east and about $280 \mathrm{ft}$. in the west. A number of small streams flow east into the Roding. Brick Kiln Wood and Rookwood Hall Wood are in the west. Abbess Roding village, in the centre of the ancient parish, is 6 miles north of Chipping Ongar. It is a nucleated village, containing the ancient church and manor house, the village hall, the former parish school, and a number of other buildings. ${ }^{7}$ From the village roads run north to Berwick Berners Hall, ${ }^{8}$ White Roding, and Dunmow, south-west to Little Laver, and east to Beauchamp Roding and the Ongar

There are a number of 16 th-and 17 th-century buildings in the parish. Most of them lie to the west of the Little Laver road, and in spite of their survival it is this part of Abbess Roding that has changed most. Until the end of the $17^{\text {th }}$ century this area was dominated by the mansion of Rookwood Hall, $\frac{3}{4}$ mile south-west of the village, the home for over 100 years of the Capel family. ${ }^{10}$ With their departure about 1700 Rookwood ceased to be a gentleman's residence and it gradually deteriorated until today it is almost a ruin. In 1696 it

3 Co. of Essex (Rural Parishes) Conf. Order, 1946 , P. I 5 .

6 O.S. 6 in. Map (Ist edn.), sheet xlii. In the tithe award ( 1843 ) the parish area was calculated at 1602 acres: E.R.O. D/CT 292.

7 See Manors, Church, School.

\& See Manors.

- O.S. $2 \frac{1}{2}$ in. Map, sheets 52/50, 51 .

10 See Manors. 
stood in a wooded park, but this had disappeared by 1777." The transformation of the area was completed between 1939 and 1945 when much of it was taken into Matching Airfield. Old roads were diverted and new concrete roads made, one of which crosses the subsidiary moated enclosure south of old Rookwood Hall. Some huts and other service buildings remain, some used as stores. Fairlands (formerly Cockerells) is on an ancient moated site $\frac{1}{2}$ mile north-west of Rookwood Hall. The house is timber-framed and probably dates from the I6th century. It is L-shaped in plan with later additions in the angle of the wings. In the middle of the rgth century the south front was faced with brick. Inside there is an original fireplace. In the room above there is said to be painted decoration, probably of the 17 th century, on the plaster panels between the exposed studs. North of the house a fragment of the moat remains. A quarter of a mile east of Fairlands is the site of the former Congregational church of Abbess Roding, which was built (1729) on land given by the then owner of Cockerells. ${ }^{2}$ Nothing remains of the church but on the east of its site is Anchor House, originally given to the church by the owner of Cockerells and later converted into a public house for the refreshment of the congregation.13 The road which runs north from Anchor House to join the White Roding-Matching Green road is modern. ${ }^{14}$ Falkiners, at one time called Offins, is 1 mile south-east of old Rookwood Hall. It is a two-story cottage row standing at right angles to the road and containing two dwellings. It is partly weather-boarded and partly plastered and has a tiled roof. The main timber-framed structure is of the 17 th century. Over a fireplace in one of the houses is a carved door-head brought here from old Rookwood Hall. These houses are charged with an ancient rent for the benefit of the parish clerk.15 Near Falkiners to the east is Sparrows, a timber-framed house with a thatched roof, recently modernized. It probably dates from the 17 th century. Leader's Farm (formerly Gilberts) ${ }^{16}$ is $\frac{3}{4}$ mile south of Rookwood Hall. It probably dates from the late 17 th century and has a central chimney with attached pilasters.

There are three old houses in the north-east of the parish, Berwick Berners. Hall and Hales and Nether Farms. Hales Farm, near the parish boundary on the Ongar-Dunmow road, is a timber-framed building probably dating from the late 17 th century. Nether Farm (formerly Nether Street), on the same road mile south of Hales, was probably built about 1700 . It is timber-framed and roughcast and has a hipped tile roof. Parts of a moat remain. Two 1 7 th-century cottages on the east side of the road south of Nether Farm, which were recorded in 1914, have now disappeared. ${ }^{17}$

Among the modern buildings of the parish are two pairs of council houses on the road between the village and Longbarns and seven pairs of 'Airey' type houses on the south-east side of the Little Laver road.

Communications have never been good in the Rodings. Defoe, visiting the area in 1724 , described it

II Oliver, Map of Essex, I696; Chapman and Andre, Map of Essex, I777, sheet xii. 12 See below, Nonconformity.

13 Ibid.

14 Cf. O.S. 6 in. Map (1st edn.), sheet xiii.

Is See below, Parish Govt. and Poor Relief.

16 Chapman and André, Map of Essex, I777, sheet $x i i$. as "famous for good land, good malt and dirty roads; the latter indeed in the winter are scarce passable for horse or man'.18 There is earlier evidence of this, in relation to Abbess Roding. In 1583 the road between Longbarns and Nether Street was said to be in ruins and the inhabitants of Abbess and Beauchamp Roding were ordered to repair it. ${ }^{19}$ In 1620 the same road was again in decay 'being very deep and unfit for carts'.20 In 1652 the inhabitants of Abbess Roding were presented at Quarter Sessions for not repairing the way from Leaden Roding parsonage to Beauchamp Roding. ${ }^{21}$ This was the same road, with an additional portion to the north. Recent alterations to the roads have already been mentioned.

During the first half of the rgth century, and probably for much of the 18 th, Abbess Roding was on the coach route from Dunmow to Ongar and London, 22 but in the I 850 's this route was abandoned in favour of a link with the railway at Bishop's Stortford, and ten years later the railway was brought to Dunmow itself and also to Ongar. ${ }^{23}$ In 1863 , however, a coach ran from Fyfield, 3 miles from Abbess Roding, daily to London. ${ }^{24}$ Now (1954) Abbess Roding is on a bus route between Dunmow and Brentwood, with two services a day in each direction and three on Saturday.

A walking postman operated between Ongar and Margaret Roding (about 8 miles) in 1844 , but in that year it was stated that this was too far for any man to travel every day and it was decided to terminate the post at Abbess Roding and to transfer the receiving house there from Margaret Roding.2s A sub-postoffice was maintained until igr4 but had been discontinued by 1922.26

Piped water was supplied by the Herts. and Essex Waterworks in 1951.27 'The new 'Airey' houses have main drainage, connected to a sewage works which. is situated near the Longbarns road and was installed by the Air Ministry during the Second World War. ${ }^{28}$ Electricity is now (1955) supplied to the village. ${ }^{29}$ A village hall for Abbess and Beauchamp Roding is situated in the grounds of The Manor. It is a converted cow-shed and has been in use for the past 20 years. ${ }^{30} \mathrm{~A}$ branch of the county library was opened in $1931 .^{31}$

Throughout the history of the parish agriculture has been almost the only occupation of the inhabitants. From about 1500 to about 1700 there was a resident landowner living at Rookwood Hall. Apart from that period it is doubtful whether the owners of any of the principal estates lived at Abbess Roding. In 1842 it was estimated that the parish contained 1,257 acres of arable, 243 acres of meadow and pasture, and 75 acres of woodland. There were then six farms over 50 acres of which the largest was 382 acres. None of these farms was occupicd by the owner. 32 An inventory of the goods and chattels of Richard Hills of Abbess Roding, made after his death in 1614 , sheds some light on the life of a small farmer of the parish at that time. ${ }^{33}$

There is very little evidence of occupations other than agriculture. The name Brick Kiln Wood, how-
17 Hist. Mon. Com. Essex, ii, 2.

18 Defoe's Tour through Great Britain, ed. G. D. H. Cole, 1927, p. 89.

I9 E.R.O., Q/SR 86/54.

20 Ibid. $230 / 31,32$. Cf. Q/SBa $1 / 42$.

21 E.R.O., Q/SR $354 / 25$

22 Pigot's Dir. Essex (1839); White's Dir. Essex (1848).

23 Kelly's Dir. Essex (185 I f.). And see Chipping Ongar.
24 White's Dir. Essex (1863), 740.

2s P.M.G. Mins. 1844 , vol. 78 , p. 629. 26 Kelly's Dir. Essex (1914, 1922).

27 Inf. from Herts. and Essex Waterworks Co.

28 Inf. from the Revd. R. T. K. Griffin.

29. Ibid. 30 Ibid.

3 Inf. from County Librarian.

32 E.R.O., D/CT 292.

33 E.R.O., D/DGe 506. 


\section{A HISTORY OF ESSEX}

ever, suggests that brickmaking was once carried on in that part of the parish, as it was in many places in Ongar hundred, and Defoe's reference to malt recalls another ancient industry of this locality.

The absence of resident landowners in the 18 th and roth centuries left local affairs in the hands of the tenant farmers, and these were sometimes indifferent to the needs of the community. ${ }^{34}$ The existence of many nonconformists may also have hampered united action in parish government and education. The provision of the village school and the restoration of the parish church in the middle of the I 9 th century were both carried out largely at the expense of Capel Cure, the patron of the rectory, who was not a landowner in Abbess Roding and had many responsibilities elsewhere.

Two notabilities were the sons of local people and probably lived at Abbess Roding in childhood. Sir Anthony Browne ( 1510 ?-67), Chief Justice of Common Pleas, was the son of Sir Wistan Browne of Rookwood. John Thurloe (I6I6-68), Secretary of State under Cromwell, was the son of Thomas Thurloe, Rector of Abbess Roding I6I 2-33.35

Before the Conquest $A B B E S S$ RODING (later known as $A B B E S S H A L L$ ) was held by

$M A N O R S$ Leuild (probably a woman) as a manor and 3 virgates. In 1086 it was held by

Geoffrey Martel as tenant of Geoffrey de Mandeville. It was then stated that the manor had previously been in the possession of Barking Abbey 'and he who held this land was only the man of Geoffrey's predecessor, and had no power to put this land in possession of anyone but the abbey'. ${ }^{36}$

Barking subsequently regained possession of the manor, perhaps as a result of the Domesday survey, and retained it until the dissolution of the abbey in I 539.37 In I29I the manor was valued at 68 i 75.38

In April I 540 Abbess Roding was granted by Henry VIII to Thomas Cromwell. ${ }^{39}$ In November of the same year, after Cromwell's disgrace and execution, the stewardship of the manor was given to Sir Richard Rich and in January I 54 I the manor itself was settled upon Anne of Cleves, the king's divorced wife.40 The manor was soon in the king's hands again, for in I 544 it was granted by the Crown to Robert Chartsey and nineteen others. ${ }^{4 I}$ In 1546 Chartsey conveyed his interest in the manor to Robert Meredith, one of the grantees of I 544, whereupon Meredith and three other of those grantees transferred their interest to Robert Long. ${ }^{42}$ In 1549 Long, in whom by this time the manor seems to have been solely vested, conveyed it to William Glascock.43 An annual rent of $245.6 \frac{1}{2} d$. from the manor was reserved from the grant of I 544 and was granted by the king in 1553 to Oliver St. John and Robert Thorneton.44

William Glascock died in 1579 and was succeeded by his son Richard. 45 In 1592 Abbess Roding was 34 See Schools, Parish Govt. 35 D.N.B. 36 V.C.H. Essex, i, 340, 505 a.

37 Ibíd. 38 Ibid. ii, 117.

39 L. E P. Hen. VIII, xv, p. 285 Cromwell was then (15t) Baron Cromwell. He became Earl of Essex in April I 540, 600 after the grant.

40 Ibid. xvi, pp. I 39, 242

41 Ibid. xix (2), p. 80. The grant was to be void if the purchase money was repaid within a year.

42 Ibid. xxi (I), p. 77.

43 Col. Pat. $1548-9,60$.

44 Ibid. 1553,83 .
$45 \mathrm{C}_{142 / 188 / 35}$.

$46 \mathrm{C} 66 / 1386$; Morant, Essex, i, 137

cf. Cal. S.P. Dom. 1591-4, 204. For

Tipper see E. St. J. Brooks, Sir Christopher

Hation, 220-30.

$47 \mathrm{C} 66 / \mathrm{ig} 508 \mathrm{~m}$. I.

$48 \mathrm{CP}_{25}(2) / 139 / 1758 ;$ E.A.T. N.s. ix

272. For Berwick Berners see below.

49 Morant, Essex, i, 137.

so Ibid.; Visits. of Essex, 1664-8, ed.

J. J. Howard, 21.

si Morant, Essex, i, 137.

52 Ibid.; Complete Peerage, ii, 8 I ; E.R.O., $\mathrm{D} / \mathrm{DZu} 203$. by the queen to William Tipper and Robert o greedy hunters after concealed lands'.46 I 599, however, the manor was restored to Richard of Rookwood (see below), younger brother of knighted, and died in 16 I 3.49

The manor passed successively to Sir Gamaliel's son, grandson, and great-grandson, each of whom was also sold or mortgaged Abbess Roding to John carried the estate in marriage to Wriothesley ef Bedford.52 In I739 their son John, She married ( 1750$)$ Wiliam the manor of Abbess Roding subsequently followed the same descent as Barringtons.54 In 1830 'Abbots m' comprised 2 I 2 acres. Parker's farm, which the 8 th century. ${ }^{56}$ In the partition of the estates of Admiral Sir Eliab Harvey, who died in 1830 , Abbess Roding to the share of Thomas W. Bramston of Skreen Roxwell, who had married the admiral's daughter abeth.57 T. W. Bramston held the property in Capel Cure but Thomas H. Bramston owned in the parish as late as 1888.50 In 1895 Hall farm was being farmed along with Rook-

Abbess Hall farm-house is timber-framed and ered and was probably rebuilt or much altered in about 100 years later. South of the house warn seven bays and two porches. The plastered panels between the fred brick are probably not more than There is a granary of similar construction to the norththe house.

The early history of the manor of $B E R W I C K$ fo trace by the existence of the manor of Berby the Berners family which also held Berwick

In I086 Eudo dapifer held a manor in Roding in mesne. Before the Conquest it had been held by Ulmar as a manor and 3 hides.6I At the time of Domesday there was a sokeman holding $\frac{1}{2}$ virgate and $8 \frac{1}{2}$ acres who could sell his land although the soke 53 Morant, Essex, i, 137 ; E.R.O., $\mathrm{D} / \mathrm{DB} \mathrm{T}_{7} 14$

54 See Burke's Commoners, ii, 434

55 E.R.O., D/DB T 714.

56 Morant, Essex, i, $138 ; \mathrm{CP}_{25}$ (2)/820 Trin. Io Wm. III; CP2 5(2)/924 East. I ] Anne; $\mathrm{CP}_{43} / 658$ rot. $264 ; \mathrm{CP}_{2} 5(2) / 1313$ Mich. 24 Geo. III.

57 E.R.O., D/DB T7 14.

58 E.R.O., D/DB T700.

59 E.R.O., Q/RPr $3 / 18$; inf. from the

Revd. R. T. K. Griffin.

60 Kelly's Dir. Essex (1895).

61 V.C.H. Essex, i, $494 b$. 
remained attached to the manor. It is probable that Eudo's manor was that which later became known as Berwick Berners. When Eudo founded the abbey of St. John, Colchester, about Iog6 he gave the monks the tithes of Roding. ${ }^{62}$ 'The same tithes are probably referred to in a later confirmation of the abbey's property by the Bishop of London, in which they are described as the tithes of Fulk dapifer in Roding Abbess. ${ }^{63}$ Fulk dapifer does not occur in Dornesday but is found as a tenant of Eudo in the reign of Henry 1.64

Eudo dapifer died without heirs in I 120 . The king later restored to Eudo's widow Rose the lands which her husband had given her in dower. ${ }^{65}$ These included 'the two Rodings'. In 1142 the lands of Eudo were granted by the Empress Maud to the notorious Geoffrey de Mandeville, Earl of Essex. ${ }^{66}$ This grant did not become completely effective, for many of Eudo's manors never seem to have belonged to Geoffrey or his heirs. ${ }^{67}$ Berwick Berners, however, probably did pass to the Mandevilles. In I 66 Geoffrey's son of the same name, also Earl of Essex, was tenant in chief of lands in Essex which were held of him by Adam son of Fulk for $I_{\frac{1}{2}}$ knight's fee. ${ }^{68}$ Early in the I $3^{\text {th }}$ century William son of Geoffrey de Roinges (Roding) son of Adam son of Fulk made a grant of an acre of land in a field called Merefeld to St. John's, Colchester. ${ }^{69}$ A William son of Geoffrey was holding land in Roding in 1240,70 but before this, in 1220 , the manor of Berwick was in the hands of the Berners family, from which it took the second part of its name. In that year Beatrice widow of William de Berners was granted dower by Ralph de Berners in Berwick and elsewhere. ${ }^{71}$ In 1166 an earlier Ralph de Berners had held 4 knights' fees of the Earl of Essex, and also $\frac{1}{2}$ fee of Henry Fitz Gerold as of the fees of Eudo dapifer. The successor of the first Ralph was apparently William de Berners. ${ }^{72}$ The tenancy in demesne is thus doubtful up to $\mathbf{1 2 2 0}$. It may have passed from Fulk dapifer to Adam son of Fulk, to Geoffrey son of Adam, and William son of Geoffrey or it may have been acquired by Ralph de Berners in the middle of the r 2 th century. The tenancy in chief is not so obscure. In 1297 the manor was held of Humphrey de Bohun, Earl of Essex, the descendant and heir of the Mandeville earls. ${ }^{73}$ It subsequently descended with the earldom of Essex until the death in 1397 of Thomas of Woodstock, Earl of Essex, and Duke of Gloucester. 74 In 1400 Berwick Berners and other manors were assigned by the king to Edmund, Earl of Stafford and his wife Anne, eldest daughter and coheir of Thomas of Woodstock and of Eleanor his wife, eldest daughter of Humphrey de Bohun, Earl of Essex (d. I 373).75 In I 42 I, however, a new partition was made of the Bohun inheritance, by which the king received the fee of the earldom of Essex. ${ }^{76}$ Berwick Berners was thus merged in the Crown. In $1623-4$ it was annexed to the Duchy of Lancaster. ${ }^{77}$

The tenancy in demesne of the manor descended in the Berners family like Barnston and Berners Roding (Essex) and West Horsley (Surr.). ${ }^{78}$ In 1336 Berwick Berners was conveyed by John son of Edmund de Berners to John son of Ralph de Berners.79 In $138 \mathrm{I}-2$ it was being administered by the bailiff of Sir John de Gildesburgh.80 The net value of the manor was then fi ros. I Id. It had been granted to Gildesburgh for life by Sir John de Berners. ${ }^{81}$ Sir John's son Sir James de Berners, a knight of the king's chamber, was executed in 1388 as an evil counsellor of Richard II.82 In I 389 Anne widow of James was granted the manor for 500 marks. ${ }^{83}$ Like West Horsley it passed with Anne to her second husband John Bryan and subsequently to her son Richard de Berners. ${ }^{84}$ Richard died in 1417 and was succeeded by his daughter Margery, who married as her first husband John Fereby. ${ }^{85}$ John and Margery were holding manor courts at Berwick Berners in 1427-40.86 After John's death Margery married John Bourchier, who was later summoned to Parliament as a peer and is thus held to have become Lord Berners. ${ }^{87}$ Berwick Berners passed to Bourchier's grandson and heir John, Lord Berners, who was holding it in 1508.88 Soon after this the manor apparently passed to Sir William Capel who by his will dated I 515 left it to his son Sir Giles Capel.89 Courts were held in 1520 for the manor of 'Berwick Capel'.90 The manor descended in the direct male line to Arthur Capel, created Baron Capel of Hadham in I64I, who was one of the royalist garrison of Colchester which surrendered on 27 August 1648 . He was beheaded in the following year.91 In 1653 his son Arthur, Lord Capel, conveyed Berwick Berners to Robert Abdy, 92 who was later created a baronet and died in 1670 . He was succeeded as 2 nd baronet by his son John.93 In I 690 Abdy conveyed the manor to John Brand, mercer of London. 94 Brand was lord of the manor in 1698.95 By 1708 he had been succeeded by Thomas Brand, who held courts at Berwick Berners in 1708-12.96 Thomas was dead by 1720 , when Margaret Brand, widow, held the court as guardian of her son Thomas Brand. 97

Thomas Brand the younger was holding the manor court in $1741.98 \mathrm{He}$ died in 1770 and was succeeded by his son Thomas who in I77 I married Gertrude Trevor Roper, suo jure Baroness Dacre. 99 According to his biographer this last Thomas Brand was 'a very celebrated and expensive commoner whose hospitality exceeded his means'. His seat was at Hoo in St.
${ }^{62}$ Cart. of St. Fohn's Abbey, Colchester (Roxburghe Club), 3 ,

63 V.C.H. Essex, i, $492 a$ (n.).

64 Ibid.; Farrer, Hons. and Knight's Fees, iii, 166-7.

65 Farrer, op. cit. iii, 273.

$66 \mathrm{~J}$. H. Round, Geoffrey de Mandeville, 167,173 .

67 Farrer, op. cit. 168 . It is curious that Farrer does not mention the grant to Geoffrey de Mandeville.

68 Red Bk. of Exch. 345 .

69 Cart. of St. Fohn's Abbey, Colchester, 242.

70 Feet of F. Essex, i, 129

71 Ibid. $\mathrm{i}, 5^{8}$.

72 Farrer, Hons. and Knight's Fees, iii, 214.

${ }_{73}$ Cal. Inq. p.m. iii, p. 273.
74 Complete Peerage, v, 136.

75 Cal. Fine R. 1399-1415, 72 .

76 Complete Peerage, vi, 476.

$77 \mathrm{DL} / 30 / 74 / 915$. It was then said to be held as of the Honor of Clare.

${ }^{8}$ Farrer, Hons, and Kright's Fees, iii,

214-16; V.C.H. Surrey, iii, 353-4.

79 Feet of $F$. Essex, iii, 39 .

80 E.R.O., D/DHf M45.

81 Cal. Pat. $1388-92,150$.

82 A. Steel, Richard II, $143,157,161$.

${ }_{33}$ Cal. Pat. $1388-92,150$

84 Feet of F. Essex, iii, 238 ; cf. V.C.H. Surrey, iii, 354 .

85 E.R.O., D/DHf $\mathrm{M}_{30}, 31$; V.C.H. Surrey, iii, 354 .

86 E.R.O., D/DHf $\mathrm{M}_{30} \mathrm{3}$ r.

87 Ibid. $\mathrm{M}_{32} ;$ V.C.H. Surrey, iii, 354 ;

Complete Peerage, ii, 153 .
88 Complete Peerage, ii, 153 ; $\mathrm{CP}_{25}(2) /$ $51 / 369$.

$89 \mathrm{Cr} 42 / 109 / 23$.

90 E.R.O., D/DP M1024-6.

91 W. Minet, 'The Capels at Rayne',

E.A.T. N.s. ix, 243-72; Complete Peerage,

iii, $5-6$.

${ }_{92} \mathrm{CP}_{25}(2) / 550 \mathrm{~B}$ Trin. 1653.

93 G.E.C. Complete Baronetage, iii, 34 ;

E.R.O., D/DHf $\mathrm{M}_{3} 8,39$.

$94 \mathrm{CP}_{25}(2) / 827$ Trin. I Wm. \& Mary;

cf. E.R.O., D/DHf $\mathrm{M}_{39}$.

${ }_{95}$ E.R.O., D/DHf M4O.

96 Ibid. M41. 97 Ibid.

98 Ibid. His mother had held it as late as $173 \mathrm{I}$.

99 Ibid.; T. Wright, Hist. Essex, ii, 343

Complete Peerage, iv, 17.

1 Complete Peerage, iv, 17. 


\section{A HISTORY OF ESSEX}

Paul's Walden (Herts.) and Berwick Berners subsequently descended along with the manor of $\mathrm{Hoo}^{2}$ In I 870 Berwick Berners Hall farm, containing 285 acres, was put up to auction by 'Thomas Lord Dacre. ${ }^{3}$ It was then let to Joseph Barker on a yearly tenancy at 6310, the tenant paying tithe rent charges. The 'manor of Berwick', i.e. the manorial rights, was not included in the sale. The present owner of the farm is Mr. N. Stacey, who bouglit it in 1937 from Mr. Robert Soper. ${ }^{4}$

A note attached to the court roll of Berwick Berners for 1390 states that Oger Fitz Michael gave to Ralph Berners his garden and curtilage in Roding Abbess 'and all his man Gervase, with 6 acres land and William Green with 3 acres land ... and Geoffrey Finch with I $\frac{1}{2}$ acres land and the relict of Richard le Fynch with I $\frac{1}{2}$ acres land'.s 'This Oger Fitz Michael was probably the man of that name who in 1233 or 1234 granted I 00 acres of land in Roding to Alice daughter of William Purle, ${ }^{6}$ and he was probably son of Michael Fitz Oger. If so, it appears that there was an estate in Abbess Roding which in the 12 th century was held by William de Selflege,' lord of Shelley (q.v.), as tenant of the Mandevilles and which descended in 1182 to Michael Fitz Oger as the purparty of his wife Sarah, daughter and coheir of William de Selflege.7 'This estate would then seem to have been acquired, in whole or in part, by Ralph de Berners from Oger Fitz Michael during the first half of the I 3 th century. In I 374 the fees of the Countess of Essex included one in Abbess Roding formerly held by Oger Fitz Michael. ${ }^{8}$ Early in the I $5^{\text {th }}$ century a knight's fee in Abbess Roding and in the hundred of Dunmow formerly held by Oger Fitz Michael was said to be held by the Abbess of Barking of the Duchy of Lancaster. ${ }^{9}$ It is possible that the ahbey's claim to land formerly belonging to Oger Fitz Michael was derived from a grant made in 1235 by Stephen de Caldecote, ${ }^{10}$ for Hugh de Caldecote had been a tenant of Michael Fitz Oger in I I 82. ${ }^{\text {II }}$ The connexion with the hundred of Dunmow was main tained by the later custom by which the inhabitants of Berwick Berners hamlet elected their own constable and sent him to attend the Dunmow hundred court (see below, Parish Government).

Berwick Berners Hall stands on the ancient site but the house does not appear to be earlier than the $17^{\text {th }}$ century. It is timber-framed and there is zigzag pargeting to the panels. The front of the house has widely spaced sash windows and a modern porch. At the back are two small wings, one containing the staircase. A third wing dates from the I gth century. North of the house are the remains of a moat and at the north-west corner of the site is a railed-in enclosure which was formerly a pound. ${ }^{12}$ A fine timbered barn of nine bays was destroyed by German incendiary bombs in 1940. ${ }^{13}$

The manor of ROOKWOOD HALL alias $B R O W N E S$ was first so styled in 1488 , when it was held of the Earl of Oxford as of his honor of Heding ham. ${ }^{14}$ The same tenure was apparently still acknowledged in 1632.15 It is not unlikely that this part of Abbess Roding was included in the manor of Roding held in 1086 by Aubrey de Vere, ancestor of the earls of Oxford, of Alan, Count of Brittany. ${ }^{16}$ 'The main part of that Domesday manor was undoubtedly in Beauchamp Roding (q.v.). ${ }^{17}$

In I 359 it was stated that the heirs of William Fitz Richard held $\frac{1}{2}$ knight's fee and William Welde I fee, both in Abbess Roding, as tenants of the Earl of Oxford. ${ }^{18}$ It is possible that the $\frac{1}{2}$ fee was that which in I 166 was held by Walter Fitz Richard of Aubrey de Vere. ${ }^{19}$ According to Morant, who quotes no sources for the statements, John Fitz Richard held Rookwood in 1250 and was succeeded by Richard Fitz William, who was the tenant in 1268.20 William Welde became lord of the manor of Beauchamp Roding (q.v.) in 1360 . This suggests that Rookwood was then part of the manor of Beauchamp Roding and it seems possible that it had been so continuously since Domesday. ${ }^{21}$

In 1467 John Browne died seised of the manor of Abbess Roding (i.e. Rookwood). He had inherited it from his brother Baldwin, who had died without issue; his own heir was another brother Thomas. ${ }^{22}$ Thomas Browne died in 1488 leaving Rookwood Hall alias Browne's manor to his son (Sir) Wistan. The manor then comprised 300 acres of land, 200 acres of pasture, 26 acres of meadow, ro acres of wood, and also a toft, garden, and $\frac{1}{2}$ acre of land, in Abbess Roding and neighbouring parishes. ${ }^{23}$

Rookwood descended in the direct male line of the Brownes until I 580 when Wistan Browne, son of George, died leaving as his heir his son Anthony. ${ }^{24}$ Anthony died without issue in 1583.25 Rookwood was then divided between his sisters Jane, wife of (Sir) Gamaliel Capel, and Katherine, wife of Nicholas Waldegrave of Borley.26 Capel apparently acquired Waldegrave's share in addition to his own. $\mathrm{He}$ certainly lived at Rookwood $\mathrm{Hall}_{2}{ }^{27}$ and there is no evidence of a continued Waldegrave connexion with the manor. After I599, when Capel bought the manor of Abbess Roding, Rookwood formed part of a larger estate in the parish and does not seem to have been named as a separate manor. Rookwood Hall, however, continued to be the residence of the Capels throughout their connexion with the parish. In their time it was a house of considerable size. Mrs. Sarah Capel, who was buried at Abbess Roding in 1698 , was probably the last of the family to live there. ${ }^{28}$ Rookwood descended as part of the Abbess Roding estate until the I 8 th century. It still formed part of the estate in 1739 but appears to have been separated from the manor of Abbess Roding by 1770 , when the owner of Rookwood was a Mr. Pratt of St. Ives (Hunts.).29

William Mills owned Rookwood in I 780 . He con-

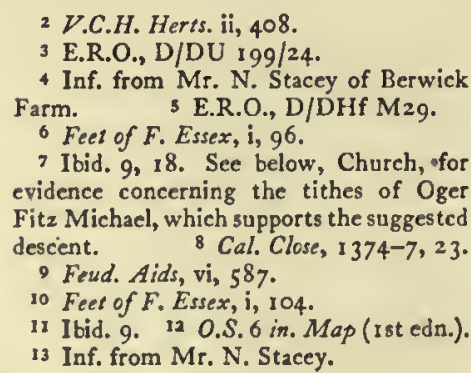

Visits. of Essex (Harl. Soc.), $166-7$. $2 s$ Morant, Essex, i, II 8. ${ }_{26} \mathrm{CP}_{25}(2) / 134 / 1710,135 / 1719,136$ 1731 27 Cal. S.P. Dom. 1603-10, 568; E.R xiii, 97.

28 E.R.O., D/P 145/1/1. Thomas Capel, buried at Abbess Roding in 1703, and Charles Capel in 1709 were both from London.

29 Morant, Essex, i, II 8; Hist. Essex by Gent. iii, 342. See above, Manor of Abbess Roding. 
tinued to hold it until about I 8 I4, when it became the property of William Perry, who had for many years been Mills's tenant. ${ }^{30}$ In 1817 or 1818 Charles Selwin became the owner. ${ }^{31}$ Rookwood Hall farm, as it was now styled, descended subsequently to Henry Selwin-Ibbetson, Baron Rookwood of Down Hall (d. 1 902). ${ }^{32} \mathrm{He}$. was succeeded by his nephew Capt. Horace W. Calverly. ${ }^{33}$ After the purchase by Charles Selwyn Rookwood became part of a large estate which was administered from Down Hall in Hatfield Broad Oak and which in 1873 contained 1,564 acres in Essex. ${ }^{34}$ In 1843 Rookwood Hall farm comprised 279 acres. 35

Only part of old Rookwood Hall remains and this is in a ruinous condition. It stands on a site of more than $3 \frac{1}{4}$ acres, enclosed by a very fine moat. A spur of the moat extends inwards on the west side and there are indications of a second moated enclosure immediately to the south.

The house has been thought to be the work of John Browne, who was lord of the manor in the second quarter of the 16 th century. ${ }^{36}$ It has several features in common with Colville Hall at White Roding which was also the property of the Brownes at that time. In I 578 Elizabeth I stayed a night at Rookwood Hall and held a Privy Council there. ${ }^{37}$

The existing building is of two stories and is Lshaped in plan with wings extending to the north and west. A second wing on the west side has been demolished ${ }^{38}$ and it is possible that at one time the house was of even greater extent. The south wing is of three bays and is mostly of timber-framed construction. The south wall has been rebuilt in $17^{\text {th- }}$ or I 8 th-century brickwork. The roof has cambered collar-beams. The structure is independent of the north block and there is some evidence that it is of earlier date. The north block consists of one large room to each floor. The lower room has moulded timbers and the remains of a brick fireplace. Above it is a fine upper chamber or solar. The roof, which is of three bays, has arch-braced collar-beams and curved wind-braces. The wall-posts have elaborate mouldings which are returned along the wall-plates to form a cornice. There was formerly a wide stone fireplace in this room and beside it a stopmoulded door-frame with a four-centred head and carved spandrels. ${ }^{39}$ This door led to the demolished north-west wing. In the east wall there were originally two six-light mullioned windows which were later blocked and are still largely concealed by plaster. The mullions are richly moulded and there are moulded sills externally. Below the windows the wall has closeset oak studs with original 'nogging', one brick wide, between them. The sides of the studs have splayed grooves to receive the brickwork and the bricks themselves are laid horizontally and diagonally in alternate panels. This form of construction is rare in Essex but is found in a small group of buildings in the immediate neighbourhood, all apparently dating from the early
I 6th century.40 The north wall is of solid brickwork, probably later, and has diaper decoration in darker brick. The house originally had a fine brick chimney consisting of two slender shafts joined at the top with octagonal moulded caps. The shafts were enriched with zigzag flutings of moulded brick.

The decline of Rookwood Hall probably began early in the I 8 th century after the departure of the Capels. By about $\mathrm{I} 770$ it had ceased to be an important house and was described as "a venerable mansion to which there formerly belonged an extensive park'.4I It was probably about that time that the walls were plastered over and sash windows were inserted. Rookwood continued to be used as a farm-house until about 1886 when a new red brick house was built south of the moated site.42 The north-west wing of the old house was demolished late in the Igth century. Between 1904 and I914 the chimney was taken down and rebuilt at a cottage in the grounds of Down Hall, now Downham School (in Hatfield Broad Oak). The house is now partly in use as an outhouse but is rapidly falling into decay.

Inside the moated enclosure are two very fine timbered barns, also probably of the early I 6 th century. Each is of eight bays and the roofs have arch-braced tie-beams with king-posts and four-way struts. Below the purlins are curved wind-braces. In the smaller barn are window openings with diagonally set mullions. Part of this barn is said by local tradition to have been the original meeting place of the Presbyterians who later built the church that formerly stood beside Anchor House.

During the Middle Ages the advowson of the parish church of Abbess Roding was held by

CHURCH Barking Abbey. 43 The first presentation after the Dissolution was made by Edward

Brook in I $54 \mathrm{I}$ by virtue of a previous grant from the abbey. Thomas Wiseman presented in 1565 and John Glascock in 1587.44 Soon after this the advowson was acquired by (Sir) Gamaliel Capel and descended with the manor until 1680, when Prosper. Nicholas presented pro hac vice.45 William Turner presented in I68z.46 In I7 I9 the advowson was conveyed to Richard Waylett by Samuel Pratt and Anne his wife and John Benson and Mary his wife.47 In $173 \mathrm{I}$ Richard Waylett conveyed it to Edward Hinton, Rector of Sheering and John Maryon, Rector of White Roding. ${ }^{48}$ Hinton and Maryon presented in 1732 and Maryon alone in 1748.49 'The next presentation, in 1786, was by Thomas Dyer and Walwyn Shepheard.sa The advowson remained in the Dyer family until about i 850 . Two members of the family were rectors of Abbess Roding.51 By I 854 the advowson had been acquired by Capel Cure of Blake Hall (in Bobbingworth, q.v.) who presented his son, L. Capel Cure, in 1858.52 The latter was rector until 19 I 2 and also held the advowson. He was succeeded as rector and patron by his son, C. L. Capel-Cure, who held the rectory
30 E.R.O., Q/RPI 685-719.

31 Ibid. $722-3$.

32 Complete Peerage, xi, 88; G.E.C.

Complete Baronetage, v, 96-97.

33 E.R. xiii, 98 ; Burke, Land. Gent. (1906), i, 253.

34 Retns. of Owners of Land, 1873

[C. 1097], Essex, p. 25, H.C. (1874), Ixxii (1). 3s E.R.O., D/CT 292. 36 E.R. xiii, 96.

37 E.R. xxvi, 127.

38 Miss Rowe of Falkiners, Abbess
$155^{8}-60,460$

43 Newcourt, Repert. ii, 498-9.

46 Ibid.

$47 \mathrm{CP}_{25}(2) / 1013$ Mich. 6 Geo. I.

48 E.R.O., D/DC $23 / 560$.

49 Morant, Essex, i, I39. For Maryon see J. E. Maryon, Recs. of Family of Maryon (E.R.O., pamphlet).

so P.R.O. Inst. Bks., Ser. C. i(I)

31 Cler. Guide, I819-36; Clergy List, $1845 \mathrm{f}$. .

32 Clergy List, I 854 f.; E.R. xxi, 226. 


\section{A HISTORY OF ESSEX}

until his retirement in 1948. In 1927 the benefice of Abbess Roding was united with that of Beauchamp Roding (q.v.). The advowson of the united benefice was vested in the Revd. C. L. Capel-Cure and the Bishop of Chelmsford alternately. The present patrons are the bishop and Mrs. L. J. Capel-Cure.53 Since I 949 the united benefice has been held along with the vicarages of Good Easter and Berners Roding.

The rectory of Abbess Roding was never appropriated but about 1096 the tithes from the lands of Eudo dapifer (see above, Berwick Berners manor) were granted to the abbey of St. John, Colchester. In about 1254 it was stated that the Abbot of Colchester and the nuns of the priory of Stratford-atte-Bow (Mdx.) then received all the tithes of Oger Fitz Michael.54 At some date, presumably after this, the Abbot of Colchester restored all the tithes to the Rector of Abbess Roding. 55 The rectory was valued at 10 marks in about 1254 , 1291 , and 1428 and a 614 IOs. in $1535 .^{56}$ Tithes were commuted $\mathrm{n}$ : 843 for 6455 ; there were then I 9 acres of glebe. 57

The original rectory house was immediately south of the churchyard. It was rebuilt in 1859 on or near the same site by L. Capel Cure. ${ }^{8}$ The new building served as the rectory only until IgI2. It is now called The Manor and is a large red-brick structure of three stories. In I9I 2 a smaller rectory was built on the opposite side of the road by C. L. Capel-Cure. This was sold to him on his retirement and has since been named Abbess House. It is a well-designed red-brick building in an informal Queen Anne style. There is now no rectory in Abbess Roding. The present (1 955) rector is also vicar of Good Easter and lives there.

The parish church of $S T$. EDMUND consists of nave, chancel, west tower, north vestry, and south porch. The walls are of fint rubble, roughly coursed except where they have been restored, and the original dressings are of clunch. The plan indicates a 12 thcentury origin and the dedication suggests that there was a church here before the Norman Conquest. The nave was probably rebuilt in the $14^{\text {th }}$ century and the chancel in the $14^{\text {th }}$ and 15 th. The tower and porch were rebuilt in $1866-8$ and the vestry was probably added before the end of the I 9 th century. The most interesting features of the church are the oak screen and the stained glass, both of the I $5^{\text {th }}$ century.

The position of the north and south doorways suggests that the nave was originally built in the 12 th century. The font is of the late 12 th century and is similar in type to others in the neighbourhood.59 The square bowl, which is bound with iron, has vine ornament carved on two sides and conventionalized flowers on another. On the fourth side appear the disk, crescent, whorl, and stars which are characteristic of these fonts. The stem is circular and has small angle shafts.

The nave was probably rebuilt in the I 4 th century. There are two pointed windows with tracery of this date. They have been partially restored but retain their external label moulds and grotesque head-stops. The doorways are also $14^{\text {th }}$-century in style but the south doorway has been completely rebuilt. West of the doorways are single-light windows which are either modern or very thoroughly restored. A I 4th-century piscina in the south wall has an ogee head on a square drain. The chancel arch, much restored, is of two moulded orders. The windows on the north side of the chancel have tracery of the I 4 th century, but the later rebuilding of the rear arches has blocked the spandrels. Between them is a small chamber or cupboard, projecting externally and having a pent roof. The opening to the chancel, now blocked, has a small doorway, probably of the I 4 th century, with a pointed head.

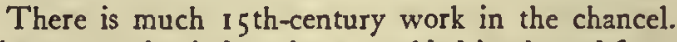
The two south windows have moulded jambs and fourcentred heads. The east window, entirely rebuilt in the r th $^{\text {th }}$ century, has tracery in the style of the $15^{\text {th }}$ century and may replace a similar window of that date.

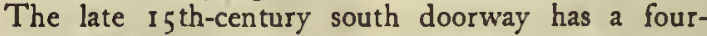
centred head with carved spandrels and a square label externally. The stonework has been partly renewed. The chancel roof has two tie-beams and a deep moulded and embattled wall-plate. Below the east tie-beam are moulded wall-posts and arched braces springing from modern corbel brackets. The nave roof, of similar date, has two tie-beams with traceried spandrels between the arched braces and the moulded wall-posts. At the west end are indications of the former bell turret, 'a little wooden turret with a spire'.60 'This is shown in an engraving of $1797^{\circ}$ I In the same picture appears a large timber-framed south porch, also probably of the I 5 th century, having seven pointed lights along the sides. The turret and porch were both rebuilt in 1867 but there is still a I $5^{\text {th-century stoup outside the south }}$ door.

The fine oak screen is of the late I 5 th century. It has evidently been brought from elsewhere and cut to fit the present chancel arch. There are three full bays, one of which forms the entrance to the chancel, and an extra half bay at the south end. The upper panels have four-centred heads and are filled with elaborately cusped perpendicular tracery. The principal mullions are carved with buttresses and crocketed finials. The rail is enriched with a running vine ornament and the lower panels have tracery carving. The cresting is modern.

In one of the 15 th-century chancel windows is some painted glass of the same period. It includes tabernacle work and two figures, one being a bishop in mass vestments and the other a woman, probably St. Margaret.

Above the pulpit is a fine early- 18 th-century sounding board with an inlaid soffit and an enriched cornice. It is supported on a fluted Doric pilaster in the angle between the south and east walls of the nave. The octagonal oak pulpit may be partly of the same date, altered later. The wrought-iron hour-glass stand near the pulpit is probably also of the 18 th century.

In I 866-7 the church was restored and refitted at the expense of Capel Cure of Blake Hall. The work included the rebuilding of the tower and the south porch. The present tower is of flint rubble with freestone dressings and is of three stages surmounted by a castellated parapet. Its style is mainly of the 14 th century. The south porch is of timber. At the same time the east wall of the chancel was completely rebuilt,
53 Crockford's Cler. Dir. passim; Chelmsford Dioc. Year Bk. 1952 .

34 E.A.T N.S xviii, I9. For Oger Fitz Michael see Berwick Berners. No other reference has been found to the Priory of Stratford in this connexion. ss Cart. of St. Fohn's Abbey, Colchester, ed. Stuart Moore, 522 .

36 E.A.T. v.s, xviii, 19; Tax. Eccl.

(Rec. Com.), $2 \mathrm{rb}$; Feud. Aids, ii, 205

Valor Eccl. (Rec. Com.), i, 437.

57 E.R.O., D/CT 292.
58 E.R. $\times x i, 226$

s9 Cf. Moreton, Little Laver, and (outside Ongar hundred) Fryerning.

60 Morant, Essex, i, 139

61 E.R.O. Prints, Abbess Roding. 
there were repairs to windows and roofs, the nave was repaved and new seats and new stained glass were installed. The total cost of the restoration was about $\delta_{2}, 000.0^{62}$ The north vestry was probably added later in the I 9 th century.

The carved oak reredos, which has traceried panels and other enrichments, is the work of the late Miss Capel-Cure and was added in 1938.63

There are three bells. Two are probably of the I 5 th century, one being by John Walgrave. The third is by John Hodson, 1665 .

The church plate includes a plated paten, cup, and flagon of the I gth century and a silver paten of 1869 . The plated paten was probably bought after an archdeacon's visitation of about I 816 when the church was ordered to sell a pewter paten and flagon and provide a paten for bread and offerings. 64

On the north wall of the nave is a fine carved and painted wall tablet of alabaster and black marble. It is in memory of Sir Gamaliel Capell $(1613)$ and has figures of himself and his wife kneeling at a prayer desk. Below, also kneeling, are six sons and three daughters. The monument was formerly in the chancel.65 On the opposite wall of the nave is a tablet in similar materials but of very unusual design. It commemorates Mildred (Capell) wife of Sir William Lucklyn (1633) and shows a lady looking out from a curtained recess, the curtains being held back by cherubs. Behind her, angels are descending to place a crown on her head. Above is a segmental pediment and an achievement of arms. Also on the south wall of the nave are two mounted brass tablets having an achievement of arms and a rhymed inscription to Edward Humberstone of Cockerells (1622). There are marble tablets to Thomas Dyer (1852) and L. Capel Cure (I II 2), both rectors of the parish, and there is also a memorial tablet to those who were killed in the First World War.

The Congregational church at Abbess Roding, once an important nonconformist

NONCONFORMITY centre for this part of Essex, originated about 1698 through the labours of the Revd. Samuel Pomfret, minister of the Presbyterian church in Gravel Lane, Houndsditch. ${ }^{66} \mathrm{He}$ is said to have visited Rookwood Hall for the benefit of his health and to have obtained from his hosts the use of a former malt house at the hall. This was used for worship until a church was built. According to local tradition this first meeting-place was part of a barn which still exists at Rookwood Hall (see above). This is probably correct. Pomfret's friends at the hall were probably the Capels, who were certainly living there in 1698 and perhaps for a few years after. Until the end of the 18 th century the church continued to be known as that of Rookwood Hall.67 It was at first Presbyterian, but became Congregational during the ministry of John Cook (174378). The first minister ordained to the church was Daniel Wilcox (1703-6). His successor, Lauchlan Ross, ministered with success from 1706 to 1740 . In
I 7 I 6 the congregation was estimated at 500 , of whom 59 were county voters and I9 were 'gentlemen'.68 If these figures are correct this was one of the strongest nonconformist churches in Essex. Ross also had licensed preaching rooms in many neighbouring villages. In 1729-30 a new church was built on land given by Joseph Springham of Cockerells Farm (now Fairlands). Within 6 or 7 years $6_{0} 630$ was raised towards the cost of the church. George Ross, who became minister in $174 \mathrm{I}$, was said by a writer of about 1820 to have been imbued with the "spirit of the very Pope himself', and his quarrels with the congregation terminated in 1743 , when he was dismissed from his office. His successor John Cook was not very well educated but served faithfully. In I745 Joseph Springham gave two freehold cottages to be used as the minister's house. ${ }^{69}$ This intention, however, never seems to have been carried out. Although the cottages were beside the church the minister continued to live in the 'gentleman's end' of Cockerells Farm until 1786 when a house at Fyfield was bought as a manse during the pastorate of Thomas Eisdell (I 784-9).

With these economic advantages the church was able to retain ministers throughout the 18 th and 19 th centuries, with only short vacancies, and some of them remained for many years. Eisdell's ministry came to an end as the result of a dispute with some of his congregation. His successor Joseph Corbishley, minister from 1790 to $183 \mathrm{I}$, was an active evangelical.70 In I 829 he reported that the congregation numbered 500.71 In 1881 it was estimated at only 250; there were 75 church members, 75 pupils in the Sunday school, and ro teachers. ${ }^{72}$ The decline in numbers probably resulted from the foundation of other Congregational churches in the neighbourhood. In 1848 it was stated that the two cottages beside the church had been 'converted into a respectable public house for the accommodation of the congregation, most of whom come from a considerable distance'.73 By 1881 there were new Congregational churches at Norton Mandeville, Moreton, and Thrushes Bush (in High Laver) (qq.v.). At Abbess Roding the contraction of the catchment area of the church was perhaps reflected by the sale ( 1852 ) of the Fyfield manse after the building of a new one in Abbess Roding. ${ }^{74}$ The income from endowments was 618 in $188 \mathrm{I}$, and that from other sources was about $\oint_{92}$. The minister received a salary of $£ 80.75$

In $1884 \mathrm{~J}$. E. Rattee became minister. He organized services at White Roding, Leaden Roding, and other neighbouring villages and persuaded the Essex Congregational Union to make a grant of 635 towards this work in 1885 , when 24 new church members were reported. ${ }^{76}$ By 1886 an iron church had been opened at Leaden Roding, and there was a mission room at White Roding, both under Rattee's supervision. He was also holding services at Aythorpe Roding and Margaret Roding.77 A chapel was built at White Roding in 1888 at a cost of $\$ 262.78$ In 1890 the old church at Abbess Roding was dilapidated and services
${ }^{62}$ E.R.O., D/P 145/5; tablet in church tower.

63 Inf. from the Revd. R. T. K. Griffin, present rector.

64 Ch. Plate Essex, 146. Cf. E.A.T. N.s. xviii, 207.

os T. Wright, Hist. Essex, ii, 344.

66 Abbess Roding Congr. Church Bk. (now in Congr. Church, White Roding). Unless otherwise stated the following

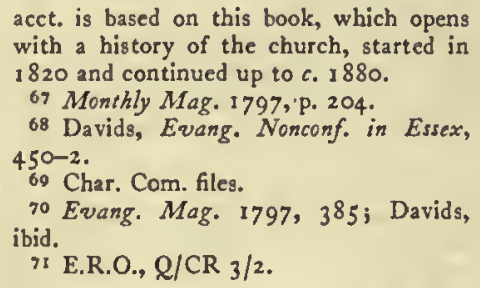

acct. is based on this book, which opens with a history of the church, started in 1820 and continued up to $c$. 1880 .

67 Monthly Mag. 1797,'p. 204.

68 Davids, Evang. Nonconf. in Essex, $450-2$.

69 Char. Com. files.

70 Evang. Mag. 1797, 385; Davids, ibid.

II E.R.O., Q/CR $3 / 2$.

32 Essex Congr. Union Rep. $188 \mathrm{I}$.

73 White's Dir. Essex (1848). For this public house, called "The Anchor", see below.

74 Char. Com. files.

75 Essex Congr. Union Rep. $188 \mathrm{I}$.

76 Ibid. 1885 ; Congr. Year Bk. 1884 , 1885 .

77 Essex Congr. Union Rep, 1886.

78 Ibid. 1898 . 


\section{A HISTORY OF ESSEX}

were being held in the schoolroom there. 79 In 1899 the old church was sold, together with the neighbouring Anchor House, for $\ell_{1}, 000,80$ and the money made over to the church at White Roding, which was extended in rgor. The manse remained at Abbess Roding until I948, when it was sold, and a new manse was built at White Roding. ${ }^{81}$ Rattee left the district in $1904-5$. He had been ill and a fund was raised to pay his debts before he left. ${ }^{82}$

The Abbess Roding church was demolished soon after 1899 and nothing now remains of it except the red-brick wall of the forecourt. It stood immediately to the west of the present Anchor House. An oil painting of the front, executed about 1876 , hangs in the Congregational church, White Roding. It shows a two-story plastered building with rusticated quoins and a hipped tile roof. At each end of the front is a doorway with flanking pilasters supporting an entablature. The windows, of which there are four to the upper story, have semicircular heads and are divided by mullions and transomes (sce plate facing p. II3). A photograph of the interior, also in the White Roding church, shows a gallery on three sides and on the fourth a high panelled pulpit set between two tall round-headed windows. To the west of the church stood the Sunday school..$^{83}$

Anchor House, which appears to have become a public house in the I 9 th century (see above) retained its licence until about 19 ro. 84 The iron anchor which served as an inn sign still hangs above the entrance door. The building is timber-framed and roughcast and probably dates from the late 17 th or early I 8 th century. To the west of it, near the site of the former church, are the remains of a moat.

The Old Manse, formerly known as Hill House, was built in 1851 to the design of the Revd. H. Stacey, then minister of the church.85 It is a square doublefronted house of brown brick.

The court rolls of the manor of Abbess Roding survive for $1472-1530^{86}$

PARISH GOVERNMENT and those of Berwick $A N D$ POOR RELIEF Berners for 1382-1819 with a gap between 1484 and 1574.87 Both courts exercised leet jurisdiction and each elected its own constable. The last recorded appointment of a constable for Berwick Berners manor was made in $168 \mathrm{I}$. A manorial pound is mentioned in the Abbess Roding roll of 1473 .

The earliest surviving minutes of parish vestry meetings are entered in a parish register. 88 They cover the period $1708-52$. They are continued in a separate parish book from about 1752 to 1803 , but most of the entries for the first dozen years of the new book are illegible owing to decay. ${ }^{89}$ The Easter vestry at which officers were elected was generally the only one in the year, and the rector usually took the chair. From 1785 , coinciding with a change of rector, the vestry's interest in the parish government almost ceased. The entries were no longer signed and recorded only the continuing in office of the same three persons as churchwarden and constables. Their accounts were passed without scrutiny and there never remained any balance to be carried over. In 1729 it was agreed to hold a vestry dinner at Easter for all ratepayers, each to pay $6 d$. whether he attended or not.

The parish clerk had an income of $£ 2$ a year from a rent charge left under the will of Nicholas Burton (proved 1678).90 In 18.34 the sum was allowed in the rent paid by the then clerk, who happened to live in Falkiners, the house charged. In 1910 the property charged was called Willington Cottages, and the clerk was still receiving the payment in 1914 . The payment is now being made from Falkiners at the rate of ros. a quarter. 91

The vestry appointed two constables, one for the 'township' and one for 'Berwick hamlet'; perhaps originally each represented a separate township or vill and subsequently the manors of Abbess Roding and Berwick Berners respectively. Morant (c. 1768) stated that the constable of the hamlet of Berwick Berners attended at the court of the hundred of Dunmow, "which causes it to be reputed within that hundred'.92 There had been an ancient connexion between the manor of Berwick Berners (see above) ${ }^{93}$ and Dunmow hundred. Separate surveyors of highways were nominated for the township and Berwick hamlet and sometimes also separate rates were levied. In 1762 a rate of $3 d$. in $f_{1}$ for the hamlet produced just over $\oint_{3}$. An earlier undated memorandum in the parish register shows that a rate for the township produced one third more than that for the hamlet. In 1836 the rateable value of the whole parish was 6859.94

During the first half of the 18 th century only one overseer was appointed and he almost invariably served for two consecutive years. There is no reference to the overseer in the parish book covering the second half of the 18 th century, but between 1824 and 1836 two overseers were sometimes appointed. 95 During the whole of this latter period five persons only shared the offices of churchwarden and overseer. They occupied the largest farms in the parish and included the widow of a previous overseer.

In 1710 the overseer spent $£ 20$ on poor relief. After that date the vestry minutes ceased to record the detailed disbursements of any officer, but only gave the balance in hand. After 1785 even this was abandoned, and for information on parish expenditure we are dependent on parliamentary returns. 96 These show that between 1783 and 1785 an average of $\oint_{1} 50$ was raised by the poor rates. This rose to a peak of over $\mathrm{f}_{0} 644$ for $1800-1$. This was the equivalent of a rate of $\mathrm{I} 5 \mathrm{~s}$. in $\oint_{\mathrm{I}}$ on the rateable assessment of 1825 . No other year's rates were as high as this but between 1800 and 1817 the annual average was about 6400 . Between 1824 and 1833 an average of $£ 330$ was raised each year by the poor rates.

In 1776 the parish was renting a house for use as a poorhouse. 97 In 1829 it united with Stanford Rivers (q.v.) and other parishes in a voluntary poor law Union under Gilbert's Act. In 1836 Abbess Roding ecame part of the Ongar Poor Law Union.
86 E.R.O., D/DP M $55-84$.

\footnotetext{
87 E.R.O., D/DHf M28-4I (I $382-$ 1484 and I 574-1 727); ibid. M I6 (I729$1819)$. The last is a book recording courts baron only.

88 E.R.O., D/P I45/I/I.

89 E.R.O., D/P $145 / 8$.

90 Rep. Com. Chor. (Essex), H.C. 2 I6, p. 24 I ( 1835 ), xxi (r); Char. Com. files.

8o Deed of Conveyance, now at White 81 Char. Com. files.

82 Essex Congr. Union Repr. 1904 , I g05.

83 O.S. 6 in. Map (Ist edn.), sheet xlii. 84 Inf. from the son of the present
owner and grandson of the last licensee. ss Abbess Rading Congr. Church Bk.
}

91 Inf. from Miss Rowe of Falkiners.

92 Morant, Essex, i, I 39.

93 p. 192.

94 E.R.O., D/P 145/11: Overseer'8 Rate Bk.

os Ibid.

96 E.R.O., Q/CR I/1, I/9, I/12.

97 Rep. Sel. Ctzee. on Overseers' Retns. 1777, H.C. ser. I, vol. ix. 
In 1807 there was no school in the parish. The rector wished to establish one because he

$S C H O O L$ thought that the children of the poor were unruly and in need of training but he had found the village too poor and the local landowners too indifferent to support one. 98 There was still no school in 1818.99 Between 1818 and 1832 local Anglicans succeeded in establishing a Sunday school and a day school which for many years remained closely connected. By I 832-3 there were 36 pupils at the day school. Parishioners then subscribed towards its expenses, but by $1846-7$ the rector alone seems to have maintained the school, paying the mistress $f, 6$ a year and providing her with board and lodging. The number of pupils was then $50 .^{\mathrm{I}}$

In 1858 Capel Cure, the patron of the church, provided a new school building with accommodation for 34 children. It remained his property and he and his heirs appointed the school managers for many years. In 187 I an inspector reported that to ensure universal elementary education in Abbess Roding 10 more places were needed than were available at the school but that these were vacant at Beauchamp Roding. ${ }^{2}$ In I 888 the Abbess Roding school was enlarged to take all local children. ${ }^{3}$ In 1893 its accommodation was estimated at 65 and average attendance was 54.4 In I904 there were 56 pupils and 2 teachers. $s$

Under the Education Act I 902 the school passed under the administration of the Essex Education Committee, Ongar District. Beauchamp Roding children attended at Abbess Roding after their own school had been closed in $1923 .^{6}$ By 1930, however, attendance had fallen to 36 and in 1937 the school was reorganized for mixed juniors and infants, the seniors going to the new central school at Ongar. In 1947 the Abbess Roding school was closed because the County Council found it impossible to bring the existing site and premises up to a proper standard. The children were transferred to the Fyfield and White Roding schools.7

The school building is now a private residence. It is single-storied, of red brick with a tiled roof. The former teacher's house, a two-story building, is attached.

CHARITIES. None known.

\section{BEAUCHAMP RODING}

Beauchamp Roding lies south of Abbess Roding, about 5 miles from Chipping Ongar. ${ }^{3}$ For ecclesiastical purposes it is united with Abbess Roding. ${ }^{2}$ For civil purposes it has since 1946 been united with Abbess Roding and Berners Roding. ${ }^{3}$ The ancient parish of Beauchamp Roding contained 1,262 acres. ${ }^{4}$ It was bounded on the north by Abbess Roding, on the east by the River Roding, on the south by Willingale Doe, and on the west by Fyfield. It contained a small detached part of Abbess Roding. ${ }^{5}$ Bird's Green, a hamlet in the extreme south-east of Beauchamp Roding, and partly in the parish of Willingale Doe, was treated for the purposes of Land Tax Assessment (1780-1832) as being in Dunmow hundred. 6

In its landscape and general economy Beauchamp Roding is similar to Abbess Roding, but there is one marked difference: unlike Abbess Roding, Beauchamp Roding has no central village grouped about its parish church. Beauchamp Roding church, on a site probably of great antiquity, is indeed in the centre of its ancient parish but it is completely isolated and can only be reached by a field track. There is not even an old manor house near it as is usually the case with the medieval churches of Essex. Most of the population is located to the east of the church, at Bird's Green and along the road leading to it. In 180 I the population was 220 . By I $88 \mathrm{I}$ it had risen to $28 \mathrm{I}$ but by I $90 \mathrm{I}$ it had declined to $22 \mathrm{I}$ and it fell further to $I 62$ in 1921 . There was then a slight increase to 173 in 1931 . The figure for the combined parish of Abbess, Beauchamp, and Berners Roding in 1951 was 515 , which implies a slight increase over $193 \mathrm{I}^{7}$ It is probable that some of this results from the building of council houses in Beauchamp Roding and of houses for the London Cooperative Society's farm workers. ${ }^{8}$

Beauchamp Roding rises from about $175 \mathrm{ft}$. above sea-level near the river to $250 \mathrm{ft}$. in the west. Two streams flow east to join the Roding. Butt Hatch Wood is in the south-west of the ancient parish. The road from Ongar to Dunmow enters the parish in the south near Butt Hatch Farm. In its earlier form 'Burnthatch', the name of this farm, goes back at least to I 542.9 The present house is a square double-fronted building dating from the early or mid-I gth century. Roden Lodge, which adjoins Butt Hatch to the north, is a similar house of the same period. The Rood Inn formerly occupied the same position as Roden Lodge, which at one time was known as Rood House.10 Half a mile north of Roden Lodge, on the west side of the road is Slade's Farm, whose name, like that of Butt Hatch, goes back to I 542.11 The present building is of the I6th century or earlier but is much altered outside. A mile north-west of Slade's is Wood End Farm, which is linked with the main road by a lane which continues west to Leader's Farm in Abbess Roding. The farm took its name from the wood which formerly lay to the west of it. 12 The name Wood End also goes back to 1542.13 The farm-house is timber-framed and plastered and has an original chimney with six octagonal shafts. The front porch, which is dated I62I, has a moulded frame and an original panelled door. There are later additions at the back of the house.
98 E.R.O., D/AEM $2 / 4$.

o0 Retns. Educ. Poor, H.C. 224, p. 266 (1819), ix (x).

1 Nat. Soc. Rep. 1832, p. $77 ;$ Educ. Enquiry Abstr. H.C. 62, p. 287 (1835), xli; Nat. Soc. Enquiry into Ch. Schs. $1846-7$, Pp. 1 6-17.

a Min. of Educ. File $13 / 2$.

3 Kelly's Dir. Essex (1899), 310.

4 Resn. of Schs. 1893 [C. 7529], P. 712 ,

H.C. (1894), jxv.

s Essex Educ. Ctiee. Handbk. 1904, p. 183 .
6 Min. of Educ. File $13 / 16$.

7 Ibid. $13 / 2$; inf. from Essex Educ. Cttee, and the Revd. R. T. K. Griffin.

I O.S. $2 \frac{1}{2}$ in. Map, sheets 52/50, 5 s. For some general remarks about the Roding parishes see Abbess Roding.

a See below, Church.

3 Co. of Essex (Rural Parishes) Conf. Order, I946, P. Is.

4 0.S. 6 in. Map (1st edn.), sheet xlii.

3 For the former boundary with Abbess Roding, and the detached part, see Abbess Roding.
6 E.R.O., Q/RPI 3 Is f.

7 Census Repores.

8 See below, Manors of Longbarns and Frayes.

- P.N. Essex (E.P.N.S.), 76.

10 E.R.O., D/CT 294 ; O.S. 6 in. Map (ist edn.), sheet xlii.

"I P.N. Essex, 76 .

ta See e.g. Chapman and André, Map of Essex, I777, sheet xii; O.S. 6 in. Map (rst edn.), sheet xlii.

13 P.N. Essex, 76. 


\section{A HISTORY OF ESSEX}

A quarter of a mile east of Slade's is the church, which is reached by a track running from the main road near its junction with the Wood End lane. Near the church to the east is the old rectory. A little to the north of the church track the main road meets the road which runs south-east to Bird's Green. Farther north, on the west side of the main road, is Longbarns (see Manors). Opposite Longbarns is Sparrow's Hope, a small cottage with an 'Off' licence. The site was formerly part of the detached strip belonging to Abbess Roding parish (q.v.). The cottage is weather-boarded and has a thatched roof and probably dates from the $17^{\text {th }}$ century. Wicks Farm, now demolished, was also in the detached strip, beside the Roding about a mile east of Longbarns. Half a mile north-east of Longbarns is Frayes (see Manors) from which a long drive leads to the main road.

On the east side of the main road near the Bird's Green turning are three pairs of council houses. Scattered along the Bird's Green road are cottages, many of which date from the 17 th and 18 th centuries. The former school, originally the parish poorhouse, is on the east side of the road $\frac{1}{4}$ mile north-east of the church. Near it on the west side of the road are four pairs of council houses. The 'Two Swans' at Bird's Green was a farm-house until the middle of the I 9 th century. ${ }^{14}$ It is a 17 th-century timber-framed house that has been refronted in brown brick. Hornets Farm, formerly Horners (see Manors) is near Bird's Green to the west. Gubbiss Farm, which formerly stood on an isolated site between Hornets and Butt Hatch, has now been demolished and the track leading to it from the Bird's Green road is largely obliterated. The house was of the 16 th century, built on an L-shaped plan, and there was an enriched plaster panel above an original fireplace arch on the ground floor. ${ }^{15}$ From Bird's Green one road runs south-west to join the Ongar road in Fyfield and another runs east via Shallow (formerly Shellow) Bridge to Berners Roding, Willingale, Shellow Bowells, and Chelmsford. Shallow Bridge, between Beauchamp Roding and Willingale Doe, seems to have been accepted as a county bridge from about $1654^{16}$ In 1596 a Beauchamp Roding man was said to be partly responsible for the repair of the bridge, ${ }^{17}$ but during the late 16 th and early 17 th century responsibility was more often assigned to Willingale Doe, ${ }^{18}$ and a more detailed history of the bridge will be given under that parish in a later volume.

In 1618 the parish surveyors of highways made a report on the statute work 19 and a detailed return was made in 1720.20 The most important road in the parish has for many centuries been the OngarDunmow road, which is marked on Norden's Map of Essex, 1594. This probably enjoyed its greatest importance in the 18 th and early I 9 th centuries when it was used by coaches running between Dunmow and

14 E.R.O., D/CT 294.

is Hist. Mon. Com. Essex, ii, $13-14$.

16 E.R.O., Q/CP 3, pp. $163,17 \mathrm{r}, 174$,

352,417 .

17 E.R.O., Q/SR I $35 / 22, \mathrm{cf.} 56 / 18$.

is E.R.O., Q/CP I, 37 Eliz., $3^{8}$ Eliz.;

Q/CP 2, pp. 62, 63, 64, 65, 66, 69, 71, 72 . $19 \mathrm{Q} / \mathrm{SBa} 4 / 5$

$20 \mathrm{Q} / \mathrm{SBb} 75$.

21 See Abbess Roding. The present bus service between Dunmow and Brentwood runs through Beauchamp Roding, as well as Abbess Roding.

22 Kelly's Dir. Essex (1886).
London. ${ }^{21}$ The decay of the road from Wood End to Little Laver in recent times has already been mentioned.

For postal services Beauchamp Roding has usually depended upon Ongar. In I 886 it received letters by foot post from Brentwood through Ongar.22 Part of the parish has a water-supply by pipes laid in 1952-3 by the Herts. and Essex Waterworks Co. ${ }^{23}$ Beauchamp Roding shares a village hall with Abbess Roding (q.v.).

As elsewhere in the Rodings hardly any occupations other than agriculture have been carried on in this parish. ${ }^{24}$ From the 16 th century until late in the I 9 th the owners of most of the land in Beauchamp Roding were non-resident. In 1840 it was estimated that the parish contained I,OII acres of arable, 172 acres of meadow and pasture, and 46 acres of wood excluding 38 acres of glebe of which 32 acres were arable and the rest meadow and pasture. ${ }^{25}$ In 1843 there were six farms of over 50 acres, the largest of which was Longbarns with Frayes, containing some 370 acres. Several farms had more than one homestead and had been formed by the amalgamation of smaller holdings. The same survey refers to a malthouse and elsewhere to a 'hop garden field' which recalls Defoe's comment on this area. ${ }^{26}$

In 1086 a manor of Roding was held by Aubrey de Vere, ancestor of the earls of Oxford, as MANORS tenant of Alan, Count of Brittany. Before the Conquest it had been held by Lewin and Etsi as a manor and as $I \frac{1}{2}$ hide. ${ }^{27}$ Most of this Domesday estate later became known as the manor of BEAUCHAMP RODING alias LONGBARNS. Part of it, however, may have split off to form the manor of Rookwood in Abbess Roding (q.v.).

Beauchamp Roding was apparently still considered as part of the honor of Richmond in the reign of Henry III, when the Earl of Oxford owed guard at Richmond castle in respect of Roding. 28 By 1358 , if not before, the tenancy in chief was held to rest in the then Earl of Oxford.29 In I 40 I it was stated that the manor had escheated to the Crown in 1389 as a result of the attainder of Robert de Vere, Earl of Oxford, and that the tenant in demesne had subsequently held directly of the Crown. ${ }^{30}$ In I 477 and I 48 I Beauchamp Roding was said to be held of the Duke of Gloucester. ${ }^{31}$ In $155^{8}$ it was said to be held in chief. ${ }^{32}$ In 1485 , however, the tenant in chief had again been stated to be the Earl of Oxford. ${ }^{33}$

It is probable that Beauchamp Roding was subinfeudated during the I 2 th century by Aubrey de Vere or one of his successors. About I I 90 the manor was referred to as Roding Willelmi filii Gaufridi.34 By I 23 I it was in the possession of John de Beauchamp of Eaton Socon (Beds.). ${ }^{35}$ This makes it probable that the William Fitz Geoffrey of about I I 90 was William Fitz Geoffrey de Mandeville, who married Olive, sister and heir of Roger de Beauchamp of Eaton Socon, for John de Beauchamp was the son of Olive de Beau-
23 Inf. from Herts. \& Essex Waterworks Co., and personal observation.

24 For some general comments on agriculture in the Rodings see Abbess Roding. 25 E.R.O., D/C'T 204. The estimate may have been slightly inaccurate but it is probably a good indication of the land use.

26 See Abbess Roding.

27 V.C.H. Essex, i, $473 a$.

28 Cal. Ing. Misc. i, p. 16g. Earl Aubrey is mentioned in the list, but this was filed among the inquisitions of Henry III's reign. After the death in 1214 of Aubrey de Vere, Earl of Oxford, there was no earl of that name and title in the $13^{\text {th }}$ cent. For Count Alan and the honor of Richmond see Early rorks. Charts. ed. C. T. Clay, vol. v.

29 Cal. Inq. p.m. x, p. 348.

30 Cal. Pat. 1 399-1402, 424; Complete Peerage, $x, 230-1$.

${ }_{31} \mathrm{C}_{14} / 56 ; \mathrm{C}_{14} / 80$.

32 Cal. Pat. I 557-8, 464

33 Cal. Ing. p.m. Hen. VII, i, p. I I.

34 J. L. Fisher, Colne Cartulary, 53. And see below Church.

3s Cal. Chart. $R$. 1226-57, 139. 
champ and her husband. In 1 235-6 Beauchamp Roding was held for I knight's fee. ${ }^{36}$ It descended along with Eaton Socon until I291, when Ralph de Beauchamp granted the reversion of it to Adam le Tailleur and Joan his wife. ${ }^{37}$ The manor was then being held for life by Richard de Brumpton, and was said to consist of a messuage, 60 acres of land, I 6 acres of meadow, 5 acres of wood, and 6 acres of pasture. In 1292 or I 293 William de Marny and Amice his wife conveyed 28 acres of land and $12 d$. rent in Beauchamp Roding to Adam de Biddik and Joan his wife. ${ }^{38}$ Adam de Biddik and Adam le Tailleur were probably identical. The manor was certainly in the hands of the Biddiks soon after 1291 . Henry de Biddik was lord in I 328 when he presented to the church. ${ }^{39} \mathrm{He}$ was dead before 1348 and Beauchamp Roding had been granted in dower to his widow Joan, ${ }^{40}$ who subsequently married Arnald Mounteneye. In $135^{\circ}$ Thomas son of Henry de Biddik granted the reversion of the manor, after Joan's future death, to Thomas de Forde of London.41 In the following year Joan and Arnald leased the manor to Simon Fraunceys of London at a rent of 40 marks a year. 42 Simon Fraunceys died in 1358,43 and in 1360 Joan and Arnald conveyed the manor to William atte Welde, draper of London, in return for an annuity of 40 marks during Joan's life.44 It is not clear what had happened to Thomas de Forde's interest in the manor: possibly it had been acquired by Joan and Arnald Mounteneye. The grant of I 360 certainly had the effect of vesting the lordship of the manor in the Welde family. Richard de Welde presented to the church in 1387 and $1389.45 \mathrm{He}$ was dead by May I39I, when the custody of Elizabeth his daughter and heir was granted to Roger Marshall.46 By October I40I Elizabeth, still under age, had married Lewis Mewes.47 Lewis or a successor of the same name presented to the rectory in 1430 and 1447 , and Thomas Mewes in 1463.48

Sir Geoffrey Gate (d. 1477) had married Agnes, probably the heir of 'Thomas Mewes.49 After Geoffrey's death Agnes married William Brown. She died in I48I leaving Beauchamp Roding to her son William Gate. ${ }^{50}$ The latter died in 1485 leaving Geoffrey Gate, an infant, his son and heir.si Geoffrey, later knighted, died in 1526 and was succeeded by his son (Sir) John Gate or Gates (I 504?-1553) who was executed for his support of Lady Jane Grey.52 In I 553, soon after Sir John's death, the Crown granted the site of the manor of Beauchamp Roding to Rowland Scurlocke. ${ }^{53}$ The Crown retained the manorial rights. It undertook to bear the cost of repairs to the houses of the manor in timber and tile, while Scurlocke was to bear those in thatching and daubing and was to have fireboot, ploughboot, harrowboot, and hedgeboot. In I 554 the manor was granted for life to Mary, widow of Sir John Gate. ${ }^{54}$ She was still alive in 1570 , when she presented to the rectory. Meanwhile in 1558 Longbarns (or presumably its reversion) was granted by the Crown to (Sir) Richard Weston of Skreens in Rorwell, then Solicitor General and later a justice of Common Pleas. $55 \mathrm{He}$ died in 1572 and was succeeded by his son (Sir) Jerome (d. 1603).56 The manor descended to Jerome's son Sir Richard ( I 577-I 635) who in I 633 was created Earl of Portland. 57 Sir Richard still held Longbarns in 1624 but he must have sold it soon after, for in 1638 it was sold by Sir John Ramsden and Anne his wife to Sir John North, K.B. 58 On North's death in 1639 the manor passed to his brother Dudley, Lord North (d. I666). 59

In I 668 this Lord North's successor sold Longbarns to Sir Michael Heneage (d. I7 I I). ${ }^{60}$ The manor descended to Michael's son Charles (d. 1738) and subsequently to Charles's daughters Elizabeth (d. I 765) and Cecil (d. I779) neither of whom married.6r By 1770 Longbarns had been acquired by the Harveys of Barringtons in Chigwell (q.v.). It was held in that year by William Harvey (d. 1779). ${ }^{62}$ It passed like Barringtons to Thomas W. Bramston of Skreens. In I 843 Bramston's estate in Beauchamp Roding comprised 629 acres which was made up mainly of the separate farms of Longbarns (some 230 acres), Frayes (see below), and Wood End.63 In I 848 it was stated that all the parish was freehold except about 8 acres and that Bramston owned most of the land. ${ }^{64}$ By I 866 Longbarns had probably been acquired by Robert Parris, who lived there from about that date until about 1880 and was described in 1878 as the lord of the manor and principal landowner.65 Since 1886 Longbarns has been occupied by a succession of farmers who have probably also been the owners. ${ }^{66}$ In 1933 Mr. John Latham was the farmer and one of the two principal landowners of the parish. ${ }^{67}$ In 1943 the farm was bought by the London Co-operative Society, together with Frayes (see below). The two farms together comprise 417 acres and mixed arable and dairy farming is carried on. 68

Longbarns farm-house is timber-framed and plastered and was probably built or rebuilt in the late 16 th century. The original part consists of a central block with cross-wings to the east and west. The upper floor of the east wing oversails at its south end. On the north front a two-story porch gives access to the central block. In line with this on the south side is a projecting staircase wing. The house was considerably altered in the I gth century. It has recently been converted into two dwellings for employees of the London Cooperative Society.

The manor of FRAYES may have derived its name from the family of John Fray, to whom a tenement in Beauchamp Roding was conveyed in 1408 by William Sudbury, draper of London, and Cecily his wife, and Peter Wymundham, also draper of London. ${ }^{69}$ In
36 Bk. of Fees, $4^{8}$.

37 Feet of $F$. Essex, ii, 70; W. Farrer,

Hons. and Knight's Fees, iii, 253 f.

38 Feet of $F$. Essex, ii, 74.

39 See below.

40 Cal. Close, $1346-9,498$.

4 Feet of $F$. Essex, iii, 98.

42 Ibid. 99. Simon was a mercer: cf.

ibid. Iog. 43 Cal. Inq. p.m. x, p. 348 4 Feet of F. Essex, iii, 129 .

45 Newcourt, Repert. ii, 502.

46 Cal. Fine R. I $383-91,356$

17 Cal. Close. I 399-1 402, 424.

48 Newcourt, Repert. ii, $502-3$.
49. $\mathrm{C}_{140 / 56 . \quad{ }^{50} \mathrm{C} 140 / 80 .}$

s I Cal. Ing. p.m. Hen. VII, i, p. I I.

52 D.N.B. Sir John Gates.

33 Cal. Pat. I 553-4, 325.

54 Ibid. 318.

55 Cal. Pat. I $557-8,464 ;$ D.N.B. Sir

Ricd. Weston (1577-1635).

$56 \mathrm{Cr} 42 / 160 / 35$; Visits. of Essex (Harl

Soc.), 319.

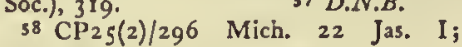

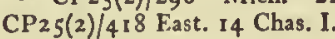

59 $\mathrm{CI}_{1} 42 / 494 / 37$

$60 \mathrm{CP}_{25}(2) / 653$ Mich. 20 Chas. II.

$\mathrm{CP}_{43} / 343$ rot. IO, 168.
${ }^{61} \mathrm{CP}_{25(2) / 1306}$ Hil. 3 Geo. III; Burke, Land. Gent. I 937 , P. I093.

62 Hist. Essex by Gent. iii, 339. Cf.

E.R.O., Q/RPI $685 \mathrm{f}$.

63 E.R.O., D/CT 294

64 White's Dir. Essex (1848), 435.

65 Kelly's Dir. Essex (1866-86). A

John Parris was tenant of Longbarns in

1813: E.R.O., Q/RPI 718. And see below Frayes.

66 Kelly's Dir. Essex (1886-1937).

67 Ibid. (r 933)

68 Inf. from London Co-op. Soc

69 Feet of $F$. Essex, iii, 250. 


\section{A HISTORY OF ESSEX}

1477 Frayes was held by the lord of the manor of Beauchamp Roding (see above). ${ }^{70}$ It followed the same descent as that manor until I6I I when Sir Richard Weston sold it to Thomas Younge. ${ }^{71}$ On Younge's death in 1638 Frayes passed by his will to his kinsman John Miller, son of Richard Miller of Great Waltham.72 It remained in the Miller family until 1704, when another John Miller sold it to George Pochin.73 In 1770 the owner was George Pochin of Ickleton (Cambs.) who was the son or grandson of the previous George.74 In 1780 'Captain Putchin' was owner.75 $\mathrm{He}$ remained in possession until $\mathrm{I} 8 \mathrm{IO}-\mathrm{I} \mathrm{I}$, when Frayes was acquired by Admiral Harvey, lord of the manor of Beauchamp Roding. ${ }^{.6}$ In I 843 Frayes Farm formed part of T. W. Bramston's Beauchamp Roding estate, and comprised I 40 acres.77 It was then and subsequently owned and worked as part of Longbarns Farm.

The manor house was probably rebuilt late in the I 7 th century to the south of the original site. Part of a moat surrounding a square enclosure is still in existence immediately to the north. Morant called Frayes house 'the chiefest in the parish', 78 but it evidently fell into disrepair at a later date. It is now being restored and modernized by the London Co-operative Society to form two dwellings for farm workers. On the south side of the drive leading to the main road are three pairs of new houses for farm workers. The drive itself has been planted as an avenue.

The manor of HORNERS (the modern Hornets Farm) lay partly in Bcauchamp Roding and partly in Willingale Doe. In I 597 it was conveyed by John Collin the elder to Robert Collin.79 In the I th century the manor appears to have been split between coheirs, for in 1649 half of it was conveyed to John Russe by Lazarus Annys and Mary his wife, John Rogers and Elizabeth his wife, and Honora Collin. 80 In 1652 John and William Russe obtained half the manor (probably the other half) from John Collin the elder, clerk, and John Collin the younger, clerk, and Katherine his wife.81 In 1722 Daniel Russe conveyed the manor to Edmund Butler. ${ }^{82}$

In I 780 Hornets Farm was owned and occupied by Richard Eve. ${ }^{83}$ He was succeeded by Henry Eve, who held the property from about I 80 I to 1820 . From 1818 to 1820 John Clift was joint owner with Henry Eve. ${ }^{84}$ Clift alone was owner from 1821 to 1832.85 By 1843 the ownership had passed to William Bush, who had for many years been tenant of the farm. It then comprised 64 acres. ${ }^{86}$ It was subsequently occupied by various farmers. From about 1909 to 1943 it was owned and occupied by the Mead family. The present (1954) owner is Mr. George Read of Butt Hatch, and a Mr. Mead is the tenant. ${ }^{87}$

The farm-house was probably built in the 18 th century. It is timber-framed and plastered and has a tile roof. A brick wing was added at the back of the house in $1922 .{ }^{88} \mathrm{~A}$ window with several trefoil-headed lights was inserted in an outhouse to commemorate the passing of the Local Government Act, 1929, by which agricultural land was de-rated. 89 The window is said to have come from a chapel in Notting Hill, London, 90 and is probably of the I gth century. Isaac Mead, a former owner, is buried beside his wife in a small patch of consecrated ground near the drive gate, where an inscribed stone marks their grave.

The advowson of Beauchamp Roding descended with the manor of that name until late in CHURCH the I6th century.93 Mary, widow of Sir John Gate, presented in 1570, presumably by virtue of her life tenure of the manor (see above). Before this, in 1560 , the advowson (presumably in reversion only) had been granted by the Crown to John Harrington and George Burden, and in the same year Harrington and Burden had conveyed it to Sir Richard Weston, who had recently acquired the lordship of the manor (also presumably in reversion after Mary Gate's death). 92 John Hoskyn, who presented pro hac vice in I 578, probably had the advowson from Sir Richard or his son Sir Jerome Weston.93 The Westons retained the advowson until I613, when the younger Sir Richard sold it to Sir Gamaliel Capel of Rookwood, Abbess Roding (q.v.).94 In 1624 Sir Gamaliel Capel the son sold it to John Mead and his son William.95 William Mead sold it in 1639 to John Siday. 96 This was presumably the John Siday who became rector in 1642.97 After his death the advowson passed to his son, also named John, who became the next rector (1689).98 The younger John (d. 1704) devised the advowson to his son John Siday (III).99 Mary Siday, widow, presented in 1704,1710 , and 1720.1 The rector whom she presented in 1720 was another John Siday, probably John Siday (III). In I739 John and Mary Siday conveyed the advowson to Thomas Bramston, who was acting for Sir John Comyns, of Writtle, Chief Baron of the Exchequer. ${ }^{2}$ At the same time Comyns bought Gubbiss Farm in this parish. According to statements made after his death he intended that the advowson and the farm should be used 'as an honorary trust for the benefit of poor clergymen and small livings in Essex'. ${ }^{3}$ 'There was, however, no such provision in his will (dated Nov. I 740). He died soon after and the advowson passed to his wife Ann, who presented in 1752.4 She was succeeded as patron by John Comyns, nephew of Sir John. In 1768 John Richard, son of John Comyns, conveyed the advowson and other property in trust to William Birch in order to provide an annuity for John Comyns's widow Mary.s In 1770 John Richard Comyns sold the advowson to the Revd. Richard Birch of Roxwell and John Birch of Boswell Court, London. ${ }^{6}$

In March I77 I the above Richard and John Birch
$70 \mathrm{C}_{140 / 56 .}$

${ }_{71} \mathrm{CP}_{25(2) / 294}$ Mich. 9 Jas. I.

$72 \mathrm{Cr}_{42 / 487 / 127 .}$

${ }_{73} \mathrm{CP}_{25}(2) / 922 \mathrm{Hil} 3$ Anne. Morant, Essex, i, 136 , has John, brother of George Pochin as purchaser from Miller.

74 Hist. Essex by Gent. iii, 340; Morant,

Essex, $\mathrm{i}, 136$

75 E.R.O., Q/RPI 685.

76 Ibid. $686-716$.

77 E.R.O., D/CT 294.

78 Morant, Essex, i, 136.

${ }_{79} \mathrm{CP}_{25}(2) / 138 / 1750$.

$80 \mathrm{CP}_{25}(2) / 550$ B East. 1649.

$81 \mathrm{CP}_{25}(2) / 550 \mathrm{~B}$ East. 1652 . For these two John Collins see J. and J. Venn, Alumni Cantab. pt. i, vol. i, p. 373.

${ }_{82} \mathrm{CP}_{25(2) / 1014}$ Mich. $9 \mathrm{Geo} . \mathrm{I}$

${ }_{3}$ E.R.O., Q/RPl 3 I5.

84 Ibid. $316-55$.

85 Ibid. 356-67.

86 E.R.O., D/CT 294

87 Inf. from Mrs. Mead of Hornets; Kelly's Dir. Essex (Ig12 f.).

88 Inf. from Mrs. Mead.

80 Inscription in situ. 90 Local inf.

91 J. L. Fisher, Colne Cartulary, 9;

E.A.T. N.s. xviii, 19; Newcourt, Repert. ii, 502 .

92 E.R.O., D/DHf Tr6: Abstract of
Title to advowson.

93 Newcourt, Repert. ii, 503.

94 E.R.O., D/DHf T I 6.

93 Ibid.

96 Ibid.

97 Newcourt, Repert. ii, 503. The pre sentation of 1642 was made by William Siday.

98 E.R.O., D/DHf T16. The presentation of 1689 was made by William Putcas: Newcourt, Repert. ii, 503.

99 E.R.O., D/DHf T 16.

1 Morant, Essex, i, 137.

2 E.R.O., D/DHf T16. 3 Ibid.

4 Ibid.; Morant, Essex, i, 137.

s E.R.O., D/DHf T $16 .{ }_{6}$ Ibid. 
sold the next presentation to Nicholas Toke of Linton (Kent), and in May of the same year 'Toke conveyed this in trust for his nephew the Revd. Nicholas Layton of Nottingham. If Layton should be alive at the next presentation he was to have the rectory or was to nominate a rector. If not, the presentation was to revert to Toke.7 In 1776 Layton in fact became rector. ${ }^{8} \mathrm{He}$ seems to have been non-resident. In 1795 Richard Birch sold the advowson to Samuel R. Gaussens, who presented in the same year.9 J. L. Barrett, D.D., who was rector in I 829 , was also patron. ${ }^{10}$ For the remainder of the 19th century the advowson was apparently acquired by or for the benefit of each successive rector. ${ }^{11} \mathrm{~J}$. Howard, who had been curate from 1882 to 1887 , became rector in the latter year and held the benefice until 1927. It was then united with that of Abbess Roding (q.v.), the advowson of the united benefice being vested in the Bishop of Chelmsford and the Revd. Capel-Cure. ${ }^{12}$ For purposes of internal organization, however, Abbess and Beauchamp Roding remain separate parishes.

Though the rectory of Beauchamp Roding was never appropriated, Aubrey de Vere, about I Ioo, gave twothirds of the tithes of his demesne lands in the parish to Colne priory. ${ }^{13}$ It is likely that this grant also included a small portion of land in Beauchamp Roding, for in 1539 , after the dissolution of the priory, the king granted "the manor or lordship of Langbornes in Beauchamp Roding, belonging to the late priory of Colne' to the Duke of Suffolk. ${ }^{14}$ In the same year Suffolk conveyed the property to John Wiseman and Agnes his wife. Is Wiseman conveyed it in 1581 to Sir Jerome Weston. ${ }^{16}$ It subsequently descended along with the manor of Beauchamp Roding. At the tithe commutation in I 843 T. W. Bramston, lord of the manor, owned twothirds of the tithes of some 500 acres of land, which was the greater part of his property in the parish. Most of the manor of Beauchamp Roding and more than half of Frayes were included in these 500 acres. John Walden owned two-thirds of the tithes of a 3-acre field called Longfield and the Trustees of the late Revd. Robert Gibson of Fyfield owned two-thirds of the tithes of a 5-acre field called English Bottom, which was part of Gubbiss Farm. It was then agreed that the tithes owned by Bramston and Walden should be merged in their freehold. A tithe-rent charge was, however, fixed on English Bottom, payable to Gibson. ${ }^{17}$ In 1794 a map of the parish was drawn for Samuel Gaussens, who was described as the impropriator. ${ }^{18}$ This probably meant that he was leasing the tithes belonging to the owner of Beauchamp Roding manor.

In about 1254 the rectory of Beauchamp Roding was valued at $\oint_{5}$ and in 1291 and 1428 at $\oint_{5} 6 s .8 d .19$ In 1535 it was valued at 616 I $35.4 d .20$ The rector's tithe was commuted in 1843 for $£ 284 .^{21}$ Sir Peter Siggiswyk, by his will proved in I 503 , left his house at Beauchamp Roding to the church of Beauchamp Roding for 40 years for the keeping of his obit and the payment of $8 d$. a year to the rector. ${ }^{22}$

The glebe terriers of 16 ro and 16 I 9 state that there

7 Ibid.

8 E.R.O., D/P 146/1/1, 146/8; D/AEM 2/3.

- $\mathrm{CP}_{25}(2) / 1311$ Mich, $36 \mathrm{Geo}$. III; P.R.O., Inst. Bks. ser. C, vol. i, pt. i, p. $204 \%$.

10 Cler. Dir. 1829 .

II Ibid. 1836 ; Clergy List, 1845 f.

12 Clergy List, $1880 \mathrm{f}$.

13 J. L. Fisher, Colne Cartulary, 5 ; was a parsonage house and some 40 acres of glebe. ${ }^{23}$ There were $4 \mathrm{I}$ acres of glebe in 1843.24 In 1618 the parsonage was found to be out of repair.2s Parts of the back wing of the present Old Rectory may date from a rebuilding soon after this report. The house is now T-shaped on plan. It is timber-framed and roughcast with a tiled roof. The long back wing appears to be of various dates but the interior was remodelled and the front wing added about 1800 . The entrance front is Georgian in style. At the south end of the front a ground-floor room was added in the I $9^{\text {th }}$ century. This is now (1954) used for parish purposes. South of the house is a large rectangular fishpond. 'The house was occupied by the rectors of Beauchamp Roding until the union with Abbess Roding in 1927. It was then sold, and is now a private residence. ${ }^{26}$

The ancient parish church of $S T$. BOTOLPH stands on rising ground, the churchyard being completely surrounded by fields. The dedication suggests that there was a church at Beauchamp Roding before the Norman Conquest. The building consists of nave, chancel, west tower, and south porch. The walls are of flint rubble mixed with freestone. The nave is built on an I I th- or I 2 th-century plan but the present structure probably dates from the I 4 th century. In the I 5 th century the tower was added and the chancel rebuilt. The porch dates from 1870 .

A piscina in the chancel may be of the 13 th century, indicating that there once existed an earlier chancel of that date.

The nave has two windows on the south side and one on the north which are of the early I 4 th century. They have pointed heads with quatrefoils in the tracery and externally they have original label-moulds and head-stops. The north and south doorways, the former now blocked, are also of the 54 th century.

The church was evidently enlarged and much altered in the $55^{\text {th }}$ century. The chancel, which was probably rebuilt then, has two fine three-light windows with four-centred heads and vertical tracery. Farther west are two smaller windows of the same period and a south doorway, now restored, with a four-centred head. The east window, rebuilt in the I 9 th century, is in similar style, and a three-light I 5 th-century window has been inserted in the north wall of the nave. The chancel arch is grooved on the underside, probably to take the tympanum of a rood loft. On the south side of the nave there is a stone staircase which formerly led to the rood loft. This forms a projection externally and is covered with a pent roof. Both upper and lower doorways are in position and there is a moulded stone bracket near the former. A piscina in the nave is also probably of the I 5 th century. Both the nave and chancel have I 5 th-century roofs. The nave, which is of two bays, has moulded king-posts with two-way struts. The tie-beam in the chancel has curved and moulded braces resting on carved stone corbels. One of these is in the form of a grotesque head, the other of an angel bearing a shield. 'The I 5 th-century west tower' is of three stages with a castellated parapet above. Over
E.R.O., D/DPr 150.

14 L. EO P. Her. VIII, xiv, p. 258. This cannot have been the manor of Beauchamp Roding alias Longbarns (see above).

is Ibid. 262

$16 \mathrm{CP}_{4}$ o/1391.

17 E.R.O., D/CT 294

18 Cat. of Maps in E.R.O., $26 b$.

19 W. E. Lunt, Val. of Norwich, 337 ;

Tax. Eccl. (Rec. Com.), 2 I $b$; Feud. Aids, ii, 205

20 Valor Ecel. (Rec.-Com.), i, 437.

21 E.R.O., D/CT 294.

22 E.A.T. N.s. xxi, 256.

23 Newcourt, Repert. ii, 502. The glebe

figures are not identical in the two terriers.

24 E.R.O., D/CT 294.

23 E.R. $x y, 49$.

26 Inf. from the Revd. R. T. K. Griffin. 


\section{A HISTORY OF ESSEX}

the west doorway is a three-light window with a fourcentred head. There are single-light windows to the second stage of the tower and larger windows with four-centred heads to the belfry. Some of the floor-tiles inside the communion rails are thought to be of medieval origin.

Some early i 7 th-century carved oak panelling which was in the chancel before $192 \mathrm{I}$ is now kept in a chest in the church. ${ }^{27}$

On both sides of the nave at the west end are curious oak benches in three stages, probably dating from the 18 th century. Oak steps to the upper stages have ring handles and can be pulled out like drawers when required.

In $187^{\circ}$ the church was thoroughly restored and in the same year the south porch was rebuilt in memory of Ann Powell. ${ }^{28}$ The exterior was restored in $1893^{29}$ and much of the stonework was covered with cement, some of which has since been removed.

In I95 I the tower and other parts of the church were restored after war damage at a cost of $f_{1}, 300 .{ }^{30}$

Memorial stained glass was inserted in various windows in $1850,1866,1870$, and 1872 . There are four bells, said to be by Miles Graye, 1664.38 In 1446-7 William Wiltshire, horner, left a chalice of the value of 30 s. to the church. ${ }^{32}$ At an Archdeacon's Visitation of about 1816 it was ordered that a pewter paten and flagon should be soid and a silver or plated paten provided.33 The plate now consists of an undated silver cup, a silver paten of 1778 , and a plated flagon given by the rector in $1835 .{ }^{34}$ There is a tablet in the chancel to William Bond (1887) rector.

The surviving parish book for Beauchamp Roding covers the period 1723

$P A R I S H$ GOVERNMENT to $18 \mathrm{I} 7.3 \mathrm{~s}$ It records $A N D$ POOR RELIEF only the annual Easter vestry meetings for the passing of accounts and the election of new officers. John Siday, rector until 1752 , presided every year at these meetings. Often the only other attendants were the churchwarden and one parishioner. Siday's successor, William Wicksted, attended frequentiy but less regularly. After I780 the name of the churchwarden always headed the list of signatures. There were never more than eight parishioners present during this period, four being the average. In 1745 the church clerk received 25 s. in wages-a sum charged to the overseer's account.

In 1699 the rateable value of the parish was $£ 693,36$ and it was not much higher in $18 \mathrm{I} 7$, when a 25 . rate produced $\oint^{8} \mathrm{I}$. Rates of $7 \frac{1}{2} d$. and $8 d$. were levied in I 790 and I79I towards the building of the new Shire Hall at Chelmsford. The parish officers seem to have conducted their business honestly. When expenditure was highest about 1800 balances of as much as $£ 75$ were successfully carried from year to year. In 1723 the rector and three parishioners resolved that every parishioner should maintain a poor person for a period proportionate to his rateable assessment, receiving I $8 d$. a week for so doing.

27 Cf. Hist. Mon. Com. Essex, ii, 13. ${ }_{28}$ Kelly's Dir. Essex (1895); inscription in porch.

29 Kelly's Dir. Essex (1895).

30 Inf. from Rev. R. T. K. Griffin.

31 Ch. Bells Essex, 373.

32 E.A.T. N.s. xiv, 35 .

33 Ch. Plate Essex, 146

34 Ibid. The cup is probably c. 1718.

33 E.R.O., D/P I46/8. Unless other-
All officers except the overseers tended to remain in office for long periods. Thus Richard Nicholas was surveyor of highways from I 74I to I 757 and churchwarden from 1753 to 1762 , and John Lunnon was constable from 1786 to 18 I5. No woman was ever appointed to a parish office between 1723 and 1817 The overseer served for only one year at a time, and service was probably by rotation. The same names recur at intervals of six or seven years, but the absence of women seems to indicate that the service was purely personal and was not associated with the occupation of particular properties. After 1792 a longer list of nominees was entered each year and the order thus established was strictly observed in subsequent years. Each person thus knew several years in advance when he was due to serve.

In I6I 3 \&2 I Is. Iod. was raised for poor relief, assessed on nineteen contributors who paid sums ranging from $2 d$. to Ios. 37 At the beginning of the I 8 th century the overseer's annual expenditure was about $£_{2} 5-£_{3} 0$, and it had not risen much by the middle of the century, when only two or three families were receiving regular relief. Expenditure thereafter rose to fig3 in 1795 and then almost doubled in the following year. It reached a peak of $£ 5$ I 5 , the equivalent of a I2s. $6 d$. rate, in $1800-1$. The average annual expenditure between 1800 and I 8 I 7 was over $£ 350.38$ It dropped slightly to $\oint_{260}$ for the period I $829-35 .^{39}$

A parish almshouse existed in 1745 and 1749 , when the overseer's accounts included sums spent on its repair. In 1776 the parish was renting a house for use as a poorhouse but its site is not known. 40 In 1830 the vestry borrowed $\oint_{35}$ from Sir Eliab Harvey, the lord of the manor (see Beauchamp Roding manor, above) for the erection of a workhouse. ${ }^{4}$ 'The final instalment of the debt was repaid in 1837 , but by that time Beauchamp Roding had become part of the Ongar Poor Law Union, formed in 1836 , and the workhouse was converted into a school.

There were stocks in the parish in 1767.42

In 1818 there was a dame school in the parish, attended by 28 children, 43 but by 1822

SCHOOL it secms to have closed. In that year the rector decided to establish a Church school.

Fearing that the parish was too poor to support the cost of building and maintaining a schoolroom he sought subscriptions for the conversion of a room in the church tower into a classroom. The National Society gave $£ 20$ and subscribers all or most of the fur ther $£ 24$ required. 44 In 1828 there were 29 pupils at the school and there were 38 in 1833 , when the only other local school was a private one with 7 pupils. By 1833 the Church school had been removed to a cottage rented by the rector, who also allowed the mistress fio a year in addition to the school pence. 45 By I 839 the old parish workhouse, on the road to Bird's Green, was being used as the school. The new rector was paying expenses with the help of his predecessor, who continued to give a large subscription, and 4 I children attended. ${ }^{46}$ Attendance rose to 43 in $1846-7$ and 45 wise stated all the following account is taken from this source.

36 E.R.O., D/P 146/1/1.

37 E.R.O., Q/SBa 3 .

38 E.R.O., Q/CR $8 / 9$.

39 E.R.O., D/DOp B39/75.

40 Rep. Sel. Cttee. on Overseers Retns.

1777 , H.C. Ser. i, vol. ix, p. 350 . In 1843

Almshouse Field adjoined Butt Hatch

Farm: E.R.O., D/CT 294.

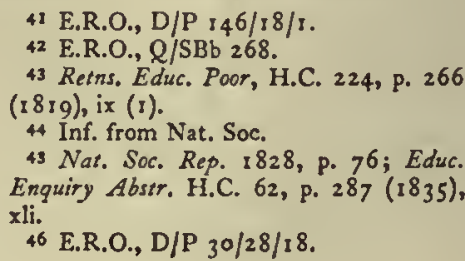




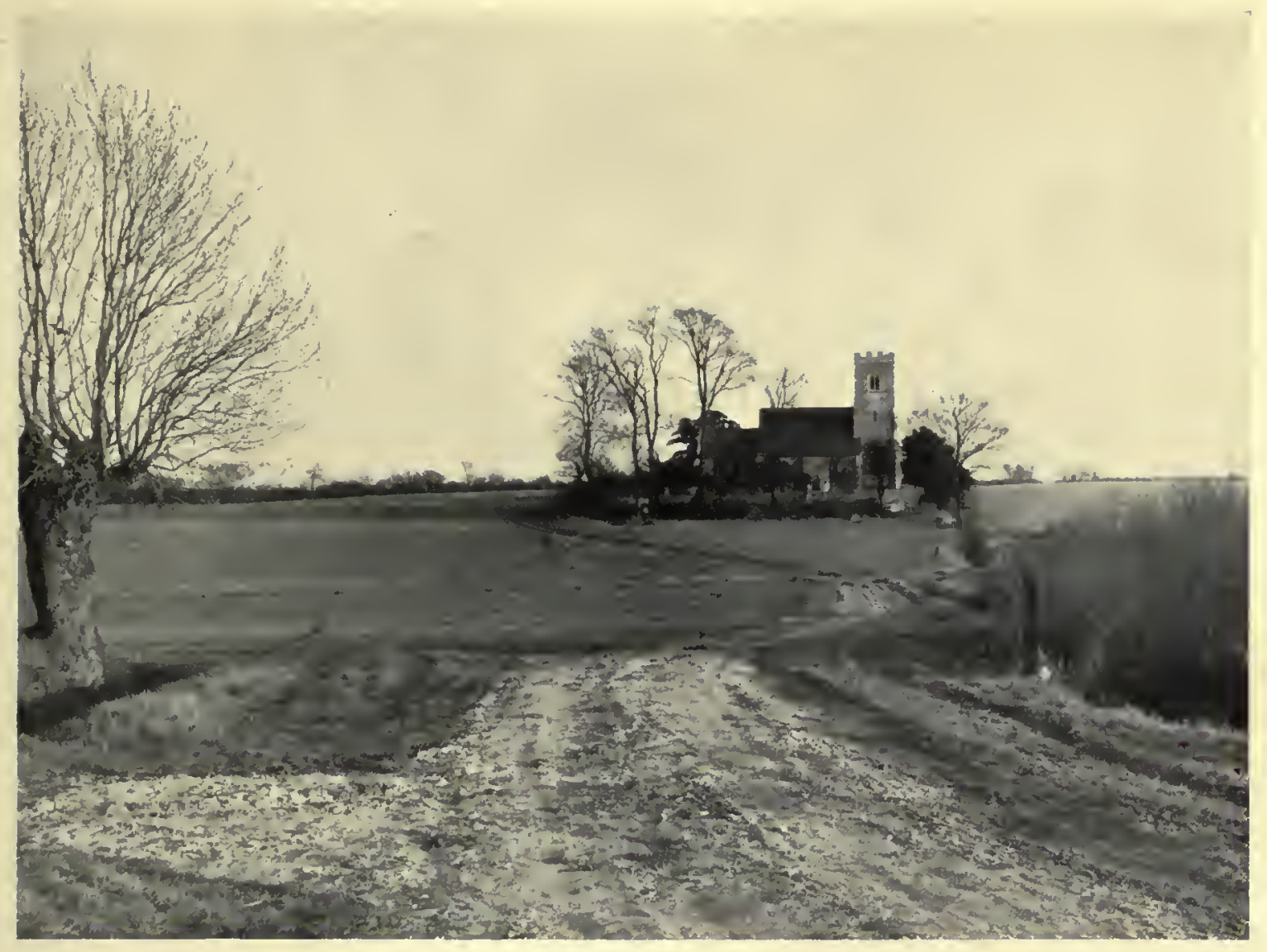

Beauchamp Roding Church



Magdalen Laver Church 

in 1871.47 In 1870 the building was enlarged and in 1871 an inspector reported that the accommodation was sufficient. 48

In I 880 a school board of five members was compulsorily formed.49 At first it hired the Church school for a small annual sum which was applied to the relief of the rates, but in $1895 \mathrm{jt}$ accepted complete transfer of the building. ${ }^{50}$ In I 880 average attendance was only 23 . It rose to 37 in 1893 and to 60 in 1899 , and this in spite of the falling population.51 In 1894 the school was enlarged to accommodate 95 children. 52 The annual government grant rose from $\{13$ in 1872 to 647 in 1893 and 678 in 1902.53

Under the Education Act of 1902 the school passed under the administration of the Essex Education Committee, Ongar District. In 1904 there were 2 teachers and 68 pupils. 54 Average attendance fell to 33 in 19 I 4 and to 24 in 1923, when the school was closed and the children transferred to the Abbess Roding school.ss The former school has been converted into two dwellings, one a bungalow. The south end of the building consists of a two-story red-brick block with a gable-end facing the road. It was formerly the schoolmaster' house and was probably built for the purpose in the middle of the I gth century. The single-story schoolrooms, which originally extended farther north, have now been plastered.

CHARITIES. None known.

\section{SHELLEY}

Shelley is a small parish immediately to the north of Chipping Ongar. I Its area is 608 acres. ${ }^{2}$ There were 32 inhabited houses in 1801 and 34 in 1811 and 1821.3 In 1801 the population was 169.4 By 1851 it had grown to 215 ; then it declined to 158 in 1901.5 Since I 918 there has been a steady increase, mainly due to the building of council houses. The population was 386 in 1931 and about 650 in $1953 .^{\circ}$

The land is about $200 \mathrm{ft}$. above sea-level in the south and slightly less elsewhere. Cripsey Brook, a tributary of the River Roding, flows south through the west of the parish. To the east of the brook lies Shelley Common. The south-eastern corner of the parish is bounded on the south by the road from Chelmsford to Epping and on the east by the road from Chipping Ongar to Dunmow. The junction of the two roads is called The Four Wants and at the north-west corner of the crossroads stands Shelley House. In about 1770 this was referred to as the only 'good house' in the parish. ${ }^{7}$ In about 1835 it was described as 'a handsome dwelling upon a moderate scale'. ${ }^{8}$ It was probably built towards the end of the 17 th century and part of the back of the house is faced with brickwork of this date or a little later. The front rooms were added about 1800 and there is a good Georgian façade facing the road. A west wing was added later in the $19^{\text {th }}$ century 9 and a small extension was built at the back about 1920.10

About 300 yds. north of The Four Wants the Dunmow road js joined by a road running north-west to Moreton. Between this Moreton road and the Epping road there is a large housing estate laid out since I 945 by the Ongar Rural District Council. When complete it will have seven new roads and will consist of about 450 houses. "I The plan provides sites for shops, a primary school, and a community hall. By November I 953178 houses had been completed and 147 were under construction. ${ }^{12}$

17 Not. Soc. Enquiry into Ch. Schs. 1846-7, pp. 16-17; Retns. Elem. Educ. H.C. 201, Pp. $110-11(1871)$, 1v.

${ }^{48}$ Kelly's Dir. Essex (1 899); Chelmsford Chron. 2 Aug. 1872

49 Lond. Gaz. 7 May 1880.

so Min. of Educ. File $13 / 16$.

31 Rep. of Educ. Cttee. of Council, 1880

[C. 2948-1], p. 575, H.C. (188 I), xxxii; Retn. of Schs. 1893 [C. 7529], p. 713 , H.C. (1894), $1 \mathrm{xv}$; ibid. 1899 [Cd. 315], p. 68, H.C. $(1900), \operatorname{lxv}(2)$.

32 Min. of Educ. File 13/16; Retn. of Schs. 1899, p. 68.

s3 Rep. of Educ. Cttee. of Council, 1872 [C. 812$],$ p. 409 , H.C. $(1873)$, xxiv;
At the south-east end of the Moreton road there are council houses, built both before and after the Second World War, including a pair made of Swedish timber. On the north-east side of the road there are 12 pairs of older council houses and near Shelley Bridge some prefabricated bungalows. From Shelley Bridge over the Cripsey Brook the road runs directly northward. On the east side of the road to the north of Shelley Bridge is Bridge House which appears to have been built about I 800 . There are gravel pits to the north-east of Bridge House. Farther north there are scattered 18thcentury cottages on both sides of the road. On the east side just before the road leaves the parish there is a pair of estate cottages dating from about I 830 , called Gothic Cottages. They follow a type of studiously 'picturesque' dwelling which was evidently popular with local landowners during the first half of the I 9 th century. Nearly opposite Gothic Cottages stands Ashlings, which was built on the site of a property called Motes. ${ }^{13}$ The present house originated in a pair of timber-framed estate cottages belonging to Blake Hall in Bobbingworth (q.v.), similar in general arrangement to Gothic Cottages but perhaps rather earlier in date. Later a third cottage was added and later still a wing at the back.

The Dunmow road is built up from the southern boundary of the parish, almost as far north as Shelley Lodge, which is about $\frac{1}{2}$ mile north of The Four Wants. This building development dates mostly from the present century. The Ongar and District War Memorial Hospital ${ }^{14}$ is on the west side of the road just beyond the turning to Moreton. Shelley Lodge is a single-story thatched cottage, built early in the Igth century by Noble of Ongar. ${ }^{15}$ From Shelley Lodge a drive runs straight to Shelley Hall, ${ }^{16}$ about $\frac{1}{4}$ mile to the north. Immediately to the east of the Hall is the church. A foot-path, formerly a lane, leads from the church, past
Retn. of Schs. 1893, p. 713 ; Schs. under Bd. of Educ. Igoz [Cd. I49o], p. 68, H.C. (1 go3), li.

si Essex Educ. Cutee Handbk. I904, p. 183 .

ss Min. of Educ. File $13 / 16$

O.S. $2 \frac{1}{2}$ in. Map, sheet $52 / 50$.

2 Inf. from Essex County Council.

3 Census, $1801,1811,1821$.

4 V.C.H. Essex, ii, 350.

3 Ibid.

6 Census, IgII f.; inf. from Essex

County Council. At the 1951 census the population was 519 .

3 Hist. Essex by Gent. iii, 365. The comment is particularly interesting in view of the fact that very soon afterwards the manor house and its lands were mortgaged to Samuel Evans who was very probably the oceupier and afterwards, if not already, the owner of Shelley House.

8 T. Wright, Hist. Essex, ii, 356 .

- A 'ladies' academy' was held in the house in c. I $863:$ see below, School.

to Inf. from Mr. Avery, present occupier.

11 Inf. from the District Surveyor, Ongar R.D.C. 12 Ibid.

13 Chapman and André, Map of Essex, 5777 , plate xii.

14 See Chipping Ongar, p. 159.

ss Inf. from Mrs. Storkey, occupier.

16 See below, Manor. 


\section{A HISTORY OF ESSEX}

the site of the rectory 17 about $\frac{1}{4}$ mile to the west, to the Moreton road north of Bridge House. Another lane leads eastward from the church to join the Dunmow road about $\frac{1}{2}$ mile north of Shelley Lodge. There are some 18 th-century cottages on the west side of the Dunmow road near the turning to the church. Almost opposite the turning a drive leads eastwards to Boarded Barns, formerly New Barns. ${ }^{18}$ The house is timberframed and plastered and an oak lintel beside an original brick fireplace is dated 1613 . There is an addition on the south side and the whole house has been altered and restored. The property is now an experimental farm belonging to Messrs. May and Baker. The farm buildings have been converted and two new red-brick laboratories for veterinary and horticultural research were built in I95I and 1952. A building on the road near the drive entrance was formerly called Boarded Barns. ${ }^{19}$ Nearly $\frac{1}{2}$ mile farther north on the west side of the road a long drive leads to Bundish Hall on the northern boundary of the parish. ${ }^{20}$

Shelley Bridge, described as a foot-and horse-bridge in 1665,21 was often in a bad state of repair. In the 16 th and 17 th centuries it was claimed that the bridge should be repaired by the parson of Shelley.22 In 1835 the Report of the Charity Commission quoted from the court rolls of Shelley, which purported to show that responsibility for repairing Shelley Bridge rested with the rector. ${ }^{23}$ In reply to a letter of inquiry the then rector, Henry Soames, told the commissioners that although he had kept the bridge in good repair since his institution in $18 \mathrm{I} 2$, he did not admit his liability to do so. ${ }^{24}$ Some time afterwards the county accepted responsibility for repairing the bridge which first appears in a list of county bridges in 1872 . In 1873 the county surveyor described it as a new iron bridge, in good repair; the roadway was not to be mended by the county.2S

The roads of Shelley were frequently presented as in need of repair but individual roads are not often distinguished. In I $_{1} 3$ the inhabitants of both Shelley and Bobbingworth were presented for not repairing the highway leading from 'Moreton Street to Shelley Bridge'.26 'This was, doubtless, the highway which led from Ongar via Shelley Bridge to Moreton and which evidently then as now lay partly in Bobbingworth, partly in Shelley, and also formed part of the boundary between the two parishes. In 1618 it was said that these parishes shared the responsibility for this road. 27 In 1632 the inhabitants of Shelley were presented for neglect of their highways to Bishop's Stortford and Dunmow; they made the cryptic answer that 'they can take it of better cheape some other waye'. ${ }^{28}$

iz See below, Church.

18 Chapman and Andre, Map of Essex,

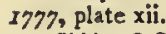
i.

Hall The farm-ton: Manor of Bundis is therefore treated under that parish.

Some of the outbuildings are in Shelley.

21 E.R.O., Q/SR $403 / 10$.

22 Ibid. Q/SR $16 / 3,42 / 20,179 / 62$, $35 \mathrm{I} / 34,403 / 10 ; E . A . T$. N.s. vii, 162 .

23 Rep. Com. Char. (Essex), H.C. 216, pp. $241^{-2}(1835)$, xxi (1).

24 Ibid.

25 E.R.O., Q/ABz 3.

26 Ibid. Q/SR 204/113

27 Ibid. $\mathrm{Q} / \mathrm{SBa} I / 32$.

28 Ibid. Q/SR $279 / 4$.

29 Inf. from Head Postmaster of Brent-
There is no post-office in Shelley. The parish is served by the Shelley Road post-office which is within the boundary of Chipping Ongar and which was opened in May $1934 .{ }^{29}$

Water is supplied by the Herts. and Essex Waterworks Co.30 Gas was supplied from Ongar in 1926 by the Bishop's Stortford Gas Co. ${ }^{31}$ Electricity mains were laid on in $1935 .{ }^{32}$ A branch of the county library was opened in July 1940 ; it is now closed. ${ }^{33}$ There is a cycle speedway in the parish. 34

In about 1770 a writer noted that Shelley is small and has but few houses in it, the inhabitants of which are chiefiy supported by husbandry'.3s Shelley remained a rural parish, engaged almost entirely in agriculture, until after the Second World War.

The lords of the manor did not live in the parish in the middle of the 16 th century but after John Green purchased the manor in 1582 the Green family lived on the estate until the early 18 th century. ${ }^{36}$ Mary Green went to live in the parish of St. George, Hanover Square, after her husband Andrew Trebeck became rector there in 1725.37 She and her son James were still resident in that parish three years after Andrew's death in 1759.38 In $1762-4$ Shelley manor house was let to two tenants, one of whom farmed the estate. ${ }^{39}$ The manor farm continued to be let until 1 8 14-15, after which Harvey Kimpton, then lord of the manor, occupied it until his death in $1817.4^{\circ}$ The Tomlinson family, who purchased the estate in $1819-$ 20 , occupied Shelley Hall from I $822-3$ until I 878-82, since when it has always been let to a tenant. 41

In 1839 the parish consisted of 601 acres. 42 Of this James Tomlinson owned 197 acres, all of which were farmed by Richard Tomlinson. ${ }^{43}$ There were in the parish only two other substantial owners, neither of whom farmed his land himself; the Revd. John Bramston Stane (of Forest Hall in High Ongar, q.v.) owned New Barns Farm ( $9^{8}$ acres) and Boarded Barns Farm (44 acres), and Thomas White owned Shelley Bridge Farm (95 acres). 4 There were 59 acres which belonged to Bundish Hall.45 No other farm in the parish was over 40 acres. 46

In Shelley as in neighbouring parishes mixed farming is carried on. In 1837 there were estimated to be 330 acres of arable, I 88 acres of meadow and pasture, and 2 acres of woodland. 47 There was also an enclosed common of 13 acres. ${ }^{48}$

In $1066 S H E L L E Y$ was held by Levedai as a manor and as 80 acres and was worth 605.49 In MANOR I086 it was held by Rainald of Geoffrey de Mandeville and was worth $64 .^{50}$ The manor was subsequently held of the Earls of Essex, wood.

30 Inf. from Herts. and Essex Waterworks Co.: date when water was first supplied not known.

3I Inf. from East. Gas Bd.

32 Inf. from East. Elec. Bd.

33 Inf. from County Librarian.

34 Inf. from Mr. D. W. Hutchings.

35 Hist. Essex by Gent. iii, 365 .

36 E.R.O., Q/RTh I, 5 ; ibid. D/DFa

Tiz; see below, Church, for memorials to Green family.

37 E.R.O., D/DFa Tr7; D.N.B. xiv, 403-4; G. Hennessy, Novum Repert. Eccl. Par. Lond. I64. The Revd. Andrew Trebeck was, however, buried in Shelley: Reg. Burials in possession of rector.

${ }_{38}$ E.R.O., D/DFa TI7. James Trebeck was Rector of Shelley from 1752 until c. I769. His brother-in-law Thomas
Newton, later Bishop of Bristol, used the parsonage as a retreat in the $1750^{\circ}$ 's (see below, Church) but whether James ever lived in the parish does not appear. Al that is certain is that in the middle of his incumbency his place of residence was St. George's, Hanover Square.

39 See below, Manor.

40 E.R.O., Q/RPl 685 f.

41 Ibid. Q/RP! 725 f.; ibid. D/CT 314 Kelly's Dir. Essex (I 859 f.); White's Dir.

Essex (1848, I 863).

42 E.R.O., D/CT 3 I 4.

43 Ibid. 44 Ibid.

4s Ibid. See Moreton : Manor of Bundish Hall.

46 E.R.O., D/CT 314.

47 Ibid.

49 V.C.H. Essex, i, 504 b.

48 Ibid.

so Ibid. 
the heirs of Geoffrey de Mandeville, by the service of one fee, until the death of Humphrey, Earl of Essez, in 1373.51 It was then assigned in dower to Joan, widow of Humphrey.52 She died in I419.53 Afterwards the manor was held in chief of Henry $V$ whose mother Mary (d. 1394) was a daughter and coheir of Earl Humphrey. ${ }^{4}$ Thereafter the manor continued to be held in chief of the Crown.

The tenant Rainald devised the manor to his daughter Aubrey who in II 34 was the widow of Eustace de Sellea and whose son and heir was Eustace. 55 In $\mathrm{r} \mathrm{r}_{2}$ William de Selflege, son of Emma, died in possession of Shelley and some other manors. ${ }^{56} \mathrm{His}$ inheritance was divided between his two daughters. ${ }^{57}$ Shelley was allotted to his elder daughter Amy, wife of Oger Fitz Oger. 58 Her heir was her son Peter Fitz Oger from whom the manor descended to his daughter Emma and afterwards to his granddaughter Joan de Saunford, daughter of Emma and wife of Waleran de Monceaux. 59 On Joan's death without issue in 1278 there were two claimants to Shelley. 60 One was Aveline, wife of Roger de Lees and daughter of Geoffrey de Cruce, son of Mirabel, sister of Peter Fitz Oger.6r The other was Sir William de Clovile, the origin of whose claim is not clear but who apparently had some connexion with a sister of one of the family, probably another sister of Peter Fitz Oger. ${ }^{62}$ Whatever the basis of his claim, Sir William evidently expected difficulty in establishing his right to Joan's lands. In 1280 he agreed to enfeoff Queen Eleanor, the king's consort, of all the lands of Joan de Saunford to which he could establish his claim, saving for himself and his heirs Joan's lands in Suffolk. ${ }^{63}$ In $128 \mathrm{I}$ William seems to have established his claim to the lands and Queen Eleanor was presumably enfeoffed with them, according to the agreement, for a consideration of 250 marks. 64 Eleanor may in her turn have disposed of her right to these lands to the king's brother Edmund, for in 1286 Edmund acknowledged the manor of Shelley to be the right of Alan Waldesef and Aveline his wife to hold to them and their joint issue with remainder to the right heirs of Aveline.6s Aveline wife of Roger de Lees seems to have married Alan Waldesef as her second husband but to have had no issue by him, for on her death in 1299 John de Legh was named as her son and heir. ${ }^{66}$ In 1302 John de Legh was recorded as holding 2 fees in Shelley and Frinton. ${ }^{67}$ In 1349 this or another John de Legh evidently held the manor of Shelley.68 In 1374 Thomas de Legh was reported as holding 2 fees in Shelley worth $f_{0} 10.69$ In 1422 John de Legh died in possession of the manor of Shelley. ${ }^{70} \mathrm{He}$ was succeeded by his son Thomas who died in 1439 leaving as his heir an infant son Thomas.71 In 1509 Thomas Legh died, 72 having settled the manor on his son Henry and Margaret, wife of Henry, with remainder to Giles, son of Henry and Margaret.73 Henry had died in I 494 and Giles de Legh therefore succeeded to the manor in 1509.74 In 1538 Giles conveyed the estate to Sir Richard Rich, afterwards Ist Baron Rich. 75 Rich died in 1567 leaving as his heir Robert, 2nd Baron Rich, who settled Shelley on his eldest son Richard when Richard married Katherine Knevett. ${ }^{76}$ Richard died, without issue, before his father who was succeeded on his death in 1581 by his second son Robert, 3rd Baron Rich.77 In I 582 Lord Rich conveyed the manor of Shelley to John and Thomas Green and William Stane.78 John Green died in 1595 and was succeeded as lord of Shelley by his sixth son Robert Green.79 Robert died in 1624 and was succeeded by his son John. ${ }^{80}$ The Green family still held the estate at the end of the r $77^{\text {th }}$ century. Hadsley Green died in 1699 leaving a son John who died in infancy. ${ }^{81}$ The manor was then divided between the two daughters of Hadsley Green, Sarah and Mary. ${ }^{82}$ In 17 I 5 in anticipation of the marriage of Mary Green to Andrew Trebeck, later the first Rector of St. George's, Hanover Square ( $\mathrm{Mdx}$.), ${ }^{83}$ it was agreed that the half of the manor which Mary inherited from her brother should be put in trust for Andrew Trebeck during his life and, after his own and Mary's death, for their eldest son and his male heirs. ${ }^{84}$ The marriage settlement also provided that Andrew Trebeck should increase the estate by the purchase of lands to the value of 6800.85 Andrew Trebeck died in 1759.86 Mary survived until at least $1769 .{ }^{87}$ By the end of 1764 James Trebeck, son and heir of Mary. and Andrew, had secured possession of the half of the manor inherited by his aunt Sarah subject to the payment of an annuity of $£ .30$ to her for life and to the payment of $£ 375$ on her death to Bernard Baker, who may have been her grandson. ${ }^{88}$ In November 1764 James Trebeck mortgaged his interest in the manor to Mary Grosvenor for 6600.89 In 177 I he mortgaged the manor to Samuel Evans for 6600 and within the next eighteen months he borrowed further sums from Evans, making
sI Feet of F. Essex, i, 9; Cal. Inq. Misc. i, p. 5 ro; Cal. Ing. p.m. ii, p. I45; Complete Peerage, v, I 35

52 Cal. Close, $1374-77,22-23$.

53 Complete Peerage, vi, 474.

$34 \mathrm{Cr}_{3} 8 / 55$; Complete Peerage, vi, 4747. A final partition of the inheritance was made in $142 \mathrm{I}$ when Henry $\mathrm{V}$ reeeived the fee of the Earldom of Essex.

35 J. H. Round, "The Early Lords of Shelley', E.A.T. N.s. xi, 363 .

36 Feet of F. Essex, i, 9, 18 .

57 Ibid. $i, 9$.

58 Ibid.

39 Col. Ing. p.m. ii, p. I45.

60 Ibid.

61 Ibid.

62 Ibid. Cf. Morant, Essex, i, 146. Aveline was certainly descended from Peter Fitz Oger's sister and not as Morant states from the sister of Joan de Saunford. Although there is not the same clear evidence in the case of Sir William de Clovile, it is probable that his claim was derived from some relationship with another sister of Peter Fitz Oger.

63 Cal. Close, 1279-88, 53 .

64 Cal. Fine $R$. i, 149 .

65 Feet of $F$. Essex, ii, 57.

66 Col. Fine $R$. i, 415, 417. By at least one more legal process in 1288 (Feet of $F$. Essex, ii, 63) Aveline had secured full rights in Shelley manor to her heirs.

${ }_{67}$ Cal. Inq. Misc, i, p. 510.

68 Col. Inq. p.m. ix, p. 314.

69 Col. Close, 1 374-77, 23. The report that Thomas held 2 fees in Shelley was probably a mistake. All other records speak of Shelley being held as I fee.

${ }_{70} \mathrm{CI}_{3} 8 / 55$.

71 Ibid.; Cr $39 / 90$

${ }_{72} \mathrm{C}_{142 / 24 / 12 .}$

73 Ibid. 74 Ibid.

$75 \mathrm{CP}_{4}$ o/ 1096 rot. $100 ; \mathrm{CP}_{25}(2) / 12 / 65$

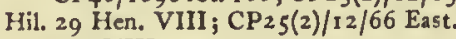
$30 \mathrm{Hen}$. VIII.

${ }_{76} \mathrm{Cr}_{12} / 147 / 141$.

$27 \mathrm{Cr}_{42 / 192 / 29}$.
${ }^{78} \mathrm{CP}_{25}(2) / 131 / 1686$.

79 Morant, Essex, i, 147.

$80 \mathrm{C}_{142} / 747 / 158$

81 E.R.O., D/DFa Ti7. John Green, son of Robert Green (d. 1624), had two sons. The elder was Robert whose son and heir John married Sarah, daughter of Edward Hadesley, and had by her John, living in 1664. Hadsley Green (d. I 699) was son of this John Green: Morant, Essex, i, 147.

82 E.R.O., D/DFa T 7

${ }^{83}$ G. Hennessy, Novum Repert. Eccl." Par. Lond. I64. St. George's was consecrated in March 1725 . Trebeck was appointed rector in May of that year. ${ }_{84}$ E.R.O., D/DFa Ti7.

85 Ibid. It seems that he did not do this. 86 Ibid. 87 Ibid.; E. $331 / 39$

88 E.R.O., D/DFa Ti7; Morant, Essex, i, 147 .

89 E.R.O., D/DFa T17. At this time Mary Trebeck, mother of James, had a life interest in 3 of the manor. 


\section{A HISTORY OF ESSEX}

the total debt in January $177363,000.90$ In the years 1762-4, when James Trebeck lived in the parish of St. George, Hanover Square, part of Shelley manor house was let to John Brecknock; the other part of the house was let with the manor farm to Robert Tabrum. ${ }^{91}$ In 1768 Trebeck was appointed Rector of St. Michael's, Queenhithe (Lond.). ${ }^{92} \mathrm{He}$ must have sold his Shelley estate soon after the period of heavy mortgaging, for by May 1780 it was owned by Thomas Richards. 93 In $179^{\circ}$ Richards was succeeded by Edward Kimpton, Vicar of Rogate (Suss.), who was apparently his nephew. 94 In November 1799 it was reported that the lord of the manor was Harvey Kimpton who was apparently the son of Edward Kimpton.95 Harvey Kimpton held the estate until his death in 1817.96 Elizabeth Kimpton, probably the widow or daughter of Harvey, then held the estate until $1819-20$ when it was purchased by James Tomlinson, a London solicitor.97 In I 839 the manor farm consisted of I 68 acres of which 138 acres were arable. 98 The Tomlinson family held the manor until I 902 or soon after. 99 In I 899 the estate was put up for sale by auction. At that time there were three copyhold tenants who paid rents totalling $f_{0}$ I $35.6 d$. a year and two freeholders who paid a total of $5 s .2 d$. a year in rents. ${ }^{2}$ At the time of the auction most of the land belonging to the estate was let to John Harvey who did not, however, occupy Shelley Hall. ${ }^{3}$ The estate was apparently not sold in $\mathrm{r} 899$ but by 1906 it had come into the ownership of W. A. Fleming who held it until after 1914.4 By 1922 it belonged to James Kerr who is still (1953) the owner.s

Shelley Hall, a timber-framed structure, has been remodelled at various times. The oldest part is at the south end where there was-originally a I 5 th-century hall of two bays, open to the roof. The hall has subsequently been divided and two ceilings inserted so that the only evidence of its existence is in the roof space. Here the original roof timbers, blackened by smoke from an open hearth, still remain and the two bays are divided by a I 5 th-century truss. The square king-post has a moulded cap and four-way struts. The hall may originally have been flanked by two cross-wings but if so the one on the south side has disappeared, the south wall at this end of the house being of more recent construction; the wing on the north side, probably the service wing, survives in a somewhat altered form. The present dining-room fireplace with other blocked fireplaces adjacent to it may represent the base of the medieval kitchen chimney.

Late in the 16 th century the house was remodelled, almost certainly by John Green who acquired the property in 1582 and had a very large family. ${ }^{6}$ The open hall was divided into two stories each of which was divided into two or more rooms. The plastered walls of one of the upper rooms were painted with the black and white stencilled decoration of the period. Later still a lower ceiling was inserted above the first floor, so that the paintings have disappeared in the room itself (now the first floor landing) but are still visible in the loft above. They consist of running designs on the timber studs with panels of a conventionalized flowers on the plaster between. ${ }^{7}$ One panel shows a large bird, probably a cock. ${ }^{8}$

Also in the late 16 th century the north wing was altered, the roof being reconstructed to give a gabled attic, and a second wing, of approximately the same size, was built beyond it. This second wing has a large external chimney. The doorway beside the chimney, now the back door of the house, has a four-centred oak lintel carved with the date $15^{87}$. The other feature of this period is the carved oak chimney-piece in the staircase hall. As there is no chimney connected with it, the assumption is that it has been moved from elsewhere, probably from some other position in the house. 9 The overmantel has pairs of round-headed arches flanking a central panel and the whole is enriched with arabesque and jewel ornament.

The present dining-room was fitted with panelling during the first half of the I 8 th century. There is a splayed bay window on the east side and the opposite wall has been splayed also to give an eight-sided room.

A writer of about $177^{\circ}$ evidently did not consider that Shelley Hall was 'a good house'." Considerable alterations took place in the first half of the Igth century; the staircase and many of the windows appear to be of this date. In about I 835 the Hall was described as 'now a handsome residence of moderate size ... retaining very little appearance of antiquity'." In 1869 it was encased in gault brick with red-brick dressings ${ }^{12}$ and the porch was added.13 The two red-brick additions to the west date from $1933 .{ }^{14}$

Among the farm buildings is a three-bay open shed, probably of the I 8 th century, with its hipped tiled roof terminating in a dove-cote.

Until the end of the rgth century the advowson of Shelley was usually appurtenant to the CHURCH manor but in and after the 16 th century there were several occasions when it appears to have been granted for single turns to persons who did not hold the manor. In about 1250 the patron was reported to be the heir of Peter, probably Peter Fitz Oger.'s The advowson probably descended with the manor through Peter's heirs to the Legh family. In 1329 John de Legh presented to the living. ${ }^{16} \mathrm{His}$ heirs continued to present until the I6th century. ${ }^{17}$ In I 509 Thomas Legh died in possession of the advow-
- Its existence was noted by Wright $c$. I 835 : Hist. Essex, ii, 354 .

so Hist. Essex by Gent. iii, 365 .

II Wright, Hist. Essex, ii, 354

12 Kelly's Dir. Essex (1912).

13 It is dated 1860 .

it Inf. from Mrs. Storkey, Shelley Lodge.

is E.A.T. N.s. xviii, 19. The patron is described here as the heir of Peter son of Roger but this is almost certainly a transcriber's error for Peter son of Oger. 16 Newcourt, Repert. ii, 520.

I7 Ibid. Thomas Arblaster who presented from 1441 to 1468 was an executor of Thomas Legh (d. 1439) and martied his widow Alice. Thomas Legh's heir was only 6 months old at the time of his father's death: Col. Pat. 1446-52, 392. 
son leaving as his heir his grandson Giles. ${ }^{18}$ In $153^{\circ}$ Richard Samford and others presented to the living. ${ }^{19}$ Giles Legh, however, was holding the advowson in 1538 and in that year conveyed it with the manor to Sir Richard Rich, later Ist Baron Rich, who presented several times between 1542 and $155^{8.20}$ Robert, 2 nd Baron Rich, presented in 1568 and $1574 .{ }^{21}$ In 1582 Robert, 3 rd Baron Rich, conveyed the advowson with the manor to John and Thomas Green and William Stane. 22 In 1589 John Jollye presented to the living but Robert Green died in possession of the advowson in $1624 . .^{23}$ In 1628 John son of Robert Green conveyed the advowson with the manor to Robert Holenden and Thomas Emevere. ${ }^{24}$ Jollye Stone, a farmer and copyholder of Shelley manor, presented in 1662 and 1664. In 1686 Hadsley Green presented, 25 and in 1732 his daughters Sarah Baker and Mary Trebeck with their husbands John Baker and Andrew Trebeck. ${ }^{26}$ In 1752 the Archbishop of Canterbury, patron by lapse, presented James Trebeck, son of Mary and Andrew Trebeck. 27 James Trebeck probably acquired his aunt Sarah's rights in the advowson when he acquired her half of the manor in about 1764 although he seems not to have mortgaged the advowson when he mortgaged the manor at the end of that year. ${ }^{28}$ In 1769 , shortly after his appointment as Rector of St. Michael's, Queenhithe, James Trebeck and his mother presented to Shelley.29 In 1771 and 1773 James mortgaged the advowson with the manor to Samuel Evans. ${ }^{30}$ The descent of the advowson during the next 40 years is not clear. It is probable, however, that it followed the descent of the manor. Nathaniel Soames presented Henry Soames in $1812 .{ }^{31}$ According to Wright (1835) James Tomlinson purchased the advowson with the manor in 1819 or 1820.32

The Tomlinson family held the advowson for most of the remainder of the Igth century.33 In $1895-6$ J. H. Tomlinson conveyed it to $\mathrm{H}$. Garnett and others who held it until I 898-9.34 In the latter year William Philp, Rector of Shelley from 1895, acquired the advowson and held it with the living until his death in I926-7.35 Afterwards the advowson was held by his executors until $1930-1$ when it was acquired by the Community of the Resurrection, Mirfield (Yorks.). ${ }^{36}$ Since 1932 it has been held by Keble College, Oxford. ${ }^{37}$ At present the rectory is held with that of Chipping Ongar. ${ }^{38}$

In 1254 the value of the rectory was assessed at 5 marks. ${ }^{39}$ A pension of 35 . was paid to the church of

${ }_{18} \mathrm{Cr}_{42 / 24 / 12}$.

19 Newcourt, Repert. ii, 520.

${ }_{20} \mathrm{CP}_{4}$ o/10g6 rot. $100 ; \mathrm{CP}_{25}(2) / 12 / 65$

Hil. 29 Hen. VIII; $\mathrm{CP}_{25}(2) / 12 / 66$. East.

30 Hen. VIII; Newcourt, Repert. ii, $52 \mathrm{I}$.

21 Newcourt, Repert. ii, 52 I.

$22 \mathrm{CP}_{25}(2) / 131 / 1686$.

${ }_{23} \mathrm{C}_{142 / 747 / 158 ;}$;ewcourt, Repert. ii, $52 \mathrm{t}$.

$24 \mathrm{CP}_{43 / 183}$.

25 Newcourt, Repert. ii, 521.

26 P.R.O. Inst. Bks. Ser. C. $i$ (1).

27 Ibid.

28 E.R.O., D/DF $\mathrm{T}_{17}$

29 P.R.O. Inst. Bks. Ser. C. i (1); G. Hennessy, Novum Repert. Eecl. Par. Lond. 249. In c. 1770 it was reported that now the Bishop of London and the lord of the manor present to the living alternately' Hist. Essex by Gent. iii, 366. There seems to be no other evidence that this was the case.

${ }^{30}$ E.R.O., D/DFa T 17

31 P.R.O. Inst. Bks. Ser. C. i (1).
High Ongar.40 In 1291 the rectory was valued at 6I I Os.4I In 1428 it was assessed at 11 marks. 42 Later valuations were $6915 \mathrm{~s}$. in 1535 and 680 in 1661.43 The tithes were commuted in 1839 for $\&_{192} I_{35 . ; 4}$ there were then 37 acres of glebe. 45

The rectory was burnt down about 1937.46 It was unoccupied at the time, the rector then living in Fyfield. The lane leading to it is now a foot-path, stillviable, and the foundations doubtless exist on the overgrown site. It was a timber-framed building dating from the I6th century, if not earlier.47 For a short time from about 1754 Thomas Newton, brother-in-law of the then Rector of Shelley, James Trebeck, and later Bishop of Bristol, used the rectory as a retreat and apparently wrote his 'Dissertation on the Prophecies' there.48 Later the house was altered and enlarged. Henry Soames, 49 Rector of Shelley from I 8 I 2 until I 860 , was said to have spent considerable sums on it by about I 835. so In 186 I the house was restored.si A photograph 52 shows a long four-gabled front with a central two-story porch.

The medieval parish church of $S T$. PETER became ruinous towards the end of the 18 th century and was considered unsafe for use after June 1800.53 In about I 768 it was described as 'of one pace with the chancel, and tyled. In the spire, which is shingled, are 2 Bells.'s4 In I8I a new church was built on the same foundations, 55 the cost being met largely by subscription. ${ }^{56}$ This was a rectangular brick structure with a steep roof and a castellated gable at the west end. The windows were gothic but there was a Georgian bell cupola. Between the windows were massive buttresses, probably added later when the building showed signs of instability. 57 In 1888 a faculty was obtained for building yet another church. $\$ 8$ The architect's report on the existing structure stated that repair was impossible and that in any case "not one single feature was worth preservation'.59 The new church was designed by Habershon and Fawckner, ${ }^{60}$ and $f_{0}, 000$ towards the cost was contributed anonymously by the Revd. W. M. Oliver, Rector of Bobbingworth. ${ }^{61}$

The church is larger than those preceding it and consists of chancel, nave, north aisle, vestry, organ chamber, and combined north porch and bell tower. The external walls are of flint with Bath stone dressings. The tower has a shingled spire. The style is a I th-century version of Early English and most of the windows are grouped lancets. The internal walls are
32 See above, Manor.

33 Cler. Guide, 1829 f.; Clergy List,

1842 f.; Crockford's Cler. Dir. (1860f.); Kelly's Dir. Essex (1 870 f.).

${ }^{34}$ Clergy List, $1896 \mathrm{f}$; Kelly's Dir. Essex (1899).

35 Kelly's Dir. Essex (1899); Clergy Lise, $1900 \mathrm{f.;}$ Crockford's Cler. Dir. (1921 f.)

36 Crockford's Cler. Dir. (1927 f.)

37 Ibid. (1932 f.); Chel. Dioc. Year Bk. 1952.

${ }_{38}$ Chel. Dioc. rear Bk. 1952.

39 Lunt, Val. of Norwich, 336.

$40 \mathrm{Ibid}$

4 Tax. Eccl. (Rec. Com.), 23.

42 Feud. Aids, ii, 205.

43 Valor Eccl. (Rec. Com.), i, 437 ;

E.A.T. N.s. xxi, 78 .

44 E.R.O., D/CT 314. 45 Ibid.

46 Inf. from Mrs. Storkey.

47 Hist. Mon. Com. Essex, ii, 212.

48 D.N.B. xiv, 403-4; Kelly's Dir.

Essex (1886); White's Dir. Essex (1 848).
49 See Stapleford Tawney, Church. He was also rector of that parish from 1839 . so $\mathrm{T}$. Wright, Hist. Essex, ii, 356 . He lived at the parsonage from about the time he became rector until at least 1839 : E.R.O., Q/RPI $721-37$; ibid. D/CT 314 . By 1848 he was living in Stapleford Tawney: White's Dir. Essex (1848).

51 White's Dir. Essex (1 863 ).

52 In possession of Mrs. Storkey.

53 Note in the Register of Baptisms $1687-1812$ in possession of rector.

54 Morant, Essex, i, 147.

ss E.A.T. N.5. xi, 174; White's Dir. $E_{\text {ssex }}(1848)$.

$56 \mathrm{~T}$. Wright, Hist. Essex, ii, 356.

57 These details are from an architects' drawing of 1886 , a copy of which is in the possession of the rector.

58 Faculty in possession of rector. 59 Ibid.

60 Foundation stone in west wall of church.

61 E.R. xiv, 186 


\section{A HISTORY OF ESSEX}

faced with red brick, having dark brick bands and stone dressings. The capitals of the nave arcade are carved with stiff-leaved foliage. The east window has plate tracery, the stained glass being the gift of Mrs. Allen in 1888.62 Formerly there were two bells dated I $810 ; 63$ only one is now in use.

On the walls of the porch are tablets from the original church. Over the door is an inscribed brass commemorating John Green (1595) and Katherine his wife. ${ }^{64}$ On the east wall of the porch is a carved and painted stone tablet to Agnes wife of John Green ( 1626$)$; it shows the kneeling figures of husband and wife with two sons and four daughters. Also mounted on the porch walls are two floor slabs from the chancel of the original church discovered when the present foundations were dug. ${ }^{6 s}$ They commemorate Margaret, daughter of John Neale (1625), and Hadsley Green (1699); this last slab has an achievement of arms.

The plate includes an undated Jacobean cup, a silver paten of 1724 given by Harvey Kimpton, 66 patron, and another of 1726 given by John Pearson, rector. There is also a beaker of 1799 given by Harvey Kimpton and two almsdishes probably of the Igth century.

In 1613 the cost of poor relief was $20 s .4 d .67$ In 1776 it was 664.68 In $1783-5$ POOR RELIEF expenditure averaged $£_{0}^{8} 9$ a year. ${ }^{69}$ In the years of scarce food at the turn of the century it almost reached $\{, 300$ and through the Napoleonic wars varied between $£_{2} 200$ and 6345.70 There was a parish poorhouse by 1776.71 In each of the three years ending at Easter I 8 I 5 there were 16 or 17 persons on 'permanent' outdoor relief and 9 or 10 persons who were relieved occasionally. ${ }^{72}$
In 1836 Shelley became part of Ongar Poor Law Union.

In 1819 there was no school in the parish. The rector, H. Soames, sent some children to

SCHOOL Chipping Ongar Sunday school and a few others to a neighbouring day school..$^{73} \mathrm{By}$ 1832 he had established a Sunday school in Shelley; 25 children attended it in 1832 and 17 in 1833.74 No day school was later founded except a 'ladies' academy' in Shelley House ${ }^{75}$ and until the Education Act of I 870 only a few Shelley children seem to have attended King's Trust School in Chipping Ongar (q.v.).76 In I 872, however, the Education Department decided that the 33 Shelley children needing an elementary education could most conveniently obtain it if Shelley and Chipping Ongar were formed into a single School District and King's Trust School were enlarged. This policy was adopted and Shelley children then attended King's Trust School, their expenses being paid by means of voluntary contributions. In $1897-9$ the rector found it very difficult to collect these contributions. 77

Harvey Kimpton, lord of the manor of Shelley, by will dated I 817, left f, 100 in trust for

CHARITIES the poor of the parish. In 1834 the income was distributed in small sums of cash to all poor parishioners including some receiving parish relief. William Bullock, by deed poll of 1822 , gave $£ 3336$ s. $8 d$. in trust for the poor, subject to a lifeinterest for himself. In 1834 the income was spent on bread, meat, and coals for all poor parishioners of good character. ${ }^{78}$ A scheme of 1863 provided for the use of both charities in support of a clothing club or for gifts in kind, but in $195^{\circ}$ for were distributed from them in gifts of cash to 20 people. ${ }^{79}$

\section{STANFORD RIVERS}

Stanford Rivers is a large parish whose north-east boundary is $\frac{1}{2}$ mile south-west of Chipping Ongar. ${ }^{\mathrm{I}}$ The soil is Boulder Clay and London Clay with small patches of gravel. The part of the parish to the north of the stream which flows into the Roding at Wash Bridge, and which includes Toot Hill and Ongar Park Wood, may originally have been part of the parish of High Ongar, and may have become part of Stanford Rivers about 1280.2 Like many other parishes in this area Stanford Rivers is made up mainly of scattered farms and cottages. There are two hamlets, one in the east and the other in the north-west, both some distance from the parish church. The population density never seems to have been unusual for the area, although until the I 9 th century the population was larger than that of High Ongar, a parish adjacent and of similar area. ${ }^{3}$ Population in I 80 I numbered 740 . It rose to a peak of 1,082 in 1851 and then gradually declined.
In 195 I it was 802.4 There has been a slight increase since I 9 I I due to council housing and private building after the break-up of the Bishops Hall estate.

The land in the parish varies in height from about $100 \mathrm{ft}$. above sea-level in the south to over $300 \mathrm{ft}$. at Toot Hill in the north-west. The River Roding forms the eastern and southern boundaries of the parish. A stream flows east across the north of the parish to join the Roding at Wash Bridge. Several smaller streams join the river farther south. Ongar Park Wood, in the north-west, is a mile long and + mile wide. A mile south of this is Knightsland Wood, and farther southeast are Twentyacre Wood and Tenacre Wood. The main road from Chipping Ongar to London passes south-west through the parish. Lying along this road, at a distance of 2 miles from Chipping Ongar, is the hamlet of Little End. There have been houses here at least since 1777.5 A recent group of council houses has

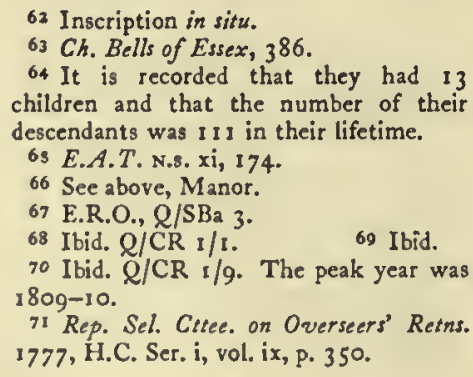

62 Inscription in situ.

${ }_{6} \mathrm{Ch}$. Bells of Essex, 386.

64 It is recorded that they had I3

children and that the number of their

descendants was I I in their lifetime.

63 E.A.T. N.8. xi, I74.

66 See above, Manor.

67 E.R.O., Q/SBa 3.

68 Ibid. $Q / C R$ I/r. 69 Ibid.

70 Ibid. Q/CR I/9. The peak year was $1809-10$.

${ }^{71}$ Rep. Sel. Citee. on Overseers' Retns.

1777 , H.C. Ser. i, vol. ix, p. 350.

72 Ibid. Q/CR 1/10.

73 Retns. Educ. Poor, H.C. 224, p. 270 (1819), ix (1).

74 Nat. Soc. Rep. 1832 , p. 80; Educ. Enquiry Abstr. H.C. 62, p. 288 (1835), $x$ li.

73 Whute's Dir. Essex (1863). This school was probably founded not long before 1863. Cf. White's Dir. Essex (1 848) and Kelly's Dir. Essex (1859).

76 E.R.O., D/AEM I/ I/I.

77 Min. of Educ. File $13 / 66$.

${ }_{78}$ Rep. Com. Char. (Essex), H.C. 216 ,

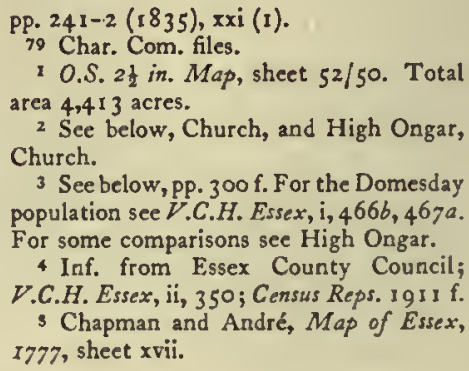

3 See below, pp. 300 f. For the Domesday population see V.C.H. Essex, i, $4666,467 a$.

For some comparisons see High Ongar.

4 Inf. from Essex County Council;

V.C.H. Essex, ii, 350; Census Reps. 19 I If.

3 Chapman and André, Map of Essex, 1777 , sheet $x$ vii. 
been built here. The factory of Piggott Bros. \& Co., tent and tarpaulin makers, is on the east side of the main road at Little End. ${ }^{6}$ Opposite the factory is the site of the former Congregational church, and also the present rectory. Stanford House, which lies near the factory to the south, is of 18 th-century date possibly with an older core. It has brick walls, to which imitation half-timbering has been applied recently. It was the home of Isaac Taylor (see below). A mile northeast of Little End is Littlebury (see below). Wash Farm, at Wash Bridge, is the name given on modern maps to Bridge Farm, alias Bridge House Farm (see below, Bridges and Piggsland). The part of the main road to the south-west of Little End has been known since at least the 17 th century as Hare Street.7

The main road is joined at Little End by a road running north-west to Toot Hill. Stanford Hall (see below) and the church lie beside this road $\frac{1}{2}$ mile from Little End. The old rectory is $\frac{1}{2}$ mile south-west of the church. The school, and Steward's Farm, are on the road between the church and Toot Hill.

Toot Hill is now the main centre of population. Does Farm here is of late 16 th-century origin, faced with brickwork in the Igth century. It has a cruciform chimney-stack with five polygonal shafts. A cottage on the north side of the road about 1 mile east of Does was part of a larger building at one time divided into three tenements. ${ }^{8}$ The east end, including a central chimney, was destroyed by fire within the last 20 years. It is of the 15 th or early 16 th century and is of timber construction, plastered and weather-boarded. Also at Toot Hill is a small cottage with one gabled cross-wing which may be of the 16 th century or earlier. On both sides of the 'Green Man' at Toot Hill is a layout of 16 post-1 945 council houses.

In the extreme south of the parish the main road is joined by a road which leads to Navestock and crosses the Roding by Shonks Mill Bridge. Half a mile northwest of the bridge is Lawns Farm. The house is of late 16 th- or early-1 7 th-century date, much restored. It is timber-framed and plastered and has a tiled roof. The front is flanked by two gables oversailing at firstfloor level. North of Lawns is Wayletts, another timber-framed and plastered house, probably of the 1 7 th century. Traceys Farm (see below) is $\frac{1}{2}$ mile north-west of Wayletts. Murrells is on the north-west side of the main road, to the north-east of Traceys. It also is timber-framed and plastered. The front has been entirely rebuilt after receiving severe damage from a flying bomb in 1944. The house probably dates from the 16 th century, but may have incorporated parts of an even older house. 9 Berwick Farm (see below, Barwicks) is in the west of the parish near Twentyacre Wood. The site of Bellhouse (see below), once the main manor house of the parish, is a mile east of Berwick.

The railway from Epping to Chipping Ongar passes through the north of the parish. North Weald station is just inside Stanford Rivers in the north-west, and Blake Hall station similarly in the north.

There are frequent references to the condition of bridges in Stanford Rivers. In 1566 Stewards Bridge, with land on both sides belonging to a Mr. Steward, was in need of repair. ${ }^{\text {Io }}$ This may have been the bridge described later as Hawkes or Hackes Bridge and as Hallyngford. "I Stewards Bridge was frequently presented in the manor court during the reign of Elizabeth $I$ as needing repair. ${ }^{12}$ The great bridge between Stanford Rivers and Navestock, Shonks Mill Bridge, is treated under Navestock (q.v.). Wash Bridge was taken over by the county in $1830 . .^{13}$ In $185^{8}$ it was described in detail by the county surveyor. ${ }^{14}$

The coach and carriers from Chipping Ongar were calling at Stanford Rivers in 1848 and 1863.15

The railway stations at North Weald and Blake Hall were probably opened as soon as the line to Chipping Ongar was completed in 1865 . There was a coal merchant's wharf at Blake Hall Station in 1869.16

Stanford Rivers had a postal receiving house in I 793.17 It was on the daily horse ride shown on the post-office map of $1813 .{ }^{18}$ In 1848 the post-office was at the 'White Bear'.19 By 1896 there was a sorting office. ${ }^{20}$ Toot Hill had a sub-post-office in 1863.21 There was a telephone service at Stanford Rivers by I 926.22

There was a resident police constable at Stanford Rivers from 1906.23. Two new police houses were built at Hare Street in 1954 .

Water was supplied to parts of the parish in 1949 by the Herts. and Essex Waterworks Co. ${ }^{24}$ There is sewerage in part of Stanford Rivers. ${ }^{25}$ Electricity was laid on in part of the parish in January 1951.26 There is no local supply of gas, but the parish is traversed by an untapped trunk main. ${ }^{27}$

There is a village hall at Hare Street and a parish room at Toot Hill, both dating from $1921.28 \mathrm{~A}$ branch of the county library was opened in April 1927.29

In 1086 the main manor of Stanford was a large and important estate containing a total of 20 ploughteams. ${ }^{30}$ Little Stanford contained I plough-team. ${ }^{31}$ There was another $\frac{1}{2}$ plough-team on the estate formerly held by a freeman. ${ }^{32}$ At the time of Domesday $5 \frac{1}{2}$ plough-teams were employed on the demesne, but the number had dropped steadily since 1066 . There was estimated to be woodland sufficient to feed a total of 520 swine. This suggests that Stanford was less densely wooded than Chipping Ongar (q.v.) immediately to the north. From the is th century until the 16 th the lords of the capital manor never seem to have been resident. This, and the size of the parish, explain why so many subordinate estates grew up. Even after the Petres had settled at Bellhouse there does not seem to have been a large demesne farm. Their estate was mostly let out to tenants farming $100-300$ acres. ${ }^{33}$ In 1842 there were 17 farms in the parish with 90 acres

\footnotetext{
6 See below, and also Parish Govt. and

Poor Relief.

7 P.N. Essex (E.P.N.S.), 78.

8 Hist. Mon. Com. Essex, ii, 222.

- Cf. Morant, Essex, i, 154.

10 E.R.O., Q/SR 20/6. This bridge was

probably near Steward's Farm.

1 See Navestock, p. I 42.

12 E.R.O., D/DP M I 127

13 E.R.O., Q/ABz I.

14 E.R.O., $Q / \mathrm{ABz}_{3}$.

ss White's Dir. Essex (1848), 437 ; ibid.
}

25 Inf. from the rector, the Rerd. J. H. Ward.

26 Inf. from East. Elec. Bd.

27 Inf. from East. Gas Bd.

28 Inf. from the rector.

29 Inf. from the County Librarian.

so V.C.H. Essex, i, $466 b$.

31 Ibid. $467 a$.

32 Ibid. 466b. For the Domesday tenants and their predecessors see below, Manor.

33 See various manors, below.

Es. IV 


\section{A HISTORY OF ESSEX}

or more. ${ }^{34}$ The largest, of 703 acres, was a comparatively new creation, of which the nucleus was Stanford Hall farm. ${ }^{35}$ The others were between 90 and 320 acres. There were also a number of smaller holdings. There were 400 acres of woodland (mostly in Ongar Park Wood). The remainder of the parish contained cultivated arable and grassland in roughly equal quantities. A field of 13 acres near Stanford Hall to the west was named Hop Gardens; but it was then being used for pasture. ${ }^{36}$

There is little to show how and when inclosure took place in the parish. In 1579 Bartholomew Combers, blacksmith of Stanford Rivers, was granted permission by the queen, as lord of the manor, to build a cottage and forge on a piece of waste ground in the manor called Bridges Green. ${ }^{37}$ The Tithe Map (1842) shows traces of former open meadow: strips or 'pieces' in Hollingford Mead, running down to the Roding, in the south-east of the parish. ${ }^{38}$

In 1086 there was a mill in the main manor of Stanford. ${ }^{39}$ There was one at Littlebury in 1260.40 Its tithes were granted about that time to Thoby Priory.4I In 1701 there was a water-mill at Littlebury. ${ }^{42}$ The present Littlebury Mill appears to be of early-I gth-century date. It is weather-boarded on a brick base. In I 946 it changed over from water to electric power, and in 1952 the mill-stream was filled in, so that the water now follows the original course of the Roding.43 In 1777 there was a windmill between Littlebury Hall and the main road.44 This is shown on the Tithe Map but it may not then have been in operation.45 The former Shonks Mill is treated under Navestock (q.v.). The map of 1777 shows this watermill beside Shonks Bridge, and also a windmill a little to the west. 46 This windmill, like that at Littlebury, is marked on the Tithe Map, but had disappeared 30 years later. ${ }^{47}$ There was also a windmill at Toot Hill in the I 9 th century. It was built about 1824.48 In 1829 it was badly damaged by lightning and the miller was seriously injured. A lithograph drawing of the mill, showing him gazing at the damage, was sold for the benefit of him and his family. ${ }^{49}$ The mill was soon working again and continued to operate until about 1900. It was finally demolished in $1935 .{ }^{\circ 0}$ It was a wooden post-mill turned by hand. The four brick piers which formerly supported the cross-trees at the base of the mill can still be seen on the site. The single-story weather-boarded mill cottage, probably built about 1824 , still exists. The mill stood on the north side of the road leading to Greenstead Green.

Spinning was carried on in the parish workhouse from 1770 to about 1800.51 The brick and tile works to the south of North Weald station existed in $187 \mathrm{I}-3.52$
A transmitting station of the Marconi Wireless Telegraphy Co. operated in the parish in about $1926-9.53$ The factory of Piggott Bros. \& Co., tent and tarpaulin makers at Little End, was formerly the Ongar Union workhouse. It was converted to $\mathrm{its}$ present use after the union was dissolved in 1930 . The central range of brown gault brick has three stories and a basement, also a splayed projecting bay at the back. It was built in about $1830-1$ as the workhouse of the voluntary poor law union which preceded the Ongar Union. The side wings, in a slightly pinker brick, were added a few years later (see plate facing p. 233).

Most of the eminent men who have been connected with Stanford Rivers were rectors of the parish; these are mentioned below (see Church). Isaac Taylor (1787-1865) artist, author, and inventor, is usually known as Isaac Taylor of Stanford Rivers. He was the son of Isaac Taylor of Ongar (1759-1829).s4 He settled at Stanford House in 1825 and lived there for the rest of his life. 55

Before 1066 the owners of land in Stanford were Lewin, who held the main manor, con-

MANORS sisting of 9 hides, Brictwin with 20 acres and a certain free man with 40 acres. Little Stanford, consisting of I hide and 80 acres, was held by the father of Alvric. After the Conquest all these estates came to Ingelric the priest and later to Eustace of Boulogne.56 Together they became a single manor later known as that of STANFORD RIVERS. This descended with Chipping Ongar (q.v.) to Richard de Lucy and subsequently to Maud de Lucy, wife of Richard de Rivers. In the I $3^{\text {th }}$ century it was usually said to be held of the king as of the honor of Boulogne. When Maud died (c. I 243) it was stated in the inquisition that the jury did not know whether her heir was her younger son Baldwin de Rivers or the son of her elder son Richard. 57 The jurors stated that the manor then included 602 acres of land, of which 2 I 2 acres were worth $\ell_{5} 6 \mathrm{~s}$. a year (at $6 d$. an acre) and 390 acres were worth f6 Ios. (at $4 d$. an acre), 24 acres of pasture worth 24 s. in all, and 24 acres of meadow, of which I 8 acres were worth 3 os. in all and 6 acres were worth 75 . in all. There is no doubt that Chipping Ongar passed to Maud's grandson John and Stanford Rivers probably did the same. Sir Philip Basset, who had custody of the infant heir to Chipping Ongar after 1243, was also a party to deeds in this period relating to Stanford Rivers. 58 Baldwin de Rivers seems, however, to have had some land in Stanford. ${ }^{59}$ John de Rivers (d. 1294) was lord of Stanford Rivers as well as Chipping Ongar. ${ }^{60}$ It was stated at his death that Stanford contained 400 acres of land, 23 acres of meadow, 10 acres of pasture, and a park. This park was that later known as Ongar Park

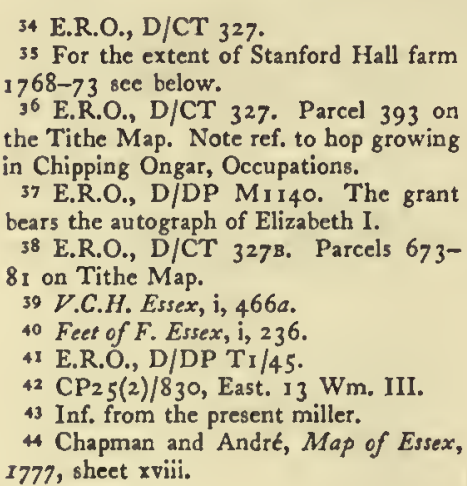

45 E.R.O., D/CT 3278. It is not shown on the O.S. 6 in. Map (15t edn.), sheet lix $(187 \mathrm{I}-3)$

46 Chapman and André, op. cit.

47 E.R.O., D/CT 327в; O.S. 6 in. Map (1st edn.), sheet Iviii (1 $870-2$ )

48 Essex Naturalist, xxviii (2), 51-54: illustrated article.

49 See plate facing p. 210.

50 Essex Naturalist, xxviii (2), 53. No miller is shown in the directory after 1902 Kelly's Dir. Essex (1874, 1902, I906). Daniel Surridge was the miller $c$. I 874-95 5 I See below, Parish Government and Poor Relief.

s2 O.S. 6 in. Map, sheet lix (1871-3).

33 Kelly's Dir. Essex (1926, 1929, 1933).
54 See Chipping Ongar.

53 D.N.B.

56 V.C.H. Essex, i, 466b, 467a. Like Chipping Ongar Stanford figured in a grant of William I to St. Martin-le-Grand, London, in 1068 , but this does not seem to have become effective. For the possible identification of Little Stanford with Littlebury see Littlebury, below.

s7 Cal. Inq. p.m. i, p. 6. The name of her grandson was John de Rivers. The original inq. is $\mathrm{C}_{132 / 1}$.

58 Cat. Anct. D. i, A. 738, 729, 806.

59 Cal. Pat. 1247-58, 586. Baldwin was dead by Feb. 1257 .

60 Cal. Inq. p.m. iii, p. 10g. The orig. inq. is $\mathrm{C}_{1} 33 / 67$. 


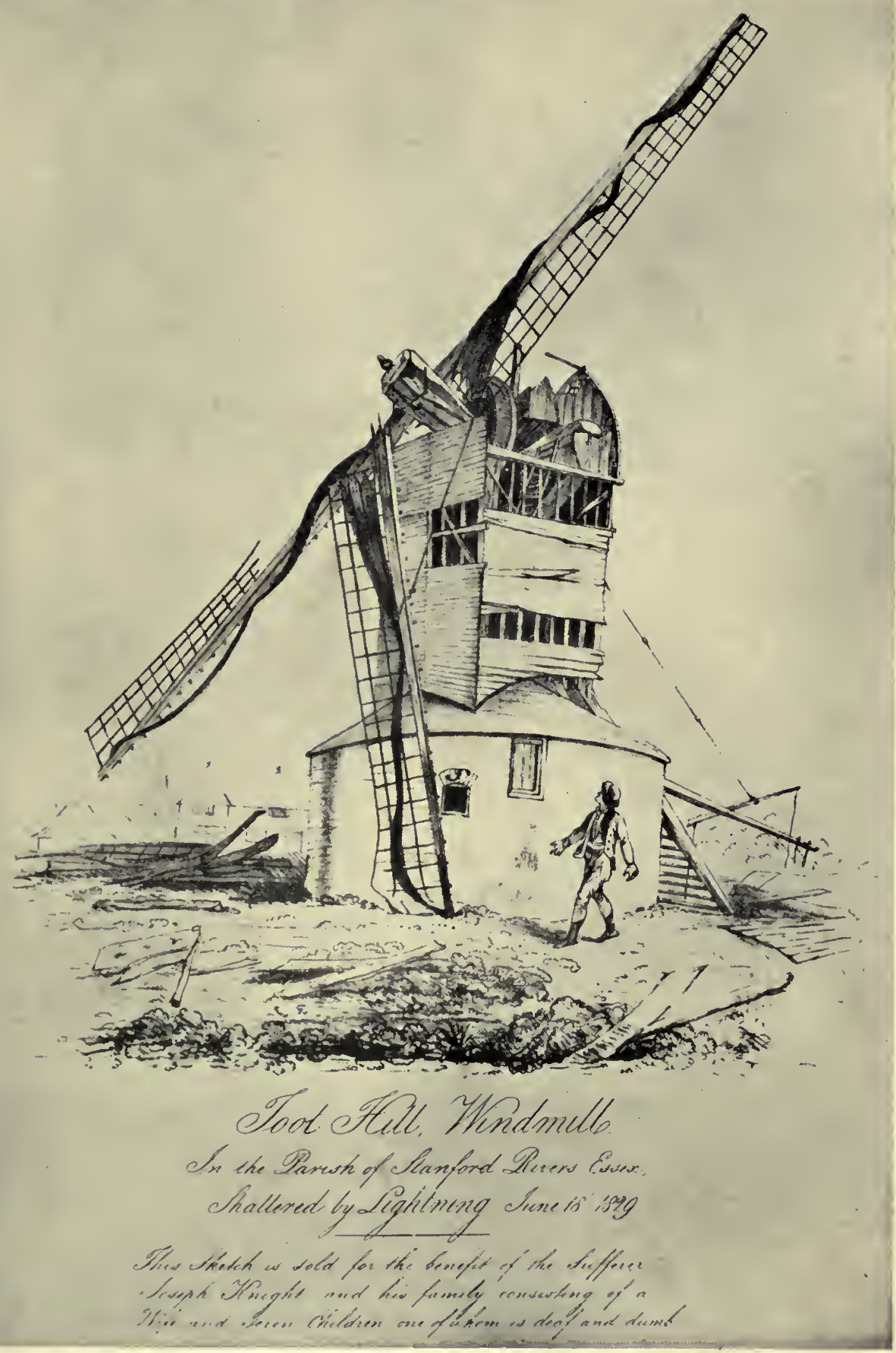



in High Ongar (q.v.). In the $3^{\text {th }}$ century this was often referred to as Stanford Park.

In 1294 John son of John de Rivers conveyed to Robert son of Richard of Chigwell his manor of Stanford Park, except the deer, stews, and woods. The grant was for six years, on the occasion of John de Rivers's departure to Gascony in the king's service. ${ }^{61}$ In 1298 de Rivers was granted the king's licence to let Stanford Park to farm to Salamon le Cutiller, citizen of London, for four years after the expiration of the lease granted in 1294.62 At the same time John de Rivers was given licence to let to farm for eight years to Fulk of St. Edmunds and John his son, also citizens of London, his manor of 'Stanford without the park'.63 In I 300 John de Rivers leased the last-named manor for sixteen years to Fulk of St. Edmunds and James son of Fulk. ${ }^{64}$ On the same day de Rivers granted to Humphrey de Walden for life the manor of Stanford, i.e. Stanford Park.65 Stanford Park was known after this as Ongar Park and is treated under High Ongar (q.v.).

The manor of Stanford Rivers alias Stanford "without the park' continued to be held as of the honor of Boulogne. This manor was granted by John de Rivers in 1308 to Richer de Refham, citizen and alderman of London, to hold for life 'and for two years after'.66 In the following year the grant was converted into a tenancy in fee.67 In 1313 Richer de Refham granted the manor to his son John.68 In 13 I 4 John de Refham granted it to John de Gras and Pauline his wife.69 In I 334 John son of John de Rivers released to Pauline, widow of Sir John de Gras, all his right in the manor. ${ }^{70}$

Pauline de Gras granted the manor in 1348 to Ralph, Baron Stafford, later Ist Earl of Stafford.71 It was thus reunited with the manor of Chipping Ongar (q.v.) and had the same descent until the death in 1460 of Humphrey Stafford, Ist Duke of Buckingham, when by virtue of a previous settlement Stanford Rivers passed to John Stafford, 3rd son of the duke, who was created Earl of Wiltshire in 1470 and died in $1473 . .^{72}$ After the earl's death Stanford Rivers was held in dower by his widow Constance until she died in 1475.73 Edward Stafford, Earl of Wiltshire, died childless in 1499 and Stanford Rivers was again reunited with Chipping Ongar in the hands of Edward Stafford, 3rd Duke of Buckingham.74 In 1524 the manor of Stanford Rivers was granted by the king to William Cary, squire of the body, and Mary his wife.75 Mary was holding a court for the manor in 1534 , but soon after this the manor reverted to the Crown, which was appointing stewards in $1544-7.76$

In 1548 Stanford Rivers was given to Princess (later Queen) Mary.77 In 1557 it was annexed by letters patent to the Duchy of Lancaster. ${ }^{78}$ The manor remained part of the duchy until $16 \mathrm{I}_{3}$, when James I sold it to Richard Cartwright and Thomas Cowley of London.79 A fee-farm rent on the manor was apparently retained by the Crown. The descent of this rent is given below. In 1614 Cartwright and Cowley conveyed the manor to Henry Spiller and Alexander Williams, who in I6I9 sold it to Sir Thomas Elliott, Kt. ${ }^{80}$ In 1623 Elliott sold the manor to William, Baron Petre. ${ }^{81}$ Lord Petre settled it in 1628 upon his $3 \mathrm{rd}$, but 2nd surviving, son William as a jointure for William's wife Lucy. ${ }^{82}$ The Petres at this time acquired all the other manors in the parish except Littlebury. Their estate in Stanford Rivers became known as Bellhouse, from the name of their capital mansion. It comprised about 1,600 acres in the 17 th century.

In I 645 Stanford Rivers was granted by Parliament to the Earl of Essex, on account of William Petre's adherence to Charles I. ${ }^{83}$ The earl died in 1646 . It was presumably after this that John Mann was granted a lease of part of the estate-apparently two-thirds. By December I650 Mann had become a member of the Essex County Committee for administering the estates of delinquents. Since it was contrary to parliamentary ordinance for any committee to lease land to one of its own members, the Essex committee appealed to the central Committee for Compounding to allow the law to be waived in Mann's favour, 'he having spent much in repairs while he was a tenant at $f_{1}$ oo before he became a commissioner'. ${ }^{84}$ The central committee refused the application ( $165 \mathrm{I}$ ) and ordered that another tenant should be found.85 Early in 1652 negotiations were taking place between the central committee, the local committee, and various prospective lessees of the estate. ${ }^{86}$ From the details of these negotiations it appears that William Petre still occupied the mansion house and one-third of the estate. Eventually he regained possession of the other two-thirds and in January 1653 ; 'begging allowance of two-thirds of the expense of rebuilding the outhouses, burnt down by lightning', was granted $£ 40$ by the central committee. 87 He had never apparently lost control of the manor court: in the court rolls for 1647-60 he is invariably entered as lord of the manor. ${ }^{88}$

William Petre died in 1677 and was succeeded by his eldest son William.89 On the death of the latter in I688 another William Petre succeeded his father as lord of the manor. He raised substantial mortgages to endow his daughters, at least five of whom became nuns. ${ }^{90}$ This outlay was, however, more than balanced by the marriage portion of $£ 4,000$ brought into the estate by Lady Mary Radcliffe, only daughter of Edward, Earl of Derwentwater (d. I705), who in 1722 married William Petre the younger, heir of his father, and brother of the girls to whom the above portions were given. ${ }^{91}$
61 Cal. Pat. $1292-1301,78$.

62 Ibid. 366.

63 Ibid.

64 Ibid. 503 .

63 Ibid. 506. It was stated that this grant was to assist John de Rivers to discharge debts incurred by him in Gascony. 66 B.M. Add. Ch. I9964.

67 Ibid. I 9982-3; Cal. Pat. $1307-13$, $28 \mathrm{r}, 554$.

68 Cal. Pat. 1313-17, 31. For the Refhams see also Littlebury, below.

69 Ibid. 174.

70 B.M. Add. Ch. 19984.

71 Ibid. 19986.

${ }^{2} \mathrm{C} 139 / 180$; Complete Peerage (orig. edn.), viii, 165 .
${ }_{73} \mathrm{C}_{14}$ \%/54.

$74 \mathrm{CP}_{2}(2) / 51 / 364$

7s. L. G' P. Hen. VIII, iv (1), p. 196.

${ }_{76} \mathrm{SC}_{2} / 173 / 81 ; L$. \& $P$. Hen. VIII,

xix (2), p. 74; xx (1), p. 327 ; xx (2), p. 397 ;

Cal. Pat. $1547^{-8}$, I 13 .

77 Cal. Pat. I 548-9, 21.

78 Cal. Pat. I557-8, 50. Under powers granted by 2 \& 3 Ph. \& Mary c. 20.

79 E.R.O., D/DP MII4I (Abstract of Title, manor of Stanford Rivers).

80 Ibid. 81 Ibid.; $\mathrm{CP}_{43} / \mathrm{I} 6 \mathrm{I}$ tot. 66.

82 E.R.O., D/DP MII4I; Visits. of

Essex (Harl. Soc.), i, 265 ; Geneal. Coll. of

R.C. Families, pt. i, ed. J. J. Howard, \&ec., p. 44 .

\footnotetext{
83 B.M. Add. MS. 5497, f. 142.

$84 \mathrm{Cal}$. of Ctice. for Compounding, 435 , 2643. 85 Ibid.

86 Ibid. $525 . \quad 87$ Ibid. 2643.

88 E.R.O., D/DP M $1129-30$.

89 Geneal. Coll. of R.C. Families, p. 44 For Wm. Petre (1602-77) see D.N.B. He translated (1669) the Flos Sanctorum of the Jesuit Pedro de Ribadeneira.

90 E.R.O., D/DSd T19; Geneal. Coll. of R.C. Families, P. 44; H. Foley, Recs. of Eng. Province of Soc. of Fesus, ii, $5^{85}$. 9I E.R.O., D/DSd TI9. There were other portions provided for the younger sons of William Petre the younger.
} 


\section{A HISTORY OF ESSEX}

William Petre the elder died in 1728.92 In 1737 his son William handed over the administration of the Stanford Rivers estate to his kinsman Robert, Baron Petre (d. 1742).93 An account book for the years $173^{8-44}$ shows that the estate (which also included the manors of Stanford Hall, Traceys, and Bellhouse, for which see below) had a rent roll of slightly over $f_{1}, 000$ a year, out of which William Petre was allowed $£_{350}$ tax free.94 William died in 1745.95 His heir was John Petre, son of his brother Edward. Shortly before William's death John, who was under age, had been given into William's care by his grandfather and previous guardian William Keep. After William Petre's death John was sent by his aunt, Lady Mary Petre, to Douai to be educated as a Roman Catholic. William Keep thereupon started an action in Chancery to regain custody of the boy. An order was made to this effect but was defied by Lady Mary. In 1747 a receiver was appointed in Chancery to administer the Stanford Rivers estate. 96 John Petre probably assumed control soon after this, for he was said to have been eighteen years old in 1745.97

John Petre died in 1762. In 1759, on his marriage to Frances Manby, he had provided that if he had no sons his estates should pass to Robert, Baron Petre (d. 1801 ), in trust for Lord Petre's second son, if one should be born to him. ${ }^{98}$ Provision was made for any daughters left by John Petre. In the event he left only one, Catherine, who became entitled on his death to a jointure of 64,000 from his estate. 99

From 1762 to 1775 the Stanford Rivers estate was administered by a steward acting for John Tempest, executor of John Petre's will. The estate accounts for this period show that the rent roll was still about $f_{0}, 000$ a year. ${ }^{1}$ Most of the income, and in some years all of it, was taken up by expenses and the payment of annuities. Catherine Petre, whose jointure of 64,000 remained in the estate, received interest at the rate of $f_{1} 60$ a year. Susan Petre, sister of John, similarly received $\delta_{11} 20$ a year as interest on a jointure of $£ 3,000$, and John Petre's widow drew $£ 300$ a year from the estate. By 1774 there was $\oint_{905}$ in hand on the running of the estate, but most of this was accounted for by the fact that the annuities had for some reason not been paid in 1772 . During the period covered by the accounts the whole estate was leased to various farmers and smallholders. ${ }^{2}$

In 1775 John Tempest conveyed the estate to Lord Petre as guardian of his second son George William Petre. ${ }^{3}$ In 1791 the estate was found to be encumbered to the extent of 69,750 : in addition to the jointures of Catherine and Susan Petre a mortgage of $\{2,750$ had been raised from a William Plumer.4 In 1793 a further mortgage of $\oint_{1} 0,000$ was raised from Thomas Heron of Chilham Castle, Kent. 5 In 1796 part of the estate (evidently Stanford Hall, for which see below) was sold to Charles Smith of Suttons in Stapleford Tawney (q.v.) for $£ 7,650 .^{6}$ George William Petre died in 1797, leaving George Petre his son and heir.7

In 1819 the remainder of the Stanford Rivers estate, including the manorial rights, was bought from George Petre for $£ 25,280$ by Judith Smith of Stratford, Essex, who was probably sister of the above mentioned Charles Smith of Suttons. ${ }^{8}$ Judith was lady of the manor up to 1830 ; in and after 1833 the lordship (and presumably the estate) had passed to Charles Joshua Smith, Bt. (d. 1831), son and heir of Charles Smith of Suttons. ${ }^{9}$ The subsequent descent was the same as that of Suttons. ${ }^{10}$

When Judith Smith bought the estate she found it encumbered with a fee-farm rent of 645 . Inquiries into the title showed that this rent had been granted by Charles II in 1672 to Sir John Banks, Ist (and only) Bt. of Aylesford, Kent. From this it seems probable that the rent had been reserved when the estate was granted by James I to Cartwright and Cowley in 1613." The rent passed on the death of Banks in 1699 to his daughter Mary, wife of Sir John Savile. Elizabeth (d. 1767), daughter and heir of Mary, married John Finch and the rent passed to her son Savile Finch (d. 1788) and subsequently to Judith, widow of Savile. By her will (1802) Judith Finch left the rent to her brother Weston Fullerton, who by his will (proved 1 819 ) left it to his nephew John Fullerton. In 1826 Judith Smith bought the rent. ${ }^{12}$

In 1412 the manor of $S T A N F O R D H A L L$, worth E.20, was held by Nicholas Bradshagh. ${ }^{13}$ It is likely that this manor was the demesne of the manor of Stanford Rivers, and that Bradshagh was merely the life tenant of the Earl of Stafford. In the later court rolls of the Stanford Rivers estate there is no mention of a manor of Stanford Hall, whereas Traceys and Bellhouse (see below) were both described as manors. Bradshagh died in 1415.14 There is no other mention of him or his family in connexion with Stanford Rivers, and it is probably significant that he had held a Northamptonshire manor for life of the Earl of Stafford. 1s

There is no further mention of Stanford Hall until 1543, when the king granted to William Grene of London 'the manor and farm of Stanford Hall, parcel of the manor of Stanford Rivers .... in the tenure of 'Thomas Grene', to hold for 2 I years at a rent of £26 13s. 4d.16 In 1548 Stanford Hall, along with the other manors formerly included in the Duke of Buckingham's estate, was in the possession of Princess Mary. ${ }^{17}$ In 1557 it was merged as part of the estate in the Duchy of Lancaster. ${ }^{18}$ After this its descent was the same as that of the manor of Stanford Rivers until I 796 when it was sold to Charles Smith of Suttons. ${ }^{19}$ If it was reunited with the main estate after the death of Judith Smith it had again been severed from it by

\footnotetext{
92 Geneal. Coll. of R.C. Families, p. 44.

3 E.R.O., D/DP A32.

94 Ibid.

os E.R.O., D/DSd Trg.

96 E.R.O., D/DP L5.

97 E.R.O., D/DSd TIg. His aunt was , idently successful in educating him as a Roman Catholic: cf. E.R.O., Q/RRp $3 / 13$.

98 E.R.O., D/DSd Trg.

99 Ibid.

1 E.R.O., D/DP A34/1. The receipts varied from 6988 in 1762 to $£_{6} 1,252$ in 1766.

a Ibid. Cf. E.R.O., D/DP $A_{33} / x$.
}

3 E.R.O., D/DSd Tig.

4 Ibid.

5 Ibid.

- Ibid.

7 Ibid.

8 Ibid. For Charles Smith see Burke, Peerage (1 $8 \mathrm{gI}$ ), pp. I 265,1267 . He was son of Chas. Smith of Stratford (d. 1777), a writer on the corn laws.

- E.R.O., D/DTe M3.

10 In 1842 the Stanford Rivers section of the estate was about 1,350 acres.

II E.R.O., D/DSd T2O. Originally the rent had consisted of sums amounting in all to $\delta_{0} 86 \mathrm{~s}, 8 d$. in Stanford Rivers and $f_{0} 13$ 6s. 8d. in Suttons in Stapleford Tawney. See below, Manors of Stanford Hall, Traceys and Bridges.

12 John Fullerton retained rent of about f. 16 on land in the parish held by $\mathrm{Capel}$ Cure. For the manor courts see below, Parish Govt. and Poor Relief.

13 Feud. Aids, vi, 443.

14 Cal. Pat. $1413-16,357,380$

Is Ibid. 380 .

16 L. \& $P$. Hen. VIII, xviii (2), p. 60

For Thomas Grene see below, Bellhouse.

17 Cal. Pat. I 548-9, 21.

18 Ibid. $1557-8,50$.

19 See above, manor of Stanford Rivers. 
I 842 when it was owned by Thomas Wilson and occupied by Maria King and Hannah Andrews. ${ }^{20}$

In 16 I 3 the tenant of the 'manor or farm' of Stanford Hall was Thomas Lake. ${ }^{21}$ In 1672 this section of the estate was burdened with a fee-farm rent of 626 I 3s. $4 d$., the exact amount paid by William Grene after I 543.22 The tenant of Stanford Hall farm in and immediately after 1745 was William Keep, whose daughter Sarah married Edward Petre and was the mother of John Petre (d. 1762).23. In I768-73 Stanford Hall farm, with Crumpscroft and Fresholts, consisted of 298 acres and was leased to Matthew Playle for $\oint_{0} 160$ a year gross. Land-tax and the cost of repairs were deducted from the rent and in 1768 Playle paid fi 29 to his landlord. ${ }^{24}$ Stanford Hall farm was purchased in 1945 by the London Co-operative Society Ltd. It now includes Little Colemans and contains in all 579 acres. Mixed arable and dairy farming is carried on. ${ }^{25}$

The present farm-house of Stanford Hall dates from the early I gth century. It is a square two-story building of red brick with sash windows and a pedimented doorcase. A two-story splayed bay, now cement rendered, on the east side may be of somewhat earlier date.

The manor of $B A R W I C K S$ (the modern Berwick Farm) probably originated in a free tenement which in I 257 was held by Richard de Berewyk of Roger de Saumford and Joan his wife. In that year Richard undertook to pay Roger and Joan an annual rent of $2 s$. and acknowledged the service of $\frac{1}{6}$ knight's fee. Roger and Joan in return gave up their claim that Richard should do suit at their court at Shenley (Herts.). ${ }^{26}$ About 30 years later Alan de Berewyk and Joan his wife acquired from William de Sutton 2 messuages, 80 acres of land, 10 acres of meadow, 6 acres of pasture, 3 acres of wood, $135.4 d$. rent, and the rent of $9 \mathrm{lb}$. wax in Stanford Rivers and elsewhere. ${ }^{27}$ In I 41 I William Skrene senior, John Skrene, and John Adkyn acquired from Thomas Berewyk and Alice his wife I messuage, 400 acres of land, I 2 acres of meadow, 30 acres of wood, 2os. rent, and the rent of $9 \mathrm{lb}$. wax in Stanford Rivers and elsewhere. ${ }^{28}$ Shortly before this, in 1398 , a certain John Chartesey had acquired from Richard Spyce and Isabel his wife 2 messuages, 2 carucates of land, 20 acres of wood, and 20 acres of pasture, and 40s. rent in Stanford Rivers ${ }^{29}$ and in 1408 John Chartesey had conveyed to William Skrene the elder all his lands in the parish. ${ }^{30}$ In 1419 John Skrene made a charter of feoffment of all his lands in Stanford Rivers and elsewhere to William Skrene the younger and Alice his wife and the heirs of William. ${ }^{31}$ William Skrene the younger died in $143 \mathrm{I}$, leaving to his son John messuages in Stanford Rivers called Berwyle and Cawnes.32 John Skrene was succeeded in 1452 by his son John.33 It was not then known of whom Barwicks was held.

The last-named John Skrene died in $1474 .{ }^{34}$ His

20 E.R.O., D/CT 327

$21 \mathrm{C} 66 / 1988$.

22 E.R.O., D/DSd T2O. For the history
of the fee-farm rent see above, Stanford

Rivers manor.

23 E.R.O., D/DP L 5 .

$24 \mathrm{Ibid} . \mathrm{D} / \mathrm{DP} \mathrm{A}_{33 / \mathrm{s}}$

23 Inf. from London Co-op. Soc.

26 Feet of $F$. Essex, i, $22 \mathrm{~J}$.

27 Ibid. ii, 236. This is from the note of

a fine.

29 Ibid. 231.

28 Ibid. iii, 255

30 Cal. Close, $1405-9,390$

31 Ibid. $1459-22,55$.

widow Elizabeth later married Richard Harper, and Barwicks seems to have passed through her to Richard (d. 1492), his son Richard Harper (d. 1507), and to George Harper, son of Richard Harper junior. ${ }^{35}$ 'The next reference to Barwick is in I 594, when the manor was in the possession of Richard Elliott and Elizabeth his wife. ${ }^{36}$ Thomas Elliott held the manor in 1612.37 He was knighted in $1615^{38}$ and in 1619 bought the manor of Stanford Rivers (see above). From this time onwards Barwicks was merged in the Stanford Rivers estate. In the court rolls of the estate for the $17^{\text {th }}$ century it is referred to as a manor. ${ }^{39}$

In I768 'Barwicks and Wallers', part of the Bellhouse estate, were leased to a Mr. Watkinson for $\oint_{0} \mathrm{I} 60$ gross. There were so many repairs in that year that Watkinson actually paid only 6.73 .40 In 1842 the farm contained 252 acres. 41

The present farm-house is partly of timber framing and partly of brick. It appears to have been rebuilt or largely altered in the late 18 th or early I gth century. The front, which may formerly have had a parapet, has pointed casements in the 'gothick' style. 'The detail of the present gables is mid or late I gth century. The fine ilex tree in front of the house may have been planted at the time of the alterations. It is said that at one time most of the farms belonging to the Suttons estate had these ilex trees. ${ }^{42}$

The manor of BELLHOUSE was held as of that of Stanford Rivers. In I 453 Thomas Thorp quitclaimed to Thomas Burgoyn and John Croke a piece of ground in Stanford Rivers called the 'Belhous' and all other lands which Thorp and Burgoyn held by feoffment of Robert Fonteyns. ${ }^{43}$

Elizabeth wife of Sir Thomas Coke, Kt., died in 1484 holding the manor of 'Belhows' in Stanford Rivers as the heir of her father Philip Malpas, citizen and draper of London.44 Bellhouse passed by settlement to John Coke, a younger son of Elizabeth, who died in 1486.45

Thomas Grene, yeoman, was evidently owner of Bellhouse in 1534, when he devised a rent from the manor for the support of a stipendiary priest. ${ }^{46}$ Grene's will was proved in 1537.47 The next reference to Bellhouse is in 1562 , when it was held by Richard Elliott. 48 This was possibly the same Richard Elliott who held it and the manor of Barwicks in 1594.49 Bellhouse subsequently descended with Barwicks and in 1623 was merged in the Petre estate of Stanford Rivers. The Petres themselves lived at Bellhouse and evidently had a small demesne farm there. After the death of John Petre in 1762 the house and farm, covering $\mathrm{IO}_{3}$ acres, were let to William Colegrave at a gross rent of $£ 85$. In 1768 Colegrave paid $£ 7$ I after deductions for land-tax.50 In 1777 Bellhouse was a small mansion with an avenue of trees running from it to the main road and another avenue running south to Murrells.51

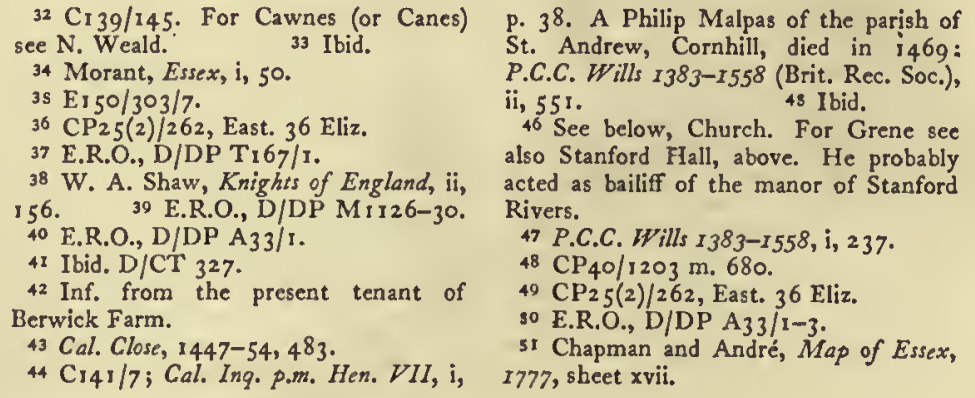

p. 38. A Philip Malpas of the parish of St. Andrew, Cornhill, died in 3469 : P.C.C. Wills 1383-1558 (Brit. Rec. Soc.), ii, $55 \mathrm{I}$. 43 Ibid.

46 See below, Church. For Grene see also Stanford Flall, above. He probably acted as bailiff of the manor of Stanford Rivers.

17 P.C.C. Wills $1383-1558, \mathrm{i}, 237$.

$48 \mathrm{CP}_{4} \mathrm{O} / \mathrm{s}_{2} \mathrm{O}_{3} \mathrm{~m} .680$.

$49 \mathrm{CP}_{2} 5(2) / 262$, East. 36 Eliz.

so E.R.O., D/DP A3 $3 / 1-3$

st Chapman and André, Map of Essex, 1777 , sheet $x$ vii. 


\section{A HISTORY OF ESSEX}

After Judith, Smith bought the Bellhouse estate she had the house repaired, but there is no evidence that she herself lived there. ${ }^{52}$ In $1839-42$ the farm was let to John Gingell and consisted of 106 acres. 53 The house is shown on the tithe map but the avenues of trees no longer existed.54 The house was probably pulled down soon after this, for it is not shown on the $\mathrm{I}$ in. Ordnance Survey map of $\mathrm{r} 843$. A few planted trees, including a cedar, now mark the site of the garden and some depressions in the field may indicate the line of a moat. There are also two large rectangular ponds near the site.

The manor or manors of BRIDGES and PIGGS$L A N D$, alias BRIDGES, PIGGSLAND, and $B O T E L E R S$, was held as part of the manor of Stanford Rivers. Bridges was probably the home of John atte Brigge (1 326) ${ }^{55}$ and William atte Bregge (1398).56 As late as 1843 it was marked on the map as Bridge House Farm.s7 Modern maps show it as Wash Farm but the earlier name Bridge Farm is still used locally. Piggsland was probably the tenement of Walter Pig ( $138 \mathrm{r}$ ). ${ }^{8}$ Its name survives in Pig Mead. Botelers has not been identified on the modern map.

Sir Hugh Stafford, Kt., brother of Edmund, Earl of Stafford, died in 1420 holding Piggsland of John Chambir. It comprised 46 acres of land, 5 acres of meadow, and 9 acres of pasture. He also held Botelers, comprising 40 acres of land and meadow, of the Abbot of Waltham.59 'The property passed on Hugh's death to Humphrey, Earl of Stafford, by virtue of a previous settlement. ${ }^{60}$ In $1446-7$ the manors of 'Pigges, Briggesland and Botteless' were together farmed by William Tyng for $6.6 .^{61}$

John, Earl of Wiltshire, died in 1473 holding the manors of 'Pyggeslond, Botelles and Brigges'.62 John's widow Constance, who died in 1475 , was found to have held the manor of Bridges and messuages called Piggsland and Botleys, of the king in chief. ${ }^{63}$

The manor subsequently descended along with that of Stanford Rivers. In 1543 it was leased, under the name of 'the manor or farm called Brygges and Piggeslande' to John Glascock of Stanford Rivers for 2 I years at an annual rent of $f_{0} 6 \mathrm{I} 3 s .4 d .64$ This was the exact amount of the fee-farm rent charged upon the manor as part of the Bellhouse estate in and after the 17 th century. 65

By 1798 Capel Cure had become the owner of Bridges, which comprised 93 acres and was part of the Blake Hall estate (see Bobbingworth). ${ }^{66}$ It was let to a tenant farmer and between 1798 and 1828 contained 54 acres of arable and 39 acres of pasture. ${ }^{67}$ In 1828 the farmer also occupied 200 acres belonging to another owner. In rgrg Bridge House Farm was put up for sale with other outlying portions of the Blake Hall estate. It then contained 89 acres and was let to Horace Palmer on a yearly tenancy at a rent of $f_{0} 6_{3}$ for the year ending Michaelmas 1919 and of $£_{172}$ for the year ending Michaelmas 1920.68

The manor of LITTLEBURY, alias the manors of LITTLEBURY and ROWENHO, first appears under those names in the $13^{\text {th }}$ century. Rowenho has been identified-on somewhat doubtful evidence-with Rocketts cottages. 69 It is possible that this manor may be identical with Little Stanford, which in 1066 was held by the father of Alvric (see above, Manor).

In 1260 Robert son of Michael de Munteny made a conveyance to John son of Adam of $\mathrm{r}$ carucate of land, 40s. rent and a mill in Littlebury.70

In I 288 John de Munteny sought to replevy his lands in Littlebury, which had been seized by the king for his default against John Lovel.71 In 1318 Richard de Munteny, son of John, granted to John de Chelmersford, clerk, 6 acres of land in two crofts with hedges and ditches which had formerly belonged to Gilbert le Man, and which the donor had of the gift of John de Munteny his father, lying between the demesne lands of Littlebury and the king's highway from Ongar to London.72 In 1320 Richer de Refham and his son John were tenants of all the land in Littlebury that had belonged to John de Munteny. The Refhams had acquired the tenancy from Sir John de Bensted, for whose life it was held. The annual rent was fro and this was the subject of a dispute (also in 1320 ) between the Refhams and Richard de Gatesbyry, the guardian of John, son and heir of John de Munteny. Richard had been given the wardship by Sir Arnulph de Munteny, 'the chief lord of the fee', and claimed arrears of rent from the Refhams. An agreement was eventually reached by which the arrears were remitted and the rent was reduced to $f 8$ a year. ${ }^{73}$ In 1333 Ralph [sic] de Gatesbery conveyed the manor of 'Littlebury near Ongar' to John son of John de Munteny and Margaret his wife. ${ }^{74}$ It was probably the same John de Munteny who in 1355 granted to Richard de Salyng, citizen of London, all lands which he had in Stanford Rivers. 75 'This grant was repeated by Edmund son of John de Munteny in 1369 and by Thomas son of Richard de Munteny in 1379.76

In I 398 Richard Salyng, the younger, son of John Salyng of Stanford Rivers, granted to Master Richard Salyng, mason and citizen of London, and Lore his wife the manors of Littlebury and Rowenho. The purpose of the grant was apparently to settle the remainder of the manors upon the children, bastard as well as legitimate, of Master Richard.77 By 1405 Master Richard had died and his widow had married John Bromhale who held Littlebury and Rowenho in her right. ${ }^{78}$ In that year it was provided that the two manors should be held by John Bromhale and Lore and the heirs of the body of Lore by Richard Salyng, with remainders as to the manor of Littlebury to John son of Richard, Richard Salyng, bastard son of Richard

\footnotetext{
52 E.R.O., D/DSd F 3 .

33 E.R.O., D/CT 327 .

54 Ibid.

53 P.N. Essex (E.P.N.S.), 78

36 Cal. Close, $1396-9,417$.

57 O.S. I in Map (1 843).

s8 P.N. Essex (E.P.N.S.), 604

so $\mathrm{Cr}_{3} 8 / 61$. For Sir Hugh Stafford see

also Traceys, below. Chambir was probably the Chaumbir of Epping who held Littlebury (see below)

$60 \mathrm{CI}_{3} 8 / 6 \mathrm{r}$.

61 E.R.O., D/DP $\mathrm{M}_{582}$.

$62 \mathrm{C}_{140 / 43}$. The earl was said to hold of the Abbot of Waltham.
}

\section{${ }_{63} \mathrm{Cr}_{4}$ o/ 54.}

64 L. \& P. Hen. VIII, xviii (2), p. 60.

65 E.R.O., D/DSd T2O. For the descent of the rent see above, Stanford Rivers manor.

66 E.R.O., D/DCe E6 (Blake Hall estate notebook).

67 Ibid.

68 Sale Cat. I9I9.

69 P.N. Essex (E.P.N.S.), 79-80. The identification is based mainly upon an intermediate form Rockenhoe given by Morant. This form has been found nowhere else. Rockett's cottages first appear under that name in the first ed. 6 in. O.S.


de Munteny and Richard de Salyng see also Myles's in Kelvedon Hatch.

76 Ibid. I 369-74, 88; $1377-81,32$ I. 72 Ibid. I 396-9, 416-1 7.

78 Feet of $F$. Essex, iii, 243-4. For the will of Ricd. Salyng, proved in 1404, see below, Church 
and the heirs male of their bodies, and the right heirs of Lore, and as to the manor of Rowenho to Richard Salyng the bastard and John son of Richard and the heirs male of their bodies and the right heirs of Lore. ${ }^{79}$

John Chaumbir of Epping held the manor of Littlebury in 1412 , when it was said to be worth $£ 20.80$ In 1424 Chaumbir remitted to William Beauchamp of London all his right in the manors of Littlebury and Rowenho.81 Chaumbir and Beauchamp were probably tenants under the Salyngs, for in 1468-9 John Salyng held the manors 82 and in 1469-70 Roger Salyng of Merton (Surr.) and his sons John Salyng of Stanford Rivers and John Salyng of Merton made a conveyance of Littlebury and Rowenho. ${ }^{83}$

Richard Salyng, who died in 1528 , was said to hold Littlebury and Rowenho of the queen as of her manor of Ansty (Herts.), parcel of the honor of Clare. ${ }^{84} \mathrm{His}$ son and heir Augustine Salyng died in 1546, leaving an infant daughter Alice. ${ }^{85}$ Augustine had mortgaged the manors in 1544 to Sir Richard Rich. ${ }^{86}$ In 1547 the wardship of Alice Salyng was given to William Morris, together with an annuity of $£ 76 \mathrm{~s} .8 \mathrm{~d}$. from the issues of Littlebury and Rowenho. ${ }^{87}$ Alice died in 1551 and the manors passed to her aunts, daughters of Richard Salyng: Elizabeth Rolfe and Katherine Johnson. ${ }^{88}$ In 1553 the manors were conveyed by Elizabeth and her husband William Rolfe and Katherine and her husband George Johnson to Robert Geyre and John Poley. ${ }^{89}$ The purpose of this conveyance is not clear, but it may have been part of the procedure necessary for securing Littlebury and Rowenho upon William Atwood, who was the second husband of Alice widow of Augustine Salyng. ${ }^{90}$

William Atwood died in 1600 holding Littlebury and Rowenho of Sir Henry Cocke as of his manor of Ansty. 91 In 1594 the manors had been settled upon John Atwood, son of William, on John's marriage to Dorothy daughter of William Walter of Wimbledon.92 John Atwood was succeeded by his son William, from whom the estate passed to his son, another William, who was alive at the time of the Essex Visitation of 1664-8.93 In I70 I William Atwood, probably the son of the previous William, and Anne Atwood, widow, conveyed Littlebury to John Bull.94 A Mrs. Bull held the estate in 1729.95

The Littlebury estate of the Atwoods was subsequently divided. In 1767 a dispute arose between John Tempest, executor of John Petre, and acting lord of the manor of Stanford Rivers, and Timothy Graves of Littlebury, whose wife was the daughter of Mrs. Bull.96 The dispute concerned manorial rights in Littlebury, which Graves claimed as his own. The depositions in the case show that the Atwoods' estate had lain along both sides of the main road and that Graves held only the part to the east, the part to the west having become the property of a $\mathrm{Mr}$. Jones. The outcome of the dispute is not clear, but Timothy Graves continued to deny that Littlebury was part of the manor of Stanford Rivers, and a few years later, when Lord Petre was administering the Bellhouse estate, there was another quarrel, over fishing rights, -in the course of which Graves pushed one of Lord Petre's servants into the Roding. ${ }^{97}$

In $18 \mathrm{II}$ Joseph Waylet conveyed to Timothy Phillips the manor of Littlebury, with ' 6 messuages, 2 mills, I dovehouse, 4 barns, 4 stables, 4 orchards, 100 acres of land, roo acres of meadow, 50 acres of pasture, 50 acres of wood, 20 acres of land covered by water and common of pasture for all cattle.' 98 In 1842 the owner of Littlebury was J. Kynaston and the tenant E. Phillips. The farm consisted of I I 3 acres. 99

The older part of Littlebury Hall is of late-16thcentury date and is of brick with an upper story of timber framing. It is T-shaped, the long arm of the T having two original windows with moulded brick jambs and hood-moulds, a moulded oak door-frame, and some original glass. The cross-wing to the north was refronted in the late I 8 th or early I 9 th century and has a Georgian doorcase flanked by two wide bay windows. Internally there is some I6th-century panelling and moulded woodwork. In the middle of the I gth century it was said of Littlebury Hall that more than 20 rooms had been taken down in living memory. ${ }^{I}$ In 192 I foundations were observed to the east of the house, showing that it was at one time of greater extent. ${ }^{2}$ For Littlebury Mill see above, p. 210.

The manor of TRAGEYS seems originally to have been held in chief, but from the middle of the $14^{\text {th }}$ century was treated as being held of the manor of Stanford Rivers.

In 1268 John de Tracy and Margery his wife conveyed to William de Tracy I messuage and I virgate of land in Stanford Rivers, to hold of John and Margery and the heirs of Margery at a nominal rent. ${ }^{3}$ In I 3 I 5 Hugh de Tracy and Agnes his sister conveyed to Margery de Tracy I messuage, I carucate of land, 25 acres of meadow, 50 acres of wood, 40 acres of pasture, and 50 s. rent in Stanford Rivers. 4 In 1325 a settlement was made securing to Margery de Tracy the life interest in 1 messuage, 360 acres of land, 25 acres of meadow, 50 acres of wood, 40 acres of pasture, and 50s. rent in Stanford Rivers and pasture for 14 cows and 14 heifers in the great park of Ongar. 5 There was to be remainder to Thomas de Tracy and Mabel his wife and the right heirs of Thomas. By I 335 both Margery and Thomas had evidently died, for in that year the king granted to Mabel Fitzwaryn, damsel of Queen Philippa, custody of the lands in Stanford, Rivers belonging to the heir of Thomas de Tracy tenant in chief. ${ }^{6}$ The heir was James de Tracy, 'who made proof of age in 1348.7 It is not unlikely that he died in the Black Death, for in 1353 Thomas de Tracy his son died seised of a tenement in Stanford Rivers called Tracy, said to be held of the Earl of Stafford by the service of a pair of spurs or $6 d$. and by the rent of I lb. pepper yearly at the earl's manor of Stanford Rivers. 8 The heir of Thomas was his kinsman Hugh de Tracy, chaplain.

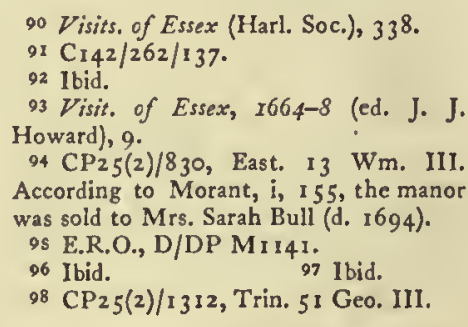

99 E.R.O., D/CT 327

MS. Hist. of Stanford Rivers by Revd. H. Tattam, D.D., rector I $850-68$, in keeping of the present rector.

2 Hist. Mon. Com. Essex, i, 221.

3 Feet of $F$. Essex, i, 266.

4 Ibid. $\mathrm{ii}, 158$.

5 Ibid. 217.

6 Cal. Pat. 1334-8, 97 .

7 Cal. Inq. p.m. ix, p. 138

8 Ibid. $x$, p. 74 . 


\section{A HISTORY OF ESSEX}

Traceys was one of the manors quitclaimed by John son of John de Rivers to the Earl of Stafford in $1359.9^{9}$ There is no mention of any member of the Tracy family after this date and it is probable that their manor escheated to the Earl of Stafford. The manor was held in 1412 by Nicholas Bradshagh (see Stanford Hall, above) and was valued at 620.10 In 1420 Traceys (like Piggsland, see above) was among the possessions left by Sir Hugh Stafford at his death. He had held Traceys for life of the Earl of Stafford, to whom it then reverted. It comprised 100 acres of land, ro acres of meadow, and 16 acres of pasture. ${ }^{11}$

The manor subsequently followed the descent of that of Stanford Rivers, although it was sometimes leased separately. In I 535 the court of the manor of Traceys was being held in the name of Mary, Lady Cary, widow. ${ }^{12}$ In 1543 a 2 I-year lease of Traceys was granted to Richard Elliott (see Barwicks, above) at an annual rent of $\delta 15 .^{13}$ In 1738 William Petre leased Traceys to John Shuttleworth for 21 years at an annual rent of $£_{15} 6$, from which $£_{042}$ was to be deducted for land tax and $f_{1} 10$ for repairs. ${ }^{14}$ In 1768 Shuttleworth was still the tenant, at the same rent. ${ }^{15}$ At the time of the tithe award (1842) John Palmer was the tenant, farming 163 acres. ${ }^{16}$

In and after the 17 th century the manor of Traceys was subject to a fee-farm rent of $\oint_{0} 15 .^{17}$

The present farm-house of 'Traceys appears to date from the late 18 th or early I 9 th century. Traces of the moat remain, both in front of the house and at the north-west corner.

The advowson of Stanford Rivers was acquired soon after the Norman Conquest by the priory CHURCH of Rumilly-le-Comte, which probably had it from Eustace, Count of Boulogne. ${ }^{18}$

The history of the advowson down to the I 4 th century is treated under High Ongar (q.v.) where reasons are given for supposing that about 1280 the parish of Stanford Rivers was doubled by the transfer to it of part of High Ongar. In and after the I 4 th century the advowson of Stanford Rivers, like that of High Ongar, was held by the king until I 538 . In that year, when the advowson of High Ongar was granted to Sir Richard Rich, that of Stanford Rivers was retained by the king. The advowson of Stanford Rivers was no doubt annexed to the Duchy of Lancaster at the same time as the manor and since the reign of Elizabeth I presentations have been made by the Chancellor of the Duchy. ${ }^{19}$

In about 1254 the rectory of Stanford Rivers was valued at 20 marks. ${ }^{20}$ In 1291,1428 , and I 535 the value was returned as 26 $^{2}$ I3s. 4 d. $^{21}$ At the tithecommutation in 1842 the total income of the rector from tithe rents was fixed at $f_{0} 1,038.22$ There were 54 acres of glebe. Land tax chargeable upon the rectory, rectorial tithes, and glebe had been redeemed in 1803 by a payment of $£_{1}, 173.23$

In I 534 Thomas Grene devised a rent of $f_{0} 6$ I $3 s .4 d$. out of the manor of Bellhouse (see above) for the support of a chantry priest who was to serve annually in the church of Stanford Rivers for 20 years after Grene's death. Grene's will was proved three years later. 'The stipendiary was being employed in $154^{8}$ when the chantries were dissolved. ${ }^{24}$

Another endowment, for an 'anniversary' in the church, consisted of ros. rent from land in Stanford Rivers called Knyghtes. In I 549 this rent was granted by the king to Henry Codenham, and William Pendred, citizen and founder, both of London.25 William Shelton, by his will proved I 552-3, left money to the parish for the payment of forgotten tithes. 26

As a valuable Crown living Stanford Rivers has been held by a number of rectors of distinction. Thomas Cole (d. 1571), one of the Puritans who emigrated to Frankfort-on-the-Main under Mary I, was rector after the accession of Elizabeth 1.27 Richard Vaughan (1550?-1607), who became rector in 1 594, was later Bishop successively of Bangor, Chester, and London. ${ }^{28}$ Richard Montagu (1577-164I), controversialist, Bishop of Chichester (1628) and of Norwich (1638), was rector from 1613 to 1628.29 Although he was a pluralist his favourite residence is said to have been at Stanford Rivers. After he resigned the living an attempt was made to secure it for Peter Delauney, preacher to the French congregation in Norwich: it was stated that this had been promised by James I to reward Delauney for translating the English liturgy into French. ${ }^{30}$ The rectory was, however, given to Roger Mainwaring, one of the chaplains of Charles $1 .{ }^{31}$ Mainwaring became Bishop of St. Davids in $1635 .{ }^{32}$ Henry Tattam (1789-1868), who became rector in I $85^{\circ}$, was a distinguished Coptic scholar and chaplain to the queen. ${ }^{33}$

The parish church of $S T$. MARGARET consists of nave, chancel, north porch (blocked), west porch, south vestry, and a west bell-turret with spire. There is a gallery beneath the turret. The walls are mostly of flint rubble with dressings of clunch and other stone. The upper part of the chancel is of brick. The church is faced externally with Roman cement. The roof is tiled.

The nave was built in the middle of the 12 th century. The original semicircular arch of the south doorway can still be seen internally. Both north and south walls have two single-light round-headed windows of the I 2 th century, but in each case those nearest the west end have been blocked and are only visible from the outside. There is a similar blocked window in the west gable with exposed flintwork surrounding it. During the first half of the $14^{\text {th }}$ century two threelight windows were inserted near the east end of the nave, one on the north and one on the south side. These probably replaced small I ath-century lights, which suggests an original arrangement of three windows to each wall. On the east splays of the two I 4 th-century windows wall-paintings, probably con-
- B.M. Harl. Chart. 55D. 3 I.

10 Feud. Aids, vi, 443 .

if $\mathrm{C}_{3} 8 / 61$.

12 E.R.O., D/DP MII26. See above, Manor of Stanford Rivers.

13 L. E P. Hen. VIII, xviii (2), p. 60

14 E.R.O., D/DP MiI42.

is E.R.O., D/DP A33/1-3.

16 E.R.O., D/CT 327.

17 For the descent of this rent see Stanford Rivers manor, above.

18 V.C.H. Essex, i, 344. The priory probably obtained it early in the 12 th cent. : E. $A . T$. N.s. viii, 227.

is Newcourt, Repert. ii, 546-7; Morant,

Essex, i, 155; Crockford's Cler. Dir. passim.

20 Lunt, Val. of Norwich, 336.

21 Tax. Eccl. (Rec. Com.), $21 b$; Feud.

Aids, ii, 205; Valor Eccl. (Rec. Com.)

$4376 . \quad 22$ E.R.O., D/CT 327.

${ }_{23}$ E.R.O., D/DSd Ti7. The tax had amounted to 632 a year.

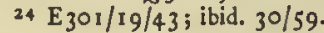

25 Cal. Pat. I 549-5 I, 146. Cf. Thomas Petit's legacy, Charities, below.

26 E. $A . T$. N.s. vii, 167.

27 D.N.B. He was rector $1564-7 \mathrm{I}$. Previously Rector of High Ongar. 28 D.N.B.

29 Ibid.; V.C.H. Essex, ii, 49.

30 Cal. S.P. Dom. I 628-9, 188.

31 Ibid. 217

32 D.N.B. (Manwaring). He was rector until I 64 I

33 D.N.B. Rector until his death. 
temporary, were visible until recently. These consisted of figures under gabled and crocketed canopies with shields of arms above. ${ }^{34}$

The present chancel also dates from the first half of the 14th century. On its north side there is a contemporary window consisting of two trefoil and ogeeheaded traceried lights. The south wall has two similar windows with a blocked doorway, probably of the same date, between them.

Richard Salyng, by his will proved in 1404 , made a bequest for the remaking of the rood loft, and provided that if he died at Stanford Rivers he should be buried in the church beside the monument to his late wife Alice. ${ }^{35}$ Late in the 15 th century the north porch was built. It is of timber and is of a type common in Essex. Many of the original timbers remain. The external arch, now blocked, is four-centred with trefoil carved spandrels, and the panels flanking it have traceried heads. It is now used as a store. The south porch, now the vestry, was probably similar. The timber-framed bell-turret was probably built in the I 5 th century. It was inserted in the westernmost bay of the nave. The massive angle-posts are stop-chamfered near floor level. The turret is weather-boarded and is surmounted by a small lead-covered spire. The roof of the nave also dates from the 15 th century. It has three trusses with rebated king-posts and four-way struts. The timbers between the trusses were exposed during the restorations in $195 \mathrm{I}$.

In the $15^{\text {th }}$ century, or early in the I6th, a wide three-light window with a segmental pointed head was inserted in the south wall of the chancel. This was later plastered over, but during the restorations of $194^{8-52}$ it was opened up and glazed and the stonework was renewed. Early in the 16th century the roof level of the chancel was raised, the walls were built up in brickwork and three segmental-headed clerestory windox's were inserted in both north and south walls. This curious arrangement may have been the preliminary to a general raising of the wall height, never carried out. The chancel arch was probably destroyed at this time, giving the present awkward junction between chancel and nave roofs. The chancel roof has curved and moulded principals and is of the early I 6 th century. The timbers between the trusses were exposed in $195 \mathrm{I}$.

At the archdeacon's visitation of 1606 the churchwardens.stated that the chancel was out of repair, both glass and stonework of the windows being broken, and the walls dirty. ${ }^{36}$ At another visitation in 1683 the churchwardens were ordered to mend both the church porches, the crack on the north side of the steeple, and the tiling towards the lower end of the church. 37 A small scratched sundial on the external jamb of the I4th-century window in the south wall of the nave probably dates from the $I 7$ th century.

In 1817 important repairs and.alterations were carried out at a total cost of about $£ 350.38$ These included the opening of the present west entrance and probably also the conversion of the south porch into a vestry, the building of the gallery, and the insertion of the present east window in the chancel. The west porch is open and of oak. It has a segmental pointed arch and pierced spandrels. The window above it is three-light with a segmental head and a wide architrave of wood. The gallery incorporates panels from a $15^{\text {th- }}$ century chancel screen. All this work was carried out by Richard Noble of Ongar under the direction of a surveyor named Foottit.

In 1944 a flying bomb damaged the south side of the church. Restoration was carried out between I 948 and 1952.39 During that period the gallery was converted into a small parish room by the fixing of a temporary partition to the front.

In 1552 there were three belis in the steeple 'of which the great bell contains I yard deep lacking 3 inches, the second bell $2 \mathrm{ft}$. 3 ins., the breadth I yd. I in., the third bell $2 \mathrm{ft}$. 3 in., and the breadth I yd. lacking 2 ins.' 40 There were also a handbell, a sanctus bell, and two sacring bells.4 There are at present two bells in the steeple, one cast by Joseph Carter in 1609, the other by Anthony Bartlet in 1662; one of these was damaged in 1944 and is no longer in use.42 The third bell appears to have been sold in 1806 and the money applied towards repairs to the steeple. 43

The early-1 3 th-century font is of Barnack stone, the octagonal bowl having sunk panels with pointed heads and the stem having eight detached shafts. There are sixteen I 5 th-century oak benches near the west end of the nave, the ends being carved with small buttresses. The communion rails have turned balusters of the late I 7 th century. They were no doubt erected as a result of the archdeacon's visitation of 1683 , when it was ordered that the communion table should be railed in. 44 The wrought-iron-work supporting the altar lamp is apparently of early-I 8 th-century date and came from Suttons in Stapleford Tawney.4s The stained glass in the east window was inserted in 1952 in memory of H. W. Millbank (d. I950). 'The electric heating was installed in 1952 . The church plate consists of a silver flagon, paten, and chalice of I 812 , presented by the Revd. E. C. Dowdeswell. 46 In 1552 there were three chalices of silver, one being partly gilt. There was delivered for service use one silver chalice. ${ }^{47}$

There are a few details of the church furnishings in past centuries. Richard Ballard, by his will proved in I 526 , left money for the 'gilding of oon of the tabernacles'.48 'The image of the Assumption of Our Lady, in the chancel of the church, is mentioned in a will of I 537.49 In 1636 f I Ios. was paid for painting the royal arms and whitewashing the church.50 In 165 I the arms of the Commonwealth were substituted for those of the king; this and the setting up of the Ten Commandments cost $f_{1}$ I 85.51 In 1660 the royal arms were again set up, at a cost of $\oint_{0} 155.52$

On the north wall of the chancel is an inscribed brass to Thomas Grene ( 1535 ) and his two wives. In his will (proved 1 537) Grene gave instructions that he was to be buried in the chancel before the image of the Assumption of Our Lady, or in the chancel of the
34 Cf. Hist, Mon. Com, Essex, ii, $22 \mathrm{I}$. This zccount mentions only the traces of painting on the south window; there are still traces on the north.

35 E.A.T. N.s. vii, 167. For Salyng see Littlebury, above.

36 V.C.H. Essex, ii, 46.

37 E.A.T. N.s. xix, 272.

38 E.R.O., D/P I40/5
39 Inf. from the present rector, Revd.

J. H. Ward.

40 E.A.T. N.s. ii, 228

41 Ibid.

42 Ch. Bells Essex, 395 ; inf. from Revd.

J. H. Ward.

43 E.R.O., D/P 140/8/3. The bell was cracked and out of order.

4 E.A.T. N.s. xix, 272
45 Inf. from Revd. J. H. Ward.

46 Ibid.

47 Ch. Plate Essex, 310

48 E.A.T. N.s. vii, 167

49 Ibid.

so E.R.O., D/P 140/1/1, f. 47

31 Ibid., f. 516 .

$\$ 2$ Ibid., f. 556 . 


\section{A HISTORY OF ESSEX}

church of Cottered (Herts.). ${ }^{53}$ Also on the north wall of the chancel are white marble tablets to Charlotte Edwards (1823) and Isaac Taylor (1865). ${ }^{44}$ On the east wall of the chancel is a white marble tablet to $\mathrm{Dr}$. Charles Gibbs ( $168 \mathrm{r}$ ), and on the south wall a brass inscription to Katherine (I609) wife of Richard Mulcaster, rector of the parish. In the nave is a stone tablet to Anne, wife of William Napper ( 1584 ), bearing a brass of a kneeling woman and her six sons. On the floor of the chancel, some of them concealed below the altar, are four floor-slabs with brasses: (I) fragment of late-16th-century slab with shield of arms; (2) Thomas, infant son of Giles Greville (1492) with a figure of a Chrisom child and shield of arms; (3) Robert Borrow (1503) and Alys his wife: figures of man in plate armour and woman in pedimented head-dress with dog at their feet and shield of arms; (4) Lucy, daughter of William Petre (1637): inscription only. Also in the chancel are many floor slabs to the Petre family, ranging in date from 1677 (William son of Lord Petre) to I 797 (Hon. George William Petre).

The Berkeley Charity, for the upkeep of the graveyard of the church, is described below, under Charities.

The old rectory is a fine late-18th-century red-brick house of two stories and attics, with a one-story wing to the south-west. The entrance front has a pedimented doorcase and on the garden side there are two slightly projecting bays with pediments. The detail here and elsewhere is of $c .1780$. Parts of the moat remain to the north of the house. The glebe terrier of I6 ro describes extensive buildings which were probably on the same site.ss There appear to be no traces of these earlier buildings.

For the present rectory see below, Protestant Nonconformity.

In the $17^{\text {th }}$ century and the first half of the 18 th Roman Catholic worROMAN CATHOLICISM ship was carried on by the Petres at Bellhouse (see above). This was one of the places served by the secret Jesuit mission in eastern England which was founded about $16_{33}$ and largely financed by the Petres. 56 The first William Petre of Bellhouse was a servant of Charles I and in I6 39 the king personally intervened to prevent him from being prosecuted for recusancy. ${ }^{57}$ In 1676 there was an unusually large number of papists in Stanford Rivers. ${ }^{8}$ There was probably a private chapel at Bellhouse, 59 and Roman Catholic worship continued there until after the death of William Petre in $1745 .{ }^{60}$ The date when it finally ceased is not certain, but it is unlikely to have continued for long after the death of John Petre in 1762 .

The Petres also contributed generously to the support of Roman Catholicism elsewhere. During the reign of Charles II an annuity of $£ 40$ out of the manor of Stanford Rivers was being paid to each of two members of the family, Richard and Robert Petre, who had become Jesuits.61 In I678, however, these revenues were seized by the government. ${ }^{62}$ William
Petre (d. 1728) made settlements on at least five of his daughters who became nuns. ${ }^{63}$ His son Robert ( 1700 66) became a Jesuit. ${ }^{64}$

On 20 October 1819 a small place of worship,

\section{PROTESTANT} originally a cottage, was opened for the use of dissenNONCONFORMITY ters. Sermons were preached at the opening service by the

Revd. James Stratten of Paddington and the Revd. Edward Andrews of Walworth. A Sunday school was attached to the chapel. Arrangements had been made for the supply of preachers from Hoxton Academy. ${ }^{65}$

On 27 June I 820 a new chapel, specially built and seating 300 , was opened in place of the converted cottage. Stratten and Andrews were again the preachers at the opening. Two local residents had each contributed $f_{0} 100$ towards the cost of the chapel. Supplies were still being sent by Hoxton. 66

In 1827 the site, chapel, and vestry, with a stable and outhouses, were conveyed to trustees, among whom were Stratten, then of Maida Vale, and Thomas Kingsbury of Stanford Rivers. The trust deed stipulated that the buildings should be used for ' $a$ congregation of Protestant Dissenters usually denominated Calvinists of the Independent Denomination'.67

In 1829 the congregation numbered 150 and there was a minister, William Temple. ${ }^{68}$ There was a minister in $1846-7$ and another in $1850-3.69$ About I 839 David Livingstone preached in this chapel while a student at Chipping Ongar. He is said to have suffered from stage-fright and to have been unable to complete his sermon. ${ }^{70}$ From about 1854 the chapel was served mainly by the ministers of the Congregational church at Chipping Ongar. ${ }^{71}$ Isaac Jennings, formerly the minister at Ongar, had charge at Stanford Rivers during his retirement in 1863.72

A new trust was appointed in 1877.73 In 1904 there were 34 Sunday-school children and 2 teachers. 74 The chapel was burnt down in 1927 . To supplement the insurance money of $£_{0} 00$ a fund was raised to rebuild the chapel as a memorial to David Livingstone. The response to the appeal was disappointing, less than $£ 400$ being received, and the scheme was not carried through. 75

The chapel was a rectangular stucco building with a pedimented front.76 It stood opposite the former Ongar Union workhouse at Little End. The site is still walled and has the original cast iron early-rgthcentury gate piers.

The present rectory, formerly the Chapel House, adjoins the chapel site and may have been built in connexion with it. It was originally a small house of gault brick, probably built in the first quarter of the I 9 th century. Additions in the same style were made about 1948 .

Records of the courts of the manor of Stanford Rivers exist for the years PARISH GOVERNMENT I 324-5 and I 327-9 and $A N D$ POOR RELIEF also for $1534^{77}$ but they are continuous only from

1560.78 Between 1560 and 1624 the court met
53 E.A.T. N.s. vii, 167.

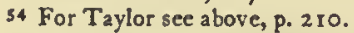

ss Newcourt, Repert. ii, 546.

$s 6 \mathrm{H}$. Foley, Recs, of Eng. Province of Soc. of Fesus, $v, 536$.

37 Cal. S.P. Dom. 1638-9, 607; ibid. $1639,427 . \quad 58$ See below, p. 311. 59 R.C. Parish of Brentwood, MS. Book (Letter of J. F. Wright, 1854).

60 See above, Manor of Stanford Rivers.

61 Cal. S.P. Dom. 1689-90, 359, 434; ibid. $1600-1,451$. For the identity of Ricd. and Robt. Petre see Foley, Recs. of Eng. Province of Soc. of 7 esus, ii, $5^{8} 5.62$ I bid. 63 See above, Manor of Stanford Rivers. 64 Folcy, Recs. of Eng. Province of Soc. of Fesus, ii, $5^{85}$.

os Evangelical Mag, xxvii, 517

66 Ibid. xxviii, 390.

67 Essex Congr. Union, Trust Deeds.

68 E.R.O., Q/CR $3 / 2$.

69 Congr. Year Bks. 1846-53.
70 E.R. xxii, 90.

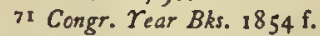

72 Ibid. 1863.

73 Essex Congr. Union, Trust Deeds.

${ }^{4}$ Congr. Year Bk. 1904.

75 Char. Com. files.

76 See plate facing p. II 3 .

$77 \mathrm{DL} 30 / 116 / 1762 ; \mathrm{SC}_{2} / 173 / 81$

78 E.R.O., D/DP M I127-40. For later court rolls (to 1923 ) see E.R.O.. D/DTc $\mathrm{M}_{3}$. 
annually, usually between July and November.79 No court appears to have met between I 624 and I 659 . The fact that constables began to be chosen by the vestry in 1637 seems to confirm that no courts leet met about this time. From 1662 courts were held regularly about Eastertide until I690.80 There was a court leet in 1710 , another in 1714, and then no more.

Twelve to seventeen men were usually sworn as a jury, the same men serving year after year. They were chosen as tenants, ${ }^{81}$ not necessarily resident within the manor. ${ }^{82}$ The jurisdiction of the court extended over all residents within the manor. ${ }^{83}$ Each court leet also transacted court baron business, and courts after 1667 , although described as 'of the View of Frank-pledge' did no true leet business except the election of constables. The primary duty of the court-to view frank-pledgewas occasionally discharged by early. Elizabethan courts. ${ }^{84}$ The immediate extension of this duty-a general surveillance of manners-frequently occupied courts about this time. ${ }^{85}$ But the commonest subjects of presentment were failures to maintain roads and bridges by those bound ratione tenure to do so. Statutory offences presented in Elizabethan courts included defaults under the first Highways Act (2 \& 3 Philip \& Mary, c. 8).86 Disrepair of the stocks was sometimes presented.

Most courts elected two constables and swore them if they were present. In I 56 I a constable was not sworn because he was absent, and this, uncommon at that date, became usual as the court declined. Of the seven appointments made after 1675 three were made in the absence of one or two of the men elected, who were ordered to take their oaths before justices. ${ }^{87}$ 'The only reference to the constables' work is their presentment for not punishing vagabonds, made in 1567 . The orders of the court were directed to the bailiff. The court had one weapon, the amercement, which was assessed or 'affeered' by two jurors appointed as 'affeerors'. It does not seem to have been very effective.

A principal cause of the decline of the court leet was the rise, chiefly as the result of the Poor Law of 1598 , of the vestry. ${ }^{88}$ In $1634-44$ five courts (one court leet and 4 courts baron) were attended by a total of 17 jurors. Of these 7 had served parish office during the same I I years. The man who served parish office most frequently ( 5 times) attended I court. The man who attended all courts served parish office 3 times.

The court and the vestry had a specific common interest-the appointment of constables-and their activities were closely co-ordinated. From ${ }^{6} 637$ con-

79 These records are not quite complete. A file of original jury presentments, draft court rolls, and miscellaneous court papers (D/DP MIr40) is stated, in the paper which begins the file, to have been assembled and handed over in lieu of certain court rolls (which were missing) upon conveyance of the manor in $16 \times 5$. Hence any statement about irregularity of meeting of the court must be suppositious : the court may have met regularly but some of its records may have perished.

80 The longest gap between courts was four years.

${ }_{81}$ e.g. D/DP M:127, 4 Apr. 1560: 2 jurors attended in right of their wives.

82 e.g. ibid. 3 Sept. 1573 : John Grene of Navestock was sworn.

83 c.g. ibid., 4 Apr. 1560 : "tenants and inhabitants of the manor.... to amend the buttes within the manor'. Cf. another stables were nominated in the vestry while courts leet were not being held. ${ }^{89}$ After 1662 the vestry appears to have nominated only when it knew that the court was not to be held for some time. When the court was to meet soon after the vestry 90 the vestrymen doubtless knew this from the bailiff's summons and did not nominate constables in the vestry. As late as 1734 constables were still being noted in the vestry book as 'chosen by Wm. Petre esq.' (lord of the manor and an active vestryman) although no court leet had met for 20 years. 91 Occasionally the tenants in court were able to assist themselves as parishioners in vestry, as for example in 1684, when the court ordered John Combers the younger to pay 2s. $6 d$. a year to the poor for a gate in Bowyers Lane.92

The earliest surviving vestry record is a brief churchwarden's account of I 592.93 Notes of the appointment of officers begin in 1604 (f. 5 ) and are defective at first. The earliest summary account signed by the vestrymen as approving it is dated 1619 (f. 35).

In the early 17 th century the vestry apparently met only at Easter, to pass accounts and appoint officers. After 1673 there was a regular additional meeting at Christmas, at which the surveyors of highways were nominated. Other meetings, rare in the late I 7 th century, became more common in the early I 8 th century, and at a meeting in November 1724 it was agreed, as one of ten standing orders, that a vestry should meet once a month, every first Thursday at 3 p.m. 94 This order was followed and the meeting in February I 786 was entitled, as something uncommon, a ' 2 month vestry'.95 Standing orders enjoined the vestry to meet in the church and prescribed that any expenses incurred if it adjourned to a public house should be borne by individuals. Nevertheless the Easter vestries of 1728 and 1744 charged the parish with $f_{0} I$ and $f_{2} 2$ s. respectively, the latter for dinner and punch. The Easter vestry of 1782 held a dinner 'at Mr. Sammes'.96

In the 17 th century the vestry was often attended by fewer than six men. Numbers rose in the next century. In the three periods I 725-7, I 750-2, 1800-2, for example, about 12 attended the Easter vestries and $6-9$ the other meetings. The chairman was never named as such in the minutes but members of the Petre family always signed first when they were present, during the first half of the $I 8$ th century; in their absence the rector signed first. About 1740 the curate sometimes appears to have written the minutes, but did not sign. When neither a Petre nor the rector was present one of the churchwardens signed first. order that 'no one neither tenants nor inhabitants within that manor, shall permit their servants and sons to break hedges within the manor'.

84 c.g. ibid. 4 Sept. 1566

85 e.g. ibid. 29 Sept. 1562 : Wm. Mylborne presented for keeping a woman suspect as a whore. On 4 July ${ }_{564}$ he was presented as a common barrator, an 'inhuman' man among his neighbours and a 'public enemy of the commonwealth' (rei publici inimicus publicus) and the bailiff was ordered to move him from his tenement.

${ }^{86}$ e.g. ibid. 4 Apr. 5 560: default of William Wood.

87 As enjoined by Poor Relief Act, I 4 Chas. II c.12 (1662).

${ }^{88}$ The loss of pecuniary interest by the lord may have contributed. The 'common fine' of $6 s .6 d$. became increasingly in- adequate as an incentive to the lord to hold the court.

${ }^{89}$ E.R.O., D/P r $40 / 1 / \mathrm{r}$. The vestry had no power to swear the constables; that power lay, at common law, with the leet or a justice.

90 e.g. 1675 : leet 8 Apr., Vestry 5 Apr. 9I E.R.O., D/P 140/8/I.

92 Ibid. D/DP Mir 31 .

93 Ibid. D/P I 40/t/r. All vestry information down to 1724 is from this source, which is also the earliest parish register. Later vestry minutes are $D / P$ I 40/8/1-7. Unless otherwise stated references below are to vestry minutes.

94 This, of course, was an hour when only a fairly wealthy employer could attend.

9s E.R.O., D/P $140 / 8 / 2$.

96. Sammes kept the 'Green Man': ef. E.R.O., Q/RLv 36 . 


\section{A HISTORY OF ESSEX}

Committees were occasionally appointed. In 1769 one of five members was appointed to negotiate with a builder for the erection of a workhouse, and in 1805 one of seven was set up to reassess the parish rating. The Easter vestry of $\mathrm{r} 824$ adopted the 2 nd Sturges Bourne Act (59 Geo. III, c. I 2) and appointed a select vestry consisting of five men in addition to the rector, churchwardens, and overseers. Each successive Easter vestry appointed a select vestry, usually of ro- 15 men, until 1834 .

The usual officers were nominated and appointed by the vestry. Three overseers of the poor were appointed until $\mathrm{r} 642$, when it was decided that two were sufficient. Before this they were usually called 'collectors'. In 1642 it was noted that the constable should be chosen first. Between 1624 and 1634 there were opportunities for 93 men to serve parish office. 97 Thirty-nine actually served. In $1750-60$ there were 88 opportunities and 30 men served. Allowing for the fact that one churchwarden served throughout the later period it appears that the incidence of office changed little, although in the 18 th century the office of overseer was more widely shared than it had been in the I 7 th century, when the responsibilities were lighter. A paid overseer was appointed in 1810 at an annual salary of fro ros., and he was reappointed every year until 1822 , when he became a constable. Women were twice chosen as overseers in the 18 th century. This indicates a rota of substantial landowners from which overseers were picked. A woman overseer's responsibility seems to have ended with providing by her 'substance' financial security for the operations of her male deputy, who attended vestry for her.

It is possible that one churchwarden was customarily chosen by the parishioners and one by the rector, and an explicit statement of this first occurs in $176_{3}$.

The standing orders of 1724 provided that an officer with an account to pass who did not appear should be prosecuted. This order was applied capriciously. In 1725 it was resolved to apply for a warrant against a defaulting overseer, who subsequently returned. In $1735 \mathrm{Mr}$. Webb, a surveyor, came to the vestry without his accounts but declared 'to the best of his know-

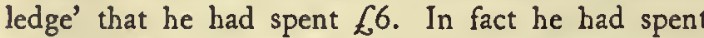
slightly less, as appeared later, but there is no hint of censure. After $175^{\circ}$ the totals of each overseer's disbursements were recorded monthly and were presumably examined by each monthly vestry.

Income from parish property and charities went far to meet the expenses incurred during the 18 th century and rates were not often required. Money was raised for special purposes by loans (e.g. 6250 to build the workhouse in 1769), the interest on which was paid from the rates. In 1806 the parish debts were paid by the sale for $\oint_{120}$ of parish lands in Shonks Mill meadow and the sale of timber worth $f 80$ 'in the field adjoining the workhouse'.

In the $17^{\text {th }}$ century and the first half of the 18 th rates were granted to each officer as required. In I 732 the surveyors were ordered to pay the surplus on their account to the repair of the church bells. In I 74I the last separate surveyors' rate was levied. 'Thenceforth all rates were levied by the overseers who reimbursed other officers. 98 The product of a $I d$. rate in 1731 was 69 . By a resolution of 1749 there was a

97 Eleven pairs of churchwardens and of surveyors; II trios of overseers; 8 pairs of sidesmen.

98 The levy of a special church rate in reassessment, probably stimulated by a sharp rise in the cost of poor relief. In 1748 a $\mathrm{I} d$. rate produced Ero 15 s., and in $1749, \oint_{1}$ I 45 . It produced 69 in 1805 and 1817 . In 1824 , after a new reassessment, the product was $6 \mathrm{1} 7.99$

An entry in the churchwardens' accounts in 1626 'for writeinge is. $6 d$.' is the first surviving record of payment to a servant of the parish. In 1674 Richard Cox bequeathed to the parish a black shroud, directing that the parish clerk should have custody of it and that he and succeeding sextons or clerks should be paid is. by each person using it. In 1744 a church clerk was appointed at a salary of $£ 2$ a year. A new vestry book was started in 1775 and most of the records of meetings in it are signed by the clerk. Previously, from the mid I 7 th century, minutes seem to have been written by the best penman present. In 1817 the salary of the clerk was raised to $f 44$ s. a year.

It was easy to relieve the poor in the 17 th century. Income came from Easter communion collections, from Green's Charity, and from casual bequests to the parish poor. In 1617 , for example, the first source yielded $8 \mathrm{~s}$, the second $\mathrm{f}_{2}$, and the third ros. Fifteen persons shared this income. They included five widows, and three men who appear from the Register of Baptisms to have been aged 70,58, and 52. The recipients of poor relief were such old and infirm people as these, some children, and travellers along the London road. Relief was by money doles, boarding out, apprenticing of poor children, providing clothes, and apparently also by providing accommodation. In $1652-3$ the sum of $\{6$ I $75.6 d$. was laid out towards the building of a cottage for the poor. No other reference has been found to the use of this cottage.

The administration of poor relief during most of the 17 th century was entrusted not to the overseers of the poor but to the churchwardens and constables. All the examples quoted above come from the churchwardens' accounts except those relating to travellers, which are from the constables' accounts. Records of the overseers handling money appear first in 1670 . During the 18 th century the duties of the overseers became increasingly heavy as the cost of poor relief rose. Between 1724 and 1754 the average cost was about $f_{1} 30$ a year. In $1754-64$ it was over $f 180$, in $1764-74$ it was $£_{2} 60$, in $1774-84$ it was $\oint_{3} 60$, in $1784-94$ it was 6440 , and in $1794-1804$ it rose to 6840. The parish spent ten times as much in $1800-1$ as in $1726-7$. The poor rate levied between $180 \mathrm{r}$ and 1817 was rarely below $\oint_{1}, 000$ in any year. ${ }^{1}$

The two overseers acted independently and rendered separate accounts. When the balance of both accounts had been struck at the Easter vestry the surplus in the hands of the outgoing officers was shared between their successors. Each overseer apparently acted for a different 'end' of the parish, either 'Toot Hill or Hare Street.

The poor in the I 8th century formed two classes. About two dozen received regular weekly doles, and the rest, varying in number with the season and the price of food, received casual aid. The recipients of the regular doles were enjoined by the orders of 1724 and 1732 to wear badges. ${ }^{2}$

Until the building of the workhouse the expedients of the previous century seem to have been adopted for 1817 , for extensive repairs to the church, tion. is the only exception.

99 A dispute with 3 ratepayers over the

I E.R.O., Q/CR I/O

2 This was under Poor Relief Act, 8 \& new reassessment was settled by arbitra- 9 Will. III, c. 30. 
the relief of the poor. Medical attention was perhaps new. In $174 \mathrm{I}$ an account for medicine of $£ 48$ s. was passed, and in 1746 there was payment of $£ 44$ s. for medical services. Paupers' rents, and from 1764 the cost of their firing, were often paid and in many cases the money went to prominent vestrymen. ${ }^{3}$

In 1769 a workhouse was built on parish land near the church. From $177^{\circ}$ payments for wool and spindles indicate that the inmates were engaged in spinning. From 177I this work brought income; the weekly sums recorded were usually greatest in the winter. This income later declined. Another source of income was the hiring of paupers' labour. From i 8 Io until I 8 I 5 regular statements of account between the governor of the workhouse and the parishioners were recorded. The overseers made monthly or fortnightly cash payments and supplied flour to the governor. He kept the paupers at an agreed rate for each person, and received extra for fuel, potatoes, and 'hair cutting, shaving, mops, brooms, thread, worsted, tape, oil \&cc.' In 1809 there were 12 beds in the workhouse and in 1830 there were 13.4

In 1829 Stanford Rivers joined with nine other parishes in a voluntary poor law union. 5 The parish raised $£_{300}$ on $£ 50$ bonds at 4 per cent., dated I $830-1$, to defray its contribution towards the cost of the new incorporated workhouse, ${ }^{6}$ and in 183 I sold its own workhouse for $£ 420.7$

The new incorporated workhouse was built (probably in I $830-1$ ) at Little End in Stanford Rivers, on land formerly owned by Capel Cure. ${ }^{8}$ After the formation of the Ongar Union in 1836 it became the property of the new union and served as its workhouse until the union came to an end in 1930 .

Stanford Rivers became part of the Ongar Union in 1836 .

In 1818 there were two day schools in the parish, with some 50 pupils. 9 In the following

SCHOOLS years one of them seems to have ceased and another to have started, so that in I 833 there were still two schools with 44 pupils. 10 - As $^{-}$ late as i $846-7$ the only schools were kept by dames. The rector, however, exercised some supervision over one of these and also gave financial help to some of the others. II The number of these schools had evidently increased with the growth of the population and in I 85 I a National School was at last built. It was on the road about half way between Toot Hill and Little End. The Department of Education gave $\mathrm{SI}_{17}$ and the National Society $£ 20$ towards the cost. The lord of the manor gave the site and $\oint_{0} 200$, and other subscriptions were collected. The rector and churchwardens were appointed trustees of the school. They

\footnotetext{
3 This is, of course, not surprising : they were of the class which owned cottages and had timber to sell.

4 E.R.O., D/P I $40 / 18 / 4$.

s The union was under Gilbert's Act $(22$ Geo. III, c. 83 ( 1782$))$. The other parishes were Abbess Roding, Bobbingworth, Greenstead, Little Laver, Shelley, Stapleford Abbots, Stapleford Tawney, Stondon Massey, and Great Warley. Al were in Ongar hundred except the last, which was in Chafford hundred. For a copy of the agreement see E.R.O., Q/RSw $\mathrm{x}$.

6 E.R.O., D/P 140/8/8. The bondholders were all London men.

7 Ibid. $140 / 18 / 3$.

E.R.O., D/DCc T 33

- Retns. on Educ. of Poor, H.C. 224 ,
}

p. 27 I (I8I9), ix (I)

${ }^{10}$ Educ. Enquiry Abstr., H.C. 62, p. 289

(1 835), xli.

"I Nat. Soc. Enquiry into Church Schs. I 846-7, Pp. I 8-19.

12 Min. of Educ. File $13 / 342$; ex inf. National Society.

13 E.R.O., D/AEM $2 / 8$.

14 Edue. Citee. of Council, Reps, on Schs. in Norfolk, Suffolk and Essex, I 858-9, p. 44 (in Min. of Educ. Libr.)

is Retns. Elem. Educ., H.C. 201, pp. I I 2 - I 3 (I 87 I), Iv.

16 Educ. Cttee. of Council, Reps, on Schs, in Norfolk, Suffolk and Essex, 1858-9, p. 44. 17 White's Dir. Essex (1863), 744.

18 Educ. Cttee. of Council, Reps. on Schs. in Norfolk, Suffolk and Essex, I858-9, p. 44 ; Rep. of Educ. Citee. of Council, of the subscribers constituted the board of there were stated to be places for II 7 chil-

The accommodation at the school was not fully used many years. In I $858-9$ there were 30 boys and I4 In 14 , the pil-teachers ${ }^{16}$ and in 1863 there were a master and The school received parliamentary grants dard of education to be low. ${ }^{18}$ In I 87 I it was that 40 school places were needed to secure and 144 in 1902 , and the annual grants rose 146 I 8 s. in $1902 .{ }^{21}$

the Education Act of 1902 the school passed mittee Ongar District Its average attendance fell inf ants, the seniors being transferred to the at Chipping Ongar (q.v.). ${ }^{22}$ In May I 95 hool was granted aided status. ${ }^{23}$

The school is an L-shaped one-story building of red ith a tiled roof. The teacher's house attached wo stories.

tit $^{24}$ (d. before 1602 ) left 5 s. a year each for the poor and 'poor folk's marriages' to the parishes of Stanford Rivers and Greenstead. It issued from lands in tanford Rivers. 25 In 1834 the money had not been por at least 23 years. The owner of the land was record of the charity.

William Green, ${ }^{26}$ by will dated I 554 , devised a 12 poor inhabitants of Stanford

I858 [2510], p. 560 , H.C. (1 859 , Sess. I), xxi (r)

10 Min. of Educ. File I $3 / 342$.

20 Rep. of Educ. Cttee. of Council, 1886 [C. 5 [ 23-1], P. 520, H.C. (1887), xxviti. 21 Rep. of Educ. Citee. of Council, 1872 [C. 8 12], p. 409, H.C. (1873), xxiv; ibid. I880 [C. $2948-$ I] , p. 579 , H.C. (I 88 I), xxxii; Schs. under Bd. of Educ., 1902 [Cd. 1490], p. 74, H.C. (1 903), li. 22 Min. Ed Edue. File 1 $3 / 342$. 23 Ex inf. Essex Educ. Cttee.

24 Rep. Com. Char. (Essex), H.C. 216 , p. 243 (1835), xxi (r); cf. E.R.O., D/P $140 / 1 / 1$ f. $143^{\mathrm{v}}$.

2s Cf. the 'anniversary' in the Church, in 1549 and earlier.

26 Rep. Com. Char. (Essex), p. 243; cf. D/P I $40 / 1 / \mathrm{I}$ f. $138 \mathrm{f}$. 


\section{A HISTORY OF ESSEX}

Rivers and $f_{1}$ to 6 poor of Chipping Ongar. In 1786 it had not been paid since 1739 .

Mary Rayner ${ }^{27}$ of Greenstead, by will proved I 873 , left $f_{4} 400$ for the upkeep of her family tomb and for the provision of clothing for the most deserving poor of Stanford Rivers. Although the primary trust was void by the rule against perpetuities, small sums were spent on the tombstone at various times. In 1950 the income was $f_{1} \mathrm{O}$ Is. $2 d$., which, together with the last year's balance was enough to give 27 parishioners ros. each for clothing.

Jessie Matilda Berkeley ${ }^{28}$ of Mere (Wilts.), by will proved 1930, left 6,500 in trust for the upkeep of the graveyard of the parish church and for the benefit of the poor provided that her family vault was maintained in good repair. ${ }^{29}$ The income in 1950 was $£ 208 s .4 d$., all of which was spent on the graveyard.

\section{STAPLEFORD ABBOTS}

Stapleford Abbots is about 5 miles north of Romford and 5 miles south-west of Chipping Ongar. I It has an area of 2,366 acres. $^{2}$ It is still a rural parish but during the past 30 years there has been some suburban development in the south, from which region there is now a good bus service to Romford. Until the I gth century the parish retained over 100 acres of woodland, part of the ancient forest of Essex, and some 300 acres of common waste and meadow. ${ }^{3}$ It formerly included also two large mansions, Albyns and Knolls Hill. Albyns, a very fine house dating from the I 6th century, is now (1954) being demolished after war damage. Knolls Hill was pulled down in the I 9 th century. In the I 8 th and early Igth centuries there was a considerable hamlet in the east of the parish at Martins Hernt but only two derelict cottages now remain there. There were 47 inhabited houses in the parish in 1801 and 78 in $1821 .{ }^{5}$ In 1801 the population was $320.6 \mathrm{By}$ 1831 it had grown to $507 .^{7}$ It remained very close to 500 until the 1880 's, when it fell to 320 in $1891 .^{8}$ It then rose again to 433 in I 1 I but fell to $39 \mathrm{I}$ in $1921 .{ }^{9}$ Since I 92 I there has been a renewed rise, the figure for I95 I being $73 \mathrm{I}^{\mathrm{IO}}$

There are hills rising to $29 \mathrm{I} \mathrm{ft}$. (Knolls Hill), $257 \mathrm{ft}$., and $300 \mathrm{ft}$. in the west, centre, and south-east of the parish respectively. In the north the land falls just below $100 \mathrm{ft}$. where the River Roding forms the parish boundary. Bourne Brook flows south-west between the hills in the centre andsouth-east of the parish. The road from Romford crosses the southern boundary of the parish and runs north-west. At Standish Farm, just inside the boundary, it is joined by a road which leads north-east to Navestock. This Navestock road branches at 'Tysea Hill Chapel, "I one branch running east to Navestock Side and the other continuing northeast to Navestock Heath. There are some 2oth-century houses on the Navestock road between Standish Farm and the chapel. Opposite the chapel are three pairs of council houses and there are another three pairs on the east side of the road to Navestock Heath, just inside the parish boundary.

On the west side of the Romford road, nearly opposite the Royal Oak public house, is a field in which a windmill formerly stood.12 The road is lined with 2oth-century houses for more than $\frac{1}{4}$ mile beyond the 'Royal Oak'. Beyond these houses it is joined by
Bournebridge Lane which runs west to Lambourne End. There are also some 2oth-century houses at the eastern end of Bournebridge Lane. Beyond them, on the east side of the lane, is Butchers Farm, a red-brick house dating from the I 8 th century; it has a dentil eaves cornice and a mansard roof with dormer windows. Beyond Butchers Farm the lane crosses Bourne Brook at Bourne Bridge, to the north-west of which is a cottage which was formerly Knolls Hill Free School.13 About $\frac{3}{4}$ mile farther west, just before Bournebridge Lane crosses the western boundary of the parish, is Knolls Hill Farm, which is on the hill-crest site of the mansion demolished in the Igth century. ${ }^{14}$ On the parish boundary, north-west of Knolls Hill Farm, is Blackbush Farm, a timber-framed and partly weatherboarded house, which probably dates from the 16 th century; it consists of a central block with gabled crosswings to the north and south.

About $\frac{1}{2}$ mile beyond the junction with Bournebridge Lane, the Romford road is joined by a lane leading east to Stapleford Hall.is On the south side of this lane there stood until a recent fire Mitchells Farm, probably a 17 th-century house. About $\frac{1}{2}$ mile farther along the Romford road is the school.16 Beyond this Hook Lane leads south-west to Blackbush Farm and Lambourne End. A drive to Battles Halli7 leads north from Hook Lane, near its junction with the Romford road. About $\frac{1}{4}$ mile north of this junction are three pairs of council houses. Beyond these the Romford road is joined by Church Lane which leads south-east to the church ${ }^{18}$ and the rectory. ${ }^{19}$ On the east side of this lane are four pairs of council houses, south of which is the site of the former parish school.20

North of Church Lane, on the east side of the Romford road, is Bons Farm, opposite which a lane leads westward to Hammonds Farm. ${ }^{21}$ Bons farm-house is timber-framed and plastered and consists of a central hall block with cross-wings to the east and west. There are indications that the east wing and some of the timbers of the hall are of medieval origin. In the I6th century the roof of the hall was raised to give another story, a chimney was inserted, and the three-story west wing was added or rebuilt. This has a small staircase wing adjoining it. At the front of the house the upper floors of both wings oversail and have original moulded bressummers. The doorway, barge-boards, and other

\footnotetext{
27 Chas. Com. files. 28 Ibid.

29 The condition was void under the rule concerning perpetuities.

1 O.S. 21 in. Map, sheets $51 / 49,51 / 59$.

2 Inf. from Essex County Council.

3 See below.

4 Chapman and André, Map of Essex, 1777 , plate xvi; E.R.O., D/CT 330.

5 Census Reports, 1801, 1821. The number of houses given in the Census

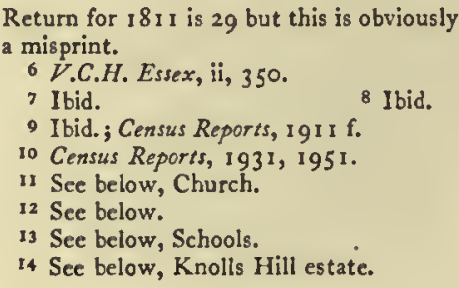

Return for 18 II is 29 but this is obviously a misprint.

6 V.C.H. Essex, ii, 350.

7 Ibid.

9 Ibid.; Census Reports, I 9 I I f.

10 Census Reports, I931, 1951.

"See below, Church.

12 See below.

13 See below, Schools.

4 See below, Knolls Hill estate.

Is See below, Manor of Stapleford Abbots.

16 See below, Schools.

I7 See below, Manor of Battles Hall.

18 See below, Church

19 Ibid.

20 See below, Schools.

2I See below, Manor of Stapleford Abbots. 
timber-work are also original. Both in the central block and in the west wing stone fireplaces of the 16 th century have been uncovered. These have four-centred arches and carved spandrels and are almost identical with fireplaces of the same period which were formerly at Albyns. In two instances there are Tudor roses and fleurs-de-lis above the lintels.

The Romford road leaves the parish at Passingford Bridge over the Roding. Immediately to the south of the bridge a lane leads south-east to Albyns, ${ }^{22}$ which lies in a park, and the main road via Abridge to London runs west. On the north side of the London road, about $\frac{1}{4}$ mile west of Passingford Bridge, is Passingford Mill. ${ }^{23}$ The former Mill House is a little farther west.

References in the Quarter Sessions rolls to communications in Stapleford Abbots chiefly relate to Passingford Bridge. ${ }^{24}$

In 1592 Bourne Bridge was presented as so broken that no horse and cart could pass.25 In $1609-10$ it was said that this bridge was in decay and should be repaired by the Crown. ${ }^{26}$ In 1656 it was reported that 'the lord of the manor of Stapleford Hall, one Chambers alias Chamberline' had failed to repair it. ${ }^{27}$

In 1896 a sub-post-office under Romford was established at Stapleford Abbots, with two rural posts. ${ }^{28}$ There was a telephone service by $1937 .{ }^{29} \mathrm{~A}$ police officer is stationed in the parish. ${ }^{30}$

Water was first supplied by the Herts. and Essex Waterworks Co. in I 935, but there is no main drainage. ${ }^{31}$ In 1935 powers were obtained by the Romford Gas Co. to supply gas to Stapleford Abbots and other villages but there is not yet a supply. ${ }^{32}$ Electricity was laid on in $1931.33 \mathrm{~A}$ branch of the county library was opened in 1931.34

Stapleford Abbots has always been a rural parish, devoted mainly to agriculture. The lords of the capital manor have never lived in the parish.3s The owners of Battles Hall were never resident after the beginning of the $15^{\text {th }}$ century. ${ }^{36}$ The owners of Albyns manor seem to have lived in the parish at some periods before the middle of the I 7 th century and the Abdys, who bought the estate in 1654 , were resident for nearly the whole of the period from 1654 , if not before, until I 840.37 After 1840 both the house and the estate were leased and the Abdys did not again live in the parish. ${ }^{38}$

In 1845 the parish consisted of 2,332 acres, most of which was occupied by tenant farmers. 39 The Crown owned 349 acres of which 226 acres (Stapleford Hall farm) were occupied by E. and C. Mollett and 123 acres (Hammonds Farm) by J. Fitch.40 Lady Mildmay owned $35 \mathrm{I}$ acres of which she occupied 140 acres, mainly woodland.4I Sir Thomas Abdy owned $35^{\circ}$ acres of which 125 acres, mainly wood and meadow, were occupied by R. Currie, 70 acres by E. and C. Mollett, and 66 acres by J. Surridge; the rest was leased in 7 parcels.42 W. J. Lockwood owned 341 acres of which I 24 acres (Knolls Hill farm) were occupied by R. Rudd, 96 acres (Blunts farm) by J. Stains, and 75 acres (Olivers Farm) by $\mathrm{H}$. Viney; the rest was leased in 4 small parcels. ${ }^{43}$ There were 3 other substantial owners, none of whom farmed the land himself: D. McIntosh owned 160 acres which he leased in 2 parcels; the Revd. John Bramston Stane owned 142 acres of which Rebecca Roach occupied 84 acres (Wiggans farm) and C. Stevens 57 acres (Tunbridge farm). 4 There were 3 other farms of over 40 acres, all of them occupied by tenant farmers. 45

Then, as now, there was mixed farming in the parish, with a predominance of pasture. In I 801 it was estimated that more than two-thirds of the parish was meadow and pasture land. 46 In 1845 there were about 800 acres of arable, $I, 250$ acres of meadow and pasture, and 200 acres of woodland and forest. 47 There were also 40 acres of land under hops. 48

There is some evidence concerning inclosure in the parish. Most of the common field and meadow land had evidently, as elsewhere in the area, been inclosed before the igth century. In 1824 , however, 291 acres of land belonging to the capital manor were inclosed. 49 This land was mainly in the east of the parish. It was largely waste but included 36 acres of common meadow (Rye Mead), 21 acres of which were in Lambourne parish. ${ }^{50}$

About 132 acres of woodland in the west of Stapleford Abbots, belonging mostly to the manor of Battles Hall, formed part of Hainault Forest. ${ }^{51}$ When the latter was disafforested in $185 \mathrm{I}$, the part of it in Stapleford Abbots was unaffected.52 In I 858 the Hainault Forest Allotment of Commons Act ${ }^{3}$ provided that I9I acres in Stapleford Abbots, Lambourne, and Dagenham should be allotted as common to the parish of Stapleford Abbots.54 This land was inclosed in I $865 ;$ I 4 acres of it were sold, almost entirely to the Crown, to pay the expenses of inclosure; 2 acres were awarded to the churchwardens and overseers to hold in trust as an allotment for the labouring poor of the parish chargeable with a rent of $£ 2$ to the Crown; 100 acres were allotted to the Crown in compensation of $i t s$ rights in the land as owner of Battles Hall manor; the remainder was allotted to various individuals in compensation for their rights of common.ss

The windmill which formerly stood opposite the 'Royal Oak' does not appear on a map of $1777^{56}$ and may have dated from the early igth century. It was a weather-boarded post-mills7 on a brick base and ceased work some years before 1910.58 In 1923 the sails were blown off 59 and the building was demolished. 60

The manor of STAPLEFORD ABBOTS was held by the abbey of Bury St. Edmunds before

MANORS the Conquest. It was recorded in the abbey's registers that one night in 1013 the lord of the manor of Stapleford was miraculously
22 See below, Manor of Albyns.

23 See Stapleford Tawney, p. 234.

24 Ibid.

25 E.R.O., Q/SR $121 / 30$.

26 E.R.O., Q/SR $189 / 92$.

27 E.R.O., Q/SR 368/24. Chambers may have acquired a lease of the manor from William Crofts : see below, Manor of Stapleford Abbots.

28 P.M.G. Mins. 1896 , vol. $574, \mathrm{~min}$. 1191.

29 Brit. Postal Guide, 1937.

30 Inf. from Chief Constable of Essex.

3r Inf. from Herts, and Essex Water

works Co.; Kelly's Dir. Essex (1937).
32 Inf. from North Thames Gas Bd.

33 Inf. from East. Elec. Bd.

34 Inf. from County Librarian.

33 See below, Manor of Stapleford Abbots.

36 See below, Manor of Battles Hall.

37 See below, Manor of Albyns and Church.

38 E.R.O., D/CT 330; White's Dir. Essex (1863); Kelly's Dir. Essex (1862 f.).

39 E.R.O., D/CT 330.

40 Ibid.

42 Ibid.

44 Ibid.

46 H.O. $67 / 56$.
47 E.R.O., D/CT 330.

48 Ibid.

49 E.R.O., Q/RDe 22.

so Ibid.

5 E.R.O., Q/RDc 42, 55 .

32 W. R. Fisher, Forest of Essex, 349.

$3321 \& 22$ Vict. c. 37.

34 E.R.O., Q/RDc 55 .

35 E.R.O., Q/RDc 65.

36 Chapman and André, Map of Essex, 1777 , pl. $x$ vi.

37 E.R. xxxii, 200.

58 E.R. xxxiii, 96.

59 Ibid.

60 E.R. $x \times x i i i, \mathrm{I}_{4} 8$. 


\section{A HISTORY OF ESSEX}

cured of a lingering illness by the presence of the body of St. Edmund, on its way back to Bury Abbey from London, and that in return for his recovery he granted the manor to the abbey for ever. ${ }^{61}$ Whether the grant was made then and in those circumstances cannot be confirmed but the abbey certainly owned the manor by 1066.62 It was then worth $45 s^{63}$ In 1086 it was worth 50 s. $^{64}$ The abbey retained $6 \mathrm{~s}$ Stapleford until the Dissolution and the manor and the parish became known as Stapleford Abbots.

In the early I th century the abbey's possessions were divided between the abbot and the convent:66 the manor of Stapleford was apportioned to the abbot. ${ }^{67}$ Abbot Hugh (I 57-I I80) let or confirmed the lease of this manor to Walter of Hatfield. ${ }^{68}$ In September I 182 , soon after his election, Abbot Samson took all his manors into his own hands.69 He pardoned Walter of Hatfield 619 arrears of rent in return for which Walter surrendered Stapleford and three other manors.70 In 1207 a meeting took place in Abbot Samson's chamber at Stapleford between King John and his nephew Otto IV; $;^{71}$ as a result of the meeting John supplied Otto with 6,000 marks.72 Later in the $13^{\text {th }}$ century the abbots again leased the manor of Stapleford. In about I 260 Abbot Simon (1 257-79) granted it to Sir Philip Basset for life.73 In 1278 Simon granted it to Laurence de Offinton for life at a rent of 610 a year.74 Afterwards Simon's successor John (1279-1 30I) granted a life interest in the manor to Hervey de Stanton, king's clerk. 75

In I 539 , after the Dissolution, a man whose name is lost but who was perhaps George Cely, petitioned Thomas Cromwell to grant him in exchange for his house and lands in Havering 'the lordship in Essex called Stapleford Abbot, lately belonging to the monastery of Bury and worth $£ 20$, within which lordship I have $\oint_{1} 5$ over and besides the $£ 20$ now the King's', ${ }^{76}$ The petitioner added that he would not have 'Mr. Chancellor's favour therein as he has promised it to Mr. Tuke who has refused it unless he may have my lands lying within the same'.77 In I 54I the manor was granted in fee to John Maynarde, mercer, of London, who immediately received licence to alienate it to Sir Brian Tuke, Treasurer of the Chamber. ${ }^{78}$ Sir Brian held his first court in October I $54 \mathrm{I}$ and three more courts before the end of February 1543.79 By April 1 545, however, the Crown had regained the estate, possibly by an exchange, ${ }^{80}$ and thenceforth retained the freehold until 1835 or soon after.

During this period the estate was let on long leases. At first it was leased in parcels and the leases did not include the manorial rights, although, occasionally at least, a lessee was appointed bailiff of the manor. Later the manorial rights were leased as well as the rest of the estate.

In 1545 George Cely was granted a lease for 21 years of the capital messuage and some of the lands appurtenant to the manor at a rent of $6_{2} \mathrm{I}$ I 3 s. $4 d$. a year. ${ }^{81}$ Cely mortgaged the lease to one Buckland for 620.82 Shortly afterwards George Cely died having devised the lease to his eldest son Walter who immediately redeemed the mortgage. ${ }^{83}$ Walter was already bailiff of the manor, having been appointed in I 546.84 In 1548 he purchased the manor of Albyns. 85 $\mathrm{He}$ died in 1549 having devised his lease of Stapleford Hall to his wife Elizabeth. 86 Afterwards Elizabeth married Thomas Smythe, clerk of the bakery, who in I 557 was appointed bailiff of the manor. ${ }^{87}$ In $155^{8}$ Smythe surrendered to the Crown the remaining term of the lease granted to George Cely in 1545 and received a new lease for 30 years at a rent of $\oint_{2}$ I I $3 s .4 d$. a year. ${ }^{88}$ This lease was apparently surrendered before its term, for in 1585 the queen granted a lease of the same property to William Dove for 21 years at 62I I 35. 4d. a year. ${ }^{80}$ Later Dove surrendered this lease to the Crown with the request that it should be granted to Roger Gittins and his wife Anne and their daughter Anne.90 In I59I a lease was granted to Roger and Anne Gittins and their daughter Anne for their lives in survivorship at the same rent as that paid by previous lessees.91 In 1594 the Crown granted a lease of the same property in reversion to John Wood, clerk of the signet, for 30 years at a rent of $£_{2}$ I I $35.4 d$. a year. 92

In January I6I7 James I demised the manor with all its lands rents and profits to Sir Francis Bacon and others for a term of 99 years. 93 In July 1629 this lease was assigned to Henry, Earl of Holland, and others in trust for Queen Henrietta Maria for her life with the power of letting the estate.94 In March I64I the queen leased the capital messuage and some lands appurtenant to the manor to William Crofts, one of her servants, for 2 I years at a rent of $£_{2}$ I I $3 s .4 d$. a year. 95 Crofts was also granted the manorial rights for $2 \mathrm{I}$ years at a rent of fi 7 Ios. a year and, for the same term, a tenement called Hammonds, which was also part of the manor and which had been leased at an annual rent of $£ 8$ Ios. since I 54 I or earlier 96

By letters patent of 7 February I650 Charles II mortgaged four manors, including Stapleford Abbots, to Sir George Carteret, Ist Bt., for $f_{0} 4,000$, part of a larger sum which Sir George had expended in the service of Charles I and which Charles 11 had bound
61 Dugd. Mon. iii, I 39, I 40.

6a V.C.H. Essex, i, $451 b$.

63 Ibid.

64 Ibid.

6s During the period 1148-56 Aubrey, Earl of Oxford (d. I194) quitclaimed a! his rights in the manor to the abbey: D.C. Douglas, Feud. Docs. of Bury St. Edmunds,

162. There is no indication, however, of what these rights were.

66 Chron. of Yocelin of Brakelond, ed. H. E. Butler, xix.

67 Ibid. 32.

68 Ibid. The same abbot granted the 'staffacre' of Stapleford Abbots to Henry son of Henry, clerk: Douglas, Feud. Docs.

Bury, 141. For meaning of this word see Chron. Focelin of Brakelond, ed. Butler, App. N, 151 .
69 Chron. Focelin of Brakelond, ed. $x \times(1), 683$. Butler, 32. 70 Ibid.

71 A. L. Poole, Dom. Bk. 10 Magna Carta $1087-1216,451$. In the index to this book Stapleford is wrongly stated to be the Cambridgeshire place of that name. 72 Ibid.

73 Cat. Anct. D. i, A. 800.

74 Cal. Fine $R$. 1272-1307, 110.

75 Cal. Pat. 1317-2 I, I60.

76 L. \& P. Hen. VIII, xiv (2), p. 358 Cf. ibid. (1) p. 63 and Dugd. Mon. iii, 176

77 L. E P. Hen.VIII, xiv (2), p. $35^{8}$

78 L. \& P. Hen. VIII, xvi, p. 281 .

$79 \mathrm{SC}_{2} / 173 / 86$.

80 Req. $2 / 23 / 49 ; L$. Eं P. Hen. VIII, xx (1), 68 3; Cal. Pat. 1 558-60, 82.

$8 I$ Req. $2 / 23 / 49 ;$ L. E' P. Hen. VIII,

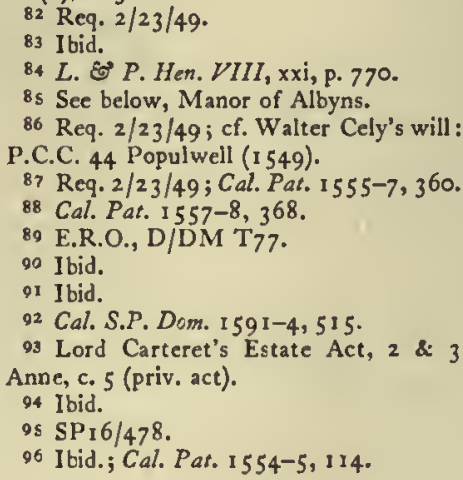


himself to repay. 97 He made this grant in ignorance, it seems, of the lease held in trust for Henrietta Maria. 98 Later Sir George Carteret discovered the existence of Henrietta's lease and in April $166_{3}$ he bought it in so as to protect his mortgage.99 In 1675, the principal sum of $f 4,000$ and most of the interest thereon having remained unpaid, Sir George took the view that the sums outstanding greatly exceeded the value of the estate and that he therefore had an absolute interest in the estate for the term of 99 years granted to him in the mortgage. He proceeded to settle the manor of Stapleford Abbots on Grace wife of his grandson and heir George, later Ist Baron Carteret, as part of her jointure. Lord Carteret died in 1695 leaving his younger children unprovided for. In order to help provide portions for these children his widow Grace, Lady Carteret, wished to sell the Stapleford Abbots estate. There were doubts, however, about the validity of her title to this estate on the grounds that the letters patent of 7 February $165^{\circ}$ could not be found and that an enrolled copy showed them to be, in any case, defective, because they did not recite some former demises. Moreover, even if the grant of 1650 were deemed valid, the fact that the Crown was not foreclosed from its equity of redemption constituted a bar to sale. To clear her title Lady Carteret obtained an Act of Parliament, ${ }^{1}$ in February 1704 , which confirmed the grant of 1650 and barred all right or equity of redemption in the Crown. By the same Act the estate, with others, was vested in trustees for the purpose of sale.

It seems, however, that for some reason Lady Carteret did not after all dispose of her interests in the manor of Stapleford Abbots for as lady of the manor she granted a tenancy of a piece of manorial waste to Sir John Fortescue-Aland of Knolls Hill in $1735 .^{2}$

Moreover there is no doubt that after her death in 1744 successive Barons Carteret were granted further leases of the estate which they held until I $805-9$ when Henry, Lord Carteret (d. 1826) transferred his lease, which had been renewed in 1805 for 30 years at a rent of 6538 14s. 6d. a year, to John Rutherforth Abdy, owner of Albyns manor. ${ }^{3} \mathrm{~J}$. R. Abdy still held the lease when it expired in $1835^{4}$ The Crown then offered the estate for sale.s At that time it comprised 582 acres of demesne land, which included Stapleford Hall farm ( 163 acres), Hammonds farm ( 123 acres), several other parcels (totalling I 62 acres) in Stapleford Abbots, and Wolves and Joyes farm (1 34 acres) in Romford and Navestock; freehold and copyhold rents totalled $\oint_{15} 7$ s. $4 d$. a year; fines averaged $\oint_{6} 65$ a year. ${ }^{6}$

The Crown was evidently unable to sell a large part of the estate. By January I 844 John Barnes had purchased the manorial rights 7 but apparently he did not buy any of the demesne land. In 1845 he owned no land in Stapleford Abbots; the Crown, however, still owned 349 acres in the parish, comprising Stapleford Hall farm (226 acres) and Hammonds Farm (123 acres). ${ }^{8}$ John Barnes was dead by November 1849 when his widow Ann held a court as lady of the manor.9 By I 85 I William Pemberton Barnes was lord of the manor.10 Afterwards the ownership of the manor remained in the family of Pemberton Barnes until I9I2-I4. II The Crown still owns Stapleford Hall farm and Hammonds farm. ${ }^{12}$

Stapleford Hall farm-house was probably built late in the 17 th or early in the 18 th century. It is timberframed and roughcast and has an L-shaped plan. It was much restored in the I gth century and most of the farm buildings are of the same date.

Hammonds farm-house is timber-framed and roughcast and probably dates from the I 7 th century. There have been alterations in the 18 th century and later.

The manor of ALBYNS has not been traced before 1409 when it was held by Sir Richard Walton, lord of Batayles, ${ }^{13}$ at the time of his death. ${ }^{14}$ In $14 \mathrm{I}_{4}$ Robert Newport and others, who were probably trustees under the will of Sir Richard Walton, founded a chantry of two chaplains in Wivenhoe church for the souls of Sir Richard and his wife Isabel and made Albyns a substantial part of its endowment. ${ }^{15}$

Immediately after the Chantries Act of $1545^{16}$ the lands with which Wivenhoe Chantry had been endowed were taken into the king's hands on the ground that in about I 538-9 John, I 5 th Earl of Oxford, lord of Batayles, had dissolved the chantry and given its revenues to Robert Rochester.17 In December I 545 the king leased Albyns to William Luther for 2 r years at a rent of $\delta_{0} 136 \mathrm{~s} .8 \mathrm{~d}$. a year. ${ }^{18}$ It is not clear whether Luther was granted the perquisites of court which amounted to 2 s. $4 d$. a year. ${ }^{19}$ In I 548 Edward VI sold the manor for . $339_{3}$ I 8 s. to Walter Cely and his heirs to hold in chief by the service of $\frac{1}{20}$ knight's fee. ${ }^{20}$ Cely evidently began to build a new inanor house but died in 1549 before it was completed. ${ }^{21} \mathrm{He}$ left the house to his wife Elizabeth 'so that she and her friends will see it finished'.22 'The heir to the manor of Albyns was Walter's son George, then a minor. ${ }^{23}$ George Cely held his first court in $1567 .{ }^{24}$ In I 570 he granted the manor to George Wiseman.2s At that time the estate consisted of 5 messuages, 240 acres of arable, 40 acres of meadow, 140 acres of pasture, and 50 acres of wood. ${ }^{26}$ Rents amounted to 4 OS. a year. ${ }^{27}$ In 1572 George Wiseman settled the manor on his daughter Anne and her husband William Fitch. ${ }^{28}$ In 1578 Fitch died, leaving the reversion of the manor after the death of his wife to his youngest son Francis. ${ }^{29}$ In I 587 Francis Fitch sold the manor to John Wood (kt. 1603). ${ }^{30}$ In 1610, shortly before his death, Sir John Wood settled the manor on his daughter Magdalen, wife of Sir Thomas Edmunds.3! Magdalen died in I 614 and Sir Thomas held Albyns until 1636 when he settled it on his eldest daughter Isabella, widow of

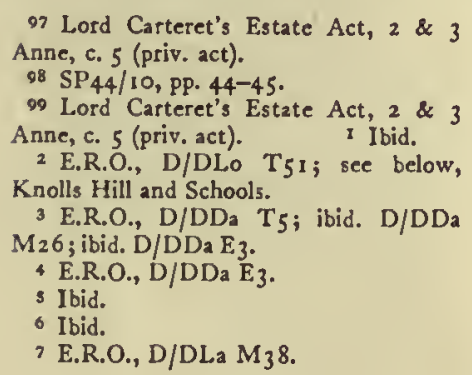

ES. IV
8 E.R.O., D/CT 330.

- E.R.O., D/DLa M38. 10 Ibid.

II Ibid.; Kelly's Dir. Essex (1 874 f.).

12 Inf. from Rector of Stapleford Abbots and from terants.

13 See below, Manor of Battles Hall.

14 Cal. Close, $1405-9,449$.

15 Cal. Pat. 1413-16, 151.

J6 37 Hen. VIII, c. 4 .

$17 \mathrm{E}_{301 / 19,20}$

$18 \mathrm{E}_{301 / 30 / 44 ;} \mathrm{E}_{315 / 68 .}$



20 Cal. Pat. 1547-8, $312 ; \mathrm{E}_{315 / 68 .}$

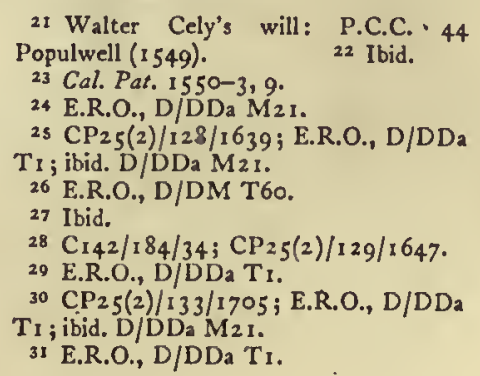




\section{A HISTORY OF ESSEX}

Henry, Baron De La Warre (d. 1628). ${ }^{32}$ In 1637 Isabella mortgaged the manor to Hugh, Ist Baron Coleraine, for $\{3,000.33$ After this debt, and the interest accruing on it, had remained unpaid for more than ten years, Coleraine began a suit for the recovery of $\{5,400.34$ In 1653, after incurring legal costs exceeding $\{r, 000$, he came to an agreement with Lady De La Warre, whereby he obtained ownership of the manor in return for cancellation of the debt.35

In 1654 Coleraine sold the estate for $\measuredangle 5,360$ to Robert Abdy, later rst Bt. (created r660) of Albyns. ${ }^{36}$ Afterwards the manor descended with this baronetcy until the latter became extinct on the death of Sir John Abdy, 4th Bt., in 1759.37 In accordance with the terms of Sir John's will the estate then passed to his aunt Mrs. Jane Crank, afterwards to Sir Anthony Thomas Abdy, 5th Bt. (created 164r) of Felix Hall, and on his death in 1775 to his nephew the Revd. Thomas Abdy Rutherforth.38 Rutherforth, who adopted the surname of Abdy on succeeding to the estate, died in 1798.39 His son and heir John Rutherforth Abdy died in I 840 leaving as his heir his nephew Sir Thomas Neville Abdy, Ist Bt. (created I $85^{\circ}$ ) of Albyns. ${ }^{40}$ Afterwards the estate, which in about 1845 consisted of 585 acres, ${ }^{4 I}$ descended with this baronetcy until the death of Sir Anthony Abdy, 3 rd Bt., in 1921.42 Shortly after this Albyns was purchased by an American ${ }^{43}$ and later by a Mr. Veryard,44 but by 1929 it was in the ownership of F. G. Mitchell who retained it until the Second World War.45 After the war it was purchased by Mr. W. H. Twyneham who is still the owner. ${ }^{46}$

There was formerly a very fine manor house at Albyns, most of which dated from the early 17 th century. It incorporated parts of a smaller house which was probably built by the Cely family in the middle of the I6th century. The building was fully surveyed in 1920 by the Royal Commission on Historial Monuments. ${ }^{47} \mathrm{~A}$ few years later the American owner removed most of the elaborate 17 th-century fittings and transported them to the United States. ${ }^{48}$ The subsequent owner demolished the north side of the house and rebuilt the façade farther back.49 In I945 the building was partly destroyed by a rocket bomb and it is now (1954) in process of demolition. ${ }^{50}$

In the I 8 th century it was generally believed that the design of Albyns was by Inigo Jones. Horace Walpole considered this unlikely: 'if he had any hand in it, it must have been during his first profession and before he had seen any good buildings. The house is handsome, has large rooms and rich ceilings, but all entirely of the King James's Gothic.'sI Later opinion confirms Walpole's view. ${ }^{52}$ Although the exterior with its tall windows and pedimented dormers is advanced for its period, there is no sign of the more mature classical work which is generally associated with Inigo Jones.

The house, which was built of brick, was arranged round four sides of a square courtyard. Parts of the south and cast ranges were of the 16th century and one of the four stair turrets in the courtyard was of the same date. A rainwater head dated 1620 has been taken to indicate the time at which the courtyard plan was completed and most of the interior work carried out. The external elevations had plain gables and large brick dormers with pedimented heads and flanking consoles. The windows were mostly of the mullioned and transomed type and on three of the fronts there were splayed bays of two stories. The symmetrical entrance front, facing north, had a central two-storied porch, the lower stage being of rusticated brickwork with moulded brick pilasters and a semicircular arch.

In the older part of the house there were three stone fireplaces and a ribbed plaster ceiling of the 16 th century. The bulk of the interior fittings, which were extremely rich, are thought to date from 1620 . A long gallery occupied the whole of the west range on the first floor and this had fine panelling, an elaborate chimneypiece, and a plaster ceiling with strapwork designs and enriched ribs and panels. The room ad joining it had a coved ceiling of similar type but including moulded pendants. The only fitting of this period which is still in situ is the fine oak staircase: it has a balustrade of carved strapwork panels and heavy square newels with moulded finials. The female figures which crowned the newels and which probably represented the Arts and Virtues have now disappeared.

Some of the woodwork on the first floor dated from the time of Robert Abdy, Ist Bt. The shields in the spandrels of the older fireplaces were painted with the date I 654 and the initials $A$ (for Robert and Katherine $\mathrm{Abdy}$ ) and the panelling bore the arms of $\mathrm{Abdy}$ and Gayre. A finely executed estate map of Albyns,53 drawn by John Kersey, survives from this period. It shows the layout of the grounds with stables and a dovehouse to the east of the mansion and a straight avenue leading south from the main entrance. An enlarged elevation of the north front proves that this side of the house suffered remarkably little change between 1654 and its final demolition in the 20 th century.

In 1754 the building was restored: an inscription in a bedroom recorded that 'this house was repaired, sashed and beautified by Sir John Abdy Bt. $1754^{\prime} .54$ Morant ( 1768 ) commented that this was done 'very judiciously, he keeping in his repairs to the old taste' in which the house was built.5s

In the first half of the Igth century the straight approach from the north was abandoned and the present curving drive constructed.56 The octagonal brick lodge is of the same period.57 Later in the century a large brick watcr tower was built over the north range of the house.

Two of the outbuildings at Albyns are of interest. East of the mansion is a contemporary red-brick range, formerly used as staff quarters and harness rooms. It has now been converted into a residence. Farther to the north-east is a coach-house block, now garages,

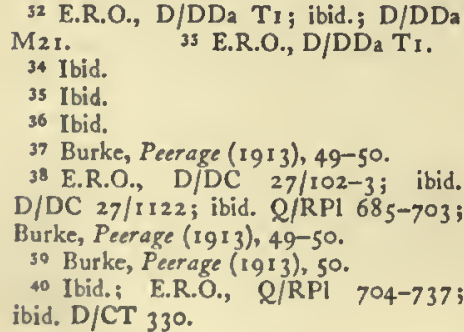

4) In the parishes of Stapleford Abbots and Navestock: E.R.O., D/CT 248, 330. 42 Kelly's Dir. Essex (1874 f.); Burke, Peerage (I 949), I.

43 Inf. from Mr. W. H. Twyneham jun., son of the present owner.

44 Ibid.

45. Inf. from Mr. W. H. Twyneham jun.

46 Ibid.

47 Hist. Mon. Com. Essex, ii, 222-5 (with

plates). The following description of the house prior to 1920 is based on this survey. 48 Inf. from Mr. W. H. Twyneham jun.

49 Ibid. 30 Ibid.

3I Anecdotes of Painting (1 828), 347.

32 E.A.T. N.s. iv, 53.

53 E.R.O., D/DC $27 /$ ir21. See pl. facing P. 226.

54 E.A.T. N.3. iv, 53

ss Morant, Essex, i, 177

56 E.R.O., D/CT 330.

57 Ibid. 




Old Loughton Hall in the early i 9 th century Burnt 1836

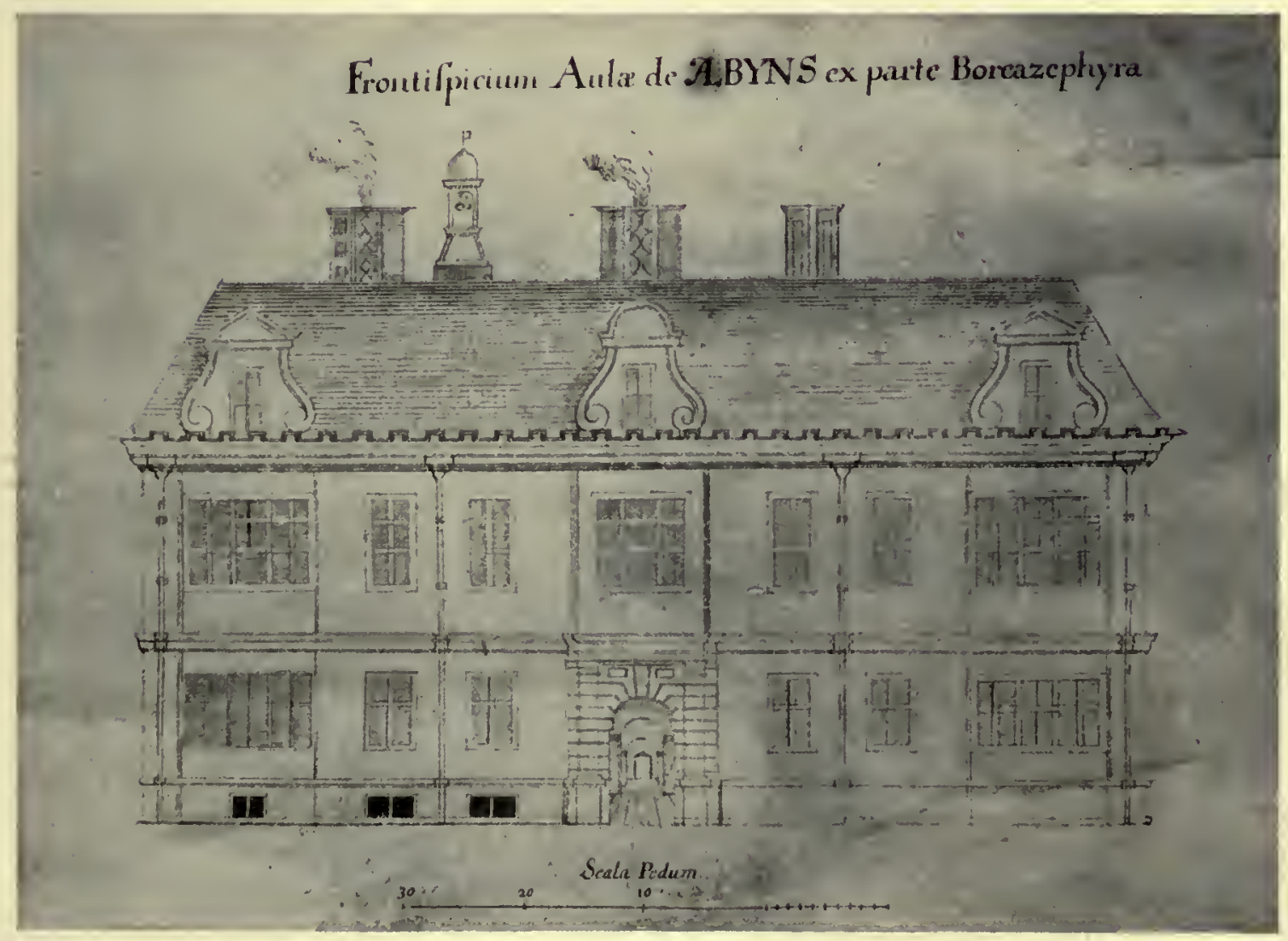

Aleyns, Stapleford Abbots, in 1654

Derelict in 1955 

which was probably rebuilt in the 18 th century. 58 In the centre is a clock turret surmounted by a domed cupola. The bell which hangs inside is said to carry the inscription: 'Anthony Bartlett made mee for Robert Abdy Esquire I6 38.'59

In 1066 the estate which became known as $B A T A Y L E S$ and later as BATTLES HALL was held by five free men as $2 \frac{1}{2}$ hides and $6 \frac{1}{2}$ acres and was worth 505.60 In 1086 it was worth 60s.61 Part of it was then held by Robert Gernon in demesne. ${ }^{62}$ One hide and a half, worth $28 \mathrm{~s}$. was held of Robert Gernon by Nigel.63

After Robert Gernon's fief had escheated to the Crown, Henry I granted it to William de Montfichet. ${ }^{64}$ In 1267 on the death without issue of Richard de Montfichet, great-grandson or great-great-grandson of William, his inheritance was divided between the issue of his three sisters Philippe, wife of Sir Hugh de Plaiz, Aveline, wife of William, Count of Aumale, and Margaret, wife of Hugh de Bolbec. ${ }^{65}$ The manor of Batayles was held of Richard, znd Lord Plaiz, great grandson of Philippe and Hugh de Plaiz, at the time of his death in 1327.66 For some time afterwards the tenancy in chief descended with the barony of Plaiz. In $1389 \mathrm{John}, 5^{\text {th }}$ Lord Plaiz, died leaving as his heir his daughter Margaret, wife of Sir John Howard.67 After her death in 1391 her husband obtained livery of her inheritance for his life. ${ }^{68} \mathrm{He}$ died in 1438.69 His heir was his granddaughter Elizabeth; only child of his son John, Lord Plaiz (d. I 409). ${ }^{70}$ Elizabeth had, however, already obtained the tenancy of the manor of Batayles through her mother Joan (see below) and the estate was therefore presumably held of the Crown in chief after 1438 .

Before I 47 the family of Batayle obtained the tenancy of the whole manor which subsequently took its name from them. Between I 108 and I $47 \mathrm{Sir}$ Hubert Batayle granted to the priory of Holy Trinity, Aldgate (Lond.) all the tithes of his demesne of Stapleford except 2 acres tithable to the churches of Stapleford and Lambourne.71 His sons William and Matthew were mentioned in the grant.72 In I 66 Richard Batayle held $z$ fees of Gilbert de Montfichet. 73 Soon after William, son of Richard Batayle, confirmed the grant made by his great-grandfather by placing a gold ring on the altar of the priory church.74 William Batayle was dead by $1200.75 \mathrm{He}$ was apparently succeeded by Richard Batayle. ${ }^{76}$ In 1216 the Sheriff of Essex was ordered to put Stephen of Oxford in possession of land which the king had granted to Richard
Batayle in Stapleford because Batayle had joined the king's enemies.77 It is not surprising that Batayle was a rebel: his overlord, Richard de Montfichet, was a prominent rebel at this time and he also had had his lands seized in consequence. ${ }^{78}$ Batayle probably regained his estates at the same time as Montfichet, in October I $217.79 \mathrm{He}$ or another Richard Batayle was holding of Montfichet in I 235-6.80 Afterwards the manor was held by Simon Batayle who was alive in I $\mathbf{z} z$ but was succeeded shortly afterwards by Richard Batayle, apparently his son. 81

In 1298 the estates of Richard Batayle were divided between his two daughters Margery, wife of William de Sutton, and Anne, wife of Peter de Taleworthe. ${ }^{82}$ The manor of Batayles fell to the share of Margery and William, whose son John succeeded his father by I 3 1 8.83 John, son of John de Sutton, died in I 393 leaving as his heir his brother Sir Richard de Sutton who died in 1396.84 At that time the annual value of the manor was $676 \mathrm{~s} .8 \frac{1}{2} d .85$ Richard's heir was his son Thomas who apparently died without issue. ${ }^{86}$ The estate passed to the heirs of Margery, who may have been the sister of Richard or Thomas de Sutton and who was the wife of John Walton. ${ }^{87}$ In 1409 her grandson Sir Richard Walton, son of John, died in possession of the manor leaving as his heir his sister Joan, wife of John, Lord Plaiz (d. I 409). ${ }^{88}$ She died in $1424 .{ }^{89}$ Her heir was her daughter Elizabeth, later the wife of John de Vere, Earl of Oxford.90 The earl was beheaded in 1462.91 In 1475 , after the attainder of her son John, Earl of Oxford, Elizabeth was forced to surrender her property to Richard, Duke of Gloucester. ${ }^{92}$ She died shortly afterwards but the earl evidently recovered the manor of Batayles after his attainder was repealed in 1485.93 He was lord of the manor by Michaelmas I $488.94 \mathrm{He}$ died in I $5 \mathrm{I} 3$ having settled Batayles on his wife Elizabeth for her life. 95 She died in 1537.96 'The manor then passed to the I 5 th Earl of Oxford and on his death to the 56 th earl, 97 who in 548 was forced to convey a large part of his estates, apparently including the manor of Batayles, to the Protector Somerset. 98 These estates were declared forfeit to the Crown in 1552 after Somerset's execution. 99 By an Act then passed, 1 the manor of Batayles was settled on Aubrey de Vere, brother of the 16th Earl of Oxford (d. I 56z). ${ }^{2}$ By I 574 the reversion of the manor had been acquired by Edward de Vere, the $17^{\text {th }}$ earl, for in that year he granted a lease of the manor for 3 I years to William Byrd, the composer, to take effect after the death of Aubrey de
58 A gabled building is shown in this position in 1654 : E.R.O., D/DC $27 / 1121$ s9 Inf. from Mr. W. H. Twyneham jun. If the inscription has been read correctly it suggests either that Robert Abdy was occupying Albyns before his purchase of the property in 1654 or that he brought the bell from elsewhere. It would also ante-date by 9 years the earliest known bell cast by Anthony Bartlet: $C h$. Bells Essex, 76 .

60 V.C.H. Essex, i, $518 a$.

61 Ibid. 62 Ibid. 63 Ibid.

64 Complete Peerage, $x, 351$; V.C.H. Essex, i, 347 .

63 Cal. Inq. p.m. i, p. 217 ; E.A.T. v, 173-207; E.A.T. N.s. v, 140-2; W. Farrer, Hons. and Kts. Fees, iii, 336; Complete Peerage, i, 35 r, x, 538.

66 Cal. Inq. p.m. vii, p. 26; Complete Peerage, $x, 537-40$.

67 Cal. Ing. p.m. x, p. 466; Complete
Peerage, $x, 541-2$.

68 CI $39 / 88$; Complese Peerage, $x, 542$. $69 \mathrm{C}_{139 / 88 .}$

20 Ibid.; Complese Peerage, $x, 542$.

7 Cat. Anet. D. i, A. 736 .

22 Ibid.

73 Red Bk. of Exch. 349-50. Cf. E.A.T. N.s. V, 140-2.

$74 \mathrm{E} 4 \mathrm{O} / 733$.

73 Feet of F. Essex, i, $23 . \quad 76$ Ibid.

77 Rot. Litt. Claus. (Rec. Com.), i, 255.

78 E.A.T. v, 193-5. 79 Ibid.

$80 \mathrm{Bk}$. of Fees, 479 .

81 Feet of F. Essex, i, 278 ; ibid. ii, 206.

82 Morant, Essex, ii, 18 .

83 Ibid.; Feet of F. Essex, ii, I86; Cal Ing. p.m. vii, p. 26.

$84 \mathrm{Cr}_{36 / 82} / 7 ; \mathrm{Cr}_{36 / 89}$ Cal. Close, I $392-6,168$.

s5 $\mathrm{C}_{13} 6 / 80$.

86 Ibid.; Morant, Essex, i, 176.

87 Morant, Essex, i, $176, \mathrm{ii}, 187$.


Complete Peerage, $x, 542$.

89 Complete Peerage, $x, 542$. 90 Ibid.

91 Complete Peerage, $x, 238$.

92 Ibid.

93 Ibid. 24 1-2.

94 E.R.O., D/DPr 139.

95 E.R.O., D/DM Mi 72.

96 Complete Peerage, x, 244

97 E.R.O., D/DM T56; ibid. D/DPr 138 ; ibid. D/DM M I 72.

98 Complete Peeräge, $x, 249$.

99 Ibid.

1 Act for Frustrating Assurances to the

Duke of Somerset made by the Earl of Oxford, 5 \& 6 Edw. VI (priv, act, no number), marked as missing in Stats. of Realm, iv, xiii.

2 Complete Peerage, $x, 249-50$; Morant, Essex, ii, 293 ; SP $12 / 157 / 25,26$; E.R.O., D/DM M I 73 . 


\section{A HISTORY OF ESSEX}

Vere. ${ }^{3}$ Soon afterwards William Lewyn, apparently acting on behalf of his brother-in-law Anthony Luther, negotiated with Byrd for the purchase of the lease. ${ }^{4}$ Byrd agreed orally to the transaction but later, considering that the oral agreement was not binding, transferred the lease to his own brother John Byrd.5 After Aubrey de Vere's death in I 579-80 Anthony Luther claimed that the lease had been lawfully conveyed to him by 'parol' from William Byrd in about I 574.6 Luther obtained the verdict of a Queen's Bench jury in his favour but Byrd was not satisfied, alleging that the jury was packed.7 In 1580 the parties agreed that the case should be referred to arbitration. ${ }^{8}$ In December 1580 the arbitrators declared that the agreement of about 1574 was lawful but that in their view Luther should surrender his claim on the ground that Byrd, having guaranteed the lease to his brother John, faced financial ruin if he could not fulfil his pledge. 9 Meanwhile in April i 580 the Earl of Oxford had sold the manor to John Byrd for $£ 620$ so that before the arbitration award was announced, John Byrd had become owner of the estate which then comprised 50 acres of arable, 40 acres of meadow, 100 acres of pasture, I60 acres of wood, 300 acres of heathland, and $f_{0} 10$ in annual rents. ${ }^{10}$ It is not clear whether the dispute about the lease continued after 1580 but in I 583 John Byrd sold the manor to Philip Smith, haberdasher, of Henley-on-Thames (Oxon.). "I

Smith held his first court in 1584 , when there were 8 freeholders and 8 customary tenants of the manor. ${ }^{12}$ In 1594 he sold the manor for $£ 1,95^{\circ}$ to Richard Wiseman of London, goldsmith, who died in 1616 leaving as his heir his son Sir Robert Wiseman. ${ }^{13}$ In 16 I 6 Sir Robert leased the estate for eighteen years to Francis Springham at $£_{02}$ 10s. a year but reserved to himself the rents and services of freeholders and copyholders and all the manorial rights. ${ }^{14} \mathrm{He}$ died in I64 I leaving as his heir his brother Sir Richard Wiseman.15 In 1648 Richard mortgaged the manor to Robert Edwarde for $£_{1} 1,500 .^{16}$ In 1650 Richard mortgaged it to Sir Thomas Hewett for the same sum in order to pay his debt to Edwarde.17 Wiseman died in 1654 leaving his debt to Hewett unpaid. ${ }^{18} \mathrm{He}$ was succeeded by his son Richard who immediately sold the manor to Carew Hervey Mildmay of Marks Hall, Romford, for a total of $£_{4}, 410$ of which $\ell_{2}, 850$ was paid to Wiseman and the remainder to Hewett in order to redeem the mortgage. ${ }^{19}$ The estate then consisted of 583 acres. ${ }^{20}$ Afterwards the manor of Battles Hall descended with Marks Hall. ${ }^{21}$ After the death in 1784 of Carew Hervey Mildmay, great-grandson of the purchaser of Battles Hall, the estate passed to his daughter Anne and afterwards, in 1789 , to his great- niece Jane, wife of Sir Henry Paulet St. John, rst Bt., who in 1790 adopted the surname of Mildmay. ${ }^{22}$ After the death of Sir Henry in 1808 his widow held Battles Hall until after 1845.23 . At that time the estate was exactly the size it had been in 1655.24 Later it was sold to the Crown, probably with Marks Hall in I 854.25 It is still Crown property. ${ }^{26}$

The manor house is of two stories, timber-framed and roughcast, and has a tiled roof with gabled dormers. It probably dates from the I 8 th century but has been considerably modernized.

At the end of the 14th century KNOLLS HILL alias KNOWLES HILL was apparently owned by Henry Despenser, Bishop of Norwich (d. 1406), who also held the manor of Bishops Hall in Lambourne (q.v.).27 By 1604 it had passed to the Stoner family of Loughton (q.v.). Francis Stoner (d. 1604) made it his seat and left his son Clement as heir to the messuage and to the 94 acres appurtenant to it. ${ }^{28}$ In 1606 Knolls Hill was the centre of an estate which comprised some 285 acres, including Knolls Hill farm (94 acres), Wrights farm (51 acres), both of which were held as freehold tenements of the manor of Battles Hall, two copyhold tenements totalling 35 acres, and the manor of Bishops Hall.29 Clement Stoner died in 16 2 leaving his son Francis as heir to this estate.30 Francis was succeeded by his daughter Amy, wife of George Waldron. ${ }^{31}$ George died in 1690 and Amy in 1712.32 They left no issue. ${ }^{33}$ Meanwhile, before 1675 , the manor of Bishops Hall had become separated from the estate. By $1734^{34} \mathrm{Knolls}$ Hill had been purchased by Sir John Fortescue-Aland, lord of the manor of Lambourne (q.v.) and it descended with that manor until the 2 oth century. ${ }^{3 S}$

Sir John Fortescue-Aland made Knolls Hill his residence and 'by several judicious improvements, at a very considerable expense, rendered it a most delightful place'. 36 'The house itself stood on part of the present farm-yard. By I 835 part of the mansion had become a farm-house but 'well executed portraits of the family are yet to be seen in one of the rooms'. ${ }^{37}$ The mansion was demolished in the middle of the Igth century; a pair of mid-Igth-century cottages, said to have been built with bricks from it, have recently been converted into a house for the present owner of Knolls Hill farm, Mr. D. Kelly. Traces of the former terraced gardens of Knolls Hill can still be seen.

The rectory of Stapleford Abbots was never appropriated. The advowson was held by the CHURCH abbey of Bury St. Edmunds, lord of the capital manor, until the Dissolution. ${ }^{38}$ It then passed with the manor to the Crown. In 154I it was granted with the manor to John Maynarde who
${ }^{3} \mathrm{SP}_{12 / 157 / 25,26 ;}$ E.R.O., D/DFa

$\mathrm{T}_{9 .}$ For Byrd see also Stondon Massey.

4 Ibid.

3 Ibid.

6 Ibid.

7 Ibid.

E.R.O., D/DFa T 9

- Ibid.

10 E.R.O., D/DM T 56

11 Ibid.

12 E.R.O., D/DM 175.

${ }_{13} \mathrm{CP}_{25}(2) / 136 / 1735$; E.R.O., D/DM T56.

14 E.R.O., D/DM TI58. In 1596 Richard Wiseman had leased the estate for 19 years to Richard Spencer, yeoman, at a rent of $f_{8} 80$ a year: E.R.O., D/DM T56. is E.R.O., D/DM T 56 .

\begin{abstract}
16 Ibid.
17 Ibid.

s8 Ibid.

20 E.R.O., D/DM P 17

In Ibid,

21 E.R.O., D/DM 183 ; ibid. Q/RPI 685-713; H. A. St. John Mildmay, Memoir of Mildmay Fomily, 163, 195

22 Burke, Peerage (1913), $1348-9$; E.R.O., Sage Coll. 760 ; E.R.O., Q/RP 685-737; H. A. St. John Mildmay, Memoir of Mildmay Family, 163, 195 .

${ }_{23}$ E.R.O., Q/RPl $714-37 ; \mathrm{D} / \mathrm{CT} 330$. 24 E.R.O., D/CT 330.

as E.R.O., Sage Coll. 760 ; H. A. St.

John Mildmay, Memoir of Mildmay

Family, 195; Kelly's Dir. Essex (1902 f.).

${ }^{26}$ Inf. from the Rector of Stapleford Abbots (1953).
\end{abstract}

27 Morant, Essex, i, 178.

$28 \mathrm{C}_{142 / 285 / 116 .}$

29 E.R.O., D/DFa E1.

$30 \mathrm{C}_{142 / 327 / 149}$.

31 Morant, Essex, i, 178

32 Ibid.

33 Ibid.

34 E.R.O., D/DLo T5 1 ; Rep. Com. Char (Essex), H.C. 216 , p. 243 (1835), xxi (I).

3s E.R.O., D/CT 330 ; T. W right, Hist. Essex, ii, 4:3.

${ }^{36}$ Hist. Essex by Gent. iv, 37. Sir John also built a school at Bournebridge for boys of Stapleford Abbots and Lambourne: see below, Schools.

37 T. Wright, Hist. Essex, ii, $4 \mathrm{I} 3$.

${ }^{38}$ E.A.T. N.s. xviii, 18; Newcourt, Repert. ii, 554-5. 
immediately received licence to alienate both to Sir Brian Tuke. ${ }^{39}$ The Crown probably regained the advowson with the manor in I 543-5.40 Thomas Smith presented pro hac vice in 1557.41 In 1560 a presentation was made by the Crown, which has since retained the advowson. 42

In the time of Abbot Samson (I I 82-I 2 I I) the value of the church was assessed by his chronicler Jocelin of Brakelond at 3 marks.43 In about 1254 the rectory was valued at 5 marks.44 The Prior of Holy Trinity, Aldgate (Lond.) then received $\frac{1}{2}$ mark for tithe from the demesne of the manor of Batayles.45 In I29I the rectory was valued at 68.46 The portion of the Prior of Holy Trinity, Aldgate, was then valued at I $35.4 d .47$ In 1535 the rectory was valued at 6.16 I5s.48 Its 'improved' value was 650 in 1604,6101 in 1650 , and $f_{120}$ in 1661.49 The tithes were commuted in 1845 for $£ 536 ; 50$ there were then 22 acres of glebe. ${ }^{51}$

In about $177^{\circ}$ the rectory was said to have been 'new built by the present . . . incumbent'.52 It is a roughcast house of two stories. The pedimented porch is contemporary and the bay windows and veranda were probably added early in the I 9 th century. There is a three-story addition of yellow brick dating from later in the I 9 th century. A deep L-shaped pond in the garden suggests that in medieval times the site was moated.

The parish church of $S T . M A R Y$ consists of nave, chancel, west tower, north chapel, vestry, and south porch. Except for the chapel, which is dated $16{ }_{3} 8$, the church was rebuilt in the Igth century.

A small engraving in the church shows the building before the Igth-century reconstruction. There was evidently a porch in the centre of the south side, flanked by what were appa rently $\mathrm{I} 4$ th-century windows. There was also, high up near the west end of the nave, a single-light window which may have been of the I 2 th century, indicating a Norman origin for the church.

In a modern lancet window in the vestry is a stainedglass panel depicting St. Edward the Confessor holding a ring; this probably dates from the early I 4 th century. In the south-east corner of the chancel there is a piscina, reset, with a pointed head and foiled drain, also probably dating from the 14 th century.

The north or Abdy chapel is of red brick and has semicircular headed windows, a coved cornice externally, and a hipped, tiled, roof. The chapel is separated from the chancel by a pointed arched opening of the Iyth century. A small entrance lobby of the I 7 th century adjoins the east wall of the chapel but is not structurally part of it. The front of this has been rebuilt in modern brick but the side walls and the external door, which has a segmental head, are probably of the I 7 th century. Above the inner door the date ' 1638 ' appears in cut brickwork. The architectural style of the chapel, however, suggests that it was rebuilt or largely altered by the Abdy family later in the $17^{\text {th }}$ century. 53

39 L. Eे P. Hen. VIII, xvi, p. 281.

40 See above, Manor of Stapleford Abbots.

4 Newcourt, Repert. ii, 555.

42 Ibid.; Kelly's Dir. Essex (1874 f.)

Chel. Dioc. Year Bk. I 952.

43 Chron. Focelin of Brakelond, ed. Butler, 63.

44 Lunt, $\mathrm{Val}$. of Norwich, 336 .

45 Ibid. Cf. Cat. Anct. D. i, A. 736 ;

E4o/733; see Manor of Battles Hall.

46 Tax. Eccl. (Rec. Com.), 21 b.
In about 1770 the church was described as "of one pace and of equal breadth with the chancel, tiled. At the west end is a neat gallery, behind which is a wooden tower containing three bells. The church is in good repair and the chancel has likewise been put into exceeding good repair by the present incumbent. The east window of the chancel is of a very singular construction.' 54

The west tower is of brown brick and was rebuilt in I 815.53 It is probable that the door and window openings were altered later when the nave and chancel were reconstructed. The parapet was formerly embattled, 56 but is now finished with a tiled coping. Internally the tower is separated from the nave by a pointed arch of chamfered orders, the whole being plastered.

The nave and chancel were rebuilt in $\mathrm{I} 86 \mathrm{I}-2$ at the expense of William Gellibrand and his sister.57 The architect was T. Jekyll of Norwich ${ }^{88}$ and the style is a I gth-century version of early 'Decorated'. The stone walls are of polygonal masonry with strongly emphasized joints. The windows have geometrical tracery and externally all the openings have small shafts with foliated capitals. The roof has exposed timber trusses.

The north vestry and south porch are of the same date. The porch is of timber arcading on a low stone wall. In I 909 a new organ was put into the tower at a cost of $£ 250.59$

In the north chapel, over the lobby doorway, is a late I 6 th-century helm with a winged cap of maintenance. The pulpit, which is hexagonal and panelled, is of the early I 7 th century. In the chancel are two late-1 7 th-century upholstered chairs. The octagonal font is modern. Above the south door of the nave are painted boards (c. I 800 ) setting out the details of William Gould's charities. 60

There are now two bells, one large, cast by $T$. Mears and acquired in 1818 , and one small, of the same date and probably by the same maker. ${ }^{61}$

The plate consists of a silver cup and two patens of I687, given by Sir John Abdy, 2nd Bt., and his wife in 1688 ; a silver flagon of 1687 given by George Nicholas and his wife; and a silver almsdish of 1692.62

The oldest monument, which is on the north wall of the tower, is to Francis Stonard ( 1604 ), his wife Lucy ( 1596 ), daughter of Sir Clement Heigham, Lord Chief Baron of the Exchequer, I 558-9, and also of Henry Stonard (1 555), brother of Francis. ${ }^{63}$ Next to this monument is a marble plaque with shield of arms to Dormer, 2nd Baron Fortescue of Credan ( 1780 ), ${ }^{64}$ who is buried nearby.

The north chapel contains three monuments to the Abdy family. On the west wall is a fine marble tablet commemorating Sir John Abdy, 4th Bt. (I759) and earlier members of his family. This was formerly in the chancel.65 On the east wall are tablets to Thomas Abdy and to John Rutherforth Abdy (I840) and his wife $(1838)$.

Tysea Hill or Pyrgo Chapel was probably built in
47 Ibid.

48 Valor Eccl. (Rec. Com.), i, 437 .

49 E.A.T. N.s. xxi, 78,83

50 E.R.O., D/CT 330 .

st Ibid.

52 Hist. Essex by Gent. iv, 37. The incumbent was W. Gould who became rector in $c_{0} 1767$.

53 Prof. Pevsner believes that it is a very early instance of the style: Buildings of Essex, 29, 336.

54 Hist. Essex by Gent. iv, 37.
35 Kelly's Dir. Essex (1886).

56 Kelly's Dir. Essex (1890).

37 Kelly's Dir. Essex (1886)

58 N. Pevsner, Buildings of Essex, 335.

s9 Kelly's Dir. Essex (1912).

60 See below, Charities.

68 Ch. Bells Essex, 398.

62 Ch. Plate Essex, 16.

${ }^{63}$ For the Stonards (or Stoners) see above, Knolls Hill estate.

64 See above, Knolls Hill estate.

63 Hist. Essex by Gent. iv, $3^{8 .}$ 


\section{A HISTORY OF ESSEX}

the middle of the I $g^{\text {th }}$ century. It is a rectangular brick structure with a porch and a bell-cote at its entrance end. Attached to the farther end is a red brick house of three stories which was once occupied by a curate. On a map of about I 870 the building is marked as a school but it cannot be identified with any known school in the parish. ${ }^{66}$ On a later map it was described as St. Edward's Church. By the end of the r gth century, if not before, it belonged to the Gibb family, of Pyrgo Park, who enlarged and redecorated it about I 892.67 The Gothic windows in the chancel are probably of this date. There were further renovations in I 12.68 Services were discontinued in about 1937. During the Second World War the building was damaged by German bombs. It was sold recently by the executors of the Gibbs. The main part of the building is used as a barn but in the summer of 1954 evangelists were holding services in the vestry.

In I953 a Roman Catholic Mission Van was scheduled to make regu-

ROMAN CATHOLICISM lar visits to Stapleford Abbots. 69

In 1672 a Presbyterian conventicle was licensed to meet in Stapleford Abbots PROTESTANT at the house of Edward NONCONFORMITY Braden.70

About $1858 \mathrm{Mr}$. Knight, of the Congregational church at Abridge (in Lambourne) was conducting services at Bourne Bridge.71

The existing vestry minute-books for Stapleford Abbots cover the period PARISH GOVERNMENT I777-1899.72 $A N D$ POOR RELIEF From 1777 until 808 vestry meetings usually seem to have been held only at Easter in each year. ${ }^{73}$ From 1808 until 1822 meetings were always held at Easter and in September but not, it seems, at any other time, except in I 81 I when there was one in May and in 1813 when there was one in January. From 1822 until after 1834 four to eight meetings a year were recorded.

The number of parishioners attending the meetings, in addition to the parish officers, varied between $I$ and 12, 3 to 6 being usual. The chairman was never named as such in the minutes until i 833 but the rector or, in his absence, one of the churchwardens, nearly always signed first. Dr. William Gould, rector from $1767-8$ until 1799, seems to have attended meetings only occasionally until I 79 I and not at all after April in that year. His successor, J. Hudson, rector until I 829 , attended nearly all the recorded meetings until 1822 . Afterwards he regularly attended the Easter and September meetings, when the officers' accounts were audited but, it seems, attended other meetings only occasionally. His successor, J. Hamilton, attended meetings regularly until the end of 1831 . Afterwards the Revd. Joseph Stanfield attended regularly on his behalf. On several occasions, including two when the rector was present, the first person to sign the minutes was John Rutherforth Abdy, lord of Albyns from $179^{8}$ to I 840.74 On several other occasions Abdy signed immediately after the rector. Abdy's attendance at vestry meetings was erratic but he showed more interest in parish business than did his father, Thomas Abdy, who seems not to have attended one meeting from 1777 until his death in 1798.75 More active than J. R. Abdy in the parish affairs were the tenants of Battles Hall,76 William Fitch and later George Fitch (from r 810 ), and those of Hammonds Farm, 77 Henry Shuttleworth and then John Fitch (from 1806-7). The Fitches rarely missed a vestry meeting. ${ }^{8}$ John Fitch was overseer from 1808 until 1810 and churchwarden from 1811 until 1815 . George Fitch was overseer in 18 I I- I 2 and churchwarden from I 815 until i 819.79

It seems to have been the Easter vestry of 1829 which adopted the second Sturges Bourne Act ${ }^{80}$ and set up a select vestry. J. R. Abdy and George Fitch were among the seven parishioners then chosen to form such a vestry. From May 1829 it met at frequent intervals until at least 1832 . In $1829-30$ Abdy seems not to have attended any meeting of the select vestry but George Fitch was chairman at several meetings. Abdy was one of I I parishioners chosen to form the select vestry for the year I $830-1$ but he did not attend a meeting of it until September 1830 .

In 1783 it was agreed that John Bastick should be Vestry Clerk at a salary of $\oint_{2} 2 \mathrm{~s}$, a year 'so long as he shall continue the school and settle all parish accounts'. In 1788 Thomas Allen was appointed to this office on the same terms. In 1803 John Richardson was appointed clerk, upon the resignation of his father David, at a salary of 68 a year. In September 1827 the churchwarden, Philip Taylor, represented to the vestry that David Richardson the clerk was ' 8 I years old and extremely infirm in body and mind and unable to perform his duty properly'. It was then decided that James Dixon should officiate for Richardson until the following Easter. In 1828 it was agreed that Dixon should be clerk at a salary of $\oint_{5}$ a year. In 1830 Dixon was dismissed and Richard Stevens was appointed in his place at a salary of $\oint_{5} 5$ a year.

The work of the open vestry consisted mainly in nominating parish officers, granting rates, and auditing officers' accounts. In 1780 the rateable value of the parish was $\oint_{1}, 158$. In 1802 receipts from rates totalling $6 s$. in the pound were $65 \times 55$ s. This implies a rateable value of about $\{1,7$ I 7 ros.

There were usually $\mathrm{I}$ overseer, $\mathrm{I}$ or 2 churchwardens, and I constable. Churchwardens usually served for at least 2 , and often 3 or 4 , years consecutively. During the period $1776-1836$ one churchwarden, R. Young, served for 9 years $(1826-35)$ consecutively and two, R. Stokes and P. Taylor, served for 8 years consecutively (1788-96 and $1827-35$ respectively). The overseer usually served for one year only. No overseer is known to have served more than 2 consecutive years until 1821 . In 1809 it was agreed that John Fitch, who had already been overseer in $1808-9$, should be

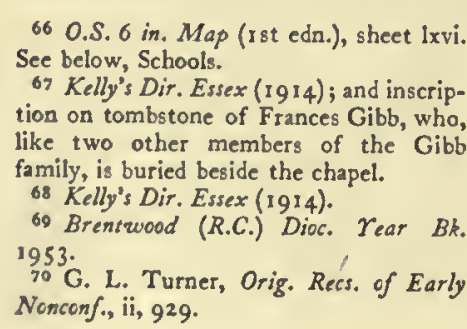

73 See Lambourne, Nonconformity.

72 For these books, which are kept by the rector, see Essex Par. Recs. 195. Unless otherwise stated all the following information is derived from them.

73 Two meetings, however, were recorded in $1802-3,3$ in $1803-4,4$ in each of the years $1779-83$, and 5 in $1788-9$.

74 See above, Manor of Albyns.

73 Thomas Abdy was, however, also Rector of Theydon Garnon and was not resident at Albyns.

76 See above, Manor of Battles Hall.

77 See above, Manor of Stapleford Abbots.

78 George Fitch attended vestry meetings more regularly, perhaps, than any other parishioner.

79 Both John and George Fitch held office again some years after their long terms of office.

${ }_{80}^{80} 59 \mathrm{Geo}$. III, c. 12. 
paid for $_{\mathrm{O}} \mathrm{for}$ performing the same office in the ensuing year. There was apparently no payment to the overseer for the year I 8 I O I I but in May I $8 \mathrm{I}$ I, a few days after the Easter vestry, it was agreed "by the major part of the parishioners' that George Fitch should serve as overseer for I 8 II-I 2 at a salary of 10 . No salary appears to have been paid to the overseers for the years I 8 I $2-15 .{ }^{81}$ The overseer for I 8 I $5-16$ may have been paid but the overseer for I $816-17$ was probably not. There is no further evidence on the matter until 1822 when at the Easter vestry it was agreed that Joseph Green, who had already been overseer in the preceding


again in $1822-3$. Green remained overseer for several years after this. It is not clear whether he was paid a salary between Easter I 823 and Easter 1829 but at Easter I 829 he was appointed assistant overseer at $E_{0}$ Io a year. He filled this office until at least $\mathrm{I} 830$. Before I 800 there were at least three illiterate overseers. ${ }^{82}$

From 1777 until 1779 the overseer, churchwarden, and constable each submitted a separate account of his term in office. From I780 until I 833 , however, neither churchwardens nor constables submitted separate accounts, their receipts and expenditure being incorporated in the overseers' accounts which con tinued to be submitted to the Easter vestry each year. Until 1808 it is not clear what the usual practice was in regard to the surveyors' accounts. 'The surveyors delivered an account in September 1779 but after this there is no evidence about them for nearly 30 years. From I 808 two surveyors regularly submitted their account each September.

At some time there was a parish poorhouse, situated at Tysea Hill. In I $84 \mathrm{I}$ the vestry resolved to sell it. It does not seem to have been used as a poorhouse during the period for which the vestry books survive.

In 1776 there were 30 poor households in the parish. Several consisted of only one person, usually old, but most of them consisted of labourers and their families. ${ }^{83}$ Few of these households appear to have had constant relief. In $1776-7$ there were 9 persons in receipt of doles, the total of which amounted to $6 \mathrm{I} 4 \mathrm{~s} .6 \mathrm{~d}$. a week. In $1777-8$ there were 10 persons receiving weekly doles totalling $\oint_{\mathrm{I}} \mathrm{gs}$. The following year there were II, and the doles totalled $\delta_{\mathrm{I}} \mathrm{I} 6 \mathrm{~s}$. $6 d$. a week. Between 1779 and I 782 there were 8 people each year, the average total of the doles being fI $_{1} 7 \mathrm{~s}$. In each of the years 18 I $3-15$ there were 17 persons, excluding children, in receipt of 'permanent relief'.84 None of these received relief in a workhouse. ${ }^{85}$ There were also 30 persons relieved occasionally in each of these years. ${ }^{86}$ Weekly doles and occasional gifts of money and clothing continued to be paid to poor persons in the parish until the end of the old Poor Law. In February I 829 an unusually large vestry, consisting of 12 parishioners in addition to parish officers, unanimously agreed 'to join for a Corporation workhouse'. ${ }^{87}$ In December 1830 an open vestry agreed that $f_{1}$ og should be borrowed towards the Incorporated House. A few days afterwards a select vestry resolved that to persons, including 5 children, should be sent to the Incorporated House forthwith. Some persons were still maintained in the parish on weekly pensions, and at least two of those committed to the Incorporated House do not appear to have gone there immediately, for in the months following their committal each was allowed a small weekly pension by the select vestry. In 1832 it was resolved to apply to Lady Mildmay, owner of Battles Hall, 88 for the grant of waste land on her manor 'for the purpose of employing and bettering the condition of the poor'. In April i 832 when Guardians for the Incorporated Workhouse were appointed for $1832-3$ it was resolved that the 'visiting Guardian be allowed $£_{3} 4$. per annum for his trouble in executing the office'. In 1833 it was proposed by the Guardians 'that certain lands in this parish belonging to the parish should be sold by public auction for the purpose of defraying the medium as far as it will go towards erecting the associated workhouse'.

In 1776 the total cost of poor relief was $£_{0} 100 ; 89$ in the three years $1783-5$ it averaged $\oint_{1} 160$ a year.90 The rise continued irregularly and in the years 1789 90, I790-I, and from 1794 onwards it appears to have been over $\oint_{2} 200$ a year rising to nearly $6_{4} 400$ in $1799-$ I 800 . In I $800-1$ it was $\delta_{6} 635$ but after Easter I 80 I it declined to $\varepsilon_{3} \mathrm{I} 3$ in $\mathrm{I} 802-3$. Between $\mathrm{I}_{803}$ and I 8 I I it varied between about $£_{0} 370$ and $£ 474$ a year. In $1812-13$ and $1818-19$ it reached peaks of $f_{6} 620$ and about $\$ 700$ respectively. In the 1820 's it was usually a little under $6_{65} 00$ and in the early I 830 's it declined, being about $£ 300$ in the last year of the old Poor Law. 91

In 1836 Stapleford Abbots became part of the Ongar Poor Law Union.

In 1734 Sir John Fortescue-Aland of Knolls Hill 92 built a school at Bournebridge, on waste SCHOOLS land belonging to the capital manor, 93 and charged his estate with $\$ 25$ a year

for the support of a schoolmaster who should teach reading and writing to 20 boys of Stapleford Abbots and 20 of Lambourne. ${ }^{94}$ The school seems to have had a continuous existence 95 but by $\mathrm{I} 807$ it was in poor condition. Owing to parents' reluctance to send their children, the master was teaching elementary subjects to only I 5 or I 6 boys. 96 By I 8 I 8 , however, 30 free pupils were attending and 16 paying pupils as well. The master lived at the schoolhouse rent-free and was paid the 625 from the endowment.97 In 1833 there were 50 pupils, presumably including those paying fees. 98 In 1835 there were 55 pupils. Of these 40 were free pupils, the children of Anglicans, who entered at 7 years of age and left at fourteen. The hours of attendance were 9 a.m. to 5 p.m. and the curriculum elementary. 99 In $\mathrm{I} 846-7$ the school was united to the Diocesan Board of Education and the teacher, now a mistress, was paid $\ell_{3} 35$ a year, though the fee-paying pupils seem then to have been very few. ${ }^{1}$ In I 863 the
81 E.R.O., Q/CR I/9.

82 In the same period there was at least one illiterate churchwarden.

83 In most cases there were $2-4$ children. 84 E.R.O., Q/CR I/10.

8 I Ibid. 86 Ibid.

87 This was the voluntary union under Gilbert's Act, which had its workhouse at Stanford Rivers (q.v.).

88 See above, Manor of Battles Hall.

so E.R.O., Q/CR I/I. 9o Ibid.
9I The exact amounts spent on poor relief are known only for the years $1776-7$, $1783-5,1800-1,1802-3$, and $1804-17$ For all other years a close approximation is possible on the basis of the overseers' total disbursements.

92 See above, Knolls Hill estate.

93 E.R.O., D/DLo T 5 t. Subsequently Sir John acquired a tenancy of the land on which the school was built.

94 Rep. Com. Char. (Essex), H.C. 216. p. $243(1835)$, xxi (1).

9s Morant, Essex, i, 178; Chapman and André, Map of Essex, 1777 , pl. xvi

96 E.R.O., D/AEM 2/4.

97 Retns. Educ. Poor, H.C. 224, p. 27 (I 8 I g), ix (r).

98 Educ. Enquiry Abstr. H.C. 62, p. 290 (1835), xil.

90 Rep. Com. Char. (Essex), p. 243.

I Nat. Soc. Enquiry into Church Schs. 1 846-7, pp. 18-19. 


\section{A HISTORY OF ESSEX}

teacher was again a master. ${ }^{2}$ In 1872 the Education Department urged that the school should be repaired and enlarged to accommodate 40 boys, as a contribution towards the provision of elementary education for all children in the parish. ${ }^{3}$ No steps were taken, however, to enlarge this or other schools in Stapleford Abbots and Lambourne, with the result that a school board was formed for the two parishes. 4 In I 878 a board school was opened.s There seem to be no references to the existence of the Knolls Hill school after that date, except in about I 907 when it was stated to be still in existence as an elementary school. ${ }^{6}$ The Knolls Hill farm estate is now charged with the annual sum of 630 I 25 . which goes towards the secondary education of a pupil from Stapleford Abbots primary school.7

The original Knolls Hill school building still stands, being now occupied as a cottage. It is of red brick with some burnt headers. The symmetrical front is of two stories and has a central doorway with a flat hood on moulded brackets. The building originally consisted of one large room to each floor, but these are now subdivided. The master's house, which is attached to the back of the school, may be a later addition.

The parochial school had its origins in the early years of the 19th century. Presumably because girls were not admitted to Knolls Hill Free School, private schools for girls existed in the parish both in 1807 and 18 18 . In 18 8 there was also a school in which 14 girls had their fees paid and some clothes given them by Mrs. Abdy of Albyns. ${ }^{8}$ 'This girls' school seems to have accepted boys as pupils at some time before 1839 , when the Abdy family was still its sole supporter. ${ }^{9}$ In I 846-7, when the school was situated on land owned by the Abdys, a little to the north of the church, ${ }^{10}$ widow Williams was being paid $£ 37$ a year to teach I 5 boys and 43 girls, including some from Navestock and Stapleford Tawney." The school continued for at least another 28 years, evidently under the patronage of the Abdy family. In 1872 the Education Department urged that certain alterations and re-equipment should be carried out so that its accommodation might be used to help provide universal elementary education in the parish, ${ }^{12}$ but this was not done ${ }^{13}$ and the school seems to have been closed on the establishment of the board school. 14

In 1878 the school board of Stapleford Abbots and Lambourne opened a new school on a freehold site at the top of the hill leading to Passingford Bridge. The cost was defrayed by a loan. is The accommodation was for 99. The average attendance rose from 49 in I 886 to 73 in I 1902 , and its annual grant from $\oint_{0} 35$ to fror.16 In r 904 there were 80 children at the school and 3 teachers, 2 of whom were certificated. ${ }^{17}$ By the Education Act of $\mathrm{I} 902$ the school passed under the administration of the Essex Education Committee as a provided mixed school. Its average attendance fell to 54 in 1909 and 32 in 1930 . In I 936 it was reorganized for mixed juniors and infants, 18 the seniors being sent to Chipping Ongar. In May 1952 there were 3 teachers and 74 pupils. The school is a singlestory, red-brick building, and it has a teacher's house attached.

Elizabeth Watson (d. 1782) left $£_{3}$ issuing from her estate of Mitchells to be disCHARITIES ${ }^{19}$ tributed to the poor on Christmas Day and Good Friday, provided that her parents' monument should be well maintained in its then position. Although all the monuments in the church were moved into the tower in 1861 , the charity money continued to be paid. There was some difficulty in collecting the rent-charge from 1930 to 1937. In 1952 the money was spent on gifts of bread to 38 recipients.

Dr. Gould, rector of the parish (d. 1799), left $£_{1} 05$ to be invested for distribution among the poor of the parish at Christmas and Easter. A board was to be maintained, bearing a description of the charity. By 1835 the charity was only distributed on alternate Easter Saturdays, when meat was given away to all the poor families of the parish in proportion to their size. In about 1888 £.30 was added to the stock, representing the endowment of the Bell Rope Charity. This was of unknown origin and had apparently consisted of a small plot of land in Hook Lane which was sold by the churchwardens in $178 \mathrm{I}$ for $\{25$. The payment of the dividends of this sum seems to have been irregular for some time: no mention of the charity was made in the Brougham Commissioners' Report of 1835 and about 8 years' arrears were paid in 1855 . In the early Igth century the income was apparently used with that of the other charities, and from I 888 it was always distributed with Dr. Gould's Charity. In 1952 the income of the two was $64 \mathrm{I} 8 \mathrm{~s} .4 \mathrm{~d}$. which was spent on meat for 4 I persons.

Alice Martin, by will proved 1946 , left the residue of her estate amounting to $£ 2,2658$ s. $5 d$. in trust for the benefit of the poor of the parish at Christmas. In 1952 the income was $£ 736$ s. $10 d$.; 43 persons received gifts in cash and 7 persons recejved them in children's clothes.

The Parliamentary Returns of 1786 recorded two charities which were then lost: Edward Masters had given $\oint_{3}$ a year to the poor in 1670 , and Captain Allen gave them fro, producing Ios. a year, in 1675 . Nothing had been received from the first 'for many years' or from the second since 1690 .
2 White's Dir. Essex (1863).

3 Chelmsford Chronicle, 9 Aug. 1872.

- Essex Standard, 29 July 1874.

s See below.

- Kelly's Dir. Essex (1878, 1882); V.C.H. Essex, ii, 563 .

7 Inf. from Mr. D. Kelly, present owner of Knolls Hill Farm.

- Reins. Educ. Poor, H.C. 224, p. 27 (1819), ix (1); see above, Manor of

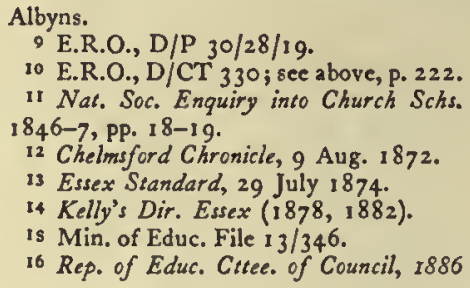

[C. 5123-1], p. 519, H.C. (1887), xxviii List of Schs. under Admin. of Bd. 1902 [Cd. 1490], p. 71, H.C. (1903), li.

17 Essex Educ. Ctice. Handbk. I 904 p. 186.

18 Inf. from Essex Educ. Cttee.

to All the information which follows is derived from the following sources: Rep. Com. Char. (Essex), H.C. 216 , pp. 243-4 (1835), xxi (1); Char. Com. files. 


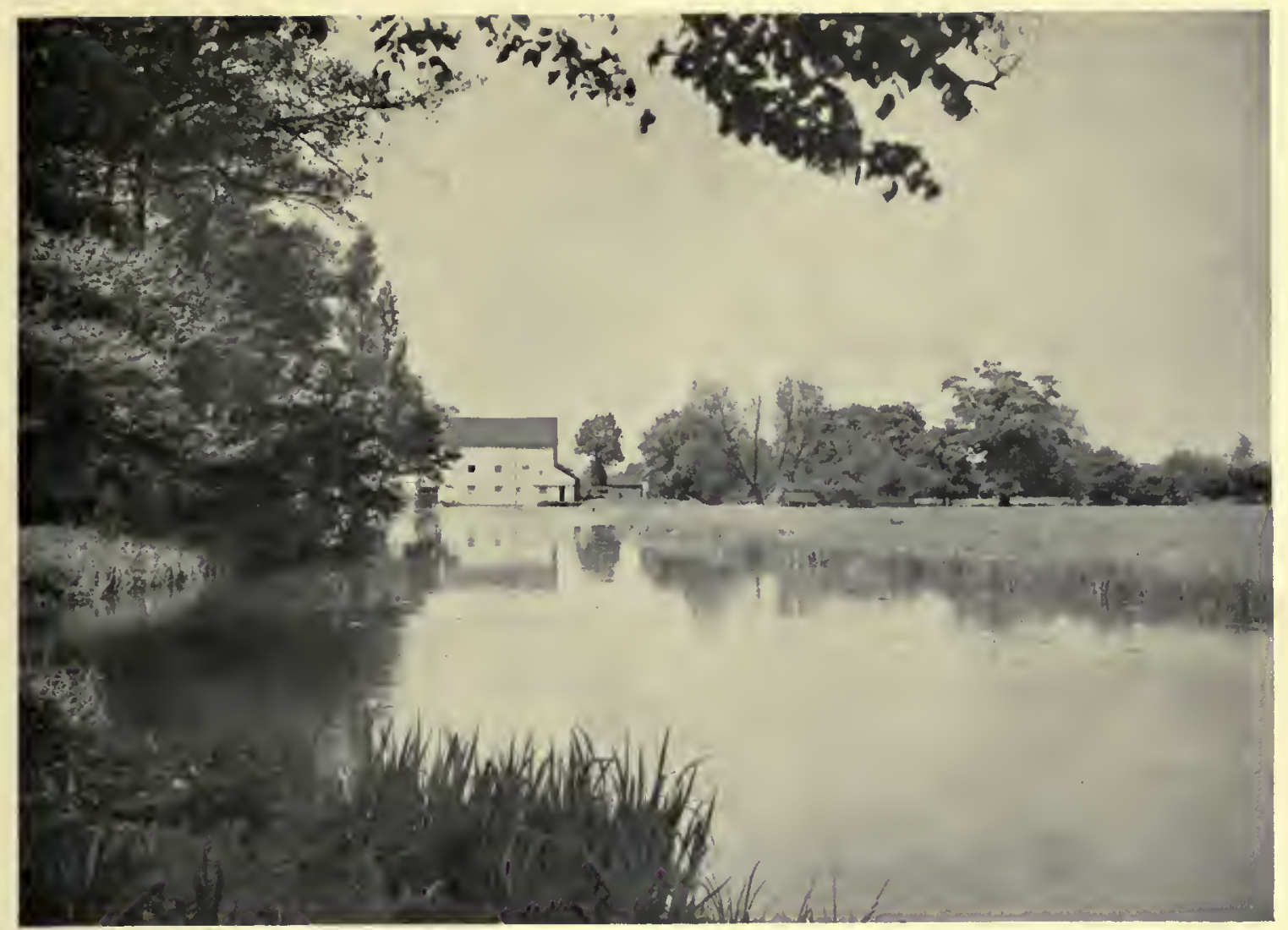

'The River Roding and Passingford Mill from Passingford Bridge

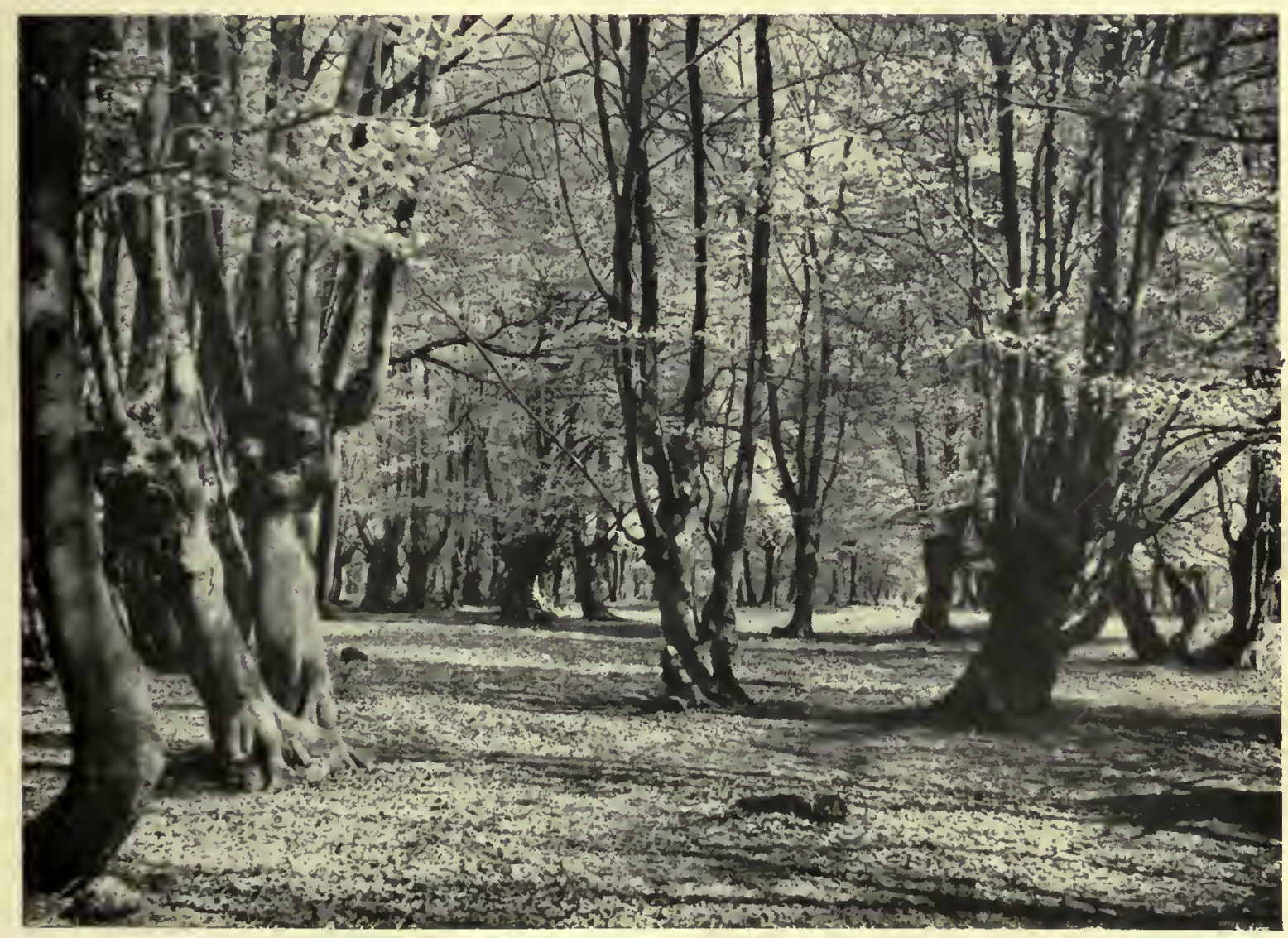

Loughton: Trees in Epping Forest showing tile effects of lopping 


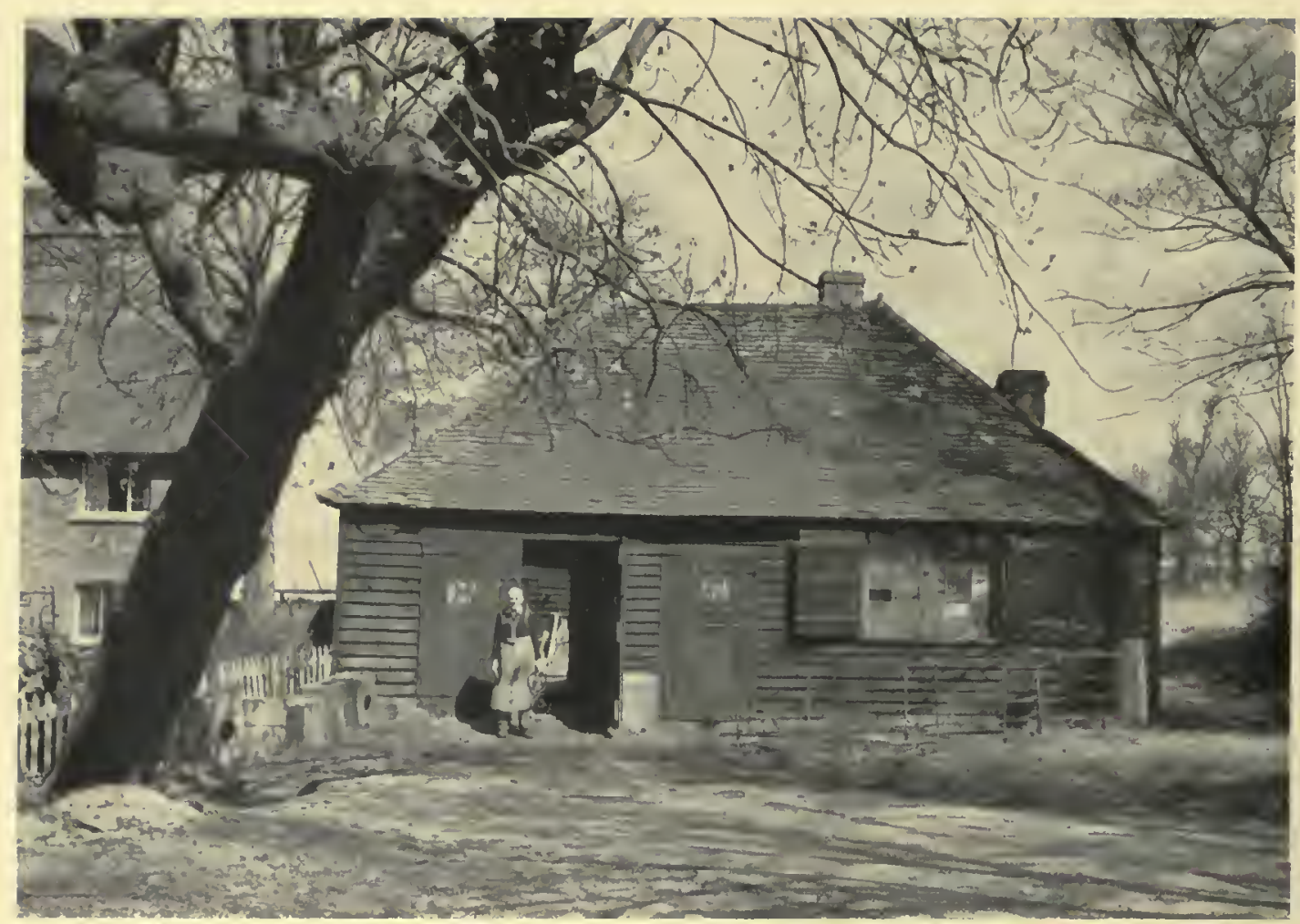

Cutlers Forge, Stapleford 'Tawney



Stanford Rivers: Tent and 'Tarpaulin Factory, Formerly the Ongar Union Workhouse 


\section{STAPLEFORD TAWNEY}

Stapleford Tawney is a parish about 7 miles north of Romford, having an area of 1,656 acres. I In I 80 I the population was 196 . It reached 350 in 1841 but has subsequently declined. ${ }^{2}$ In I 95 I it was only $153 .^{3}$ Since 1755 the rectory of Stapleford Tawney has always been held jointly with that of Theydon Mount (q.v.) but the two parishes have remained separate for civil purposes.

The south of the parish, where the River Roding forms the boundary, is about $100 \mathrm{ft}$. above sea-level. From here the land rises gradually to over $300 \mathrm{ft}$. in the north. A stream flowing south into the Roding forms much of the western boundary. A wood called Shales More lies in the south-west of the parish and Bob's Barn Wood lies on the eastern boundary. The road from London and Woodford to Chipping Ongar enters the parish by Passingford Bridge and runs north-east. On the west side of this road, immediately north of the bridge, stands a group of buildings most of which appear to date from the late I 8 th or early Igth century. North-east of this group, at the junction of the main road with a by-road to Theydon Mount and Theydon Garnon, stands Cutler's Forge (see plate facing p. 233) which is said to have belonged to the Cutlers' Company of London in the 17 th century. ${ }^{4}$ It is an L-shaped weather-boarded building, the older part of which has a roof truss probably of 17 th-century date. The forge is still in use and has two brick furnaces. The cottage next to the forge is also probably of 17 th-century date with a later frontage of red brick. Farther along the main road to Chipping Ongar, in a park which occupies most of the south-eastern corner of the parish, is Suttons. 5 The by-road from Cutler's Forge runs westward to Theydon Mount. Running north from this Theydon road is the road to the church a mile north. The site of Stapleford Tawney Hall' lies on the west side of the road, immediately to the sou th of the churchyard. South of this site stands Great Tawney Hall.' North of the church stands the former schoolhouse, now the village hall. 8 Farther north on the east side of the road is the former rectory. 9 North of this the road turns east to Colliers Hatch, but a by-road continues north to Little Tawney Hall, an I 8th-century building later refronted. Bell's Cottages are $\frac{1}{2}$ mile from the rectory on the east side of the Colliers Hatch road. These Cottages, formerly Bell's Farm, have an overhanging upper story on the west side and are prob-

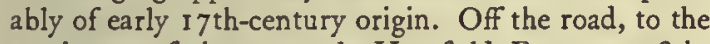
south-east of them, stands Howfield Farm, an I 8thcentury building. ${ }^{10}$ About $1 \frac{1}{2}$ mile farther north, at Wood Hatch, is the Moletrap Inn. This and its neighbouring cottages are timber-framed, and are probably of the early i 8 th century. Half a mile farther north, in the extreme corner of the parish near Colliers Hatch, stands Moat Cottage, which dates from the late I 8 th or early igth century. The cottage is surrounded by a rectangular moat, well preserved and full of water. North of this is a pair of weather-boarded cottages with timber framing of the 16 th or early 17 th century. There is also a small $\mathrm{T}$-shaped cottage of the same period on Tawney Common south-west of Colliers Hatch.

There are frequent references in the records to Passingford Bridge, important because of its position across the Roding on the main road from London to Ongar. In the late I6th century there was uncertainty as to who was responsible for the bridge, probably because it spanned the parish boundary with Stapleford Abbots."I By 1593, however, the county had accepted responsibility for repairing it. ${ }^{12}$ In 1785 it was rebuilt in brick. ${ }^{13}$ In 1858 the county surveyor commented that the bridge was narrow and situate at a very inconvenient angle with the road'.14 It has been strengthened and repaired at various times and one pier was rebuilt in $1952 .{ }^{1 S}$

The post-office in Stapleford Tawney has from the first been situated a little to the north of Passingford Bridge. It was at first described by the name of the bridge. It was kept by a receiver in $1793 .{ }^{16}$ In I 8 I 3 it was on the daily ride between Ongar and Epping.17 In 1881 a money-order office was established, 18 and in 1896 the name changed to Stapleford Tawney. ${ }^{19}$ In 1897 a telegraph office was set up under guarantee, ${ }^{20}$ and in 1930 a rural auto-telephone exchange. ${ }^{21}$ The present post-office building appears to date from the first half of the I 9 th century.

Water was supplied by the Herts. and Essex Waterworks Co. in 1949 to most of the parish.22 Electricity was laid on in December 1932 but not on Tawney Common.23 The village hall was formerly the school. ${ }^{24}$

In 1771 a writer noted that Stapleford Tawney 'hath but few houses in it and, like the other [Stapleford], seems to carry on no other business than that of husbandry'.2s Stapleford Tawney is still a rural parish devoted almost exclusively to agriculture.

The lords of the capital manor were resident in Stapleford Tawney at the end of the 15 th century ${ }^{26}$ and for at least a short period, $1550-85$, in the 16 th century.27 After 1585 they no longer lived in the parish. 28 The lords of Suttons may have been resident in the $13^{\text {th }}$ century but they did not live in the parish for some three centuries after I 3 I 2.29 During this period the manor was usually farmed out on long leases. ${ }^{30}$ Since the Luthers purchased the manor in the
O.S. $2 \frac{1}{2}$ in. Map, sheets $51 / 49,51 / 59$, $52 / 40,52 / 50$.

2 V.C.C. Essex, ii, 350.

3 Census, 1951.

4 Inf. from a painted inscription (modern) inside the forge. By 1649 , however, the forge was owned by Thomas Luther, lord of Suttons manor: E.R.O., D/DSd 4 .

s See below, Manor of Suttons.

6 See below, Manor of Stapleford

Tawney Hall. 7 Ibid.

8 See below, Schools.

- Sce below, Church.

so The building was described as How. field House in Chapman and André, Map of Essex, 1777 , sheet xvi.

11 E.R.O., Q/SR $25 / 7,23 / 25,39 / 30$, $42 / 33,74 / 37$.

12 Ibid. $123 / 29$.

t3 E. Jervoise, Anct. Bridges of Mid-and East. Eng. 136.

14 E.R.O., Q/ABz 3 .

13 Inf. from local police constable.

16 Cary's English Atlas, 1793.

17 Western's Post Office map, I 813. See Chipping Ongar, p. 158.

18 P.M.G. Mins. $188 \mathrm{r}$, vol. 207 , $\mathrm{min}$ 945.

19 Ibid. 1896 , vol. 573 , min. $119 \mathrm{r}$.
20 Ibid. 1897 , vol. 6 I 5 , min. 12547. 21 Ibid. $1930, \mathrm{~min}$. 11645

22 Inf. from Herts. \& Essex Waterworks Co. and from Rector of Theydon Mount and Stapleford Tawney.

${ }^{3}$ Inf. from rector 2nd East. Electr. Bd. 24 See below, Schools.

as Hist. Essex by Gent. iv, 40.

26 E.R. Ixii, no. 245 , p. 44. See below, Church.

27 E.R. lxii, no. 246, pp. 46,50

28 Ibid. p. 51. See below, Manor of Stapleford Tawney.

29 See below, Manor of Suttons.

30 Ibid. 


\section{A HISTORY OF ESSEX}

early I 7 th century the owners of the estate have been resident. ${ }^{31}$

In 1838 the parish consisted of 1,570 acres.32 Of this the lord of the capital manor owned 7 I I acres and the lord of Suttons 348 acres. ${ }^{33}$ Mrs. S. West was the only other substantial owner (245 acres). ${ }^{34}$ These landowners let nearly all their land to tenant farmers. The largest farm in the parish was Stapleford Tawney Hall farm comprising 374 acres. There was one other farm of over 200 acres. There were three farms of $100-200$ acres and six of $40-100$ acres. 35

In this parish mixed farming is carried on. In I 837 there were estimated to be 49 I acres of arable, 768 acres of meadow and pasture, and 125 acres of woodland. ${ }^{36}$

Passingford Mill, which is about mile west of Passingford Bridge, just within the boundary of Stapleford Abbots, ${ }^{37}$ belongs to Suttons and is said to have replaced an earlier mill south of Suttons. ${ }^{38}$ It is a timber-framed and weather-boarded building of three stories and probably dates from the I 8 th century. Inside the mill are the names and dates of various millers, the earliest being a Zach Tuck, I760. In about I93 I a turbine was installed and later the water wheel was cleared away. 39 In a map of 1777 a windmill as well as a water-mill is shown in this position. 40 The present Mill House has been converted from a pair of weather-boarded cottages, probably dating from the late 18 th century. The former Mill House is farther west. It was probably built late in the I 7 th or early in the I 8 th century and has a treble hipped roof. The chimney has diagonal shafts. On the south wall is a painted wood sundial with a pedimented top; this bears the date 1635 and the inscription 'Horas non numero nisi serenas'.

In I066 STAPLEFORD TAWNEY was held by Godric as 1 manor and as 5 hides. ${ }^{11}$ Of MANORS these 5 hides he 'gave to his Io free men freely 4 hides, retaining I hide in demesne'.42 After the Conquest Robert Fitz Wimarc had the I hide by the king's gift and his son Swein of Essex added the 4 hides to it after his father's death. 43 In 1086 the manor was held of Swein by Siric. 44 At that time the manor, which had been worth 68 before I 066 , was worth 610.45 In 1086 Swein of Essex held the honor of Rayleigh, and the manor of Stapleford Tawney continued to be held of that honor, which escheated to the Crown in the I 2 th century, until after 1550.46 In I 296 and I 30 r the manor was held by the service of 2 knights' fees. 47 In 1303,1346 , and 1428 it was said to be held by the service of I fee. ${ }^{48}$ In I 3 I 7 and I $34 \mathrm{I}$ it was reported that the manor was held by the service of $\frac{1}{2}$ fee.49 In I 49 I the manor was held in socage by a rent of $75.8 d .50$ In 1550 it was held in socage by a rent of $35.8 d .{ }^{\text {si }}$

By I I I-I 2 the tenant of the manor was Richard Fitz William. ${ }^{52}$ After 1232-3 Richard was succeeded by his son William who died in about I 246 leaving as his heir his daughter Margaret, wife of Richard de Tany. 53 It was from the Tany family that this manor and parish took the second part of its name-Tany or Tawney-to distinguish it from Stapleford Abbots (q.v.).

In I 264 Richard de Tany obtained licence to enclose his wood of Stapleford Tany within the bounds of the forest of Essex together with 5 acres of his demesne land adjoining the wood, in order to make a park.54 Richard de Tany died in 1270 leaving as his heir his son Richard who, unlike his father, had taken the king's side in the recent baronial wars. 55 In the quo warranto proceedings of I 274-5 Richard claimed to hold the assizes of bread and ale and view of frank-pledge but was unable to produce any charter confirming these rights. $56 \mathrm{He}$ was ordered to seek judgement of the king.s7 At the time of the second Richard's death in I 296 the manor included 60 acres of 'foreign wood in the forest which is a loss to the lord because he assigned a tenant to the keeping of the wood, who used to render him 4s. 6d. a year for his land and now renders nothing'. 58 Richard left as his heir his son Roger who came of age in I 299. ${ }^{59}$ Roger de Tany died in I $30 \mathrm{I}$ leaving as his heir his son Laurence, a minor. ${ }^{60}$ The king granted the custody of the estate during the minority of Laurence to Queen Margaret.6r In I 306 Margaret sold the custody to William de Estden, king's clerk, who then sold it to John de Uvedale.62 The manor was still in the custody of Uvedale when Laurence de Tany died in 1317 leaving as his heir his sister Margaret, wife of John de Drokenesford.63 Margaret predeceased her husband who died in 1341.64 The heir of John and Margaret was their son Thomas who died in 136 I and was succeeded by his daughter Anne, afterwards wife of Sir Thomas Mandeville.65 In ${ }^{6} 382$ Thomas and Anne granted a life interest in the manor to Thomas Lampet at a rent of $£, 20$ a year. ${ }^{66}$ Sir Thomas Mandeville was dead by $1399.67 \mathrm{His}$ son and heir Thomas died in 1400 while still a minor. ${ }^{68}$ The heirs of the young Thomas were his sisters: Alice, wife of Helming Legat, and Joan, wife of John Barry. ${ }^{69}$ A partition of their inheritance was made in 1400 and the annual rent due from Thomas Lampet for the manor of Stapleford Tawney was allotted to Joan and John Barry. ${ }^{70}$ It is not clear what arrangement was made at this time about the reversion of the manor after the 3s Hist. Mon. Com. Essex, ii, 226; E.R.O., Q/RPI 685-737; White's Dir. Essex (1848), p. 439; Kelly's Dir. Essex (1874, f.).

32 E.R.O., D/CT 331.

33 Ibid. See below, Manors.

34 E.R.O., D/CT 331.

35 Ibid.

37 See Stapleford Abbots, 36 Ibid

38 Inf. from Mr. W. H. Twyneham, jun. of Albyns, Stapleford Abbots. There are obvious mill-cuts in the River Roding, south of Suttons.

39 Inf. from Mr. W. H. Twyneham, jun.

40 Chapman and André, Map of Essex, 1777 , sheet $x$ i.

is V.C.H. Essex, i, 490a.

42 Ibid.

43 Ibid. For Robert Fitz Wimarc and his heirs see Manor of Theydon Mount. 4t V.C.H. Essex, i, $490 a$.

45 Ibid.

46 Bk. of Fees, ii, 1463 ; Cal. Inq. p.m. i, pp. 248,302 ; ibid. iv, pp. $12-13$; ibid. xi, pp. $182-3$; Cr42/208/181; E.R.O. $\mathrm{D} / \mathrm{DRg}$ r/ $1 \times 5$.

47 Cal. Inq. p.m. iii, p. 201 ; ibid. iv, PP. I 2-13.

48 Feud. Aids, ii, 136, 160, 222

4 Cal. Inq. p.m. vi, p. 69 ; ibid. viii, pp. $228-9$.

50 Cal. Inq. p.m. Hen. VII, i, p. 334.

sI E.R.O., D/DRg 1/1 15

52 Red Bk. of Exch. 595 .

s3 Ex. e Ror. Fin. (Rec. Com.), i, 449 ;

Cal. Ing. p.m. i, pp. 283,$302 ; B k$. of Fees, ii, 1463 . Cf. E.A.T. N.s. xviii, 18 . In c. 1254 the patron of the living was reported as William son of Richard. It is virtually certain, however, that William was dead by March 1246 .

54 Cal. Pat. $125^{8-66,394}$

35 Cal. Inq. p.m. i, p. 248.

36 Plac. de Quo Warr. (Rec. Com.), 232.

57 Ibid.

58 Cal. Inq. p.m. iii, p. 201.

so Ibid.; Cal. Close, 1296-1302, 270.

60 Cal. Inq. p.m. iv, pp. 12-13.

63 Cal. Pat. $1301-7,439,464$.

62 Cal. Pat. $1301-7,464$.

${ }^{63}$ Cal. Ing. p.m. vi, p. 69 .

64 Cal. Inq. p.m. viii, pp. 228-9.

65 Cal. Inq. p.m. xi, pp. 182-3.

66 Feet of F. Essex, iii, 197. For Thoma:

Lampet see under manor of Lampetts in

Fyfield.

$67 \mathrm{C}_{137 / 14}$.

68 Ibid.

69 Ibid.

70 Cal. Fine R. 1399-1405, 75 . 
death of Thomas Lampet. By a series of conveyances ending in 1410 , however, Alice and Helming Legat obtained the sole reversionary rights, apparently by grant from Joan and John Barry.7I In 1412 it was reported that Alice, widow of Helming Legat, was holding Stapleford Tawney manor which was worth fo. 20.72 Alice married as her second husband Roger Spice and after she died in 1420 Roger was lord of the manor until his death, or shortly before his death, about I 459.73 The manor then descended to Clement Spice, son of Roger and Alice. ${ }^{74}$ In 1466 Raphael Vannell, grandson of Joan and John Barry, tried to dispossess Clement.75 Between I 467 and 1473 Clement filed a bill in Chancery against Raphael and evidently won his case. ${ }^{76}$ Between 1480 and 1485 Clement Spice sold the manor to William Scott, lord of the manor of Woolston in Chigwell (q.v.). ${ }^{77}$ By a deed of feoffment in May 1485 the manor of Stapleford Tawney was settled on William and his wife Margery for their lives in survivorship with remainder to their eldest son John. ${ }^{78}$ William died in 1491 and his wife in 1505.79 John Scott died in 1527 and was succeeded by his grandson Walter, son of his son Thomas. ${ }^{80}$ In 1534 Walter also inherited the manor of Woolston (q.v.) and afterwards the manor of Stapleford Tawney followed the same descent as that of Woolston until the death of George Scott in 1589.82 In 1550 the manor of Stapleford Tawney consisted of 40 acres of arable, 60 acres of meadow, 40 acres of pasture, 100 acres of wood, and rents totalling 40s. a year. ${ }^{82}$ The net annual value of the manor was $\$ 26$ gs. $8 d .83$ In 1589 it passed to Elizabeth and Mary, daughters of George Scott, and was afterwards allotted to Elizabeth and her husband Sir Edward Aleyn, Ist Bt. ${ }^{84}$ Sir Edward died in 1638 and was succeeded by his grandson Edmund, 2nd Bt. ${ }^{85}$ In 1656 Edmund died leaving as his heir his daughter Arabella, wife first of Francis Thompson and afterwards of Lord George Howard, son of Henry, Duke of Norfolk (d. I684).86 In I7I 7 Arabella and Lord George Howard conveyed the manor to $\mathrm{Sir}$ Edward Smyth, Bt., of Hill Hall, Theydon Mount ${ }^{87}$ (q.v.). Afterwards the manor descended along with Hill Hall until the break up of the Hill Hall estate. ${ }^{88}$ The manor then passed with the manor of Theydon Mount (q.v.) to Mrs. Battye and Mrs. Stafford Northcote who held it until after 1937.89

In 1838 the estate in Stapleford Tawney consisted of 7 I I acres of which 247 acres were arable. 90

The site of Stapleford Tawney Hall is immediately to the sonth of the churchyard. It now consists of a walled garden, surrounded by a dry moat.

Great Tawney Hall, standing immediately south of the site of Stapleford Tawney Hall, probably superseded the old manor house. It is a timber-framed farmhouse, apparently of the 18 th century, and was probably built for the occupation of the tenant of Stapleford Tawney Hall farm after the manor had passed to the Smyths of Hill Hall. In 1838 it was owned by Sir John Smijth of Hill Hall but was in the occupation of the executors of Edward Potter, late tenant of Stapleford Tawney Hall Farm. ${ }^{91}$ It has two stories and a basement. The five-window garden front has been refaced with red brick, probably about the middle of the Igth century.

Nothing has been found concerning the manor of SUTTONS until I29I. It derived its name from John de Sutton (see below).92 Then and afterwards it was held of the manor of Stapleford Tawney by knight service, the amount of which was reported as $\frac{1}{3}$ fee in 1303 and 1428 , as $\frac{1}{2}$ fee in 1317 , and as $\frac{1}{1}$ fee in 1326.93

In I 29I Thomas de Bredstrete granted to John de Sutton and his wife Maud I messuage, I mill, 220 acres of arable, Io acres of meadow, 50 acres of pasture, 8 acres of wood, and 4 s. rent in Stapleford Tawney and Navestock, to hold to them and their son John and his issue, with remainder to the right heirs of John the son. 94 In I 3 I 2 or I 3 I 3 John the elder granted this estate to Gilbert de Clare, Earl of Gloucester, and his wife Maud and to Gilbert's heirs.9s Gilbert died in I 314 and his wife in I 320.96 The estate then descended to Margaret, sister and coheir of Gilbert, and her husband Hugh, Ist Lord Andley.97 In I 32 I Lord Audley forfeited this estate to the Crown, with the rest of his lands, when he joined the rebellion against the king. ${ }^{98}$ The manor was still in the possession of the Crown in 1326 when the sisters of John de Sutton the younger, who was then dead, claimed the estate as their brother's heirs. ${ }^{99}$ Their claim failed and the manor was restored to Lord Audley who died in 1347 leaving as his heir his daughter Margaret, wife of Ralph, later ist Earl of Stafford. I Ralph survived his wife and died in possession of Suttons in $1372.2^{2}$ The manor then followed the same descent as that of Stanford Rivers (q.v.) until the I 7 th century. It was usually farmed out, on long leases, at a rent of \&1 3 6s. 8d. a year. ${ }^{3}$ One of the lessees in the I6th century was Walter Cely, lord of Albyns in Stapleford Abbots and also lessee of part of the manor of Stapleford Abbots (q.v.).4

In I6I 3 James I sold Suttons, with the manor of Stanford Rivers, to Richard Cartwright and Thomas Cowley of London.s Nothing more has been found concerning Suttons until I 649 when the lord of the manor was Thomas Luther. ${ }^{6}$ He died in 1694 leaving as his heir his son John who was dead by 1713.7 Thomas Luther, son of John, died in 1722 leaving his estates heavily encumbered with debts. ${ }^{8} \mathrm{He}$ devised Suttons to his mother Jane Luther for life with remainder to his sister Rebecca Goebell for life and

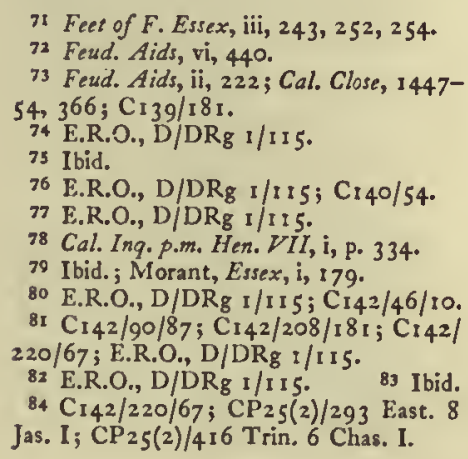

98 Cal. Inq. p.m. vi, pp. 454-5; Cal. Find R. I 3 19-27, 57; Complete Peerage, i, 346; ibid. $v, 7 \times 6$.

99 Cal. Inq. p.m. vi, pp. 454-5

I Cal. Inq. p.m. ix, p. 56 .

${ }^{2} \mathrm{C}_{35 / 230 / 1 ;}$ Complete Peerage, i, 347.

3 E.R.O., D/DP M $582 ; L$. E P. Hen. VIII, xviii (2), p. 60; Req. 2/30/73; C66/1988.

4 Req. $2 / 30 / 73$; P.C.C. 44 Populwell (1549).

5 C66/i 988.

6 E.R.O., D/DSd T 4

7 Ibid.

8 E.R.O., D/DSd Tr. 


\section{A HISTORY OF ESSEX}

afterwards to her son John Goebell.9 Jane Luther died in 1745 after paying off her son's debts to the extent of $\oint_{8} 8,500.10$ In 1752 Rebecca Goebell and her son John mortgaged the manor for $£_{2}, 000$. II In I 768 , after Rebecca's death, John Goebell borrowed another $\{2,000$ on the security of the estate and when he died in 1777 the two mortgages were still unredeemed. 12 He left his estate to his sister Rebecca and her husband Gerrard Goebell, a London sugar refiner. ${ }^{13}$ Rebecca died a month after her brother. ${ }^{14}$ In 1778 , partly in order to pay off his brother-in-law's debts, Gerrard Goebell mortgaged the estate for $£ 9,000$ to John Baker, from whom he borrowed another $\oint_{\mathrm{I}}, 000$ in I784..$^{15}$ Gerrard Goebell died in I786 leaving the estate encumbered with the debt of $\oint_{0} 10,000.16 \mathrm{He}$ devised all his estate to his second wife Ann who in I 787 sold it to Charles Smith of Mile End (Mdx.) for $\oint_{1} 5,725$ out of which she paid the $\oint_{1} 0,000$ owing to John Baker. ${ }^{17}$ The manor was held by Charles Smith until I8I4 when he was succeeded by his widow Augusta Smith, who held it until after 1832.38 By I 838 it had passed to Sir Charles Cunliffe Smith, Bt., grandson of the purchaser of the manor. ${ }^{19}$ It has since descended with this baronetcy. ${ }^{20}$ In 1838 the manor farm consisted of 219 acres.21 At about that time Suttons was the centre of an estate of at least 1,868 acres of which 1,384 acres $^{22}$ lay in Stanford Rivers, 348 acres in Stapleford Tawney, ${ }^{23}$ and I 36 acres in Lambourne. ${ }^{24}$ It included the manors of Stanford Rivers, Barwicks, Bellhouse, and Traceys in Stanford Rivers (q.v.) and the manors of Hunts and Pryors in Lambourne (q.v.) as well as Suttons in Stapleford Tawney.

Suttons was at one time a two-story timber-framed house of the I 7 th century or earlier. The original plan probably consisted of a central hall with two crosswings. At the back of the south wing is an early- or mid-1 7 th-century staircase with flat moulded balusters and square newels. The hall has fine panelling, pilasters, and cornice of the early i 8 th century. About I 8 I 5 the house was cased in brickwork and covered with stucco, the eaves were raised and the garden front added. The weather-boarded outbuildings and brick dovecote are probably of the 18 th century.

The advowson of Stapleford Tawney was held by the lords of the capital manor until 1925.25

CHURCH It has subsequently descended with the advowson of 'Theydon Mount (q.v.)

In about 1254 the rectory was valued at 9 marks. ${ }^{26}$ In 1291 it was valued at 6.6 I $35.4 d .{ }^{27}$ In 1428 the church was still taxed on this valuation. ${ }^{28}$ In 1535 the rectory was valued at $\oint_{1} 5$ 8s. $8 d .{ }^{29}$ Its 'improved' value was 680 in 1604 and 6200 in 1661.30 The tithes were commuted in 1838 for $\{384$; there were then 127 acres of glebe. ${ }^{31}$ Since 1755 the rectory has always been held along with that of Theydon Mount but they have never been formally united.

Henry Soames ( $1785-1860)$, who held the united living of Stapleford Tawney and Theydon Mount from 1839 until his death, was a noted ecclesiastical historian and was appointed Chancellor of St. Paul's Cathedral in 1842.32

The former rectory was originally a two-story timber-framed house built probably early in the 17 th century. In the mid i 8 th century two sides were faced with red brick and a new roof with dormer windows was added, and inside there are panelled rooms and fireplaces of the same date. In 1771 it was described as 'an exceeding good house'. ${ }^{33}$ About 1840 a new staircase hall and a bay-windowed drawingroom were built. Since I95 I the rector has lived at Theydon Mount.

The parish church of $S T . M A R Y$ consists of chancel, nave with west bell-turret, south chapel, and vestry. The walls are of flint-rubble with dressings of limestone. The roof is tiled. The bell-turret is timber-framed and weather-boarded and has a shingled spire.

The chancel was built about 1220 . In the north wall is a lancet window which may be original, though the splay stones have been recut.

The nave was built shortly after the chancel. A blocked north doorway with chamfered jambs and two-centred arch, partly restored, can be seen externally.

The south chapel was built about the middle of the I $3^{\text {th }}$ century. On the east side are two wall-arches, the smaller of which is partly original I 3 th-century work. Enclosed under the larger is an original lancet window. Three lancet windows in the south wall and one in the west wall may also be of the $13^{\text {th }}$ century, much restored.

In the $15^{\text {th }}$ century a square-headed two-light window was inserted in the south wall of the chancel; the stonework of this is much decayed. The bell turret at the west end of the nave was probably added in this century. It stands on four chamfered oak posts with tie-beams, curved braces, and diagonal struts.

Some roof timbers of the south chapel are of the I6th century.

In 862 the church was largely rebuilt and the north vestry, organ chamber, and south porch were added. ${ }^{34}$ The three lancet windows in the east wall of the chancel are of this date as well as the two-light windows of I4th-century design in the nave. The arcade of two bays between the south chapel and the body of the church was built or rebuilt at this time.

In February I 862 the vestry accepted an offer, made by Sir Charles Cunliffe-Smith, Bt., of Suttons (see above), of 6300 towards the cost of restoring the church.35 It is not clear what the final cost of restoration was. In May I 862 George Carter of Hornsey Road, Holloway (Lond.), offered to do the work required 'at the Church and Chancel' for $£ 526$ of which $f_{0} 05$ was for repairing the chancel. He also offered to supply new fittings for an additional $f_{0} 23$ of which $£_{24}$ was for seats in the chancel. ${ }^{36}$ A vestry



${ }^{20}$ Kelly's Dir. Essex (1874 f.); Burke, Peerage (1 949), $186 \mathrm{I}-2$.

21 E.R.O., D/CT 33 I.

22 E.R.O., D/CT 327.

23 E.R.O., D/CT 33 t.

24 E.R.O., D/CT 202.

25 Cal. Inq. p.m. iv, pp. I 2-13; ibid. vi, p. 69; Newcourt, Repert. ii, 555-6 Morant, Essex, i, I 8 I ; Crockford's Cler. Dir. passim; E.A.T. N.s. xix, $74 ; K e l l y$ 's Dir. Essex (1926).

26 Lunt, $V$ al. of Norwich, 336.

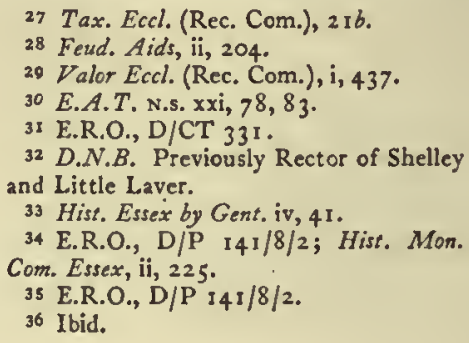


held on 27 May 1862 seems to have accepted Carter's tender for repairs and fittings in the 'Church and Chapelry' at a cost of $\$ 520$. At the same time it was estimated that the fees of the architect, Mr. Turner, and incidental costs would amount to about $£ 200.37$ It is not clear that this vestry accepted Carter's tender for restoration of the chancel.

The organ, presented by Reginald Heber Prance, was built in $1869 .{ }^{38}$

In 1884 a new roof of panelled pine was constructed. 39 Cusped and pierced boarding was inserted to suggest a chancel arch.

There are two bells, one of I6 I I by William Carter, and the other of 1630 by Robert Oldfield.40 At a visitation held in I6 I I it was reported that the bell was broken and it was not known 'who pulled it down'.41 The date on Carter's bell indicates that the broken bell was speedily replaced.

The communion rails date from the $\mathrm{I} 7$ th century and have unusual flat moulded and pierced balusters. The font in the form of a Norman column dates from the roth century but the wooden cover is older. The stone pulpit is of the roth century. The mosaic reredos, representing the Last Supper, was presented by Sir Charles Cunliffe-Smith, Bt., of Suttons (see above). ${ }^{42}$

The plate consists of two cups, one of which was presented by John Luther in 1698 ; three patens, one of which was presented by John Nicholson in 1698 and another of which bears the Luther arms; and an alms-dish of 1685 , also bearing the Luther arms.43

On the floor of the chancel is a slab to William (Scott) (r 49r) and Margery his wife (I 505).44 This has a fine achievement of arms and cross in brass, and also part of a marginal inscription. Near it is a slab to Sir Edward Lowe, LL.D. (I684). Both in the chancel and nave are floor slabs to many members of the Luther family who died in the I7th and early I 8th centuries. Also in the nave are slabs to John Nicolson (1710) and Gerrard Goebell4s (18th-century date partly worn away). In the nave and in the south chapel there are tablets commemorating Charles Smith (I8I4) and members of his family.

During the restoration of 1862 two stone coffins and slabs, probably of $13^{\text {th-century date, were found }}$ below the chancel.46 One of these is now outside the church on the south side. The slab is said to be amongst the finest in Essex. It is slightly coped, the central shaft forming the ridge. On the shaft are three crosses, those near the head and foot having triangular arms. Between them on the shaft is a small circular 'cross-paté'. North of the church stands the second coffin with a shaped head. The tapered threshold to the blocked north doorway may be the slab belonging to it.

For the Church lands see Charities, below.

Parish books survive for Stapleford Tawney from 1723 and detailed overPARISH GOVERNMENT seers' accounts from $A N D$ POOR RELIEF. I 745 to I 836.47 Before I78 I vestry meetings were usually held twice a year, at Easter and Christmas, for the election of officers and andit of accounts. After that date additional meetings were called at irregular intervals each year to pass the overseer's accounts. The average attendance, inclusive of parish officers, was from 4 to 6 , and most of the parishioners who attended usually served at some time as parish officers. Some rectors attended regularly, notably Parson Parkes between 1723 and 1732 , William Smijth between 1754 and 1775, and Richard Smijth between $178 \mathrm{I}$ and 1793. Thereafter, except in $1831-2$ when the rector, another Richard Smijth, presided at nine meetings, neither the rector nor the curate often attended vestry meetings. In their absence the churchwarden generally presided. It was stated in 1823 that a vestry dinner was held every year at a cost of abont 66 , which was charged to the overseer's account.

There was a tendency from an early date to use the poor rates for all purposes and after 1784 this became the general practice. In $\mathrm{I} 749$, for example, the surveyor's and constable's accounts were paid by the overseer, and in 1778 the overseer's disbursements included the payment for a bottle of wine for the sacrament. From 1784 the overseer levied one general rate for the whole parish out of which he paid other officers' bills and was responsible for the final annual balance. This practice was abandoned in 1823 after an investigation into the keeping of accounts between $18 \mathrm{ro}$ and $\mathrm{r} 822.48$ A rate of $\mathrm{I} d$. in the pound produced $E_{3} \mathrm{II}$ Is. $2 d$. in 1727. A century later a rate of $\mathrm{I} s$. brought in between 6.53 and 6.54 .49 A new valuation was made in I 839 , when the approval of the Board of Guardians was sought for the payment of $£ 36$ out of the poor rates towards the expense of making it. A further valuation was made in 1861 , when the rateable value was fixed at over $\{2,658$.

The parish officers served unpaid until 1817 , when Charles Clark, overseer for the two-years I8I7-19, was allowed a salary of $f \mathrm{r} 5$ each year. This practice was apparently not continued with his successors. Other parish officers tended to serve for long periods at a time but the overseer was usually changed each year. Women were appointed as overseers on two occasions in the r 8 th century, and of these Mrs. Haddon of Tawney Hall served for two consecutive years $1725-7$. The overseer was responsible for levying rates and keeping accounts but he was relieved of some of the labour of attending to the wants of the poor during the years when this duty was most pressing. Between 1798 and I 830 the task of paying weekly doles was delegated to others, principally to John Shuttleworth, who periodically submitted an account to the overseer.

Occasional bills for medical attention for the poor were included in the overseer's accounts from at least 1757 , but a regular medical attendant was not appointed until I79r, when the apothecary's salary of $£ 55$ s. was first recorded. A note was entered in the parish book in 1726, just after the parish school (see below) was founded, stating that the schoolmaster was to pay the church clerk 30 s. a year for life, but it is not clear whether the clerk was to give any assistance in return. The pound stood in the road about 120 yds. north of the church.so

\author{
37 Ibid. \\ 38 Wall tablet in chancel. \\ 39 Kelly's Dir. Essex (1 9 12). \\ 40 Ch. Bells Essex, 398-9. \\ 41 E.R. xv, 46. \\ 42 Kelly's Dir. Essex (IgI2).
}

43 Ch. Plate Essex, 104

44 See above, Manor of Stapleford Tawney.

4s See above, Manor of Suttons.

46 E.A.T. N.s. vii, 392-3

47 E.R.O., D/P 141/8/1-2; ibid. D/P
14I/12/1-3. Unless otherwise stated all the following information is derived from these books.

$48 \mathrm{Sec}$ below.

49 E.R.O., D/P I4 I/I I/z.

so $0 . S .6$ in. Map (ist edn.), sheet lviii. 


\section{A HISTORY OF ESSEX}

Rents for two parish houses were received in 1723 . In 1767 repairs were carried out at two parish houses, described as the Parish House and the Church House. In 1826 a bill was paid for the erection of a cottage on Tawney Common. All the parish property, then described as consisting of cottages on Tawney Common and two adjoining the church, was offered for sale in 1837 and the proceeds were used to repay to Lady Smith the money borrowed by the parish for their share in building the incorporated workhouse. The cottages by the church are said to have been demolished about 1887 .

Annual expenditure on the relief of the poor, after averaging about $f_{0} 33$ during the period $1725-50$, rose steadily to over $f_{0} 100$ for the first time in 1772 and then remained fairly constant for the next 20 years. The parish subscribed to the scheme, formulated by Mr. Conyers of Epping in 1794, for the promotion of industry.51 From 1793-4 expenditure rose steeply until 1801 when it amounted to over $\oint_{428}$ and a general rate of $8 s .6 d$. in the pound was levied. This figure was surpassed in $1814-15$ when over $£ 540$ was spent. An average of about $£ 360$ was raised by the rates each year between $180 \mathrm{I}$ and 1817 . Special grants, occasioned presumably by the inclinations of individual overseers, supplemented the normal forms of relief. During a scarlet fever epidemic in 1822 , the sick were provided with 'neck of mutton and bullocks' feet for jelly', and in 1829 and 1830 the expenses of two weddings, including licence, ring, and fees, were borne by the parish.

The vestry did little to control its officers in the discharge of their duties until a crisis had occurred in the parish in 1823 . In January of that year the vestry refused to grant a rate requested by the overseer, Thomas Ford, a man whose well-meaning schemes for relief did not always meet with general approval.52 'Owing to the depressed state of agriculture', various unemployed paupers had applied to him, as overseer, to find work for them. As a result he hired some of them on his own small farm, in excess of his actual requirements, paying them a basic wage of Is. a day himself and supplementing this with a further $6 d$. each for themselves and every member of their families out of the poor rates.53 The vestry objected to this, stating that the basic wage had been fixed at Is. $6 d$. a day, and refused to grant a rate. Thereupon Ford paid off his surplus labour and bought them Is. worth of marbles, with parish money, to keep them out of mischief. He then counter-attacked by questioning the accuracy of the overseers' accounts for the years $1810-22$. He claimed that, owing largely to the disappearance of some arnual balances and the failure to produce vouchers for the overseers' payments on the accounts of other parish officers, over $f_{625}$ remained unaccounted for. A committee of four, including Thomas Ford and the curate, William St. Andrew Vincent, who presided, investigated the charges and, under the curate's influence, cleared the officers concerned, to the evident dissatisfaction of Ford. The committee recommended, however, that in future over- seers should account only for sums spent on the poor. The vestry thenceforth began to control more closely the overseers' disbursements and the audit of their accounts and each succeeding overseer was made to sign both for the receipt of the account book and for his predecessor's balance.

In I 839 Stapleford Tawney joined with nine other parishes in the voluntary establishment of an incorporated workhouse under Gilbert's Act $(22 \mathrm{Geo}$. III, c. $83(1782)) .54$ The accounts of the overseer in $183 \mathrm{I}$ included the payment to Capel Cure of Stapleford Tawney's share of the mortgage raised for building this workhouse.

In 1836 Stapleford Tawney became part of the Ongar Poor Law Union.

A schoolhouse seems to have been built in $\mathbf{1} 725$ or 1726 by direction of the parish vestry so SCHOOLS that elementary subjects, the catechism, and Church of England doctrine should be taught to poor children.ss In I725 Sir Edward Smyth, lord of the capital manor (see above), lent $£ 20$ towards the cost of building, to be repaid from the rent of the Church lands. 56 In the same year, however, Mrs. Jane Luther, lady of Suttons (see above), repaid this debt. ${ }^{57}$ It would seem, moreover, that Mrs. Luther undertook the entire cost of building for she stated in her will, dated 1745 , that she had built the schoolhouse at her expense and had afterwards received a rent of 30 s. a year for it. 58 She then stipulated that after her death this rent was to be used primarily to keep the schoolhouse and its premises in repair, the residue being used to purchase bibles and prayer-books for distribution amongst the poor.59 Meanwhile in I 726 the vestry had decided to employ a schoolteacher at a salary of $£ 5$ a year (see Charities). 60 It is not clear, however, for how long the parish employed a salaried schoolteacher or who occupied the schoolhouse before Mrs. Luther's death in 1745 . Soon after her death the schoolhouse was being rented by Thomas King, who also rented the Church house. In April 1748 it was reported that King owed $\delta_{3} 3$ for two years' rent of the schoolhouse. ${ }^{61}$ From $1750-1$, if not before, the schoolhouse or at least the schoolroom was occupied by a master to whom the parish sent children on a per capite basis. In $1750-1$.5 $18 \mathrm{~s}$. was paid to the schoolmaster out of rents from the Church house and lands. 62 In $1751^{-2} \& 5 \mathrm{I}_{3}$. Iod. was paid from the same source for alterations 'in the schoolroom', it being stated that 'the shelves and partition was put up by the parish to be left when the tenant goes out'.63 In the same year Mr. Lewthwaite was paid $f_{2}$ I $7 s$. for 'schooling' and from then until 1783 , if not later, 'children's schooling' was usually the main item of expenditure in the churchwarden's annual account of parish property. ${ }^{64}$ This item varied in amount from year to year. In $1752-3$ three children were sent to school at a total cost of I2s. 6d.65 Usually, however, the annual cost was between $£ 2$ and $\oint_{0.66}{ }^{66}$ It is not clear what arrangements were made for educating the poor children of Stapleford Tawney after 1783 . In 1818 it was stated that there was no school of any kind in the parish. 67 In
31 Account of the origin and progress of the Society for the Promotion of Industry in the Hundreds of Ongar and Harlow and the Half Hundred of Waltham in the County of Essex (1797).

$52 \mathrm{He}$ was also responsible for telief during the scarlet fever epidemic, 1822 .

33 i.e. A man with 2 wife and 2 children received 2s, a day from the parish.

54 This voluntary union had its workhouse at Stanford Rivers (Q.v.).

ss E.R.O., D/P I $41 / 8 / 1$.

56 Ibid.

37 Ibid.

38 Rep. Com. Char. (Essex), H.C. 216 ,

pp. 244-5 (1835), xxi (I).
39 Ibid.

60 E.R.O., D/P I I I/8/I

6r Ibid.

62 Ibid.

63 Ibid.

65 Ibid.

64 Ibid. 66 Ibid.

67 Retns. Educ. Poor, H.C. 224 , p. 27 I (1819), ix (r). 
1831 a meeting of the vestry recommended that the rector should 'allow 64 per annum to Samuel Parish schoolmaster being the rent for the house which he now lives in on condition that he continues to educate the poor children on the Sundays'.68 In I 835 it was stated that the schoolhouse built at Mrs. Luther's expense was occupied rent-free by a schoolmaster who had been placed there by the rector and who had 30 feepaying pupils. ${ }^{69}$ At this date the master probably still taught the poor children of the parish on Sundays in return for his rent-free house. The schoolhouse was still occupied rent-free by a master in 1848 and possibly in 1861 but probably not as late as 1863 and almost certainly not as late as 1871.70

By 1839 the poor children of the parish were attending a day school in Theydon Mount (q.v.). ${ }^{71}$ In $187 \mathrm{I}$ an inspector proposed that 30 Stapleford Tawney children should be accommodated at Theydon Mount and that the remaining 6 in need of elementary schooling should be found places at Stapleford Abbots. Churchmen in Stapleford Tawney, however, decided to found their own school on land given by the lord of the manor of Stapleford Tawney (q.v.). ${ }^{72}$ A deed of 1873 appointed the rector and churchwardens as trustees of the school and declared that the religious teaching should be according to Anglican principles.73 The new school, with accommodation for 60 , was built in 1873-4, next to the church. A teacher's house was attached. The school was opened in 1874 under a certificated mistress 74 but, despite the receipt of annual grants from 1875 and an average attendance of 32 in that year, the falling population of the parish caused average attendance to fall to 15 in 1893.75 In 1904 there were 30 pupils on the roll under two mistresses, one of them certificated, and the average attendance was $25 .{ }^{76}$ By the Education Act of 1902 the school passed under the administration of the Essex Education Committee as a non-provided Church school. Average attendance continued to be low; in 1910 it was $19^{77}$ and in I9I I the possibility of closure was discussed.78 Average attendance rose, however, to 23 in 1920 and to 32 in 1936. After the reorganization of the school for mixed juniors and infants in 1936 the average attendance again fell, reaching 15 in 1938 . In 1939 , in view of the low number of pupils, the school was closed.79 The building is now used for village activities. It is a gabled building of red brick with bands of blue. The gables have pierced bargeboards.

68 E.R.O., D/P I41/8/2.

60 Rep. Com. Char. (Essex), H.C. 216 ,

p. $245(1835)$, xxi (I).

70 White's. Dir. Essex (1848), p. 438 ;

ibid. (1863), p. 746; Coller, People's Hist.

Essex, 490 .

72 E.R.O., D/P 30/28/19.

$72 \mathrm{Min}$. of Educ. File $13 / 367$.

$73 \mathrm{Min}$. of Educ. File $13 / 347$.

74 Chelmsford Chronicle, 9 Jan. 1874

75 Rep. of Educ. Cttee. of Council, I875

[C. $1513-1$ ], p. 534, H.C. $(1876)$, xxiii

Rein. $1513-1$ ] P. 534, H.C. $(1876), x \times 11 i$, 1893 [C. 7529$],$ p. 716 ,
Rehs.

H.C. (1894), lxv.
There is no record of the origin of the Church lands, which comprised 4 acres of arable near

CHARITIES Colliers Hatch.80 Their rent rose from 62 10s. in the 18 th century to f6 6 Ios. in $1834^{81}$ The property was sold in 1869 for .495 which was invested in stock. 82 Before 1750 the income was spent chiefly on church repairs and, from then until 1783 at least, it was used to educate the poor children of the parish.83 It was apparently applied to the poor rates until 1820 and was from then on generally used to give clothing to the poor. ${ }^{84}$ In I 949 the income of $6136 \mathrm{~s} .8 \mathrm{~d}$. Was spent with that of the other charities for the poor, on the distribution of coal, bread, and clothes. 85

Thomas Luther of Suttons, ${ }^{86}$ by will proved 1722 , left 6.5 a year issuing from land in the parish to the poor. ${ }^{87}$ In 1726 the vestry decided to use it to pay the parish schoolteacher. 88 This practice was discontinued by 1750,89 and the money was apparently applied to the rates until 1820 when it was given to the poor with the Church lands income.90 About I86I there was difficulty in securing payment as the land was in Chancery and in 1869 half the charge was redeemed for stock. The other half was apparently paid until 1949 when only \& $2_{2}$ I s. $8 d$. income from the stock was received. It was spent with the other charities.91

Jane Luther of Suttons, 92 by will proved 1745 , left 6.6 a year, issuing out of an estate at Little Warley.93 Of this sum $\oint_{2}$ 175. 6d. was to go to Kelvedon Hatch (q.v.); of the remainder, $5 s$. was to be paid to the parish clerk for weeding the gravel walk from the road to the church and the remaining $f_{0} 2175.6 d$. was to be given to the poor in bread. In 1834 both sums were paid by the owner of Suttons, as by this time the lands actually charged were unknown.94 Both rent-charges were redeemed in 1950 for $\oint_{1}$ I 5 stock for the poor and $\delta_{1} 10$ for the clerk. 95

The charities of Sir John Smijth, gth Bt., and the Revd. Sir Edward Bowyer Smijth, Ioth Bt., called the Hill Hall Charity, were founded by an indenture of 1840 . There were in 1953 separate endowments of fiog and firg stock for Stapleford Tawney and Theydon Mount respectively. That for Theydon Mount is said to represent legacies of 6.50 made under each of the two benefactors' wills together with E. 10 accumulation of interest: presumably the Stapleford Tawney stock represents similar legacies. Both charities are to be distributed in kind and were used with the other charities for the poor in 1949.96
26 Essex Educ. Cttee. Handbk, rgo4, p. 187 .

$77 \mathrm{Min}$. of Educ. File $13 / 347$.

78 Essex County Chronicle, I Dec. $19 \mathrm{II}$.

79 Min. of Educ. File $13 / 347$.

so Rep. Com. Char. (Essex), H.C. 216 , Pp. 244-5 (1835), xxi (r).

81 E.R.O., D/P $141 / 8 /$ r.

82 Char. Com. files.

83 E.R.O., D/P I41/8/1.

84 E.R.O., D/P I $41 / 1 / 3$.

is Char. Com, files.

${ }^{86}$ See Manor of Suttons above.

87 E.R.O., D/P 141/8/1; Rep. Com.
Char. (Essex), pp. 244-5.

88 E.R.O., D/P I4I/8/1.

89 Ibid.

90 Rep. Com. Char. (Essex), pp. 244-5. 91 Char. Com. files.

92 See Manor of Suttons.

93 Rep. Com. Char. (Essex), pp. 244-5. It has been suggested that Little Warley is a mistake for Little Warlow, alleged to have been an estate absorbed in Suttons by the I $g$ th cent.

94 Rep. Com. Char. (Essex), Pp. 244-5. is Char. Com. files.

96 Ibid. 


\section{A HISTORY OF ESSEX}

\section{STONDON MASSEY}

Stondon Massey is about 2 miles south-east of Chipping Ongar and 4 miles north-west of Brentwood. ${ }^{I}$ It is one of the smallest parishes in the hundred, having an area of 1,127 acres. In shape it is roughly like a reversed $L$, of which the short arm lies along a ridge about $300 \mathrm{ft}$. high above the Roding and the long arm extends north-west down to the river, containing the valley of a small stream which flows into the river near Hallsford Bridge, and also a spur extending north-west from the left bank of the stream. The scenery is varied. There are stretches of woodland in the upland areas, notably Oak Wood and the park at Stondon Place, both on the main ridge, and Church Wood on the subsidiary spur. Along parts of the road which runs northwest through the parish to Hallsford Bridge there are high hedges, while the approach east from Kelvedon Hatch is by a road without hedges but lined with tall trees. From the higher ground at Church Hill there are good views across to Chipping Ongar and also north-east in the direction of Blackmore. During the past 30 years the parish has become increasingly suburbanized. It retains several farms on old sites but the buildings have mostly been rebuilt during the past 150 years.

Stondon Massey was one of the three parishes at this end of Ongar hundred where Roman Catholic worship was maintained through the years of persecution in the late 16 th and early 17 th centuries. ${ }^{2}$ Another point of special interest in the history of the parish is the connexion with Marks Hall in Margaret Roding (Dunmow hundred). ${ }^{3}$

Stondon means 'stone hill'.4 This suggests that the oldest Saxon settlement was on the subsidiary spur, where there are still gravel pits, and it is there that the ancient manor house of Stondon Hall (now a farm) is situated, and near it the parish church. Most of the other houses in the parish, old and new, are also on the higher ground. The farms include Mellow Purgess, Clapgates, and Chivers in the west, Soap House on the Kelvedon Hatch road, Brook and Cannon's on the main road in the centre of the parish, Little Myles's to the west of the church and Woolmongers on the eastern boundary. Bridge Farm, which is exceptional in its situation, is on the low ground just east of Hallsford Bridge. Stondon Place and Stondon House, both near Cannon's Farm, are large houses each of which in turn succeeded Stondon $\mathrm{Hall}$ as the residence of the lord of the manor. The old rectory, now Stondon Massey House, is mile south of the church. The new rectory is farther south near Cannon's. The 'Bricklayers' Arms', the village inn, is at the cross-roads south of Cannon's, and the post-office is near the inn. Until recent years one of the focal points of the village was the cross-roads opposite Stondon Place. Here on a small green are the remains of a sign-post to which are fixed the irons formerly belonging to the parish whipping-post. Immediately north of this green is the site of the former village school and beyond it the village hall, now little used, its entrance overgrown. Since the Second World War the parish appears to have lost some of its corporate life. The two big houses have been empty (Stondon House now has a tenant but Stondon Place is still unoccupied), there is now no resident rector and the village school was closed in 1953.

The medieval settlement of the parish probably spread south from Stondon Hall. Brook Farm, Woolmongers, and several other farms derive their names from medieval tenants. $s$ Apart from Stondon Hall, part of which may date from the 15 th century, ${ }^{6}$ none of the secular buildings which now survive appears to contain medieval work. By the 18 th century there were houses on most of the present farm sites, and some of the existing buildings are of this period or slightly earlier. Brook Farm is a curious looking building consisting of two wings connected by a narrow covered passage. It is said to have been rebuilt about $1873^{7}$ but the north wing is certainly older than this. Heavy ceiling beams are visible on the ground floor and this part of the house may date from the 17 th century. Cannon's Farm opposite is a small two-story house with double-hung sashes, probably built in the $\mathrm{s} 8$ th century but recently modernized. Little Myles's was so named to distinguish it from Great Myles's in Kelvedon Hatch (q.v.) of which estate it formed part. In about 1700 there was a very small house there, with a 14 acre holding attached to it, but during the 18 th century the house and the farm were both greatly enlarged. 8 The present building is of two stories, roughcast, with a tiled roof, and plain brick chimneys. In general appearance it is of the 18 th century but it probably incorporates parts of the previous building at the back. Woolmongers is a small two-story building, timberframed, plastered and whitewashed and is also probably of the I 8th century. Clapgates, which took its name from the gates which formerly stood at this point to prevent cattle straying from Kelvedon Common, was called Stondon Grove in $1777 . .^{\circ}$ It has been considerably modernized but may date from the 18 th century. At Mellow Purgess, where the old farm-house was demolished about 1850 , there still survives a small whitewashed cottage with dormers and a thatched roof which was probably that shown in a drawing of $178 \mathrm{~g} . .^{10}$ Chivers Farm is not shown on the 1777 map and the present house is in any case a rebuilding of 1898.11 Soap House, which took its name from the soap boiling carried on there in the 18 th century, was rebuilt about $1902^{12}$ but may contain parts of an 18 th century or even an earlier building. Bridge Farm (otherwise Hallsford House) was demolished in $\mathbf{8} 899$ and replaced by a new house on higher ground. A photograph of the old house shows an $\mathrm{H}$-shaped plan, suggesting that it dated from the 16 th century or earlier. One of the beams removed from it was $23 \mathrm{ft}$. long and measured a foot square in cross-section. ${ }^{13}$ Stondon Place, which was in existence in the 16 th century; was rebuilt about 1707 and again, after a fire, about 1880.14 Stondon House, which was probably built about 1740 , was also burnt down in the $r$ th century and the present building is of about 1870.1 is The Giles Almshouses, at the south

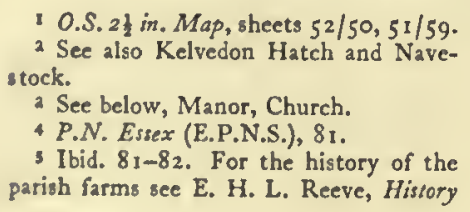

curious name of this farm see P.N. Essex, 81.

6 See below, Manor.

7 Reeve, Siondon Massey, 123.

8 E.R.O., D/DFa PI, P6.

- Chapman and André, Map of Essex, 1777 , sheet xvii.

to Reeve, Stondon Massey, 126. For the

1 Reeve, op. cit. 124.

13 Ibid. 124,119

14 See Manor.

Is Ibid. 
entrance to the village, were rebuilt in 1860 . The original cottages were of the 16 th century. ${ }^{16}$ The 'Bricklayers' Arms' is a late-I gth-century building on the site of a tarred weather-boarded cottage which in the early I gth century served as a small provision shop. 17

Perhaps the most impressive building in the parish is the former rectory, built about $1800 .{ }^{18}$ Near it to the south is Rectory Cottage, a tiny house with a very tall chimney, a high-pitched roof, and round-arched central door between two similarly arched 'Gothic' windows. It was formerly thatched but is now slated. Its style is similar to that of some other cottages in the district, for example the gardener's cottage at Marden Ash in High Ongar (q.v.) and is of the early 1 1 th century. The house has been known locally as the Doll's House and is said to have been built by the owner of Stondon House for one of his daughters. ${ }^{19}$ There are several other 19 th-century houses and there has been considerable development since the First World War, mostly along the road to Hallsford Bridge. There are many privately built houses, including some bungalows and a number of council houses of which the most interesting are nine pairs built about 1947 in Reeve's Close, opposite the Giles Almshouses. Near Hallsford Bridge there is a small engineering works, opened about 1952.

The population of Stondon Massey was 200 in 1801.20 It rose to a peak of 299 in 1831 and remained at about that level until late in the r 9 th century, when it declined gradually to 213 in 1921.21 Since then there has been a great increase, to 282 in 1931 and 489 in 1951.22

The road system of the parish is simple, consisting only of the Hallsford Bridge and Ongar road, that to Kelvedon Hatch and Blackmore, the road to Paslow Wood Common and Chelmsford, and the loop to the farms in the west of the parish. There have probably been few changes since the Middle. Ages. The most important was the building of Hallsford Bridge in the late 18 th century (see below). The only other change that has been noticed was the disappearance of a track leading from Mellow Purgess to Kelvedon Common. This was in use up to about 1550 but soon after this the right of way was barred by the farmer of the neighbouring land. About 1604 the rector, John Nobbs, sued William Byrd, then tenant of the land, in an attempt to reopen the track, but he was evidently unsuccessful.23

No mention has been found of a bridge at Hallsford before the 18 th century. The map of 1777 shows only 'All Ford'24 but by this time steps had been taken to build a bridge. In 1775 a petition was sent to Quarter Sessions by the inhabitants of Stondon and others complaining that the ford was dangerous. They asked for a bridge to be built and this was done. ${ }^{25}$ Hallsford Bridge appears in the lists of county bridges from about 1800.26 In 1858 the county surveyor reported that the bridge was a recent erection in timber. ${ }^{27}$ The present bridge was built in concrete in $1934 .^{28}$ The building of a bridge at Hallsford greatly improved communications between Stondon and Chipping Ongar, but the parish was not on a main road and until the coming of motor-buses after the First World War there was no public transport there. There are now fairly good bus services to Brentwood and via Blackmore to Ongar.

Stondon was in 1852 being served by a postal messenger from Kelvedon Hatch.29 It was later served through Brentwood ${ }^{30}$ and it was not until i 898 that it had its own post-office.31 There was a telephone service by 1930.32 Water is supplied to the parish by the Herts. and Essex Waterworks Co. ${ }^{33}$ Electricity was laid on in June 1938.34 There is no gas supply. The village hall was opened in 1919.35 The Blackmore, Stondon and District Ex-Servicemen's Club, founded in 1922, is just outside Stondon parish, at Tips Cross on the south. ${ }^{36} \mathrm{~A}$ branch of the county library was opened in 1927.37

In this parish as elsewhere in the hondred mixed farming is carried on. In 1848 it was estimated that there were some 600 acres of arable in the parish and 400 acres of meadow and pasture. ${ }^{38}$ In 1849 there were 10 farms in the parish of over 40 acres and several smaller holdings. 39 'The only farms of over 100 acres were Stondon Hall (23I acres), Chivers (127 acres), and Little Myles's which was partly in Stondon and partly in Kelvedon Hatch. In general therefore this was a parish of small farms, and it appears to have been so for centuries.40 In the igth century the ownership of the land was also widely distributed. The Stondon Place estate was reduced in about 1816 . In 1849 it contained only 250 acres. ${ }^{41}$ The Revd. G. G. Stonestreet then owned Stondon Hall farm and Woolmongers totalling 247 acres, and John Fane owned Little Myles's and Clapgates, totalling 138 acres. No other owners had as much as 100 acres. ${ }^{42}$ During the 1850 's P. H. Meyer increased the Stondon Place estate slightly but he never came near to owning the greater part of the parish as did his friend Capt. Budworth in Greenstead (q.v.). In the I 8th century, however, and previously in the 16 th century and even earlier the lord of the manor had owned much more than in Meyer's time. In this connexion it is perhaps significant that there was never more than one manor in Stondon. From the 16th century at least the lords of the manor were usually resident in the parish. In the 18 th and 19th centuries they took an active interest in the life of the parish. William Taylor-How (d. 1777) left a legacy for the village schoolmaster.43 P. H. Meyer contributed generously to the village school and the church and led the local Volunteers. ${ }^{44}$ The parish was also fortunate in having a succession of able and publicspirited rectors during the same period. The agricultural depression of the 1870 's may not have affected Stondon quite so severely as some neighbouring
16 See below, Charities.

17 Reeve, Stondon Massey, 49.

18 See below, Church.

19 But cf. Church. If this is the former

Bell Rope Cottage it is of $c, 1842$.

20 For census figures $1801-1901$ see

V.C.H. Essex, ii, 350.

21 Ibid.; Census, I 91 I-2 I.

22 Census, 1931, 195 เ.

23 Reeve, Stondon Massey, 126

24 Chapman 2nd André, Map of Essex,

3777 , sheet xvii. 2s E.R.O., D/DFa E $43 / 36$. For a photo of Hallsford in flood, I903, see Reeve, Stondon Massey, 162.

26 E.R.O., Q/ABr I, 2

27 E.R.O., Q/ABz 3 .

${ }_{28}$ Inf. from Essex County Surveyor.

29 P.M.G. Mins. 1852 , vol. 127, p. 28 .

30 Kelly's Dir. Essex, 1886, \&c.

31 P.M.G. Mins. 1898 , vol. $631, \mathrm{~min}$. 8 i 37 , vol. $640, \mathrm{~min}$. 14753 .

32 Brit. Post. Guide, 1930.

33 Inf. from Herts. \& Essex Water- works Co.

34 Inf. from Eastm Elecy. Bd.

35 Inf. from Mr. C. H. Hackney,

36 Ibid. 37 Inf. from County Librarian.

38 E.R.O., D/CT $337 . \quad 39$ Ibid.

40 Cf. Reeve, Stondon Massey, pt. III, ch. iv.

4 I E.R.O., D/CT 337. And see below,

Manor. 42 E.R.O., D/CT 337.

43 Reeve, Stondon Massey, 47.

44 Ibid. 50-51. And see Church, 


\section{A HISTORY OF ESSEX}

parishes because there were in this parish several wealthy families-notably at Stondon Place, Stondon House, and the rectory - which did not depend wholly upon farming for their incomes, and which brought money into the parish. An example of the way in which this effect may have been produced comes from a slightly earlier period: the prosperity of the 'Bricklayer's Arms' was built up partly upon the liberality of Miss Hollingworth of Stondon Place.45 The depression did, however, have one striking result in the parish. Stondon Hall farm, which in 1868 had been bought by the tenant, James French, for $\oint_{0}$ I, 000 , was sold after his death soon afterwards at a substantial loss. The purchaser was a Welsh cattle-dealer who turned the whole farm over to pasture. 46

There have been few occupations in the parish other than those connected with agriculture. Gravel digging has probably been carried on in a small way for centuries. One gravel pit, to the north-east of the church, was opened as recently as I 886.47 Soap House perpetuates the memory of a local industry carried on in the I 8 th century. It was occupied from I 696 to 1743 by Robert Dennett, a soapboiler, and the industry is said to have been carried on there until about 1800.48 The new engineering works near Hallsford Bridge deals mainly with repairs to agricultural machinery and implements.

By far the most eminent of Stondon's worthies was William Byrd (1543-1623), the musiWORTHIES cian, who lived for the last 30 years of his life at Stondon Place.49 The history of his residence there is one of frequent bickering with his neighbours.

Sir John Hende (d. I4 I 8), lord of the manor of Stondon, was Mayor of London in 1391 and 1404.50 His two sons, both named John, were sheriffs of Essex, the elder in 1443 and 1447 and the younger in 1456.31 Walter Wrytell, son-in-law of the elder John Hende, was sheriff in 1469 and 1471.52 Sir Edward Belknap (d. I52I), a later lord of the manor, accompanied Henry VIII to the French war in I5I3 and was knighted at Tournai. In I 520 he was one of the special commissioners responsible for preparing the Field of Cloth of Gold and received a letter from Wolsey instructing him to ensure that the cardinal's tent was pitched in a dry place. 53 Rainold Hollingsworth (d. 1573), a wealthy resident of Stondon, was one of the royal commissioners for dealing with church goods under Edward VI. His brass is in the parish church. 54 Sir Nathaniel Rich (d. I636), another lord of the manor, was a Member of Parliament, Merchant Adventurer of London, and a Puritan who promoted colonial enterprises in America.55 His nephew and successor Col. Nathaniel Rich (d. I70I) fought for Parliament in the Civil War. He was a close friend of Cromwell but eventually quarrelled with him and was deprived of his command. ${ }^{56}$ Nathaniel Ward (I 578 I652), Rector of Stondon 1623-33, was deprived of the living by Laud for nonconformity. He subse- quently emigrated to New England and helped to draft the I64 I Code of Laws for the colony of Massachusetts. He returned to England in I 647 and spent the last four years of his life as Rector of Shenfield. 57

The Puritan connexion in Stondon represented by the Riches and Nathaniel Ward is an interesting parallel to the Roman Catholic connexion. Byrd was a Roman Catholic and so also was William Shelley (d. 1597), lord of the manor of Stondon, whose religion led him to plot against Elizabeth I and to imprisonment in the Tower. ${ }^{38}$ William was the grandson of Sir William Shelley (d. I 548), a justice of the Common Pleas and son-in-law of Sir Edward Belknap.59

Sir John Hende and Sir Nathaniel Rich represent a connexion with London trade which was shared by several other men of less individual distinction. These include Andrew Bridham (d. I442) of Stondon and St. Michael's, Cornhill, John Wheler (d. I 521 ), and George Webb (d. I 579). ${ }^{60}$ Richard Hall (d. I 54I), citizen and ironmonger of London, lived for a number of years in Stondon and left legacies for some of its people. ${ }^{61}$ John Carre (d. 1570 ), whose brass is in the parish church, became a member of the Ironmongers' Company under the sponsorship of Hall, whose brother John was his godfather.62 Henry Giles, nephew of Carre, was his apprentice and duly joined him in the company. ${ }^{63} \mathrm{He}$ inherited a large sum of money under Carre's will and used some of it to found the almshouses in Stondon. 64

Johr Oldham, rector from I79I until his death in I $84 \mathrm{I}$, had studied law before entering the church. He was for many years a county magistrate and was nicknamed 'Chief Justice Oldham'.6s $\mathrm{He}$ is said to have designed the impressive rectory built about 1800 . Altogether he made a lasting impression in this part of Essex during his long incumbency.

From 1849 to 1936 the rectory was held in succession by E. J. Reeve (d. I 893) and his son Canon E. H. L. Reeve (d. 1936). Both were good friends to the parish and E. H. L. Reeve became its historian. ${ }^{66}$

The early history of the manor of STONDON $M A S S E Y$ has not been traced with cerMANOR tainty. Stondon is not mentioned in Domesday Book. It derived the suffix Massey from the family of Marcy and it has been suggested that in 1086 it formed part of the manor of Kelvedon Hatch (q.v.) then held by Ralph de Marcy. ${ }^{67}$ That manor did perhaps include some land in Stondon, but the succession to Ralph's Navestock estate (q.v.), to which his Kelvedon Hatch estate probably became attached, suggests very strongly that the Marcys who became lords of Stondon were not his heirs. In the early I $3^{\text {th }}$ century the heir to this Navestock estate, in direct succession from Ralph (see Magdalen Laver), was another Ralph de Marcy; this last Ralph did not inherit Stondon.

The origins of the manor of Stondon are probably to be found not in Ralph de Marcy's estate in Kelvedon Hatch but in the manor held in 1086 by Serlo de Marcy

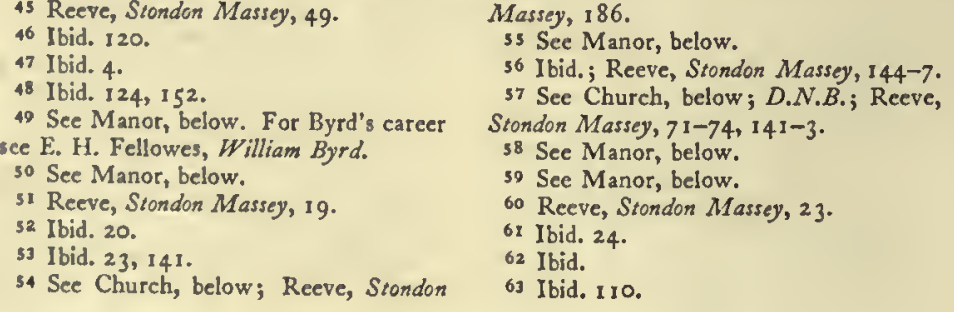

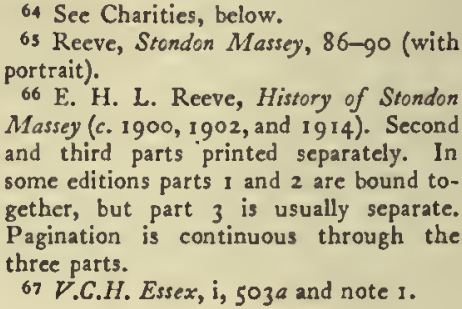
portrait).

66 E. H. L. Reeve, History of Stondon Massey (c. 1900, 1902, and 1914). Second and third parts printed separately. In some editions parts $I$ and 2 are bound together, but part 3 is usually separate. Pagination is continuous through the three parts.

67 V.C.H. Essex, i, $503 a$ and note 1. 
in Margaret Roding. ${ }^{68}$ This manor, which was held of Hamon dapifer as I hide and I5 acres was then worth $£ 5$. Serlo had a son Hamon living in 1131.69 In the early I 3 th century, and probably by II97, another Serlo de Marcy held the manor of Stondon as well as lands in Margaret Roding later known as Marks Hall. He had apparently succeeded a Hamon de Marcy. ${ }^{70}$ The manor of Marks Hall constituted a chapelry dependent upon the rectory of Stondon Massey, to which it has continued to pay tithes until the present day.71 It is thus probable that Stondon as well as Margaret Roding was held from the 11th century by the first Serlo de Marcy and his descendants.

In I 2 10-1 2 Serlo de Marcy held I $\frac{1}{3}$ knight's fee in Roding (i.e. Marks Hall). ${ }^{72} \mathrm{He}$ died before 1244 leaving as heirs his two sisters, Alice wife of John de Merk and Agnes, wife of Nicholas Spigurnel. In I 244 it was agreed between the sisters that Agnes and Nicholas and the heirs of Agnes should hold the manor of Stondon of Alice and John and the heirs of Alice. ${ }^{73}$ In 1296 and 1308 it was reported that the manor was held of Ralph de Merk by knight service, the amount of which was said to be $\frac{3}{4}$ fee in 1296 and $\frac{1}{2}$ fee in 1308.74 In 1485 the tenure was said to be of the Duke of Bedford as of his hundred of Ongar, by $8 d$. rent for all services. 75

Nicholas Spigurnel died before 1275 and was succeeded by his son Edmund. In 1275 an inquisition ad quod damnum was held relating to Edmund's proposed inclosure of his wood at Stondon. The verdict was that grave detriment would result from any inclosure of the great wood but none from inclosing a wood of 4 acres adjoining the manor house. ${ }^{76}$ Edmund died in 1296 and was succeeded by his brother John who died in 1308.77 John's epitaph, in Norman French, is said to have been visible in the parish church as late as $1768.78 \mathrm{He}$ was succeeded by his son Edmund who died in 1316 leaving as heir his infant daughter Joan, later wife of William Gobyon.79 Joan and William were confirmed in their possession of the manor of Stondon in $1333 .{ }^{80}$ She was still living in I 385 but by 139 I the lord of the manor was John Gobyon, perhaps her son. ${ }^{81}$ John was still living in I 396 but was succeeded before July I 4 I 0 by William Gobyon. ${ }^{82}$ By 1412; if not earlier, the manor had passed to Sir John Hende, who had been Mayor of London in 1391 and $1404 .{ }^{83} \mathrm{He}$ died in 1418 leaving two sons both named John, to the younger of whom he devised the manor of Stondon. ${ }^{84}$ John Hende the younger died in $1464 .{ }^{85} \mathrm{He}$ had devised the manor, in default of his issue, to Joan daughter of his elder brother John and wife of Walter Wrytell, in tail, with remainder to Joan's mother Griselde, wife of John
Hende the elder and daughter of Hamon Belknap, and Griselde's heirs. ${ }^{86}$ Joan Wrytell died before her uncle John Hende and Stondon descended to John Wrytell her son, who died in 1485 leaving as his heir an infant son John. ${ }^{87}$ In 1486 the king committed the custody of Stondon during John's minority to Sir Reynold Bray, Sir Edmund Shaa and John Shaa.88 John Wrytell died in 1507 leaving an infant daughter and heir Juliana who died in 1509.89 The manor then passed, according to the entail created by John Hende the younger, to Sir Edward Belknap son of Sir Henry Belknap (d. 1487 ) brother of Griselde Hende. 90 Sir Edward died in $152 \mathrm{I}$ leaving as his heirs his four sisters. Stondon fell to the share of his sister Alice, wife of Sir William Shelley, a Justice of the Common Pleas. ${ }^{9 I}$ Sir William died in I 548 having devised the manor to his eldest son John. ${ }^{92}$ In I 550 John Shelley died leaving Stondon to his younger son William, then a minor. 93 About this time the manor may have been leased to Rainold Hollingsworth (d. I 573) whose brass is in the parish church. 94

William, son of John Shelley, was an active Roman Catholic. He was imprisoned as a recusant in 1580 and spent most of the remainder of his life in confinement. Between 1580 and 1584 he was released several times on bail and during one of his periods of freedom he appears to have become implicated in the Throgmorton plot.95 He was rearrested in 1584 for treason and in 1586 pleaded guilty and was sentenced to death. He was subsequently reprieved but his estates were declared forfeit and he remained in prison until I596, when he was released in failing health, to die early in 1597.96 He left no children and his heir was his nephew John Shelley. After William's death his widow Jane tried to obtain possession of Stondon Place, which was part of the estate and which she claimed as part of his marriage jointure. This tenement had been leased by William Shelley in 1582 to Lawrence and William Hollingsworth for 21 years. 97 In 1589 the Hollingsworths divided the property between them. Lawrence died soon after, leaving his share to his nephew John Hollingsworth, who sold it to William Hollingsworth, who thus became sole tenant under the Crown. William then mortgaged his lease to William Chambers and in 1593 he and Chambers assigned their interest in the property to William Byrd, the musician, for $\{300$. Stondon Place then consisted of about 200 acres. Part of it had been sub-let to Dennis Lolly, whose lease expired in I 597.98 In I 595 Byrd secured a Crown lease of the whole of Stondon Place for the lives of his three children successively. His position was remarkable: although a well-known recusant himself, he was willing to profit by the forfeiture of a fellow
68 Ibid. 5or $a$ and $b$, note 4 .

69 Pipe R. Ir30 (Rec. Com.), 54, 59.

70 Feet of $F$. Essex, i, 10, 148; Red Bk.

of Exch. (Rolls Ser.), 505; Pipe R. II97

(Pipe R. Soc. N.s. viii), 74; Pipe R. I20I

(Pipe R. Soc. N.s. xiv), 70; Pipe R. 1202

(Pipe R. Soc. N.s. xv), 269; Pipe R. 1203

(Pipe R. Soc. N.s. xvi), 133.

71 See below, Church.

72 Red. Bk. of Exch. (Rolls Ser.), 505.

73 Feet of F. Essex, i, 148 . Cf. J. H.

Round, 'Stondon Masscy and its Chapelry', E.A.T. N.s. $\mathrm{xv}, 14^{8}-52$. It was also agreed in 1244 that Alice and John de Merk should hold Serlo's land in Margaret Roding. It was from the Merks that Marks Hall took its name.

74 Cal. Inq. p.m. iii, p. 197 ; ibid. v, p. 43.
$7 s$ Cal. Ing. p.m. Hen. VII, i, pp. 61-62.

76 Ci $43 / 4 / 6$.

77 Cal.Ing. p.m. iii, p. 197; ibid. v, p. 43.

78 Morant, Essex, i, 187.

79 Cal. Ing. p.m. v, pp. $43,278$.

80 Feet of F. Essex, iii, 28.

81 Newcourt, Repert, ii, 545.

82 Ibid.

83 Feud. Aids, vi, 445; A. B. Beaven, Aldermen of London, i, 81, 217.

84 Morant, Essex, i, i 88 ; Cal. Inq. P.m. (Rec. Com.), iv, p. 37.

85 Cal. Inq. p.m. (Rec. Com.), iv, p. 323.

$86 \mathrm{Cal}$ Ing.p.m. Hen. VII, i, pp. $6 \mathrm{I}-62$

87 Ibid.

88 Matls. Hist. Reign Hen. VII (Rolls Ser.), i, 474 .

$89 \mathrm{C}_{142 / 21 / 2} ;$ L. $\Leftrightarrow$ P. Hen. VIII, p. 103.

90 L. EP. Hen. VIII, i, p. 103.

or $\mathrm{C}_{142 / 36 / 69}$.

92 Reeve, Siondon Massey, 31.

$93 \mathrm{C}_{142 / 93 / 70}$.

94 Reeve, Stondon Massey, 30; see below, Church.

is N. E $Q$. (roth ser.), iii, 441-3; Conyers Read, Sir Francis Walsingham, ii, 387.

${ }_{96}^{\circ} N$. \& $Q$. (roth ser.), iii, 441-3. He had lands at Michelgrove (in Clapham, Suss.) and jure uxoris in Herefordshire.

97 Lawrence and William were cousins of Rainold Hollingsworth : Reeve, Stondon Massey, 30 .

98 E. H. Fellowes, William Byrd, 20. 


\section{A HISTORY OF ESSEX}

Roman Catholic and was allowed by the Crown to do so. 99

Jane Shelley's attempt to regain her husband's property included an attempt to eject Byrd from Stondon Place. Her petition to Elizabeth I was unsuccessful but in 1603 James I issued letters patent securing her title to Stondon Place. ${ }^{\text {I }}$ She then resumed her efforts to eject Byrd, but although she had been recognized by the Crown as the owner of the property his lease remained good and he remained at Stondon Place. ${ }^{2}$ Meanwhile, in I604, John Shelley had regained possession of the manor of Stondon, paying $\oint_{1}$ I, 000 to the Crown for this. Of that sum $\complement_{1}, 000$ went to Lord Howard of Effingham, who had been negotiating for the purchase of the manor, by way of compensation. Jane Shelley died in 1610 and shortly afterwards John Shelley sold his rights in Stondon Place to William Byrd, who continued to live there until his death in I $623 .^{3}$

Stondon Place remained in the possession of the Byrds until about 165 I when it was bought by Thomas Coffin. From about 1638 , however, they no longer lived there. In $16_{53}$ John Leech bought the property from Coffin and about 1655 Prosper Nicholas became the owner.4 Nicholas died in 1689 and Stondon Place passed to his eldest daughter Martha, later wife of Dr. Josiah Woodward. Soon after 1700 she sold it to Richard How of Broxbourne (Herts.). ${ }^{s}$

John Shelley sold the manor of Stondon in about 16 ro to Sir Nathaniel Rich. ${ }^{6}$ He died in 1636 leaving Stondon to his nephew, also Nathaniel Rich.7 He died in 1701 and was succeeded by his son Nathaniel, receiver-general of the Land Tax for Essex. ${ }^{8}$ In I 706 an Act was passed enabling the latter to compound with the Lord Treasurer for the amount which he owed.9 The manor of Stondon was then sold to Richard How, already the owner of Stondon Place. He rebuilt Stondon Place, which was henceforth the manor house. ${ }^{10}$

How died in 1708 and was succeeded in turn by his two sons Richard (d. I723) and John (o.s.p. I 748)."1 John left Stondon to a distant relative, William Taylor of Much Hadham (Herts.). Taylor died in 1752 and was succeeded by his son William, who in accordance with John How's will assumed the additional surname of How. William Taylor-How (d. I777) was succeeded in turn by his sisters Jane Taylor (d. 1793) and Ann. In 1816 Ann Taylor sold the manor, including Stondon Place, to Miss Joanna Hollingworth, an old friend. Shortly before this conveyance took place part of the Taylor estate had been detached. Cannon's Farm was sold to the Society of Friends and old Stondon Hall and its farm to the Revd. G. G. Stonestreet, later Prebendary of Lincoln. Miss Hollingworth died in 1829 . During the last few years of her life she was joined at Stondon Place by Mrs. Ann Meyer, the widow of a wealthy Hamburg merchant who had been a cousin of Miss Hollingworth. After the death of Miss Hollingworth Mrs. Meyer bought the manor from the executors, the purchase money being divided under the terms of Miss Hollingworth's will among
Mrs. Meyer's son and grandchildren. Mrs. Meyer died in 184 I leaving her estate to her grandson Philip Herman Meyer. P. H. Meyer enlarged the estate by the purchase of Chivers Farm (I 842 ) and Gates ( 1848 ). In 1849 he owned land in the parish amounting to some 250 acres, ${ }^{12}$ and in 1850 he further acquired Grove Farm, of 33 acres, which had belonged to the estate before 1814 and in $1838-42$. He was not resident in the parish in 1849 but in 1857 he returned to live at Stondon Place. In 1861 he bought Stondon House and went to live there, letting Stondon Place to Capt. James Hastie. In I 866 Stondon House was burnt down; many manorial documents were destroyed with it. The house was rebuilt and Meyer died soon after, in 1870 . The manor was held after his death by his widow, who in 1874 married Col. F. J. Baker. A manor court was held at Chivers in 1897 , perhaps for the last time. Mrs. Baker was succeeded on her death in 1907 by her nephew H. J. Meyer. Before this, in I 904 , Stondon Place and about 75 acres of land had been sold to Tyndale White, who had been the tenant from about 1885.13 The house had been burnt down in 1877 and rebuilt a year or two later. White's house was thus the third of the name. H. J. Meyer was still stated to be lord of the manor in I9I 7 but by 1922 the manor had been acquired by Mr. A. S. Cochrane.14 No substantial estate now (I954) remains attached to any of the former manor houses.

The oldest surviving manor house is Stondon Hall, which probably stands on the site of the original manor house. ${ }^{15}$ It has for 250 years been merely a farm-house. The building is of two stories with tiled roofs, possibly built on an $\mathrm{H}$-shaped plan but altered and seemingly partly rebuilt.

'The principal (west) front has projecting gabled wings, the northern of which is partly timber-framed and retains some external plastering. This wing is probably the oldest part of the present building and may date from the I $5^{\text {th }}$ century. The projecting brick chimney on the north side was entirely built after bomb damage received during the Second World War. The southern wing dating from the early 17 th century is of brick.

Internally there are beams, panelling, and doors of I6th- and I 7 th-century types and on the first floor in the north wing a plaster overmantel with twin roundarched recesses and surmounted by an entablature. The hall is now divided into two tenements. Behind it to the east are the remains of a moat now (1953) in course of being filled in.

The second manor house, Stondon Place, had originally been a farm-house but was rebuilt about I 707 (see above) and was the residence of the lord from then until I $86 \mathrm{I}$. This $\mathrm{I} 8$ th-century house was completely destroyed by the fire of $1877 . .^{16}$ A new building was erected on the same site a year or two later and this still survives. It is in Georgian style of two stories in red brick with round bays at each end of the main front. ${ }^{17}$ It has a small lodge by the main entrance and extensive outbuildings. It is now untenanted and neglected and overgrown with creeper.

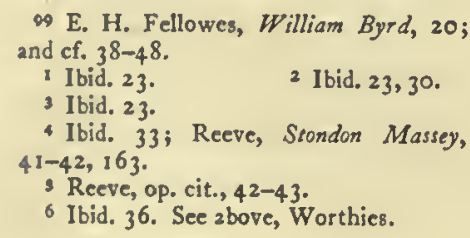

7 Ibid.

8 Morant, Essex, i, 188.

- C. $. \times \nabla, 357$.

10 Reeve, op. cit.

II The following descent is from Reeve, op. cit. 43-53, 151-3.

12 E.R.O., D/CT 337.

13 E.R.O., Sale Cat. 1923; Kelly's Dir.

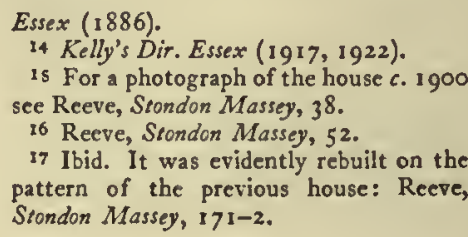


Stondon House, to which the lord of the manor moved in I $86 \mathrm{I}$, is said to have been built by Richard Jordan about 1740.18 About 1824 it was leased by a Mr. and Mrs. Page for usc as a girls' school. P. H. Meyer had lived there only five years when this house was burnt down. ${ }^{19}$. It had been rebuilt by the time of Meyer's death in $1870 .{ }^{20}$ The present house is a large building of brick with a slate roof and has extensive outbuildings. For some years after the Second World War it was empty and neglected but it is now occupied and is in good repair. ${ }^{21}$

The advowson of Stondon Massey descended along with the manor until the $17^{\text {th }}$ century.22

CHURCH In I 660 Edward Otway was presented by Col. Rich, but the next presentation, in I69I, was made by the trustees of the estate of Anthony Luther of Myles's (in Kelvedon Hatch, q.v.). ${ }^{23}$ In 1696 William Kendall of Takeley presented James Crook. The new rector afterwards acquired the advowson, and on his death in 1707 left it to his widow Mary. She presented Thomas White, who resigned the living in the same year, and then Thomas Smith, whom she later married. The advowson passed on her death in 1728 to her husband. He died in 1732 and in his will directed that the advowson was to be sold and the proceeds divided among his family. This does not seem to have been carried out. Smith's eldest son Richard presented the next rector (1733) and in 1735 Richard's younger brother Thomas was presented by John How, one of the executors of Thomas Smith the elder. The younger Thomas Smith held the rectory for no fewer than 56 years, dying in 1791 . The advowson had previously been acquired by John Oldham, who presented himself and was rector for 50 years. Before his death in I 84 I he sold the advowson to John Hubbard, of Cornhill, who presented his son Thomas. In 1849 the advowson was again sold, this time to Edward Reeve, who presented his son Edward J. Reeve. The latter died in 1893 and was succeeded as patron and rector by his son Edward H. L. Reeve. In I936, on the death of E. H. L. Reeve, the advowson was vested in the Bishop of Chelmsford. ${ }^{24}$

The rectory of Stondon was valued at 7 marks in about $1254, s^{25}$ at $£_{5} 6 \mathrm{~s}$. 8d. in $129 \mathrm{r},{ }^{26}$ and at $£_{1} 36 \mathrm{~s} .8 \mathrm{~d}$. in $1535 .{ }^{27}$ In 1849 the tithes were commuted for f355 IOs. ${ }^{28}$ The connexion between this rectory and the manor of Marks Hall in Margaret Roding has been described above. ${ }^{29}$ There was a chapel at Marks Hall in 137 I and 1410 , when it was said to be annexed to the rectory of Stondon. The chapel was 'decayed' by the 17 th century but tithes from Marks Hall continued to be paid to the rector of Stondon. An undated terrier, probably of the early 17 th century, stated the value of those tithes to be $\{10$ a year. Until the early I 9 th century the parishioners of Stondon included Marks Hall in the annual beating of their bounds. In 1845 , when the tithes of Margaret Roding were commuted, the Marks Hall estate comprised 317 acres, of which
262 acres paid tithes to Stondon. ${ }^{30}$ These last were commuted for 680 ros. $6 d$., which sum was not included in the above figure for the commutation of the tithe in Stondon itself. The tithe rent charge from Marks Hall has continued to be paid to the Rector of Stondon until the present day. ${ }^{31}$

Early in the 17th century it was stated that the rectory house of Stondon had been newly built and repaired by John Nobbs, then rector. There were also a barn, an orchard, and 60 acres of glebe. The rebuilding was probably to provide accommodation for Nobbs's family of ten children. ${ }^{32}$ His house remained until about 1800 when it was completely demolished and a new rectory built. A drawing of the 17 th-century house and a description of it were contributed to the Gentleman's Magazine in January and February 1805. It was a large irregular house with many gables, timberframed and weather-boarded and having a chimneystack with grouped diagonal shafts. 33 The new rectory was sited farther from the road. John Oldham, the rector who built it, is said to have been his own architect, and to have evolved the plan during a tour in Switzerland. ${ }^{34}$ It is an imposing brick mansion, square and compact in plan, with roof pediments. At the time of the rebuilding the grounds were laid out by a landscape gardener, perhaps an associate of 'Capability' Brown. ${ }^{35}$ In 1810 , in a description of the rectory which he sent to the bishop, Oldham stated that it had been built about ten years earlier and that it had in addition to the living-quarters a stable, barn, granary, cowhouse, and brewing-house. ${ }^{36} \mathrm{~A}$ cottage with a thatched roof which still adjoins the former rectory may have been one of the outbuildings mentioned in 18 ro. It was at one time used as a laundry. ${ }^{37}$ Oldham's house remained in use as the rectory until about 1936 . It is now a private house and the land is being farmed. ${ }^{8}$ The present rectory, built about 1939, is a large red-brick house of irregular plan situated near Cannon's Farm.

The church of ST. PETER AND ST. PAUL consists of nave, chancel, north vestry, organ chamber and chapel, south porch, and western bell turret with spire. The nave and chancel date from about I 100 , the bell turret and the porch were added in the $15^{\text {th }}$ century and in the I gth century the vestry, organ chamber and chapel were added and the porch rebuilt. 39 The walls are mainly plastered over outside but where exposed at the west end are seen to be of neatly coursed flints with lacing courses of tiles, possibly Roman.

Of the original structure, apart from the walls, there remain two characteristic narrow Norman window openings (one now blocked externally) in the north side of the nave, one in the south side of the nave and one in the south wall of the chancel. The south doorway is also of that period. It has an unornamented stone surround with rough, quoined jambs and rudimentary impost blocks. A north doorway of similar date was in use until $185^{\circ}$ but is now blocked externally. Other features which may in part be survivals
18 Ibid. 45 .

19 Ibid. 51 .

20 Ibid.

21 Inf. from occupant.

22 Newcourt, Repert. ii, 545. In $155^{8}$ and 1563 the advowsons appears to have been sold pro hac vice.

23 Unless otherwise stated the authority for statements in the Church section is Reeve, Stondon Massey, 57-90.

24 Chel. Dioc. Year Bk. 1937.

23 E.A.T. N.s. xviii, 19.
26 Tax. Eccl. (Rec. Com.), 216.

$27 \mathrm{Val}$. Eccl. (Rec. Com.), i, 437.

28 E.R.O., D/CT 337.

29 See Manor; E.A.T. N.s. xv, 148-52 Newcourt, Repert. ii, 544,505 .

30 E.R.O., D/CT 298.

31 Inf. from University Coll., Oxford

The rent charge is now (1954) 884 19s. and is paid through the Church Commissioners.

32 Newcourt, Repert. ii, 544; Reeve, Siondon Massey, 70 .
33 Reeve, Stondon Massey, 70, 87; see plate facing p. 136 .

34 Reeve, Stondon Massey, 86-88.

35 Ibid. 86. Brown himself died in 1783 and therefore could not, as Reeve states, have designed the gardens.

36 Ibid. 88.

37 Inf. from occupier.

38 Ibid.

30 For an historical description of the church by F. Chancellor $(1898)$ see $E . R$. vii, I $39 \mathrm{f}$. 


\section{A HISTORY OF ESSEX}

from the original building are the narrow lancetshaped window and three small circular openings in the western gable of the nave. The original chancel was probably apse-ended.

Late in the I $4^{\text {th }}$ century a two-light traceried window was added to the south wall of the chancel and a similar window of three lights to the south wall of the nave. It was possibly at the same period that the chancel-arch was removed and the apse replaced by a square end.

Early in the $15^{\text {th }}$ century there were further considerable alterations, including the reconstruction of the roof, the addition of the bell turret and south porch and the insertion of a new west window. The roof (now ceiled) has heavy moulded wall plates with three king-post trusses over the nave portion. The bell turret rises from the west end of the nave and is carried on stout chamfered corner posts from the ground with ornamental bracing in which the western-most rooftruss is incorporated. Externally the bell turret is rectangular and weather-boarded with a short octagonal broach spire covered with shingles. It was rebuilt in I 888.40. The west window is of two lights with traceried head within a four-centred arch. The porch, which was reconstructed in the Igth century, retains one original cambered beam with plate, posts, and braces.

The chancel screen dates from the late i 5 th century. It has five narrow bays with traceried ogee arches on each side of a wider central opening with a four-centre arched head. It has been much restored, especially in the lower part.

Extensive alterations and repairs were begun in I 850 , soon after E. J. Reeve became rector.4I The lord of the manor, P. H. Meyer, and the patron, Edward Reeve, helped in the work. The roofs of the nave and chancel were covered with tiles in place of the previous slates. A vestry was added, the porch rebuilt, the north doorway walled up, a new priest's door provided in the chancel, and the east window, previously a makeshift sash, replaced by a three-light traceried window.

Further extensions were made in $1873-4$ as a memorial to P. H. Meyer.42 These included a new vestry with heating cellar beneath, an organ chamber, and a mortuary chapel. The chapel consists of two bays vaulted in stone in Early English style, with lancet and three-light traceried windows. Externally it is faced with random flint work with stone dressings and has a gable at the north end with an arched doorway and angle buttresses. The chapel is entered from the nave, from which it is divided by a glazed screen, and the organ chamber from the chancel, both through wide arches the construction of which occasioned the removal of a Norman window in the chancel. The abutment of the west wall of the chapel against the nave caused another Norman window to be blocked up.

The last major repairs to the church were those of I 888, when the bell-turret and spire were rebuilt.

The pulpit is octagonal and has panelled sides with arabesque ornament, and inside it is ' 2 TIM. 4 . 2.' The reading-desk, also panelled and carved with jewel ornament, bears the date 1630 . The pulpit and the desk were previously combined in three-decker fashion but were separated during the restorations of $1850.43 \mathrm{~A}$ gallery erected on the north side of the nave by Philip Hollingworth in 1825 was removed in 1850.44 The singers' pew at the west end of the nave was then enlarged to form a new gallery but this was in turn removed in $1873-4.45$

There are three bells. 46 'The oldest, which was no doubt installed when the belfry was built, was made by John Bird early in the I $5^{\text {th }}$ century: this is the second in the peal, and is inscribed 'Johannes Cristi Care Dignare Pro Nobis Orare'. The first in the peal is by Robert Mot, 1588 , and the third by Thomas Gardiner, I 737. The Bell Rope Charity, of unknown origin, consisted in 1834 of a cottage and I acre of land, the profits of which were intended for the purchase of bell ropes. 47 At that date the rent of $£ 2$ 2s. was carried to the churchwarden's general account. In 1842 the parish vestry agreed to let the property to William Page at 64 a year on a 21 -year lease on condition that he rebuilt the cottage. At the end of that period the lord of the manor obtained the lease at an annual rent of $£ 8$, renewable each year. After his death in 1870 the property continued to be rented by the tenant of Stondon House. By a Charity Commission Scheme of 1892 the rector and churchwardens were made trustees and the trusts were declared to be the maintenance and repair of the parish church. By 1933 the cottage was in a bad state of repair and was sold with the land for $\$ 260$ which was invested in stock. In 1952 the income of $f_{8} \mathrm{I} 4 \mathrm{~s} .6 \mathrm{~d}$. was paid into the church account. The cottage is probably that now known as Rectory Cottage, on the opposite side of the road from Stondon House. 48

The church plate consists of a silver cup of I 564 , another of 1824 given by Elizabeth, widow of Thomas Smith, a former rector, a silver paten of 1905 given by the rector E. H. L. Reeve in I gog to match the old cup, an undated paten of silver on copper, and a silver flagon of 1885 given by Tyndale White.49

The font, which dates from the I $5^{\text {th }}$ century, is octagonal, the sides of the bowl being panelled with quatrefoils.

The monuments include two notable sets of brasses. The first, in the north-eastern corner of the chancel, is to John Carre, I570, ironmonger and Merchant Adventurer of London, and shows him flanked by his two wives, with the shields of arms of the City of London, the Ironmongers' Company and the Merchant Adventurers, and Carre's own monogram.so The second, now on the north wall of the nave, was formerly in the chancel: it is to Rainold Hollingworth, 1573, and shows him in armour with his wife beside him. This is a palimpsest on earlier Flemish brasses, the patterns of which survive on the backs of the figures.51 There are floor slabs: in the chancel to ( 1 ) John Leigh (1650) and his son Thomas, I 685, (2) James Crooke, rector ( 1707 ), and in the nave (3) to Prosper Nicholas (1689) and his wife Mary (1702).52 Other monuments include a number to owners of Stondon Hall, Stondon Place, and Stondon House. ${ }^{53}$ One of these, a slab in the nave, gives details concerning the How and Taylor-How families, 1708-1831. Monu-

\footnotetext{
40 Kelly's Dir. Essex (1 go6).

11 Reeve, Siondon Massey, 92. For drawing of the church before restoration sec A. Suckling, Mems. of Essex, $\mathrm{I}-3$.

42 Ibid. $9^{6}$.

44 Ibid. 91,93

4s Ibid. $93,96$.
}

\author{
$46 \mathrm{Ch}$. Bells Essex, 403. \\ 47 Rep. Com. Char. (Essex), H.C. 216 , \\ pp. 245-6 (I 835$)$, xx (I); Char. Com. \\ files; Reeve, Stondon, I $16-17$. \\ 48 Cf. O.S. 6 in. Map (Ist edn.), sheet \\ lix. And see above, p. 241. \\ 49 Church Plate Essex, I41; Reeve,
}

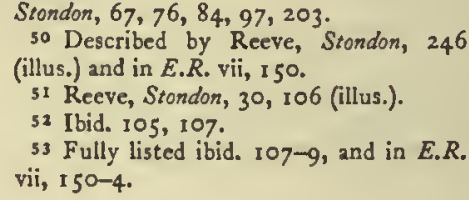


ments to rectors include those to Thomas Smith (1791), E. J. Reeve (I 893), and his son E. H. L. Reeve (1936). On the south wall of the nave is an enriched stone memorial in Jacobean style to William Byrd the musician (d. 1623). It was erected in 1923 to mark the tercentenary of his death. On the north wall of the nave is an oak panel in memory of men who fell in the First World War.

For Canon Reeve's legacy for the church see below, Charities.

At Stondon, as at Navestock and Kelvedon Hatch, some of the gentry reROMAN CATHOLICISM mained Roman Catholic after the Reforma-

tion. William Shelley, lord of the manor in the late I 6 th century, suffered imprisonment and forfeiture of his estates for his recusancy and for his part in Catholic plots.54 William Byrd the musician, of Stondon Place, was also a Roman Catholic. In I 605 he and his wife, son, and daughter-in-law were all presented to the archdeacon for their recusancy and failure to attend the parish church. Byrd was also charged with having seduced into popery John Wright, son and heir of John Wright of Kelvedon Hatch.55 In 16 I 2 Byrd was presented again, this time for failure to pay a church rate. ${ }^{56}$ Other members of his family were presented as recusants from time to time after his death. 57 No evidence has been found of any recusancy in the parish after they ceased to live there.

Nathaniel Ward, Rector of Stondon from I626, was deprived of the living by PROTESTANT Laud in 1632 for disNONCONFORMITY obedience of the canons. ${ }^{8}$ He had probably been presented to Stondon by Sir Nathaniel Rich, then lord of the manor, who was a zealous Puritan.59 Nathaniel Rich the younger was also a Puritan. His religious view did not change in old age. In 1684 the churchwardens of Stondon presented that he had come to church only once in the past fourteen years, and that for a funeral. ${ }^{60}$ His will provides the only evidence of organized nonconformity in the parish: he left $f_{10}$ to a Mr. Paget 'minister of Stondon meeting'. This meeting appears to have been short lived. ${ }^{61}$

The parish book for Stondon Massey covers the period I 7 I I 1922.62

PARISH GOVERNMENT Detailed overseers' acAND POOR RELIEF count books alsosurvive for $174 \mathrm{I}-1801$ and $1821-42.63$ The parish vestry usually met only on Easter Monday, for the annual audit of accounts and election of officers. Before 1721 and again between 1772 and 1793 the minutes were not signed. Between 1725 and 1743 John How of Stondon Place, the lord of the manor, acted as chairman whenever he was present. Between 1743 and $I 772$ the rector, Thomas Smith, usually took the chair. His successor John Oldham was chairman from 1793 to 1821 . After I82 I Oldham ceased to attend and there was no regular chairman. The average attendance was six parishioners, including parish officers and the chairman. In 1737 the vestry agreed to allow the parish clerk, who was also sexton, 40s. a year. The expenses of a vestry dinner were regularly included in the overseers' accounts during the second half of the $\mathrm{r} 8$ th century.

Before 1795 a distinction was usually maintained between the expenses of the church and those relating to poor relief, and separate rates were levied. It was recorded in 1737 , however, that repairs to the churchyard were customarily met out of the poor rates. From I 795 the churchwarden's expenditure, after the deduction of rent received for the parish land, was usually carried over to the overseer's account and paid by the latter official 'with the consent of the rector'. A rate of Is. in $£_{1}$ produced $\oint_{2}$ I 85. in 1723 . By the end of the I 8 th century it produced nearly 40 . New assessments were made in 1822 , when the rateable value of the parish was assessed at $f_{\mathrm{I}} \mathrm{I}, 425$, and in $\mathrm{I} 848$ when it was raised to $f_{\mathrm{I}}, 836.64$

One churchwarden, one constable, and usually one overseer were appointed each year. Until about $175^{\circ}$ each overseer usually served for two consecutive years. On the rare occasions when women were nominated for this office they served by deputy. In 1798 it was agreed that the office should be held in rotation by the owners of specific properties, and the rota was entered at the end of the parish book. From 1806 the overseer was allowed a salary of 5 guineas and all expenses except those for making rates and for journeys to Ongar. In I 799 William King was paid one guinea for serving as parish constable.

In 1749 the constable was authorized to erect stocks at the parish expense. These probably stood at the cross-roads near Stondon Place, where the ancient whipping-post certainly stood.65 The parish pound was a few yards south of the whipping-post. ${ }^{66}$

Expenditure on poor relief was small in the early I 8 th century and did not exceed , ioo before $178 \mathrm{I}$. The cost of medical attention for the poor was from an early date a prominent item in the annual expenses. In I 74I, the first year for which detailed accounts survive, it amounted to $\oint_{4}$ out of a total of $£ 25$ I 4 s. In I 746 it was decided that the sanction of a parish officer or four other parishioners was necessary before the surgeon and apothecary could be summoned to attend the poor. From about 1760 the parish doctor received a regular salary. In 1833 John Potter, who had been parish doctor at least since 1822 , agreed to a contract giving him $f_{12}$. In the following year he accepted a less favourable contract whereby he undertook to attend all cases (instead of three, as previously) of midwifery and surgery within 3 miles of the parish, the incorporated workhouse at Stanford Rivers included, at a salary of $£ \mathrm{I} O$.

In 1794 expenditure on poor relief was $£ 130$. In that year the parish subscribed $f_{\mathrm{s}} 6 \mathrm{~s}$. to the poor relief scheme of John Conyers of Epping, which was designed to reward children for knitting or spinning, and parents for rearing large families without parish relief. ${ }^{67}$ The peak of expenditure on poor relief was
S4 See above, Manor.

ss E.R.O., D/AEA 23. And cf. Kelvedon Hatch.

s6 E. H. L. Reeve, 'William Byrd', E.R. xxxii, 168 .

s7 Reeve, Stondon Massey, 37 and n.

For Byrd's Catholic associations see E. Fellowes, William Byrd, chap. iii.

s8 Reeve, Siondon Massey, 71-72. And see above, Worthies.

s9 Ibid. 37. See above, Worthies.

60 Ibid. 39. See above, Worthies.

6 I Ibid.

62 E.R.O., D/P $98 / 8$. Some use of this book was made by E. H. L. Reeve in his Hist. Stondon Massey, 83 f. and his Supplemeniary Noies, 200-3.

63 E.R.O., D/P $98 / 12 / 1-7$. Unless otherwise stated all the following information is taken from these account books and the parish book.

64 E.R.O., D/P 98/11/1-3: Ratebooks 1 797-1 850 .

66 E.R.O., D/CT 337.

67 Acct. of Soc. for Promotion of Industry in hundreds of Ongar and Harlow and halfhundred of Waltham (1 797). 


\section{A HISTORY OF ESSEX}

reached in $1800-1$, when it was over $£ 35^{\circ}$. In I 801 29 persons were receiving weekly pensions totalling f. 4 ros. $9 d$. and in addition 20 of these were receiving pickled pork and potatoes valued at $£_{2}$ 6s. a week. The review of expenditure that produced these figures was followed by economies. Half a hundredweight of rice costing $16 s .6 \mathrm{~d}$. replaced the pork and potatoes and general expenditure was also reduced, its average for the next 20 years being under $\$ 250.68$ In 1828 the parish contained 12 permanent and 67 occasional paupers out of a total population of 230 . A parish poorhouse had existed in 1793; an inventory of goods there then included three spinning-wheels. The statistics of 1801 do not suggest that a poorhouse was then in use, but in 1834 the parish was renting two cottages, divided into a total of five tenements, from the trustees of Giles's Charity, for use as poorhouses. 69

In 1829 Stondon Massey joined the voluntary poor law union under Gilbert's Act with Stanford Rivers and other neighbouring parishes.70 Thereafter annual expenditure on poor relief in Stondon rose by about 50 above the average of the four years previous to the union. The parish guardian of the poor succeeded to the salary previously given to the overseer. In 1836 the parish became a member of the Ongar Poor Law Union.

There was a schoolmaster in Stondon Massey in 1777, but his school had been closed by SCHOOLS 1791 , when John Oldham became rector. Oldham was a subscriber to the Society for Promoting Christian Knowledge and he set up a day school in the parish with a labourer's wife as the mistress. In 1807 about 12 Stondon children attended and possibly others from outside the parish. The curriculum was confined to reading, sewing, and knitting. Expenses were paid by the rector. ${ }^{71}$ In 1818 this school, still kept by the labourer's wife, remained the only one in the parish. The mistress taught 30 or 40 pupils to read but sent them to Chipping Ongar to learn writing and arithmetic. ${ }^{22}$ The school had come into union with the National Society in 1816 , and remained so at least until $\mathrm{r} 832$. During that period the number of day pupils seems to have been kept at 34 , while a further $5^{\circ}$ attended the Sunday school held in connexion with the day school. ${ }^{73}$ In 1833 the day pupils increased considerably in numbers. They all paid fees except 6 whose fees were paid by benefactors. 'There were some dame schools and there was a girls' boarding-school at Stondon House, which was founded in 1824 and which by 1833 had 26 pupils. 74

In 8844 the lord of the manor, P. H. Meyer, built a parish school with accommodation for 48 pupils. The trust deed of that year placed it in union with the National Society, required that the religious teaching should be in accordance with Anglican principles and appointed the rector and churchwardens as trustees.75 In 1870 there were some 42 pupils, and in 1871 an inspector reported that the accommodation was suffi- cient for the needs of the parish. ${ }^{76}$ Some years passed before the school received a government grant because the rector would not accept a conscience clause for the benefit of nonconformist children on the ground that the founder had specifically required that the principles of religious teaching should be Anglican. When the income of the school was reduced by the agricultural depression that began about 1875 , and the rector saw that the conscience clause had been accepted in other Church schools, he also accepted the clause. 77 The school received a government grant of $£_{51}$ in 1893 and one of 660 in $1899 .{ }^{78}$ Average attendance in the I $880^{\circ}$ 's was about 36.79 The school was enlarged in 189 I for 70 children, but in spite of this there was little increase in the attendance, which averaged 39 in I 898.80

By the Education Act of 1902 the school passed under the administration of the Essex Education Committee, Ongar District, as a non-provided school. In 1 904 , when accommodation was estimated at 75 , there were 45 pupils and 2 teachers. ${ }^{81}$ In 1910 the average attendance was 31 and in 1920 it was 36 . In 1930 the school was reorganized for mixed junjors and infants. Attendance subsequently increased and in 1939 the infants were being taught in the adjacent village hall. ${ }^{82}$ In May 1952 there were 47 pupils and 2 teachers. The school was closed in 1953 , the children being transferred to that at Kelvedon Hatch. ${ }^{83}$ The building was of one story, of red brick with tiled roof. It was inscribed 'Stondon Massey National School, built I 844 , enlarged I 89 r.' It was demolished in July I 954

Henry Giles, by deed of 1575 , left two cottages and about 5 acres of land on the west of CHARITIES ${ }^{84}$ the Ongar-Blackmore road in trust for an annual distribution to the poor.

In 1834 the two cottages were used as five almshouse whose inmates were appointed by the overseer. ${ }^{85}$ The parish then paid no rent and the trustees did not repair the cottages. The land was let for $£ 75^{5}$., which was distributed at Christmas in shares varying from 3 s. to 5s. according to the size of families. In 1841 the lord of the manor supplemented the endowment by a small piece of waste land between the cottages and the road. $\mathrm{He}$ also rebuilt and enlarged the cottages in 1860.86 Part of the property, including one of the five cottages, has been sold since $193 \mathrm{I}$. In 1951 the stock held was Ei 55 . In 1952 the total rents received were $f_{2} 8 \mathrm{is}, 2 \mathrm{~d}$. Most of this was spent on repairs, the cottages being in poor condition; $f \mathrm{I}$ was given away in relief.

Giles Charity Cottages are a group of five two-story houses in red brick with pilasters on the outer angles, pantile roofs, pierced ornamental barge-boards to the end gables and porches, diagonal chimney-stacks, and 'Gothic' casements. The pantiles were substituted for thatch about 20 years ago.87 On the north-east end wall of the block is a stone slab inscribed: "The gift of Henry Giles to Stondon parish 1574. Enlarged and repaired 1860.' The repairs of 1860 seem to have con-

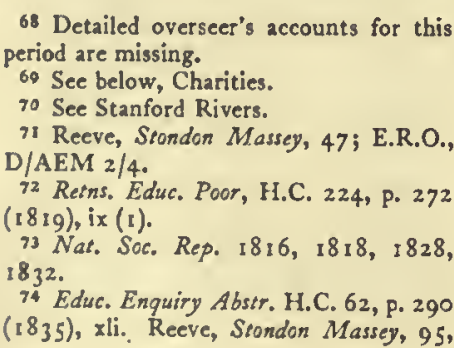

49. The Stondon House school closed before I $86 \%$.

75 Reeve, op. cit. 95-96; Min. of Educ. File I $3 / 356$.

76 Reins. Elem. Educ. H.C. 201, pp. 112-13 (1871), Iv; Min. of Educ. File $13 / 356$.

77 Reeve, op. cit. 95-96.

78 Retns. of Schs. 1893 [C. 7529 ], p. 7 [6, H.C. (1894), lxv.; ibid. 1899 [Cd. 315], p. 74, H.C. (1900), 1xv (2). 79 Kelly's Dir. Essex (1 882, 1886, 1890).
80 Ibid. (1898).

81 Essex Educ. Cttee. Handbk. 1904, p. 187 .

82 Min. of Educ. File $13 / 356$

83 Inf. from Essex Educ. Citee.

84 Rep. Com. Char. (Essex), H.C. 2 I 6 , Pp. 245-6 (1835), xxi (1); Char. Com files; Reeve, Siondon Massey, 110-17.

8s See Parish Government and Poor Relief.

86 Kelly's Dir. Essex ( 1878 )

87 Inf. from an occupant. 
stituted an almost complete rebuilding, but the central cottage is said to contain timbers from the earlier house. Before I 860 the cottages were apparently weatherboarded and tarred buildings and known as Black Cottages. There is some doubt whether they were the original cottages. 88

Before I $684 \mathrm{Mrs}$. Alice Thomlinson left fI ros. a year, issuing from Braintrees Farm in Hatfield Broad Oak, to buy waistcoats for six poor widows of Stondon Massey. In 1834 the churchwarden gave equal shares of money to all the poor widows each March. Under the $189_{2}$ Scheme which was framed for this and Giles's Charity the income was to be spent on relief in money. The rent was not paid in 1952 ; in 1951 the whole amount was given to one widow.

The Bell Rope Charity is described above (see Church).

Canon E. H. L. Reeve, formerly rector, by will proved I 936 left legacies of $£ 600$ and $£ 750$, subject to two life interests, for the repair of the church and for the immediate repair of the Giles Almshouses. These charities had not yet come into effect in 1953.

\section{THEYDON BOIS}

Theydon Bois is 2 miles south of Epping and 15 miles north-east of London.I During the past I oo years much building has taken place near the railway station and many residents travel to work in London. In spite of this the parish retains a number of rural features. The village green is an attractive centre and part of the parish lies within Epping Forest. Local people are proud of their village and have formed the Theydon Bois Rural Preservation Society. ${ }^{2}$

The ancient parish of 'Theydon Bois contained 2,198 acres. ${ }^{3}$ In 1896 those parts of it lying within the Epping Special Drainage Area were transferred for civil purposes to the newly formed Epping Urban District. This affected about 60 acres in the north of the parish.4 In 1934 a small part of Theydon Bois was transferred to Epping Uplands and in 1946 there were further slight adjustments of the boundary between these two parishes. ${ }^{6}$

Theydon Bois is the most westerly of the three Theydon parishes. It takes its distinctive name from the family of Bois (de Bosco) which held the manor in the 12 th and I $3^{\text {th }}$ centuries.7 The parish is bounded on the south by the River Roding. The ground rises from about $75 \mathrm{ft}$. above sea-level by the river to $370 \mathrm{ft}$. in the north-west, where the parish includes some 300 acres at the north end of Epping Forest. The road from Abridge (in Lambourne, q.v.) enters the parish by Abridge Bridge over the Roding and runs northwest through Theydon Bois to the 'Wake Arms' in Epping Forest, where it meets the main road from London to Newmarket and Norwich. At Theydon Green in the centre of the parish the Abridge road is joined by those going north to Epping and south to Loughton. The railway, now part of the Central London (Underground) line, runs north through the parish to Epping. Theydon Bois station, on this line, is mile east of Theydon Green. Theydon Green has been a village since the 18 th century or earlier and retains a large open green and pond. The modern parish church and the village school are on the northwest of the green and the Baptist church is on the southwest. Modern development has been mainly to the north, south, and east of the green. There is a small group of houses at Ivy Chimneys, in the north of the ancient parish. This is in the ecclesiastical parish of
Theydon Bois and includes an iron mission room, but for civil purposes it is in Epping Urban District.

Theydon Hall, which is on the site of the ancient manor house, is about I $\frac{1}{2}$ mile south of the green on the Abridge road. Beside it is the site of the old parish church, demolished in 1843 . Theydon Hall ceased to be the manor house early in the 17 th century. Its place was taken by Birch Hall, $\frac{1}{2}$ mile west of Theydon Green. The present Birch Hall is a Igth-century house, but the name is derived from a medieval family which no doubt had a house on the site. ${ }^{8}$ The other old manor house of Gregories was probably about $\frac{3}{4}$ mile north-east of the church, where there is still a homestead moat. The modern Great Gregories Farm is about $\frac{1}{2}$ mile north-west of the moat. Parsonage Farm is mile east of the railway station. 9 It probably dates from the $15^{\text {th }}$ century. The parish almshouses, dating from the I 8 th century, are in Coppice Row. ${ }^{10}$

In the Middle Ages Theydon Bois was a thinly populated rural parish. In 1428 it was one of the few parishes in the hundred which were exempted from taxation because they contained fewer than Io households. II In addition to those already mentioned there was probably a medieval house to the north of'Theydon Green where traces of a rectangular moat could still be seen at the end of the 19 th century.12 Gaunts Wood and Redoak Wood, 1 mile south-west of Theydon Green, take their names from medieval tenants, whose houses may have been in the neighbourhood.13

Chapman and Andrés map of 1777 shows about a dozen houses round Theydon Green but few others in the parish apart from those above. ${ }^{14}$ Blackacre Farm is shown, mile south of Theydon Green. It is a timber-framed and plastered house now surrounded by buildings of a much later date. Details which survive are of the 17 th century but subsequent alterations have made it impossible to trace the original form of the house. One chimney retains parts of four octagonal shafts and two more, which originally had diagonal shafts, have moulded brick cappings at the base. Internally there is a 17 th-century staircase with moulded newels and pendants and heavy turned balusters.

In general there are few buildings in the parish that are earlier than the 19th century. At Theydon Green the Bull Inn, part of it of the I 7 th century, still stands.

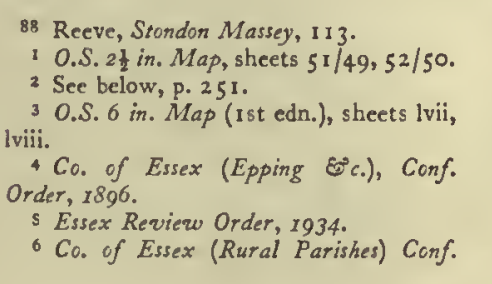

ES. IV Order, 1946.

7 P.N. Essex (E.P.N.S.), 82-83. The explanation of the name Theydon given there has been withdrawn. It is now thought to mean "valley where thatch (material) grows' : P.N' Wilts. (E.P.N.S.), xvi.

8 P.N. Essex, 83. For the manor houses see below, Manors.
9 See below, Church.

10 See below, Charities.

11 Feud. Aids, ii, 204.

12 O.S. 6 in. Map (Ist edn.), sheet lvili; cf. E.R.O., D/DBx PI.

13 P.N: Essex, 83.

14 Chapman and André, Map of Essex, 1777 , sheet $x$ vi. 


\section{A HISTORY OF ESSEX}

A smithy and wheelwright's shop stood near by in 1848.15 Between the 'Bull' and the 'Queen Victoria' is a row of weather-boarded cottages probably built early in the 18 th century. Facing the green on its east side are a few scattered cottages which may date from the $17^{\text {th }}$ century or earlier. By the early I 9 th century there were a number of cottages in the northern part of Coppice Row. There were also some in the north of the ancient parish, now part of Epping Urban District. ${ }^{16}$ In 1801 the population of 'Theydon Bois was $334 .{ }^{17}$ It rose to 676 in 183 r but sank to $53^{8}$ in 1841 . It was 591 in 1851 and 610 in 1861 .

The extension of the railway from Loughton to Epping and Ongar in 1865 had a rapid effect on Theydon Bois, and must be held mainly responsible for building development there during the later $r$ th century and after. Building had, however, started a little before 1865 , perhaps in anticipation of the railway extension. In Theydon Bois, as in Loughton (q.v.) and the other forest parishes, there was a strong movement to inclose the forest, and in some cases to clear it for building. ${ }^{18}$ As early as 1848 the sites of the houses now called Manor Villas were laid out on newly inclosed land to the north of Theydon Green. ${ }^{19}$ The houses themselves were built between 1870 and 1872 . Farther north, beyond the golf course, are houses of similar character standing in good gardens. The most imposing of these is Theydon Towers, dating from about 1880 . It is an irregularly shaped house of brown brick with a four-story tower-like feature forming part of the entrance front. In this area there are also some largish houses of a later date. Building in this area was, however, checked by the preservation of Epping Forest.

Elsewhere the development, although extensive, is composed of smaller units. Terrace houses on the south-west side of Theydon Green date from between 1890 and 19ro. Theydon Park Road, which leaves the Green at its south corner and finally becomes an unmade track parallel to the railway, is built up with small houses and bungalows. Some of these date from the late I 9 th and early 20 th centuries but the majority were built between the two World Wars. Two culde-sac roads on its west side are of similar character. A new shopping centre has been formed immediately west of the station and a large new residential area is under construction between here and Piercing Hill.

There were formerly two 'Retreats' in Coppice Row about 100 yards west of the parish church. Both were destroyed by German bombs in the Second World War ${ }^{20}$ together with four houses on the north side of the road.

Red Oaks Mead is an estate on the north-west side of Loughton Lane consisting of ten pairs of roughcast council houses built before the Second World War. Opposite this a post-war layout is known as Graylands. Here there are 40 council houses, including some old people's bungalows. Green Glade and Pakes Way are two new crescent-shaped roads on the east side of Theydon Green. They form a large council housing estate, recently completed.

The population of Theydon Bois has naturally reflected these developments. It increased steadily to 1,257 in I 901 and then remained almost stationary for 20 years. There was an increase from 1,267 in 1921 to 1,504 in 1931.21 The population in 1951 was $2,665.22$

Until the construction of the new road between Loughton and Epping early in the 17th century the main road from London to Newmarket and Norwich was via Abridge Bridge and Coopersale (in Theydon Garnon, q.v.), and part of it thus ran through Theydon Bois. ${ }^{23}$ After the $17^{\text {th }}$ century the parish roads were of purely local importance. There was a full report on them in 1720.24 When the railway was built it crossed the Abridge road by a level crossing. This was replaced about 1940 by a bridge, and the road itself was transformed from a winding country lane into a good motor road. 25

The bridge between Abridge and Theydon Bois has already been treated under Lambourne(q.v.). Theydon Bois was sometimes held responsible for the foot-bridge which lay alongside Abridge Bridge. In 1625 the inhabitants were indicted because of $i t s$ ruined condition. ${ }^{26}$ In 1652 it was described as a 'long footbridge' to be repaired by the county.27 In 1665 it was said to be impassable; again the county was responsible. ${ }^{28}$

Until the coming of the railway Theydon Bois was dependent for communications with the outside world mainly upon coaches and other horse transport using the main roads via Epping and Loughton, to north and south, and via Abridge to the east. Travel to the west was for long difficult and dangerous because of the barrier of Epping Forest. There was indeed a road through the forest from Theydon Bois as early as $1594,{ }^{29}$ but the prevalence of highway robbery there, which was still a menace in the late 18 th century, ${ }^{30}$ must have deterred travellers from using this route.

The branch railway line from London, which had been carried as far as Loughton (q.v.) by 1856 , was extended to Epping and Ongar in 1865 , and Theydon Bois station on this line was opened in the same year. ${ }^{31}$ The section of the line as far as Epping was electrified in r 949 , and became part of the Central London Line. ${ }^{32}$

In 1853 a sub-postmaster was appointed on the understanding that his wife performed the duties. ${ }^{33}$ In 1867 the post-office there was reorganized. 34 A moneyorder office was established in 1886 and a telegraph extension in the same year. ${ }^{35}$ The telephone was established by $1921 .{ }^{36}$

Water was supplied by the Herts. and Essex Waterworks Co., about 1884.37 Main drainage presumably existed before 1896 in the parts of the parish which were then part of the Epping Special Drainage Area, ${ }^{38}$ and there is now drainage in most of Theydon Bois. ${ }^{39}$ Gas was first supplied (from Epping) in 1872.40

\footnotetext{
15 E.R.O., D/CT $349 . \quad 16$ Ibid.

17 Census figures 1801-1901 are from

V.C.H. Essex, ii, 350.

18 For the forest see below.

I9 E.R.O., D/CT 349 ; A. A. West, MS.

Hist. Theydon Bois.

${ }_{20}$ Theydon Bais Official Guide, p. 5 .

21 Census Reports, 1921 , 1931.

22 Censut Report, 1951.

$23 \mathrm{~B}$. Winstone, Epping and Ongar Iighway Truit, 91.
}

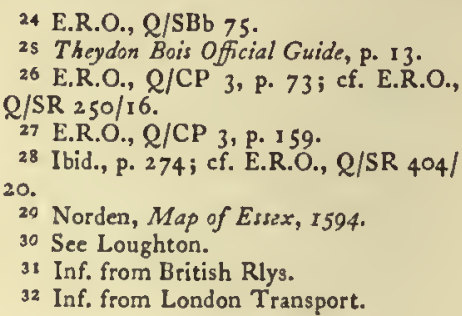

32 Inf. from London Transport.

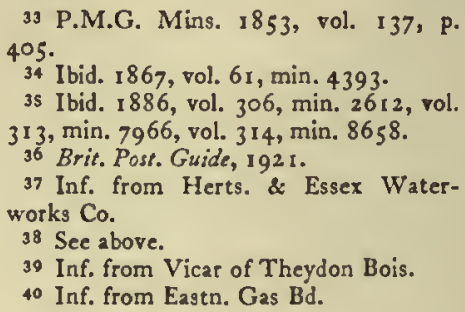


Electricity was laid on in 1928.41 A police station has existed since about I 886.42 A branch of the county library was opened in 1928.43 There are two public halls, both temporary wooden buildings erected since 1 946.44 One is a church hall, the other a village hall. There are many village organizations, including a branch of the United Nations Association. Most of them are linked by the Village Association, in which is vested the management of the village hall.45 There is a playing-field behind the hall. The Theydon Bois Rural Preservation Society was formed about eight years ago 'to preserve the rural character of the countryside in and around Theydon Bois as an appropriate and natural setting to Epping Forest'.46 It has helped to produce a parish guide, issued by the parish council.

Apart from the distributive trades in recent times no occupations unconnected with the land have been important in the life of the parish. In the Igth century there was brickmaking on a site north of Birch Hall Farm now occupied by Oakhill Farm.47 In this parish, as elsewhere in the district, mixed farming is carried on. In 1849 it was estimated that there were 709 acres of arable, 956 acres of meadow or pasture, and 86 acres of woodland in Theydon Bois. This was exclusive of 345 acres of forest waste which lay within Epping Forest. 48 At the same date there were some I 5 farms in the parish of over 20 acres, the largest of which was Theydon Hall Farm with 26r acres. About 8 were over 100 acres. 49

Theydon Bois lay only partly within the bounds of the royal forest. It was stated in 1872 that of 2,176 acres in the manor of Theydon Bois 800 acres lay outside the forest.so The movement to disafforest and inclose Epping Forest has been described above (see Loughton). At Theydon Bois, as at Loughton, the Crown was negotiating, during the 1850 's, for the sale of its forestal rights to the lord of the manor. In 1857 R. W. H. Dare bought those rights for the area of his manor at a cost of I $^{1}, 353 .{ }^{51}$ Between I 857 and I 87 I he and his son inclosed over 300 acres of the forest.s2 Inclosure was halted by the action of the government in the first Epping Forest Act. As a result of the Epping Forest Act, 1878 , most of the forest area in Theydon Bois was again thrown open and became subject to the provisions of the Act for the future preservation of the forest. At Theydon Bois the inhabitants claimed ancient rights of estovers, exercised, as at Loughton, from 12 November in each year to the following 23 April. These rights were recognized by the Act, which provided for their extinguishment in return for compensation. ${ }^{53}$

James Theodore Bent (1852-97), explorer and archaeologist, married (1877) a daughter of R. W. H. Dare. He is buried at Theydon Bois. 54 Frances Mary Buss (d. r 894), pioneer of education for women at her North London Collegiate School, is also buried there.5s For John Strype (1643-1737) see below, Church.

42 Inf. from Eastn. Elec, Bd.

42 Kelly's Dir. Essex (1886 f.)

43 Inf. from County Librarian.

44 Inf. from Vicar of Theydon Bois.

45 Theydon Bois Official Guide, p. 7.

46 Ibid., P. I 5 .

47 E.R.O., D/DBx PI; 0.S. 6 in. Map

(ist edn.), sheet lviii.

48 E.R.O., D/CT 349.

49 Ibid.

so Mins. of Epping Forest Comm. p. 426.
In 1066 THEYDON BOIS was held by Hacun as a manor and as $3 \frac{1}{2}$ hides and 80 acres. In MANORS ro86 it was held in demesne by Peter de Valognes. An additional 2 hides and $\mathrm{r} \frac{1}{2}$ virgate, previously held by 7 freemen, had by 1086 also been acquired by Peter, who claimed to hold the property by exchange. He was also tenant in chief of $\frac{1}{2}$ hide and 40 acres, which had formerly belonged to Ulwin. Peter had it in mortgage by the king's permission. It was held of him by Walter.s6 The tenancy in chief of these estates descended in the Valognes family like North Weald Basset (q.v.) until the death of Gunnore, whose second husband was Robert Fitz Walter. Fitz Walter, who died in December 1235 , appears to have held part of the barony of Valognes, including Theydon Bois, in right of his wife, after her death. $57 \mathrm{He}$ also outlived their daughter and heir Christine, widow of William de Mandeville, Earl of Essex, and after his death Theydon Bois evidently passed to Christine, wife of Peter de Maule, one of the coheirs of Christine de Mandeville.58 As the tenant in chief of the manor Christine de Maule was a party to its conveyance about $1288-97$ to Waltham Abbey (see below).

In I 66 Osbert son of Ralph de Wetmere held I knight's fee in Theydon Bois of Geoffrey de Valognes, while William de Bosco held 1 fee of the new feoffment.59 The subsequent history of the first of these fees has not been traced, but in $1235-6$ a William de Bosco was holding in Theydon Bois what was variously described as I fee and as $\frac{1}{2}$ fee. ${ }^{60}$ The manor must have continued in the same family, for in 1248 Hugh de Bosco released his right in the advowson of 'Theydon Bois (see Church) and the manor was later in the possession of a Henry de Bosco, who died holding it. ${ }^{6 r}$ Henry was succeeded by John, son of Peter de Tany, a nephew. John de Tany in or before 1289 enfeoffed Reynold, Abbot of Waltham, with the manor. ${ }^{62}$ It was then agreed that Christine de Maule was to receive $f_{0} 5$ from the abbey after the death or removal of each abbot, by way of compensation for the loss of the feudal incidents due to her as tenant in chief. This transaction was contrary to the Statute of Mortmain (1279). The parties evidently realized this after it had been concluded and took steps to secure the abbey's title. It had been provided by the statute that where land had been alienated to a religious house the tenant in chief, if he acted within a year, might occupy the property concerned. Christine de Maule therefore pleaded the statute and renounced the agreement with Waltham Abbey. She next enfeoffed Anthony Bek, Bishop of Durham, and Richard de Cokham, Rector of Lambourne, Essex, with the manor of Theydon Bois. ${ }^{63}$ In 1297 Bek, Cokham, and Peter de 'Tany all released their rights in the manor to the abbey, and the king confirmed their grants. ${ }^{64}$ The account in the Waltham Abbey cartulary from which much of the above has been taken adds that Christine had excluded her son and heir

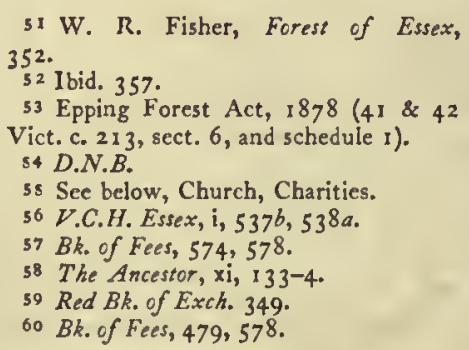

61 B.M. Cott. MS. Tib. c.ix f. 106v

62 Ibid. Reynold's successor, Abbot Robert, was elected in $1289:$ V.C.H. Essex, ii, 17 I.

63 B.M. Cott. MS. Tib. c.ix f. $196^{\mathrm{V}}$ 'Processus qualiter Abbas de Waitham perquisivit manerium de Theydon Bois'. 64 B.M. Harl. MS. 3739 ff: $267-72$. The grants included the reversion of land held in dower by Maud, widow of Richard de Bosco. 


\section{A HISTORY OF ESSEX}

William from the manor and assigned it to William's son Henry, but that in spite of this assignment Henry was never seised of any service from the manor, in whose time there were three abbots, Reynold, Robert, and John (elected 1302, died I 307). Henry assigned his right in the manor to Agnes de Valence, but this was void since he was not legally seised.6s Some light is thrown on this statement by the history of the manor of Gregories (see below). The abbey certainly seems to have successfully resisted any claims by Henry de Maule or Agnes de Valence.

Meanwhile, in 1293, Henry, son of the previous owner Henry de Bosco, had arraigned an assize against Peter de Tany, alleging unlawful disseisin of the manor by Tany and others. ${ }^{66}$ Tany's counsel stated that Henry was illegitimate, having been born while his father was in deacon's orders. The jurors found that Henry was indeed illegitimate but on the ground that his parents bad not been married at the time of his birth. The title to the manor was again challenged in $I 3 I 3$ and on this occasion a charter of 1308 was produced whereby Lawrence de Theydon Bois acknowledged that he had released his right in the manor, which had been of Henry du Boys his father. ${ }^{67}$

Theydon Bois was retained by Waltham until the dissolution of the abbey in 1540 . The manor thereupon passed to the Crown and in May 1540 was granted for life, together with other manors formerly belonging to the abbey, to Robert Fuller, the last abbot. ${ }^{68} \mathrm{He}$ died later in 1540,69 and the manor was again vested in the Crown until July 1543 , when it was granted for life to John Soda, the king's servant, presumably that John Soda whose will was proved in November I 551.70 In his will, dated I 545, Soda described himself as born in Catalonia, but dwelling at that time in the City of London in the service of the Lady Mary, the king's daughter. In December I $55 \mathrm{I}$ Theydon Bois was granted to Sir Thomas Wroth, one of the four principal gentlemen of the Privy Chamber, for which he was to pay $36 \mathrm{~s}$. a year in respect of the knight service due from the manor and also $\oint_{5}$ I $8 \mathrm{~s}$. $3 \frac{1}{2} d$. a year at the Court of Augmentations. ${ }^{71}$

Wroth died in 1573 , leaving Theydon Bois to his son Robert, who held it until his death in 1606 . His son, another Sir Robert, died in I6r4. James, son of the last Sir Robert, was an infant at his facher's death, and died in I6I6.72 In his will Sir Robert provided that Theydon Bois and other estates should be vested in his uncle, brother, and cousin, all named John Wroth, to be sold as they thought fit to pay off his large debts. ${ }^{73}$ In I61 6 the manor was accordingly conveyed to Edward Elrington, the owner of the impropriate rectory and the advowson. ${ }^{74}$

Elrington died in 1618 . His heir was his son, another Edward. 75 An Edward Elrington was holding the manor in I 652 but by March I 657 John Smart and two others were being named as lords. ${ }^{76}$ This confirms Morant's statement that Elrington sold the manor to John Smart about 1656.77 In 1670 Smart bought out the fee farm rent of $\varnothing_{55}$ I $8 \mathrm{~s}$. $3 \frac{1}{2} d$. reserved in the royal grant of 155 I for a payment of $6.1556 s .9 d .78$ What happened to the other rent of $36 \mathrm{~s}$. is not clear. Since it had been connected with the knight service due from the manor it may have lapsed with the abolition of feudal tenures.

There is no reference to Theydon Bois in John Smart's will, which was proved in 1679,79 but the manor seems to have passed to his son John Smart who must have died shortly afterwards, for Ben jamin Smart, brother of the younger John, in his will proved in 1684 , stated that he and his other brother Joseph acquired the manor under the will of John Smart their brother. 80 Benjamin left his moiety to Joseph, who thus held the whole of the manor, apparently until his death in 1702.81 Joseph's son and successor Ben jamin was still lord of the manor in $1753 .{ }^{82}$ In 1762 the lord of the manor was John Hopkins, who was dead by I773, when his trustees Benjamin Bond and William Jacomb were named as lords. ${ }^{83}$ The manor was held in 1783 by Elizabeth Bond, widow, and in 1789 by John Hopkins Dare, then an infant. ${ }^{84}$

$\mathrm{J} . \mathrm{H}$. Dare died in I 805 , leaving his estate in trust for his mother Elizabeth, then wife of John Marmaduke Grafton, and his half-sister Elizabeth Grafton, who were to take the name and arms of Dare. Grafton did so in the same year and died in 1810 . His widow died in 1823 and was succeeded by her daughter, the above Elizabeth, then wife of Robert Westley Hall. R. W. Hall took the name and arms of Dare and died in 1836 , being survived for some years by his widow. Their son and successor, Robert Westley Hall Dare, in I 853 obtained a private Act of Parliament authorizing the sale of parts of his estate, in order that he might settle in Ireland, his wife's country. ${ }^{85}$ Theydon Bois, however, remained in the family. R. W. H. Dare died in I 866 and was succeeded by his son Robert Westley Hall Dare who in I90I sold Theydon Bois to Gerald Buxton. Buxton was succeeded on his death in 1928 by his son Lt.-Col. Edward North Buxton. ${ }^{86}$ In $185^{\circ}-1$ the Hall Dare estate included 781 acres in Theydon Bois and 47 acres in Loughton. 87

The Elrington family was settled at Birch Hall in Theydon Bois before they acquired the manor in 1616 (see above) and from that date Birch Hall was the manor house. In 1633 Edward Elrington sold Theydon Hall, which must previously have been the manor house, to Frances Muscott, by the name of the site of the manor of Theydon Bois. 88 This conveyance was accompanied by litigation, as Thomas Smith claimed that Elrington had concluded a bargain with him. ${ }^{89}$ In I644 Frances Muscott settled Theydon Hall upon her daughter Charity, wife of George Duncombe.90 The estate was subsequently owned by George Meggott, certainly by 1680 when he claimed tithe from certain properties in the parish.91 His son Robert Meggott married Anne daughter of Gervase

\footnotetext{
63 B.M. Cott. MS. Tib. c.ix f. 196\%.

66 J.I. $1 / 1298$, m. $66 a, d$.

67 J.I. $1 / 1352, \mathrm{~m} .2 \mathrm{r}(\mathrm{l}) d$

63 L. \&० P. Hen. VIII, xvi, p. 7 I 5.

69 E. A. Webb, Recs, of St. Bartholomew's

Priory 6ீc. i, 259.

70 L. P. Hen. VIII, xix (1), p. 644

P.C.C. 34 Bucke.

ir Cal. Pat. I 550-3, 188-90.

72 For the Wroths see also Loughton.

71 P.C.C. 60 Lawe.

$74 \mathrm{CP}_{25}(2) / 295$ Mich. I4 J2s. I.
}

$75 \mathrm{C}_{142 / 369 / 168 .}$

76 E.R.O., D/DBx Mz.

77 Morant, Essex, i, 162

78 E.R.O., D/DBx Tr.

70 P.C.C. 49 King.

80 P.C.C. 8 I Hare.

81 Morant, Essex, i, 162.

82 E.R.O., Q/RSg 3 ; and see below, Charities.

83 Ibid.; E.R.O., D/DBx M7

84 E.R.O., D/DBx My

8s Hall Dare's Estate Act 16 \& 17 Vict.
(1853), c. 8 (priv. act). All the above details in this paragraph are from the preamble to the Act, or from Burke, Lend. Gent. (1871), 564-5.

86 Burke, Land. Gent. (1937), 2568 ; Burke, Peerage (1931), 435 ; St. Mary's, Theydon Bois (pamphlet)

87 E.R.O., D/CT 349, 225.

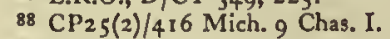

$89 \mathrm{C}_{2}$ Chas. I, S. $100 / 36,37$.

so $\mathrm{C}_{142 / 777 / 96}$

or EI 34/30 Chas. II East. 8. 
Elwes. Their son John, born in 17 I4, was heir to his uncle Sir Hervey Elwes and took the name and arms of Elwes in I75 I, succeeding to Sir Hervey's estates on his death in 1763.92 Both Sir Hervey and John Elwes were notorious misers. John disposed in his will (dated 1786) of property worth about $£ 500,000$. He had inherited property in London about the Haymarket and built Portland Place, Portman Square, and much of Marylebone. He died in 1789 and was succeeded by his grand-nephew John Timms, who took the name and arms of Hervey-Elwes in 1793.93 The descendants of John Hervey-Elwes owned Theydon Hall until Igrg.94 The property has since been broken up. The house is now owned by Mr. Gordon Norton and the farm-yard by Mr. Webster of Parsonage Farm. 95

In 1850 the Theydon' Hall estate consisted of 425 acres in Theydon Bois. ${ }^{96}$ It also included I49 acres in Theydon Garnon when the tithes of that parish were commuted in I 840.97 The owner of the estate also owned part of the tithes on his property. 98

The front range of the present Theydon Hall was rebuilt or added during the last quarter of the 18 th century. It consists of a main two-story block of yellow brick flanked by single-story wings. The round-headed doorway has fluted pilasters and a good semicircular lead fanlight. To the left of the doorway the frontage breaks forward to form a two-story bay. The marble fireplaces, cornices, and doorcases of the principal rooms have ornament of the Adam type. The style is reminiscent of the great building schemes which were being carried out in London at this period and this part of the house may well be the work of John Elwes. At the back is a timber-framed structure which is thought to be the earlier house. It appears to date from the second half of the I 7 th century. It is now derelict.

The former manor house of Birch Hall lay between Birch Hall Farm and the present mansion. By the end of the 18 th century it had been demolished and in I 848 the site was known as 'Old House Ground'.99 The present house is of red brick. It was built in I 892. I The two lodges and several of the cottages in Coppice Row appear to be of the same period.

The manor of GREGORIES occupied the northeast corner of the parish and probably took its name from Gregory son of Ralph who held 1 knight's fee in Theydon of the barony of Valognes in $1235-6 .{ }^{2}$ This Gregory may be identical with the Gregory de Theydon who was a verderer of the Forest of Essex in $125^{0.3}$ 'The manor was originally known as that of Theydon Bois, without anything to distinguish it in name from the capital manor. On one occasion during the I $5^{\text {th }}$ century it was actually found necessary to show that the two manors were distinct. 4

A document drawn up in a $15^{\text {th-century lawsuit }}$ traces the history of the manor from Amy, wife of Henry Boys, who alienated a tenement and lands in Theydon Bois to her son Harry. He conveyed to Stephen Morice, who in turn conveyed to Gilbert son of Gregory de Theydon.s The difficulty in accepting this descent is that the property could not have been held by Gregory, from whom the manor was probably named. Perhaps, however, the tenement referred to in the I 5 th-century descent was added to an earlier holding which was already in the possession of Gregory in I 235-6. In I $59 \mathrm{I}$ an estate that was probably the manor of Gregories was said to be held of the manor of Theydon Bois by knight service. ${ }^{6}$ This and the other evidence strongly suggests that Gregories was originally part of the capital manor of 'Theydon Bois.

A Gilbert de Theydon was holding lands in Essex in $1291^{7}$ and in 1299 the homage and service of Gilbert de Theydon from his tenement in Theydon Bois were conveyed with the manor of Hertingfordbury (Herts.) by Henry de Maule to Agnes de Valence. ${ }^{8}$ This conveyance is probably that mentioned in the Waltham Abbey cartulary as being without legal force (see above). Gilbert de Theydon was dead by $1299 .{ }^{\circ}$ His heir was his son Gilbert, then a minor. Agnes de Valence claimed the right of wardship and seized the estates of Gilbert. ${ }^{10}$ Before January I 30 I, however, Walter de Huntyngfeld appears to have acquired the custody of the lands, and to have forfeited it to the king for his default before the justices of the Bench against Henry de Enefeld who vouched him to warranty against Rose, Gilbert's widow.II Agnes de Valence died in 1308 . The inquisition taken after her death makes no mention of any rights in Theydon Bois. ${ }^{12}$ Later in the Middle Ages Waltham Abbey appears to have been exercising rights of overlordship over Gregories. ${ }^{13}$

In 1323 Gilbert son of Gilbert de Theydon, for a consideration of 40 marks, conveyed to William de Clyf, clerk, the manor of 'Theydon Bois (i.e. Gregories) and 60 acres of land in Theydon Garnon and Epping Heath, of which property one-third was in reversion only, it being held by 'Thomas de Chetingdon of London and his wife Joan, in dower. ${ }^{14}$ In 1324 there is the note of a final concord (which may not actually have been levied) by which William de Clyf conveyed the same property to Robert Spynay and his heirs.15 In 1326 the property, apparently without any part then in reversion, was conveyed by Richard de Clyf to Alice Spynay, to hold for her life with successive remainders to her son William and his heirs, and then to James, his brother, and his heirs. ${ }^{16}$

In 1340 John de Goldingham and three others, presumably feoffees, conveyed the manors of Theydon Garnon (q.v.) and Theydon Bois (i.e. Gregories) to William Gernon and Isabel his wife, with remainder to their son Thomas and his heirs. The fine is endorsed with the claim of Gilbert, son and heir of Gilbert de Theydon. ${ }^{17}$ From 1340 until the death of Elizabeth Hampden in $153^{8}$ the manor of Gregories descended along with that of 'Theydon Garnon.

By a fine levied in I 345 John Colepepir granted Gregories to Walter Colepepir for life with remainder to Thomas son of William Gernon, Lucy his wife, and
92 V.C.H. Northants. Geneal. Vol. 68$69 ;$ D.N.B. John Elwes.

${ }_{93}$ D.N.B. John Elwes.

94 E.R.O., Sale Cat. B. 6 I 5.

os Inf. from Mrs. Norton.

96 E.R.O., D/CT 349.

97 E.R.O., D/CT 350.

98 See below, Church.

90 E.R.O., D/DBx PI (Estate Map,

1799); E.R.O., D/CT 349.
I The house was built by Gerald Buxton: A. A. West, MS. Hist. Theydon Bois.

${ }^{2}$ Bk. of Fees, 578 .

3 W. R. Fisher, Foress of Essex, 374.

4 E.A.T. N.s. v, 22.

5 Ibid. 8 .

6 See below.

7 Cal. Close, 1 288-96, 191.

8 Feet of F. Essex, ii, 86 .
- E.A.T. N.s. v, $2 \sigma_{3}$ n.

Io Ibid.

11 Cal. Close, 1296-1 302, 474-5.

12 Cal. Inq. p.m. v, p. 105.

13 E.A.T. N.s. v, 22.

14 Feet of $F$. Essex, ii, 207.

Is Ibid. 242.

16 Ibid. 225.

17 Feet of F. Essex, iii, 55. 


\section{A HISTORY OF ESSEX}

Thomas's heirs. On this occasion Alice Spynay put in her claim. ${ }^{8}$ It will be seen that this fine differed in detail from that concerning Theydon Garnon levied at the same time. In I 450-I Simon Wythiale alleged that one Tylby, a clerk, had enfeoffed John Wythiale, citizen and goldsmith of London, and his heirs of the manor of Gregories and that Simon Wythiale his son, entering the property after his father's death, had been disseised by John Prince. Prince, however, won the case, the jury finding that Wythiale had not been so disseised. 19 About 20 years later John son of the above John Prince was defendant in a suit brought by William Floure, which was apparently an echo of the above. In 1472 Floure granted to Richard, Duke of Gloucester, and two others the manor of Gregories, which he claimed to have held jointly with John Kilpek, also a goldsmith of London, by feoffment of Thomas Wythiale, another goldsmith. ${ }^{20}$ Floure entered the lands and when Prince re-entered upon them brought an action against him and John Jenyn, the farmer of the manor. The evidence suggests that an attorney had delivered seisin of the manor to Thomas Averry by virtue of an alleged feoffment from Floure to Richard, Duke of Gloucester, Averry, Thomas Wythiale, and another. Averry was a violent man and three times attacked Prince, once actually within Theydon Garnon church. Prince finally appealed to the mother of the Duke of Gloucester (who was also the mother of the king) and she wrote to the duke, whose men had particjpated in these assaults. It was then agreed that the matter should be submitted to arbitration. The details of the settlement have not been discovered, but they were clearly in Prince's favour. ${ }^{2 I}$ It was during this dispute that the documents proving the separate identities of the manors of Theydon Bois and Theydon Bois alias Gregories and setting out the early descent of Gregories were drawn up.

On the division of Elizabeth Hampden's estate Gregories passed to Christopher Carleton in right of his wife Jane. He died in I 549 or $155^{\circ}$ and Jane later married Francis Michell. ${ }^{22}$ In I 591 it was presented at the manor court of Theydon Bois that Jane Michell had died holding 200 acres of the manor by knight service. This was almost certainly Gregories. Her heir was found to be John Carleton, a son by her first husband. The jury added that part of the land, the exact quantity being unknown, had been conveyed to the use of Francis Michell.23 In I638 Gregories was held by George Carleton and was settled upon him and his wife Olive for their lives with remainder to $\mathrm{Sir}$ Ralph Freeman, who paid $\oint_{0} 1,000$ to Alexander Carleton. ${ }^{24}$ In May I643 Freeman convenanted to stand seised of the manor of Gregories for life, with remainder to his youngest son George. George Carleton may have been dead by this time; he was certainly dead by April I644, when his will was proved. 25 In 1649 the settlement of r 643 was revoked and the property, subject apparently to the life interest of Olive, now the wife of John Rjvers, was sold to Fulk Wormlayton of Wapping (Mdx.) distiller, and William Hiccocks of Southwark, brewer, for $£_{0} 7,690$. It was agreed between Wormlayton and Hiccocks that each should en joy half the property with no right of survivorship and that within 30 days after the death of Olive Rivers the property should be divided between them according to the disposition of four arbitrators. It was further covenanted that neither party should attempt to buy out Olive's life interest. ${ }^{26}$ In 1650 John and Olive Rivers leased to Wormlayton for Olive's life and for $\delta_{24} 4^{\circ}$ certain rooms, including the hall, the great parlour with the larders or butteries adjoining, two cellars, and three chambers, part of the house called Gregories, with other buildings and about 200 acres at an annual rent of $6_{0} 60$. In 1652 , presumably on the death of Olive Rjvers, the property was divided, Wormlayton taking the lands included in his lease and Hiccocks the remainder, together with the manorial rights.

Fulk Wormlayton was dead by 1676 and was succeeded by his son John (d. ante Sept. 1680) ${ }^{27}$ and grandson of the same name who in 1727 sold the property to Jacob Houblon of Bobbingworth for $£, 3,000$. During the lives of the two John Wormlaytons mortgages were often raised on the property. In 1735 the property was settled upon the marriage of Jacob Houblon with Mary Cotton, becoming subsequently absorbed in the Coopersale estate in Theydon Garnon (q.v.). ${ }^{28}$

The other half of Gregories, including the manorial rights, descended from William Hiccocks (d. 1674) to his grandson of the same name.29 In 1700 it was conveyed by a John Hiccocks to John Hyett, who died in 17 rg leaving it to his grandson John, son of his deceased son Thomas. ${ }^{30}$ In his will John Hyett the elder provided that the manor should be charged with an annuity for apprenticing poor boys. ${ }^{31}$ The manor was still held by the Hyetts in 1759 , when Elizabeth Hyett was party to a conveyance, but by 1777 it was apparently owned by the Crewe family. ${ }^{32}$ In 1783 it was sold by John Crewe of Bolesworth Castle (Chesh.) to John Tysoe Read of London, banker, whose assigns sold it in 1785 to Daniel Giles of London. ${ }^{33}$ Giles died in I 800 and was succeeded by his son, Daniel Giles of Youngsbury (Herts.). ${ }^{34}$ In I 849 the manor was owned by Lady Louisa Giles Puller of Youngsbury. ${ }^{35}$ It had presumably descended with the manor of North Weald (q.v.). In I 850 Lady Puller's estate consisted of 159 acres in Theydon Bois, then occupied by Thomas Mills. ${ }^{36}$

About 600 yds. east of the end of Gregories Lane is a rectangular moat which probably represents the site of the medieval manor house of Gregories. A field beyond the end of the lane was known in 1848 as 'Gregory's Garden'.37 The present farm of Great Gregories was in existence in 1848 but the farm-house appears to have been rebuilt early in the 20 th century.

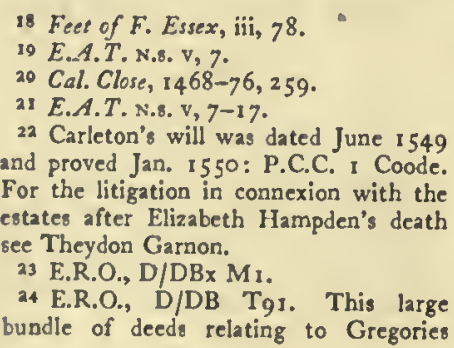

covers the period $1638-1735$. These deeds, and the single deed D/DB T86, have been abstracted in E.R.O., D/DWv $T_{5}$ I. Unless otherwise stated the following descent is derived from $\mathrm{D} / \mathrm{DB} \mathrm{T}_{9} \mathrm{I}$.

23 Archd. Essex 139 Whitehead.

26 E.R.O., D/DB T86.

27 Arch. Essex Act Bk. 51

28 E.R.O., D/DWv T 5 I.

29 P.C.C. IO7 Bunce.

$30 \mathrm{CP}_{2}(2) / 9^{2} 3$ East. 8 Anne; P.C.C. 184 Browning.
31 See Charities, below.

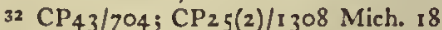

Geo. III. Evidently they acquired it by marriage: Complete Peerage, v, 2478.

33 E. Ogborne, Hist. Essex, 260

34 V.C.H. Herts. iii, $35^{8}$; Ogborne, Hist. Essex, 260.

35 E.R.O., D/DTc T7

36 E.R.O., D/CT 349

37 Ibid. 
A farm in Gregories Lane was known in the Igth century as Little Gregories. ${ }^{38}$

There was a church at Theydon Bois in the 12 th century and perhaps earlier.39 The CHURCH advowson was originally held by the lord of the capital manor. William de Bosco granted the church to the priory of St. Bartholomew, Smithfield. This was confirmed by Henry II in I $187^{40}$ and in 1248 Hugh de Bosco quitclaimed the advowson to the prior.41 The priory retained the advowson until its dissolution in 1539 . It presented rectors until 1335 when the rectory was appropriated to the priory.42 No vicarage was instituted and the church was thenceforth a curacy or donative. In I 540 the rectory and advowson were granted by the Crown for life to Robert Fuller, who had been the last Abbot of Waltham, and who was also granted the manor of Theydon Bois. 43 He died in the same year44 and the rectory and advowson reverted to the Crown, which granted them in I 544 to Edward Elrington, the last lessee of the rectory under the priory. $45 \mathrm{He}$ died in $1559.46 \mathrm{His}$ son and heir Edward Elrington died in 1578 and was succeeded by a son of the same name.47 It was the third Edward Elrington who in 1616 acquired the manor of Theydon Bois, and the manor, rectory, and advowson subsequently descended together.

The rectory of Theydon Bois was valued in about I 254 at $£ 4$ I 3 s. $4 d ., 48$ at $£ .5$ in 1257,49 and 2 t $£ 4$ I 3 s. $4 d$. again in 1291.50 Before 1306 it was customary for the priory to reccive 2 marks a year from the glebe lands, but a rental of that year stated that those lands had long been uncultivated and it was therefore agreed between the priory and the then rector that only I mark should be paid until the land had been brought into cultivation. This rent was received by the cellarer of the priory. In the same document the church was said to be taxed at $£_{5} 6 \mathrm{~s} .8 d$. and to be worth $\oint_{0} 10.51$ In 1526 the priory leased the rectory to Juliana Fenrother at an annual rent of $£_{4}$, and in the following year she was granted leave to cut down and retain all wood on the property, except great trees, and provided that she did not damage the young springs, for the payment of $£_{2}$. As security against damage she had to deposit $£ 4 . .^{52}$ She died in 1536 , leaving the lease of the rectory to Edward Elderton alios Elrington, grandson of her late husband. 53 In 1538 it was leased to Elrington by the priory, still at an annual rent of $64 .{ }^{54}$

The tithes of Theydon Bois were commuted in 1850 for $6_{4} 63$ I $9 s_{\text {., }}$ of which $f_{1} 93$ I 5 s. was payable to the owners of Theydon Bois manor (the Hall Dares), fro3 I 5 s. to Henry Elwes, owner of Theydon Hall, and I $_{1} 66$ gs. to the curate. 55 The tithes payable to Elwes were those arising from his own estate. At the time of the commutation the curate had glebe amounting to 8 acres.

The curate's income was very small. In 1604 it was estimated at only $\sum_{1} 36$ s. $8 d .56$ In 1650 the cure was

38 O.S. 6 in. Map (1st edn.), sheet lviii.

30 See below.

40 E. A. Webb, Recs. of St. Bartholomew's

Priory, i, 481 .

41 Feet of F. Essex, i, 172.

42 E.R. liv, 35; Newcourt, Repert. ii, 582 ; Cal. Pat. $1334-8$, I 73.

43 L. \& P. Hen. VIII, xvi, pp. 715-1 6.

44 Webb, Recs. of St. Bartholomew's

Priory, i, 259.

43 L. \& P.Hen.VIII, xix (1), p. 278

$46 \mathrm{Cr}_{42} / 1 \mathrm{I} 8 / 52$.

$47 \mathrm{CI}_{42} / \mathrm{s} 80 / 47$

48 Lunt, $V$ al. of Norwich, 336 .

said to be destitute, there being not more than $£ 20$ a year assigned for a minister, so that 'no godly able minister will accept of it'. ${ }^{57}$ 'The tithe commutation figures show, however, that by 1848 there had been an endowment of the curacy with some tithes and a small amount of glebe. 58 The living was also augmented out of Queen Anne's Bounty and in 1870 the incumbent, the Revd. George Hambleton, set out to raise f 300 by private subscription to increase the stipend and so qualify for further assistance.59 Under the Incumbents Act (1 868 ) the curacy became a titular vicarage. 60

It seems from Chapman and Andrés map of 1777 that the present Parsonage Farm was then the residence of the curate. ${ }^{6 I}$ In estate maps of 1799 and about I 800 , however, it was called Theydon Manor Farm and was occupied by a tenant of John $H$. Dare.62 It is a timber-framed house probably dating from the I $5^{\text {th }}$ century. In its original form it was a wellrecognized type of late medieval 'hall' house of which Bridge Farm, Theydon Garnon (q.v.), is another example. In 1920 its medieval origin was confirmed by the architect in charge of restoration work, who reported the existence of an open hearth on the floor of the hall.63 This hall, in the centre of the main block, was originally open to the roof while the side wings were of two stories. All three sections were combined under a single roof, gabled at the ends. At the front of the house the side wings oversailed at first-floor level but the wall of the hall was vertical. Large curved braces, one of which can still be seen, helped to support the deeply overhanging eaves of the central section and originally stood clear of the wall. In the I6th or early I 7 th century the hall was divided into two stories and the upper part of the front wall was built out to incorporate the curved braces. A slight break in the moulded bressummers which cover the joist ends makes it clear that the central overhanging section is 2 later insertion. The large brick chimney would be contemporary with the division of the hall, but the two bay windows at the front of the house are modern. One of the projecting wings at the back was open to the roof within living memory and may have formed part of the medieval house. There have been further additions to the house in recent times and the timber-framing has been exposed both inside and out. Internally there is a doorway with moulded jambs and a four-centred head and a window with square mullions set diagonally. Parts of the entrance door also appear to be ancient.

In 1832 the Dares as lord and lady of Theydon Bois manor and patrons successfully applied to the Treasury for 5 acres of the manorial waste in the forest as the site of a house, with glebe, for the incumbent of Theydon Bois.64 Failure to build within the stipulated period of one year vacated the grant, but a fresh grant was made in 1838 to trustees on the application of Elizabeth Dare, now a widow. ${ }^{65}$ The house was duly

49 Cal. Papal Letters, i, 347.

so Tax. Eccl. (Rec. Com.), 2 ib. 3 Webb, Recs. of St. Bartholomew's Priory, i, 382, 440 .

32 Ibid. i, 333. Her husband Robert Fenrother had died in 1524 leaving her lands in Theydon Bois: P.C.C. Ig Bodfelde. $\quad 33$ P.C.C. 37 Hogen. 34 Webb, Recs. of St. Bartholomew's Priory, i, 333, 384 .

35 E.R.O., D/CT 349. For these owners see above, Manors.

56 H. Smith, Eccl. Hist. Essex, 17.

37 V.C.H. Essex, ii, 64 ; H. Smith, Ece.
Hist. Essex, 273.

58 The endowment was much better than that of the curacy of Norton Mande ville (q.v.) at the same period.

30 E.R.O., D/DBx F I.

603 I \& 32 Vict. c. 117.

6I Chapman and André, Map of Essex, 1777 , sheet xvi.

62 E.R.O., D/DBx Pr, 2.

63 E.R.O., Sale Cat. A. 82 I.

64 The application was made under the Crown Lands Act, ro Geo. IV, c. 50 (1829).

65 E.R.O., D/DBx T2. 


\section{A HISTORY OF ESSEX}

built in 1839 at the south end of Piercing Hill opposite the entrance to the churchyard. It is a square house of gault brick with the date inscribed on a stone near the front door.

John Strype (1643-1737), ecclesiastical historian and biographer, was curate of Theydon Bois in I $669-70.66$

In 1349 St. Bartholomew's Priory acquired from Edmund de Grymesby, king's clerk, 30 acres of land and 3 acres of wood in Theydon Bois, with certain lands in Middlesex, to find a chaplain to celebrate in the conventual church every year on Edmund's anniversary for his soul, and to feed five poor persons on the same day for ever. ${ }^{67}$ The lands in Theydon were held of Waltham Abbey and were worth only $2 \frac{1}{2} d$. an acre because they were sterile and rocky. The woodland was worth only $3 d$. an acre because it was devastated. ${ }^{68}$ In 1359 the priory further acquired from Master Richard de Shamelesford a messuage, a toft, and 91 acres of land, a lane called Pakeswey, and 25.6 d. rent in Theydon Bois and Theydon Garnon, in satisfaction of $£ 6$ out of $£ 20$ a year of land and rent which it had royal licence to acquire. ${ }^{69}$ These lands, lying partly within the forest, were worth only $27 \mathrm{~s}$. a year.70

The old parish church of $S T$. MARY, which may earlier have been dedicated to $S T$. BOTOLPH,71 stood next to Theydon Hall, about mile north of Abridge Bridge. An engraving of $18 \mathrm{I} 4$ shows a view of the church from the south. ${ }^{72}$ It was a small building with nave, chancel, south porch, and wooden bellturret at the west end of the nave. In the chancel was a single-light window and door. In the nave were two single-light windows and two blocked openings. The building may well have been of the 12th century, though the drawing is too crude to prove it.73 In about 1770 there was said to be neither monument nor inscription in the church, 74 and in 1819 'neither monument nor inscription of note', 75 but two monuments from the old church are in fact preserved in the present building.

In 1843 the parish vestry resolved to build a new church in a more central situation, and a faculty was accordingly obtained. The old church was pulled down, the materials being sold for $£ 78$ and the barrel organ for $£ 20.76$ The site is now marked only by a few tombstones overgrown with grass and young trees.

The new church was erected at Theydon Green at a total cost of $\{2,231$. Among the subscribers was Queen Adelaide, who gave $£ 20.77$ The curate, George Hambleton, published a poem of 418 lines 'to seek agreeably to delineate to those who have kindly helped forward the cause of Theydon Bois new church, the extreme desirableness of this erection'. A further $£, 20$ then (1843) remained to be raised. To the poem was prefixed a view and plan of the new building, by Abbott and Habersham, architects, St. Neots. 'The church consisted of chancel, nave and west tower.
The accommodation was for 360 and the value of the contract $\oint_{1}, 45^{8.78}$ The church was consecrated in I 844 , but owing to faulty construction it had to be taken down in 1850 and the present church was then built in its place.

The present church of St. Mary, the third to bear this dedication and the second on the present site, was designed by Sydney Smirke and consecrated in 1851.79 The cost was about $£ 2,000$; the curate paid half this amount and the other half was provided by the architects of the previous church. ${ }^{80}$ The church consists of a nave, chancel, north vestry, and large western tower with spire. The belfry stage of the tower and the tall spire are octagonal. The building is of red brick with stone dressings. Internal repairs were carried out in 1887,1901 , and 1906. The spire was covered with copper in 1920.81

There are three bells, two of which came from the medieval church. The first was recast in 1843 by Thomas Mears. The second was cast about 1460 by John Danyell and is inscribed Sancta Margareta Ore Pro Nobis. The third, dated 1567 , was probably by Robert Dodds. There were three bells in the church in 1552 . The bell frame is dated 1727.82 Owing to its condition the bells have not been rung for about 100 years, but are only chimed. ${ }^{83}$

No plate survives from the earliest church. The oldest existing piece is a paten of 1804 , given in 1844 by Sir Edward Bowyer-Smijth. 84

The pulpit, which is of walnut, was given in 1900 as a memorial to the Revd. C. E. Campbell, formerly vicar. It was designed by Paul Waterhouse. ${ }^{85}$ New oak benches for the choir and other furnishings have been installed within the past five years.

The royal coat-of-arms of James I hangs over the west door. ${ }^{86}$ There are six other hatchments, four of the Wild family of Theydon Hall and two of the Dares. There is also a monument to the Dare family, dated $18 \mathrm{ro}$, and below the chancel is their vault, containing thirteen coffins, at least seven of which must have been brought from the medieval church. ${ }^{87}$ On the south side of the nave is a wall monument to Samuel Wild ( $18 \mathrm{r} 7$ ) and his wife Elizabeth (1844). Below this a marble tablet and a painted inscription set out Elizabeth Wild's charitable bequests. Among the later monuments is one to George Hambleton (1874), vicar for 34 years. The stained glass in the east window was also given in his memory. Another stained window is a recent memorial to the Buxton family, patrons of the vicarage, and there is also one to Frances Mary Buss, who is buried in the churchyard.

For several years about I 885 occasional services and Sunday schools were held in a mission hut at Ivy Chimneys. In 1895 a second-hand 'iron room' was bought for $£ 84$ and erected on a site in Theydon Road at the branch road to Great Gregories and opposite Delaford Cottage. The total cost with fittings was
66 D.N.B.

67 Cal. Pat. I $348-50,270$

$68 \mathrm{C}_{143 / 294 / 6 .}$

60 Cal. Pat. I $358-6$ I, 185 ; cf. ibid. $334-8,542$.

70 Webb, Recs. of St. Bartholomew's

Priory, i, 333.

71 P.N. Essex (E.P.N.S.), 82-83

72 E. Ogborne, Hist. Essex, 257.

73 If the earlier dedication to St. Botolph

is accepted there may have been a Saxon

church on the same site.

74 Hist. Essex by Gert. iii, $4 \mathrm{II}$.
75 Excursions in Essex, ii, 48 .

76 St. Mary's, Theydon Bois (pamphlet on sale in church); Theydon Bois Official Guide (and edn.), 10.

77 St. Mary's, Theydon Bois.

78 G. Hambleton, Picture of Theydon Bois (1843).

${ }_{79}$ St. Mary's, Theydon Bois; Pevsner, Buildings of England, Essex, 351. Smirke had designed St. John's Church, Loughton (q.v.), a few years earlier. 80 Ibid.
81 Kelly's Dir. Essex (I 937). For a recent photograph of the church see plate facing p. 270 .

${ }_{82}$ Ch. Bells Essex, 4 ro-1 I.

83 St. Mary's, Theydon Bois.

84 Ibid.; Ch. Plate Essex, 104.

8 K Kelly's Dir. Essex (1937).

86 St. Mary's, Theydon Bois, meations other James I royal arms, which are rare, at Blisland in Cornwall, Winsford in Somerset, and Marham in Norfolk.

87 Inf. from Mr. A. E. B. Williams. 
about $f_{0} 6_{5}$. A bell and turret and two rooms at the rear were added later. ${ }^{88}$ In 1913 the iron room was moved to a new site on the south side of Ivy Chimneys Road about roo yds. east of the junction with Theydon Road. At present (1954) there is a flourishing Sunday school here, and evensong is held every Sunday. The building is not consecrated. ${ }^{89}$

Roman Catholic services have been held at Theydon Bois since 1927. They ROMAN CATHOLICISM are at present conducted priest from Epping. 90 in the village hall by the

In 1834 the house of James Cavill at Theydon Bois

\section{PROTESTANT} was licensed for the worship NONCONFORMITY of Protestant dissenters.91

\section{founded here about I 885.92} In 1900 it had 20 members and 60 Sunday school children. 93 The membership rose steadily to 85 in I $95 \mathrm{I}$, when there were $\mathrm{r} 35$ children in the Sunday school; the church then had a resident minister. 94 The present building, of brown brick with round-headed windows, stands on the south-west side of Theydon Green. It is dated $1894^{95}$ and seems to have been altered and restored later.

No local records are known to survive of the parish government and poor relief in POOR RELIEF Theydon Bois before 1832.96 Returns made to parliamentary inquiries provide details of the cost of poor relief for some years in the late 18 th and early roth centuries. In 1776 the parish spent $\oint_{0} 100$ on relief. 97 In the three years $1783_{3}-5$ the average sum was $\oint_{0} 166.98$ In I 80 I it had risen to $\oint_{0} 34.99$ Between that date and 1820 it fluctuated considerably, the highest figure being 6.592 (in 1820 ) and the lowest $6_{0} 283$ (1803). ${ }^{3}$ For the years $1803-9$ it never exceeded $£ 350$. After 1809 it was never under 6400 except in I 8 I 5 when it was 6360. A parish poor house existed in about $1800 .^{2}$ In 1836 Theydon Bois became part of the Epping Poor Law Union.

Despite a rapidly increasing population there was little educational provision in Theydon SCHOOLS Bois in the early I gth century, possibly because of the absence of a resident clergyman or landlord and the poverty of the inhabitants. ${ }^{3}$ In 1807 and 1818 there was no school in the parish.4 In 1822 a small school was set up in union with the National Society, but in 1828 it had only 8 pupils and in 1833 only 12 , all of whom paid fees. 5 This was probably the school which in 1839 had 14 pupils and was administered in connexion with a Sunday school. Conditions were by then more favourable to the establishment of a proper school. Both the
Sunday school and a dame school in the village were well attended, an adult school existed and it was thought that there would be local support for a new school. ${ }^{6}$ In 1840 the curate organized the building of a schoolroom for 60 children on a freehold site given by the patron of the curacy, Mrs. Dare. The National Society gave $f_{0} 30$ towards the building, the government $\ell_{3} 32$, and Mrs. Dare apparently $\ell_{0} 100$. The total cost was $£_{0} 300$ and the deficit was met by other local subscribers. The school was affiliated to the National Society. The trustees were to be the curate and churchwardens. They and 12 parish representatives were to act as managers. It was proposed that the school should be financed partly by annual subscriptions and partly by fees of $2 d$. a week for each child. 7

The school seems to have made progress from the start. In I 846-7 it had 40 children under a mistress and 2 monitors who between them were paid $f_{3} 35 \mathrm{a}$ year. 8 In $\mathrm{I} 85 \mathrm{I}-2$ an inspector found the schoolroom attractive and the children neatly dressed. The mistress, he reported, was untrained, but seemed 'well adapted by character for such a school, where no great amount of intellect is required and where the attainments are necessarily confined'. 'Arithmetic', he added, 'moderate. Geography etc., mere names.'9 Attendance probably increased at this time and in 1860 the building was enlarged at considerable cost, the government granting fioo and local subscribers making large donations. ${ }^{10}$ In 187 I there was estimated to be accommodation for I 2 children, not quite sufficient to ensure universal elementary education in the parish. II The population continued to grow and in 1894 the school was enlarged to provide places for 127.12 In I 898 the average attendance was given as 87.13 In 1900 it was 109 , and in I 903 the school was again enlarged to provide I 88 places. ${ }^{14}$ Local subscribers contributed generously to the school: in 190066 were giving $2 s .6 d$. a year or more. ${ }^{\text {Is }}$ The government grant was $£_{45}$ in 1893 and E. 17 in 1902.16

By the Education Act of 1902 the school passed under the administration of the Essex Education Committee, Epping District, as a non-provided school. In 1906 the average attendance was I 50.17 In 1912 the school was transferred to the Essex Education Committee and became a provided council school. In r 929 the average attendance was 144 . In 1932 the school was reorganized for mixed juniors and infants. In I948, owing to increased attendance, temporary accommodation was hired at the local telephone exchange. ${ }^{18}$ In May 1952 there were 6 teachers and 206 children. ${ }^{19}$ The original school is a one-story building of brown brick with a slate roof, bearing the inscription 'Theydon Bois School 1840'. It stands

88 A. A. West, MS. Hist Theydon Bois (per Mr. A. E. B. Williams).

80 Inf. from Mr. A. E. B. Williams.

90 Brentwood (R.C.) Dioc. Year Bk. 1953. 11 E.R.O., Q/RRw I. files.

93 Baptist Handbk. 1900.

94 Ibid. 1901 f., 1940, 1951.

is Cf. E.R. iii, I5\%.

96 Vestry Min. Bks. survive for $1832-$ 99: inf. from Mr. A. E. B. Williams, churchwarden. These are not noted in Essex Par. Recs.

97 E.R.O., Q/CR I/1. 98 Ibid.

99 Figures for $1801-16$ are from E.R.O., Q/CR $1 / 9$.

ES. IV

I Figs. for $1817-20$ are from E.R.O., Q/CR 1/12. 2 E.R.O., D/DBx $\mathrm{P}_{2}$. E.R.O., D/P 30/28/19; inf. from Nat. Soc.

4 E.R.O., D/AEM 2/4; Retns. Educ.

Poor, H.C. 224 , p. 273 (1819), ix (I).

3 Nat. Soc. Rep. 1828, p. 83 ; Educ.

Enquiry Abstr. H.C. 62, p. 291 (1 835), xli.

E.R.O., D/P $30 / 28 / 19$; inf. from Nat. Soc.

7 Nat. Soc. Enquiry into Ch. Schs. 1846-7, pp. 18-19; Min. of Educ. File $13 / 365$; Mins. of Educ. Cttee. of Courcil, 1857 [2380], p. 96, H.C. $\left(1857^{-8}\right)$, xlv; inf. from Nat. Soc.

8 Nat. Soc. Enquiry into Ch. Sehs. 1 846-7, pp. 1 8-i 9 .
- Mins. of Educ. Cttee. of Council, $185 \mathrm{I}$ [1480], p. 286, H.C. $(1852\}$, xli. 10 Rep. of Educ. Ctice. of Council, 1863 [3349], p. 439, H.C. (1864), xlv.

II Min. of Educ. File $13 / 365$.

12 Schs. under $B d$. of Educ. 1902 [Cd. 1490], p. 74, H.C. (1903), li.

13 Kelly's Dir. Essex $(18 \mathrm{~g} 8)$

14 Min. of Educ. File $13 / 365 ;$ Educ.

Citee. Handbk. 1904, p. I 51 .

is Min. of Educ. File $13 / 365$.

16 Retns. of Schs. 1803 [C. 7529 ], p. 716

H.C. (1 894$)$, lxv; Schs. under. Bd. of

Educ. 1902.

17 Kelly's Dir. Essex (1906).

$18 \mathrm{Min}$ of Educ. File I $3 / 365$

I0 Inf. from Essex Educ. Cttee. 


\section{A HISTORY OF ESSEX}

beside the parish church. There are later additions, including a large classroom dated 1903.

An unknown donor before 1786 gave a rent-charge for the benefit of eight old poor people CHIRITIES ${ }^{20}$ of the parish not receiving poor relief. In 1834 the land charged was Theydon Hall and the money was distributed at Christmas in shares of $25.6 \mathrm{~d}$. each to poor people, most of whom were in fact receiving parish relief.

The Poor's Land comprised two small pieces of pasture in Theydon Mead. The rent of 30 s. a year was said in 1835 to have been paid until 1833 into the poor rate, and after that into a fund made up of voluntary contributions, which was used to buy bread and clothes for the poor. The land was sold in I $92 \mathrm{I}$ for $64^{\circ}$ which was invested in stock.

The almshouses were established under a deed of I 753 by which Benjamin Smart, then lord of the manor, gave a small piece of land in trust for the building of cottages for poor old people receiving parish relief.' Some cottages seem to have been built soon after. There was no mention of the almshouses in the I 835 Report. In 1905 they were four in number, in one block, each consisting of two rooms; they had been renovated two years earlier by the lord of the manor. Their use was limited by lack of endowment and though' stipends were paid to the inmates from 1907 out of Elizabeth Wild's Charity (see below), by I 95 I only two of the cottages were occupied and all were in very bad repair. In I 953 part of the site was sold for $\$_{5} 80$ and the almshouses were repaired and converted in to two cottages. By a scheme of that date all the existing parish charities are managed together under the name of the United Charities and all their incomes, which had been unspent for several years, are applicable to the upkeep of the almshouses, after the payments for Elizabeth Wild's tomb and memorial tablet. The almshouses are on the north side of Coppice Row opposite Birch Hall. They consist of a single-story range, rough-cast with a tiled roof. The mullioned windows have four-centred heads to the lights. There are three gabled porches to the front, the large central porch containing two doorways.

Elizabeth Wild, by will proved I 844 , left $\oint_{1}, 000$ to be invested for the maintenance of her vault and a tablet reciting the terms of her bequest, and subject thereto for the payment of $\oint_{0} \mathrm{I} O$ each Christmas to poor parishioners chosen by the trustees. The surplus was to be given to four poor widows resident in the parish for 20 years before, or if there were none, to the poor in general. By a Scheme of 1907 the income after the expenses of the vault and tablet was to be used in the payment of stipends to the almspeople. In I $95^{\circ}$ the payment of stipends was stopped; part of the income of 624 I 4 s. $4 d$. was spent on repairs to the almshouses.

Louisa Elizabeth Young, by will proved I 89 I, left 6489 I 6 s. stock of which half was to go to the National School and half to support a clothing club, and if this was discontinued, for the benefit of the poor of the parish in general. In fact the stock received by each beneficiary was only II $_{6} 9 \mathrm{ss} .9 \mathrm{~d}$. The clothing club was still in existence in 1905 . In 1950 the income was 645 s.

Frances Mary Buss, by deed of 1897 , gave $\oint_{1} 100$ in trust for the benefit of poor members of the Church of England or for purposes connected with it. There was a gift over to the Memorial Scholarship Fund on failure to keep her grave in repair. In I 950 the income was £2 I 6s. rod.

John Hyett, by will proved I 7 I 9 , left $£, 5$ a year for the apprenticing of poor boys, preferably resident in the manor of Gregories (see above, Manors). The sum was charged on the manor and was apparently paid in 1721.21 In about 1814 it had not been received for some years 22 and there is no later record of it.

The Theydon Bois Nursing Association was left with a balance of 6500 when it was wound up in I949.

\section{THEYDON GARNON}

Theydon Garnon adjoins Epping to the east. ${ }^{1}$ The ancient parish boundary was a little to the east of Epping High Street, so that Theydon Garnon formerly included much of the town. ${ }^{2}$ In I 840 the area of the parish was 3,16I acres. 3 In 1896 the part of Theydon Garnon lying within the Epping Special Drainage Area was included in the newly formed Epping Urban District. 4 'The area affected comprised about 770 acres in the north-west of the parish, containing about threequarters of the population. This reduced Theydon Garnon to a completely rural parish. There were further transfers of small areas from Theydon Garnon to Epping Urban District in $1934^{5}$ and to Epping Upland in 1946.6 In 1948 it was proposed by the county council that Theydon Garnon should be abolished as a civil parish by adding the part north of the railway to North Weald and incorporating the rest in Theydon Bois.? The main proposal was not ap- proved by the Minister of Health. Theydon Garnon remained a parish and there were only minor boundary changes: the part of this parish north of the railway was transferred to North Weald (q.v.) and the parts of North Weald and Epping Upland to the south of the railway were added to Theydon Garnon. ${ }^{8}$ In 1953 the area of Theydon Garnon was 2,342 acres.?

Most of the sections of this article relate to the whole ancient parish. The architectural descriptions, however, of those parts of the ancient parish which lie in Epping town and its suburbs to the east of the railway, and the history of nonconformist churches and of any industry in the Epping town portion of the ancient parish are reserved for treatment under Epping.

Theydon Garnon, the largest of the three Theydons, takes its distinctive name from the family of Gernon which held the capital manor from the I 3 th century. ${ }^{10}$ From at least the late 16 th century, and especially in

\footnotetext{
20 Rep. Com. Char. (Essex), H.C. 216 , pp. $246-7$ (1835), xxi (t); Char. Com. files.

11 E. Ogbome, Hist. Essex, 260.

22 Ibid.

O.S. $21 \mathrm{in.} \mathrm{Map,} \mathrm{sheet} 51 / 49,52 / 40$

2 O.S. 6 in. Map (rst edn.), sheets ! Iviii.

3 E.R.O., D/CT 350.
}

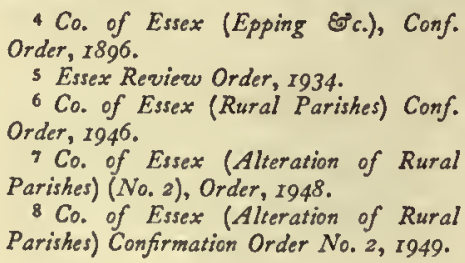

- Inf. from Essex Co. Council.

to See below, Manors; P.N. Essex (E.P.N.S.), 83. Dr. Reaney errs in identifying Theydon Garnon with Theydon Paulyn; the latter was in fact identical with Theydon Mount (q.v.). For a note on the meaning of Theydon see under Theydon Bois. 
the I 8 th and early I 1 th centuries, the parish was known also as Coopersale, ${ }^{11}$ but this name was subsequently restricted to that northern part of the ancient parish served by the district church of St. Alban, Coopersale, consecrated in 1852.12

The southern boundary of Theydon Garnon is the River Roding. A stream which rises in the centre of the parish flows south to join the river near the eastern boundary. The ground rises from about $100 \mathrm{ft}$. above sea-level by the river to $350 \mathrm{ft}$. in the north of the parish. The extreme north-east is well wooded and includes Gernon Bushes, about 100 acres of ancient forest waste. The road from Passingford Bridge to Theydon Bois passes through the southern tip of the parish about $\frac{1}{2}$ mile north of the Roding. From this a road runs north and west through Hobbs Cross, and over the stream at Mason's Bridge to Fiddlers Hamlet, Coopersale Street, and Epping. From Hobbs Cross a lane goes north-east to Toot Hill in Stanford Rivers. From Fiddlers Hamlet roads run east to Theydon Mount and west to Steward's Green and Ivy Chimneys. From Coopersale Street a road runs north to Coopersale Common. Fiddlers Hamlet, which takes its name from the Merry Fiddlers Inn, has been a centre of population at least since the 17 th century. Coopersale Street has been a considerable hamlet since the I 8 th century or earlier. The village of Coopersale Common has developed mainly during the past century. The Epping-Ongar railway runs through the west and north of the ancient parish.

Garnish Hall, which stands on the site of the ancient manor house, is I mile south-west of Fiddlers Hamlet. Near it to the south are the parish church and the former rectory, now called Theydon Priory. Gaynes Park, a I gth-century mansion $\frac{1}{2}$ mile east of Coopersale Street, stands in a wooded park near the site of the ancient manor house of Gaynes Park Hall. The third old manor house of the parish was Hemnalls. The site of this is not precisely known. It was in the north-west of Theydon Garnon, probably in the neighbourhood of the modern Hemnall Street, Epping. Coopersale House, formerly the centre of an estate owned by the Archer-Houblon family, lies to the west of the road between Coopersale Street and Coopersale Common. The parish school is on the road north of Fiddlers Hamlet. At Hobbs Cross are the former Fitzwilliam almshouses. ${ }^{13}$

In the Middle Ages, before the development of Epping town, Theydon Garnon was an ordinary rural parish, probably consisting of scattered farms and cottages. In addition to the three manor houses ${ }^{14}$ there are known to have been medieval houses at Masons (now Bridge Farm), Is Gardners, Little Thornhall, Hydes, Stonards, and Peak's Farm. ${ }^{16}$ Bridge Farm stands south-east of Mason's Bridge. It is a late medieval timber house of a type which was formerly thought to be peculiar to Kent and Sussex but which has in fact a much wider distribution. In its original form it had an open hall in the centre, flanked by cross-wings of two stories. Instead of having the usual gabled fronts these wings are combined with the hall under a single roof, the line of the eaves being continuous along the front of the house. The side wings oversail at first floor level, but the central portion, having no upper floor, is in the same plane from ground to eaves. The wallplate at eaves level is carried across in front of this recessed portion and in an unaltered example there would be two large curved braces springing from the angle-posts of the side wings to support the plate. ${ }^{17}$ At Bridge Farm the hall was subsequently divided into two stories and at the front the upper floor now oversails almost in line with the floors of the side wings. Probably at the same time a chimney was inserted in the north bay of the hall. That these features are later alterations is clear from the survival of the original roof timbers, including the main open truss with its arched braces, king-post, and four-way struts. These timbers are all blackened with smoke from an open hearth on the floor of the hall. A small section of the original front wall of the upper part of the hall still exists, together with the coved plaster of the former eaves.

The 16th- or early 17th-century fireplace in the central ground-floor room has a long oak lintel, forming a four-centred arch. One spandrel is carved with a shield and foliage; on the other side the carving has been cut away. At the south-east corner of the house is a slightly lower projecting wing, also probably of medieval origin. There is some evidence that here also the upper floor was inserted at a later date.

Gardners, $\frac{3}{4}$ mile south-west of Fiddlers Hamlet, is a timber-framed house, part of which may date from the I $5^{\text {th }}$ century. The remains of a king-post roof-truss were recorded here in $1920 .{ }^{18}$ The main roof is probably of the I6th century and has curved wind-braces and queen-post trusses. On the ground floor an original window, now blocked, has moulded mullions. There is an altered 17 th-century staircase with heavy turned balusters and some I 6 th-century panelling.

Hydes probably dates in its present form from the 16th century. External weather-boarding has recently been removed and much of the original timbering exposed. The front has two gables and a central gabled porch of two stories. The house is $\frac{1}{2}$ mile south of the parish church.

Stonard's is a timber-framed house probably dating from the I 7 th or early i 8 th century, though on the site of a medieval house. One end of it has been refaced in red brick. It is near the railway $\frac{1}{2}$ mile west of Coopersale Street; the road formerly passed the farm, 19 but was evidently straightened when the railway bridge was built.

About 200 yds. south of the present Peak's Farm part of a rectangular moat survives. In 1838 there was a farm-house on this site, the property of the BowyerSmijths of Hill Hall in Theydon Mount (q.v.). ${ }^{20}$ Peak's Farm, a timber-framed house mostly dating from the I 8 th century, formerly had a gabled wing of the 16 th century or earlier. ${ }^{21}$ In 1930 this was demolished and the present red brick wing was built. ${ }^{22}$ The farm is in the extreme east of the parish, adjoining Hill Hall park.

By the middle of the 17 th century the construction of the new road to Newmarket via Loughton and
11 P.N. Essex, 23.

12 See below, Church.

13 See below, Charities.

14 See below, Manors.

Is E.R. $\times \times \times \mathrm{v}, 198$; Chapman and André, Map of Essex, 1777 , sheet xvi.

16 P.N. Essex, 23, 84-85 gives references to medieval tenants.
$37 \mathrm{Cf}$ house at Little Waltham: Hist. Mon. Com. Essex, ii, plate p. 96, and Monks Barn, Newport, ibid. i, p. 204. See also Parsonage Farm, Theydon Bois. Bridge Farm differs from these examples in havin a hipped roof. Another unusual feature is the incorporation of the screens passage in the north wing instead of in the hall itself.

18 Hist. Mon. Com. Essex, ii, 233.

19 Chapman and André, Map of Essex, 1777 , sheet $x v i$

20 E.R.O., D/CT 350.

21 Hist. Mon. Com. Essex, ii, 233.

22 Inf. from present occupier. 


\section{A HISTORY OF ESSEX}

Epping ${ }^{23}$ was probably causing increased building development in the Epping town part of Theydon Garnon. As early as 1613 and 1631 parishioners presented in the archdeacon's court for not attending church replied that they attended service in Epping, since it was nearer. ${ }^{24}$ This is a good indication that the people on the western boundary of Theydon Garnon regarded themselves as belonging to Epping.25 By this time also there was a small hamlet at the cross-roads to the north of Mason's Bridge. The name Fiddlers Hamlet for this part of the parish is of much later origin, but it is possible that the 'Merry Fiddlers' was already the focus of settlement in the 17 th century. The inn itself probably incorporates part of a 17 thcentury building. Another building which is known to have been erected in the $17^{\text {th }}$ century is the block of almshouses at Hobbs Cross founded by Lady Fitzwilliam. Hill Farm, in the extreme south of the parish, is a timber-framed farm-house which may date from the 16th century or even earlier. It consists of a central block flanked by gabled cross-wings. In modern times timbering has been applied as a decorative feature. The dentilled barge-boards to the gables are original.

A large timber-framed house at Coopersale Street, formerly a farm, probably dates from the late I6th century. The front has two gables, the attic window on one side being original. A I 7 th-century addition to the south-west was once known as the brewhouse. The pedimented doorcase and the sash windows are I 8 th-century insertions. The annexe to the house is now the post-office.

Jacksons Farm, which formerly stood beside the Roding near Hill Farm, appears to have been on or near the site of the ancient Garnish Mill, and was known until about roo years ago as Gernon Mill Farm. ${ }^{26}$ It was demolished about 1950.27 In I 920 the building was described as two tenements, probably of the $17^{\text {th }}$ century, partly refaced with modern brick. A document temp. Henry VIII refers to a "costlewe byldyng at a ferme callyd Garnouns myll, new bylded'.28

Chapman and Andrés map of 1777 shows hamlets at Fiddlers and Coopersale Street and also a line of houses on the west side of the road to the north of Hobbs Cross. ${ }^{29}$ Development on the Epping side was continuing. Houses which probably date from the 18th century are the Home Farm and Elms at Fiddlers Hamlet, and Coopersale Lodge, about roo yds. southeast of the post-office at Coopersale Street. All are timber-framed houses. The Elms has a modern redbrick front.

In 180 I Theydon Garnon had a population of 517.30 There was a steady increase to 1,237 in 1851 . There was a slight decrease in $1851-61$ but this was subsequently arrested, probably by the extension of the railway from Loughton to Epping and Ongar in $1865 .{ }^{31}$ Epping station, on the new line, was built about $\frac{3}{4}$ mile north-west of Fiddlers Hamlet, within Theydon Garnon parish, and North Weald station I mile north-east of Coopersale Common. The population rose to I,37I in I 891 . This was the last census before the ancient parish was dismembered. Much of the I gth-century increase was due to the development of Epping town. At the I gor census the reduced parish of Theydon Garnon had only 317 inhabitants ${ }^{32}$ but there were 1,746 in the area of the ancient parish. ${ }^{33}$ It should also be noted, however, that the part transferred to Epping Urban District included Coopersale Common, Coopersale Street, and Fiddlers Hamlet. At Coopersale Common there had been considerable development during the second half of the I gth century. This included the district church of St. Alban, built to meet the needs of this end of the parish. Other larger buildings dating from the I 9 th century include Theydon Bower, Gaynes Park, and Hobbs Cross Farm. Theydon Bower, near Epping railway station, is a large house standing on a hill. It is thought to have been built about I $800^{34}$ but there have been later additions at varions times. It is of brown brick, partly ronghcast. The style is consciously romantic; there is a castellated parapet and mullioned windows. Hobbs Cross Farm was built in the middle of the century by Sir William Bowyer-Smijth of Hill Hall to replace one nearer to Hill Hall which he demolished.3s Coopersale Hall, which dates mainly from the I th century, may incorporate parts of an earlier building. In the 17 th and I 8 th centuries it was the home of the Chevely family. ${ }^{36}$ A bell-cote on the roof contains a bell dated 1816.37 The entrance front is of this period.

During the present century there has been much development at Coopersale Common, which appears to be something of a unit on its own, unlike the eastern parts of Epping that were also formerly in Theydon Garnon parish. St. Albans Road and Laburnam Road form a new layout north of the church and are entirely built up. Opposite the post-office are two pairs of council houses. The Coopersale Institute is a brick and roughcast building in St. Albans Road. On the east side of the main road there is a cricket ground.

This development within Epping Urban District is not paralleled by any increase of population in the present civil parish of Theydon Garnon. Since Igor the population of the parish has declined and in I95 I was only 176.38

The road from Hobbs Cross to Toot Hill was probably part of the Roman road running south from Dunmow. In I 594, and probably for many years before this, the main road from London to Newmarket ran through Theydon Bois and Theydon Garnon via Abridge Bridge. ${ }^{39}$ Early in the 17 th century a new road was built through Epping Forest between Loughton and Epping and this took the place of the longer Abridge section of the route. 40 After that date none of the roads in Theydon Garnon seems to have been of more than local importance. Among the parish books are constable's accounts 1719-1 868 with details of the constables' work in connexion with the parish
23 See Loughton.

24 E.R.O., D/AEA 27, f. 273 ; ibid. $3^{8}$, f. 199 .

2s Their legal obligation to pay Theydon Gamon parish rates was of course unaffected 1

26 O.S. I in. Map (1st edn. I 805) quoted in E.A.T. N.s. xvii, $172 ; 0 . S$ 6 in. Map (ist edn.), sheet lviii.

27 Inf. from Mr. Padfield, present owner.

28 E. A.T. N.s. v, 28.
29 Chapman and André, Map of Essex, 1777, sheet xvi.

30 For census figures I80I-190I see V.C.H. Essex, ii, 350.

31 The opening of the railway had a similar effect on the population of North Weald (q.v.)

${ }^{32}$ Kelly's Dir. Essex (1906).

33 V.C.H. Essex, ii, 350.

34 Inf. from Mrs. Bell, present occupier. It is said to have been built by Lord Frankfort.
33 Howard and Burke, Theydon Mount, p. $x$.

${ }_{36}$ E. R. xxxv, 198; Chapman and André, Map of Essex, I777, sheet xvi. It has been suggested that it was formerly known as Little Gregories.

37 Inf. from present occupier.

38 Census, $1911-51$.

30 Norden, Map of Essex, 1594.

40 For the new road see Loughton. 
roads, and surveyors' accounts $18 \mathrm{I} 0-36.41$ In $158 \mathrm{I}$ the surveyors reported on those defaulting in their road service.42 An interesting dispute over the number of days' work due from parishioners on the roads was heard in 1684. Andrew Partridge of Theydon Garnon declared that 36 years earlier he was hired to do two days' work in Waitham Lane, and he believed that two days was the rule for the parish.43

Theydon Bridge, alios Mason's Bridge, was described in 1641 as a cart bridge and the feoffees of Stonards were said to be responsible for its repair. 44 In about 1800 and 1835 it was listed as a county bridge. $4 \mathrm{~s}$ In 1858 , however, the county surveyor reported that after careful inquiries from local inhabitants he was unable to identify a bridge of this name, and he sug gested Coopersale Bridge (although that had been repaired by the parish) or Daws Bridge. 46 In I 866 the county surveyor had identified the bridge correctly but there was some doubt whether the parish was not responsible for its upkeep.47 In his report of r 866-7, however, Mason's Bridge was accepted by the county and by $\mathrm{I} 869$ it had been rebuilt. 48

A new brick bridge called Brook House Bridge was described by the county surveyor in 1858 . It had been built since 1836.49

For communications in general Theydon Garnon has relied mainly on Epping. In the I 8 th and early I 9 th centuries there were coach services running through Epping along the London-Norwich road. The extension of the railway to Epping and Ongar (1865) has been mentioned above. In 1949 this line was electrified as far as Epping. so

As late as 1894 there was no post-office in Theydon Garnon.si By I 898 one had been set up at Coopersale Street, though it had no telegraph or facilities for dealing with money orders.s2 There are now post-offices at both Coopersale Street and Coopersale Common.

The public services provided for Epping have in general been available for the urban part of the ancient parish of Theydon Garnon. By 1886 the town had piped water, supplied by the Herts. and Essez Waterworks Co., and main drainage.53 The water-supply was extended to the rural part of Theydon Garnon by the same company in 1898.54 The Epping Special Drainage Area, which in 1896 became Epping Urban District, included Coopersale Common, Coopersale Street, and Fiddlers Hamlet.ss There is now main drainage also in the present civil parish of Theydon Garnon.s6 Gas was first supplied in I 865 or I 866,57 and electricity by 1933.58 Electricity was extended to the rural parts of Theydon Garnon in 1950.59

Many of the landowners of the parish have been resident and have taken an active interest in its affairs. So far as can be judged the lords of Theydon Garnon manor were resident for much of the $13^{\text {th }}$ to $15^{\text {th }}$ centuries. The lords of Gaynes Park lived on their manor for part of the $14^{\text {th }}$ century and probably at other periods in the Middle Ages; in the 16 th century the Fitzwilliams were probably resident there. The Archers (later Archer-Houblons) of Coopersale were probably resident continuously from the I 6 th century to the I 9 th. Lady Fitzwilliam of Gaynes Park endowed the almshouses. Henry Archer of Coopersale founded another charity. Thomas Abdy, lord of the manor of Theydon Garnon, granted land for use as a potato ground for the poor and later substituted a voluntary free gift of bread. In general this parish is exceptionally well provided with charities endowed by the local landowners and resident gentry. ${ }^{60}$ In the I 9 th century Miss Archer-Houblon built the village school, St. Alban's church, and the vicarage at Coopersale.61

In the Middle Ages the capital manor of Theydon Garnon was probably much larger than any other estate in the parish. This was, however, divided in the I6th century and from the I 7 th century Gaynes Park and Coopersale both increased. In I 840 the Garnish Hall property consisted only of 228 acres, while Gaynes Park and Coopersale each contained over 700 acres. ${ }^{62}$ In the same year there were 19 farms in the parish containing more than 50 acres, 7 of over 100 acres and I over 200 acres. $^{63}$

In Theydon Garnon, as elsewhere in the hundred, inclosure took place at an early date, and details of the process are lacking. One exception was Gernon Bushes, Coopersale Common. Some inclosure of forest waste appears to have taken place there between 1777 and $I 838,64$ but a substantial part still remains. Mired farming is carried on in the rural part of the parish. In 1838 there were estimated to be some 770 acres of arable, I,740 acres of meadow or pasture, 264 acres of wood, and roo acres of common (most of which was in fact woodland). $6 \mathrm{~s}$

A small mound just north of the railway near Stonards Farm is marked on the map of $\mathrm{I} 777$ as Mill Hill. There was no mill there then, but a windmill is shown on the map about $\frac{1}{2}$ mile farther north. Garnish Mill, on the Roding, has already been mentioned above. It was no longer operating in 1777 . It may have been the mill on the manor of William son of Constantine in I086.66

In I 305 the king granted to Hugh Gernon a weekly market and an annual fair at his manor of Theydon Garnon. ${ }^{67}$ In 1872 a fair formerly held at Fiddlers Hamlet on 20 July was abolished at the petition of its owner, T. C. Chisenhale-Marsh. ${ }^{68}$

Robert Fabyan (d. I5I3), chronicler, acquired Halsteads in Theydon Garnon on his marriage.69 Sir Daniel Dun or Donne (d. I6I7), M.P. for Oxford I 604 and I6I 4 , an authority on marriage law, was lord of the manor of Theydon Garnon.70 Sir John Archer (I 598-I682), a justice of the Common Pleas, lived at Coopersale House.71 Thomas Dimsdale (1 $712-1800$ ), physician, who inoculated the Empress Catherine of Russia against smallpox, was born at Theydon Garnon.72.
41 E.R.O., D/P $152 / 10 / 1,152 / 21 / 1$.

42 E.R.O., Q/SR 78/28.

43 Ibid. $446 / 93$.

44 Ibid. $312 / 25$.

45 E.R.O., Q/ABz 2 ; ibid. Q/ABz 1.

46 E.R.O., $\mathrm{Q} / \mathrm{ABz} 3$.

47 E.R.O., Q/ABp 46.

48 E.R.O., Q/ABz 3 .

49 Ibid.

50 Inf. from London Transport.

s1 Kelly's Dir. Essex (1894).

52 Ibid. ( 1898 ).

53 Ibid. (I 886 ).
54 Inf. from Herts. \& Essex Waterworks Co.

53 See above.

36 Inf. from Rector of Theydon Garnon. 57 Inf. from Eastn. Gas Bd.

58 Kelly's Dir. Essex (1933).

so Inf. from Eastn. Elec, Bd.

60 See below, Charities.

61 See below, Chureh, School.

62 E.R.O., D/CT 350.63 Ibid.

64 Chapman and André, Map of Essex,

I777, sheet xvi; E.R.O., D/CT 350.

6s E.R.O., D/CT 350 .
66 Chapman and André, Map of Essex, I 777, sheet xvi; V.C.H. Essex, i, $5^{6} 3 a$. 67 Cal. Chart. R. $1300-26,62$.

68 Lond. Gaz. 9 July 1 872, p. 3106. 69 D.N.B.; E.H.R. iii, 3 r8-2 I. For his will, with many references to Theydon Gamon, see Nerw Chrons. of Eng. and France (ed. Ellis, 18 I 1 ), iii-xiii.

70 D.N.B. See below Manors, Church.

71 D.N.B.; E.R. xxxi, 160-73, 179-94. 72 D.N.B. He was perhaps the doctor mentioned below, Parish Govt. and Poor Relief, or a relative of that doctor. 


\section{A HISTORY OF ESSEX}

Thomas C. Chisenhale-Marsh ( 18 I I-75) of Gaynes Park published an edition and translation of the Essex portion of Domesday Book. For John Molyns (d. I591) see below, Church.

In I086 a manor of THEYDON, assessed at I hide and 40 acres, was held in demesne by Eudo

MANORS dopifer. Before the Conquest it had belonged to Ulmar.73 Another manor of Theydon, held in 1066 by Suen, was held in demesne in 1086 by William son of Constantine. This manor was assessed at 2 hides and 40 acres. ${ }^{74}$ It is probable that both these Domesday manors were in Theydon Garnon. It appears that they continued to have separate tenants in chief but that during the $\mathbf{I} 2$ th century they came to be held by a single tenant in demesne, whose manor later became known as that of THEYDON GARNON.

Eudo dapifer died in I 120 and his honor escheated to the Crown.75 Part of it, including Theydon Garnon, was granted by Henry II soon after his accession to his chamberlain Warin Fitz Gerold. He died in about II 59 and was succeeded by his brother Henry Fitz Gerold (d. I 174 or I I75). Henry's son and successor, Warin Fitz Gerold, held the honor until his death in 1216 . He was succeeded by his daughter Margery, who married Baldwin de Rivers. She died in 1252 , leaving as her heir her grandson Baldwin de Rivers, Ear] of Devon, who died without issue in 1262 and was succeeded by his sister Isabel, who married William de Forz. Isabel died in I293. One of her heirs was Warin de Lisle, great-grandson of Henry Fitz Gerold, brother of Warin Fitz Gerold (d. I 2 I 6). ${ }^{76}$ Warin succeeded to the part of Eudo's honor that had been held by Isabel and that included Theydon Garnon, and from this time the part of the manor of Theydon Garnon held in 1086 by Eudo was held by the tenants in demesne as of the honor of Lisle, which came to the Crown in 1368 and was later merged in the Duchy of Lancaster.77 In 1368 the tenant of Theydon Garnon had suit at the two courts of the honor, at Walbrook (London) and Arkesden (Essex), every three weeks. 78 In 182 I the Duchy still claimed the right to exclude county coroners from the parish, on the ground that it was parcel of the Duchy liberties.79

The descent of the tenancy in chief of the manor held in 1086 by William son of Constantine is not certain, but it is likely that it passed in the I 2 th century to the Munchensy family, who during the same period became tenants in chief of William son of Constantine's other manor of Southcote in Stone (Bucks.). ${ }^{80}$ In $125^{8}$ the tenant in demesne of the manor of Theydon Garnon was found to hold $\frac{1}{3}$ knight's fee of Denise de Munchensy, widow of Warin de Munchensy. ${ }^{81}$ This fee descended to her granddaughter Denise de Munchensy who died in I 3 I 3 leaving as her heir her cousin Aymer de Valence, Earl of Pembroke.82 He died in 1324 , holding 43 knights' fees in Theydon,
Leighs, and Latchingdon, for which he was owed service by William Gernon, and also $\frac{1}{2}$ fee held by 'the lady of 'Theydon'.83 In 1325 the escheator was directed to deliver this $\frac{1}{2}$ fee, valued at 6os. a year, and the 4 fees, valued at $\oint_{3} 30$, to Aymer's widow, Mary, in dower. ${ }^{84}$ Aymer's lands were divided among coheirs, one of whom was Lawrence, Lord de Hastinges (d. I 348), later Earl of Pembroke, and it is evident that the $\frac{1}{2}$ fee with the $4 \frac{3}{4}$ fees fell to John de Hastinges, Earl of Pembroke, who died seised of them in I 375.85 In $14354 \frac{1}{2}$ fees in Theydon Garnon, Leighs and Latchingdon and also the $\frac{1}{2}$ fee were held, presumably in dower, by Joan (who died in that year), widow of William de Beauchamp, Lord Bergavenny, ${ }^{86}$ who had been one of the heirs of John de Hastinges (d. 1389) Earl of Pembroke. ${ }^{87}$ These fees passed to Joan's grandson Edward Neville, Lord Bergavenny, who died in 1476.88

In I 166 Ralph son of Peter son of Constantine held 2 knights' fees of Henry Fitz Gerold as of the fees late of Eudo dapifer. 89 Ralph was probably but not certainly related to the Domesday tenant William son of Constantine. In r 200 Ralph son of Peter granted to Ralph Gernon for life a marsh in Theydon and other property, to hold for $8 \mathrm{s.} 4 \mathrm{~d}$. at a scutage of $20 \mathrm{s.90}$ In 1207 the king confirmed to Gernon the hundred of Lexden and the gift which Ralph son of Peter made to him of all his land in Theydon, in exchange for Ralph's land in Fowlmere (Cambs.) ${ }^{91}$ In 1220 Cecily, widow of Richard son of Ralph, released to Ralph Gernon all claim to the property in Theydon which she held in dower, as Gernon had granted her $\frac{1}{3}$ of all her husband's land in Fowlmere for her dower and also the custody of the other $\frac{2}{3}$ until her sons in Gernon's custody came of age. ${ }^{22}$ In 1224 the sheriff of Essex was directed to let Ralph Gernon have his scutage of 2 knights' fees of the fee late of Warin Fitz Gerold. ${ }^{93}$ In I 235-6 Gernon held of Margery de Rivers 2 knights' fees in Theydon and elsewhere. 94 He died in 1247 leaving his son William as heir. Part of the manor was said to be held for $\frac{1}{3}$ knight's fee of the heirs of Ongar (i.e. the Rivers family of Stanford Rivers and Chipping Ongar, q.v.). It is not clear how this tenure had become associated with Theydon Garnon. 95 In 12 I 2 Gernon had held 6 fees of the honor of Ongar. ${ }^{96}$ There is apparently no Jater evidence of a connexion between Theydon Garnon and the honor of Ongar than that of 1265 (see below) when the connexion appears to have been successfully denied by the tenant of Theydon Garnon. Most of the manor was in 1245 held of Margery de Rivers; there was then no mention of the tenure of the Munchensy family. The demesne of the manor was said to be worth $6417 \mathrm{~s}$. a year, the rents of assize $6.7 \mathrm{I} 9 \mathrm{~s} .4 \frac{1}{2} d$., the customary services $37 s .4 d$., pasture and meadow so $^{2} \mathrm{I} 6 \mathrm{~s} .2 \mathrm{~d}$., and a mill $30 \mathrm{~s}$. The total annual value was thus 618 r 9 s. $10 \frac{1}{2} d .97$

William Gernon died in $125^{8}$ holding part of the

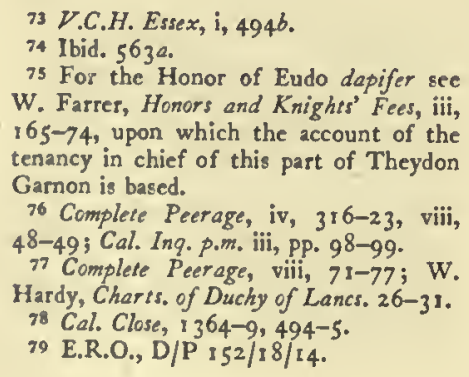

75 For the Honor of Eudo dapifer see W. Farrer, Honors and Knights' Fees, iii, $165-74$, upon which the account of the tenancy in chief of this part of Theydon Garnon is based.

76 Complete Peerage, iv, 316-23, viii, 48-49; Cal. Inq. p.m. iii, pp. 98-99. 77 Complete Peerage, viii, $71-77$; W. Hardy, Charts. of Duchy of Lancs. 26-31. 7 Cal. Close, $1364-9,494-5$. 79 E.R.O., D/P I52/18/14.

80 For Southcote see V.C.H. Bucks. ii, 308-9. For the Munchensys see Germains in Kelvedon Hatch.

81 Cal. Inq. p.m. i, p. $12 \mathrm{I}$.

82 Complete Peerage, ix, 424; Cal. Inq.

p.m. v, p. 268.

83 Cal. Inq. p.m. vi, p. 332.

84 Cal. Close, $1323-7,267$.

85 Complete Peerage, $x, 393$; Cal. Inq.

p.m. ix, p. is 8 .

${ }_{86} C_{1} 39 / 76 / 35$.

87 Complete Peerage, i, 24.

${ }_{88}$ Cal. Inq. p.m. (Rec. Com.), v, p. 379.
89 Red Bk. of Exch. 355 ; cf. Farrer, Hons. and Knights' Fees, iii, 202.

90 Feet of $F$. Essex, i, 23.

or Rot. Chart. (Rec. Com.), i, 17 Ib;

Farrer, Feud. Combs. 217-18.

92 Cur. Reg. $R$. viii, 348.

93 Rot. Litt. Claus. (Rec. Com.), i, 618, 643.

$94 B k$. of Fees, 477 , cf. 608

95 Cal. Inq. p.m. i, p. 292.

96 Red. Bk. of Exch. 612.

$97 \mathrm{C}_{3} 2 / 44 / 3$. 
manor of Denise de Munchensy and part of it of Baldwin de Lisle. His heir was his son Ralph. 98 Ralph Gernon was an adherent of Simon de Montfort and in 1265 his estates were consequently seized by the Crown. Theydon Garnon was valued at $£ 16$ and John de Rivers, the lord of the honor of Ongar, had received the Michaelmas rent of S4 $_{4}$ s. I I d. because Ralph had denied service and did not claim to hold the manor of him. 99 Ralph was pardoned in 1267 and in $127 \mathrm{I}$, three years before his death, he subinfeudated the manor for one knight's fee to his youngest son John, who was to pay an annual rent of foro during his father's lifetime. ${ }^{I}$ Ralph died in $1274 .^{2}$ John, who was described in 1293 as one of the four nephews and coheirs of Nicholas Tregoz of Tolleshunt Darcy, the husband of Eve de Valeynes, ${ }^{3}$ was probably the John Gernon who died in 1321.4 Long before this, however, he must have alienated the manor, for in 1305 it was held by Hugh Gernon, apparently the son of William, who was the heir of the last-named Ralph Gernon. ${ }^{3}$ The mesne tenancy created by the conveyance of 1271 thus appears to have been extinguished. In $1309 \mathrm{Hugh}$ Gernon granted to William Deen the reversion of the manor, then said to be held for life by William Gernon and his wife Isabel, of Hugh's inheritance. ${ }^{6}$ In 1311 Deen, then a knight, released to William and Isabel and the heirs of William his rights in the manor, which rights had previously been recognized by Hugh Gernon, son of William. ${ }^{7}$

In I 320 William Gernon the elder granted to his son William the reversion of the manor, then held for life by Richard de Teye, parson of Theydon Garnon; Ralph, brother of the younger William, was to have remainder after him. 8 The elder William died in 1327 and Richard de Teye in $1329 .{ }^{\circ}$ In 1339 John, son and heir of Sir John Gernon, brother of the elder William, released to the younger William his right in the manor, to which he claimed to have the reversion after the younger William and his heirs. io In 1340 the manor was conveyed by John de Goldingham and others, no doubt feoffees, to William Gernon and his wife Isabel and the heirs of William, with remainder to their son Thomas.II William must have died shortly after, for later in the same year Isabel was a widow. ${ }^{12}$ In 345 the manor was conveyed by John Colepepir to Thomas son of William Gernon and Lucy his wife, daughter of Maud de Whetynton. Theydon Garnon was then said to be held by Walter Colepepir as security for a debt of $\oint_{1} 100$ owing to him. ${ }^{13}$ In 1346 John, son and heir of Sir John Gernon, again released his rights in the manor. ${ }^{14}$

Thomas Gernon was living in 1354 but was apparently dead by 1361 , when Lucy Gernon was said to be one of the lords of whom the manor of Gaynes Park (see below) was held. Is About this time the manor of Theydon Garnon was evidently acquired by John Stokes, who presented to the rectory in 1367 and 1368 and was described as lord of the 'town'. ${ }^{16} \mathrm{He}$ was probably identical with John de Stokesby who with his wife was holding 2 fees in Theydon and elsewhere when the honor of Lisle was given to the king in 1368.17 $\mathrm{He}$ was still alive and living at Theydon Garnon in 1 $371 . .^{18}$ It is possible that he had married Lucy Gernon and held the manor in her right. By 1375 , however, Lucy had married Thomas Lampet, for in that year Sir Thomas Colepepir released to Thomas and Lucy all his interest in the manor for the term of her life. 9 Lucy died soon after this, leaving her son Thomas Gernon still under age. ${ }^{20}$ In 1379 , having presumably attained his majority, Thomas leased the manor for three years to his stepfather Lampet, at an annual rent of 35 marks. ${ }^{21}$

In 1407 Lampet released to Thomas Gernon his right in the manor, which he held as a feoffee, and next day directed the delivery of seisin to Gernon and three others, to the use of Gernon and of Robert Prince who was said to be the tenant in tail.22 Robert was son of Gilbert Prince and Elizabeth, sister of Thomas Gernon.23 By 1428-9 Gernon was dead and Robert Prince had been put in possession of the manor. In that year Prince enfeoffed Thomas Morsted and Adam May in all the lands which came to him after the death of his uncle, and the feoffees permitted the profits to be taken by Elizabeth, widow of William Massey, one of the feoffees of 1407.24 On Prince's death Morsted as surviving feoffee released his right to Elizabeth, now the wife of Sir Thomas Cobham, and she and her husband continued to take the profits.2s Cobham presented to the rectory in $1442 .{ }^{26}$ In 1444 , however, John Prince, nephew of Robert, took proceedings against Morsted as tenant of the freehold by Robert's feoffment. Morsted allowed him to recover seisin by default, but the Cobhams remained in possession until Prince tortiously entered the lands. Judgement was given in his favour in 1446 , but the verdict was impugned by the Cobhams. ${ }^{27}$ The matter seems to have been decided by arbitration in $1448-9$, Prince being confirmed in the manor. ${ }^{28} \mathrm{He}$ had held his first court there in $1447 .{ }^{29}$ In 1467 he and his wife had licence from the Pope to have a portable altar.30 $\mathrm{His}$ will was dated 1470 and he was dead by February $1471 .{ }^{31}$ Under the will his wife Joan should have inherited the manor absolutely, but a dispute arose over the will and eventually it was settled by arbitration that Joan should receive 10 marks a year in compensation for her dower and her rights in the manors of Theydon Garnon and Gregories in Theydon Bois. This was confirmed by John Prince son of Joan. He was to receive $f_{2} 0$ at the sealing of this deed, with all the goods left by Joan at both manors. ${ }^{32}$

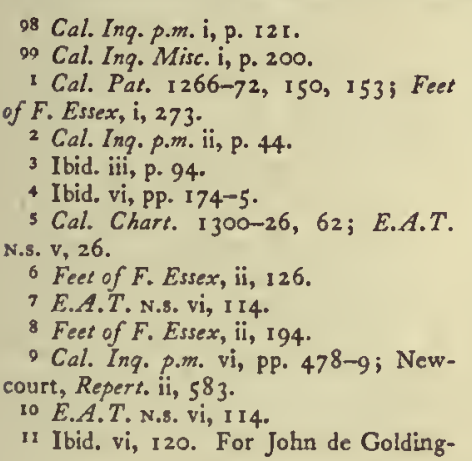

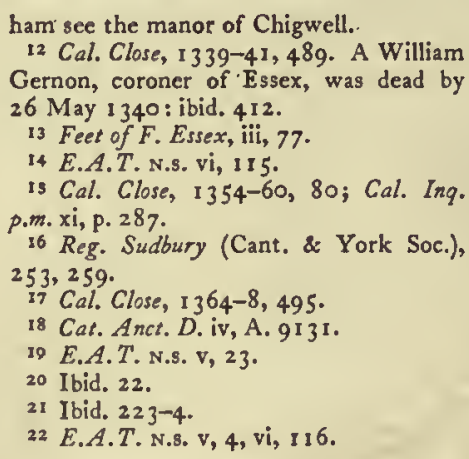

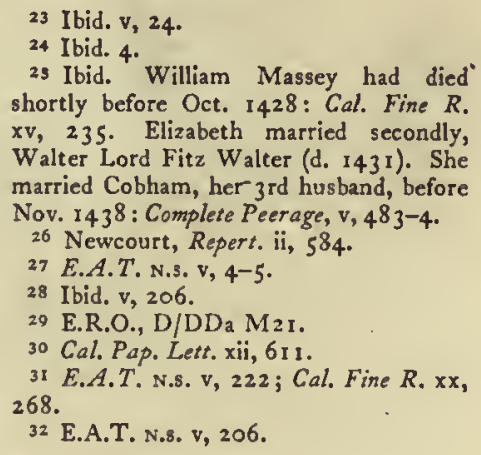
shortly before Oct. 1428: Cal. Fine $R$. $x v, 235$. Elizabeth married secondly, Walter Lord Fitz Walter (d. 143I). She married Cobham, her 3 rd husband, before Nov. I 438: Complete Peerage, $v, 483-4$. 26 Newcourt, Repert. ii, 584 .

27 E.A.T. N.s. v, 4-5

28 Ibid. v, 206.

29 E.R.O., D/DDa M 2 I.

30 Cal. Pap. Lett, xii, 6 I 1 31 E.A.T. N.s. v, 222 ; Cal. Fine R. xx, 268.

32 E.A.T. N.8. v, 206. 


\section{A HISTORY OF ESSEX}

In 1474 the last named John Prince made a conveyance of the manors for the surety of his wife's jointure and of their children, and in 1482 Theydon Garnon and Gregories were settled upon John and Lucy his wife for life. ${ }^{33}$ In I 497 John and Lucy leased the manor house of Garnons Hall, except the parlour and three rooms over it at the upper end of the high dais of the hall, with access thereto through the garden on the south side, to John Wylkinson of Epping, maltman, for to years at an annual rent of $£ 8 . .^{34}$ Prince was living at Waltham Holy Cross at the time of his death in I 499. In his will, proved in the same year, he left all his properties to his daughter Elizabeth and her husband William Sparowe, subject to an annuity of E 15 to be paid to Lucy for her life out of Theydon Garnon and Gregories. ${ }^{35}$

Early in 1499 , however, shortly before making his will, Prince had sold to Humphrey Coningsby for 300 marks the reversion upon his death of Theydon Garnon and Gregories, saving the life interests of Lucy and of William and Elizabeth Sparowe in certain lands. Prince had agreed to deliver up his evidences before Whitsun 1499, but although he was still alive in July I 499 , for he then made his will, he had failed to do so and the bargain remained uncompleted at his death. ${ }^{36}$ Sparowe refused to surrender the evidences and Coningsby took the matter to law, claiming 6400 damages. In 1500 Sparowe and his wife agreed with Sir Thomas Tyrell to settle Theydon Garnon and Gregories and a messuage in Theydon Garnon called Garnish Mill on themselves and Elizabeth's heirs with remainder to Tyrell who covenanted to bear the cost of the actions between the Sparowes and Coningsby. ${ }^{37}$ In 1501 Sparowe bound himself and his wife in the sum of 6600 to obey an award of arbitration, and to make no default in an assize of novel disseisin arraigned by Sir Reynold Bray, one of Coningsby's feoffees. ${ }^{38}$ In the same year Sparowe died and Elizabeth married Francis Hampden, who was then named with her as defendant in the suit. In 1502 he, with Sir John Hampden and another, entered into reciprocal bonds with Coningsby to accept arbitration. ${ }^{39}$ The dispute, however, went on. Francis and Elizabeth evidently remained in possession of the properties and in $I 504$ leased to Robert Pecok for nine years at an annual rent of $67 \mathrm{I} 3 \mathrm{~s} .4 \mathrm{~d}$. what was described as the site of the manor of Theydon Garnon being the outer court, without the moat, and all the housing in that court except the Long House. 40

Hugh Oldham, Bishop of Exeter, who was the last survivor of the feoffees created by Coningsby, died in I 5 I g. It was subsequently claimed that the legal estate in the manor of Theydon Garnon passed to Oldham's heir Adam Travers, Archdeacon of Exeter. Travers seems to have enfeoffed a certain Nowers, but when Nowers and others brought an action against Francis and Elizabeth Hampden the plaintiffs claimed to hold under a previous feoffment. 41 In 1523 there was a further appointment of feoffees, and in 1527 Coningsby

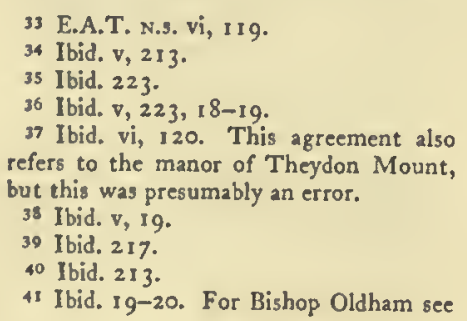

D.N.B.

42 Ibid. $2 \times 7-19$

43 Ibid. $2 I$.

44 Ibid. 219

$45 \mathrm{CP}_{4}$ o/1121 m. 34I. For the plead-

ings see $\mathrm{Cr} / 967 / 3,4$

$46 \mathrm{Cr}_{42} / 73 / 63$

47 P.C.C. 14 Tashe; C78/50, No. 20.

48 E.R.O., D/DDa TI 3 ; for Carleton's

will (pr. 1550$)$ see P.C.C. I Coode.

49 E.R.O., D/DDa TI 3. entered into another bond of 6600 to abide by the award of three justices of the Common Pleas. A settlement was at last reached and later in 1527 Coningsby, Nowers, and the other feoffees released their right in Theydon Gamon and Gregories to Francis and Elizabeth Hampden and Elizabeth's heirs. Francis and Elizabeth were to pay 350 marks to Coningsby, who was to deliver up his evidences. In I 529 Francis and Elizabeth made a conveyance of the two manors to Thomas Tyrell and others, no doubt in connexion with the agreement of I 500.42 Before the final settlement of the dispute, in 1525 , they had settled one-third of their lands upon Margery their eldest daughter and her husband John Shirley. ${ }^{43}$ In 1538 the third part of the manor of Theydon Garnon was leased to John ap Rice of London for 690 a year.44

Elizabeth Hampden died, a widow, in 1538 , leaving three daughters and coheirs, the above Margery Shirley, Jane wife of Christopher Carleton, and Ellen, later wife of John Branch. Shortly after Elizabeth's death Carleton instituted proceedings in Chancery which seem to have resulted in the transfer to him of Gregories manor and a rent of 3 os., while Branch was given Garnish Mill farm and a rent of $\ell_{1} \mathrm{O} O$, and Margery (now Edward Bishop's wife) retained Theydon Garnon manor. This new arrangement was confirmed in the Common Pleas in 1544 and it was then also provided that the common and waste and Garnons Wood should be divided into three. Presentations to Theydon Garnon rectory, as already arranged, were to be made in turn, the first vacancy to be filled by Margery, the second by Carleton, and the third by Branch.45

Margery Bishop died in 1545 , leaving an infant son Edward. $46 \mathrm{He}$ evidently died soon after, for on the death in 1553 of Margery's husband Edward Bishop, who had held Theydon Garnon for life, the manor passed to her two sisters. 47 In 1556 the manor was allotted to John and Ellen Branch, together with Margery's turn in the advowson. Jane, formerly wife of Christopher Carleton (d. c. 1 549) and now of Francis Michell, received two parts of the wood upon the common and the waste lands.48 Further disputes occurred and in 1562 there was another settlement which confirmed the manor to John and Ellen Branch, settled the advowson upon them in reversion after the death of Jane, divided the freehold lands between the sisters but gave to John and Ellen all Margery's share in the waste grounds of Garnons Wood.49

Ellen Branch had died in 1567.50 John Branch held the manor for life after her death. In I 568 he married Ellen Minors, sI said elsewhere to be daughter of William Nicolson. ${ }^{52}$ He was Lord Mayor of London I $580-1$ and was knighted in that year. ${ }^{53}$ In 1587 he settled the reversion of the manor after the deaths of himself and his wife on his nephew Sir Daniel Dun. ${ }^{54}$ Branch died soon after this and in 1589 his widow released to Dun her life interest in the manor. ${ }^{55}$ At some time after this, and before 1672 , Garnish Mill farm




was separated from Theydon Garnon manor and became part of the Suttons estate (see Stapleford Tawney).56 In 1605 George Carleton grandson of the above Christopher Carleton, sold his rights in Garnons Wood to Dun for $£ 30.57$

Sir Daniel died in 1617.58 His sons John (d. 1620) and Caesar (d. $16{ }_{3} 6$ ) both predeceased their mother, Joan Dun, who held the manor in dower until her death in 1640.59 She was succeeded by Daniel Dun, son of the above Caesar, who in 1652 sold the manor of Theydon Garnon with the advowson to Robert Abdy of London for $£ 3,800.60$ Two years later Abdy acquired the manor of Albyns in Stapleford Abbots (q.v.) and Theydon Garnon descended along with Albyns until 1858 when Sir Thomas Abdy, Bt., conveyed Theydon Garnon to Thomas C. ChisenhaleMarsh of Gaynes Park' (see below) who in 1867 succeeded his father as lord of the manors of Gaynes Park and Hemnalls (see below). Since 1867 the manors of 'Theydon Garnon and Hemnalls have had the same descent as Gaynes Park. In 1650 Garnish Hall farm comprised 220 acres and was valued at $£ 176$ a year when leased: this figure included $f_{1} 12$ for quit rents. ${ }^{62}$ In 1840 John R. Hatch Abdy owned a total of 228 acres in the parish. Of this 196 acres formed Garnish Hall farm, then let to Thomas Mills. ${ }^{63}$

Some references to the manor house about I 500 have been given above. In about 1650 it was described as a timber house with a court and two gardens lying within a moat, with two drawbridges and containing two kitchens, two halls, two 'very fair parlours', and several other rooms and offices. A map of the estate made in 1652 has as an inset a large scale drawing of the south front of the house. ${ }^{64}$ It shows a timber-framed building about $90 \mathrm{ft}$. long with a central entrance flanked by several gabled wings. Immediately east of the entrance are a clock turret and a bell hanging in a domed cupola. The irregular spacing of the windows and general lack of symmetry suggest that the structure was of medieval origin with later alterations. The house was surrounded by a square moat with bridges to the south and west. Beyond this the stream on the south side and ditches to the north and east may have formed an outer defence. The map shows several ponds, complete with their sluices, including those in the strip of woodland south-west of the house. This is still known as Fiveponds Wood.

The original house with its inner moat disappeared completely during the next hundred years. In the middle of the 18 th century the present farm-house was built on the same site, ${ }^{65}$ probably with timber from the earlier Hall. It is a square structure, partly plastered and partly weather-boarded, with a symmetrical redbrick front. Internally a considerable amount of 16 thor early-17th-century panelling has been reused and there is a carved overmantel of about 1650 . A 16 thcentury stained glass quarry in the staircase window has a heart-shaped device and the initials $I$. and $T .8$.

The manor of GAYNES PARK appears to have originated in the $13^{\text {th }}$ century. Previously it had prob- ably formed part of the manor of Theydon Garnon. Until about 1400 it was known also as the manor of Theydon Garnon, and this ambiguity has caused much confusion in accounts of its history. ${ }^{66}$ In 1274 the king ordered the escheator to deliver the manor of "Tayden Garnet' to John Engaine and his wife Joan daughter of Joyce de Montfichet, as it had been found that Joyce held nothing in chief at her death and that the manor was held of William de Lambourne.67 William was lord of the manor of Lambourne (q.v.). It is probable from subsequent statements that Gaynes Park was in fact held as of the capital manor of Theydon Garnon. It is possible that Joyce had held a part of her land of the manor of Lambourne, but there is no further evidence even of this. Joyce had married as her first husband Sir Gilbert de Greinville, who was the father of her daughter Joan. After Gilbert's death Joyce married Richard de Montfichet who in 1253 had licence to inclose his wood in 'Theydon with a low hedge and ditch, so that the king's deer could go in and out, and to assart a hay called Ruhedon. ${ }^{68}$

It was no doubt from John Engaine that Gaynes Park derived its name. In 1287 he and his wife granted the manor for life to Robert Fitz Walter, to hold of them at an annual rent of $\mathrm{I} d$. After his death it was to be held by Walter, son of Robert and his wife Joan, who was daughter of John and Joan Engaine, and her heirs. ${ }^{69}$ In 1294 Robert Fitz Walter, then about to depart for Gascony, had licence to lease the manor, said to be held in chief, to Nicholas de Barrington and Eustace de Masshebury for two years. ${ }^{70}$ In 1298 the king confirmed a grant of the manor for life made by Fitz Walter to Walter de Langton, Bishop of Coventry, promising that if Robert should die leaving an heir under age he would take nothing in the manor as a custody, nor distrain therein for any debts that Robert might owe to him. ${ }^{71}$ Two years later the bishop had a grant of free warren in his demesne lands in Theydon. ${ }^{72}$ Langton, who was Treasurer under Edward I, was arrested on the accession of Edward $\mathrm{II}^{73}$ but in 1308 the Sheriff of Essex was ordered to value the corn and other goods in the manor of "Theydon Mountfichet' and deliver them to the bishop along with the manor, after taking security from him for rendering thereof at the king's will.74 In 1309 , however, Langton petitioned the king to restore three little manors, one of which was 'Theydon Mountfichet, because he had had no restitution of his property other than the bishop:ic.75 No further reference has been found to Langton at 'Theydon, but since he was eventually released from prison and reinstated as Treasurer it is possible that he recovered the manor and held it to his death in $132 \mathrm{I}$, at which time, if not before, it would have reverted to Fitz Walter.

Robert Fitz Walter died in 1326 ; he had outlived both his son Walter and Joan, wife of Walter, and the manor passed under the settlement of 1287 to Adam, Lord de Welle, son of Joan by her second husband" Adam, Lord de Welle (d. 1311 )..$^{76}$ An inquisition of 1326 , nominally on the death of Joan (d. 13 1 5), found
56 E.R.O., D/DSd Tr, D/CT 350.

37 E.R.O., D/DDa Ti3.

58 D.N.B.s.v. Donne.

39 $\mathrm{Cr}_{12} / 3^{8} 4 / 141 ; \mathrm{C}_{142} / 541 / 93$.

60 E.R.O., D/DDa Tr 3 .

6 E.R.O., D/DTc Mi2, p. 3 I6.

62 E.R.O., D/DB M I 19

63 E.R.O., D/CT 350

64 E.R.O., D/DC.27/I 124.

65 It is shown on an estate map of 1772 :
E.R.O., D/DC $27 /$ I I I 9.

${ }_{66}$ e.g. Salmon, Hiss. Essex, 48 ; Morant,

Essex, i, I 59. About I 300 Gaynes Park was sometimes called Theydon Mountfichet: see below.

67 Cal. Close, $1272-9,74$

68 Cal. Chart. 1226-57, 433; Complete

Peerage, v, 72.

69 Feet of $F$. Essex, ii, 59; Complete

Peerage, v, 475
70 Cal. Pat. 1292-1301, 84-85. For Nicholas de Barrington see Barringtons in Chigwell.

71 Ibid. $3^{89}$.

72 Cal. Chart. I $257-1$ 300, 48 I.

73 D.N.B.

${ }^{74}$ Cal. Fine R. ii, 33.

75 Cal. Close, $1307-13,80$

76 Complete Peerage, v, 474-5. 


\section{A HISTORY OF ESSEX}

that the manor contained a capital messuage, a park, and 100 acres of land held of William Gernon by service of $6 s ., 2$ pair of gilt spurs, and I lb. pepper, 40 acres of land held of John de Sutton by service of $18 d$. and I lb. cummin, 2 acres held of Richard de 'Teye by service of $12 d$., and 2 acres held of Richard de Stonhurst.77 According to a valuation of the manor made a few weeks later the capital messuage within the park was ruinous and worth nothing, there was an unsound (debile) dovecote worth I $2 \mathrm{~d}$., I Io acres of arable of which 40 acres were worth in all $135.4 d$. and 70 acres were worth I Is. $8 d$. a year, Io acres of meadow worth 20s. in all, a park with wild beasts, the grass in which was worth I 35. 6d. a year beyond what was necessary to feed the beasts, and the underwood 4 s.; the rents of assize of the free tenants were $£ 7$ Ios. a year and there were 58 acres of arable called le Fermelond, worth in all gs. $8 d$. The profits of the court were said to be worth $12 d$. a year and the total annual value of the manor was thus $\oint_{0}$ I I 4 s. $2 d$. The details of tenure were repeated, the service due to Richard de Stonhurst being given as I $5 \mathrm{~d}$., while each of the tenements held of Stonhurst and Richard de Teye was said to have a marl pit. 78

Adam de Welle was a minor at the time of these inquisitions, but later in 1326 he did homage and received his lands. 79 In 1333 the keeper of the royal forests south of the Trent was ordered to cause the park of Adam de Welle of Theydon, which adjoined the forest and was taken into the king's hand for defect of the inclosure, to be replevied until the coming of the justices of the forest so that it could be sufficiently inclosed meanwhile. ${ }^{80}$ About the same time Adam granted to Alma de Furnyvall an annual rent of $\$ 26$ from his manors of Theydon Garnon (i.e. Gaynes Park), Hemnalls (see below), and Madells in Epping. ${ }^{81}$ Adam died in $1345 .^{82}$ Before his death he had granted Gaynes Park, together with properties in the counties of Northampton and Lincoln, to his son John and Maud his wife. ${ }^{83}$ Adam was said to have held the manor of Thomas Gernon, who was lord of the capital manor of Theydon Garnon, by service of 75 . and $\mathrm{I}$ lb. pepper annually. ${ }^{84}$

John, Lord de Welles (as the name was subsequently spelt) died in $136 \mathrm{I}$, holding jointly with his wife the manor, a messuage, and lands in Theydon Garnon, Epping and Theydon Bois, said to be held of the Earl of Stafford, the Abbot of Waltham, Reynold Malyns, and Lucy Gernon. The jury did not specify of which of these lords the manor itself was held. John's heir was his son John, then a child. 85 In 1362 the king ordered his escheator not to meddle further with the properties since they had not been held in chief, but held by John jointly with Maud his wife, by gift of his father. ${ }^{86}$ In 1387 Maud granted Gaynes Park, Hemnalls, and Madells to Sir William de Skipwith and others, presumably feoffees, 87 and three days later they leased the manors to Sir Richard and Sir Stephen Scrope, Thomas Lampet and Robert Marschall for their lives. ${ }^{88}$ Maud died in 1388 , and was presumably succeeded by her son John. ${ }^{89}$ In the same year he was summoned to take his place in Parliament as Lord de Welles, and reproved for his previous excuses. ${ }^{90}$ On his death in I 421 he was succeeded by his grandson Lionel de Welles, whose father Eudo had predeceased him.9I

Lionel, Lord de Welles, married first (1417) Joan Waterton and secondly (I 447) Margaret, widow of John Beaufort, Duke of Somerset.92 In 1447 he settled his Essex manors upon himself and Margaret for their lives, and in his will, dated I457, he left the properties after Margaret's death to John de Welles, his son by her, and his heirs male and then to his own right heirs. ${ }^{93}$ Lionel was killed at the battle of Towton in I 46I. He was subsequently said to have held Gaynes Park of the hundred of Ongar. 94 His heir was Sir Richard de Welles, his son by his first wife, who had married Joan, daughter of Robert (d. I 452), Lord Willoughby de Eresby, and had been summoned to Parliament from 1464 in right of his wife as Lord Willoughby.9s Lionel de Welles was included in the Act of attainder passed in 1461,96 and in 1462 the king granted the reversion of Gaynes Park, Hemnalls, and Madells after the death of Lionel's widow Margaret to Thomas Colt and his heirs male. 97 The grant was repeated in $1464,{ }^{98}$ but in that year Richard de Welles, Lord Willoughly, had a grant of all his father's goods, 99 and in 1468 he obtained a full restitution of blood and honours as Lord Welles.' The three Essex manors continued in Margaret's possession. ${ }^{2}$ In I 469 Richard was taken prisoner as a Lancastrian and executed. His son Sir Robert de Welles was captured soon after and was also executed, and in 1475 an Act of attainder was passed against them both. ${ }^{3}$ In that year the reversion to Gaynes Park after Margaret's death was granted to Richard, Duke of York, the king's son.4 Hemnalls and Madells were not mentioned in this grant. Margaret died in 1482.5 In April 1485 Richard 111 granted Gaynes Park, valued at $\int_{2} 6$ I 3s. 4d. a year, to Sir John Pykeryng and his son Hugh and Hugh's heirs male for good service against the rebels, to hold by knight service and an annual rent of 40 s. There was again no reference to Hemnalls and Madells. ${ }^{6}$

After the accession of Henry VII John, son of the above Lionel, Lord de Welles, and Margaret his second wife, obtained restitution of the family estates. 7 In I 487 he was created Viscount Welles and in the same year married Cecily daughter of Edward IV.8 In I 49 I the estates were settled upon him and his wife and their heirs by Act of Parliament. 9 He died in 1499, his two daughters having died in infancy. ${ }^{\text {10 }}$ Another Act of Parliament in 1503 provided for the

\footnotetext{
77 Cal. Inq. p.m. vi, pp. 453-4. The service owed to Stonhurst is now illegible in the MS.

${ }_{78} \mathrm{C}_{145 / 102 / 8 .}$

20 Cal. Fine R. iii, 4ro; Cal. Close, 1 323-7, 606-7. For his pedigree see Complete Peerage (orig. ed.), viii, 76 , and S. N. Smith, 'Welle or Welles, Barons Welle', Mise. Gen. et Herald. (5th ser.), ix, 44-48.

so Cal. Close, $1333-7,181$.

82 Earl Fitzwilliam (Milton) Deed 1680.

82 Complete Peerage (orig. ed.), viii, 76.

33 Feet of F. Essex, iii, 79 .

s Cal. Ing. p.m. viii, p. 433
}

83 Ibid. xi, p. 187.

86 Cal. Close, i $360-4,305$.

87 Earl Fitzwilliam (Milton) Deed $\mathrm{I}^{68} 3$.

88 Ibid. I684.

$89 \mathrm{C}_{136 / 57 / 17}$

90 Cal. Close, i $385-9,478$.

91 Complete Peerage (orig. ed.), viii, 77.

92 Misc. Gen. et Herald (5th ser.), ix, 46;

Complete Peerage, xii (I), 48.

$93 \mathrm{C}_{140 / 3 / 32}$.

94 Ibid.

95 Complete Peerage (orig. ed.), viii, 77 143.

96 Rot. Parl. (Rec. Com.), v, 480.

97 Cal. Pat. 1461-7, 116.




disposal of his estates after Cecily's death. Gaynes Park, Hemnalls, and Madells were to pass to the king for ten years, and then to William, Lord Willoughby, and his heirs for his purparty as one of the heirs of Lionel, Lord Welles."1 Cecily died in 1507, holding the manor of Gaynes Park of the manor of Theydon Garnon by fealty, a rent of 6s., and I lb. pepper. Gaynes Park was then said to contain 3 messuages, 200 acres of land, 40 acres of meadow, 350 acres of pasture, 250 acres of wood, and $610 \mathrm{I} 6 \mathrm{~s} .61 d$. rent in Theydon Garnon and 6 acres of meadow in Theydon Bois, valued at a total of 614 I 4 s. $3 d^{12}$

In April I 508 Lord Willoughby sold Gaynes Park, Hemnalls, and Madells to William Fitzwilliam, alderman of London, at the same time covenanting that he would prosecute the manors out of the king's hands and that he would acquit the king of the interest which he had in them under the Act of 1503 . In default he was to allow Fitzwilliam a rebate of 50 marks for each year that the properties remained in the king's hands. In June 1508 the parties agreed that Fitzwilliam should undertake these proceedings in return for an abatement of 460 marks in the purchase money. ${ }^{13}$ In September 1508 the king released his interest in the properties to Lord Willoughby and licensed him to enter upon them without proof of age. ${ }^{14}$ 'The conveyance to Fitzwilliam presumably became effective at once.

Sir William Fitzwilliam died in 1534 and was succeeded by $\mathrm{Sir}$ William his eldest son. Is In 1543 Gaynes Park, Hemnalls, and Madells, together with Marshalls in North Weald (q.v.) were settled on Anne, daughter of Sir William Sidney, at her marriage with Sir William Fitzwilliam's son, another William. ${ }^{16}$ This William succeeded his father in $157^{17}$ and in 1596 settled his Essex estates on his wife for life with remainder to his younger son John and his heirs male. 18 Sir William died in 1599,19 and his wife in 1602.20

The last named Sir William Fitzwilliam had held the office of vice-treasurer and treasurer at wars in Ireland from I 559 to I 573 , and as such had incurred debts to the queen amounting to $£_{3}, 964$. In 1572 he was pardoned $\oint_{\mathrm{I}}, \infty 00$, but by his death only $\oint_{\mathrm{I}}, \mathrm{I} 85$ of the residue had been paid.2I After his widow's death their elder son William became responsible for the debt and this led to a dispute over the ownership of Gaynes Park. By the settlement of I 596 William's younger brother John was heir to Gaynes Park but in I 602, soon after Lady Fitzwilliam's death, William seized some of the furnishings and other goods at Gaynes Park and challenged John's title to the manor, going so far as to mortgage the estate to the queen, presumably as a means of repaying the debt to her. William and John brought countercharges against each other for wrongful entry in to Gaynes Park and the dis- pute was finally brought before the Court of Exchequer. Precise details of the result have not been found, but John certainly gained possession of the Essex estates. ${ }^{22}$

In I609 John Fitzwilliam entailed Gaynes Park upon himself, with remainder to his executor for ten years after his death for such purposes as should be declared in his will, or if he left no such declaration, then to the use of Sir Richard Wingfield, son of his father's sister Christiana. At the end of the ten-year period the property was to pass to Sir Richard and his heirs male, with reversion to. Nicholas, second son of Sir John Byron of Newstead (Notts.) by his wife Margaret, sister of John. In the deed of settlement John mentioned the dispute with his brother and also the support which he had received from Sir Richard Wingfield. ${ }^{23}$ In the following year John Fitzwilliam made a new settlement in which he repeated the above provisions, altering only some later remainders. ${ }^{24}$

Fitzwilliam died without issue in 1612.25 In his will he confirmed the settlement of 1610 , with the additional clause that if Sir Richard Wingfield or whoever should then be next in tail would undertake to pay his debts and legacies then he should have immediate possession of the properties. 26 Wingfield took advantage of this clause, taking a lease from the executors for the ten years, and settled the manor upon himself and his wife and their heirs male, with remainder to the above Nicholas Byron.27 Wingfield was created Viscount Powerscourt in 1618 and died without issue in 1634 , having outlived his wife. ${ }^{28}$

Gaynes Park passed to Sir Nicholas Byron. In 1637 he agreed with John and Margaret Harrison that the manor should be settled in trust for the use of Harrison but that if Byron paid $£ 4,400$ at any time within the next seven years the manor was thereafter to be held for his use. In addition Byron was to pay 6800 , to settle a quarter of the manor of South -Stoke (Lincs.) on Harrison and to release to Harrison two annuities charged upon Gaynes Park for the lives of Byron, his wife and their eldest son William.29 A month after this agreement Byron mortgaged the estate for $\&_{300}$ to John Fountaine.30 In 1639 he raised a further mortgage of $£ 200$ from Fountaine and in 1642 pledged an annuity of $\oint_{2} 20$ out of the estate to secure payment of $£_{3} 00$ to Anne Beverley. ${ }^{31} \mathrm{He}$ died in 1648 , leaving Gaynes Park to his widow Sophia for life, with successive remainders to his sons William and Ernestus. ${ }^{32}$ In 1657, after the death of Sophia and William, Ernestus Byron sold the estate to William Turner for 6. $3,000,33$

The next known owner of Gaynes Park was the Earl of Anglesey (d. I686), who was holding it in 1662.34 It is possible that Turner was acting on his behalf in the above conveyance. The manor apparently descended with the earldom of Anglesey until



20 M.I. in Theydon Garnon church. $21 \mathrm{C66/1627}$. For Sir William see also p. 289 .

22 Ei 34/2 Jas. I Mich. 31, cf. EI33/10/ 1513; Earl Fitzwilliam (Milton) Deeds I $734,173^{8}, 1745$; E.R.O., Q/SR $15^{8 / 3^{8}}$, 55 and $160 / 147$.

23 E.R.O., D/DB Tgo.

24 Ibjd.

25 Burke's Peerage \&ீc., Fitzwilliam.

26 P.C.C. 50 Fenner; cf. E.R.O., D/DB

T9o.

27 E.R.O., D/DB Tgo.

28 Complete Peerage, $x, 636$.

29 Contemporary MS. vol. in possession of Mrs. A. D. Bell. Complete Peerage, v,
520, describes Lord Fitzwilliam (d. 1644) as of Gaynes Park, and states that he sold the manor in 1636 . This is probably a false conclusion drawn from a final concord of 1636 by which he released his right in the manor to John and Margaret Harrison: $\mathrm{CP}_{25}$ (2)/4I7 East. 12 Chas. I. Fitawilliam was the son of William Fitz. william who had tried to seize Gaynes Park in 1602 .

30 MS. vol. in poss. Mrs. A. D. Bell.

31 Ibid.

32 P.C.C. 176 Essex.

33 MS. vol. in poss. Mrs. A. D. Bell,

34 E.R.O., Q/RTh I. 


\section{A HISTORY OF ESSEX}

1761.35 It then passed to Arthur, son of the 6th earl, who was held to have succeeded to the family's title of Viscount Valentia although he failed to secure recognition as Earl of Anglesey. ${ }^{36}$ In a 17th-century document the total rents from the Gaynes Park estates (including Hemnalls) were stated to be $\left\{25 \mathrm{I}^{37}\right.$

Valentia retained Gaynes Park until about 1792.38 He sold it to Sir Thomas Coxhead, who died in $18 \mathrm{II}$ leaving it to William Coxhead Marsh, described as the natural son of Sarah Marsh late of Ashwell (Herts.). ${ }^{39}$ Marsh had been living at Gaynes Park from about 1806.40 From I8I I Gaynes Park descended in the Marsh (later Chisenhale-Marsh) family. The present owner is Mr. Hugo Chisenhale-Marsh.41 In 1840 W. C. Marsh owned 718 acres in Theydon Garnon, of which 497 acres were in his own occupation. $42 \mathrm{He}$ also owned 18 acres in Theydon Mount.43 In 1873 Thomas Coxhead Chisenhale-Marsh owned a total of I, 36 1 acres in Essex, with an estimated gross rental of $62,357.44$ Part of the increase, but not all of it, is accounted for by the acquisition of the manor of Theydon Garnon (see above) in $185^{8}$.

In the I 7 th century Gaynes Park Hall was described as a well-built brick house with gardens, orchards, yards, stables, and outhouses, enclosed with brick walls and fish ponds, and it was said to have cost $f 8,000$ to build.4S This house existed in 1696 but had been demolished by about I740.46 By 1777 a new house had been built about $\frac{1}{4}$ mile farther north. 47 This was usually known as Park Hall. A print of 1818 shows a long white front of two stories having a central bay flanked by Venetian windows. 48 After the middle of the I th $^{\text {th }}$ century Thomas Coxhead Chisenhale-Marsh incorporated this building in a large stone mansion of Kentish rag which he completed in 1870.49 The house is in Tudor style with a pierced parapet and many gables.

The manor of HEMNALLS seems to have comprised the north-west corner of the ancient parish of Theydon Garnon. The modern Hemnall Street in Epping, which runs parallel with High Street to the south-east, was formerly just within the boundary of Theydon Garnon. The name probably derives from the family of Henry de Emhal' (c. I 248) and Roger de Hemenhal (c. I 254) who may have come from Hempnall (Norf.). ${ }^{50}$

Hemnalls is first referred to as a manor in about 1340, when Adam de Welle granted a rent which issued partly from it (see Gaynes Park, above). At the inquisition made after Adam's death in I 345 Hemnalls was described as a tenement in Theydon Garnon and Theydon Bois, held of John Fitz Walter by service of 26 s. a year. The jurors did not know whether it was held by knight service or by socage. ${ }^{55}$ It was referred to again as a manor in 1387 and was always subsequently so termed. 52 In $146 \mathrm{I}$ it was said to be a member of Gaynes Park ${ }^{53}$ but in 1507 and 16 I 2 to be held of the manor of Hubbards Hall in Harlow at a rent of $26 s .54$

From about I 340 to I $8 \mathrm{II}$ the tenancy in demesne descended with the manor of Gaynes Park, except for two brief periods when that manor appears to have been granted separately (1475 and 1485). On the death in $18 \mathrm{II}$ of Sir Thomas Coxhead Hemnalls passed under his will to his widow Deborah for life, with remainder to Thomas Coxhead Marsh of Union Wharf, Wapping (Mdx.), who was also the natural son of Sarah Marsh of Ashwell (Herts.). 35 T. C. Marsh died, apparently without children, in 1847 , and Hemnalls passed under the terms of Sir Thomas Coxhead's will to W. C. Marsh of Gaynes Park.s6 T. C. Marsh appears to have spent his later life in Paris, where he had a hotel.57 He owned no land in the parish of Theydon Garnon in 1840,58 so that by that time, if not earlier, his interest in Hemnalls consisted only of the manorial rights, if any. Since 1847 Hemnalls has once again descended along with Gaynes Park. The site of the ancient manor house is not known.

COOPERSALE HOUSE was formerly the seat of the Archer family and subsequently one of the residences of the Archer-Houblon family. Although never styled a manor it was the centre of one of the largest estates in Theydon Garnon.

References to the Archers are found very early in the history of 'Theydon Garnon, but the first of them to become important was Henry Archer who on his death in 1616 held a capital messuage of the manor of Hemnalls.s9 His successor was his son Sir John Archer (d. I 682), a justice of the Common Pleas. John Archer, son and heir of Sir John, died without issue in 1707 , leaving the estate to William Eyre of Gray's Inn on condition that he should adopt the name of Archer and marry Eleanor Wrottesly, John Archer's niece. Eleanor died without issue and William Eyre (now William Eyre Archer) later married Susanna, daughter of Sir John Newton, Bt. Their son John Archer succeeded to the estate in 1739 although he had no connexion by blood with the original family of Archer. $60 \mathrm{He}$ died in I 800 , leaving as his heir his daughter Susanna, who in 1770 had married Jacob Houblon (d. 1783 ) of Hallingbury Place.6I She went to live at Coopersale at her father's death. 'The house had been unoccupied since her mother's death in 1776.62 In 1819 Susanns adopted the name of Mrs. Houblon Newton.63 She died in 1837 , the estate passing to her grandson John Archer-Houblon. ${ }^{64}$ In $1838-40$ he owned 703 acres in 3s Complete Peerage, $i, 534$. It is possible that the 5th Earl held Gaynes Park in 1707,3 years before succeeding to the title: E.R.O., Q/RSg

36 Complete Peerage, i, I 38.

37 E.R.O., D/DAC 228

${ }^{38} \mathrm{CP}_{43} / 837 \mathrm{M} 27$ s-3; E.R.O., Q/RPl 697.

39 P.C.C. 525 Crickitt.

40 E.R.O., Q/RP1 $711, \mathrm{D} / \mathrm{P} 152 / 51 / 3$ Q/RSg 4 .

41 For the pedigree see Burke's L.G. (1952 edn.), s.v. Marsh, also J. J. Howard and F. A. Crisp, Visit. of Eng. and $W$ ales, iv, $6-8$.

42 E.R.O., D/CT 350.

43 Ibid. 351.

44 Reins. of Oruners of Land, 1873
[C. 1097], Essex, p. 29, H.C. (3874), Ixxii (s).

45 E.R.O., D/DAc 228.

46 Oliver, Map of Essex, 1696 ; N.

Salmon, Hist. Essex, 48.

47 It is shown in this position by Chap-

man and André, Map of Essex, 1777 , sheet $x$ i.

48 E:R.O., Prints, Theydon Garnon.

49 The date appears on a gable.

so P.N. Essex (E.P.N.S.), 23

sI Cal. Ing. p.m. viii, p. 433 .

32 Ear! Fitzwilliam (Milton) Deed 1683.

${ }_{33} \mathrm{C}_{3} 40 / 3 / 32$.

54 Cal. Ing. p.m. Hen. VIl, iii, p. 270 ; C $142 / 665 / 50$.

Ss P.C.C. 525 Crickitt. s6 For T. C. Marsh's will see P.C.C. 340,1847 .

57 Ibid.

58 E.R.O., D/CT 350

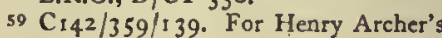
Charity see below, Charities.

60 E.R. xxxi, 165; Lady Alice ArcherHoublon, Houblon Family, its srory and times, ii, 306, 323. For Sir John Archer and his heirs see P. 280.

61 Lady Alice Archer-Houblon, Houblon Family, ii, 279, 322. For the marriage settlement see E.R.O., D/DB T; 20.

62 Houblon Family, ii, 279-80.

63 Ibid. 274. She was heir to the Newton family as well as those of Archer and Houblon.

64 Ibid. 293. 
Theydon Garnon and 18 acres in Theydon Mount. 65 He was also owner of 82 acres in Theydon Bois when the tithes of that parish were commuted in I 850.66

After 1837 the Coopersale estate descended along with Hallingbury Place in the Archer-Houblon family. Coopersale House was successively the residence of Mrs. Mary Anne Archer-Houblon (d. I 865), widow of John Archer Houblon (d. 1831), Miss Harriet Archer-Houblon (d. I 896), and Mrs. Eyre.67 It then remained for some years unoccupied. 68 The contents of the mansion were sold in 1908 , and the whole Coopersale estate in 1914.69 Coopersale House was then bought for a religious order which occupied it during the First World War. In I920 it was sold to Mr. E. Camps. From I 936 to about 1944 it belonged to Mr. Dudley Ward who sold it to Countess Howe. It was bought in 1946 by Major Jocelyn Hambro, who is the present owner. ${ }^{70}$

In I 920 the house was a large three-storied mansion, roughly L-shaped on plan. ${ }^{71}$ It contained fittings dating from the early $I 7$ th century but the structure itself had been altered and enlarged at subsequent periods. The north-east wing, which had mullioned and transomed windows, was probably built about $1670-80$. The principal block had a Georgian front of nine bays and a modillion eaves cornice with a central pediment. The sash windows and other details were of the I 8 th and early Igth centuries, but some older carved chimney-pieces had been preserved internally. At the back of the house two grotesque brackets of the 17 th century had been incorporated in a Georgian doorcase. The ground-floor room on the left of the entrance hall was of two stories and may have represented the great hall of the original house. At a later date it was used as a chapel and had a painted ceiling thought to represent William III casting out popery. Two semicircular bays on the south front were probably part of the improvements made by Mrs. Susannah Houblon Newton after I 800.72 At some period panelling and a carved overmantel were removed to Hallingbury Place.73

Immediately after 1920 the house was greatly reduced in size. The second story of the principal block was removed and most of the north-east wing demolished. The sash windows were replaced by mullioned and transomed casements of 17 th-century design. Panelling and carved chimney-pieces from the demolished rooms were reused and the principal staircase was reconstructed with balustrades from the northeast wing. ${ }^{74}$ In recent years some of the panelling has been taken out and three of the I 7 th-century chimneypieces are missing.

A gateway north of the house has a four-centred brick arch of the I 7 th century. The lake below the house on the south is probably the work of John Archer between 1739 and 1776 .

63 E.R.O., D/CT 350, 351.

66 Ibid. 349

67 Houblon Family, ii, 312, 297, 314

Kelly's Dir. Essex (I g02, 1906).

68 Kelly's Dir. Essex (1912, 1914).

69 E.R.O., Sale Cat. B. 130 , A. 1045.

70 E.R.O., Sale Cat. A. 53 ; inf. from

Mrs. E. Camps and Mrs. Hambro.

71 Hist. Mon. Com. Essex, ii, 61 and Hist.

Mon. Com. MS. Recs. Most of the

following details are from this source.

72 Houblon Family, ii, 279-80.

73 Nat. Bdgs, Rec. Coll. Measured drawing. Hallingbury Place has since been demolished. A : 6th-century painted
The advowson of Theydon Garnon was appurtenant to the manor and descended along with it CHURCH until 1858. Presentations pro hac vice were sometimes granted by the lords of the manor to others. 75 When Sir Thomas Abdy, Bt., sold the manor in 1858 he retained the advowson and this descended with the baronetcy until 1945 , when it was vested in the Bishop of Chelmsford. ${ }^{76}$ In I 834 the advowson, with other properties, was mortgaged by John R. H. Abdy to Charles G. Parker of Springfield Place. On his death in $1840 \mathrm{Abdy}$ allowed his trustees to sell the next presentation and to apply the proceeds towards the redemption of the mortgage, or if this had already been redeemed, on the purchase of freeholds. 77

In about 1254 the rectory of Theydon Garnon was valued at 15 marks, and the same valuation was given in 1291.78 In 1507 the rector leased the church and parsonage with the tithes to William Hyll, chaplain, and Francis Hampden for three years at an annual rent of $\ell_{8} 8$, reserving the lodging by the gate (see below). ${ }^{79}$ In 1535 the rectory was valued at $6_{0} 7.80$ In 1650 the 'improved' value was $\oint_{0} \mathrm{7} 74$, of which $\oint_{1} 124$ represented composition in lieu of tithes. ${ }^{81}$ The tithes were finally commuted in 1840 for $\oint_{0} 650$. There were then 71 acres of glebe. ${ }^{82}$

A terrier of 16 Io mentions the parsonage house with glebe and outbuildings including a cottage called the Gatehouse. ${ }^{83}$ 'The former rectory house, now known as Theydon Priory, was sold to the Revd. C. G. B. Hotham after his retirement in 1893 . The present owner (1954) is Mr. W. J. Keswick. ${ }^{84}$ The house is about $300 \mathrm{yds}$. south of the church. The rectory was certainly on this site in $1648^{8 \mathrm{~s}}$ and the core of Theydon Priory, consisting of the south range and west wing, may represent the house of 1610 . The building was largely reconstructed in the 18 th century, when the south side was given a symmetrical front of red brick with sash windows and a pedimented doorcase. Until recently the main entrance was at this side. Additions made later in the 18 th century include a large room with a splayed bay on the north side, now the entrance hall. Interior fittings date from about I 700 and later. In the present century additions were made to the east and west. The entrance porch is also modern.

The present red-brick gabled rectory, which is immediately south of the church, was built in I 895-6 at a cost of $£ 3,300.86$

John Molyns (d. I 591), who was Rector of Theydon Garnon from I561 until his death, had been among the Puritan clergy who emigrated to Frankfurt-amMain under Mary I. He became Canon of St. Paul's and Archdeacon of London in 1559.87 Samuel Searle, who became rector in 1609 , was a turbulent man whose offences appear to have included manslaughter and brawling in church. ${ }^{88}$ In $1622-3$ he was suspected door, formerly in Coopersale House, is now in the Victoria and Albert Museum. 74 Details from Mrs. E. Camps.

75 Lunt, $V$ al. of Norwich, 336; Newcourt, Repert. ii, 583-4.

76 London Gaz. 28 Dec. 1945, p. 6286.

77 E.R.O., D/DDa TI3; P.C.C. 223 Arden.

${ }^{78}$ Lunt, $V_{a l}$. of Norwich, 336; Tax Eccl. (Rec. Com.) 216 .

79 E.A.T. N.s. vi, $109-11$.

80 Valor Eccl. (Rec. Com.), i, 437.

81 H. Smith, Eccl. Hist. Essex, 273.

82 E.R.O., D/CT 350.
83 Newcourt, Repert, ii, 583. A terrier of 1621 gives similar, though not identical details: ibid. $\mathrm{Cf}$. the Gatehouse with the Priest's House, below.

84 Essex in the zoth century (Pike's New Century Ser. No. 27), 49 ; inf. from Mrs. W. J. Keswick. Hotham was Rector of Theydon Garnon $1887-93$.

85 E.R.O., D/DC 27/1123.

86 Kelly's Dir. Essex (1 898$)$. A new rectory is now (1955) being built.

87 D.N.B.

88 E.R.O., D/AEA 30 fo. $107^{\vee}$; St. Ch. $8 / 275 / 4$. 


\section{A HISTORY OF ESSEX}

of being an accessory to murder, and in 1624 he was deprived of his benefice. ${ }^{89}$

At the Dissolution of the Chantries in 1548 there were found to be obits in the church of Theydon Garnon supported by annual rents of 8 s. $4 d$., $6 s .8 d$., and $6 s .8 d$., charged on the lands of John Rogers, Richard Archer, and John Archer respectively.90 The rents were granted in I 549 to Robert Woode of the Inner Temple. 91

The church of ALL SAINTS consists of nave and chancel, north aisle, north porch, south porch, north vestry, and west tower. The walls of nave and chancel are of flint rubble and those of the tower, aisle, and north porch are of brick. The chancel probably dates from the $13^{\text {th }}$ century. The nave appears to have been rebuilt in the $15^{\text {th }}$ century. The tower was built about I 520. In I 644 the north aisle and north porch were added and a north arcade of timber built. The south porch was built in the 18 th century, and in the 19 th century there were numerous alterations including the addition of a north vestry and organ chamber. The church is of special interest from its dated tower of I 520 and dated north aisle of 1644 .

The chancel, which was probably built in the $13^{\text {th }}$ century, has in its south wall a $13^{\text {th }}$ century lancet window, and on the north side a niche of uncertain date. There is no structural division between chancel and nave.

In the 15 th century the nave was probably rebuilt. In the south wall there is a 15 th-century window of three cinquefoiled lights in a segmental-pointed head, with moulded label and the arms of Gernon.92 Also in the south wall is a 15 th-century doorway with moulded jambs and a two-centred arch under a square moulded label with traceried spandrels. The east window in the chancel is also of the 15 th century. It has four cinquefoiled lights with vertical tracery in a two-ceritred head.

About I 520 the west tower was added. It is of red brick, with some blue brick, of three stages with an embattled parapet. The date is recorded on a stone panel on the outside of the south wall, where it is stated that Sir John Crosbe, late alderman and grocer of London, and his wives Anne and Annes gave 650 towards the building of the tower. ${ }^{93}$

The north aisle and porch were built in I 644. They are of red brick which it is interesting to compare with the earlier brick of the tower. The date is picked out in dark brick on a panel on the outside of the east wall of the aisle. A corresponding panel on the outside of the west wall has the letters $1 . \mathrm{H}$. The timber arcade which divides the nave from the aisle also dates from 1644. It consists of five bays with octagonal oak columns and semi-octagonal oak responds. The oak arches are roughly three-centred to the east bays and semicircular to the west bays and have a horizontal moulded fascia above them mitred down in the middle of each arch to form a key block. The nave roof was probably reconstructed at this time but retains several rebated king-posts of the I5th century. Along the south side of the nave are two gabled dormer windows. These were largely remodelled in the $\mathrm{I}$ gth century but the frames probably date from 1644 .

During the 17 th century several other new windows were added. In the chancel are two windows, one on the north wall and one on the south, both having two pointed lights, and the west window of the tower is also probably of the same century.

In 1762 repairs were carried ont on the church costing over $£_{0} 100$. 'The largest part of this sum, $£_{0} 67$, was for carpenter's work, including roof repairs. 94 In 1770 there is said to have been a gallery in the north aisle. 95 It is not clear what form this then took. In 1774 the parish vestry released to John Deakins and the future occupiers of his dwelling the seat where the psalm singers used to sit on the north side of the church, in return for 15 guineas towards the building of a singers' gallery. 96 The balance of the carpenter's bill towards the building of the gallery was paid in December 1774.97 The restoration of the north porch and the insertion of the west doorway in the tower also took place in the 18 th century.

The Revd. Sir Cavendish Foster, Bt., rector from 1843 to 1887 , substantially altered the church. In 1863 the gallery was removed 98 and five new windows inserted in the aisle, three in the north, one in the east, and one in the west wall.99 The previous north wall windows are said to have been wide and square with wooden frames and the previous east window small and square.' 'The east window has now been blocked. Further restorations appear to have been carried out during Foster's incumbency. ${ }^{2}$ The vestry and organ chamber were added in 1892 at the expense of the Revd. C. G. B. Hotham, Foster's successor as rector, and W. S. Chisenhale-Marsh of Gaynes Park. ${ }^{3}$ A new heating apparatus was installed in 1899 at the expense of the Kemsley family. 4

A glazed screen between the west end of the nave and the tower was erected by the Chisenhale-Marsh family as a memorial to those who fell in the First World War. In I 934 general repairs to the church were carried out and the lancet window in the south wall of the chancel, which had been blocked for several centuries, was opened at the expense of $\mathrm{Mr}$. Hugh Kemsley. 5 Further repairs have been done during the past ten years.

The communion rails were set up in $1683-4$ at a cost of $f_{0} 4$, in obedience to the orders of the archdeacon at his visitation of $1683 .{ }^{6}$ "The pulpit is a 'two-decker' and has a large sounding-board of the early 18 th century. There are three chairs of the same period in the chancel. Some 16 th-century seats formerly in the nave were removed about 1920.7 There is 16 thcentury panelling on the south wall of the nave and some of about 1700 in the tower. In the vestry is a large oak chest with iron bands given in 1668 by Sir John Archer. ${ }^{8}$ In it are some manorial records. 9 At the west end of the nave is an oak door-frame taken from the Priest's House (see below).

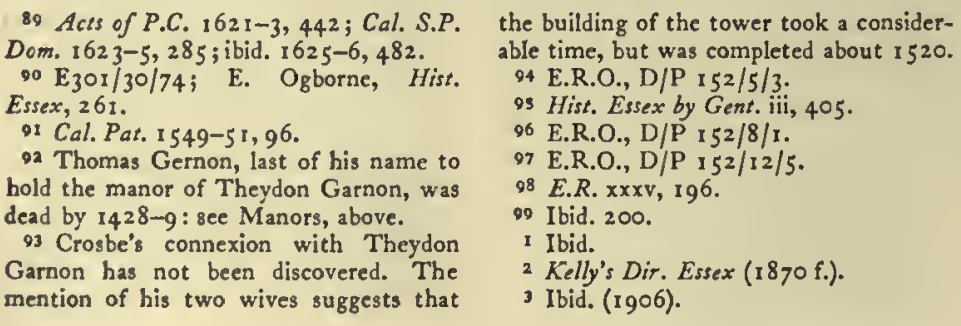

3 Ibid. (1 g०6).

4 Ibid. Joseph Kemsley, churchwarden, had died in 1897 : see below.

s Kelly's Dir. Essex (1937).

6 E.R.O., D/P $152 / 5 / \mathrm{r} ; E . A . T$. N.s. xix, 273.

Hist. Mon. Com. Essex, ii, 233.

8 H. W. Lewer and J. C. Wall, Church Chests of Essex, 206-8.

$\checkmark$ W. C. Waller, 'An old church chest', E.A.T. N.s. v, $1-32,200$. 


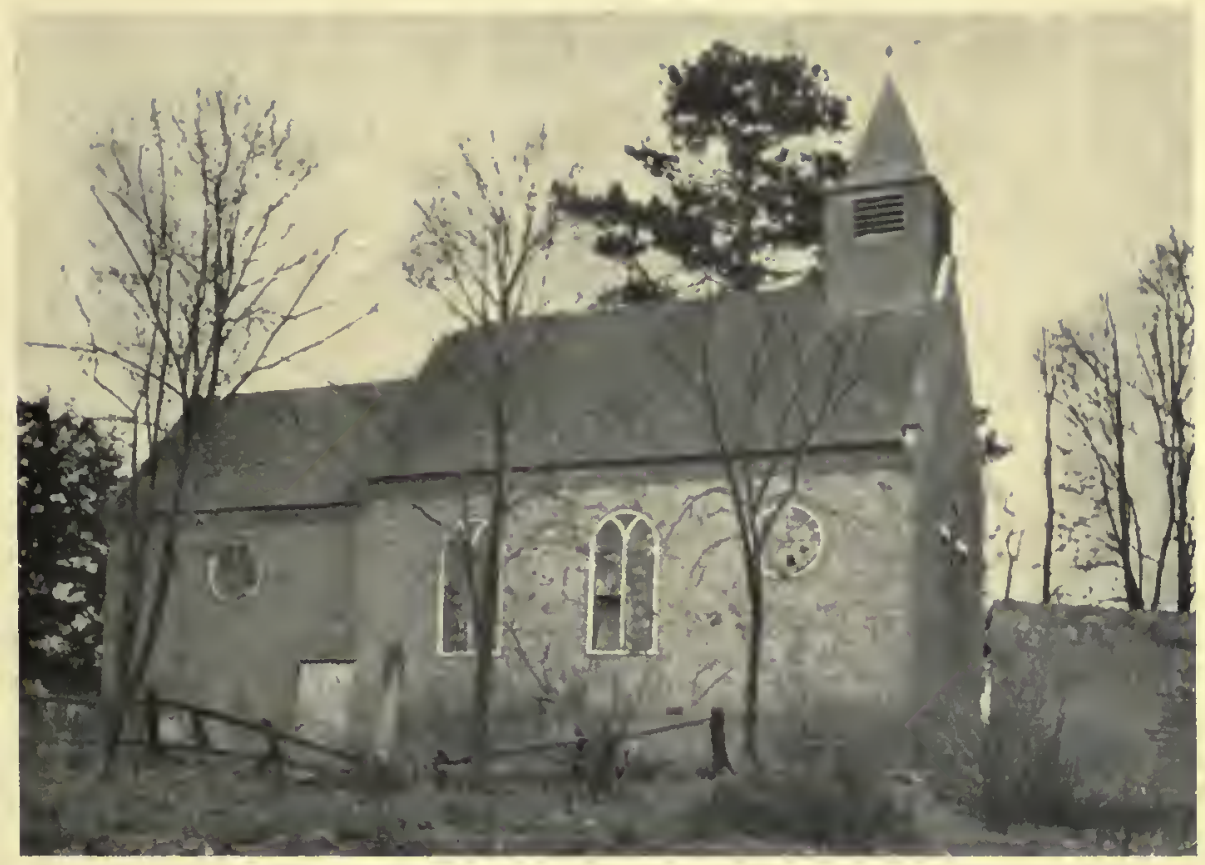

Kelvedon Hatch Old Church, built 1750-3



Theydon Bois Church, built I $85^{\circ}$



Theydon Mount Church, built I6I I-I4

Post-Reformation Churches 


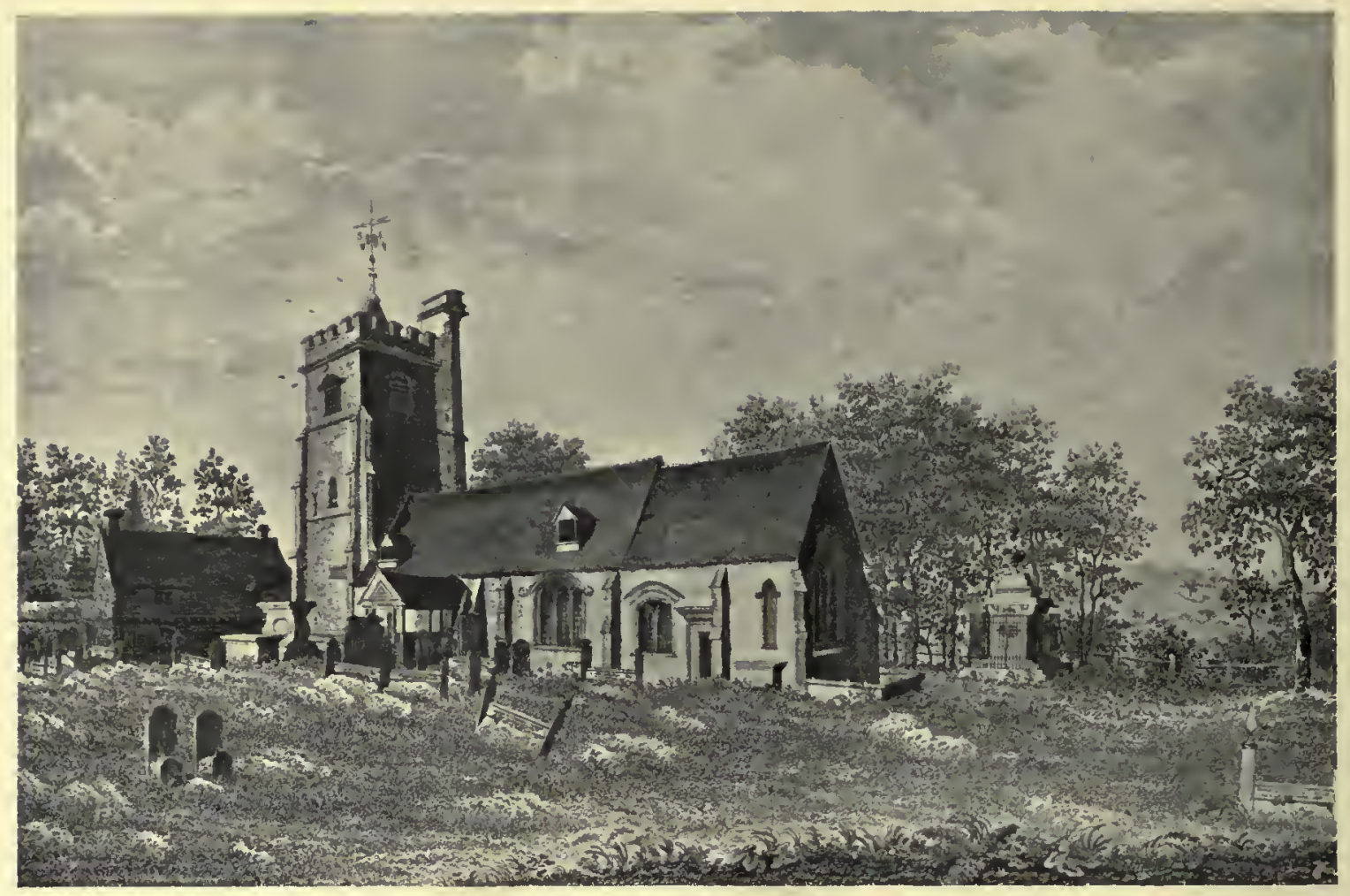

The Church and Priest's House, Theydon Garnox, in i 8 I 8

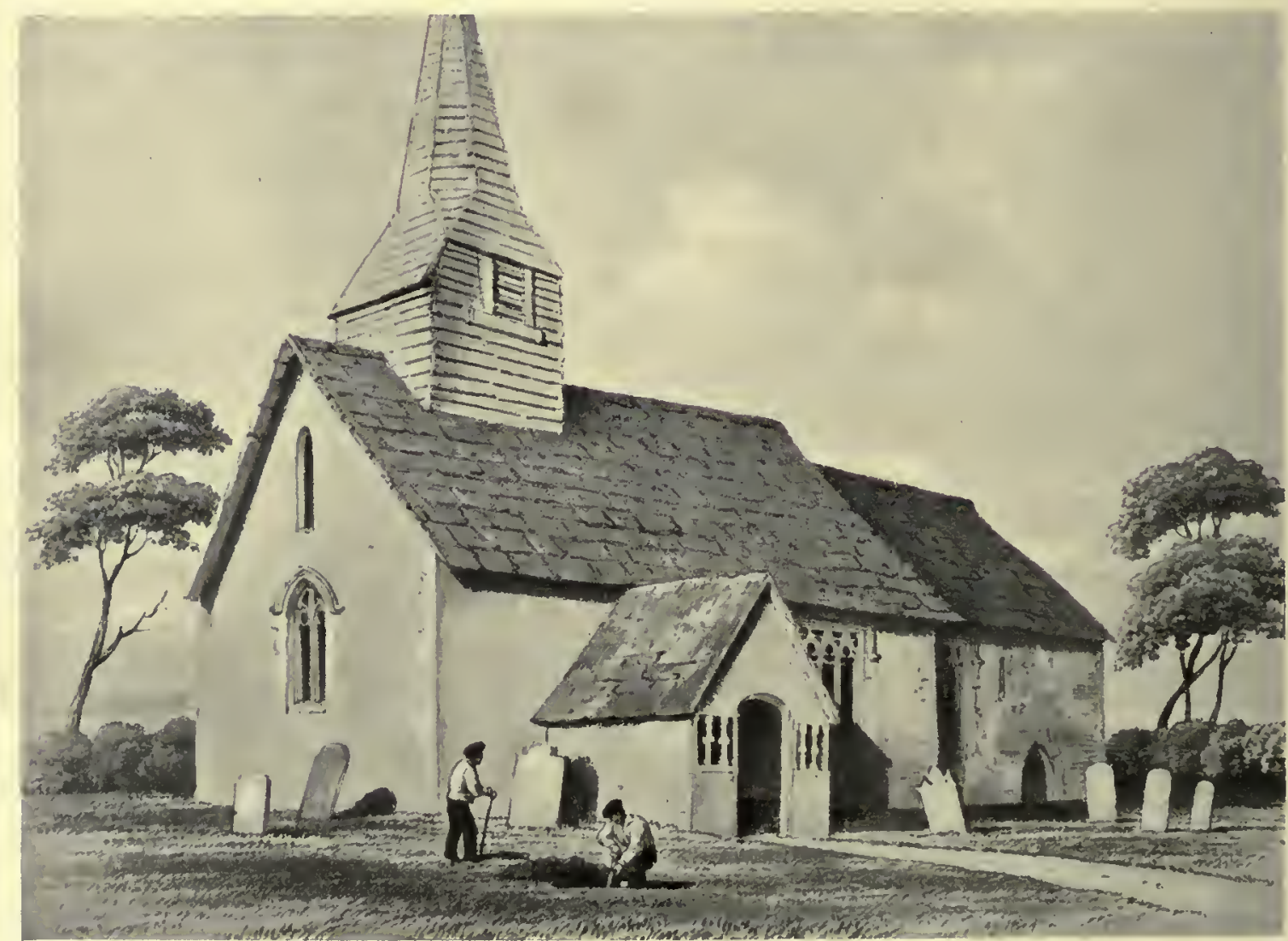

Stondon Massey Church in I 833 
There are five bells. The first four were cast by Miles Graye in 1628 and the fifth by Robert Phelps in 1732 . In 1733 the parish vestry agreed to borrow 6,22 at 5 per cent. interest to pay for the casting and hanging of this last beli.10 The church plate consists of a cup and paten cover of I 562 ; two flagons of $I 650$, given in $167 \mathrm{I}$ by the rector James Meggs; a paten of I 702 given by John Baker and an undated almsdish also bearing Baker's name and probably of 1702 ; and an almsdish of $r 895$. All the pieces are silver. In 18 r 6 all the then existing plate was repaired at a cost of $63 .^{\text {II }}$

On the north wall of the chancel is a brass to William Kirkeby, rector, $\mathrm{r} 458$ with a figure of a priest in cope with shield of arms. This was formerly in the nave and was set up in its present position with a modern inscription between $\mathrm{I} 8 \mathrm{I} 2$ and $\mathrm{r} 835^{\mathrm{I2}}$ Also in the chancel are a brass to Ellen (Hampden), wife of John Branch, 1 567, and monuments to Lady Anne (Sidney), wife of Sir William Fitzwilliam, I602; Sir Daniel Dun, 1617 and his wife Joan, r640; James Meggs, rector, 1672; Sir John Archer, r681; and Sir William Eyre Archer, 1739 . The last is a large standing wall monument with grey sarcophagus and obelisk and medallion of the deceased flanked by three cherubs. Set into the north wall of the chancel is a grey marble altar-tomb with a flat-arched canopy resting on small side-shafts and having a frieze of quatrefoil panels. At the back of the recess is a brass of a kneeling man in armour, his wife, two sons, and three daughters, with indents of two inscription plates, two shields, a Trinity and another group, of about I 520 . Opposite is another similar altar-tomb of slightly later date with the canopy set on twisted shafts, also with indents for brasses at the back of the recess. There are floor slabs in the chancel to Henry and Thomas Meggs, r670, Margaret wife of James Meggs, I68I, and Richard Butler, I688.

In the nave is a wall monument to Denton Nicholas, M.D., 1714 , moved there from the chancel in 1934 . There is a floor slab in the nave to Jane, widow of John Wormlayton, 1725 , and their daughters Jane, I 705, and Anne, 17 I2. Other later monuments include plaques to Charles B. Abdy, 1843, Joseph Kemsley, churchwarden, 1897 , and William S.' ChisenhaleMarsh, 1929. There is a stained-glass window in memory of the Revd. Sir Cavendish Foster, Bt. (see above).

A few yards west of the church there stood until recently a cottage called the Priests' House. It was of two stories, the upper projecting on the east front with exposed joists and curved brackets. It was apparently built in the late $15^{\text {th }}$ century. ${ }^{13}$ It may have been identical with the Gatehouse (see above) of 1507 and 16ro. If so it consisted in $r 507$ of a parlour, with a chimney and larder at one end and two chambers; above were a study and 'wyddraughte', i.e. a sink or drain. ${ }^{14}$ In 1624 there was an alehouse in the churchyard; ${ }^{15}$ this may well have been the same house since a map of 1648 shows no other buildings in the churchyard. ${ }^{16}$ 'The Priests' House has now been destroyed except for a door-frame (see above). An engraving of the church published in 1810 shows in the distance a small part of the house. ${ }^{17}$ Another of I 8 I 8 by the same hand shows the whole house. ${ }^{18}$

The small brick building outside the churchyard has been used as a Sunday school. ${ }^{19}$ It probably dates from the late Igth or early 2oth century. An avenue of limes and chestnuts leading from the south side of the churchyard to the former rectory is now known as the Monks' Walk.

The church of ST. ALBAN, Coopersale, was built at the expense of Miss Archer-Houblon in I 852.20 It was consecrated in the same year and a particular district assigned to it.2I The advowson was vested in Miss Archer-Houblon and it remained in her family until ror4 when it was transferred to the Bishop of Chelmsford. ${ }^{22}$ The building is of flint and consists of chancel, nave, south porch, and north vestry with bellcote at the west end of the nave. The vicarage was also built at Miss Archer-Houblon's expense. It stands to the north of the church and is a gabled house of variegated brickwork. Opposite the church is the Parish Room, a single-story building dating from about 1865 , of brown brick with dressings of red and black.

For charities relating to the church see Charities, below.

Only one volume of vestry minutes ${ }^{23}$-from 1754 to I 827 - survives for PARISH GOVERNMENT Theydon Garnon and $A N D$ POOR RELIEF this contains little more than the annual appointment of parish officers and summarized details of the parish accounts. Other vestry resolutions have been entered elsewhere, in the overseers' rate and account books, but even so it is impossible to put together a comprehensive picture of the parish government, and for many details it is necessary to rely on entries of payments in the account books, which cover the periods I 7 I 5-I 8 I 7 and I 826-36.24

The Easter vestry was usually attended by some 6 to Io persons; at such other vestry meetings of which records survive it apparently varied between 3 and 24 . Between 1780 and 1796 the rector usually presided at the Easter vestry. In 1729 the vestry resolved that every officer not attending the public vestry on the first Saturday in every month should be fined $6 d$., and that every other parishioner not attending every quarterly vestry should be fined $3 d$., but in 1737 it was resolved that the vestry should meet no more than once in every three months, and in 1780 that the vestry should be held in the church on the first Saturday in the month. In 1774 a vestry clerk, to attend the vestry each month, was appointed at a salary of 6 guineas. $\mathrm{He}$ was discharged, however, in 1780 and the office abolished.

In the second half of the 18 th century there were always two persons in each of the parish offices. The overseers nearly always served for one year only. A woman was occasionally appointed to the office. The churchwardens and constables usually remained in office for at least two years and often for much longer
30 E.R.O., D/P $152 / 12 / 2$.

"E.R.O., D/P I52/5/3. The repairs were done by Thomas and Storrs, I 6 Mincing Lane, London.

12 Ogborne, Ifist. Essex, 266; T. Wright, Hist. Essex, ii, 380 .

${ }^{13} \mathrm{H}$. H. Collett, "The churchyard cottage at Theydon Garnon', E.R. xvii, 18-21; Hist. Mon. Com. Essex, ii, 233.
I4 E.A.T. N.s. vi, 110.

is E.R.O., D/AED io f. $25^{v}$.

16 E.R.O., D/DC $23 / 11123$.

17 Gents. Mag. Ixxx (ii), 601; E.R. xxxi, 186 .

18 See plate facing p. $27 \mathrm{I}$.

o.S. 6 in. Map (3rd edn.), sheet lxi.

20 Kelly's Dir. Essex (1933).

23 London Gaz. 22 Oct. 1852, pp.
$2758-9$.

22 Ibid. I 3 Nov. 1974 , P. 9259.

23 E.R.O., D/P I $52 / 8 / 1$.

24 E.R.O., D/P 152/12/1-10. Unless otherwise stated all the following information is derived from these account books and from the minute-book referred to above. 


\section{A HISTORY OF ESSEX}

periods. From 1756 until I78 I the surveyors usually served for I or 2 years consecutively but the Revd. T. A. Abdy and John Palmer served in the office throughout the period $1781-1792$. In 1780 it was resolved to appoint an assistant to the overseer at a salary of 6 guineas; by April I 8 1 4 the salary was $\$ 20$. In 1792 among the parish officers appointed was a 'reive of the waste.'

Between 1715 and 1817 all bills of the churchwardens and constables, and of the parochial charities were paid out of one account - that of the overseers. There was also a single and undifferentiated rate. A Id. rate in $1683-4$ produced $£^{8} 35.4 d .25$ and it does not appear that this assessment was altered. In ${ }^{7} 78_{3}$ a resolution to do so was defeated. ${ }^{26}$

The vestry appears to have been watchful of the general interests of the inhabitants. In 1776 , for example, the vestry agreed to prosecute Richard Palmer of Epping should he complete the building of cottages for the habitation of poor persons within the parish without intending to lay 4 acres of land, which it was deemed would bring great charge to the parish. Palmer, who was present, agreed not to go on with the building. In $\mathrm{I} 78 \mathrm{I}$ the vestry adjourned to supervise the overthrow of fences on illegal encroachments made by the people of Epping upon the waste of the manor of Hemnalls, and in 1797 it was agreed that a gate should be erected to keep off forest cattle. One scandal occurs in the parish records. In $\mathbf{I} 774$ it was reported that William Le Cocq, one of the overseers, and then in Chelmsford Gaol, had not delivered in his account, and the vestry ordered the parish officers to borrow $£_{\mathrm{I}} 00$ to pay off his debts.

Most of the parish business naturally concerned poor relief. When the parish accounts begin it appears that the policy was one of out relief only. In I7 I 5 there was a payment of $\varepsilon_{3}$ for badges for paupers. There were similar payments for badges in 1729 and in 1746 it was ordered that badges should be worn by all those receiving weekly doles. In 1728 there were I9 people receiving doles; in 1732 16 people, and in 1733 I 3 people, were receiving doles totalling respectively $f_{1} \mathrm{I}_{3}$ s. $7 d$. and $f_{\mathrm{I}} 6$ s. $4 d$. a week. There were also frequent payments for the provision of clothing, for nursing at home, and for rents. Occasionally, at least, paupers' children were bound out as apprentices. In June 1785 it was decided to advertise in the Chelmsford papers in order to get 3 or 4 boys placed as apprentices; in the following month one was apprenticed to a baker at Henham.

There is a reference to a parish house in 1714,27 but this may have been only a pest house, which is mentioned in August 1766. In August I 729, however, the vestry resolved that the churchwardens and overseers should look for a convenient place and house for a workhouse, and in September of that year it was resolved to provide a workhouse. In March 1730 it was again resolved that the parish officers should look for a workhouse with all speed, but there does not appear to be any evidence of one until 1742 when it was agreed to take Mr. Rogers's house for three years at $\ell_{8}$ a year. In 1746 the vestry agreed to take the house on a yearly

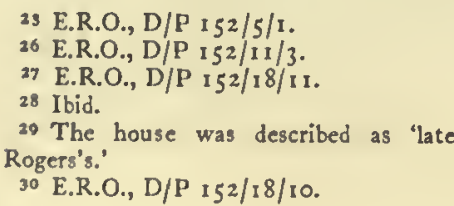

tenancy at a rent of $\{7.28$ Subsequent entries for the payment of the rent make it clear that this was being used as a workhouse, and sometimes describe it as in 'The Street', presumably Coopersale Street. The parish appears to have let an orchard attached to this building to John Palmer at an annual rent of ros. By April I774 the parish had leased another house, Mr. Bishop's, at a rent of $£ 9$. Rogers's house, which in June I 775 was described as 'the old workhouse', was still in use until June 1776 , when the parish accounts record a payment for beer when the people were carried out of 'the old workhouse.' In 1782 the vestry agreed that a house called Newmans, belonging to John Palmer, ${ }^{29}$ should be leased for 2 I years and converted into a workhouse. In 1805 the parish was given notice to quit both Palmer's and Bishop's houses.30 By June 1793 the parish had leased a cottage on the common from the lord of the manor at a rent of $f_{1} 1$ ros.; the parish was given notice to quit this house in 1807.31 In 1829 the parish held a house at Coopersale Common; it was then occupied by William Brown, a 'poor person', who in November of that year was given notice to quit. 32

In February 1774 Edward Robinson was appointed master of the workhouse, in succession to the "late Mr. Jepp', at a salary of I 3 guineas. He was also allowed one pint of ale a day, but was not permitted to charge for tea and sugar brought in. In June 1775 Giles Ashby of Halstead was appointed 'to be the master and mistress of the workhouse' at a salary of 12 guineas, with an allowance of I guinea for tea. ${ }^{33}$ In I 803 the parish made an agreement with Thomas Finch for the farm of the poor. He was to be allowed 35 . a head weekly whilst flour should remain under 3 s. a peck, and to be allowed a surplus according to the exact consumption in the house to be proved by the bills of parcels. He was to provide three meals daily, to include 'hot meat dinner' on Sundays, Tuesdays, and Thursdays. He was also to be allowed the benefit of all the work ${ }^{34}$ produced by the poor in the house, an extra guinea for every lying in with $3^{5}$. a week for the child at one month old, 4 . for every pauper dying in the house (the parish, however, paying the cost of burial), I guinea for loss of time and trouble for every pauper laid up with a broken or fractured limb, and $2 \frac{1}{2}$ guineas for shaving the paupers once a week and for sweeping the chimneys.35 In 1816 the parish contracted with William Nutt for the maintenance of the poor in the workhouse for one year; the contract was renewed in I 8 I 7 , Nutt being allowed 5 s. a head weekly. ${ }^{36}$ There is in the records one undated proposal, from John Stubbs of Orsett workhouse, for undertaking to maintain the poor at $5 \mathrm{~s}$. a head, with an allowance of $I \frac{1}{2}$ chaldron of coal. ${ }^{37}$ In 1828 the parish seems to have found some difficulty in arranging a price per head for the workhouse, and two letters survive from people willing to enter into a contract. ${ }^{38}$

At first it seems that the parish tried to get all its poor into the workhouse, and the weekly doles ceased in 1762 . It was, however, found necessary to reintroduce them during the worst period of the depression at the end of the century, and in November 1799 it was resolved that every family should be allowed is.

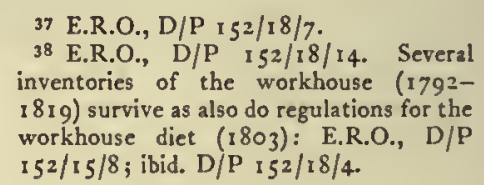
inventories of the workhouse (17921819) survive as also do regulations for the workhouse diet $(1803)$ : E.R.O., D/P $152 / 15 / 8$; ibid. D/P $152 / 18 / 4$ 
a week for every child above the number of two under the age of 10 . There were 37 people in the workhouse in 1793 and 30 in 1805 . In I 81 I the house was enlarged. 39

In 1796 the lord of the manor granted the parish $2 \frac{1}{2}$ acres of waste upon condition that 2 acres be planted with potatoes for eventual sale to the poor inhabitants. Payment for digging potatoes on the common piece is recorded in the account books in October 1797 and in March 1798 there were two entries of money received for 'taters'.

The parish always seems to have given much attention to the relief of the sick poor. The first mention of a parish doctor occurs in I 72 I when Dr. Dimsdale's bill for $£_{5}$ for treating a pauper was settled, and there are other references to the settling of apparently casual bills, but this method seems to have caused some alarm, for in 1729 the vestry, after approving Dimsdale's bill, ordered that for the future no bill was to be allowed, unless those afflicted had procured an order in writing from a churchwarden or overseer, except in an emergency. This order was repeated in 1737 . The last payment to Dimsdale was in January 1742. In April I 743 the parish settled a bill of Dr. Davies for $£$ IO and there is at least one other similar payment, in March 1744, but these may have been casual payments and need not imply a definite contract. The first definite reference to a salaried doctor occurs in 1749 when Thomas Fletcher agreed to take care of the poor of the parish in pharmacy and surgery at an annual salary of 8 guineas; in 1756 Francis Mitten agreed to take the poor under his care and to supply them with physic and attend in all cases of surgery at a salary of 8 guineas, and also to attend every maternity case at $\frac{1}{2}$ guinea a case.40 On one occasion, in June 1764 , the parish resolved to pay Mitten 6 guineas for curing a broken leg; he was then described as surgeon at Epping. In I777, however, Richard Boodle was appointed to attend the poor when necessary and all cases of surgery, midwifery, and inoculation at a salary of ro guineas. The vestry ordered that one of the overseers should wait on Mitten, who was on this occasion merely described as an apothecary, to pay his salary, to return the thanks of the parish for what he had done for the poor, and to inform him that his future attendance was no longer required, as $\mathrm{Mr}$. Boodle was chosen in his place, the parish not thinking 'the parish business an object worth his notice'. Boodle's appointment was to date from Easter I 777, but these arrangements were apparently abortive, since Mitten received salary to Easter 1778 , and Boodle was appointed as surgeon, apothecary, and man midwife at a salary of ro guineas at the Easter vestry meeting of that year. In 1788 William Stewart was appointed apothecary and man midwife at a salary of $\mathbf{1 2}$ guineas; his duties were to include inoculation, and he was to attend accidents to parishioners even if they occurred outside the parish. He was succeeded in 1790 by C. C. Stuart who held the position, on the same terms as his predecessor, at least until April I 806.



ES. IV

51 Kelly's Dir. Essex (1 899 )

52 Inf. from Mr. Temple, Headmaster of the school; Kelly's Dir. Essex (i 870).

53 Reps. on Schs. in Norfolk, Suffolk and Essex, $1858-9$, p. I9 (in Min. of Educ. Libr.).

54 Retns. Elem. Educ. H.C. 201, pp. I 10-II (187 I), Iv.

35 Kelly's Dir. Essex (1899); Rep. of Educ. Cuce of Council, r 880 [C. 2948-r],
In I613-I4 the cost of poor relief was $6^{8.41}$ In 776 it was $£ 355.42$ In $1783-5$ expenditure averaged $£ 295$ a year. 43 In $1800-I$ it reached $\oint_{1}, 152.4$ In 80I-2 the cost was $694 I$ and in $1802-3 \quad f_{762.45}$ ways between $f_{5} 50$ and 6600 a year.46 In $1809-10$ anged between $£ 650$ and $£ 850$ a year, being highest in $1812-13.47$

In 1836 Theydon Garnon became part of the Epping Poor Law Union.

In I 8 I 8 the parish clerk and his wife kept a school at Theydon Garnon, which was attended

SCHOOL by 20 boys and 26 girls. Six of these children attended as the result of a grant from Baker's Charity (see Charities, below) and the fees of seventeen others were paid by benevolent persons. 48 This was still the only day school in the parish I 839 , when 12 boys and I 4 girls attended it. The decline in attendance was probably due to increased educational provision at Theydon Mount and Epping. By that time there was also a Sunday school at Theydon the parish clerk's school. He and an assistant mistress

In $185^{\circ}$ Harriet Archer-Houblon of Coopersale ouse (see above) built a National School and teacher's house at Coopersale. During the following years she contributed much of the school's income and took a t in its work.sI The Vicar of Coopersale supervised the school and local Anglicans conuccessful. In $1858-9$ it had an average attendance of was described by an inspector as 'a fair village chool'.53 By I87 I attendance was over 100.54 It continued to rise and in 1879 Miss Archer-Houblon enlarged the school at a cost of $£ 300$ to provide total accommodation for $I 80$ pupils. In 1880 average attendance was I 17.55 The annual government grant rose 6.37 in 1873 to $f_{1} 128$ in 1902.56

89 I the school was placed under the management of the Rector and churchwardens of Theydon , the Vicar and churchwardens of Coopersale, England, and the National Society became the owner in trust, the deed requiring that religious teaching hould be according to Anglican principles. 57 By the administration of the Essex Education Committee, ping District, as a non-prôvided school. Attendance was I 55 in I9O4, and there was a staff of 4 teachers, a probationer, and a monitress. 58 In I 9 Io the school was urther enlarged, but by 1926 average attendance had allen to 100 . There was a further decrease after the been reorganized in 1932 for mixed junior's and infants. 59 In 1938 there were only 67 pupils but transferred to Theydon Garnon after the closure of their school. In May I 952 there were I 57 pupils and 4 teachers at Theydon Garnon. In view of financial P. 579 , H.C. (1 881 ), xxxii.

${ }_{56}$ Rep. of Educ. Citee. of Council, 1873 [C. rorg], p. 325, H.C. (1 874), xviii; Schs. under Bd. of Educ. 1902 [Cd. 1490], p. 74 , H.C. $\left(\mathrm{s}_{\mathrm{g}} \mathrm{O}\right)$, li.

57 Min. of Educ. File $13 / 366$.

58 Essex. Educ. Citce. Handbk. 1904 , p. $15 \mathrm{x}$.

59 Min. of Educ. File $13 / 366$; Kelly's Dir. Essex (1922). 


\section{A HISTORY OF ESSEX}

difficulties the managers have applied for controlled status. 60 The school is single-storied, of red brick with a tile roof. It bears the date I850. A two-storied teacher's house is attached. In the playground is a prefabricated building added in $194^{8.61}$

In 186 I the Charity Commission held an inquiry into the complex affairs of the charities CHARITIES ${ }^{62}$ of Epping and Theydon Garnon. This revealed that six of the eleven existing charities were in practice managed together. Two schemes were made following this inquiry, which were designed to give legal sanction to this arrangement and to make it more efficient. The first scheme, made in 1863 , dealt with Baker's and Reynolds's Charities. A year later another scheme was made for Archer's, Winstanley's, Mrs. Kirwan's, and Lady Fitzwilliam's Charities. Both these schemes dealt only with the appointment, \&c., of trustees, leaving the trusts unchanged. In 1898 the separation of the ecclesiastical and non-ecclesiastical charities under the Local Government Act of 1894 created three new charities: John Baker's, John Reynolds's, and Elizabeth Cain's ecclesiastical charities. There were already two other ecclesiastical charities, Rogers's and Black's. Another scheme of I go I provided for the management of all the charities except Baker's and Reynolds's church charities and Black's Charity. It regulated the use of all funds applicable to the benefit of the poor: other purposes were left untouched. Money for the poor was to be spent on stipends for inmates of Lady Fitzwilliam's almshouses, the support of coal or clothing clubs or other institutions for the benefit of the industrious poor of the parish, or in gifts in kind to the poor. The income of Winstanley's, Archer's, Lady Fitzwilliam's, Mrs. Kirwan's, and Hylard's Charities, Elizabeth Cain's non-ecclesiastical charity, and half the income of Baker's and Reynolds's non-ecclesiastical charities, amounting in all to 6 I I 153 3s. $8 d$., was spent in 1952 as follows: after the payment of expenses $£ 8$ was given to the provident club and 66 to the school boot club; $£ 42$ was spent on Christmas presents, and $£ 444$ s. Iod. was given to Baker's Educational Foundation.

According to an inscription in the church John Hylard, alderman of London, gave $£ 50$ at an unknown date to the poor of Theydon Garnon. The money was used to buy two houses. In I 834 the original property was supposed to have been sold and replaced by two cottages inhabited by paupers put there by the parish overseer. In 1862 the cottages were in bad repair; they had no endowment and were occupied rent free. The parish successfully resisted attempts to include this charity in the scheme made in I 864 . In I 898 the cottages were occupied by two widows and an annual donation was received from Baker's Charity. After the sale of Lady Fitzwilliam's almshouses (see below) in 1904 their endowment was to be applied to the support of Hylard's Charity. In 1947 the property, which was in Coopersale Street, was sold for 655 . The income from this is spent with that of the other charities for the poor.

Baker's or Stonard's Charity was founded by the will of John Baker of Epping, dated I 5 18. He directed that the profits of his lands called Stonard's were to be used for the care of the highways between Harlow and London and for other charitable works. The profits

60 Inf. from Essex Educ. Cttec.

61 Inf. from Mr. Temple.

62 Unless otherwise stated all information in this section is from Rep. Com. Char. of the wood from part of the property were to be given alternately for the use of the churches of Epping and Theydon Garnon. Part of the property was sold in $1864-5$ for $£ 3,347$ and other small pieces of land were sold at various times so that by 195 I the endowment consisted of $\{2,145$ in stock as well as Stonard's Farm in Theydon Garnon and Epping.

In 1637 a decree was made by the Commissioners of Charitable Uses regulating the charity, which had apparently been mismanaged. A Chancery decree was also made concerning it before 1651 . Between I 814 and 1842 the income was spent on bread and meat for the poor, which was distributed on the Sunday before Christmas. ${ }^{63}$ In 1834 the income from rents was $\oint_{107}$ of which Theydon Garnon received 215 i 55 . In addition $£ 300$ stock was held at that time for Theydon Garnon, chiefly comprising profits from wood. The income from this was used to apprentice the sons of parishioners. Other profits from wood were received in 1805,1806 , and 1822 and were spent on repairing and beautifying the church. In 186 I a donation was given to the parish school and the gifts for apprenticing had been abandoned. In 1952 the Theydon Garnon moicty of the charity's income from rents and dividends was $£ 68$ I 6s. $6 d$.

When the ecclesiastical portion of the charity was split off, the stock held in respect of it was divided between the two parishes. The Theydon Garnon holding is now $£ 793$ 1 5s. 7 d. which is paid into the church expenses account.

Thomas Winstanley, by will dated 1570 , left all his lands in North Weald Bassett in trust to pay 40s. a year to the poor of Theydon Garnon. The property consisted of a house and small pasture called Baker's (later Bulle's). In 1923-4 it was sold for 6310 , which was invested in stock.

Between 1570 and 1834 the rent rose from $£_{2}$ to E12. It was generally distributed to the poor in small sums, ${ }^{64}$ apparently of cash, until 1834 when it was spent on food with Baker's Charity. In 1952 the income was $\mathrm{E}_{12} 5_{5}$. Iod., which was spent with that of the other charities for the poor.

In 1834 a tablet in the church recorded a gift made in 1584 by Henry Archer, who gave to the poor a rent charge of $£ 2$ to be distributed every Whit-Sunday. It issued from the Coopersale House estate (see above, Manors) and in I 834 was distributed with Baker's Charity. The charge was redeemed in Ig I I for $f_{0} 80$ stock which in 1952 produced $E_{2}$.

Anne Sidney, Lady Fitzwilliam, by will proved 1602 , directed that an almshouse should be built in Theydon Garnon and a rent charge purchased to give four poor widows $I 2 d$. a week each. The almshouses were duly built and an annuity of $\delta_{0} 12$ bought which issued from an estate in Stoke Doyle (Northants.). ${ }^{65}$ In 1834 the almshouses were in good repair and were occupied by four old widows who received, in addition to their stipends, I guinea every Christmas. In I 862 three out of the four inmates received poor relief. By 1895 it was becoming difficult to find occupants because of the dilapidated condition of the almshouses and their distance from the village. Eventually in 1923 the land and buildings, then rented as two cottages, were sold for $£ 3$ ro which was invested and produced an income of $f 10$ IOs. $8 d$. in 1952 . The almshouse
(Essex), H.C. 216 , pp. 247-50, 253-5, 6s For copies of demand notes sent to $(1835)$, $x$ ( 1 ) and Char Com files. 63 E.R.O., D/P I $52 / 25 / 2$. 64 E.R.O., D/P I $52 / 25 / \mathrm{I}$. the owners of the estate c. 1780 see E.R.O., D/P $152 / 12 / 6$ and $152 / 8 / 1$. 
building, which still survives, is a low red-brick range dating from the 17 th century. The original four dwellings each consisted of one ground-floor room and a small attic. There are now only two doorways to the front. The brass plates on the doors are comparatively modern. The attics are lighted by casements in the gable-ends and by two small dormers at the back. There are two cruciform chimneys, set diagonally. The brickwork has been much patched and the woodwork in general has been renewed.

John Reynolds, by deed dated I 647, left land in Theydon Garnon in trust for the benefit of Epping and Theydon Garnon. For Theydon Garnon \&4 a year was to be paid to the best-behaved poor, 20s. to the preacher of a sermon on 3 November, and $5^{s}$. to the sexton. The surplus was to be shared between the poor of the two parishes. In 1861 the property was sold for $£_{040}$, which was invested in stock. In 1834 the Theydon Garnon share of the $\mathrm{I}_{5} 5$ rent was spent with Baker's Charity. In $186 \mathrm{I}$ f 1 and 5 s. went to the sermon and the sexton and $6715 \mathrm{~s}$. to the poor in bread and money. In 1952 the Theydon Garnon mojety of the income was $105 \mathrm{~s} .8 \mathrm{~d}$.

In 1898 the ecclesiastical part of the charity was separated from the rest and was to receive L $^{1} 5^{5}$. a year from the Baker and Reynolds non-ecclesiastical charities, to be spent as before. In 1952 the payments were duly made.

Richard Rogers, by will proved 1794 , left $\oint_{0} 100$ in trust to repair his family vault and tomb in the church. The charity was not mentioned in the 1835 Report, but in 1862 the dividend of $£_{3} 3$ was spent in accordance with the trusts. The dividends were not received for some years in the late I 9 th century. In I 933 the income of $£_{3} 3$ was spent on the maintenance of the tomb and vault.
Elizabeth Cain, by codicil to her will proved I 835 , left $f_{\mathrm{I}} \mathrm{roo}$ for the repair and painting of her tomb; any surplus was to go to poor widows in the parish. It was said in 1862 that the tomb was repaired and painted every three or four years and that the surplus was distributed. The stock was held with that of Rogers's Charity and the dividends were similarly lost for some years before 1898 . In 1952 the whole income of 62 Ios. was spent on the poor, since the tomb, the care of which is now a separate ecclesiastical charity, was in good repair.

Mrs. Kirwan, by will proved in or after I 847 , left £200 free of legacy duty in trust for a yearly distribution to the poor of Coopersale. It was apparently originally the gift of her husband, Clement Kirwan. In I 862 the income was spent with that of Baker's Charity. In 1952 the income was 67 is.

In 1790 the Revd. Thomas Abdy, the lord of the manor, provided $2 \frac{1}{2}$ acres of waste of the manor on which the parish officers were to grow potatoes to be sold to the poor at a price sufficient to cover the costs. The parishioners were to maintain the land as a garden for the use of the poor. The arrangement was, however, found burdensome to the parish and Abdy substituted a yearly gift of roo loaves of bread, and, later, of $£_{2}$ in cash. The charity lapsed, however, after his death.

William Black, by deed of 1793 , gave an annuity of 40s. issuing from his house, The Grove, to be distributed on Sundays to communicants. In 1834 the payment was made at Christmas, but from 1904 the rector declined to distribute the charity money, since he looked upon it as a bribe to take the sacrament. Instead the money was given away to the poor in tea and beef. The annuity has not apparently been receiv, since I 9 I 5 and is now presumed to be lost.

\section{THEYDON MOUNT}

Theydon Mount, the most easterly of the three Theydon parishes, lies between Theydon Garnon and Stapleford Tawney at a distance of 3 miles from Epping and 15 miles from London. The second part of its name is derived from the hill near its centre upon which stand the church and Hill Hall. It has also been called in the past Theydon Paulyn, Theydon Lessington, and Theydon Briwes, from the names of former lords of the manor. The form Theydon Parva (Little Theydon) has also been used. ${ }^{2}$ Theydon Mount is a small rural parish that has been dominated for four centuries by the great mansion of Hill Hall, formerly the seat of the Bowyer-Smijth family, and now an open prison for women. Although so near to London the parish remains entirely rural, and sparsely populated. The area was given in 1838 as 1,500 acres. ${ }^{3}$ Later calculations put it as 1,564 acres. 4 In 1086 there were I villein tenant and 17 bordars in the manor of Theydon Mount.5 In 1428 the parish appears to have had a smaller population than at Domesday: it was specially exempted from taxation because there were less than ro households. ${ }^{6}$ The population was 193 in 1801.7 It rose to a peak of 249 in 1831 and then declined steadily to 123 in $190 \mathrm{r}$. The population in I 951 was 162.8

The parish is long and narrow, running from north to south for over 3 miles with an average width of less than $\frac{1}{2}$ mile. The Roding forms the southern boundary. From there the land rises steeply to a height of over $250 \mathrm{ft}$. at Hill Hall, which stands in a large park. The parish church, $\frac{1}{4}$ mile south-east of the Hall, adjoins the park. Farther north the ground falls away but rises again to $300 \mathrm{ft}$. at Mount End and over- $350 \mathrm{ft}$. near the North Weald boundary. There are several patches of woodland in the north of which the largest is Beechet Wood. Apart from Hill Hall with its prisoners the main centres of population are at Mount End, which contains the former parish school, now used as a village hall, and on Mount Hill. A map of I 777 shows a few houses at Mount End. ${ }^{9}$ Some of the. surviving houses there appear to date from the first half of the 18 th century.

From Mount End roads run north-east to Stanford Rivers, east to Stapleford Tawney, south-east to the church, south-west to Hobbs Cross in Theydon Garnon (a farm lane), and west to Coopersale and
I O.S. $2 \frac{1}{2}$ in. Map, sheets 5 r $/ 49,52 / 40$.

2 P.N. Essex (E.P.N.S.) 82-83, 85, which, however, wrongly assigus the form Theydon Paulyn to Theydon Garnon. For the meaning of Theydon see Theydon
Bois.

3 E.R.O., D/CT 351

4 O.S. 6 in. Map (Ist edn.), sheets I, lviii. $\quad$ V.C.H. Essex, i, $490 b$. 6 Feud. Aids, ii, 205.
7 For census figures $1801-1901$ see V.C.H. Essex, ii, 350

8 Census, $195 \mathrm{I}$.

- Chapman and André, Map of Essex, 5777 , sheet $x v i$. 


\section{A HISTORY OF ESSEX}

Epping. The approach to Hill $\mathrm{Hall}$ is by a drive off the Stapleford Tawney road. ${ }^{10}$ North Farm, at the Mount End cross-roads, appears to date from the first half of the I 8 th century. Tarlings, nearly opposite the north lodge of Hill Hall, was formerly a smithy. ${ }^{11}$ About $\frac{1}{4}$ mile south-east of North Farm is the site of a former brick and tile works. The new rectory has recently been built here. ${ }^{12}$ Near the rectory, in the lane leading to Beechet Wood, are two pairs of council houses. Coleman's Farm, 1 mile east of Hill Hall, is about 50 years old. There was a building on this site in 1777 , then called Cotes. ${ }^{13}$ Near Coleman's, on the edge of Hill Hall park, is Icehouse Plantation, which probably takes its name from the former icehouse of Hill Hall. This may have dated from the 17 th or 18 th century. ${ }^{14}$ In the extreme south of the parish is Skinners, a timberframed house to which a gabled brick front was added late in the rgth century. In the dairy is the threecentred arch of a former oak doorway in which a mullioned window has been inserted. This suggests that the house dates from the I6th century or earlier. Brook House, $\frac{1}{2}$ mile west of Skinners, probably dates from the early 18 th century. ${ }^{\text {Is }}$

The lane from Mount End to Hobbs Cross and part of the road from Mount End to Stanford Rivers follow the line of a Roman road. Roman remains were found in this area in the Igth century. ${ }^{16}$ The Hobbs Cross road was presented at Quarter Sessions in $1582-3$ as a 'noisome way'. ${ }^{17}$ The road to Coopersale, which now passes to the north of North Farm, is shown on the 1777 map as farther south. ${ }^{8}$ Between 1777 and about I 800 Hill Hall park was extended to the east. This involved the diversion of the road so as to bring the church within the park, from which it was fenced off in 1953-4.19 About this time the old rectory near the church was demolished ${ }^{20}$ and (perhaps somewhat later) the former manor house of Mount $\mathrm{Hall}$ was also taken down. ${ }^{21}$

For transport and postal services Theydon Mount has depended upon Epping and Romford. Piped water is supplied by the Herts. and Essex Waterworks Co. ${ }^{22}$ but there is no main drainage. ${ }^{23}$ Electricity was supplied by the Eastern Electricity Board in 1950.24 A branch of the county library was opened in $1935^{25}$ The village hall is the former school.

From the I 5 th century until the 2oth most of the and in the parish was in the hands of a single owner. With the building of Hill Hall in the I6th century the parish became more than ever dominated by the manor house. In $1838 \mathrm{Sir}$ John Smijth owned all but some 70 acres of the parish. ${ }^{26}$ The Hill Hall estate had increased in size since 1700 , when three other owners had land in the parish. ${ }^{27}$ During its four centuries as a private house Hill Hall must have provided substantial opportunities for local employment. Those of the inhabitants of the parish not employed there were mainly engaged in agriculture. There has been very little industry in Theydon Mount. The market and fair granted to Paulinus de Theydon in 1225 (see below, Manor) did not survive into modern times. One industry, brick- and tile-making, appears to have gone on (perhaps intermittently) from the 16 th century to the 2oth. The brick-works to the north of Hill Hall was still in operation in $1914 . .^{28}$ It was perhaps the successor of the works from which bricks were provided about 1580 for the completion of Hill Hall itself,29 and of the brick kiln 'on the top of Mount Hill' in $1655^{30}$

Before 1066 THEYDON MOUNT was held by Godric as a manor and as 3 hides and 80 MANORS acres. After the Conquest it was given by William I to Robert Fitz. Wimare, who was still alive in 1069 but had been succeeded in or before 1075 by his son Swein. Robert was Sheriff of Essex and the office was later held by Swein. ${ }^{31}$ Swein made his castle at Rayleigh, which became the head of his honor and from that time the manor of Theydon Mount was always held of the Honor of Rayleigh. ${ }^{32}$ In 1086 the manor was held of Swein by one Robert. ${ }^{33}$ Swein was succeeded by his son Robert of Essex, the founder of Prittlewell Priory, and Robert of Essex was succeeded by his son Henry of Essex. ${ }^{34}$

In I 63 Henry of Essex, then Constable of England, failed to clear himself of a charge of cowardice during a war against the Welsh, and was deprived of all his lands. ${ }^{35}$ Henry II appears to have granted 3 knight's fees in the Honor of Rayleigh to one William, thereafter known as William de Theydon. This William was apparently alive in I $194 . .^{36}$ Upon his death these lands passed to Robert de Theydon, probably his son. Robert or a namesake had had the wood at Theydon as early as 1163 and when this property was taken by the king he received compensation of 20 s. a year. ${ }^{37}$ Robert was succeeded by his son Henry de Theydon who seems to have been in possession of Theydon Mount early in the reign of John. In I 2 I 5 Henry was one of the garrison of Rochester castle when it surrendered to the king. ${ }^{38} \mathrm{His}$ lands were undoubtedly taken in to the king's hands but in 1217 Henry's son Paulinus de Theydon was granted the lands formerly held by his father in Gloucestershire ${ }^{39}$ and it is probable that he received Theydon Mount at the same time. Paulinus certainly held Theydon by 1225 when he was given licence to hold a weekly market and an annual fair there.40 In 1227 he was also granted deer for the park.41 He died in or shortly before January
10 For Hill Hall see Manors, below. and see below, Manors.

11 O.S. 6 in. Map (1st edn.), sheet Iviii.

12 See Churches, below.

13 Chapman and André, Map of Essex, 1777, sheet xvi.

$14 \mathrm{Cf}$. Icehouse Wood near the site of Bellhouse in Stanford Rivers.

is 'Brock House', mentioned 1600 (E.R.O., Q/SR 149/43), may have been on this site.

16 Proc. Soc. Antig. (2nd ser.), ii, 184-6; iv, 446.

i7 E.R.O., Q/SR 84/24.

18 Chapman and André, Map of Essex, I777, sheet $x v i$.

19 Ibid. Cf. O.S. I in. Map (Ist edn.).

20 See Churches, below.

21 In $183^{8}$ there was only a eottage on the Mount Hall site: E.R.O., D/CT 351 ;
22 Inf. from Herts. \& Essex Waterworks Co. About 1900 Mount End was supplied with piped water from a well dug by Sir William Bowyer-Smijth: Howard and Burke, Theydon Mount, xi.

23 Inf. from Rev. E. B. Rees.

24 Inf. from Eastn. Elec. Bd.

23 Inf. from County Librarian.

26 E.R.O., D/CT 351.

27 J. J. Howard and H. F. Burke, Theydon Mount, xi.

28 Kelly's Dir. Essex (1914)

29 Sec Hill Hall.

30 E.R.O., D/DSh T2.

3I V.C.H. Essex, i, 490b. For the date of Robert's death see: H. W. C. Davis, Regesta Regum Anglo-Normannorum, 22; J. H. Round, Cal. Docs. France, 2I;
Freeman, Norman Conquest, iv, 736

32 Cf. Wards 5/3/1203 (Feodary Survey Apr. 1632 )

33 V.C.H. Essex, i, $490 b$.

34 J. H. Round, Geoffrey de Mandeville, 391.

3S This paragraph is based on A. L. Browne, 'The de Theydon Family', E.A.T. N.S. $\times x i, 84-88$ and J. H. Round, "The Manor of Theydon Mount', ibid. xii, 198-202. For Henry de Essex see p. 287 .

36 Rot. Cur. Reg. (Rec. Com.), i, I 22.

37 Pipe R. 1163 (Pipe R. Soc. vi), 22, and later Pipe Rolls.

38 Ror. Lit. Pat. $18 \mathrm{gb}$.

39 Rot. Lit. Claus. i, 320.

40 Ibid. ii, 62 .

41 Ibid. 180 . 
1233, when Walter de Evermue was granted the custody of the daughter and heir of Paulinus. ${ }^{42}$ Paulinus had held 3 knights' fees in 'Theydon and Little Wakering. ${ }^{43}$

Beatrice de Theydon, daughter of Paulinus, married before I 236 Robert de Briwes. 4 In I 239 Robert and Beatrice were granted a weekly market and annual fair in their manor of 'Theydon.45 In 1248 the manor and the advowson of the rectory were sub-infeudated for I 00 marks to John de Lessington, to hold of Robert and Beatrice and the heirs of the latter, doing service of 2 knights' fees at the court of the Honor of Rayleigh.46 An inspeximus of the accompanying charter gives the consideration as 1,000 marks and the object to acquit Robert and Beatrice of what they owed to the king as executors of the will of Hubert de Burgh and of their debts to the Jews for themselves and for Walter de Evermue their ancestor.47 In 1250 John de Lessington had licence to keep inclosed, with a hedge and ditch, the close which he had made in the wood of his manor of Theydon, but so that the deer could have ingress and egress. 48 He died in 1257 holding the manor, which contained 3 carucates of land, of Robert de Briwes for the service of 2 knights' fees. His heir was his brother, Henry de Lessington, Bishop of Lincoln.49 The bishop died in 1258 , being succeeded by his two nephews William, son of Roland de Sutton, and Richard de Markham. ${ }^{50}$ They divided this inheritance (which lay in several counties) between them in I 259, Theydon Mount falling to Sutton's share.51

William de Sutton was succeeded by his son Robert, who was a supporter of Simon de Montfort and forfeited his property to the king after the battle of Evesham.s2 The township of Theydon Mount was

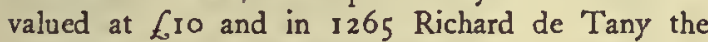
younger received the Michaelmas rent of 405.53 In October of the same year the king granted the manor to Robert de Briwes, presumably the same man who had sub-infeudated to John de Lessington in 1248 . But Richard de Tany, who was lord of the adjacent manor of Stapleford Tawney, coveted Theydon Mount, put out de Briwes, and in support of his action produced a charter dated three days earlier than that of de Briwes and contrived to have it entered on the Charter Roll. De Briwes declared de 'Tany's charter to be a forgery and upon investigation by the justices coram Rege this was proved to be the case. The chancery official who had the Chancellor's list of grants admitted that de Tany had said to him "Theydon is a pretty manor and lies next to mine at Stapleford; it would just do for me', and had clearly responded to the hint.s4

In 1269 Beatrice daughter of Henry de Terays released to Sir Robert de Briwes all her right in the manors of Theydon and Wakering and in all the lands late of Paulinus de Theydon and the said Henryss and when Robert went on pilgrimage to Pontigny in I 273 he appointed William and Richard del Jardyn to prosecute his right to the custody of Theydon Mount.56

The manor must, however, have been restored to Robert de Sutton, possibly as a result of the Ban of Kenilworth, for on his death in 1274 he was found to hold in Theydon Mount a messuage, 200 acres of arable, 2 I acres of meadow, 5 I acres of pasture, a. windmill, foreign wood, and 645 s. $6 \frac{1}{2} d$. rent of assize, $\& c$., of the Honor of Rayleigh by service of suit at the court of the honor,a gilt spur or $6 d$. yearly, and scutage for 2 knights. His heir was his son Richard, aged 8.57

Robert de Briwes, the former mesne lord, died in I 276 , leaving his son John as his heir. $\mathrm{s}^{8}$ No further references have been found to their lordship, the tenants in demesne thenceforth always bolding immediately of the Honor of Rayleigh.

In I 282 a commission of oyer and terminer was issued touching the persons who felled and carried away trees in the wood of "Theydon Lessington' late of Robert de Sutton the younger, while in the hands of Oliver de Sutton, Bishop of Lincoln, who had custody of the land and heir.59 In I 303 Richard de Sutton was returned as holding $\frac{1}{2}$ fee of the king of the Honor of Rayleigh.60 In 1308 he had licence to grant the manor of Theydon Mount in fee to his son John de Sutton and Margaret his wife.61

In 1322 John de Sutton leased the manor for twelve years to Henry de Malyns and in the following year released to him all his right in the property. Malyns must have died soon after, for in 1324 John de Sutton released his right in the manor to Edmund de Malyns, Henry's son and heir. ${ }^{62}$ In 1326 Edmund was pardoned for acquiring in fee this property which was held in chief of the Honor of Rayleigh and entering upon it without licence. ${ }^{63}$ In 1346 he held $\frac{1}{2}$ knight's fee in Theydon Mount. ${ }^{64}$

Sir John de Sutton of Dudley (Worc.), son of the above John and Margaret de Sutton, disputed de Malyns' title to the manor, claiming that it descended to him after the death of his parents. In 1348 and again in I 350 the matter was heard before the court of Common Pleas, but Malyns evidently won his case. ${ }^{65}$ He was apparently alive in 1357 but had been succeeded by his son Reynold Malyns before December I36r, when the latter presented to the rectory of Theydon Mount. ${ }^{66}$ Sir Reynold died in 1384 holding the manor jointly with his wife Florence. His son and heir was Edmund Malyns. ${ }^{67}$ Florence was still holding the manor in 1390.68 In 1400 the manor was conveyed by Thomas Waller and two others, presumably feoffees, to Reynold Malyns and his wife Alice and the beirs of Reynold. ${ }^{69}$ In 141 8 Reynold and Alice conveyed the manor of Theydon Mount and Hill Hall (see below) to feoffees to hold of the chief lords with successive remainders to the heirs of Reynold and then to Edmund Hampden and his heirs. ${ }^{70}$ In 1428
42 Cal. Close, 123 I-4, 18 s; cf. Cal. Pat. $1225-32,334$.

$43 B k$ of Fees, 1463.

44 The following paragraph is based on

E.A.T. N.8. xii, $198-202$.

45 Cal. Chart. 1 226-57, 244.

46 Feet of F. Essex, i, 179 .

$47 \mathrm{Cr}_{4} 6 / 9852$. This is the original

inspeximus and fills the gaps given in Cal.

Chart. $1226-57,346$.

4 Cal. Pat. $1247-58,64$.

40 Cal. Ing. p.m. i, pp. 102-3.

so Ibid., p. rog.

s1 Feet of F. Essex, i, 232-3.
52 A William de Sutton died in 1268. If this was the lord of Theydon Mount he must have made over the manor to his son before his death: Cal. Ing. p.m. i, p. 2 I 5. s3 Cal. Ing. Misc. i, 200.

st E. F. Jacob, Baronial Reform and Rebellion, I99-201, 376-8; Cal. Chart. $1257^{-1} 300,57$; E.A.T. N.s. xx, $164-5$.

ss Cal. Chart. 1257-1 300, 123.

s6 Cal. Close, $1272-9,50$.

s7 Cal. Ing. p.m. ii, p. 43 .

58 Ibid., p. I 19.

s9 Cal. Pat. 1 $281-92,92$.

60 Feud. Aids, ii, 136.
61 Cal. Pat. 1307-13,69.

62 Cal. Close, $1330-3,290-1$.

63 Cal. Pat. 1324-7, 251.

64 Fend. Aids, ii, 160

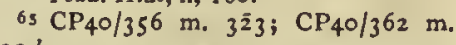
$20 d$.

${ }_{66}$ Cal. Close, I 354-60, 316 ; Newcourt,

Repert. ii, 585 . $67 \mathrm{Cr}_{36 / 36 / 9}$.

$68 \mathrm{C}_{143 / 409 / 7}$.

69 Cat. Anct. D. vi, C. 4794 .

70 Feet of $F$. Essex, iii, 267. The Hampden and Malyns families were related by marriage: Lipscomb, Hist. Bucks. ii, 302. 


\section{A HISTORY OF ESSEX}

Reynold was found to hold $\frac{1}{2}$ fee in Theydon Mount formerly held by Richard de Sutton. ${ }^{71} \mathrm{He}$ died in 1431. There is no specific reference to Theydon Mount in his will, nor any mention of children, 72 and in $\mathbf{1 4 3 4}$ Alice his widow released her right in the manor to Sir Hugh Halsham, kt., and others who held it by her feoffment. ${ }^{3 ?}$

Thomas Hampden died holding the manor in 1486.74 He was the grandson of an Edmund Hampden who died in 142075 and who was probably the man upon whom the remainder of the manor had been settled in 1418 . If this identification is correct the manor had probably passed after the death of Alice Malyns to John Hampden (d. I450-1), son and heir of Edmund and father of the above Thomas. Thomas's heir was his son John, but Theydon Mount was left to his widow Margery. ${ }^{76}$ She appears to have held it until her death in 1506 , as her will refers to her property at Hill Hall.77 The manor then seems to have passed to her grandson (Sir) John Hampden, son of John Hampden. In 1532 Sir John settled it, excepting chief rents, for the jointure of his wife Philippa, daughter of William Wylford of London, merchant. ${ }^{78}$ In 1548 he further settled the manor upon himself and his wife for their lives, with remainder to Edward Ferrers son of one of Sir John's daughters, and his wife Bridget, daughter of William, Lord Windsor, in tail.79 Sir John Hampden died in 1553 and in the following year his widow married Sir Thomas Smyth, son of John Sinyth of Saffron Walden.80 Sir Thomas ( 15 I 377) Secretary of State under Edward VI and Elizabeth I, Ambassador to France I 562-6, and author of $D e$ Republica Anglorum, lived at Theydon Mount and started building the present Hill Hall. ${ }^{81}$ In 1556 he purchased from Ferrers and his wife their reversionary interest in the manor in return for an annuity of 636 s. $8 d$. payable during the life of Philippa and of f. 30 thereafter. In $1559-60$ Ferrers released to Smyth all his interest in these annuities, binding himself in the sum of 6400 to join with his wife in a final concord to extinguish her rights therein. Ferrers, however, never carried out this obligation and Smyth brought an action in Chancery, complaining that Ferrers had died leaving neither goods nor lands in fee simple, whereby he might have execution of the recognizance, and that Bridget, who had later married Andrew Ognall, had refused to make her release, so that Smyth still remained charged with the payment of the rents. It was also alleged that just before the conveyance of 1556 Ferrers had leased the manor in two parts, one part with the mansion house of Mount Hall to Robert Fynche for an annual rent of $f_{20}$, the other part called Hill Hall to Thomas Luther and his mother for fro a year, so that Philippa lost her jointure. In consequence of this, according to Smyth's statement, her brother John Wylford had put into execution a bond under which Ferrers was obliged to maintain the jointure, and it was for this reason, among others, that Ferrers had sought financial help from Sir Thomas in return for the sale of his reversionary interest in the manor. In
1576 the case was decided in Sir Thomas's favour. ${ }^{82}$

During Sir 'Thomas Smyth's tenure of the manor it was said to be held of the Honor of Rayleigh at an annual rent of 3 s. $8 d .83$ He died in 1577 and his wife in 1578 . The manor then passed under a settlement made by Sir Thomas shortly before his death to his natural brother George Smyth. George died in 1584 and the manor passed successively to his son (d. 1626 ) and grandson (d. 1632), both named Sir William Smyth. Edward, son and heir of the second Sir William, died in 1652 , being succeeded by Thomas, brother of that Sir William, who was created a baronet in $\mathbf{r} 66 \mathrm{r}$. The manor subsequently descended with the baronetcy of Smyth (later Bowyer-Smijth) until r9I6, when the I 2 th baronet, Sir William Bowyer-Smijth, died unmarried. 84 The baronetcy then passed to a cousin of the 12 th baronet, but the manorial rights of 'Theydon Mount seem to have passed to his sisters, Mrs. Battye and Mrs. Northcote. ${ }^{85}$ In the later title deeds of the manor it is always called Mount Hall.

For the manor houses of Mount Hall and Hill Hall see below, Hill Hall.

The manor of HILL HALL was held of that of Theydon Mount. In 1373 Richard de Northampton, herald, and Katherine his wife made conveyance of a messuage, 210 acres of land, 28 acres of meadow, 4 acres of wood, and $8 d$. rent in Theydon Mount and Theydon Garnon, and properties in Hertfordshire. ${ }^{86}$ In 1384 they conveyed the same properties to John Cokyng, Robert Somerset, and Thomas de Kent, presumably as feoffees. ${ }^{87}$ In his will, proved in 1389 , Northampton left the 'manor of 'Theydon Mount' to his wife Joan to support a chaplain in the church of Theydon. ${ }^{88}$ Soon after the probate Cokyng, Somerset, and Kent granted an annual rent of ro marks to John Hemersthorp and others from the manor of Hill Hall and a few days later they conveyed to Nicholas Exton, alderman of London and Joan his wife all the properties conveyed to them in $1384 .{ }^{89}$ In 1390 they received the royal licence to found a chantry in the church of Theydon Mount and endow it with $\frac{1}{2}$ acre of land and ro marks rent from the manor of Hill Hall. The manor was then said to be held of Florence Malyns as of her manor of Theydon Mount by knight service and an annual rent of $\mathrm{I} 5$ s. 7 d., $\mathrm{r} \mathrm{lb}$. wax, $\mathrm{I} \mathrm{lb}$. pepper, and 2 capons, and besides the above land and rent $\mathrm{Hill} \mathrm{Hall}$ was worth $40 \mathrm{~s}^{9} 90$ In I $39 \mathrm{I}$ it was found that the licence was not valid as Hill Hall was not a manor, and a new licence was issued in which the phrase "issuing from their messuage, 2 ro acres of land, 28 acres of meadow, and 4 acres of wood' was substituted for 'issuing from the manor called Hill Hall'. ${ }^{91}$ In 1397 Walter Pynchon of London and Joan his wife quitclaimed to William Gascoigne and four others properties described in the same terms as in the conveyances of 1373 and 1384.92 This suggests that Joan Pynchon was formerly Joan Exton, and she may also have been identical with Joan widow of Richard de Northampton.
"1 Feud. Aids, ii, 222.

72 Reg. of Hen. Chichele, Abp. Cant.

(1414-43), ed. E. F. Jacob, ii, 453-4.

73 Cat. Anct. D. vi, C. 5547.

74 Cal. Inq. p.m. Hen. VII, i, p. 50.

73 Lipscomb, Hist. Bucks. ii, 232-3.

76 P.C.C. 27 Logge.

77 P.C.C. I Adeane. After Hampden's death she had m. Ried. Godfrey. ${ }_{78} \mathrm{C}_{54 / 426}$, No. 34 .
79 Shakespeare's Birthplace, Stratfordupon-Avon, Baddesley Clinton Deed 313.

80 Visits. of Essex (Harl. Soc.), ror.

81 For his career see D.N.B.

$82 \mathrm{C}_{7} 8 / 47 / 28$.

83 E.R.O., D/DU $40 / 78$

$84 \mathrm{C}_{142 / 180 / 36 ;}$ G.E.C. Complete Baronetage, iii, 234-7; the form Smijth was adopted in the 18 th cent. and the additional name of Bowyer in 1839 . 8s Kelly's Dir. Essex (1937). Inf. from the Revd. E. B. Rees.

86 Feet of F. Essex, iii, 170.

87 Ibid. 202.

88 Commissary of London 185 : Courtney.

89 Cal. Close, $1380-02,60$

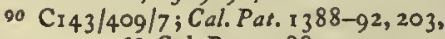

224. 91 Cal. Pat. I388-92, 290.

92 Feet of $F$. Essex, iii, 228. 
In and after I 4 I 2 Hill Hall descended along with the main manor of Theydon Mount, and was sometimes styled a manor. The above account suggests that Hill Hall may originally have formed the demesne of the manor of Theydon Mount. From the I 6th century onwards the mansion of Hill Hall was the seat of the lords of the manor of Theydon Mount. It remained so until towards the end of the I 9 th century, when it was for some time unoccupied.93 From about I 900 to I 908 it was let to an eccentric who called himself the Duke de Moro. 94 Soon after 1908 Charles Hunter became the tenant.95 Mrs. Charles Hunter left the house in 1925 and in the same year it was bought by Sir Robert Hudson. 96 It was subsequently the residence of Lady Edward Hay, was later acquired by the Prison Commissioners, and in 1952 was opened as an open prison for women. 97

When Sir Thomas Smyth acquired Theydon Mount on his marriage to Sir John Hampden's widow there were two houses there. These were known as Mount Hall and Hill Hall,98 and probably represented a survival from the time when the two manors were in separate ownership. Mount Hall is thought to have stood about 100 yds. north of the church and to have survived as a farm-house until the I gth century.99 It then disappeared during improvements to the southeast corner of Hill Hall park.' The position of the original Hill Hall is not known. The present brick mansion, which stands on a commanding site about $450 y$ ds. north-west of the church, was largely the work of Sir Thomas Smyth himself. If in the first instance he made additions to an existing medieval structure, all trace of this has now vanished. It is true that some features of the present Hill Hall are slightly earlier in style than the rest of the house but these are unlikely to date from before the middle of the I 6 th century. Even at this period the use of brick in a richly timbered area was an innovation.

Evidence concerning the exact dates of Sir Thomas Smyth's work at Hill Hall is conflicting. According to Strype the shell of the house was finished in $1568 . .^{2}$ In Smyth's own diary (not used by Strype) the following entries occur:

I 557 Montaulam aedificavi.

I 558 Aedificavii adhuc Montisaulam.

I 568 Coepi aedificare fortius et splendidius partes boreales et occidentales Montisaulae.

I 569 Hoc anno perfeci. ${ }^{3}$

It has been suggested that these entries may refer to Mount Hall, and that Smyth did not start work on Hill Hall until some years later. 4 Certainly much still remained to be done at Hill Hall at Smyth's death in $\mathrm{J} 577$, and he made provision in his will for the completion of the house. He left $f 20$ to his chief architect ${ }^{5}$ Richard Kirby, to be paid when the building was tiled,



August I 577 Philippa, Sir Thomas's widow, agreed with his executors to allow them the materials from 'within the ground of Hill Hall or Mount Hall' to make 150,000 bricks and sufficient wood and straw for two years as shall suffice for the covering and furnishing of the said new building'.7 Four years after Smyth's death $f_{0} 800$ had already been spent by his executors and the house was still unfinished. 8 It was then explicitly stated that 'some few years' before his death Smyth had 'laid the plot of a fair and goodly house of brick'.9 At the time of his death Smyth had had personal possessions at both Hill Hall and Mount Hall.1a From I 554, when he married Philippa, until at least I 557 he appears to have lived at Hill Hall, while Thomas Luther lived at Mount Hall."I In several documents relating to 'Theydon Mount at this period there is confusion of nomenclature between Hill Hall and Mount Hall. ${ }^{12}$ On the whole, however, it seems probable that the building of the present Hill Hall was carried out in two stages, the first being finished in 1569 and the second, more ambitious stage being started some time later, during the last years of Sir Thomas's life.

The courtyard plan on which Hill Hall is built follows the usual arrangement of the Tudor period, but the special architectural interest of the house lies in its early use of renaissance detail, in particular the application of classical orders to the external walls. These are carried out in plaster, intended to simulate stone. The fact that much of the plaster was replaced by cement in the I 9 th century has led some authorities to suppose that the external orders were applied at that time. ${ }^{13}$ There is ample evidence, however, that they were part of the original design. Sir Thomas Smyth was one of a group of notable men who had been associated with the Protector Somerset when old Somerset House, probably the first building in the country to use classical detail on an extensive scale, was being constructed. The influence of Somerset House is seen in the subsequent building activities of other members of the group including Sir John Thynne and William Cecil, later Lord Burghley. ${ }^{34}$ Sir William Smyth's own interest in architecture is proved by the existence in his library of several editions of Vitruvius. ${ }^{\text {Is }}$ The early renaissance style in this country owes more to French than to Italian influence and Sir Thomas had special opportunities of observing the architecture of France during his embassies abroad. The details in the courtyard at Hill Hall have been compared with those at the château of Bournazel near Toulouse. ${ }^{16}$ Smyth stayed at Toulouse in 1565 and again in $157 \mathrm{I} .{ }^{17}$ The external columns at Hill Hall are known to have been in existence in the 17 th and 18 th centuries and to have been accepted then as the work of Sir Thomas Smyth. ${ }^{18}$

Another outstanding feature of $\mathrm{Hill} \mathrm{Hall}$ is the set of
93 Kelly's Dir. Essex ( 1895 )

94 Ibid. (1902); E.R.O., Sale Cat. A. 68.

os Kelly's Dir. Essex (1912).

96 E.R.O., Sale Cat. A. 6; E.A.T. N.8.

xix, 74 .

97 E.R. xliii, 117. Inf. from Min. of Works.

${ }_{98} \mathrm{C}_{2} \mathrm{r} / \mathrm{S}_{3} / 5$.

99 See above, p. 276.

Ibid.

3 J. Strype, Life of Sir Thos. Smyth (orig. $1698 ; 1820$ edn.), 173.

3 Archeologia, xxxviii, 119 (orig. B.M. Add. MS. 325).

4 This is the view of Mrs. M. Dewar who is now preparing a biography of $\mathrm{Sir}$ Thomas Smyth.

3 In the sense, then current, of a senior artificer who sometimes, but not always, made the original drawings for a building. In this case it seems clear that the design was by Sir Thomas Smyth himself.

6 Strype, op. cit. 171.

7 E.R.O., D/DSh T 25.

$8 \mathrm{C}_{7} 8 / 124 / 1$.

$10 \mathrm{C} 2$ Eliz./S $17 / 43$.

$11 \mathrm{C} 21 / \mathrm{S}_{3} / 5$.

12 e.g. $\mathrm{C}_{7} 8 / 124 / \mathrm{I}$, in which Hill Hall is also referred to as Mount Hall.

13 Hist. Mon. Com. Essex, ii, 235-6;
H. Avray Tipping in Country Life, $x$ li (1917).

14 For the activities of these men in Elizabeth's reign see John Summerson, Architecture in Britain, $1530-1830,17-$ 20.

is Strype, op. cit. 274-81 (Catalogue of Sir Thos. Smyth's library at Hill Hall, I 566).

16 N. Pevsner, Bdgs. of England, Essex, 354 .

17 Strype, op. cit. 88, 100.

18 Ibid. 172 ; W. Watts, Seats of Nobility and Gentry $\&^{\circ} c$., pl. 84 (engraving 1780 and descriptive note). 


\section{A HISTORY OF ESSEX}

I6th-century wall-paintings, some discovered as recently as 1951. A modern authority has described their technical accomplishment as "without parallel among surviving examples in England'. 19

The subsequent history of the house involved many alterations, making it difficult to date accurately the different parts of the building. The first major reconstruction took place in the late 17 th and early 18 th centuries when the east range was rebuilt by $\mathrm{Sir}$ Edward Smyth, 2nd bt. ${ }^{20}$ The work was probably completed by his son. Early in the I 9 th century there were alterations and restorations by Sir William Smijth. Soon after 1912, during the tenancy of Mrs. Charles Hunter, the house was extended and the interior much embellished by Mr. (later Sir) Reginald Blomfield.21 In 1940 the explosion of a German landmine near the west range caused considerable damage. In 1950-2, when the building was being prepared for its use as a prison, a thorough restoration was carried out by the Ministry of Works under the direction of its Ancient Monuments Inspectorate.

As it stands today Hill Hall consists of four ranges of building enclosing a central courtyard. In the main it is of two stories, but at the ends of the south front there are two tower-like projections, each of three stories. A lower wing continues the line of the north range at its west end, and north of this is a single-story service wing. At the junction of the north and west ranges there is an octagonal angle buttress. The projecting wing contains the remains of a gatehouse which has a three-centred arch and a semi-octagonal stair turret flanking it. All these features are typically Tudor in character, and it is possible that they were the work of Sir Thomas Smyth during an early phase of his building at Hill Hall. One authority has suggested that they were in existence before his time. ${ }^{22}$ The north range itself has mullioned and transomed windows and in the centre are moulded Tudor arches leading into the courtyard. At least one of the massive chimneys is original. Internally the first-floor rooms of this range are decorated with wall-paintings of Sir Thomas Smyth's time representing the story of Cupid and Psyche. These have been identified as copies of a set of contemporary engravings after paintings by Michael Coxic (b. 1499). ${ }^{23}$ They were probably executed by a foreign artist. Each of the scenes has life-size figures surrounded by a wide border of fruit and foliage. Parts of two scenes were discovered in 1940 and presented to the Victoria and Albert Museum. Three others, which came to light in $195 \mathrm{I}$, have been restored and left in situ. ${ }^{24}$ Traces of the painted border elsewhere suggest that the series originally extended over the whole first floor of the north range. At the north-west corner of this floor and possibly at one time extending into the west range is a set of biblical subjects. These are at frieze level, probably indicating that the lower part of the room was panelled. The two most complete of the remaining pictures show Hezekiah at the temple door and the destruction of Sennacherib. The latter scene has always remained exposed and it is possible that others were not papered over until early in the 19 th century. ${ }^{25}$ Other early features in the north range include an oak staircase, possibly not in its original position, a stop-moulded door-frame, and several plastered fireplaces. An elaborately carved overmantel, formerly on the ground floor, ${ }^{26}$ is now missing. At one time the courtyard windows in this range contained a quantity of stained glass, all reset.27 Many of the heraldic subjects, including the arms of Smyth, the Tudor Royal Arms, and the crowned badges of Henry VIII and Elizabeth I, date from the time of Sir Thomas Smyth. One scene from a set of the Seven Deadly Sins described by Strype 28 was still in existence in 1920. The glass was damaged in 1940 and is still under repair. Some has been reset in other windows of the house.

In the courtyard all four walls have a classical treatment now generally believed to be the design of Sir Thomas Smyth. It consists of a somewhat unorthodox version of two superimposed Roman orders, Doric below and Ionic above. The widely spaced Doric columns stand on high bases and support an enriched entablature resting on a row of modillions. The imitation stone appears to have been renewed early in the igth century.

Across the courtyard the south range contains the great hall with the original kitchen adjoining it on the west. Two kitchen fireplaces with massive arches were uncovered in $195 \mathrm{I}$. Both these rooms, or parts of them, originally extended to the height of two stories. The chambers above are partly in the roof and have I6th-century brick dormers, whereas elsewhere in the house the attics are modern insertions. The fittings of the great hall were always classical in character. The fireplace still exists and has half-round Doric pilasters and a pediment. Its ornament includes a bust of Sir Thomas Smyth and shields bearing his arms and those of his second wife's family. Two oak screens have been replaced by the present imitation marble columns. ${ }^{29}$ The west screen had round-headed openings and Corinthian columns on high bases. Above it are the arms of Elizabeth I. The two-story screen on the north side may have been altered in the I 8 th or early 1 th century. It is said to have been used originally for the display of a collection of armour which largely disappeared at the time of the Commonwealth. ${ }^{30}$

The south front of this range has an applied classical order with a deep entablature at eaves level and large Doric columns at the angles of the two projecting towers. If these last are the work of Sir Thomas Smyth they represent an isolated and very early example of the use of giant columns in this country.

The first extensive alterations to the house were probably completed in 1714 , a date which appears on the rainwater heads of the east front. The sash windows on the south and west fronts may have been inserted at this period. The north front was brought up to date by the addition of a central pediment (now missing), a Doric portico, and a clock turret surmounted by a bell cupola. The absence of any older work inside the east range suggests that it was built or rebuilt at this time. Facing east a fine new façade was contrived in the style of Queen Anne and during the
19 J. E. A. Roberts, Burlington Mag. xxviii, 9 .

20 Strype, op. cit. 172.

21 H. A. Tipping, in Country Life, xli.

22 Ibid.

23 Burlington Mag. lxxviii, 86-92.

24 All inf. concerning the restoration of
I $950-2$ was supplied by the Anct. Mons. Inspectorate, Ministry of Works. For photos. of the newly discovered paintings see Illus. Lond. Nerus, 5 July I 952.

2s Penny Mag. I9 July I $845,278$.

26 Hist. Mon. Com. Essex, ii, 236.

27 Ibid. The MS. records of the Hist.
Mon. Com. include a complete list of the glass existing in 1920.

28 Strype, op. cit. $17^{2}$. He gives 1569 as the date of this glass.

29 Country Life, $x x, 22-25$ has photos. of the screens before alteration.

so Strype, op. cit. $172 \mathrm{n}$. 


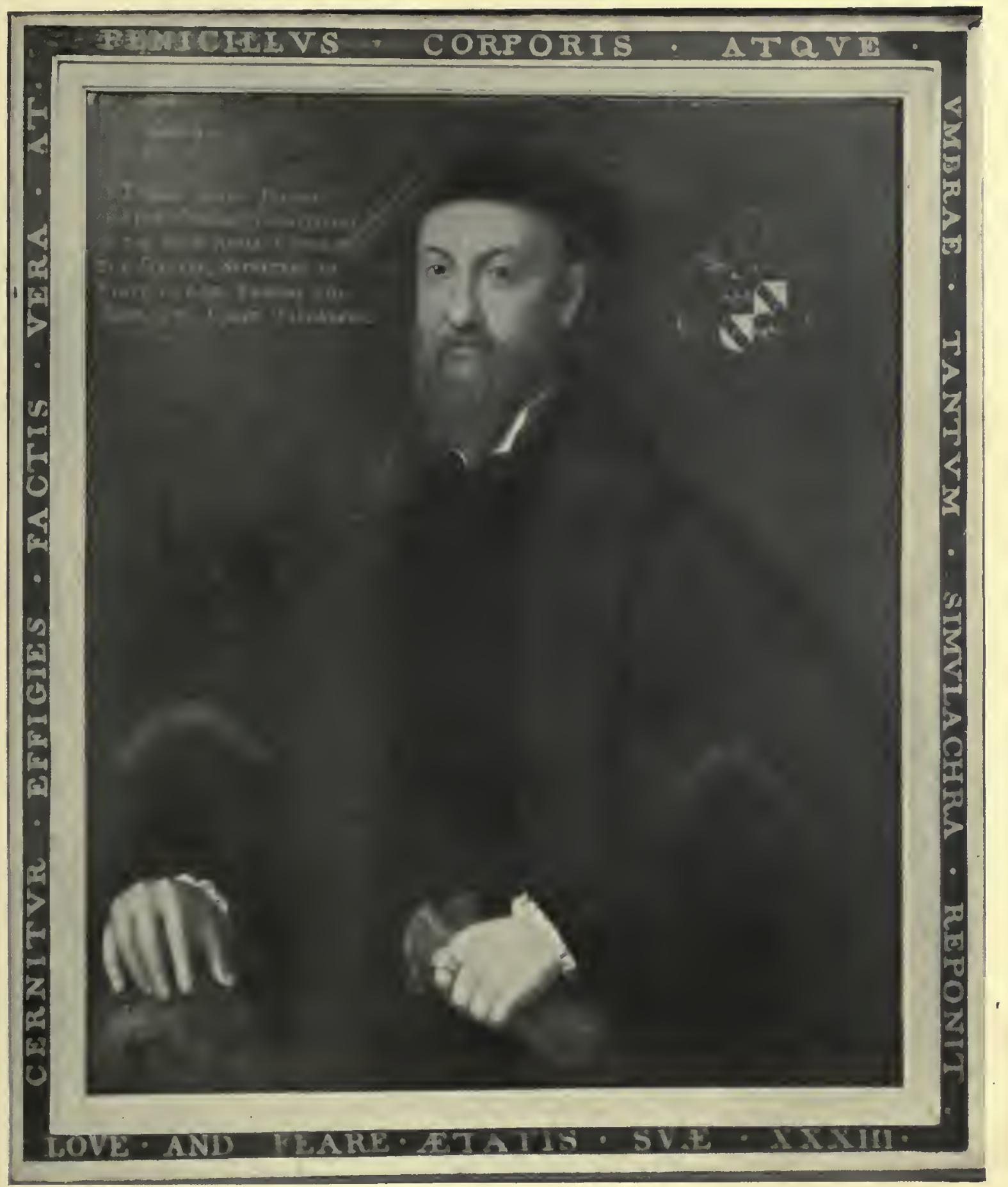

SIR 'Thomas S.MYth (I I I 3-77) 




Hill Hall: East Front, c. i 908

Copyright Country Life

Reconstructed $c$. I 7 I 4

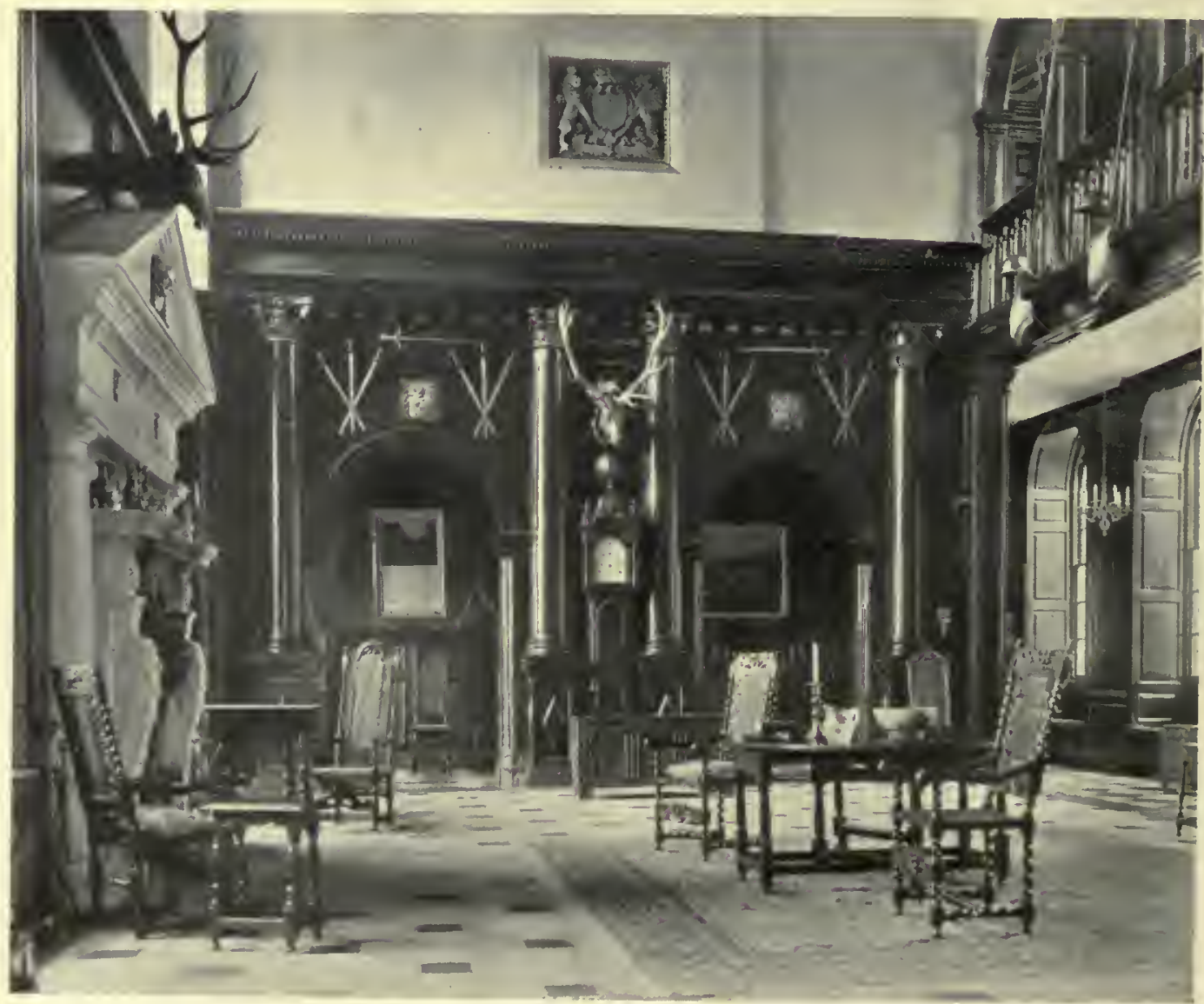

Copyright Country Life

Hill Hall: The Great Hall $c$. I go8, before 20 th-Century alterations 
18 th century this was considered the 'principal front'. ${ }^{3 t}$ We must assume that the great columns, similar to those on the south side, were adapted or copied to form part of the new composition. This includes a less ponderous entablature and a central pediment. The tall sash windows have the segmental heads and rusticated quoins of the period. The treatment of the central doorway is modern. In the pediment is a cartouche bearing the arms of Smyth impaling Hedges. ${ }^{32}$

A general simplification of the exuberant Elizabethan roof-line probably took place at this period. Plain parapets replaced gables and the chimneys are known to have been rebuilt. The sundial on the south front and the wrought-iron grille at the north entrance are of the same period. Internally many insertions were made, among them the fine inlaid staircase occupying the tower at the south-east corner of the house. A heavily ornamented marble fireplace with flanking consoles was added to the chimney-piece of the Great Hall, but this was later removed to the upper corridor of the west range. 33

The dates 1768,1815 , and 1844 all appear on the walls of the house and it may be assumed that alterations were carried out at those times. A tablet in the courtyard is dated 1815 and bears the initials of $\mathrm{Sir}$ William Smijth (d. 1823) and his wife. This was probably the date at which the cement work was renewed.

Soon after 1912 major alterations took place and Hill Hall became one of the more luxurious country houses of that time. Attics with hipped dormers were inserted in the north and west ranges. The north-west wing, incorporating the old gatehouse, was rebuilt as staff quarters. A new kitchen wing was added. The oak screens were removed from the hall. The interior was expensively fitted out, many of the furnishings being museum pieces. The dining-room was lined with 17 th-century carved woodwork of Venetian origin. ${ }^{34}$ This and many other fittings were later removed.

The restoration of $195^{\circ-2}$ brought to light many original features besides the wall-paintings in the north range. Owing to its condition the pediment on the north front was taken down, but as far as possible all existing details were left unaltered.

During his lifetime Sir Thomas Smyth paid great attention to the grounds of Hill Hall. He planted orchards and a tree-lined walk. The approach avenue to the north is said to be his work ${ }^{35}$ and two of his fishponds remain in the garden as ornamental pools. Many 'improvements' were made to the park during the late I 8 th and early igth centuries, including the removal of Mount Hall, the inclusion of the parish church within the park, and the construction of the long curving drives to north and south. ${ }^{36}$

There appears to have been a church at Theydon Mount in 1236 , for in that year CHURCHES Robert, parson of the church at Theydon, was involved in a dispute. with Robert de Briwes and his wife Beatrice over 26 acres of land. ${ }^{37}$ In 1248 the advowson passed with the manor of Theydon Mount to John de Lessington. ${ }^{38}$ They continued to descend together until 1925 , when the advowson was sold with Hill Hall to Sir Robert Hudson. The advowson then passed with $\mathrm{Hill} \mathrm{Hall}$ until the house was purchased by the Prison Commissioners, when it remained with Lady Edward Hay, now Lady Menzies. ${ }^{39}$ Since 1755 the rectory of 'Theydon Mount has always been held jointly with that of Stapleford Tawney (q.v.) although not formally united with it.

In I 29 I the rectory of Theydon Mount was valued at $£ 46$ s. $8 d .40$ In 1428 the. value was said to be 6 marks. ${ }^{41}$ In 1535 the valuation was $£_{1} 36$ s. 8 d.42 The 'improved' value was given as $£ 30$ in I 604 and as $£ 92$ in 1650.43 The tithes were commuted in $183^{8}$ for $£ 307$ I 55.44 In 1621 the glebe consisted of five pieces of land totalling 40 acres.45 In 182427 acres belonging to the rectories of Theydon Mount and Stapleford Tawney were exchanged for lands in Stapleford Tawney belonging to the Hill Hall estate. ${ }^{46}$

In 1777 the parsonage house of Theydon Mount was shown as lying between the church and Hill Hall.47 By this time the union of Theydon Mount and Stapleford Tawney had rendered one of the rectory houses redundant. In the I gth century the rectors lived at Stapleford Tawney and the house at Theydon Mount was evidently demolished. ${ }^{48}$ The rectory continued to be at Stapleford Tawney until the time of the present rector, the Revd. E. B. Rees, who arranged for the sale of the old house and built a new one at Theydon Mount in $195 \mathrm{I}$. This is a red-brick building to the north of Hill Hall.49

In his will of 1389 John de Northampton provided for the endowment of a chantry in the parish church of Theydon Mount, out of the income from Hill Hall (see above). It is not clear how long this chantry lasted. In 1421 the feoffees of Edmund Herde conveyed to Simon Archer and two others properties in Theydon Mount for the purpose of providing a suitable priest to celebrate in the parish church for two following years for the souls of Edmund and his father Thomas. The priest was to receive an annual stipend of $f_{1} \mathrm{IO}$ I 3 s. $4 d$. unless the trustees could drive a better bargain (nisi meliori precio poterint). 50 'The chantry certificates of I 546-8 contain no reference to a chantry in Theydon Mount.

The original parish church of Theydon Mount was dedicated to $S T$. MICHAEL and ST. STEPHEN. In 1400 the Pope offered indulgences to those who should visit the church and contribute to its upkeep.sI Reynold Malyns (d. I43I) left 66s. $8 d$. to the church and for the seats that had been made there.52 This church was burnt down in I6II; it is said to have been struck by lightning. ${ }^{53}$ The present church was certainly in use by 1614.54 Unlike its predecessor it is dedicated to $S T$. MICHAEL only. It adjoins the park of Hill Hall. This was effected between 1777 and about 1800 by the diversion of the road south-east of Hill Hall.ss The church consists of nave, chancel, south .

\footnotetext{
31 Watts, Seats of Nobility and Gentry

Ec., note to pl. 84 .

${ }^{32}$ Anne Hedges, Ist wife of Sir Edw.

Smyth, d. 1719.

33 Country Life, xx, 22, 25 (photos.).

34 Ibid. xli.

35 Strype, op. cit. 17 I-3.

36 Howard and Burke, Theydon Mount, p. x. And see above, p. 276

37 Cal. Close, $1234-7,516$.

38 Feet of $F$. Essex, i, 179.

39 Kelly's Dir. Essex (1922, 1926);

Chel. Dioc. Year Bk. 1937 f.
}

the park on the site of the present North Farm.

48 O.S. I in. $\operatorname{Map}$ (c. 1801); O.S. 6 in. Map (c. I 870), sheet vviii; E.R.O., D/CT 351 ; White's Dir. Essex (1848); Kelly's Dir. Essex (1859 f.).

49 Inf. from Rev. E. B. Rees.

so B.M. Add. Chart. 28836 ; Winstone,

Epping and Ongar Highway Trust, 279-80.

sI Cal. Pap. Letts. v, 277.

32 Reg. Chichele, ed. E. F. Jacob, ii, 453.

s3 Howard and Burke, Theydon Mount,

xiii, 4. $\quad 34$ Ibid. ss See above, p. 276. 


\section{A HISTORY OF ESSEX}

porch, and west tower. It is of red brick with plaster dressings. Its special interest lies in the fact that it dates from the single period $16 \mathrm{I}-14$ and has had few alterations. One or two early renaissance details have been used but the main structure is of late gothic style and arrangement (see plate facing p. 270).

Externally the window and door openings are of moulded brick covered with plaster to simulate stone. The windows on the north and south sides and in the upper stages of the tower have four-centred heads. The larger east and west windows have interlacing tracery and may date from the I 8 th century.

The square tower is of three stages with a castellated parapet and a small shingled spire. The stair turret on the north side reaches to the belfry and has splayed angles. Near the top these are corbelled out to give a square section, a feature which is also found on a stair turret at Hill Hall. The parapet is of moulded brick and has a segmental pediment. The stair is lighted by pierced quatrefoil openings.

The south porch has a curvilinear gable with a heavily moulded brick coping. The archway is fourcentred with classical imposts from which rise flanking pilasters supporting an entablature and pediment. This entrance feature is plaster covered and is the only typically renaissance detail to be found externally.

Inside the church the, chancel and tower arches are pointed and the general impression is gothic. Many of the fittings are of the original date. The marble font, which stands against the west splay of the south doorway, is of most unusual design and may be by the same hand as some of the family monuments which are described below. The stem consists of a square pillar supporting a moulded bowl of black marble. Above the bowl is a bearded mask set in a shell-headed niche.

In the west window are several pieces of heraldic glass of the 16 th century and later, all of which have been moved from Hill Hall. They include a Tudor royal arms, crowned badges of Henry VIII and Elizabeth I, the arms of Sir Thomas Smyth, and a damaged achievement of arms that has not been identified. On the south wall of the nave the Lord's Prayer and the Creed are painted in black letter of the original date. The Ten Commandments in similar script are visible above the chancel arch. ${ }^{36}$ The oak benches in the nave are apparently original. The reredos, which has coupled and fluted Corinthian pilasters, dates from about I 700. The black and white floor paving is of the same period.

In 1762 the spire was reshingled, the gutters releaded, the windows reglazed, and the flooring of the seats made good at a total cost of $\oint_{32.57}$ In 1837 the church was restored and a gallery was erected under the west tower. This was for the use of the musicians and for the servants at Hill Hall.s8 The communion rails and those of the gallery at that period were of cast iron.s9 The oak pulpit, reading-desk, and credence table were presented in I 888 by the Revd. L. N. Prance. ${ }^{60}$ The stained glass in the east window was given as a memorial to Major Charles Hunter (d. I917). In 1926 another restoration took place during which the rafters of the roof were exposed, the gallery removed, and the iron communion rails replaced by oak.6r The square pew belonging to Hill Hall was removed in 1953 .

There is one bell cast by John Clifton in 1653 . The church plate, all of silver, consists of cup and paten cover dated 1587 , paten given in 1714 by Dame Jane Smyth, flagon given in 1824 by the rector, the Revd. Edward Smijth, and a salver of 1780 . In 1683 there was some pewter plate ${ }^{62}$ but none of this now remains.

There is a fine series of monuments to the Smyth family. The first of these, that of Sir Thomas Smyth (d. I 577) and 'Philip' his wife (d. I 578), was preserved from the earlier church. It was put in hand during the lifetime of Sir Thomas and there is a suggestion that it was of his own design. ${ }^{63}$ It is of alabaster and black marble and stands against the north wall of the chancel. The reclining effigy of Sir Thomas is in armour and Garter robes and has a salamander at its feet. Below is an inscribed altar tomb and above an arched canopy under which are a long inscription and symbolic carving. There are flanking Ionic pilasters supporting an entablature. Above the cornice are two black marble obelisks and an achievement of arms.

Opposite is a monument of similar proportions to Sir William Smyth (d. 1626 ) and Bridget his wife A crested helmet and part of a surcoat, said to have belonged to Sir William Smyth, ${ }^{64}$ hang near by together with a painted cartouche shield.

Against the north wall of the chancel is the alabaster tomb of the second Sir William Smyth (d. I632). The carving is of fine quality and the costumes are of great interest. Opposite this monument is an alabaster and black marble tomb enriched with consoles and cherubs' heads. On it is the recumbent effigy of Sir Thomas Smyth, bt. (d. I 668), in armour and with a curled wig.

On the walls of the chancel are many tablets to members of the Smyth family dating from the 18 th and $I$ th centuries, and several painted hatchments of the same family. The two black-letter inscriptions on the south wall of the nave have been adapted as memorials. One serves as a memorial for the First World War and the other is in memory of Sir Robert Hudson (d. I927).

Vestry minute-books of Theydon Mount survive for the period $1715-$ PARISH GOVERNMENT I942.65 Apart from the $A N D$ POOR RELIEF nomination of the surveyors of highways for 1 7 19-92 at vestries held first in December and at a later period in September, the books have very few entries other than those for the annual Easter vestry for the passing of accounts and the nomination of new officers. It is therefore not possible to obtain a complete picture of the administration of the parish. The attendance at the Easter vestry was usually about five.

In 1715 the rateable value of the parish was $£ 909$ a penny rate thus producing $6315 \mathrm{~s} .9 d$. In that year there was a churchwardens' rate of Id., a constable's rate of $2 \frac{1}{2} d$., and two overseers' rates totalling $5 \frac{1}{4} d$. The churchwardens' rate was usually $\mathrm{I} d$. until $\mathrm{I} 766$, when it was merged in a general rate. The constable's rate was also I $d$. for most of the period I $72 \mathrm{I}-2$ to $I 756-57$, when it was merged with that of the overseers. The overseers' rate had slowly increased, apparently to

\footnotetext{
s6 Hist. Mon. Com. Essex, ii, 234 ; inf. from the Revd. E. B. Rees.

37 E.R.O., D/P I $42 / 8 / 8$

s8 Howard and Burke, Theydon Mount, $x$. For repairs to the bass viol, 1796 , see E.R.O., D/P $142 / 12 / 1$.
}

\author{
50 Hist. Mon. Com. Recs. (photographs). \\ 60 Howard and Burke, Theydon Mount, \\ xi. \\ 62 Ch. Plate Essex, 105-6. \\ 61 E.R. xxxv, 224 \\ ${ }^{63}$ John Strype, Life of Sir Tho. Smyth \\ (ed. I 820 ), 154 .
}

\footnotetext{
64 Howard and Burke, Theydon Mount, vii.

6s E.R.O., D/P I $42 / 8 / 1$, 2. Unless otherwise stated all the following informa tion is derived from these vestry books.
} 
$10 d$. in $1727-8$ and $1 s .6 d$. in $1752-3$. In $1759-60$, however, it was only $3 d$. and in $1765^{-6}$ it was is. In and after 1766 there was only one parish rate and one account, known as the overseers' account, from which the churchwardens' and constables' bills were settled as well as those for poor relief. About 1766 also the vestry books cease to give details of disbursements, these being transferred to separate volumes, ${ }^{66}$ and only contain brief totals of income and expenditure. In $1774-5$ the general rate was $25.6 d$., producing $£ 107.67$ It rose to $5 \mathrm{s.} 6 \mathrm{~d}$. in $1796-7$ and in $1800-1$ the rate was 9 s., producing 6422 . This was the peak. The income from the rates dropped to $\$ 254$ two years later and in I $828-9$ was f. I 85.68

The parish had at least one poorhouse by 1776.69 In most cases, however, the poor seem to have been relieved outside the poorhouse, by cash payments and to a lesser extent by the provision of clothing, fuel, and rent. ${ }^{70}$ On at least two occasions, in $\mathrm{I}_{7} 83$ and $\mathrm{I} 789$, a spinning-wheel was purchased. In March 1796 I6 people were receiving weekly relief. In 18 ro Robert Burton Hayward, surgeon of Epping, was engaged to attend the poor for a year at a salary of 6 guineas, with travelling allowances and Ios. for confinements. There are references to the inoculation of pauper families in $1772-3,1792$, and 1793 . In the period $1757-8$ to I 789-90 the overseers held office for two years. Thereafter they served only for one year. Sir William Smijth, Bt., of Hill Hall was overseer in 1792-3. Between $I 745$ and 1770 four women served as overseers. In I 833 an assistant overseer was appointed at a salary of firo.

A church clerk is mentioned in the churchwardens' account of $1756-7$, and again in the overseers' account of $1792-3$. His wages were 10 s. and Ios. $6 d$. respectively. In $\mathrm{I} 842$ the parish appointed a paid constable. This is of special interest because the Essex County Constabulary had been founded two years earlier. Theydon Mount appears never to have had a police constable, even in later years.

During the period I 7 15-92 there were only five years when a member of the Smijth family was not nominated as one of the surveyors. Usually it was the baronet who was nominated.

In 1836 Theydon Mount became part of Ongar Poor Law Union.

In 18 I 8 there was no school in the parish, although the poor were said to desire schooling for SCHOOLS their children.71 In $1826 \mathrm{Mrs}$. Letitia (later Lady) Bowyer Smijth set up a girls' school in some cottages, paying the fees of needy children and taking an active interest in the work. It is possible that these cottages were situated at the brickfield near Hill Hall. In I $836 \mathrm{Sir}$ John Smijth established a boys' school, which the Smijth family largely maintained in the years following. In 1839 the rector, besides making financial contributions, carried out most of the detailed administration at both schools. There were 33 boys and 42 girls in attendance, the fee evidently being Id. per week. The textbooks of the National Society were used but neither school was a National School. 72

About i 846 a new mixed school was built, apparently on the site of the boys' school of 1836 . Members of the Smijth family seem to have paid most, if not all of the cost, and to have remained for many years the owners and chief source of income; in I 846-7 Sir E. Bowyer-Smijth was stated to be the only contributor. Children attended the school from Stapleford Tawney as well as from Theydon Mount. After a successful start the school seems to have declined. In 1846-7 there were about 70 pupils under a master and a mistress who were paid 640 and 614 a year respectively. ${ }^{73} \mathrm{By} \mathrm{I} 87 \mathrm{I}$ there were only some 36 pupils and the building was in poor condition, despite continued support from the Smijths. The government declared that it could not be considered an efficient school for the 3 I children from Theydon Mount and the 30 from Stapleford Tawney needing elementary schooling unless it was thoroughly repaired.74 Theydon Mount parishioners were now prepared to accept responsibility for the school and in February 1873 the Smijth family transferred ownership to the rector and churchwardens as trustees. The building was repaired so as to accommodate up to 50 pupils, the building of a new school at Stapleford Tawney making greater accommodation unnecessary.75

In 1880 the school seems to have been reorganized and officially reopened as Theydon Mount Church of England school. In I 88 I the first government grant was received, one of $\oint_{12}$, and this amount rose slowly to an average of about 644 in $1890-1900$. Other income came from 'school pence' and from a voluntary rate which in 1880 yielded some $f 33$. The master was paid $£_{3} 6$ in 1877 and 652 in 1886 . In $\mathrm{s} 887$ he was replaced by a mistress who also received $£ 52.76$ The population of the village was declining and average attendance at the school was only 27 in 1893 and 23 in 1899.77 Under the Education Act of 1902 the school passed under the administration of the Essex Education Committee, Ongar District, as a nonprovided, mixed elementary school. Its average attendance was 37 in 1900,45 in 1910, 36 in 1929, and only 24 in 1938 . In 1939 it was reorganized for mixed juniors and infants and in 1942 it was closed because of the insufficient number of pupils. The children were transferred to Theydon Garnon school. 78 The building is now used for parochial and social purposes. ${ }^{79}$ It is single-storied and of brick, with a slate roof.

CHARITIES. For Theydon Mount charitjes see Stapleford Tawney.
66 E.R.O., D/P 142/12/1, 2.

67 E.R.O., D/P 142/12/t.

68 E.R.O., D/P $142 / 11 / 1,2$.

69 Rep. Sel. Cttee. on Overseers Retns.

1777 , H.C. ser. I, vol. ix, p. 350.

${ }_{70}$ The following paragraph is based on the overseers' account books: E.R.O., $\mathrm{D} / \mathrm{P} 142 / 12 / 1,2$.

${ }_{71}$ Retns. Educ. Pcor, H.C. 224 , p. 273
(1819), ix (1).

72 Howard and Burke, Theydon Mount, $x$; E.R.O., D/P 30/28/19.

${ }^{3}$ Nat. Soc. Enquiry into Ch. Schs. I 846-7, pp. 18-19; E.R.O., D/AEM $2 / 8$.

74 Retns. Elem. Educ. H.C. 201, pp. $112-13(1871)$, Iv; Min. of Educ. File 1 3/367; Chelmsford Chron. 9 Aug. 1872.
75 Min. of Educ. File $13 / 367$

76 E.R.O., D/P I $42 / 28 / 4$.

77 Reln. of Schs. 1893 [C. 7529 ], p. 716 , H.C. (1894), lxv; ibid. 1899 [Cd. 315], p. 74, H.C. (1 900$), 1 \times v(2)$

${ }_{78} \mathrm{Min}$. of Educ. File $13 / 367$; inf. from Essex Educ. Cttee.

70 Inf. from Chelmsford Dioc. Council for Relig. Educ. 


\section{A HISTORY OF ESSEX}

\section{NORTH WEALD BASSETT}

North Weald Bassett lies in the extreme north-west corner of Ongar hundred, the parish being divided almost equally between this hundred and that of Harlow. I It is 3 miles north-east of Epping and I9 miles from London. The name Weald (forest land) is no longer appropriate, for very little woodland now survives, and much of the parish is open and bare. The main road from London to Newmarket and Norwich runs through the west and that from Epping to Chelmsford through the south of the parish. The EppingOngar railway runs through the southern tip of North Weald. A large R.A.F. station and wireless masts are prominent features of the landscape and there has recently been much domestic building. But some parts of North Weald are still rural. At Woodside in the south-west a leafy lane runs past Wintry Wood and in the north of the parish there is a view across to the woods of Harlow Park.

In $1873-4$ the total area of the parish was 3,433 acres of which 1,739 acres were in Ongar hundred. The part in Harlow hundred was made up of the tithing of Thornwood in the west ( 901 acres) and that of Hastingwood in the north (793 acres). A detached portion of the parish consisting of II acres to the northeast of the main body and near Weald Lodge was situated locally in Magdalen Laver parish. ${ }^{2}$ This was transferred to Magdalen Laver in $1883 .{ }^{3}$ In 1946 the part of North Weald to the north of Weald Bridge, including Weald Bridge Farm, Weald Lodge, and Bowlers Green was also transferred to Magdalen Laver.4 In 1949 the parish was considerably enlarged by the addition of parts of Netteswell and Latton parishes in the north-west, part of Harlow in the north. east, part of Theydon Garnon in the south, and part of Epping Upland (including Wintry Wood) in the south-west. ${ }^{5}$ The present area of the civil parish is 4,032 acres. $^{6}$

The highest parts of the parish are in the south and west, rising to $300 \mathrm{ft}$. and affording good views. From there the land slopes gently down to Cripsey Brook, which rises in the west, flows north-east through the centre of the parish, and forms part of the northeastern boundary. Shonks Brook, which joins Cripsey Brook, forms part of the northern boundary.

Population is mainly concentrated along the EppingChelmsford road and to the north of it. There are also villages at Thornwood and Hastingwood.

In 1086 North Weald was one of the most thickly wooded places in Essex. Peter de Valognes' manor was said to contain woodland sufficient for 1,500 swine, a figure larger in proportion to the parish area than those even for Waltham Holy Cross, Loughton, and the 'Theydons.7 'The 'wood of Henry of Essex' in North Weald was mentioned in 1248.8 In 1260 Philip Basset, Henry's successor as lord of the manor, complained that many robberies were being done in this wood near the road between Ongar and Waltham, and he secured the king's permission to assart 6 acres of the wood. 9 Other assarts were taking place in the $13^{\text {th }}$ century, particularly in connexion with some of the estates which later became manors. ${ }^{10}$ The park belonging to the principal manor was still in existence in 1540.1 It gave its name to Park Corner in the southwest of the parish. Late medieval conveyances do not mention any other large areas of woodland except in the Paris Hall area, where about 60 acres were reported as late as 1520.12 Norden's Map of Essex, I 594, does not show North Weald as a densely wooded parish. In 1777 there was apparently no woodland there apart from Weald Hall Coppice. ${ }^{13}$ This is specially interesting in view of the survival of large woods in neighbouring parishes. Weald Hall Coppice still (1954) survives, and there is also a small wood at Canes.

The ancient manor houses were Weald Hall, near the centre of the parish, Canes I mile farther north, Marshalls near Woodside, and Paris Hall at Hastingwood. All four were on moated sites and there were also moats at Newhouse Farm in Vicarage Lane and at Schoolgreen Farm. Paris Hall, on the original site, was rebuilt about 1600 . Marshalls was rebuilt on a new site in the $17^{\text {th }}$ century. Canes, Weald Hall, and New House were rebuilt in the rgth century. ${ }^{14}$ In addition to the four manor houses there were probably substantial medieval dwellings at Tylers Green, Bowlers Green, Bridge Farm (near Weald Bridge), and possibly one or two other places. ${ }^{\text {is }}$ The parish church, which dates from the 14 th century, is $\frac{1}{2}$ mile east of Weald Hall.

In 777 there was a concentration of houses around four commons: at Weald Gullet, Tylers Green, Thornwood, and Hastingwood. There, as well as on the older sites, a number of houses survive from the I 8 th century and earlier. Apart from the church the oldest existing building in the parish is probably Tylers. This is a timber-framed and plastered house consisting of a central block with a gabled cross-wing at each end. It may date from the 16 th century but there is some evidence that the central block was an earlier open hall with a screens passage at its south-west end. A large curved and chamfered brace, which appears to have been part of a main roof truss, was recently removed from the first floor of this block. Bluemans Farm, which formerly stood immediately north-east of Tylers, may have been a I6th-century building, but it has recently been demolished. It was timber-framed with oversailing gable-ends at the back and front. ${ }^{16}$ From the 17 th century several houses survive. Hastingwood Farm, known locally as Rainbow Farm, was demolished in 1954. It was a timberframed building of which parts dated from the 17 th century or earlier. Two small crosswings projected on the south side and there was a central chimney with four diagonal shafts. Little Weald Hall, formerly New Hall, near the church, is a timber-framed building probably of the I th century, also having a chimney with diagonal shafts. The 'King's Head' at Weald

\footnotetext{
I O.S. $2 \frac{1}{2}$ in. Map, sheets $52 / 40,52 / 50$.

2 O.S. 6 in. Map (Ist edn.), sheet 1.

3 By the Divided Parishes and Poor Law Amendment Act, 39 and 40 Vict. c. 61 .

4 By the Co. of Essex (Rural Parishes) Confirmation Order, 1946.

5 By the Co. of Essex (Alteration of
}

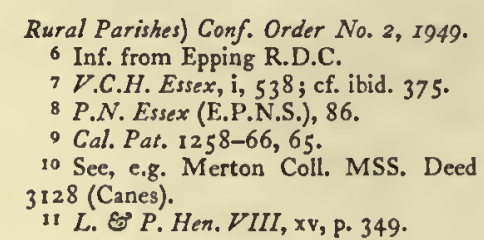

Rural Parishes) Conf. Order No. 2, 1949.

6 Inf. from Epping R.D.C.

V.C.H. Essex, i, 538 ; cf. ibid. 375

P.N. Essex (E.P.N.S.), 86.

e.g. Merton Coll MSS, Deed it L. \& P. Hen. VIII, xv, p. 349.

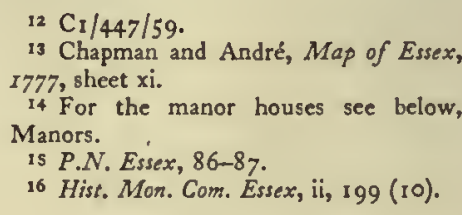


Gullet is a timber-framed building probably of the same period. It was restored about 1927.17 Wheelers, on the north side of the Chelmsford road near the post-office, was mentioned as an estate by Morant. ${ }^{18}$ The house is an irregular timber-framed structure dating from the I 7 th century or earlier. East of Wheelers is Brickwall House, formerly a farm. ${ }^{\text {19 }}$ It dates from the late 17 th century and has a hipped, tiled roof and a central chimney with joined diagonal shafts. Of the smaller buildings the former school house by the church is probably the original i 7 th-century house, ${ }^{20}$ and there is another 17 th-century cottage to the east of the vicarage: this has external chimneys at the gable-ends. Two ancient timber-framed cottages which formerly stood on the north side of the main road near the end of Church Lane were destroyed in a German air raid in $194 \mathrm{r}^{21}$

Schoolgreen Farm, at the north end of School Green Lane, is timber-framed and plastered and dates from the I 7 th or early I 8 th century. Opposite this, part of a homestead moat survives. Esgors, formerly Isgoe, 22 at Thornwood, is a square red-brick house dating from about $175^{\circ}$. It formerly had a frontage on the common but is now set back about 100 yards from the main road. Weald Place, at Duck Lane, is a good redbrick house of about the same period. A number of other buildings in Duck Lane and Woodside date from the 18 th and early I 9 th centuries. It is probable that the development in this area resulted from the improvement in the main road north and south after the formation of the Epping Turnpike Trust in 1768 .

In 1801 North Weald, with 620 inhabitants, was one of the more densely populated parishes of the hundred. ${ }^{23}$ In the r 9 th century the population followed the trend normal in rural Essex until about I86I: there was an increase to 886 in $183 \mathrm{I}$ and a subsequent slight decrease. But between I 86 I and I $90 \mathrm{I}$, when the agricultural depression was depopulating most villages, the population of North Weald rose from 842 to I, I 35 . This was clearly due to the coming of the railway in I 865. Building development in the I gth century was also encouraged by the inclosure of the commons, which took place shortly before the opening of the railway, and it was at Thornwood and Hastingwood that most of the development took place in that period. Several of the larger houses in the parish, including Newhouse Farm, were rebuilt in the Igth century. Hastingwood House, which was built about I $84^{\circ}$, was a completely new residence. It is a large gault brick house standing in extensive grounds. New places of worship in the roth century were the Congregational chapel in Weald Bridge Road, built about 1830 but closed about 1874 , the chapel of ease at Hastingwood (1864), the iron mission church at Thornwood (I 888), and the Wesleyan churches at Thornwood (1883) and Weald Gullet (I 888). ${ }^{24}$ The original school was relinquished in favour of a larger building and the new school was extended in about I 842 and again in 1871.25

The population rose very little during the first 20 years of the present century, and was only 1,239 in

17 Inf. from present licensee.

18 Morant, Essex, i, I5I.

19 E.R.O., D/CT 387 .

20 See Schools.

21 Inf. from Mr. H. King.

22 Chapman and André, Map of Essex, I777, sheet $x i$.

23 For census figures 1801-1901 8ec

V.C.H. Essex, ii, 350 .

24 See Nonconformity, Church.
$1921 .{ }^{26}$ There was an increase to 1,642 in 1931 and then a burst of building lasting until the Second World War. Between the World Wars development was greatest along the Chelmsford road. On the part of it to the west of Church Lane all the buildings are connected with the R.A.F. Station. Between here and Tylers Green building is almost continuous, much of it dating from the 1930's. A few council houses were built before I939: 8 pairs in School Green, to the north of the Chelmsford road, 5 pairs opposite the post-office, and 9 pairs on the road to Epping Upland. The Post Office Radio Station (formerly owned by Cable and Wireless Ltd.) was established at Weald Gullet in 1921.27 During the Second World War a few buildings were destroyed by German bombing. Two of these have been mentioned above; a third was the Woolpack Inn, which stood opposite them. ${ }^{28}$

Since 1945 three large housing estates have been built: at Queen's Road and Bluemans by the rural district council, and at School Green by the R.A.F. In 1953 the estimated population of North Weald was 3,200-an increase of almost IOO per cent. on I $93 \mathrm{I}^{29}$ It should rise still further, on the completion of the School Green estate. The provision of public buildings has not kept pace with that of houses. The iron mission church at Thornwood was replaced in 1923 by a brick church and in I93 I the Wesleyan church at Weald Gullet was rebuilt. In 1939, however, the Wesleyan church at Thornwood was closed owing to lack of support. ${ }^{30}$ A village hall was built in 1928 , on the south side of the Chelmsford road near Church Lane. ${ }^{31}$

Until the I 7 th century the Epping-Chelmsford road was probably the most important in the parish. ${ }^{32}$ In I 786 a petition was presented to the Epping Highway Trust by the people of North Weald asking that the road should be taken over by the trust, in the first place as far as Ongar. ${ }^{33}$ An Act of Parliament for this purpose was passed in the following year. ${ }^{34}$ A toll-gate was erected at the junction of the main road and Woodside. The gate-keeper lived at first in a rented cottage but a toll-house was built about $1818.3 \mathrm{~s}$ This still survives: a single-story building of brick, now plastered, with a tiled roof.

The other main road became important early in the I 7 th century as part of the new route to Newmarket. ${ }^{36}$ This was one of the roads taken over by the Epping Highway Trust at its formation in 1768.37 There was a toll-gate at Thornwood Common. ${ }^{38}$ Since the coming of motor traffic this road has become one of the busiest in Essex.

The minor roads of the parish probably changed little between the Middle Ages and the I 9 th century. The main change in recent times has been the closing of the eastern section of Weald Hall Lane owing to the building of the airfield. Another lane which has disappeared formerly ran south of the Chelmsford road from Weald Gullet to Skips Corner. This existed in I 777 and 1838 but had disappeared by $1873-4 .{ }^{39}$ The parish boundary follows this line.

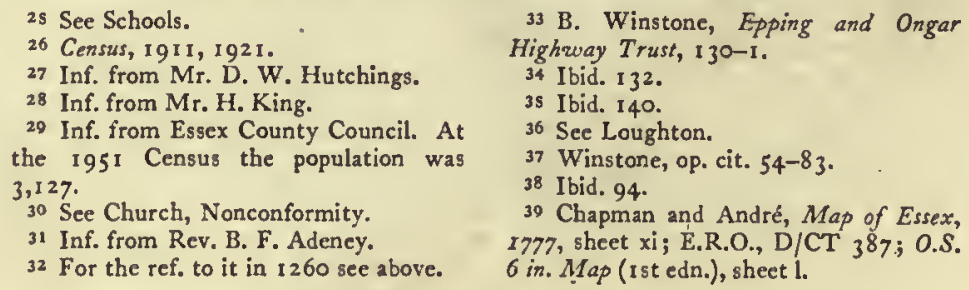

33 B. Winstone, Epping and Ongar Highway Trust, 130-1.

34 Ibid. 132.

$3 s$ Ibid. 140

36 See Loughton.

37 Winstone, op. cit. $54-83$. 38 Ibid. 94.

39 Chapman and André, Map of Essex, I777, sheet xi; E.R.O., D/CT $387 ; 0 . S$. 6 in. Map (rst edn.), sheet 1. 


\section{A HISTORY OF ESSEX}

Weald Bridge has always been the most important in the parish. Between I 556 and I 652 it was frequently presented at Quarter Sessions as in need of repair, and responsibility for it was doubtful.40 In 16 I 5 and 1652 the parish was said to be responsible.4I In I 653 the inhabitants protested that they had been wrongly indicted for not repairing the bridge: they had spent 64 I 5s. on it; but they asserted that it was a county charge and asked for the repayment of their expenses. 42 The justices thereupon ordered that several hundreds should be taxed for the repair of this and other bridges.43 Weald Bridge appears in the lists of county bridges from about 1800.44 In $185^{8}$ the county surveyor described it in detail.45 It appears not to have been altered since that date. Cracks Bridge, at Weald Gullet, was taken over by the county in $188 \mathrm{I}$, when the surveyor reported that it must be rebuilt. This was done within the next year. ${ }^{46}$

During the late I 8 th and early 19 th centuries North Weald was fortunate in its communications with the outside world, since it possessed two turnpike roads, and was near to Epping. In I 865 coach travel in this area was superseded by the opening of the railway through Epping to Ongar, with a station at North Weald. This brought London within easy reach. This line was electrified as far as Epping in 1949.47 Beyond Ongar public transport was poor until the introduction of motor buses. There are now (1954) frequent bus services to Epping, Ongar, Brentwood, and Chelmsford.

North Weald was late in getting its own post-office, probably because it was served directly from Epping. In 1883 a day mail was established at North Weald and a sorting-office sanctioned.48 A telegraph office was set up in I 886.49 The telephone service was introduced in 1920.50

Piped water was supplied to North Weald by the Herts. and Essex Waterworks Co. before I 886.5I Main drainage was introduced at Thornwood and Weald Gullet in I9I I-I 2.52 Electricity was first supplied in I93 I and gas about 1932.53 The village hall, opened in 1928, has already been mentioned. There are football clubs at Thornwood and North Weald. A branch of the county library was opened in 1932.54 There has been a police station in the parish since about I 886.55

For much of their history the larger estates in North Weald have had absentee landlords. This applies specially to the two largest estates, Weald $\mathrm{Hall}$ and Canes (see below, Manors). In I 84 I Weald Hall had an area of 800 acres and Canes of almost 300 acres. ${ }^{56}$ Each was let to a single farmer. This is interesting in the case of Weald Hall for very few farms in the hundred were as large as 500 acres. There were then no other estates in North Weald of more than 200 acres, but even the small farms outside the main estates in the parish were mostly rented by tenant farmers. In all there were some 16 farms in the parish in I84I, of which about half were over 100 acres. Not more than four were owned by their occupiers. At that time there were approximately equal amounts of arable and pasture-about $\mathrm{I}, 34^{\circ}$ acres in each case-and more than 300 acres of uninclosed common.

The inclosure of the commons at Hastingwood, Thornwood, Weald Gullet, and Tylers Green was carried out by Act of Parliament passed in 1857.57 The inclosure award was made in $186 \mathrm{I}$. The inclosed area amounted to 280 acres.

Until recent years North Weald has been mainly an agricultural parish. One old field name, Teazle Field, suggests a connexion with the cloth industry. $58 \mathrm{Com}-$ mercial fruit-growing and market-gardening have been carried on since about 1900.59 This was made possible by the railway, which brought the London markets within rapid reach. It now includes tomato growing in large greenhouses in the Vicarage Lane area.

A windmill belonging to the manor of North Weald was mentioned in $1281^{60}$ and there was a mill at Marshalls in I $359 .{ }^{61}$ A fair called 'Gullet Fair' is said to have been held at one time on the former green at Weald Gullet. ${ }^{62}$

In 1888 an army post, later described as a fort with six guns, was in existence at Weald Gullet. ${ }^{63}$ It was no doubt one of the establishments planned by the War Office for the defence of London 64 and it continued to exist until the First World War.6s

The R.A.F. Station, first established in 1917 and reopened in 1928,66 has become an important part of parish life. It occupies some 400 acres between Weald Hall Lane, Church Lane, and the Chelmsford road. During the Battle of Britain in I940 it was one of the fighter bases engaged in the defence of London.

Richard Biscoe (d. I 748), a nonconformist minister who later conformed and became chaplain to George II and Boyle lecturer 1736-8, was Vicar of North Weald from 1738 to 1748.67

There is some doubt about the identification in Domesday of the manor of NORTH MANORS WEALD, but it was probably made up of two estates which in 1086 belonged to Peter de Valognes and were held of him by Ralf. The larger of these estates was 'Walia', which was entered in Domesday after Loughton and Theydon Bois and would therefore seem to have been, like them, in Ongar hundred. ${ }^{68} \mathrm{~W}$ alla had been held in 1066 by two freemen as two manors and as two hides and 40 acres. Peter de Valognes had it by exchange. ${ }^{69}$ In the hundred of Harlow Ralf held of Peter de Valognes 'Walda', consisting of 30 acres which before 1066 had been held by a freeman. 70

The tenancy in chief of the manor descended as part of the barony of Valognes until the I 3 th century, when the barony was divided among coheirs. North Weald

\footnotetext{
40 E.R.O., Q/SR 2/19, I4/32, $21 / 22, \quad$ D/P $84 / 8$. $142 / 17,206 / 55$.

41 Ibid. 209/55, 354/1 30.

42 E.R.O., Q/SBa $2 / 83$.

44 E.R.O., Q/ABz I, 2.

43 Ibid.

s3 Inf.

45 E.R.O., Q/ABz 3 .

47 Inf. from London Transport.

48 P.M.G. Mins. 1883 , vol. 261 , min.

I 5782 , vol. 254 , min. 10599 .

49 I bid. 1886 , vol. $303, \mathrm{~min} .43$.

so Ibid. I920, min. 6422 .

si Kelly's Dir. Essex (1886)

32 Ibid. 1922. The provision of sewers had been considered by the parish vestry in 1868, but was then shelved: E.R.O.,

Gas Bd.

s4 Inf. from County Librarian.

ss Kelly's Dir. Essex (1886 f.).

s6 E.R.O., D/CT ${ }_{3} 87$

37 E.R.O., Q/RDc 54.

58 E.R.O., D/CT 387 ; ff. V.C.H. Essex,

ii, 423 .

s9 Kelly's Dir. Essex (1 898 f.).

60 Cal. Inq. p.m. ii, p. 227.

6t Feet of $F$. Essex, iii, 123

62 Inf. from Mr. H. King.

63 See below, Nonconformity; Kelly's

Dir. Essex (1890).

64333 Parl. Deb. 3rd ser. 1412-1 3 ; Sir William Butler, An Autobiography (I9I I), 355-6.

$6 s$ Kelly's Dir. Essex (1914).

66 Inf. from Mrs, S. Young.

62 D.N.B.; Morant, Essex, i, 152

68 V.C.H. Essex, i, 538, 406 n., 396-7.

69 A holding of 40 acres is separately mentioned at the end of the Walla entry. It had been held by a freeman and Peter had it also by exchange. It may have been part of the estate of 2 hides and 40 acres. 70 V.C.H. Essex, i, 536b. For Peter de Valognes and his tenant Ralf see also Loughton.
} 


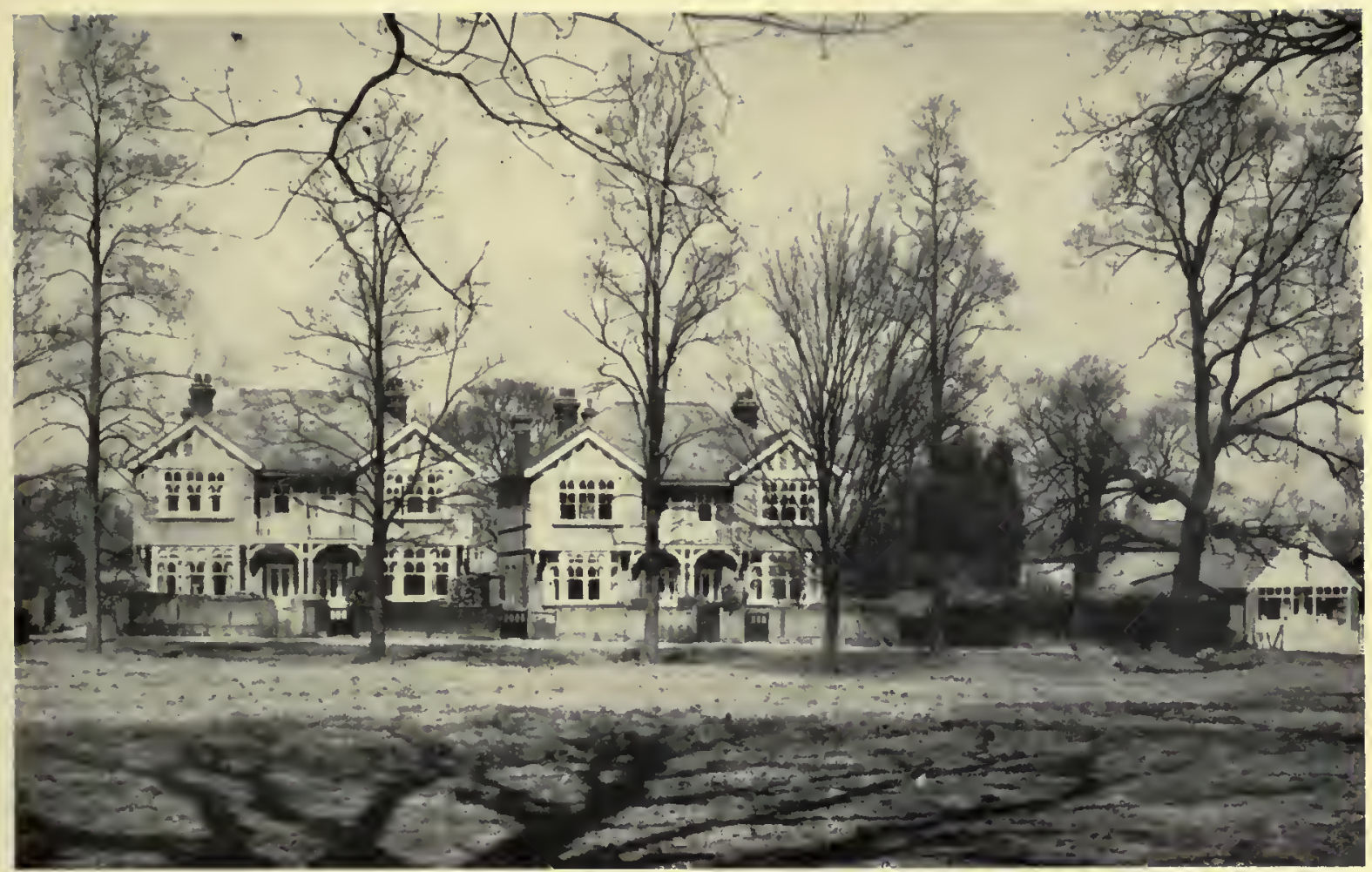

Semi-detached Houses at Theydon Bois Built $c$. I 900



Post-I 945 Housing Estate at North Weald 

fell to the share of Lore, wife of Henry de Balliol and thus continued to follow the same descent as the manor of Benington (Herts.) which had been the caput of the barony. ${ }^{7}$ In 1325 North Weald was said to have been held of John de Benstede (d. I 323), Lord of Benington. ${ }^{72}$ This seems to have been the last occasion on which a connexion with Benington was noted. In I33 I North Weald was said to be held of the king in chief.73 Subsequent inquisitions usually report the manor as being held in chief.

The descent of the tenancy in demesne during the I 2 th century is not clear. By the end of that century it was held by the family of Essex. $74 \mathrm{~J}$. H. Round suggested that it had been brought into that family by Cecily, mother of Henry and Hugh of Essex. She was the wife of Henry of Essex, the king's constable, who was defeated in judicial combat in I I 63 by Robert de Montfort after having been charged with throwing away the royal standard in battle with the Welsh.75 Henry's lands were forfeited to the king as the result of his defeat. For this reason one would not expect to find that North Weald, which apparently was not forfeited, had belonged to him in his own right. Henry of Essex, the younger, was his eldest son by Cecily. 76 In I 236 Henry of Essex held 5 knights' fees in Sutton, Springfield, and Layer-de-la-Hay (Essex), Barningham (Suffolk), and 'Ikenton' (Layston, Herts.) of the barony of Valognes.77 In 1244 Henry, son of Hugh of Essex, was engaged in litigation concerning the advowson of North Weald. ${ }^{8}$ Ten years later Henry of Essex compounded with Lore de Balliol for the customs and services due from his tenement to her at Benington, and agreed to render suit at her court there twice a year.79 In 1267-8 Hugh, son of Hugh of Essex, granted to Philip Basset and Ela, Countess of Warwick, his wife, that they should hold North Weald for their lives from him and the heirs of his body. 80 Soon after this Baldwin, son of Hugh of Essex, granted Philip and Ela the manor of North Weald and 5 knights' fees belonging to it. ${ }^{81}$ The 5 fees were specified as being one in Springfield, one in Layer-de-la-Hay, two in Sutton (Rochford hundred), and one in Barningham (Suff.). From this it is clear that the whole of the knight service had been imposed on the appurtenant manors, leaving North Weald itself free of charge.

Philip Basset died in 1271 , leaving as his heir a daughter Aline, wife of Hugh le Despenser (d. 1265) and later of Roger Bigod, Earl of Norfolk (d. 1306 ). 82 Aline died in $128 \mathrm{I} .{ }^{83}$ She was succeeded by her son Hugh le Despenser, who was later summoned to Parliament as a peer and in 1322 was created Earl of Winchester. ${ }^{84}$ In 1310 it was stated that North Weald belonged to him and not to his son Hugh le Despenser the younger. ${ }^{85}$ It may have been about this time that John de Rivers, lord of the hundred of Ongar, granted (the elder ?) Despenser view of frank-pledge of all his men in the manor of North Weald, exempting Hugh and his heirs from all tourns and suits of the hundred. ${ }^{86}$

The two Despensers were deeply involved in the civil wars during the reign of Edward II and the ownership of North Weald between I 320 and I 33 I is not always clear. In 1320 the younger Despenser conveyed to Hugh de Audley the younger, Lord Audley, I knight's fee in North Weald and the manor of North Weald except for $5 \frac{1}{2}$ fees in it. The agreement was made by precept of the king. ${ }^{87}$ In the following year Audley was deprived of the manor as a rebel, and it was granted to Robert Cole. 88 In 1322, however, North Weald was granted to the younger Despenser, to be held of the king by the service of one sparrowhawk annually. ${ }^{89}$ The manor presumably remained in the younger Despenser's possession until his execution in 1 326. In 1327 it was granted to Edmund, Earl of Kent.90 Edmund was executed in his turn in 1330 and North Weald was granted for life to Bartholomew de Burghersh, Lord Burghersh (d. 1 355).91 In the same year the king granted that Edmund, Earl of Kent (d. I 33 I), should inherit his father's title and lands.92 North Weald was presumably affected by this grant, for it was among the possessions of John, Earl of Kent (d. 1352 ). ${ }^{93}$

The manor descended with the earldom of Kent until the death in 1416 of Alice, widow of Thomas, Earl of Kent (d. 1 397), who held it in dower.94 It was then assigned to the purparty of Eleanor, wife of Thomas Montagu, Earl of Salisbury, who was Thomas, Earl of Kent's third daughter, and coheir of her brother Edmund, Earl of Kent (d. 1408).95 On Salisbury's death in 1428 the manor passed to his daughter Alice, suo jure Countess of Salisbury. ${ }^{96}$ It was forfeited in I459 as a result of the rebellion of Alice's husband Richard Neville, Earl of Salisbury.97 North Weald probably passed to Richard's son Richard, Earl of Salisbury and Warwick, 'the Kingmaker' (d. I47 I), for it was among the possessions of Warwick's daughter Isabel, wife of George, Duke of Clarence (d. I 478), at her death in 1476.98 The manor descended to Isabel's son Edward, Earl of Warwick, but was administered by the Crown during his minority. 99 On Edward's execution in 1499 it was forfeited to the Crown.

North Weald was held by Humphrey Torrell at his death in I 5 I 7.1 He presumably had it by royal grant. The manor appears to have been restored to Margaret, Countess of Salisbury, only sister of Edward, Earl of Warwick (d. 1499), for after her execution in I 54 I it was in the king's hands as part of her lands. In $\mathrm{r} 544$ the king granted it to Sir Richard Higham, who then conveyed it to Sir Richard Rich, later first Baron Rich. ${ }^{2}$

The manor descended in the Rich family until. 162 I, when Robert Rich, Earl of Warwick (d. 1658),
71 Cf. V.C.H. Herts. iii, 74.

72 Cal. Inq. p.m. vi, p. 286.

73 Ibid. vii, 225. For the service see

below.

74 J. H. Round, "North Weald Basset

and the Essex family', E.A.T. N.s. xiv,

II I - I 4 ; and see below, Church.

75 E.A.T. N.3. xxiii, 24.

76 E.A.T. v, 106.

77 Ibid. N.s. xiv, II $1 ; B k$. of Fees, 578.

78 See below, Church.

79 Feet of $F$. Essex, i, 203.

80 F.A.T.N.s. xiv, I 12 ; Fet of F. Essex,

i, 266.
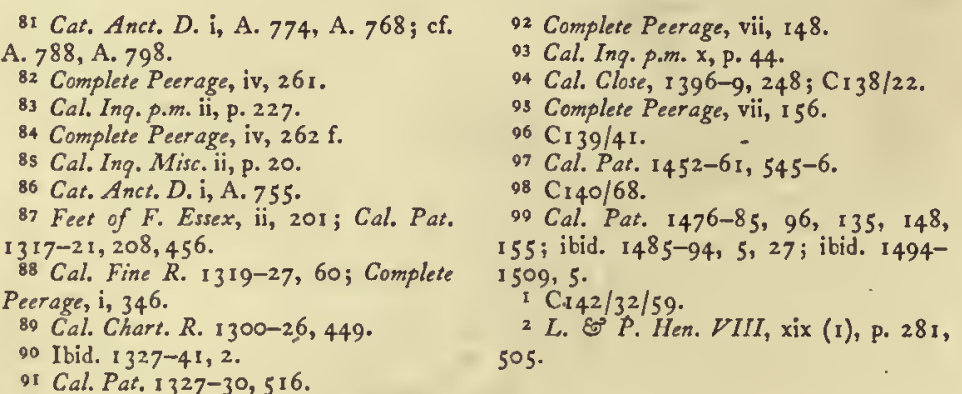


\section{A HISTORY OF ESSEX}

conveyed it to Sir Thomas Cheeke, Kt. ${ }^{3}$ In $1652 \mathrm{Sir}$ Thomas. settled it upon his second son Thomas. ${ }^{4}$ It descended from Thomas Cheeke to his son Edward (d. I 707) and then to Edward Cheeke, son of Edward, who died childless in 17 I 2.5 North Weald then passed to Ann, daughter of Thomas Cheeke and wife of $\mathrm{Sir}$ Thomas Tipping, Ist Bt. 6 She died in 1727 and the manor descended to her daughter Katherine, wife of Thomas Archer, later created Baron Archer. 7 Katherine died in 1754 and her husband in 1768.8 The manor passed to their son Andrew, Lord Archer (d. I 778). 9 Andrew left four daughters and coheirs: Sarah, who married Other Windsor Hickman, Earl of Plymouth (d. I799), Ann who married Christopher Musgrave, Maria who married Henry Howard, and Harriott who married Edward Bolton Clive. ${ }^{10}$

Between I79I and I793 North Weald was bought by Daniel Giles, Governor of the Bank of England. "I It subsequently followed the same descent as Youngsbury, near Ware (Herts.), until about I g00.12 Christopher Giles-Puller was lord of the manor in 1899 , but by I 902 the manorial rights had passed to Henry E. Paine and George F. Beaumont. ${ }^{13}$ In I 84 I Lady Louisa Puller owned $80 \mathrm{~J}$ acres in the parish, including Great Weald Hall, and William C. Kirkby was her tenant in all except 4 acres of it. ${ }^{14}$

The farm-house known as Weald Hall Farm was probably built early in the I 9 th century. It is a square two-story building of gault brick. To the south of the farm-yard and on the perimeter of the airfield there was formerly a circular moat, probably representing the site of the medieval manor house. The north half of the moat was recently filled in and at the same time an embankment west of the farm was levelled. The square red-brick house on the north side of the road, now known as Weald Hall, dates from the late I gth century.

The manor of $C A N E S$ or CAWNES took its name from the family of Calne or Caune which held it during the $13^{\text {th }}$ and $14^{\text {th }}$ centuries. ${ }^{15}$ Richard de Calne was a litigant concerning land in the parish in 1204-5.16 About the same time Richard de Caune granted an assart called 'Unere Redene' in Weald to his brother Walter de Caune. ${ }^{17}$ Richard de Caune had sons Richard and John, both of whom held land in North Weald about I 230.18 In 126 I a Richard de Caune held land in the parish.19 Joan, widow of Richard de Caune, is mentioned in deeds of about I 290.20 In one of these is a reference to the 'greenway' leading to Richard's hall.2I In I 295 Joan granted to Thomas, son of Richard de Caune, all the tenements which she held in dower in North Weald. In return Thomas granted her an annuity of I 2 marks for life, to be paid in her chamber at Hedingham Priory. 22 Thomas de Caune was alive in $1335 .{ }^{23}$ His son and heir John had apparently succeeded him by April 1343 .
Katherine widow of Thomas, was then still living. ${ }^{24}$ Sir John de Caune, kt., held land in the parish in 1349.25

In I 37 I John Caune (possibly son of Sir John), then about to leave for Gascony, enfeoffed Sir John atte Vyne and others with all his lands in North Weald and elsewhere to the uses of his will. If he returned from Gascony he was to enjoy the property for life. If he died abroad it was to be sold and the money was to be applied for the salvation of his soul and those of his parentes and benefactors, and in works of charity. ${ }^{26}$

It is not clear whether John de Caune died in Gascony, but he was apparently the last of his line to hold Canes. By October 1406 the manor was held by Thomas Caune, son of John le Rous of Norton Mandeville (q.v.). ${ }^{27}$ This Thomas presumably assumed the name of Caune after acquiring the manor. ${ }^{28}$ The name of Rous was evidently readopted by Thomas, second son and ultimate heir of the above Thomas Caune. ${ }^{29}$ The manor descended along with that of Norton Mandeville until about I 864 , when Norton was sold by Merton College, Oxford. Canes remained in the possession of the college until I 1923 when it was sold to the lessee, William Hart. 30

Between I 536 and I 593 the manor was leased by Merton College to successive members of the Springer family. ${ }^{31}$ In 1841 the property consisted of 292 acres and was farmed by Frederick Chaplin. ${ }^{32}$

The present farm-house of Canes dates from about 1 840 . It is a square stucco building with a low-pitched slate roof. South of the farm buildings is part of a large moat. In the early I gth century it extended farther north, almost enclosing the farm-yard. ${ }^{33}$ The pond in front of the farm-house may represent part of a second moat.

The manor of MARSHALLS was held of that of North Weald. It derived its name from the family of Ralph le Mareschal or Marchal who held land in the parish in 1280.34 In I 300 Hugh le Despenser, lord of North Weald, granted to John son of Laurence le Mareschal, of Laver, clerk, land which Laurence once held of him, at a yearly rent of 40 ., John agreeing that if the rent should be in arrears not only this land but also his property in Magdalen Laver might be distrained. $3 \mathrm{~s}$ In I 306 William de Sutton and Margery his wife conveyed to Peter Mareschal and Amiane his wife 2 messuages, I 23 acres of land, 2 acres I rood of meadow, and $20 \mathrm{~d}$. rent in North Weald. ${ }^{36}$ Peter and Amiane were still alive in I 3 I 7.37 In I 33 I Robert son of Peter Mareschal was holding a messuage, 199 acres of land, 18 acres of meadow, 3 acres of wood, and 5os. rent in North Weald and Theydon Garnon. ${ }^{3}$ 'The reversion of this property was settled upon his son Thomas and the heirs of his body, with remainder to Thomas's brother Robert and his right heirs. In I 359 Robert le Mareschal settled an estate in North Weald and

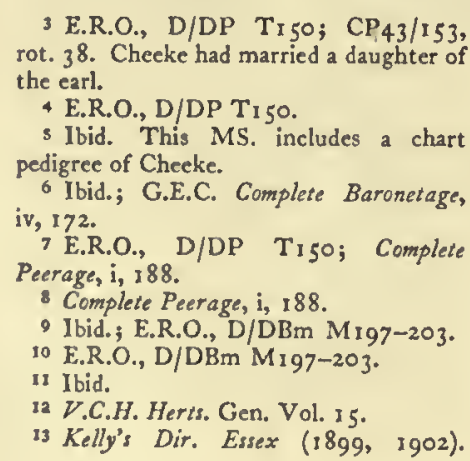



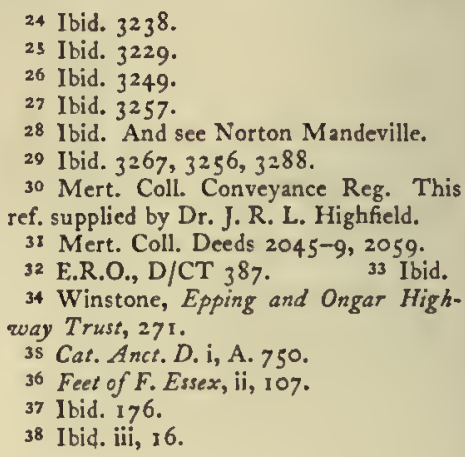


Theydon Garnon slightly larger than that of I 33 I upon his son Roger and Margaret, Roger's wife. ${ }^{39}$ Robert Mareschal occurs in I $374 .^{40}$ Margaret, widow of Roger Mareschal of North Weald, executed a charter in 1402.41

For most of the I $5^{\text {th }}$ century the descent of the manor has not been traced. In I 496 Joan, widow of Sir Robert Billesdon, died holding 8 parcels of land called Marshalls.42 Sir Robert (d. 1492) was a haberdasher of London, alderman for Bread Street Ward and mayor $1483-4$. He was knighted in 1485.43 His wife was daughter and heir of John Williams; her heir was her son Thomas Billesdon.44 Soon after her death Marshalls was acquired by Sir William Fitzwilliam (1460?-1534), merchant tailor of London, who was probably connected in some way with Sir Robert Billesdon because he lived and traded in Bread Street, and was alderman for Bread Street Ward.45 In I 543 Marshalls was settled upon Sir William's grandson Sir William Fitzwilliam ( $526-99$ ) on his marriage to Anne daughter of Sir William Sidney.46

In 1554 Sir William Fitzwilliam sold Marshalls to John Searle.47 The Searles were a local family, many of whose names occur in the parish registers of North Weald. 48 John was succeeded on his death in I 59 I by his eldest son John.49 In I605 the latter settled the reversion of the manor upon his eldest son Samuel.50 In I6 16, after John Searle's death, the manor was claimed by Mary, widow of Thomas Searle, a younger brother of Samuel Searle, but Samuel's right was maintained by the court.51 Samuel, who was a clergyman, was still alive in $16,36.52$ He was succeeded by his son Samuel, citizen and stationer of London. ${ }^{53}$ In I660 Samuel Searle the younger sold the reversion of Marshalls after his death to John Archer, serjeantat-law, for $£ .680 .54$

Archer, who became a justice in the court of Common Pleas and was knighted in 1662 , died in 1682.55 It is doubtful whether he himself ever took up the reversion of the manor. Samuel Searle was still lord of Marshalls in 1680 , and the next court, in 1683 , was held in the name of Eleanor widow of Sir John Archer. ${ }^{56}$ In 1676 Sir John had settled the reversion of the manor upon his eldest son John, and the latter succeeded to Marshalls in or after 1687 , in which year his mother is last known to have held the court. 57 John Archer died childless in 1707 . He left a will desiring that Eleanor Wrottesly, daughter of his sister Eleanor, wife of Sir Walter Wrottesly, should marry William Eyre of Highlow (Derbs.) and that Eyre should assume the name of Archer and inherit Marshalls in his own right.58 The will had an unusual result. Eleanor duly married William Eyre but died childless,

39 Ibid. 123 .

40 Ibid. 17 .

${ }^{41}$ Cal. Close, 1402-5, 119-20: cf.

V.C.H. Worcs. iii, 283 .

42 Cal. Inq. p.m. IIen. VII, i, p. 542.

43 A. R. Beaven, The Aldermen of the

City of London, i, 47 .

44 Cal. Inq. p.m. Hen. VII, i, p. 542.

45 L. है P. Hen. VIII, xviii (1), p. 46.

For Sir William Fitzwilliam see D.N.B.

He also held Arneways in Lambourne and

Gaynes Park in Theydon Garnon. It is

possible that he was related to Joan

Billesdon's father.

${ }^{46}$ L. 6 P. Hen. VIII, xviii (1), p. 46. For Sir William the grandson see D.N.B. He was Lord Deputy of Ireland undes Eliz. I.

47 E.R.O., D/DB Tro4. Consideration

Es. 1 V

stated to be $f 200$.

48 E.R.O., D/P 84/1/1, 2 .

49 E.R.O., D/DB TrO4.

50 Ibid.

51 Ibid. Samuel Searle was b. 1676 Thos. Searle in r680: E.R.O., D/P $84 / 1 / 1$.

52 Cal. Docs. Essex Arch. Soc.: N. Weald 2, 3. For his early career see Foster, Alumni Oxonienses, 1500-1704, S-Z, p. 1330 .

53 Cal. Docs. Essex Arch. Soc.: N. Weald, 2,3 .

54 E.R.O., D/DB TrO4.

55 D.N.B. For Archer and his heirs see also Theydon Garnon, Coopersale House. 56 E.R.O., D/DB M73. For lists of quit-rents paid by some 30 manotial tenants between 1623 and 1682 see ibid. and Marshalls subsequently passed to Eyre's son by his I9I4, when Capt. indsay Archer-Houblon sold the manorial rights to Woublon owned 63 acres in North Speed.60

moat enclosing an overgrown area Arks the position of the medieval site of Marshalls. to the cast of Woodside, a little south of it detached shafts set diagonally.

The the I 3 th and I 4 th centuries. In I 280 Sir Humphrey de Hastings granted Roger de Paris, citizen of London, the lands which he holds of my fee in North Weald Id. (a year).... Saving to me and my heirs the as appertains to the fee of one knight; and the Ralph . 20 s. at two terms of the year, From this it apper by $\mathrm{Sir}$ Humphrey de Hastings of Ralph le hich adjoins Paris Hall. ${ }^{63}$

In I 298-9 Robert de Lincoln and Joan his wife 列 of wood, and 5 s. rent in North Weald which they had claimed as the dower of Joan of the endowment of illiam de la Haye, formerly her husband.64 In I 303 conveyed land in Weald and Harlow oland.65 A survey of the knights' fees in of Roger de Paris, and Alice, William's wife, owledged the right of Adam de Masshebury to pasture, and I 35 . rent in North Weald Hasting he property to William and Alice, and also the reversion of one-third which Beatrice, late wife of Roger de Paris, held in dower of the inheritance of Adam. ${ }^{67}$

M77.

57 Ibid. ; E.R.O., D/DB TI 16.

58 Lincs. Archives Cttee. Archivist's Rep. 1951-2, p. 20; Lady A. Archer-Houblon, Family of Houblon, ii, pp. $306,322$.

59 Family of Houblon, 306, 322 ; E.R.O., $\mathrm{D} / \mathrm{DTc} \mathrm{M}_{4}$.

6o E.R.O., D/CT 387.

$6 x$ Morant, Essex, j, I 50.

62 Winstone, Epping and Ongar, Highway Trust, $27 \mathrm{I}$.

63 A Robt. de Hastings lived in the parish in $1248: P . N$. Essex, 87 .

64 Feet of F. Essex, ii, 88.

65 Ibid. 93. In 1316 Roland conveyed the property to. John Frosshe of London: ibid. 170 .

66 E.A.T, N.s. xxii, 241.

67 Feet of F. Essex, ii, 216. 


\section{A HISTORY OF ESSEX}

The agreement was made in the presence of Beatrice, who did fealty. ${ }^{68}$ Adam here appears to have been a mesne lord.

A William de Paris of North Weald died about I 338 , leaving tenements in the parish of All Hallowsthe-Great, London, to Roger de Waltham, corder, and to Sir Ralph Spigurnel and Alice his sister, wife of the testator. 69

No further mention of the estate has been found until late in the $15^{\text {th }}$ century. In $1482-3$ Paris Hall seems to have been held by John Symonds, who in that year was said to have made an agreement with Sir Thomas Tyrell providing for the settlement of the manor upon John and Joan his wife and their issue, with remainder to Tyrell.70 John and Joan were also said to have agreed to pay Tyrell $£ 4$ a year during their lives.7I In I 5oI Joan Symonds, now a widow, filed a suit in Chancery against Tyrell and other persons alleged to be trustees and to have refused to make over to John and Joan their estate in the manor. Tyrell replied that the annual rent of $£ 4$ had not been paid for more than seventeen years and that the other persons named in the writ had never actually been enfeoffed to uses.72 Joan did not appear in court and the case was dismissed.73 Two years later Paris was among the possessions left by Sir John Shaa (d. I 503). ${ }^{74}$ The manor was then said to consist of 600 acres of land, I 20 acres of meadow, 200 acres of pasture, 60 acres of wood, and $£ 5$ rent in Harlow, Latton, North Weald, and other parishes. Sir John was succeeded by his son Edmund. Some time later, between 1515 and 1529 , Edmund was engaged in litigation with the trustees of the settlement of the manor made upon him by his father. $7 \mathrm{~s}$

Edmund Shaa's heir was his daughter Alice, who married William Pooley of Boxted (Suff.) in I 548.76 After William's death (1 587) Paris Hall passed to his son John. ${ }^{77}$ John Pooley died in 1593 and was succeeded by his brother William.78 In I 594 William Pooley conveyed the manor to Thomas and Katharine Fuller. ${ }^{79}$

According to Morant Fuller was a clothier of Coggeshall. 80 Paris Hall descended in his family for about 180 years. A William Fuller held it in $1705^{81}$ and another of the same name in Morant's time ( $c$. I 768). ${ }^{82}$ By I 775-6 Paris Hall had been acquired by William Hollick. ${ }^{83}$ He conveyed the manor in $179^{8-9}$ to William Wedd Nash. 84 Nash held it only until 1 804-5 when it passed into the possession of John Denner. ${ }^{85}$ In $1822-3$ it came to a Mr. Chatham. ${ }^{86}$ In $1825-30$ the owner was Mrs. Chatham. ${ }^{87}$ James Ewing held Paris Hall in $184 \mathrm{I}$ and 1848.88 By this time it had ceased to be styled a manor. In I $84 \mathrm{I}$ it was a farm of about 120 acres.

In 1780 Paris Hall was leased to Joseph Clarke. ${ }^{89}$ Thomas Stallibrass was the tenant in $1796-1822$ and

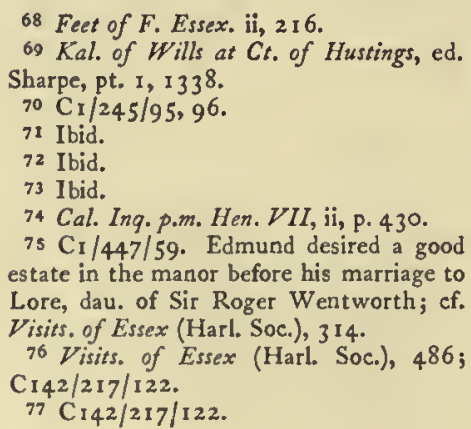

John Stallibrass in $1823-4.90$ In $1825-30$ John Skingle was tenant ${ }^{91}$ and in 1841 Charles Smith.92 Early in the present century the farm belonged to Frederick Bond, who owned it until about 1938 . It was then bought by a Mr. Good. In I 946 or 1947 it was bought by a Mr. Parris and it is now owned by his sons, Messrs. V. and L. Parris. 93 The house and garden, apart from the farm, were bought at the same time from Mr. Good by Mr. Denning, their present owner. 94

Paris Hall is a timber-framed house built late in the I6th century, possibly by Thomas Fuller after he acquired the property in I 594. It is a long rectangular building with gabled ends and a fine central chimney with six tall octagonal shafts. Near the west end a small staircase wing projects on the south side of the house and at the farther end there is a single-story service wing, evidently a later addition. Four lateI6th-century fireplaces have been uncovered inside the house. To the south and west of the house are two arms of a rectangular moat.

In the late I 2 th century the advowson of North Weald was appurtenant to the manor.

CHURCH Before I I6I Henry de Essex had made a grant to the nunnery of St. Mary, Clerkenwell, of a tithe of his food, drink, candles, and game. 95 After his fall in 1163 certain payments were made to Clerkenwell out of his estate. 96 Before Ig October I 86 the rectory and advowson of North Weald had been granted to the nunnery by his wife Cecily. This grant was confirmed by her son Henry de Essex, the younger, and in I I 94 by Hugh de Essex, another son.97 It has been suggested that the grant was made in place of the previous annual payment. 98

William, Bishop of London ( I I g9-I 22 I), confirmed the grant on condition that a competent vicar should be assigned.99 In I $275 \mathrm{John}$, Bishop of London, confirmed the appropriation of the rectory but ordained that he and his successors the bishops of London should hold the advowson of the vicarage. ${ }^{I}$ The bishops subsequently presented the vicar at every vacancy until 1495, when the Prioress of Clerkenwell again presented. ${ }^{2}$ At the next vacancy in 15 II the right of presentation was disputed. The bishop presented on this occasion but the issue was taken before the Archbishop of Canterbury and the Chief Justice of the King's Bench, who in I 5 I 5 decreed that in future the prioress and the bishop should present alternately. The prioress duly presented in I5I9 but before her next turn the priory was dissolved. 3 The Bishop of London continued to present in his turn until I 852 , when the alternate patronage was transferred to the Bishop of Rochester.4 Later rearrangements of dioceses have resulted in the alternate patronage being transferred successively to the Bishop of St. Albans and to the Bishop of Chelmsford. 5
91 Ibid. 466-7I.

92 E.R.O., D/CT 387

93 Inf. from Mrs. Denning. 94 Ibid. 95 W. O. Hassall, 'Essex Properties of the Nunnery of St. Mary, Clerkenwell', E.A.T. N.s. xxiii, 24.

98 Ibid.; E.A.T. N.s. xiv, I 12.

99 E.A.T. N.s. xxiii, 24.

I Ibid. 25. The bishop was patron of the nunnery.

2 Ibid.; Newcourt, Repert. ii, 643.

3 Ibid.

4 Lond. Gaz. 4 June 1852,1585 .

5 Crockford's Cler. Dir. I $852 \mathrm{f}$.
96 Ibid. 97 Ibid.

$$
290
$$


The alternate patronage previously vested in the Prioress of Clerkenwell was exercised in 1553 by one $\mathrm{H}$. Brown. ${ }^{6}$ In $\mathrm{5} 60$ the queen granted it to William Doddington of London. 7 The next presentation in this turn was made in 1570 by John Searle, probably the man of that name who had recently acquired the manor of Marshalls (see above). ${ }^{8}$ The presentation was not again exercised in this turn until I660, when John Searle presented. 9 It would seem probable that the patronage had descended not to John, eldest son of the first John Searle but to a younger son Edward (d. 1625) who was father of the John Searle of 1660.10 The latter was probably the John Searle who died in I66. II He left a son and heir, also named John, who made conveyances of the alternate patronage in 1677 and 1698.12 Andrew, son of the last-named John Searle, succeeded his father but is said to have died childless soon after his marriage. ${ }^{13} \mathrm{His}$ widow later married Capt. Andrew Searle, a relative of her husband, and had two sons, Andrew and John.I4 In I 706 presentation was made in this turn by John Searle, and the new vicar was John Searle, formerly Rector of Willingale Doe, son of a John Searle and perhaps brother of the Andrew Searle who had died childless. ${ }^{\text {IS }}$ According to Morant the alternate patronage was conveyed by John Searle, the patron of 1706 , to his sonin-law George Finch, who subsequently sold it to William Plummer of Gilston Park (Herts.). ${ }^{16}$ It descended with Gilston Park and in 1836 was held by Robert Plummer Ward, who had married Jane, widow of William Plummer. ${ }^{77}$ In 1848 John Barnes was patron in this turn and in $1866-74$ Pemberton Barnes. ${ }^{18}$ Mrs. Pemberton Barnes was patron from about 1874 to about 1916 when the alternate patronage was vested in the Church Pastoral Aid Society.19

In 1227 , when the king released Clerkenwell Priory from the payment of a sixteenth on its Essex churches, the sum remitted included $4 s .2 d$. from North Weald. ${ }^{20}$ In I 29 I the vicarage was valued at $£_{4} 4$ I 3 s. $4 d$.2x In I 535 the rectory was valued at 675 s. $4 d$. and the vicarage at $\mathrm{L}_{1} 33^{5} .4 d^{22}$ In the following year the Prioress of Clerkenwell granted the rectory on a $2 \mathrm{I}$ year lease at $£_{6}$ I $3 s .4 d$. a year to John Avere. By I 555 Avere's interest in the property had been acquired by George Broke, and in that year the Crown granted Broke a new lease for 21 years at the same rent as before. ${ }^{23}$ In I 560 the rectory was granted, along with the alternate patronage of the vicarage, to William Doddington. ${ }^{24}$ From that time the rectory descended with the alternate patronage to the Searles and their successors. About I 826 the rectory was acquired from the Plummer family by Daniel Giles, owner of Weald Hall (see Manors). ${ }^{25}$ In I 84 I Lady Giles Puller owned $\frac{2}{3}$ of the great tithes and 27 acres of glebe as impropriator. The vicar of North Weald owned $\frac{1}{3}$ of the great tithes and all the small tithes and 14 acres of glebe. Their tithes were commuted in that year for 6426 and $\$ 446$ respectively. 26 It is clear from these figures and those of 1535 that the vicarage was better endowed than was usually the case when a rectory had been appropriated. That this was so was no doubt due to the special relationship between the parish and the bishops of London in the Middle Ages.

A vicarage house beside the churchyard was mentioned in a terrier of the early 17 th century. ${ }^{27}$ The present vicarage is a red-brick and roughcast building probably dating from the early igth century.

In I 33 I and I4II there was a manorial chapel attached to Weald Hall, then owned by the earls of Kent. ${ }^{28}$

The parish church of ST. ANDREW consists of nave, chancel, south aisle and lady chapel, west tower, and north vestry. It is built of flint rubble, brick, and limestone. The red-brick Tudor tower and the chancel screen are of special interest.

There was certainly a church in North Weald in the I 2 th century, but the oldest parts of the present building date from about $\mathrm{I} 330$. These are the nave, aisle, and chapel. The walls are of flint rubble with dressings of limestone and clunch and the roofs are tiled. Separating the nave and aisle is an arcade of five bays with octagonal columns and semi-octagonal responds. The two-centred arches are of two chamfered orders; the middle arch is narrower and lower than the rest. At its east end the aisle is widened to form the lady chapel.

In the south wall of the aisle is a I 4th-century window of two trefoiled ogee lights in a square head, containing fragments of I 4 th-century glass. Farther east is a I 4 thcentury south doorway; the door is modern. Farther east still, in the south wall of the chapel, are two I 4 thcentury windows in the heads and trefoils of which is I4th-century glass consisting of tabernacle work. The sill of the most easterly window has been carried down to form stepped sedilia. At the side is a piscina, also of the I 4 th century. The stonework to the windows and the head of the piscina have been partially restored.

The east window of the lady chapel consists of three trefoiled ogee lights with tracery in a two-centred head. This is a I 4th-century window which has been largely restored. At the side of it is a stone bracket with a flat top which may have been intended to support an image. The roof of the chapel is gabled, with trussed rafters of uncertain date. The moulded wall-plate on the south wall is of the I 4 th century. Separating the chapel from the aisle is a two-centred arch.

The north wall of the nave contains a I4th-century doorway with chamfered jambs and a two-centred arch with a moulded label. This is now blocked and a floor slab has been set upright in the recess. The original door, of battens with ornamental hinges, dating from the late I $3^{\text {th }}$ or early I $4^{\text {th }}$ century, has been left externally.

A carved oak screen, dating mostly from the early I 6th century, divides the nave and chancel. It consists of five bays, the centre one containing a pair of doors. The side bays have four-centred traceried heads, subdivided by pendants which are a later addition. Moulded posts support a cusped and ribbed loft. This is said to be the only case in the county where the
6 Newcourt, Repert. ii, 643 .

7 Cal. Pat. I 558-60, 386-8.

8 Newcourt, Repert. ii, 644.

- Ibid. Simon Lynch, who became vicar in 1592 , held the living for 64 years.

10 E.R.O., D/DB TIO4; D/P 84/1/1;

Morant, Essex, i, I 50.

II Hist. Mon. Com. Essex, ii, 198.

$12 \mathrm{CP}_{25}(2) / 654$ Mich. 29 Chas. II;

$\mathrm{CP}_{25}(2) / 829$ Mich. I0 Wm. III.
13 Morant, Essex, i, I 50.

It Ibid.; E.R.O., D/DW EII/3.

25 Morant, Essex, i, 152 ; J. and J. Venn,

Alumni Cantab. pt. i, vol. iv, p. 38 .

16 Morant, Essex, i, I 51 .

17 Cler. Guide, 1836; Burke's Commoners, i, $7 \mathrm{I}-72$

18 White's Dir. Essex (1848); Kelly's Dir. Essex (1 866-74)

19 Kelly's Dir. Essex (1878-1914);
Chel. Dioc. rear $B k$. $1916 \mathrm{f}$

20 Rot. Lit. Claus. (Rec. Com.), ii, 193.

2I Tax. Eccl. (Rec- Com.), 2 ib.

22 Val. Eccl. (Rec. Com.), i, 437.

23 Cal. Pat. $1554-5$, p. 323.

24 Ibid. I 558-6o, pp. 386-8.

25 E.R.O., Q/RPl $730-2$.

26 E.R.O., D/CT 387.

27 Newcourt, Repert. ii, 643 .

28 E.A.T. N.s. xvi, $120, \mathrm{xx}, 289$. 


\section{A HISTORY OF ESSEX}

coved underside of a former rood loft has survived.29 The lower panels have fluted panelling of 'linenfold' type and a rail carved with a running vine and conventional ornament. The doors have traceried lower panels. There is a lettered inscription: 'Orate pro bono statu 'Thome Wyher, diacon.' 'The cornice is modern.

The west tower was built about 1500 . It is entirely of brick and is unusually high, in four stages with an embattled parapet resting on a corbel table of small segmental arches. The two-centred tower arch is of moulded brickwork. It consists of four orders, chamfered, moulded, and plain. The responds have two shafts each, with continuous moulded caps and spreading bases. The west doorway has double chamfered jambs and a two-centred arch of stone with a moulded brick label. The west window is modern except for the splays and rear arch. Across the southwest angle is a chamfered four-centred doorway to a turret staircase. 'This has a door of about i 500 with studded battens and strap hinges. In the north wall is a brick fireplace with a four-centred head. The windows to the upper stages are of single lights in three-centred heads and in each wall of the bell chamber there is a window of two four-centred lights under a four-centred head. On the south wall is a sundial dated 1706 .

In 1865 the church was reroofed. A church rate of $6 d$. in fi was levied for the purpose and permission was given to borrow on the rates. ${ }^{30} \mathrm{New}$ pews were installed about the same time. ${ }^{31}$ 'These, however, incorporate I 8 th-century panelling in the seats in the nave, chapel, and choir stalls.

In 1867 the chancel was rebuilt. ${ }^{32}$ Presumably it had originally been built in the 14th century along with the nave and aisle, and this style was repeated in the new work. In the north wall of the nave there are three windows which are apparently of the same date as those in the chancel.

In 1889 the north vestry was added and a new ceiling put into the church. A new organ chamber was built and the organ renovated. At the same time the tower was restored and a new west window inserted. 33 The tower was again repaired in 1936, the brickwork being repointed and the bells rehung. A new wooden screen between the tower and the west end of the nave has been added within the last year. ${ }^{34}$

There are six bells, dated 1755 , I 887 (the recasting of a I 7 I 2 bell), I $712,1755,1673$, and I 803.35

The church plate consists of two cups dated 1563 and 1876 and a third undated; patens of 1567 and I 875, a flagon of 1730 , an almsdish of I682, two undated almsdishes, and another bought recently. ${ }^{36}$

In the south aisle there is a plain I6th-century chest with strap hinges, and also a partially restored I 5 thcentury chair. There is a 17 th-century chair in the chancel. In the aisle is a modern octagonal font.

On the north wall of the nave, in the recess formed by the blocking up of the I4th-century door, is a floor slab with brass effigies of William Larder and his wife, three sons, and two daughters. It is surmounted by shields with a partially destroyed inscription and is dated 1606 . Other floor slabs in the nave are to John Searle (1665) and his wife (1676) and to Thomas Arrowsmith, vicar (1706), and his wife (1702). The only other monuments are wall plaques dating from 1900 onwards. 'The stained glass in the east window of the chancel is a memorial to Henry Cockerell, vicar for 52 years, who died in 1880 . The glass in the east window of the chapel is in memory of his wife.

On the south side of the church is a memorial to those who died in the two world wars.

The lychgate in the churchyard was dedicated in I912.37 On the north side of the churchyard is a burial ground for members of the Royal Air Force and the Essex Regiment. A stone memorial appears to have been recently completed.

The chapel of ease at Hastingwood was built in I 864 and consists of a nave and small chancel. ${ }^{38}$ It is of red brick with diaper ornament and has a small bellcote at the west end. The east window contains memorial glass to John Stallibrass of Paris Hall ( 1872 ) and his wife (1868).

The church of $S T$. $\mathcal{F} O H N$, Thornwood Common, was built in 1923, and was the gift of Mr. and Mrs. C. E. Hart. ${ }^{39}$ It replaced a small corrugated iron church which lies on the opposite side of the main road a little to the south of the turning to Epping Upland. This iron church had been built in $1888 ; 40$ it is now almost derelict. The new church is of red brick and has pointed doors and windows. It consists of nave, chancel, and small western bell-cote. It is also a chapel of ease to St. Andrew's.

In I672 the house of a Mr. Bennett in North Weald was licensed for worship by

NONCONFORMITY Presbyterians.4I A conventicle in the parish was licensed in

I 704.42

No nonconformist place of worship was mentioned in the returns of 1829 as then existing in North Weald, ${ }^{43}$ but a Congregational chapel was opened soon after. This was probably the chapel shown on the parish map of 1838 , near the south end of Weald Bridge. 44 In 1841 Richard Cecil, minister of the Congregational church at Chipping Ongar (q.v.), reported that students under his care had resumed preaching at North Weald 'amidst encouraging circumstances'.45 Before 1847 a resident evangelist, Mr. Vale, had come to North Weald and was receiving financial assistance from the Essex Congregational Union.46 About $185^{\circ}$ he began preaching at Moreton (q.v.), 47 where he was living by 1857.48 By 1859 he was preaching there more often than at North Weald. Thenceforth the congregation at North Weald seems to have declined,49 and services probably ceased altogether about $1874 .{ }^{\mathrm{so}}$ The former chapel has apparently been demolished, although the house beside it remains.

From about 1867 to I 875 services were held in the parish at Tylers Green, in connexion with the Congregational church at Abridge in Lambourne (q.v.). SI

In 1883 a Wesleyan Methodist chapel at Thorn-
29 N. Pevsner, Buildings of Essex, 282.

30 E.R.O., D/P 84/8/2.

3t Kelly's Dir. Essex (1870), but cf. ibid. (1886).

32 Ibid. (1886).

33 Ibid. (1 906). The present glass in this window is dated 1927 .

34 Inf. from the Rev. B. F. Adeney, 1954.

35 Ch. Bells Essex, p. $44^{\circ}$.

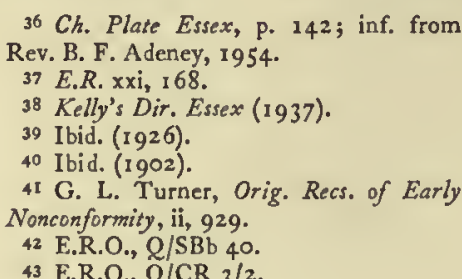

${ }^{36} \mathrm{Ch}$. Plate Essex, p. 142 ; inf. from Rev. B. F. Adeney, 1954 .

37 E.R. xxi, 168.

38 Kelly's Dir. Essex (1937).

39 Ibid. ( 1926$)$.

40 Ibid. (1902).

4 I G. L. Turner, Orig. Recs. of Early

Nonconformity, ii, 929 .

42 E.R.O., Q/SBb 40.

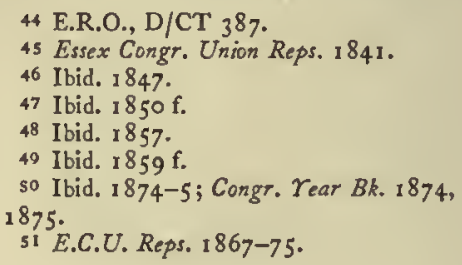

44 E.R.O., D/CT 387

46 Ibid. I 847

47 Ibid. $1850 \mathrm{f}$

40 Ibid. 1859 .

1875 . E.C.U. Reps. $1867-75$. 


\section{ONGAR HUNDRED}

wood Common was placed on the plan of the Wanstead and Woodford circuit. 52 In 1892 the chapel was in debt, but a mission was established to help it and by the next year the debt had been reduced to $£_{0} . .^{53}$

In 1898 a sub-committee was formed to inquire into the affairs of the chapel, which, it was feared, were not conducted in accordance with Methodist regulations. 54 In $1899 \mathrm{Mr}$. Childs was appointed lay agent at a salary of $£ 25$ a year and in June of that year he reported a steady growth and a renewed observance of Methodist principles. $\$ 5$

The society at Thornwood was never large, although at one time it had the largest Sunday school in the circuit. 56 In 1935 the need for extensive repairs to the chapel became evident.57 In the following year land was given for a new building by a Mr. Slack, 58 but it was not used and in 1939 the chapel was finally closed because there was not sufficient support to justify either the erection of a new building or repairs to the old. The chapel was demolished and the site sold.s9 It stood on the west'side of the main road nearly opposite Weald Hall Lane.

In December 1888 a committee was formed by the Wanstead and Woodford circuit to consider building a Wesleyan chapel at North Weald, where military barracks had recently been erected. 60 In the following year it was decided to erect a rustic wooden chapel at a cost of $£_{150.61}$ A plot of land was leased from $\mathrm{Mr}$. W. J. Smith at a rent of Ios. a year. ${ }^{62}$ The new chapel was opened in 1890 , the cost of building having been raised by public subscription. ${ }^{63}$

The new society was not very successful and in 1905 it was decided to continue it only on the recommendation of the Local Preachers' Meeting. ${ }^{64}$ In 1907 an adjacent plot of land was purchased for £ $\mathrm{r} 20$. In 1910 the original lease was renewed and a new trust formed.65

In 1925 it was decided to build a new chapel at North Weald.66 On the recommendation of the circuit development committee the chapel was built in 1929 at a cost of $f_{1} 1,074 .^{67}$ In 1930 it was reported that young men from Woodford were doing valuable work at North Weald, but in 1934 a committee was set up to consider the work there. 68 In 1950 the problem of the lease, which had been four times renewed since I 9 IO, was solved by Mr. T. J. E. Bird, who bought the freehold for $f_{0} \mathrm{I} 2$ and gave it to the trustees. The church has been under the supervision of the Epping ministcr, who is at present the Revd. E. B. Roebuck. The society has a membership of $19 .{ }^{69}$ 'The chapel is a small brick building, cement rendered.

The existing court rolls of the manor of Marshalls cover the period I $572-$ $P A R I S H$ GOVERNMENT 1728 and there is also a $A N D$ POOR RELIEF court book for I832I 924.70 For the manor of North Weald there are rolls for $1741-93 .{ }^{71}$ In each case the business recorded is that of a court baron only.

One general parish book survives for North Weald,

52 Address by Mr. A. W. Leach,

Wanstead, 19 Dec. 1919. (Reported in Mins. of Local Preachers' M tgs. Wanstead and Woodford Circuit, 1879-1930.) s3 Mins. of Circuit Quarterly Mtgs. I $887-99$.

54 Ibid. 35 Ibid.

56 Address by Mr. Leach.

57 Mins. of Circuit Quart. Mtg. I93 I41.

s8 Ibid. covering the years $1679-1879.72$ From about $175^{\circ}$ to I 790 there were usually vestry meetings at Easter and in the autumn of each year. Otherwise there were meetings at Easter but rarely at any other time. The average attendance throughout the period 1679-1836 was fairly high, being about 10. 'The highest recorded was 2 I at the Easter vestry of I702. George Hellier, the curate, usually presided between I 709 and 1727 . Of the vicars only Francis Stanley attended regularly. He usually presided between 1765 and 1781 . After $178 \mathrm{I}$ the churchwarden was usually in the chair. John Benton was probably parish clerk in 1687. He was then recorded as living in the Church House. He wrote the rate in the parish book, receiving Is. for this, and also washed the surplice. After his death his son Isaac succeeded him. In 1774 the clerk was receiving a salary of 2 guineas. In I 803 John Stokes agreed to retire from the office of clerk on payment to him of $£, 5$ and the promise that the parish should provide him with a house for life, 'the workhouse excepted'. John Benton, parish clerk in 1707 , was also sexton, for which office he was supposed to receive $4 d$. a year from each house in the parish.

General rates 'for the use of the church and the poor' were levied each year by the overseers. The churchwarden did not usually levy a separate rate but was reimbursed by the overseers. 'The hamlets of 'Thornwood and Hastingwood were separately assessed and levied their own rates. In 1679 a rate of $\mathrm{I} d$. in $\mathrm{EI}$ produced a total of $£ 92 \mathrm{~s} .6 \mathrm{~d}$., of which $£ 4$ I $8 \mathrm{s.} 9 \mathrm{~d}$. came from the main body of the parish, $f_{2} 5$ s. $9 \mathrm{~d}$. from Hastingwood, and $\mathrm{E}_{\mathrm{I}} \mathrm{I} 8 \mathrm{~s}$. from Thornwood. There was little change in the assessment during the next century: in 1786 a $1 d$. rate produced $£ 8$ I 7 s. I I $d$. for the whole parish.

Although the vestry met only once or twice a year it maintained a check on the actions of its officers by requiring that no grant of weekly pensions or firewood to the poor was to be made without an entry in the parish book and the subsequent approval of the vestry. It also tried to ensure that all parishioners took their fair share of common burdens. Thus in 1697 it was recommended that all should in turn take poor children as apprentices, with an allowance of 40 s. for clothing. Of the I 3 persons present 8 did so and 4 others followed their example later in the same year. In 1804 a Mr. Wilson was paid fio when his son was drawn for the militia.

Until about I766 4 overseers and 3 surveyors of highways were appointed. Thornwood and Hastingwood each had I overseer and the other 2 were responsible for the rest of the parish. There was apparently I surveyor for each division of the parish.73 These arrangements were already established by 16I 3.74 After I 766 the total number of overseers was. reduced to 3 , there being I instead of 2 for the body of the parish. This continued until I 8 Io when a single salaried overseer was appointed for the whole parish. From I 8223 overseers were again appointed. There s9 Papers re sale.

60 Mins, of Circuit Quart. Mtgs. I $887-$ 99.

6I Ibid.

62 Trust Deeds in Circuit safe. Except where otherwise stated the account is based on these deeds.

63 Mins. of Quart. Mtgs. 1887-99.

64 Ibid. I 899-I 909

65 Ibid. $1909-16$.

66 Ibid. I 925-30.
67 Ibid.

68 Ibid. I93 I-4I.

69 Circuit Plan Jan.-Apr. 1953.

70 E.R.O., D/DB M68-76; D/DTc M4. 7 E.R.O., D/DBm M 197-203.

72 E.R.O, D/P 84/8. Unless otherwise stated all information in this section is taken from this book.

73 The appointment of surveyors was not regularly recorded.

74 E.R.O., Q/SBa 3. 


\section{A HISTORY OF ESSEX}

was evidently a system of rotation for service in this office, for in 1766 an overseer was described as serving out of his turn. Before the I 9 th century only I churchwarden was usually appointed, but sometimes 2 .

The parish owned 2 houses, each divided into 2 tenements, for accommodating the poor. One of the houses stood at Weald Gullet and was copyhold of the manor of North Weald; it was acquired for parish use in 1766.75 The other was at Skips Corner and was freehold. How long the parish had owned it is not clear, and in 1838 when the houses were sold the deed of conveyance did not recite any earlier deed and only stated that the house had been 'for many years' parish property. 76

In $16 \times 3-14$ the four overseers spent 66 I6s. I Id. on poor relief, making grants of money, paying rents, and supplying wood.77 By 1680 disbursements had risen to some $£ 30-£ 40$ a year. There was a steady increase throughout the I 8 th century, $f_{200}$ being reached in $176 \mathrm{I}$ and $f_{3} 300$ in $178 \mathrm{I}$. By I $80 \mathrm{I}-2 \mathrm{ex}-$ penditure had risen to $£^{86} 6_{3}$ and it averaged about $£_{800}$ between 1810 and 1822 . The division of expenditure between the hamlets and the main body of the parish varied considerably but usually approximated to their respective proportions of the rateable assessment. The parish overseer accounted for about half the expenditure: in $1801-2$, for example, his expenses amounted to $£ 455$, those of the Thornwood overseer to $£ 237$ I 4 s. and of the Hastingwood overseer to $6_{0}$ I 70 i Is. The hamlets were not so independent that they were left to bear the burden of their expenditure alonc. The same rates were levied on all, whatever their share of the total expenditure, and at the final audit at Easter a deficit in one account was balanced by the surplus of another. Usually all overseers had surpluses which were paid to the churchwarden to meet his accounts. Doctors' bills for attending the poor were being paid from 1738 . From 1778 the parish doctor received a regular salary of 7 guineas a year. North Weald was one of the parishes which contributed to the Society for the Promotion of Industry founded in I 794 by John Conyers of Epping. In I 836 the parish became part of the Epping Poor Law Union.

Simon Thorogood, fishmonger of London, by his will proved in 1635 , left 6.50 to build a SCHOOLS schoolroom at North Weald, and endowed it with fio a year from an estate called Hartsgrove in Barking to pay a schoolmaster to teach children from this and neighbouring parishes. 78 The school was not actually established until 1678 , because of what Morant called 'some bad management'.79 It subsequently flourished and seems to have had a continuous existence throughout the 18 th century. ${ }^{80}$ By the early Igth century it had apparently declined. In 1818 there were said to be only 6 pupils on the foundation, possibly because two other schools had been established in the parish. ${ }^{81}$ About 1829 the vicar revived the school by increasing the number of pupils and by establishing in conjunction with it a Sunday school which flourished for many years. In 1833 he was receiving, in addition to the trust income of $£_{1} \mathrm{I}$, about $\oint_{\mathrm{I}} \mathrm{2}$ in local contributions. ${ }^{82}$ $\mathrm{He}$ supervised the school and appointed the master, who lived rent free and taught in a cottage situated between the road and the churchyard and thought to be the original I 7 th-century schoolhouse. The pupils paid Id. a week to learn to read and a higher fee for writing; the girls were taught plain needle-work, apparently by the master's wife. 83 In 1838 the school was occupying one of a pair of houses immediately east of the old cottage. ${ }^{84}$

The population of the parish was almost 900 at this time and the schoolhouse could not accommodate all the children needing education. In 1839 there were 63 attending it; another 40 went to dame schools in the parish. 85 In I 842 the vicar, Henry Cockerell, collected subscriptions for a new school. The pair of cottages previously mentioned was either rebuilt or incorporated in 2 new school building of red brick. 86 Although called a National School throughout the remainder of the century it does not seem to have been in union with the National Society. 87 The attendance increased rapidly after the building of the new school, reaching 95 in 1846-7.88 The master and mistress, who were untrained, were then receiving $£ 42$ a year, a salary which the vicar thought insufficient to attract competent teachers. Attendance at the school remained steady for 20 years: in 1867 there were 97 pupils, all children of farm workers, taught by an uncertificated master and mistress. ${ }^{89}$ There was a special class for the free scholars, said to number 40 in 1848.90

After the Education Act of 1870 Churchmen in the parish decided to increase the accommodation, which the official inquiry in I 871 showed to be quite inadequate.91 The Education Department pressed for the provision of places for all the 160 children in the parish needing elementary education.92 A building committee was therefore established, which collected $£_{334}$ in voluntary subscriptions and raised a further $\$ 256$ by means of a voluntary rate of $9 d$. The school was extended at a total cost of $6_{6} \mathrm{I} 5$ to accommodate about I 50.93 A government proposal at this time to amalgamate North Weald and Stanford Rivers (q.v.) in a single school district was dropped after strong opposition from North Weald.

The enlarged accommodation and the increasing population of the parish made possible an increase in average attendance, from 59 in $I 875$ to $8 I$ in $I 886$ and 122 in 1893 ; the annual grant to the school increased from $£, 33$ to $6.6 \mathrm{I}$ and $£ .93$ at the same dates. 94 In 1894 the accommodation was further increased to 214 places by the addition of an infants' room at a cost of $£ 250$, defrayed by local contributions and some grants from church organizations. In I 897 a new teacher's house was built in place of the old cottage in the churchyard.95 In 1902 the average attendance

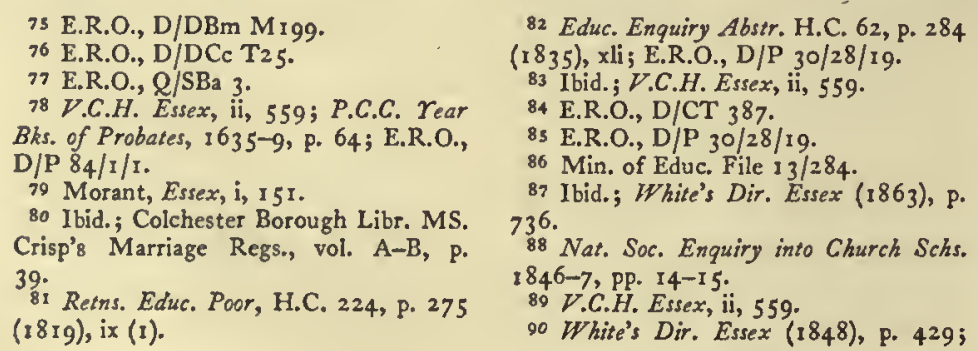

D. W. Coller, People's Hist. Essex, 48 r. 91 Retns. Elem. Educ. H.C. 20I, Pp. I IO-II (I 871$)$, Iv. 92 Min. of Educ. File $13 / 342$ 93 E.R.O., D/P 84/8.

94 Rep. of Educ. Cttee. of Council, 1875 [C. $1513-1]$, p. 533 , H.C. $(1876)$, xxiii; ibid. 1886 [C. 5123 ], p. 520, H.C. (I 887 ), xxviii; Retn. of Schs. 1893 [C. 7529], p. 7 I 5, H.C. (1894), lxv. 95 Ex. Inf. Nat. Soc. 


\section{ONGAR HUNDRED}

was I 50 and the annual grant $f_{0}$ I $54 .{ }^{96}$ Further income came from the contributions of local churchmen, 2 I of whom gave $25.6 d$. or more in 1900 , and from the original endowment of $\{10$ a year.97

By the 1902 Education Act the school passed under the administration of the Essex Education Committee, Epping District, as a non-provided, mixed school. The number of pupils continued to grow for some years. In 1904 there were 176 on the roll, with an average attendance of 160 , and the staff comprised 5 teachers and 2 monitresses.98 Average attendance fell to 134 in 1910 and 101 in 1929 . In 1932 the school was reorganized for mixed juniors and infants and by 1938 the average attendance was only 71.99

In June I 940 the school was closed because of its proximity to North Weald airfield. For several months a system of home tuition was carried on in the village while some children attended the primary school at Chipping Ongar. In March I 94I a temporary school was opened in the parish at Wildingtree Farm, a twostory red-brick house on the west side of the road to Magdalen Laver. In 1953 this building was still in use but a new primary school was in course of construction north of the housing estate at School Green. In May 1952 there were 167 children under 6

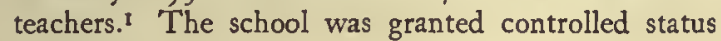
in 1952.2

The small timber-framed cottage between the road and the churchyard, said to be the original i 7 thcentury school, still exists. The stairs and partitions are probably later insertions. Adjoining the cottage to the east is the Igth-century school, now used for storage purpose and some village activities. The back of this building is of two stories and probably represents the schoolmaster's house of about I 842 . The road frontage appears to be mostly of 187 I with later alterations and additions. The barge-boards of the central gable have the inscription: "Train up a child in the way he will go and when he is old he will not depart from it.' 'The teacher's house, on the opposite side of the road, is also of red brick and is dated I 897 .

96 Schs. under Bd. of Educ. 1902 [Cd. 1490], p. 73, H.C. (1903), li

97 Min. of Educ. File $13 / 284$.

98 Essex Educ. Cttee. Handk. 1904. $\mathrm{I} 50$.

99 Min. of Educ. File $13 / 284$.

Richard Rainsford of Epping (d. 1604) left $£_{5}$ to found a charity. ${ }^{3}$ By a deed of 1610 , CHARITIES of which a copy was extant in 1834 , the income was to be applied for the relief of the poor. There is no later record of the charity. 4

A Dr. Searle, ${ }^{5}$ at an unknown date, left 36 bushels of barley a year to the poor of the parish. In 1834 the cash equivalent was paid by the rector in respect of land adjoining the glebe. The charge was redeemed in 1936 for $£ 302$ stock. In $1949 £ 9$ was given to 36 persons in $5^{5}$. shares. ${ }^{6}$

Mrs. Anna M. Burrell, by will proved 1809 , left $£ 400$ stock in trust for equal annual payments to four poor widows of the parish. In 1834 and 1949 the income was given in cash to widows. 7

George Rayment's Charity was apparently founded by an indenture of 1862 , but since payments from it were later made for the repair of a tomb, it may have originated in a will. The endowment is 6150 stock, held in trust for payments every February to four poor persons with dependent families. In I 949 the income seems to have been absorbed in that of other charities: $\mathrm{f}_{2} 8$ was given away in small amounts of money apart from gifts to widows.

The Revd. Frederick Vane, by will proved I 865, left $£ .50$ in trust for the poor of the parish, to be distributed on St. Thomas's day. About I 87 I the income may have been applied to the parish school. In 1949 the income was distributed along with that of the other charities.

Harriet Smith, by will proved 1887 , left $£_{3} 00$ in trust to maintain the tomb of her parents for 60 years. The surplus, and after that period the whole income, was to be used to distribute bread each year to the poor. The bequest for the tomb was void. In I $949 £_{\mathrm{I}}$ os. I I $d$. was spent on bread and the rest of the income was spent with the other charities.

The North Weald Comforts Fund was formed in 1949 from the balance of between $£, 500$ and $\delta_{0} 600$ left when the District Nursing Association was terminated. The fund is to be used to help the sick. In I950 $\mathrm{fr} 7$ were spent. ${ }^{8}$

I Ex Inf. Essex Educ. Cttee.

2 Ibid.

3 E.R.O., D/P 84/1/1. See Morant, Essex, i, 50.

4 Rep. Com. Char. (Essex), H.C. 216 , pp. 2 50-2 (I 835$)$, xxi (I).
5 Ibid. A John Searle, D.D., was vicar from I706 to 17 I 5. See Church.

6 Rep. Com. Char. (Essex), pp. 250-2; Char. Com. files.

7 Ibid.

8 Char. Com. files. 


\section{ANALYSIS OF SOME MEDIEVAL TAX ASSESSMENTS: ONGAR HUNDRED}

The tables below bring together certain statistics derived from medieval fiscal records. They aim at showing how the places in Ongar hundred compared in wealth and density of settlement with one another and how the whole hundred compared in those respects with other parts of Essex and of England.

\section{Taxes on Movables}

By the last quarter of the I $3^{\text {th }}$ century Englishmen had grown accustomed to tax assessments based upon the value of movables, a fraction of the assessed value of each eligible taxpayer being taken in tax. Until 1332 a different fraction was taken whenever Parliament granted a tax and a new assessment was made on the occasion of each grant. In and after 1334, however, it became the rule to take a fifteenth in country villages and a tenth in boroughs and on ancient demesne of the Crown. ${ }^{\mathrm{I}}$

The assessment of 1320 (summarized below, Table 1 ) shows the form of these assessments up to 1 332. In the original roll each place has a boldly written heading beneath which appear the names of the inhabitants who are liable to tax. The assessment of the movables of the inhabitants is given, followed by the sum representing the fifteenth part of this value, the individual's tax liability. A total (summa) for each place is given. 'Totals for the hundred and for the county also appear. ${ }^{2}$

In I 334 (see Table I) the whole appearance of the rolls changes. In place of lists of names there are only lists of villages. This change mirrors the change in the basis of taxation. The Exchequer was now content to collect the tax on the basis of a single payment from the whole vill. So long as this payment reached at least the sum of individual villagers' payments in I 332 the Exchequer did not intervene. The appropriate sum for each vill was left to be fixed by local negotiation between the representatives of vills and the royal officials.

There is no suggestion that Edward III intended this arrangement to become permanent, but in fact the sums allotted to each village in 1334 continued to form the basis of their assessment until the reign of Charles I. If the Commons granted a sum greater than a fifteenth would have brought in, then some additional money was raised from a new form of tax (such as the poll tax of 1377 , see below); or else more than one-fifteenth was granted, ${ }^{3}$ so that each village made a payment of two or three times the sum allotted to it in I334. 'This sum, for brevity, will be referred to as 'the basic village quota'. 'The difference between $132^{4}$ and $1334^{5}$ may be illustrated from Lambourne. The summa of individual assessments in I 332 was 53 s. I $0 d$. The basic village quota fixed in I 334 was $57 \mathrm{~s}$. For the whole hundred of Ongar the total in 1332 was 66217 s. $9 d$. In 1334 it was $6666 s .3 d$.

Since they give the names of the principal property-owners the tax-lists up to and including 1332 have long been used by genealogists. Economic historians have also found them interesting as a rough indication of the varying levels of prosperity to be found in different places. A village like Theydon Bois which collected $33 s .5 \frac{3}{4} d$. from 23 taxpayers in 1320 is clearly different from a village like Theydon Mount where approximately the same sum (in fact, 35s. I $\frac{1}{4} d$.) came from only 7 taxpayers. ${ }^{6}$ In the rather different social and agricultural conditions of the North Riding of Yorkshire, it has been suggested that a vill with one outstandingly large taxpayer probably had a lord working his own demesnes, while a number of roughly equal assessments indicate a vill with a weakened manorial structure and a fair number of tenants occupying part of the demesne.7

Interesting as are the questions they raise, these pre-1 334 assessments are only of limited value in redetermining the relative wealth of Essex villages and of little, if any, value in determining their populations. There are several reasons for this. Some types of movable property were not assessable to tax, while some persons were too poor to be taxable at all. There was probably also a good deal of evasion and under-assessment. It is as though we were allowed to inspect the top of an iceberg but

I For details of the methods of assessment and collection see J. F. Willard, Parl. Taxes on Personal Property 1290-1334; Surr. Tax. Retns. (Surr. Rec. Soc. xi), v-lxxvi.

2 The totals for Essex in the various years have been brought together by J. F. Willard: E.H.R. exviii, 5I 9-2I, xxix, 319-2I, xaxx, 72-73. For the period after 1334 the totals will be found enrolled in $E_{359}$.

3 e.g. 1404, two Ioths and I5ths; 1419 , one and one-third roth and I 5 th.

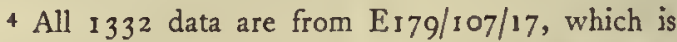
wrongly dated in the P.R.O. Typescript calendar as 1334 .

5 All I 334 data are from EI79/107/4I which has been checked in $\mathrm{E}_{1} 64 / 7$, a I 5 th-cent. engrossment of the whole country.

6 All 1320 data are from EI79/107/I IO-I I.

7 T. A. M. Bishop, 'Distribution of Manorial Demesne in the Vale of Yorkshire' (E.H.R. xlix), 386-406. 


\section{ONGAR HUNDRED}

debarred from looking under the water. It is not very useful to regard the recorded number of taxpayers as being a fixed proportion of the whole village. A prosperous village would have a much higher proportion of its inhabitants named on the tax-list than a poor village with only one or two names recorded.

Taking Ongar hundred as a whole, these early assessments enable one standard to be applied which may yield interesting results when all the hundreds have been compared. Thus, in the earliest extant roll, that for $1237-8$, Ongar hundred ${ }^{8}$ paid $£ 36$ IIs. I I $d$. out of the Essex total of 67 I0 7 s. Id., or about 5 per cent. of the whole. In 1320 it paid $£ 68$ Is. $6 d$. out of $£_{\text {I }}, 333$ I 25 ., or about 5 per cent. of the whole, while in 1332 it paid $£ 62$ I 7 s. $9 d$. out of $£ 1,178$ I I s. $6 d$,, or again a share of just over 5 per cent. In 1334 the share of this area was $£ 666 s$. $3 d$. out of $£_{1}, 234$ I $4 s .7 d$., or a share of just under 5 per cent.

The various local assessments are set out in Table I for the 25 units of collection, or 29 named places. In studying the table the first matter to be considered is the range of size exhibited in the village quotas of 1334. In Ongar hundred most villages paid between 20s. and 6os. Only two, Shelley and Stondon Massey, paid less then 20s., and only 5 paid more than 60s. The average of the 25 sums is 535 ., 4 of these sums representing a payment for 2 places. In 1334 the corresponding average for Essex as a whole is $68 s .7 d$.

Although the basic village quotas of 1334 remained unaltered there were occasions when they were temporarily modified, abatements or reliefs being allowed in view of the impoverishment of a particular vill. Such occasions were the three collections of a tenth and a fifteenth granted in I 35 I when impoverished vills were reimbursed out of a fund provided by fines collected under the Statute of Labourers. Thus one effect of the Black Death was mitigated by applying moneys drawn from those who were attempting to profit from the general shortage of labour. The amount which the Justices of Labourers had to distribute in relief to the villages depended, of course, on the fines imposed. The total in Essex was large. In $1352 £_{7}$ I 10 Ios. was so collected, of which, after expenses, $£_{675}$ I Is. was allotted among the impoverished vills. Since the total tax obligation was only $£_{1}, 234$, more than half the year's assessment on Essex was made up from the pool of fines.9

Some villages received an allowance equal to the whole of the tax due: Thorpe-le-Soken, 5 Is. $4 d$.; Bocking I03s. I $d$. Comparison with the list of fines paid, which has also survived for this year, shows that Thorpe had lost on the deal, $6_{4}$ I Is. $4 d$. having been collected there in fines for breach of the Statute. No place in Ongar hundred received such munificent relief, and only two places received any relief at all: High Laver was given 40 s. (55 per cent. of the tax due) and Magdalen Laver 20s. (48 per cent.). It is difficult to resist the conclusion that local opinion considered these two vills to have been especially badly hit by the plague, but, as the poll-tax figures for 1377 show, they were certainly far from being depopulated. 10


the confiscated goods of fugitives and felons were applied to the same use but no record from Ongar hundred has yet been found. ${ }^{12}$

In 1433 there began a long series of abatements whereby a sum of $£ 4,000$ and later $£ 6,000$ was distributed among the over-taxed and impoverished villages of the kingdom. For at least the first 30 years of the abatements the evidence indicates that a genuine reassessment of need was made at each new collection of a subsidy; the Devonshire figures show quite wide differences in the sums allowed to each borough from one collection to the next. Unfortunately there are only two surviving rolls for Essex in this period, dated I 433 and 1436 , and in these rolls the rate of allowances in Ongar hundred is the same in each year; the county was relieved of its obligation to pay $£ 12375.5 d$. (or about Io per cent. of the sum due) and in its turn the hundred of Ongar was relieved in the same proportion, $f_{6} 6$ I $2 s .6 \frac{3}{4} d$. being allowed. ${ }^{13}$ In addition to the general abatements granted by statute, some villages in Essex seem to have been allowed a second sum for losses suffered per inundacionem aquarum et alia infortuna [sic] pericula. Thus Langham received Ios. for flood damage. No food relief was given in Ongar, but Chipping Ongar obtained 3 s. $4 d$. extra relief in 1436 for pericula infortuna which were not specified. The abatements were assessed by the Abbot of Colchester and the two knights of the shire in the current Parliament: in 1436 Edward Tyrell and 'Thomas Torell. A document from Totnes suggests that at the end of the Parliament the knights actually brought the relief back with them for . distribution, but the procedure in Essex is not specifically known. ${ }^{14}$

The size of the abatement allowed in 1433 and 1436 for each of the places in Ongar hundred is set out in Table 2. It will be seen that the rate of abatement was everywhere the same, apart from the one extra allowance to Chipping Ongar.

8 EI $19 / 107 / 1$.

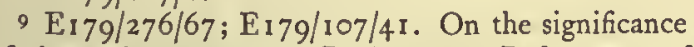
of these abatements see B. Putnam, Enforcement of Statutes of Labourers, passim.

ro $\operatorname{E}_{179 / 276 / 67} \operatorname{E}_{137 / 1} 1 / 2$. The list of fines in the latter document provides other means of establishing the minimum number of people in each village.

II Putnam, Statutes of Labourers, 316*.

12 Ei79/107/42-43. ${ }_{13}$ EI79/108/107-9.

14 H. R. Watkin, Hist. Totnes, i, 409. 


\section{A HISTORY OF ESSEX}

Had more documents survived one could have watched the rise and fall of abatements at each of the subsequent Parliamentary grants until the abatements themselves became conventionalized and inflexible, so that Elizabethan villages were receiving the abatement fixed under Edward IV or Henry VII. The arrival of the new 'subsidy'1s of Henry VIII, assessed on goods, wages, or land, brings the wheel full circle: the Exchequer is again attempting what had been done before I334, a realistic assessment not on a whole village but on individuals with more than a minimum amount of property or income.

The medieval evidence examined so far has dealt only with sums of money, the relative wealth of villages. It has had very little to say about numbers, and the only effective contribution to population history which the tax lists before 1334 can make is to provide a minimum number of taxpayers.

The parish tax of 1428 was of a nature quite different from the fifteenths and tenths so far considered.16 It was in proportion to the sum at which the parish was taxed for the ecclesiastical tenths, but a special exemption was provided for those parishes with fewer than ten householders. The names of such parishes were enrolled and have been printed in Feudal Aids. Five such tiny parish populations were recorded in Ongar hundred: Theydon Bois, Theydon Mount, Little Laver, Shelley, and Norton Mandeville. Only Shelley had been among the bottom five places in the 1334 assessment, although three other places of those exempted in 1428 were in the bottom ten in 1334 . None of the five exempt in 1428 had obtained tax relief in 1352 .

\section{Poll Taxes}

The final set of tax documents here considered is unequivocally concerned with heads as well as with pockets. The poll tax was levied on three occasions, 1377,1379 , and 1381 ; but only the first collection is useful to demographers. The poll taxes of 1379 and 1381 were extensively evaded, and indeed the attempt to check the evasion in an Essex village is usually reckoned the immediate cause of the Peasants' Revolt. 'The lists of names and occupations in the surviving documents of I 379 and 138 I are interesting to the genealogist and indicate the 'spread' of occupations, but they can only be regarded as minimal lists, so great was the evasion. Table 3 shows in column I the actual number of taxpayers in 1377.17 Column 2 is compiled from a nominal list which, though undated, is certainly either of 1379 or 1381.18 The extent of the evasion is made clear if columns 1 and 2 are compared together. Chigwell has lost 67 taxpayers, Beauchamp Roding 12, and Navestock 77. Even the tax of 1377 did not fall on all heads: the groat was only exacted from those over 14, and if the total number of persons in a village is to be estimated, it is necessary to invoke some such assumption as that of Professor Russell, 19 that one-third of a village was under 14 years of age. If this assumption is accepted, another 50 per cent. must be added to the numbers recorded on the tax receipts of 1377 . But there is no reason why one should not add 40 or 60 per cent. In Ongar hundred the average number on each receipt is 85 , perhaps 130 persons. ${ }^{20}$

The arbitrariness of such assumptions limits the utility of the poll-tax returns for demographers. The returns, however, are a useful guide to the relative size of villages in 1377 . So long as the proportion of boys and girls to adults was roughly the same in each village then the numbers on the poll tax receipts will be in proportion to the size of the village. We can say without too many qualifications that Stanford Rivers, with 180 taxpayers, was about six times the size of Theydon Bois with its 30 taxpayers. We can also arrange the villages in order of size, as has been done in Table 5, and say that Chigwell, with 203 taxpayers, heads the list, with Little Laver and Morrell Roding bringing up the rear with 24 and 19 taxpayers. All these statements can be made without knowing exactly how many persons there were in each village when (or before) the tax collector called.

Table 3 sets out the number of taxpayers in each vill as recorded on the receipts filed in the Exchequer. These receipts, given by the collectors to the constables of each vill, give both the sum paid and the number of heads, 'de capitibus'. No names, other than the constables', appear. Names were unnecessary as long as everyone was paying a flat $4 d$. When, in 1379 and 1381 , the flat rate was supplanted by a graduated tax, varying with social status, nominal and occupational lists had to be compiled.

\section{Ranking by size}

It is now possible to bring together the various tax assessments which have been considered. One effective method of comparison is the technique of 'ranking', a simple comparison of the relative position of each place in relation to its neighbour. A ladder may be imagined, with the successive rungs representing the villages, the top rung being the largest tax assessment and so on to the lowest. It will be seen from Table 4 that a village does not always maintain itself on the same rung from one tax col-

is $\operatorname{Er} 79 / 108 / 214$.

16 Feud. Aids, ii, 204-6.

$17 \mathrm{E}_{179 / 107 / 51 .}$

18 EI79/107/60.

\footnotetext{
I9 J. C. Russell, Brit. Medieval Population, 23-24, 143.

20 The clergy were taxed separately and do not figure in the returns.
} 


\section{ONGAR HUNDRED}

lection to the next; nor are the villages with the greatest tax assessments always those with the greatest number of heads recorded on their poll-tax receipts in 1377 .

Until comparable figures have been published for other parts of the county and for other counties it is not possible to deduce very much from what is, statistically, a very small batch of figures. Theydon Bois and Little Laver seem to move down the ladder as the years pass while Loughton and Stondon Massey rise. Consideration of the individual parish histories may offer an explanation in terms other than the effects of the Black Death. Remembering that only two vills received reliefs in 1352 , and that the ranking of neither of these changes very much, we may hazard that the long-term effect of the Black Death was not serious in this particular hundred. A different story may emerge from those hundreds of Essex where substantial reliefs were granted in 1352.

In the small sample afforded by the 25 sets of data in Ongar hundred only the most striking changes in 'ladder' position are likely to be significant. It will be noticed that in terms of absolute size, whether in 1334 or 1377 , the first three places are held by the same three villages, Stanford Rivers, Navestock, and Chigwell with Woolston. Shelley and Kelvedon Hatch occupy consistently low positions, while Stondon Massey and Loughton seem to improve their status over the years. Only Little Laver shows a headlong decline from a middle to a bottom rung.

It is significant that the villages high on the absolute-size 'ladder' are not at the top of the density 'ladder'. The top place is firmly held by Chipping Ongar whose 500 acres were not the sole means of its inhabitants' support. Little Laver, whose fall has been noted above, also shows a fall in terms of density. The improved position of Stondon Massey is also repeated.

The allotment of reliefs in $1433-6$ was so uniform that the order in which the assessments stand in 1334 is very little disturbed, only Norton Mandeville falling a place.

In the final column of the Table an attempt is made to indicate the degree of inequality existing in the 1320 assessments, where the average tax paid per taxpayer varies considerably from village to village-from 6s. 1od. at Stapleford Tawney to $1 s .6 d$. at Theydon Bois. The great differences in ranking between this and the other 'ladders' indicates that there is no simple connexion between the absolute size of a village assessment in 1320 and the number of villagers among whom the assessment was shared.

These preliminary comparisons are intended more as a suggestion for further investigation locally than as a final verdict. In the same way inter-village comparisons of density and size become really significant only when an area wider than a single hundred is available for study. ${ }^{21}$ Comparisons with some other areas of England have been made in Table 6.

\section{Densities}

The Tables of densities printed below (Tables 5 and 6 ) have been contrived on the assumption that the fiscal units, which were vills, were equal in area to the parishes of 1801 . For this there is no warrant, but it is the nearest approximation that can be reached. No important changes in parish boundaries within the hundred can be traced between about I 300 and I $84 \mathrm{I}$.

The consideration of densities may be related to the settlement history of the hundred. Anyone accustomed to the much more clear-cut settlement history of the Midlands and the northern plains must find, Essex, and this part of Essex in particular, a hard county to study. In the Midland areas the work of colonization and clearing was almost complete by the time that Edward III's fifteenths and tenths were being collected. Apart from the villages with some non-agricultural occupations, the population as shown in the poll-tax receipts was maintained by the area of field-land roughly corresponding to the modern parish area. A density figure, obtained by calculating taxpayers per thousand acres, is a useful concept and serves to draw attention to the different agricultural experiences and potentialities of different villages. In the same way, the tax paid per thousand acres in the 1334 village quotas can be calculated, and this will be referred to as a 'tax density'.

In Essex the same calculations can be made, and the results are set out in Table 5, but the implications of the results are less certain than in the Midlands. In the Essex parishes there was a much greater area of surviving woodland; the nucleated village at the heart of continuous open-field land could only have been found in a very limited area of the county. Of the four largest villages in the medieval tax-lists of Ongar hundred, only Chigwell has any substantial village nucleus; while Stanford Rivers, Theydon Garnon, and Navestock have isolated or semi-isolated churches and very scattered settlement.

The density figures in I 377 show that half the vills in Ongar hundred had densities of between 32 and 44 taxpayers per thousand acres, indicating very similar environmental opportunities. Apart from this group stand Theydon Bois and High Ongar with markedly low densities, and at the other extreme is Chipping Ongar, a market-town with 108 taxpayers in its 500 acres.

If the density for Essex as a whole is calculated, it works out at 47 per thousand acres, about the

2I Tables giving sizes and densities for Midland Eng. 25 I-3, 407-9. counties appear in M. W. Beresford, Lost Villages of 


\section{A HISTORY OF ESSEX}

same as for Somerset, Buckinghamshire, and Nottinghamshire. The average for Ongar hundred is only a little smaller: $3^{8}$ per thousand acres. If similar calculations of tax density are made in terms of shillings per thousand acres in 1334 , Ongar hundred again appears within a few pence of the average density for Essex (23s. 8d. as against 23s. 5d. for the county) and again at about the same average as for Somerset, Buckinghamshire, and Nottinghamshire. ${ }^{22}$

\section{TABLE I}

\section{TAXES ON MOVABLES, 1320 AND 1334: ASSESSMENTS}

\begin{tabular}{|c|c|c|c|c|c|c|}
\hline \multirow{2}{*}{\multicolumn{2}{|c|}{ Place }} & \multirow[t]{2}{*}{$\begin{array}{l}\text { Number liable } \\
\text { to tax } \\
1320\end{array}$} & \multicolumn{2}{|c|}{$\begin{array}{c}\text { Total of } \\
\text { personal assessments } \\
I 320\end{array}$} & \multicolumn{2}{|c|}{$\begin{array}{c}\text { Basic village } \\
\text { tax quotas } \\
\text { from } 1334\end{array}$} \\
\hline & & & s. & d. & s. & d. \\
\hline Bobbingworth & . & 9 & 40 & $4 \frac{3}{4}$ & 44 & $5 \frac{1}{2}$ \\
\hline Chigwell with Wools & . & 30 & II 5 & & 97 & \\
\hline Fyfield & . & 33 & 96 & $7 \frac{1}{2}$ & 86 & $1 \frac{1}{2}$ \\
\hline Kelvedon Hatch & . & II & 25 & $\mathrm{I}$ & 28 & \\
\hline Lambourne & . & 13 & 54 & $2 \frac{1}{4}$ & 57 & o $\frac{1}{4}$ \\
\hline Laver, High & . & 15 & 74 & $5 \frac{3}{4}$ & & II $\frac{1}{2}$ \\
\hline Laver, Little . & . & 12 & 51 & 51 & 48 & $8 \frac{3}{4}$ \\
\hline Laver, Magdalen & . & II . & 33 & $4 \frac{3}{4}$ & $4 \mathrm{I}$ & 10 \\
\hline Loughton & . & 9 & 23 & 0 & $3 I$ & IO $\frac{1}{2}$ \\
\hline Ior & . & 23 & 60 & $0 \frac{3}{4}$ & 53 & \\
\hline Javestock & . & 42 & 156 & $3 \frac{1}{2}$ & 132 & $3 \frac{1}{3}$ \\
\hline Norton Mandeville & ittle Norton. & included $\mathrm{i}$ & High On & & 32 & \\
\hline Ongar, Chipping & 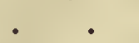 & I 5 & 45 & $7 \frac{1}{2}$ & 50 & $2 \frac{8}{4}$ \\
\hline$h$ with $P$ & & 26 & 76 & $2 \frac{1}{2}$ & 53 & \\
\hline ess with & rell Roding & I I & 28 & $9 \frac{\pi}{2}$ & 36 & 101 \\
\hline auchamp & . . & 12 & 35 & 8 & $3 \mathrm{I}$ & $3 \frac{3}{4}$ \\
\hline & . & 4 & 17 & 3 & 16 & $10 \frac{3}{4}$ \\
\hline ivers & . & 44 & 164 & I & 141 & II \\
\hline bbots & . & 19 & 37 & 3 & 44 & \\
\hline Tawney & . & 7 & 48 & $2 \frac{3}{4}$ & 36 & 50 \\
\hline Iassey & . & II & 22 & $4 \frac{3}{2}$ & I7 & \\
\hline The & . & 23 & 33 & $5 \frac{3}{4}$ & 39 & \\
\hline anon & . & 33 & 55 & & 55 & $3 \frac{1}{2}$ \\
\hline They & . & 7 & 35 & I & & \\
\hline orth, $\mathrm{Ba}$ & & 12 & $3 \mathrm{r}$ & $9 \frac{1}{2}$ & 42 & 72 \\
\hline Total . & - & 32 & 668 & 6 & $£ 66 \quad 6$ & \\
\hline
\end{tabular}

\section{TABLE II}

\section{TAXES ON MOVABLES, 1433 AND 1436: RELIEFS}

\section{Place Statutory Reliefs*}

s. $d$.

Bobbingworth

\section{Chigwell with Woolston .}

Fyfield .

Kelvedon Hatch

Lambourne

Laver, High

Laver, Little

Laver, Magdalen

Loughton

Moreton

Navestock

Norton Mandeville with Little Norton

$\begin{array}{cc}4 & 5 \frac{1}{4} \\ 9 & 8 \frac{1}{4} \\ 8 & 7 \frac{1}{4} \\ 2 & 10 \\ 5 & 8 \frac{1}{4} \\ 7 & 3 \frac{1}{2} \\ 4 & 10 \frac{1}{4} \\ 4 & 2 \frac{1}{4} \\ 3 & 2 \frac{1}{4} \\ 5 & 4 \frac{1}{2} \\ 13 & 2 \frac{3}{4} \\ & \\ 3 & 3 \\ 5 & 0 \frac{1}{4} \dagger\end{array}$

Place

\begin{tabular}{|c|c|}
\hline \multicolumn{2}{|c|}{ Statutory Relief } \\
\hline s. & \\
\hline 5 & $4 \frac{1}{4}$ \\
\hline 3 & 81 \\
\hline 3 & I $\frac{1}{2}$ \\
\hline I & 87 \\
\hline I 4 & $2 \frac{1}{4}$ \\
\hline 4 & 5 \\
\hline 3 & $7 \frac{1}{5}$ \\
\hline I & $8 \frac{3}{4}$ \\
\hline 3 & II \\
\hline 5 & $6 \frac{1}{4}$ \\
\hline 3 & $4 \frac{3}{4}$ \\
\hline 4 & $3 \frac{1}{4}$ \\
\hline$\{6 \quad 12$ & $6 \frac{3 f}{4}$ \\
\hline
\end{tabular}

- See above, p. 299 .
$t$ In addition Chipping Ongar obtained an abatement of $35.4 d$. in 1436 for 'pericula infortuna': see above, p. 299. This made ita total relief 17 per cent. of its tax quota as against the 10 per cent. allowed to other places in the hundred.

F In the manuscript the total is given as $£^{6} \times 25.6 \frac{1}{4} d$.

22 Other Essex tax assessments in this period which 1327: Er79/107/12; the subsidy on aliens of 144r: have not been incorporated in the tables are those of E $_{179 / 270 / 3 I}$ with a nil return for Ongar hundred. 


\section{ONGAR HUNDRED}

\section{TABLE III}

\section{POLL TAXES 1377-81}

\begin{tabular}{|c|c|c|c|c|c|}
\hline Place & $\begin{array}{c}\text { Taxpayers } \\
\text { in } 1377\end{array}$ & $\begin{array}{l}\text { Names recorded } \\
\text { in } 1379 \text { or } 1381\end{array}$ & Place & $\begin{array}{c}\text { Taxpayers } \\
\text { in } 1377\end{array}$ & $\begin{array}{l}\text { Names recorded } \\
\text { in } 1379 \text { or } 1381\end{array}$ \\
\hline Bobbingworth . & 52 & 48 & Roding, Abbess & $5^{2}$ & 43 \\
\hline Chigwell with Woolstor & 203 & 136 & Roding, Beauchamp & 43 & 31 \\
\hline Fyfield : . & 143 & 127 & Roding, Morrell. & 19 & $*$ \\
\hline Kelvedon Hatch. & 44 & 45 & Shelley . & 36 & 42 \\
\hline Lambourne & 84 & 93 & Stanford Rivers . & 180 & 97 \\
\hline Laver, High & 102 & 89 & Stapleford Abbots & 86 & 67 \\
\hline Laver, Little & 24 & 34 & Stapleford Tawney & 61 & 52 \\
\hline Laver, Magdalen & 51 & 42 & Stondon Masscy. & $5^{2}$ & $4 I$ \\
\hline Loughton . & $8 I$ & 44. & Theydon Bois & 30 & 45 \\
\hline Moreton & II 4 & 5ot & Theydon Garnon & 134 & 99 \\
\hline Navestock . & 163 & 86 & Theydon Mount. & 50 & 42 \\
\hline Norton Mandeville with & & & Weald, North, Bassett & 73 & 49 \\
\hline $\begin{array}{l}\text { Little Norton . } \\
\text { Ongar, Chipping. }\end{array}$ & $\begin{array}{r}52 \\
108\end{array}$ & $\begin{array}{l}48 \\
65\end{array}$ & Total . & - 2,117 & $1,592 \dagger$ \\
\hline Ongar, High with Paslov & 80 & 77 & & & \\
\hline
\end{tabular}

- May be included with Abbess Roding.

† In addition there are some illegible names in the Moreton list.

\section{Table IV}

\section{RELATIONSHIP BETWEEN PLACES}

This table is derived from Tables I, III, and V. The numbers are ordinals. Thus in the first column Stanford Rivers has the highest assessment and Shelley the lowest.

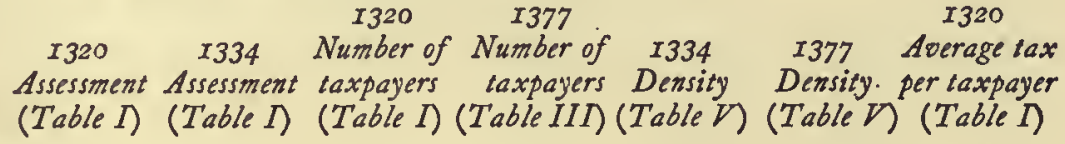

Place

Bobbingworth

$\begin{array}{rrr}13 & 12 & 21 \\ 3 & 3 & 5 \\ 4 & 4 & 3 \\ 22 & 23 & 16 \\ 8 & 6 & 12 \\ 5 & 5 & 10 \\ 9 & 11 & 13 \\ 18 & 15 & 16 \\ 23 & 21 & 21 \\ 6 & 8 & 6 \\ 2 & 2 & 2 \\ & & \\ 20 & 21 & 20 \\ 12 & 10 & 10 \\ 11 & 9 & 9 \\ & & \\ 21 & 17 & 16 \\ 15 & 22 & 13 \\ 25 & 25 & 5 \\ 1 & 1 & 1 \\ 14 & 13 & 8 \\ 10 & 18 & 23 \\ 24 & 24 & 16 \\ 17 & 16 & 6 \\ 7 & 7 & 3 \\ 16 & 19 & 23 \\ 19 & 14 & 13\end{array}$

$\begin{array}{rr}21 & 16 \\ 5 & 1 \\ 3 & 4 \\ 16 & 21 \\ 12 & 10 \\ 10 & 8 \\ 13 & 25 \\ 16 & 19 \\ 21 & 11 \\ 6 & 6 \\ 2 & 3 \\ & \\ 20 & 16 \\ 10 & 7 \\ 9 & 12 \\ 16 & 14 \\ 13 & 22 \\ 5 & 23 \\ 1 & 2 \\ 8 & 9 \\ 23 & 15 \\ 16 & 16 \\ 6 & 24 \\ 3 & 5 \\ 23 & 20 \\ 13 & 13 \\ & \end{array}$

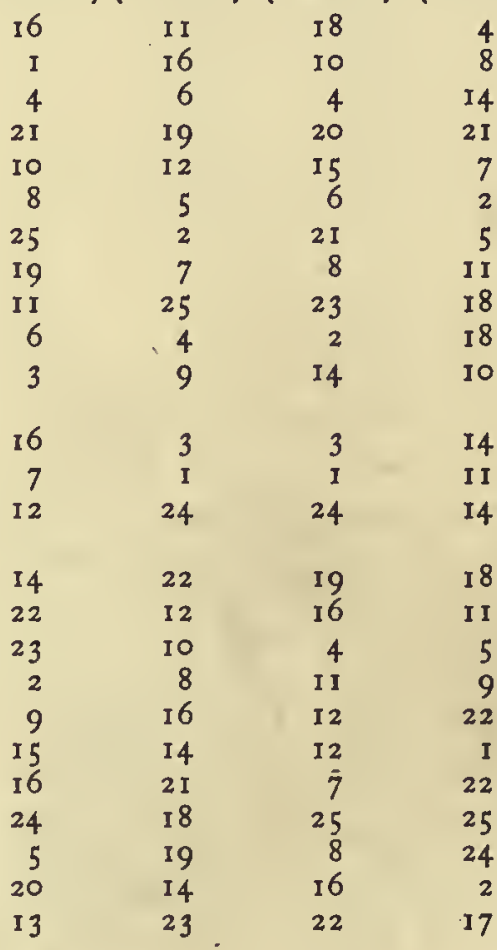

- Had fewer than 10 househoids in 1428 . 


\section{A HISTORY OF ESSEX}

TAble V

DENSITIES OF POPULATION, 1320-1436

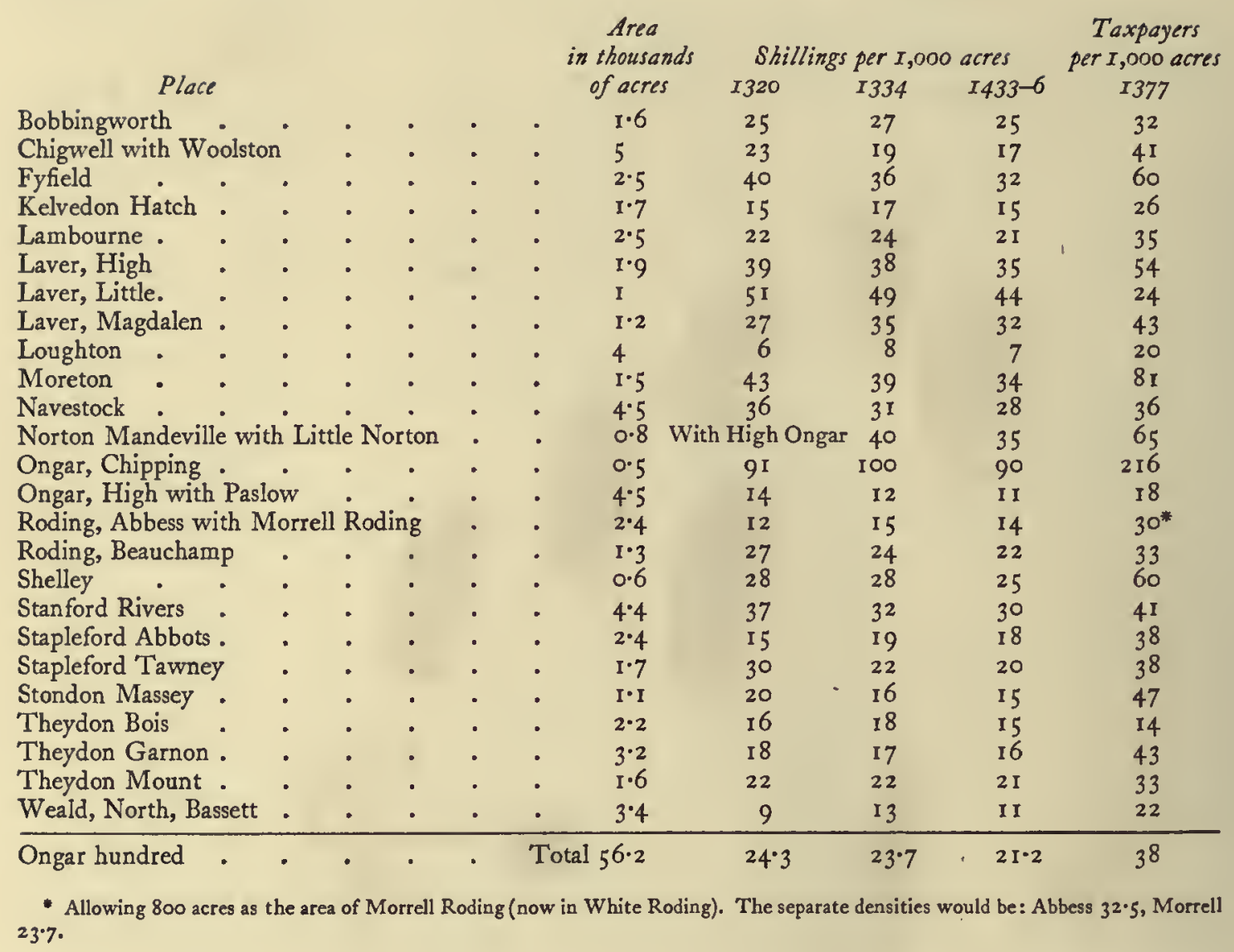

\section{TABLE VI}

\section{COMPARISONS WITH OTHER AREAS}

\begin{tabular}{|c|c|c|c|c|}
\hline & & Densi & ty per & ,ooo acres \\
\hline Area & & in $I$ & & in 1377 \\
\hline Essex & & & & \\
\hline Whole county & .. & 23 & 5 & 47 \\
\hline Ongar hundred & . & 23 & 8 & 38 \\
\hline Berkshire & & & & \\
\hline Whole county & . & 46 & o & 42 \\
\hline Hertfordshire & & & & \\
\hline $\begin{array}{l}\text { Whole county } \\
\text { Leicestershire }\end{array}$ & - & $3 I$ & 4 & 49 \\
\hline Whole county & • & 29 & 7 & $5^{8}$ \\
\hline $\begin{array}{l}\text { Norfolk. } \\
\text { Whole county }\end{array}$ & . & $5 \mathrm{I}$ & 5 & 65 \\
\hline Suffolk & & & & \\
\hline Whole county & . & 30 & 4 & 60 \\
\hline Yorkshire & & & & \\
\hline East Riding. & . & 28 & I & 36 \\
\hline
\end{tabular}




\section{ANALYSIS OF HEARTH TAX ASSESSMENTS FOR ONGAR HUNDRED, 1662, 1670, AND 1674}

For those of the years between 1662 and 1674 when the Hearth Tax was administered direct by the Crown there exist for Essex five Exchequer copies (not all complete) and two county duplicates of Assessments made under the Hearth Tax Act, 1662 (14 Chas. II, c. 10).' Of these Assessments those portions of the Michaelmas 1662, Lady Day 1670, and Michaelmas 1674 Assessments relating to Ongar hundred have been selected for analysis here, for their value in illustrating the distribution of population and, to some extent, the varying levels of prosperity.

Apart from an alphabetical rearrangement of the parishes (the High Ongar hamlets of Bobbingworth and Marden End are shown beneath the parish) the principle of analysis follows closely the method of compilation. The number of entries per hearth total, in columns for $1-16$ hearths and another for 17 hearths and above, is shown against each parish or hamlet and two further columns supply the total entries and total hearths. For the Michaelmas I 662 roll one line per parish is adequate, footnotes being provided to distinguish empty houses. For the later rolls separate lines are needed for the chargeables, certified exempt, paupers, and empty houses. In the rolls the empty houses are generally intermingled with the chargeables and have been transferred to the 'empty house' line in the appropriate hearth column. New building has been distinguished by footnotes which also draw attention to other peculiarities.

The Michaelmas 1662 Assessment is taken from the county duplicate (E.R.O. Q/RTh I), the Exchequer copy of which, preserved at the Public Record Office (EI79/246/8), being now defective. The Assessment was enrolled at the Quarter Sessions at Chelmsford on 15 July and its adjournments on 24 July and 26 August and subsequently returned into the Exchequer on a date now missing from the Public Record Office copy. It served for the collection of the tax for the three half years Michaelmas 1662 to Michaelmas 1663 .

This, the least comprehensive of names of the three Assessments here printed, gives details only of all those persons legally liable for the tax together with their hearths, for no provision was made in the Hearth Tax Act of 1662 for the enrolment of those legally exempt. Assessments for Michaelmas 1662 are, generally speaking, the least useful for a local study. They are, however, those most widely preserved throughout the country and thus form a useful basis of county by county comparison for the same year.

The Michaelmas 1670 Assessment is taken from the county duplicate (E.R.O. Q/RTh 5), the lists of which it is the enrolment having been received at the county Quarter Sessions on 2 May I67 I. The Exchequer copy is no longer extant. It served for the collection of the tax for the three half years Michaelmas I669 to Michaelmas 1670 . It seems to be the case that Assessments made at this time, where preserved, are the most comprehensive of the Assessments made during the second period (Michaelmas 1669-Lady Day 1674) of Crown administration of the tax. This roll, compiled in accordance with the Revising Act of 1663 ( 15 Chas. II, c. I3), shows first those liable for the tax, followed by those whose property qualifications and exemption from church and poor rates excused them from Hearth Tax payments on certification by the local justices. In some 16 parishes and hamlets a third group is shown: the parish paupers who as recipients of alms were automatically excluded. The inclusion of so many lists of paupers in this Assessment, which is paralleled in other counties, is probably due to the fact that these 1670 Assessments were the first to be made by a new administration. It is this roll above all which yields most information on the pattern of settlement and prevailing prosperity levels in Ongar hundred in the 17 th century.

The Lady Day 1674 Assessment is taken from the Exchequer copy ( $\left.E_{1} 79 / 246 / 22\right)$, returned into Quarter Sessions at Chelmsford on I 3 April 1675 and delivered into the Exchequer on 16 August 1675. In this Assessment fewer parishes are found returning paupers and their hearths. Instead of 16 parishes and hamlets, 3 parishes only enrol their paupers and 2 of them give no details of the paupers' hearths. This decline in the enrolment of paupers is also paralleled in other counties; it is probably due to the need for reducing unnecessary listing and enrolling. In some parishes where paupers are omitted, e.g. Chigwell, Kelvedon Hatch, and Theydon Garnon, there is a gain among the certified exempt, suggestive of mobility in the prosperity scale. In other parishes the paupers vanish from the rolls and

1 Exchequer copies not mentioned in this Introduction are those for 1664 Mich. (serving for Michaelmas 1664-Michaelmas 1665), incomplete, and 1673 Lady Day (serving for Lady Day 1672-Lady Day 1673), damaged. Most of the original lists from which the latter were enrolled are preserved at the Essex
Record Office. For some account of the Tax and its administration see V.C.H. Cambs. iv, 272. The compiler of the present tables is indebted to Mr. C. A. F. Meekings for the correct tax dating of these Assessments and for other advice. 


\section{A HISTORY OF ESSEX}

the gross total for these parishes is decreased. Fluctuations in prosperity appear also to account for the return of paupers by Bobbingworth, Beauchamp Roding, and Stapleford Tawney in 1674; the entries are significantly similar to their certified exempt of 1670 . Similarly the decreased number of those chargeable in 1674 is roughly balanced by increases in the certified exempt. In general, however, there is a total loss of some roo entries due to the omission of paupers.

These differences in totals do not alone justify the inclusion here of extracts from the 1674 roll. The value of the 1674 Assessment lies in the indications it contains that the 1670 Assessment is less comprehensive than would at first appear. In the 1674 roll there are 23 entries in 18 parishes declaring that a particular person is charged on a stated number of hearths in 2 or 4 houses. Thus in Theydon Bois Thomas Bradley is charged on II hearths in 2 houses; in Lambourne Robert Masters has 9 hearths in 4 houses. When such entries are compared with those relating to the same taxpayer in the earlier Assessments, it is found that the taxpayer is charged on usually the same number of hearths, but in one house only, or that his name occurs more than once in the list of entries. Thus in 1662 and I670 the same Thomas Bradley is charged on II hearths in one house but Robert Masters appears three times in the 1670 document with 1,3 , and 3 hearths respectively.' If the Bradley type of entry was a commoner practice in 1670 than the evidence has so far revealed it means that many families may be masked behind the Assessment entry.

One further omission from the Assessments earlier than 1670 may be noted, that of Morrell Roding. A search of the I 662 roll and the books for Lady Day I 666 (EI 79/246/19 and EI 79/246/20) shows that neither the hamlet of Morrell Roding as such nor its 4 taxpayers appear in Assessments made before the Michaelmas I670 Assessment.

The information contained in these Assessments, despite possible omissions, enables the areas of settlement to be plotted with reasonable accuracy. There emerges from the data a somewhat complex pattern of settlement. The densest concentration is in the parish of Chipping Ongar with most of the population crowded into the small market-town. Then come the 3 contiguous parishes of Fyfield, Moreton, and Shelley north of Chipping Ongar. To the south-east there is a fairly high level of density, and a marked density in the case of Navestock. In the south-west, except for Chigwell, density is lower. The lowest densities are found in the sparsely inhabited parishes of Abbess Roding and Beauchamp Roding.

To some degree the stratification of society also is reflected in the Assessments. The larger houses, with 10 or more hearths, are found in all but 5 parishes but are most numerous in the south-west, a more fashionable area near London. Smaller houses on the other hand, except in the detached hamlets, are evenly scattered and the proportion of houses with I hearth and 2 hearths is remarkably uniform throughout.

One of the most striking features is the relatively low level of pauperism in this hundred when compared with some of the other Essex hundreds, particularly Hinckford. Expressed as a percentage of the total of taxpayers and paupers in parishes returning paupers in 1670 we find that paupers in Ongar hundred amount to I 3 per cent. of the total. In the same Assessment, paupers in Hinckford hundred exceed 50 per cent. and outnumber by I 10 entries those on whom the Poor Rate was levied. 


\section{ONGAR HUNDRED}

\section{MICHAELMAS 1662}

\begin{tabular}{|c|c|c|c|c|c|c|c|c|c|c|c|c|c|c|c|c|c|c|c|}
\hline & \multicolumn{17}{|c|}{ Total of entries, with hearths } & \multicolumn{2}{|c|}{ Totals } \\
\hline & $x$ & 2 & 3 & 4 & 5 & 6 & 7 & 8 & 9 & Io & $I I$ & $x 2$ & $x 3$ & $x_{4}$ & $x_{5}$ & $I 6$ & $x 7+$ & Entries & Hearths \\
\hline BOBBINGWORTH . & II & 2 & 6 & 5 & I & $\mathbf{I}$ & • & $\cdots$ & 3 & $\cdots$ & . & I & .. & . & .. & . & & 30 & IO3 \\
\hline Chigwell & $5^{2}$ & 29 & I9 & 14 & 6 & 9 & 8 & $\mathbf{I}$ & 3 & 2 & I & 2 & I & 2 & . & . & $I(I 7)$ & 150 & 511 \\
\hline FYFIELD : & 33 & 10 & 8 & 3 & 2 & 5 & $\cdots$ & $\cdots$ & $\therefore$ & $\cdots$ & $\cdots$ & $\mathbf{I}$ & $\cdots$ & .. & . & $\cdots$ & $\cdots$ & 62 & I4I \\
\hline $\begin{array}{l}\text { GREENSTEAD } \\
\text { 'HAMLET' }\end{array}$ & 3 & 3 &  & $\cdots$ & 2 & $\mathbf{r}$ & $\therefore$ & $\cdots$ &  & $\mathbf{I}$ & I & $\cdots$ & $\cdots$ & $\cdots$ & $\cdots$ & .. & . & II & 46 \\
\hline KeLvedon Hatch & I 3 & 2 & 3 & I & $\mathbf{I}$ & . & 3 & $\cdots$ & $\mathbf{I}$ & $\cdots$ & . & $\cdots$ & I & I & I & I & $\cdots$ & 28 & 123 \\
\hline LAMBOURNE & I I & 10 & $8^{2}$ & $7^{\mathrm{b}}$ & 6 & 2 & i & $\mathfrak{I}$ & 3 & .. & $r$ & $\mathbf{I}$ & .. & $\therefore$ & . & .. & $\ldots$ & $5^{1}$ & 190 \\
\hline LAVER, High . & 4 & 7 & 5 & $4^{c}$ & $I$ & $I$ & .. & 1 & $\therefore$ & $\cdots$ & . & . & .. & .. & . & . & .. & 23 & 68 \\
\hline $\begin{array}{l}\text { LAVER, LiTtLe . } \\
\text { LAVER, }\end{array}$ & 3 & 5 & I & $\cdots$ & .. & $\mathbf{I}$ & . & I & $\cdots$ & $\cdots$ & $\cdots$ & . & $\cdots$ & .. & .. & . & . & I I & 30 \\
\hline MAGDALEN . & 7 & 2 & 5 & 4 & 3 & $\mathbf{I}$ & I & I & $\cdots$ & $\cdots$ & . & . & .. & .. & .. & . & $\therefore$ & 24 & $7^{8}$ \\
\hline LOUGHTON . & 12 & $19^{d}$ & 15 & $14^{e}$ & 6 & 3 & I & I & .. & $2^{f}$ & $\mathbf{J}$ & . & $\cdots$ & .. & $\cdots$ & $\cdots$ & $I(35)$ & 75 & 280 \\
\hline MoReton. & 9 & 9 & 3 & 3 & 3 & 3 & I & . & .. & $\mathbf{I}$ & . & . & 1 & .. & . & . & .. & 33 & I I I \\
\hline NAVESTOCK & 47 & 24 & II & 12 & 3 & $I$ & 4 & 3 & 2 & $\cdots$ & $\cdots$ & $\mathbf{I}$ & 1 & $\cdots$ & $\cdots$ & $\cdots$ & $\cdots$ & 109 & 292 \\
\hline $\begin{array}{l}\text { Norton Mande- } \\
\text { ville }\end{array}$ & 6 & 5 & I & 4 & 2 & . & . & I & $\ldots$ & . & $\cdots$ & $0^{\circ}$ & & . & & & . & I9 & \\
\hline Ongar, Chipping & 8 & 18 & 9 & 5 & 4 & . & I & 2 & 3 & .. & $\mathbf{I}$ & . & .. & $\mathbf{I}$ & . & . & . & $5^{2}$ & 186 \\
\hline $\begin{array}{l}\text { ONGAR, HIGH } \\
\text { Hamlets of: }\end{array}$ & 29 & 16 & 8 & 3 & 4 & 3 & .. & I & .. & .. & . & . & 1 & $\cdots$ & .. & . & . & 65 & 556 \\
\hline BOBBINGWORTH & $\cdots$ & I & 2 & . & .. & I & . & $\cdots$ & .. & .. & . & . & .. & .. & . & $\cdots$ & - & 4 & 14 \\
\hline Mard & 2 & I & I & I & . & .. & . & I & I & $\ldots$ & . & . & $\ldots$ & .. & $\cdots$ & $\cdots$ & & 7 & 28 \\
\hline $\begin{array}{l}\text { Roding, AbBzss. } \\
\text { Roding, Benu- }\end{array}$ & 3 & 2 & 4 & I & . & $\mathbf{I}$ & . & $\ldots$ & $\ldots$ & .. & . & . & . & .. & $\cdots$ & $\cdots$ & $I(20)$ & 12 & 49 \\
\hline СНАMP . & 7 & I & I & 4 & I & .. & I & . & .. & .. & . & . & .. & .. & $\ldots$ & .. & . & 15 & 40 \\
\hline HELLEY - & I & 6 & 2 & 2 & $I$ & . & I & I & .. & .. & . & $\ldots$ & .. & .. & $\ldots$ & $\ldots$ & . & 14 & 47 \\
\hline $\begin{array}{l}\text { Stanford Rivers } \\
\text { Stapleford }\end{array}$ & I I & Io & 8 & 3 & 6 & 4 & I & 4 & 2 & I & .. & $\ldots$ & .. & .. & $\mathbf{I}$ & $\cdots$ & .. & $S I$ & 203 \\
\hline $\begin{array}{l}\text { ABBOTS } \\
\text { TAPLEFORD }\end{array}$ & IC & $5^{8}$ & 8 & 5 & 2 & I & I & 2 & .. & .. & • & 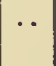 & . & 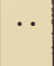 & I & . & $1(40)^{B}$ & 36 & $15^{8}$ \\
\hline TAWNEY & 4 & 4 & 5 & 2 & . & . & .. & I & 2 & .. & . &  & .. & .. & I & $\ldots$ & . & 19 & 76 \\
\hline Stondon Massey & 2 & 4 & 7 & . & $\mathbf{I}$ & $\mathbf{r}$ & $\mathbf{I}$ & 2 & $\mathbf{I}$ & . & - & $\cdots$ & $\cdots$ & $\cdots$ & $\cdots$ & $\cdots$ & $\cdots$ & 19 & 74 \\
\hline Therdon Bols & 9 & II & 5 & 4 & 2 & . & $\mathbf{I}$ & . & . & .. & I & $\cdots$ & $\cdots$ & 1 & $\cdots$ & $\cdots$ & 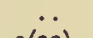 & 34 & 104 \\
\hline Theydon Garnon & 15 & 8 & 14 & 6 & 7 & 7 & 5 & $\mathbf{I}$ & . & . & I & I & . & 1 & $\cdots$ & $\cdots$ & $\begin{array}{r}2(22) \\
(23)\end{array}$ & 68 & 299 \\
\hline $\begin{array}{l}\text { Theydon Mount } \\
\text { WEALD, NoRth }\end{array}$ & 9 & 3 & 4 & 3 & I & $\mathbf{I}$ & I & .. & .. & . & $\cdots$ & .. & $\cdots$ & .. & .. & $\cdots$ & $I(22)$ & 23 & 79 \\
\hline BASSETT & 16 & 9 & 9 & 4 & $\mathbf{I}$ & 6 & $\cdots$ & $\cdots$ & $\cdots$ & $\cdots$ & $\cdots$ & $\cdots$ & $\ldots$ & $\therefore$ & $\cdots$ & $\cdots$ & $\cdots$ & 45 & 118 \\
\hline Totals. & 337 & 226 & 172 & 114 & 66 & 53 & 32 & 25 & $2 I$ & 7 & 7 & 7 & 5 & 6 & 4 & 1 & 1 & , 90 & $3,657^{b}$ \\
\hline
\end{tabular}

(a) Includes an entry that Robert Masters is charged on 3 hearths in an empty house.

(b) The entry states that Henry Oddin in 2 houses is chargeable on 4 hearths.

(c) Includes an entry for the parsonage.

(d) Includes an entry for an empty house with 2 hearths.

(e) Includes an entry which states that John Rodgers and- John Avery are jointly charged on 4 hearths.

(n) Includes an entry which states that-Collard gentleman and John Cudge are jointly charged on ro hearths.

(B) An entry which states that Sir Robert Abdy, Bt., is charged on 40 hearths and also for 2 in an empty tenement.

(h) In $E_{3} 60 / 54$ Benjamin Wright the sheriff is charged on 3,693 hearths. 


\section{A HISTORY OF ESSEX}

MICHAELMAS 1670

\begin{tabular}{|c|c|c|c|c|c|c|c|c|c|c|c|c|c|c|c|c|c|c|c|c|c|c|}
\hline & & \multicolumn{19}{|c|}{ Total of entries, with hearths } & \multicolumn{2}{|c|}{ Totals } \\
\hline & & $\boldsymbol{I}$ & 2 & 3 & 4 & 5 & 6 & 7 & 8 & & 9 & 10 & $I I$ & 12 & 13 & 14 & 15 & & 16 & $I 7+$ & Entries & Hearths \\
\hline \multicolumn{23}{|c|}{ BOBBINGWORTH } \\
\hline $\begin{array}{l}\text { Charged } \\
\text { Exempt }\end{array}$ & \multirow{3}{*}{\multicolumn{2}{|c|}{$\cdot{ }^{1}$}} & \multirow{3}{*}{$\begin{array}{l}3 \\
. \cdot\end{array}$} & \multirow{3}{*}{$\begin{array}{r}5 \\
. .\end{array}$} & \multirow{3}{*}{$\begin{array}{l}5 \\
.\end{array}$} & \multirow{3}{*}{$\begin{array}{c}1 \\
.\end{array}$} & \multirow{3}{*}{$\begin{array}{r}\mathbf{I} \\
.\end{array}$} & . & ? & & 3 & $\cdots$ & $\cdots$ & $I$ & $\cdots$ & . & .. & & $\cdot \cdot$ & . & 32 & 104 \\
\hline $\begin{array}{r}\text { Exempt } \\
\text { Total }\end{array}$ & & & & & & & & - & $\cdots$ & & $\cdots$ & $\cdots$ & $\cdots$ & $\cdots$ & $\cdots$ & $\cdots$ & * & & $\cdots$ & $\cdots$ & 8 & 8 \\
\hline Total & & & & & & & & & & & & & & & & & & & & & 40 & 112 \\
\hline Chigwele & & & & & & & & & & & & & & & & & & & & & & \\
\hline Charged & - & 36 & 28 & 19 & 14 & 5 & 10 & 6 & $\because$ & & 4 & 2 & I & I & . & 2 & & I & $\cdots$ & $I(24)$ & 130 & 478 \\
\hline $\begin{array}{l}\text { Exempt } \\
\text { Paupers }\end{array}$ & $:$ & $\begin{array}{r}17 \\
8\end{array}$ & 4 & $\ddot{x}$ & 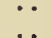 & $\because$ & $\because$ & $\because$ & $\because$ & & $\because$ & $\because$ & $\ddot{.}$ & $\because$ & $\ddot{*}$ & $\because$ & $\because$ & & $\because$ & $\ddot{0}$ & $\begin{aligned} 2 I \\
12\end{aligned}$ & 25 \\
\hline $\begin{array}{l}\text { Paupers } \\
\text { Empty . }\end{array}$ & $\cdot$ & .. & $\therefore$ & .. & $\ddot{2}$ & $\ddot{0}$ & $\because$ & $\mathrm{I}^{\mathrm{a}}$ & $\because$ & & $\because$ & $\because$ & $\because$ & $\therefore$ & $\because$ & $\because$ & 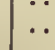 & & $\because$ & $\because$ & 3 & $\begin{array}{l}1 \\
15 \\
\end{array}$ \\
\hline Total & - & & & & & & & & & & & & & & & & & & & & 166 & 535 \\
\hline FYFIELD & & & & & & & & & & & & & & & & & & & & & & \\
\hline Charged & $\cdot$ & 22 & 12 & 10 & 3 & 3 & 3 & I & . & & .. & . & .. & .. & . & .. & . & & . & $\cdots$ & 54 & 128 \\
\hline $\begin{array}{l}\text { Exempt } \\
\text { Paupers }\end{array}$ & $\cdot$ & 25 & 2 & $\cdots$ & .. & $\cdots$ & $\cdots$ & .. & $\cdots$ & & -. & $\cdot \cdot$ & . & . & . & .. & .. & & $\cdots$ & . & 27 & 29 \\
\hline Paupers & $\bullet$ & & $\cdot$ & $\cdots$ & $\cdots$ & $\cdots$ & $\cdots$ & $\cdots$ & $\cdots$ & & $\cdots$ & $\cdots$ & $\cdots$ & $\cdots$ & $\cdots$ & $\cdots$ & $\cdots$ & & & $\cdots$ & 8 & 8 \\
\hline Total & $\cdot$ & & & & & & & & & & & & & & & & & & & & 89 & 165 \\
\hline $\begin{array}{c}\text { GREENSTEAD } \\
\text { 'HAMLET' }\end{array}$ & & & & & & & & & & & & & & & & & & & & & & \\
\hline Charged & - & 4 & 2 & $I$ & 2 & I & I & .. & $\cdots$ & & - & $\cdots$ & 2 & .. & .. & .. & $\cdots$ & & $\cdots$ & $\cdots$ & 13 & $5^{2}$ \\
\hline KELVEDON H & ТСH & & & & & & & & & & & & & & & & & & & & & \\
\hline Charged & $\cdot$ & 8 & 2 & 2 & I & I & . & 3 & . & & 1 & .. & .. & $\cdots$ & I & .. & 2 & 2 & $\mathbf{I}$ & $\cdots$ & 22 & II 6 \\
\hline $\begin{array}{l}\text { Exempt } \\
\text { Paupers }\end{array}$ & $:$ & $\begin{array}{l}1 \\
8\end{array}$ & I & $\ddot{x}$ & $\cdots$ & $\cdots$ & . & . & . & & $\cdots$ & $\cdots$ & $\cdots$ & .. & .. & .. & $\cdots$ & & $\cdots$ & $\cdots$ & 2 & 3 \\
\hline Paupers & 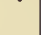 & & 1 & $\cdots$ & $\cdots$ & $\cdots$ & $\cdots$ & $\cdots$ & $\cdots$ & & $\cdots$ & $\cdots$ & $\cdots$ & $\cdots$ & - & $\cdots$ & $\cdots$ & & $\cdots$ & $\cdots$ & 9 & \\
\hline Total & - & & & & & & & & & & & & & & & & & & & & 33 & 129 \\
\hline LAMBOURNE & & & & & & & & & & & & & & & & & & & & & & \\
\hline Charged & . & 10 & 6 & 7 & 8 & 5 & 3 & I & I & & 3 & $\cdots$ & 1 & I & $\because$ & - & $\cdots$ & & $\cdots$ & $\because$ & 46 & 183 \\
\hline Exempt & - & 3 & . & .. & .. & . & $\cdots$ & . & -. & & • & $\because$ & $\cdots$ & $\cdots$ & $\cdots$ & . & * & & - & $\therefore$ & 3 & 3 \\
\hline Paupers & $\cdot$ & 3 & I & $\cdots$ & $\cdots$ & $\cdots$ & $\cdots$ & $\cdots$ & * & & * & $\cdots$ & $\cdots$ & $\cdots$ & $\cdots$ & $\cdots$ & $\cdots$ & & $\cdots$ & $\cdots$ & 4 & \\
\hline Total & $\cdot$ & & & & & & & & & & & & & & & & & & & & 53 & 191 \\
\hline Laver, High & & & & & & & & & & & & & & & & & & & & & & \\
\hline Charged & . & 6 & 10 & 6 & I & I & I & I & I & & -. & $\cdots$ & .. & . & . & .. & $\mathrm{x}$ & I & .. & .. & 28 & 89 \\
\hline & - & Io & 2 & .. & . & .. & $\cdots$ & .. & . & & $\cdots$ & $\cdots$ & . & .. & $\cdots$ & . & .. & & $\cdots$ & $\cdots$ & 12 & 14 \\
\hline Paupers & $\cdot$ & 2 & $\cdots$ & $\cdots$ & $\cdots$ & $\cdots$ & $\cdots$ & $\cdots$ & $\cdots$ & & $\cdots$ & $\cdots$ & $\cdots$ & $\cdots$ & $\cdots$ & $\cdots$ & $\cdots$ & & $\cdots$ & $\cdots$ & 2 & 2 \\
\hline Total & - & & & & & & & & & & & & & & & & & & & & $4^{2}$ & ros \\
\hline $\begin{array}{l}\text { LAVER, } \\
\text { MAGDALEN }\end{array}$ & & & & & & & & & & & & & & & & & & & & & & \\
\hline Charged & . & 8 & 7 & 6 & 6 & 3 & 2 & 3 & * & & .. & $\mathbf{I}$ & $\cdots$ & .. & . & . & . & & $\cdots$ & $\cdots$ & 36 & 122 \\
\hline Exempt & . & 5 & 2 & .. & . & $\cdots$ & .. & . & $\cdots$ & & $\cdots$ & $\cdots$ & .. & .. & .. & . & . & & . & . & 7 & 9 \\
\hline Paupers & $\cdot$ & 2 & $\mathbf{I}$ & $\cdots$ & . & $\cdots$ & $\cdots$ & . & $\cdots$ & & $\cdots$ & $\cdot \cdot$ & $\cdots$ & . & . & . & . & & $\cdots$ & $\cdots$ & 3 & 4 \\
\hline Total & $\cdot$ & & & & & & & & & & & & & & & & & & & & 46 & 135 \\
\hline LOUGHTON & & & & & & & & & & & & & & & & & & & & & & \\
\hline Charged & $\cdot$ & 12 & 15 & $16^{c}$ & $12^{c}$ & 4 & 3 & I & I & c & I & $\mathbf{I}$ & I & .. & .. & .. & . & & . & $I(27)$ & 68 & $24^{8}$ \\
\hline Exempt & $:$ & $\begin{array}{r}10 \\
8\end{array}$ & 2 & .. & .. & $\cdot \cdot$ & $\cdots$ & .. & $\cdots$ & . & $\cdot$ & $\cdots$ & . & . & .. & .. & .. & & -. & -. & $\begin{array}{l}12 \\
10\end{array}$ & 14 \\
\hline Paupers & 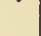 & & & .. & $\cdots$ & - & $\cdots$ & $\cdots$ & $\cdots$ & & $\cdot$ & $\cdots$ & $\cdots$ & $\cdots$ & - & - & $\cdots$ & & $\cdots$ & $\cdots$ & & \\
\hline Total & . & & & & & & & & & & & & & & & & & & & & 90 & 274 \\
\hline MoREton & & & & & & & & & & & & & & & & & & & & & & \\
\hline & . & 16 & 9 & 3 & 3 & 3 & 2 & I & & & I & .. & .. & .. & I & .. & .. & & .. & . & & III \\
\hline Exempt & $\cdot$ & I 3 & .. & .. & . & $\cdot \cdot$ & $\cdots$ & $\cdots$ & * & & $\cdot$ & $\cdots$ & $\cdots$ & . & . & $\because$ & *. & & $\cdots$ & $\cdots$ & ${ }^{1} 3$ & 13 \\
\hline Paupers & $\cdot$ & 5 & $\cdots$ & - & $\cdots$ & $\cdots$ & $\cdots$ & . & $\cdots$ & & $\cdot$ & $\cdots$ & $\cdots$ & $\cdots$ & * & $\cdots$ & $\cdot$ & & $\cdots$ & $\cdots$ & 5 & \\
\hline Total & . & & & & & & & & & & & & & & & & & & & & 57 & 129 \\
\hline Navestock & & & & & & & & & & & & & & & & & & & & & & \\
\hline & $\cdot$ & $4 I$ & 17 & $18 \mathrm{~d}$ & 10 & 3 & I & 4 & 2 & & 2 & 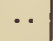 & & I & I & .. & . & & .. & .. & 100 & 277 \\
\hline Exemp & - & 13 & 2 & .. & .. & $\cdots$ & $\cdots$ & . & . & . & . & $\cdots$ & $\cdots$ & . & .. & .. & - & $\cdot$ & . & $\cdots$ & 15 & 17 \\
\hline Paupers & . & 12 & 2 & I & . & $\cdots$ & $\cdots$ & -. & $\cdots$ & & - & $\cdots$ & $\cdots$ & $\cdots$ & . & . & - & & $\cdots$ & -. & I5 & 19 \\
\hline Empty . &  & $\cdots$ & - & .. & 3 & $\cdots$ & . & . & - & & -. & $\cdot \cdot$ & . & . & . & . & - & & $\cdots$ & $\cdots$ & 3 & 12 \\
\hline Total & $\cdot$ & & & & & & & & & & & & & & 11 & & & & & & ${ }^{1} 33$ & 325 \\
\hline $\begin{array}{l}\text { NoRTON MAN } \\
\text { VILLE }\end{array}$ & & & & & & & & & & & & & & & & & & & & & & \\
\hline Charged & . & 4 & 4 & .. & 4 & 3 & . & . & 1 & & . & $\cdots$ & $\cdots$ & . & - & $\cdots$ & • & & .. & $\cdots$ & 16 & 51 \\
\hline Exempt & . & 3 & 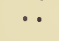 & .. & . & $\cdots$ & $\cdots$ & . & . & & $\cdots$ & $\cdots$ & $\cdots$ & $\cdots$ & .. & $\cdot$ & & $\cdot$ & $\cdots$ & $\cdots$ & 3 & 3 \\
\hline Total & & & & & & & & & & & & & & & & & & & & & 19 & 54 \\
\hline
\end{tabular}

(a) This entry is among the paupers.

(b) The entries for Little Laver are included in Magdalen Laver return.

(c) Includes an entry which states that Robert Dawges refused to pay for 3 separate houses in his possession with 3,4 , and 7 hearths respectively.

(d) Includes an entry, inserted below but separate from the certified exempt and presumably misplaced in error, which states that 
ONGAR HUNDRED

MICHAELMAS 1670 (cont.)

\begin{tabular}{|c|c|c|c|c|c|c|c|c|c|c|c|c|c|c|c|c|c|c|c|}
\hline & \multicolumn{17}{|c|}{ Total of entries, with hearths } & \multicolumn{2}{|c|}{ Torals } \\
\hline & & 2 & 3 & 4 & 5 & 6 & 7 & 8 & 9 & Io & $I I$ & 12 & 13 & 14 & 15 & 16 & $I 7+$ & Entries & Hearths \\
\hline Ongar, Chitping & & & & & & \multirow[b]{2}{*}{2} & & & & & \multirow[b]{2}{*}{ if 1} & \multirow[b]{2}{*}{$\cdots$} & \multirow[b]{2}{*}{$\cdots$} & \multirow[b]{2}{*}{.. } & \multirow[b]{2}{*}{$\cdots$} & \multirow[b]{2}{*}{$\cdots$} & \multirow[b]{2}{*}{$x(20)$} & \multirow[b]{2}{*}{$5^{6}$} & \\
\hline $\begin{array}{l}\text { Charged } \\
\text { Exempt }\end{array}$ & $\begin{array}{l}8 \\
2\end{array}$ & 15 & I5 & 4 & $5^{\mathrm{e}}$ & & $\mathbf{I}$ & 2 & 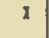 & $\mathbf{I}^{\mathrm{f}}$ & & & & & & & & & \\
\hline Paupers & 3 & 7 & $\because$ & $\because$ & $\because$ & $\because$ & 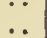 & $\because$ & $\ddot{.}$ & $\because$ & $\because$ & $\because$ & $\because$. & $\because$ & $\therefore$ & $\because$ & $\ddot{x}$ & $\begin{array}{l}27 \\
10\end{array}$ & $\begin{array}{l}32 \\
17\end{array}$ \\
\hline Empty . & I & I & $\cdots$ & $\cdots$ & .. & .. & .. & .. & .. & .. & .. & $\cdots$ & .. & $\cdots$ & $\ldots$ & . & $\cdots$ & 2 & 3 \\
\hline Total & & & & & & & & & & & & & & & & & & 95 & 261 \\
\hline ONGar, Hig & & & & & & & & & & & & & & & & & & & \\
\hline Charged & & $10 \mathrm{~B}$ & 7 & 4 & 5 & 3 & .. & 2 & .. & .. & .. & $\cdots$ & .. & $\cdots$ & $\cdots$ & .. & . & 46 & 131 \\
\hline Exempt & & 5 & - & $\cdots$ & $\cdots$ & $\cdots$ & - & $\cdots$ & $\cdots$ & $\cdots$ & $\cdots$ & $\cdots$ & $\cdots$ & $\cdots$ & $\cdots$ & $\cdots$ & $\cdots$ & 16 & 21 \\
\hline $\begin{array}{l}\text { Paupers } \\
\text { Empty. }\end{array}$ & $\begin{array}{l}7 \\
1\end{array}$ & ${ }^{2}$ & $\because$ & $\because$. & $\because$ & $\begin{array}{l}\cdots \\
\cdots\end{array}$ & $\because$ & $\because$ & $\because$ & 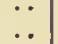 & $\because$ & $\because$ & $\because$ & $\because$ & 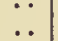 & $\because$. & $\ddot{.}$ & $\begin{array}{l}9 \\
I\end{array}$ & $\begin{array}{l}\text { II } \\
\text { I }\end{array}$ \\
\hline Total & & & & & & & & & & & & & & & & & & 72 & 164 \\
\hline BOBBINGWOR & & & & & & & & & & & & & & & & & & & \\
\hline 'HAMLET' & & & & & & & & & & & & & & & & & & & \\
\hline Charged & & I & 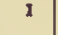 & 1 & $\cdots$ & I & $\cdots$ & $\cdots$ & .. & $\cdots$ & $\cdots$ & $\cdots$ & $\cdots$ & $\cdots$ & $\cdots$ & $\cdot \cdot$ & $\cdots$ & 4 & 15 \\
\hline $\begin{array}{l}\text { Exempt } \\
\text { Pauper }\end{array}$ & 2 & $\because$. & $\therefore$ & $\therefore$ & $\because$ & $\because$ & $\because$ & $\cdots$ & $\because$ & $\because$ & $\cdots$ & 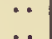 & $\because$ & $\because$ & $\cdots$ & $\cdots$ & $\because$ & $\begin{array}{l}2 \\
1\end{array}$ & $\begin{array}{l}2 \\
1\end{array}$ \\
\hline Pauper & & & & $\cdots$ & 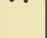 & $\cdots$ & & $\cdots$ & $\cdots$ & & $\cdots$ & $\cdots$ & $\cdots$ & 1 & $\cdots$ & $\cdots$ & $\cdots$ & & -8 \\
\hline Total & & & & & & & & & & & & & & & & & & 7 & 18 \\
\hline $\begin{array}{l}\text { MARDEN EN } \\
\text { HAMLET }\end{array}$ & & & & & & & & & & & & & & & & & & &  \\
\hline Charged & 2 & 2 & I & .. & . & I & .. & .. & 2 & .. & .. & . & $\cdots$ & $\cdots$ & .. & . & .. & 8 & 33 \\
\hline $\begin{array}{l}\text { Roding, ABE } \\
\text { Charged }\end{array}$ & 4 & 2 & 4 & I & . & I & . & $\cdots$ & . & $\cdots$ & .. & $\cdots$ & $\cdots$ & $\cdots$ & $\cdots$ & $\cdots$ & $I(20)$ & 13 & 50 \\
\hline $\begin{array}{l}\text { Roding, BEA } \\
\text { CHAMp }\end{array}$ & & & & & & & & & & & & & & & & & & & \\
\hline Charged & 7 & I & 3 & 2 & 2 & .. & 1 & .. & .. & .. & .. & .. & .. & .. & .. & .. & $\cdots$ & 15 & $3^{8}$ \\
\hline Exempt & 3 & $\mathbf{I}$ & $\cdots$ & $\cdots$ & $\cdots$ & . & $\cdots$ & $\cdots$ & $\cdot \cdot$ & $\cdots$ & $\cdots$ & $\cdots$ & $\cdots$ & $\cdots$ & $\cdots$ & $\cdot \cdot$ & $\cdots$ & 4 & 5 \\
\hline Total & & & & & & & & & & & & & & & & & & 19 & 43 \\
\hline $\begin{array}{l}\text { Roding, Mo } \\
\text { Charged }\end{array}$ & & $\cdots$ & I & I & I & I & $\cdots$ & $\cdots$ & $\cdots$ & $\cdots$ & $\cdots$ & $\cdots$ & . & $\cdots$ & $\cdots$ & $\cdots$ & .. & 4 & 18 \\
\hline Shezley & & & & & & & & & & & & & & & & & & & \\
\hline Charged & 2 & 6 & 2 & I & 2 & .. & I & $\mathbf{I}$ & .. & .. & .. & .. & .. & $\because$ & $\cdots$ & .. & . & 15 & 49 \\
\hline Exempt & 6 & $\cdots$ & $\cdots$ & $\cdots$ & $\cdots$ & $\cdots$ & $\cdots$ & $\cdots$ & $\cdots$ & $\cdots$ & $\cdots$ & $\cdots$ & $\cdots$ & $\cdots$ & $\cdots$ & $\cdot$ & $\cdots$ & 6 & 6 \\
\hline Total & & & 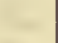 & & & & & & & & & & & & & & & 21 & 55 \\
\hline StANFoRd $R$ & & & & & & & & & & & & & & & & & & & \\
\hline Charged & 16 & II & II & 10 & 7 & 5 & I & 2 & $\because$ & I & $\cdots$ & $\cdots$ & $\cdots$ & .. & $\cdots$ &  & . & 65 & 225 \\
\hline Exempt & 12 & 3 & $\cdots$ & .. & $\cdots$ & $\cdots$ & $\cdots$ & $\cdots$ & $\cdots$ & $\cdots$ & $\cdots$ & $\cdots$ & $\cdots$ & $\cdots$ & $\cdots$ & $\cdots$ & $\because$ & $\begin{array}{r}15 \\
1\end{array}$ & 18 \\
\hline Empty . & I & $\cdots$ & $\cdots$ & $\cdots$ & $\cdots$ & $\cdots$ & $\cdots$ & $\cdots$ & $\cdots$ & $\cdots$ & $\cdots$ & $\cdots$ & $\cdots$ & $\cdots$ & $\cdots$ & $\cdots$ & $\cdots$ & $\frac{1}{0}$ & \\
\hline Total & & & & & & & & & & & & & & & & & & 81 & 244 \\
\hline $\begin{array}{l}\text { STAPLEFORD } \\
\text { ABBOTS }\end{array}$ & & & & & & & & & & & & & & & & & & & \\
\hline $\begin{array}{l}\text { ABBoTs } \\
\text { Charged }\end{array}$ & 12 & 5 & 8 & 4 & 2 & 2 & 3 & .. & .. & .. & .. & .. & .. & .. & I & .. & $I(40)$ & 38 & 160 \\
\hline Exempt & 7 & I & $\cdots$ & . & $\cdots$ & $\cdots$ & $\cdots$ & .. & $\cdots$ & $\cdots$ & $\cdots$ & $\cdots$ & $\cdots$ & $\cdots$ & $\cdots$ & $\cdots$ & $\cdots$ & 8 & 9 \\
\hline Total & & & & & & & & & & & & & & & & & & $4^{6}$ & 169 \\
\hline $\begin{array}{c}\text { STAPLETORD } \\
\text { TAWNEY }\end{array}$ & & & & & & & & & & & & & & & & & & & \\
\hline $\begin{array}{l}\text { Tawney } \\
\text { Charged }\end{array}$ & 4 & 3 & 4 & 3 & I & .. & 1 & .. & 1 & .. & .. & .. & .. & 2 & 2 & .. & $\cdots$ & & 84 \\
\hline Exempt & 6 & i & .. & .. & .. & .. & .. & $\cdots$ & .. & .. & .. & .. & . & $\cdots$ & $\cdots$ & . & .. & 7 & 8 \\
\hline Total & & & & & & & & & & & & & & & & & & 26 & $9^{2}$ \\
\hline STONDON M & & & & & & & & & & & & & & & & & & & \\
\hline Charged & 5 & 2 & 5 & I & .. & I & .. & 3 & .. & $\cdots$ & .. & I & $\cdots$ & $\cdots$ & $\cdots$ & .. & $\cdots$ & 18 & $70^{\circ}$ \\
\hline Exempt & 6 & I & .. & . & .. & . & .. & $\cdots$ & $\cdots$ & $\cdot \cdot$ & $\cdots$ & $\cdots$ & $\cdots$ & $\cdots$ & $\cdots$ & $\because$ & $\cdots$ & 7 & $\begin{array}{l}8 \\
6\end{array}$ \\
\hline Paupers & 4 & I & .. & . & .. & $\cdots$ & $\cdots$ & $\cdots$ & $\cdots$ & $\cdots$ & $\cdots$ & $\cdots$ & $\cdots$ & $\cdots$ & $\cdots$ & $\cdots$ & $\cdots$ & 5 & \\
\hline Total & & & & & & & & & & & & & & & & & & 30 & $84^{\circ}$ \\
\hline TheYDon Bo & & & & & & & & & & & & & & & & & & & \\
\hline $\begin{array}{l}\text { Charged } \\
\text { Exempt }\end{array}$ & $\begin{array}{l}8 \\
5\end{array}$ & $\begin{array}{l}16 \\
\ldots\end{array}$ & $\begin{array}{l}3 \\
. .\end{array}$ & $\begin{array}{c}4 \\
. .\end{array}$ & ${ }^{2}$ & $\begin{array}{l}. \\
.\end{array}$ & I & $\because$ & $\because$. & . & 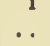 & $\begin{array}{l}1 \\
.\end{array}$ & .. & $\because$ & $\because$ & $\ddot{.}$ & $\cdots$ & $\begin{array}{r}30 \\
5\end{array}$ & $\begin{array}{r}105 \\
5\end{array}$ \\
\hline Total & & & & & & & & & & & & & & & & & & $4 I$ & 110 \\
\hline
\end{tabular}

Robert Greene is charged on 3 newly built hearths. A Robert Greene is also found among the chargeables with 2 hearths. Cf. 1674 Lady Day where he is charged on 5 hearths in 2 houses.

(e) Includes an entry for 5 newly built hearths.

(i) This entry charges Elizabeth Gouldesborough on 6 hearths for the castle for which she has not been charged in the earlier entry of ro hearths. (g) Includes an entry which states that Christopher Watson refused to pay and has nothing for distress. 
A HISTORY OF ESSEX

MICHAELMAS 1670 (cont.)

\begin{tabular}{|c|c|c|c|c|c|c|c|c|c|c|c|c|c|c|c|c|c|c|c|c|}
\hline & & \multicolumn{17}{|c|}{ Total of entries, with hearths } & \multicolumn{2}{|c|}{ Totals } \\
\hline & & $I$ & 2 & 3 & 4 & 5 & 6 & 7 & 8 & 9 & Io & $I I$ & 12 & 13 & 14 & I5 & $\mathrm{r} 6$ & $17+$ & Entries & Hearths \\
\hline \multicolumn{2}{|c|}{ Theydon Garnon } & & & & & & & & & & & & \multirow[b]{2}{*}{2} & \multirow[b]{2}{*}{$\cdots$} & \multirow[b]{2}{*}{$\cdots$} & \multirow[b]{2}{*}{$\cdots$} & \multirow[b]{2}{*}{$\cdots$} & \multirow{2}{*}{\multicolumn{2}{|c|}{63}} & \multirow[b]{2}{*}{892} \\
\hline Charged & $\cdot$ & 8 & 9 & 14 & 8 & 6 & 10 & 3 & $\cdots$ & $\cdots$ & . & I & & & & & & & & \\
\hline Exempt & - & 5 & 8 & .. & .. & . & . & $\cdots$ & .. & .. & . & .. & .. & \multirow{3}{*}{ 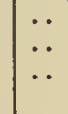 } & \multirow{4}{*}{$\begin{array}{l}\ldots \\
\cdots \\
\cdots\end{array}$} & \multirow{4}{*}{$\begin{array}{l}\cdots \\
\cdots\end{array}$} & \multirow{4}{*}{$\begin{array}{l}\cdots \\
\cdots\end{array}$} & \multirow{4}{*}{$\begin{array}{l}\cdots \\
\cdots\end{array}$} & 13 & 21 \\
\hline Paupers & - & 3 & 2 & $\cdots$ & .. & . & - & . & . & . & . & .. & $\cdots$ & & & & & & 5 & 7 \\
\hline Empty . & - & . & . & . & . & $\cdots$ & . & I & . & $\cdots$ & . & $\cdots$ & . & & & & & & $\mathbf{I}$ & 7 \\
\hline Total & - & & & & & & & & & & & & & & & & & & 82 & 327 \\
\hline \multicolumn{21}{|c|}{ Theydon Mount } \\
\hline Charged & . & 8 & 4 & 4 & 2 & I & I & 2 & . & .. & .. & . & .. & .. & .. & .. & . & $I(22)$ & 23 & 83 \\
\hline Exempt & $\cdot$ & 8 & .. & . & .. & $\cdots$ & - & . & . & .. & .. & . & .. & .. & .. & .. & . & .. & 8 & 8 \\
\hline Paupers & \multirow[t]{2}{*}{$\cdot$} & \multirow[t]{2}{*}{3} & \multirow[t]{2}{*}{$\cdots$} & \multirow[t]{2}{*}{$\cdots$} & \multirow[t]{2}{*}{$\cdots$} & \multirow[t]{2}{*}{ - } & \multirow[t]{2}{*}{ - } & \multirow[t]{2}{*}{$\cdots$} & \multirow[t]{2}{*}{ - } & \multirow[t]{2}{*}{ - } & \multirow[t]{2}{*}{. } & \multirow[t]{2}{*}{. } & \multirow[t]{2}{*}{. } & $\cdots$ & $\cdots$ & $\cdots$ & $\cdots$ & $\cdots$ & 3 & 3 \\
\hline Total & & & & & & & & & & & & & & & & & & & 34 & 94 \\
\hline $\begin{array}{c}\text { WeALD, No } \\
\text { BASSETT }\end{array}$ & & & & & & & & & & & & & & & & & & & & \\
\hline Charged & . & 14 & 6 & 12 & 3 & 2 & 5 & $\mathbf{I}$ & - & $\cdots$ & $\cdots$ & $\cdots$ & $\cdots$ & $\cdots$ & $\cdots$ & $\cdots$ & . & . & 43 & 121 \\
\hline Exempt & - & 4 & . & . & .. & $\cdots$ & . & . & . & .. & . & $\cdots$ & . & . & .. & .. & . & . & 4 & 4 \\
\hline Paupers & - & 14 & I & I & . & $\cdots$ & $\cdots$ & $\cdots$ & $\cdots$ & $\cdots$ & $\cdots$ & $\cdots$ & $\cdots$ & $\cdots$ & $\cdots$ & $\cdots$ & $\cdots$ & . & 16 & 19 \\
\hline Total & . & & & & & & & & & & & & & & & & & & 63 & 144 \\
\hline Total & . & 592 & $27^{2}$ & I9I & 123 & 68 & 60 & $3^{8}$ & I 6 & 19 & 6 & 8 & 8 & 3 & 3 & 6 & 2 & 8 & 1,423 & $4, I I 2$ \\
\hline
\end{tabular}

LADY DAY 1674

\begin{tabular}{|c|c|c|c|c|c|c|c|c|c|c|c|c|c|c|c|c|c|c|c|c|}
\hline & & \multicolumn{17}{|c|}{ Total of entries, with hearths } & \multicolumn{2}{|c|}{ Totals } \\
\hline & & $I$ & $z$ & 3 & 4 & 5 & 6 & 7 & 8 & 9 & TO & $I I$ & 12 & 13 & 14 & 15 & $x 6$ & $I 7+$ & Entries & Hearths \\
\hline \multicolumn{2}{|c|}{ BOBBINGWORTH } & \multirow{5}{*}{$\begin{array}{c}12 \\
\cdots \\
I^{c}\end{array}$} & \multirow[b]{2}{*}{2} & \multirow[b]{2}{*}{6} & \multirow[b]{2}{*}{6} & \multirow[b]{2}{*}{2} & \multirow[b]{2}{*}{. } & \multirow[b]{2}{*}{. } & \multirow[b]{2}{*}{. } & \multirow[b]{2}{*}{ I } & \multirow[b]{2}{*}{.. } & \multirow{3}{*}{$\ldots$} & \multirow{3}{*}{$\cdots$} & \multirow[b]{2}{*}{$\ldots$} & \multirow{3}{*}{$\cdots$} & \multirow{3}{*}{$\ddot{0}$} & \multirow{2}{*}{\multicolumn{2}{|c|}{$1(21)^{a}$}} & \multirow{3}{*}{$\begin{array}{r}30 \\
6\end{array}$} & \multirow{3}{*}{$9^{8}$} \\
\hline Charged & . & & & & & & & & & & & & & & & & & & & \\
\hline Paupers ${ }^{b}$ & . & & . & . & . & . & $\ldots$ & .. & .. & .. & .. & & & $\cdots$ & & & . & . & & \\
\hline Empty . & $\dot{\cdot}$ & & \multirow[t]{2}{*}{ I } & \multirow{2}{*}{. } & \multirow[t]{2}{*}{. } & \multirow{2}{*}{$\cdots$} & I & $\cdots$ & $\cdots$ & . & $\cdots$ & $\cdots$ & $\cdots$ & $\cdots$ & $\cdots$ & $\cdots$ & $\cdots$ & $\cdots$ & 3 & 9 \\
\hline Total & 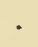 & & & & & & & & & & & & & & & & & & 39 & 107 \\
\hline Chigwerz & & & & & & & & & & & & & & & & & & & & \\
\hline Charged & . & $20^{d}$ & $21^{\mathrm{e}}$ & 20 & $16^{a}$ & 6 & 9 & 8 & I & 3 & 2 & I & I & $\mathrm{I}^{\mathrm{f}}$ & $2 \mathrm{~g}$ & . & $\mathbf{I}$ & $I(33)$ & 113 & 494 \\
\hline Exempt & - & 33 & 3 & .. & . & . & . & .. & .. & $\therefore$ & $\ldots$ & $\cdots$ & $\cdots$ & .. & $\cdots$ & $\cdots$ & $\cdots$ & . & 36 & 39 \\
\hline Empty . & $\cdot$ & $\cdots$ & I & $\cdots$ & . & . & I & $\cdots$ & . & $\cdots$ & $\cdots$ & $\cdots$ & $\cdots$ & . & .. & . & . & $\cdots$ & 2 & 8 \\
\hline Total & $0^{\circ}$ & & & & & & & & & & & & & & & & & & 151 & $54^{1}$ \\
\hline FyField & & & & & & & & & & & & & & & & & & & & \\
\hline Charged & - & $2 I$ & 6 & 8 & 2 & $3^{a}$ & $3^{\mathrm{h}}$ & . & .. & $\mathbf{I}$ & $\cdots$ & $x^{a}$ & $\mathbf{I}$ & . & .. & .. & . & .. & 46 & I 30 \\
\hline Exempt & . & 27 & 3 & . & . & $\cdots$ & $\cdots$ & $\cdots$ & $\cdots$ & . & $\cdots$ & $\cdots$ & $\cdots$ & $\cdots$ & $\cdots$ & $\cdots$ & $\cdots$ & $\cdots$ & 30 & 33 \\
\hline Total & $\theta^{\circ}$ & & & & & & & & & & & & & & & & & & 76 & 163 \\
\hline GREENSTEA & & & & & & & & & & & & & & & & & & & & \\
\hline 'HАMLET' & & & & & & & & & & & & & & & & & & & & \\
\hline Charged & . & 2 & 2 & . & .. & 2 & $2^{a}$ & $\cdots$ & . & . & $\because$ & 2 & $\cdots$ & $\cdots$ & $\cdots$ & $\cdots$ & $\cdots$ & $\cdots$ & 10 & 50 \\
\hline Kezvedon & TCH & & & & & & & & & & & & & & & & & & & \\
\hline Charged & . & 8 & 3 & 2 & 2 & I & $\cdots$ & 3 & . & I & . & $\ldots$ & $\ldots$ & I & .. & I & I & .. & 23 & 107 \\
\hline Exempt & $\cdot$ & 9 & I & $\cdots$ & .. & . & $\cdots$ & $\cdots$ & . & . & $\cdots$ & $\cdots$ & $\cdots$ & $\cdots$ & $\cdots$ & . & - & $\cdots$ & 10 & II \\
\hline Total & - & & & & & & & & & & & & & & & & & & 33 & II 8 \\
\hline LAMBOURNE & & & & & & & & & & & & & & & & & & & & \\
\hline Charged & . & 5 & 8 & 5 & 7 & 6 & 2 & I & 1 & $4^{1}$ & . & I & I & $\cdots$ & $\cdots$ & .. & . & $\cdots$ & $4 I$ & 180 \\
\hline Exempt & · & 9 & $x$ & $\cdots$ & $\cdots$ & . & $\cdots$ & $\cdots$ & . & $\cdots$ & $\cdots$ & $\cdots$ & $\cdots$ & $\cdots$ & $\cdots$ & $\cdots$ & . & $\cdots$ & Io & II \\
\hline Total & • & & & & & & & & & & & & & & & & & & 51 & 191 \\
\hline
\end{tabular}

(a) Includes an entry which states that the taxpayer is charged on the given number of hearths in 2 houses.

(b) No paupers' hearths given.

(c) Includes an entry which states that the I hearth shown is decayed.

(d) Includes an entry that the taxpayer is charged on 1 hearth that is newly built.

(e) Includes one entry that the taxpayer has newly built 2 hearths and is chargeable on 2 total of 2 hearths and another entry that a second taxpayer has newly built 2 heartbs; no total number of hearths is given.

(f) Includes an entry that the taxpayer has newly built I 3 hearths; no total number of hearths is given.

(g) Includes an entry that the taxpayer has newly built 2 hearths and his total of hearths is 14.

(h) Includes an entry that the taxpayer has newly built 2 hearths and his total of hearths is 6 .

(1) Includes an entry which states that the taxpayer is charged on the given number of hearths in 4 houses. 


\section{ONGAR HUNDRED}

\section{LADY DAY 1674 (cont.)}



Charged

(k) MS. is defective, not all hearth entries are legible and the total in the final column is that shown on the rofl.

(1) Includes an entry which states that the taxpayer is chargeable on 4 hearths and on a further 5 in respect of the parsonage.

(m) Includes an entry which states that in 2 houses there is I hearth decayed, leaving a total of 14 hearths.

(n) Includes an entry that $I$ hearth is decayed leaving I on which the taxpayer is charged.

(o) Includes an entry which states that F. Warner, in an empty house, the schoolhouse, is chargeable on 2 hearths and that there is nothing for distress.

(p) The entry states that there are 4 persons, presumably heads of households, who are in receipt of alms and are therefore omitted; they have 5 hearths. 


\section{A HISTORY OF ESSEX}

\section{LADY DAY 1674 (cont.)}

\begin{tabular}{|c|c|c|c|c|c|c|c|c|c|c|c|c|c|c|c|c|c|c|c|c|}
\hline & \multicolumn{17}{|c|}{ Total of entries, with hearths } & \multicolumn{2}{|c|}{ Totals } \\
\hline & & $x$ & 2 & 3 & 4 & 5 & 6 & 7 & 8 & 9 & 10 & $I I$ & 12 & $x_{3}$ & 24 & $x_{5}$ & 16 & $x 7+$ & Entries & Hearths \\
\hline \multicolumn{21}{|l|}{ SHELLEY } \\
\hline $\begin{array}{l}\text { Charged } \\
\text { Exempt }\end{array}$ & \multirow{3}{*}{ 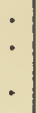 } & \multirow{3}{*}{$\begin{array}{l}4 \\
4\end{array}$} & \multirow{3}{*}{$5^{5^{q}}$} & \multirow{3}{*}{$\begin{array}{c}3 \\
.\end{array}$} & \multirow{3}{*}{$\begin{array}{c}\mathbf{1} \\
. .\end{array}$} & \multirow{3}{*}{$\begin{array}{c}2 \\
\cdots\end{array}$} & \multirow{3}{*}{ I } & \multirow{3}{*}{$\begin{array}{l}\mathbf{I}^{\mathrm{r}} \\
. \cdot\end{array}$} & \multirow{3}{*}{$\because \cdot$} & \multirow{3}{*}{$\because$} & \multirow{3}{*}{$\because}$. & \multirow{3}{*}{$\because$} & \multirow{3}{*}{$\because}$. & \multirow{3}{*}{ 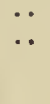 } & \multirow{3}{*}{$\because$} & $\cdots$ & $\cdots$ & $\cdots$ & 17 & 50 \\
\hline Exempt & & & & & & & & & & & & & & & & $\cdots$ & $\cdots$ & $\cdots$ & 4 & 4 \\
\hline Total & & & & & & & & & & & & & & & & & & & 21 & 54 \\
\hline Stanford $R$ & & & & & & & & & & & & & & & & & & & & \\
\hline Charged & - & I I & 7 & 10 & 9 & 7 & 5 & I & $2^{d}$ & $\cdots$ & $\mathbf{I}$ & .. & $\cdots$ & $\cdots$ & $\mathbf{r}^{\mathrm{d}}$ & .. & $\mathbf{I}$ & $\cdots$ & 55 & 219 \\
\hline Exempt & - & 24 & 5 & $\cdots$ & $\cdots$ & $\cdots$ & $\cdots$ & $\cdots$ & $\cdots$ & $\cdots$ & $\cdots$ & $\cdots$ & $\cdots$ & $\cdots$ & $\cdots$ & $\cdots$ & $\cdots$ & $\cdots$ & 29 & 34 \\
\hline Total & - & & & & & & & & & & & & & & & & & & 84 & 253 \\
\hline $\begin{array}{l}\text { STAPLEFORD } \\
\text { ABBOTS }\end{array}$ & & & & & & & & & & & & & & & & & & & & \\
\hline Charged & - & II & 5 & $8^{8}$ & 3 & $\mathbf{I}$ & 2 & $4^{a}$ & .. & $\cdots$ & $\cdots$ & $\cdots$ & $\cdots$ & .. & $\cdots$ & 1 & .. & $I(40)$ & $3^{6}$ & 157 \\
\hline Exempt & . & 8 & $\mathrm{I}$ & .. & .. & $\cdots$ & $\cdots$ & $\cdots$ & . & $\cdots$ & . & .. & . & $\cdots$ & $\cdots$ & .. & $\cdots$ & . & 9 & 10 \\
\hline Empty & - & $\cdot \cdot$ & $\cdots$ & $\cdots$ & $\cdots$ & I & $\cdots$ & $\cdots$ & $\cdots$ & $\cdots$ & $\cdots$ & $\cdots$ & $\cdots$ & $\cdots$ & $\cdots$ & - & $\cdots$ & $\cdots$ & $\mathbf{I}$ & 5 \\
\hline Total & - & & & & & & & & & & & & & & & & & & 46 & 172 \\
\hline STAPLEFORD & & & & & & & & & & & & - & & & & & & & & \\
\hline Charged & - & 4 & 4 & 3 & 4 & $I$ & $\ldots$ & I & .. & $I$ & . & .. & .. & .. & I & $\mathbf{I}$ & . & . & 20 & 87 \\
\hline Paupers ${ }^{b}$ & - & - & $\cdots$ & $\cdots$ & $\cdots$ & $\cdots$ & $\cdots$ & $\cdots$ & $\cdots$ & $\cdots$ & $\cdots$ & $\cdots$ & $\cdots$ & $\cdots$ & $\cdots$ & $\cdots$ & $\cdots$ & $\cdots$ & 6 & \\
\hline Total & - & & & & & & & & & & & & & & & & & & 26 & 87 \\
\hline STONDON M & & & & & & & & & & & & & & & & & & & & \\
\hline Charged & - & 2 & 4 & 7 & $\cdots$ & $\cdots$ & 1 & $\cdots$ & 3 & $\cdots$ & $\cdots$ & . & $\cdots$ & 1 & $\cdots$ & $\cdots$ & $\cdots$ & $\cdots$ & 18 & 74 \\
\hline Exempt & 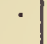 & 8 & I & $\cdots$ & $\cdots$ & $\cdots$ & $\cdots$ & $\cdots$ & $\cdots$ & $\cdots$ & $\cdots$ & $\cdots$ & $\cdots$ & $\cdots$ & $\cdots$ & $\cdots$ & $\cdots$ & $\cdots$ & 9 & 10 \\
\hline Total & . & & & & & & & & & & & & & & & & & & 27 & 84 \\
\hline THEYDON Bo & & & & & & & & & & & & & & & & & & & & \\
\hline $\begin{array}{l}\text { Charged } \\
\text { Exempt }\end{array}$ & · & 6 & II & 5 & 1.6 & 2 & $\cdots$ & 1 & $\mathbf{I}$ & $\because$ & $\because$ & $\mathbf{1}^{\mathbf{a}}$ & $\because$ & $\cdots$ & $\because$ & $\because$ & $\because$ & $\because$ & 33 & 103 \\
\hline Exempt & - & 12 & 1 & $\cdots$ & $\cdots$ & $\cdots$ & $\cdots$ & $\cdots$ & $\cdots$ & $\cdots$ & $\cdots$ & $\cdots$ & $\cdots$ & $\cdots$ & $\cdots$ & $\cdots$ & $\cdots$ & $\cdots$ & 13 & 14 \\
\hline Total & - & & & & & & & & & & & & & & & & & & 46 & 117 \\
\hline THEYDON G & & & & & & & & & & & & & & & & & & & & \\
\hline Charged & & 5 & 126 & 14 & $7^{4}$ & 8 & $9^{a}$ & I & 1 & $3^{a}$ & $\cdot \cdots$ & 1 & I & $\cdots$ & $\cdots$ & $\cdots$ & $\cdots$ & $\begin{array}{r}2(22) \\
(24)\end{array}$ & 64 & 304 \\
\hline Exempt & . & 17 & 4 & . & . & $\cdots$ & $\cdots$ & $\cdots$ & . & $\cdots$ & .. & .. & .. & .. & .. & .. & .. & $\cdots$ & 21 & 25 \\
\hline Empty . & - & $\cdots$ & $\cdots$ & 1 & 1 & $\cdots$ & $\cdots$ & $I^{2}$ & $\cdots$ & $\cdots$ & $\cdots$ & $\cdots$ & $\cdots$ & $\cdots$ & $\cdots$ & $\cdots$ & $\cdots$ & $\cdots$ & 3 & 14 \\
\hline Total & - & & & & & & & & & & & & & & & & & & 88 & 343 \\
\hline THEYDON $M$ & & & & & & & & & & & & & & & & & & & & \\
\hline Charged & & 7 & 3 & 5. & 2 & $\mathbf{I}$ & 1 & 2 & $\cdots$ & $\cdots$ & $\cdots$ & $\cdots$ & $\cdots$ & $\cdots$ & $\because$ & $\cdots$ & $\cdots$ & $1(22)$ & 22 & 83 \\
\hline Exempt & • & 9 & 1 & $\cdots$ & $\cdots$ & $\cdots$ & $\cdots$ & $\cdots$ & $\cdots$ & $\cdots$ & $\cdots$ & $\cdots$ & $\cdots$ & $\cdots$ & $\therefore$ & $\cdot \cdot$ & $\cdots$ & $\cdots$ & 10 & 11 \\
\hline Total & . & & & & & & & & & & & & & & & & & & 32 & 94 \\
\hline $\begin{array}{l}\text { WEALd, Not } \\
\text { BAsS ITT }\end{array}$ & & & & & & & & & & & & & & & & & & & & \\
\hline $\begin{array}{l}\text { BAsSETT } \\
\text { Charged }\end{array}$ & • & $15^{w}$ & $9^{a}$ & $I^{x}$ & 3 & 2 & 4 & I & $\cdots$ & I & $\cdots$ & .. & $\cdots$ & .. & .. & .. & . & .. & 46 & 128 \\
\hline Exempt & . & II & 4 & $\cdots$ & $\therefore$ & . & .. & $\cdots$ & .. & $\cdots$ & .. & .. & .. & .. & .. & .. & .. & -. & 12 & 13 \\
\hline Total & - & & & & & & & & & & & & & & & & & & $5^{8}$ & 141 \\
\hline Totals & . & 512 & 217 & 178 & 122 & 78 & 59 & $3^{6}$ & 19 & 23 & 6 & 10 & 5 & 4 & 5 & 4 & 3 & 8 & $1,3 \circ 3^{y}$ & $4,010^{y}$ \\
\hline
\end{tabular}

(a) Includes an entry that there are 2 newly built hearths in a total of 2.

(r) Includes an entry that there are 7 newly built hearths in a total of 7

(s) Includes an entry that there are 3 newly built hearths in a total of 3

(t) Includes an entry that there are 2 newly built hearths in a total of 2 .

(u) Includes an entry that I hearth is decayed leaving a total of 4.

(v) The entry states that there are 3 empty houses with a total of 7 hearths.

(w) Includes an entry that $I$ hearth is newly built; the total is $I$.

(x) Includes an entry that Richard Gladwin and John Bevan are jointly charged on 3 hearths.

(y) In cross-totalling allowance must be made for the omission of 2 entries in the Magdalen Laver chargeables and of the pauper bearths in Bobbingworth and Stapleford Tawney. 


\section{ANALYSIS OF BISHOP COMPTON'S CENSUS OF 1676: ONGAR HUNDRED}

In a letter of 1676 to Henry Compton, Bishop of London, Archbishop Sheldon required the bishop through the various archdeacons, parish clergy, and churchwardens, to compile an ecclesiastical census. I Compton was to inquire (i) the number of persons 'or at least families' who by 'common account and estimation' inhabited the respective parishes, (ii) how many popish recusants 'or such as are suspected of recusancy' there were among such inhabitants and (iii) how many 'other dissenters' were resident in the parishes.

These instructions are patently ambiguous. In particular, since detailed information about the method of parochial compilation is lacking, it is not clear whether the first column of the manuscript ${ }^{2}$ census relates to conformists, as the manuscript would seem to suggest, or to the total of inhabitants as in some dioceses they seem to be. It is equally difficult to know whether the returns include all adults over 16 , or only males over 16 , or all inhabitants including children, or families or (as seems to have been the case in some dioceses) a mixture of some of these.

Printed below are abstracts of the returns for most of the parishes in Ongar hundred. No figures are given for Norton Mandeville, Abbess Roding or Theydon Garnon, although the parish names have been entered. The parishes of Loughton and Navestock are missing from the return.

The rearranged abstracts are here reproduced as they appear in the returns together with some guesses, where possible, at their proper interpretation, based on a comparison with fiscal data derived from the Hearth Tax Assessments printed above. ${ }^{3}$ In all cases the first column headed 'conformists' has been understood to refer to the conformist element in the parishes and not to the total of inhabitants, \&c.

\section{BISHOP COMPTON'S CENSUS 1676}

\begin{tabular}{|c|c|c|c|c|c|c|}
\hline & & Conformists & Papists & $\begin{array}{c}\text { Non- } \\
\text { conformists }\end{array}$ & Total & Possible interpretation \\
\hline Bobbingworth . & . & 86 & -. & .. & 86 & All adults \\
\hline Chigwell . & . & 500 & $\cdots$ & . & 500 & \\
\hline Fyfield . & . & 210 & . & . & 210 & 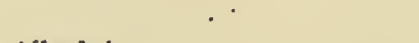 \\
\hline Greenstead 'Hamlet'. & . & 25 & $\cdots$ & . & 25 & All adults \\
\hline Kelvedon Hatch . & - & 107 & - & . & 107 & \\
\hline Lambourne & - & 100 & . & . & 100 & All adults \\
\hline Laver, High . & . & I 35 & $\cdots$ & 10 & 145 & \\
\hline Laver, Little & . & 44 & 9 & I & 54 & Total population \\
\hline Laver, Magdalen & . & $9 I$ & $\therefore$ & 9 & 100 & \\
\hline Moreton . & . & I 27 & . & 3 & I 30 & All adults \\
\hline Ongar, Chipping & . & 213 & . & I & 214 & All adults \\
\hline Ongar, High - . & . & $198^{\circ}$ & . & 2 & 200 & \\
\hline Roding, Beauchamp . & . & 79 & . & $\mathbf{I}$ & 80 & Total population \\
\hline Shelley . . . & . & 56 & . & . & 56 & All adults \\
\hline Stanford Rivers. & . & 490 & Io & . & 500 & $\begin{array}{l}\text { This figure seems too high even } \\
\text { for total population }\end{array}$ \\
\hline Stapleford Abbots . & . & 90 & - & $\cdots$ & 90 & All adults \\
\hline Stapleford Tawney . & . & 83 & . & . & 83 & \\
\hline Stondon Massey & - & 77 & . & 3 & 80 & \\
\hline Theydon Bois . & - & 100 & - & . & 100 & \\
\hline Theydon Mount & - & 99 & . & . & 99 & \\
\hline Weald, North, Bassett & • & 263 & $\cdots$ & I & 264 & Total population \\
\hline
\end{tabular}

I Engl. Hist. Doc, viii (ed. A. Browning), p. 4 I I. The compiler of this table is indebted for assistance to Miss E. A. O. Whiteman.
2 Preserved in the William Salt Library, Stafford.

3 pp. $305 \mathrm{f}$. 



\section{INDEX}

Nore. The following abbreviations are used, sometimes with the addition of the letter $s$ to form the plural: abp., archbishop; adv., advowson; agric., agriculture; Alex., Alexander; And., Andrew; Ant., Anthony; Art., Arthur; b., born; Bart., Bartholomew; Ben., Benjamin; bp., bishop; bro., brother; Bt., baronet; Cath., Catherine; Cathm., Catholicism; ch., church; char., charities; Chas., Charles; Chris., Christopher; ct., court; ctss., countess; d., died; dau., daughter; Dan., Daniel; dchss., duchess; Edm., Edmund; Edw., Edward; Eliz., Elizabeth; Elnr., Eleanor; Eus., Eustace; f., father; fam., family; Fran., Francis; Fred., Frederick; Geo., George; Geoff., Geoffrey; Gil., Gilbert; govt., government; Hen., Henry; Herb., Herbert; hos., houses; Humph., Humphrey; hund., hundred; inc., inclosure; ind., industry; Jas., James; Jos., Joseph; jr., junior; Kath., Katherine; Laur., Laurence; Lawr., Lawrence; ld., lord; Lond., London; m., married; man., manor; Marg., Margaret; Mat., Matthew; Mic., Michael; Nat., Nathaniel; Nich., Nicholas; noncf., nonconformity; par., parish; Pet., Peter; Phil., Philip; pop., population; Prot., Protestant; pub., public; rect., rectory; Reg., Reginald; rel., relief; Revd., Reverend; Ric., Richard; riv., river; rly., railway; Rob., Robert; Rog., Roger; Rom., Roman; s., son; Sam., Samuel; Sar., Sarah; sch., school; Sim., Simon; sis., sister; sr., senior; Steph., Stephen; stn., station; svces., services; Thos., Thomas; top., topography; vct., viscount; vctss., viscountess; w., wife; Wal., Walter; Wm., William.

Abberbury, John and his w. Alice,

Abbott, Rob. and his w. Bethia, 27

Abbott \& Habersham, architects, 256

Abdy, Sir Ant. Thos. (d. 1775), 226 Sir Ant. (d. 1921), 226; Chas. B., 271; Joanna, 184; Caroline, see Hatch; Sir John, Bt. (d. I691) 191, 229; Sir John, Bt. (d. 1759), 226, 229; Kath., 226; Sir Rob., Bt. (d. 1670$), 27,28$, 191,226 227, 265, $305 n$; Sir Rob., Bt. (d. 1748), 32; Revd. Thos. (d. 1798), 229, 230, 261, 272, 275; Sir Thos. Neville, Bt. (d. 1877 ), $223,226,265,269$; fam., 223, 229, 232; see also Rutherforth (later Abdy)

Abdy (later Hatch-Abdy), Caroline, see Hatch; John Rutherforth, 26, $225,226,229,230,265,269$

Abercrombie, Prof. Patrick, $159 n$

Abridge, in Lambourne, 4, 19, 35, $45,72-77,83,84-86$, I 4 I, I 44 , $158,223,230,249,250,260,292$

Abridge Brewery Co., 76

Adam, Geoff. s. of, see Roinges, Geoff, de

Adam, John s, of, 214

Adam S. of Fulk, 191

Adam le Tailleur and his w. Joan

I99
Adams, John, 100; Sar., 117

Addington, Ralph, $29 n$; Thos. (d. 1543), 29; Thos. (fl. 1543), 29

Addison, Wm., I $11 n, 112 n, 113 n$, $117 n, 124 n, 126 n$

Adeane, Anne, see Jones; Hen. J., 30; Gen. J. W., 30; Rob. Jones,

Adelaide, queen of Wm. IV, 256

Adeney, Revd. B. F., $285 n, 292 n$

Adkyn, John, 213

Elfstan (A. C. 1043-5), 159

Æthelgyth (Ailid) (fl. c. 1043-5), 159

Ailid, see Ethelgyth

Ailmer, Roger Fitz, 121

Ailric (fl. I066), 65

Ainsworth, Wm., I68

Air Ministry, the, 180,189

Air raids, see War damage

Airfields, 73,76, I 50, 181, 180

Alan, Count of Brittany, 192, 198

Albyns, in Stapleford Abbots, 27, $222,223,224,225-7,235,265$

Alchorne, Wm., 184

Alderton, in Loughton, $2,110,111$, $118,119,120,121$

ES. IV

Alderwich, Nich. and his w. Alice, 133

Aldgate (Lond.) 21, 22, 45, 74, 157; St. Botolph's ch., 6 I

Alestan (fl. 1066), 5 I

Alexander, Anna Caroline, see Ewing; Caledon du Pré, 106; Edw., 16r; Hen., 145; Nich., 16r, 164, 172; Thos., 157

Alexander (later Bennet), Bennet, $161 n, 162$

Aleyn, Arabella m. I Fran. Thompson, 2 Ld. Geo. Howard, 235; Eliz., see Scott; Sir Edm., Bt., 235; Sir Edw., Bt., 235

Algar (fl. 1066), 65

Alger, Steph., 132; Wm. Hill, 130, 132; Wm. White, 132

Algor, Ric., 110

All Hallows-the-Great (Lond.), par., 290

Allam, I., 55

Allen, Thos., 23o; Capt., 232; Mrs., 208

Alsop, Geo., 163

Altham, Jas., 29; 'Thos., 107

Alvric, the father of, 210,214

Alwin (fl. 1066), 49, 88

America, United States of, 242; see also Massachusetts, Rhode Island

Amice, Abbess of St. Sulpice (France), 88

Andrews, Alice, 34; Revd. Edw., 218; Hannah, 213; Rog., 33, 34; Thos., 33, 34; Wm., 33

Anesti, Ric. de, 160

Anglesey, earls of, see Annesley; earldom of, 267

Anne, Queen, 88, 119

Anne (of Cleves), queen of Hen. VIII, 190

Anne (of Denmark), queen of Jas. I, I I9

Anne, dau. of Thos, of Woodstock, Duke of Gloucester, m. Edm. Stafford, Earl of Stafford, 191

Annesley, Art., Earl of Anglesey, 267; Art., Vct. Valentia, 268; Ric., Earl of Anglesey (d. 176r), 268

Annys, Lazarus and his w. Mary, 200

Ansell, Thos., 102

Ansty (Herts.), 215

Antrobus, Revd. Ric., 70

Apilton, 'Thos. and his w. Anne, 26

Appeltons (Old Farm) in Chigwell, 20,26

Arblaster, Alice, see Legh; Thos. 206
Archer, And., Ld. Archer, 288; Ann m. Chris. Musgrave, 288; Elnr. m. Sir Wal. Wrottesley, 289; Elnr. w. of Sir John, 289; Geo., 168; Harriott m. Edw. Bolton Clive, 288; Hen. (H. 1584), 261, 274; Hen. (d. 1616), 268; John (fl. 1548), 270; Sir John (d. I682), 14, 261, 268, 270, 271, 289; John (d. 1707), 268, 289; John (d. 1800), 268, 269; Kath. Lady Archer, see Tipping; Maria m. Hen. Howard, 288; Ric., 270; Sar. m. Other Windsor Hickman, Earl of Plymouth, 288; Sim., 281; Susanna m. Jacob Houblon, later assumed surname of Newton, 268, 269; Susanna, see Newton; Thos. Ld. Archer, 288; fam., 261, 268, 289 Archer (formerly Eyre), Sir Wm., 268, 271, 280

Archer-Houblon, Harriet, 261, 269, 271, 273; John (d. 1831), 269; John (fl. 1841), 268, 269, 289; Capt. Lindsay, 280; Mary Anne w. of John, 269; fam. 259, 26r 268, 289

Ardeley, Wm., Abbott of St. John's, Colchester, 297

Arderne, Sir Pet., 1 I, 13

Ardleigh, 77

Arkesden, 262

Arneway, Adam, 78

Arneways, in Lambourne, see Arnolds

Arnold, John, 24; John Roger, 24; Mat., poet, 126; see also Dent and Arnold

Arnolds (Arneways), in Lambourne, $73,75,76,78,8$ I

Arnulph, Prior of Rumilly, 182

Arrowsmith, Revd. Thos., 292

Arundel, earls of, see Fitz Alan

Arundel Herald, see Cosoun, John

Ascelyn, Ric., 177

Asevile, Ralph de, 68

Ash, John, $45 n$; Wm., $45 n$; fam., $45 n$

Ashby, Giles, 272

Ashfeld, Thos., 56

Ashhall, see Nash Hall

Ashley, Sir John, II; Solomon (d. 1778), 26; Solomon (fl. 1783), 26; Wm., 11 ; Winifred, see Pitfield

Ashlyns, in Robbingworth, formerly in High Ongar, 4, 9, $89 n, 171$, $172,177,183$

Ashpitel, W. H. and his s., 68

Ashwell (Herts.), 268 


\section{A HISTORY OF ESSEX}

Aske, John de, 47

Assartis, Ralph de, I 21

Aston Hall, in Oswestry (Salop), 28

Atforth, Adam, 13

Atkin, Mrs. J. Worthington, 52

Atkinson, Rob., 29

Attlee, Wm. I7 1

Atwood, Alice, see Salyng; Anne, 215: Dorothy, see Walter; John, $215 ; \mathrm{Wm}$. (d. 1600), $215 ; \mathrm{Wm}$. . of John (d. by I 664-8), $215 ; \mathrm{Wm}$. (fl. 1664-8), 215; Wm. (f.. 1701), 215 ; Wm. (f. c. 1723 ), 163

Aubrey dau. of Rainald $m$. Eus. de Selflege, 205

Aubrey, Mary Lady, see Colebrooke; Sir Thos., Bt., 79

Audelin, Wm. Fitz, I75; his w. Juliane, see Doisnel

Audley, Hugh de, Earl of Gloucester, 105, 160, 235, 287; Marg. de, Ctss. of Gloucester, see Clare; Marg. de, m. Ralph Stafford, Earl of Stafford, I 60, 235; Sir Thos., 79 Auger, Thas., 64

Aumale, Count of, see Forz

Austin, Anne, see Bingham; Wm. (d. 1634 ), 178; Wm. (f. 1650 ), 178 Australia, 36

Austry, John, 100

Avery (Averry, Avere), John (f. 1536), 291; John (fl. 1662), $305 n$; Thos., 254; Mr., $203 n$

Avranches, Maud de, m. Hamon de Crevequer, I3I; Sim. de, $131 n$; Wm. de (f. c. 1174-82), I 31,134 ; Wm. de (d. 1230$), 131 ; W m$. de (d. by I 235), I3I

Aylesford (Kent), I 50, 212

Aylett, John, 1 o6; Wm., ro6

Ayloffe, Audrey, see Shaa; Thos., $178 n$; Wm. (d. 1517), 178; Wm. (d. 1584), 178; Sir Wm. (fl. 1610), 178

Babington, Norman and his $w$. Marg., 31; Rob., 31; Thos., 31 ; Sir Wm. (d. I454), $3 \mathrm{I}$; Wm. (d. I 474), 31

Babraham (Cambs.), 30

Bacon, Sir Fran., 224; John, sculp-

tor, I 47; Sir Nich., 81

Bagstar, Geo., 77

Bainard, Ralf, 159

Baker, Bernard, 205; Bramston, 179 , I86; Col. F. J., 244; John (d. c. 1518), 274; John (f. 1702), 271; John (fl. 1732), 207; John (f. I784), 236; Marianne, see Meyer; Sarah, see Green; Wm. (fl. 1 536), 29; Wm. (f. I 718 ) , 175, 179, I86; Wm. (fl. 1849), I 79

Balaclava, battle of, 83

Baldwin, Edwin, Ioo; Geo., 125

Ball, Edw. Hughes, see Hughes (formerly Ball); Miss, $129 n$

Balliol, Hen. de, 287; Lore w. of Hen. de, 287

Ballard, Ric., 217

Bampton, John de (H. 1362), 176; John (fl. 1369), 99

Bancilhon, Eliz., 158

Bangor, bp. of, see Vaughan

Banham, P. R., $155 n$

Bank of England, 288

Banks, Sir John, Bt., 212; Mary m. Sir John Savile, 2 I 2

Bannister, Revd. John, 68

Bannockburn, battle of, I60 $n$

Barbados (West Indies), 102

Barfoot (Barefoot, Barfott), John, 74, 77; Kath. w. of Rob., 81; Rob., 77, 81, 83; Thos. I4, 77, 86; fam., 77
Barford, Ric., 77; Mary w. of Ric., 77

Barfott, see Barfoot

Barker, F. H., I70 $n$; Jos., I 92

Barking, 26, 274; see also Claybury

Barking, Abbey of, 190, 192, 193

Barkway (Herts.), see Nuthampstead

Barley (Herts.), 74

Barlow, Dr. Nat., I 7o; Nat. s. of Dr. Nat., 170 ; Wal., 170

Barnaby Rudge, by Chas. Dickens, 20

Barnard, Hen., I66; Sam., I86; Revd. T. M. R., I64; Wm., 90

Barnes, Ann w. of John, 225; John, 225, 291; Wm. Pemberton, 225, 291; Mrs. Pemberton, 29

Barnes, in Springfield, 176

Barnet, John, Bp. of Bath and Wells, 146

Barnet (Herts.), 166

Barneys, Wm., I 63

Barningham (Suff.), 287

Barnston, 19

Barrett, Revd. J. L., 201

Barrington, Alice de, 9 I $n$; Alice, see Battail, 91: Anne Lady, see Rich; Edm., 27; Eliz. m. John Sulyard, 91 ; Eus. de, 27; Humph de (fl. 12th cent.), 27; Humph. s. of Humph. de (fl. I 3 th cent.) 27; Humph. (d. by 1487), 27 John (d. c. 1368), 27; John (fl. 1412), 91; John (d. c. 1426), 27 John (d. 1 537), 27; Kath. m. John Pykenham, 91 ; Margery de, $91 \boldsymbol{n}$ Sir Nich. de (fl. 1249), 27; Nich. (d. by 1274), $27 n$; Nich de (d. $c$. 1330), 27, 265; Nich. de (fl. I344) 27; Nich. (d. ${ }^{1505)}$, 27 ; Nich. d. (1515), 27; Thos. (d. 1472) and his w. Anne, 27; Thos. (f. I th cent.) and his w. Marg., 27; Thos. (f. 1563 ) 27 ; fam., 26,27

Barrington (Cambs.), 27

Barrington Hall, in Hatfield Broad Oak, 27

Barringtons (Little Chigwell; later Rolls Park), in Chigwell, 4-5, 19 20, 23-24, 26-28, 37-38, 190, I 99 Barrow, Maurice, 161,162

Barry, Joan, see Mandeville; John, 234,235

Bartlet, Ant., bellfounder, 101, $16_{4}$, 217,227 ; Jas., bellfounder, 83

Barwicks (Berwick) in Stanford Rivers, 213,236

Basevi, Geo., architect, 14

Basing, Anne, see Pawne; Bridget $m$ Wm. Chatterton, $153,178,179$ Rog., 178

Basire, Jas. (d. 1822), 24; Jas. (d. 1869), 24

Baskerville, Wal. de (d. 1244), 59 Wal. de (A. 1279), 59, 6o

Basle (Switzerland), 83

Basset, Aline m. I Hugh le Despenser, 2 Roger Bigod, Earl of Norfolk, 287; Ela, Ctss. of Warwick, see Ela : Fulk, Bp. of London, 31 ; Sir Phil., $160,182,210,224,284,287$

Bastick, John, 230

Bataille, see Battail

Batayle, see Battail

Batayles, in Stapleford Abbots, see Battles Hall

Batells, see Ongar Park

Bath and Wells, bps, of, see Barnet, Burnell

Battail (Bataille, Batayle), Alice, m John Barrington, 9I; Alice, see Walden; Anne, m. Pet. de Taleworthe, 227; Elnr., see Oudeby; Eliz., see Enfield; Hubert, 227 Isabel w. of Thos. $\mathrm{m}, 2 \mathrm{Rab}$.
Thornhill, 106, 177; John (fl. 1397), 91; John (d. I 474), 106, 107, I77; John (fl. 1513), 107, 177; Marg. m. John de Boys, 9I: Margery $\mathrm{m}$. Wm. de Sutton, 227, 288; Mat., 227; Ric. (H. II66), 227; Ric. (f. 1217), 227; Ric. (f. I235-6), 227; Ric. (f. c. 1272), 227; Ric. (d. 1540), 177; Sim., 227; Thos. (H. I4th cent.), 9I; Thos. (d. I 439), 106, I 76, I77; Wm. (f. I108-47), 227; Wm. (d. by 1200 ), 227; fam., I75, 227

Battersea (Lond.), 123

Battle (Suss.), abbot of see Lucy

Battles Hall (Batayles), in Stapleford

Abbots, 26, 75, 76, 78, 85, 223 , $225,227-8,229$

Battye, Wilhelmina, see BowyerSmijth

Bayeux (France), bp. of, see Odo

Bayles, Mr., $73 n, 76 n$

Bayley (Bayly), Eliz., I53; John, 33

Bayn, Ann, 100

Baynes, T. M., architect, I 56

Beachcroft, Mary, see Matthews;

Sam., go; fam., 9o,

Beattie, Dr. N., 21 ; Mrs. N., $35 n$ Beauchamp, Joan de, Lady Bergavenny, see Fitz Alan; John de (f. 1231), 198; John de (fl. 1320), 46; Mathias de, 46; Maud de, see Lucy; Nich. de (d. I 243), 46; Nich. de (f. 1332), 46; Olive de, $\mathrm{m}$. Wm. Fitz Geoff. de Mandeville, 198; Ralph de, 199; Rog. de (fl. c. I190), I98; Rog. de (d. 1281), 46; Revd. S. C., 101; Wm. de, Ld. Bergavenny (d. I4II), $31 n, 262$; Wm. (fl. 1424), 215

Beaufort, John, Duke of Somerset 266; Marg. w. of John, Duke of Somerset m. 2 Lionel de Welles, Ld. de Welles, 266

Beaumont, Geo. F., 288

Beckenham (Kent), $16 \mathrm{I}$

Becontree, hund. of, 3 , I 18

Beddington (Surr.), 47

Bedford, dukes of, see Russell, Tudor

Bedford, earl of, see Russell

Behnes, Wm., sculptor, 147

Bek, Ant., Bp. of Durham, 25 I

Bekke, John, 26

Belfield, Chas., 145

Belgian refugees, in First World War, I 8

Belknap, Alice w. of Sir Wm. Shelley, 243; Griselde $\mathrm{m}$. John Hende, 243; Sir Edw., 242, 243; Hamon, 243; Sir Hen., 243

Bell, Mrs. A. D., 260 n, $267 n$; Chas., 37

Bellamy, Mrs. E., 107

Bellhouse, in Stanford Rivers, 209 211, 212, 213-14, 216, 218, 236, $276 n$

Bellin, Sam., 24

Belret, Hen., 67

Benington (Herts.), 287

Benlace, Ric. de, 32

Bennet, Eliz. Amelia, see Burrell; Emilia Eliz. m. Sir John Swinburne, Bt., 161 ; Isabella Julia $\mathrm{m}$. Sir Jas. Willoughby Gordon, Bt., 161; Ric. Hen. Alex. (d. 1814), 161 ; Ric. Hen. Alex. (d. 1818),

Bennet (formerly Alexander), Bennet, I6I $n, 162$

Bennett, Jos., 162 ; Mr., 292

Benson, John and his w. Mary, 193

Bensted, Sir John de, 214, 287

Bent, Jas. Theodore, $25 \mathrm{I}$

Bentley, Revd. W., 123

Bentley, in South Weald, 141, 166 


\section{INDEX}

Benton, Alex., 49; John., 293; Ric., 109

Bere, T. E., 145, $146 n$

Berewyk, Alan de and his w. Joan, 213; Ric. de, 213; Thos. de and his w. Alice, 213

Bergavenny, Barons, see Beauchamp, Neville

Berkeley, Jessie Matilda, 222

Berkshire, medieval tax assessments for, 302

Bermondsey (Surr., later Lond.), Priory (later Abbey) of, 52; abbot of, $53 n$

Berners, Anne w. of Sir Jas. m. 2 John Bryan, I9I: Beatrice w, of Wm. de, IgI; Edm. de, I II; Sir Jas. de, 19 ; J John s. of Edm. de (A. 1336), 191; John s. of Ralph de (fl. 1336), 191; Sir John de (f. before I38I), I9I; Margery de $m$. I John Fereby, 2 John Bourchier, Ld. Berners, I9I; Ralph de (fl. I 166), I91; Ralph de (fl. I220), I9I, I92; Ralph de (A. before 1336), I91; Ric. de, 191; Wm. de, I9I; fam., 190-I

Berners, barons, see Bourchier

Berrisford, John, 28

Berwick, in High Easter, 190

Berwick, in Stanford Rivers, see Banwicks

Berwick Berners, in Abbess Roding, $4,5,6$, 188, 189, 190-2, 196

Berwick-on-Tweed (Northumb.), 38

Beston, John de, 93

Bettis, John, 186

Betts, Lewis, 149

Bevan, John, 310

Beverley, Anne, 267; fam., 54

Bickerdike, Thos., 4 I

Biddik, Adam de and his w. Joan, 199; Hen. de, 199; Joan w. of Hen. de m. 2 Arnald Mounteneye, 199; Thos. de, 199

Bigod, Aline, Ctss. of Norfolk, see Basset; Rog., Earl of Norfolk, 287

Billericay, 157

Billesdon, Joan, see Williams; Sir Rob., 14, 289; Thos., I4, 289; fam., I4

Bilsdens (Monkis, Bobynford Gippes), in Bobbingworth, 9, I0, I 2-14

Bingham, Anne m. 2 Wm. Austin I78; Laur., $178 n$; Wm. and his w. Eliz., 178; Mr., I65

Bingley, Percival $\mathrm{H}$., I 7 I

Binkes, Wm., 153

Birch, John, 200; Revd. Ric., 200, 201; Wm., 200

Bird, H. L., I78; John, bellfounder, 246; Ralph, 32; T. J. E., 293; see also Byrd

Bird's Green, in Beauchamp Roding and Willingale Doe, 5, 197, 198 202

Birmingham, Eliz. de, see Multon; Wal. de, 66

Biscoe, Revd. Ric., 286

Bishop, Amy, I 70; Edith, I 70; Edw. (f. 1 545), z64; Edw. (d. 1553) 264; Margery, see Hampden, 264; Rog. and his w. Alice, $8 \mathrm{r}$; Mr., 272

Bishops Hall, in Lambourne, 73,74 , $75,77,79-80,82,83,208,228$

Bishop's Stortford, see Stortford, Bishop's

Bishop's Stortford Gas Company; I 58, 204

Bishopsgate (Lond.), 74

Bismere, Reynold, 80

Black, Wm., 275

Blackburn, Eliz., see Blades; John, 26; Joshua, 26; fam., 26
Blackmore, $63,153,174,178,185$ 240, 241, 248; see also Fingrith Blackwall, Alice, see Prest; Ric., I45

Blades, Eliz. m. John Blackburn, 26 ; John, 26

Blake Hall, in Bobbingworth, 9, Io 12, I4, I6, 5 I $n, 76 n$, I $05 n$, I 31 , $152,153,175,176,193,203,214$

Blewett, Chas., 77

Blisland (Cornw.), $256 n$

Blomfield, Sir Art., architect, 34; Sir Reg., architect, 280

Blowes, Mrs. B. S., $43 n$

Blucke, Mat., 98, 100

Blund, And., 25

Blunt, Wal. le and his w. Maud, 79

Boarstall (Bucks.), 79

Bobbingworth (Bovinger), 4, 9-18 58,103, I 29, I 30, I 57, I $59 n$, I 7 I, 175, I77; adv., 13, I 4; agric., 10 Bp. Compton's census, 31 i Bobbingworth Hall, 9, 10, 1 2, I3; Bovinger Mill, 9; char., I 8 ; ch. $9,14,184$; hearth taxes, 304-6, 308, 3 10 $n$; hos., 9, I 2, 1 3, I 4, I 5 mans., 10-14, $89 n, 254$; medieval taxes, $300-2$; par. govt. and poor rel., I 5, $120 n, 221 n$; pop., 9; postal svces., 9 ; pub. svces., IO rly., 9; rect., I 5; roads, 9, 204 sch., 9, I7, I 39; top., 9; see also Ashlyns, Bilsdens, Blake Hall

Bobbingworth 'hamlet', see High Ongar

Bobynford, see Bilsdens

Bocking, 297

Bodle, Eliz., see Scott; Louisa m. Geo. Watlington, 32 ; Mary Eliz. 32; Rob. (d. 1785), 32 ; Rob. (d. I85I), 32; Wm., $32 n$; see also Boodle

Bodley, G. F., 34

Bohun, Elnr. de, m. Thos. of Wood. stock, Duke of Gloucester, IO I9 I Humph. de, Earl of Hereford and Essex (d. I298), I 2, I9I Humph. de, Earl of Hereford and Essex (d. I322), Io; Humph. de, Earl of Hereford and Essex (d. 1361), 6; Humph. de, Earl of Hereford and Essex (d. I 373), 6, 10, 19I, 205; Joan de, Ctss. of Essex, 192, 205; Mary m. Hen. Earl of Derby, later King Hen. IV 205: Maud de, Ctss, of Hereford, see Fiennes; Wm. de, Earl of Northampton, Io

Bois, see Boys

Bois Hall, in Navestock, 67, I40, I 4I, I 42, I 44-5, I 49

Bolbec, Hugh de, 227; Marg. de, see Montfichet

Bolesworth Castle, in Broxton (Malpas par., Ches.), 254

Bolles, John (d. by 1495), 66; John (d. I 533), 66; Kath., see Haugh; Ric. (d. I52I), 66; Ric. (fl. I 538), 66

Bond, Benj., 252; Eliz., 252 ; Fred., 290; Revd. Wm., 202

Boodle, Edw., 164; Ric., 273 ; fam., I64; see also Bodle

Boodle's Club (Lond.), I64

Boote, John, 33

Booth, Mr., 35

Borley, I 92

Borrow, Rob, and his w. Alys, 2 I 8

Bosco, see Boys

Bosworth, battle of, $77 n$

Botelers, in Stanford Rivers, see Bridges and Piggsland

Boughton, Mary, see Ramsey; Sir Wm., I 34

Boulogne, Eus. Count of, I 2, 49, 75 , 88,98 , 100, 105, I 59, I 60, I 82,
210, 216; Geoff. of, 76, $105 n$; Maud of, $m$. King Stephen, see Maud; Pharamus of, $12,49,76$, I05; Sibyl of, $m$. Ingram de Fiennes, I 2, 49, 76, 105; Wm. Count of, $49,76,88,160$

Boulogne, honor of, $76,88,105,160$, 210, 2 I I

Bourchier (Bousser), Anne, Baroness Bourchier, m. Thos. Parr, later Earl of Essex, 59, I3I ; Bart. Ld. Bourchier, 32, I3I ; Eliz., I 31 ; Hen. Earl of Essex (d. 1483), 59, 13 I, I 34; Hen. Earl of Essex (d. 1540), 59, I3 I; John le (fl. 1325), 98; John, Ld. Bourchier (d. I400), 32, 59, 98, I 3 I; John, Ld. Berners (d. 1474), I 91 ; John, Ld. Berners (d. I533), I9I; Margery, Lady Berners, see Berners; Rob. Ld. Bourchier, 59, 98, 131; Wm., I62 Bourchiers Hall alias Little Laver Hall, see Little Laver

Bourchiers Hall, in Moreton, see Nether Hall

Bournazel (near Toulouse, France), 279

Bourne, Alice m. John Digby, Earl of Bristol, 13, 13 ; Anne, see Day; John, 59, 60; Kath., I 3; Marg. w. of Wm., I4; Ric. (b. I 599), 59; Ric. (fl. I643), 49; Ric. (d. I660), 59, 62; Ric. (d. I682), I 3 I ; Rob. (f. I612), 49; Rob. (d. I639), I2, I 3, I4, I 5, I3 I; Rob. (d. I666), $13,17,18,131$; Rose, see Walcott; Wm. (d. I58 r), I 4, I 5, 59; Wm. (d. I608), 59, 60; Wm. (f. I608), 59; fam., 15

Bousser, see Bourchier

Bovill, E. W., 99

Bovinger, see Bobbingworth

Bow (Mdx., later Lond.), I66

Bowes, Mr., 95

Bowtell, Fran., I09

Bowyer-Smijth, Adela m. Cyril C. Stafford Northcote, 235, 278 Revd. Sir Edw:, Bt., 239, 256 282,283 ; Letitia w. of Revd. Sir Edw., Bt., 283; Wilhelmina $m$ Art. B. Battye, 235, 278; Sir Wm. Bt. (d. 1883), 260; Sir Wm., Bt. (d. I9I6), $276 n, 278$; fam., 259 , 275 ; see also Smyth (later Smijth) Boxted (Suff.), 290

Boyle, Lady Mary m. Chas, Rich, Earl of Warwick, I 8

Boys (Bois, Basco), Amy w. of Hen. de, 253; Hen. de (d. by I 289), 25 I 252; Hen. de (fl. I 293), 252; Hen

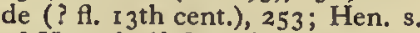
of Hen. de (? f. 1 3 th cent.), 253 Hugh de, 251, 255; John de (d. by 1317) and his w. Christine 1 44; John de (fl. 1412), 91; John de (d. I4I9), I44-5; Lawr. de 252; Marg. de, see Battail; Maud w. of Ric. de, 25 I $n$; Ric. de, $25 \mathrm{I} n$; Wm. de (fl. I I66), $25 \mathrm{I}$, 255; Wm. de (f. 1235-6), 25 I

Brace, J. \& Sons, 98

Brackley, Sam., 134

Bradborne, Frances, see Prest; Wm., I 45

Braden, Edw., 230

Bradley, Thos., 304

Bradshagh, Nich.,-21 2, 2 I 6

Bradwell-juxta-Mare, 187

Braham, Frances m. I John J. H

Waldegrave, 2 Geo. Edw. Earl

Waldegrave, 3 Geo. G. Harcourt

4 Chichester S. P. Fortescue, Ld.

Carlingford, 142, I 44, I 47

Braintree, 157

Brakelond, Jocelin of, 229 


\section{A HISTORY OF ESSEX}

Bramston, Eliz., see Harvey; Thos. (fl. 1739), 200; Thos. Berney (fl. c. I $80 \mathrm{I}$ ), I 80 ; Thos. H. (f. I 888), 190; Thos. W. (f. I 868), I 9o, I99, 200,201 ; see also Stane (formerly Bramston)

Branch, Ellen (d. I 567), see Hampden; Ellen (fl. I 589), see Nicholson; Sir John, 264, 271

Brand, Fred. Jos., I 23; Gertrude, Baroness Dacre, see Roper; John, 191; Marg. w, of Thos., I9I; Thos. (d. 1718), $49 n$, I9I; Thos. (d. I770), 49, I91; Thos. (f. I 780), 45, 49, I9I; Thos. Ld. Dacre (d. I85I), 45, 49, I 92 ; Tìm., 49; fam., 45,54

Brandon, Chas., Duke of Suffolk, 135,201

Brasenose College, Oxford, 132

Brawn, Revd. Sam., I22, I23; the Misses, 127

Braxted, Great, 177

Bray, Sir Reynold, 243, 264

Breauté, Gil. de, 68, 105, I47; Joan de, see Mary

Brecknock, Anne, 139; John, 206

Bredstrete, Thos. de, 235

Bregge, see Brigge

Brendish, see Bundish

Brent, Joan m. John Trethek, I3; Sir Rob. (d. I421), I3; Rob. (f. c. I 504), I $3 ;$ - (fl. I 496), I 4

Brentwood, $63,64,70,141,142$, 149, I 55, I $58,159 n, 165,172$, $174,189,198,240,241,286$

Brentwood School, 29

Brewer, Galiena, see Dammartin; John, I5I ; Wm., I 5 I

Brewing, 2, 75, 76, I72, I75

Brewster, Mrs., $84 n$

Brickmaking, $2,24,76,116,167$, 175, I90, 210,276

Brictmar (fl. I 066 ), 49, 98

Brictwin (f. 1066), 210

Bridges, Geo., 45; Jas., 8 I

Bridges and Piggsland (Bridges, Piggsland and Botelers) in Stanford Rivers, 214

Bridgman, Thos., 186

Bridham, And., 242

Brigge (Bregge), John atte, 214; Wm. atte, 2 I 4

Brinson, Maj. J. G. S., I $88 n$

Bristol, bp. of, see Newton

Bristol, earl of, see Digby

Bristow, Andrew Alfred Collyer, 47. 182

Britain, Battle of, 286

Brito, Alice m. Sir Wm. de Goldingham, $25 n$; Philippa w. of Rob., 25; Ralph, 25 ; Rob., 25 ; Wm., 25 ; Wm. a. of Wm., 25

Brittany, count of, see Alan

Briwes, Beatrice de, see Theydon; John de, 277; Rob. de, 277, 28I

Brock, Wm., 148

Brockett, Edw., 30

Broke, Geo., 29 I

Bromfield, see Broomfield

Bromhale, John, 214; Lore, see Salyng

Bromley (Mdx., later Lond.), 26; see also Bow, Stratford Bow

Brook, Sir Edw., 193

Brooks, Sam. $90 n$

Broomfield (Bromfield), Eliz. m. Nich. Staphurst, 81 ; John s. of John, 78, 81, 86; John s. of Rob., 78 ; Rob., 78,83 ; fam., 83

Brown (Broun, Browne, Brun), Agnes, see Gate; Ant. (A. c. I 5436), 78; Ant. (fl. I 554), I63; Sir Ant. (d. 1567), 29, I90; Ant. (d. 1583), 192; Baldwin, I92; Bennet le, 98; Emma la, I52; Geo., I92; H. (fl. 1 553), 291 ; H. (fl. I 892), I67; Jane m. Sir Gamaliel Capel, 192; John (d. 1467), I92; John (f. I6th cent.), 193; John (fl. 1849), I 82 ; Jos., I 23 ; Kath. m. Nich. Waldegrave, I92; Lancelot ('Capability'), 245; Thos. (d. 1488), 192; Thos. (H. 1726) cartographer, I 44; Wm. (fl. I 477) I99; Wm. (d. I665), 77, 78; Wm. (f. I 678 ), 78; Wm. (A. I 829), pauper, 272; Sir Wistan (f. 1488), I 90, I 92 ; Wistan (d. I 580 ), 192 ; W. H., 35 ; elder and younger, 92 ; fam., I 92

Broxbourne (Herts.), 244

Broxton, in Malpas (Ches.), see Bolesworth Castle

Bruce, Rob., King of Scots, 6

Brucesmith, Benj., I I

Brumpton, Ric. de, 199

Brun, see Brown

Brundish, in Moreton, see Bundish

Brundish (Suff.), I 33

Bryan, Anne, see Berners; John, I9I

Bryce, Thos., 63

Brygges, Sir John, 26

Buchanan, Wal., I65

Buckford, Thos. (d. I 688), 26; Thos (f. 1692$), 26$

Buckhurst (Munkenhill, Monkhams), in Chigwell, 20, 26, 28

Buckhurst Hill, in Chigwell, I, 2 I $8-24,28,34,36-42$, I I 3 , I I 4 , 116

Buckhurst Hill, Urhan District of, I 8, I I0; U.D. Council, 22

Buckingham, dukes of, 80, I6I; see also Stafford

Buckinghamshire, I 77; medieval tax assessments in, 300

Buckland, Mr., 224

Budworth, Chas. E. D., 62; Revd. D. P. D., 93; Revd. Phil. (d. I 86 I), 60, 62, 93, 95, 96; Capt. Phil. J. (d. I 885), 60, 62, 92, 93 , I 59, I67, 24I; Ric. (fl. I777), 93 ; Revd. Ric. (d. 1805 ), 93,95 Canon R. D., 93; fam., 95

Bull, John (fl. I 701 ), 2 I 5 ; John ( $f$ I7IO), 54; Sarah, 2 I 5 n; Mrs. (fl. I 729), 215

Bullock, Wm., 208

Bundish (Brendish, Brundish), in Moreton, 129, I 30, 133-4, 204

Burden, Geo., 200

Burford, Jas. Wm., Io7; Pet. Thos and his w. Ann, 107; Thos., I07; fam., 107

Burgate, Ánastasia de m. John le Merk, I5 I, I52; Galiena de, see Dammartin; Pet. de, I5I, I52; Rob. de, I 5 I, I 52

Burgh, Eliz. de, Ctss. of Ulster, m Lionel, Duke of Clarence, I05 Eliz. de, see Clare; Hubert de, Earl of Kent, 277; John de, 133

Burghersh, Bart. Ld. Burghersh, 287

Burghley, baron, see Cecil

Burgoyn, Thos., 2 I 3

Burling, Mrs., $9 n$

Burndish, John de (d. I336), I3I 133; John de (f. 1353), I34; Nich. de, I 34

Burnell, Phil., 76; Rob. Bp. of Bath and Wells, $49,76, I_{3}$

Burnet, Sam., I00

Burnevill, John de, I05; Rob. de (f. 1270), I05; Rob. de (f. 1285), I05

Burney, Geo., I12, I I 5

Burns, fam. (paupers), I 48
Burrell, Anne M., 295; Eliz. Amelia m. Ric. Hen. Alex. Bennet, I6I John, I68; Pet., I6

Burton, Ann, see Hicks; Nich., I 96

Mic., 25; Mr., architect, I5

Bury St. Edmunds (Suff.), 22, 60

Bury St. Edmunds (Suff.), Ábbey

of, 223, 224, 228; abbots of, see

Hugh, John, Samson, Simon

Bush, Wm, 200

Buss, Frances Mary, 251, 256, 258

Bussell, Revd. Fred. Wm., I32

Butler, Edm., 200; J. W., I70 $n$;

Ric., 27I; Wm., 33

Buxhull, Alan de, 29

Buxton, D. A. J., 162; Edw. North (d. I 224$), 40$, I 15 ; Lt.-Col. Edw. North (f. 1 928), 252; Gerald, 252, $253 n$; fam., $25^{6}$

Byles, Revd. Thos., 166

Byrd, John, 228; Wm., musician, 70, $227-8,241,242,243,244,247$; fam. 244; see also Bird

Byron, Ernestus, 267; Sir John, 267 ; Marg., see Fitzwilliam; Sir Nich., 267; Sophia w. of Wm., 267 ; Wm. (d. I 648), 267

Cable and Wireless Ltd., 285

Cadbury, North (Som.), 5 I

Cade, Jack, rebel, I77

Caen (France), 134

Cain, Eliz., 275

Calamy, Edm. (d. I685), I 35

Calcroft, Mrs., $206 n$

Caldecote, Hugh de, I 92 ; Steph. de, I92

Calne, see Caune

Calne (Wilts.), $288 n$

Calverly, Horace W., I 93

Calvert, Revd. A., I36; Mary m. John Martin, 8I ; Mrs., sis. of Rob. Tooke, 8 I

Cambes, John, 4 I

Cambridge, 22, I I 3

Cambridge University, 68; see also Cheshunt College, Christ's College, Corpus Christi College, St. John's College

Cambridgeshire, migrants from, 38

Campbell, Revd. C. E., 256

Camps, E., 269; Mrs. E., $269 n$

Canes (Cawnes), in North Weald Bassett, I 52, 2I 3, 284, 286, 288

Canfield, Little, 42,128

Canford School Trust, 52

Canning, Geo., statesman, $133 n$

Cantebrigg, join ae, 105,170

Canterbury, abp. of, 207; see also Cranmer, Laud, Odo, Sheldon, Stafford, Warham

Capel, Art. (d. 1632), I90; Art. Ld. Capel (d. 1649), I9r; Art. Ld. Capel, later Earl of Essex (d. 1683), 191; Chas., I $92 n$; Edw., I3; Sir Gamaliel (d. 1613), 190, 192, 193, I95, 200; Sir Gamaliel (d. I652), I90, 200; Gamaliel (d. I683), I90; Gamaliel (d. I720), I 00 ; Sir Giles, I3, I9I; Hen. I3 Jane, Lady, see Brown; Mildred m. Sir Wm. Lucklyn, I 95; Sar., 192; Thos., $192 n$; Sir WVm., 13 , I I ; fam., I 88, I0I, I95

Capel-Cure, Revd. C. L., 193-4, 201 ; Mrs. L. J., I 94 ; Miss, I 95 ; see also Cure

Capper, Fran., I 34

Carleton, Alex., 254 ; Chris., 254 , 264, 265; Geo., 254, 265; Jane, see Hampden; John, 254; Olive w, of Geo. m. 2 John Rivers, 254 Carlingford, baron, see Fortescue 


\section{INDEX}

Carlisle, bp. of, $100 n$ Carpenter, Thos., 77

Carre, John, 242, 246

Carroll, Sir Geo., I 7

Carter, Ric., 184

Carter, Geo., builder, 236; Jos., bellfounder, 217; Wm., bellfounder, 184,237

Carteret, Sir Geo., Bt. (d. I680), 224, 225; Geo. Ld. Carteret (d. 1695), 225; Grace w, of Geo. Ld. Carteret, 225; Hen. Ld. Carteret, 225

Carteret, barons, 225

Cartwright, Ric., 2 I I, 2 I 2, 235

Carver, Jonathan, 139

Cary, Mary Lady, 21 I, 216; Wm.,

Castlemaine, vct., see Child

Catalonia (Spain), 252

Catchpole, Jos., I 59

Catherine (of Aragon), queen of

Hen. VIII, 215

Catherine, Empress of Russia, 26I

Caton, John (f. 1847), 150, 153 John (d. 1892), 154; John C. (d. c. 1806$), 155$

Caune (Calne), Joan w. of Ric. de, 288; John de (fl. C. 1230), 288; Sir John de (A. I 1349), 288; John de (f. I 371), 288; Kath. w. of Thos. de, 288; Ric. de (fl. 1 204-5), 288 ; Ric. de (fl. c. 1230), 288; Ric. de (f. 126I), 288; Thos. de (A. 1335), I 76, 288; Wal. de, 288; (or Rous) Eliz. (f. I 422), w. of Thos., I52; Eliz. (f. 1451), w. of Thos., I52; John, 152; Ric., 152; Thos. (d. by I 422), 1 52, 288; Thos. (d. by I 45I), 152,288

Caversham (Berks.), 148

Cavill, Jas., 257

Cawnes, see Canes

Cecil, Revd. Ric., 165, 292; Wm. Ld. Burghley, 279

Cecily, dau. of King Edw. IV, m.

John de Welles, Vct. Welles, 266, 267

Cely, Eliz. w. of Wal. m. 2 Thos. Smith 224, 225; Geo. (f. I 545), 224; Geo. (fl. 1570), 225; Wal., 224, 225, 235; fam., 226

Cern', Rob. de, 182

Chaderton, Hen. (d. 1444), 67; Hen. (fl. 1444), 67

Chadwick, Adam, I 41

Chafford, hund. of, $221 n$

Challis, A. J. B., 54

Chamberlain, Charlotte m. Ric. Luther, 68; Eliz. w. of Sir Rob., I78; Sir Rob., I78

Chambers (Chamberline), Wm., 243; Mr., 223

Chambir (Chaumbir), John, 214, 215

Champion, Ant., $x 76$; Pet., 176

Chancellor, Fred., 15, 61, 184

Chandler, Percival, 29; Dr., 68

Channon, Hen., 66; Lady Honor, see Guinness

Chantries, I3I, 216, 28

Chaplain, Herb. the, 29

Chaplain, John the, 134

Chaplin, Audrey, see Latham; Fred. 288; John, I30, 134; P., I67; Thos., I 34

Chapman, John (f. 1668), 27, 28; Wm., 15

Chapman \& Mears, Bellfounders, 154

Chard (Som.), 33

Charles I, 8I, 2II , 2I6, 2I 8, 224

Charles II, 212, 224

Charles, John, 77

Charlesworth, Revd. W. H., 36
Chartesey, John, 213

Chartsey, Rob., 190

Chase, Frances, see Lingard; Rob., 134

Chater \& Son, makers of stained glass, 164

Chatham, Mr. and Mrs,, 290

Chatterton, Bridget, see Basing; Henrietta Lady, 24; Wm., I53, 178

Chaumbir, see Chambir

Chauvel, Revd. A. R., 33

Cheeke, Ann m. Sir Thos. Tipping Bt., 288; Edw. (d. 1707), 288; Edw. (d. I712), 288; Sir Thos. (f. I652), 288; Thos. s. of Sir Thos. (fl. 1652), 288

Chelmersford, John de, 2 I 4

Chelmsford, bps. of, 33, 34, 93, 100, 107, I 35, I 53, I94, 201, 245, 269, 271,290

Chelmsford, I 50, I 54, I 55, I 58, I 73 , $174,198,202,203,241,272,284$, 286, 303

Chene, Joan de, see Lambourne; Wm. de, 76

Cheshunt College, Cambridge, 36

Chester, Archdeacon of, see Everdon

Chester, Bp. of, see Stubbs, Vaughan

Chetingdon, Thos, de and his w. Joan, 253

Cheval, Wm., 93

Chevely, fam., 260

Chevers, Sir Wm. de, $178 n$

Chewton, Vct., see Waldegrave

Cheyne, Eliz. m. Geo. Scott, 34

Chichester, bp. of, see Montagu

Chigwell, Margery de, 29; Ric. of (f. before 1 294), 2 I I ; Ric. of and his w. Joan (fl. I304-5), 80; Rob. of, 2 I I

Chigwell, I, 2, 4, 7, 18-43, 45, 72, II I; adv., 32 ; agric., 23, 75; Bp. Compton's census, 3 I I char., I 9 , 42; Chigwell Hall, I $8,20,23$, $24-26,28,29,30,32,34,37,38$; Church Ho, 20, 21 ; chs., I0, 20, 32; fire stns., 22-23; Grange Farm Camp, 2I; Guild of Holy Trinity, 33, 37; hearth taxes, 303-5, 308; hospitals, 22; hos., I, I0-21, 26 , $28,30,32$; inds., 23-24; inns, 20 , 24 ; mans., $7,24-32$; medieva taxes, 298-302; noncf., $35,83-84$, 123; par. govt. and poor rel., 37, $186 n$; pars., I 8 ; pop., 20, 21 ; postal svces., 22; pub. svces., 22 ; rect., 33 ; rlys., $21-22$; R.A.F Stn. I 8; roads, I 8-2 I, I I 3; Rom. Cathm., 35 ; schs., 18, 20, 21 , 24 , $35,38,85$; stage coach svces. 2I-22; top., I8-I9; Turnours, 2 I, 35 ; vicar of, 39 ; vicarage, 33 ; woods, I 8, 23; worthies, 24; see also Barringtons, Buckhurst, Buckhurst Hill, Chigwell Row, Grange, Grange Hill, Hainault, West Hatch, King's Place, Luxborough, Stocktons, Woolston

Chigwell and Woodford Bridge

(later Chigwell, Loughton and Woodford) Gas Co., 22, 75, 113

Chigwell, Little, see Barringtons

Chigwell Row, in Chigwell, I8, I9, $21,22,23,24,34,35,38,39,40$, $41,42,73,83-84$

Chigwell, Urban District of, 1,18 . 72, I 10 ; U.D. Council, 22, II 3

Child, Lady Dorothy, I8I; Sir

Josiah Bt., I $8 \mathrm{I}$; Sir Ric. Bt., later Vct. Castlemaine and Earl Tylney, 18 r

Childs, Mr., 203

Chilham (Kent), 212

China, I 53
Chingford, 19, 20, $34 n, 42$

Chipperfield, Hen., 22

Chisenhale-Marsh, Hugo, 268; Thos. Coxhead, 261, 262, 265. 268; W. S., 270, 27I ; fam., 268; see also Marsh

Chishull, John, Bp. of London, 290

Chivers End, in High Ongar, 4

Chivers Hall (Passfield Chivers), in High Ongar, $153,173,175,178$ I 80 , I 86

Chivers Hall, see Withers Pawne

Chivers Pawne, see Withers Pawne

Cholmley, John, 133; Lewen (A. I 722), I 33 ; Lewen (d. I753), I 33; Mary, 133

Christ Church, Albany St. (Lond.) 108

Christ Church Hospital (Lond.), 178

Christ's College, Cambridge, 94

Church, John, 55; R., 55; Wm., his w. and dau., $78 ; \mathrm{Mr} ., 78 n$

Church Association Trust, i 83

Church Commissioners, see Ecclesiastical Commissioners

Church Pastoral Aid Society, 52, 29I

Church Society Trust, $183 n$

Churchill, John Spriggs, I 59

Clapham (Suss.), see Michelgrove

Clare, Eliz. de, 'Lady of Clare', $m$ John de Burgh, I 3, 105; Gil. de Earl of Gloucester (d. 1295), $13 n$; Gil. de, Earl of Gloucester (d. 1314), I 3, $105 n, 151,152,160$ 235,289 ; Joan de, see Joan of Acre; Marg. de m. Hugh de Audley, Earl of Gloucester, 105 160, 235: Maud w. of Gil. de Earl of Gloucester, 160,235

Clare, honor of, I 51 , I91 $n, 215$

Clarence, Hen., I 29

Clarence, dukes of, see George, Lionel

Clark (Clarke), Ann m. Sir Narbrough D'Aeth, I 3 ; A., 78; Cath. m. Barnabas Eveleigh Leigh, I 3 ; Chas., 237 ; Dennis, .1 3; Geo., 33 H. E., $76 n$, 78 ; Jas., 78 ; John (d. I726), I3; John Fran. (d. 1898), I06; Jos., 290; Joyce, I78 J., I 78; Oswald, I7 I ; Ric., Io, I3; Sam., I65; IVm. (f. I 80r), 99, roo; Wm. (fl. I809), 16; Wm. (f I 878), I 70

Clarkson, Revd. John (fl. I799), 70n: Revd. J. R. (fi. 1875), I 37

Clay, Ric., I I ; Ric. Lomax s. of Ric., I I ; Wm. Nicholls, roo

Claybury, in Barking, 23

Claydon, Constance w. of Lawr. I 45; Wm., 2 I, 22

Clayton, Revd. J., 123

Cleeve, Alex., 59, 60, 62, 93; Anne dau. of Alex., 6o; Anne and w. of Alex., 6o; Jane m. Revd. Thos. Velley, 6o; Revd. John, 6o, 93, 95 Mary ist w. of Alex., 60, 62 Mary m. - Hatt, 60; fam., 95

Cleland, Wm., 28

Clements, Steph., 45, 74, I 57-8

Clemmory, Wm., 102

Clerk, John the, of Ongar, I 64

Clifford, Rog. de, 59

Clift, John, 200

Clifton, John, bellfounder, $8_{3}, 282$

Clive, Edw. Bolton, 288; Harriott, see Archer

Cloth industry, $138,167,210,221$ $247,272 n, 286$

Clovile, Sir Wm. de, 205

Clyf, Wm. de, 253

Clynton, Wm. de, Earl of Huntingdon, 132

Cobham, Eliz., see Massey; Sir Thos., 263 


\section{A HISTORY OF ESSEX}

Cochrane, A. S., 244

Cocke, Sir Hen., 215 Cockerell, Revd. Hen., 292, 294

Cocq, Wm. Le, 272

Codenham, Hen., 2 I 6

Codicote (Herts.), 79

Coe, Wm. (fl. 1775), r86; Wm. (fl. I838), 166

Coffin, Thos., 244

Coggeshall, 157, 290

Coke, see Cook

Cokham, Ric., 25

Cokyng, John, 278

Colchester, 64, 165, 191 ; see also St. Botolph's Priory, St. John's Abbey

Cole, Geo., 93; Hen. (fi. r 730), 106

Hen. (d. c. 1760), 106; Rob., 287

Thos., 2 r6; Wm. (d. I Feb. 1730), 106, 108, 109, 132;Wm. (d. 24 Feb. 1730), 106, 108; fam., I 32

Colebrooke, Sir Jas., Bt., 79; Mary m. Sir Thos. Aubrey Bt., 79; Mary Lady, see Skinner

Colegrave, Wm., 213

Colepepir, John, 253, 263 ; Sir Thos. 263 ; Wal., 253, 263

Coleraine, Baron, see Hare

Coleridge, Sam. Taylor, poet, $133 n$

Colford, Agnes m. Ric. Makyn, 147

Collard, - (gentleman), $305 n$

Collins (Collin, Collen), Dorothy w. of Thos., 99; Honora, 200; John (fl. 1574), 9I, 98, 99, roo; John (f. I 597), 200; John the elder (f. i652), 200; John the younger ( $\mathrm{fl}$. 1652), and his w. Kath., 200; John (d. I750), 45, 5 I, 56, 57; Mary $m$. Revd. Jacob Wragg, 5 I ; Nich. (fl. I565), $5 \mathrm{I}$; Nich. (fl. 1609), 99, 100; Ric., 98 n, 99, 100; Rob., 200; Thos. (fl. 1584), 98 99; Thos. (fl. r6 60 ), 99; Thos. (fl. 1660), 99; Wm. (f. c. I714), $98 n$; Mrs., 102; fam., 5 I, 54, 56, 91 , 97,98

Collinson, Revd. G., 123

Collyer, Kitty, 78; Phil. B., 78; fam., 78

Colne, Earls, priory of, 201

Colne, Wakes, 27

Colshill, Mary, see Crayford; Thos. (f. 1 167), 26; Thos. (d. 1595), 34; $\mathrm{Wm}$. and his w. Barbara, 33

Colston, Edw., 163

Colt, Thos., 266

Colvill, Edm. and his w. Kath., 79

Colville Hall, in White Roding, 193

Colwall, Arnold, 29; Dan., 29; Eliz. 29; John, 29; Susanna w. of Arnold, m. 2 Foot Onslow, 29

Combers, Bart., 210 ; John, 219

Commons (common wastes), 2, 63 $64,140-1,150,175,204,233,261$ $284,285,286$

Community of the Resurrection, Mirfield (Yorks.), 207

Compton, Hen., Ld. Compton, 29 Hen., Bp. of London, 3 I r ; Pet., 29; Sir Wm. (d. 1528), 29; Wm. Ld. Compton, later Earl of Northampton (d. 1630), 29

Compton Abdale (Glos.), 13

Compton Monceux, in King's Sombourne (Hants), 176

Comyn, Anne, see Denny; Fran. (d. 1697), 27, 28; Fran. (A. 1700), 27

Comyns, Ann w. of Sir John, 200 John Ric. (fl. I 770), 200; Sir John (d. I740), 200; John (fl. I 752), 200; Mary w. of John, 200

Coningsby, Humph., 264

Constantine, Wm. s. of, 26 r, 262

Convers, Nich. le, 67; Rog. le (A. 1261), 67; Rog. le (A. 1318), 67
Conyers, John, poor rel. scheme of, $38,238,247,294$

Cook (Cooke, Coke), Sir Ant., 74, 81, ro6; Eliz. Lady, see Malpas; Frances, see Grey; John (d. 1486), 26, 106, 213; John (fl. 1 503), 106; Revd. John (fl. 1 778), 1 95; Marg., 106; Sir Phil., 26, 106, 107; Sir Thos. (d. 1478), 26, 106, 107, 213 ; Thos. (d. by 1540), 26; Tristram, 26; Wm. (f. I520), 26; Wm. (d. 1589), 106; Sir Wm. (A. 1608), 106; Mr. (of Fyfield), $44 n$; Mr. (of Kelvedon Hatch), $67 n$

Cooper, Anne, m. Chas. Fowler, 13 ; Dorothy, m. Ric. Thompson, 13; John, 13

Coopersale, in Theydon Garnon, 250, 254, 259, 260, 26I, 27I , 272, 275

Coopersale House, in Theydon Garnon, 259, 26r, 268-9, 274

Co-operative Wholesale Society, 32

Copley, Anne, I $77 n$; Mary, I $77 n$; Wm., 177

Corbishley, Revd. Jos., ร37, I 95

Corbun, W. (fl. 1086), I 18

Corney, Sam., 10, 16

Cornhill (Lond.), 245

Corpus Christi College, Cambridge, $32,82,86$

Corunna, battle of, 147

Cosoun, John, Arundel Herald, and his w. Agnes, I 80

Cottered (Herts.), 2 1 8

Cotton, Edw., 28; Mary m. Jacob Houblon, 254

Coulson, Thos., 42 ; fam., 42

County of London Electric Supply Co., 22

Cousens, Revd. H., 36

Covell, Eliz., m. Roger Forster, 29; Thos., 29

Coventry, bp. of, see Langton

Cowarne, Great (Herefs.), 59

Cowee, Thos., 156

Cowley, Thos., 2 I I , 212, 235

Cowley, earls, see Wellesley

Cox, Revd. F. A., 36; Revd. J. R., 36 ; Ric., 220

Coxhead, Deborah Lady, 268; Sir Thos, 268

Coxie, Mic., painter, 280

Cozens, Eliz. w. of John, 106, 107; Hen., I32; John (d. 1766), 106, 108, 132; John (d. 1784), 106, 107; John (f. 1832), ro6; Wm., r30, 132; fam., 108

Crabb, John, I68; Rob., I0, I3, I6

Craig, Hugh, 175

Crane, Sam., 78; fam., 78

Crank, Jane, 226

Cranmer, Thos., Abp. of Canterbury, I35

Crauford, Sir Alex., Bt., 33; Cecilia, 33; Jas., 33; Jane, see Crokatt; John, 33

Crayford, Mary m. Thos. Colshill,

34
Crevequer, Agnes de m. John de Sandwich, I3I; Eleanor de $\mathrm{m}$. Bart. de Kyriell, r 3r; Hamon de, I3I; Isabel de m. Hen. de Gaunt, I3I; Iseult de $m$. Nich. de Len-

ham, 13 I; Maud de, see Avranches

Crewe, John, 254; fam., 254

Cricket, 10, 142

Cripsey Brook, 9, 58, 87, 103, 129, 1 $30,155,157,171,172,203,284$

Crofts, Wm., $223 n, 224$

Crokatt, Jas., 28, 33; Jane m. Sir Alex. Crauford, Bt., 33

Croke, John, 2 I 3

Cromwell, Jane m. Tobias Pallavicine, r64; Oliver, Lord Pro- tector, 91, 190, 242; Sir Oliver, 164; Thos., Earl of Essex, 190, 224

Crook, Revd. Jas., 245, 246; Mary w. of Revd. Jas. m. 2 Revd. Thos. Smith, 245

Crosbe, Sir John and his wives Anne and Annes, 270

Crouchman, Jonas, 138

Crowe, Chris., 161

Crowfoot, John, 43

Croydon (Surr.), 68

Cruce, Aveline de m. I Rog. de Lees, 2 Alan Waldesef, 205; Geoff. de, 205; Mirabel de, see Oger

Crush, - (a tenant farmer), 92

Cudge, John, $305 n$

Cudworth, Damaris w. of Ralph, 94 Ralph, Master of Christ's College, Cambridge, 94-95

Cure, Capel (d. I816), 10, $13,15^{-17}$, 153, I77, 214 ; Capel (d. 1878 ), ro $12,13,14,17,139,152,153,190$ I93, 194, 197, 2 I2 n, 221, 238 Maj. G. E. Capel (d. 1943), I8; Revd. L. Capel (d. I912), 190, 193, 194, 195; Maj. N. Capel, $15 n$. fam., 12-15, I7, 175; see also Capel-Cure

Currey, E. S., 124

Currie, R., 223

Curton, Ernald de, 49; Eust. de, 49 ; Oger de, 49; Wm. de, 49

Curwen, Mary Ann, see Ewing: Rob. Ewing, 106

Curzon, Cecily, see Lampet; Mary m. (Sir Thos. ?) Tey, 77; Rob., 76 77; Wm. (fl. c. 1456), 76, 77; Wm. (d. 1485$), 76,77$

Cutiller, Salamon le, 2 I I

Dacre, barons, see Brand; baroness, see Roper

Dacre, Marg. Lady Dacre, see Fiennes

D'Aeth, Ann Lady, see Clark; Sir Narbrough (fl. 1770), 13; Sir Narbrough (f.. 1789 ), I3

Dagenham, 19, 75, 223

Dalton, Millican, I 17

Dammartin, Bart. de, I5I, I53 Galiena de m. I John Brewer, Rob. de Burgate, 3 Ernald de Mandeville, I5 I, 152, 153; John de, I79; Manasser de, 59, I5I: Odo de, 151, 179; Wm. de, 151

Danyell, John, bellfounder, 256

dapifer, Eudo, 190-1; Rose w. of, 191 dapifer, Fulk, I91

dapifer, Hamon (d. by c. Iroo), 59, $65,143,151,243$

dapifer, Hamon (d. c. I I 30 ), I $5 \mathrm{I}$

Darby, Dulcibella w. of Thos., 90 Geo., 90; 'Thos., 90

Darby (later St. Quintin), Wm. (d. 1805), 90

Darcy, Rob., 31 ; Thos. Ld. Darcy, II 8

Dare, Eliz. m. 2 John Marmaduke Grafton (later Dare), 252; John Hopkins, 252, 255; Rob. Westley Hall (d. 1866), 252; Rob. Westley Hall (f. I gor), 252; fam., 255, 256 ; see also Grafton (later Dare), Hall (later Dare)

Dashwood, Eliz., 90

David (fl. 1086), 76

Davies, Jos., 88; Dr., 273

Daw, Rob., 190

Dawges, Rob., $306 n$

Dawson, Fran. and Mrs., 187 ; Revd. W., II 7 
Dawtrey, fam., 68

Day, Anne m. 2 Wm. Bourne, 3 Ric. Young, 59, 60; G., 90; Mrs. G., $17 n$; Thos., author, 76

De La Warre, Baron, see West

Deakins, John, 270

dean, Wm. the (of St. Paul's), 179

Death, Wm., 28

Debden, in Loughton, 1, 2, 110, II I, $113,117,118,119,120,121,122$,

Deen, Sir Wm., 263

Defoe, Dan., 166, 189, 190, 198

Delauney, Pet., 216

Dellar, Cath. m. Wm. Stubbs, Bp. of Chester, later Oxford, 143

Denn, Wm., 184

Denner, John, 290

Dennett, Rob., 242

Denning, Mr., 290; Mrs., $290 n$

Dennis, Ric., 24

Denny, Anne w, of Edm. m. 2 Fran. Comyn, 27, 28; Edm., 27

Dent and Arnold, watchmakers, 24

Deorwulf, Bp. of London, 143

Depeden, John de (fl. 1346) and his w. Maud, 89; John de (fl. after I 358), 89

Derham, Anne, see Scott; Revd. Wm., 78

Derwentwater, earl of, see Radcliffe

Despenser, Aline le, see Basset; Hen., Bp. of Norwich, 79, 228; Hugh le (d. 1265), 287; Hugh le, Earl of Winchester (d. 1326), 287, 288; Hugh le, the younger (d. 1326), 287; Isabel, m. Ric. Fitz Alan, Earl of Arundel, 3 I

Deu, Agnes de, see Multon; Hamon de, 8o; John (fl. 1262), 80; John (f. 1 301 ), 80; Juliane w. of John, 80; Thos., 80

Devereux, Rob. Earl of Essex, 21 I

Devon, earl of, see Rivers

Devonshire, medieval tax assessments, 297

Dewar, Mrs. M., $279 n$

Dews Hall, in Lambourne, 73, 74, $75,77,78,79,80,82,83,84$

Dibben, A. A., $78 n$

Dickens, Chas., see Barnaby Rudge

Digby, Alice, Ctss. of Bristol, see Bourne; John Ld. Digby and later Earl of Bristol, 13, 14, 131

Dimion, Mrs., 125

Dimsdale, Thos., 261; Dr., 273

Disney, Dr., 49

Ditchfield, Edw. the elder, 153 Edw, the younger, 153; John and his w. Eliz., 153; Thos., 153

Dive, Charlotte, m. Sam., Ld. Masham, 92; John, 92

Dixon, Jas., 230

Dod, Revd. Pierce, 125

Doddinghurst, 63,68

Doddington, Wm., 29 r

Doddridge, Revd. Phil., 164

Dodds, Rob., bellfounder, 256

Dodyngsells, John de, 25; fam., 25

Doe, Ernest \& Son, 46; Mrs., $45 n$

Doisnel, Juliane m. Wm. Fitz Audelin, 175, 176; Rob., I75

Dolby, Chas. (d. 1755), $64 n, 69$; Chas. (d. 1781), 64; Chas. (fl 1834), 72; Louisa, 72; Wm. (fl. 1788), 64; Wm. (d. 1819), 69

Dollman, F. T., 34

Donne, see Dun

Doreward, John (fl. 1404), 32; John (fl. 1 439), 32; Wm., 32

Dorling, A. W., $36 n$; Revd. Wm., 36

Dorset, marquess of, see Grey

Douai (Franct), 212

Doule, Hen. and his w. Eve, 30

Dove, Wm., 224
Dover, Rose of, see Lucy

Dowdeswell, Revd. Edw. C., 79, 217

Down Hall, in Hatfield Broad Oak, 193

Drake, Fran., 131 ; Sam., 158 ; Thos., $131 ; \mathrm{Wm} ., 131$

Dransfield, Chas. and his w. Alice, 47

Draper, And. le, 79; Mary, 21 Rob., 78, 8I ; Wm., 78, 81

Drokensford, Anne de m. Sir Thos. de Mandeville, 234; John de, 234 ; Marg. de, see Tany; Thos. de, 23

Dryffeld, Marg. w. of Thos., 177 , and see Walden; Thos., 177

Dudley (Worcs.), 277

Dun (Donne), Caesar, 265 ; Sir Dan. (d. 1617), 261, 264, 265, 271; Dan. (fl. 1652), 265; Joan w. of Sir Dan., 265, 271; John, 265

Duncombe, Charity, see Muscott Sir Edw., ro6; Eliz., see Poyntz; Geo., 252; Wm., 161

Dunmow, 22, $27 n, 43,74,157,166$, $188,189,197,198,203,204,260$

Dunmow, hund. of, $2,4,5,188,192$, 196, 197

Dunmow, Little, priory of, $8 \mathrm{r}$; prior of, see Hugh

Durham, bp. of, see Bek

Dyer, Thos. (fl. 1786), 193; Revd. Thos. (d. 1852), 195; fam., 193

Ealdred, alderman, 143

Earle, Tim., 100; Revd. Wm., 41

East End Mission, 73

East India Co., 153

East London Waterworks Co., 22 113

Easter, Good, 194

Easter, High, see Berwick

Eastern Electricity Board, to $n, 88 n$ $97 n, 104 n, 130 n, 275$

Eaton Socon (Beds.), 198-9

Ecclesiastical Commissioners (now Church Commissioners), 33, 34, 144

Edgar, King, 143

Edick, Jas., 132

Edmund, St., 60, 61, 224

Edmund, Earl of Kent (d. 1330 ), 287

Edmund, Earl of Kent (d. 1331), 287

Edmund, Earl of Lancaster, 205

Edmunds, Isabella m. Hen. West, Ld. De La Warre, 226; Magdalen, see Wood; Sir Thos., 225

Edric, Wm. Fitz, 28

Edward the Confessor, $65 n, 118$, I 81, 229

Edward I, 100, 182, 265

Edward II, 160, 265, 287

Edward III, 6, 29, 134, 296

Edward IV, 29, 254, 266

Edward VI, 25, 225

Edward VIl, $80 n$

Edward VIII, as Prince of Wales, 108

Edward, Earl of Warwick, 287

Edwarde, Rob., 228

Edwards, Charlotte, 218; Jas., 106

Effingham, baron Howard of, see Howard

Egan, Edm., architect, 112, 113,117

Egremont (Lincs.), 65

Eisdell, Revd. Thos., 195

Ekco Electric Ltd., 76

Ela, dau. of Wm. de Longespée, Earl of Salisbury, m. 1 Thos. de Newburgh, Earl of Warwick, 2 Sir Phil. Basset

Elderton, Wm. (d. 1755), 153; Wm. (fl. 1763), 153; see also Elrington

Eldred, fam. (paupers), 148
Eleanor (of Castile), queen of Edw. $1,12,13,100,105 n, 182,205$

Eleanor (of Provence), queen of Hen. III, 31

Electricity supply, 45, 58, 65, 75, 97 , $113,142,151,158,174,189,204$, $209,223,233,241,251,261,286$; see also County of London Electric Supply Co., Eastern Electricity Board

Elford, Judith, 136

Elizabeth 1, Queen, 54, 118, 16I, $193,210,224,242,244,280$ 282

Elliott, Edw., 153; Eliz. w. of Ric., 213; Ric., 213, 216; Sir Thos., I53, 211, 213

Ellis, Revd. W. W., 100

Elrington (Elderton), Edw. (d. 1559), 255; Edw. (d. 1578), 255; Edw. (d. 1618), 252, 255; Edw. (f.) 1652), 252; fam., 252

Elwes, Anne m. Rob. Meggott, 252; Gervase, 252; Hen., 255; Sir Hervey, 253; see also Meggott (later Elwes), Timms (later Hervey-Elwes)

Ely, bp. of, see Hotham

Emevere, Thos., 207

Emhal', see Hemenhal

Enfield (Enefeld), Alice de m.

Ralph de Tyle, I1, 99; Alice w. of Sir Hen. de, 46 ; Eliz. de $m$. Thos. Battail, 9r; Sir Hen. de (fl. 1299), 46, 91, 99; Hen. de (fl. 1301), 253; Sir John de (fl. 1 325), 46, 91, 99; John de (d. 1375), I1, 99 ; Maud de, 11 ; Ric. de, $91,99 n$; Thos. de (f. 1 1329), 99; Thos. de (f.. 1399), I1, 99; Thos. de (f. 1409), I1; Wm. de, 91,99

Enfields, see Envilles

Engaine, Joan m. I Walter Fitz Walter, 2 Adam de Welles, Ld. de Welles, 265; Joan, see Greinville; John, 265

England, Bank of, 288

Envilles (Enfields), in Little Laver, $45,46,91,97,98,188$

Epping, boundary of, 4,258 ; bus svces., 158, 174, 286; char., 274-5; coach svces., 114, 261; Copped Hall, 177; Hayles, 90; Hemnall St., 259, 268; inhabitants of, 29 , $85,215,238,264,272,274,283$, 289, 294; lands in, 253, 274; Madells, 266; magistrates at, 115 , 125 ; noncf., $36,83,84,165$; postal svces., 158, 233, 286; rly., 2,74 , IIO, III, 114, 249, 250, 259, 260,286 ; roads to, $9,19,20,103$, $110,111,113,141,173,174,203$, 249, 250, 260; Rom. Cathm., 166, 257; tithing of, $3-4$; otherwise mentioned, 260, 272, 273, 275, 284

Epping and Ongar Highway Trust, 114,285

Epping Forest, 1, 2, 18, 21, 23-24, $110,112,113,114-16,123,124$, $155,249,250,25 \mathrm{I}$; see also Waltham Forest

Epping Poor Law Union, 22, 38, 109, 1 16, 125, 257, 273, 294

Epping Rural District Council, 22, 1 13,1 i 6

Epping Upland, 249, 258, 284

Epping Urban District, 249, 258, 260, $26 \mathrm{r}$

Epstein, Sir Jacob, 117

Ernle, Mary m. Hen. Goodricke, 29; Mary, see Penington; Mic., 29 Errington, Geo., Abp. of 'Trebizond in partibus, 70

Escoiis, see Scohies 


\section{A HISTORY OF ESSEX}

Essex, Baldwin of, 287; Cecily of 287 , 290; Hen. of (disgraced 1163 ), 276, 287, 290; Hen. of ( $\mathrm{f}$. c. 1186 ), 287,290 ; Hen. of (f 1 244), 284, 287 ; Hugh of (fl. 1194 ), 287,290 ; Hugh of (fl. $1267-8$ ) 287; Ralph of, 99 ; Rob. of, 276 ; Swein of, 234, 276; fam., 287

Essex, earls of, 204 ; see also Bohun, Bourchier, Capel, Cromwell, Devereux, Fitz Peter, Mandeville, Parr, Thomas of Woodstock; earldom of, 191

Essex, I, 23; maps of, 4, 198; medieval tax assessments, 297-9, 302

Essex Committee for Compounding, 211

Essex Congregational Union, 35, 40, $55,83-84,137,195,292$

Essex County Council, I 80

Essex County Libraries, 10, 36, 45, $65,75,104,118,130,142,159$ I 74, 189, 204,209, 223, 241, 25 I, 276,286

Essex Regiment, 159, 292

Esshe, Lancelot and his w. Dorothy, 47

Estden, Wm. de, 234

Estoft, Kath., see Thorley; Wal., I I, I 3

Ethelston, Louisa, see Perry; Rob. Peel, 32 ; Rob. Wicksted, 32, 90

Etherwey, Wm., Abbot of Stratford Langthorne, 28

Eton College, 135

Etsi (f. 1066), 198

Eudo dapifer, 190, 191, 194, 262; his w. Rose, 191

Evans, John, 100; Lucy, 45; Sam., $203 n, 205,206 n, 207$; see also Jones, Marg. Mary

Eve, Hen., 200; Ric. (f. I780), 200 Ric. (f. I 787 ), I 30 ; W., I 30 ; fam. 130

Everdon, Sylvester de, Archdeacon of Chester, 182

Evermue, Wal. de, 277

Evesham, battle of, 277

Ewing, Anna Caroline m. Caledon du Pré Alexander, 106; Frances Eliz. m. Wm. Jas. Tyrwhitt Walker, I06; Jas., 104, 106, 290 . Louisa $m$. Winthrop Mackworth Praed, 106; Mary Ann m. Rob. Ewing Curwen, 106

Exeter, archdeacon of, see Travers

Exeter, bp. of, see Oldham

Exning (Suff.), 106

Exton, Nich. and his w. Joan, 278

Eyles, Sir John, Bt., $3 \circ n$; Sir Jos. 28, 30

Eyre, Mrs., 260

Eyre (later Archer), Sir Wm., 268, 271, 289

Eyver, John, 78

Fabian, Rob., 26r

Fairbairn and Mansfield House, in West Ham, boys' clubs, 73

Fairlop Fair, 24

Fairs, 24, 75, 105, 1 30, 160, 167, 175, $182,261,276,277,286$

Fambridge, Wm. de, 46

Fane, Charlotte, see Luther; Fran., 68; Revd. F. A. S., $153 n$, 174; Capt. F. L., $63 n, 65 n, 68 n$; Hen., 68; John (d. 1824), 68; John (f.' 1849), 65, z41; John Luther (fl. 1943), 68; Thos., Earl of Westmorland, $68 n$; fam. 65,68

Farm, Old, see Appeltons

Felde, Ric. de la, 177
Felix Hall, in Kelvedon, 226

Felsted, I3 I, I 52

Felton, Edmond, 177

Fen, Hugh, 33

Fenrother, Juliana, 255 ; Rob., $255 n$ Fenton, Rog., 24

Fereby, John, 191; Margery, see Berners

Ferguson Radio Ltd., 76

Ferne, Joan $\mathrm{m}$. Wm. Shelton, 177

Ferrers, Bridget, see Windsor; Edw., 278; Wm. de (? Ld. Ferrers, d. 1 371), 93; Wm. de, Ld. Ferrers (d. 1445$), 93$

Field, Margery, I 9

Fields, common, 2, 23, 75, 116 , I $51 n, 223$

Fiennes, Ingram de, 49, 76; Ingram s. of Wm. de, $49,76 n$; John de, 176; Marg. de (m. Edm. de Mortimer), $105 n$; Marg., Lady Dacre, m. Samson Leonard, 176; Maud de $m$. Humph. de Bohun, Earl of Hereford, 12; Maud de, see Monceux; Sibyl de, see Boulogne; $W m$. de (fi. c. I320), I2, 49, 76, I05; Sir Wm. de (d. I302), 12, 13 , $49,76,105$

Fifhide, Ric. de, 134

Filkes, Revd. J., I 48 , I 49

Filshie, Mr., $43 n, 44 n$

Finch (Fynch), Dan., Earl of Nottingham, 135; Eliz., see Savile; Essex, Ctss. of Nottingham, see Rich; Geoff., I92; Geo. (f. c. I706), 29I; Geo., Earl of Winchilsea (d. 1826), 142; John, 212 ; Judith, see Fullerton; Ric. le and his w., I92; Rob., 278; Savile, 212 ; Thos., 272

Fineux, John, Chief Justice of King's Bench, 290

Fingrith, in Blackmore, $31 n$

Fisher, Barbara, 42 ; John Brett and his w. Judith, 49; Revd. T. R., 83 ; W. R., 114

Fitch, Anne, see Wiseman; Fran., 225; Geo., 230, 231 ; John, 223 , 230 ; J. P., $64 n, 65 n, 70 n$; Wm. (d. 1578), 225; Wm. (fl. 1804), 230

Fitz Alan, Alice, see Warenne; Edm., Earl of Árundel, 31; Eliz. m. Thos. de Mowbray, Duke of Norfolk, 31; Isabel, Ctss. of Arundel, see Despenser; Joan, $m$. Wm. de Beauchamp, Ld. Bergavenny, 31, 262; Marg. m. Rowland Lenthal, 31; Ric. Earl of Arundel (d. 1376), 31 ; Ric. Earl of Arundel (d. 1397), 31 ; Thos., Earl of Arundel, 31

Fitz Alcher, Alcher, 89, 93; Hen. (d. 1 234), 88,89 ; Hen. (d. I 3०3), 89 Hen. (f. 1343) and his w. Beatrice 89, 93; Ric. (fl. I212), 89; Ric. (d. c. 1253), 88, 89; Steph., 89 ; Wm., 89

Fitz Edric, Wm., 28

Fitzgerald, Mrs., 104n

Fitz Gerold, Hen., 191, 262; Margery $m$. Baldwin de Rivers, 262 Warin (d. c. I I 59), 262; Warin (d. 1.216), 262

Fitz Gilbert, John, 29

Fitz Peter, Geoff., Earl of Essex, 160

Fitz Richard, John, r92; Wal., I92; Wm., 192

Fitz Robert, Maud w. of Wal., see Lucy; Wal., 25

Fitz Walter, Christine $\mathrm{m}$. Wm, de Mandeville, Earl of Essex, 25I; Eliz. Lady Fitz Walter, see Massey; Emma dau. of Ric., 91 ; Eus., 91; Gunnore w. of Rob., see
Valognes; Joan, see Engaine; Joan, see Multon; John, 268; Rob. (d. 1245), z5 I ; Rob. (d. I326), 265 Rob. (f. c. 1330), 66; Rob. Ld. Fitz Walter (d. 1406), 25; Wal. (d. by 1326), 265; Wal. Ld. Fitz Walter (d. I 43 I), $263 n$; fam., 25

Fitzwaryn, Mabel, 215

Fitzwilliam, Anne Lady Fitzwilliam, see Sidney; Christiana m. Sir Ric. Wingfield, 267; John, 267; Marg. m. Sir John Byron, 267; Sir Wm. (d. 1 534), 14, 78, 81, 267, 289; Sir Wm. (d. I 576), 78, 267; Sir Wm. (d. I 599), 267, 271, 289; Wm. (fl. I602), 267; Wm. Ld. Fitzwilliam (d. 1644), $267 n$; fam. 26 I

Fleming, W. A., 206

Fletcher, Hen., 35; Jos., 35; Thos. 273

Flint, Jas., 153; Mary Anne, see Searle

Floure, Wm., 254

Fobbing, $100 n$

Foley, Revd. B. C., $70 n$

Foliot, Ric., Archdeacon of Middlesex, 151,179

Foliots Hall, see Forest Hall

Fonteyns, Rob., 213

Foottit, Mr., surveyor, 217

Ford (Forde), Fran., 68; Rev. Jas. 143, I 47, I 48; Thos. (fl. I 350), 199; Thos. (fl. 1823), 238

Fordham, John, I65

Forest Hall (Foliots Hall, Norton, Norton Foliot), in High Ongar, $43,45,47,51,150,151,152,154$, $172,175,176,179-80,181,186$ 204

Forests, 2, 63, 80, 1 40, 222, 234, 259 261; see also Epping Forest, Hainault Forest, Waltham Forest

Forster, Eliz., see Covell; Mary, see Penington; Rog., 29

Fortescue, Chichester S. P., Ld. Carlingford, I 44; Frances, Ctss. Waldegrave and Lady. Carlingford, see Braham

Fortescue-Aland, Dormer, Ld. Fortescue, 77, z29; John, Ld. Fortescue, $75,77,78,85,225,228$, 231

Forteye, Rob. atte, $19 n$

Forz, Aveline de, see Montfichet; Isabel de, see Rivers; Wm. de, Count of Aumale (d. 124I), 227 Wm. de, Count of Aumale (d. 1260), 262

Foster, Anna w. of Abraham, 90; Abraham, 90; Revd. Sir Cavendish, Bt., 270, 271 ; Jacob and his w. Sarah, 90, 93; Mary m. Lewis Scawen, 90; Pet., I 85; Reynold, 90 ; Sar. m. Ric. Merry, 90

Foulger, Bart. Hartley, 35

Fountain (Fountaine), John, 267; Mary, 42

Fowler, Anne, see Cooper; Chas., 13

Fowlmere (Cambs.), 262

Fox, Revd. Hen. E., 165

Francies, Wm. R., I27

Francis, H. H., I 17

Frankfort, Ld., 260

Frankfurt-am-Main (Germany), 260

Franks, Aaron, I77; Hen., I77; Isaac, I77; Jacob Hen., I77; Napthali, 177; Phylah m. Napthali, I 77

Fraunceys, Sim., 199

Fray, John, 199

Frayes, in Beauchamp Roding, 182, 1 98, 199-200, 201

Freeman, Geo., 254; Sir Ralph, 254 


\section{INDEX}

French, Chas., 106; Eliz., 24; Jas., 242 ; IV. \& C., Ltd., 24, I82

Frere, Jane, see Hookham; John (d. 1807), 133; John Hookham (d. $1846), 130,133$

Frinton, 205

Frit, Wm. del, r8o

Frith, Wm. le and his w. Parnel, 15 I

Frith Hall (Old Frith, Old Thrifts), in High Ongar, $57 n, 173,180$

Frosshe, John, 289

Frost, W. J., 137

Fryerning, $194 n$

Fulham, John, 33; Nich., 33

Fulk, Adam s. of, 19r

Fulk dapifer, $19 \mathrm{I}$

Fuller, Hen. (d. 1590), 26, 30; Hen. (d. I602), 26; Hen. (f. 1621), 30 ; Hen. (d. 1623), 26; Hen. (A. I668), 26; John (d. c. 1671), 23; John (fl. c. 1700), 30; Kath. w. of Thos. z9o; Ric., 30; Rob., Abbot of Waltham, 252, 255; Thos. (d. c. 1575), 26; Thos. (f. I 594), 290 Wm. (fi. I705), 290; Wm. (fl. c. 1768$), 290$

Fullerton, John, 212; Judith m. Savile Finch, 212; Weston, 212

Furnyvall, Alma de, 266

Fyfield, 2, 43-58, $155,159 n$, 17r, 189, 195, 198, 201, 207; adv., 52; agric., 45-46; Bp. Compton's census, 311 ; char., $43,55-56,57$, 180 ; ch., 43,52 , IOI $n, 153,182$ Church Houses, 54; Clatterford End, 43; Dame Anna's Farm, 43, 44,45 ; Fyfield Bridge, 44, 45 ; Fyfield Hall, $7,43,44,45,47-49$ I80; Fyfield $\mathrm{Pea}, 46$; hearth taxes, $304-6$, 308; hos., 43-45, 47-52; inds., 46; mans., 6, 46-52, 99, I8 r ; medieval taxes, 300- $z$; mills, 44 ; noncf., 44, 55 ; Norwood End, 43 , $44,45,55 n$; par. govt. and poor rel., 55; Pickerells (Ash Farm), 44, 45, 49, 54; pop., 43; postal svces., 45 ; pub. svces., 45 ; rect., 52 ; roads, $43-45$; schs., 43,55 , $6 z, 186,188,197$; stage coach svces., 45, 74; top., 43-45; 'Vicarage', 44, 52; woods, 43; see also Herons, Lampetts

Fyfield, 'the other Fyfield' (Domesday village), 2

Fynch, see Finch

Gaisford, G. J., 37

Gallard, Anne, widow, m. 2 John Wroth, 30; John, 30

Gallop, Canon E. H., ro $n$, I $5 n$

Gamage, Mrs. T. W., $53 n, 54 n$

Gardening, landscape, $1,64,68,93$, I $44,228,245,28$ I

Gardiner, Thos., bellfounder, 136 , 246

Gardner, Wm., 27, 28

Garnett, H., zo

Gas Light and Coke Co., 22

Gas supply, 58, 209, 250, 26r, 286. see also Bishop's Stortford Gas Co., Chigwell \& Woodford Bridge Gas Co., Gas Light \& Coke Co., Ongar Gas Co., Romford $\mathrm{Gas} \mathrm{Co}$.

Gascoigne, Wm., 278

Gascony (France), 21 1, 265, 288

Gate (Gates), Agnes w. of Sir Geoff. m. 2 Wm. Brown, 199

Gate, Sir Geoff. (d. 1477), 199; Sir Geoff. (d. I 526), 199; Sir John, 199, 200; Mary w. of Sir John, 199, 200; Wm., 199

ES. IV
Gatesbery (Gatesbyry), Ralph or Ric. de, $2 \mathrm{I} 4$

Gaunt, Hen. de, I3I; Isabel, see Crevequer

Gaussens, Sam. R., 201

Gaynes Park, in Theydon Garnon, $78 n, 259,26$

Gellibrand, Wm., 229

Geoffrey, Prior of Waltham, 89

Geoffrey s. of Adam, see Roinges, Geoff. de

Geoffrey, Wm. Fitz, 198

Geoffrey, Wm. s. of, see Roinges, Wm. de

George II, 92, 286; as Prince of Wales, 78

George III, as Prince of Wales, 92 George, Duke of Clarence, 287, his w. Isabel, see Neville

Germain, Gil., 67; Rog., 67; Wm (fl. 1 368), 67; Wm. (fi. 142r), 67

Germains, in Kelvedon Hatch, 63 67

Gernon, Eliz. m. Gil. Prince, 263; Hugh, 26r, 263; Isabel, 253, 263; John (d. I32 r), 263; Sir John (f. c. I339), 263; John (fl. 1346), 263 ; Lucy, see Whetynton; Ralph (d. 1235-6), 49, 262; Ralph (d. 1274), 263; Ralph (f. 1320), 263; Rob. 26, 27, I18, 227; Thos. (d. by 136r), 253, 263; Thos. (d. by 1428-9), 263; Wm. (d. 1 258), 262; Wm. (d. I327), 262, 263, 266 $\mathrm{Wm}$. (d. I340), 253, 263; fam. 258,270

Gerry, J., 156

Gervase, 192

Geyre, Rob., 215

Gibb, Frances, $230 n$; fam., 230

Gibbs, Dr. Chas., 218

Gibson, Charlotte, 58 ; Hen., I 59, 162, I67; Jane m. Geo. Scott, 32

Revd. Rob., 58, 20r; Thos., 29

Giddins, G. H., 35

Giffard, John de and his w. Eleanor, I3I, I33

Gilbert, Ann, see Taylor; Anne, roo: J. C., 165

Gilbert, John Fitz, 20

'Gilbert' Poor Law Union (1 829),

2 I I, 22 I, 231 $238,247,248$

Gilbertson, J. M., 88

Gilderson, Eliz., I I9

Gildesburgh, Sir John de, 19

Giles, Dan. (d. 1800), 254, 288 Dan. (d. 1832), 254, z91; Hen., 242, 248; Sar., 86

Giles-Puller, Chris., 288

Gilston Park, in Gilston (Herts.) 29

Gingell, D. Taylor, 1 33; John, 214 Mr., 36,37

Ginger, Mr., 58 n

Gippes, see Bilsden

Gittins, Anne, 224; Rog. and his w Anne, 224

Gladwin, Ric., 3 ro $n$

Glascock, Geo., 13; John (fl. 1512), 13; John (f. 1543), 214; John (fi I564), I3; John (ค. I587), I93; John (fl. I 598), I3; John (fl. 1628), 13; Ric., 190; Wm., 190; fam., 64 Glasse, T., 99

Gloucester, Hugh de, 167

Gloucester, dukes of, see Richard III, Thomas of Woodstock

Gloucester, earls of, see Audley, Clare, Robert, William; earldom of, $x 51$

Gloucester, honor of, 160

Gloucestershire, lands in, 276

Gobyon, Joan, see Spigurnel; John, 243; Wm. (f. 1333), 243; Wm. (fl. I4 ro), 243
Godfrey, Margery, see Hampden; Ric., $278 n$

Godid (Gotil, Gotild) (f. ro66), 59, 143, 15 I, 179

Good, Mr., 290

Godric (fl. ro66), 234, 276

Godwin, Mr., 95

Goebell, Ann w. of Gerrard, 236; Gerrard, 236, 237; John, 236; Rebecca m. Gerrard, 236; Rebecca, see Luther

Goldingham, Alan, 25; Sir Alex. de, 25, 26, 29, 32; Alice de, see Brito Aline w. of Wm. de, 29; Elnr. de m. John Mannock, 25; Eliz. w. of Sir Wal. de m. 2 Mat. Hay, 25; Isabel w. of Sir Alex. de, 25; John de (? d. by 1 235), 25; John de (d. by 1316$), 25$; John de (fl. 1340), 253, 263; Sir John de (d. c. 1362 ), 25,32 ; Sir Wal. de, 25, 32; Wm. de (f. I 169), 25: Wm. de (f.. 1258), 25, 29; Sir Wm. de (? fl. I3th cent.), $25 n$

Golding-Palmer, Revd. Hen. and his w. Isabella, 100

Goldringe,,- 27

Goldsborough (Gouldesborough), Eliz., 162, $307 n$; Eliz. m. Ric. Turner, 164; Thos. (d. by 1664), I6r; Thos. (d. I703), I6r $n$; Thos. (fl. 1718), $16 \mathrm{r}$

Goodall, Revd. A., $165 n$

Goodricke, Hen., 29; Mary, see Ernle

Goodwin, Chas., 148; Geo., 136

Gordon, Isabella Julia Lady, see Bennet; Sir Jas. Willoughby, I6I

Gotild (fl. r 066), see Godid

Gough, Ric., antiquary, $60 n$

Gould, A. \& C., 130; Isaac, 35 ; I. Chalkley, Ir7; Revd. Wm., 229, 230, 232

Gouldesborough, see Goldsborough

Grafton, Eliz. m. Rob. Westley Hall (later Dare), 252, 255, 257

Grafton (later Dare), Eliz., see Dare; John Marmaduke, 252

Grainger, Mary, 42

Grange, man. of, in Chigwell, 29

Grange Hill, in Chigwell, 18, 19, 20, $21,22,24,29,34$

Gras, John de, $2 \mathrm{I}$; Pauline w. of John de, 2 II

Gravel digging, 203, 242

Graves, Tim., 215

Graye, Miles, bellfounder, 136, 147 . 202, 271

Grays Inn (Lond.), 29, 268

Great West Hatch, see Hatch, West Greatherd, Anne (dau. of Rob. Hill), 164

Green (Greene, Grene), Agnes w. of John, 208; Chas., 30; Christian, I47; Edw. and his w. Ann, 30; Hadsley, 205, 207, 208; Jas., 132 ; John (f. 1586), 142, I $44 n, 145$, $210 \mathrm{n}$; John (d. 1595), 204, 205, 206, 207, 208; John (f. 16z4), 205, 207; John (d. c. 1626), 149; John (fl. c. 165o), $205 n$; John (d. 1653), I45, I47; John (d. 1659), 145; John (f. I664), $205 n$; John (f. 1699), 205; John (f. 1707), 30; John (d. 1725), I45; John (d. 1752), I45; Jos., 231; Kath. w. of John, 208; Mary m. Revd. And. Trebeck, 204, 205, 207; Dr. Maurice, 145; Nat., 132; Rebecca m. Thos. Thorold, 147; Ric., 143; Rob. (d. 1624), 205, 207; Rob. (f. c. 1624), 205; Rob. (fl. 1637), I45; Rob. (f. I670), $307 n$; Sarah m. John Baker, 205; Sarah, see Hadesley; Thos. (d. by 1 537), 213 , 


\section{A HISTORY OF ESSEX}

Green (cont.):

216, 217; Thos. (f.. 1543), 212 ; Thos. (f. I 582), 205, 207; Thos. (fl. c. 1600), 145; Wm. (fl. c. 1 233) 192; Wm. (fl. 1543), 212,213 Wm. (d. c. 1554), I 7 I, 221 ; fam., I45, 204, 205

Greenstead, 4, 58-63, 157, 159 $n$ I I I, 222; adv., 60; agric., 58; Bp. Compton's census, 311 ; char., 62 , 221 ; ch., 1, 60-62, 162, 163; Greenstead Green, 9, 58, 59, 62 , 210; Greenstead Hall, 58, 60; hearth taxes, $305,306,308$; hos. $58,60,155$; man., 6, 59-6o, 160 , 241 ; par. govt. and poor rel., 62 , I68, 221 i $n$; par. united with Chipping Ongar, 61, 163 ; pop., 58 pub. svces., 58 ; rect., 61 ; schs., 62 , I 69, I 70; top. 58

Greenstead by Colchester, $60 n$

Gregories, in Theydon Bois, 253-5

Gregory s. of Ralph, 253

Greinville, Sir Gil., 265; Joan m John Engaine, 265; Joyce w. of Sir Gil., m. 2 Ric. Montfichet, 265 Grene, see Green

Greville, Anne Lady, see Poyntz Sir Fulke, 161; Giles, 218; Thos. 218

Grey, Frances m. Wm. Cook, ro6; Lady Jane, I06, I 99; Ld. John, I 06; Thos., Marquess of Dorset, ro6 $n$

Griffin, Revd. R. T. K., I $89 n$, I $90 n$, I $95 n, 197 n, 201 n, 202 n$

Griffinhoeff, Revd. N., 70

Gros, Wm. le, 33

Gross, Alfred W., 35

Grosvenor, Mary, 205; FieldMarshal Thos., II

Groves, Miss, 164

Grymesby, Edm. de, 256

Guercis, Balthasar de, 117

Guild of All Souls, I 62

Guildford (Surr.), 29

Guilds, religious, $33,136-7$

Guilliams, Abel, 122

Guinness, Lady Honor m. Hen. Channon, 66

Gwyne, John, 93

Gyes, John, 100

Gynne, Thos., 55

Habershon and Fawckner, architects, 207

Habhale, John, I I

Hackney, C. H., $241 n$

Hackney (Mdx., later Lond.), Poor Law Union, 156

Hacun (fl. 1 066), 25

Haddon, Mrs, 237

Hadesley, Edw., $205 n$; Sarah m. John Green, $205 n$

Hadham, Much (Herts.), 190, 244

Hadler, Councillor, $58 n$

Hadsley, Mary, 154; Rob., I 52, I 54

Hainault, in Chigwell, 1, 2, 19, 21 , $35,37,40,41$

Hainault Forest, I, I8, 21, 23, 24 72,75, I I $4,143,223$; see also Waltham Forest

Hakeney, Kath. (f. 1332) w. of Rob. de, II; Kath. de (fl. 136I), II ; Rob. de, 11, I4; Thos. de, I I

Halden, Thos., 98, 99

Hale, Ric., 178 ; Rob., I 78 ; Thos. 79; Wm., 79; fam., 79

Hall, John (f. c. I 540), 242; John (fl. I 799), 99; John (f.. I 848), 99 Revd. Martin, 93; Ric., 242; Wm., 133

Hall (later Dare), Rob. Westley (d.
1836), 252; his w. Eliz., see Grafton

Hallingbury, Great, 12 ; Hallingbury Place in, 268

Halsham, Sir Hugh, 278

Halstead, 272

Haltoft, Agnes, see Haugh; Wm., 66

Ham, East, Old People's Home, 144

Ham, West, Open Air Sch., 43, 57: see also Stratford, Stratford Langthorne, Fairbairn and Mansfield House

Hambleton, Revd. Geo., 255, 256

Hambro, Maj. Jacelyn, 269; Mrs. J., $269 n$

Hamburg (Germany), 244

Hamey, Baldwin, 178

Hamilton, Revd. Ant., I I4, 120 , I 2 I $n$, I 22; Revd. J., 230; Wal. Kerr, Bp. of Salisbury, I 7

Hammersmith (Mdx., later Lond.), $8_{3}$

Hamon dapifer (d. by c. 1100), 59 $65,143,151,243$

Hamon dapifer (d. c. I I 30 ), I 5

Hamon, Rob. Fitz, i 5 I

Hampden, Edm., 277; Eliz., see Prince; Ellen $m$. John Branch, 264, 27 I ; Fran., 264, 260; Jane $m$. 1 Chris. Carleton, 2 Francis Michell, 254, 264; John (d. 1450I), 278; John (fl. I 486), 278; Sir John (fl. 1502), 264; Sir John (d. 1553), 278, 279; Margery m. John Shirley, 2 Edw. Bishop, 264 Margery w. of Thos. m. 2 Ric. Godfrey, 278; Philippa Lady, see Wylford; Thos., 278

Hamshire, Wm., 16

Hanchett, Wm., 74

Hancock, Hen., 26

Hanley, Mr., 83

Hanover Square (Mdx., later Lond.), 92

Hanson, Emily Jane, 122

Harbert, Wm., bellfounder, 136

Harcourt, Frances, Ctss. Waldegrave, see Braham

Hardbene, John, 66

Hardyng, John, bellfounder, I 47 Rob., 31

Hare, Hugh, Ld. Coleraine, 226

Harewes, Ric. de, Abbot of Waltham, 89

Harlow, 87, $94 n, 103,129,158,167$ 274, 284, 289, 290; see also Hubbards Hall

Harlow, half hund. of, $3-7,38,284$, 286,289

Harold Hill, in Romford, 142

Harold, King (d. 1066), 24, 30, 65 , I 8, I 8 I

Harper, Eliz., see Skrene; Geo. (f 1507), 213 ; Geo. (fl. I542), I6I I 8 I ; Ric. (d. 1492), 2 I 3 ; Ric. (d. I507), 213

Harrington, John, 200

Harrison, John, 267; Marg., 267

Harrod, 'Goodman', Iog

Harsnett, Sam., Abp. of York, 24 34,38

Hart (Archibald), 98; Mr. \& Mrs. C. E., 292 ; Wm., 288

Hartley, Revd. B., I $74 n$

Harvey, Sir Eliab (d. 1699), 5, I9, 24, 27; Adml. Sir Eliab (d. I 830), $5,24,28,190,200,202$; Eliz. m. Thos. W. Bramston, 190; Emma, see Skinner; John, 206; Josias, I $о 7 n$; Louisa m. Wm. Lloyd, 23 , 28 ; Thos., ro7 $n$; Wm. (d. 173 I), 27, 28; Wm. (d. I742), 28; Wm. (d. I 763) $28,38,100 ; W m$. (d. I779), 28, 30, I99; fam., 30

Harvey-Elwes, see Timms
Harwich, 157

Hasilden, Wm., 91

Hastie, Capt. Jas., 244

Hastings (Hastinges), Sir Humph. de, 289; John de, Earl of Pembroke (d. 1375), 262; John de Earl of Pembroke (d. 1389 ), 262 Lawr. de, Earl of Pembroke, 262 Rob. de (fl. 1248), $289 n$; Rob. de (fl. 13 I 4), 13

Hastingwood, in North Weald Bassett, $4,5,284,285,286,289$, $292,293,294$

Hatch, Caroline m. John Rutherforth Abdy (later Hatch-Abdy) 26, 229, 232; Jas. 23, 26, 28, 30 $34 n, 42$; Jemima $m$. Chris. Jas. Mills, 26; Louisa m. Wm. Rufus Rous, 26; fam., 34

Hatch, West (Great West Hatch), in Chigwell, 10-22, 26

Hatch-Abdy, fam., 34; see also Abdy, Hatch

Hatfield, Wal. of, 224

Hatfield Broad Oak, 27, 95, I 88 , 249; see also Barrington Hall, Down Hall, Hatfield Heath

Hatfield Forest, 27

Hatfield Heath, in Hatfield Broad Oak, 95

Hatt, Mary, see Cleeve

Haugh, Agnes de m. Wm. Haltoft 66; Joan de, 66; Joan de, see Welby; John de (fi. 1333), 66; John de (f. I 347), 66; John de (fi. I 395), 66; John de (f. I457), 66; Kath. de m. John Bolles, 66; Ric de, 66; Thos. de (f. 1370), 66; Thos. de (fl. I 406), 66

Haute, Kath. Lady see Wrytell; Sir Ric., $177 n$

Havering-atte-Bower, 79, I 18 , 139 14I, 224; see also Pyrgo

Havers, E. 55, 56

Hawkins, John and his w. Sar., 27

Hay (Haye), Lady Edw., see Latham, Audrey; Eliz., see Goldingham; Joan w. of Wm. de la, m. 2 Rob. Lincoln, 289; Mat., 25; Rog. de la, 59; Wm. de la, 59, 60

Haydon, Jas., 80

Hayle, Ric. and his w. Agnes, 20

Haymarket (Lond.), 253

Hayward, Burton, 283

Heald, Miss M. E., $127 n$

Heales, Mrs., 93

Heard, John, 160

Heath, Noah (fl. I85r), I 6 ; Noah (f. I 894), 36; - (a tenant), I 25

Hedges, Anne $m$. Sir Edw. Smyth, $28 \mathrm{I} n$; fam. (arms), $28 \mathrm{I}$

Hedingham Castle, honor of, 27,192

Hedingham, Castle, priory of, 288

Heigham, Sir Clement, 229; Lucy m. Fran. Stoner, 229

Hellier, Rev. Geo., 293

Helston (Cornw.), 79

Hemenhal (Emhal'), Hen. de, 268; Rog. de, 268

Hemerford, And., 16

Hemersthorp, John, 278

Hemnalls, in Theydon Garnon, 259, $266,268,272$

Hempnall (Norf.), 268

Hende, Griselde, see Belknap; Joan m. Wal. Wrytell, 243; Sir John (d. I4I8), 242, 243; John (fl. 1447), 242,243 ; John (d. 1464 ), 242, 243 Hendry, Thos., 158

Heneage, Eliz., I 99; Cecil (a woman), I 99; Chas., I 99; Sir Mic., 199

Henham, 272

Henley-on-Thames (Oxon.), 228

Henrietta Maria, queen of Chas. I, 224,225 


\section{INDEX}

Henry I, 59, I 5x, 227

Henry II , 5, 89, I 60, 262, 276

Henry III, 7, I 8 I

Henry IV, I 35; his Ist w. Mary, see Bohun

Henry V, 205

Henry VI, I 35

Henry VII, 29, 267

Henry VIII, 5, 25, 100, 135, I 84 $190,216,224,242,280,282$

Henry, Prince of Wales (d. 1612), I 17, I 19

Henry s, of Henry, $224 n$

Henry, John s, of, I 52

Henshaw, Rev. Jos., I83, $186 n$

Herbert, Hen. and his w. Anne, 134

Wm., Earl of Pembroke (d. 1630), $120 n$

Herbert, Ivo nephew of, 65

Herde, Edm., 28 I; Thos., 28 r

Hereford, ctss. of, 91

Hereford, earls of, see Bohun

Herefordshire, lands in, $243 n$

Herne (Kent), I50

Heron, Revd. A., 136; Eliz. w. of John, 91, and see Pykenham; John, 91; Thos., 212

Herons, in Fyfield, 43, 45, 49-51, 52, 180

Herringham, Revd. W., 168

Herstmonceux (Suss.), 176

Hertfordshire, lands in, 89,278 ; medieval tax assessments, 302 ; migrants from, 38

Herts, \& Essex Waterworks Co. I0, $45,58 n, 65,75,88,97,104$ I $30,142,151$, I $58,174,189$, I 98 $204,209,223,233,241,250,261$ 276,286

Hertingfordbury (Herts.), 253

Hewett, Thos. (d. c. I 564), $37 n$; Sir Thos. (f. I654), 228; W'm., 6I

Hewitt, Mrs. A., 52

Hewyt, John, I9 $n$; Ric., 62

Heybridge, 54

Hiccocks, John, 254; Wm. (fl. I655), $100 ; \mathrm{Wm}$. (d. 1674), 254; Wm. (fl. 1674), 254

Hickling (Norf.), priory of, 79

Hickman, Other Windsor, Earl of Plymouth, 288; Sar., Ctss. of Plymouth, see Archer

Hicks, Ann, m. - Burton, 25; Sir Henry (Harry), Bt., 25 ; Howe, 25; Martha, m. - Petty, 25; Mic., 25, 26; Sir Rob., Bt., 25; Sir Wm. Bt., 25

Hicks (later Hicks-Beach), Mic., 25 , 26

Higgins, Wm., 115

Higham, Sir Rich., 287

Highfield, Dr. J. R. L., $288 n$

Highgate (Mdx., later Lond.), 147

Highlow (Derbs.), 289

Hill, Anne, see Greatherd; Anne, see King; Eliz., see Senewe; John (f I6th cent.), 26, $37 n$; Maj.-Gen. John (d. I735), 92; Ric., 54; Rob. 164; Sir Rowland, inventor of penny post, 4 I ; Revd. T., 35, 83

Hill Hall, in Theydon Mount, 1,60 $235,259,260,275,276,277,278$ 8

Hills, Ric., $x 80$

Hinchingbrook (Hunts.), I64

Hinckford, hund. of, 304

Hinson, John, 92

Hinton, Revd. Edw., I 93

Hoard, Sam., I 35

Hoare, Gerard Noel, 62

Hodson, John, bellfounder, 195

Holbrook, Mrs., 60

Holenden, Rob., 2.07

Holland, Alice, w. of Thos. Earl of Kent, 287; Edm., Earl of Kent
287; Elnr. m. Thos. Montagu,

Earl of Salisbury, 287; Thos. Earl of Kent, 287

Holland, earl of, see Rich

Holland, emigrants from, I $9 n$

Hollick, Wm., 290

Hollingsworth, John, 243; Lawr., 243; Rainold, 242, 243, 246; Wm., 243

Hollingworth, Joanna, 242, 244; Phil., 246; Ric., 24

Hollis, Thos. Brand (f. c. I804), 49

Holloway, J. C., 127

Holman, Alex., 179; Anastasia, 179; Eliz., 179; Geo., 179; Sir John, Bt., 179; Phil., I 79; fam., 179

Holy Trinity, Aldgate (Lond.), priory of, 227, 229

$\mathrm{Hoo}$, in St. Paul's Walden (Herts.), 191-2.

Hoo, Thos., 3 I

Hookham, Jane m. John Frere, 133 ; John, 133

Hop growing, 2, 75, 166, 198, 210

Hopkins, John, 252

Hormead, Great (Herts.), 3 I $n$

Horner, Thos., 47; W. S., 53

Horners (Hornets), in Beauchamp

Roding, 198,200

Hornsey (Mdx.), 106

Horsley, West (Surr.), r 9

Horsman, Thos. and his w. Marg.,

Hoskyn, John, 200

Hospitallers, Knights, 77, 79

Hotham, Revd. C. G. B., 269, 270; Ivetta, see Scrope; John (d. I35 I), 46; John, Bp. of Ely (d. 1337), 46: Sir John (f. 1 337), 46; Pet., 46

Houard (fl. I o66), I43

Houblon, Chas,, I0, I2, I 4; Revd. Jacob (d. I698), I 37; Rev. Jacob (d. 1740), 12 $n, 14-16,163$; Jacob (d. I 770), I2, I 5, 254; Jacob (d. I 783), 268; John Archer, 10, I 2, 86, I04; Mary, see Cotton; fam., I 2,16

Houblon (later Newton), Susanna, see Archer

Houghton, Olivia, .128

Houndsditch (Lond.), 195

Housham, in Matching, 9

Housing, council, 9, I0, 2 I, 44, 58, $64,73,87$, I 03, I 04, I I 3, I 29, I 4I, I 72, 173, I $89,198,203,208,209$, $222,250,276,285$

How, John, 244, 245, 247 ; Ric. (d. I 708), 244; Ric. (d. I 723), 244; fam., 246

Howard, Lady Arabella, see Aleyn; Lord Edm., 133; Eliz., 227; Eliz. m. John de Vere, Earl of Oxford (d. 1462), 227; Ld. Geo., 235; Hen., Duke of Norfolk (d. I684), 235; Hen. (fl. c. I 780 ), 288; Joan, see Walton; John, Duke of Norfolk, I33, I34; John, Ld. Plaiz (d. I409), 227; Sir John (d. I 438), 227; Revd. J., 201; Marg., see Plaiz; Maria, see Archer; Thos. Duke of Norfolk (d. I524), I33; Thos., Duke of Norfolk (d. 1 554), I33; Wm. Ld. Howard of Effingham, 244

Howe, Ctss., 269

Howe, John, 145

Howell, Ann, 4I; Cath., 4I ; Miss, 4 I

Howitt, Sam., ${ }^{24}$ m. Wriothesley

Howland, Eliz. m. Wriothesley John, I go; fam., 145

Hoxton Academy (Lond.), 2 I 8

Hubbard, John, 245; Revd. Thos., 245
Hubbards Hall, in Harlow, 268

Hudson, Revd. J., 230 ; Sir Rob. $279,28 \mathrm{r}, 282$.

Hugh, Abbot of Bury St. Edmunds, 214

Hugh, Prior of Dunmow, 8

Hughes, Adml. Sir Edw., 24, 74, 75 79, 83; John, 92 ; Revd. J., I23; Ruth w. of Adml. Sir Edw., 28

Hughes (formerly Ball), Edw. Hughes Ball, 79

Hulson, John, 59; Rob., 59

Humberstone, Edw., 195

Hundreds, boundaries of,

Hunsdon (Hèrts.), 98

Hunt (Hunte), John, 8o; Maurice, roo; Ric. le and his w. Cecily, 80; Rog. le and his w. Estrilda, 79

Hunter, Chas., 279, 282; Mrs. Chas., 279, 280 ; Hen., 178

Huntingdon, earl of, see Clynton

Hunts, in Lambourne, see Patch Park

Huntyngfeld, Wal. de, 253

Hurlock, Brook, I 63

Hurren, Hannah, 4

Hutchings, D. 'W., $73 n$, I $56 n$, I $58 n$, I59 $n$, I $66 n, 167 n$, I70 $n$, I $71 n, 174 n, 185 n, 204 n, 285 n$

Hyett, Eliz., 254; John (d. 1719), 254, 258; John (f. I 7 19), 254 ; Thos., 254

Hylard, John, 274

Hyll, Wm., 269

Ickleton (Cambs.), 200

Ikenton (Herts.), see Layston

Ilderton, Thos., 33, 34

Ilford, 19, 21, 22; see also Fairlop

Fair, Newbury Park

Ilford, Little, 42

Ilger, Ranulf brother of, Io

Ince, Revd. E. G., 33

Inclosures, 2, 23, 59, 63, 64, 75, I I 4-I $6,140-1,175,185,204,210$ $234,250,251,26$ I, 286

Indies, West, see Barbados

Ingatestone, I $5 \mathrm{I}$; Hall, 70

Ingelric the priest, $88,159,18 \mathrm{I}, 210$

Ingham, John, I 33

Inkersole, John, 88, 92; Thos., 88,

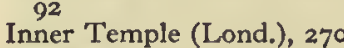

Intilsham, Thos., 145

Ireland, 267

Islip (Oxon.), I35

Iunanus (fl. 1086), 49

Iveagh Trustees, 67

Ivo nephew of Herbert, 65

Jackson, Hen., 27; Ralph, 164

Jacob, John, 29

Jacobs, W. W., author, XI7

Jacomb, Wm., 252

James I, 8, 100, I17, I19, $120 n, 2$ I , $212,216,224,235,244,256$

James II, II 9

James, Wm., 54

Jane (Seymour), queen of Hen. VIII, I 84

Jardyn, Ric. del, 277; Wm. del, 277

Jeffryes, Eliz., murderess, $24 n$

Jekyll, John, 28; T.; architect, 229

Jennings, Revd.' Isaac, 218

Jennyns, John and his w. Joan, 9 I

Jenour, And., $27 n$; Joshua, 24, 38 ;

Mary m. I Steph. Wiseman, 2 Wm. Tyffin

Jenyn, John, 254

Jepp, Mr., 272

Jerusalem, 9 I 


\section{A HISTORY OF ESSEX}

Jessopp, Sympson, 60

Jessup, Mr., I69

Jesuits, 70, 2 II $n, 218$

Joan of Acre, dau. of Edward I, m.

Gil. de Clare, Earl of Gloucester, $13 n$

John, King, 25, 80, $160 n, 224$

John, Abbot of Bury St. Edmunds, 214

John, Abbot of Waltham, 252

John of Gaunt, Duke of Lancaster. 29

John, Earl of Kent, 287

John s. of Adam, 214

John s. of Henry, 152

John s. of Waleran, 46,175

John the chaplain, 134

John the clerk of Ongar, 164

John the miller and his w. Agnes, 29

John (A. c. 1258), 151

Johnson, Geo., 215 ; John (d. I814), architect, I30, 155; Kath., see

Salyng; Ralph, 28; Thos., 24

Johnston, Hen., 175

Jollye, John, 207

Jones, Anne m. Gen. J. W. Adeane 30; Rev. C. G., 107; Inigo, 120, 226; John, Ioo; John Algernon and his w., 66, 70; J. W. B., 66, $68 n, 69$; Marg. Mary w. of John (? dau. of John Evans), Ioo, and see Weller; Rob., 30; S. H., I72 $n$; Miss, $175 n$; Mr. (f. I767), 2 I 5 Jonge, see Young

Jonson, Ben., dramatist, I I7, I 19

Jordan, Ric., 245

Joscelin, Anne, see Torrell; Hen. 145; Sir Thos. (f. I6th cent.), 145 Sir Thos. (f. 1604 ), 67, 145

Katherine (of Aragon), queen of Henry VIII, I I

Keble College, Oxford, 207

Kebyll, John, bellfounder, 60

Keep, Sarah m. Edw. Petre, 213; Wm., 212, 213

Kelly, D., 228, $232 n$

Kelvedon (Witham hundr.), 63, I 57 and see Felix Hall

Kelvedon Hatch, 63-72, $153 n$ $159 n, 247$; adv., 68; agric., 65; Bp. Compton's census, 311 ; char. 72; Church Ho., 69; chs, 68-69; communications, 64 ; hearth taxes, 303-6, 308; hos., $63-64,66,67,68$ Kelvedon Common, $63,64,65,71$, 240, 241 ; Kelvedon Hall, 63, 66-67, 69,70 ; Langford Bridge, $63-65$, 172 ; mans., $6,59 n, 65-68$, 105 , 143,242 ; medieval taxes, 209302 ; mill, 64, 65; par. govt. and poor rel., 70; pop., 64; postal svces., 65; Prot. noncf., 70; pub. svces., 65 ; rect., 68 ; roads, 64 Rom. Cathm., 63, 65, 67, 68, 70, 71,148 ; schs., $64,65,66,71,248$; top., 63-64; see also Germains, Myles's

Kemp (Kempe), John, 25; Thos. Bp. of London, 32, $152 n$

Kemsley, A. M., 84, 1 37; Hugh, 270 ; Jos., $270 n, 27$ r ; fam., 270

Kendall, Wm., 245

Kent, A., 55 ; Thos. de, 278

Kent, earls of, see Burgh, Edmund, John, Holland; earldom of, 287

Kent, 18, 145, 259; migrants from, 38 ; sheriffs of, 145

Kerr, Jas. (fl. 1919), 177; Jas. (f. 1953), 206; T. C., 177.

Kersey, John, cartographer, 226

Keswick, W. J., 269; Mrs. W. J., $269 n$
Kilpek, John, 254

Kimpton, Revd. Edw., 206; Eliz. 206; Harvey, 204, 206, 208

Kindleton, Geo., I08

Kineton (Warws.), 95

King, Anne m. Rob. Hill, 164; H. $285 n, 286 n$; John (f. I 368), I 4 ; John (fl. I 502), 106, I07; John (d. I657) and his w. Eliz., I64; John (f. 1678), 108; Jos. (d. 1679), 164, 169; Jos. (fl. 1717), 158 Lionel, I58; Maria, 213; Martha, 131 ; Rob., 167; Thos. (fl. 1659), 28; Thos. (fl. 1748), 238 ; Wm., 247; Mrs. (f. c. 1693), 109; Mrs. (fl. I795), 4 I

King's Bench, chief justice of, see Fineux

King's Place (Langford's, Potells), in Chigwell, 20, 29-30

King's Sombourne (Hants), see Compton Monceux

King's Walden (Herts.), 79

Kingsbury, Thos., 218

Kinsman, Mrs., $58 n$

Kipling, Rudyard, 117

Kirby, Ric., architect, 279

Kirkby, Wm., 288

Kirkeby, Wm., 27

Kirton-in-Holland (Lincs.), 188

Kirwan, Elnr., 45; Clement, 275; Mrs., 275

Klingender, F. C. L., 4 I

Knapp, John, 93

Knevett, Kath. m. Ric. Rich, 49, 205

Knight, Rob. (d. I744), 30; Rob. Ld. Luxborough (d. 1772), 28 , 30; Mr., 83, 230

Knights, Edw,

Knightsbridge (Mdx., later London), 53

Knolls Hill (Knowles Hill), in Stapleford Abbots, 73, 79, 85, $222,223,225,228,231-2$

Kynaston, J., 215

Kyne, Revd. Father, 165

Kyng, Ric. le, I74

Kyriell, Bart. de, 131 ; Elnr. de, see Crevequer

\section{Lacemaking, 175}

Lacy, Jas. de (fl. I361), 11 ; Jas. ( $f$. 1691), $60 n$; Mary w. of Nathan, 60; Nathan (d. 1700), 60, $165 n$; Revd. Nat. (A. I707), I 65

Lady Hall, in Moreton, see Upper Hall

Lagden, Ric. Thos., 72

Lagefare, Eus. de, 98

Lake, Canon M. N., $122 n$; Thos., 2 I 3 ; Miss, 41

Lambourne, Chris. of, 76 ; Sir Jas. of, 76 ; Joan of, $\mathrm{m}$. Wm. de Chene, 76 ; John of and his w. Eliz., 76; Rob. of, $76,8 \mathrm{I}$; Thos. of, 76 Wm. of (f. 126r), 76; Wm. of (d. 1 300$), 76,265 ; \mathrm{Wm}$. of (d, 136I) 76 ; fam., 76

Lambourne, baron, see Lockwood

Lambourne, 72-86; adv., 8I ; agric. 75, 223; Bp. Compton's census, 311; brewery, 76 ; char., 86 ; chs. $81-83,227$; hearth taxes, 304-6, 308 ; hos., $73,77,78,79,80,81$ Lambourne Hall, $7,73,75,77,86$; mans., $76-81,228,236,265$ medieval taxes, 296, 300-2; Mynchynlands, 81 ; noncf., $35,83-84$ 230,292 ; par. govt. and poor rel. 84 ; pop., 72 ; postal svces., $74-75$; pub. svces., 75 ; rect. 82 ; roads, $73-74$; schs., $85,231,232$; stage coach svces., 74; top., 72-74 worthies, 76; see also Abridge Arnolds, Bishops Hall, Dews Hall, Patch Park, Pryors, St. Johns

Lambourne End, in Lambourne, 19 $72,73,74,75,83,84,85,86,222$

Lampet, Cecily m. Wm. Curzon, 76 Isabel (Eliz.) w. of Thos., 51, 76 ; John, 76; Lucy, see Whetynton; Thos. (f. 1382), 234, 235; Thos. (f. 1407 ), 263, 266; 'Thos. (d. by I 4 I I) 5 I, $76 ; \mathrm{Wm} ., 76$

Lampetts, in Fyfield, $43,45,51,52$, $89 n$

Lancaster, Rog. de and Philippa his w., 27

Lancaster, duke of, see John of Gaunt; duchy of, $118,119,120$ $121,191,192,211,212,216,262$

Lancaster, earl of, see Edmund

Land, Wm., bellfounder, 62

Landscape gardening, see Gardening

Langenhoe, 145

Langford, Rob., 29

Langford's, see King's Place

Langham, 297

Langton, Sir John de, 47; Steph. de see Normanby (later Langton) Wal. de, Bp. of Coventry, 265

Larder, Wm., 292

Larkin, see Lorkin

Lascelles, Geoff. de, I60; Maud de, see Lucy

Lash, Jas., I 48

Latchingdon, 262

Latham, Audrey m. 2 Ld. Edw. Hay, 3 Niall Chaplin, 4 Maj.Gen. Sir Stewart Menzies, 279 281; John, rog

Latton, $132,284,289,290$

Laud, Wm., bp. of London, later Abp. of Canterbury, 242, 247

Launders, in Rainham, $80 n$

Lavender, John, 184; Mr., $134 n$

Laver (Domesday village), 2

Laver, High, 87-07, 103, 132; adv., $90 n$, 93; agric., 88 ; Bp. Compton's census, 3 II ; char., 94; ch. $87,93,107$; hearth taxes, 305, 306, 309; hos., 87, 91, 93, 95; High Laver Hall, 87, 91; High Laver Bridge, 87, 129 ; mans., 6, 11 , 51 , $88-93,98 n$, 99; medieval taxes, 297, 300-2; noncf., 95, I 95; par. govt. and poor rel., 95, IO2 $n$; pop., 87; postal svces., 87 ; pub. svces., 88; rector of, 60,138 ; rect. 93 ; roads, 87 , 104; schs., 96,102 $104,110,138$; 'Tilegate Green, 87, 104, Iro; top., 87 ; worthies, 88 ; see also Matching Green, Otes, Thrushesbush

Laver, Little, 87, 97-103, 129, 188, I 89 ; adv., 100, I35, 182-3; agric. 97-98; Bp. Compton's census, 311 ; char., 102 ; ch. $54 n, 100-\mathrm{r}, 182-3$ hearth taxes, $305,306 n, 309$; hos., $97,98,99$, I00, 101, 102; Little Laver Hall, alias Bourchiers Hall, 97, 98, 99, 100, 102; mans., 88 , $91,98-100,182$; medieval taxes, 298-302; mill, 97, 98; par. govt. and poor rel., ro1 $221 n$; pop., 97 ; postal svces., $96 ;$ pub. svces, 97 rect., 100-I; roads, $87,97,198$; Rom. Cathm., ro1; sch., 96, ro2; top., 97; see also Envilles

Laver, Magdalen, 4, I 03-10, 129 $176 n, 284,288$; adv., 93-94, 107; agric., ro $; \mathrm{Bp}$. Compton's census, 311 ; Bushes, 104 ; char., 1 10; ch., 68, $107-8$; hearth taxes, 305, 306, $309,310 n$; hos., 103-4, 106-7; Magdalen Laver Hall, r $0_{4}$; man. 
Laver, Magdalen (cont.)

$7,13,59 n, 76 n, 105-6,132,143$, 242; medieval taxes, $297,300-2$; noncf., 108; par. govt. and poor rel., 108; pop., 103; pub. svces. 104; rect., 107 ; roads, 87,104 ; sch., 87, 97, 104, 109; top., 103-4; Wynters Armourie (Winters), 103 , 10.

Lawson, Sir Hen., 66

Layer-de-la-Hay, 287

Layston (Jkenton) (Herts.), 287

Layton, Revd. Nich., 201

Leach, A. W., $37 n$

Leake, Frances, Ctss. of Scarsdale, see Rich; Nich., Earl of Scarsdale, 135

Lebbon, Herb., 127

Lee, Jeffery, 122

Leech, John, 244

Lees, Aveline de, see Cruce; Rog. de, 205

Lefsi (fl. 1066), 76

Legat, Alice, see Mandeville; Helming, $11,234,235$

Legh, Adam de and his w. Maud 46; Alice w. of Thos. $\mathrm{m} .2$ Thos. Arblaster, $206 n$; Giles de, 205 207; Hen. de and his w. Marg. 205; John de (fl, 1299), 205; John de (fl. 1349), 134, 205, 206; John de (d. 1422); Thos. de (fl. 1374) 205; Thos. (d. 1439), 205, $206 n$; Thos. (d. 1509), 205, 206; fam. 206 ; see also Ieigh

Leicester, earls of, see Montfort, Sidney

Leicestershire, medieval tax assessments, 302

Leigh, Barnabas Eveleigh, 13 ; Cath. see Clark; John, 246; Thos., 246; see also Legh

Leighs, Little, 131, 262; priory of, 49

Lenham, Iseult de, see Crevequer John de, 131, 133; Margery de 131; Nich. de, 131

Lenthal, Marg., see Fitz Alan

Leofcild (fl. I 666 ), 118

Leonard, Marg. w. of Samson, see Fiennes, Marg., Lady Dacre:

Samson, 176

Lepyngeden, John, 99

Lessington, Hen. de, Bp. of Lincoln 277; John de, 277, 28 I

Lester, Thos., bellfounder, 136, 184

Lestock, Adml. Ric., 24

Lethieullier, Smart, 61

Leueva (fl. 1066), 65

Leuild (f. 1066), 100

Leuric (fl. Io66), 46, 175

Levedai (f. r 066 ), 204

Levenoth, Geoff., 28; Rose w. of Geoff. m. 2 Mat. de St. Tronius,

Leventhorpe, John de (f.. 1419), 80;

John (fl. 1454), I77; Thos. de, 80

Leventhorpes, in Wennington, 80

Lever Art Gallery, Port Sunlight, 77

Leverpole, Wm., i 80

Lewer, H. W., 117

Lewin (f. 1066), 88, 198, 210

Lewin, Mary, 93; Sam., 93; and see Lewyn

Lewis, Jonathan, Io, 16; Revd. L. Elwyn, 53; Revd. Morgan, 85; Mr., 39

Lewthwaite, Mr., 238

Lewyn, Wm., 228; see also Lewin

Lexder1, hund. of, 262

I eyton, see Ieytonstone, Ruckholts

Leytonstone, in Leyton, 19, 35

Libraries, see Essex County Libraries

Limesi, Alan de, 25; Gerard de, 25

Ralph de, 24, 25; fam., 25
Lincoln, bps. of, see Lessington, Sutton, Winniffe

Lincoln, Hen., I17, 123, 124; Joan de, see Haye; Rob. de, 289

Lincolnshire, lands in, 266

Ling, And., 182

Lingard, Anne, 134; Eliz., I34; Frances m. Rob. Chase, 134; John, 134; Sar., I 34

Linton (Kent), $20 \mathrm{I}$

Lionel, Duke of Clarence, 105; his dau. Philippe, m. Edm. Mortimer, Earl of March, 105; his w. Eliz., see Burgh

Lipyeatt, Revd. J., I6; Revd. J., the younger, 16

Lisle, Baldwin de, 263; Warin de, 262

Lisle, honor of, 262,263

Little End, in Stanford Rivers, 208, 209, 218,221

Little, John, 17

Littlebury (Rowenho), in Stanford Rivers, $67 n, 210,211,214^{-15}$

Littlehales, Baker J., 28

Littleton, Sir Adam Bt., 161; Audrey Lady, see Poyntz

Livesaye, Wm., 29; Wm. s. of Wm., 29

Livingstone, Dr. C. H., 22; David, missionary and explorer, 159,165 , 218

Lloyd, And. F., 28; Lt.-Gen. Sir Fran., 28; Louisa, see Harvey; Ric. T., 28; Revd. Rossendale, 28

Locke, John, philosopher, 88, 91, 92, 94, 95

Lockwood, Amelius R. M., Ld. Lambourne, $75,77,80,82,127$; Revd. Edw, (d. 1802), 77, 80: Edw. (d. 1804), see Percival (formerly Lockwood); Capt. Geo. 83 ; Col. J. C., 80 n, 82 ; Ric. (d. I696), 80; Ric. (fl. 1735), 8o, 83 84 ; Ric. (d. 1794), 80 ; Wm. J., 77 $79,80,85,223$; Wm. M., see Wood (formerly Lockwood); fam. $75,80,83$

Loft Hall, in Navestock, 144, 145

Lofte, Isabel atte, i 45

Lolly, Dennis, 243

London, aldermen of, 12,28 , I I $134,211,267,270,274,289$ citizens of, II $59,63,79,211,213$ $214,216,242,254,289$; city of, $15,115,134,246$; coach svces. to $21,22,45,114,157,158,189,198$, $26 \mathrm{r}$; common serjeant of, 134 Cutlers' Co., 233; flight of Queen (then Princess) Anne from, 119 Grocers' Co., 15; Ironmongers Co., 242, 246; inhabitants with occupations stated, $18,27,29,31 \mathrm{n}$ $32,45,59,60,63,78,79,90,101$ $111,123,149,153,154,164,167$ $177,179,199,206,213,214,216$, $224,228,236,242,254,270,271 n$ $278,289,294$; inhabitants without occupations stated, $25,27,37,54$ $67,83,92,192 n, 215,221 n, 235$ $252,264,265,278,291$; juidge of sheriff's ct., 145; (Lord) Mayors of $26,30,178,243,264$; Mercers Co., 83; Merchant Adventurer of, 242,246 ; migrants from, 38 ; passage of St. Edmund's body from, 6o, 224; Quaker meeting ho., Gracechurch St., 163; rlys to, 2, 64, 75, $110,111,114,155$ I 58, 249, 250, 286; Recorder of 145: Tower of, 143; otherwise mentioned, $1,18,19,20,72,73$ $110,155,172,188,208,220,223$ $233,249,250,260,274,275,284$ 304; see also Aldgate; All Hallows-
the-Great; Battersea; Bermondsey Bishopsgate; Boodle's Club Bow; Bromley; Christ Church Albany St.; Christ Church Hospital; Cornhill; County of London Electric Supply Co.; East End Mission. East London Waterworks Co.; Grays Inn; Hackney; Hammersmith; Hanover Square; Haymarket; Highgate; Holy Trinity, Aldgate; Houndsditch; Hoxton Academy; Inner Temple; Knightsbridge; Maida Vale; Marylebone; Metropolitan Police; Metropolitan Water Board Middle Temple; Mile End; North London Collegiate School; Notting Hill; Paddington; Poplar; Portland Place; Portman Square; Queenhithe; St. Andrew, Cornhill; St. Bartholomew, Smithfield; St. Bartholomew's Hospital; St. George's Chapel, Albemarle St. St. George's, Hanover Square: St. Martin-le-Grand; St. Mary, Clerkenwell; St. Michael's, Cornhill; St. Paul's Cathedral; St. Thomas's Hospital; Shadwell; Shoreditch; Somerset House; Southwark; Spurgeon's College; Stepney; Stepney Academy; Tottenham; Twickenham; Victoria and Albert Museum; Walbrook; Walworth; Wapping; Westminster: Westminster Abbey; Whitechapel; Wimbledon

London, Archdeacon of, see Molyns

London Baptist Association, 36

London, bps. of, $32,33,61,100 n$, $207 n, 200,291$; see also Basset, Chishull, Compton, Deorwulf, Kemp, Laud, Vaughan, William of Ste. Mère Église

London Congregational Union, 84

London (formerly Stratford) Cooperative Socjety, 175, 179, 180, $182,197,199,200,213$

London County Council, 72, 75: housing estates, 2 , and see Debden, Hainault

Long, Cath. m. Wm. Pole-TylneyLong-Wellesley, 181; Sir Jas. Tylney, Bt., 181 ; Rob., 190

Longbarns, in Beauchamp Roding, $7,182,188,189,198-9,201$

Looe, West (Cornw.), 79

Lordell, Jas., 14

Lorkin (Larkin), John, 163, 164

Loughteborough, Rob. de and his w. Marg., 30; Wm. de, 30

Loughton, $1,2,3,4,21,1$ IO- 28 , $251,284,286$; adv., 121, 122; agric., I $16 ; \mathrm{Bp}$. Compton's census, 311; char., 117, 128; chs., 121-3; Goldings, 111 ; hearth taxes, 305 , 306, 309; hos., 110-13, I20, 121; inds., I 16 ; Loughton Bridge, 19, 110, I13, 116; Loughton Camp, 110 ; Loughton Hall, 110 , I 11 , I 12 , $113,116,118,119,120,122,125$; mans., $6,25,77 n, 79,118-21$, medieval taxes, 299-302; Monk Wood, 118, 119, 121; par. govt. and poor rel., 124; pop., $110-13$; postal svces., 114 ; Preservation of Epping Forest, 114-16; Prot. noncf., 37, 123-4; pub. svces., 113; rly., 22-23, 74, 114 ; rect., 121 ; roads, 20, 110-14, 249; Rom. Cathm., I23; top., I10-14; wor-

thies, 117; see also Alderton, Debden

Loughton Urban District, I8, I ro;

U.D. Council, i 16

Loundres, Sir John de, 13 


\section{A HISTORY OF ESSEX}

Lovell (Lovel), Elnr. m. Sir Edw. Waldegrave, Bt., 144; John, 214; Sir Thos., 144

Loveney, $\mathrm{Wm}$., I I

Lovetot, John de, I4

Lowe, Sir Edw., 237; John, 81; Sam., 95

Lowrey, Sir Jos., 123, 127

Luck, T., 55, 56

Lucking, Jas., 5 I

Lucklyn, Mildred Lady, see Capel; Sir Wm., I95

Lucy, Geoff. de, I60; Godfrey de, Bp. of Winchester, I60; Herb. de, I60; Marg., see Multon; Maud de, 'Lady of Ongar' m. I Geoff. de Lucy, 2 Ric. de Rivers, 160 , I66, 210; Maud de m. Walter Fitz Robert, 25; Maud de m. Wm. de Beauchamp, 160; Ric. de (d. II 79) $5,25,59,155,160,210$; Ric. de (d. by II 82), I60; Rose de $\mathrm{m}$. Fulbert of Dover, I6o; Thos. Ld. Lucy, 66; Wal. de, Abbot of Battle, I6o

Luke, Alice, see Stalbroke; Wm., 178

Lungevill', Thos. de, 49

Lunnon, Ric., 202

Luther, Amy, 69; Ant. (fl. 1580) 228; Ant. (d. I627), 63, 67, 69, 72; Ant. (d. 1665), 68, 72, 245; Charlotte m. Hen. Fane, 68; Charlotte, see Chamberlain; Edw., 68; Jane (d. 1745$), 72,235,236,238,239$; John (d. by 1713), 235, 237; John (d. I786), 68, 69; Rebecca (d. by 1768) m. Florian Goebell, 235 , 236; Rebecca (d. 1780 ), 69; Ric. (d. 1638 ) $63,67,69$; Ric. (fl. 1677), I57; Ric. (d. by 1691), 68; Ric. (d. I767), 68; Thos. (fl. c. 1556), 278, 279; Thos. (A. I 585), 67: Thos. (d. by I 694), $233 n, 235$; Thos. (d. I 722), 81, 235, 239 ; Wm., 225; fam., 65, 69, 233, 237 Luxborough, baron, see Knight

Luxborough, in Chigwell, 18, 20, 21 , $24,25,26,28,30,74$, I 8

Lymsey, Edw., 91 ; John, 91

Lynch, Sim., 291 $n$

Lynton (Devon), 99

Lyon, Geo., 28; Hen., 28; Hen. s. of Ric., 28; John (d. 1564) and Alice his w., 28 ; John (f. 1616), 28; Ric. 28

Mabel, Abbess of St. Sulpice (Brittany), 88

Mabel, dau. of Rob. Fitz Hamon, m. Rob. Earl of Gloucester, I 5 I

Maida Vale (Lond.), 218

Maidenheth, Reynold de, Abbot of Waltham, $89 n$

Maidstone (Kent), 79

Mainwaring, Rog. Bp. of St. Davids, 2 I 6

Maitland, Ebenezer F., 45, 51, I 30; Miss I. R., $120 n$; John (d. I831) I I9; Revd. John Whitaker (d. 1909), II 2, I I4-I6, I I 7, II I, X20, I21, I22, I24; Cmdr. J. W., I 6 n; Wm. Whitaker (d. I86I), I I I, I I4, 119, 120;Wm. Whitaker (d. 1926), II 9,120

Makyn, Agnes, see Colford; Jas., I47; Ric., I47

Maldon, 24, 157

Malpas, Eliz., m. Sir 'Thos. Cook, 26, 213; Phil., 26, 213

Malta, 133

Malyns, Alice w. of Reynold de, 277 278; Edm. de (fl. I357), 277;
Edm. de (fl. 1 384 ), 277; Florence w. of Sir Reynold de, 277, 278; Hen. de, 277; Sir Reynold de (d. 1384), 266, 277; Reynold (d. 1431) $277,278,28$ I

\section{Man, Gil. le, 214}

Manby, Frances m. John Petre, 212 Manchester, duke of, see Montagu Manchester, earl of, see Montagu

Mandeville, Alice de m. I Helming Legat, 2 Rog. Spice, 234, 235; Anne de, see Drokensford, Christine de, see Fitz Walter; Ernald de (f. I 2 th cent.), I5I; Ernald de (fl. 13th cent.), $15 \mathrm{r}$, I79; Galiena de, see Dammartin; Geoff. de (fl. I086), 190, 204; Geoff. de, Earl of Essex (d. I I 44), 15I, 191; Geoff. de, Earl of Essex (d. II66), I9I; Hugh de, I5I; Joan de, m. John Barry, 234, 235; John de, I5I, I52, I79; Olive de, see Beauchamp; Sir Thos. (d. by 1399), 234; Thos. (d. 1 400), 234 ; Wm. de, Earl of Essex, 25r; Wm. Fitz Geoff. de, 198

Mann, John, 2 II

Mannock, Ëlnr.,' see Goldingham;

Geo., 25 ; John (d. I471), 25 ; John (d. 1476$), 25,26$

Maple, Thos., 161

Maps, see Essex

March, earls of see Mortimer

Marchal, see Marshall

Marconi Wireless Telegraphy Co., 210

Marcy, Agnes de m. Nic. Spigurnel, xo, 243; Agnes w. of Serlo de, Io; Alice de m. John de Merk, Io, 14, 243; Denise w. of Hamon de, 10, 14; Hamon de (f. 1 $3_{\text {th }}$ cent.), Io, I4; Hamon de (d. before $c$. I1 197 ), 243; Hamon de (f. 1 1 31), 243; Joan de, m. Gil. de Breauté, I05. I47; Ralph de (f. I 086) 65, 67, I05. 143, 242; Ralph de (d. by xI 89), 59 , ro5; Ralph de (d. by I217I8?), x05, 242; Ralph de (fi. 1248 ), 49 ; Ric. de, 59 ; Serlo de (fl. I086) 242-3; Serlo de (d. by 1244), Io $59 n, 243 ; W m$. de (d. by I I 52 ?) 105, I43; Wm. de (d. by I 205), I05; fam., 59, 65, 67, 105, 143 242

Marden Ash (Marden End), in High Ongar, 4, 155, 161, I71, 172, I 74

I $83, x 86,241,303,305,307,309$

Mareschal, see Marshall

Margaret, St., 194

Margaret, queen of Edward I, 234

Margaret, Ctss. of Salisbury, 287

Margaret, dau. of Wm. Fitz Ric., m. Ric. de Tany, 234

Margaretting, 3 I $n$

Marham (Norf.), $256 n$

Markets, $167-8,261,276,277$

Markham, Ric. de, 277

Marks Hall, in Margaret Roding, 2, $3,240,242-3,245$; see also Stondon Massey

Marks Hall, in Romford, 228

Marks Hall, near Coggeshall, 77

Marling, Hen., 96

Marlow (Bucks.), ro3n

Marmion, Hen., 32

Marny, Wm. de and his w. Amice, 199

Marrable, Jas., builder, ${ }_{13} 6$

Marschall, see Marshall

Marsh, Sar., 268; Thos. Coxhead 268; Wm. Coxhead, 268; fam 268; see also Chisenhale-Marsh

Marshall (Marchal, Mareschal, Marschall), John le, 288; Laur. le, 288; Marg. w. of Rog., 288; Pet. and his w. Amiane, 288; Ralph le, 288, 289; Rob. (f. I331), 288 Rob. le (f. I374), 288, 289; Rob. (fl. I 387), 266; Rog. le (fl. I33I), 289; Rog. (f. I39I), I99; Thos. 288

Marshalls, in North Weald Bassett, $14,78 n, 267,284,286,288-9,293$

Martel, Geoff., I90

Martin, Alice, 232; John, 81 ; Mary, see Calvert; Sarah Cath., II 7 Adml. Sir Thos. B., 117

Marton, Edw., 29; Oliver (d. 1744), 29; Revd. Oliver (fl. I 759), 29

Martyrs' Memorial 'Trust, 52

Mary I, Queen, 118, 143,211, 212, 252, 269

Mary Macarthur Holiday Home, 172

Marylebone (Lond.), 253

Maryon, Revd. John, 193

Masham, Abigail Lady, 88; Charlotte, see Dive; Damaris Lady, 88 , 95 n; Eliz., 94; Sir Fran., Bt., 88, $91,94,95,96$; F. C., 95 ; Henrietta, see Winnington; Sam. Ld. Masham (d. 1758), 88, $91,92,94$ 95, 98; Sam. Ld. Masham (d. I776), 9z, 98, 99; Wm. (f. 16I4), 9I; Sir Wm., Bt. (d. c. I656), 91 ; Sir Wm., Bt. (d. c. 1662), 91; fam., 88,95

Mason, Revd. S. C., 107

Massachusetts, U.S.A., 242

Massey, Eliz. w. of Wm., m. 2 Wal. Fitz Walter, Ld. Fitzwalter, 3 Sir Thos. Cobham, 263; Wm., 263

Masshebury, Adam de, 289, 290; Eus. de, 265

Master, Ric., 49

Masters, Edw., 232 ; Rob., $304,305 n$

Matching, 93, 95, 96, 98, 102, 188; see also Housham

Matching Green, in High Laver, 87 $95,96,97$, I02, I 89 Matthews, Mary m. Sam Ma ${ }_{r_{t h}}$,
croft, 90 ; Ric. and his w. 90, 93; Mr. (f. 1877), 95

Maud, Empress, 19I

Maud, queen of Stephen, 88, I6o

Mauduit, Geoff., 25 ; Gil., 25

Maule, Christine w. of Pet. de, 25 I

Hen. de, 252, 253; Pet. de, 25I; Wm. de, 252

Mavor, Revd. W. S., 69

May, Adam, 263

May \& Baker Ltd., Manufacturing Chemists, 204

Maynarde, John, 224, 228

Mayor, Geo, 52

McCorquodale, H. M., I80; Kenneth, $150 n, 180 n$

McIntosh, D., 223

McKinlay, Mrs., I 50

Mead, Isaac, 200; John, 200; Wm. (fi. I6 39), 200; Wm. (fl. I 7 II), I 86; Mr. (f. I839), 75; Mr. (f. 1954), 200; Mrs., $200 n$; fam., 200

Meadows, common, 75, 86, I43, 2 10, 223

Mears, Thos., bellfounder, I 84,229 , 256; Wm., bellfounder, 83

Medley, Geo., 8 I

Meekings, C. A. F., $303 n$

Meggott, Anne, see Elwes; Geo., 252; Rob., 252

Meggott (late Elwes), John, 253

Meggs, Jas., 27I; Hen., 271; Marg. w. of Jas., 27I ; Thos., $27 \mathrm{I}$

Melbourne, Wm., I 42

Melcesborn, Wm. de, 26

Menzies, Audrey Lady, see Latham

Mere (Wilts.), 222

Meredith, Rob., I90 


\section{INDEX}

Merk, Alice de, see Marcy; Anastasia le, see Burgate; John de (fl. 1244), 10, I4, 243; John le (d. by 1285), I $5 \mathrm{I}, 152$; John le (f. 1285), 152 ; Galiena le m. Gil. de Theydon, 152; Ralph de, 10, 14, 243; Wm. de, ro

Merrick, Eliz., 148

Merrington, Jas., 158

Merry, Ant., 90; Ric., 90; Sar., see Foster

Merton (Surr.), 215

Merton College, Oxford, 152, $180 n$, 288

Metcalfe, W. C., II4

Metropolitan Police, $26 n, 38$, I 13

Metropolitan Water Board, 22, I 3

Mewes, Eliz., see Welde; Lewis, I99; Thos., 199

Mews, Peter, Bp. of Winchester, 76, 82

Meyer, Ann, 244; Anna Maria, rog; Christian P., 98, 99, 102, 105 ; Herman P. D., 99, 102; H. J., 244; Jas. (d. c. I 828), 99 ; Jas. (f. 1930), 99; Marianne w. of Phil. H., m. 2 Col. F. J. Baker, 244; Phil. H., 24I, 244, 245, 246, 248

Michael Fitz Oger, 192; his w. Sar., see Selflege

Michael, Oger Fitz, 192, 194

Michelgrove, in Clapham (Suss.), $243 n$

Michell, Fran., 254, 264; Jane, see Hampden

Middle Temple (Lond.), 68

Middlesex, archdeacon of, see Foliot

Middlesex, lands in, 256; migrants from, $3^{8}$

Middlesex and Essex Highway Trust, 19

Mildmay, Ambrose, 176 ; Anne, 228; Carew Hervey (d. I676), 228; Carew Hervey (d. 1784), 228; Jane $m$. Sir Hen. Paulet St. John (later Mildmay), Bt., 85, 223, 228, 231 ; Judith $\mathrm{m}$. Ben. Wallinger, 176; 'Thos., 176; Wal., 176

Mildmay (formerly St. John), Sir Hen. Paulet, Bt., 228

Mile End (Mdx., later Lond.), 6o, 236

Millbank, H. W., 217

Miller, John the, and his w. Agnes,

Miller, Revd. Fran. R., 95; John (fl. 1638), 200; John (fl. 1704), 200; Ric., 200; Rob., I86; fam., 200

Mills, 2, 9, 10, 44, 46, 59, 64, 65, 98, 99, I16, 130, 134, 152, 175, 210 , $223,234,26 \mathrm{I}, 286$

Mills, Chris. Jas., 26; Jas., 23, 26 28; Jemima, see Hatch; Thos., 254, 265; Wm., 192-3

Milton (Northants.), 78

Mineral spring, see Spring

Ministry of Works, 280

Minors, Ellen, see Nicholson

Minshull, Mary, 177; Sir Ric. (d. 1667), 177; Ric. (f. I700), I77

Missenden (Bucks.), abbey of, 15 I

Mitchell, F. G., 226; Septame, 171

Mitten, Fran., 273

Moats, $1,9,26,43,44,51,63,73,79$, $87,99,100$, I01, $103,104,107$ $129,134,140,146,150,162,173$, $178,189,192,193,196,200,216$ $233,235,244,249,254,264,265$, $284,285,288,289,290$

Mollett, E. and C., 223

Molyns, John, Canon of St. Paul's and Árchdeacon of London, 262, 269
Monceux, Enguerrand de, 176 ; Joan de, see Saunford; John de, 176 ; Maud de $m$. John de Fiennes, 176 ; Waleran de (d. by 1212), 176; Waleran de (? f. c. 1258), 15 I, 205; Wm. de, 175, 182 $n$

Monkhams, see Buckhurst

Monkis, see Bilsdens

Montagu, Alice m. Ric. Neville, Earl of Salisbury, 287; Anne, Ctss. of Manchester, see Rich; Chas. Earl of Manchester, 181, 183; Edw. Earl of Manchester, 135: Elnt. Ctss. of Salisbury, see Holland; Ric. Bp. of Chichester, later Norwich, 216; Rob. Duke of Manchester, 183; Rob. Earl of Manchester, 18I; Thos. Earl of Kent, 287

Montfichet, Aveline de $\mathrm{m}$. Wm. de Forz Count of Aumale, 227; Gil. de, 227; Joyce de, see Greinville; Marg. de m. Hugh de Bolbec, 27 227; Philippe de $\mathrm{m}$. Sir Hugh de Plaiz, 227; Ric. de (d. I202), I 18 ; Ric. de (d. 1267), 27, 118, 227, $265 ; \mathrm{Wm}$. de, 28, 227

Montfort, Rob. de, 287; Sim. de, Earl of Leicester, $65,263,277$

Montgomerie, W., 178

Montgomery, Sir Thos., I6I

Moore, Edw., I 47 ; John, 147

Mordaunt, Anne m. Hen. Torrell, 145; Wm., 145

More, Fran., 26

Morell, Joan w. of Luke,' II, I4; Luke, II

Moreton, 9, 43, 57, 99, 103, 129-39, I59 $n$; adv., I34-5; agric., 130; Bp. Compton's census, 3 r r ; char., I 37,139 ; ch., $54 n, 100,101,129$ 134-7; fair, 130; Guild of All Saints, 136-7; hearth taxes, 304-6, 309; hos., 1 29-30, 133, I 34, I 35 137; mans., 131-4; medieva] taxes, 300-2; mill, r29, 130, 134 Moreton Bridge, 9, 129, 130 ; Moreton End, 129; noncf., 84,95 , I $33,137,165,195,292$; par. govt. and poor rel., $137-8$; pop., 129; postal svces., 87, 97, 130; pub. svces., I 30 ; rect., 135 ; roads, $129-$ 30,204 ; schs., 96,138 ; top., $129-$ 30 ; see also Bundish, Nether Hall, Upper Hall

Morgan, Ric., 77

Morice, see Morris

Morley, John, 27

Mornington, earls of, see PoleTylney-Long-Wellesley

Moro, 'Duke de', 279

Morrell Roding, see Roding Morrell Morris (Morice, Morrice), Anne w. of Wm., r6r; Edw., I6r; Eliz. w. of Jas., I6r ; Jacob, r 35 ; Jas., I6r, 166; John (fl. 1591), 135; John (fl. I647), 16r; Rob., 95; Steph. 253; Wm., I61, I63, 215

Morris (later Poyntz), Sir John, I6r Morsted, Thos., 263

Mortain, honor of, I60; Anne m. Ric. Earl of Cambridge, I05

Mortimer, Anne w. of Edm. Ear of March, 10, ro5; Edm. Earl of March (d. 138r), 105; Edm. Earl of March (d. 1425), I0, 105 Marg. de, see Fiennes; Philippe, see Lionel, Duke of Clarence; Rog. Earl of March, 105

Moss, Mary, $4 \mathrm{I}$

Mot, Rob., bellfounder, 246

Moulton (Lincs.), 80

Mounteneye, see Munteny

Mountnessing, see Thoby Priory

Mowbray, Anne de, I33; Eliz. de,
133; Eliz., see Fitz Alan; John, Ld. Mowbray (d. 1368) 132 ; John de, Earl of Nottingham (d. 1383), 133; John de, Duke of Norfolk (d. 1432), 133; John de, Duke of Norfolk (d. 1476), 31, 133 ; Thos. de, Duke of Norfolk (d. 1399), 3I $n$, 133; Thos. de, Earl of Nottingham (d. 1405 ), 133

Mulcaster, Kath. w. of Ric., 218; Ric., 218

Mullocks, John, I 53

Multon, Agnes w. of Hen. de (prob. dau. of John Deu), 8o; Eliz. de m. Wal. de Birmingham, 66; Hen. de, 65,66 ; 80 ; Joan dè $m$. Rob. Fitz Walter, 66; John de, Ld. Multon, 66; Juliane de $m$. Ric. de Welby, 66, 80; Lambert de, 65 : Marg. de $m$. Thos. Lucy, Ld. Lucy, 66; Thos. de (d. 1240), 6 ; Thos. de (d. 1294), 65, 66, 67 Thos. de, Ld. Multon (d. 1322), 66; fam., 65

Munchensy, Denise (d. I 304) w. of Warin de, 67, 262, 263; Denise de (d. 1313), 262; Warin de, 262

Munkenhill, see Buckhurst

Munteny (Mounteneye), Arnald, 199; Sir Arnulph de, 214; Edm. de, 2 I 4 ; Joan, see Biddik; John de (fl. I 288), 2 14; John de (fl. 1355), 67, 2 I 4; Marg. w. of John de, 214 Mic. de, 2r4; Miles de and his w. Agnes, 67; Ric. de, 214; Rob., 214; Thos. de, 67, 214; fam., $67 n$ Murimuth, Adam de, I 43,144

Muscott, Charity m. Geo. Duncombe, 252; Frances, 252

Musgrave, Ann, see Archer; Chris., 288

Mylborne, Wm., 2 rg $n$

Myles's, in Kelvedon Hatch, 63,64 $65,67-68,143,240,245$

Napoleonic wars, sale of timber during, 60,120

Napper, Anne w. of Wm., 2 r 8 ; Rob. I77; Wm., 218

Nash, Lance, $78 ; \mathrm{Wm}$. Wedd, 290

Nash Hall (Ongar, Little Ongar, Ashhall), $173,175,180,182,185$

National Freehold Land Society, 30 National Telephone Co., $22 n$

Navestock, 2, 139-50, 2 19 $n, 225$; adv., 146; agric., 142-3; Bp. Compton's census, $31 \mathrm{I}$; bridges, I4O, I4I, 142; char., I49; ch., $67,146-7$; commons, 140-1; communications, 142; cricket, I42; earthworks, 140; hearth taxes, 304-6, 309; Horseman Side, I 40 I $41,147,148$, I 49 ; hos., I $40-1$, I 44, I 45, I 46; inc., 141; mans., $6,59 n, 65,67,105,143-6,242$; medieval taxes, 208-302; mills, I4O, I4I; Navestock Hall, I40, I4I, 142, I44; Navestock Heath I40, I 4I, I 42, 149, 222; Navestock Side, I $40,141,142, I 40$ 222 ; par. govt. and poor rel., I 48; pop., I $4 \mathrm{I}$; postal svces., I 42; Protestant noncf., 148; pub. svces., 142 ; rect., 146 ; roads, 63 , 140-1; Rom. Cathm., 147; schs., I 4 1, 1 49, 232 ; Shonks Mill Bridge, 142, 209; top., 139-43; vicarage, 141,146 ; woods, 139 , I40 worthies, I43; see also Bois Hall, Loft Hall, Slades

Navestock, 'the other Navestock'

(Domesday village), 2

Nazeing, 123 


\section{A HISTORY OF ESSEX}

Neale, Marg., 208; John, 208

Neller, Revd. F., 35

Nelson, A. \& C., coach owners, 22, I 58

Nesfield, Eden, $120 n$

Nether Hall (Bourchiers Hall), in Moreton, 98, $106 n, 130,13 \mathrm{I}-2$, 133

Netteswell, 284

Nettleton, Revd. John, 165

Neuton, John de, Treasurer of St. Peter's, York, 89

Neville, Alice, Ctss. of Salisbury, see Montagu; Cecily (mother of Edw. IV and Ric. III) m. Ric., Duke of York, 254; Edw. Ld. Bergavenny, 262; Geo. Ld. Bergavenny, $3 \mathrm{I}$; Isabel m. Geo. Duke of Clarence, 287; Ric. Earl of Salisbury (d. 1460), 287; Ric. Earl of Salisbury and Warwick (d. I 47I), 'the Kingmaker', 287; Miss, 188

New Hall, in High Roding, $193 n$

Newall, John L., 47, I52, 154, 180, I82; J. W., 43, 180; fam., 175

Newarks Norton, in High Ongar, 6, I $50,172,175,180,181,185$

Newburgh, Ela de, Ctss. of Warwick, see Ela

Newbury Park, in Ilford, 19

Newman, Joan, 28; John Thos., architect, 69

Newmarket, 20, II3, 249, 259, 26o, 284,285

Newport, Rob., 225

Newport, $259 n$

Newstead (Notts.), 267

Newton, Sir John, Bt., 268; Susanna m. Wm. Archer (formerly Eyre), 268; Susanna Houblon, see Archer, Houblon; Thos., Bp. of Bristol, 204 n, 207; see also Neuton

Nichol, Thos., 45; see also Nichols

Nicholas, Ant. (A. 1685), 153; Ant. (d. 1727), I 53 ; Denton, 271 ; Geo., 229; John, 153; Martha m. Josiah Woodward, 244; Mary w. of Prosper, 246; Prosper, 193, 244, 246; Ric., 202; Wm., 153

Nichols (Nicholls, Nycolls), Humph., 52 ; John, printer and author, $60 n$; Thos. (fl. 1724), 16; Thos. (ff. 1826), I57; see also Nichol

Nicholson, Ellen, m. I - Minors, 2 John Branch, 264; John, 237; Wm., 264

Nigel, 227

Nile, Battle of the, 156

Nix, Ric., Bp. of Norwich, 79

Noaks, fam. (paupers), 148

Nobbs, John, 24I, 245

Noble, Ric., 164; the Misses, 170

Noble \& Son, builders, $156,162 n$, $165,172,184,203,217$

Nodes, Eliz., see Wollsey; Wm., 122

Nollekens, Jos. (d. 1823), sculptor, I 64

Nooke, Rob., 52

Norden, John, cartographer, 198

Norfolk, dukes of, see Howard, Mowbray

Norfolk, earl of, see Bigod

Norfolk, medieval tax assessments, 302 ; migrants from, 38

Norman, Rob., 89

Normanby, Alan de, 46

Normanby (later Langton), Steph. de and his w. Alice, 46

North, Dudley, Ld. North, 199; Sir John, 199

North London Collegiate School, $25 \mathrm{I}$

Northampton, 77

Northampton, earl of, see Bohun, Compton
Northampton, Joan w. of Ric. de, 278; John de, 28I; Kath, w, of Ric. de, 278 ; Ric. de, 278

Northamptonshire, lands in, 266

Northcote, Adela, see BowyerSmijth

Norton, Gordon, 253; Mrs., 253 n

Norton, see Forest Hall

Norton Foliot, see Forest Hall

Norton Mandeville, 4, $\mathbf{1 5 0 - 5}$, $159 n$, I7 I ; adv., I 52-3; Bp. Compton's census, $31 \mathrm{I}$; char., 155 ; ch., $52 n, 54 n$, IOI $n$, I $52-4$ $172,182,255 n$; curate of, I 74 fields, $150-2,166 n$; hearth taxes, 305-6, 309; hos., 150, 15 I, I52; man., 6, 59, 1 $51-2,179,180,288$ medieval taxes, 298-302; noncf., 154, 195; Norton Hall, I 50, 151 152; Norton Heath, I 50, I 51 , I 52 , $154,159 n, 173$; Norton Manor House, I 50; poor rel., I54; pop. 150 ; pub. svces., 151 ; rect., 13 153; schs., 154, I 87 ; top., I 50-I; vicarage, 153

Norwich, 22, 216, 229, 249, 26r, 284

Norwich, bps. of, 79; see also Despenser, Montagu, Nix, Suffield, Wauton

Notting Hill (Lond.), 200

Nottingham, 165, 200

Nottingham, earl of, see Finch, Mowbray

Nottinghamshire, medieval tax assessments, 300

Nowers, - (fl. 1519), 264

Nowes, Chas. and his w. Ann, 49

Nuthampstead, in Barkway (Herts.), $31 n$

Nutt, Geo. (d. by 1656), 28; Geo (fl. 1656), 28; Wm. (fl. 1669), 28; Wm. (d. 1721), 28; Wm. (fl. 1725) 28; Wm. (fl. 1816), 272; Wm. (fl. 1848), 65

Nycolls, see Nichols

Nynge, Amphyllis m. John Shereff, 134; Isabel, I 34; Marg., see Wynslowe; Thos., r 34; Wm., I 34

Oakley, Sir John, 67

Ockendon, North, 16

Ockendon, South, 134

Oda, Abp. of Canterbury, 143

Oddin, Hen., $305 n$

Odo, Bp. of Bayeux, 65

Offinton, Laur. de, 224

Offley, Jos., 134 ; Thos., 134

Oger, Emma Fitz m. - Saunford 205

Oger Fitz Michael, 192, 194

Oger Fitz Oger, 205; Amy w. of, see Selflege

Oger, Mic. Fitz and his w. Sar., 192

Oger, Mirabel Fitz m. - de Cruce, 205

Oger, Peter Fitz, 205, 206

Ognall, And., 278 ; Bridget, 278

Old Farm, see Appeltons

Old Frith, see Frith Hall

Old Thrifts, see Frith Hal

Oldfield, Rob., bellfounder, 237

Oldham, Hugh, Bp. of Exeter, 264 Revd. John, 242, 245, 247, 248

O'Leary, J. G., $166 n$

Oliver, Abraham, 76; Ben., 100; John, $101 ; R$. and H., 51 ; Revd. W. M., I4, 15, I 54, 207

Olmestede, John de, 167

Ongar, John the clerk of, I 64

Ongar (Domesday village), 2

Ongar, see Nash Hall

Ongar, Chipping, $I, 2,4, x_{55-7}$ I 209; Ackingford Bridge, 9, 58,
155, 157; adv., I62, 182; agric., I66: Assembly Rms., 156; Bp. Compton's census, 311 ; bridges, 157, 174; Budworth Hall, 156 I59; castle, 5, 155, I 59, I60, I6 I, I62; Castle House, 155, 162 ; char. I7I; ch., I62-4, 182, 207; fair 160 , 167 ; fire-brigade, 158 ; hearth taxes, 304-5, 307, 309; hospitals, 159; hos., 155-6, 162, 163; 'King's Head', I 55, I67; market, I 55, I67; man., $5,6,59,88 n, 159-62,182$, 210,21 I, 262; Mechanics' Inst., 159 ; medieval taxes, 297, 299-302; occupations, 166-7; Ongar Bridge, $155,156,157,172$; par. govt. and poor rel., 167-9; par. united with Greenstead, 61, 163; pop., I56-7; postal svces., 158, 233; Protestant noncf., 1 37, 164-5, 218,292 ; pub. svces. and social life, 60 , $158-9$, 174; rly., 74, III, I I4, I 55, I58, 209, 250; rect., 162-3; roads to, $38,58,63,64,72,87,97,141,144$, $150,188,189,203,204,214,233$, 24I, 285; Rom. Cathm., I65; schs., 18, 62, 110, 139, 169-71, $187,197,208,221,232,248,295$; stage coach svces., 2 I, I $57-8$, 189, 209; top., I 55-7; town enclosure, 155; town hall, 156, 167, I69 $n$; White House, 155, 156, 159 , I62, 163; worthies, I59; otherwise mentioned, $43,58,63,97,103$, I 29, 142, I $51,171,174,188,198$, $203,204,222,240,241,247,286$

Ongar Gas Company, I 58, I 74

Ongar, High, 9, 64, 68, I 59 , I66, I67, I $71-88$; adv., I 82-3; agric., I 75; Bp. Compton's census, 311 ; Bobbingworth hamlet (Westwood hamlet), 4, 1 72, 186, 303, 305, 307, 309 ; brewery, 172; char., 187; chs., $52 n, 152,172,182-5$; fair, 175, 176, 182; Fane Nursing Home, 174 ; hearth taxes, 303,305 , 307,309 ; hos., $172-3,176,177$, $178,179,180,181,182,183$; incl., 175,185 ; inds., 167,175 ; mans., I 75-82; medieval taxes, 299-3ò2; mill, 175; noncf., 185; High Ongar Bridge, 155, 173, 174; par. govt. and poor rel., 185-6; pop., I 71,208 ; postal svces., I74; pub. svces., 174 ; roads, 58 , 174 ; rector of, 175 , 182; rect., $182-3$; schs., I 54, 186-7; top., 171-4; see also Ashlyns: Chivers Hall: Forest Hall; Frith Hall; Marden Ash; Nash Hall; Newarks Norton; Ongar Park; Paslow Hall; Paslow Wood Common; Passfield; Withers Pawne

Ongar, honor of, $59, \mathrm{r} 60,262$

Ongar, hund. of, I-8, $18,38,76$, $85 n, 142,143,179,188,221 n$, $243,266,286-7$; medieval tax assessments, 296-302; hearth tax assessments, 303-10; Bp. Compton's census, $3 \mathrm{II}$; see also Wardstaff

Ongar, Little, see Nash Hall

Ongar Park (Batells), in High Ongar, 13, 105, 166 $n, 171,172$, $175,183,210,211$; see also Stanford Park

Ongar Poor Law Union, 17, 56, 62, $7 \mathrm{I}, 85,96,102,138,148,154,169$, $174,186,196,202,208,210,221$, $23 \mathrm{I}, 238,248,283$; workho., 210 , 221

Ongar Rural District, I; R.D. Council, 156, 203

Onslow, Foot, 29; Susanna, see Colwall 


\section{INDEX}

Oram, Mrs., 102

Orcop (Herefs.), 59

Ord, Craven (d. 1832 ), 60, 62; Revd. Craven (d. 1836 ), 6o; Capt. Harry and Mrs., 45; Mary, see Redman

Ormond, Jas., Earl of Wiltshire, 31 ; John, 3I; Thos., 31

Orr, T. W., 35

Orsett, 272

Osier growing, 75

Ospring (Kent), I53

Oswestry (Salop), see Aston Hall

Otes, John, 9 I

Otes, in High Laver, $80 n, 88,91-93$, 99, $103 n$

Otto IV, Emperor, 224

Otway, Edw., 245

Oudeby, Elnr. m. Thos. Battail, 176; Thos., 176

Overman, Thos., $8 \mathrm{I}$; Wm., 8 I

Owen, Thos. A., I7I

Oxford, 78

Oxford, bp. of, see Stubbs

Oxford, earls of, $27,78,79,80,198$; see also Vere

Oxford, Steph. of, 227

Oxford University, Ford Lectureship, 143; see also Brasenose College, Keble College, Merton College, Trinity College, University College

Pack \& Chapman, bellfounders, I 84 Paddington (Lond.), 2 I 8

Padfield, Mr., 260 ; Mrs. S., 77

Page, Ámbrose, I32; Wm., 246; Mr. and Mrs., 245

Paget, Mr., 247

Paine, Hen. E. 288

Pall Mall (Lond.), Schomberg House in, 14

Pallavicine, Horatio, I64; Jane, see Cromwell; Tobias, I 6

Palmer, Ada, 21 ; Edw. (f. I624), 74 78 ?; Edw. s. of Edw. (d. c. I680), 78 ?, 80; E. J., brewer, 175 ; Hen., 74, 80; Hen. Billingsley, 80; Horace, 214 ; Revd. H., I OI; Jas. 1 76; John (fi. I659), 54; John (fl 1781-92), 272; John (f.. 1842), 216; J. \& J., brewers, I75; Ric. (fl. 1776), 272; Ric. (f. 1801), 92, 99, 100; Revd. Ric. (f. I872), I0I Rob., 92, 99, 100; S. Caroline, 101; Thos., 54; Mrs., I76; fam. $21,75,80$; see also GoldingPalmer

Panfield, priory of, 134,135

Paris, Alice w. of Wm. de, 289 ; Alice de, see Spigarnel; Beatrice w. of Roger de, 289, 290; Nich. de, 289; Rog. de, 289; Wm. de, 289, 200; fam., 280; see also Parris

Paris Hall, in North Weald Bassett $284,289-90,292$

Parish, Sam., 230

Parishes, detached parts of, $4,9,103$ 129, I $71-2,182-3,188$, I 97,245

Parker, Chas. G., 269; Hen., 180 ; Jonathan, Ir9; Rog., 180

Parkes, Revd. Parson, 237

Parliament, forged Acts of, I6I; members of, see Sir Dan. Dun, Adml. Sir Eliab Harvey, Amelius R. M. Lockwood, John Luther (d. I 786), Cmdr. J. W. Maitland Sir Nat. Rich, Sir Hen. SelwinIbbetson, Bt., John Strachey, Thos. Walker, J. W. Perry Watlington, Sir Rob. Wroth (d. r606)

Parndon, Little, I5
Parr, Anne, Baroness Bourchier and Ctss. of Essex, see Bourchier; Thos. Ld, Parr, later Earl of Essex, 59, I3 I

Parris, John, $199 n$; Rob., r99; V. and L., 290; Mr., 290; see also Paris

Parrish, Miss, I 44; Mr., 68

Parsons, John, 96

Partridge, And., 261; Hen., 176

Partrych, Bart., 142

Pasfield, see Paslow Hall

Paslow Hall (Pasfield), in High Ongar, 5, 6, 47, 173, 175, 180, 185. I86, $300-2$

Paslow Wood Common, in High Ongar, I71, I73, I 74, I75, 185 , I86, I87, I 88, 241

Passfield, in High Ongar, 2, 4

Passfield Chivers, see Chivers Hall

Passmore, Revd. W., 95, 137

Patch Park (Hunts.), in Lambourne, $73,78,80,236$

Patche, John, 8I

Paul, Wm. \& Son, I 16

Paveley, Jas., I86

Pavell, John, $90 n$

Pavitt, G., 10

Pawne, Anne m. Rog. Basing, 178 ; Wm. (fl. 1498), 178, 179; Wm. (d. 1570), I 53, I 78 ; Wm. (d. I 578), $153,178,179,186$; fam., 175,178 , I79

Peacock, Chas., 77; Edw. (fl. 1626), I67; Edw. (fl. 1641), 77; Ric., 77; Rob., 264; Wm., I88

Peach, Sam., 28

Peake, Mr., 160

Pearse, Nich., 128; Sar., 128; Mrs., 122

Pearson, Geo., I27; Revd. John, 208 Pebmersh, Cecily w. of Ralph de, 178; Ralph de, 178; Wm. de, 178 Pecok, see Peacock

Pekkebrigge (Peghbrigg), John, 64 Pelby, Mrs. John, I 24

Pembroke, earls of, see Hastings, Herbert, Valence

Pendred, Wm., 216

Penington, John, 29, 34; Mary, m. I Rog. Forster, 2 Mich. Ernle, 3 Sir Thos. Perient, 29

Penn, Wm., Quaker, 24

Penruddock, John, I 78, I79

Percival, Edw. Lockwood (d. I842), $77,84,85$; Louisa Eliz. Lockwood, 79

Percival (formerly Lockwood), Edw. Lockwood (d. I804), 75

Peregrine, Revd. D. W. and Mrs,, 68,69

Perient, Mary Lady, see Penington; Sir Thos., 29

Perry, Isaac, $83 n$; Louisa, m. Robert Peel Ethelston, 32; Maria Jane, see Watlington; Revd. N. F., 36; R., I6; Thos., 32; Wm., 193

Peter Fitz Oger, 205, 206

Peter, Ralph s. of, 262

Petre, Cath., 212; Edw., 212, 213 ; Frances, see Manby; Geo. (fi. 1819), 2 1 2 ; Geo. Wm. (d. 1797), 2I 2, 218; John, 2 I 2, 213 , 215, 216 ; Lucy dau. of Wm., 2 r8; Lucy $w$. of Wm., 2II; Lady Mary, see Radcliffe; Ric., Jesuit, 218 ; Rob. (f. 1678), Jesuit, 2I8; Rob. Ld. Petre (d. 1742), 212 ; Rob. (d. I766), Jesuit, 2 I 8 ; Rob. Edw. Ld. Petre (d. 180I), 142, 212, 215 ; Sar., see Keep; Susan, 212 ; Wm. Ld. Petre (d. 1637), 2 I i; Wm. (d. 1677), 211, 218; Wm. (d. I688), 211; Wm. (d. 1728), 2 I 1 , 212,218 ; Wm. (d. 1 745), 2 1 2, $216,218,2$ 19;
Wm. Bernard, Ld. Petre (d. 1884), 165; fam., 209, 218,219

Petty, Martha, see Hicks

Peverel, Rob., 160, 162, I66

Phelps, Ric., bellfounder, 164; Rob., bellfounder, 271

Philippa, queen of Edw., III, 215

Phillips, E., 215; Miss E. A., $41 n$, $127 n$; Tim., 215 ; Revd. Wm., 207 Pig, Wal., 214

Piggott Bros. \& Co., tent makers, 209, 210

Piggsland, in Stanford Rivers, see Bridges and Piggsland

Pinchon, David, I 48

Pirgo, see Pyrgo

Pitfield, Winifred m. Solomon Ashley, 26

Plaiz, barons, see Howard; barony, 227

Plaiz, Sir Hugh de, 227; John, Ld. Plaiz, 227; Marg. m. Sir John Howard, 227; Philippe de, see Montfichet; Ric. Ld. Plaiz, 227

Playle, Mat., 213

Pleshey, 6

Ploket, Nich., 26

Plomer, Wm. le, 3

Plumer, Wm., 212

Plummer, Jane w. of Wm. m. 2 Rob. Plummer Ward, 291; Wm., 291

Plumtuna (Domesday village), 3

Plymouth, earl of, see Hickman

Plympton (Devon), 79

Pochin (Putchin), Geo. (fl. I 7oo), 44 Geo. (f. r704), 200; Geo. (fl. I770), 200; John (? fl. I704), $200 n$; John (f. 1720), 54; Capt., 200; fam., 54

Poldu (Cornw.), I 3

Pole-Tylney-Long-Wellesley, Cath. see Long; Wm. Earl of Mornington (d. 1863 ), 47,182

Pole-Tylney-Long-Wellesley (formerly Wellesley-Pole), Wm. Ear of Mornington (d, I857), 45, I8 I I 82

Poley, John, 215

Police, $38,45,65,75,130$, I 59, 174 $200,223,251,283,286$; see also Metropolitan Police

Polstead (Suff.), 76

Pomfret, Revd. Sam., 195

Pond, Sam., I 85

Pontigny (France), 277

Poole (Pool), John (d. I602), I I, 12 ; John (d. I633) and his w. Anne 12; John (d. c. 1676), I2; John (d. by I701), 12, I6; John (f. 1 708), Io, I2, I4, I6; John (d. c. I839), 8; Lora w. of John, 12; Mary, see Powell; Ric., II; Wm. (fl. I 740), I6; fam., 15, I6

Pooley, Alice, see Shaa; John, 290 ; Wm. (d. I 587), 290; Wm. (fl. 1594), 290

Poor Law Union (1829), see 'Gilbert' Poor Law Union

Pope, Edw., 37, 95, 117, 123; Sir Thos., 146

Poplar (Mdx., later Lond.), I 32

Port Sunlight, see Lever Art Gallery

Porter, Miss O., I $42 n$; Revd. R. I. 163

Portland, earl of, see Weston

Portland Place (Lond.), 253

Portman Square (Lond.), 253

Potel, Ric., $29 n$

Potells, see King's Place

Potter, Edw., 235; John (d. c. 1546), 30; John (fl. I 834), 247; Thos. and his w. Marg., 30

Powell (Powel), Ann, 202; Mary, m. John Poole, 12, 14 ; Jas., 125 ; Mrs., 122; fam., I 17 


\section{A HISTORY OF ESSEX}

Powerscourt, vct, see Wingfield

Powling, Wm., 2

Poynder, Thos., 98

Poynings, Rob., I 77

Poyntz, Anne m. Sir Fulke Greville, 161; Audrey m. Sir Adam Littleton, 161 ; Eliz. m. Wm. Duncombe, 161; Sir Gabriel, 161; Sir Jas., 16I; Kath. m. (Sir) John Morris (later Poyntz), I6r ; Poyntz, 161; Ric., I6I; Thos., I61

Poyntz (formerly Morris), Sir John, 106,161

Praed, Louisa, see Ewing; Winthrop Mackworth, 106

Prance, Revd. L. N., 282; Reg. Heber, 237

Pratt, Revd. Benj., 6o; C., I45; Sam. and his w. Anne, 193; Mr., 192; fam., 145

Prentice, Thos., 132

Prest, Álice w. of John (second husb.) m. 3 Ric. Blackwall, I 45; Frances m. Wm. Bradborne, I 45; John, 145; Thos. (d. 1852), 24 ; Thos. (d. 1877), 24; Wm., I45

Preston, Geo., 64

Prestwood, John, 27

Price, Howel J. J., $60 n, 63$

priest, Ingelric the, $88,159,181,210$

Prince, Eliz. (d. c. 1796), 149; Eliz. m. 1 Wm. Sparowe, 2 Francis Hampden, 253, 254, 264; Eliz. see Gernon; Gil., 263 ; Joan w. of John, 263; John (d. by 147 I), 254, 263; John (d. I 499), 254, 263, 264 ; Lucy w. of John, 264 ; Rob., 263

Prior (Priour), And., 145; Edm., 67 , 145; Elnr., see Ramsey; John, 145; Ric., 80 ; fam., 145 ; see also Pryor

Prison Commissioners, 279, 281

Prittlewell, priory of, 276

Pryor, Mrs. L. F., $142 n, 144 n$

Pryors, in Lambourne, $73,78,81$ 82,236

Pugh, R. B., $77 n$

Puller, Sir Chris., $288 n$; Lady Louisa Giles, 254, 288, 29

Purca, Eliz., 60

Purcas, Wm., $200 n$

Purle, Alice dau. of Wm., 192; Wm., I92.

Putchin, see Pochin

Puxon, E. W., 68; his w., 69

Pykenham, Eliz., ? m. John Heron, 91; Geo., 91 ; John (d. 1436), 91 ; John (fl. 1445), 9I; Kath., see Barrington, $9 \mathrm{I}$; Margery dau. of Thos., 91; Margery w. of John, 91 ; Thos., 91

Pykeryng, Hugh, 266; Sir John, 266

Pynchon, Wal. and his w. Joan, 278

Pyrgo (Pirgo), in Havering-atte-

Bower, 106, 230

Pyrle, John s. of Rog. le, I 18

Quakers, see Society of Friends Queenhithe (Lond.), 206, 207

Rabett, Ann m. Ric. Stane, 179 Radbourne, Mr., $\mathrm{IO}_{4} n$

Radcliffe, Edw. Earl of Derwentwater, 211; Hen. Earl of Sussex, 81; Lady Mary m. Wm. Petre, 211,$212 ;$ Rob. Earl of Sussex, 8 I

Railways, 2, 9, 19, 21, 22, 58, 64, 74 $114,155,158,209,250,25 \mathrm{r}, 26 \mathrm{I}$, 286

Rainald (fl. 1086), 204, 205

Rainald, Aubrey dau. of, m. Eus, de Selflege, 205
Rainham, see Launders

Rainsford, Ric., 295

Ralf (Ralph) (fl. I 086 ), 59, I I8, I3 I, 286

Ralph, Gregory s, of, 253

Ralph, Ric. s. of, 262 ; his w. Cecily, 262

Ralph s. of Peter, 262

Rampston, Rob., 34, 42, 122, I 28

Ramsden, Sir John and his w. Anne, I 99

Ramsey, Elnr. m. I Ralph Wrytell 2 Ric. Prior, 89; Joan w. of Rob. 95; John (fl. 1412), 89; John (fl 17 th cent.), 134; Mary m. Si Wm. Boughton, 134; Rob. (fl. 1406), 89; Rob. (fl. 1 43 1), 89, 95 ; Wm., I 34

Randal, Sam., 148

Ranulf, brother of Ilger, Io

Rattee, Revd. J., ro5-6

Ray, John, 4I; Revd. P. W., 61, 62; Rob., 132

Rayleigh, 157, 276

Rayleigh, honor of, $234,276,277$, 278

Rayment, Geo., 295

Rayner, Edw., I68; Mary, 63, 222

Read, Geo. (f. 1721), 16; Geo. (f. 1954), 200; John Tysoe, 254

Rebotier, Chas., 60; David, 6o; Esther, 60

Red Cross convalescent home, 66

Redington, Thos., 108

Redman, John, 6o; Mary m. Craven Ord, 6o, 6z

Rees, Revd. E. B., $276 n, 281,282 n$

Reeve, Edw. (f. 1849), 245, 246; Revd. E. H. L. (d. 1936), 242, 245 246, 247, 249; Revd. E. J. (d. 1893), 242, 245, 246, 247, 248; Jos., 93

Refham, John de, 211,2 I 4; Richer de, 211,214

Reformation Church Trust, 107

Reynold, Abbot of Waltham, 251, 252

Reynolds, John, 275

Reyntot, Edw., I 8 ; Geoff., I2I

Rhode Island, U.S.A., 94

Ribadeneira, Pedro de, 21 I $n$

Rice, John ap, 264

Rich, Anne m. Edw. Earl of Manchester, I8I; Anne m. Sir John Barrington, Bt., 135; Chas. Earl of Warwick, $5,85 n, 135,181$; Essex m. Dan. Finch, Earl of Nottingham, 135; Frances $\mathrm{m}$. Nich. Leake, Earl of Scarsdale, 135; Hen. Earl of Holland, 224; Kath., see Knevett; Mary, Ctss. of Warwick, see Boyle; Mary m. Sir Hen. St. John, Bt., I 35 ; Sir Nat. (d. 1636$), 242,244,247$; Col. Nat. (d. I70 I) 242, 244, 245, 247; Nat. (f. 1706), 244; Ric. Ld. Rich (d. $1567), 5,13,14,47,49,51,52$, $59,85 n, 98,99,100$, I $31,133-5$, $162,172,179,181,183,190,205$, $207,215,216,287$; Ric. (d. I 580), 49, 205 ; Rob. Ld. Rich (d. I 581 ), $49,59,131,134,135,205,207$; Rob. Ld. Rich, later Earl of Warwick (d. I619), 45, 49, 88, I 31 , I34, I 35, 205, 207; Rob. Earl of Warwick (d. 1658), 135, I75 $n$, I8r, 287; Rob. Earl of Warwick (d. 1659), 135; Wm., 125; fam., 287

Richard (fl. 1086), I0, 49, 98

Richard I, 89, 175, I81

Richard II, I35, 191

Richard III, 266; as Duke of Gloucester, I98, 227, 254

Richard, Duke of York (d. I460), I05; his w. Cecily, see Neville Richard, Duke of York (d. 1483),

Richard Fitz William (fl. 1232-3), 234

Richard Fitz William (fl. 1268), 192

Richard s. of Ralph, 262; his w. Cecily, 262

Richard, Wm. Fitz, 234

Richards, Thos., 206

Richardson, David (fl. 1803), 230; David (fl. 1827), 230; John, 230 ; Thos. and his w. Anne, 49

Richmond, honor of, 198

Rigges, Wm., I 79

Risley, Sir John, 20

Rivers, Baldwin de (d. 1216), 262; Baldwin de (A. c. 1243), 210 ; Baldwin de, Earl of Devon (d. 1262 ), 262; Isabel de $\mathrm{m}$. Wm. de Forz, 262; John de (d. 1294), 5, 6, $160,167,182,210,263$; John de (d. 1314 ), 160 $n$; John Ld. Rivers (d. c. 1322), 160, 211,287 ; John de (fl. 1334), 211, 216; John (f. 1649), 254; Margery de, see Fitz Gerold; Maud de, see Lucy; Olive, see Carleton; Ric. de (d. 1221 or 1222), 160, 210; Ric. de (d. by 1243), I60, 167, 210; fam., 5, 262 Roach, Rebecca, 223

Roast, Steph., 98

Robert (fl. I086), 276

Robert, Abbot of Tilty, 29

Robert, Abbot of Waltham, 25 I $n$ 252

Robert, Earl of Gloucester, 59, 151 \% his w. (Mabel), I 5

Robert, Rector of Theydon Mount, 281

Robert Fitz Hamon, 15 I

Robert Fitz Wimarc, 234, 276

Robert, Walter Fitz, 25

Roberts, Mr., 119

Robessart, Sir Lewis, I I

Robinson, Edw., 272; Revd. Jas., Iro; John, 14; Rev. Thos. Jas., 110

Roche, Thos., 180

Rochester, Alice de m. Rob. de Scales, 98; Edw., 12; Eus. de, 98 ; Gresilda, see Wrytell; John f. of Wm., II, 51 ; John s. of Wm., II 12, 14; Ralph de, 98 ; Ric. de, 98 ; Rob., 225; Wm., 11, 5 I

Rochester, bps. of, 290

Rochester (Kent), Castle of, 276

Rochford, I 53

Rochford, earl of, see Zuylestein

Rockells, in Willingale Doe, 180

Roddington, Thos., go $n$

Rodgers, John, $305 n$

Roding, riv., 1, 2, 18, 19, 43-45, 63 $64,68,72,73,110,129,139,140$ $141,142,143,150,151,155,171$ $172,173,174,181,183,188,197$ $198,203,208,209,210,215,222$ $233,234 n, 240,249,259,260$, 261,275

Roding, Abbess, $\mathrm{I}, 4,5$, I88-97 Abbess Hall, 190; adv., 193-4 agric., 188, 189; Bp. Compton's census, 31 I ch. 103-5; Cockerells, 189, 195; hearth taxes, 304 $305,307,308$; hos., I88-9, 190 192, 193, 194, 196; inds., I89-90 mans., 6, 7, 190-3, 196; medieval taxes, 300-2; noncf., $137,195-6$ par., 188, 197; par. govt. and poo rel., 196, 22 I $n$; pop., I88; posta svces., I 80 ; pub. svces., I 89 rect., 194 ; roads, 189 ; sch. 197 stage coach suces., 189 ; top. 188-9; woods, 7, I 88-9; worthies, I90; see also Berwick Berners, Rookwood Hall 


\section{INDEX}

Roding, Aythorpe, 195

Roding, Beauchamp, I, 99, 197-203 adv., 200-r; agric., 198; Bp. Compton's census, $311 ;$ ch., 2,00-2; hearth taxes, 304, 307, 309; hos., 197-9, 200, 201, 203; mans. $6,7,182,192,198-200$; medieval taxes, 298, 300-2; par., r 97, 20r; par. govt. and poor rel., 202; pop. 197; postal svces., 198; pub. svces., 198; rect., 201 ; roads, 189 198; sch., 197, 202-3; Shallow Bridge, 198; top., $197^{-8}$; see also Bird's Green, Frayes, Horners, Longbarns

Roding, Berners, $181,182,188,190$, 191, 194, 197, r 98

Roding, High, see New Hall

Roding, Leaden, $157,189,195$

Roding, Margaret, 2, 3, 188, I89, r 95; see also Marks Hall

Roding Morrell, in White Roding, 4 $6,188,298,300-2,304,307,309$

Roding, White, 4 , 188, 189, 195-6, r 97; see also Colville Hall, Roding Morrell

Rodinges (Domesday village), 2,188

Rodings, the, $43,155,158,188$

Rodney, Hon. Sim., $64 n$

Roebuck, Revd. E. B., 293

Rogate (Suss.), 206

Roger Fitz Ailmar, 121

Roger (A. 1086), 46, 51, 52, 105, 175

Rogers, Geo., 130, 133; John ( $f$ 1548), 270; John (fl. 1649) and his w. Eliz., 200; Ric., 275; Mr., 272 ; Revd., 127

Rohrweger, Julius, I 17

Roinges, Geoff. de, r91; Wm. de, r9r

Rokewood, Thos., 99

Roland, Nic., 289

Rolfe, C., architect, 164; Eliz., see Salyng; Wm. (f. 1553), 215 ; Wm. (f. 1629$), 27$

Rolls Park, see Barringtons

Rolte, Wm., 25, 29, 153

Romford, 19, 83, 139, 141, 142, 449 $158,174,222,223,225,228,233$ 276 ; see also Harold Hill, Marks

Romford Gas Co., 65, I 42, 223

Rookery, the, see Withers Pawne

Rookwood, baron, see Selwin-Ibbetson

Rookwood Hall, in Abbess Roding, $7,188,189,190,192-3,195,198$ 200

Root, Mr., $35 n$

Roper, Gertrude Trevor, Baroness Dacre, m. Thos. Brand, 49, r 91

Rose w. of Eudo dapifer, 191

Ross, Revd. Geo., r95; Revd. Iauchlan, 195

Round, J. H., 59, 159

Rous, Agnes w. of John le, 152 John le (d. by 1311), 152; John elder s.. of John le (d. by $13 \times x$ ), 152; John younger s. of John le (d. by 1332), 152; John le (f. 1366), I 52, 288; Louisa, see Hatch; Maud w, of John le, r 52 ; Nich. le, r52; Ric. (fl. 1490), r 52 ; Rob. le, 152 ; Thos. (fl. I 473), I52; Wm. John, 26; Wm. Rufus, 26; see also Caune (alias Rous)

Rouse, Clive, 83

Rowe, Geo. Rob., 24; John, 38 ; Miss, $193 n$, г $96 n$

Rowenho, in Stanford Rivers, see Littlebury

Rowley, John, 99

Roxwell, 153,200 ; see also Skreens

Royal Air Force, 14, 18, 26, 76, 284-6, 292

Royal College of Physicians, 178 of, 255,256 178 2 I 1 ; John of, 2 I 1 (Lond.), rog

St. Ives (Hunts.), 192 Paulet, Bt., 228 135 $84-85$ Stillington 290, 291 Neuton of, 134 $106 n, 178$ see Levenoth Montagu Neville
Salisbury, Revd. Wm., I37-8

Salmon, Revd. Rob., $186 n$

Salyng, Alice, 215 ; Alice w. of Augustine, m. 2 Wm. Atwood, 215 ; Alice w. of Ric., 217; Augustine, 215; Eliz. m. Wm. Rolfe, 215; John f. of Ric. (f. c. 1398), 214 ; John s. of Ric. (fl. 1405), 2 1 4, 215 ; John (f. 1469-70), of Merton (Surr.), 215; John (fl. 1469-70), of Stanford Rivers, 215 ; Kath. $m$. Geo. Johnson, 215; Lorc w. of Ric., m. 2 John Bromhale, 214 , 215 ; Ric. s. of John (f. 1398 ), 214 ; Ric. (d. by 1405), 67, 214, 2 r7; Ric. (fl. 1405), 214,215 ; Ric. (d. 1528), 215 ; Rog., 215 ; fam., $67 n$

Samford, Ric., 207

Sammes, Edw., 63, I56, 164, I71; Mr., innkeeper, 219

Sampforth, Ric., r8o; see also Sandford

Sabine, Wm. fitz, 140

Sadler, Sir Ralph, 81, 153

Saffron Walden, see Walden, Saffron

St. Albans, bps. of, roo, r 27, 290

St. Andrew, Cornhill (Lond.), $213 n$

St. Aubyn, Alice de, see Sergeaux

St. Bartholomew, Smithfield, priory

St. Bartholomew's Hospital (Lond.),

St. Benet's Hulme Abbey (Norf.), 79

St. Botolph's, Aldgate, see Aldgate

St. Botolph's Priory, Colchester, 32

St. Davids, bp. of, see Mainwaring

St. Edmund, see Edmund

St. Edmunds, Fulk of, 2 I I ; Jas. of,

St. George's Chapel, Albemarle St.

St. George's, Hanover Square (Lond.), 204, 205, 206

St. Hilary, Pet. de, 89

St. John, Mary Lady, see Rich; Sir Hen., Bt., 5 ; Oliver, r 90

St. John (later Mildmay), Sir Hen.

St. John's Abbey, Colchester, I9I, 194; abbot of, see Ardeley

St. John's College, Cambridge, ró,

St. John's, in Lambourne, 73, 77-78,

St. Margaret, see Margaret

St. Martin-le-Grand (Lond.), college of, $159,18 \mathrm{I}, 210 n$; dean of, see

St. Mary, Clerkenwell, priory of,

St. Michael's, Cornhill (Lond.), 242

St. Neots (Hunts.), 256

St. Paul's Cathedral, 32, 67, 142 , $143,145,146,147,151,1_{52}, 1_{72}$, 179,260 ; dean of see William

St. Paul's Walden (Herts.), see Hoo

St. Peter's, York, treasurer of, see

St. Quintin, Wm. (d. 1859), 88, 90; see also Darby (later St. Quintin)

St. Stephen, Caen (France), abbey

St. Sulpice, abbey of (France), 88; abbesses of, see Amice, Mabel

St. Thomas's Hospital (Lond.),

St. Tronius, Mat. de, 28; Rose de,

Salisbury, bps. of, see Hamilton

Salisbury, ctss. of, see Margaret,

Salisbury, earls of, see Montagu, munds, 224, 229

Sandale, John de, r6o

Sanders, J., $34 n$

Sandford, Edw., 150 n, r80; John, 180 ; fam., 180; see also Samp-

Sandwich, Agnes de, see Crevequer: John de (fl. c. 1235), 131 ; John de de Segrave, 131, 132, 133; Nich. de, 132; Nich. s. of Nich de, 132

Sanford, Alice de, m. Rob. de Vere, Earl of Oxford, 31 ; Cecily de, 31 ; Gil. de, 31; John de, 31; see also Sandford

Sarto, Andrea del, 136

Saumford, Rog. de and his w. Joan, 213

Saunders, Fran., 30; John, 28

Saunford, Emma, see Oger; Joan de m. Waleran de Monceux, 205

Savile, Eliz. m. John Finch, 212; Mary, see Banks; Sir John, 212

Savill, John, 49; Lawr. L., 28; Phil. (d. c. 1922), 43; Phil. (fl. 1926), 28; Thos., 74

Sawbridgeworth (Herts.), 158

Scales, Alice de, see Rochester; Rob. de (d. by 1250), 98; Rob. de, Ld. Scales (d. I 325), 98 ; Rob. de, Ld. Scales (d. 1369 ), 98

Scarsdale, earl of, see Leake

Scawen, Lewis, 90; Mary, see Foster; Rob., 90; Thos, 90

Schaefer, Revd. Father, 166

School boards, 39-41, 65, 71, 86, 126, 203

Schooling, John, 132; Wm., I 32

Schwier, Ernest, r 32 ; fam., 132

Sclater, Revd. Chris., 124-5; Revd. Wm., 125

Scohies (Escoiis, Scociis), Wm. de, 131,134

Scott, Anne m. Revd. Wm. Derham 78 ; Eliz.m. Sir Edw. Aleyn, Bt., 32 235; Eliz.,m. Wm. Bodle, $32 n$; Eliz. see Cheyne; Geo. (d. 1534), 3 I Geo. (d. 1588), 19; Geo. (d. Feb 1589), 31, 32, 235 ; Geo. (d. Déc. r 589), 32; Geo. (fl. 1625), 99; Geo (d. I648), 32 ; Geo. (d. 1683), 32, 34 Geo. (d. 1727 ), 32 ; Geo. (d. 1780 ) 32, 78; Hugh, 31 ; Jane, see Gibson John, 3 I , 235; Margery w. of Wm. 235, 237; Mary, 32, 235; Rog., 31 32 ; Thos. (d. 1512 ), 235 ; Thos. (d. 1733), 32, 78; Wal., 31, 235; Wm. (d. 1491 ) $31,32,235,237$; Wm (d. 1597 ), 32; Wm. (d. I725), 32 34,78 ; fam., 33
Samson, Abbot of Bury St. Edforth, Sanford (f. 1349), 132; Juliane de m. John

Saward, Jacob, 78 


\section{A HISTORY OF ESSEX}

Scrope, Alice le, Baroness Scrope m. Sir Hen. le Scrope, 47; Eliz. dau. of Alice, Baroness Scrope, 47; Eliz. sis. of Geoff. le, Ld. Scrope, 47; Eliz. w. of Thos. le, Ld. Scrope, 47; Geoff. le (fl. c. 1337), 46; Geoff. le, Ld. Scrope (d. I 5 r 7), 47; Hen. le, Ld. Scrope (d. I392), 46; Hen. le, Ld. Scrope (d. I4 I 5), $44,45,47,54$; Ivetta, m. John Hotham, 46; John le, Ld. Scrope and his w. Eliz., 47; Margery w. of Steph. le, Ld. Scrope, 47; Ralph le, Ld. Scrope and his w. Elnr., 47; Sir Ric., z66; Sir Steph. (ff. 1387), 266; Steph. le, Ld. Scrope (d. 1406), 46; Thos. le, Ld. Scrope (d. I475) and his w. Eliz., 47, 5 I ; Thos. le, Ld. Scrope (d. I493), 47 Scruby, Jas., r 58 ; Maria, I 58 ; Wm., 158

Scurlocke, Rowland, I 99

Sealy, Mrs. Geo., I06

Searle, And. (d. by 1706), 291; Capt. And. (A. c. 1706), 29I ; And. s. of Capt. And. (f. c. 1706), 29I; Edw., 29I; John (d. r 59I), 289, 29I; John (d. 1616), 289, 291; John (d. I665), 29I, 292; John (f. 1698), 291; John (? t. 1703), 154; John (fi. I 706), 29I; Revd. John (A. I706), 29I, $295 n$; John (A. 1772), 153; Mary w. of Thos., 289; Mary Anne m. Jas. Flint I 53 ; Pet., 78; Sam. (f. 1624), 269 Sam. (f. I636), 289; Sam. (fl. I680), 289; Thos., 289; Dr., 295

Sedley, John (d. by I 5 I 4 ), 145 ; John (d. I58I), I45; Wm. (A. I 547), 145; Sir Wm., Bt. (d. I6I8), I 45 I 50; Sir Wm., Bt. (d. I656), I45

Segrave, John de (d. 1343), I32; John de, Ld. Segrave (d. I325) 132; John de (d. 1349), I 32, I33n; John de, Ld. Segrave (d. I 353) 133; Juliane de, see Sandwich; Mary de, 132

Selflege (Sellea), Amy de m. Oger Fitz Oger, 205; Aubrey de, see Aubrey dau. of Rainald; Emma de, 205; Eus. de (d. by II 34), 205 ; Eus. de (fl. I I 34), 205; Sar. de m. Mich. Fitz Oger, r92; Wm. de, I 92, 205

Sellar, David, I 47

Sellea, see Selflege

Selwin, Chas., I 93

Selwin-Ibbetson, Sir Hen., Bt., later Ld. Rookwood, I 17, I 93

Senewe, Eliz. m. John Hill, 26; John, 26

Sergeaux, Alice de m. I Guy de St. Aubyn, 2 Ric. de Vere, Earl of Oxford, 3 Sir Nich. Thorley, I I, I 3

Serjaunt, Rog. le, $30 n$

Serjeanties, $31,131,175$

Serjeants, see Stocktons

Serlo (fl. r 086), 59

Settlement, patterns of, I, 2, 63 r 97, 240; see also Villages, nucleated

Sewardstone, in Waltham Holy Cross, II 5

Sewell, Edw., 78; Sam., 78; Sar., 78

Sexi (fl. 1066), 105, I 3 I

Sewerage, $10,22,45,58,65,75,88$, I I 3, I 30, I 42, I 58, I 74, I89, 209 $223,250,26 \mathrm{r}, 276,286$

Seymour, Edw. Duke of Somerset, Protector, 227, 279; Jane, queen of Henry VIII, see Jáne

Shaa, Álice m. Wm. Pooley, 290; Audrey m. I John Wrytell, ? Wm. Ayloffe, r77; Sir Edm. (A I486), 243 ; Edm. (fl. c. I 515 ), 290; Sir John, I77, I78, 243, 290; Lore,
see Wentworth

Shadwell (Mdx., later Lond.), 35

Shamelesford, Ric, de, 256

Shanke, Rob., 142

Shardelowe, Sir John, 93; John s. of Sir John, 93

Sheering, I93

Sheldon, Gil., Abp. of Canterbury, 3 I I

Shelley, Alice Lady, see Belknap; Jane w. of Wm., 243-4; John (d. I 550), 243; John (fl. I610), 243-4 Sir Wm. (d. 1548), 242, 243; Wm. (d. 1597), 242, 243, 247

Shelley, 9 , I 55 , I $59 n$, I79, I80, I 8 I $183,203-8$; agric., 204; adv., 206-7; Bp. Compton's census, 311 ; char., 208; ch., 206-8; common, 203, 204; cycle speedway, 204; hearth taxes, 304-5, 307, 310; hos., 203-4, 206, zo7 man., 6, 134, 204-6; medieval taxes, 297-302; poor rel., 208 $221 n$; pop., 203 ; rect., 207 ; roads, 204; schs., 169, 170,208 ; Shelley Bridge, 204; Shelley Hall, I68, 204, 206; top., 203-4

Shellow Bowells, i 88

Shelton, Humph., I77; Joan, see Ferne; Wm. (d. by 1553), 177 , $216 ; \mathrm{Wm}$. (d. I62I or 1622 ), I77

Shenfield, roo $n, 242$

Shenley (Herts.), 2 r 3

Shepheard, Walwyn, 193

Shereff, Amphyllis, see Nynge; John,

Sherfield upon Loddon (Hants), I 80

Shipton, a pauper, roo

Shirley, John, 264; Margery, see Hampden

Shoreditch (Lond.), 125

Shuttleworth, Hen., 230; John, 2 I 6

Siday, John (d. I689), 200; John (d. 1704), 200; Revd. John (fi. I720), 200, 202; Mary, 200; Wm., $200 n$ Sidney (Sydney), Anne m. Sir Wm.

Fitzwilliam, 260, 261, 267, 271, 274, 289; Mary m. Sir Rob. Wroth, I 7 , I I9, I 20; Sir Phil., I 9 ; Rob. Ld. Sidney, later Earl of Leicester, II9; Sir Wm., 267, 280 Siggiswyk, Sir Pet., 1 57, 185, 201 Simon, Abbot of Bury St. Edmunds, 224

Simon, Abbot of Waltham, 89

Singleton, Revd. G. E., 95

Siric (fl. ro86), 234

Skingle, John, 290

Skinner, Emma m. Wm. Harvey, 30 190; E. W., 35; Mary m. Sir Jas. Colebrooke, Bt., 79; Mary w. of Steph., 79; Mat., 1 34; Rob., 1 34; Steph., 79, 190; Thos., cartographer, 153

Skipwith, Sir Wm. de, 266

Skreens, in Roxwell, 180, 190, 199

Skrene, Alice w. of $\mathrm{Wm}$., 213 ; Eliz. w. of John, m. 2 Ric. Harper, $21_{3}$; John (fl. 1419), 213 ; John (d. I452), 2 I 3 ; John (d. I474), 2 I3; Wm. (f. I 408 ), 21 3 ; Wm. (d. I 43 I), 2 I 3

Slack, Mr., 293

Slades, in Navestock, 67, 141, I42, $144,145-6$

Sleybrond, Geoff. and his w. Rose, 81

Slocock, E, 68; Revd. Sam., 68

Slocombe, Chas., printer, I67

Smart, Benj. (d. by I684), 252 ; Benj. (A. 1753), 252, 258; John (d. by I679), 252; John (A. I 679), 252 ; Jos., 252
Smijth, see Smyth, Bowyer-Smijth Smirke, Sir Rob., architect, 122; Sydney, architect, 122, 256 Smith (Smyth, Smythe), Augusta, 236; Chas. (d. I777), $212 n$; Chas. (d. 1814), 81, 212, 235, 237; Chas. (f. I 84r), 290; Sir Chas. Cunliffe, Bt. (d. 1905), 236, 237 ; Sir Chas. J., Bt. (d. I83r), 2 12; Revd. D., 70; Eliz., see Cely; Eliz.w. of Thos., 246; Fred. and his w., I 23 ; Harriet, 295; Judith, 212, 2 I 4; Revd. J. S. Boys, I $35 n$; Mary, see Crook; Phil. 228; Ralph, 135 ; Ric., 245 ; Rodney ('Gipsy'), evangelist, 123; Sydney, quotation from, ro; Thos. (fl. 1557), 224, 229; Thos. (A. I633), 252; Thos. (A. 1652), 59; Revd. Thos. (d. 1732), 245 ; Revd. Thos. (d. I79 I), 245, 246, 247 ; Wm., 62; W. J., 293; see also Smyth (later Smijth), Bowyer-Smijth

Smyth (later Smijth), Anne Lady, see Hedges ; Bridget w. of Sir Wm 282; Edw. (d. 1652), 278; Sir Edw., Bt., (d. I7I3), 280; Sir Edw. Bt. (d. 1744), 235, 238, $281 n$ Geo., 278; Jane Lady, 282; John (f. I6th cent.), 278; Sir John, Bt. (d. 1838 ), 235, 239, 276, 283 ; Philippa, Lady, see Wylford Revd. Ric. (d. I8I I), 237; Revd. Ric. (fl. I83I-2), 237; Sir Thos. (d. I 577), 278-82; Sir Thos., Bt. (d. I668), 282 ; Sir Wm. (d. I626) 278,282 ; Sir Wm. (d. 1632), 278 282 ; Revd. Sir IVm., Bt. (d. I777) 237; Sir Wm., Bt. (d. 1823), 280 $28 \mathrm{I}, 283$; fam., $28 \mathrm{I}, 282,283$; see also Bowyer-Smijth

Smythe, see Smith

Snaring, Geoff. de, 121 ; Phil. de, I2 I Snelling, Chas., I 47

Soames, Revd. Hen., 204, 207, 208, 236; Nat., 207

Soap making, 242

Society for the Protection of Ancient

Buildings, $130, \mathrm{r} 64$

Socicty of Friends, 244

Soda, John, 252

Solihull (Warws.), see Wolverley

Sombourne, King's (Hants), see Compton Monceux

Somerset, Rob., 278

Somerset, dukes of, see Beaufort, Seymour

Somerset, medieval tax assessments, 300

Somerset House (Lond.), 279

Soper, Rob., 192

Sorrell, Anne w. of Rob., I80; John, I 80 ; Rob., 180; Thos., I 80

South Sea Co., 30, 80,132

Southcote, in Stone (Bucks.), 262

Southwark (Lond.), 254

Spakman, Rob., 33

Sparowe, Eliz., see Prince; Wm., 264

Speed, Eliz., 96; John, 12; Thos.

(fl. I 789), $94 n$; Thos. (fl. I84I) I2, 289; fam., 90

Spencer, Ric., $228 n$; Thos. (f I597), 29; Thos. (A. I64I), 60

Spenser, John le, IO4

Spice (Spyce), Alice, see Mandeville; Clement, 235; Ric. and his $w$ Isabel, 213 ; Rog., 235

Spigurnel, Agnes, see Marcy; Alice m. Wm. de Paris, 289, 290 Clarice w. of Sir Edm., I I; Si Edm. (d. I 296), I r, 243; Edm. (d. I316), z43; Hen., I I, I 4; Joan m. Wm. Gobyon, 243 ; John, I I, 243 Nic., 10, I I, 243; Sir Ralph, 290

Thos., I I, I 4

Spiller, Hen., 2 I I 
Spilsby (Lincs.), I $16 n$

Spooner, Hen., 54

Spring, mineral, 22

Springer, fam., 288

Springfield, 287; Springfield Place in, 269; see also Barnes

Springham, Fran., 228; Jos, 195

Spurgeon's College (Lond.), 36

Spyce, see Spice

Spynay, Alice, 253; Jas., 253 ; Rob., 253; Wm., 253

Stacey, Revd. H., I 96; J., 10; N., 192

Stafford, Anne, Ctss. of Stafford, see Anne; Anne, w. of Humph., Duke of Buckingham, 10, 88, I $77 n_{\text {; }}$ Constance w. of John, Earl of Wiltshire, 2I I, 2I 4; Edm. Earl of Stafford, I9I, 214; Edw. Earl of Wiltshire (d. 1499), 211 ; Edw., Duke of Buckingham (d. 152I), $80,91,161,211,212$; Hen. Duke of Buckingham (d. 1483), I1, 88, I6I; Hugh, Earl of Stafford, I60, 176; Sir Hugh (d. 1420), 214, 216; Humph. Earl of Stafford, later Duke of Buckingham (d. 1460), 10, 88, 98, 211, 214, 216; John, Abp. of Canterbury (d. 1452), 32 ; John, Earl of Wiltshire (d. 1473), 2II, 214; Kath. w. of Hen. Duke of Buckingham, $m .2$ Jasper Tudor, Duke of Bedford, I I, 88; Marg. Ctss. of Stafford, see Audley; Ralph, Earl of Stafford, I 60, 2 I1 215,2 I6, 235, 266; Thos. Earl of Stafford, 160 ; fam., 5

Stafford, earls of, 5, 6, I60-1, 212, 215,216

Stains, J., 223

Stalbroke, Alice w. of Sir Thos., m. 2

Wm. Luke, I78; Sir Thos., 178; fam., 178

Stallibrass, John (f. $1823-4$ ), 290; John (d. 1872), 292; Thos., 290

Standon (Herts.), see Youngsbury

Stane, Alice w. of Wm., I 80; Ann, see Rabett; John (f. 1614), 179 John Bramston (fl. 1862), 45, I 52 I80; Mary Alice m. John Westbrook, I80; Ric. (d. I60I), 179; Ric. (d. I6I4), I79; Ric. (d. I714), $178,179,180,181,184,185$; Ric. (f. 1725 ), I80; Wm. (ค. 1582), 205, 207; Wm. (f. 1675), 178; Wm. (f. 1 125), 175, 178, 180 Wm. s. of Wm. (A. 1 125 ), 180 ; Wm. (fl. 1742), I86; fam. I 75

Stane (formerly Bramston), Revd. John, 45, 49, 152, 176, 180, 204, 223

Stanfield, Revd. Jos., 168, 230

Stanford, Little, in Stanford Rivers, 2, 209, 210,214

Stanford Park, in Stanford Rivers, I 76, 2 I I ; see also Ongar Park

Stanford Rivers, 65, 142, 159,160 , I $77,208-22,275-6$; adv., $182-3$, 216; agric., 209-10; Bp. Compton's census, 311 ; bridges, 209 chantry, 216; char., 62, 171, 2212; ch., 182-3, 216-18; hearth taxes, 305, 306, 310 ; hos., 208-10 $213,214,215,216,218$; inds., 210 mans., $6,88 n, 153 n, 166,172$ $175,176,182-3,209,210-16$ 218-19, 235, 236, 262; medieval taxes, 298-302; mills, 210; par., 208, 216 ; par. govt. and poor rel., 196, $218-21,248$; pop., 17I, 208; postal svces., 158, 209; Prot. noncf., 148, I65, 2 I 8 ; pub. svces., 209; rly., 209; rector of, 79; rect., 182-3, 216, 218; Rom. Cathm., 212, 218 ; schs., 62, 170, 221, 294 Stanford Hall, 58, 182, $210,212-$
13; top., 208-9; Wash Bridge, I 7I, 183, 208, 209; woods, 208, 209 . 210 ; worthies, 210,216 ; see also Barwicks; Bellhouse; Bridges and Piggsland; Little End; Littlebury; Stanford, Little; Stanford Park; Toot Hill; Traceys

Stanlake, Ant., 90

Stanley, Fran., 293

Stansted Mountfichet, 27

Stanton, Hervey de, 224

Staphurst, Eliz., see Broomfield, Nich. (fl. $c$. I 687), 8I; Nich. (f). I7I3), 81,82

Stapleford (Cambs.), $224 n$

Stapleford (Domesday village), 2

Stapleford Abbots, 75, 222-32, 233 ; adv., 228-9; agric., 223; Bp. Compton's census, 311 ; Bourne Bridge, 223, 230, 23I; char., 232; ch., 228-30; common, 223; hearth taxes, 305, 307, 310; hos., 222, $223,225,226-7,228,229,232$; inc., 223, man., $6,78,79,223-8$; medieval taxes, 300-2; mills, 223; par. govt. and poor rel., $221 n$, 230-1; pop., 222; postal svces., 223; Prot. noncf., 83, 230; pub. svces., 223; rect., 229; road, 74 ; Rom. Cathm., 230; schs., 85-86, 231-2, 239; Stapleford Hall, 223 , 225; top., 222-3; Tysea Hill chapel, 229-30; see also Albyns, Battles Hall, Knolls Hill

Stapleford Tawney, I4, I59 $n$, 233-9, 275, 276; adv., 236, 28I; agric., 233-4; Bp. Compton's census, 3 II ; char., 239; ch., 236-7; Cutler's Forge, 233; Great 'Tawney Hall, 233, 235; hearth taxes, $304-5,307,310$; hos., 233, 234, 236; mans., 6, 31, 234-6, 277; medieval taxes, 299, 300-2; mill, 234; par. govt. and poor rel., 22 I $n, 237-8$; Passingford Bridge, 223, 232, 233, 259; pop., 233; postal svces., 233 ; pub. svces., 233; rect., 236; sch., 232, 238-9, 283; Stapleford Tawney Hall, 233, 234, 235; Tawney Common, 233,238 ; top., 233 i see also Suttons

Starkey, Hen, 133: Eliz, w, of Sir Humph., 145; Emma m. Hen. Torrell, 145; Sir Humph., 67, 145 Starkins, Geo., 92, 96

Steeple Aston (Oxon.), 38

Stephen, King, 88, I60, 18

Stepney (Mdx., later Lond.), 33

Stepney Academy (Mdx., later Lond.), 123

Stevens, C., 223; Fran. Worral, 4r ; Ric., 230

Steward, Mr., 200

Stewart, Wm., 273; see also Stuart

Stillington, Rob., Dean of St. Martin-le-Grand (Lond.), I8I; Wm., I 81

Stocktons (Serjeants), in Chigwell, $20,23,30$

Stoke by Nayland (Suff.), 25

Stoke Doyle (Northants.), 274

Stoke, South (Lincs.), 267

Stokes, John (f. 1 368), 263; John (f. 1803), 293; Ric., I 70, I7I; R., 230; Thos., I78, I80; Wm., I 70 ; Mrs., 178

Stokesby, John, 263; Julia, 121

Stokton, John, 30 ; Wm., $3 \circ$

Stonard, see Stoner

Stonarde, see Stoner

Stondon Massey, 63, 68, I 81,186 , 240-9; adv., 245; agric., 24I-2; Bp. Compton's census, 3 I I ; char. 248-9; ch., 245-7; Hallsford
Bridge, I 72, 173, I 74, I8 I $n, 240$ 241; hearth taxes, $305,307,310$ hos., 240-1, 244-5, 248 ; inds. 242; man., 242-5; medieval taxes, $297,299-302$; par. govt. and poor rel., 22 I $n, 247-8$; pop., 241 ; postal suces., 24I; Prot. noncf. 247; pub. svces., $24 \mathrm{I}$; rect., 3. 243, 245; roads, 24I; Rom. Cathm., 240, 243, 244, 247; schs. 248 ; Stondon Hall, I $40,240,24 I$ 242, 244, 246; Stondon House, $240,242,244,245,246,248$ Stondon Place, 240, 242, 243-4 246,247 ; top., $240-1$; worthies, 242 ; see also Marks Hall, in Margaret Roding

Stone (Bucks.), see Southcote

Stone Hall, in Little Canfield, 42 , I 45

Stone, Jollye, 207

Stoner (Stonard, Stonarde, Stonnard), Amy $m$. Geo. Waldron 228; Anne w. of John, 30; Clement, 79, 228; Fran. (d. 1604) $79 n, 228,229$; Fran. (fl. 1612), 79, 228; Geo. 25, I I 8, I 21 , I 22 ; Hen., 229; Joan w. of John, I 22 ; John (d. I 540), II 8, I II, I 22 : John (fl. I 543), 5, 6; John (fl. 1555), 29; John (d. 1579), 25, 30, I 18 ; Kath. w. of John, I22; Lucy see Heigham; Rob., 5; Susan m. Sir Rob. Wroth, 25, 30, i18; fam. 79,228

Stonestreet, Revd. G. G., 24I, 244

Stonhurst, Ric. de, 266

Stonnard, see Stoner

Storey, 'Goodman', 109

Storkey, Mrs., 203 n, $206 n$

Stortford, Bishop's (Herts.), I30 I 58, I 89, 204; see also Bishop's Stortford Gas Co.

Strachey, Rt. Hon. John, M.P., 82

Stradbroke, earl of, 26

Straker, Mr., 36

Stratford Bow, in Bromley (Mdx. later Lond.), Priory of, 8 1, I 53, I 94

Stratford, in West Ham, 78, I Io, I I 4, I $55,164,212$

Stratford Co-operative Society, see London Co-operative Society

Stratford Langthorne, in West Ham, abbey of, 28, I 8,12 I; abbots of, 28 , see also Etherwey

Stratten, Revd. Jas., 2 I 8

Streatham (Surr.), I90

Strelley, Nich. and his w. Eliz., 47

Strickland, Marrock, 69

Stringer, Ant., 181

Strype, Revd. John, 251, 256

Stuart, C. C., 273; Humph., 26; see also Stewart

Stubbs, Cath., see Dellar; John, 272 ; Wm., Bp. of Chester, later Oxford, I 43, I 46

Stucle, Wm. de, 99

Stukeley, Wm., antiquary, 140

Suasso, fam., II9 $n$

Sudbury, Wm. and his w. Cecily, ig9

Suen (fl. I 066), 262

Suffield, Wal. de, Bp. of Norwich, 79

Suffolk, duke of, see Brandon

Suffolk, lands in, 205 ; medieval tax assessments, 302 ; migrants from, 38

Sulyard (Suliard), Ann m. John Wright, 69; Anne w, of Edw., 80; Edw. (d. I 5 I6), 9 r; Edw. (f. I 574), 80, 9 I ; Eliz., see Barrington, 9I; Eus., 80, 91, I6I; John (f c. I412), 9I; Sir John (d. I488) 91 ; John (fl. I 547), 80; Mirabel w. of 'Edw., 94; Sir Wm., 80, 91, I03 $n$; fam., $80 n$ 


\section{A HISTORY OF ESSEX}

Sunbury (Mdx.), 90

Surrey, earls of, see Warenne

Surrey, mans. in, 15 I $n$; migrants from, $3^{8}$

Surridge, Dan., 2 10 $n$; J., 223

Sussex, 259

Sussex, earls of, see Radcliffe

Sutcliffe, Revd. Rob., 84

Sutton, John de and his w. Maud (f. I291), 235; John s. of John de (f.. 129r), 235; John de (fl. 1318), 227; John de (fl. 1324), 266, 277 ; Sir John de (fl. 1348), 277; Sir John de (f. 1 376 ) , 76, 79; John de (d. 1393), 227; Marg. w. of John de, 277; Margery de, see Battail; Oliver de, $\mathrm{Bp}$. of Lincoln, 277; Ric. de (f. 1308), 277, 278; Sir Ric. de (d. 1396), 144, 227 ; Rob. de, 277; Roland de, 277; Thos. de, 227; Wm. de (A. 1258), 277; Wm. de (f. $c$. 1287), 213; Wm. de (d. by 1318 ), $75,227,288$; fam., 145

Sutton, 287

Sutton (Surr.), 133

Suttons, in Stapleford Tawney, 72 , $81,212,217,233,234,235-6,238$ 239

Swan, John, murderer, $24 n$

Swein of Essex, 234, 276

Swinburne, Algernon C., 162 ; Emilia Eliz. Lady, see Bennet; Adml. Chas., 162; Lady Jane, 162 ; Sir John, Bt., I6r, I66, I67

Switzerland, 245

Sydney, see Sidney

Symonds, Joan w. of John, 290; John, 290

Sympson, Joan, 19, 29, 42; Nich., $37^{n}$

Tabor, Jas., I $44 ;$ Wm., I 84,187

Tabrum, Litchfield, I45, 149; Rob., 206

Tailleur, Adam le and his w. Joan, 199

Takeley, 245

Talbot, Wm., $129 n, 136,139$; Mr., $137 n$

Taleworthe, Anne de, see Battail; Pet. de, 227

Tanner, Lilla, I64; Miss L. W., 164

Tany, Emma w. of Gil. de, $46 ;$ Gil. de, 46, 175; Graeland de, 46, 52; Hasculf de (f. 1094), 46, 52; Hasculf de (d. I 192-3), 46, 52; John de, 25I: Laur. de, 234 ; Marg. de m. John de Drokensford, 234; Marg. de, see Margaret, dau. of Wm. Fitz Ric.; Maud w. of Hasculf de, 46, 52; Pet. de, $25 \mathrm{I}$, 252; Ric. de (d. 1270), 234, 277 ; Ric. de (d. 1296), 234, 277; Rog. de, 234

Tarling, - (a builder), 94

Tasburgh, Wm., 26


$166 n$

Tattam, Revd. Hen., 216

Taunton (Som.), 38

Tavare2, Revd. Dr., 70

Taverner, Eliz. w. of Rob., 77 ; Rob. (d. 1556), 77, 78, 81; Rob. (f. 1625), 78; Thos., 77, 78; fam., 75 , 81

Taylor, Ann (f. 1816), 244; Ann m. Jos. Gilbert, 159, $165 n$; Revd. Isaac (d. 1829), I $37 n, 159,162$, $165,185,210$; Isaac (d. 1 865), 159 , 210, 218; Jane (d. 1793), 244; Jane (d. 1824), I 59, 165; Josiah, 78; Phil., 230; Dr. Rob., 92, 99; Wm. (d. I 752), 244; fam., I 65, 246
Taylor (later Taylor-How), Wm. (d. 1777), 241, 244

Tee, Jas. Herb., 123,124

Telegraph and Telephone services, $22,45,65,75,114,130,142,158$, $209,223,233,241,250,261,286$

Tempest, John, 212, 215

Temple, Revd. Wm., 148, 218; Mr. $273 n, 274 n$

Tendring, 49

Terays, Beatrice de, 277; Hen. de 277

Terling, Cecil de, 105

Tey (Teye), Mary, see Curzon; Ric. de, 263, 266; Sir Thos., 77

Thames, riv., valley of, 18

Theydon, Beatrice de m. Rob. de Briwes, 277, 28I; Galiena de, see Merk; Gil. de (f., 1297), 152; Gil. de (d. by 1299), 253; Gil. de (H. 1323), 253; Gregory de, 253; Hen. de, 276; Paulinus de, 276, 277 Rob. de, 276; Rose de, 253; Wm. de, 276

Theydon (Domesday village), 2

Theydon Bois, Lawr. de, see Boys

'Theydon Bois, 2, 80, 86, I1 15,249

$58,266,286$; adv., 255; agric. $25 \mathrm{r}$; Birch Hall, 249, 252-3; Bp. Compton's census, 3 II; char. 258; ch., 255-7; forest, $25 \mathrm{I}$; hearth taxes, 304-5, 307, 310; hos., 249-50, 253, 254, 255, 258 ; inc., 250, 25I; mans., 251-5; medieval taxes, 296, 298-302; poor rel., 257; pop., 249, 250; postal svces., 250; Prot. noncf., 257; pub. svces., 250-I; rly. 250,251 ; rect., 255 ; roads, I9, $72,74,113,250,250,260$; Rom Cathm., 257; Rural Preservation Society, 249, 25I; schs., 257-8 Theydon Green, 249, 250, 256 , 257; Theydon Hall, 25 r, 252, 253 258; top., 249-50; Village Association, $25 \mathrm{I}$; worthies, $25 \mathrm{I}$; see also Gregories

Theydon Garnon, 2, 4, 255, 258-75, $278,284,288-9$; adv., 264, 269 . agric., $26 r$; Bp. Compton's census, 3 II ; char., 274; ch., 254, 269-7I fair, 26I; Fiddlers Hamlet, 259 260, 26I; forest, 259; Garnish Hall, 26I, 264, 265; hearth taxes, $303,305,308,310$; hos., 259-60, $265,268,269$; inc., $26 \mathrm{r}$; mans., 7 $67,253,254,262-9$; market, 261 medieval taxes, 299-302; mills, $260,26 \mathrm{r}, 264$; par. govt. and poor rel., 27I-3; pop., 260; postal svces., 26I ; Priests' House, 271 pub. svces., 261 ; rector of, $230 n$ rect., 260; roads, 260-I ; sch., 273 283: Theydon Bridge (Mason's Bridge), 26r ; top., 258-6r; worthies, 261; see also Coopersale, Coopersale House, Gaynes Park, Hemnalls

Theydon Mount, 2, 258 $n, 259$ 275-83; adv., 236, 28r ; Bp Compton's census, 3II; brick making, 276; chantry, 28r ; char. 239 ; chs., $281-2$; fair, 276,277 hearth taxes, 305,308 , 310; hos. $275,276,279-81$; mans., 6,235 276-8r ; market, 276, 277; medieval taxes, 296, 298, 300-2; Mount End, 275, 276; Mount Hall, 278 279,281 ; par. govt. and poor rel. $282-3$; pop., 275 ; pub. svces., 276 rector of, see Robert; rect., 233 236,281 ; roads, 276 ; schs., 239 273,283 ; top., 275-6; see also Hill (1)

Theydons, the, 2,284
Thistlewood, G., 10

Thoby Priory, in Mountnessing, 210

Thomas of Woodstock, Earl of Essex and Duke of Gloucester, I9I; his dau. Anne, 191; his w. Elnr., see Bohun

Thomas, Sir Godfrey J. V., 108; John, 67

Thomas \& Storrs, $271 n$

Thomlinson, see Tomlinson

Thompson, Arabella, see Aleyn; Dorothy, see Cooper; Fran., 235; Ric., I3; Wm., and his w. Agnes, 13

Thorley, Alice, see Sergeaux; Kath. m. - Estoft, 11, 13; Sir Nich., I1, 13

Thorn Electrical Industries, 76

Thorneton, Rob., I90

Thornhill, Isabel, see Battail; Rob., 177

Thornthwaite, Mr., 770

Thornwood, in North Weald Bassett, $4,5,284,285,286,292,293,294$ Thorogood (Thorowgood, Thorrowgood), Abraham, 90, 95; Catlyn, 74, 80, 82; Sir John, 178; Pate, 80; Sim., 294; fam., 75

Thorold, Rebecca, see Green, Thos., 147

Thorowgood, see Thorogood

Thorp, Thos., 213

Thorpe-le-Soken, 297

Thorrowgood, see Thorogood

Thoumaian, Revd. G., 4 I

Threshers Bush, see Thrushesbush

Thrifts, Old, see Frith Hall

Throckmorton, Eliz. w. of Geo., ro6; Geo. (f. 1676), 106, 108; Geo. (A. I703), 106; John, 106; Thos., 106; Wm., 106

Throgmorton plot, 243

Thrushesbush-(Threshers Bush), in High Laver, 87, 95, 195

Thurgot (A. c. 1043-5), I 59

Thurkettle, Rob. and his w., 69

Thurloe, John, 190; Thos., 190

Thurstan s. of Wine, 1 59, 166

Thynne, Sir John, 278

Tilbury, 155, 172

Tilty, 78

Tilty Abbey, 29; abbot of, see Robert

Timms (later Hervey-Elwes), John, 253

Tindal, Rob., 132

Tipper, Wm., r9o; Lady, 149

Tipping, Ann, Lady, see Cheeke, 288 ; Kath. m. Thos. Archer, Ld. Archer, 288; Sir Thos., Bt., 288

Tirell, Sir Hen., 162; Rob. and his w. Joyce, 99; Revd. Wm., $65 n$, $68,69 n, 72 n$; see also Tyrell

Titanic, sinking of the, 166

Titchmarsh (Northants.), 77

Todd, John, $78,8 \mathrm{r}$

Toesni, Ralf de, 105

Toheham, Maurice de, 59

Toke, Nich., 201

Tolleshunt d'Arcy, I 45, 263

Tomlinson (Thomlinson), Alice, I88, 249; Jas., 204, 206207 ; Josiah, 184 ; J. H., 207; Ric., 204; fam., 204, 206, 207

Tooke, Revd. John, 8r, 84; Rob., 81 ; Revd. Thos., $81,82,83$; Miss, see Calvert; fam., 83

Toot Hill, in Stanford Rivers, 5, 58, $159 n, 208,209,210,220,221$, 259, 260

Topping, Revd. W. D., $95 n$, $107 n$, $108 n$

Torkeseye, Mat. de, 29

Torrance, Mat., 104, 106, 178 
Torrell (Torell), Anne m. Hen. Joscelin, 145: Anne, see Mordaunt; Emma, see Starkey; Hen. (d. I481), 145; Hen. (d. 1526), I 45 ; Humph. (A. 1503), I 45 ; Humph. (d. 1517), 287; Humph. (d. 1544), I45; Thos., 297

Torrells Hall, in Willingale Doe, I 82

Tottenham (Mdx.), 4I

Toulouse (France), 270

Towton, Battle of, 266

Tozer, Revd. Isaac, I65

Traceys, in Stanford Rivers, 212 , 215-16, 236

Tracy, Agnes de, 215; Hugh de (f. 1315), 215; Hugh de (fl. I353), 2 I5; Jas. de, 2 15; John de and Margery his w., 215; Mabel w. of Thos. de, 215; Margery de, 215 ; Thos. de (d. by 1335), x76, 215 ; Thos. de (d. 1353), 215 ; Wm. de, 215

Trafalgar, Battle of, 24, 138

Traherne (Trayherne), Phil. (f. 1677), I67; Phil. (fl. 1694), 5; Rowland, 5

Travers, Adam, Archdeacon of Exeter, 264

Trayherne, see Traherne

Trebeck, Revd. And., 204, 205, 207;

Revd. Jas., 204, 205, 206, 207 Mary, see Green

Trebizond, abp. of, see Errington

Tregoz, Eve, see Valeynes; Nich., 263

Tretheck, Joan, see Brent; John, I3;

Wm., 13

Trigg \& Moore, builders, 69

Trinity College, Oxford, I43, I46

Trotter, Raymond E., 289

Tuck, Zach, 234

Tudor, Jasper, Duke of Bedford (d. 1495), I0, 243; Kath., see Stafford

Tugendhat, Mrs., $60 n$

Tuke, Sir Brian, 224, 229

Tunbridge, Josias, 90; Thos., 90

Turner, Eliz., see Golsborough

Ric., 164; Wm. (fl. 1657), 267;

Wm. (f. 1682), 193; Wm. Fred.

(d. c. 1905), 117,128 ; Mr., archi-

tect, 237; - \& Son, architects, 10I

Turnpikes, 19, 20, I I 3-I 4, I74; see also Epping and Ongar Highway Trust, Middlesex and Essex Highway Trust

Turpin, Dick, highwayman, II 4

Turstin the Red, 143

Turvin, John, $93 n, 183$

Tuson, Thos., 122

Tusser, Wm., I45

Twickenham (Mdx.), Io6

Twyneham, W. H., 226; W. H., jr. $226 n, 227 n, 234 n$

Tyffin, Mary, see Jenour; Wm., 27

Tylby, - , a clerk in holy orders, 254

Tyle, Alice de, see Enfield; John de, I I, 99; Ralph de, I I, 99

Tylney, earl, see Child

Tyng, Wm., 214

Tyrell, Edw., 297; Sir Thos. (A 1 464), 1 I; Sir Thos. (f. 1 482-3), 290; Sir Thos. (fl. I 500), 264 ; Thos. (f. I 529), 264; see also Tirell

Tyro, Mr., I6

Tyser, Wal. P., I42, 144

Tyson, Revd. Mic., $82 n$

Ulmar (fi. 1066), 190, 262

Ulsi (A. r 066 ), I 43

Ulster, ctss. of, see Burgh

Ulvric (f.. I 066 ), I I 8

Ulwin (f. I 066 ), 25

University College, Oxford, $245 n$
Upminster, 78

Upper Hall (Lady Hall), in Moreton, 130, 131

Urania by Mary, Lady Wroth, I I 9 , 120

Uvedale, John de, 234

Vale, Mr., 95, r 37, 292

Valence, Agnes de, 252, 253; Aymer de, Earl of Pembroke, 262; Mary w. of Aymer de, Earl of Pem. broke, 262

Valentia, vct., see Annesley

Valentyne, Marg., 30

Valeynes, Eve de m. Nich. Tregoz, 263

Valognes, Geoff. de, 25I; Gunnore de m. Rob. Fitz Walter, 25 $x$; Pet. de, $116, I 18,121,251,284,286$; fam., $25 \mathrm{I}$

Valognes, honor of, I2 I, 25 I, 253 286, 287

Vane, Revd. Fred., 149, 295

Vannell, Raphael, 235

Vaughan, Ric., Bp. successively of Bangor, Chester, and London, $135,163,216$

Velley, Jane, see Cleeve; Revd. Thos. (?d. 1750), I6, 60, I68; Thos. (d. I806), 93, I 59 ; fam., 95

Vere, Alice de, Ctss. of Oxford, see Sergeaux; Alice de, see Sanford; Aubrey de (f. 1086), I92, 198; Aubrey de (fl. early I2th cent.), 27, 201 ; Aubrey de (f. I 166), 192; Aubrey de, Earl of Oxford (d. I I94), $224 n$; Aubrey de, Earl of Oxford (d. 1214), $198 n$; Aubrey de (d. 1579-8o), 227-8; Edw. de, Earl of Oxford, 227-8; Eliz. de, w. of John de Vere, Earl of Oxford (d. 15 13), 227; Eliz. de, Ctss. of Oxford, see Howard; Hugh de, Earl of Oxford, 31 ; Joan de, $m$. Wm. de Warenne, 31 ; John de, Earl of Oxford (d. I 360), 27, I92; John de, Earl of Oxford (d. I462), I I, 227; John de, Earl of Oxford (d. 1513), 91, 192, 227; John de, Earl of Oxford (d. I 54o), 225, 227; John de, Earl of Oxford (d. I 562), 227; Rob. de, Earl of Oxford (d. 1296), 3r; Rob. de, Earl of Oxford (d. 1392$), 198$

Veryard, Mr., 226

Victoria and Albert Museum (Lond.), $269 n, 280$

Victoria, Queen, 216

Villages, nucleated, I, 43, 72-73, I 10-1 I, I 73, I 88

Vincent, Wm. (f. r 924), I27; Revd. Wm. St. And. (f. 1823 ), $23^{8}$

Viney, H., 223

Vivian, Revd. C. H., I 26

Vyne, Sir John atte, 288

Waddell, Rosetta, 42

Wade, Sir John, Io6

Wakering, Little, 277

Walbrook (Lond.), 262

Walcott, Rose m. Rob. Bourne, I3

Walde, E. H. S., I $50 n$

Waldegrave,'Anne, Ctss. Waldegrave, 149; Chas., I 44; Edw. (fl. c. I 509) II, 5 I, 90, I77; Sir Edw. (d. I 56I) 143, I46, 147: Sir Edw., Bt. (f. I643), 144; Edw. (d. I809), 147 Elnr., see Lovell; Frances Lady (d. I599), I 44; Frances, Ctss. Waldegrave, see Braham; Francis (Frances) m. John Wright, 69;
Geo. Edw. Earl Waldegrave, 144, I47, I49; Gresilda, see Wrytell Henrietta Lady Waldegrave, 147 Hen. Ld. (d. I689), I44; Jas. Earl Waldegrave (d. I74I), 140 I 47; Jas. Earl Waldegrave (d. 1763), I 45; John, Earl Waldegrave (d. 1784), I42, I45; John Jas. Earl Waldegrave (d. I835) I44; John Jas. (d. I 840), I 44; Kath., see Brown; Nich., r92 Wm. Fred. styled Vct. Chewton, I 47 ; fam. $65,67, \mathrm{r} 42, \mathrm{r} 43, \mathrm{r} 45$, 147

Walden, Alice de m. - Battail, 176 And. de, 106, I76; Humph. de (d. 1331), 105, 176, 211 ; Humph. de (f. r 336), I76; Joan w. of And. de, I76; John, 20I ; Marg. w. of Thos. de, ?m. 2 Thos. Dryffeld 176, 177; Rog. de, 176; Thos. de (f. I 336), I76; Thos. de (d. I420) 106, I76; fam., 175

Walden, King's (Herts.), 79

Walden, Saffron, $157,166,278$

Walden, St. Paul's (Herts.), see $\mathrm{HoO}$

Waldesef, Alan, 205; Aveline, see Cruce

Waldron, Amy, see Stoner; Geo. 228

Waleran, John s. of, 46, 51, 52, 175

Wales, I 3 I

Wales, prince of, see Edward VIII, George II, George III, Henry

Walgrave, John, bellfounder, 147 I95

Walker, Revd. Ant., 43, 52, 54, $55 n$ $56,57,180$; Chas., 175; Frances Eliz., see Ewing; Revd. Jos. Gordon, 132; Leonard, stained glass artist, I $64 n$; Thos., 79,80 Wm. (d. I 708), 79, $80 n, 82$; Wm. Jas. Tyrwhitt (f. I 865), ז06; Revd. W. H., 165; fam., 75

Wall, Howard, $43 n$

Wallenger, see Wallinger

Waller, Humph., I88; Jane M., I 28 . Thos., 277; W. Chapman, 34, 112, II $6,117,122,124,128$

Wallinger (Wallenger), Ant., 176 ; Ben., 176; Jas., I 49 ; Judith, 176 ; Judith, see Mildmay; Wal., I 76

Wallis, Geo. Starkins, $88,92 n$

Walpole, Sir Edw., 28; Horace, 226

Walsingham, Sir Edm. (d. r 550), 9o; Edm. (d.1589), 90; Sir Fran., I $78 n$; Elnr., see Wrytell; Jas., II, 90, I 77-8; Sir Thos. (d. I 584), I I, I2, 13, I4, 90; Sir Thos. (d. 1630), I2, I3, I4, 90; Sir Thos. (fl. $c$. I655), 90

Walter (fl. 1086), 25 I

Walter, Dorothy m. John Atwood, $215 ; \mathrm{Wm} ., 215$

Walter Fitz Robert, 25

Waltham Abbey (par.), see Waltham Holy Cross

Waltham, abbey of, 28, 81, 88, i 6 , $118,121,175,181,251-3,256$; abbots of, 28, 8r, 2 r 4, 266; see also Fuller, Harewes, John, Maidenheth, Reynold, Robert, Simon; prior of, see Geoffrey

Waltham Cross (Herts.), i 6

Waltham Forest, 20, 8I; see also Epping Forest, Hainault Forest

Waltham, Great, 27, I3 I, 200

Waltham, half-hund. of, $4 n, 5,38$

Waltham Holy Cross (Waltham Abbey), 5, 30 $n$, I I3, II 5, 264, 284 ; see also Sewardstone

Waltham, Little, $259 n$

Waltham, Rog. de, 290

Walthamstow, 78, I I r $, 123,190$ 


\section{A HISTORY OF ESSEX}

Walton, Isabel w. of Sir Ric., 225; Joan m. John Howard, Ld. Plaiz, 227; John (fl. 13th cent.), 227; John s. of John (f. 13th cent.), 227; John de (fl. 1319), 140; Margery, 227; Sir Ric., 225, 227

Walworth (Lond.), 218

Wankford, Mrs., 109

Wanstead, $37,111,123,181$

Wapping (Mdx., later Lond.), 254 268

Var damage, 35, 69, $111,122,123$, $141,144,146,147,185,192,209$, $217,222,226,230,244,250,280$, 285

Warblington, Wm. de, 176

Ward, Dudley, 260; Jane, see Plummer; Revd. J. H., $209 n$, $217 n$; Nat., 242, 247; Rob. Plummer, 291

Wardstaff, of Ongar hund., $5-8,76$, 80; of Harlow half-hund., 7

Warenne, Alice de m. Edm. Fitz Alan, Earl of Arundel, 31 ; Joan de, see Vere; John de, Earl of Surrey (d. 1 304), 31; John de, Earl of Surrey (d. 1347), 31; Wm. de, 3 I

Warham, Wm. Abp. of Canterbury, 290

Warley, Great, $221 n$

Warley, Little, 239

Warner, F., $309 n$; John \& Sons, bellfounders, 154

Warwick, ctss. of, 85 ; see also Ela

Warwick, earls of, see Edward, Neville, Rich

Warren, Revd. W. H., 62

Water supply, 113, 158, 276 $n$; see also East London Waterworks Co., Herts. \& Essex Waterworks Co., Metropolitan Water Board

Waterhouse, Paul, designer, 256

Waterloo, battle of, III, 138

Waterton, Joan m. Lionel, Ld. de Welles

Watkinson, Mr., $2 r_{3}$

Watlington, Geo., 32; John Watlington Perry, 32, 9o; Louisa, see Bodle; Maria Jane $m$. Thos. Perry, 32

Watson, Chris, $307 n$; Eliz. (d. 1782), 232; Eliza (d. by 1871 ) 128; Fothergill, 156 ; John and his w. Eliz., 30; T. H., architect, 122

Watts, Jas., 107

Wauton, Sim. de, Bp. of Norwich, 79 Waylett (Waylet), John (d. 1566), 13 51,181 ; John (f. 1566), 181; John (d. 1612), 181; John (f. 1620) 181; John (fl. 1728), bellfounder 184 ; Jos., 215; Ric., 193; Wm. (f. r 569), 181; Wm. (f. 1785), 79

Weald Bassett, North, 2, 3, 4, 26 $103,153,176,177,258,274,275$ 284-95; adv., 290-1; agric., 286 ; army post, 286 ; Bp. Compton's census, 311 ; char., 295; ch. $290-2$; commons, $284,285,286$; Cracks Bridge, 286; fair, 286 ; G.P.O. Radio Stn., 285; hearth taxes, 305, 308, 310; hos, 284-5, $288,289,290,291,295$; inc., 286 ; man. chapel, 291; mans., 6, 251 , 254. 286-90; medieval taxes, 300-2; mills, 286; noncf., 137 292-3; par. govt. and poor rel., 293 ; pop., 285 ; postal svces., 286 ; pub. svces., 286 ; rly., 286; R.A.F Stn., 284, 285, 286, 295; rect., 291 ; roads, 285 ; schs., 221 , 294 ; top., 284-6; Tylers Green, 284 $285,286,292$; vicarage, 291 ; Weald Bridge, 286; Weald Gullet, $284,285,286,294$; Weald Hall,
$284,286,288,291$; woods, 284 . see also Canes, Hastingwood, Marshalls, Paris Hall, Thornwood

Weald, South, 29, 66, 70, 139, 140 , 141 ; see also Bentley, Wealdside Wealdside, in South Weald, 148

Weaver, Revd. Sam., 165

Webb, Geo, 242; Mr. 220

Webster, Julia, 170; Sir Thos., Bt., 177 ; Mr., 253

Weir, Revd. A. W. I., $136 n$

Welby, Ada de, 80 ; Eliz. de, 66,80 Joan de $\mathrm{m}$. John de Haugh, 66 8o; Juliane de, see Multon; Marg. de, 80 ; Ric. de, 66,80

Welde, Eliz. de $\mathrm{m}$. Lewis Mewes, 199; John de, 163, 184; Ric. de, 199; Wm. atte, 192, 199

Wele, John, 31

Welle, see Welles

Weller, Jane $\mathrm{m}$. Sir Thos. Spencer Wilson, Bt., 10o; John Badger, $100 n$; Marg. Mary w. of John Badger (? dau. of John Evans), see Jones

Welles (Welle), Adam de, Ld. de Welles (d. 1311), 265; Adam de, Ld. de Welles (d. 1345), 265, 268 ; Cecily de, Vrtss. Welles, see Cecily, dau. of Edw. IV; Eudo de, 266; Joan de, Lady de Welles, see Engaine; Joan de, Lady de Welles, see Waterton; John de, Ld. de Welles (d. 1361), 266; John de, Ld. de Welles (d. 1421), 266; John de (f. 1457), 266; John de, Vct. Welles (d. 1499), 266; Lionel, Ld. de Welles, 266, 267; Marg. de, Dchss. of Somerset, see Beaufort; Maud, Lady de Welles, 266; Ric. de, Ld. Willoughby and Ld. de Welles, 266; Sir Rob. de, 266

Wellesley, Art. Duke of Wellington, 111; Gerald, Duke of Wellington, 66; Hen. Earl Cowley (d. 1884), 47; Wm. Earl Cowley, 47, 52

Wellesley-Pole, Wm, see PoleTylney-Long-Wellesley

Welling (Kent), 137

Wellingborough (Northants.), 38

Wellington, dukes of, see Wellesley

Wells, Revd. J., 16; W. C., 83

Welsh cattle dealer, 242

Wennington, see Leventhorpes, $80 n$

Wentworth, Lore m. Edmund Shaa, $290 n$; Ric., 11, 13; Sir Rog., 290; Thos. Ld. Wentworth, 54

West Hatch, see Hatch, West

West, Hen. Ld. De La Warre, 226; Isabella, Lady De La Warre, see Edmunds; John, 158; Sir Reynold, 11, 13; Mrs. S., 234

West Indies, see Barbados

Westbrook, John, 180; Mary Alice, see Stane

Westminster, 92

Westminster Abbey, 65, 66, 18 ,

Westminster, abp. of, see Wiseman

Westmorland, earl of, see Fane

Weston, Sir Jerome, 199, 200, 201; Sir Ric. (d. 1572), 199, 200; Ric. Earl of Portland (d. 1635), 199, 200

Westwood 'hamlet', see High Ongar

Westwood, Mrs. Ann, 69

Wetherspane, see Withers Pawne

Wetmere, Osbert de, 25I; Ralph de, $25 \mathrm{~s}$

Wheeler, Hen., 100

Wheler, John, 242

Whetynton, Lucy de m. I Thos. Gernon, 2 Thos. Lampet, 253, 263, 266; Maud de, 263

Whiston, Edw., 100
Whitaker, Anne, 119, 126, 128; Wm. and his w. Anne, 119

Whitbread \& Co., brewers, 76

White, G. and D. W., 47; John, 158 ; J. (of Fyfield), 45 ; J. (of Moreton), 130; Ric., 16 ; Revd. Thos. (f. 1707), 245; Thos. (f. 1839), 204; Tyndale, 244, 246; Mr., 84

Whitechapel (Mdx., later Lond.), 21 , $42,74,114,157$

Whitehouse, Canon I., $34 n$

Whiteman, Miss E. A. O., $311 n$

Whitley, Revd. W. T., 123

Whitmore, Sir Thos., Bt., 161; Sir Wm., Bt., 161

Whitney, G., 45

Whytehorne, John, 33

Wicksted, Revd. Wm., 202

Wight, Isle of, 65

Wilcox, Revd. Dan., 195

Wild, Eliz. w. of Sam., 256, $25^{8}$; Sam., 256; fam., 256

Willets, Emily, 170

Willey, - carrier, 74

William I, 30, 65, $118,143,159$, $210 n, 276$

William III, 26

William IV, as Prince Wm., I17

William of Ste. Mère Eglise, Bp. of London, 81, 290

William the Dean of St. Paul's, 179

William, Earl of Gloucester, 59

William Fitz Audelin, 175; his w. Juliane, see Doisnel

William Fitz Edric, 28

William Fitz Geoffrey, 198

William Fitz Richard, 234; his dau. Marg., 234

William Fitz Sabine, 140

William, Ric. Fitz (f., 1232-3), 234

William, Ric. Fitz (f. 1268), 192

William, Robert, of Havering, 7

William s. of Constantine, 26r, 262

William s. of Geoffrey, see Roinges, Wm. de

Williams, Alex., 211 ; A. E. B., $256 n$ $257 n$; Helen Maria, 24; Joan m. Sir Rob. Billesdon, 14, 280; John (fl. $15^{\text {th }}$ cent.), 14, 289; Sir John (f. 1543), 181; John (fl. 1851) 120; Rog., founder of Rhode Island, U.S.A., $94 n$; Mrs., 232

Willingale, Alf., 115 ; Sam., 115 ; Thos., 115,116

Willingale (modern par.), 150, 171, 198

Willingale Doe, 5, 197, 198, 200, 291 ; see also Bird's Green, Rockells, Torrells Hall

Willingale Spain, 180

Willoughby, Joan m. Ric. de Welles, Ld. Willoughby and Ld. de Welles, 266; Rob., Ld. Willoughby, 266; Wm. Ld. Willoughby, 267

Wills, Trenwith, 66

Wilmer, Thos., 27

Wilson, Jane Lady, see Weller; Sir John Maryon, Bt., 45, 98, 100 Jos., 74; Leonard, 116; Si Spencer Maryon, Bt. (d. 1897 ) 100; Thos. (A. 1842), 213; Si Thos. Maryon, Bt. (d. 1821), 100 Sir Thos. Spencer, Bt. (d. 1798), 100; Revd. Wm. (d. 1822), 135 , 138, 139; Revd. W. L. (f. 189o) 41, $127 ; \mathrm{Mr}, 293$

Wilton, John, 22

Wiltshire, earls of, see Ormond, Stafford

Wiltshire, Wm., 202

Wimarc, Robert Fitz, 234, 276

Wimbledon (Surr.), 215

Wimund (f. 1086), 151

Winchilsea, earl of, see Finch 


\section{INDEX}

Winchester, bps. of, see Lucy, Mews Winchester, earl of, see Despenser

Windsor, Bridget $m$. I Edw. Ferrers, 2 And. Ognall, 278; Wm. Ld. Windsor, 278

Wine, Thurstan s. of, I 59

Wingfield, Christiana Lady, see Fitzwilliam; Sir Ric., later Vct. Powerscourt, 267

Wingham, Rev. P. H., $35 n, 37 n$

Wingrue, Jonathan, 69

Winkworth, D. E., $127 n$

Winniffe (Wynnyff), John, 83; Thos. Bp. of Lincoln, 76, 81, 83

Winnington, Henrietta m. Sam. Ld. Masham, 92, 99

Winsford (Som.), $256 n$

Winstanley, Thos., 274

Winter, Alice, ro3

Wiseman, Anne m. Wm. Fitch, 225; Geo., 225; John and his w. Agnes (fl. I 539), 20I ; John (d. I6I 5), 27 Mary, see Jenour; Nich., Cardinal and Abp. of Westminster, $70 \mathrm{n}$, 165; Ric. (d. 1616), 228; Sir Ric. (d. I654), 228; Ric. (fl. I654), 228; Sir Rob., 228; Steph., 27; Thos. (d. $\left.{ }^{56} 6_{3}\right), 27$; Thos. (f.. 1565), 193; Thos. (f. 1617), 27; Wm., 27

Witham, 157

Withers Pawne (Wetherspane, Chivers Pawne, Chivers Hall, the Rookery), in High Ongar, 173, I74, I79, I 82, I 85

Wivenhoe, 225

Wodeward, see Woodward

Wollsey, Eliz. m. Wm. Nodes, 122

Wolsey, Thos., Cardinal, 242

Wolverley, in Solihull (Warws.), 24

Wood (Woode), Alan and Joan his w., 62; Hen., I58; Sir John, 224 225; Magdalen $m$. Sir Thos. Edmunds, 225 ; Rob., 270; Wm. (A. 1719), 186; Wm. (A. 1828), I69; Mr., 64

Wood (formerly Lockwood), Lt.Gen. Wm. M., 77,85

Woodford, I9, 20, 21, 22, 28, 35-36, 84, IIO, III, II4, II 9, 233, 293

Woodham, Walter, 25

Woods, Geo. A. H., 154; Ric., landscape gardener, 64,68

Woodstock, Thos. of, Duke of Gloucester, see Thomas
Woodthorp, Thos., I6

Woodward (Wodeward), John, 132 133; Josiah (ff. c. 1700), 244 Revd. Josiah (f. I710), 131, 132 Martha, see Nicholas; Wm. and his w. Agnes, II

Woolston, in Chigwell, 2, 6, 19, 20, $23,26-27,30-32,37-38,78,235$, 299-302

Wootton, Wm., 80

Wormlayton, Anne, 27 I ; Fulk, 254 Jane, 27I; Jane w. of John, 271 John (d. by I 680), 254; John (d. by 1725), 271; John (fl. 1727), 254

Wormsley (Oxon.), 68

Wragg, Revd. C., 70; Revd. Jacob 5I; Mary, see Collins; Revd. Thos., I6

Wright, Ann, see Sulyard; Anne, 70; Ben., $305 n$; Revd. D. V., I22 $n$; Edw. Carrington, 66, 70; Eugenia (d. I 7 ro), 70; Eugenia w. of John, 70; Frances, see Waldegrave; Geo., 7r; John (d. 1551), 66, 69; John (d. I608), 67, 68, 69, 247 John (d. 1654), 69, 70, 72 ; John (d. 1656), 69, 72; John (d. 1661), 247 John (d. I73I), 70; John (d. I75I) $66,69,70$; John (d. 1792), 70 John (d. I826), 66; John Fran. (d. 1868), 65, 66, 70; Wm., 186; Mrs. (fl. 1870 ), 93; fam., 63,65 $66,69,70$

Writtle, I 54, I 78, I 80, 200

Wroth, Anne, see Gallard; Eliz. $\mathrm{m}$ John Wroth, II9, I25; Hen. (d. c. I656), 25, 30, I19; Sir Hen. (fl. 1669), 25, I I4; Jas. (d. 1616), 77 II9, 252; Jane $\mathrm{m}$. Wm. Hen. Zuylestein, Earl of Rochford (d. I 709), I I9; John (d. I642), 30, 77 , 119, 252; John (d. 1662), 25, 30 I I9; John (f. I 703), 83; John (d. 1708), 30, I 19; John (d. I718), 30, I 19; Mary Lady, see Sidney; Sir Rob. (d. I606), 25, 30, 77, II8, 120, 252; Sir Rob. (d. 1614), 77 I17, 119 , 120, 252; Susan Lady, see Stoner; Sir Thos. (d. 1 573), 25 74, 252; fam., 122

Wrottesley, Elnr. m. Wm. Eyre (later Archer), 268, 289; Elnr. Lady, see Archer; Sir Wal., 280

Wrytell, Audrey, see Shaa; Elnr. m.
James Walsingham, II, 90, I77-8; Elnr., see Ramsey; Gresilda m. I John Rochester, 2 Edw. Waldegrave, I1, 51, 90, 177; Joan, see Hende; John (d. I485), $88 n, 89$, 177, 243; John (d. 1507), 89, 177 , 178, 243; Juliane, 90, I77; Kath. w. of Wal., m. 2 Sir Ric. Haute, 5 I, $88 n, 80$ 177; Ralph, 80; Wal. (d. 1475), II, $26 n, 5$ I, $88 n, 89$, $90,177,242,243$; fam., 5 I, 89 , $177 n$

Wyberd, John, 188

Wyher, Thos., 292

Wylde, Sim. le and his w. Joan, 152

Wylford, John, 278; Philippa m.

1 Sir John Hampden, 2 Sir Thos.

Smyth, 278, 279, 282; Wm., 278

Wylkinson, John, 264

Wymundham, Pet., I 99

Wynnyff, see Winniffe

Wynslowe, Marg. m. Wm. Nynge, 134; Thos., I34

Wynter, Ric., I 73

Wythiale, John, 254; Sim., 254; Thos., 254

Wyvill, Marmaduke and his w. Agnes, 47

Yeallett, Geo., 45

Yeates, Revd. J. T., 83

Yonge, see Young

York, abp. of, see Harsnett

York, dchss. of, see Neville

York, duke of, see Richard

Yorkshire, lands in, 80,90 ; medieval tax assessments, 296, 302

Young (Jonge, Yonge, Younge); Anne, see Day; Geo., I $79 n$; Art., agriculturist, 23; Edw., 60; Greg., I79; Jane, I79; Kath., 6o; Louisa Eliz., 258; Ric., 59, 6o; Rob., 6o; R., 230; Mrs. S., $286 n$; Thos., 200; Wm., $60 n$

Youngsbury, in Ștandon (Herts.), 254,288

Zuylestein, Jane, Ctss. of Rochford, see Wroth; Wm. Hen., Earl of Rochford (d. 178I), I19 
PRINTED IN GREAT BRITAIN

AT THE

UNIVERSITY PRESS

OXFORD

BY

CHARLES BATEY

PRINTER

TO THE

UNIVERSITY 




DA The Victoria history of the

670 county of Essex

ETV6

v. 4

PLEASE DO NOT REMOVE

CARDS OR SLIPS FROM THIS POCKET

\section{UNIVERSITY OF TORONTO LIBRARY}


